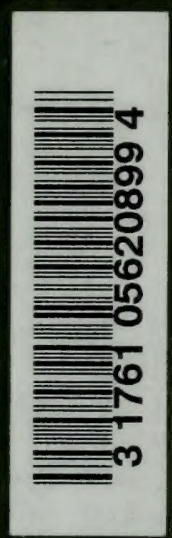



Digitized by the Internet Archive in 2010 with funding from University of Toronto 


\section{BRITISH LICHENS}





\section{A MONOGRAPH}

OF THE

\section{BRITISH LICHENS}

A DESCRIPTIVE CATALOGUE

OF THE SPECIES IN THE

DEPARTMENT OF BOTANY, BRITISH MUSEUM

\section{PART I.}

SECOND EDITION

BY

ANNIE LORRAIN , SMITH, F.L.S.

Acting Assistant, Department of Botany

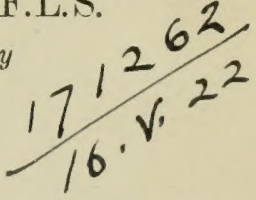

\section{LONDON}

PRINTED BY ORDER OF THE TRUSTEES OF THE BRITISH MUSEUM

AND SOLD BY

LONGMANS, GREEN \& CO., 39, PATERNOSTER ROW, E.C. 4 ;

B. QUARITCH, LTD., 11, GRAFTON STREET, NEW BOND STREET, W. 1;

DULAU \& C0., LTD., 37, SOHO SQUARE, W. 1;

AND $A T$ THE

BRITISH MUSEUM (NATURAL HISTORY), CROMWELL ROAD, S.W. 7. 



\section{PREFACE TO SECOND EDITION}

THE long interval of time between the publication of the two Parts of the Monograph of British Lichens rendered necessary the preparation of a new edition of Part I. as soon as possible after the completion of Part II., and fortunately Miss Lorrain Smith was able to undertake the work.

The present volume covers the same ground as the first edition of Part I. by the Rev. J. M. Crombie, but has been completely re-written; much new material has been incorporated, and considerable alterations in arrangement. and classification have been made. It thus forms an independent work companion to Part II., by the same author, issued in 1911.

By the addition of an Appendix, in which are contained those Orders that under the accepted scheme of arrangement would have been included in Part II., the two Parts are correlated; together they form a complete modern presentment of the British Lichens. Miss Smith has also added, in the form of an Introduction, a general account of the Lichens.

The small blocks in the text illustrating the genera have been replaced by a series of plates similar to those issued with Part II.

A. B. RENDLE.

\section{Department of Botany, \\ British Museum (Natural History), Cromwell Róad, S.W.}

July 1918. 


\section{PREFACE TO FIRST EDITION}

THE re-arrangement of the British Lichens in the Herbarium of the British Museum and the incorporation of a great series of specimens made a revised Catalogue of these plants a necessity.

The large number of authentic specimens from Dillenius, Hudson, Sowerby, Dawson Turner, T. 'Taylor, Salwey, Mudd and Leighton contained in the Herbarium supplied material for determining the species of these lichenologists which does not exist elsewhere; while the extensive series of British Lichens, including the collections of Buddle, E. Forster, R. Brown, Carroll, Piggot, Holl, Crombie and Larbalestier, made it possible to determine with certainty the geographical distribution of the species within the British Islands.

The Rev. J. M. Crombie, M.A., undertook the preparation of a Monograph based on these materials. This volume contains descriptions of half the known British species. The remainder (consisting of the Lecidei, Graphidei, Pyrenocarpei, Peridiei and Myriangiacei) is so advanced that it may be expected to appear in 1895, and will contain a complete index to the genera. and species of the whole work.

WILLTAM CARRUTHERS.

March 1894. 


\section{CONTENTS}

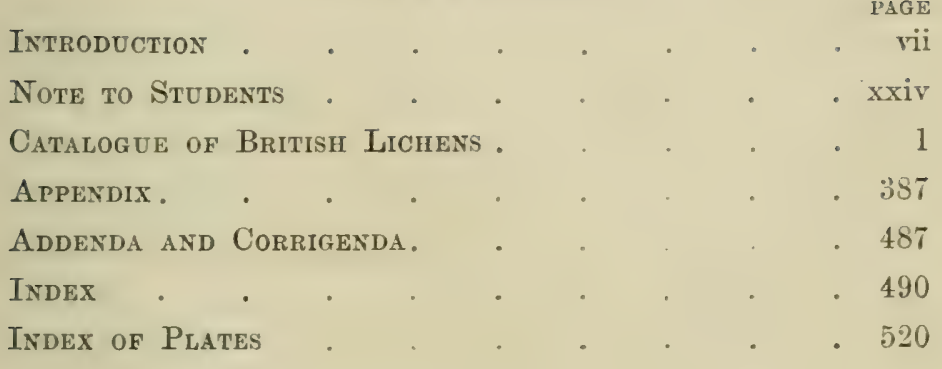





\section{INTRODUCTION}

\section{THE LICHEN-PLANT.}

Lichens are a class of thallophytes of lowly organization that inhabit soil, rock, wood, trees, etc. The vegetative thallus is of varying form and colour; the reproductive organs are akin to those of fungi. They differ from all other members of the vegetable kingdom in their composite structure, being formed from the union in intimate symbiotic relationship of two separate plants, a fungus and an alga. This can easily be demonstrated in any part of the thallus or vegetative structure; a thin section, examined under the microscope, shows a ground structure of colourless cells or hyphæ, the fungal elements; and a series of green cells which are the algæ. If the latter are confined to a narrow zone near the upper surface, the thallus is termed heteromerous (see figs. 5, 6), but if they are scattered more or less evenly through the thallus it is then described as homoiomerous (fig. 1).

12 This old division of lichens into

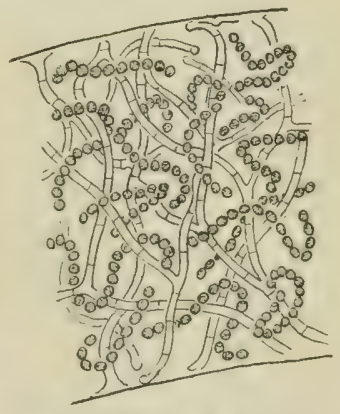

FIf. 1.-Section of homoiomerous thallus of Collema. $\times 250$.

heteromerous and homoiomerous does not entirely correspond with the modern more exact system of classification based on the reproductive organs; but the type of structure thus indicated is generally well marked, and a valuable character in identification.

Fungal elements of the thallus.-These have undergone considerable modification as lichen constituents, and cannot its it rule be traced back to any particular species or genus of fungi. The British lichens, however, are all associated with Ascomycetes, and approximate to certain groups within that class of fungi. 
In the tropics there are lichens in which the fungus belongs to the Hymenomycetes.

Lichen-hyphe, as they issue from the germinating spore and lay hold on the algae, are thin-walled, and similar to those of fungi (fig. 2). The various tissues are formed by the branching

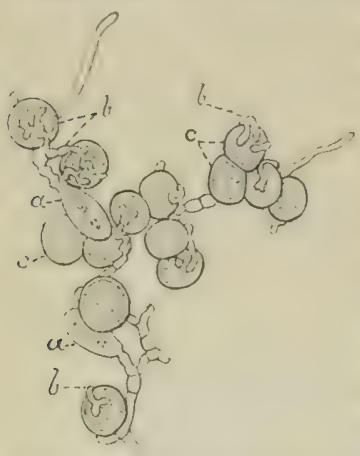

Frc. 2.-a, Germinating syores ; $b$, clasping fllaments ; $c$, alcal cells. (After Bonnier $\times 350$.) and septation of these hyphæ. In the growing regions, at the apex or edges of the thallus, or in the gonidial region, the cells remain comparatively thin-walled; but in the other parts of the thallus, especially in the medulla, the walls become very thick, with the exception of the gelatinous lichens, in which the thickening is less marked. In the cortex of the foliose and other species, there is frequently a formation of pseudo-parenchyma (plectenchyma). It arises from the rertical, multiseptate tips of the hyphes which lie elosely packed together and present the appearance of cellular structure. In many cortices, more especially of crustaceous lichens, the walls are so swollen that the celllumen practically disappears and the tissue becomes an amorphous gelatinized mass.

strengthening elements are provided by the coherent parallel srowth of thick-walled hyphe which form fibre-like bundles or chondroid strands that give support to the thallus.

Lichen-hyphe retain many of the characteristics of those of the higher fungi. Pure cellulose has not been found, the cellwalls being formed of various hemi-celluloses, and nearly all the cell-membranes contain more or less chitin. The cells enclose a nucleus, protoplasm, gluenes and sometimes vil-drops; glyeogen nceurs in the cells of the reproductive system. Spheroid cells lilled with greenish oil are a constant feature of the lower rhizoidal layer of calcicolous lichens: wil cells also occur occasionally in other lichens.

Alyul elements of the thullus.-.-The algal constituents of the compusite thallus helong to the tavo elasses-(1) Myxophycere, enerally termed blue green algar, and (2) Chlorophycea, which are refermed to as brightegreen. Most of them are acrial forms and, in a free condition, they inhabit moist sharly situations. They multiply by division within the thallus: zonspores are 


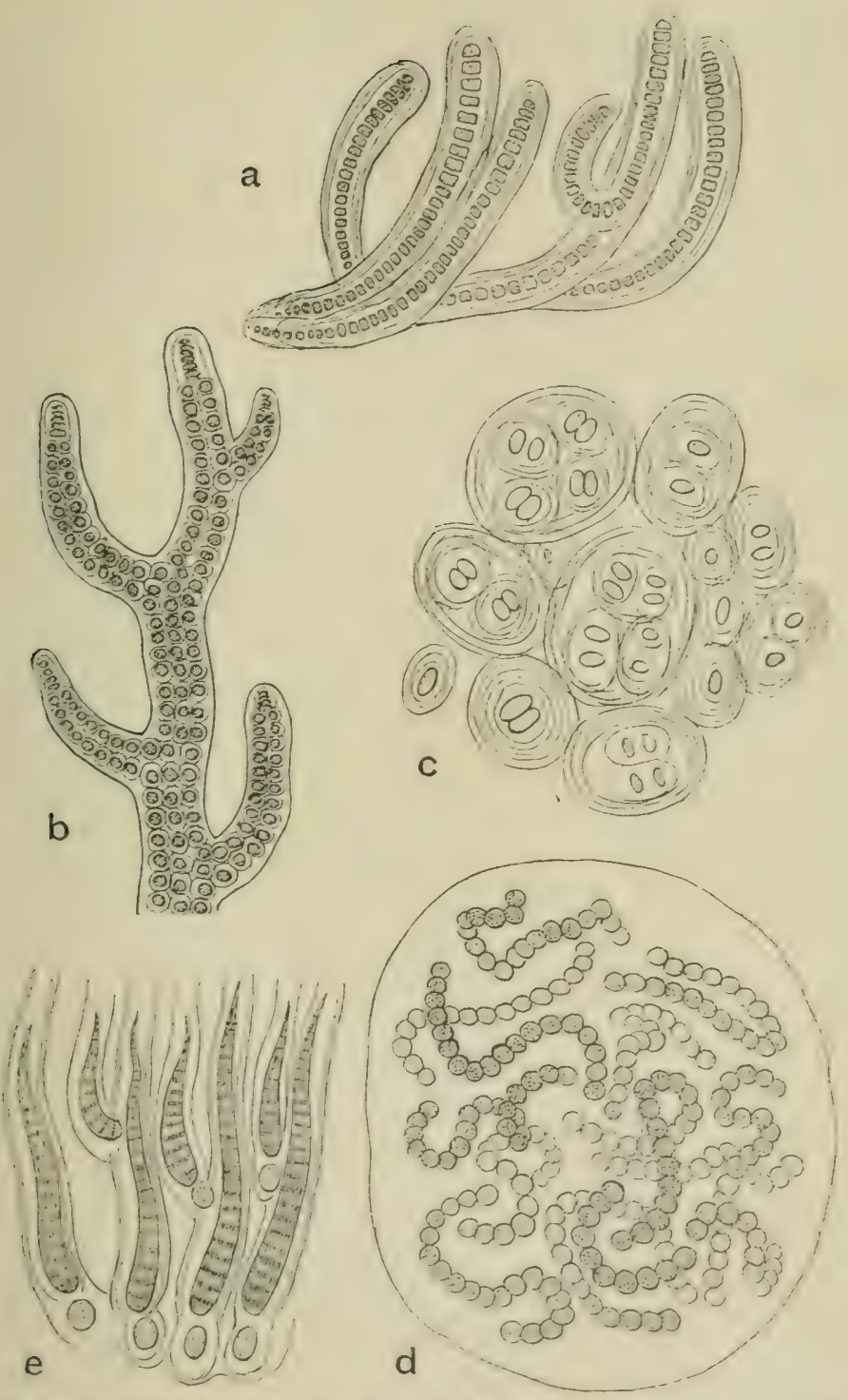

FIG. 8.-bluegreen algie that form grunilia. a, sintonema; b, Stigoneme; c, Gloeo fapsa; d, Nostoc; c, Ilivularia. (a, b, e, after Kuitzing, $\times 350$; c, after Cooke. $\times 400 ; d, \times 450$.) 
never produced except in cultivation outside the thallus. The determination of the genera and species to which they severally belong is often uncertain, but their distribution in British lichens is somewhat as follows:-

1. Myxophycea associated with Phycolichenes, many of them gelatinous lichens (fig. 3). They are:-

Scytonema vecurring in Thermutis, Spilonema, Leptogidium, Gyalectu (in part), Placynthium, Polychidium, Porocyphus and Coccocarpia.

Stigonema in Ephebe and Ephebeia.

Glœocapsa in Euopsis, Pyrenopsis, Synalissu and Psorntichia.

Nostoc in Collema, Leptogium, Peltigera, Pannaria and Parmeliella.

Rivularia in Lichina and Pterygium.

Nylander gave the name gonimia to the blue-green algae of the thallus, retaining the term goniclia for the bright-green species. The distinction is not generally maintained.

2. Chlorophycere associated with Archilichenes (fig. 4), ats follows :-

Protococcus (Cystococcus, Pleurococcus) and Palmella in the greater number of the larger lichens and in many crustaceous genera, such as Lecrnora, Lecidea, Pertısaria, Verrucaria, etc.

Trentepohlia in Cunogonium, Dirimu, Rocella, ciraphi. dacex, Pyrenulacex, and also in Thelotrema and Gyalecta, rarely in Lecanora and Lecidea.

Cladophora in Racodium.

Though as a general rule the alga is less aftected than the fungus by the symbiotic life, it also may become modified in ippearance. The blue-green forms may lose their colour, as in Gilococapas ; or the strings of eells may be broken up, as occasionally in Nosfor, Scyfonema, ete. Among the Chlorophycear, there is occasional change of form both in Profococus and in Timentolilia ; they revert to their original appearance in free cultivation. 


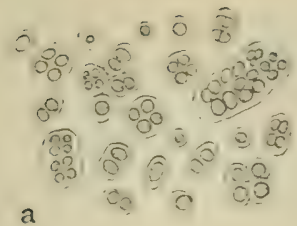

b
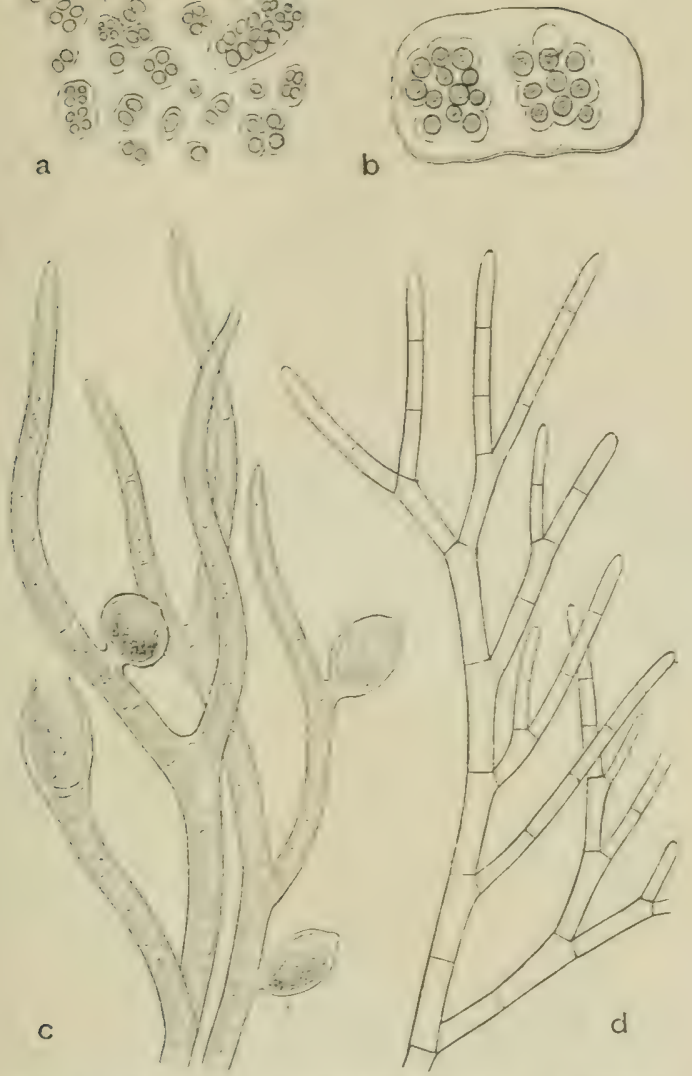

FIG. 4.-Bright-green algre that form gonidia a, Protococcus; b, Palmella; c, Trentepohlia ; d, Cladophora. ( $\mathrm{a}, \mathrm{b}, \times 250$, after Hassal ; c, after Cooke, $\times 250$; d, after West, $\times 60$.)

\section{MORPHOLOGY.}

There are three principal types of development in the vegative body or thallus of lichens:-

1. Crustaceous, or encrusting lichens which spread over trees: rocks or soil, with a more or less well-developed crust varying in thickness, form and colour. The thallus consists generally of an upper cortical layer of hypha: beneath the cortex a zone of algal cells and lower still a medulla of fungal filaments, the latter resting directly on the substratum; sometimes the crust is only 
a thin structureless mixture of hyphe and alga. Though mostly superficial the crustaceous thallus is, in certain genera or species, partly or wholly embedded in the bark or rock on which it yrows. It is thus often difficult to recognize the different tissues. The lower hyphe in many of the superficial species form a thin spreading layer called the hypothallus; it is usually dark in colour and often appears as a black border to the thallus, either as a firm limiting line or as dendritic filaments. A patch of crustaceous lichen on tree or rock may bclong to one species and yet be composed of many individuals which have starter from different centres, each growing centrifugally. The dark lines rhiefly occur where the different individuals encounter each other. A striking instance of such intersecting lines occurs in the thallus of the well-known Rhizocarpon geographicum. Strong boundary lines also frequently divide different species inhabiting the same substratum.

2. Foliose, foliaceous or leafy lichens; as the name implies, these are spreading leaf-like expansions of one or many lobes, which adhere more or less firmly to the support on which they srow. Like the crustaceous forms, they are dorsiventral in structure; the upper surface is provided with a distinct hyphal cortex, beneath which lies the gonidial zone and the medulla. There is also a lower cortex which is frequently of a darker colour and which is mostly provided with hairs or with rhizoids formed of strands of hyphe that are chiefly organs of attachment.

3. Fruticose or shrubly lichens: these are upright branching forms rising from a basal point, and they are either cylindrical or strap-shaped. The structure is radial, with a central pith of fungal hyphex, a surrounding hand of algre and an outer cortex of fungal elements. There is considerable variety of form in this group from the short, stiff, strap-shaperl lobes of some liamaline to the long pendulous thread-like strands of Alectoria or Usnea. Intermediate forms connect these different groups. In the Cladoniacese there is a hasal thallus, either crustaceous or of small lohes, and there is also an upright stalk called a "podetium," which in many eases opens out into a cup-like structure called a "scyphus." The podetia may be simple or iranched, and as the reproductive bodies in this family are borne (n) the tips of the branches or on the edges of the scyphi, the upright thallus has been frequently remarded as a modified fruitstalk. 


\section{VEGETATIVE STRUCTURES PECULIAR TO THE LICHEN-THALLUS.}

Soredia.-These are small powdery bodies that consist of one or several algal cells closely surrounded by lichen-hyphre. They occur as grayish powder on trees, or on the ground, representing the first stage of thallus formation; as white or greyish granules on the squamules and podetia of many Cladonix, or they are massed on the surface of the thallus into well-defined pustules called soralia. The soralium is formed by an increased growth of soredial gonidia and hyphe at certain points within the thallus, the overlying tissue finally bursting and allowing the escape of the soredia. Soralia me generally constant in form and in position on the thallus. Each soredium can give rise to a new lichen-plant. It is a method of regetative reproduction that secures a ready and wide dispersal of species.

Isidia.-The isidium is a small outgrowth from the surface of the thallus which contains both the algal and fungal constituents, but differs from the soralium in being covered by a cortex. Usually the isidia are like minute cones on a narrow stalk; occasionally they are branched.

Cephalodia.-On the thallus of various lichens there are developed abnormal, and generally darker-coloured swellings,

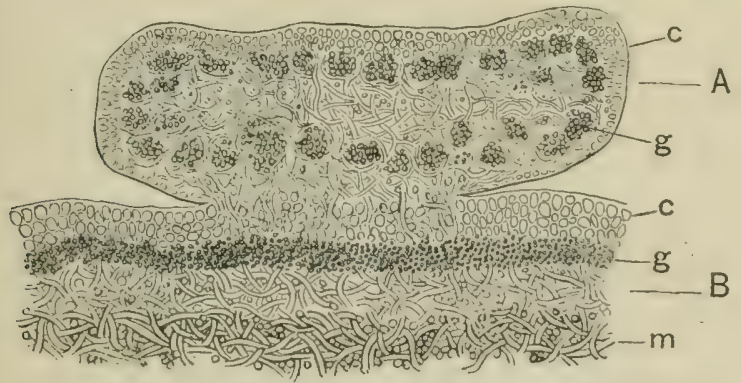

FIG. 5.-Vertical sention of thallus and cephalodium of Peltigera aphthosa. A, Cephalodium ; B, 'Thallus ; c, cortex ; g, gonidia ; m, medulla. (Greatly magnified.)

tubercles or warts, composed of the normal lichen hyphie, hut containing a different algal constituent, which is almost invariably one of the Myxophycen (Nostoc, Stigomema, ete.). Cephatodia are constant in form and occur as flat orbicular light-coloured expansions (Lecanora gelida), sroups of dark hranchlets (Lebaria 
xiv

laciniata), or irregular warts (Peltigera, Stereocaulon). They also form internal packets in certain species which are termed endotrophic cephalodia. They are probably of value in retaining moisture (fig. 5).

Cyphella and Psendo-cyphellx.-These are small roundish bodies scattered over the lower surface, mostly in the genus Sticta. They are of definite form with a distinct rim (cyphella),

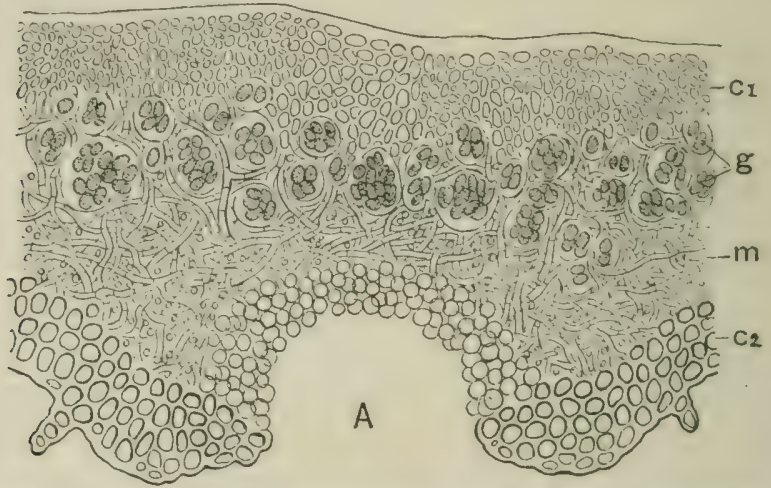

Fro. 6.-Vertical section of thallus and cyphella of Sticta sp. A, Cyphella. $e_{1}$, upper cortex; $c_{2}$, lower cortex; g, gonidia ; m, medulla. (Greatly magnified.)

or they are mere openings in the cortex through which hyphas project (pseudocyphellax). They serve most probal)ly as aerating organs as do the lare areas on the under surface of Lobaria pulmonaria, etc. (fig. 6).

Definite breathing pores have been demonstrated in only one lichen, Parmelia exusperata ; hut openings and breaks oceur frequently and allow rearly communication between the internal tissues and the outer air.

\section{REPRODUCTIVE ORGANS.}

Apothecia and Peritherin.--With the execpution of a few fropioml genera of IIymenolichemes, all known lichens belong to the sulediss Ascolichenes and produee their spores in fruitsaperberia or peritheciat-somewhat similar to those of the Ascomycetes.

Apothrium. - In "pen fruit with a more or less exposed dise, comparable to that of the biscomycetes amomg fungi. The 
simplest type of apothecium is formed solely from the fungal constituent as in the Lecideacere, usually a round button-like disc, which is either soft and often brightly coloured (biatorine)

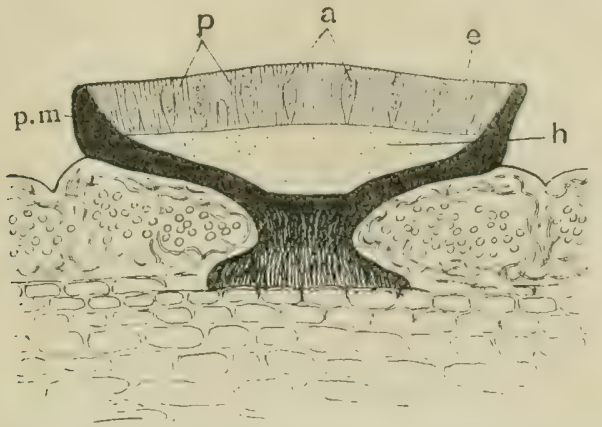

FIG. 7.-Vertical section of lecideine apothecium. a, asci ; $\mathrm{p}$, paraphyses; $\mathrm{e}$, epithecium ; $\mathrm{h}$, hypothecium ; p.m, proper margin. (Greatly magnified.)

(fig. 8), or dark and mostly hard and carbonaceous (lecideine) (fig. 7). The dise is formed of compact upright rows of asci or thecæ (a) which contain the spores, and of sterile threads, the paraphyses $(p)$ of which the tips generally project beyond the

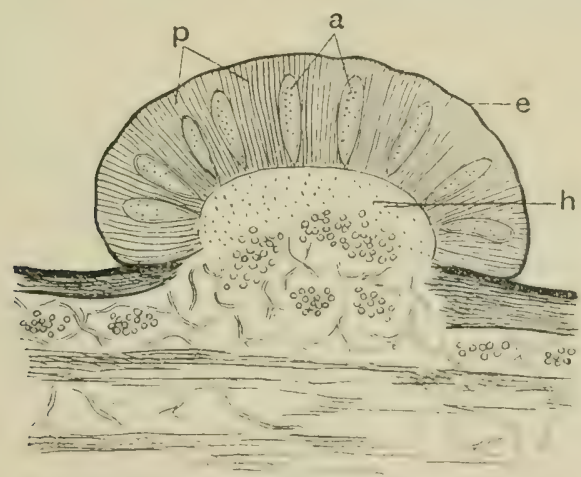

Frg. 8.-Vertical section of biatorine apothecium. $a$, asci ; $p$, paraphyses ; $e$, epithecium ; $h$, hypothecium. (Greatly magnitled.)

asci and form the epithecium (e). The combined asci and paraphyses are the hymenium. The tissue of the fruit immediately below the hymenium is the hypothecium (h), and as continued up and round the fruit is called the parathecium or "proper margin" (p.m). It may be formed of loosely interwoven light- 
coloured hyphe, or it may be dark and carbonaceous. Frequently it is excluded by the growth of the disc (fig. 8).

In the more highly developed lecanorine apothecium (fig. 9) the thalline lissue containing sonidia develops along with the

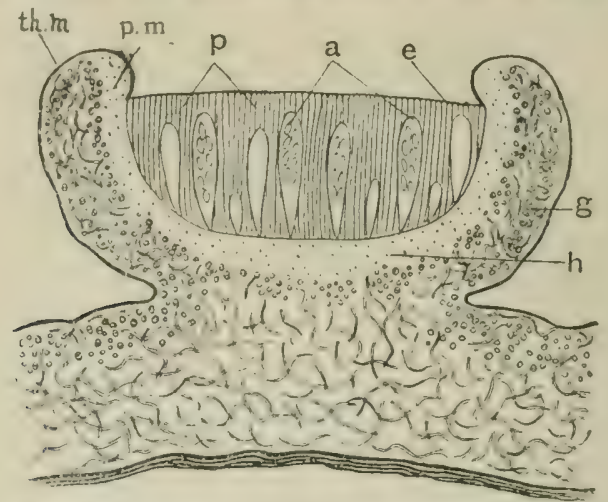

Frg. 9.-Vertical section of lecanorine apothecium. $a$, asci ; p, paraphyses ; e, epithecium ; g, gonidia ; h, hypothecium; p.m, proper margin; th.m, thalline margin. (Greatly nagnified.)

other apothecial tissues. This outer protective wall or amphithecium is generally called the "thalline margin" (th.m); it closely surrounds and forms an integral part of the apothecium. Apothecia vary greatly in size from about 0.25 to $10 \mathrm{~mm}$. or more in diameter.

Perithecium.-When the fruit is a closed body with only a
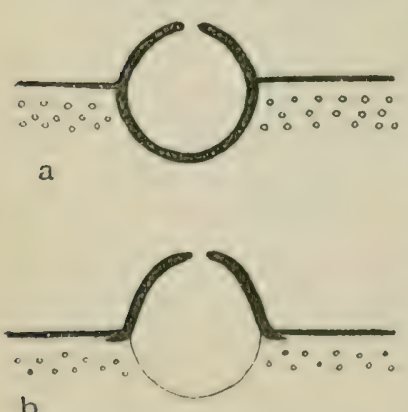

b

Fic, 10.-Vertical section of peri. thecia. $\mathrm{n}$, entire; $\mathrm{b}$, dimidiate. (Greatly enlarged, diagramatic.) narrow opening or ostiole it is called a perithecium (fig. 10). Generally it is surrounded by a wall and the perithecium is thon entire (a), or the wall is absent or reduced to a thin line below the base and it is then described as dimidiate (b). Perithecia are always small bodies and usually they are partly immersed in the thallus or substratum.

As a rule lichen-fruits grow slowly. Spores may be produced almost any time in the year, but for a number of species there is a double spore-bearing season, in spring and again in autumn. The same fruits often persist for sereral years, new asci heing 
continually formed. It is therefore no unusual experience to find the spores shed in seemingly well-fruited lichens.

Lichen spores vary considerably in size, form, septation and colour. Usually there are $s$ in the ascus, but in some genera or species the ascus contains only one large spore, in others they are innumerable and of small dimensions. The largest spores are found in Pertusarin and in Varivellaria, the 1-septate spore of the latter measuring up to $350 \mu \times 11 \% \mu$. In the family, Physiacex, the cross wall of the septate spore is so thichened that the lumen of each cell is reduced to a small area at the ends; hence the term polari-bilocular. This is a type of spore without any parallel among fungi. Each cell of a septate spore may give rise to a hyphal filament on germination. The large one-celled spores of Pertusaria and other lichens contain many nuclei and produce germinating tubes all over the surface (tig. 11). The newly formed hyphal filaments become associated with an algal cell, and clevelopment proceerls (fig. 2), or, if no alga is encountered, the hyplie in time die off. In some genera of Prrenocarlacess (Endocarpon and Staurothele) gonidia occur

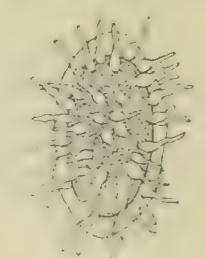

Fir. 11. - Mrulti-nucleate spore of Lexidea san. guinaria var. afinis, with germinat iug tules. (After de Bary. $x$ alnut 250.) in the hymenium alongside of the asci. They escape from the perithecia with the spores and together they build up a new plant.

Spermogones or Pycnidia.-These are small perithecia-like bodies which oceur on many lichens, generally scattered over the thallus, but occasionally confined to detinite areas: to the periphery of the lobes (Parinclia pliysortes), the margins (Cetraria islundira) or the tips of the podetia (Cladonia). They vary in form, being ovoid, globose, etc., and sometimes irregrular with folds of tissue projecting inwards, thus subdividing the interior. The inmer wall is lined by simple or hrancher hyphre, the sterigmata or by a cellular tissue on which spermatia are borne. The spermatia are usually minute, and more or less cylindrical, and are provided with a cell-wall and contain a nucleus, ete. Many lichenologists have luohed on these horlies as the male organs of the plant bearing non-motile spermatia. They are larely functionless, and as germination of the "spermatia" has leen olserved in at number of forms, it seems probalie that they should rank as secondary fruit forms or lycnidia, their contents would then be more properly deseribed as sporophores and pyonidiospores. 
The form of the sterigmata (or sporophores) varies, and the differences have been macle use of in classification. Nylander divided the spermogones into two groups: those with simple "sterigmata" and those with "arthrosterigmata." In the former, the more usual type, the sterigmata are more or less upright, variously branched, and sometimes anastomosing; they are usually sparingly septate, and the spermatia are acrogenous on the tips of a secondary branch. The arthrosterigmata are divided up into short cells, each cell clirectly giving rise to a pleurogenous spermatium (or spore). This type of sterigma is found in Physcin and Sticta. In Endocarpon the arthrosterigmata form a tissue lining the wall.

The spermatia also show great variation in form. Usually they are extremely minute, or if elongate, extremely narrow and thread-like. Some undoubted pycnidia contain larger stouter spores which do not differ from the others except in size, though the term "pyenirles" was wholly reserved for these by Lindsay.

\section{PHYSIOLOGY.}

Nutrition.-In the higher plants there are green cells containing chlorophyll and colourless cells forming tissues with different functions. We find the same distinctions between the tissues in lichens, but with this great difference, that whereas, in the higher plants, all the cells have the same initial starting point, in lichens, the two kinds of cells have a widely separate origin. In lichens, as in the higher plants, the green cells-the lichen gonidia-do the work of assimilation and by photosynthesis prepare carbohydrates for the whole plant. The colourless cells or hypha are the organs of alsorption, and, in return for the algal carbohyclrates in the form of sugar's or glucoses, they supply water, nitrogenous sulustances and salts, which they have absorbed from the substratum or from the environment and converted into a state in which they can be used by the protoplasm of the green cell.

Symbiosis. - The relationship between the two organisms was at first remarded as that of algal host and fungal parasite, but further consideration showerl that this riew was not entirely satisfactory, and licinke pointed out that each member of the joint thallus might be regarded as the "consort" of the other. This view was further elaterated hy De Bary, who brought forwart a sinilar theory of "symbiosis," or conjoint life with more 
or less advantage to each member or symbiont of the dual organism. The alga unduubtedly grows with great vigour in the lichenthallus, being excited to increased vitality by contact with the fungus, or by conditions, such as increased moisture, supply of inorganic salts, shelter, ete., that are specially favourable to its wowth. On the other hand, the fungus withdraws from the alga the necessary carbohydrates. The presence of hyphe within the algral cells olsserved in certain lichens, and of empty algal membranes in others, testify to the occasional harmful ravages of the fungus; but any thenry of lichens as merely parasitic fungi is incompatible with the continuous healthy development of the lichen plant.

Excretory prorlucts.-In many lichens there is an abundant formation of oxalate of lime; it is laid down in crystals on the outside of the hyphe, medullary or cortical. In Lecanora esculenta, a limestone desert lichen, it has been proved that the crystals form sixty per cent. or more of the dry substance of the thallus.

There is also an enormous production of lichen acids, organic products of varying chemical formulie found only in lichens, and due undoubtedly to the peculiar symbiotic relationship of fungus and alga. Among the best known are parietin (chrysophanic acid), which gives the brilliant yellow colour to several lichens, and the valuable series of acids that produce the orchill of commerce, called also cudbear and litnus. Orchill prorides a heautiful purple dye, and though it can be extracted from a number of lichens, the chief commercial source is Roccella tincforict, which grows in great abundance on the rocky cousts of southern Europe. The crustaceous lichen Lecunora tartarea also yields a purple dye.

\section{ECOLOGY AND DISTRIBUTION.}

Lichens are xerophytic in structure and well-adapted by their composite nature to withstand extrene drought and extreme weather conditions. In some cases water may be absorbed from the soil, but in most lichens the habitat precludes that possibility : they live nearly always in xerophytic conditions - on the hark of trees, on the bare rock, on acid moorland soil, on sandy wastes or by the seashore. The hyphe swell up and retain for a long time the moisture they receive mostly from mist or rain. There is no regular provision for transpiration except in a few 
cases. Growth is extremely slow, and there is in consequence little demand on the metabolic activity of the cells. A plant of Parmelia saxutilis kept under observation for a considerable period was observed to increase about $1 \mathrm{~cm}$. in diameter in a year. The gonidial layer is usually several cell-rows below the surface and is often obscured by pigments in the cortical cells; they recjuire therefore abundant light and pure air, and are alway's most luxuriant in well-lighter situations, such as the sunny side of a wall, and on the outskirts of a wood rather than in its shady glades. They soon die out or learl an impoverished existence in the near precincts of a large town, owing to the smoke. They are the most casmopolition of all plants and the pioncers of vegetation, occupying great tracts of mountain and arctic regions where no other plants can live. Distribution in the case of some genera and species is limited by climate or by the nature of the substratum. On the other hand, there are species, like the mountain-loving Rhizocurpon geographicum, that spread almost from pole to pole.

\section{ECONOMIC USES OF LICHENS.}

In addition to their use as dye-plants, lichens are to a very limited extent valuable as a food supply. The lichenin stored in the cell-walls of Cetruria islandica, the Iceland Moss, can be so prepared as to be both nutritous and appetising and has been often utilised by northern peoples. Species of Gyrophora, "tripe de roche," have been eaten by travellers when no other food was available, but though they contain some nourishment they are tor bitter for esnsumption. Reindeer pasture largely on C'ladonin rangiferina, and snails, slugs, mites, ctc., revour eagerly many different kinds of lichens.

In the economy of Nature a considerable part is pliyed by crustaceous saxicolous lichens in breaking up the rock and preparing it for plants more dependent on loose soil. Calcareous and granite rocks are thus slowly hut gradually disintegrated. Volcanic rocks with their smoother harder surface are less affecterl. Topographlically as well as geouraphically, lichens are indispensable pisneers. Many lichens grow on trees, where they are epiphytie, thomgh occasionally their root-lases penetrate the living tissue: only one spreies, a leaf-lichen in the tropies, has been recorded as constantly pritasitic. Sometimes the growth of laty and shubly forms is so luxmiant as to cover the entire 
bark and thus impede the aeration of the tree. On the other hand, it is suggested that they probably protect the tree from extreme cold. They do, however, indirect harm by providing harbourage for insect pests.

\section{PHYLOGENY AND CLASSIFICATION.}

Lichens as regard: both their symbionts are polyphyletic in origin, the alga which furm gonidia belonging to widely separated groups, and the fungi which form lichen-hypha being derived from the two great subclasses Basidiomycetes and Ascomycetes.

All the British lichens are derived from the Ascomycetes, and they are again polyphyletic within the subclass. They fall into two great series :--

I. Gymnocarpere, in which the fruits have more or less open dises.

II. Pyrenocarpex, with closed fruits.

The Gymnocarpese are livided into three subseries:-

1. Coniocarpinex, characterized by a "mazedium" type of fruit, and, in most of the families, by a primitive thallus. The derivation is doubtful.

2. Cyclocinpinere, with open fruits corresponding to those of the Discomycetes. Their fungal ancestors are to be sought for among the Pezizinea and most probably in the family Patellariacere.

3. Graphidinex. The fruits are characterized by a narrow generally elongate disc. The nearest allies among fungi are the Hysteriacer.

In the arrangement of the various Orders or families, special attention has been given to the derelopment of the lichen-plant as a whole within each series.

The Coniocarpinese are a subseries apart, intimately connected with fungi ancl have been placed first. The almost closed form of the fruit suggests, however, allinity with the Pyrenocarpese.

In the Cyclocarpinew, the first group inclucles those fiunilies in which the fruit is highly developed, the alpothecia with few exceptions having a thalline mangin (lecanorine). It was 
impossible to place the lesis highly dereloped lecideine families first as they are already described in Part IT. The lichens containing blue-green algae (Myxophycere) have been considered first; those with a simple homoiomerous thallus being followed by those with a heteromerous thallus, reaching the highest development in the Peltigeracere and Stictacese, which include genera with both types of gonidia, blue-green and bright-green.

To aroirl any break in the arrangement, the Parmeliacea, which are allied to the Stictacese, are placed next. The gonidia in this and the following families are bright-grreen. Then follow the Usneacere, and after that family the Physciaces, marked by the peculiar polarilocular spores. The genera of Physciacea range from fruticose to crustaceous forms. The Lecanoracere and other crustaceous families close the first group.

The second great group of Cyclucarpinere includes those families in which the apothecia are without a thalline margin (biatorine or lecideine), the gonidia taking no part in the formation of the fruit: they are thus more primitive phyiogentically than the preceding. Begrinning with the highest families of the group, we place first the ('yrophoracen with a well-developer foliose thallus, followed by the Clacloniacere, the filamentous Cœnogoniaces-very poorly represented in northern countriesand finally the great family of Lecideacere with a crustaceous or, at most, minutely squamulose thallus.

In subseries Graphidinea, the families have a crustaceous thallus, with the exception of Rocellacer, which is fruticose and highly developed, the gonidia are all Chlorophyces and mostly from the genus Trentepohlir. The arrangement depends on the character of the fruit.

Series II., Pyrenocarpeae, includes a small family of Pyrenidiacese with blue-green gruidia (Myscophyceaces), the others all contain Chlorophyeere. There is one family, Dermatocarpacea, which is foliose, the other families are all crustaceous and are arranged according to perithecial chalateters. They are derived from the Pyrenomycetes.

The arrangement adopted has been partly necessitated by the order of publication. In the previous Monograph (by Crombic), the thallus rather than the fruit formed the basis of classifieation. If it had leeen possible to republish the whole work simultaneously, a better scientific grouping would have been to begin with the Pyrennearpese, in which the fruit form is more 
primitive, to be followed by the Gymucarper, with the three subseries in orler of development:-1. Coniocarpinese; 2. Graphirlinea, 3. Cyclocirpinea. In Cyclocarpines the more simple lecideine fimilies should precede the great lecanorine group, which includes the most highly evolved lichens.

The term "Order" has been retained in place of the now senerally acepted term "Vamily" to maintain conformity with Part II. The ()ders that should have been included in the latter work are printed in the Appendix to the present volume. The sequence of arrangenent arlopted will be found at pp. 1-2, 25-6 and $387-8$.

In preparing the Monograph it has been found necessary to depart in many insitancess from the scheme of classification and method of description arlhered to by the Rev. J. M. Crombie in 1894 , but J desire to recond my very great indebtedness to the work done by him both in lis publications and in the herbarium of the British Museum. I wish to thank those who have grenerously sent we rare or new specimens:-Mr. Hebden, Rev. IV. Johnson (especially for Surcopyrenic gibbu), Miss Knowles, Mr. Paulson, Mr. Travis, Mr. Watson and Mr. Wheldon. I have also to thank IDr. Rendle for his ready advice, my colleagnes in the Cryptogamic herbarium, Mr. A. Gepp and Mr. J. Ramsbottom, for their unfailing assistance in all doubtful points, and Mr. P. Highley for his careful drawings.

The metric system has been used for measurement; the (ireek letter $\mu$ indicates the one-thousandth part of a millimeter. () ther abbreviations refer to chemical reagents: + signifies a colour-reaction, $\mathrm{f}+\mathrm{a}$ faint reaction, - no reaction. Iodine solution-(I), iodine 1 grain, potassium iodide 3 grains, water ${ }_{2}^{0} \mathrm{oz}$, is used as a test for starch or glycogen ; potassium hydrate $(\mathrm{K})$,-equal parts of caustic potash and water; calcium hypochlorite or bleaching-powder $(\mathrm{CaCl}), 1$ part in half its weight of water' mol nitric acid $\left(\mathrm{NO}_{3}\right)$, indicate by colour-reactions the presence of lichen-icids in the thallus. $K+$ yellow indicates a general yellow reaction; $K$ rellow, a reaction in the uper portion or cortex. $\mathrm{K}$ followed by $\mathrm{C}_{\mathrm{a}} \mathrm{Cl}$ frequently gives a reaction and is expressed thus:- $\mathrm{K}(\mathrm{CaCl})+$ yellow. The meaning of these valrying reations is that the colour of the acids is liberated by the application of an alkali alome, ly bleaching-powcler alone or after previous treatment with an alkali. Reactions camnot always be relied on, ats the production of acids may have been inhibited by absence of light, etc. 


\section{NOTE TO STUDEN'TS}

To the Lidhen Floras recrmmenented to students in Part IT. should he added Harmand's "Liehens de France, Paris, 1905-13," still unfortunately incomplete, only five fascicles having heen issued. Various groups of lichens-Orders, frenera, retc-Dhave beon revised liy morlem lichenolugists, and the results, when truching on British Lichens, have been freely used. The following are the more important:-

ALxǫurst, S., MIonographia Arthoniarum Scaudinavia. K. Sveusk. Vet. Akad. Handl, xvii. n. 6. 69 pp. 1879.

Brandt, Theovor, Beitr. zur Anatom. Kenntn. Flechton-Gattung, Ramalina. Hedwigia xlv. pp. 124-58 (5 pls.). 1905-6.

Darbishire, O. V., Die deutschen Pertusariaceen, etc. Engler's Bot. Jahrb. xxii. pp. 593-671 (39 figs.). 1897.

Darbisinre, O. V., Monographia Roceelleorum. Stuttgart, 1898.

Forsselu, K. B. J., Beitr. Kenntn. Anat. Syst. Glaelichenen. Nov. Act. reg. Soc. Sci. Upsal. Ser, 3. 118 pp. 1885.

Fries, Th. MI., MIonographia Stereocaulorum et Pilophorum. Upsala. 76 pp. (1 pl.). 1858.

Grïcr, Hugo, Entwurf zu einer vergleicheuden Morphologie der Flechten-Spermogonien. Heidelberg, 1899.

Howe, Hener, A Manual of the gouns Usnea, otc. (North and Middle America). Bull. Torrey Bot. Club xxxvii. pp. 1-18 (7 pls.). 1910.

Howf, Hensr, Ameriean species of Alecturia, ete. Mycologia iii. pp. 10650 (7 pls.). 1911.

Hown, Hener, Classification de la Famille des Usuencere daus l'A mérique du Nord, etc. Paris, 1912.

Fluv, A., Lichenum generis Crocynia MIassal., otc. Mém. Soc. Sci. Nat. Math. Cherb. xxxvii. pp. 223-54 (3 figs.). 1909.

Hux, A., Lichenes Morphologice et Anatomice Disp. Genus xlviii, Aspicilia Massal. Nouv, Arch. Nus. Paris, Sér. 5, ii. pp. 1-120. 1910.

Hue, A., Causerie sur lo Lecanora subfusca. Bull. Soc. Bot. Fr. 1. pp. 22-86. 1903.

Lnsdan, Bouny In, Recherehes sur les Lichens des Envirous de Dunkerque. Dunkerque, 1910.

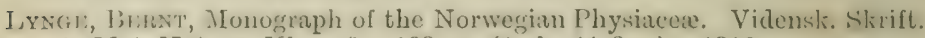
1. Mat.-Naturv. Kl. n. 8. 109 pp. (3 pls. 11 figs.). 1916.

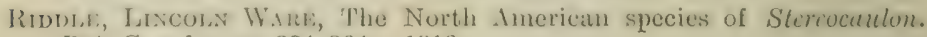
Bot. Ga\%. 1. pp. 281-301. 1910.

Rost:xintl, Finnmen, Vergleichend-intitomische Untersuchungeu äber die braunon Parmolion. Abh. IK. Leop.-Carol. Doutsch. Akad. Naturf. Ixxxvii. 11. 3. pp. 405-59 (4 pls.). 1907.

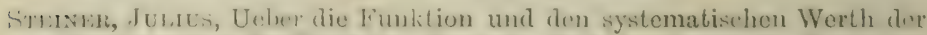

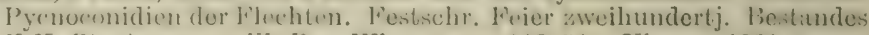
K.K. Staatsgymn. viii. Boz. Wiens. pp. 119-51. Vienma, 1901.

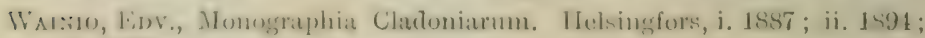
iii. 1897.

Zopw, W., Dio Flechtenstoffe. Joun, 1907. 


\section{CATALOGUE \\ OF \\ BRITISH LICHENS. \\ PART I.}

Stroctass ASCOLTCHENES.

Series I. GYMNOCARPEA.-Fruit a more or less open apothecium.

Series II. PYRENOCARPEA.-Fruit closed, a perithecium.

\section{SERIES I. G Y M N OCARPEÆ.}

Suloseries I. CONIOCARPINEA. - Apothecium partially closed, retaining the spores when mature in a powdery mass (mazædium).

Subseries II. CYCLOCARPINEA.-Apothecium with open disc ; spores ejected when mature.

Subseries III. GRAPHIDINEA-Apothecium with elongate narrow dise (lirella) or roundish (ardella); spores ejected when mature.

\section{Subseries I. CONIOCARPINE ZE.}

Thallus crustaceous (or wanting), or frutierse (fuliose in some

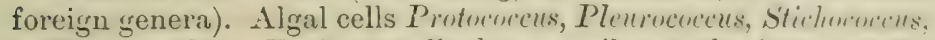
or Trentepolilia. Fruit a stalkerl or sessile apothecium, usually hyphal in origin, with a capitulum open or partially clused : asci usually cylindrical, dissolving eariy, so that the spores as they 
mature lie loose in the apothecium, like powcler or clust, formings a. mazædium.

The Coniocarpinese are distinguished from all other lichens by the peculiar form of the mature fruit. Some of the gencra and species are parasitic on other lichens; others have no recognizable thallus. such forms are closely connected with fungi and have been classified as such by some mycologists (see Rehm in Rabenhorst's Krypt. Fl. i. 3) (1887-96), p. 382). The British species have all been included among lichens. There are two British Natural Orders:-

Thallus crustaceous............... i. Caliciace...

Thallus foliose or fruticose....... ii. SPHærophorace..

\section{Order I. CALICIACE丑.}

Thallus effuse, thin, granular-crustaceous, often olsolete.

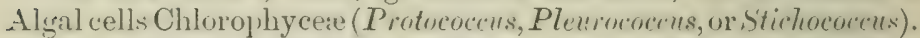
Fruit usually a stalked, top-shaped or slobose apothecium (capitulum), the stalk, when present, simple or sometimes lrancher, without gonicliar; asci rlissolving early, the spores forming a powdery mass (mazaclimm), mostly dark-coloured.

The Caliciacese, as here understood, include genera ant species with stalkerl and sessile apothecia. In most cases, the algal constituents of the thallus talie no part in fruit-formation; in one genus only (Cyphlimm), a thalline marrin is present in some of the species. The following genera are British :

Thallus wanting or doubtful, mostly parasitic on

Pertusaria.......................................... 1. Sphinctrina.

Thallus granular, crustaceous, sometimes obsolete.

Apothecia stalked.

Spores spherical, simple.

Spores dark in the mass....

2. Chænotheca.

Spores yellow in the mass............... 3. Coniocybe.

Spores oblong, septate, dark-colouxed.

Spores 1-septate......................... 4. Calicium.

Apothecia sessile.

Spores 3- or more-septate.............. 5. Stenocybe.

Spores oblong, septate.

Spores 1. or more-septate, darkcoloured

6. Cyphelium.

1. SPHINCTRINA Fr. Fyst. (Mrb. p. 120 (1825) (as a genus uf Fungi); De Not. in Gionn. lint. Ital. ii. p. 314 (1846). (Pl. 1.)

Thallus doubtful or nome proper. Aprothecia small, sloboseturbinate, sessile or shortly stallierl, somewhat shining, l, lack, with a thick commivent projer marein : asci subpersistent: spores lilack in the mass, simple (rarely l-septate), blackish. Finermogones immersed; spermatia long, acicular, bent.

The species of this genus are mostly parasitie on the thallus of l'retustrin or other lichens. 'The entire genus has been included by

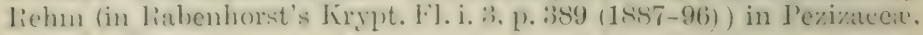
suborder Dermatencex. 
1. S. turbinata Fr. 1. c. cit Summ. Ver. p. 340 (18+9) (as a fungus); De Not. l. c.-Thallus wanting. Apothecia small, globose or somewhat tup-shaped, shortly stalked or almost sessile; spores protrurling in a mass from the narrowed disc, slobose or subglobose, small, $3-8 \mu$ in diam.; hymenial gelatine pale bluish then sordid dark-coloured with iodine.-Nyl. Syn. Lich. i. p. 142, t. 5, f. 1 ; Mudd Man. p. 255, t. 4, f. 102; Cromb. Lich. Brit. p. 11 ; Leight. Lich. Fl. p. 38 ; ed. 3, p. 38. Lichen gelasinatus With. Arr. ed. 3, iv. p. 8, t. 31, f. I (1796)? Calicinm turbinatum Pers. Tent. Disp. Meth. Fung. Suppl. p. 59 (1797). C. sessil, Pers. 1. c. ; Engl. Bot. t. 2520; Turn. it Bonr. Lich. Brit. p. 128; Hook. in Sm. Engl. Fl. v. p. 138. C stigonellum Ach. ILeth. p. \&8 (1803). Shlizerin splineterien Sowerb. Engl. Bot. iii. t. 386, fig. 1 (1<03). Aculinin stigonellum S. F. Gray Nit. Arr. i. p. $482(1821)$.

Exsicc. Leight. n. 132; IIudd n. 241. Carroll Lich. Hib. n. 26 ; Johns. n. 168 .

The apothecia are usually numerous on the host, though scarcely visible without a lens. The spermogones are scattered among the apothecia and are not infrequent with spermatia $12-15 \mu \times 1 \mu$. Lichen gelusimutus With. is somewhat doubtful, both in description and in figure.

Hab. Parasitic on the thallus of Pertusaria communis and sometimes of $P$. fallax, on the trunks of trees, chiefly oaks.-Distr. General and not uneommon in England and in S.. and Central Scotland, race in Ireland.-B. $M$. Rozel, Jersey; Guernsey; near Tithiel, Cornwall ; Ventnor, Isle of Wight; New Forest, Hants; Balcombe Hurst, Takiehurst, Damy, Henfield and St. Leonard's Forest, Sussex; Sibertswold, Tient; Shiere, Surrey; Great Totham and Gosfield Hall, Essex; Chedworth Woods and (Oakley Park, near Cirencester, Gloucestershire; near Worcester; Shrewsbury, Shropshire; Llanbrymmair, Montgomeryshire; Hay Wood, Hereforlshire; Leven's Park, Westmoreland; near Ayton, Clereland, Torkshire; New Galloway, Kircudbrightshire; Roseneath, Dumbartonshire; Pitfour, Carse of Gowrie, Perthshire; Blarney and Andrum, Cork; Curraghmore near Waterford; Glenstale, Tipperary.

2. S. tubæformis Massal. Mem. Lich. p. 15.), f. 190 (18.55); Jatta Syll. Lich. Ital. p. 477 (1900). -Thallus none. A pothecia minute, sessile or shortly stalked, globose or somewhat topshaped ; spores fusiform-ellipsoid, large, 11-16 $\mu$ long, $7-\delta \mu$ thick; hymenial relatine faintly bluish with iodine.-., mirrocrphala Nyl. in Act. Foc. Linn. Bord. sér. 3, i. p. 280 (1856); Cromb. Lich. Lrit. p. 11 \& Monogr. i. p. st; Leight. Lich. Fl.

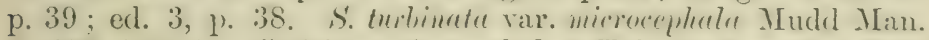

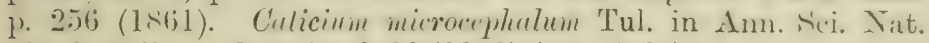
sér. 3, xvii. p. 78, t. 15, f. 20 (1852) (non Ach.).

Closely allied to the preceding but with rather smiller more scattered apothecia, and larger differently shaped spores. Ifahm

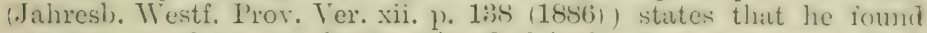
growing on the same f'ertusurin (I'. leinpluen) spermogones which 
he associates with this species. They hare short stout sterigmata and somewhat ellipoid spermatia measuring $1-5 \mu$ long, $\ddot{z}-4 \mu$ thick.

$\mathrm{Hab}$. Parasitic on the thallus of several species of corticolous Pertusaria (P'. meluteuen, $P$. fullar. P. Iciopluea and $P$. ITulfenii).Distr. Rare in the Channel Islands aud S. England, probably orerlooked elsewhere.-B. II. Near Brockenhurst, New Forest, Hants.

3. S. kylemoriensis Cromb. in Journ. Bot. xx. p. $27 t$ (1882). -Thallus none proper. Apothecia minute with a short pale slender stalk or almost sessile ; spores small, globose, dark-brown, 4-6 $\mu$ in diam.; hymenial selatine pale bluish and then sordid with iodine.-Culicium liylemoriense Larb. ex Leight. in Trans. Linn. Soc. ser. 2, i. p. 242, t. 33, ff. 12-14 (1878) \& Lich. Fl. ed. 3, p. 42 .

Differs from S. turbinatu in the smaller apothecia, the light stalk and in the habitat on saxicolous lichens.

$H a b$. Parasitic on the thalli of Lecanora parellu and of L.nitens on maritime rocks.-Distr. Local and rare in the Channel Islands and in W. Ireland.-B. MI. Island of Sark; Tiylemore, Comenara, Galway.

4. S. microcephala Kioerb. Parerg. Lich. p. 2xis (1861).Thallus (if proper) effuse, thin, granular, unequal, greyish-brown or olive-green, sometimes evanescent. Apothecia small, scattered, sessile or shortly stalked, globose or top-shaped, about $1 \mathrm{~mm}$. in height; spores slobose, $7-9 \mu$ in diam. or sometimes ellipsoid or oblong, 8-13 $\mu$ long, 6-9 $\mu$ thick; hymenial gelatine bluish with iodine.-S. angliea Nyl. Syn. Lich. i. p. 143, t. 5, f. 3 (1860): Mudd Man. p. 25.5; Carroll in Journ. Bot. iii. p. 287 (1 1865$)$; Cromb. Lich. Brit. 1. 11 ; Leight. Lich. Fl. p. 38; ed. 3, p. 38. Lirhen mirmerptlalus Sn. Engl. Bot. t. 1865) (1808). Culirimm micruceplerluin Ach. Syn. Lich. p. 57 (1814); Turn. \& Borr. Lich. Brit. 130; Hook. in Sm. Engl. Fl. v. p. 13s. Pluetimn (errore Plaretinem) microceplenlum S. F. Gray Nat. Arr. i. 1. 48.2 (18:1).

Rehm (tom. cit. p. 392) describes this species as parasitic on other Lichen crusts, growing on bark of pine trees as well as on rails. The British specimens are all on old rails, especially oak.

$I I a b$. On bark of pines, de., also on old rails, in shady situations. -Distr. ()nly sparingly in a few localities in S. and Central England. -B. M. Arlingly and Albourne, Sussex; Twyeross, Leicestershire; Caister, near Yarmouth, Norfolk.

2. CH ENOTHECA Th. Fr. Lich. Aret. 1. 250 (186i0). Culicinm Pers. in Tst. Ann. Bot. vii. p. 20 (1794); Cromb.

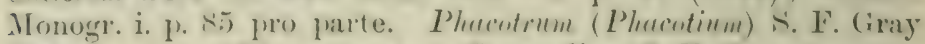
Nat. Arr. i. p. 482 pro parte. Stron! linm S. F. Gray tom. cit.

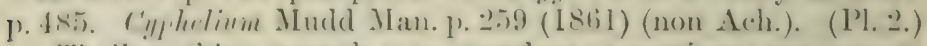

Thallus thin, granular or powdery, sometimes evanesient, rory ramly squanulose, or none fmoper. Apothecia stalked, the capitulun top-shaped or subghose, small, hlackish-brown, often 
finely powlered with a white-grey or yellow pruina: paraphyses slender, thread-like; spores uniseriate in the ascus, usually globose, one-celled, dark-coloured. Spermogones junctiform, black, with simple or sparingly branched sterigmata and short ellipsoid spermatia.

Distinguished by the dark-coloured simple spores which form a mazredium as in the other Coniocarpinex, and are often protruded in a dark mass. No gonidia take part in the formation of the fruiting body. The thallus is usually well-leveloped, though by some botanists it is considered to be distinct from the apothecia, the latter being described as fungi parasitic on various lichen thalli.

\section{Apothecia yellow-or yellowish-green-pruinose.}

1. Ch. chrysocephala Th. Fr. 1. c.-Thallus citrine or bright greenish-yellow, thickly granular, the granules rounderl, scattered or conglomerate. Apothecia scattered, black or blackish-brown, on a short slender stalk, the capitulum somewhat turbinatelentiform, citrine-juuinose at the margin; spores dark umberbrown, slobose, small, 3-6 $\mu$ in diameter.-Calicium chrysereplertum Ach. Meth. Suppl. p. 15 (1803); Engl. Bot. t. 2501: Hook. in Sm. Engl. Fl. r. p. 140 ; Cromb. Lich. Brit. 1) 11 it Monogr. i. p. 87 ; Leight. Lich. Fl. p. 39 ; ed. 3, p. 39. Lichen chrysocepthalus Turn. ex Ach. 1. c. \& in Trans. Linn. Soc. vii. p. S8, t. s, f. 1 (180t). Pharotrum (Ploceotimn) chrysocephlatum S. F. Gray Nat. Arr. i. 1) 484 (1521). Cyphelium chrysocerhalum De Not. in Giorn. Bot. Ital. ii. 1). 318 (18+6); Mudd Man. 1. 261.

Exsicc. Nudd n. 251 ; Leight. n. 134.

Easily recognized by the greenish-yellow thallus and by the bright Jellow pruina on the margin and underside of the capitulum; the pruina disappears in old plants. The apothecia are move or less scattered, and the stalks are occasionally branched.

$H a b$. On bark of old trees and on worked wood in maritime and upland tracts.-Distr. Local and scarce in a few localities throughout Fingland; very rare in S. and Central Scotland, not recorded from Ireland.-B. II. Cadnam and Lrndhurst, New Forest, Hants; Hawl: hurst and Bolney, Sussex; Peashurst, Fent; Walthamstow, Fssex; Hatfield. near Worcester; Downton Castle, Herefordshire ; Hay P'ark, near Ludlow, Shropshire; Rosedale, Cleveland, Yorkshire.

Var. filaris Dalla Torre \& Sarnth. Flecht. Tirol, 1) j00 (1902).-Thallus somewhat scattered. Apothecia with more

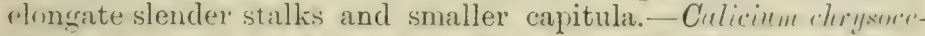
fluchum var. filuris Ach. Lich. Univ. p. 2:39) (1810) ; t. filur, Cromb. MLonogr. i. p. 88 (1894).

A seemingly distinct variety, though possibly, as Crombie surgests, the characters may be due to the habitat.

Hat. On the bark of old firs in moist upland situitions.-I)istr. Local and rare among the S. Gramyians, Scotland.-L. II. Aberfuldy and Ben Lawers, Perthshire. 
Var. melanocephala A. L. Su.-Thallus as in the species. Aprothecia fasciculately branched, pruinose only at the margin: spores globuse or ellipsoid, pale brown, $t-16 j \mu$ longe, $t-i$ ' $\mu$ thick.

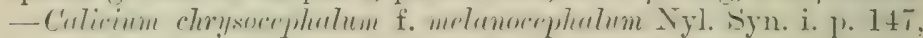
t. v. f. 19 (1860); Leight. Lich. Fl. p. 40 ; ed. 3, p. 39 ; Cromb. in Grevillea xv. p. 14 (1886) \& Monogr. i. p. 87.

Exsicc. Leight. n. 134 pro parte.

Differs from the species in the constantly tark epithecium, aml especially in the colour and form of the slores, which rary from being globose and small to considerably large and ellipsoid. I have been unable to verify this from Leighton's specimen.

$H a b$. On old palings (associated with the species). $-B . M$. Downton Castle, Herefordshire (the only locality).

2. Ch. trabinella A. I. Sn.-Thallus ashy-grey or olivebrown, thickish, granular, composed of winute congesterl sul)squamulose crenate granules. Apothecia small, the stalks rather short, slender, pale brown or blackish, the capitulum top-shapedlentiform, greenish-yellow-pruinose, the sporal mass dark-brown and some what plane ; spores minute, ghlobuse, :3-5 $\mu$ in cliameter.Ch. phrocephlala Th. Fr. Lich. Arct. p. 251 (1860); Lichen trubinellus sm. Ensl. Bot. t. 1540 (1 205$)$; L. phæoneplenlus Turn. in Trans. Linn. Soc. viii. p. 260, t. 6, f. I (1807). Calirimn fheorephalum Turn. \& Borr. Lich. Brit. p. 14.) (18:39) ; Hook. in sm. Engl. Fl. p. 140 ; Cromb. Lich. Brit. p. 11 \& IIonogr. i. p. is: Leight. Lich. Fl. p. 40 ; ed. 3, p. 39. Phacotrum (Phacotium) trabinellum S. F. Gray Nat. Arr. i. p. 484 (1821). Cypleelium

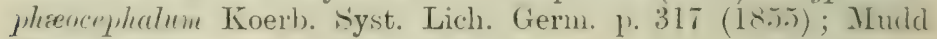
Man. p. 261.

Not to be confused with Calicium xylonellum var. trabinellum Wahlenh. ex Ach. Meth. p. 93 (180:3). The gramular squamulose thallus, by which the species is characterized, varies in thickness and colour, accorling to the habitat. The British forms are typical, though the plant varies in other comtries. The aputhecia are numerous, and almost sessile on thicker thalli.

$\mathrm{Hab}$. On old boarded buildings, rarely on palings in wooded district. -D istr. Local and scaree in S.F. and W. England.-D, M. Albourne. Hurstpierpoint and Woolmancote, Sussex: ILay Park near Innlow, Shropshire; Jiruisyart. Suftolk; Lakenhan near Norwich, Norfolk.

3. Ch. acicularis Zwackh in Flora xlv. p. 535 (1862).Thallus sreyish, rery thin, powelery, smetimes obsulete. Apothecia numerous, minute with a short slender dark-inrown stalk, the eapitulun somewhat narrow, top-shaperl, and obenical, more

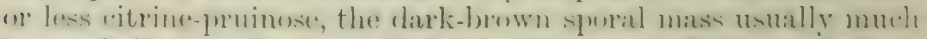

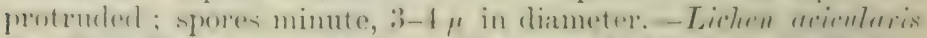

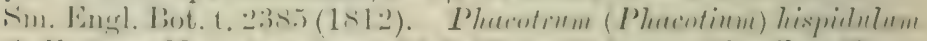

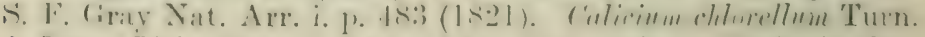
\& Borr. Lich. Brit. p. 146 (1839) (non Ach.); Hook. in Sm. 
Engl. Fl. v. p. 1t0. C. arivhlare Fr. Summ. Teg. p. 11! (1846); Leight. Lich. Fl. 1. 40; ed. 3, p. 40 ; Cromb. Monogr. i. 1. S8.

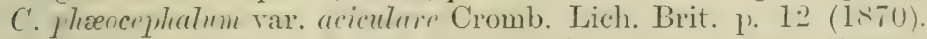

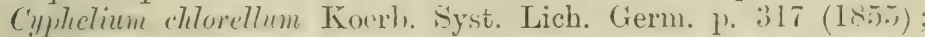
Mudd Man. p. 262.

Exsice. Leight. n. 170 ; Mudd n. 252 ; Larb. Lich. Hib. n. 81 ; Bohl. n. 98

Allied to the preceding, but cliftering in the thin powdery thallus, the longer and narrower head, and the frequent protrusion of the sporal mass by which the citrine pruina is pushed to the margin.

$\mathrm{Hab}$. On trunks of old trees.-Distr. Very local and scarce in S.E. and N.IV. England, not recorded for Scotland or Ireland.B. M. New Forest, Hants; Danny and Bolney, Sussex; Boxley, Tient; Wheatfield Park, Oxfordshire; liempsey, Worcestershire; Bury, Suffolk; Brantsdale and Bousdale Gill, Yorkshire; Lerens Park, Westmoreland.

\section{Apothecia whitish-or greyish-pruinose.}

4. Ch. trichialis Th. Fr. Lich. Aret. p. 251 (1860).--Thallus thinnish, granular-squamulose, greyish-yellow or greyish-glaucousgreen. Apothecia small, scattered or crowded, with a slender black stalk, the capitulum globose-lenticular, black, greyishIruinose, at length naked; spores small, $2 \cdot 5-4 \cdot 5 \mu$ in diameter.Culicium trichiale Ach. Lich. Univ. p. 243 (1810); Cromb. Lich. Brit. p. 12 \& Monogr. i. p. 85 ; Leight. Lich. Fl. p. 41 ; ed. 3, p. 40. C. æruginosum var. coerulescens Turn. \& Borr. Lich. Brit. p. 156 (1839); Hook. in Sm. Engl. Fl. p. 1tl. Cyphelium trichale De Not. in Giorn. Bot. Ital. ii. p. 318 (1St6); Mudd Man. p. 259.

Crombie placed this species in the subgenus Allodium $\mathrm{Nyl}$. (Flora lxiii. p. 392), on account of the cylindrical shortly septate alga (Stichococcus), a growth form only, which forms the gonidia. The scale-like granules are scattered and minute, or crowded, and then somewhat larger.

Hab. On the trunk of old trees and on old palings (fir) in sharly regions.-Distr. Rare in S. and N. England, S. Scotland and S. IV. Ireland.-B. M. Menstrie, New Forest, Hants; Church Stretton, Shropshire; Ingleby Park, Cleveland, Yorkshire; Bimnie Woods, Haddingtonshire; Tervoe, Limerick.

Sulssp. cinerea A. L. Sim.-Thallus finely granular, greyish or whitish. Apothecia with the stalk often brownish and partly greyish-puinose, the capitulum greyish or whitish pruinose beneath; spores 3-5) $\mu$ in diameter.-Calicium rineremm I'ers. Tcones, p. 58, t. 14, ff. 4 \& 5 (1798-1800). C. tricliale var. cinerentu Carroll in Journ. Jiot. is. 1). 22 (1s(i6) : Tecight. Lich. Fi. p. 41 : erl. :3, 1) 40 ; subsp. rinerenu Nyl. ex Vorrl. in Mexlil. Siillsk. Faun. \& Fl. Fenn. i. 1. 10 (15i6); Cromb. Munogl. i. p. 86 . 
Diflers from the species in the full granulations of the thallus and in the browner partly pruinose stalks.

Hat). On the bark of old oaks in wooded tracts.-Distr. S. Ireland. - B. M. Deer Park, Castlemartyr, Cork; Terroe, near Limerick.

5. Ch. æruginosa A. L. Sm.-Thallus thinnish, powclery, @reyish-glaucous or greenish-yellow. A pothecia black or brownishblack, the stalk varying in length, clark-brown, the capitulum srey-pruinose beneath or nearly naked; sporal mass umber or reddish-brown; spores small, $2 \cdot 5-4 \cdot 5 \mu$ in diameter-Culicium aruginosum Sm. Engl. Bot. t. 2502 (1813); Tum. \& Borr. Lich. Brit. 1. 156. Plareotrum (Plucotimu) ærunginssum S. F. Gray Niat. Arr. i. p. $48 t$ (1521). Culicium triviule var. stemoneum Ach. Lich. Univ. p. 243 (1810); Cromb. Lich. Brit. p. 12 ; Leight. Lich. Fl. p. 41 ; ed. 3 , p. 40 ; subsp. stemoneum Nyl. ex Norrl. in Nedd. Sällsk. Faun. \& Fl. Fenn. i. p. $10(1876)$;

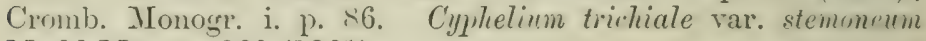
Mudd Man. p. 260 (1861).

Exsice. Leight. n. 227; Mudd n. 248.

Closely allied to the preceding, differing chiefly in the finely powdered greener thallus.

Hab. On the branches of old trees, stumps, and palings in shady situations.-Distr. Local and scarce in S.IV. and N. England.B. M. Lymdhurst, New Forest, Hants ; Danny and Cuclifield, Sussex; Hadleigh, Essex; Leith Hill, Surrey; near Henwich, Worcestershire; Brantsdale and Bousdale Gill, Yorkshire.

6. Ch. brunneola Muell. Arg. in Mem. Soc. Phys. Mist. Nat. Genive xvi. 2, p. :360 (1862).-Thallus effuse, very thin, occurring in spots, sreenish-or greyish-white $(\mathbf{K}+$ rerl), often evanescent. A pothecia small, numerous, the stalk slender, elongate, clarklrwwn or l, lackish, the capitulum small, globose-lenticular, brwwn; spores $2 \cdot 5-4 \mu$ in diameter, the sporal mass redelish-brown or ferrusginous. Calicium lrunmolum Ach. in Tet. Acarl. Handl. 1816 , p. 279, t. 8, f. 12. C. trichicle var. Urunneolum Cromb. Lich. lirit. 1). 1: (1870); Leight. Lich. Fl. p. 4:2: ed. :3, p. 41.

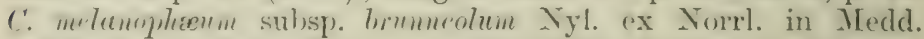
Siallsk. Faun. it Fl. Fenn. i. p. 10 (1STij); Cromb) in (irevillea

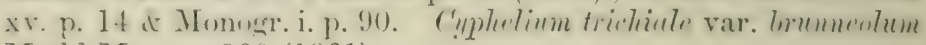
Mudd Man. p. 260 (1861).

Exsicc. Leight. n. 252 ; Mudd n. 250.

Allied to the preceding, but differing in the character of the thallus, which is often entirely evamescent, and in the more slemier apothecia.

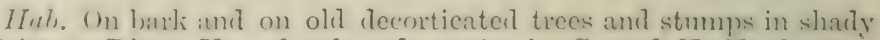
districts.-Distr. Very local and scarce in S. and N. England.-

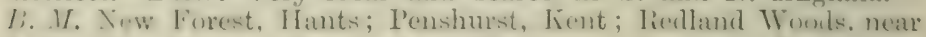

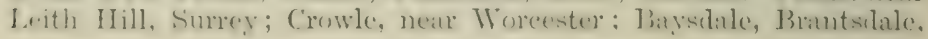


near Stokesley, and Ingleby Park, Cleveland, Yorkshire; Hexham, Northumberland.

Var. elassosporum A. L. Sm.-Thallus thimnish, glaucous or grlaucous-greenish, or almost obsolete. Aputhecia numerous, similar to the species; spores minute, $2 \cdot 5 \mu$ in diameter or even smaller, the sporal mass umbrose.-Calicium elussosporum Nyl. in Flora lviii. p. 441 (1875); Cromb. in Grevillea iv. p. 180 (1876) \& Monogr. i. p. 90 ; Leight. Lich. Fl. ed. 3, p. 41.

Exsicc. Cromb. n. 111.

Differs from the species in the scantier thallus and in the smaller spores. Nylander states also that the gonidia are smaller, a character difficult to be sure of in specimens with very scanty thallus. The apothecial stalks are sometimes branched.

Hab. On decorticated trunks of elders in mountainous districts. $-B . M$. Glen Lochay, Perthshire (the only locality).

\section{Apothecia not pruinose.}

7. Ch. melanophæa Zwackh in Flora xlv. 1). 535 (1862).Thallus thickish, granular, greenish, whitish or cream-coloured $(\mathrm{K}+\mathrm{red})$, sometimes nearly obsolete. Apothecia scattered, the stalk short and stoutish, or long (up to $2 \cdot 5 \mathrm{~mm}$. and more), slender, black, the capitulum top-shaped, black; sporal mass occasionally protruded ; spores spherical, $2 \cdot 5-8 \mu$ in diameter.Calicium melanopharum Ach. in Vet. Acad. Handl. 1816, p. 276, t. 8 , f. 8 ; Cromb. Lich. Brit. p. 12 \& MLonosr. i. p. 89 ; Leight. Lich. Fl. p. 42 ; ed. 3, p. 41. Cyphelinm melunophrom Nudd Man. p. 259 (1861).

Exsicc. Leight. n. 315.

The thallus somewhat resembles that of Ch. trichialis, but has more rounded granules. The apothecia are irregularly scatterei and rather rare in British specimens.

Hab. On the trunks of old firs and decorticated oaks, rarely on decaying posts in wooderl tracts.-Distr. Local and scarce in S.E. and N. England and in Central Scotland.-B. .Y. Ardingly, Sussex; Epping Forest, Essex; Oakley Park and Hailey Wood, near Cirencester, Gloucestershire; Shropshire; Lounsdale. Cleveland, Yorlsshire; Eglestone, Durhan; New Galloway, Kirreudbrightshire; Braes of Doune, Blairdrummond, and Aberfeldy, Perthshire.

Var. ferruginea A. L. Sm.-Thallus crowded, granular or nearly powdery and often sprinked with irregular rusty spots. Apothecia almost sessile, the stalk immersed in the thallus, the capitulum rather large; spores $4-11 \mu$ in cliameter.-Cólicium

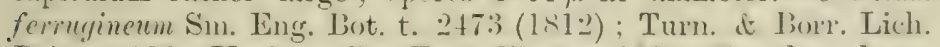
Brit. p. 136; Hook. in Sm. Engl. Fl. v. 1. 139. (' melumoplaxum var. ferngineum Schær. Enum. p. 172 (1850); Cromb. in Grevillea xv. p. 14 \& Monogr. i. p. 89. C. trichiale var. frrmenimeum Cromb. Lich. Lirit. p. 1: $(1 \leqslant 70)$; Leight. Lich. Fl. p. 41 ; ed. 3, p. 41 . Phacotrum (Placotium) ferrugineum S. F. 
Gray Nat. Arr. i. p. 484 (1821). Cyphelium trichiale var. ferrugineum Mudd Man. p. 260, t. 4, f. 106 (1861).

Exsice. Johns. n. 45 ; Mudd n. 249.

Difiers from the species in the charucter of the thallus and in the subsessile apothecia. It is often sterile, but when fertile the apothecia are numcrous, and sometimes two or more become confluent.

Hal. On old palings, rarely on decorticated oaks in shady lowland and upland tracts.-Distr. I'retty general, and common where it occurs, throughout England, chiefly in the south.-B. M. Horsham. Sussex; near Reignte, and Redland Toods, neir Dorking. Surrer; near Millhill, Middlesex; Hadleigh Wool, Damburr, Gostield Hall, and Walthamstow, Lssex; Oakley Park, Cirencester, Gloucestershire; Gopsall Wood and Twreross, Leicestershire; Pachington Parti and Bagley Park, Torcestershire; Moor Park and Har Park, near Ludlow, Shropshire; Suffolk; Framlingham. near Norwich. Norfolk; Brantsdale and Hoggints Trood, Ingleby, Cleveland, Yorkshire.

3. CONIOCYBE Ach. in Tet. Acarl. Hanrll. 1:16, 1. 2-3 ; emend. Tyl. in MIém. Soc. Sci. Nat. Cher\%. iii. p. 168 (1S.5.). (Pl. :3.)

Thallus effuse, thin, crustaceous or pulverulent or almost obsolete. Apothecia usually with a rather long slender stalk. the capitulum globose, pulverulent with the protruded sporal mass; paraphyses slender; spores spherical, simple, colourless. yellowish or pale-brownish. Spermogones with simple sterigmatil and oblong or ellipsoid spermatia.

The genus is characterized by the pale. or brightly-coloured apothecia and spores.

1. C. furfuracea Ach. in Vet. Acad. Handl. 1\$16, 1. 2-8s.-Thallus powderv, julverulent, yellowish-green or sulphur-culumed. Apothecia small or moderate in size, similar in colour to the thallus or rarely greyish-pruinose; the stalk elongate, slender, pulverulent: capitulum globose, the sporal miss yellow or pale brownish; parablyses becoming branched, spores colourless w pale yellow, minute, $2 \cdot 5-3 \mu$ in diameter.- Mudel Man. p. 26.9, t. t. f. 108 (excl. var. sulplemrella) : Cromb. Lich. Brit. p. 14 (excl. var. sulfulurella) ; Leight. Lich. Fl. p. 46 ; ed. 8, 1. t.j. IInre furfurarems L. Sp). Pl. exl. 2, p. 16.5) (176:3). Cluthrus

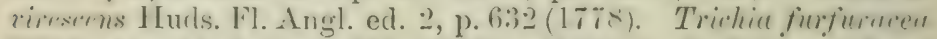

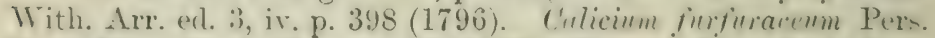
Tont. D)isp. Meth. Fung. p. 60 (17!7): Tum. diorr. Lich. Brit. 1. 1.59; Honk. in Sin. Engl. Fl. v. p. 14:. C. capitellatum Ach.

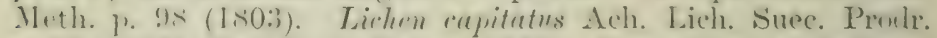

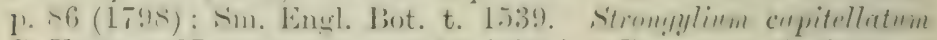
S. F. Gray Nat. Arr. i. p. 485 (1821). Bromyces furfuraceus Iayl. in Mackay li. Hib. ii. p. 78 (1836).

Exsicc. Bohl. 12. 62; Cromb. 11. 10 ; Johns. 1. 207; Leight. ก. $2 \cdot 25$. 
The thallus is more or less eftuse, and frequently infertile. The apothecia, when present, are numerous, and scattered or crowled; the stalks long and more or less flexuose.

Hab. On the roots of decayed trees and on dead twigs, occisionally on the ground and on decaved mosses, rarely on rocks in sharly places.-Distr. General throughout England, rave in Wales, in S. and Central Scotland, and in E. Ireland.-B. M. Near Shanlilin, I. of Wight; Irndhurst, and near Meustrie, New Forest, and Blackwater, Hants; Esher, Surrer; Langford, near Shalford Common, and Walthamstow, Essex; I3ury, Suffolk; near Alfrick, Malvern Wells, and Little Ialvern, Worcestershire; Oswestry and Church Stretton, Shropshire; near Bamouth. Merionethshire; Forden, Montgomeryshire; Peel, I. of Man; South Wiugfield, Derbyshire; Jiantsilale, Yorkshire; Bassenthwate Lake, Cumberland; near Gateshead, Durham; Calderbank, near Glasgow; Falls of Moness, near Aluerfeldy, and Blair Athole, Perthshire.

Form fulva Fr. Lich. Eur. p. 382 (18:31). - Stulk short and rather stout; capitulum hemispherical; otherwise similar to the species.-Mudd Man. p. - $6 \stackrel{-2}{-}$; Cromb. in Grevillea xr. p. 14. Tar. fulen Schar. Enum. p. 17:) (1850); Leight. Lich. Fl. ed. 3, p. 100. Mucor fulvus L. Sp. Pl. ed. 2, p. 1658 (1763).

Only a form of the species; transition states have been observed on the same specimen.

Hab. On dead stems and mosses on walls, and on the ground in upland tracts.-Distr. Somewhat rare in IV. England and Central Scotland.-B. M. Garryside, Blair Athole, Perthshire.

2. C. sulphurea Nyl. ex Cromb. in Grevillea xv. p. 14 (1886).-CThallus effuse, powdery, very thin, greyish or greyishwhite, often obsolete. Apothecia small, sulphur-pulverulent; stalk short and slender; capitulum minute, globose, the sporal mass sulphur-yellow; spores minute, $2 \cdot 5-3 \mu$ in diameter.- $C$. fufuracer t. smlphurella Fr. Lich. Eur. p. 382 (1831); Mudd Man. p. 262 ; var. snlplenrellu Schare. Fnum. p. 175 (1850); Cromb. Lich. Brit. 1) 14 ; Leight. Lich. Fl. 1. 47; ed. 3, 1. 46. Lichen sulphurens Retz. in Tet. Acarl. Handl. 1769, p. 219.

Differs from the preceding in the more scanty. lighter-colouren thallus, and in the brightly-coloured apothecia.

Hab. On decaving trumls of old oalis in wooded upland tract:. -B. M. New Forest, Hants; Brantsdale, Yorkshire; Teesdale, Durham.

2. C. pallida Fr. Sicherl. Crit. i. 1) :3 (18:4).-. Thallus very thin, powdery, white, often olsolete. Apothecia small: stallmorlerate in size, stoutish, whitish or yellow, rarely lowwish above; capitulum slobose or hemispherical, the sporal mass white or pale-lnxwish ; spores rather large, $4-10 \mu$ in diameter.Murld Man. 1. „21;-; Cromb. Lich. Brit. p. 14: Jeight. Lich. Fl. p. 47 ; ed. 3, p. 46. Calicium pallidum Pers. in Ust. Ann. Bot. vii. 1. 20, t. 3, tigs. 1-: (1794). ('. nerom llmm Ach. Meth. 
p. 96 (180:3); Winch Bot. Guide ii. p. 42 ; Turn. \& Borr. Lich. Brit. 1. 158; Hook. in Sm. Engl. Fl. v. p. $1+1$. C. cantherellum Ach. Lich. Suec. Prodr. p. 85 (1798); Engl. Bot. t. 2557. Phacotrum (Placotium) contherellum S. F. Gray Nat. Arr. i. p. 484 (1821).

Similar to C. sulphurea in the colour of the thallus, but differing in the apothecia, which are very pale yellow, often with a tinge of cinnamon on the upper side of the capitulum.

Hab. On stumps and trunks of old decayed trees in shady places. -Distr. Very rare in Central and N. England, probably overlooked elsewhere.-B. M. IIundon, Essex; Teesdale, Durham; near Hexham, Northumberland.

4. C. hyalinella Nyl. in Act. Soc. Linn. Bord. sér. 3, i. p. 279 (1856-8).-Thallus obsolete. Apothecia small; stalk slender, whitish, brownish above; capitulum globose, the sporal mass white or pale-reddish ; spores minute, $2 \cdot 5-4 \mu$ in cliameter.Cromb. Lich. Brit. p. 14 ; Leight. Lich. Fl. p. 47 ; ed. 3, p. 46.

Closely allied to C. pallida, but differing in the smaller apothecia and spores. Occasionally there are doubtful traces of a thin whitish thallus.

Hal. On decayed trunks of trees. $-\mathcal{B} . M$. Brantsidale, Yorkshire.

4. CALICIUM Pers. in Ust. Ann. Bot. vii. p. 20 (1794); emend. De Not. in Giom. Bot. Ital. ii. p. 309 (1846). Placotmin (errore Placotium) S. F. Gray Nat. Arr. i. p. 482 rro parte. Strongylium S. F. Gray tom. cit. p. 485 pro parte. (Pl. 4.)

Thallus thin, granular or pulverulent, rarely squamuluse, sometimes obsolete or none proper. Apothecia stalkerl, the capitulum top-shaped or subglobose, blackish-brown, often finely powlered with a white, yellow or reddish pruina; paraphyses slencler; spores elongate or ovate, 1-septate, dark-coloured. Spermogones similar to those of Chrenotheca.

Similar in ontward appearance to Chanotheca, differing chictly in the spore characters. Some of the species have been classified hy Continental botanists as fungi.

\section{Capitulum yellow-pruinose.}

1. C. arenarium Nyl. ex Lamy in Jiull. Aoc. Bot. Fr, xxy. 1. :3t5) (1ミ75). - Thallus none proper. Apothecia congregate or scattered, rather small, the stalk stoutish, clongate, rusty-brown, semetimes with a yellowish pruina: apitulum globose-lentiform; spores whons, hecoming 1-septate. rarely with a slight constriction in the mirldle, pale-brown, (i-11 $\mu$ lome, $2 \cdot 5-3 \cdot 5 \mu$ thick, fanaphyses slender, scanty.-Cromb) in (irevillen xv. p. 14 (1s,66).

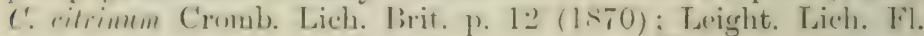
p. 45 ; ed. 3, p. 44. Cipphelium arenarium Hampe ex Massal. 
Misc. Lich. p. 50 (1856). Coniurybe citrina Leight. in Ann. Mag. Nat. Hist. ser. 2, xix. p. 130, t. 8, figs. 7-9 (1857).

Exsicc. Leight. n. 269.

Somewhat resembling Coniocybe furfuracea in the general appear. ance of the fructification. It grows frequently in shady places, where the spores do not develop fully.

Hab. Parasitic on the powdery yellowish-green thallus of Lecinted lucida, a saxicolous lichen.-Distr. Rather local and scarce in Wales, N. England, and the Central Highlands, Scotland, $-B$. M. Crossfaen, Mommouthshire; Llanymawddy, Llandyssil, near Bala, and between Bala and Corwen, Merioneth; Dent, Yorkshire; Glen Fender, Blair Athole, Perthshire.

2. C. roscidum Floerke Deutsche Lich. 3, p. 1 (1815); Nyl. Syn. Lich. i. p. $153(1 \& 60)$.-Thallus ashy-grey, thin or almost obsolete. Apothecia moderate in size, blackish; stalk black, rather short and stout; capitulum lentiform, the margin or the entire head greenish-yellow-pruinose; spores brown or blackish, fusiform-ellipsoid, 1-septate, slightly constricted at the septum, brownish or blackish, 9-18 $\mu$ long, $4-8 \mu$ thick.-Mart. ex A. L. Sm. Monogr. ii. p. 351 . C. Jiyperellum var. roscidum Ach. Lich. Univ. p. 238 (1810).

Easily distinguished by the colour of the pruina and by the spore characters.

Hab. On oak bark.-Distr. Rare in N. England.-B. M. Ingleby, Cleveland, Yorkshire; Lowther Park, Westmoreland.

\section{Capitulum reddish-pruinose.}

3. C. hyperellum Ach. Meth. p. 93 (1803).-Thallus granular or pulverulent, bright greenish-yellow. Apothecia black, moderate in size with an elongate firm stalk; the capitulum globose-lentiform, reddish beneath; spores ellipsoid or slightly narrower at each end, 1-septate, dark-brown or blackish in the mass, 9-16 $\mu$ long, 4-6 $\mu$ thick.-Hook. in Sm. Engl. Fl. $\mathrm{r}$. p. 139 ; Tayl. in Mackay Fl. Hib. ii. 1. 77 ; Turn. \& Borr. Lich. Brit. p. 140; Mudd Man. p. 258, t. 4, fig. 105; Cromb, Lich. Brit. p. 12 ; Leight. Lich. Fl. p. 42 ; ed. 3, p. 42. Coralloides fungiforme arboreum nigrum, vix erustosum Dill. Hist. MIusc. p. 78, t. 14, tig. 33 B. (1740). Lichen hyperellus Ach. Lich. Suec. Prodr. p. 85 (1798); Engl. Bot. t. 183:. Phacotrum (Phacotium) hyperellum S. F. Gray Nat. Arr. i. p. 483 (1821).

Exsicc. Bohl. n. 61; Johns. n. 8; Leight. n. 23 ; Mudd n. ‥4.

Resembling Chanotheca chrysocephala in the brightly-coloured thallus. It usually spreads over large areas, though also to be formit in small patehes. The apothecia are rather rarely developed, but, when present, they are numerous and prominent.

$H a b$. On the trunks of old trees, in wooded districts,-Distr. Pretty general and common in England, rare in Wrales, $S$. and Central Scotland, and in Irelimi.-B. I. . New Forest. IIants; 
Hurstpierpoint. Woodmancote, St. Leonarl's Forest and Avgmering Park. Suscex; Penshurst Park. Kient; Epping Forest, Stanstearl, Mountfitehet Park. Gosfield Hall and Ulting. Essex; Stapleton and Sapperton. Gloucestershire; Hindlip. Worcestershire; I'aclington Park. Warwickshire; Bala, Merioneth ; Iuilth, Brecknockshire ; Hay Park, near Ludlow; and Almond I'ark, near Shrewsbury, Shropshire; Fettws-y-Coel, Carnarvonshire; Welshpool, Montromeryshire; Gopsall Park, Leicestershire ; Derbrshire ; Burr, Suffolk ; Earsham, Norfolk; Inglebr. Brantsdale and Fildale, Cleveland, Forkshire; Leven's I'urk. Viestmoreland; Catterlin, Cumberlimi ; Wark-on-Trne, Northumberland; Firkcomel, Springlell, Dumfriesshire; Glenlee, New Gialloway, Kirkculbrightshire; Falls of Clycle, Lanarkshire; Aberfeldy, Perthshire; Killarney, Kerry.

Form viride Cromb. in Grevillea xr. p. 14 (18R6) it Monogr. i. 1. 91.-. Thallus thin, pulverulent or somewhat grauular, grcenishyellow. Stalk of apothecium occasionally rery short, the apitulum often greenish-or greyish-pulverulent, black beneath. - Var. viride Nyl. Syn. i. p. 153 (1860). C. viride Pers. Ust. Ann. Bot. vii. p. 20 (1794).

I)istinguished from the species by the more pulverulent thallus and by the colour of the apothecium, a character not always constant. The stalk is sometimes very short, a condition referred to by Turner and Borrer in Lich. Brit. p. 142.

Hab. On trumks of old trees and on palings in wooded situations.Distr. Local and scarce in E.. \$. and TV. England and among the S. Grampians, Scotland.-J. M. New Forest, Hant.; Sapperton, Gloucestershire; Malvern, Worcestershire; Ichworth, Suftolli; Jien Lawers, Perthshire.

Form baliolum Croml). 11. c.-Apothecia larger, the stalk thicker and compressed at the hase.-C. Ualinlum Ach. IIth. p. 94, t. 2, fig. 4 (1803).

Differs from the species in the form of the stalk. In the only British specimen the apothecia are numerous and some are nearly sessile.

Hor). On old palings in wooded recrions.-13. M. Near I yndhurst, New Forest, Hants.

4. C. sphærocephalum Wahlent). Fl. Lapl. p. 4\$6 (1×1:2).-Thallus finely Eranular, very thin, sreysh-white or often (1) Molete. Ajothecia morlerite in size, usually numerous, scattered or crowderl, black, the stalk short and stout or elonerats? and slenrlicr, the capitulum tup-shapeal-glolose, redrlish heneath; sfores dark-colomerl, l-sejetate, slightly comstricted in the middle,

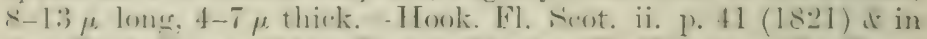

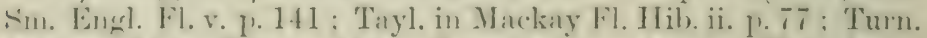

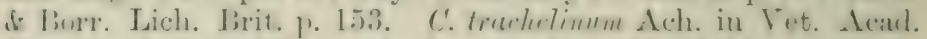
Handl. 1816, p. 272, t. 8, figs. 7 A d B ; Mudd Man. p. 258;

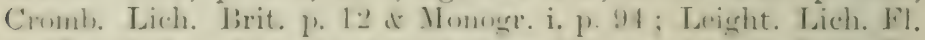
P. 43 ; ed. 3, p. 42 ; var hemiphodium Nyl. ox Leight. Lich. Fl. ed. 3, p. 43 (1579); form hemiplixum Ny]. ex Cromb. in 


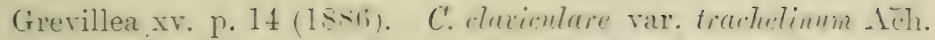

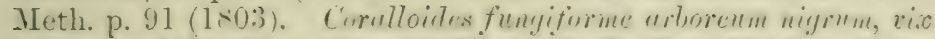

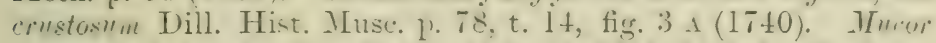

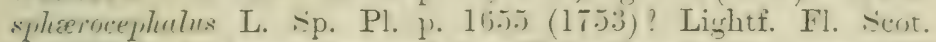

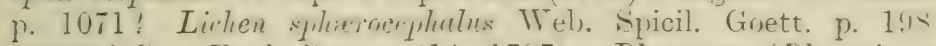
(1778)? Sun. Engl. bot. t. $11 \pm$ (1797). Phucotmm (Pharentium) sphærocephalum S. F. Gray Nat. Arr. i. p. 483 (1821).

Exsicc. Cromb. n. 112 pro parte; Leight. n. 270; Mudd n. 246 .

Tiesembles the pieceding in the redtish tinge of the apothecinm (visible under the microscope as minute red granule:-), but easily distinguisher by the difference in the thallus. As in other species it is often more or less suffused by a yellowish Lerrurin, which remains when the proper thallus has disiappeared. In form hrmipham (errore hemiplutium), the whole stull is more or less suffused with red, an unusual state. There has been much confusion over the identity of Mucor spharocephalus Linn., of which no specimen exists in the herbarium at the Linnean Society. Simith s specinen described in 1797 certainly represents this plant.

Hrb. On the trunks of old trees and on palings in maritine and upland clistricts.-Disti. Not very seneral nor common thronghont the British Isles.-B. M. New Forest, Hants; Lewes, Danny and Hentield, susiex; Clting. Thomdon Hall and Lea Brirlge Iioad, Essex; Chedworth Thoods, Gloucestershire; near Cricklade. Wiltshire; near Worcester; Pophills, Warmickshire; Earsham, Norfolk; Pen-y-law, near Oswestry, Shropshire; Ingleby Park and Fildale, Cleveland, Yorkshire ; Egglestone, Durham ; Leven's Park, Westmoreland; Ben Lawers and Den of Dupplin, I'erthshire; Mar Lodge, Braemar. Aberdeenshire; Castlehermard Park, Bandon, Cork.

Var. xylonellum A. L. Sm.--Thallus very thin. Apothecia with a blackish, usually more globose capitulum, the margin intlexed, sometimes browni-h. C'alivinm aylonellum Ach. Meth.

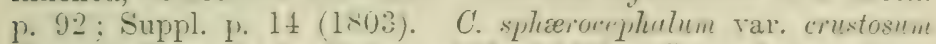
Turn. it Lorr. Lich. Brit. p. 15:3 (18:39). C. tincletinum va:. aylunellum Nyl. Syn. i. p. 15.j (1860): Cromb. Monogr. i. p. 95.

Hab. On old palings in wooded tracts.-Distr. Very local and scarce in E. and S. England and (firte Nyl. l. c.) in Ireland.-B. . Ir. Stoney Cross, New Forest, Hants; Penshurst, Tient; Bury st. Edmund's, Suffolk.

\section{Capitulum whitish-pruinose.}

5. C. quercinum Pers. Tent. Fung. p. 59 (1797).-Thallus thin, granular, julverulent or nearly smooth, greyish-white. or nearly evanescent. Alnthecia moderate in size, the stalle strutish, black, the eapitulum top-shapech-lentiform, at first white-pruiuose, then naked, beneath srey-pruinse; slores darkcoloured, small, 1-siptate, slightly constricted in the middle, 5-9 $\mu$ long, 3-5 $\mu$ thick. - Nyl. Syn. i. p. 155, t. 5. fig. 25; Muckl Man. 1) 2257: Cromb. Lich. Brit. 1) 1:3 (exch. subst. (urtum); Leight. Lich. Fl. p 43; ed. 3, p. 43. C. clavellum 
Turn. \& Borr. Lich. Brit. p. 138 (18:39); Hook. in Sm. Ensl. Fl. т. p. 139 ; C. racienlare Ach. Meth. p. 90 (1803). Lichen clecrllus Ach. Lich. Snec. Prodr. 1) \&:3 (1798); Engl. Bot. t. 1465). Phucutrum (Phacotiun) claciculare S. F. Gray Nat. Arr. i. p. 413 (1821).

Exsicc. Bohl. n. 95 ; Mudd n. 244.

Frequently the thallus is but little risible; but the species may always be recognized by the gres pruina on the under side of the capitulum. The apothecia are frequent, and the spermogones usually abundant and crowded.

Hab. On old palings and decayed trunks of trees.-Distr. Local and scarce throughout England and S. Scotland; not recorded for Treland.-B. M. Lyndhurst, New Forest, Hants; Hurst, Ardingly, Heathfield Park, Yapton and Henfield, Sussex; Hay Park, Ludlow, Shropshire; Birkland, Nottinghamshire ; Lakenham, Norfolk; Brantsdale and Baysdale, Cleveland, Yorkshire; Hexham, Northumberland ; Falls of Clyde, Lanarkshire.

Var. lenticulare Nyl. Syn. i. p. 156 (1860).-Thallus thin, granular-pulverulent, whitish, scarcely any, sometimes obsolete. Apothecia moderate in size, numerous, the stalk stoutish, black, the head dilated and rather flat or lens-shaped above, sometimes entirely naked; spores as in the species or narrower, about $5-9 \mu$ long, 3-4 $\mu$ thick.-Subsp. lentirulare Cromb. I.ich. Brit. p. 13. Calicium lenticulure Ach. in Tet. Acad. Handl. 1816, p. 262, t. 8 , fig. 4 .

Exsicc. Cromb. n. 112 pro parte; Johns. n. 9.

Distinguished from the species by the more lentiform head and less distinct pruina.

$H a b$. On old oak palings.-Dist. Local and scarce in S. and W. England and in N. Wales.-B. M. Near Bovey Tracey, S. Devon; Lewes, Sussex; Brockenhurst, New Forest, Hants; Balcombe and Shiere, Surrer; Barmouth, Merioneth ; Ennertale, Cumberland.

Subsp. curtiusculum Cromb. in Grevillea viii. p. $114(1880)$, emend.-Thallus effuse, granulate, whitish or greenish-yellow. Apothecia black, the stalk very short, the capitulum lentiform, white pruinose at the margin; spores $6-10 \mu$ long, $3 \cdot 5-4 \cdot 5 \mu$ thick. C. ourtiusculum Nyl. in Flora lxii. p. 360 (1879). C. quercinm var. lenticulure f. chlorerles Nyl. ex Cromb. in Grevillea xv. p. 14 (1886) and Monogr. i. p. 93.

Exsicc. Larb. Lich. Hb. n. 82.

Diflers from the species in the almost sessile apothecia. The form chlomes has similar apothecia with a somewhat brighter coloured thallus.

Ifab. On palings and bitk of old firs,-Distr. Found only sparingly

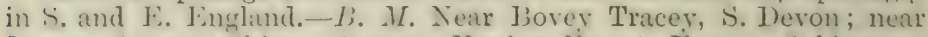
Lewes, Sussex; Shiere, Surrey; Epping Forest, Essex; Oakington, Cambridgeshire.

6. C. curtum 'Turn. it Borr. ex Sun. Eingl. lint. t. 250:3 (1:13)

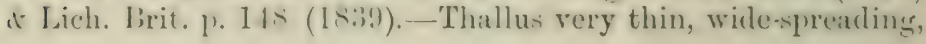


granulose, greyish, sometimes obsolete. Apothecia small, black, the stalk short and stoutish, the capituium somewhat top-shapedcylindrical, white-pruinose at the margin, with the sporal mass generally much protruded; spores ellipsoid, 1-septate, $7-1+\mu$ lone, $4-7 \mu$ thick; hymenial selatine frequently bluish with iodine.-Hook. in Sm. Engl. Fl. v. p. 140 ; Mudd Man. p. 25r; Leight. Lich. Fl. p. 44; ed. 3, p. 43. C. quercinum subsp. curtum Nyl. Syn. p. 156 (1860); Cromb. Lich. Brit. p. 13. Phacotrum (Phacotium) curtum S. F. Gray Nat. Arr. i. p. 485 (1821).

Exsicc. Bohl. n. 99 ; Cromb. n. 113 ; Johns. n. 169; Larb. Lich. Hb. nos. 83, 321; Leight. n. 133; Mudd n. 99.

Differs from the preceding in having the capitulum pruinoss at the margin only, and in the protruded sporal mass which gives the apothecium "a miniature resemblance to a painter's brush" (Turm. it Borr. l. c.). The apothecia vary considerably in size even on the same specimen; they are usually numerous and crowled. The prominent black spermogones are frequent and often congregate.

$H a b$. On old palings and decayed branches of trees, chiefly oals in woorled districts.-Distr. General and plentiful in most parts of Great Britain, but local and scarce in the Channel Islands and Ireland.-B. M. Guernsey; Lyndhurst, New Forest, Hants ; Bolney, Washington and Tilgate, Sussex: near Hythe, Kent; Shiere, Surrey; Braydon Forest, Wilts; Tetsworth, Oxfordshire; Gopsall Iark and Bradgate Park, Leicestershire; Hay Park, Herefordshire; Hatfield, near Worcester; Church Stretton, Oswestry and Stiperstones, Shropshire; Bala and Aberdorey, Merioneth; Walthamstow, Langford and Epping Forest, Essex; Bury, Suffolk; Middle Forest, Westmoreland ; near Ayton and Bousdale Gill, Clereland, Yorkshire; Teesdale. Durham; Wark-on-Tyne, Northumberland; New Galloway, Kirculbrightshire; Barcaldine and Glen Falloch, Argyll; Loch Rannoch, Txillin, Craig Calliach and Blair Athole, Perthshire; Countesswell's Wood, near Aberdeen; Castlemartyr, Cork.

\section{Capitulum not pruinose.}

7. C. pusillum Flserke Deutsche Lich. 10, p. 6 (1815)).Thallus in greyish or whitish spots or olssolete. Apothecia small, entirely black, the stalk slender; capitulum top-shaped, with a flat or convex dise; spores fusiform or clavate, 1-septate, sometimes slightly constricted in the middle, $5-10 \mu$ long, $2 \cdot 5-5 \mu$ thick.-Cromb. in Journ. Bot. xx. p. 272 (1882).

Tesembling a minute form of C.quercinum. In the few British specimens the thallus is obsolete and the apothecia are seattered.

Hab. On recorticated wool in woodel situations.-B. M. Castlemartyr, Cork.

8. C. debile Turn. iv IBorr. ex Sm. Engl. Pot. t. 2162 (1812) a Lich. Brit. 1. 1.)1.-Thallus very thin, areyish-white, or wanting. Apothecia small, scattered, the stalle shont and slemler, the capitulum lens shaped or somewhat top-shatied : sporial mats (ompact; spores fusiform ellipsist, nearly always simple, about 
7-11 $\mu$ long, 3-6 $\mu$ thick.-Hook. in Śm. Engl. Fl. v. p. 141. (. mimut.llum Ach. in Tet. Acaul. Handl. 1816, p. 118, t. 5. f. 2. C. printimm Ach. 1). cit. [). 260, t. s, t. 1, .1, s: Crumb. in

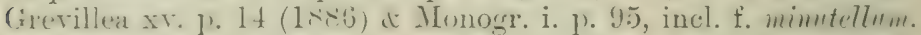
Var. minutellum Nyl. Syn. i. p. 159, 1860. C. subtile Pers. Tent. Disp. Meth. Funs. 1. (60 (1797)? Mudd Man. 1. ¿.s: Croml, Lich. Brit. 1. 1:3: Leight. Lich. Fl. p. 44: ed. 3, p. 14.

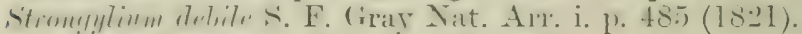

E.rsicc. Leight. n. 314 ; Mudd n. $24 \%$.

The species has a very doubtful or no recognizable gonidiacontaining thallus, and has been usually classified anong fungi by recent Continental botanists. It is retained here on account of its aftinity to lichen species. The spores arree in form with those of Culicium rather than with those of Chanotheca and are occasionally septate. Form minutellum has smaller apothecia which are some. times greyish-pruinose beneath.

Hab. On the trunks of decorticated dend trees and on old palings and timber.-Distr. Local and rave in S., Central and N. England,B. M. Henfield, Sussex; Lrndhurst, New Forest, Hants; Wheatfield Park, near Tetsworth, Oxfordshire (f. minutellum); Buysdale, Cleveland, Yorkshire.

9. C. populneum I) Brond. (x Duby Bot. Gall. ii. p. 638 (1 $\$ 30)$.- Thallus developed under the bark (hypophloodal) in pale or whitish spots. Apothecia minute, scattered, entirely hlack, somewhat shining, the stalk vory short and slender; capitulum top-shaped; spores blackish, 1-septate, 10-11 $\mu$ long, 5-6 $\mu$ thick.--Mudd Man. 1. 25), t. t, f. 10t; Leight. Lich. Fl. p. 45 ; ed. 3, p. 44 . C. curtum var. poputinum Turn. \& Borr. Lich. Brit. p. 149 (1839) ; Houk. in Sm. Engl. Fl. r. 1. 140. C. triste Korly. Syst. Lich. Germ. p. 30s (15.5) ? : Cromb. Lich. Brit. p. 13 (1870).

Distinguished from the preceding by the smooth shining thallus and by the larger spores.

Hall. On the smooth bark of poplars in wooled upland tracts.Dists. Fare in the S. Wr. Highlands of scotland and in S.W. Ireland. -B. M. Airds, Appin, Argyll; Killarney, Kerry.

10. C. diploellum Nyl. in Flora li, p. 161 (1868).-CThallus (if froper) efluse, very thin, sreyish-white. Apothecia minute, scattrerel, entirely black, the stalk very short; capitulum topshaperl open, the sproral masis scareely prominent: spores simple or at length 1 -septate, $6-9 \mu$ long, $: 3-1 \mu$ thick.-Carroll in Journ. but. vi. 1) 109 (186is): C'romb. Lich. lirit. p. 13; Leight. Lich. Fl. p. 39 ; ed. 3, p. 39.

The smallest of all the specics, and considered by Nylander as clu-ely allied to ('. risseminatum, a Continental species. The speedmen-in the herbatium of the britinh Musemm are rery imperfect.

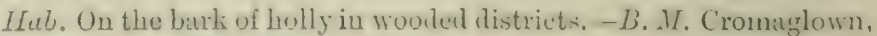
Fillarney, Kerry (the only locality). 
11. C. retinens Nyl. in Flora li. p. 161 (1868).-Thallu: effuse, then finely powdery, whitish. A pothecia minute, se-sile, black; sporal mass indistinct ; spores oblong or oblong-crlindrical, 1 -septate, $s-11 \mu$ long, $-2 \cdot 5-3 \cdot 5 \mu$ thick; hypothecium brownishred.-Leight. in Anu. Mag. Nat. Hist. ser. 4, i. p. 4s:- (186r) d Lich. Fl. p. 45; ed. 3, p. 44; Cromb. in Grevillea xr. p. 14. Specimen not seen.

Differs from other species of Calicium in the sessile apothecia an from species of Cyphetium in the absence of a thalline margin to the fruits. It has been collected only once.

Hab. On the trunk of an old oak, Jersey (the only locality).

5. STENOCYBE Nyl. in Bot. Not. 18.54, p. 84 (nomen); Koerb. Syst. Lich. Germ. p. 306 (1855). (Pl. 5.)

Thallus occurring in spots (macular), thin, often obsolete or none proper. Apothecia scattered, black, stalked, the capitulum top-shaped or clavate; paraphyses slender, thread-like, colourless; spores ellipsoid or fusiform, becoming 3-(or more-) septate, colourless, then brown, not massed in a mazedium.

The scanty or obsolete thallus and the absence of a mazædium furm of fruit render the position of the genus somewhat uncertain, and might justify its transference to the Class Fuxgr. Owing, how: ever, to its close resemblance to the other Caliciacer, it has been included here. The species are all somewhat inconspicuous.

1. S. major Nyl. in Bot. Not. 1854, p. 81; Koerb. Syst. Lich. Germ. p. 306 (1855).-Thallus scarcely any proper or very diffuse or obsolete. Apothecia sparsely scattered, very small; stalk slender; capitulum clavate; spores 3 -septate $(5-\bar{j}$-septate ficle Crombie), $18-36 \mu$ long, $7-11 \mu$ thick. -S. euspor ( Nyl. ex Cromb. in Journ. Bot. xx. p. 272 (1882) \& Monogr. i. p. 97, fig. 2.). Caliciun ensporum Nyl. in Bull. Soc. Bot. Fr. xr. p. 549 (1856); Carroll in Journ. Bot. iii. p. 287 (1865) pro parte.

Has been confused with the following species, $S$. septuta, which has very large spores. The specimens in the herbarium of the British Museum are too scanty to admit of examination.

$H a b$. On old stumps of holly in upland situations.-B. $M$. Mangerton, Kerry.

2. S. septata Rehm in Rabenhorst's Krypt.-Fl. i. 3, p. 414 (1891).- Thallus effuse, and very thin or obsolete, or none proper. Apothecia small; stalk short and stoutish or slender and more elongate ; capitulum elavate-truncate with the marwin of the dise inflexed; paraphyses slender, crowderl, spores ellipsoirl, 3 -septate, umber-brown, large, 44-70 $\mu$ long, 14-20 $\mu$ thick. S. ensporum Mudd Man. p. 256, t. 4, fig. 103 (1861) (non Nyl.). S. trajerta Nyl. ex Cromb. in Journ. Bot. xx. p. 272 (158.) di Monogr. i. p. 97. Sphinetrina septatu Leight. in Ann. MIas. Nat. Hist. ser. 2, xix. p. 132, t. 8, figs. 20-4 (1857). Calirinm tru. 
juctum Nyl. in Flora xlviii. p. 211 (1865); Carroll in .Journ. Bont. iii. p. 287 (1 65) pro parte; Cromb. Lich. Brit. 1. 13 ; Leight. Lich. Fl. p. 46. C. ensprom Cromb. Lich. Brit. p. 13 (1.).0) (non Nyl.). C. septatum Leight. Lich. Fl. p. 45 ; ed. 3, p. 45.

Exsice. Leight. n. 228 ; Mudd n. 242.

The thallus is so thin as to be scarcely distinguishable from the hark on which it grows, or there is none proper. The apothecia are sometimes 2-3 congregate, with the stalks varying in length up to $6 \mathrm{~mm}$., and, when long, becoming branched.

Hat7. On the bark of holly, and also parasitic on the thallus of Thelritremu trutimum and Graphis elegans in upland rooded districts.-Distr. Common, where it occurs, in S. and X. England and in S. and W. Ireland.-B. M. Near Lrndhurst, New Forest, Hants: Sheffiell Park and nenr Withyham. Sussex; Ingleby I'ark and Ioustale Gill. Cleveland, Iorkshire; Glenbower Trood and Castlemartyr, Cork; Tore MIt., Tillarney, Tierry; Lough Feagh, Connemara, Galway.

3. S. byssacea Nyl. in Bot. Not. 1854, p. 84.-Thallus scarcely visible or ol,solete. Apothecia small, scattered; stalk very slender, smmetimes brancherl; capitulurn clarate-tubiform ; sprires at first simple then 1-3-septate, 15-23 $\mu$ long, $5-7 \mu$ thick. Croml), in Grevillea xv. p. 14 (1886). Corlicium bysareum Fr. Scherl. Crit. i. p. o (1N24); Cromb. in Journ. Bot. xi. p. 13:3 (1873) ; Leight. Lich. Fl. ed. 3, p. 45.

Smaller and more slender than the preceding species. The apothecia are frequently branched and oceasionally fasciculate.

$H a b$. On trunks and branches of alders in upland wooded distriet.-Distr. liare in WV. Englind, N. Wales, and Central Seotland.-L. M. Hay Park, near Ludlow, Shropshire; Canel Curig. Carnarwonshire; Glen Lochay and Jjair Athole, Perthshire.

6. CYPHELIUM Ach. in Tet. Acad. Handl. 1815, p. 261.Trurluylia Fr. in Tet. Acad. Handl. 1N21, p. 324 pro parte: Nyl. in IĹm. Suc. Ści. Nat. Cherb. iii. p. 167 (1855) it Lich. Scar.d. 1. 4 (note); Cromb. Mronogr. i. p. 101. Acrlium S. F. Gray Nat. Arr. i. p. 482 (1821); Mudd Man. p. 253. (Pl. 6.)

Thallus effuse, crustacerous, sranular or furfuracenus. Apotheria cesile, smetimes almost immersed in the thalline cranules, semi-elobese, becoming open and plane, black, with a thin thatline maresin, sporal mas plane, black ; paraplyyses seanty, slencler: slores l-septate, rarely pluri-septate and muriform, ellipsoid, lnownish-hlack. Spermogness with short simple sterigmatit and with ellipsoded or elongate and hent spermatia.

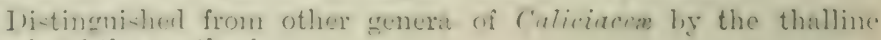
margin of the apothecia.

1. C. tigillare Ach. tom. cit. p. 266.-'Thallus effuse,

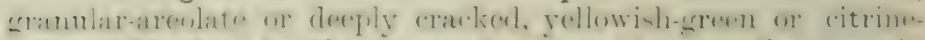
reflow (K-). Apotheria small, flane, innate, the margin 


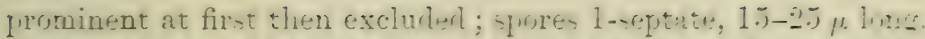

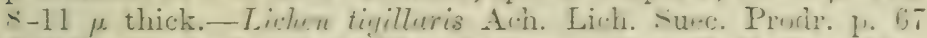

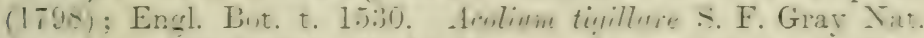

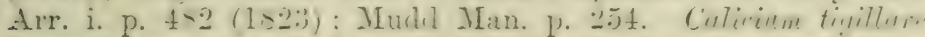

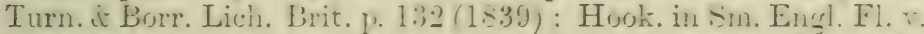

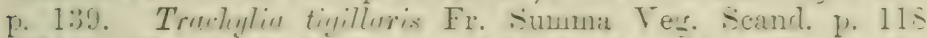
(1s46): Crunb. Lich. Irit. p. 1t; Lticht. Lich. Fl. 1. t‘: ed. 3, p. 47 .

The thallus is creener in (amu) shory places, and is then baren. The ayothecia are inmeite in the larger granules. The minne bluck sperwogones are trenueut, the sperwatia $5-7 \mu$ lon $-2,2 \cdot 5-3 ; \cdot 5$ it thick.

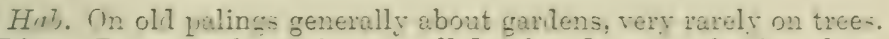
-Distr. Rare, at least in a mell-dereloped state, haring been gathered only sparingly in E. and 1 . England. and now extinct in several of the reerndel localitie ifile Crombier.-E. M. Talthewstrow. Loughton, Maliton, and Colchester. Essex; Herringleet and near Yarmouth, Suffolk; Ayton, Cleveland, Yorkshire.

2. C. inquinans Trev. in Flora xir. I) 4 (1S62).-Thallus effuse, orarsely granular, the granules concrescent, sonetimes deeply cracked, thin or rather thick, grey or whitish (K-yellowish). Aprothecia mrolerate in size, prominent, plane, liach, sometimes slishtly sereyruinose, with a blach, thin, prominent marsin, which is sometimes white-pruingse, and at lenuth evanescent; spores 1-septate, constricted at the septum, 10-15 $\mu$.

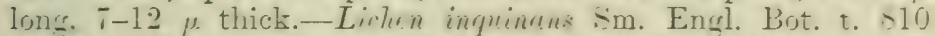

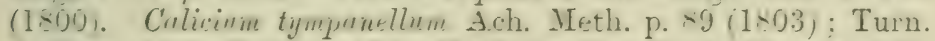
\& Eorr. Lich. Hórit. p. 13t: Hrok. in Fin. Engl. Fl. r. p. 139. Arolium tymprellum :. F. Gray Yat. Arr. i. p. 4×2 (1.21): Mudd Man. p. 254, t. 4, f. 101. Tracleylia tympanella Fr. sunma Verg. scand. p. $118(18+6)$; Carmoll in Journ. Brot. iii. 1. $2 \leq-7$ (1sijo); Crunh. Lich. Writ. p. 1t; Leisht. Lich. Fl. p. 48 ; ed. 3, p. 47.

Exsicc. Cromb. n. 114; Leight. n. 88 (under the name Lecidea dubia Turn. \& Borr.); Mudd n. 240.

The apothecia have largely the aspert of a $L$ cirl a except for the loose sprores, which stain the finger-bluckish when touchel. The thallus usually spreals extensirely over the substratum.

Hil, On old posts and palings. rarely on the barls of trees in inlawi iistrict.-Distr. General anl usually plentiful in Englant. ware in Ireluni, not reporterl from Scotlanri.-B. M. Lew Forest. Hants: Shentuanbury, Walstead Common. Albourne and Lindfield. Sus-ex: new Totteringe, . Hirllesex; Lrid and near Penshurst, Iient : Ulting. Wickhan Jjishop:. Walthamstow, anil near Colchester, Esiex; near El-tree. Herts; near Wootton 13aset. Gloucestershire; O-westry, Haughmond Hill. and neur Shrewbury, Shrop-hire; Twrewors and Gopsall I'ark. Leicestershire; Bilston. Stafiorishire; Harboro Mingna. Warwickshire; Colwall, Malthon, and near Walvem. Worcettor-lire: Derisyshire; Yamouth and Tckworth, Sulfilk: Eurshan, Sorfoll: : Rosedale, Yorkshire; Curraghmore, Waterford. 
3. C. stigonellum A. Zahlbr, in Engler do Prantl Pflanzenf. i. $1^{*}$, p. \&t (190:3).--Thallus none proper. Aprothecia parasitic, small or moderate, searcely prominent, plane, black, the manin back, prominent, sometimes pruinose, disappearing; spores blunt at the apices, 1-septate, 9-17 $\mu$ long, $7-10 \mu$ thick.-Calicinm stifonellnim Ach. Meth. p. is (1803) pro prarte; C. sessile var. meriginutum Turn. \& Burr. Lich. Brit. p. 128 (1839); Hook. in sm. Fngl. Fl. v. p. 138. Trachyliu stigonella Fr. Summa Vegr. scand. p. 118 (1846); Cromb. Lich. Brit. p. 15 it Monogr. i. 1. 10: ; Leight. Lich. Fl. p. 49 ; ed, 3, p. 47. Acolinu stigonellum Mudd Man. p. 254 (1861).

Exsicc. Leight. n. 226; Cromb. n. 11 ; Johns. n. 401.

Iiffers from the other species in the smaller apothecia and in the parasitic habit.

Hab. On the thallus of various Pertusarix.-Distr. General, though not common throughout England, rare in Central Scotlant,B. .11. Lrudhurst, New Forest, Hants; St. Leonard's Forest, Sussex; Shiere, Surrey; Stansted Mount Fitchet Park, Thorndon Hall, Locking, and Epping Forest, Essex; Cirencester, Gloucestershire; Gopsall. Leicestershire; Hindlip, Worcestershire; Barmouth, IIerioneth; Llanforda and Haughmond Hill, Shropshire ; Penmaenmawr, Carnarvonshire; Easby Wood, Ingleby and Cleveland, Yorkshire; Leven's Park, Westmoreland ; Teesdale, Durham; Ben Lawers, Perthshire.

4. C. Notarisii A. Zahlbr. in Engler d Prantl Pfanzenf. i. $1 \%$ p. \&t (1903).--Thallus bright greenish yellow, granularareolate. Apothecia innate, plane: spores brownish-black, ellipsoid or irregularly glolose, 1-i)-septate and often with a longitudinal sepitum in one or more of the cells, $14-2.5 \mu$ long, 10-1 $1 \mu$ thick. - Acolium Noturisii 'Tul. in Ann. Sci. Nat. sér. :3, xvii. p. 86 (1852).

Differs from other species in the genus in the muriform spores. The apothecia are numerons, each one surrounded by the granular brishtly-coloured thallus. The only specinem in the hexharium is in Iferb. Davies (collecter by Larbalestier), miler the name Acolium tigillare.

Hul,. On worked wook.-B. Al. Walton, Suffoll: (the only British locality).

\section{()ณ๐: II. SPHÆROPHORACEÆ.}

Thatlus frutionse (foliose in some foreign sencra). Algal

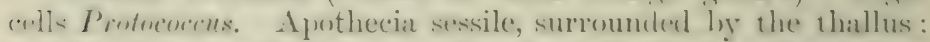

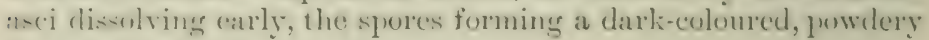
mass (mazrdium).

There is only one genus represented in Britain :-

Tl..Hlus frutivese. Aprothecia terminal............ 7 . Spherophorus.

7. SPHEROPHORUS Pers. in Ust. Ann. lint. vii. 1. 2::

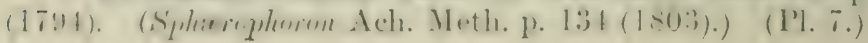


Thallus shrubler, composed of upright stalks, irresularly branched, the cortical laver cartilasinous, smooth and shining, the central medullary layer white and rather soft. Arothecia terminal on the primary stalks or branches, innate in the swollen tips, globose or subslobose, the surrounding thallus at lenstr bursting irregularly: sporal mass copious, black; paraphyses slender ; asci 8-spored, evanescent; spores globose, simple, with a dark-coloured erispore. Apermogones terminal, functiform, black: spermatia oblong, pleurogenous, on short-celled tissue-like sterigmata lining the walls of the spermogone.

1. S. melanocarpus S'cherr. in Meisner's Naturwis. Anzeiger, v. p. 4:3 (152).-Thallus shrubby, erect, irresularly branched, whitish ( $\mathrm{K}-$, medulli I-), the branches short, compressed, much divided, naked, more or less laterally and minutely fibrillose. Apothecia moderate in size, oblique, slobose-depresserl, the covering thallus torn and the rlisc at length open; spores shobuse, $7-11 \mu$ in ciiameter. $-S$. compressus. Ach. Meth. p. 135 (1803); Hook. Fl. Scot. ii. p. 67 \& in Sm. Engl. Fl. r. p. 2.32; S. F. Gray Nat. Arr. i. 1. 487 ; Turn. it Borr. Lich. Brit. p. 115 ; Mudd Man, p. 264; Cromb. Lich. Brit. p. 1.5; Leight. Lich. Fl. p. 49 ; ed. 3, p. 48. S. corclloides var. compressum Tayl. in Mackay Fl. Hil), ii. p. \&:3 pro parte. Liclenoides nom tulnlosnm, ramulis scutellis nigris terminntis Dill. in Ray Syn. ed. :, p. 66, n. 1:3 (1724). Corclloirtes alpinum Dill. Hist. Alusc. 1) 116, t. 17, fig. 34 c (1741). Lichen melanorurpus Swartz Prodr. Descr. Tow. p. 147 (1788). L. fragilis , im. Engl. Bot. t. 114 (1793) (non L.).

Exsicc. Dicks. Hort. Sicc. Fase. 8, n. 23; Johns. n. 170; Larb. Lich. Hb. n. 205 ; Mudd n. 254.

The description by Swartz of the compressed branches is too charracteristic to leare any doubt as to the identity of his plant. The thallus is normally whitish, but, in most places, the branches are occasionally a greenish-grer, and sometimes tinged with red. The spermogones, rare on British specimens, are tuberculose, brownichblack, situated on the main branches, rarely on the fibrille, and with minute ellipsoid spermatia, $3 \mu$ long, $1 \mu$ thick.

Hab. On rocks and boulders in upland tracts.-Distr. General, though not common, throughout the British Isles.-B. M. Island of Guernsey; Dartmoor, Devon; Ardingly, Sussex; High rochs near. Tunbridge Wells, Kent; Aberdovey and Dolgelly, Merioneth; ('rnn. ford Moor, near Matlock, Derbyshire; Farndale, Yorkshire; Teesdale, Durhan; Wark, Aorthumberland; Black Craig. New Galloway: Jincaldine, Lorne, Argyll ; The Trossachs and Loch Tay, I'erthshire; Countesswells Woorl, near Aberleen; Lochaber, Inverness-hire : Jore IIt. and Cromaglown, Kerry; Diamond Mt., Comemara. Galway: Achill Island, Mayo.

2. S. globosus A. L. .im.-Thallus unequally and somewhat loncely branched, ascending, erereish-white on reddish-lnown (K-, medulla I + bluish), the branches numerus, rather shert. with compound lateral fibrillee. A Iothecia shobese, moderate in 
size, irregularly dehiscent above; spores spherical, 9-15 $\mu$ in diameter.-S. coralloiles Pers. in Ust. Ann. Bot. vii. p. 23 (1794); Hook. Fl. Scot. ii. p. 67 \& in Sm. Engl. Fl. v. p. 232 (incl. var. lainm, excl. var. respitosmm); S. F. Gray Nat. Arx. i. 1. 487; Tavl. in Mackay Fl. Hil, ii. p. 83 (excl. vars.); Turn. \& Borx. Lich. Brit. p. 110 (excl. var. cæspitosum); Leight. Angioc. Lich. p. 7 , t. 1, tig. 1 (incl. var. laxum, excl. var. virspitosum) \& Lich. Fl. p. 50; ed. 3, p. 48; Mudd Man. p. 26:3, t. 5, fig. 109 ; Cromb. Lich. Brit. p. 15 \& Monogr. i. p. 104, fig. 28 (incl. f. conyestus Lamy in Bull. Soc. Bot. Fr. xxv. p. 349 (1878)). Lichenoides uom tubulosum ramosissimum, firuticuli specie, cinereo-fuscum Dill. in Ray Syn. ed. 3, p. 65, n. 9 (1724). Coralluirtes cupressiform, capitulis glolosis Dill. Hist. Musc. p. 117, t. 17, fig. 3is (17+1). Lichrin globosus Hurls. Fl. Angl. p. 460 (1762). L. glulifirus L. Mant. p. 133 (1767); Lightt. Fl. Scot. ii. p. $887(177 \%)$; Engl. Bot. t. 115; With. Arr. ed. 3, iv. p. 40 .

E.rice. Bohl. n. 5 ; Johns. n. 208; Leight. n. 316; IIudel n. 253.

Distinguished from the preceding by the rounded laxly-growing thallus, the shorter branches, and the more globose apothecia. It occurs in extensive patches, varying in colour from bluish-grey in shady, to brownish or eren reddish, in exposed situations. The apothecia remain closed for a considerable time; the spermogones are similar to those of S. melanocarpus, though more frequent. Hudson: Lichen globosus was based on Dillenius, t. 17. fig. 35.5 . Form comgestus is, as Crombie suggested, a stunter contition of the species ; there are numerous connecting stages.

$H a b$. On rocks and boulders, rarely on the mossy roots of trees.Distr. General and common in the hilly and mountainous tracts of Great Britain and Ireland, rarer in the Channel Islands.-B. M. Island of Guernsey; near Wring Cheese, near I'enzance, and Helminton, Cornwall; Dartmoor, Bovey Tracey, and Lustleigh Cleeve, Deron; Erirlge rocks and Ardingly, Sussex; Tunbridge Wells, Kent: Buckstone, near Mommouth; Charnwood Forest, Leicestershire ; Malvern Hills, Worcestershire; Cader Idris, Cwm Bychan, and Aberlovey, Merionetl ; Cacl Caradoe and Pentregaer, Uswestry. Shropshire; Trefriw, Citpel Curig, Llanberis, and Conway Falls, ('ar. narronshire; ('romfort Moor, near Matlock, Derbyshire; Kiliale Inor, Cleveland, Forkshire; Firglestone, Durham; Iientmere, West. moreland; The Cheriots, Northumberland; New Gallowar, Kirkcurlbrightshire; l'entlanil Hills and Dalmahoy Hill, near Eilinburgh; Inverary and Inch Creran, Argyll; Nigg, Kincarlineshire; Sidlaw IIills, liecky Lim, and Clova, Forfarshire; Loch liannoch, Craiir Calliach, near C'rieff. Bracklinn Jiridge, Jien Lawers, and Falls ct Jiruar, Perthshive; Lochnagar, Craig Coimmoch, Morrone, Braenatr. Aberleenshire; (ilen Nevis, Inveruessshire; near Naim; Applecross. liosshire; Forres, Elginshire; near Lairg, Sutherland ; Achill Island and C'roaghmore, ('lare Island, Mayo; Deris Mt., Antrim.

3. S. fragilis Pers. in Ust. Ann. Bot. vii. p. 23 (1794).'Thallus more or less densely ceespitose, sparingly and dichoro- 
monsly branched, greyish-white, brownish or dark-greyish ( $\mathrm{K}+$ yellowish, medulla $\mathrm{I}-$ ), the branches rounded, clusteres and erect, naked, without fibrillar. Apothecia globose or sub)ulubuse, irrecularly dehiscent above; spores spherical or globustellipsuid, 7-16 $\mu$ in diameter.-Engl. Bot. t. 247t; S. F. Gray Nat. Arr. i. p. 487 ; Hook. Fl. Scot. ii. p. 67 ; Cromb. Lich. Brit. p. 1.); Leight. Lich. Fl. p. 51 ; ed. 3, p. 49. S. cespitosnm DC. Fl. Fr. ii. p. 327 (1805). S. coralloides var. cæspitosum Turn. \& Borr. Lich. Brit. p. 111 ; Hook. in Siu. Engl. Fl. v. 1. 2:32 ; Leight. Angioc. Lich. 1. 8, t. 1, fig. 2 ; var. fiecyitis Tayl. in Mackay Fl. Hib. ii. p. 83 (1836); Mudd MIan. p. 264. Corralloistes alpinum, Corallina minoris facie Dill. Hist. Muse. p. 116 , t. 17 , fig. 34 A, B (1741). Lichen fragilis L. Sp. Pl. 1. 1154 (1753); Lightf. Fl. Scot. ii. p. 888 pro parte. L. corpitosus Roth Tent. Fl. Germ. i. p. 513 (1788).

Exsicc. Croall n. 199 ; Johns. n. 209.

Somewhat similar to ciespitose forms of the preceding, but distinguished by the branches being without fibrillæ. It grows in cushion-like masses less than an inch in height; the branches are often darker below, and are sometimes reddish. When fertile, which is rare, the apothecia are borne on longer protruding branches. The 1ycnidia are frequent with minute spores, $3 \mu$ long, $1 \mu$ thick.

Hab. On mossy or bare rocks and boulders in upland to aloine situations.-Distr. Common in the hilly and mountainous tracts of the British Isles.-B. M. Near Vixen Tor and Hay Tor, Devon; Ardingly Rocks, Sussex; Charnwood Forest, Leicestershire; Phewgreidden, Merioneth; Snowdon, Carnarvonshire; Helsby; Cheshire ; Ingleboro and Farndale, Yorkshire; Egglestone and Teesdale, Durham; West Allen Carrs, Northumberland; Ennerdale, Cumberland; New Galloway, Kirkeudbrightshire; Ben Lomond, Dumbartonshire; Clova, Forfarshire ; Craig Calliach, Ben Lawers, near Crieff, and Loch Ericht, Perthshire; Craig Coinnoch, Glen Callater, Loch-na-gar, and Ben-naboord, Braemar, Aberdeenshire; Ben Nevis, Invernessshire; near Forres, Elginshire; Hills of Applecross, Rossshire; Glandarry and Slievemore IIts., Achill Island, Mayo; Malin Head, Donegal.

\section{Subseries II. CYCLOCARPINEA.}

Thallus crustaceous, squamulose, foliose or fruticose. Algal cells blue-green (Mixxophycea) or bright-green (Chlorophyceir). Fruit a roundish apothecium, open or partially open from the first, marginate or immarginate, the margin composed of hypha alone (proper) or including gonidia (thalline). Asci and spores various.

The Cyclocarpineve include a large and raried series of lichens, that differ widely in the characters of thallus and fruit. The algit are blue-green in a comparatively small number of orders and genera; mostly they are bright-green (or yellow). In the former case the thallus is frequently gelatinous when moist, as are the algie, which are distributed equally through the thallus (homoiomerous), though also sometimes non-gelatinous with the alge arranged in a definite 
zome (7.etrinacrous). The thallus containing bright.green algie is non-gelatinous, and nearly always heteromerous.

The Natural Orders are grouped as follows:-

Thallus homoiomerous, gelatinous when moist (more or less). Alga blue-green, distributed equally through the thallus.

Thallus with Scytonema or Stigonema. algæ, more or less minutely fruticose...

Thallus with Glococapsa algæ, crusta. ceous, minutely squamulose or minutely fruticose ..................................

Thallus with Rivularia algæ, fruticose or squamulose, small....................

Thallus with Nostoc algæ, crustaceous, squamulose or foliose......................

Thallus heteromerous, not gelatinous when moist. Algæ in a definite zone.

Algæ blue-green (bright-green in Psoroma). Apothecia small.

Thallus crustaceous, squamulose $01^{\circ}$ subfoliose, minute..................

Algæ blue-green or bright.green. Apo. thecia large.

Thallus foliose. Spores septate.

Apothecia without a thalline margine, adnate................

Apothecia marginate, scutellate

Algre constantly bright-green (or yellowish).

Apothecialarge, with thalline margin. Thallus foliose. Spores simple

'Thallus fruticose. Spores simple or septate.

Apothecia small to moderate in size, with thalline margin.

Thallus various. Spores polaribilocular .........................

Apothecia usually small, with thalline margin.

Thallus crustaceous or minutely squamulose.

Apothecia single, superficial (or immersed at first). Spores various.............

Apothecia several in thalline verruce ......................

Apothecia with a double margin .....................

Apothecir without a thalline margin.

T'hallus foliose, cxpanded.........

Thallus squamulose, with up. right podetin ....................

Thellus pothetin .

'Thallus crustrceous or minutely squamulose ....................

iii. Ephebaceit.

iv. PYrexopshidele.

v. LICHINACEæ.

vi. Collemacez.

vii. Pannariace

viii. Peltigerace.

ix. Stictace五.

x. Parjeliace.

xi. USNeACEE.

xii. Physciace.

xiii. Lecanoracex:.

xiv. P'ertusariche.

xพ. 'THELOTRLMACE.

xi. Girophoracez.

xvii. Cladoniachi.

xviii. CenogonaChis.

xix. Lleideacex. 


\section{ORDER III. EPHEBACE无.}

Thallus more or less gelatinous when inoist, minutely fruticore or tilamentous, crustaceuns or partly squamulose, corticated or non-conticated. Algal cells Myxophycese (S'rytonemu or Stignumen). Apothecia rather small, discoil, with a proper margin (lecicleine); spores $\&$ in the ascus, colourless, simple or septate. Spermogones partly immersed in the thallus, with simple or septate sterismata and minute ellipsoid acrogenous or pleurogenous spermatia.

The lichens of this Order belonging to the British Flora are crustaceous, minutely shrubby or filamentous, and slightly gelatinous when moist. The alga is a species of Scytonema, with cell-rows in one series, or of Stigonema, with the cell-rows in several series. The resulting lichen is of a somewhat stouter texture than the alga. They are all somewhat uncommon. The crustaceous lichen Magmopsis argilospila Nyl. included by Crombie among Ephrbacei (AIonogr. i. p. 29) should be classified among Pyrenidiaceie. The following genera are British :-

Thallus with Scytonema.

Thallus crustaceous.

Thallus minutely fruticose.

Filaments without a cortex

8. Porocyphus.

Filaments with cellular cortex.

Apothecia moderate in size, spores 1 -septate ............................. Apothecia minute, spores simple... 11. Leptogidium.

Thallus minutely squamulose - coralloid;

spores 1- or more-septate .................. 12. Placynthium.

Thallus of larger Lichina-like fronds, fructification unknown.

9. Thermutis.

10. Polychidium.

13. Schizoma.

Thallus with Stigonema, fruticose.

Filaments minute, apothecia black........... 14. Spilonema.

Filaments somewhat elongate, apothecia pale.

Thallus not spiny, apothecia without paraphyses............................ 15. Ephebe.

Thallus with spiny branchlets, apothecia with paraphyses.

16. Ephebeia. (Pl. 8.)

ミ. POROCYPHUS Lioerb. Syst. Lich. (Ferm. p. 4.5 (.1 1 5.

Thallus crustaceous, continuous or areolate or granular, noncorticated, slightly gelatinous. Algal cells Seytoneme. Apotheria very small, immer'sed, closed then open, with a stout thalline marmin; paraphyses slender, diserete; asci rather irregular in form, often bent or twisted, si-spored; spores ellipsoirl, simple, colourless. Spermogrones immersed, almost globose, with acrogenous short or elongate ellipsoid spermatia.

1. P. areolatus Ko(r). Syst. Lich. Gexm. 1) 4.5 (15,5).Thallus granular-areslate or somewhat continuous and thimish, 
brownish-lilack. Apothecia minute, dark-coloured, with a thick thalline marwin; parapliyses slender; asci elongate, often bent:

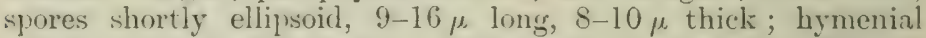
selatine hluish with iodine.-Collemopsis lecomoposides Nyl. ex Cromb. in Journ. Bot. xii. 1). 332 (187t) pro parte; Cromb). Monogr. i. p. 78 pro parte; Leight. Lich. Fl. ed. 3, 1. 35 pro parte.

Hab. On primitive rocks in mountainous regions. $-B$. $I$. Craig Tulloch, Blair Athole, Perthshire.

9. THERMUTIS Fr. Syst. Orl). Verr. p. 302 (1S25). Gomioman Nyl. in Mém. Soc. Sci. Nat. Cherb. iii. p. 163 (185.)) Leight. in Ann. Mag. Nat. Hist. ser. 3, xvi. p. 8 (1S65); Croml). Lich. Brit. p. 1 \& Monog1. i. p. 18. (Pl. 9.)

Thallus minutely shrubby or felted, composed of thread-like sparingly branched filaments. Alsal cells Siytonema, a single cell row in each filament, the lichen hyphas growing parallel within the gelatinous sheath of the algia. Apothecia small, flattened-globose, lateral on the filaments; paraphyses unbranched, slender; asci elongate, 8-spored; spores colourless, ellipsoid or elongate, simple. Śpermogrones lateral or terminal on the filaments, somewhat globose ; sterigmata septate; spermatia minute, ovate or elongate, pleurogenous.

1. Th. velutina Th. Fr. Lich. Arct. 1). 287 (1:60).-Thallus of slender filaments, felted, sometimes spreading extensively, brownish when moist, dark-brown when dry. Apothecia minute, clark-brown, pale within, with a tumid nargin; spores oblonsellipsoid, 10-15 $\mu$ long, 6-7 $\mu$ thick.-Lichen velutimus Ach. Lich. Suec. Prodr. 1). 2Is (1798); Polyrhidium velutimm S. F. Gray Nat. Arr. i. p. 402 (1821). Goniomeme velutimum Nyl. in Mém. Soc. Sci. Nat. Cherb. iii. 1) 163 (1855) ; Leight. in Ann. Mas. Nat. Hist. ser. 3, xvi. 1. \&, t. 4, tigs. 1-6 (186.) ) Lich. Fl. p. 11 ; ed. 3 , p. 9 ; Cromb. Lich. Brit. p. 1 \& Monogr. i. p. 18.

Exsice. Jolıns, n. 41.

The apothecia are very rarely met with in this country. The spermogones are described as pale reddish with minute spermatia. $2 \mu$ long, and $1 \mu$ thick.

Hab. On mica-schist rocks in mountainous districts.-Distr. Rare in N. Wiales, N. England, and among the Grampians, Scotland, jrobal,ly often orerlooked.-1). II. Near Barmouth and Cader Irris, Merioneth; Friar's ('rag, lieswich, C'mberland; Jen Cruachan, Argyll ; Jien Tawers and ('raig Tulloeh, P'erthshire; Glen Callater, Abericenshire.

2. Th. compacta A. L. Fim.-Thallus of dark-brown crowiled filaments forming a tomontum or felt. Apothecia globulose, redulish, beeming dark, the epithecium rather indistinct; spores

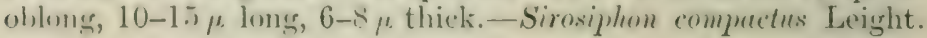


Lich. Fl. ed. 3, p. 9 (1879) (Küitz. Tab. Phyc. ii. p. 10, t. 36, fig. :3 (1850-52) as alga). Gunionema rompactum Nyl, in Flora lrvi. p. 104 (1883) ; Cromb. in Journ. Bot. xxiii. p. 195 (1885) it AIonogr. i. p. 19.

Exsicc. Johns. n. 1 (?).

Closely allied to, and possibly identical with, the preceding, differing chiefly, according to Nylander, in the form of the filaments, a variable character. The spermatia are described as somewhat smaller, measuring $1 \mu$ long and $\frac{1}{2} \mu$ thick. The synonymy has generally included that of the alga Seytonema compactum Ag. Disp. Alg. p. 39 (1812). Leighton first included it among lichens, though the apothecia were then undiscovered. The specimens in the herbarium of the British Museum, with the exception of that from IIardale, present considerable difficulty in identification, and are doubtfully lichenoid, the filaments being mostly of a purely algoid nature, and apothecia wanting.

Hab. On moist rocks in upland and subalpine districts.-Distr. Tiather rare in N. Wales, N.W. England, Scotland, and N.W. Ireland.B. M. Mardale, Westmoreland ; Wastdale, Cumberland; (?) Dolgelly, Merioneth; (?) Appin, Argyll ; Blair Athole, Perthshire.

10. POLYCHIDIUM S. F. Gray Nat. Arr. i.p. 401 (1821); emend. A. Zahlbr. in Engler \& Prantl Nat. Pflanzenf. i. 1*, p. 156 (1906). Collema, Sect. Polychidium Ach. Lich. Univ. p. 658 (1810) pro parte. (Pl. 10.)

Thallus foliose with narrow lacinie or minutely shrubby and branched, the branches terete with a well-developed cellulan' cortex. Algal cells Scytonema, in parallel longitudinal lines. Apothecia moderate in size; sessile, lateral or terminal, brown; asci 8-spored; spores elongate-fusiform, 1-septate, colourless. Spermogones with septate sterigmata, the spermatia pleurogenous, small, thicker at the ends.

The only species of this genus in the British Isles has been included by recent writers in Leptogium, from which however it differs in the algal constituent and the consequent form of the thallus.

1. P. muscicolum S. F. Gray Nat. Arr. i. p. 402 (1821).Thallus minutely shrubby, formed of slightly compressed or rouncled dark-brown or olive-blackish filaments, branched, sometimes anastomosing, often nodulose at the tips, suberect or decumbent, in cushion-like tufts. Apotbecia moderate in size, brownish-red, with a thin paler margin; spores oblong-fusiform, 1-septate, $23-27 \mu$ long, $7 \mu$ thick.-Mudd Man. 1. 49, t. 1, f. 9. Lichen muscicolu Swartz in Nov. Act. Acad. Upsal. iv. p. It (178t) (excl. Syn. Dill.) ; Dicks. Pl. Crypt. Fasc. ii. 1. 2:?, t. 6, f. 9 ; With. Arr. ed. 3, iv. p. 46 ; Engl. Bot. t. 2264 . Collema muscirolu Ach. Lich. Univ. p. 660 (1810): Hook. lis. Sicot. 1. 72 “ in Sul. Engl. Fl, v. 1. 214: Tayl. in Mackay Fl. J Lib. ii. p. 111. Leptenginm muscirolum Fr. Summa Vreg. Ficand. 1'. 122 (1St6); 
Xyl. Srn. i. p. 131, t. 4, figs. 11-15; Crom1). Lich. Brit. 1. 10 it MIonogr. i. p. 68 ; Leight. Lich. F]. p. 27 ; ed. 3, p. 34.

Exsicc. J.eight. n. 395 ; Larb. Lich. Hb. n. 121.

Owing to the somewhat gelatinous nature of the thallus the filaments teud to eolicre, and the rather broad apothecium looks as if perched on several different branches. It resembles roung and pale states of Parmelia pubescens.

Hab. Anrong mosses on rocks and walls.-Distr. General and not uncommon in maritime and upland districts.- J. M. South Brent, Bottor Rock and near Hunter Tor, Devon; Breiddon, Montgomeryshire; Cader Idris, Drews-y-nunt and Ty-gwyn, near Dolgelly, Merioneth; Shropshire; Llimberis and Snowdon, Carnarronshire; Jientumaris, Anglesea; Kentmere, Westmoreland; New Gilloway, Firlicudbrightshire; Ben Cruachan, Oban, Loch Creran and l'ass of Brander, Argyll; Ben Lawer's and near St. Fillans, Perthshire; Craig Guie, Braemar, Aberdeenshire ; Luggelaw, Wiclilow; Tillarney, Kerry; Kylemore, Galway.

11. LEPTOGIDIUM Nyl. in Flora lvi.p. 195 (1873). (PI. 11.)

Thallus minutely shrubloy and tangled, the branches terete, with a well-developed cellular cortex and a central medullary strand of hyphre. Algal cells Scytonema, in parallel longitudinal lines. Apothecia small, reddish or brownish; spores colourless, ellipsoid, simple.

Almost exclusively a tropical genus, S. TT. Ireland being the only locality where it occurs in Europe.

1. L. dendriscum Nyl. 1. c. (note).-Thallus of short, slender, intricately branched filaments which are rounded or obsoletely crmpressed, olive-greenish or pale-yellowish at the base. Apothecia small, pale or pale-reddish, the dise somewhat conrex; spores ellipsoid, 10-16 $\mu$ lowg, 6-8 $\mu$ thick.-Cromb. in Journ. Isot. xii.p. 337 (187t); Leight. Lich. Fl. ed. 3, p. 13. Leptogium Arusl.ismm Nyl. Syn. Lich. i. p. 135 (1858). L. MIomeii Hepp ex Carroll in Journ. Bot. iii. p. 287 (1865); Cromb. Lich. Brit. 1. 10; Leight. Lich. Fl. 1. 27. Ephebe byssoides Carring. in Trans. Bot. Soc. Edinb. vii. p. 411, t. 10, fig. 2 (1863).

The few specimens collected in Ireland are without apothecia and with only imperfectly developed spermogones.

IFal. On mossy trunks of trees in S.W. Ireland.-W, M. Cromaglown, Glengarriff and Glena, Killarney, Kerry.

12. PLACYNTHIUM \&. T. (imay Nat. Arr. i. p. 395 (18:1). Collemu sect. Placymllium Ach. Lich. Univ. P. 628 (1810). Pammlaria Nyl. in Flora lxii. p. 360 (1859) pro parte; Cromb. Mlonogr. i. p. 340 pro parte. (Pl. 12.)

Thallus granular-erustaceous and areolate or minutely coralloid-syuamulose, almost mitrely homoiomerous with a plect(nchymatous (echlular) cortex and usually with a well-derchoped 
bluish-black hypothallus. Algal cells Siytonemen. Apotheuia sessile, plane or convex, with a proper margin only : paraphrsestoutish, unbranched, septate, thicker and dark-coloured at the tips; asci clavate, S-spored; spores elongate or ellipsoid-urate. 1-i-septate, colvurless. Śpermogones minute with cylinchicial, straight or bent, pleurogenous spermatia.

Placed by Crombie and some other lichenologists in or near Pannaria, but classified among the Ephebacen on account of the homoiomerous thallus.

1. P. nigrum S. 1. Gray Nat. Arr. i. p. 39.) (18:1).-Thallus subdeterminate, brownish, minutely squamulose-coralloid, cracked into granular-like areolex, dark-greyish-or brownish-black; hypothallus bluish-black. Apothecia small, plane or slightly convex, the proper margin entire, internally pale-whitish; hypothecium brownish in thin section; paraphyses stoutish, septate, darkbluish at the tips; spores ellipsoid, 1-3-septate, $11-18 \mu$ long, $5-7 \mu$ thick ; hymenial gelatine deep-bluish then dark-violet with jodine.-Lichen niger Huds. Fl. Angl. ed. 2, p. 524 (1778); With. Arr. ed. 3, iv. p. 10 ; Engl. Bot. t. 1161. Collema nigrum Ach. Lich. Univ. p. 628 (1810) pro parte; Hook. in Sm. Engl. Fl. v. p. 207 ; Tayl. in Mackay Fl. Hib. ii.p. 10T. Lecothecium niymum Massal. Ric. Lich. p. 109, f. 215 (1852); Mudd Man. p. 175, t. 3, f. 65 (incl. var. fuscum). Biatora corallinoides var. fuse Hepp Flecht. Eur. 11. 10 (1553). Pannaria nigra Nyl. Lich. Scand. p. 1:6 (1861) ; Cromb. Lich. Brit. p. 43 ; Leight. Lich. Fl. p. 168 : ed. 3, p. 15t. Panmularia niyra śtiz. Lich. Hels. p. S:2 (1882): Cromb. in Grevillea xii. p. 58 \& Monogr. i. p. 342.

Exsicc. Johns. n. 254; Leight. n. 366 ; MIudd n. 144.

The spores are normally 1 -septate, but they vary even in one apothecium to 3-septate. The hypothecium is light yellowish-brown in thin sections, though dark in the mass.

Hab. On calcareous rocks, mortar, and flint pebbles in maritime, lowland and upland regions.-Distr. General and common throughout the British Isles.-W. W. Guernsey; Mt. Orgueil Castle and Gorey. Jersey; St. Ninver, Cornwall; Paignton near Torquay, Devon; Shanklin, I. of Wight; Beeding and Glynde, Sussex; Shiere, Surrey; near Stroud and Sapperton, Gloucestershire; Bathampton Down. Somersetshire; Marlborough, Wilts; Breedon Hill, Leicestershire; Llanymyech Hill and Bridgenorth, Shropshire; Barmouth, Merionetl ; Bilsdale, Cleveland, Yorkshire ; Levens, Westmoreland; near Whitehaven, Cumberland; Egglestone, 1)urham; Appin, Argrll; I3en Lawers and Craig Tulloch, Blair Athole, Perthshire; Bracmar, Aber. deenshire; Applecross, Rossshire; near Belfast, Antrim.

Form psotina Hue in Bull. Soc. Linn. Norm. sér. .j, ix. p. 147 (1905).-Thallus similar to that of the species. Apothecii internally somewhat paler ; spores more constantly 3-septate and 4-guttulate. - Collema trarlyomm Tayl. in Lond. Journ. Bot. vi. p. $193(1847)$ ? Pennuria nigra f. psotina Nyl. Lich. Seand. 
1. $126(1-61)$ : sulisp. pisotina Cromb. in Journ. Bot. xi. p. 13:3 (1873). Panumria psotinu Leight. Lich. Fl. ed. 3, p. 156 (1879). Panmelaria nigra subsp. psotina Cromb. in Grevillea xriii. p. $4 t$ (1889) \& Monogr. i. p. 343.

Exsicc. Johns. nos. 30, 25 อั.

Outwardly like the species, but with a lighter coloured hypothecium :unl with more pronouncedly :3-septate spores, which are sometimes irregular and blunt at the ends.

$H a b$. On calcareous rocks and mortar of walls in maritime and inland districts.-Distr. Tare in the Channel Islanils, England and IV. Ircland.-11. 1\%. The Vale, Guernsey; Eastbourne, Sussex; near the Horse. Windsor Great Park, Berks; Whiteharen, Cumberland; Hexham, Northumberland; Westport and Castlebar, Mayo.

Form triseptatum Hue in tom. cit. p. 148.-Thallus subdeterminate, granular-crustaceous, cracked-areolate, brownishback; hypothallus blackish, not very distinct. Apothecia rather swall, with a thin proper margin, brownish-black, internally whitish; spores ellipsoirl, 3-septate, 16-22 $\mu$ lons, 6-9 $\mu$ thick.-Penuaria niefre f. triseptuta Nyl. Lich. Scand. p. 126 (1861); Cromb. Lich. Erit. p. 43 ; subsp. triseptata Nyl. ex Crmb. in Grevillea i. p. 171 (1<73). P(tmmlaria triseptutre Nyl. ex Cromb. in op. cit. xriii. p. 44 (1889); Cromb. ILonogr. i. p. 343.

With slightly larger spores and more crustose thallus than in the species.

Hul. On mica-schist rocks in mountainous regions.-Distr. Tare among the Scottish Grampians.-13. 1\%. Achrosagan Hill, Appin, Argyll; Craig Calliach and Ben Lawers, Perthshire.

2. P. delicatula A. L. Sm.-Thallus thin adnate, minutely sranular-crustaceous, brown. Apothecia small, somewhat convex, Irownish-black (reddish when moist); hypothecium colourless: paraphyses yellowish-brown at the clavate apices; spores fusiformrernicular, straight or sulsstraight, 7 -9-septate, 40-76 $\mu$ long, $\bar{j}-\bar{\tau} \mu$ thick; hymenial gelatine and asci bluish with indine.Arromin delicatula Th. Fr. Lich. Arct. p. 28T (1860). Pammlarin A. Ticutula Xyl. ex Cromb. in Journ. Jiot. xx. p. 27t (18\&:2); Cromb. Monogr. i. p. 345.

I'lacert in the gemus I'lacynthium on account of the plectenchynatous homoionerous thallus, and the multi-septate spores.

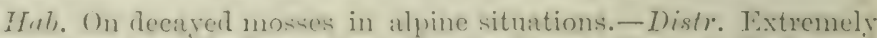
me anong the 's. Grampians, Seotland, and XIts. of W. Irelanil (Connemara, Galway).-B. M. Ben Lawers, Perthshire.

1:3. SCHIZOMA Nyl, ex (moml), in (irevillea r. p. 10s (18Ti) (note). (Pl. 13.)

Thallus laciniate-linear, enlatinous when moist, non-corticate.

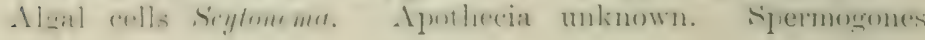


somewhat prominent, spermatia minute, cylindical, slightly wider at the ends, acrogenous on sparingly branched sterigmata.

The genus is placed along with others containing Scytonema, though the systematic position is uncertain so long as the fructification is unknown. The Scytonema filaments are occasionally intact towarts the centre of the thallus; as a rule ther are broken up into groups, as in the genus Hepria. They are massed under the cortex, and the medulla is formed of crowded thin-walled branching hyphre, mostly parallel with the long axis.

1. S. lichenodeum Nyl. ex Cromb. in Grevillea v. p. 108 (IS75).-Thallus of ligulate cylindrical-angular dichotomously branched lobes flattened when dry and canaliculate, about j-10 mm. in leugth and about $\frac{1}{2}$ mm. wide, occasionally sprinkled with isidiose granules dark-brown. Apothecia not yet seen.Collemu lichunarlenm $\mathrm{Nyl}$. ex Carmoll in Journ. Bot. iii. p. 287 (186.j); Cromb. Lich. Brit. 1. 3; Leight. Lich. Fl. p. 18; ed. 3, p. 15 ; Cromb. in Journ. Bot. xii. p. 332 (1874).

Confusion has arisen in the rentering of the specific name, but Carroll's is the first published. The fronds bear a considerable resemblance to those of Lichina.

Hab. On decared mosses and on the ground in crevices of rocks in alpine places.-Li. M. Summit of Ben Lawers (the only locality).

14. SPILONEMA Bornet in Mém. Soc. Sici. Nat. Cherb. iv. p. 226 (1856). (Pl. 14.)

Thallus minutely shrubby with branching filaments. Alsal cells Stigonemu, in rows of sereral series of cells. Apothecia suall, lenticular; paraphyses usually thickish, septate; spores simple or 1-sejtate, colourless. Spermogones like small tubercles, the sterigmata septate with pleurogenous oblong spermatia.

The thallus is well distinguished from the preceding genera by the algal constituent. As in the genus Thermutis, many of the filaments of the various species are algoid in our specimens.

1. S. paradoxum Bornet l. c. tt. 1 it -2-Thallus dark-hown or brownish-black, of slender cylindrical branches, intricate and felted, the secondary branchlets senerally unilateral. Ajothecia small, terminal on the main stalks, hemispherical, black; hypothecium dark-coloured ; praphyses clavate; asci clavate, arising from the lowest cell of a paraphysis ; spores oblong-ellipsoid, simple, $9 \mu$ lons, $t \mu$ thick; hymenial gelatine clecp.blue, then dark-riolet with indine.-Mudd Minn. 1). 3.); Leight. in Ann. Mag. Nat. Hist. ser. 3, xvi. 1) 9, t. 4, figs. 7-11 (1, ifin) it Lich. Fl. p. 11 ; ed. 3, p. 10 ; Cromb. Lich. Brit. p. 1 \& in Journ. Bot. xii. p. $331(1874)$.

\section{Exsicc, Leight, n. 347.}

The thallus bears a considerable resemblance to that of the more common Eiplulue pulusens, but it is altosether smaller, and the fructification is different. 
Hah. On rocks in maritime and subalpine ristrict.--Distr. Rare in N. Wales and S.WT. Highlands of Scotland. B. M. Barmouth, Merioneth; Barcaldine, Argyll.

2. S. revertens Nyl. in Flora xlviii. 1. 601 (1865).-Thallus of branching filaments, occurring in small conpact agglutinate black or brownish-black julvinuli. Apothecia adnate, slightly convex, immarginate, black, dark-greyish within : hypothecium not dark-coloured; paraphyses stoutish, somewhat thicker and blackened at the apices; spores colourless, oblong, simple, 8-11 $\mu$ long, $5-6 \mu$ thick; hymenial gelatine bluish, the tips of the asci deep-blue, with iodine.-Cromb. in Journ. But. xii. p. 331 (1874); Leight. Lich. Fl. ed. 3, p. 11.

Differs from $S$. paradorum in the small compact growth of the thallus. In the only British specimen the apothecia are but sparingly present, too few for examination, as are also the spermogones, stated by Crombie (Monogr. i. p. 21) to be globose. immersed and colourless, with somewhat curved spermatia.

Hab. On moist rocks in subalpine districts.-B. M. Craig Tulloch, Blair Athole, Perthshire.

3. S. scoticum Nyl. in Flora lii. p. 82 (1869).-Thallus minutely brancher, in small compact somewhat convex agglutinate black or brownish-black pulvinuli. Apothecia minute, black, thinly margined, the dise slightly conrex; hypothecium colourless ; paraphyses somewhat slender; spores ovoid-oblong, 1-septate, 10-14 $\mu$ long, 4-5 $\mu$ thick; hymenial gelatine bluish, the asci violet, with iorline.-Cromb. in Journ. Bot. vii. P. 105 (1^69) \& Lich. Brit. p. 1 ; Leight. Lich. Fl. p. 12 : ed. 3, p. 11.

Very similar to the preceding in the form of the thallus, but distinguished by the intermal characters of the apothecia. The latter are very rare.

Hab. On rocks and on dead mosses (also on Stereocaulon condensatum) in subalpine regions.-Distr. liare, though perhaps overlooked, in N. Wales, N. Eugland and the S. Grampian s. Scotlaud.B. M. Llyn Aran, Dolgelly, Merioneth; Teestale, I) urhan; Ben Lawers and Craig Calliach, Perthshire.

15. EPHEBE Fr. Nyst. (oh). Veg. i. p. 2.j6 (1:25) emend. : Xyl. in Flora lviii. p, $6(1875)$. Girardin S. F. Gray Nat. Arr. i. p. 287 (1821) pro parte. (Pl. 15.)

Thallus filmmentous, in spreading tufts, branched and intrieate, without a cellular cortex. Alsal cells Stigmemu, the lichen hyphas cxternal to the alga in young stages. forming central strands in the older branches. Aputheria minute, solitary or angresate, immeresel in swollen portions of the filamentous

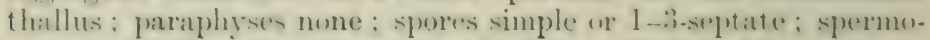

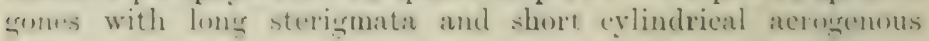
spermatia. 
Distinguished from the previous genera by the much stouter extensively spreading thallus.

1. E. lanata Wain. in Medd. Soc. Faun. \& Fl. Fenn. xiv. p. 20 (1888).-.Thallus dark-olive-green or brownish-black, somewhat shining, much branched, decumbent, the filaments slender, uneren on the surface, tapering at the apices. Apothecia minute, slightly paler than the thallus; spores simple or 1-septate, colourless, 11-16 $\mu$ long, 3-4 $\mu$ thick; hymenial gelatine not tinged or faintly violet-coloured, the asci tawny-yellow, with iodine. Spermogones lateral on the branches, the spermatia $5 \mu$ long, $1 \mu$ thick.-E. pubescens Nyl. Syn. Lich. i. p. 90, t. 2, figs. I it 17-20 (1858); Mudd Man. p. 34; Leight. in Ann. Mag. Nat. Hist. ser. 3 , xvi. p. 10, t. 4, figs. 12-14 (1865) \& Lich. Fl. p. 12 ; ed. 3, p. 10 ; Cromb. Lich. Brit. p. 1 \& in Grevillea v. p. 124. Lichen lanatus L. Sp. Pl. p. 1155 (1753). L. pubescens L. Fl. Suec. n. $1126(1745)$ pro parte; Engl. Bot. t. 2318. L. exilis Lightf. Fl. Scot. ii. p. 894 (1777) pro parte; With. Arr. ed. 3, iv. p. 47 pro parte. Conferva atrotivens Dillw. Brit. Conf. p. 60, t. 25 (1803). Cornicularia pubescens Ach. Meth. Lich. 1. 305 (1803); S. F. Gray Nat. Arr. i. p. 406. Scytonema (?) atrovirens Ag. Disp. Alg. p. 39 (1812); Hook. Fl. Scot. ii. p. 78. Givardia atrovirens S. F. Gray Nat. Arr. i. p. 287 (1821). Stigonema atrovirens Ag. Syst. Alg. p. 42 (1824); Hook. in Sm. Engl. Fl. ヶ. p. 363 ; Hass. Br. Freshw. Alg. p. 227, t. 66, fig. 1. Alertoria lanata f. minuscula Leight. Lich. Fl. ed. 3, p. 81 (1879) pro parte. Exsicc. Johns. n. 163.

Hudson's Lichen scaber has been quoted as a srnonym, but the description by him of the "black concave marginate scutellie" refers it rather to Parmelia pubescens. The apothecia are rare. The spermogones are more frequent, and are usually borne on separate plants.

Hab. Forming matted irregular tufts in somewhat large patches, on moist shady rocks, especially by streams. - Distr. General and fairly abundant in hilly and mountainous regions. $-B . M$. Roughton, Cornwall; near Iry Bridge, Chagford, and near Tor, Devon ; Barmouth and Dolgelly, Merioneth; Capel Curig, Snowdon and Llanberis, Carnarronshire; near Holyhead, Anglesea; Mrardale, Westmoreland; Ennerdale, Cumberland; Teesdale, Durham; New Galloway, Tïirkeudbrightshire; Appin and Loch Awe, Argyll; Glen Lochay and Ben Lawers, Perthshire; Graig Guie, Braemar, Aberdeenshire; Glen Neris, Invernessshire; Loch Shin, Sutherland; Applecross, Rossshire; Glengariff, Kerry; Kiylemore, Galway; Glandarry Wood, Achill Island, Mayo; near Belfast, Antrim.

16. EPHEBEIA Nyl. in Flora lviii. p. 6 (1к75). (Pl. 16.)

Thallus tilamentous, in sprealing tufts, branched and intricate, without a cellular cortex. Algal cells Stigonema, the hyphe external to the alga in young stages, but forming central strands in the older branches. Apothecia solitary, lateral, minute; 
paraphyses numerous, slender, slightly clavate at the tips ; spores constantly simple, colourless.

Distinguished from the preceding genus by the presence of paraphyses in the apothecium.

1. E. hispidula Nyl. in Flor:a lx. p. 231 (187T).-Thallus olive-green or dark-brown, much brancherl, decumbent, the filaments slender, rather uneven on the surface, with spine-like branchlets. Apothecia closed at first and subglobose, the disc becoming open and somewhat depressed; pariphyses slender, sparingly hranched, slightly clavate; spores oblong-ellipsoid, 10-15 $\mu$ long, 4-5 $\mu$ thick.-Cromb. in Journ. Bot. xxiii. p. 195 (1885). Cormicularia hispidulu Ach. Lich. Univ. p. 617 (1810). E. pubescens var. hispidulu S. F. Gray Nat. Arr. i. p. 406 (1S21). Exsicc. Johns. 11. 2.

Distinguished from Ephebe pubescens by the minute branchlets on many of the filaments, giving it a spinous or hispid appearance.

Hab.-On damp quartzose and schiztose rocks in subalpine districts.-Distr. Liare in N. Wales, S. and N. England, and among the Grampians, Scotland.-B. M. Iry Bridge, Tevon; Cader Idris, Nerioneth; Snowdon, Carnarronshire; Ben Lawers and Craig Tulloch, Perthshire.

Sulsp. Martindalei Cromb. in Journ. Bot. xxiii. p. 195 $(1885)$.-Diftering from the species in the less hard and spiny branching. Apothecia bluish-green above : spores oblong-ellipsoid, $9-1+\mu$ long, $4-6 \mu$ thick. E Elleberin Thartimelatei Cromb. ex Nyl. in Flora lxvi. p. 104 (1ธะ3) \& in Grevillea xii. p. 89 (1\&\$t).

The damp locality where the plant was collected may have influencer the growth. It is lighter in colour and softer looling.

Hat. On moist rocks in mountrinous districts.-D. M. Mardale. Westmoreland.

\section{ORDER IV. PYRENOPSIDACE压.}

Thallus gelatinous when moist, crustaceous or partly squamulose or minutely fruticose, non-corticited. Algal cells M yxophyceac (filocertpsa, Chroorocens). Apothecia small, open or subimmersed anrl partly closed; spores is in the ascus, colourless, simple or rarely septate. Sipermogones with minute ovate or elongate acrogrenous spermatia.

The algal cells occur in small colonies, each surrounded by mucilige; they are hlue-freen, or colomed red or vellow, especially towath the simfice of the thallus, by various eoloming substances. 'The following genera are British:-

Alge with reddish sheath, externally.

Thallus crustaceous.

A potlecir open or plane. 17. Euopsis.

Apothecia almost closed...................... 18. Pyrenopsis.

'Thallus fruticose, of short tufts ................... 19. Symalissa.

Algat with yellow sheath, extemally.

Thallus crustrecous, dark-coloured..............20. Psorotichia. 
17. EUOPSIS Nyl. in Flom lviii. p. 36.3 (1575). (Pl. 17.)

Thallus crustaceous, granulatrareolate, fracile. Apothecia small or moderate in size, discoid, with a thalline marsin ; paratphyses distinctly septate; spores in in the ascus, ellipsoid, simple, colourless. Spermogones with minute acrogenous spermatia.

Separater? by Nylander from the genus I'yrenopsis on account of the distinetly discoid apothecia and septate paraphrses. The thallus has a reddish colour due to the gluecapsin of the alga, which is more pronounced when moist.

1. E. pulvinata Wain. in Medu. Faun. it Flor. Fenn. vi. p. 85 (18\$1).- Thallus effuse, granular, coarsely areolate, rlark-blondred. Apothecia usually numerous and crowded, dark-blood-red or paler, becoming darker, plane or becoming convex and iumarsinate; spores ellipssid, 11-16 $\mu$ long, 6- $7 \mu$ thick; hymenial selatine, especially the asci, deep-blue with iodine.E. hamalea Nyl. in Flora lviii. p. 363 (1875); Cromb. in Grevillea xv. p. $10(1$ \&86) it Monogr. i. p. 22. Lecirlea pultimata Scher. in Meisner Naturw. Anz. ii. p. 11 (1818). Collema hromuleum Sommerf. Suppl. Fl. Lapl. 1. 117 (1:26). Pyrenusis Tremalea Stirton in Grevillea ii. p. il (1:7:3): Cromb. in .Journ. Bot. xii. p. 332 (1874); Leight. Lich. Fl. ed. 3, p. 15.

The red colour of the thallus due to the algal sheath is more pronounced when the lichen is moist.

$H a b$. On mica-schist rocks in subalpine and alpine regions.Distr. Local and scarce among the Grumpians, Scotland, and in W. Ireland.-B. M. Ben Cruachan, Argyll ; Ben Lawers, Perthshire; Kylemore Mts., Connemara, Galway.

2. E. granatina Nyl. in Flora lviii. p. 363 (1\&75). - Thallus effuse, thin granular, widely crackerl-areolate, reddish-brown or reddish, the granules rounded, aggregate, Apothecia small, shining, congregate in the thalline granules, reddish, whitish within, the margin thin, entire, at length excluded ; the sprores simple or spuriously 1 -septate, ellipsoid, $9-1 \cdot 2 \mu$ lons, $4 \cdot 5-5 \cdot 5 \mu$ thick; hymenium, especially the asci, bluish with iodine.Cromb. in Grevillea xv.p. 10 (1risti). Leerenora yrunatina sommert. Suppl. Fl. Lapp. p. 90 (1826). Pyiemopsis yranutinu Nyl. ex Cromb. Lich. Brit. 1. 27 (1870); Leight. Lich. Fl. 1) 14; єd. :3, p. 15.

I) iffers from the prece:ling in the more brightly-coloured thallus and in the rouncter masserl granules. It is much more conspicuous in wet weather. Forsell (Iot. Centrilbl, xxii. p. 5t (18.5.)) considers that this plint should be clissified under Lermum, as there aro Palmella gonidia in the thallus as well as Glococapsa.

IIn\}. On rocks and bonlders in alpine regions.-Distr. Ritre annmg

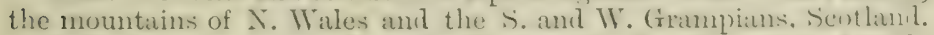
- li. 11. Llyn Aran, near Dolgeliy, Merioneth; Jen ('ruathan, Aryll; Craig Calliach and Ben Lawers, Perthshire. 
18. PYRENOPSIS Nyl. in Mém. Soc. Sici. Nat. Cherb. v. p. 88 (1857) \& Syn. Lich. p. 97 (1858). (Pl. 18.)

Thallus crustaceous, granular, rarely subsquamulose, or subfruticulose. Apothecia somewhat innate and partly closed, small or minute; paraphyses simple, slender; spores 8 in the ascus, simple, rarely numerous. Sipermogones with oblong minute acrogenous spermatia.

The species are all darker than those of Euopsis, but they also show the red colouration in a thin section.

1. P. hæmatopis Th. Fl. Lich. Arct. p. $284(1 \& 60)$.-Thallus effuse, crustaceous, the granules rounded, unequally aggregate, dark- or reddish-brown, similarly coloured within or darker towards the base. Apothecia superficial, small with thick connivent entire margins; spores 8 in the ascus, 10-12 $\mu$ long, 5) $-6 \mu$ thick; hymenium, especially the asci, bluish with iodine-Carroll in Journ. Bot. iv. p. 22 (1866); Cromb. Lich. Brit. p. 2 ; Leight. Lich. Fl. p. 14 ; ed. 3, p. 14 . Collema hemulenim var. hexuatopis Sommerf. Suppl. Fl. Lapp. p. 117 (1826).

The spermogones of this species are somewhat frequent, though the apothecia are rarely seen; when sterile, it is distinguishable from Euopsis hrmalea by the thicker, darker thallus.

Hab. On shady rocks in alpine places.-Distr. Extremely rare among the S. Grampians, Scotland.- I . II. Ben Lawers, Perthshire.

2. P. homœopsis Nyl. in Flora li. p. $342(1 \leqslant 68)$.--Thallus effuse, granular, rather thick, deeply crackerl-areolate, the areolie granular, plane, dark-redlish-brown. Apothecia minute, the margins comnivent, pale within, the epithecium narrow, colourless; paraphyses slender ; spores 8 in the ascus, 11-18 $\mu$ long, $7-10 \mu$ thick; hymenial gelatine red or tawny-wine-colourerl with iodine. Cromb. in Joum. Bot. vii. P. 48 (1869) \& Lich. Brit. P. 2: Leight. Lich. Fl. p. 15 ; ed. 3, p. 14.

Closely allied to $I^{\prime}$. grumuliferu, a Finland species (Nyl. l. c.). In Nylander's original diagnosis the thallus is described as thin, but in the specimens from Jen Lawers in Herb. Crombie, as also in all the other specinens, it is comparatively thick and deeply diffract also.

Hal). On mica-schist rocks in alpine places..-Distr. Tare on the S. (irampians, Scotlank.-13, II. Summit of Ben Lawers and Craig Calliach, Perthshire.

3. P. fuscatula Nyl. in Mém. Soc. Neci. Nat. C'herb. v. p. 143 (1857).- Thallus rffuse. granular, the granules often in small seattered ageregations, dark-hrown or hrownish-black. Apothecia small with thick comivent margins; epithecium yellowish : spures 8 in the ascus, small, $8-10) \mu$ long, $4-5 \mu$ thick ; hymenial gelatine bluish then violet with iocline- - Le ight. Lich, Fl. p. 16; ed. 3, p. 14; Cromb. in Journ. Bot. xii. p. 332 (1874). 
Distinguished by the dark-brown colour and the thinner spreading thallus; considered by Nrlander (1. c.) as closely allied to $P$. fuliginosa, a continental species. In this species the spermogones are more common than the apothecia. The spermatia are oblong-cylindrical, and very minute.

$H a b$. On granite and schistose rocks in maritime districts. - Distr. Rare in the Channel Islands, N. Wales and S. W. Highlands of Scotland.-13. II. La Moye and Boulay Bay, Jersey; Barmouth, Nerioneth ; Lismore, Argyll.

4. P. subareolata Nyl. Lich. Scand. p. 27 (1861) nomen; Cromb. MIonogr. i. p. 24 (1894).-Thallus effiuse, cracked-areolate, the areolie plane, blackish. Apothesia small, innate, blackish; spores $\delta$ in the ascus, $15 \mu$ long, $S \mu$ thick; hymenial gelatine bluish then wine-reddlish with iodine.--Cromb. in Journ. Bot. xx. p. 271 (1882).

Comparable with $P$. concordaluta, a Finland species, but with smaller spores (Nyl. in Flora lviii. p. 440 (1875)). The thallus, which spreads over fairly large patches of the rock, is very dark in colour and rather thin. Crombie has suggested (Monogr. i. p. 24) that Verucaria imbrida Tayl. (Lond. Journ. Bot. vi. p. 153 (1847) ) may be a synonym.

Hab. On moist rocks in mountainons districts.-Distr. Local and scarce in N. Wales and S.IV. Ireland.- $-B$. M. Near Barmouth, Merioneth; near Killarney, Kerry.

5. P. phylliscella Nyl. in Flora lviii. p. 102 (1875). - Thallus effuse, composed of small flattened adpressed squamules roundish and congresgate but not contiguous, dark-brown. Apothecia immersed, minute, 5-15 in each squamule, the thalline margin thin, almost covering the epithecium ; paraphyses few ; spores 8 in the ascus, oblong-ellipsoid, $5-7 \mu$ long, $3 \mu$ thick; hymenial gelatine bluish, the asci dark-violet, with iodine.-Cromb. in Grevillea iii. p. 190 (1875) ; Leight. Lich. Fl. ed. 3, p. 14.

Considered by Nylander to be closely allied to P. tasmanica. The squamuline character of the thallus is not very pronounced, the squamules themselves are minutely granular; the apothecia, when present, are numerous and crowded. The spermogones are not uncommon, the spermatia narrowly oblong or oblong-fusiform.

Hab. On quartzose boulders in a stream. $-B . M$. Ben-y-Gloe, Blair Athole, Perthshire.

6. P. furfurea Nyl. ex Cromb. in Journ. Fot. xii. p. $3: 32$ (1\&74).-Thallus effuse, thinnish, granular-areolate, brownishblack, reddish-black when moist. Apothecia minute with tumid connivent margins : spores $10-12 \mu$ long, $7-8 \mu$ thick : hymenial selatine wine-red with iodine.-Leight. Lich. Fl. ed. 3, 1. 14. Cullema furfureum Nyl. in Flora xlviii. p. 353 (1865) : Carroll in Journ. Bot. iii. 1. 2x6 (1865); Cromb. Lich. Jrit. p. 3 ; Leight. Lich. Fl. p. 17. 
The apothecia are rave in the few British specimens and the spores barly developer. The gonidia are chroococeoid. the internal structure thus resembling that of l'hylliscum, under which genus it should perlatus be classified. The nuterial is too scanty and poor for exact determination.

Hab. On moist mica-schist rocks.-B. M. Summit of Ben Lawers, Perthshire.

19. SYNALISSA Fr. Syst. Orl). Teg. p. 297 (1,2.)). (Pl. 19.)

Thallus minutely fruticose or partly crustaceous, darkcoloured. Algal cells Gilorapsi. Apothecia teminal, party immersed, at first closed then open, with a thalline margin; spores 8 in the ascus or numeroms, simple, colourless. Spermugones immersed, with simple steriguata and ncrogenous spermatia.

Chiefly distingrished from the other genera of Irrenopsidacete by the fruticose habit. The thallus is tinged red or dart-brown on the surface by glococapsin.

1. S. ramulosa Fr. Srst. (1)b. Ver. 1). 297 (1825).-Thallus in blackish pulvinate tufts, the branches short, erect, obtuse at the apices or nodulone. Apothecia minute, at first immersed hecoming open, with a tumid thalline margin; spores S-2.t in the ascus, ellipsoid or spherical, small. 9-11 $\mu$ long, $6-7 \mu$ thick ; bymenial gelatine not tinged with iodine.-S. s!mm lerrer Xyl. Syn. Lich. p. 94, t. 3, fig. 2 (1858) ; Mudd Man. p. 35̃, t. 1, fig. 2 ; Cromb. Lich. Brit. p. 3 d Monogr. i. 1. 37, fig. \& : Leight. Lich. Fl p. 16 ; ed. 3, 1. 13. S. rulyaris Thwaites in Ann. Mag. Nat. Hist. ser. 2, iii. p. 220, t. 8, figs. 1-3 (1849). Collema ramulosum Hoffm. Deutschl. Flora ii. p. 161 (1795). C. symplenenm DC. Fl. Fr. ii. 1) 382 (180-5). C. symalismm Ach. Lich. Univ. p. 640 (1810) pro parte; Tayl. in Mackay Fl. Hib. ii. p. 108.

Oecurs frequently with other lichens, Lecilcu luritu. I. testurer. Lecanora crassa, ete. The apothecia are very rave. The spermogrones are also rarely scen; the spernatia are very minute, $3 \mu$ lons. $1 \mu$ thick.

Hab. On calcareous rocks in maritime and upland districts. Distr. liare in S., W. and X. Ingland and in S. W. Scotland; record

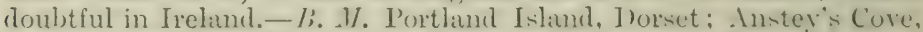
'Torquay, and near J3abbicombe, Jevon; St. Vincent's linclis, 13ristol. Gloucestershire; Malvern, W. Yorkhire; Jarealline, Argyll.

․ S. intricata $\mathrm{Ny}$. in Flora lxvi. p. 53t (1s:i). Thallus spreacline, lnancherl, brownish-blark, the branches narrow, roumeres, somewhit olituse or slightly moluluse at the apices. Apothecia not seen.-Cromb. in Journ. Bot. xxiii. p. 195

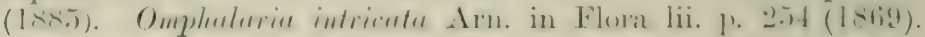
Nematonostoc intrieatum Nyl. in Flora 1xvi. p. 104 (1S\&3).

Of doubtful position owing to the charncter of the algal cells.

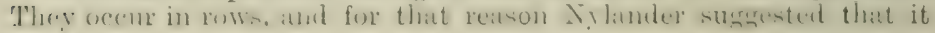


might be the type of a new genus Synalissina. Apothecia have not been found, but spermogones are present in the British specinen.

$H a b$. On moist granite rocks in an upland region.-B. M. New Gallowoy, Kirkeudbrightshire (the only British locality).

20. PSOROTICHIA Massal. Framm. Lich. p. $15(18.5)$; emend. Forssell in $K$. Vetensk.-Soc. Nova Acta, ser. 3, xiii. n. 6, p. 66 (1885). Collemepsis Nyl. in Flora lvi. p. 17 (15i3) (note); Cromb. in Joum. Bot. xii. p. 332 (1874) \& Monogr. i. p. 7\%. (Pl. 20.)

Thallus crustaceous, cranular-areolate, more or less corticated and loosely affixed to the substratum. Algal cells Gloem (1) su, sect. Xanthocapsa. Apothecia innate, urceolate, small, the marcrin usually tumid and connivent; paraphyses usually simple, slencler, and discrete; spores \& in the ascus, ellipsoid, simple, colourless. Spermogones with simple sterigmata and oblong minute acrogenous spermatia.

Closely allied to Pyrenopsis, but differing in the yellow colour of the algal sheath. It also somewhat resembles Panmularia, but is outwardly distinguished from that genus by the absence of a hypothallus.

1. Ps. Schæreri Arn. in Verh. K. K. Zool.-Bot. Ges. Wien xxii. p. $313(1872)$. - Thallus effuse, granular-areolate or minutely granular-syuamulose, rather thin, brownish-black. Apothecia small or moderate in size, plane, with a distinct thalline marwin, brownish or reddish-black; spores ellipsoid, 14-21 $\mu$ long; $7-11 \mu$ thick; hymenial gelatine pale-blue and then tawny with iodine. - Pannaria Sehaereri Massal. Ric. Lich. p. 114 (1852). Pyrenopsis Schareri Nyl. in Flora xlix. p. $37+(1866)$; Cromb. Lich. Brit. 1. 2) Leight. Lich. Fl. p. 15. Collemopsis Schareri Cromb. in Journ. Bot. xii. p. 332 (1874) \& Monogr. i. p. 78 ; Leight. Lich. Fl. ed. 3 , p. 35 .

Exsicc. Johns, n. 242.

The thallus is more squamulose and continuous as it becomes more fully developed. The apothecia are usually numerous and crowded.

Collema trachyopum Tayl. (Lond. Journ. Bot. vi. p. 193 (1847)) is referred by Tucherman to this species (Prof. Furlow in litt.). The specimen was collected by Taylor on limestone at Durham, Kerry.

$\mathrm{Hab}$. On cretaceous pebbles, and limestone walls and rocks in moist shady situations.-Distr. Not uncommon in England, among the Grampians, Scotland, and in W. Ireland.-B. M. Near Gomshall and Shiere, Surrey; Bathampton 1)owns and Babingrton. Somerset; Chelford, Oakley Park, and near Cirencester, Gloucistershire; Buxton, 1)erhyshire; Egremont, Cumberland; Craig Tulloeh, Blair Athole, I'erthishire; Craig Guie, Aberdeenshire; Kylonore. Galway.

2. Ps. furfurella Boist. Nour. Fl. Lich. Part 2, p. 312 $(1902)$. - Thallus effuse, thin, furfuraceous-granular, or in small 
ceattered granules, sometimes intermixed with larger, brownishblack. Apothecia minute, impressed in the granules, concolorous with the thallus, with a thick connivent margin; spores ellipsoid, rarely well-developed, 11-17 $\mu$ long, $8-11 \mu$ thick; hymenial gelatine wine-red with iodine.-Collema furfurellum Nyl. in Not. siallsk. Faun. \& Fl. Fenn. iv. p. 229 (1859); Carroll in Journ. Bot. iii. p. 286 (1865); Cromb. Lich. Brit. p. 3 \& MIonogr. i. p. 79 ; Leight. Lich. Fl. p. 17 . Collemopsis furfurella Nyl. ex Cromb. in Journ. Bot. xii. p. 332 (1874); Cromb. Monosr. i. p. 79 ; Leight. Lich. Fl. ed. 3 , p. 35.

More distinctly granular and seattered than either of the preceding species, differing also in the habitat.

$H a b$. On moist schistose rocks in alpine localities. $-B$. $M$. Above Loch-na-Gat, Ben Lawers, Perthshire.

3. Ps. diffundens Sydow Flecht. Deutschl. p. 324 (1Rs7).Thallus effuse, thin, with minute granular squamules, crackedareolate, black. Apothecia small, innate, somewhat plane or marginate, recldish, pale within ; spores ellipsoid, 16-23 $\mu$ lons, $7-11 \mu$ thick; hymenial gelatine bluish, then wine-red with iodine.-Pyrenopsis diffundens Nyl. in Fiora xlviii. p. 602 (1865); Carroll in Journ. Bot. iv. p. 22 (1866); Cromb. Lich. Brit. p. 3 ; Leight. Lich. Fl. p. 15. Collema diffractum Nyl. ex Carroll in Journ. Bot. iii. p. 287 (1865). Cullemopsis diffundens Nyl. ex Cromb. in Journ. Bot. xii. p. 332 (1874) ; Leight. Lich. Fl. ed. 3, p. 36 ; Cromb. Monogr. i. p. 80.

The specimens in the British Museum are sterile. The plant has not been found again at Maidstone, Keut, where it was first discovered.

$H a b$. On sandstone and schistose rocks.-Distr. Rare in S.E. England and N. Wales.-B. M. Barmouth, Merioneth.

4. Ps. pyrenopsoides Forss. in K. Vetensk.-Soc. Nova Actir, ser. 3, xiii. n. 6, p. 73 (1885). - Thallus effuse, thin, granularareolate or nearly continuous and somewhat scabrous, darkbrown or brownish-black. Apothecia small, concolorous with the thallus, the margin prominent, comnivent; spores 4 to 8 in the ascus, cllipsoid, rather large, 12-20 $\mu$ long, 6-11 $\mu$ thick ;

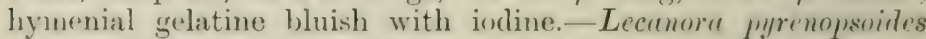
Nyl. in Bot. Not. p. 1633 (185:3). Pyrenopsis lermupusuides Nyl. in Flora lxix. p. 374 (1866); Carroll in Journ. Bot. r. p) 254 (1867); Cromb. Lich. Brit. p. 3 ; Leight. Lich. Fl. p. 15. Collemensis leronemsersides Nyl. ex Cromb. in Journ. Bot. xii. p. 33.2 (1874) pro parte; Cromb. Monogr. i. p. is pro parte: Leight. Lich. Til. ed. 3, p. 35 pro parte.

I specinen from Craig Tulloch, lerthshire, was relegrater to this species, but examination shows that the thallus eontains sryfomma and not Glococapsa, and is therefore a species of Porocyphus.

Hoh. On calcaroous rocks in maritime and mountimous recrions (Kenmare, lierry). 


\section{ORDER V. LICHINACEÆ.}

Thallus gelatinous when moist, crustaceous, sometimes lobed at the circumference, squamulose or minutely fruticose. Algal cells Rivuluria. Apothecia immersed and partly closed or open and with or without a thalline margin; paraphyses simple; asci 8 -spored ; spores crlourless, globose or ellipsoid, simple or septate.

There are only two British genera :-

Thallus minutely shrubby, maritime.

21. Lichina.

Thallus crustaceous, lobed or squamulose

22. Pterygium.

21. LICHINA Ag. Syn. Alg. p. xii. (1817) (as an alga); Mont. in Dict. Hist. Nat. vii. pp. 342 \& 351 (1849). (Pl. 21.)

Thallus minutely fruticose, crowdedly branched, indistinctly curticated, dark-coloured. Apothecia terminal, immersed in the slobose swollen tips, almost closed; paraphyses slender, sparingly branched; asci almost cylindrical, 8-spored; spores colourless, ellipsoid, simple. Spermogones single or crowded, borne near to the apothecia, with slender sterigmata and minute ellipsoid acrogenous spermatia.

A small maritime genus long regarded as belonging to the brown algie. The species grow freely over rocks washed by the tide, or by the spray from the sea.

1. L. pygmæa A@. Syn. Alg. pp. xii. \& $9(1817)$.-Thallus about 1 inch in height, composed of short, crowded, flat, erect lobes dichotomously branched and the ultimate branchlets narrower, blackish-brown. Apothecia forming a globose swelling at the tips of the fertile branches, slightly open or irregularly dehiscent; spores ellipsoid, uniseriate in the ascus, large, $22-29 \mu$ long, 11-16 $\mu$ thick.-S. F. Gray Nat. Arr. i. p. 388; Hook. Fl. Scot. ii. p. 96 \& in Sm. 'Engl. Fl. v. p. 270; Grev. Fl. Edin. p. 286 i Scott. Crypt. iv. t. 219 ; Tayl. in Mackay Fl. Hib. ii. p. 170 : Mudd Man. p. 33, t. 1, fig. 1; Leight in Ann. Mag. Nat. Hist. ser. 3, xvi. p. 12, t. 4, fig. 21 (1865) \& Lich. Fl. p. 13 ; ed. 3, p. 11 ; Cromb. Lich. Brit. p. 2. Fucus pygmæus Lightf. Fl. Scot. ii. p. 964, t. 32 (177T); With. Arr. ed. 3, iv. p. 100 ; Engl. Bot. t. 1332 ; Turn. Fuci iv. p. 16, t. 204, figs. " to h. F. pumilus Huds. Fl. Angl. ed. 2, p. 58t (17 8 ).

E.rsirr. Chalm. Alg. Scot. n. 40 ; Wyatt Als. Danm. n. 15i); Leisht. 11. 260; Larbal. Lich. Ciesar. n. 51 : Cromb. n. 1 : Johns. n. 42 .

Long classified as a dininutive liucus, though Lightfoot pointed out its great similarly to a Lichen.

$H a b$. On maritime roclis below high tide.-Distr. General and common on rocisy coasts, not recorted from X.T. Seotland. J). M. Guemsey, Alderney and Jersey; Scilly Isles; Mounts Jhay and st.

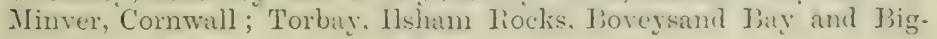


hurr Bar, Deron; Termouth. Dorset; Tentnor. I. of Tight; Tenby and St. Iride's Jay. P'embrokeshire; near Peel, Isle of Mam ; Conway Bas, Cimnarvonshire; st. Bees. Cumberland; Oll Cambus, Berwickshire; near Edinburgh; shores of Loch Linnhe, coasts of Islay, near Portuabaven and I. of 1Iull. Argrll ; near Castlefreke, Cork; Tienorle, Commemara, Galway; Dugort Bay, Achill. Mayo; neay Dunree, Donegal ; Larme, Antrim.

2. L. confinis Ag. Sp. Alg. i. p. 105 (1823).-Thallus of minute erect or somewhat decumbent rounded fronds, densely (aspituse, olive or b]ackish-hrown. Apothecia minute, terminal, slightly open or irregularly dehiscent; spores larse, -2.-29 $\mu$ long, 11-16 $\mu$ thick.-Grer. Fl. Edin. p. 286 it Scott. Crypt. ir. t. 2.1 ; Hook. in sm. Engl. Fl. v. p. 270 ; Tayl. in Mackay Fl. Hib. ii. p. 170; Mudd Man. 1. 34: Leight. in Ann. Mag. Nat. Hist. ser. 3, xvi. p. 12, t. 4, fig. 22 \& Lich. Fl. p. 13 ; ed. 3 , 1. 12 ; Cromb. Lich. Brit. p. 2. Lichon confinis Ach. Lich. Suec. Prodr. p. 20s (1798); Engl. Bot. t. 257.5. Fucus jy!mæens var. minos Turn. Fuci p. 16, t. 204, figs, $i-1$ (1819). Lichina pmmiln S. F. Gray Nat. Arr. i. p. 388 (1821). Lichina pygmxa var. minor Hook. Fl. Scot. ii. p. 96 (1821).

Exsice. Chalm. Alg. Scot. n. 41 ; Greville Alg. Brit. n. 4; Johns. n. 3 ; Larbal. Lich. Hb. n. 281 \& Lich. Crsar. n. 1; Wyatt Suppl. n. 202.

Altogether smallar than the preceding species; the branches are more slender and round and the fruits smaller. It grows higher un on the beach and is frequently sterile.

Hal. On maritime intertital rocks or those which are only washerl by the spray of the sea.-Distr. General and abundant on rocky coasts.-B. M. Jersey, Aldemer and Guernser; Scilly Isles; Whitesand Bay, Lands End. Mounts Bay, near Anthony. Penzance andi Gerrans. Cornwall ; Brocastle and southem Down, Glamowanshire; Tenly, Pembrokeshire; Barmouth, Merioneth; Puffin Island, Anglesea. Port Soderick. Isle of Man; Morecambe Bar, Westmoreland; St. Jees, Cumberland; near Caroline I'ark, Islinburgh ; const of Thincardineshire; Island of Mull, Islay, near Portnaharen amil Loch Creran, Argyll ; Fenmare, Kerry; Lonishurgh and Achill Somul Bay. Mayo; Malahide, Dublin; Ballycastle, Antrim.

22. PTERYGIUM Nyl. in Bull. sim. Bot. i. p. 32. (1E.t).

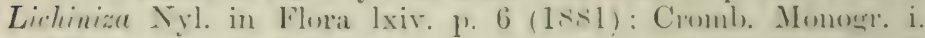
P. 33.

Thallus suarcely celatinous when moist, crustacems, granular or eranular-ateolate, or minutely squamuluse and usually somewhat inberl at the circumference. Algal cells Rirmlario, in rows within the thallus, the hyph:e multisenate ame linearecollular. Apotheria sensile, without a thalline margin, the proper marsin collular: prapaphyse septate, unbranched: spores elliparid or wate, colourless, $\mathrm{i}$-3 septate. Spermosones with septate branched sterigmata and pleurogenous spermatia. 
Differs from the preceling genus in the more or less crustaceous thallus, in the spore characters and in the habitat. The sterigmata are also unlike those of Lichina.

1. Pt. filiforme A. L. Sm.-Thallus crustaceous, granular in the centre, laciniate-radiate at the circumference, the lacinia narrow, centrifugal, chestnut-brown or blackish-brown. Apothecia cloubtrul.-Pt. centrifuynm Nyl. in Bull. Soc. Bot. i. p. 32s (1554); Cromb. Monogr. i. p. 34. Parmeliu tiliformis Garov. ex Nyl. in Bot. Not. 1853, p. 164.

I have not seen the fructification of this species which is mostly sterile. Apothecia have beendescribed as small, reddish, with a paler margin; spores s' in the ascus, elongate, ellipsoid or fusiform, colourless, 3 -septitte, $14-15 \mu$ long, $6-7 \mu$ thick. It seems doubtful if they are the apothecia of this species.

Hah. On calcareous rocks, rare.-Tiecorded from Cheildar Clifls, Somersetshire.

2. Pt. lismorense Cromi). in Grevillear v. p. 10R (1ヘז7).Thallus thin, sul,furfuraceous, thinly or obsuletely radiate, arlnate, irregularly cracked or confluent, blackish or olive-black. Apothecia small, thinly margined, the epithecium hluish-black; hypothecium cellular, violet-blackish; spores ovoid, 1-septate, 10-11 $\mu$ long, 5-6 $\mu$ thick; hymenial gelatine bluish then dark-yellowish with iodine.-Nyl. in Flora lx. p. 221 (187T); Leight. Lich. Fl. ed. 3, p. 12 .

Exsicc. Cromb. n. 101.

Crombie has described the thallus as spreading extensivel y though not continuously, the radii being more discrete in younger states. It is allied to $\mathrm{Pt}$. aspercllum Nyl., a Scandinavian species.

Hab. On calcareuns rocks in maritime tracts.-B. M. I. of Lismore. Argyll (the only locality).

3. Pt. pannariellum Nyl. in Sillsk. Faun. Fl. Femn. Not. iv. p. 236 (1599).-Thallus crustaceous, rather thin, composed of minute crowded inanulate squamules, areolate, generilly racliate at the circumference, olivaceous-brown or -black. Apothecia small, plane or slightly convex, black : spores ellipsoid, :3-septate, 15-20 $\mu$ lons, 6-s $\mu$ thick; hymenial gelatine deep-blue with indine.-Cromb. in Grevillea v. p. 10s (1હт ed. 3, 1. 12. Panmerin nigna subsp. triseptata Xyl. ex Cromb. in Grevillea i. p. 171 (1873).

The minute crowled lacinice give a finely granular appearunce to the thallus. The radiate circunference is not developer on the British specimen. There is only one record in our Islands.

$H a b$. On schistose rocks in alpine situations.-B. $M$. Craig Tulloch, Perthshire.

4. Pt. kenmorense A. L. Fin.-Thallus of stoutish suall crowder ar scattererl squamules with an irresularly gramulat 
appearance, brownish-black. Apothecia and spores not properly developed.-Lichiniza lipnnorensis . Nyl. in Flora lxiv. p, 6(1 Croml, in Grevillea x. 1. 22(1,81). Symulisan kiemunrensis Holl ex Nyl. l.c.

The structure of the thalline squamules agrees exactly with that of Plerygium. Crombie states that he detected a young apothecium terminal on one of the globular squamules. The species requires further investigation.

$H a$ 1). On mica-schist rocks in upland regions. $-B$. II. Shores of Loch Tay, Kenmore, Perthshire (the only locality).

\section{ORDER VI. COLLEMACEÆ.}

Thallus gelatinous when moist, crustaceous, fruticose or foliaceous, mostly homoiomerous, corticated or not corticated, sometimes with rhizine. Algal cells Nostor. Apothecia partly closed or open, immersed or sessile, a thalline margin present or wanting; spores usually 8 in the ascus, varying in form, simple, septate or muriform. Spermogones with pleurogenous or acrogenous spermatia.

In this family are found the most highly dereloped of the gelatinous lichens. The Nostoc chains retain as a rule their original form, and are scattered fairly equally through the thallus, except in some species of Leptogium which have more of a heteromerous character.

The following genera are British :-

Thallus non-corticated.

Spores simple.

23. Physma.

Spores septate-muriform

24. Collema.

Spores elongate, pluriseptate

25. Synechoblastus.

Thallus more or less corticated.

Spores simple

26. Lemmopsis.

Spores septate-muriform

27. Leptogium.

23. PHYSMA Massal. Neag. Lich. p. 6 (1854); emeni. A. Tahlbr. in Encler \& Prantl Pflanzenf. i. 1*, P. 170 (1906). Lemplestrmma Koerh. Syst. Lich. Germ. p. 400 (18.5.). Collemen Sect. A. Lempholemma Cromb. Monensr. i. p. 39 (1894). (Pl. 2:3.)

Thallns crustaceous, warter, squamulose or variously lobed, or minutely fruticose, non-corticated, gelatinous when moist, with or without rhizinae. Apothecia imnate, with a thalline margin which is sometimes cellular; paraphyses slender, simple: asci clisvate, often bent or twisterl, s-spored ; spores fusiform-ellipsoid or ulohose, simple, colourless. Spermognes with slender sterigmata and short cylindrieal acrogenous spermatia.

The gemus is characterized by the less highly developed thallus and by the simple spores. The British species belong to Sect. Lrmilicelemmu, in which the thallus lies close on the substratum. 
1. Ph. polyanthes Arn. in Verh. K. K. Zool. Bot. Ges. Wien xxix. p. 352 (1879).-Thallus olive-green or blackish, imbricatelobed or irregularly crustaceous, the lobes crowded, folded and crisp. Apothecia minute, numerous, crowded on the thallus lobes, somewhat concave, reddish, the thalline margin tumid; asci cylindrical ; spores globose or subglobose, $9-12 \mu$ in cliameter or 11-1: $\mu$ long, 9-10 $\mu$ thick; hymenial gelatine wine-red with iocline.-Lichen polyunthes Bernh. in Schrad. Samml. Crypt. Gen. n. 138 (1797) it in Schrad. Journ. Bot. i. p. 12, t. 1, fig. 4 (1799). L. myriocorcus Ach. Lich. Suec. Prodr. p. 127 (1798). Collemu myriococeum Ach. Lich. Univ. p. 638 (1810); Cromb. in Journ. Bot. xii. p. 147 (1874) \& Monogr. i. p. 40 ; Leight. Lich. El. ed. 3, p. 16.

Exsice. Cromb. n. 3.

The thallus when dry is very dark-coloured and is densely sprinkled over by the small apothecia which also are rather dark-coloured.

Hab. Among mosses on old walls, in shady places in inland districts.-Distr. Plentiful where it occurs in W. England, S. Wales and N.E. Ireland, probably orerlooked elsewhere.-B. M. Nen Cirencester, Stroud and Ablington, Gloncestershire; Pembrolieshire; near Belfast, Antrim.

2. $\mathrm{Ph}$. chalazanum Arn. in Verh. K. K. Zool. Bot. Ges. Wien xxiii. p. $52 \pm$ (1873).-Thallus spreading, continuous, rather thin, appressed on the substratum, irregularly turgid, plicate and tuberculose. Apothecia small, numerous, the disc reddish, the margin somewhat tumid ; spores ellipsoid, 20-24 $\mu$ long, 8-1:3 $\mu$ thick, or rather longer, or sometimes smaller; hymenial gelatine wine-red with iodine.-Collema chalazanum Ach. Lich. Univ. p. 530 (1810) ; Nyl. Syn. Lich. i. p. 104 (1858); Carroll in Journ. Brot. iv. p. 22 (1866); Cromb. Lich. Brit. p. 4 it Monogr. i. p. 39 ; Leight. Lich. Fl. p. 17 ; ed. 3, p. 16 . C. maritimum Tayl. in Lond. Journ. Bot. vi. p. 194 (1847)?

Soft and gelatinous when moist, almost resembling Nostoc. When dry the apothecia are inconspicuous, being almost immersed in thalline tubercles. The spermogones are not infrequent, with minute oblong spermatia.

Hab. Among mosses on the ground.-Distr. Rare in S.W. England, X. Wales, S.W. Highlands of Scotland and in S.W. Ireland.-B. M. Lipson Road, near Plymouth and Laura Bridge, Devon; Cherdar Cliffi, Somerset; near Tiendal, Westmoreland ; Lamplugh, Cumberland; Appin, Argyle; Dunkerron, Kerry.

3. Ph. chalazanodes A. L. Sm.-Thallus dark-green or blackish, spreading, continuous, thin, wrinkled and partly lobed or liciniate. Apothecia small, numerous, the disc reddish, the margin tumid: asci clavate; spores ellipsoid or subgloluse, small, $12-17 \mu$ long. 5) $\mu$ and upwards, thick; hymenial gelatine wine-red with iodine.

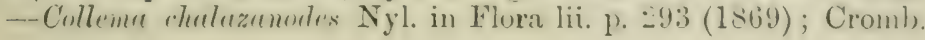


in Journ. Bot. vii. p. " $34(1 \& 69)$; Lich. Brit. p. 4 \& Monogr. i. p. 40 ; Leight. Lich. Fl. p. 17 ; ed. 3, p. 16.

Distinguished from the preceding species by the smaller spores. In the British specimens the thallus is also more wide-spreading.

$H a b$. Among mosses on old walls.-Distr. Local and scarce in W. England.-B. II. Bradley Wood, Newton Bushell, Devon; Coln Rogers, Gloucestershire.

4. Ph. confertum A. L. Sm.-Thallus blackish-brown, composed of minute turgid squamules. Apothecia numerous, croweled, small or moderate in size, the dise reddish, the marmin tumid; paraphyses slender; spores ellipsoid or fusiform-ellipsoid, 17-23 $\mu$ long, $8-10 \mu$ thick; hymenial gelatine bluish with iorline.Collema turgidum var. confertum Ach. Lich. Univ. p. 634 (1810). C. confertum Nyl. in Flora 1. p. 330 (1867); Leight. in Amm. Mag. Nat. Hist. ser. 3, xx. p. 259 (1867) it Lich. Fl. p. 18; ed. 3, p. 16 ; Cromb. Lich. Brit. p. 4 \& Monogr. i. p. 41.

I have been unable to verify the character of the spores in the single small specimen in the British Museum.

Hab. Amongst mosses on the ground in a maritime district.B. $M$. Dunwich, Suffolk.

24. COLLEMA Wiggs. Prim. Fl. Hols. p. 89 (1780); emend. 1. Zahlbr. in Engler it Prantl Pflanzenf. i. 1\%, p. 171 (1906). Enchylium S. F. Gray Nat. Arr. i. p. 396 (1821). (Pl. 24.)

Thallus variously lobed, or stuamulose or almost crustaceous, swollen and gelatinous when moist, mostly' without rhizina, more or less appressed to the substratum, non-corticated. Algal cells distributed through the thallus (hmoiomerous). Apothecia with a thalline margin which is sometimes of plectenchyma; liypothecium colourless; paraphyses simple, mostly septate, and conglutinate; spores 8 in the aseus, fusiform or ellipsoid, variously septate and becoming muriform. Spermogenes with colourless wall and with septate sterigmata and pleurogenous minute spermatia.

The genus Collemu, ats enented by Zahlbruckner, inclutes species with a non-eorticate thallus, and with variously septate muriform spores.

\section{Thallus gramular-crustaceous or indistinct.}

1. C. terrulentum Nyl. in Floria Wrii. p. :305 (1<it). -Thallus small, thin, granular, olive-hown on hownish-black. Apotheria small, concave, redelish-l,emw, the thalline margin thickish,

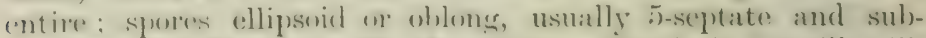

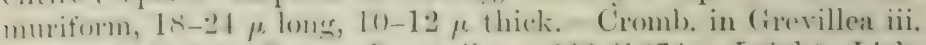

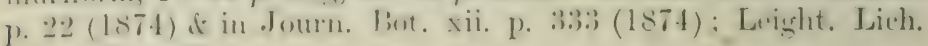
Fl. ed. 3, p. 25. 
An easily overloolied plant; possibly a reduced form of some other species. The only specimen gathered occurred in small scattered masses, most of which were sterile.

$H a b$. On the bark of an old ash-tree.-B. M. Shores of Loch Katrine, Perthshire.

2. C. isidioides Nyl. ex Am. in Flora liii. p. 232 (1870).Thallus of isiclia-like granules in crowded groups, blaclish. Fructitication unknown.-Nyl. in Flora 1xvi. p. 98 (18S3). Cromb. in Journ. Bot. xxiii. p. 195) (1885). Specimen not seen.

First collected by Arnold in the Bavarian Alps; of uncertain position in the absence of all fructification.

$\mathrm{Hab}$. On calcareous rocks in mountainous districts (Warton Craig, Westmoreland).

3. C. glaucescens Hoftim. Deutschl. Fl. ii. p. 100 (1795).Thallus thin, appressed, dull-or dark-olivaceous-green, indistinctly lobate, the lobes small, round or oblong, contiguous or scattered, entire or slightly crenate, scarcely noticeable when dry. Apothecia moderate in size, appressed, plane, reddish-brown or red, with a thin scarcely prominent entire or slightly crenate margin; paraphyses stoutish; spores usually 4 or 6 in the ascus, oroid, 4-5-septate, with one or more longitudinal septa, 27-38 $\mu$ long, 14-16 $\mu$ thick.-Cromb. in Grevillea xv.p. 11 (1886). C. limosm Ach. ex Bnrr. in Engl. Bot. Suppl. t. 2704, tig. 1 (1831) ; Hook. in Sm. Engl. Fl. v. p. 208 ; Tayl. in Mackay Fl. Hib. ii. p. 108; Cromb. Lich. Brit. p. 4 ; Leight. Lich. Fl. 1. 21 ; el. 3, p. 19. C. pulposum var. limosum Mudd Man. p. 39 (1861).

Readily recognized by the agglutinate thallus, with small almost granular lobes. The spores are larger' with more definite longitudinal septa than those of the preceding species. The thallus is sometimes evanescent, when the plant may easily be overlooked.

$H a b$. On moist clay soil in maritime and inland tracts.-Distr. Tare in S.W. and E. and N. England, and in the W. Highlands, Scotland.-B. M. Hassocks and Albourne, Sussex; Croham Quarry, Kent; Bocking, Essex; Wootton-under-Elge and near Cirencester, Gloucestershire; Bulstrode, Buclis; Hawford and Norton, Worcestershire; Buxton, Derbyshire; near Ayton, Cleveland, Yorkshire ; Spelie, Lancashire; Milnthorpe, Westmoreland; Fort Augustus, Inrernessshire.

Thallus lobes crovded, erect, coralloid or moliferous.

4. C. ceraniscum Nyl. in Flora xlviii. p. 35:) (186.) ).-Thallus small, the lobes minute, erect, coralloid, obtuse and nodulose at the apices, congested in small compact cushion-like masses, dark olive-sreenish or olive-brown (I+ wine-rerl in section). Apothecia minute, somewhat concave, brownish-red or black, the thalline margin thin, entire; spores usually 4 (sometimes 8$)$ in the ascus, oblong-ellipsoid, blunt at the cucls, :-6 septate, irregularly and very distinctly muriform, -27-:34 $\mu$. 
long, 18-21 $\mu$ thick.-Carroll in Journ. Bot. iii. p. 287 (1865); Cromb. Lich. Brit. T. 6 d in Journ. Bot. xii. p. 33:; (1874); Leight. Lich. Fl. p. 23; ed. 3, p. 17. C. ceranoides Murld Man. p. 41 (1861) pro parte (non Borr.).

A very distinct species both in the characters of the thallus and of the apothecia which are rather rare. It is not unlike Synalissa ramulosa in habit.

Hub. On damp shaded rocks among mosses in alpine places.Distr. Rare among the $\$$. Grampians, Scotland.-B. M. Ben Liwers and Craig Calliach, Perthshire.

\section{Thallus lobes smooth, somevohat spreading.}

5. C. pulposum Ach. Syn. Lich. p. 311 (1814).-Thallus thickish, pulpy, subimbricate-lobed, olive-l)rown or clark-greenish, the lobes small, thick and swollen, nearly ertire or somewhat uneven, crenate, often plicate and wrinkled, generally crowded (I + redilish). Apothecia moderate in size, concare, becoming plane or conrex, redclish or dark-red, with a thick entive marcin, hecoming thinner with age: spores oroid, 3-septate, later with longitudinal septa, 16-24 $\mu$ long, $7-10 \mu$ thick.-Mudd Man. p. is jro parte (excl. virs.); Croml. Lich. Brit. p. 4 ; Leight. Lich. Fl. p. 19 (excl. var. trnux) ; ed. 3, p. 18 (excl. f. gramulutum, and vars. ceremoirles, pulposulum, tencec); var. compurtum Nyl. Syn. Lich. i. 1. 109 (1858); form crmpactum Cromb. in Joun. Lot. xii. 1). 333 (1§7t) ; Leight. Lich. Fl. ed. 3, 1. 18. C. rompartum Ach. tom cit. p. 313. Lirhennides gelutiumsun folies

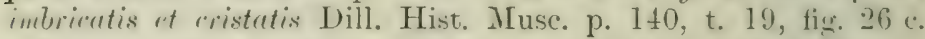
(1740). Lichen pulposus Bernh. in Schrad. Journ. Bot. i. p. 7, t. 1, fig. 1 (1799). L. crispus Sm. Engl. Bot. t. 834 (1801). n. 4.

Eisire. Carroll Lich. Hib. n. :39; Leight. n. 290; Cromb.

Jistinguished by the thick pulpy often crowded lobes of the thallus, and by the entire nuargin of the apothecia. It is not conspicuons except in wet weather. The apotheeia are sometimes so abundant as amost to obscure the thallus; they are chiefly centrial and may become confluent.

Hab. On the ground and on old walls, chicfly calcareous, in maritime and inland district.-D Jist). General throughout the British

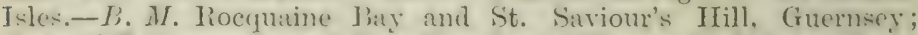
Enderclifl, Luecombe and shanklin, Isle of Wight; St. Minver, Cornwall; Stareross, near Plymouth, Torguay and lirixham, levon; Fasthourne, liottingrlean, Posnings, Lewes and IInrstpierpoint, Sussex; Shoreham, Kent; lieirate Hill, Surey; I'reston, llilts; Jathumpton 1)owns, Somerset; Tetbury and Cirencester, Gloncestershire; Norton and Malvern, Woresistershire; Manorheer, I'emlnolie. shire; Jarmouth, Merioneth; Cleveland, Yorkshire; Teesdale, Durhann; Kendal, Westmoreland; near Whitehaven, (umberland; Aprin and I. of Iismore, Argyll; Killin, I'erthshire; Great Island, Cork; Killarney, Kerry; Castlebar, Mayo. 
Var. pulposulum Nyl, ex Cromb. in Journ. Bot. xii. p. 147 (1874). - Thallus scattered or but little developed, with small lobes. Apothecia numerous, small or large and irregular ; spores fusiform-oblong, 3-septate with 1 or 2 longitudinal divisions, $20-28 \mu$ long, $7-10 \mu$ thick.-Leight. Lich. Fl. ed. 3, p. 19. Colleme pulpusuluin Nyl, in Act. Soe. Linn. Bord. r. p. 59 (1864).

Exsice. Johns. n. 281.

Differs from the species chiefly in the larger spores.

$H a b$. On old walls in shady places. $-B . M$. Near Cirencester, Gloucestershire, anıl Blackhall Rocks, Durham (maritime).

6. C. concinnum Flot, in Linniea xxii. p. 361 (1849) d xxiii. p. 157 (1850).--Thallus rather small, orbicular, lobed, olivebrown or dark-grlaucous-green, the lobes round or variously cut and narrow, more or less ascending or depressed. Apothecia submorlerate in size, plane, reddish, with entire margin; spores

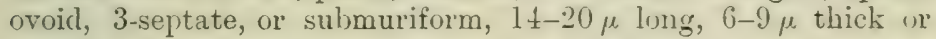
larger.-Cromb. in Journ. Bot. xx. p. 272 (1882).

Exsicc. Larb. Lich. Hb. without a number.

A somewhat indefinite species midway between C. pulposum and C. tencex, differing from the former in the flatter lobes, from the latter in the more superficial apothecia.

$H_{u b}$. On rocks and wall-tops in maritime districts.-Distr. Local and rare in S. W. England, N. Wales and W. Ireland.-B. M. Near Penzance, Cornwall; Barmouth, Merioneth; Achnanure Ciastle, Galway.

7. C. tenax Sm. Engl. Bot. t. 2349 (1\&11).-Thallus thickish, dark-greenish or bluish-green, lubed, the lobes imbricate, roundish and obtuse, or crenate and subpalmate ( $\mathrm{I}+$ reddish). Apothecia moclerate in size, innate, reldish, with an entire margin often becoming larger and irregularly convex; spores oroid or oblong, ;3-septate, with a longitudinal septum, 18-2.5 $\mu$ long, $7-10 \mu$ thick. -Hook. in Sm. Engl. Fl. v. p. 209; Mudd Man. p. 39. C. 1 Mlposum var. tenax Cromb. Lich. Brit. p. 4 (1870); Leight. Lich. Fl. p. 19 ; ed. 3, p. 19 . Lichen tenax Swartz in Nov. Act. R. Sur. sici. Ups. iv. 1). 29 (178t). Enchylinut tencec S. F. Gray Nat. Arr, i. p. 397 (1821).

Eivier. Larb. Lich. Hb. n. 201 ; Leight. 11. 10.) as C. limoxum; Iudd n. 1.

Closely allied to the preceding, differing chiefly in the habitat, and in the more spreading thinner erenate or palmate lobes, which are often of a glaucous colour.

Hub. Among mosses on rocks and on the bare grommd in inliand distriets.-Distr. Rather rare throughout Englind, S. Wales, s. and W. Highlands of Scotland and in W. Ireland,- D. Mr. Luecombe, Isle of Wight; Ardingly locks, Hurstpierpoint and Litsthm. Sussex; near Ightham, Iient; Peigite, Surrey; Mendip, Somersetshire; St. 
Tincent Piocks, Bristol; Hathrop Castle and near Circncester, Glouestershire; Cranley, Herefordshire; near Bewiller, Claines and near Malvern. Worcestershire; Twrford, Leicestershire; Pentremaer; Oswestry, Shropshire; near Brigsteer. Westmorelant; Ashr, Cumberland; near Arton. Clevelami, Yorkshire; Killin. Perthshire; Kylemore, Connemara, Galway.

Tar. coronatum Ioerb. Parers. Lich. p. 413 (1s6.) $)$ - Thallus rather thimner ant more appressed; apothecia superficial, plane or slightly convex, with sulventire margin, often large, confluent and wrinkled.-Cromb. in Journ. Bot. $\mathrm{xx}$. p. 272 (1882). C. pulposum var. cristatum Ach. Lich. Univ. p. 632 (1810); Mudd Man. 1) 39 pro parte. C. 'ristrtum Hook. in Sm. Engl. Fl. v. p. 20s (18:3.3) (non Hofm.) ; Tayl. in Nachar Fl. Hib. ii. p. 108. Liehen previllus migricans de. Buddle Hort. Sice. ii. fol. 6, n. 10 in Hert). Floane. Livhemoirtes foliis pritosis mussimibus, obscure virentibus Dill. in Ray Srn. ed. 3, p. 74, n. 68 (17.2t). Lichennides gelatimasm folies imbricatis et cristatis Dill. Hist. Musc. p. 140, t. 19, figs. 26 a, b, d (1741). Lichen cristatus Huds. Fl. Angl. p. $4 t 7$ (1762); Lightf. Fl. Scot. ii. p. 821 ; With. Arr. ed. 3, iv. p. 75.

Exsice. Johns. n. 4 ; Leight. n. 106.

Distinguished chiefly by the more appressed lobes. The apothecia as a rule are larger and more wrinkled, but that character is often nearly approached in the species; sometimes they appear as if crowned by the thallus.

Hub. On the gromel and on walls in maritime and inland districts. -Distr. General throughout the British Islands.-B. M. Amberley, Sussex; near Claverton, Somerset; Ross. Hereford; near Malrern, Torestershire; near Shrewsbury, Shropshire; Bammonth. Merioneth; near Ayton, Clevelant. Iorlishire; Lamplugh, Cumberdant; Campie Glen, near Stirling; Apurin, Argrll; Jlackstone Bridge. Cork; Dunkerron, Kerry.

8. C. cheileum Ach. Lich. Unir. p. 6:30 (1510).-Thallus dark olive-sreen or grefnish-hlack, composed of morterate-sized lobes somewhat erect and imbricate or, in the centre, minute, rounded, crenate and overlapping: interual tissue of thallus very compact, the stoutish hyphe often emereing as rhizine, especially below the apothecial. Apothecia moclerate in size or rather larese, dark-reddish, the margin thin or often with small crenulate or stanulate lobes: spores obloms-ellipovid, :-septate,

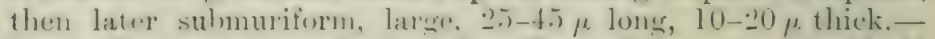
Howk. Fl. seot. ii. p. 7 l a in sm. Engl. Fl. v. p. 20 s: IIudd Min. p. 40, t. 1, fier. 4: (romb. Lich. Brit. p. 6: Leight. Lich. Fl. p. 20 ; ed. 3, p. 20. Lichenoides gelutinosum atro-virens,

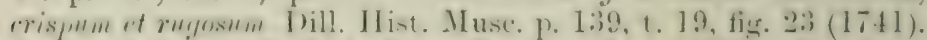

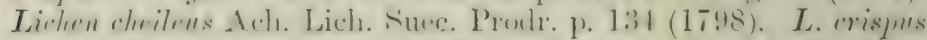

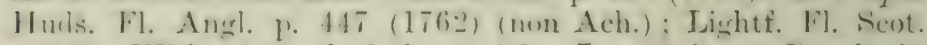
p. 820 ; With. Arr. ed. 3, iv. p. 76. L. maryinatus Bernh. in Schrad. Journ. Bot. i. p. 6, t. 1, fig. 2, a (1799); Dicks. Pl. 
Crypt. Fasc. iv. p. 25. Enchylium crispum S. F. Gray Nat. Arr. i. p. 396 (1821).

Exsicc. Mudd n. 3 ; Larb. Cresar. n. 52 \& Lich. Hb. n. 203 ; Carroll Lich. Hib. n. 40 ; Johns. n. 5.

Hudson's name Lichen crispus has priority, but it has been emploverl for another Collema. There is considerable variation in the form of the lobes, but usually it may be recognized br the minute overlapping central lobes and the more expanded ones at the circumference, as well as by the rhizine. The Nostuc chains are frequently broken up into groups somerhat like those of Synechollastus multipartitus. Above all, it is distinguished, when fertile, by the very large spores.

Hab. On the mortar of old walls, rarely on calcareous roclis, chiefly in inland situations.-Distr. General and usually common in the Chamnel Islands and most parts of Great Britain and Ireland.-P. If. Ouenvais, Jerser; near Tentnor and Shanklin, Isle of Wight; St. Minver, Comwall; Rottingilean and Falmer, Sussex; Reigate Hill, Surrey; Walthamstow and Saffron Wallen, Essex; Bathampton Downs, Somerset; near Cirencester, Gloucestershire; Oalser; IVilts; Cradley and near Malrern, Worcestershire; near Oswestry and near Shrewsbury, Shropshire; Caer Leon. Mommouthshire; near Barmouth, Merioneth; Milton and near Cullesilon, Oxfordshire; Thetford, Norfolk; Ayton and Pinchingthorpe, Cleveland, Yorkshire; Kendal, Westmoreland; Arlecton and near Whitehaven, Cumberland; near Darlington, Durham; near Erlinburgh ; near Glasgow; Appin, Argyll ; Fillin, Perthshire; near Aberdeen; Fort William, Invermessshire; Irallow and near Cork; near Kylemore, Galway; Clare Island, Mayo.

Form nudum Leight. Lich. Fl. el. 3, p. 20 (1879).-Thallus paler in colour with somewhat broader naked lobes, the smaller lobes undeveloped.-Cromb. M[onour. i. p. 50. C. crispum var. nudum Schær. Enum. Lich. p. 257 (1850) nomen.

Hab. On the mortar of old walls.-Distr. Somewhat scarce in S. and W. England, S. and W. Highlands of Scotland and S. Ireland. - B. M. Near Torquay; Little Danny, Sussex; near Cirencester; near Farlow. Shropshire; Ben Lawers, Perthshire; Fillarney and Dunkerron, Kerry.

Form monocarpum Cromb. in Journ. Bot. xii. 1. 334 (18it) it Ionosr. i. p. J0.-Thallus with minute lobes or ahmost whliterated, and visible chietly round the apothecia.-Leight. Lich. Fl. edl. 3, p. 20 ; var. munocurynin Cromb. in Journ. Bot. xii. p. 147 (1sit). Conllema menorarpum Duf. ex Nyl. Syn. Lich. i. p. 111 (1858).

Hab. On the mortar of old walls, rarely on calcareous rocks in maritine arid inland sitnations. - Distr. Searce in S. and S. IV. England. -E. M. Shamklin, I. of Wight; Hastings and Glynde, Sussex; near Cirencester, Gloucestershire.

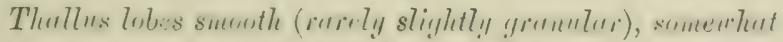
erect and crowided.

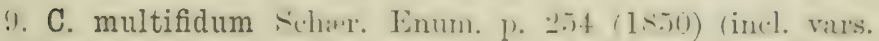

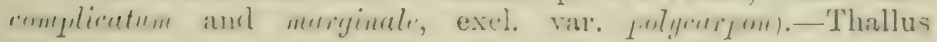


greenish-or olive-black, generally orbicular in outline, with deeply cut lacinia, rarely granular, the lohes narrow or somewhat broad, often crowded and imbricate, more or less erect at the marnins, crisp and crenate or lacerate ( $I+$ wine-red in thin section). Aprothecia small to morderate in size, sessile or somewhat prominent, on or near the margins of the lobes, reddish-brown or blackish, the thalline margin entire or crimped or brealing into granules; spores oroil, 2-3-septate, irregularly muriform, 21-27 $\mu$ long, 9-11 $\mu$ thick -C. melænum Ach. Lich. Univ. p. 636 (1810) (incl. var. marginale) ; Hook. Fl. Scot. ii. p. 71 (1821); Grer. Fl. Edin. p. 350; Mudd Man. p. 37 ; Cromb. Lich. Brit. p. 5 if Journ. Bot. xii. p. 334 (1874) (incl. f. murginole of f. complicatum); Leight. Lich. Fl. p. 19 (incl. var. complicatum); ed. 3, p. 20 (incl. f. moryincte and var. complicutum). C. marginale Hook. in Sm. Engl. Fl. v. p. 210 (1833); Tayl. in Mackay Fl. Hib. ii. p. 109. C. muriculutum var. pinfuescens Xyl. in Flora lv. p. 353 (187.) \& lxvi. p. 534 (185:8); Cromb. in Journ. Bot. xi. p. 133 (1873); Leight. Lich. Fl. ed. 3, p. 17. Lichenoides yclotinasum fuscum, Jacobaes maritima dicisuru Dill. Hist. MIusc. p. 140, t. 19, fig. 25 (1741). Lichen multifirlus Scop. Fl. Carns. p. 396 (1772). L. matginatis Huds. Fl. Angl. ed. 2, p. 534 (1778); With. Arr. ed. 3, iv. p. 34; Engl. Bot. t. 1924. Enchylinm maryinale S. F. Gray Nat. Arr. i. p. 397 (1821).

Exsicc. Croall n. 604 ; Johns. nos. 43, $28 \%$.

The thallus is rery dark-coloured when dry, with crowded, rather thin lobes, and often rather wide-spreading. The margins of the lobes are often deeply lacerate-crenate and sometimes bordered with minute outgrowtbs. The apothecia are generally numerous, their position exactly on the margin-a distinguishing character of f. muryinuliis not constant.

$H a b$. On calcareous rocks and walls in maritime and inland district.-Disir. Probably general, though somewhat uncommon, throughout the British Islands.-D. M. Near Torquay, Deronshire; Minorheer, I'enbrokeshire; I'entregaer, near Oswestry, Shropshire; Llangollen and Wrexham, Denbigh ; near Buxton, Derbrshire; near Settle, Yorkshire; near Tendal, Westmoreland; near Alston and Lamplugh, Cumberland; Teesdale, Durham; Island of Lismore and Appin. Arerll; Glen Tilt. Fillin, Ben Lawers and Craic Tulloeh, T'erthshire; Jiraenar, Aberdeenshire; Gairloch. Rossshire; Mitlleton, Cork; Dunkerron, Kerry; Loughcooter, Galway.

Var. jacobæifolium Schar. Enum. 1. 25. -Thallus more deeply laciniate, the lobes radiate, pimnatifid, narrow and canaliculate, the margins crisp and lacerate. Apothecia marginal, with

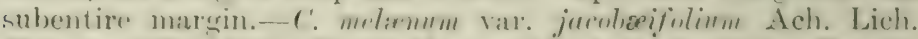

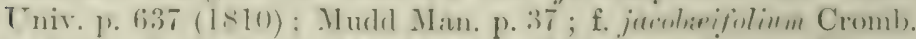

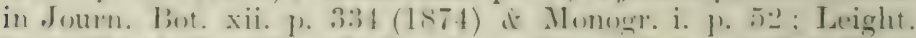

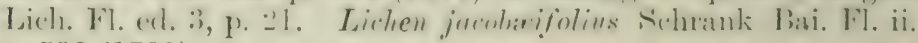
p. $530(1789)$.

Exsice. Larb. Lich. Causar. n. 2. 
Differs from the species in the narrower raliating lobes. British specimens are rarely fertile.

$H a b$. On calcareous rocks in maritime districts.-Distr. Local and rure in the Channel Islanis and $\rightarrow$. England; not ret foumd clisewhere.-B. M. Quenrais, Jersey; I. of Wight.

Tar. gyrosum A. L. Sim.-Thallus of crowderl upright complicate lohes, crisp and crenate and often bordered with granules. Apothecia scattered, marginal, the thalline margin entive or slightly sranulate.-C. melenuin var. myrosum Ach. Lich. Univ. p. 638 (1510) ; f. gyrosm Cromb. in Jumn. Bot. xii. p. 334 (1sit) \& Monogr. i. p. 52; Leight. Lich. Fl. ed 3, 1. 21. Lichen !)yัus!s Ach. Lich. Suec. Prodr. p. 135 (1798).

The crowded undulate lobes all about the same height give a grrose appearance to the thallus. The apothecia are very rave in a fully developed condition.

Hat. On the ground among calcareous rocks in inland situations. -Distr. Local and scarce in Central England and among the Grampians. Scotland.-B. M. Near Buxton, Derbyshire; Craig Tulloch, Blair Athole, Perthshire.

10. C. hypergenum Nyl. in Flora lix. p. 23.2 $(1876)$.- Thallus dark-greenish or blackish, the lobes short, upright or spreading, with crisp crenate margins ( $I+$ wine-red to crimson in thin section). Apothecia marginal or submarginal, crowded, moderate in size or rather large, the dise reddish or dark-brown, the margin entire, sometimes excluded; spores broadly fusiform, 2-3-septate and muriform, $26-36 \mu$ long, $10-16 \mu$ thick.-Cromb. in Grevillea v. p. 25 (1876); Leight. Lich. Fl. ed. 3, p. 21. C. melronum subsp. hyperyenum Cromb. Monogr. i. p. 52 (189t).

Exsicc. Johns. n. 284.

Closely allierl to the precerling, differing chiefly in the larger spores, and from $C$. cristatum in the entire margin of the apothecium.

$H a b$. On calcareous rocks in inland districts.-Distr. Rare in X. England and W. Ireland.-B. M. C'umberland; Tullywhee Bridge, Galway.

11. C. cristatum Hoffm. Deutschl. FI. ii. p. 101 (179.)).Thallus intricately laciniate, olive- or blackish-green, the lnbes short, crowcled, undulate and crisp, the margins dentate or crenate $(\mathrm{I}+\mathrm{red})$. A pothecia rather large, plane, reddish-bruwn, the margin becoming crenulate; spores broadly fusiform, :3-septate and irregularly muriform, $26-3+\mu$. long, 10-1 $2 \mu$ thick. - Ticherr. Enum. p. 25.) (150); Cromb. in Journ. Bot. xii. p. 334 (15it); Leight. Lich. Fl. erl. 3, p. 22-2. ('. sulpplirntite Tyl. ex Cromb. in Journ. Bot. xii. p. 147 (1874) (non Nyl. in Flora lviii. p. 297$)$.

Closely allien to the two precerling species, differing chietly in the more deeply eut margins of the lobes, the lamer later apotheriat, and the larger spores. 
Hab. Among mosses on old walls, rocks, and on the gromed in maritime and inland districts.-Distr. Fiather rare in W. England, WV. Hichlands, Scotland, and in W. and S.WV. Ireland.-B. M. St. Michael's Tor, Devon; near Cirencester, Gloncestershire ; I. of Lismore and Appin, Argyll; Killin and Craig Tulloch, Perthshire; Killarney, Kerry; Castlebar, Mayo.

\section{Thallus lobes granular.}

12. C. granuliferum Nyl, in Flora lviii. p. 103 (1875).Thallus dark-olive-green or blackish, imbricate-lobate, the lobes firm, usually somewhat crowded, erect in the centre and sprinkled with globose isidiose granules, beneath often longitudinally wrinkled when dry ( $\mathrm{I}+$ red in section). Apothecia moderate in size, slightly concare or plane, the thalline margin acute or becoming subcrenate and granular; spores oroid, 3-septate, sometimes with 1-2 longitudinal septa, rather largre, 21-32 $\mu$ long, 8-12 $\mu$ thick.-Cromb. in Grevillea iii. p. 191 (1575); Leight. Lich. Fl. ed. 3, p. 21 (incl. forms meizolubum and minor). C. pulposum var. yranulatum Mudd Man. p. 38 (1861). C. flacritum var. mirrolubum Nyl. ex Carroll in Journ. Bot. vi. p. 100 (1868) fide Crombie; Cromb. Lich. Brit. p. 5. C. sulpplicatile form meizolobum Nyl. ex Cromb. in Journ. Bot. xii. p. 333 (1874).

Exsice. Johns. n. 165 ; Larb. Lich. Hb. n. 204.

Distinguished from C. mulposum by the larger lobes and especially by the globose granules with which these are often entirely corered. The apothecia are rare. Crombie (Monogr. i. p. 50) states that this species also was incluted in Lichen gramulatus of older British authors.

Ifab. On calcareous walls and rocks, rarely among mosses on the ground.-Distr. I'robably general and common throughout Great Jritain and Ireland.-B. II. Shanklin, I. of Wight; St. Minver, ('ornwall; Plymouth, Flburton, Paignton, Ogwell and near FirgsInilge, Devon; Jathamp̨ton Downs, Weston-super-Mare and Cheilda: (1lifis, Somerset; Halnalier, Sussex; Leigh Wooks, near J Jristol, Glonecstershire; T'enby, l'embrokeshire; Heamuris, I. of Anglesen; near Tuxton, Derhyshire; Safiron Walien, Wssex; near Whitehaven, Cunlerland; Appin, Arroll; Killin and lien Istwers. I'erthshire; near Fort Willim, Invernesshire; Killarney, lierry; near liylemore and Recess, Connemara, Galway.

13. C. crispum Ach. Sin. Lich. 1, 311 (1k14).-Thallus dark bluish-ereen or lorownish-hiack, lobate, the lobes granular and crowded, someshat ereet in the eentre, depressed and more dilated at the cireumference, the lareer lobes with granular. renate margins (I + reddish). Apothecia molerate in size or beroming expanded and larger, plane, redelish or dark-red, with wranular-erenate maroin: speres overil, usually 3-septate and irregularly muriform, $16-21 \mu$ long, $7-11$ p thick. - liorr. in Engl. Bot. Suppl. t. 2716, fig. 1; Hook. in Sm. Engl. Fl. v.

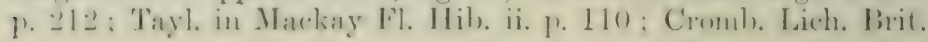


p. 4 ; Leight. Lich. Fl. p. 21 ; ed. 3, p. 19. Lichen crispus Ach. Lich. Suec. Prodr. p. 126 (1798) (non Huds.).

Exsice. Johns. n. 282 ; Larb. Lich. Hb. n. 202 ; Leight. n. 346 ; Mudd n. 2.

Differs from the preceding in the gramular margins of the lobes and of the apothecia. The central lobes are usually crowded and erect.

Hub. Among mosses on gravelly soil and on the tops of old walls, chiefly in inland districts.-Distr. 'Somewhat scarce in the Channel Islands, Great Britain and Treland.-B. M. St. Minver, Cornwall; St. Lawrence and Sandown, I. of Wight; near Torguay, Devon; The Downs and Falmer, Sussex; Bathampton Downs, Wilts; near Cirencester, Gloucestershire; Sandwich, lient; Cradley, near Malvern, Worcestershire; Runton, Norfoll; Redcar and Cotham Marshes, Cleveland, Yorkshire; Appin, Argyll.

Subsp. ceranoides Nyl. ex Cromb. in Grevillea xr. p. 12 (1886) (incl. f. cristatulum). - Thallus dark-green or brownishblack, lobate, the lobes rather dilated upwards, with coarsely granular or proliferous margins, subimbricate and erect in the centre, flatter and more entire at the circumference ( $I+$ reddish). Apothecia rather large, plane, reddish or dark-red, the margins subentire or partly granular; spores ovoid, 3-septate and muriform, 17-25 $\mu$ long, 7-9 $\mu$ thick.-C. ceranoides Borr. in Engl. Bot. Suppl. t. 270t, fig. 2 (1831). Hook. in Sm. Engl. Fl. v. p. 209; Mudd Man. p. 41 pro parte; Cromb. Lich. Brit. p. 6 ; Leight. Lich. Fl. p. 23. C. pulposum var. ceranvides Cromb. in Journ. Bot. xii. p. 333 (1874) ; Leight. Lich. Fl. ed. 3, p. Is. C. crispum var, cristatulum Nyl. ex Cromb. in Journ. Bot. xii. p. 334 (1874) ; Leight. Lich. Fl. ed. 2, p. 468 ; ed. 3, p. 20.

Exsicc. Johns. n. 164.

Distinguished from the species by the proliferous margins of the longer lobes and by the almost entire margin of the apothecium. It is rarely fertile.

$H a b$. On cretaceous or calcareous soils, on walls, and sometimes on shell-sand in maritime and inland districts.-Distr. Rare in the Chamel Islands and in S.W. and N. Englind.-D. M. I. of Herm; st. Minver, Cornwall; Babbicombe Downs, Anstey's Cove, Torquay and near Seaton, Devon; near Brighton, The Dorms, Inalnaker, Joxgrove and Pottingdean Cliffs, Sussex; Sundwich, Kent; Shiere, Surrey; Jathampton Downs, Somerset; near Irristol and near Cirencester. Gloncestershire; Malvern, Worcestershire; Windsor Great Park, Jierks; Madingley, Cambridgeshire; Cahler Bridge, Cumberland; near Redear, Cleveland, Yorkshire.

14. C. granosum Schere. Enum. p. 25:3 (1850) (excl. var. mromides). Thallus membranacerus, of rather larese lobes, which are irregularly laciniate, renate, and somewhat inbricate in the centre, more or less gramular, dull ghaucous-green or olive-brown $(\mathrm{I}+$ blood-red in thin section). Apothecia moderate in sizt, lnight 
or elull rerlilinh-brown, scattererl, sessile, eoncare, hecoming nearly plane, with entire margin: laraphyses slender, free but conglutinate abrove in a yellow mucilage; spores 8 in the ascus, broarlly fusiform or ovoirl, 3-septate with one or more cells longitudinally seytate, $22-27 \mu$ long, 10-15 $\mu$ thick.-C. dermutinum Ach. Lich. Univ. 1) 648 (1810)? Borr. in Fngl. Bot. Suppl. t. 2716, tig. 2 (two upper figs.) (1831); Hook. in Sm. Engl. Fl. r. p. 212; Mudd Man. 1) 36. C. anriculatum sulssp. granosum Nyl. ex Cromb. in Grevillea xv. p. 11 (1886) \& Monogr. i. p. 43. Lirlenoides gelatinosum atro-virens, aurirulatum et granosum Dill. Hist. Musc. p. 140, t. 19, fig. 24 (1741). Lichen ymosns Scop. Fl. Carn. ed. 2, ii. p. 397 (1772) ; Wulf. in Tacq. Coll. iii. p. 131, t. 10, fig. 2 (1789). L. grammlutus Huds. Fl. Angl. ed. 2, 1, 536 (1758) pro parte; With. Arr. ed. :3, iv. p. 73 (non Engl. Bot. t. 175\%). Lextenginm dermutimmu Leight. Lich. Fl. p. 29 (1871); ed. 3, p. 32.

Characterized by the large laciniate subcoriaceous granular loles. Collema granosum has been taken to represent the speeies as being of earlier dite than $C$. auriculatum. There is some confusion as to the identity of Lichen gramulatus Huds. with Lichen granosus. Both of then are baserl on the plant collected and described by Dillenins, which was determined by Crombie as identical with this species (MIonogr. i. p. 43), though in an earlier publication he had referred it to C. furvum (Journ. Linn. Soc. xvii. p. 566 (1880)).

$H a b$. On calcareous rocks and walls.-Distr. Local and scarce in S. and Tr. England, X. Wales and S.W. Ireland.-B. M. Pornings, Sussex; Chudleigh, Devon; Chedilar Cliff's and opposite St. Y'incent's Rocks, Bristol, Somersetshire; Pentragaer, Oswestry, Shropshire; Llangollen, Denbighshire; N. Wales.

Var. auriculatum A. L. Sm.-Lobes of the thallus rather larger, somewhat imbricate, irregularly curved and hent, rounded and crenate, but not inciserl and laciniate, otherwise as in the species. - Crillemu arrirulutum Hoffim. Deutschl. Fl. ii. p. 98 (1795): Cromb, in . Tourn. Bot, viii. p. 96 (1<70); Leight. Lich. Fl. 1 . 21 ; ed. :3, 1) 17 (excl. var. pinguescens) ; var. mumbrunueru Krempelh. Lich. 11. Bay. p. 92 (1861) ; f. memlranaren Cromb. in Journ. Jsot. xii. p. 333 (187.) ; Leight. Lich. Fl. exl. 3, p. 17. C. dermatimum Borr. in Engl. Bot. Suppl. t. 2716, fig. 2 (lower fig.).

Eixsice. Johns, n. 202.

Distinguisher from the species by the latger more shell-lilie auriculate lobes which are often wrinkler and densely covered with isidiose granules.

Hab. On rocks and old walls, chiefly calcareous, Distr. Local and searee in W. Central and N. Lingland, X. Wales, S. Wr. Highlands

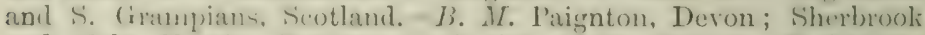
and Cole Heath, linxton, Derbyshire; Grassington, Forkshire; Keswick and Asheill lonce, Alston, Cumberland; Appin, Argsll; Killin, P'erthshire. 
15. C. furvum Ach. Lich. Univ. p. 650 (1\&10).-Thallus rommlly lobed, more or less granular on both sides, dark greenish-brown or olive-black, the lobes entire, usually undulate and crisp, somewhat ascendant in the centre, appresserl at the circumference ( $\mathrm{I}+$ blood-red when dry). Apothecia morlerate in size, scattered over the lobes, plane, brown, the margin entire; spores ovoid or ellipsoid, 3-septate, becoming irregularly muriform, 18-24 $\mu$ long, 9-11 $\mu$ thick.-Hook. Fl. Scot. ii. p. 72 ; Mudd Man. p. 36 ; Cromb. Lich. Brit. p. 5 ; Leight. Lich. Fl. p. 24 ; ed. 3, p. 17 ; C. gramulatum Hook. in Sm. Engl. Fl. v. p. 211 (183:3); Tayl. in Mackay Fl. Hib. ii. p. 110. Lichenoides getutinosum lobis crassioribus fusen-viridibus Dill. Hist. ALuse. p. 13: t. 19, fig. 22 (1741). Lichen furvus Ach. Lich. Suec. Prodr. p. 132 (1798). L. gramulatus Sm. Engl. Bot. t. 1757 (1807) (non Huds.). Lathagrinim furvum S. F. Gray Nat. Arr. i.p. 400 (18:21). Exsicc. Cromb, n. 102 ; Johns n. 204.

Distinguished from the preceding by the somewhat darker apothecia and by the presence of granular isidia on both surfaces of the lobes. The thallus differs from that of Synechoblastus rupestris in the narrower lobes and in the reaction with iodine.

Hab. On rocks and old walls, chiefly calcareous, rarely on the ground.-Distr. Widely distributed though somerhat uncommon.B. MI. Ditcham and Torquay, Devon; Woolsonbury, Bognor and Poynings, Sussex; East Barnet, Midullesex; Marlborough, Wilts; Whalthamstow and Chingford, Essex; Rodmorton and near Cirencester, Gloucestershire; Ludlow, Shropshire; Garregwn rocks, Denbighshire ; Frosterley, Durham; near Alston and near Whitehaven, Cumberland; Trirkby Lonsdale, Westmoreland; Appin, Argyll; Killin and Blair Athole, Perthshire; Clare Island, Majo.

Form tunæforme Cromb. in Journ. Bot. xii. p. 333 ( $1 \leqslant 74)$.Differs from the species in the longer more deeply inciserl lobes. Collemu tunaforme Ach. Syn. Lich. p. 322 (1814); Hook. in Sin. Fug. Fl. v. p. 211 ; Mudd Man. p. 36. Lichenoides gelutinosum foliis latioribus tuniformibus Dill. Hist. Musc. p. 142, t. 19, fig. 29 A, B. Lichen tunxeformis Ach. Lich. Suec. Prodr. p. 13: (1798); Dicks. Pl. Crypt. Fasc. iv. p. 25 (1801).

Hab. On calcareous rocks and walls.-Distr. Rare in W. and N. Englani, S.TW. Highlands, Scotland, and S.WW. Ireland.-B. M. Near Winson, Gloucestershire; Aberdover, Merioneth; Teestale, Durhinn; I. of Lismore, Argyll ; Dunkerron, Kerry.

25. SYNECHOBLASTUS Trer. Caratt. tre nuor. gen. Cullem. Partora 1853; Komb. Syst. Lich. Germ. p. 411 (18.50); Mudd Man. p. 42. Lathargriem S. F. Gray Nat. Arr. i. p. 399 (1 -2) pro parte. (Pl. 25.)

Thallus variously lobed, gelatinous when moist, without rhizina, more or less appressed to the substratum, non-corticated. Algral cells Nostor distributed equally thromgh the thallus (homesomerous). Apothecia with a thalline margin; spores 8 in 
the ascus, elongate-fusiform or acicular, pluriseptate, colourless, Spermogrones with septate sterigmata and pleurogenous minute spermatia.

Differs from Collema in the form and structure of the spores.

\section{Thallus of narrow smooth lobes; on calcareous substrata.}

1. S. polycarpus Dalla Torre is Sarnth. Flecht. Tirol. p. iт.) (190:).- - Thallus rather small, radiate-lobate, appressed, clarksreen or reddish-black, the lobes narrow, short, complicate and somewhat erect in the centre, more expanded and flattened at the circumference (I+purplish-red). A pothecia small, numerous, becoming somewhat convex, dark-red or blackish, the margin thin, entire: spores oblons, or broadly fusiform, 3- rarely 5-septate, 18-:7 $\mu$ long, 6-7 $\mu$ thick. Coillemu multifirlum var. jollywarjon S'char. Lich. Helr. Spic. p. 532 (184:). C. stygimm Del. ex Schrer. tom. cit. p. 544? Cromb. in Journ. Bot. xi. p. 132 (1873) it xii. p. $33 t(1874)$; Leight. Lich. Fl. ed. 3, p. 23. C. polyecryom Koerb. Parerg. Lich. p. 417 (1865); Cromb. in Journ. Bot. xi. p. 133 (1873) ; xii. 1. 334 (1874) \& Monogr. i. p. 53 ; Leight. Lich. Fl. ed. 3, p. 22.

Exsice. Cromb. n. 103 ; Johns. n. 285 ; Iarb. Lich. Hb. n. 1.

Easily known by the small apothecia which are very prominent and abundant. The name $C$. stygium is doubtful.

Hub. On calcareous rocks and walls in inland hilly district:Distr. Tare in W. England, S.WT. Highlands, Scotland, and N. IT. Ireland.-B. M. Cleve Hill and Cheddar Cliff, Somerset; Sinipton and near Cirencester, Gloucestershire; Lathhill and Buxton, Derbyshire; W. Torkshire; near Fiendal, Hevenham Head and Levens, Westmoreland; Appin, Argyll; Kylemore, Galway.

2. S. Laureri Flot. ex Koerb. Syst. Lich. Germ. p. 414 $(1.5 .5)$.- - Thallus decply laciniate, smooth, or slightly roush, the lobes somewhat dilated and rouncled, crowded, imbricate and undulate in the centre, more or less spreading at the circumference, the margins erect and nearly entire (I + redelish when (lry). Apothecia rather small, plane, redelish-hrown or clark-red, the marcin entire or slightly crenate: spores linear-obloms, chtuse, i-septate, 20-24 $\mu$ long, 5-6 $\mu$ thick.-S. romplientus. Murlel Man. 1). 44, t. 1, fig. (i (1861). Collema Lumeri Nyl. ex Croml, in Jomm. Lint. xi. p. $13: 3$ (187:3) : xii. p. 334 (18it) i Monogr. i. p. 54 ; Leight. Lich. Fl. ed. 3, p. 22.

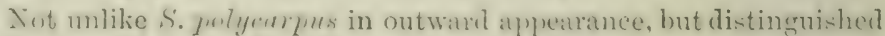
by the broad lobes and by the obtuse spores.

Hab. On limestone walls, rare.-B. M. Teestale, Durham (the only British locality).

¿. S. multipartitus Muld Man. 1. 1:3.-- Thallus laciniatemaliate, somewhat ohicular, the lobes multifiel, narrow, rather 
convex, undulate and twisted, divided and dirergent at the apices, olive-brown or -black. Apothecia moderate in size, plane or convex, dark-redclish, the thalline margin thickish, becoming thimner, entire or sometimes crenulate; paraphyses stoutish, septate; spores cylinclical, straight or curved, usually 3-septate, the cells variously guttulate, $28-48 \mu$ long, $4-7 \mu$ thick. Collema multipartitum Sm. Eugl. Bot. t. 258-2 (1814) ; Hook. in Sim. Engl. Fl. v. p. 210; Tayl. in Mackay Fl. Hib. ii. p. 108 (excl. var. fluvintil.); Cromb. Lich. Brit. 1). 7 \& Monogr. i. p. 56 ; Leisht. Lich. Fl. p. 26 ; ed. 3, p. 24.

Exsicc. Bohl. n. 70 ; Johns. n. 6.

The thallus lobes radiate from a common centre or they are broken up and form irregular patches. The Nostoc chains are frequently congested as in Collema cheileum, but chains of cells are also present.

$H a b$. On shady calcareous rocks in maritime and inland districts. -Distr. Not very frequent throughout Great Britain and in S. and IV. Ireland.-B. M. Mendip Hills, near Yatton and Cleve Hill, Somerset; Barnsley Park, Cirencester, Gloucestershire; Nant Glym and Llangollen, Denbighshire; near Kendal, Orton Scar, Haversham Head anil Cunswick Scar, Westmoreland; Lamplugh, Cumberlaud; near Settle, Iorkshire; Teesdale, Durham; Achosragan Hill, Appin, and I. of Lismore, Argyll; shores of Loch Tay and Ben Lawers, Perthshire; Middleton, near Cork; O'Donoghue's Prison, Kenmare and Killarney, Kerry; Kylemore, Galway; Louisburgh, Mayo.

\section{Thallus of upright tufted lobes; on trees.}

4. S. fascicularis A. L. Sm.-Thallus rather small, lobate, the central lobes erect, in tufts, dilated upwarcls, those at the circumference more spreading and somewhat crenate, brownishgreen or dark-green (I+blood-red). Apothecia small, numerous, crowderl on the tips of the tufted lobules, at first concave, then convex, redclish, with a thin almost obliterated margin, sjores fusiform, 3- (sometimes 1-) septate, 16-29 $\mu$ long, 4-6 $\mu$ thickS. conglomeratus Mudrl Man. p. 43) (1861). Lirhenoides yelatinosum palmatum, tuberolis conglomeratis Dill. Hist. MIusc. p. 141, t. 19, f. 27, A, B (1741). Lichen fascicularis L. Mant. ed. 2, p. 13:3 (1767); Lightf. Fl. Scot. ii. p. 841; Huds. Fl. Angl. ed. 2, 1. 536 ; With. Arr. ed. 3, iv. p. 76 ; Engl. Bot. t. 1162. Cullemu congloniriatum Hoffm. Deutschl. Fl. ii. p. 102 (1795); Cromb). Lich. Irit. p. 6 : Leight. Lich. Fl. p. 2:) C fuscirulare Ach. Lich. Univ. p. 6:39 (1810) ; Hook. Fl. Scot. ii, p. 71 is in sin. Engl. Fl. p. 210; Cromb, in Journ. Bot. xii. p. $334(1874)$ it Monogr. i. p. 56 ; Leight. Lich. Fl. ed. 3, p. 24. Eimluylimu fasciculare S. F. Gray Nat. Arr. i. p. 398 (1821).

Easily recognized by the central fasciculate lobules willening from a common stalk-like base.

Hub. On the trunks of old trees in wooded, generally upland, districts.-Distr. Local and not plentiful in S. and W. England and Highlands of Scotland.-B. M. St. Leonard's Forest, Heeding, Hen- 
field and Tunbridge Wells, Sussex; near Barmouth, Merioneth Nant Glyn, Denbighshire; Ambleside, Westmoreland; Clova, Forfarshire; Aberfeldy, Kenmore and Loch Earn, Perthshire.

\section{Thallus of rather large granular lobes; mostly on irees.}

5. S. nigrescens Anzi Catal. Lich. Sondr. p. 4 (1860).Thallus thinnish, large and spreading, more or less orbicular, almost monophyllous, roundly lobed and radiately wrinkled and plicate, with a few smooth erect secondary lobes at the centre, the larger lobes of the circumference depressed, with entire or slightly crenate margins, and sometimes densely isicliose-granulose ( $\mathrm{I}+$ reddish when dry). Apothecia numerous, crowded, small, plane, becoming convex, reddish, the margin thin, entire: spores fusiform-cylindrical, pluriseptate, 34-42 $\mu$ long, $5 \mu$ thick.MIudd Man. p. 42, t. 1, fig. 5. Muscus licheniformis membromecens nigrimes drc. Buddle Hort. Sicc, ii. fol. 6, n. 11 in Herl). Sluane. Lirhenoidrs saxatile membranacenm gelatiuosum tenue, nigrescens Dill. in Ray Syn. ed. 3, P. 72, n. 53 (1724). Lirhenoiles gelatinosum membranacentm teme nigricans Dill. Hist. Musc. p. 138, t. 19, fis. 20 (1740). Lirhen nigresens Huds. F]. Angl. p. 450 (1762); With. Arx. erl. 3, iv. p. 74 ; Engl. Bot. t. 345. L. vespertilio Lightf. Fl. Scot. ii. p. 840 (1757). Collema nigpesens Ach. Lich. Univ. p. $6+6(1810)$; Hook. Fl. Scot. ii. p. 71 it in Sim. Jingl. Fl. v. p. 211; Grev. Fl. Edin. p. 350 ; Tayl. in Mackay El. Hib. ii. p. 110 ; Cromb. Lich. Brit. p. 6 \& Monorr. i. 1. jt; Leight. Lich. Fl. p. 24; ed. 3, p. 24. Lathagrium nigrescens S. F. Gray Nat. Arr. i. p. 399 (1821).

Exsicc. Cromb. n. 104 ; Dicks. Hert. Sicc. Fasc. xi. n. 22 ; Johns. n. 361 ; Larb. Lich. Cresar. n. 53 ; Leight. n. 104.

I)istinguished by the radiate folds of the usually larese preading thimish thallus, and by the small crowed apothecia. It was likened by Dillenius to a "bat's wing "; hence Lightfoot's designation.

Hal. On the trunks of old trees, chietly poplars and willows in woorled districts.-Dist). Generial and not uncommon throughout the Initish Isles, chiefly in westem regions.-B. M. Noimont, Rozel, St. ()wen's Ihay, St. I'eter's and Jeleroute J3ay. Tersey; near Fivde; ('arishooke Castle and Shauklin, I. of Wight; Withiel, near I'enzance, linconnoc and linan Minor, Cornwall; Lidford, 'Totnes, l'aignton, Toryua, Jiolt Head, Sidmouth and Cornworthy, I)evon; Frairlight (ilen, Hastingr, Henficld, Damny, Sudlleseomb, Jeeding and ('hyton, Sussex; liemble, near Cirencester. Gloucestershire; Stackpole Court, I'embrokeshire; Aberdorey, Merioneth; Jettw-y-Coed, C'arnarvonshire; Barrow IIill, Malrem and liroadwas. Worcestershire: J.evens. Westmoreland; near Guishoro', ('leveland. Yorkshire ; near Galloway, Kirliculbrightshire; Glen Lochy and Jarealdine. Argyll ; l)en of Glanis, Forfarshire; near callemer, (blen Lochay and

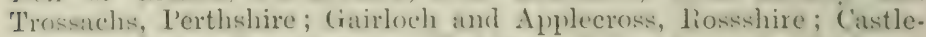
martyr, Cork; l'owerscourt, Wicklow; Killarney and Muckross, Kerry; Louisburg, Mayo. 
6. S. aggregatus Th. Fr. Lich. Arct. p. 280 (1860).-Thallus rather small, somewhat rigid, lobate and irregularly plicate, thes lobes rather short, sometimes crenate, or often granular and crisp at the margins ( $\mathrm{I}+$ redi). Apothecia small to moderate in size, crowderl, plane, becoming convex, redllish or dark-red, the margin thin, entire or becoming granular; spores 8 (rarely 6 ) in the ascus, fusiform-cylindrical, straight or curved, pluriseptate, 33-65 $\mu$ long, 3-5 $\mu$ thick.-. Indd Man. p. 4:3. Lichenoirles yelatinosum palmatum tuberculis romglomerutis Dill. Hist. Musc. p. 141, t. 19, fig. 27 B (1741). Coilema fasciculare var. aggregatum Ach. Lich. Univ. p. 640 (1810). C. afygrefgatum Nyl. in Mém. Soc. Sci. Nat. Cherb. ii. p. 318 (1854); Cromb. Lich. Brit. p. 6 \& Monogr. i. p. 55 ; Leight. Jich. Fl. p. 26 ; ed. 3, p. 25. Enchylinu fusciculure var. aggregutum S. F. Gray Nat. Arr. i. p. 398 (1821).

\section{Exsice. Cromb. n. 105.}

Distinguished from the preceding, to which it is closely allied, by the smaller thallus with short, irregularly wrinliled lobes, and by the longer spores. The apothecia, when present, are crowded, and are also somewhat larger and more irregular in form.

$H a b$. Among mosses on the trunks of old trees in wooded inland tracts.-Distr. Rather rare in S.W. and N. England, N. Wales, the TV. Highlands of Scotland and S.IV. Ireland.-B. .T. St. Leonard's Forest and Henfield, Sussex; New Forest, Hants; Tunbridge Wells, Kent; near Barmonth, Merioneth; Ingleby, Cleveland, Yorks; New Galloway, Kirkcudbrightshire; Barcaldine, Argyll; near Fillin and Aberfeldy, Perthshire; Loch Limnhe, Invernessshire; O'Sullivan's Cascade and Muckross, Killarney, Kerry.

7. S. rupestris A. L. Sm.-Thallus broadly lobed, smooth or partly covered with blackish isidiose granules, dark-green or greenish-brown, the lobes rounded, entire, rather wavy, limp and flaccid when moist. Apothecia moderate in size or rather small, scattered over the t:allus, concave then plane, or somewhat convex; paraphyses rather slender, conglutinate above: spores fusiform-elongate, 3-5-sejtate, $23-2 \pi \mu$ long, $7-10 \mu$ thick.S. flureidus: Kuerb. Syst. Lich. Germ. p. 413 (1855) : Mudd Man. p. 42. Lichen ingestris Swartz Meth. Nuse. p. 37 (1781) (excl. Syn. Dill) : With. Arr. ed. 3, iv. p. 76 . L. Haccidus Ach. in K. Vet. Acad. Handl. xvi. p. 14, t. 1, fig. 4 (1795). Collemu flurcitum Ach. Lich. Univ. p. 647 (1810) pro parte ; Engl. Bot. t. 1653 ; Hook. Fl. Scot. ii. p. 72 \& in Sm. Engl. Fl. v. p. 211 ; Tayl. in Mackay Fl. Hib. ii. p. 110 ; Cromb. Lich. Brit. p. 5) \& Monogr. i. p. 44 ; Leight. Lich. Fl. p. 35 ; ed. 3, p. 23. Lrithergrim flucerdum A. F. (iray Nat. Arr. i. p. 400 (1821).

Exsice. Johns. n. 241 ; Leight. n. 345.

Easily distinguisher by the spore characters and in a sterile condition by the large entire granular lobes.

$\mathrm{Hab}$. On old walls, rocks and trunks of trees in shady places in inland districts.-Distr. General and common where it occurs 
throughout Great Britain and Irelant.- - . M. Boconnoc, Camelford, St. Minver and Looe, Cormmall; near I'lymouth, near Plymstock, Fingsherswell, Cockington, near Torduay, near Treston Mills, and Totnes, Deron; I. of Wight; l'vecombe, Sussex; Gopsal, Leicestershire; near Worcester and Malvern. Worcestershire; Barmouth, Dolyelly and Llyn Gremau. Merioneth; Nant Grymant, Camarronshire; Anglesea; Rievaulx, Yorlishire; near Kendal and Windermere, IVestmoreland; Feswich, Cumberland; New Galloway, Firlicudlirightshire; Ting's I'ark, Filinburgh; Barcaldine, Argyll; Killin, Tienmore, Tímnoul Hill and Craighall, Perthshire ; Lochaber, Invernessshire; Applecross, Rossshire; Millow, Cork; Blackwater Bridge, Kerry.

26. LEMMOPSIS A. Zahllor. in Engler of Prantl Nat. Pflanzenf. i. 1\%, p. 171 (1906). Leptogium sect. Lemmopsis Wainio Lich. Brésil i. p. 221 (1890). (Pl.26.)

Thallus effuse, thin, granular-crustaceous, corticated. Algal cells Nostoc. Apothecia sessile on the thallus, with a proper margin; spores ellipsoid, colourless, simple.

The corticated thallus agrees with that of Lrpfogium, but the habit of the genus, and the spore characters are different.

1. L. Arnoldiana A. Zahlbr. 1. c.-Thallus effuse, thin, granular-crustaceous, scattererl, olive- or dark-brown. Apothecii small, somewhat prominent, with a proper margin, reddish or dark-red, the margin paler ; paraplyyses slencler, septate; spores ellipsoid with granular oily contents, rather large, $17-20 \mu$ long, $5-7 \mu$ thick; liymenial gelatine slightly bluish then pale winered with iodine.-Pliysmu Ammldicenn Hepp. ex Arn. in Flora xli. p. 94 (1858). Collemopsis Ainoldinna Nyl. in Flora lvii. p. :30.5 (1874); Cromb. in Journ. Bot, xir. p. 3.59 (1876) it Monosr. i. p. 79 ; Leight. Lich. Fl. ed. 3, p. 36.

Usually forming a thin dark-coloured cruat on the stones; the waxy-looking apothecia are usually numerous and distinctive.

Hab. On calcareous stones in shady inland situations.-Distr. Apparently local and rare in S. and W. England.-D. M. Cowcombe Wood near Chalford, Gloncestershire; Gomshall and shiere, Surrey.

2. L. oblongans A. I. Sm.-Thallus effuse, thin, minutely Emanular, and continuous, brownish-olive.' Apothecia small, reddish or yellowish-red, the margin rather thick and connivent ; paraphyses slender: spores oblong, clongate, simple (ur spuriously i-septate), 16-30 $\mu$ long. $6-7 \mu$ thick; hymenial gelatine faintly bluish then lightly wine-red with iodine.-

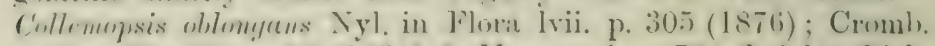

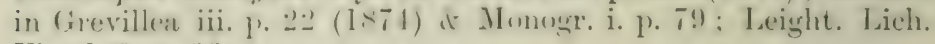
Fl. ed. 3, p. 36.

liesembling the previons speries in the structure of the thallus. but lighter in colour and with larger spores.

Ifah. On the gronum in shaty arevioes of limestone rockis.-B. M. Haverbrack Hill, Westmorelaud (the only locality). 
3. L. leptogiella A. I. Sim.-Thallus effuse, coralloid-areolate, composed of extremely minute upright norlulose or irregular branchlets, with a well-developed cortex, dark olive-brown. Apothecia minute, slightly margined, brownish- or yellowish-red, the disc rather concave or at length almost plane; paraphyses slencler, discrete or partially coherent, very slightly thickened at the tips; spores oblong-ellipsoid, $10-17 \mu$ long, $5-7 \mu$ thick; hymenial gelatine greenish-blue then tawny wine-red with iodine. -Collemopsis leptogiella Nyl. in Flora lx. p. 2:0 (1877); Cromb. in Grevillea vi.p. $18(1877)$ \& Monogr. i. p. 80 ; Leight. Lich. Fl. ed. 3, p. 36.

The leptogioid structure and the Nostoc alga leave no doubt as to the inclusion of this species in Lemmopsis. The apothecia are numerous on the specimen, but difficult to detect.

$H a b$. On quartzose shady rocks. $-B$. M. Kylemore, Comnemara (the only locality).

27. LEPTOGIUM S. F. Gray Nat. Arr. i. p. 395 (18:21). Collema sect. Leptogium Ach. Lich. Univ. p. $65 t$ (1810). Collemodium Nyl. ex Lany in Bull. Soc. Bot. Fr. xxv. p. 341 (1878); Cromb. Monogr. i. p. 57. Scytenium S. F. Gray Nat. Arr. i. p. 398 (1821). Mallotium S. F. Gray tom. cit. p. 399 ; Mudd Man. p. 44. (Pl. 27.)

Thallus more or less gelatinous when moist, lobate, the lobes minute and almost granular or large and spreading, corticated. Algal cells Nostoc distributed through the thallus or sometimes zoned. Apothecia with a thalline margin of plectenchyma; paraphyses simple, conglutinate; spores 8 in the ascus, variously elongate, blunt or pointed at the ends, septate and muriform, colourless. Spermogones with septate sterigmata and minute pleurogenous spermatia.

Differs from Collema in the corticate thallus, a very distinct character in some species, in others difficult to distinguish, especially in some of those included by Nylander in the genus Collemorlium. As a rule the thallus is less swollen than in Collcma, the lobes being often very thin.

\section{A. Cortical cells somewhat indistinct (Collemodium). Growing on trees.}

1. L. fragrans Cromb. Lich. Brit. p. \& (1870) (excl. syn. Mudd Man. p. 46). - Thallus composer of small nodulose lobule's, generally crowded in cushion-like masses or effuse and coarsely granular-areolate, the lobules erect, crenate, somewhat dilated and appressed at the circumference, dark-green or olive-brown. Apothecia small, numerous, crowded, concave, reddish-brown, the margin entire, paler; spores ovoid-ellipsoid, 3-5-5eptate and muriform, 16-28 $\mu$ long, $8-11 \mu$ thick.-Leight. Lich. Fl. I. 30. pro parte; ed. 3, 1. 30. L. microplugllnim Leight. Lich. Fl. ed. 3. 
p. ¿26 (1кт9). Lirlerne frograms Sm. Engl. Bot. t. 1912 (1808). Collemu microply llum Ach. Lich. Univ. p. 630 (1810); Borr. in Engl. Lot. Suppl. t. 2721 (1531): Hook. in Sim. Engr. Fl. v. 1. 207: Mudd Man. 1) 41 ; Cromb. Lich. Brit. p. 6; Leight. Lich. Fl. p. 22. C. fragrans Ach. Syn. Lich. p. 311 (1814); Huok. in Sm. Engl. Fi. v. p. 20s. Enchylium mirropluyllum s. E. Gray Nat. Arr. i. p. 396 (1821). E. fragrans S. F. Gray 1.c. Collemodinm mirrmpleyllum Nyl. ex Lamy in Bull. Soc. Bot. Fr. xxx. p. 337 (18.3) : Cromb. in Grevillea xт. p. 12 \& Monogr. i. p. 58.

Exsicc. Larb. Lich. Hb. n. 2 \& Lich. Crar. n. 3 ; Leight. n. 258 .

The cellular cortex is mostly somewhat indistinct. The fragrance from which it obtainer its specific name was accilental (see Borrer l. с.).

$H a b$. On the trunks of old trees, chiefly ash and elm, in shady situations.-Distr. Not uncommon in the Channel Islands and throughout England, not recorded from Scotland or Ireland.-B. M. St. Brelade's Bay, Jersey ; Lyndhurst, New Forest, Hants ; Southwick, near Lewes, Henfield, Hurstpierpoint, Glynde, Damny and Wiston, Sussex; Copthall and Gosfield Hall, Essex; Claines, Torcestershire; near Ostrestry, Shropshire; near Bury, Suftolk; Wimpole P'ark, Cambridgeshire; Ingleby Park, Cleveland, Yorkshire; Leven's Park, Kendal, Westmoreland.

\section{Growing on rocks or soil.}

2. L. biatorinum Leight. Lich. Fl. erl. 3, p. 2.) (1ء79).Thallus effuse, very minutely papillate-lubate, imbricate, brown or brownish-green. Apothecia minute, innate, brown or reddish, with a thickish pale entire margin; spores ovoid, 3-4-septate, hecoming sparingly muriform, 25)-30 $\mu$ long, 11-12 $\mu$ thick.Collema biutorimum Nyl. in Act. Sónc. Linn. Bord. sér. 3, i. p. 268 (1856); Carroll in Journ. Bot. ir. 1) 22 (1866): Crumb. Lich. Brit. p. jo it in Joum. But. xii. p. $335 \overline{5}$ (1874); Leight. Lich. Fl. 1. -21. Collemantinm biatorinum Syl. ex Cromb, in Grevillea xx. p. 12 (1886) \& Monogr. i. 57.

Exsice. Johus. 11. 44 ; Larb. Lich. Hb. n. 282.

Distinguisherl by the waxy-looking, somewhat fryalectr-like apothecia, which are irenerally immersed in the thallus. The thallus cosers the sulsstritum with a thin lobulate blackish semf. The lobules are indistinctly cellular.

Hab. On cretaceous soil and the mortar of old walls in damp plawe matrime and inlanl.-Distr. L'lentiful where it oceurs in the

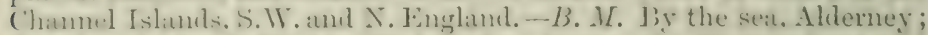
Bunchurch, I. of Wight; Wadebridge, ('ormwall; Woolsonbury and

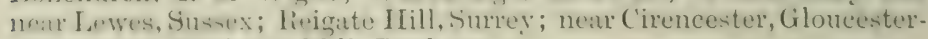
shire; near Winlaton Mill, Durham.

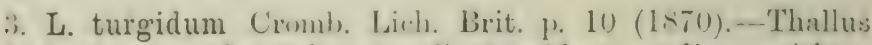
thickish, lobate, the lubes small, turgil, ascending, with at

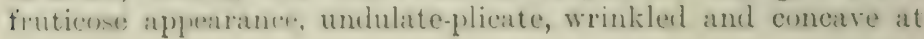


the circumference, sometimes densely isicliose-granulose, dark. olive or reddish-black. Apothecia usually numerous, moderite in size, concave, becoming sumewhat plane, reddish- or darkbrown, the thalline margin turgid, entire or sometimes slightly granular; spores oblons-ovoid, 3-septate and muriform, $233-32 \mu$ long, 10-12 $\mu$ thick.-Leight. Lich. Fl. p. 28 ; ed. 3, p. 33. Collemu turgidum Ach. Lich. Univ. p. 634 (1810); Hook. in S.sm. Engl. Fl. v. p. 209 ; Mudd Man. p. 38. Enchylium turgidum S. F. Gray Nat. Arr. i. p. 396 (1821). Collemodium turyidum Nyl. ex Lamy in Bull. Soc. Bot. Fr. xxv. p. 342 (1878); Cromb. in Grevillea xv. p. 12 \& Monogr. i. p. 61 (incl. var. derpressum, a growth form, Cromb. 1l. c.).

Exsicc. Leight. n. 257 ; Larb. Lich. Hb. n. 42.

The smaller firmer lobes and the presence of isidia distinguish this species from L. plicatile and Collema pulposum, which have a similar habitat. The crowdedly branched appearance is especially noticeable in dry plants. Sometimes the thallus (on calcareous stones) is rery scanty and in scattered lobules.

Hab. On limestone and brick walls, also on calcareous and cretaceous soil.-Distr. Somewhat rare throughout England, rare in S.TV. Highlands, Scotland, not recorded from Ireland.-B. M. Near Shanklin, I. of IVight; Wadebridge, Cornwall; Plymouth, Deron; Tangmere, Lewes, Aldbourne and near Hastings, Sussex; Chelsfield, Kent; Reigate Hill and Shiere, Surrey; Chew Magna, near Bristol, Cleve Hill and near Yatton, Somerset; Charfield and near Cirencester, Gloucestershire; Sevenhampton, Wilts; near Shiffnall, Shropshire; Barrington Hill and Malvern, Worcestershire; Tetsworth, Osfordshire ; Gorleston, Suffolk; Appin, Argyll.

4. L. fragile Nyl. in Mím. Soc. Sci. Nat. Cherb, v. 1. 333 (1857).--Thallus small, laciniate or nodulose, the lobes crowded in a roughly granular crustose manner or somewhat racliate, convex and crenate at the circumference, dark olive-green or brown. Apothecia rather rare, minute, concare, becoming plane. clark-brown, the margins entire, thickish; spores ovoid, variously septate and muriform, about $29 \mu$ long, $13 \mu$ thick.-Croml. Lich. Brit. p. 7 ; Leight. Lich. Fl. p. 36 ; ed. 3, p. 27. Collema frugile Tayl. in Mackay Fl. Hib. ii. p. 109 (1836); Mudd Man. p. 37. Collemodium fragite Nyl. ex Cromb. in Grevillea xv. 1. 12) (1886) \& Monogr. i. p. 59.

The cellular cortex is crushed in cross section and not easily seen. In some instances the thallus is like a much stouter $L$. cretrerum, in others the radiating stellate licinixe recall Collema multipartitum. Apothecia are sparingly present.

$H a b$. On calcareous rocks in maritime and inlind district. - D is $/ r$. Tare in S. and N. England and in S.W. Ireland.-B. M. Anstey's Core, Torquay, Deron; Barrownouth, Cumberland; Dunlierron. lierry.

5. L. plicatile Nyl. (x Cromb. in Journ. Int. xii. 1'. :336; $(187.4)$ (incl. f. minor). - Thallus of thickish upight or sprealing 
plicate lohes, slishtly wrinkled, often crisp at the margins and more or less manular. Apothecia scattered, rather small, concave or plane, reddish-brown, with a thick entire persistent margin; spores ovoirl, 3-septate and muriform, 18-30 $\mu$ long, 8-16 $\mu$ thick.-Leight. Lich. Fl. ed. 3, p. 30 (incl. f. minor). Lichenoides gelatinosum atro-virens, anviculatum et granosum Dill. Hist. DIusc. p. 140, t. 19, figs. 24 B-D (1741). Lichen plicutilis Ach. in K. Vet. Acad. Handl. xvi. p. 11, t. 1, fig. 2 (1795). Collema plicatile Sim. Engl. Bot. t. 2348 (1812) ; Hook. in Sm. Engl. Fl. v. p. 209 ; Mudd Man. p. 38 ; Cromb. Lich. Brit. p. 5 ; Leight. Lich. Fl. p. 22. Enchylium plicatile S. F. Gray Nat. Arr. i. P. 397 (1821). Collemortinm plicatile Nyl. ex Lamy in Bull. Soc. Bot. Fr. xxx. p. 337 (1983); Cromb. Monogr. i. p. 59 (incl. f. minus).

Exsice. Cromb. n. 106.

Distinguished by the very thick plicate often granular lobes, hence Nylander's name L. firmum (Lich. Scand. p. 34 (1861)). There is a thin inconspicuous cellular cortex. The lobes are sometimes rather thinner (f. minus).

$H a b$. On calcareous rocks and walls, rarely on trunks of trees, in maritime and inland districts.-Distr. Somewhat scarce in S.W. England, rare in WV. Highlands of Scotland and S. W. Ireland.-D. M. Tpton, Bablicombe and Plymouth, Devon; Shoreham, Beeding, Aldbourme and Lewes, Sussex; near Maidstone, Kient; near Cirencester, Gloncestershire; Mendip Hills, Somerset; Marlborough, Wilts ; I. of Lismore and Appin, Argyll; near Kenmore, Ardtully and Dunkerron, Kerry.

Var. hydrocharum A. L. Sm.-The thick rigid lobes more spreading and depressed, greyish or glancous-grey.-Parmelin liydrochare Ach. Meth. p. 222 (1<03). Collema julpesum f. hydrorharum Cromb. in Journ. Bot. xii. p. 333 (1\&74) ; Leight.

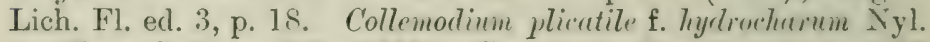
in Flora lviii. p. $302(1875)$; Cromb. in Grevillea xv. p. 12 (1886) \& Monogr. i. p. 60.

Hab. On damp calcareous rocks.-B. M. Craig Tulloch, Perthshire.

6. L. fluviatile Cromb. in Journ. Bot. xii. p. 336 (1874).Thallus laciniate-lobate, thin or thickish, the lobes oblong, somewhat uneven in outline, flexuous and folded, simple or proliferous, greyish-green or dark greyish-glaucous. Apothecia small, subinarginal, prominent, somewhat concave or plane, dark-red, with a paler entire margin; spores ellipsoid, usually 3-septate, hecomning muriform, $16-23 \mu$ long, $7-9 \mu$ thick.-Leight. Lich. Fl. ed. 3, p. 32. Lirhenoides grlatinosum on mutiovides Dill. in Ray. syn. ed. 3, p. 72, n. 58 (1724). Lirhenurdes gelotimesum folies angustionilus tunerformilus Dill. Hist. Musc. p. 142, t. 19, f. 28 (174). Lirlen flucintilis Jluds. Fl. Angl. ed. 2, p. 536 (17Ts); With. Arr. ed. 3, iv. p.97 : Engl. Lot. t. 2039. Collema fluciatile (errore fluciele) Ach. Syn. p. $31+(1814)$; Hook. in Sm. Engl. F. ง. [1. 209; Mudd Man. P. 40; Cromb. Lich. Brit. p. 5; 
Leight. Lich. Fl, 24. C. multipmitum var. fluxintile Tare, in Mackay Fl. Hih. ii. p. 109 (1536). Euthylimm fluciale S. F. Gray Nat. Arr. i. 1. 397 (1 -21). Collementium Anciutile Nyl. ex Cromb. in Grevillea xv. p. 12 (1886) \& Nonogr. i. p. 60.

Distinguisher from $L$. plicntile by the thimer more extended lobes, and by the habitat. Very few of the British specimens are fertile. Collema vivulare Ach. Syn. Lich. p. 326 (1814) is partly identical with this species. The lobes of a specimen from Lanark in $\mathrm{Hb}$. Borrer have hairs on the under surface. The cellular cortex is often indistinct.

$H a b$. On moist rocks and boulders in streams mostly in upland situations. -Distr. Rave in $\mathrm{W}$. and $\mathrm{N}$. England, N. Wales. S.W. and Central Scotland and S.IT. Ireland.-B. M. St. Minver. Cornwall; East Lyn River, Devon; River Elwy; Denbighshire; Snowdon, Carnarronshire; Falls of the Clyde near Lanark; near Leven, Fifeshire; River Isla near Ruthen Wood, and Loch Earn, Perthshire; Ardtully, Kenmare, Kerry.

\section{Cortical cells more fully developed (Eu-Leptogium).} Thallus gramular; growing on rocks or mortar.

7. L. glebulentum Nyl, ex Cromb. in Journ. Bot. xx. p. 272 (1882).-Thallus thickly isidiose, with small subentire or lacerate lohes at the circumference, olive-brown or blackish. Apothecia and spermogones unknown. Collemodium glebulentum Nyl. ex Cromb. in Grevillea xv. p. 12 (1886) \& Cromb. Monogr. i. p. 61.

Of doubtful position owing to the absence of fructification. The isidia are in thick cushion-like masses. The cellular cortex is mell developed.

$H a b$. On moist limestone rocks in alpine localities. $-B$. M. Abore Loch-na-gar, Ben Lawers, Perthshire; Craig Grue, Braemar, Aberdeenshire.

8. L. rhyparodes Nyl. in Flora xlviii. p. 210 (186.)).-Thallus diffuse, thin, furfuraceous or granular and unequal, cracked, brownish-red or blackish-brown ( $\mathrm{I}+$ wine-red). Apothecia small, at first concave, becoming plane, with the marmin excluded, reddish-or brownish-black; spores oroid, septate and muriform, 20-3s $\mu$ long, 11-16 $\mu$ thick.-Carroll in Jourin. But. iii. p. $2 \times 7$ (1865); Croml, Lich. Brit. p. 7 ; Leight. Lich. Fl. p. 35 ; ed. 3, p. 26. Collema psorellum Nyl. in Flora xlviii. p. 602 (1865); Carroll in Journ. Bot. iv. p. 2.2 (1866) ; Cromb. Lich. Brit. 1) , o in Journ. Bot. xii. p. 33.) (1sit): Leight. Lich. Fl. p. 26.

The thallus sometimes spreads extensively and is occiationally almost evanescent. On moist shady rocks the thallus is less developerd (Collema psorellum).

Hab. On schistose rocks in subulpine and alpine localities. - Distr. Local and rare among the S. Grampians, Scotlimt.-B. If. Craifir Calliach, above Loch-na-gar and the summit, Ben Lawers, and Gilen Lyon, Perthshire. 
9. L. humosum Nyl. in Mém. Soc. Sci. Nat. Cherb. p. 90 (185i) if Syn. Lich. i. p. 119 (1858).--Thallus effuse, consisting of closely aggregate lobulate granules mostly small with larger sranules intermixed, brown or brownish-black. A prothecia small, somewhat concave, black; spores 4 to 8 in the ascus, ovoid, or bhlong-ovoid, variously septate and muriform, 20-34 $\mu$ long, $8-16 \mu$ thick.-Cromb. in Journ. Bot. xxiii. p. 195 (1885).

Distinguished by the coarsely granular, very dark thallus. Nylander has included with this species Leptogium tetrasporum Th. Fr. in Vet. Akad. Förh. 1864, p. 276 (see Crombie Monogr. i. p. 65).

Hab. On mortar of walls.-B. M. Port Gorey, Island of Sark (the only British locality).

\section{Thallus of small lobes; growing on soil, mortar, etc.}

10. L. pusillum Nyl. in Mém. Soc. Sci. Nat. Cherb. v. p. 90 (1857) \& Syn. Lich. i. p. 121.-Thallus effuse, papillate-lobate, the lobules erect, crowded, olive- or greenish-brown. A pothecia swall, concave then plane, somewhat prominent, becoming darkreddish, the margin concolorous; spores ovoid or broadly fusiform, 3-4-septate and muriform, 18-.30 $\mu$ long, 8-10 $\mu$ thick.Cromb. Lich. Brit. p. 7 ; Leight. Lich. Fl. p. 30 ; ed. 3, 1. 27.

Exsicc. Larb. Cæsar. n. 54.

Somewhat similar to $L$. biatorinum in the appearance of the thallus, though more developed and more densely papillate, but chiefly distinguished from it by the darker-coloured superficial apothecia.

Hab. On mortar of old walls and on chalky soil.-Distr. I.ocal and rare in the Channel Islands and S., W. and N. England.D. M. St. Brelade's Bay, Jersey; St. Peter's Port, Guernsey; Bonchurch, I. of Wight; Shiere, Surrey ; Freshford, near Bath, Somerset; Cheltenham, Stroud, Cowcombe, Chedworth Woods and near Ciren. cester, Gloucestershire.

11. L. tenuissimum Kioerb. Syst. Lich. Germ. p. 419 (1855).Thallus effuse, of deeply cut or crenate thin lacinise congested into a clense crust, olive- or brownish-green. Apothecia moderate in size, deeply concave, becoming somewhat plane, embededed among the laciniae, reddish-brown, the margin pale, thickish; spores wovid or oblong, generally narrower at the ends, 3-5-septate and muriform, 18-3f $\mu$ long, 11-13 $\mu$ thick.-Mude Man. 1.46 ; Cromb. Lich. IBit. 1. 7 ; Leeight. Lich, Fl. p. 35: exl. 3, p. 26. Lirlien trmissimus I)icks. Pl. Crypt. fase. i. p. 12, t. 2̈, fig. \& (1785): With. Arr. ed. 3, iv. p. 6i : Engl. Bot. t. 1427. Collomu

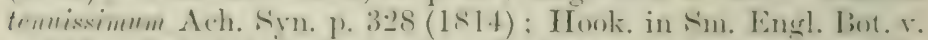
1. 213. Polyrhidium temuissimmm S. F. (iray Nat. Arr. i. 1. 401 (1821).

E.xsicc. Mudd n. 4.

Jistinguished from other soil species by the pulvinate srowth of the thallus. The alotheciat are rather large with age, but they remain 
immersel, and the margin is generally fringed by the lacinie. Not to be confused with $L$. lacerum var. pulvinatum, which has brouder lacinix and superficial apothecia.

Hab. On the ground among mosses and short grass in maritime and inland districts.-Distr. Rare throughout England, Scotland and Ireland.-B. M. Sandown and near Shanklin, I. of Wight; near Penzance, Cornwall ; Twineham and near Hastings, Sussex; Writtle, Essex; near Yarmouth, Suffolk; near Norwich, Norfolk; near Easby, Cleveland, Yorkshire; New Galloway, Kirlicudbrightshire; near Cramond, Edinburgh; Appin, Argyll ; Ben Lawers, Perthshire; Middleton, Cork.

12. L. subtile Nyl. in IĹ́m. Soc. Ści. Nat. Cherb. v. p. 90 (1857:--Thallus effuse, composed of minute lacinire, deeply divided or granular-crenate, dark- or brownish-green. Apothecia very minute, superficial and pale-brown or reddish, darker when dry, the margin thin, entire, pale-brown; spores ovoid, 3-5-septate and muriform, 20-23 $\mu$ long (or longer), 8-10 $\mu$ thick.-IIudd Man. p. 46 , t. 1, fig. 8 ; Cromb. Lich. Brit. p. $\delta$; Leight. Lich. Fl. p. 31 ; ed. 3, p. 29. Lichen subtitis S'chrad. Spicil. Fl. Grerm. p. 95 (1794) ; Dicks. Pl. Crypt. fase. iv. p. 25 ; Engl. Bot. t. 1008. Collema subtile Ach. Syn. p. 328 (1814); Hook. in Sm. Engl. Fl. v. p. 213 ; Tayl. in Mackay Fl. Hib. ii. p. 111. Poly. chidium subtile S. F. Gray Nat. Arr. i. p. 401 (1821).

The thallus is normally appressed to the soil, and the laciniate character difficult to see clearly. It is distinguished by the persistently minute apothecia and by the usually rather small spores.

$H a b$. On clay soil, on cretaceous stones in the ground, rarely on the roots of old trees in inland districts.-Distr. General though not very common throughout the British Isles.-B. M. The Grove, Jersey ; Luccombe and Shanklin, I. of Wight; Withiel, Cornwall; near Henfield and near Tunbridge WVells, Sussex; near Wootton-under-Edge, near Cirencester, Gloucestershire; Folliestone, Kent; Shiere, Surey; near Hale End, Epping Forest, Essex; Colwall. Herefordshire; Tilton Hills, Leicestershire; Pembrolieshire; near Ayton, Cleveland, Yorkshire; Sunnyhow, Cumberland; Dunkerron, Kerry.

13. L. amphineum Nyl. Lich. Scand. p. 32 (1861)...Thallus thin, unequal, agglutinate, crustaceous, appressed to the substratum, hluish- or brownish-green. Apothecia small, pale or reddish, becoming darker, concave, becoming plane, with at distinct entire margin; spor'es ellipsoid or ovoid, 3-septate and muriform, $2: 3-2 \overrightarrow{7} \mu$ long, $9-11 \mu$ thick.-Cromb. in Journ. Bot. xi. p. 133 (1873); Leight. Lich. Fl. ed. 3, p. 26. Collema amphineum Ach. ex Nyl. l. c.

scarcely to be distinguished from the precenting except by the more agrintinate-crustaceous thallus and by the apothecia becoming somewhat larger.

Hub. On the gromed, rately on roots of old trees in shaty plices. -Dist. Foumd only sparingly in S. and W. Engramd. B. M. Newlyn Cliff, Penzance, Cornwall; Henfich, Sussex; Newbury. Worcestershire; Wooton-under-Edge, Gloucestershire. 
14. L. minutissimum Fr. Summ. Veg. p. 122 (1546); Koerb. Parer. Lich. p. $4: 3$ (1565). - Thallus thin, minutely lolate, the lobes imbricate, more or less deeply crenate, olive-or bluish-green or brownish. Apothecia superficial, minute, concave, reddishbrown, with a paler thin entire margin; spores oblong-ovoirl, 5-septate and irregularly muriform, $21-30 \mu$ long, 9-1.5 $\mu$ thick. -L. frotgrans Mudd Man. p. 46 (1861) (non Cromb.); Leight. Lich. Fl. p. 30 pro parte. L. lacerum var. crenatum Nyl. ex Carroll in Journ. Bot. iv. p. 22 (1866). L. simuatum var. cremulatum Nyl. ex Cromb. in Journ. Bot. xii. p. 336 (1874); Leight. Lich. Fl. ed. :3, 1. 30. L. subtile f. latiusenlum Nyl. ex Joshua in Grevillea iv. p. 43 (1875) (errore flatinsenhmu) ; Leight. Lich. Fl. ed. 3, p. 29. Collema mimutissimum Flarke Deutsch. Lich. `. p. 14 (1819). C. firmmens Tayl. in Mackay Fl. Hib. ii. p. 107 (non Hook.).

Allied to L. subtile but differing in the more dereloped thallus and the persistently large spores. It looks somewhat like a miniature $L$. lacerum. The apothecia are numerous and crowded and extremely regular and dainty in appearance.

$H a b$. On the gromd, rarely on trunks of old trees in inland districts.-Dist. Scarce in S.W., Central and N. England and in S. Ireland.-B. M. Halstead, Iient; Butler's Holt, Bucks; near Cirencester, Gloucestershire; Ayton, near Cleveland, Yorkshire; Bantry, Cork.

15. L. cretaceum Nyl. in Act. Soc. Linn. Bord. sér. 3, i. p. $270(1857)$. Thallus effuse, appressed or in small clustered rosulate lobules, or of deeply crenate minute lobes, unequal and rather crowded, olive-brown or dark-olive (I + red). Apothecia small, at first concave, becoming plane, reddish-brown, the margin entive, paler; spores ovoid, 3-7-septate and muriform, $2 \cdot 2-40 \mu$ long, 11-17 $\mu$ thick.- Nudd Man. p. 45; Cromb. Lich. Brit. p. 7 ; Leight. Lich. Fl. p. 32 ; ed. 3, p. 27. Lichen cretucens Sim. Engl. Bot. t. 73s (1800). Encleylium eretucemm s. F. Gray Nat. Arr. i. p. 398 (1521). Cullema retuerm Hook. in Sm. Engr. Fl. v. p. 210 (1833).

The rosulate lobes are very characteristic, even though often but poorly dereloperl. Sometimes the thallus is largely formed of isidiose granules.

Hab. On cretaceous and siliceous chalky nodules in moist shady inland tritets. Distr. Lather rare in the Chalk and ()olite districts of S. and W. England, probably often orerlooked.-I). W. I. of Wight; Plumpton, West l)ean. lieston and Wastham, Sussex; Jisley Common, Chedworth Woorts and near Northleach, Gloucestershire; Folkestone, Kent; Shiere, Surrey; Stoliesay, Shropshire.

16. L. diffractum Kiempelh. ex Arn. in Flora xliv. p. ojis

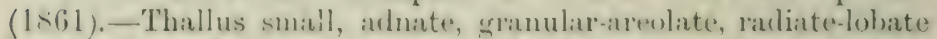
at the circumference, sranules amb lobes comvex, light or dark

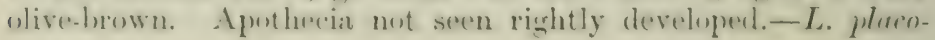


dielleum Nyl. in Flora xlviii. p. 210 (1865); Cromb. in Journ. Bot. xx. p. 272 (1882) \& Monogr. i. p. 68.

The form of the lobes is that of a minute L. fragite or L. Schrarteri; they vary from being rather narrow to slender and wiry.

Hab. On calcareous rocks in hilly districts.-Distr. Rare in W. England.-B. M. Cleve Hill, Somerset; Warton Crag, Lancashire.

17. L. microscopicum Nyl. in Act. Soc. Linn. Borrl. sér. 3, i. p. 272 (1856).-Thallus effuse, minute, of crowded erect slender nodulose branchlets, unequally rounded, somewhat constricted or attenuate at the base, dark olive-brown. Apothecia rare, minute, scattered, concave, pale-or reddish-brown, with an entire margin ; spores oroid or oblong, 3-5-septate and muriform, 2:-27 $\mu$ long, 9-14 $\mu$ thick.-Leight. Lich. Fl. ed. 2, p. 468; ed. 3, p. 34 ; Cromb. in Journ. Bot. xii. p. 336 (1874).

Exsice. Cromb. n. 7.

Considered at one time to be a form of $L$. lacerum; it is, however, distinct in the form of the thallus and in the apothecia, which were discovered by Crombie on a specimen collected at Shiere.

Hab. On the trunks of old trees and on slaty rocks, but chiefly on chalk pebbles and calcareous walls in maritime and inland districts.Distr. Local, though common where it occur's in the Channel Islands, S. and WV. England and S.W. Highlands, Scotland.-B. M. Rozel and coasts of Jersey; near Lewes, Sussex; near Gomshall and Shiere, Surrey; near Maidstone, Kent; Cheddar Cliffs, near Porlock, near Clevedon, Yatton, and Weston-super-Mare, Somerset; near Chalford, Stroud, Brinscomb and near Cirencester, Gloucestershire; St. Fagan, Glamorganshire; Malvern and Aston, Worcestershire; Blaxton, Yorkshire; Eden, TVestmoreland.

\section{Thallus of larger lobes, usually dark-brown.}

18. I. Schraderi Nyl. Syn. Lich. i. p. 133 (1855).-Thallus in crowded tufts of rather narrow elongate dichotomously branched lobes, irregularly wrinkled and somewhat angular, dilated in the middle, dull olive-green or dark reddish-brown. Apothecia rare, lateral, small, concave, reddish, with an entire paler margin; spores ellipsoid, :3-5-septate and muriform, $2: 3-33 \mu$ long, $11-15 \mu$ thick.-Mudd Man. p. 49 ; Cromb. Lich. Brit. 1. 9; Leight. Lich. Fl. p. 36 ; ed. 3, p. 34. Lichen Schraderi Bernh. in Schrad. Journ. Bot. i. p. 22, t. 2, fig. 5 (1799). Collema Schrarteri Ach. Lich. Univ. p. 6.5 (1810) ; Engl. Bot. t. 22st; Hook. in Sm. Engl. Fl. v. p. 213. Polyelidium Scluaderi s. J'. Gray Nat. Arr. i. 1. 402 (1821). Collemolinm Schmoleri Nyl. ox Cromb. in (irevillea xv. p. 12 (1\$x6) : Cromb. Monogr. i. 1) (52.).

Exsice. Larb. Lich. Hb. n. 4.

Easily distinguished by the long narrow somewhat erect crlindrical lobes which have a distinctly cellular cortex. Sometimes they are broader and occasionally very much reduced. 
Hub. Among mosses on cretaceous and calcarcous soil, rarely on the mortar of old walls, in maritime and inland situations.-Distr. General but not common throughout the British Isles.- B. M. Moulin Huet, Guernsey; Shanklin, I. of Wight; St. Minver, Cornwall ; near Plymouth, Torquay and Babbicombe, Deron; the Downs, Eartham, Woolsonbury, Oftham and Halnalier, Sussex; Shiere, Surrey ; Cheddar Cliffs and Bathampton Downs, Somerset; near Cirencester, Wyndcliff and near Bristol, Gloncestershire; near Oswestry, Shropshire; Jiller's Dile, Derbyshire; Anglesea; Appin, Argyll; Blackrock near Cork; Muckross, Killarney and Dunkerron, Kerry; Dawros, Connemara, Galway; Sheep Walk, Armagh.

19. L. sinuatum Massal. Mem. Lich. p. 88 (1853).-Thallus of rather small lobes, crowded and suberect, plicate, wrinkled, rarely smooth, crenate and denticulate at the margins, those at the circumference rather larger, dark-brown or rarely glaucousleaden-coloured. Apothecia rather small (up to $1 \mathrm{~mm}$. in diameter), concave or plane, reddish, the margin thick, entire: spores oroid or ellipsoid-fusiform, 3-septate and irregularly muriform, 21-50 $\mu$ long, 8-18 $\mu$ thick.-1Iudd Man. p. 47 pro parte; Leight. Lich. Fl. p. 34; ed. 3, p. 29 pro parte; var. rrenatum Leight. Lich. Fl. erl. 3, p. 30 (1879). L. scotimum var. crenctum Nyl. in Flora lviii. p. 106 (1855); Cromb. in Grevillea xv. p. 13 (1886) \& Monogr. i. p. 73 . Lichenoides tenue crispum, fulies parvis depressis Dill. Hist. Musc. p. 145, t. 19, fig. 33 (17+1). Lichen simuatus Huds. Fl. Angl. ed. 2, p. 535 (1Tis); With. Arr. ed. 3, iv. p. 75 ; Engl. Bot. t. 772. Collema sinuctum Hoffm. Deutschl. Fl. ii. add. to p. 104 (1795); Hook. in. Sm. Engl. Fl. v. p. 213 ; Tayl. in Mackay Fl. Hib. ii. p. 110. Lathagrine sinuatum S. F. Gray Nat. Arr. i. p. 400 (18:1). L. seritium var. simutum Malbr. in Bull. Soc. Nat. Rouen, 1\&66, p. 365 ; Cromb. Monogr. i. p. 72.

Exsicc. Cromb. n. 109 ; Johns. n. 167.

Inistinguished from the preceding by the more flattened, closely imbricate lobes and by the larger apothecia. The plant deseribed by Mrudd and Leighton and by Crombic (Lich. Brit. p. 8, as L. scotinum) includes both the species and the variety.

Ilat. Anong mosses on old walls and bouklers, chicfly in maritime and hilly regions.- Distr. Thather rare in Great Britain, chiefly in the W., rare in S. and W. Ireland- $-B, M$. Near St. Lawrence, I. of Wight; ('hagford, I)eron ; Storrington, Sussex; near Mialdon, Lissex; near' ('irencester, Gloncestershire; (ian, l)enbighshire; l'entregater, (1) westry; Teesdale, Weardale and neat Stathope, Ihuham; Jowling, [ numbartonshire; Appin, Argyll ; (ilen I'ender and lillin, l'erthshire; Iforone, Jimemar, Aberleenshire; near Forres, Elgin; Jilarner, Cork; Dunkerron, Kerry.

Form Polinieri Leight. Lich. FI. exl. :3, 1. 30 (1879).--Thallus

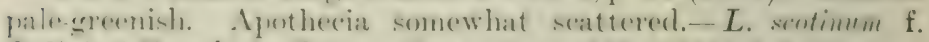

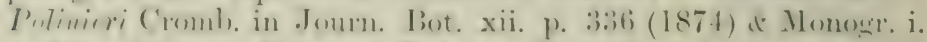
1) 72. Collema Polinieri Del. ex Nyl. Syn. Lich. i. p. 123 (1858). 
The bright-meen colour of the thallus is persistent both in a moist and dry condition.

Hab. Among mosses on shady walls, rarely on rocks.-Distr. Tery local and scarce throughout the British Isles.--D. M. Henfield, Sussex; Garn, Denbighshire ; Appin, Argyll ; Blarner, Cork; Killarney, Kerry.

Tar. scotinum Koerb. Syst. Lich. Germ. p. 419 (1:.5).-Thallus lobes rounded, entire, slightly larger than those of the species; otherwise similar.-Liclen srotimns Ach. Lich. Suec. Prochr. p. 128 (1798). Leptrigium scotinum Fr. Summ. Veg. p. 122 (1846); Cromb. Lich. Brit. p. s, pro parte \& Monogr. i. p. 71 .

\section{Exsice. Mrudd n. 6 ; Cromb. n. 109 ; Johns. n. 7.}

Hab. Similar to the species.-Distr. General and common where it occurs in Great Britain; not recorded for Ireland.--B. M. Horle Sands, Cornwall; Poynings, Sussex; Chew Magna, Somerset; near Cirencester, Gloucester; Garn, Denbighshire; Bettws-T-Coed, Carmarthenshire ; Lake Ogwen and Capel Curig, Carnarronshire; Bilsdale and Buckden, Yorkshire; High Force Inn, Teesdale, near Stauliope and Wear Valley, Durham; by the Kent, Westınoreland; Whiteharen and Alston, Cumberland; Appin and I. of Lismore, Argrll ; Irillin and Ben Lawers, Perthshire.

20. L. lacerum S. F. Gray Nat. Arr. i. p. 401 (1821).Thallus of rather large subimbricate lolses, longitudinally wrinkled, subascending, crisp and finely crenulate and denticulate at the margin, bluish lead-coloured or dark-brown. Apothecia rare, small, seattered orer the lobes, brownish or pale-red, with a thickish entire margin; spores ovoid or broadly fusiform, irregularly muriform, 34-48 $\mu$ lons, 10-16 $\mu$ thick.-Mü Md Man. p. 47 ; Cromb. Lich. Brit. p. 8 it Monogr. i. p. 69 ; Leight. Lich. Fl. 1. 32: ed. 3, p. 28. Lichenuides scixutile temue mufesmus Dill. in Ray Syn. ed. 3, p. 77, n. 89 (17:24). Liehenvides pellucirmm, molicire folies tenuilus rrispis Dill. Hist. Musc. 1). 14:3, t. 19, fig. 31 A, B. (1741). Lichen atro-creruleus, laciniatus \& ciliatus Hall. Hist. Stir). Helv, iii. p. 94 (1768). Lirlen tremmlluites Lightf. Fl. Scot. ii. p. $8 \pm 2$ (17T7) (non Linn. fil.); Hucls. Fl. Angl. edl. 2, p. 537. L. lawns Liljeblar sirensk. Flora p. :3:).5 (1792); Ach. in K. Vet. Acad. Handl. xvi. p. 18 (1795). L. Tiemellı Roth Tent. Fl. Germ. i. p. 50:3 (17Es)? With. Arr.

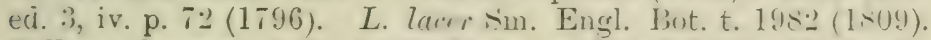
Colleme luermin Ach. Lich. Univ. 1). 65) (1810): Hook. Fl. Scot. ii. 1' $7: 2$ it in Sm. Engl. Fl. v. 1. 213 ; 'Tayl. in Mackity Fl. Hib, ii. p. 111.

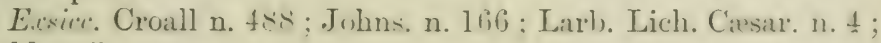
IIudd n. 5 .

Well characterized hy the lacerate marcin of the thallus; the whole plant is very thin and, when moist, subpellucid.

Hul. Among mosses on the gromd and on old walls in shaty places. 
-Distr. General though not common throughont the British Isles. - D. M. Quenvais, Tersey ; Ventuor and near Shanklin, I. of Wight; Penzance and near. Withiel, Cornmall; Buckfastleigh, Morleigh aud near Torguay, Devon; Ardingly, near Brighton, Aldrington and Arundel, sussex; Shiere, Surey; Cheddar Cliffs, Somerset; near C'irencester, Gloucestershire; Broadwas and Alfric, Worcestershire; Garn Dingle, Denbighshire ; Beammaris, Anglesea; near Cambridge; Cotteral Clough, Lancashire ; near Fiendal, Westmoreland; Feswick, Cumberland; Nulgrove Castle and near Ayton and Baysdale, Cleveland, Yorkishire; New Galloway, Kirkeudbrightshire; Reeky Liun, Forfarshire; Bracklinn Bridge, Perthshire; Appin, Argyll; Corriemulzie, Braemar, Aberleenshire; Blarney and Kilworth, Cork; Killarney and Dingle Bay, Kerry ; Connemara, Galway ; near Belfast.

Form fimbriatum Nyl. Syn. Lich. i. p. 122 (1858).-Laciniæe somewhat broader, with the margins densely fimbriate and ciliate, the cilia very much branched.-Cromb. in Journ. Bot. xii. p. 335 (1874); Leight. Lich. Fl. ed. 2, p. 468 ; ed. 3, p. 28. Lichenoides pellucidnm, entivize foliis temulues, crispis Dill. Hist. Musc. p. 143, t. 19, fig. 31, c (1741). Collema fimbrintum Hoffm. Deutschl. Fl. ii. p. $104(1795)$.

Exsire. Cromb. 11. 108 ; Johns. n. 205; Mudd n. 5 pro parte.

Scarcely to be distinguished from the species, though generally with more densely fimbriate margins of the thallus.

$H a b$. Similar to that of the species.-Distr. Recorded only from S.W. and N. England and from S. Highlands of Scotland.- $B$. $M$. Luccombe, I. of Wight; near Totnes and Tavistock, Devon; Haywards Heath and Tunbridge Wells, Sussex; Chalford, Gloncestershire; Caddesdon, Oxfordshire; Broadwas and Alfrick, Worcestershire; Barmouth, Merioneth; Kildale, Clevelaud, Yorkshire; Xew Galloway, Tirkeudbrightshire; Appin and Inverary, Argyll; Killin, Perthshire; near Fort William, Invernessshire; Applecross, Rossshire.

Var, pulvinatum Koerb. Syst. Lich. Germ. p. 418 (18.5.). Thallus of smaller lobes than the species, denticulate at the margin, crowded in pulvinate masses, dark-brown. Apothecia central on the thallus, rather rare.-Mudd Man. p. 47 ; Cromb. Lich. Brit. p. \&; Leight. Lich. Fl. p. 33 ; ed. 3, p. 28. Sulsp. fmlvinatum Cromb. in Journ. Linn. Sose. Bot. xrii. p. 567 (18iso)

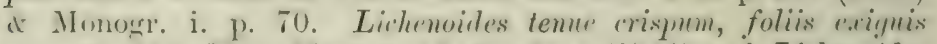
surrertis Dill. Hist. Musc. t. 19, fig. 34 a (17+1) and Lichemointes

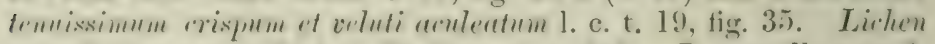
tremelloides var. $\gamma$ Lighth. Fl. Ácot. ii. p. s4.2. L. tremellu var. 3,

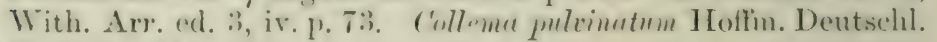
Fl. ii. p. $104(1795)$.

Easicc. Johns. n. 206 ; Larb. Casar. n. 55 \& Lich. Hb. ก. 241 .

Jifias from the species in the persistently brown thallus, but more especially in the pulvinate growth. The licinia at the circumference are more spreading. 
Hab. On rockis, old walls and on the ground among mosses.-Distr. Frequent and plentiful where it occurs throughout the British Isles. -B. M. Quenvais, Jersey; near Launceston, Cornwall ; near Plymouth, Devon; Bonchurch and Luccombe, I. of Wight; near Arundel and Cisbury, Sussex; Shiere and Reigate, Surrey; Bathampton Downs, Somerset; Coln Rogers, and near Cirencester, Ablington and Stroud, Gloucestershire; Epping Forest, Essex; Newbury, near TVorcester; Clee Hills, Shropshire; Cromer, Norfolk; Kildale, Cleveland, Yorkshire ; Stavely, Westmoreland ; Alston, Cumberland; Appin, Argyll; Tíllin and Ben Lawers, Perthshire; Inchigaggin, Cork.

Var. Iophæum Nyl. Syn. Lich. i. p. 123 (1858).-Thallus of very crowded lobes, somewhat pulvinate in hal,it, the lobes minute, with cylindrical branching cilia almost obscuring the lobes. Apothecia unknown.-Cromb. Lich. Brit. p. \&; Leight. Lich. Fl. p. 33 ; ed. 3, p. 29 . Subsp. lophan Cromb. in Grevillea xv. p. 13 (1886) \& Monogr. i. p. 71. Parmelia scotina var. lophæa Ach. Meth. p. 238 (1803).

Considered by Crombie and others to be almost specifically distinct; but occasionally the lobes are a little more spreading, and the affinity with the species is then more apparent.

$H a b$. On decaying stumps of old trees.-Distr. Rare in N. Wales and the TV. Highlands of Scotland.-B. M. Barmouth, Merioneth; Barcaldine, Argyll.

\section{Thallus of large spreating lobes, dark or bluish-leaden colourer. Smooth beneath.}

21. L. palmatum Mont. in Webb \& Berth. Hist. Nat. Iles Canar. Sect. iv. p. 128 (1840).-Thallus laciniate, the lacinire thin, often long and narrow, revolute at the margins and hornlike, or rather broad, suberect and crowded, greenish- or glaucousbrown, often tinged purplish. Apothecia rare, minute, sessile on the lobes, pale red, with an entire prominent margin; spores ellipsoid or broadly fusiform, irregularly muriform, 28-40 $\mu$ long, 16-18 $\mu$ thick.--Iucld Man. p. 48 ; Cromb. Lich. Brit. p. 9; Leight. Lich. Fl. p. 34; ed. 3, p. 31. Lichenoides gelutinosum tenerius laciniatum ex fusco purpurascens Dill. in Ray Syn. ed. 3, p. 72, n. 54 (1724). Lichenoides pellucidum fuseum corniculatum Dill. Hist. IIusc. p. 143, t. 19, fig. 30 (1741). Lichen palmatus Huds. Fl. Angl. ed. 2, p. 536 (1778) ; With. Arr. ed. 3, ir. p. 74 ; Engl. Bot. t. 1635. Scytenium pulmatum S. F. Gray Nat. Arr. i. p. 398 (1821). Collema pretmatum Ach. Lich. Univ. p. 643 (1810) ; Hook. in Sm. Engl. Fl. v. p. 210.

Distinguished from the preceling by the revolute margins of the nearly erect lacinie. It is occasionally the host of the parasitic lichen Obryzum corniculatum.

Hab. Among mosses and short grass in sandy and gravelly plitees. -Distr. General in the Channel Islands and England, rare in Scotland and Ireland.-D. M. St. Brelute's Bay, Jersey; Iustleigh Cleeve, Bottor Rock and near Olichumpton, Devon; near Stoney Cross, New 
Forest, Hants; Studlani, near Swanarge, Dorset; Hale End, Epping Forest, Essex; Dunder, Somerset; Machynlleth, Nerioneth; near Malrern, Worcestershire; Yarmouth. Norfolk; near Ayton, Clereland, Yorkshire; near Killin, J'erthshire; Luggelaw, Wicklow.

2.2. L. tremelloides S. F. Gray Nat. Arr. i. p. $400(18: 21)$.Thallus lobed, thin, somewhat smooth or covered with isidia, the lohes oblong, imbricate, often crisp, with entire margins, dull olive-green, or, usually, glaucous leaden-coloured. Apothecia rare, moderate in size, concave, becoming plane, redclish with a paler thick entire margin; spores ovoid or broadly fusiform, 3 -septate and muriform, $21-27 \mu$ long, $8-9 \mu$ thick.-Mudd Man. 1. 18 ; Cromb. Lich. Brit. 1. 8; Leight. Lich. Fl. p. 28 ; ed. 3, p. 31 (incl. f. polypliyllum Nyl.; Cromb. MIonogr. i. p. 74). Lichen tremelloides Linn. fil. Suppl. Pl. Syst. p. 450 (1781); Engl. Bot. t. 1981. L. cochlertus Dicks. Pl. Crypt. fasc. i. p. 13, t. 2, fig. 9 (1785); With. Arr. ed. 3, iv. p. 74 . Collema tremelloides Ach. Lich. Univ. p. 65) (1810); Hook. Fl. Scot. ii. p. 72 \& in Sm. Engl. Fl. v. 1). 213 ; Tayl. in Mackay Fl. Hih. ii. p. 111 ; var. pichnenm Ach. Syn. Lich. 1). 343 (1814); Cromb. in Grevillea xv. p. 13 (1886).

Exsice. Cromb. n. 110 ; Larb. Lich. Crsar. n. 5.

Differs from the two preceding species in the almost constant leaden colour, the large thin entire lobes, and the large apothecia. The lobes are occasionally rather smaller (f. polyphyllum), or some of the lobes may be densely isidiose (f. pichneum).

Hab. Among mosses on moist rocks in maritime and mountainous districts.-Distr. General aud usually plentiful in the Chamnel Islands, S. and W. Britain and E. and S.WW. Ireland.-B. M. Guernsey; St. Peter's Valley, Jersey; St. Lawrence, I. of Wight; St. Issey, near I'enzance and Saltash, Cornwall; Totnes, near Ditsham, Wembury, Cornworthy, Haberton, near Brixham and near Torquar, Deron; Tenby, Pembrolieshire; J3amonth and Harlech Castle, II Ierioneth. shire ; Garn, Denbighshire; Llimberis Pass, Carnarronshire ; Anglesea ; Jumbarton Castle; Loch Creran and Barcaldine, Aplin, and I. of MIull, Argyll ; Dunkerron Mt., Blackwater and Fillarney, Kerry; nea: Kylemore, Connemara, Galway.

23. I. ruginosum Nyl. ex Cromb), in Grevillen xr. p. 1:3 (18sici).--Thallus of round rather thin large lobes, plicate, undulite and crowded, with numerous longiturlinal wrinkles, and often furfuraceous with concolorous or slightly darker isiclia, the margins of the lobes entire or crenulate, brownish- or greenishlearlon coloured. Apothecia ratre, rather large, slishtly concare or plane, red or l,rownish-rexl, the margin thick, wrinkled, plicate or sranular: spores ellipsoid w broally fusiform, 3-.i-septate

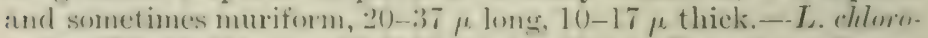

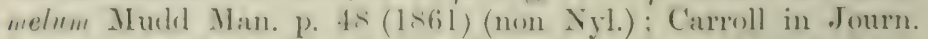

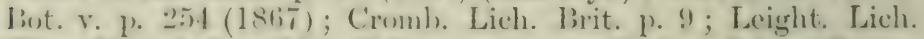

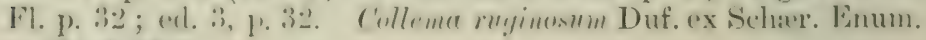
1. $251(1,50)$. 
The strongly wrinkled and densely isidiose thallus distinguish this species from all others. It bas not been found fertile in Great Britain. It has sometimes been confused with two exotic species, L. Brebrissonii Mont. and L. chloromelum Nyl. The former is less wrinkled and whitish-or greyish-downy beneath; the latter, an American species, has a subsmooth thallus.

$\mathrm{Hab}$. On the trunks of old trees and on rocks among mosses in maritime and mountainous districts.-Distr. Sparingly in S. England, N. Wales and S.IV. Ireland.-B. $M$. Torquay, Devon; Garth, near Dolgelly and Barmouth, Merioneth; Eagle's Nest and Dinish, Killarney, Kerry.

\section{Tomentose beneath.}

24. L. saturninum Nyl. in Act. Soc. Linn. Bord. sér. 3, i. p. 272 (1856).-Thallus olivaceous- or leaden-brown coloured, usually large, thickish, submonophyllous or polyphyllous with the lobes sinuate, round and entire at the margins, smooth or furfuraceous, beneath greyish and densely tomentose, the hairs sometimes fasciculate. Apothecia very rare, moderate in size, plane, reddish-brown, the margin thin, entire, prominent and cup-like; spores ellipsoid, 3-septate, becoming muriform, 16-24 $\mu$ long, 9-11 $\mu$ thick.-Cromb. Lich. Brit. p. 9 ; Leight. Lich. Fl. p. 29 ; ed. 3, p. 32 . L. Hildenbrandii Nyl. 1. c.; Cromb. in Journ. Bot. xii. p. 336 (1874) \& Monogr. i. p. 76. Lichen saturnimu Dicks. Pl. Crypt. fasc. ii. p. 21, t. 6, fig. o (1790); Sm. in Trans. Linn. Soc. i. p. 84 (1791) \& Engl. Bot. t. 1980 ; With. Arr. ed. 3 , iv. p. 60 . Colleme saturnimu Ach. Lich. Univ. p. 644 (1810); Hook. Fl. Scot. ii. p. 71 \& in $5 \mathrm{~m}$. Engl. Fl. v. p. 211. C. Hildenlurandii Garov. Catal. Alc. Critt. ii. p. 51 (1838). Mallotium saturninum S. F. Gray Nat. Arr. i. p. 399 (1821).

\section{Exsicc. Cromb. n. 5.}

Somerwhat similar in habit to Collema furvum. In damp shiudy places the thallus often becomes blackish above when try, contrasting with the light-grey colour of the under surface. The hairs in all the specimens tend to grow in rhizina-like strands. Apothecia are rather rare.

$H a b$. On the trunlss of old trees, generally ash, by streams in upland or mountainous districts.-Distr. Tather rare in N. England and the mountainous districts of Scotland.-B. M. Teesdale, Durham; Clova, Forfarshire; Glen Lochay, Glen Lyon, Fortingall, Loch Earm Glenample, Craighall and Finlarig, Killin, Perthshire; Inverary and Appin, Argyll; Loch Limnhe and lothiemurchus, Invernessshire.

25. L. Burgessii Mont. in Webly \& Berth. Hist. Nat. Mles Canar. p. 1:29 (1840). -Thallus greenish-or learlen-brown coloured, large, crowdedly lobate, the lobes somewhat imbricate, crenulate or lacerate and crisp, beneath greyish and more or lesis minutely tomentose. Apothecia numerous, morlerate in size to litrge : concave or becoming plane, reddish-brown or dark-red, the 
thalline marsin crowded with short crisp lacinie ; spores ellipsoid or broadly fusiform, 3-i)-septate and muriform, 30-40 $\mu$ long, 13-17 $\mu$ thick. Cromb. Lich. Brit. p. 9 ; Leight. Lich. Fl. p. 30; ed. 3, p. 33. Lichen Burgessii Lightf. Fl. Scot. ii. p. 827, t. 26 (177\%); Huds. Fl. Angl. ed. 2, p. 538 ; Fngl. Bot. n. 300; WTith. Arr. ed. 3, iv. p. 57. Collema Burgessii Ach. Lich. Univ. p. 645 (1810); Hook. Fl. Sent. ii. p. 71 \& in Sm. Engl. Fl. v. p. 211 ; Tayl. in Mackay Fl. Hib. ii. p. 110. Mrllotium Burgessii S. F. Gray Nat. Arr. i. p. 399 (1821); Mudd Man. p. 45.

Exsice. Cromb. n. 6 ; Dicks. Hort. Sicc. fase. iii, n. 24.

Well distinguished from all other Collemacex by the laciniate margin of the apothecium. The plant may be rather small and orbicular, or it may spread irregularly to a large extent.

$H_{a b}$. On the trunks of old trees near water (lakes and rivers), rarely on old walls, in wooded districts.-Distr. General ancl usually common in the western districts of the British Isles.-B. M. Iry Bridge and Lydford, Devon; Nannau, near Dolgelly, Cwm-Bychan and Barmouth, Merioneth; Hafod, Cardiganshire; Mardale, Westmoreland; New Galloway, Kirkeudbrightshire; Moffat and Rae Hills, Dumfriesshire; Head of Loch Awe, Inverary and Appin, Argyll; Glen Lochay, Inverarnan and Glen Falloch, Perthshire; Lochaber, Invernessshire; Eagle's Nest, Cromaglown, Dinish and Derrycuintry, Killarney, Kerry; Connemara, Galway.

\section{ORdER VII. PANNARIACEA}

Thallus not gelatinous when moist, heteromerous, granular, syuamulose or foliose, with hypothallus and rhizina. Algal cells blue-green (Myxophycese), rarely bright-green (Chlorophycese). Apothecia disciform, with or without a thalline margin: paraphyses simple, or rarely branched ; spores 8 in the ascus, simple or septate, colourless or slightly brownish. Spermogones with upright septate sterigmata and cylindrical pleurogenous spermatia.

Though containing blue-green algæ, the Pannariacese differ from the previous Orders in the non-gelatinous heteromerous character of the thallus. The following genera are represented in the British Isles :-

Algal cells Nostoc.

Apothecia without a thalline margin; spores usually simple... 28. Parmeliella.

Apothecia with a thalline margin; spores usually simple................................

29. Pannaria.

Algal cells Seytonema.

Apothecia without a thalline margin; spores 1.septate. 30. Massalongia.

Algal cells bright-green (Dactylococcus ?).

Apothecia with a thalline margin; spores simple.......................................... 31. Psoroma. 
28. PARMELIELLA Müll.-Ar'g. in Mém. Soc. Phys. Hist. Nat. Genève xri. p. $376(186 \%)$. Pammuluria Nyl. in Flora lxii. p. 360 (1879) pro parte; Cromb. Monogr. i. p. 340 pro parte. Coceocurpia Nyl. Syn. ii. p. 41 (1885) pro parte (non Pers.); Cromb. Monogr. i. p. 345. P(ennaria Mudd Man. p. 121 (1861) pro parte. (Pl, 28.)

Thallus squamulose or almost foliose, corticate, with hypothallus and rhizinæ. Algal cells Nostoc. Apothecia without a thalline margin, sessile, small ; spores $S$ in the ascus, elongate or ellipsoid, simple, rarely 1 -septate, colourless.

Distinguished from other genera of the Order by the small apothecia without a thalline margin.

1. P. corallinoides A. Zahlbr. in Ann. K. K. Naturhist. Hofmus. Wien xiii. p. 462 (1899).-Thallus minutely granular, thinly coralloid-squamulose, brownish-green or leaden-grey, the hypothallus bluish-black or blackish. Apothecia small, plane or convex, brown or reddish-brown, usually paler at the margin, internally brownish-black; paraphyses slender, sparsely septate; spores ellipsoid, simple, 12-19 $\mu$ long, 6-8 $\mu$ thick; hymenial gelatine intensely blue with iodine.--Stereocaulon corallinoides Hoffm. Deutschl, Fl. ii. p. 129 (1795) fide Wainio in Mledd. Soc. Faun. \& Fl. Fenn. xiv. p. 23 (1888). Lichen microphyllus Sm. Engl. Bot. t. 2128 (1810) (non Swartz). Lecidea microphylla Hook. Fl. Ścot. ii. p. 41 (1821) (Ach.?). Lepidoma triptopliyllum S. F. Gray Nat. Arr. i. p. 462 (1821). Placodium microphyllum Hook. in Sm. Engl. Fl. v. p. 198 (1833). Parmelia plumbea rar. miropleylla Tayl. in Mackay Fl. Hib. ii. p. 142 (1833). Pannaria triptropleylla Nyl, in Act. Soc. Linn. Bord. sér. 3, i. p. 313 (1856) pro parte; MIudd Man. p. 123 ; Leight. Lich. Fl. p. 167 ; ed. 3, p. 152 ; Cromb. Lich. Brit. p. $42 . \quad$ Panmularia triptophlylla Stiz. Lich. Helv. p. 82 (1882); Cromb. in Grevillea xriii. p. 44 (1889) \& Monogr. i. p. 341 .

Exsicc. Cromb. n. 153.

Differs from $P$. microphylla in the less dereloped thallus and the darker hypothecium on which the squamules are adnate and plane, becoming broken up into granules later. It varies in colour according to situation, and may be almost black (f. nigricans Leight. Lich. Fl. ed. 3, p. 153). It is rarely fertile in the British Isles.

Hab. On the trunks of old trees in wooded districts.-Distr. Some. what local, though plentiful where it occurs in the hilly or mountainous regions of Great Britain and Ireland.-B. M. St. Breock, Cornwall; near Lyddord, Hustyn's Wood and Lyn, Devon; Dolgelly, Barmouth, Cwm-Bychan and Harlech, Merioneth; Beddgelert, Carnarron ; Iientmere, Westmoreland; New Galloway, Kirkeudbrightshire; Inverary, J3arealdine and Appin, Argyll; Crianlarich, Loch Katrine and (ilen Lochay, Perthshire ; Craig Cluny, Braenar, Aberdeenshire; Moidart, Invernessshire; Glen Ach-na-Shilloch, Rossshire; Glen Bower: Woods and (⿳亠口冖lengariff, Cork; 'Tore MIt. and Dinish, Killarney, Kerry. 
Var. incrassata A. L. Sm. - Thallus thick, of densely crowcled closely packed upright sifuamules, the whole coarsely cracked, brownish-grey on a black hypothallus. Apothecia very rare, convex, brownish-black.-Pamaria triptophylla var. incrussutu Nyl. in Not. Sillsk. Faun. \& Fl. Fenn. Förh. v. p. 124 (1866). P. lasiella Stirton in Scott. Nat. iv.p. 16t(1877-8). Pammlaria triptopluylla var. incrussutu Cromb, in Grevillea xviii. p. It (1889) \& Monogr. i. p. 341.

Differs from the species in the more massive thallus.

$H a b$. On trunks of old trees, rarely on mossy ground among rocks, in upland wooded districts.-Distr. Local and scarce in the Scottish Highlands.-B. 11. Barcaldine, Argyll; Glen Lochay, Killin, Perthshire.

2. P. microphylla Miull.-Arg. in Flora 1xxii. p. 507 (1889).Thallus subdeterminate, minutely squamulose, irregularly rracked, the squamules closely imbricate, crenate, tawny- or pale-grey, often whitish at the margins, hypothallus brownish-black. Apothecia rather small, usually convex, brownish or reddish, internally pale; paraphyses clark at the tips; spores ellipsoid, guttulate, $10-17 \mu$ long, $5-8 \mu$ thick ; hymenial gelatine bluish then wine-red with iodline. Lirhen microphyllus Swartz ex Westr. in Vet. Acad. Handl. xii. p. 301 (1791). L. escharoilles Sin. Engl. Bot. t. 1247(1803)? Letrideu coronutu var. eschurvides Hook. in Sin. Engl. Fl. v. p. 182 (1833). Pannurin microplyylla Massal. Ric. Lich. p. 112 (1852) ; Mudd Man. p. 123 ; Cromb. Lich. Brit. p. 42 ; Leight. Lich. Fl. p. 166 ; ed. 3, p. 152. Panmeleria mirroplaylla Stiz. Lich. Helv. p. 82 (1882-3); Cromb). Monogr. i. p. 340.

Exsicc. Larb. Cresar. n. 71 \& Lich. Hb. n. 89.

Well characterized by the minute crowidedly imbricate squamules. The apothecia are scattered or crowded.

Hab. On rocks or ou the ground in maritime districts.-Distr. Father rare in the Channel Islands and WV. Scotland, more frequent in W. Ireland.-B. M. Guernsey; Rozel, Jersey; near Penzance, Cornwall; Loch Creran and Barcaldine, Argyll ; Connemara, Galway; near Croagh Patrick and Clare Island, Mayo.

Var. cheilea A. L. Sm.-Thallus darker than in the species, not whitish at the margins. Apothecia somewhat immersed and plane, spores ellipsoicl-oblong, frequently 1-septate.-P'Anuariu rhaten Nyl. ex Mudd Man. p. 126 (1861); Cromb. Lich. Brit.

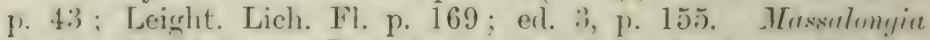

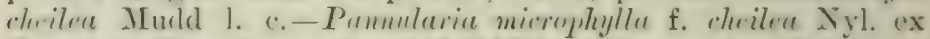
(cromb) in (irevillea xviii. p. 4:3 (1s89) a Monogr. i. p. 341.

Like the species exeppt in the darker thallus and the septate

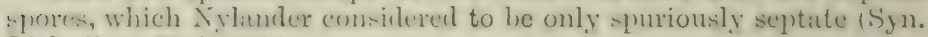
Lich. ì. p. 35 (1885)).

Hub. On damp schistose rocks.-Distr. Local and searce in 
TI. Scotland and S.IT. Ireland.-B. M. Loch Creran, Barcaldine, Argyll; Western Blasquet Island and Dlackwater Bridge, Kerry; Killree, Clare.

3. P. lepidiota Dalla Torre \& Sarnth. Die Flechten Tirol itc. p. $97(1902)$.- Thallus of small squamules, firm, crenulate and often with ascending margins, imbricate-crowded, especially towards the centre, rather dinsy brown or tawny-whitish. Apothecia molerate in size, plane or convex, dark-red or brown, internally pale-whitish; spores ellipsoid, simple, 15-23 $\mu$ long, $\$-12 \mu$ thick; hymenial gelatine bluish then wine-red with iodine.-Lichenoides yranosnm subglanem, tuberulis planis niyricrentibus Dill. Hist. Musc. p. 5t4, t. 82, ticr. 2 (17t1). Lecirlere ramosa var. lepirliota Sommerf. Supp. Fl. Lapp. p. 17t (1826). Pummlaria levidiotu Stiz. Lich. Helr. p. 82 (1882); Cromb. in Grevillea xviii. p. 43 (1889) \& Monogr. i. p. 340.

The crimped and crenate margins of the squamules give the plant often a granular appearance.

Hab. Spreading over decayer mosses on the ground in alpine sitnations. - B. M. Above Loch-na-gat, Ben Lawers, Perthshire.

4. P. plumbea Wain. Lich. Brés. i. p. 206 (1890).-Thallus highly developed, orbicular, coriaceous or membranaceous, submonophyllous, adnate, the surface marked with radiating lines and concentric shell-like conformations, occasionally with hluishgreen isidiose granules, and often crowdedly tuberculuse or isidiose, the outer margin broadly crenate, dull-greyish or leadencoloured, with a thickish rhizinose leaden-bluish hypothallus. Apothecia small, plane or convex, reddish- or dark-brown, the proper margins thin, entire, paler, often obliterated, pale within; paraphyses septate, brown at the slightly swollen tips; spores ellipsoid, simple, colourless, 16-:30 $\mu$ long, $7-11 \mu$ thick; hymenial gelatine bluish with iodine-Lichenoide's temere et molle', Ayarivi frecie Dill. Hist. Musc. p. 179, t. 24, fig. $73(17+1)$. Lirhen plumbeus Lightf. Fl. Scot. ii. p. 826, t. 26 (lower fig.) (187 ) ; With. Arr. ed. 3, iv. p. 60 ; Engl. Bot. t. 353. L. cornlescens Huds. Fl. Angl. ed. 2, p. 531 (1778). Parmelire plumber Ach. Meth. Lich. p. 212 (1803) ; S. F. Gray Nat. Arr. i. p. 440 ; Hook. Fl. Scot.ii. p. 5:3 ; Tayl. in Mackay Fl. Hib. ii. p. 142 pro parte. Pamuric jlumber Del. ex Duby Bot. Gall. p. 606 (18:30) (incl. var. myriourpa) ; Musd Man. p. 121 (incl. var. myriorarya) ; Leight. Lich. Fl. p. 170 ; ed. 3, p. 15t (incl. f. myroerrepu). Placorlinm

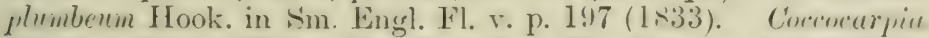

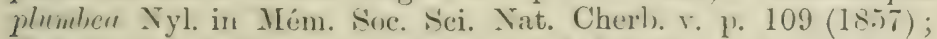

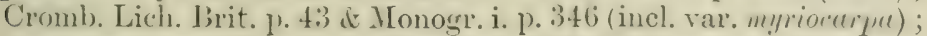
var. myriocarpa Nyl. Lich. Scand. p. 128 (1861).

Erever. Croall n. 96; Cromb. nos. 56,57 : Dicks. Hort. viece. fase. x. n. 24 ; Johns. nos. 96, 321 ; Larb. Cresar. n. 72 \& Lich. Hb. n. 2.53 ; Leight. n. 233. 
The genus Coecocaryia, in which this lichen has been included by Nylaniler and other's. was hased on species from which $I$. plumber differs in the structure of the thallus and in the algal constituents. As already remarlied by Nylander (l. c.), var. myriocarpa is scarcely to be distinguished from the species. It is marked by crowled tubercles, especially towirls the centre of the thallus, and is evidently. a growth form, as there are all gradations from the tuberculose to the smooth thallus eren on one specimen. The rhizinose lypothallus is sometimes very luxuriant (pamniform). The apothecia are normally bright-coloured, but may become dark-brown.

$H_{r} 7$. On the trunks of old trees, on mossy boulders and walls in maritime and inland wooded regions.-Distr. General and common throughout the British Isles.-B. M. La Coupe, Jersey; Guernsey; Alderney; near Penzance, Bodmin, Pentire, Bocconoc and Respring, Cornwall; Clovelly, South Brent, Bolt Head, Throwleigh, Totnes, near Slapton, Lidford, Oliehampton and Torquay, Deron; Appuldurcomb, I. of Wight; Danny Wood, Tilgate and Erilge Rocls, Sussex; Romner Marsh, Tient; Aberdover, near Dolgelly and near Barmouth, Merioneth; Bettws-y-Coed, Denbighshire; I. of Anglesea; Egglestone and Teesdale, Durham; Wimdermere, Westmoreland; Keswick and Ennertale Iake, Cumberland; MIaxwelton, Dumfriesshire; New Galloway, Firkculbrightshire; near Campsie, Stirlingshire; near Inverary, Barcaldine, Appin, Oban and Head of Loch Awe, Argyll; Glen Falloch, Glen Lochay, The Trossachs, Aberfelity, Rammoch and Fillin, Perthshire; Clora, Forfarshire; Craig Coinnoch, Braemar, Aberdeenshire; S. of Fort Trilliam and Glen Neris, Invernessshire; Cawdor Castle, Tairnshire; Applecross. Possshire; Castlebernard, Cork; Cromaglown and Jlackwater Bridge, Nerry; Comnemara, Galway; Achill and Louisburgh, Mayo.

5. P. melantera A. L. Sm.-Thallus effuse, squamulose, cracked into areolix, black, the squamules thickish, minutely papillose, bluish-black heneath. Apothecia small, sessile, plane or sornewhat shining; hrpothecium brownish; paraplyses septate, rather stout; spores elousate, simple or 1-3-septate, $30-4.5 \mu$ long, 4-5 $\mu$ thick; hymenial gelatine bluish, the asci tawny, with iodine.-Pomurin melontera Stirt. Scott. Nat. v. p. 16 (1579); Leight. Lich. Fl. ed. 3, p. 54t. Pammlariu melonteru Cromb. in Grevillea xviii. 1) $44(15 i 9)$ it Monogr. i. 1). 344. Specimen not seen.

A doubtful Parmelirla, but imposible to classify with certainty in the absence of data as to the gonidia contained in the squamules.

Hab. On mica-schist rocks, Ben Lawers, Perthshire.

29. PANNARIA I).]. ex I)uby lot. Gall. 1). $606(1 \times 30)$; emend. Nyl. in Flora lxii. p. 360 (1879). (Pl. 29.)

Thatlus granular, squamulue, or almust follose, with a dark lygpothallus of folted liyplise on the under surface, the upper cortex a plectemrhyma of vertical cell rows. Alesal cells Nostox. Aputhecia hecoming superforal, disceiform with a thalline margin;

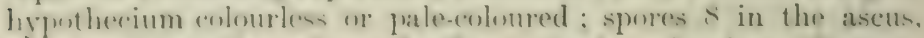
fomeate-elliprobl, or alumst fusiform, simple, enlourless. Fipermo. 
gones in thalline tubercles, with septate sterigmata and short pleurogenous spermatia.

A widely-spread genus, the species of which are mostly exotic. European species are nearly all represented in the British Isles.

1. P. rubiginosa Del. in Duby Bot. Gall. p. 606 (1830).-Thallus orbicular, sfuamulose, appressed to the substratum, dull-glaucous or pale, the squamules lobulate-crenate at the circumference, crenate or crentalate in the centre and silverywhite at the margins; hypothallus spongy-tomentose, bluishblack. Apothecia numerous and crowded, moderate in size, red or reddish-brown, with a silvery-white crenate margin; spores ellipsoid, sometimes with pointed ends, 17-30 $\mu$ long, 6-11 $\mu$ thick; hymenial gelatine bluish with iorline.--Mudd Man. p. 122; Cromb. Lich. Brit. p. 42 ; Leight. Lich. Fl. p. 164 ; ed. 3, p. 150. Lichen rubiginosns Thunb. ex Ach. Lich. Suec. Prodr. p. 99 (1798). L. affinis Dicks. Pl. Crypt. fasc. iv. p. 24, t. 12, fis. 6 (1801); Engl. Bot. t. 983. Parmelia mbiginosa Ach. Meth. Lich. p. 212 (1803) ; S. F. Gray Nat. Arr. i. p. 440 ; Hook. Fl. Scot. ii. p. 5:3. $P$. Mlumber var. refinis Tayl. in Mackay Fl. Hib. ii. p. 142 (1836). Squemerift affinis Hook. in Sm. Engl. Fl. v. p. 196 (1833).

Eeesiec. Cromb. n. 53 ; Larb. Lich. Hb. n. 11 ; Leight. n. 234.

Well marked by the silvery-white margins of the syuamules and apothecia. The squamules may be crowded and imbricate at the centre, they are radiating at the circumference.

Hab. On the trunks of old trees, rarely among mosses on walls and rocks, in maritime and upland districts.-Distr. General and usually plentiful in hilly or mountainous districts.-B. $M$. Guernsey; Bocconoc and near Respring, Cornwall; Cornworthy, Totnes and Clovelly, Devon; Appuldurcomb, I. of Wight; Chalton Forest, Hants; Erilge Park, Sussex; Hay Coppice, Herefordshire; Aberdovey, Merioneth; Windermere, Westmoreland; Keswick and Ennerdale, Cumberland; Teesdale and Egglestone Woods, Durham; New Galloway, Kirkendbrightshire; Inverary, Head of Loch Awe, Appin, Barcaldine, and near Oban, Argyll ; Glen Falloch, Glen Lochay and Aberfeldy, Perthshire; Corriemulzie Falls and near Braemar, Aberdeenshire; near Fort William, Invernessshire; Dunkerron and old Dromore, Kerry ; Connemara, Galway.

Var. conoplea Koerb. Syst. Lich. (ierm. p. 105 (185.5).-Sirgumules pulverulent, sorediose at the edges, except those of the extreme circumference, but towards the centre the soredia often covering the whole surface, the powdery sranules bluish-grey, minutely coralline. Apothecia small, apyressed, rather rare, the thalline margin pulverulent; spores usually rather smaller than in the species.-Cromb. Lich. Irit. p. 42; var. arvuleu-burlin II ukli Man. P. 12.2 (1861); Lefight. Lich. F!. p. 164; erl. 3,

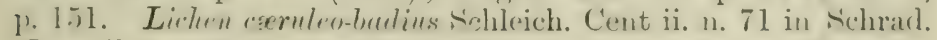
Neu. Journ. Bot. p. 197 (1806) nomen nudum. Purmelia 
conoplea Ach. Lich. Univ. p. 467 (1810). P. plumbea var. tumescens Tayl. in Mackay Fl. Hib. ii. p. 142 (1833).

Exsice. Cromb. n. 54 ; Larb. Lich. Hb. n. 12.

Almost specifically distinct, but connected with the species by intermediate states.

Hul. On the trunks of old trees in maritime and inlaud districts.Distr. General and not uncommon throughout the British Isles.B. M. La Coupe, Jersey; Guernsey; Withiel, Cornwall; Newton Bushell, Liciford and near South Hrent, Deron; Appuldurcomb, I. of Wight; St. Jeonard's Forest, Jlack Down and Tilgate, Sussex; Charlton Forest, Fent; Dolgelly, Merioneth; Capel Curig, Catnarvonshire; Fentmere, Westmoreland; Borrowdale, Cumberland ; Teesdale, Durham; New Galloway, Kirkeudbrightshire; Barcaldine, Argyll; Glen Lochay, Killin, Aberfeldy and Den of Peichip, Perthshire ; S. of Fort William, Invernessshire; Glenferness, Nairnshire; Killarver, Kerry; Doughruagh IIts., Connemara, Galway.

2. P. pezizoides Leisht. Lich. Fl. p. 165) (1871); ed. 3, p. 150 (excl. var. cormuta). - Thallus subcircular, often rather widespreading, granular-squamulose, the squamules small, crenite, densely crowded and imbricate, with a granular appearance, tawny-or greyish-brown; a thin arachnoid greyish-white hypothallus sometimes visible. Apothecia moderate in size or rather large, plane, red, or reddish-brown, the thalline margin crenulate: spores fusiform-ellipsoid, minutely warted, 15-28 $\mu$ long, $7-11 \mu$. thick; lymenial grelatine bright-blue then sordid-bluish with iocline.-P. Irumnea Massal. Ric. Lich. p. 113 (18.5-2) pro parte; Nyl. Lich. Scand. p. 123 (1861); Mudd Man. p. 123, t. 2), fig. 37 (excl. var. coronatri): Cromb. Lich. Brit. p. 4.2. Liclen pezizoides Web. Spicil. Fl. Goett. p. 200 (1778). L. Urmmens Swart\% in Nov. Act. Upsala iv. p. 247 (1784); Engl. Bot. t. 1246. Leranor, brmmen Ach. Lich. Univ. p. 419 (1810) pro parte; Hook. Fl. Scot. ii. p. 51 ; Grev. Fl. Edin. p. 335. Psoroma bruneum S. F. Gray Nat. Arr. i. p. 446 (1821). Lecidea comomta Borr. ex Howk. in sm. Enel. Fl. v. p. 1к2 (1s3:3) (nom Hoffm.) pro parte ; Tayl. in Mackay Fl. Hib. ii. p. 127.

Exsicc. Croall n. 590 ; Cromb. n. 55 ; Johns. n. 253 ; Larb. Lich. Hb. n. 14 ; Mudd n. 90.

Freynently confused with $P$. nelnilosa. The thallus of looth is dark-bluish-green when moist, lut in $I^{\prime}$. prizizoliles it dries to a tawnybromn. and the fommation of the thallus is different. In shady situations it is more bluish-grey with paler apothecia. At high altitudes, as on lien Iawers, thallus and apothecia are darlier, and the hypothallus blackish.

Hab. On the ground on decayed mosses, rarely on stones or dereying wool in uplamd regions.-Distr. General and not uneommon in maritime and hilly rergons of Great Jritain and Ireland.- B. M.

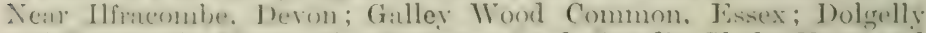

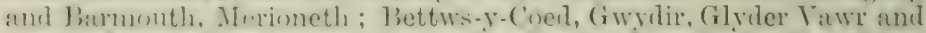

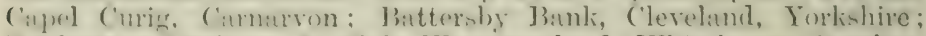

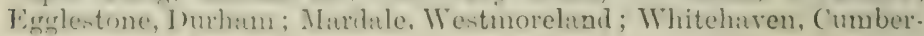


lani?; The Cheriots, Northumberland; New Galloway, Tirkcudhright. shire; near Toslin Castle, Midlothian; Bowling Bar. Dumbartonshire; Barealdine, Airds and Appin. Argyll; Fortingall, Killin, Ben Lawers, Craig Calliach and Den of Reichip, Perthshire; near Forfar; Linn of Dee and Corriemulzie and Glen Ey, Braemar, Aberdeenshire; near Fort William and Invemmoriston, Invernessshire; Brandon Mt., Tore Mt., Cromaglown, Dunlierron and Killarney, Kerry; Killery Bay, Connemara, Galway.

3. P. Hookeri Nyl. in NIém. Soc. Sci. Nat. Cherb. v. p. 109 (1857).-Thallus squarnulose, the squamules lobate-radiate and somewhat plicate at the circumference, appressed, crowded and imbricate, crenate towards the centre, greyish-brown or leaden-greyish in colour ; hypothallus black. Apothecia rather small, plane, blackish, pale within, with a thin grey somewhat crenulate margin; spores ellipsoid-ovoid, 12-19 $\mu$ long, 5-9 $\mu$ thick; hymenial gelatine bluish then sordid-red with iodine.Mudd MLan. p. 12:) ; Cromb. in Grevillea xviii. p. 43 (1890) (incl. var. lencolepis). P. lencolepis Nyl. Lich. Scand. p. 123 (1861); Cromb. Lich. Brit. p. 42; Leight. Lich. Fl. p. 165 ; ed. 3, p. 151. P. Hookeri var. leucolepis Nyl. Syn. ii. p. 33 (1885); Cromb. MLonogr. i. p. 339. Lichen Hookeri Burr. in Sm. Engl. Bot. t. 2283 (1811). L. leucolepis Wahlenb. Fl. Lapp. p. 410 (1812). Lecenoru Hootieri Hook. Fl. Scot. ii. p. 51 (1821). Squamaria leucolepis Hook. in Sm. Engl. Fl. v. p. 194 (1883).

Exsicc. Leight. n. 267.

Characterized by the leaden-coloured thallus. It is usually well fertile with crowderl apothecia, which become black with age.

$H a b$. On micaceo-schistose rocks in alpine places.-Distr. Local and scarce on the Scottish Grampians.-B. M. Ben Lawers, MIael Graedha and Craig Calliach, Perthshire.

4. P. nebulosa Nyl, in Mém. Soc. Sci. Nat. Cherb. ii. 1. $324(1854)$ \& Lich. Scand. p. 125.-Thallus effuse, granularcrustaceous, irregularly cracked, the granules crowded, greyish or dark-bluish-grey, often blackish-green. Apothecia small, 1lane, or somewhat convex, red or reddish-brown, internally lale-coloured, with an interrupted sranular margin (coronate); spores ellipsoid-fusiform, the wall slightly uneven, $15-21 \mu$ long, (j-9 $\mu$ thick; hymenial gelatine faintly bluish then wine-red with iodine.-Cromb. Lich. Brit. p. 42 ; Leight. Lich. Fl. p. 16r; ed. 3, p. 153. P. brumere var. rmonatu Massal. Ric. Lich. p. 115 (18.5) ; Leight. Lich. Fl. 1. 166 (1871); ed. 3, p. 152. Liden peizivides Dicks. Pl. Crypt. fasc. i. p. 10 (1785) (non Web.); With. Arr. ed. :), iv. p. ¿21. Patellariu nolulos" Hoffm. Pl. Lich. ii. p. 55, t. 40, fig. 1 (1794), Vermearia coronata Hoftim.

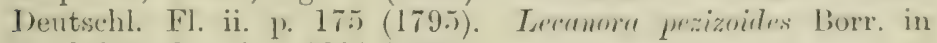
Engl. Bot. Suppl. t. 2801 (1837).

Exsice. Johns. n. 95 ; Larb. Cæesar. n. 26 \& Lich. Hb. n. 13 ; Leight. n. 235. 
Easily distinguisher from the preceling by the granular crustaceous thallus and by the persistently dark-greenish colour. The granules forming the margin of the apothecium gave origin to the name coronata.

Hab. On sandy soil, earth-covered walls and hedge-banks, rarely on decaying stumps in maritime and inland districts.-Distr. Local though plentiful where it occurs throughout the British Isles.- $B . M$. Quenvis, St. Brelade's Bay and Noirmont, Jersey; Guernsey; Alderney; Wadebridge, St. Germains, Penzance and Withiel, Cornwall; near Bovey Tracey and Cornworthy, Devon; I. of WVight; near Hartfield and Tunbridge Weils, Sussex; Epping Forest, Essex; Hay Forest, Herefordshire; Barmouth, Merioneth ; near Malvern, WVorcestershire; Bangor, Carnarvonshire; I. of Man; Egglestone, Durham ; near Ennerdale, Cumberland; New Galloway, Kirkcudbrightshire; Airds, Appin, Argyll; Loch Tay, Taymouth and Killin, Perthshire, Cork.

30. MASSALONGIA Koerb. Syst. Lich, Germ. p. 109 (185\%). (Pl. 30.)

Thallus squamulose, the cortex of the upper surface of the squamules plectenchymatous, the lower surface decorticate with a dark rhizinose hypothallus. Algal cells S'ytonema. Apothecia plane, without a thalline margin; asei clavate, 8-spored; spores colourless or becoming brownish, 1-septate. Spermogrones with septate sterigmata and pleurogenous short cylindrical straight or bent spermatia.

Separated from Pammia owing to the difference in the algal constituents of the thallus.

1. M. carnosa Ḱverb. Syst. Lich. Germ. p. 109 (18:5)).Thallus of medium-sized dull- or tawny-brown squamules, adnexed or partly ascending and imbricate, granular-crenate and lighter coloured at the margins (when dry), the whole squamule bluishsreen when moist, whitish beneath, the hypothallus brownishblack, evanescent. Apothecia rather small, plane or slightly concave, reddish-lorown, the margin paler; spores oblong-fusiform or rarely ellipsoid, 1-septate, $16-31 \mu$ long, $5-8 \mu$ thick ; hymenial relatine yellow, the apices of the asci deep bluish, with iodine.Mudd Man. 1). 126, t. 2, fig. 39. Lirhen crmosus Dicks. Pl. Crypt, fase. ii. p. 21, t. 6, fig. 7 (1790); With. Arr. ed. 3, iv. 1. 33: Enegl. Bot. t. 1684. Lecanora rermosa ILook. Fl. Seot. ii.

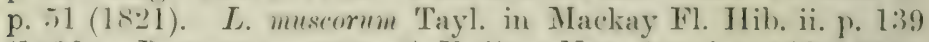

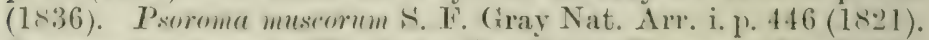

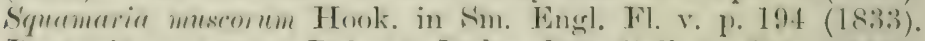
I'anuariu muscormm Del. ex J)uby Jiot. Gall. p. (iot (18:30): C'romh). Lich. Jirit. 1). 13. I’. carurse J.eisht. Lich. Fl. p. 16!)

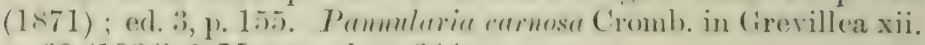
p. 62 (1884) \& Monogr i. p. 344.

Exsicc. Cromb. n. 154 ; Leight. n. 393.

The thalline squamules are rather thin and may spread extensively over the substratum, or they may be crowded together. 
Hab. Among mosses on rocks and boulders in maritime and mountainous districts.-Distr. Somewhat common in S. W., W. and N. England and N. Wales, rarer in S. Scotland and among the Grampians and in E. Ireland.-B. M. Penzance, Cornwall ; Didworthy and near South Brent, Deron; Oswestry, Shropshire, Cader Idris, Dolgelly. Cwm Brchan and Barmouth, Merioneth; Teesdale, Durbam; New Galloway, Kirkcudbrightshire; Head of Loch Awe, Argyll ; foot of Ben More, Glen Lochay and Ben Lawers, Perthshire; Glen Ey, Braemar, Aberdeenshire; by Loch Linnhe, Invernessshire; Kippure Mts., Dublin.

Var. determinata A. L. Sm.-Thallus rather paler than in the species, the squamules with darker granular margins. Apothecia dark-reddish with a light-reddish margin; paraphyses stouter and spores larger than in the species, the latter guttulate, 26-36 $\mu$ long, $7-8 \mu$ thick.-Pannuria musornm var. determinata Nyl. Lich. Ścand. p. 128 (1861) ; Cromb. Lich. Brit. p. 4.3. P. carnosa var. determinata Leight. Lich. Fl. p. 169 (1871); ed. 3, p. 156. Pammilaria curnosa var. determinata Cromb. in Grevillea xviii. p. 44 (1889) \& Monogr. i. p. 345.

Owing to the guttula in the spores, these may appear to be pluriseptate.

$H a b$. On moist soil in upland districts.-Distr. Apparently local and rare in E. Ireland.-B. M. Luggelaw, Wicklow.

31. PSOROIIA Ach. Lich. Suec. Prodr. p. 2 (1798) pro parte; Nyl. in Mém. Soc. Sci. Nat. Cherb. iii. p. 175 (18:5). Lecanora subgen. Psoroma Nyl. in Not. Sillsk. Faun. \& Fl. Fenn. Fürh. v. p. 1:5 (1866) ; Cromb. Monogr. i. p. 349 . (Pl. 31.)

Thallus minutely squamulose-granular, corticate, the upper cortex of plectenchyma, the lower of closely packed parallel hypha, some of which pass out as rhizoidal filaments. Algal cells bright-green (Dartylurocus? Pleurncocus?). Apothecia with a thalline marsin; hypothecium colourless; parajhyses simple, septate; asci 8-spored; spores colourless, ellipsoid or slobose, simple (rarely :-celled). Spermogones with septate sterigmata and pleurogenous short cylindrical spermatia.

Though containing bright-green gonidia the aftinity of this genus is with the Pannariace:e. Forssell has stated (Floril lxvii. p. 187) that squamules containing blue-green algie are frequently mixed with the normal thallus and that they are exactly lilie those of Pannaria perizoilles. He regards the fungus as the same in these two lichens.

1. P. hypnorum S. F. Gray Nat. Arr. i. p. 445 (1821).Thallus granular-squimulose, the squamules crenate or gramulate. tawnyellow or yellowish-lorown $\left(\mathbf{K}^{-}-\right.$). Apothecia moderate in size, or rather large up to about $4 \mathrm{~mm}$. in liam. It first ureeolate, lecoming plane, redrlish-brown; pataphyses steptate, clavate and yellowish-hown at the tips: spores ellipsoid, often somewhat acute at one or beth ends, the outer wall uneven, l6-2.) $\mu$ long, 
8-11 $\mu$ thick; hymenial gelatine bluish then wine-red with indine-Cromb. Lich. Brit. p. 44 (incl. var. deraurata); Leight. Lich. Fl. 1. 16:3 ; ed. :3, p. 149 ; f. dentritri Nyl. Lich. Scand. p. 121 (1861); Cromb. Ionogr. i. p. 850. Lichen hypmortum Dicks. Fl. Crypt. fasc. iii. p. 14 (1793) (excl. syn.); With. Arr. ed. 3, iv. p. 22 ; Engl. Bot. t. 740. Lecanora hipporum Ach. Lich. Univ. j. 417 (1810) ; Hook. Fl. Scot. ii. p. Jl ; Grev. Fl. Edlin. p. 334 : Tayl. in Mackay Fl. Hil). ii. p. 139. L. lepidora viur. deuneren Ach. tom. cit. p. 418. Squanuria leyjunornm Hook. in Sim. Engl. Fl. v. p. 194 (1833). Pannaria hypmornu Koert. Syst. Lich. Germ. p. 108 (1855); Mudd Man. p. 124.

Exsice. Cromb. n. 58 pro parte ; Larb. Cresar. n. 70.

The squamules are either scattered or crowded, sometimes extremely prominent on the margin of the apothecium. Form deaurata does not differ except in the slightly brighter colour.

$\mathrm{Hab}$. Among mosses on the ground, rocks and walls in maritime and inland districts.-Distr. Not infrequent in the Channel Islands and in Great Britain, not recorded in Ireland.-B. M. Grosnez. Jersey; Guernsey; Tresco, Scilly Islands; liespring, Cornwall; Dartmoor, Devon ; Shoreham Beach and Aldington Beach, Sussex; Hale's End, near Malvern, Worcestershire; Cym Brchan and Aberdovey, Merioneth; Egglestone, Durham; the Cheriots, Northumberland; Pentland Hills near Edinburgh; Hills above Greenock, Renfrewshire; Appin, Arggll; Killin, Craio Calliach, Falls of Bruar, Glen Lochay, Jen Lawers and Glen Fender, Perthshire; Clovit, Reeky Linn, Kinnorty, Esk Burn and near Dundlee, Forfarshire; Corriemulzie, Falls of Garrawalt and Craig Cluny, Briemar, Aberdeenshire, Glen Tevis, Invernessshire; Glen Dale, I. of Skye.

\section{ORdER VIII. PELTIGERACEÆ.}

Thallus foliacerns, membranaceous, heteromerous, the upper' cortex of plectenchyma, lower surface non-corticate, or partly corticate, provided with loose hyphe or with rhizoids. Algal crlls blue-green ( Nostor) or loright-green (Dartylucoress). Apothecia mostly marginal and roundish, adnate on the uper or lower surface of the thallus, without a thalline margin; hypothecium colourless; paraphyses stoutish, simple, septate; spores $2-5$ in the ascus, elongate, fusiform or ellipsoirl, l-or more- septate, (1)hourless or dark-coloured. Spermogones absent or rare. Cephlaleslia enclosing Nostor present in some of the grenetar. 'The following are British :-

Apothecia marginal, superficial.

On upper surface of the thallus

32. Peltigera.

On lower surface of the thallus.

33. Nephromium.

A pothecia scattered, sunk in the thallus

34. Solorina.

8. PELTIGERA Willa. Fl. Therol. p. :37 (1787). Pelliden

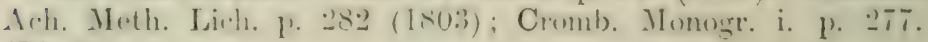
(11. 32.) 
Thallus often wide-spreading, submonophyllous or polyphyllous, corticate on the upper surface : not corticate below, tomentose or nerved and more or less rhizinose. Algal cells blue-green, Nostoc, Iright-green Dactylococcus. Apothecia marginal, adnate on the upper surface of the frond; spores elongate-fusiform, 3- or pluriseptate, colourless or brownish. Pycnidia sometimes present, with ovoid acrogenous spores.

In most of the species of this genus the algæ are blue-green. In a few the gonidial zone is bright-green, but in these there are always present groups of Nostoc cells enclosed in cephalodia, as small tubercles on the upper or lower surface, or within the thallus. The reins below are due to intercalary growth in the upper cortical layers, causing stretching and pulling apart of the tomentum below so that the white medulla becomes more or less exposed. The genus is divided into two sections:-

Thallus with blue.green gonidia

i. Eupeltigera. Thallus with bright-green gonidia and with cepha. lodia..... ii. Pelitidea.

\section{§ i. Eupeltigera Hue in Nouv. Arch. Mus. Hist. Nat. Paris sér. 4, ii. p. 92 (1900).}

Algal cells blue-green (Nostoc); cephalodia not present.

Thallus downy above.

1. P. canina Willd. Fl. Berol. p. 347 (1787).-Thallus large, spreading, rather thick, of large rounded lobes usually downy above, brownish-green when moist, glaucous-grey or fawncoloured when dry, beneath whitish, with prominent pale nerres and long white rhizina of fasciculate hypha. Apothecia moderate in size, roundish, beconing revolute, brown or brownish-red, entire or slightly crenulate at the margin; spores elongatefusiform, 3-5-septate, $66-70 \mu$ long, about $4 \mu$ thick.-Mudu Man. p. 8.2, t. 1, fig. 22 (excl. vars.); Cromb. Lich. Brit. p. 29 (incl. var. membranucea) ; Leight. Lich. Fl. p. 107 ; ed. 3, p. 101 (excl. f. crispra); var. membranacea Nyl. Syn. i. p. 324 (1860); Cromb. Monogr. i. p. 288. Lichenoides peltutum terrestre cinereum uncius, follis divisix Dill. in Ray Syn. ed. 3, p. 76, n. 87 (17-4). Lirhenoides rligitutum cineren, Lacturæe foliis sinuoxis Dill. Hist. Muse. p. 200, t. 27 , fig. 102 E $(17+1)$. Lichen coninus L. Sp. Pl. 1. 1149 (1753) ; Huds. Fl. Angl. p. 454; Lightf. Fl. Scot. ii. p. 845 ; With. Arr. ed. 3, iv. p. 69 ; Engl. Bot. t. 2299. Peltideu cuniun Ach. Lich. Univ. p. 517 (1810); S. F. Gray Nat. Arr. i. p. 428 : Hook. Fl. s'eot. ii. p. 60 (excl. var. rufeserens) of in Sm. Engl. Fl. v. p. 215; Tayl. in Mackay Fl. Hib. ii. 1) 15i3.

Exsice. Croall n. 492 ; Johns. n. 26; Larb. Cantab. n. 28 ; Leight. n. 141 ; Mudd n. 59.

Distinguished from other species by the white under surface, ami the numerous long white rhizina. The thallus is rariable in size, 
and the downy covering of the surface, due to the outgrowth of large branching anastomosing hyphie, tends to disappear on raised or exposed portions of the thallus (a characteristic of var. membran. acert). Pyenidia occasionally occur in tubercles on the margins of the lobes; they are brownish-black with spores $9-12 \mu$ long, $4-5 \mu$ thick.

Hab. Among mosses on the ground, the tops of old walls and on boulders, etc.-Distr. General and common throughout the British Isles.-B. M. Guernsey; Jersey; near Penzance, Withiel and Land's End, Cornwall; Lustleigh, Devon; New Forest, Hints; Sheffield Park and Maresfield, Sussex; Hyde Park, London, Middlesex (18th cent.) ; near Hereford; Malvern, Worcestershire; Iolesworth, Warwickshire; Clee Hill and Haughmond Hill, Shropshire; Barmouth and near Dolgelly, Merioneth; Snowdon and near Conway, Carnarvonshire; Anglesea ; Chatsworth, Derbyshire ; Mildenhall, Suffolk; Ayton, Cleveland, Yorkshire; Teesdale, Durham; The Cheviots, Northumberland; near Berwick-on-Tweed; Alston and Calder Bridge and Patterdale, Cumberland; New Galloway, Kirkcudbrightshire; Appin, Barcaldine and Inverary, Argyll; Glen Lochay, Killin and Blair Athole, Perthshire; Strathmartin, Forfarshire; Durris, Kincardineshire; Corriemulzie, Castleton of Braemar and Countess WVells, Aberdeen; near Forres, Elgrinshire; Glen Nevis, Invernessshire; Applecross, Rossshire; Rostellan and Castlemary, Cork ; Killarney, Kerry; Kylemore and Doughruagh MIts., Connemara, Galway ; Achill Island and Clare Island, Mayo ; near Belfast, Antrim.

Var. erumpens Hue in Nouv. Arch. Mus. Paris sér. 4, ii. p. 96 (1900).-Thallus greyish-green, decumbent, thin, small, lobate, the lobes at first rounded, subintegrate, smooth or thinly tomentose, with central glaucous or whitish soredia, beneath whitish with reticulate reins.-Peltidea erumpens Tayl. in Lond. Journ. Bot. vi. p. 184 (1847). Specimen not seen.

Distinguished by the small size and the superficial soredia. Hue gives the size of the varicty as $1 \mathrm{~cm}$. long, $6-10 \mathrm{~mm}$. wille. but Taylor's specimen is recorded as much larger, the thallus being 1-2 inches wide.

$H a b$. On sides of dry banks, Dunlierron, Kerry.

2. P. spuria DC. Fl. Franc. ii. p. $406(1805)$.--Thallus small (2)-1 cm.), subascending, somewhat downy or prumose, greyishsreen, leneath whitish with rather strong white nerves and fow white rhisina. Apothecia on digitate lobes, rather small, romulish, then oblong and revolute, brown or reddish-brown, minutely cremulate or denticulate rouml the margin: spores ; -7 -septate, 56-75 $\mu$ long, :3-5-1.5 $\mu$ thick.-Leight. Lich. Fi. p. 108 ; ed. 3, p. 103. P. canina var. pusilla Fr. Lich Eur. 1. 45 (18:31): Mudrl Man. 1) 8.:. P. rufescens subsp. spmia

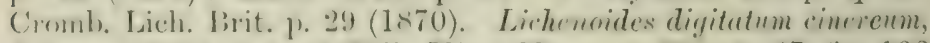

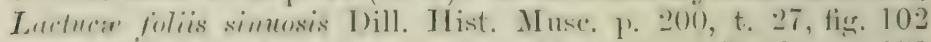
A-1) (17i1). Lichen spurius Ach. Lich. Suec. Prodr. p. 159

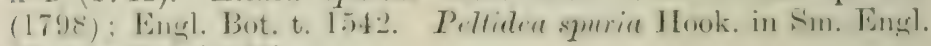
[il. v. p. 215 (1833).

Exsier. Johns, n. 308. 
Resembles the precerling in the colourless under-surface but is much smaller, sometimes resembling $P$. venosa in form.

$H a b$. On the ground among mosses and short grass, also on the stumps of trees in maritime and upland districts.-Distr. Rather rare in S.IV. and N. England, N. Wales, and among the Grampians, Scotland.-B. M. Totnes, Devon; near Ryde, Shanklin and Ventnor, I. of Wight; Sussex Downs, near Brighton, Hurstpierpoint and Haywards Heath, Sussex; Ightham. Iient; Epping Forest and Ulting, Essex; near Cirencester, Gloucestershire; Sotterley, Suffolk; Gogmagog Hills, Cambridgeshire ; Oswestry and Church Stretton, Shropshire; Ynsfaig, N. Wales ; Ingleby, Cleveland, Yorkshire ; Streatlam, Durbam ; Appin, Argyll ; The Trossachs and Falls of Tummel, Perthshire; Durris, Kincardineshire.

3. P. rufescens Hofim. Deutschl. Fl. p. 107 (1795).-Thallus spreading, horizontal, rather thickish, downy above, roundly lobed, often crisp at the edges, greenish- or greyish-brown when moist, light-brown or greyish-red when dry, beneath with thick brownish or dark nerves and scattered dark rhizina. Apothecia moderate in size, roundish or somewhat oblong, red or brownishred, the margin denticulate; spores 3-5-septate, 42-72 $\mu$ long, 4-5 $\mu$ thick.-Cromb. Lich. Brit. p. 29; Leight. Lich. Fl. p. 108 ; ed. 3, p. 102. P. canina var. rufescens Mudd Man. 1) 82 (1861). Lichenoides jeltatum terrestre rufescens Dill. in Ray Syn. ed. 3, p. 77, n. 88 (1721). Lichenoides digitatum rufescens, foliis Lactucre crispis Dill. Hist. Muse. p. 203, t. 27, tig. 103 (1741). Lichen coninus var. mfescens Weiss Pl. Crypt. Gott. p. $79(1770)$; Lightf. Fl. Scot. ii. 1). 846. L. rufescens Neck. Meth. Muse. p. 79 (1771) ; With. Arr. ed. 3, iv. p. 405 (L. rufus errore p. 70) ; Engl. Bot. t. 2300. Peltidea vufescens Ach. Meth. Lich. p. 285 (1803); Hook. in Sm. Engl. Fl. v. p. 216 (1833). P. canina var. crispa Ach. Lich. Univ. p. 519 (1810); var. rufescens Hook. Fl. Scot. ii. p. 60 (1821). P. crisuc S. F. Gray Nat. Arr. i. p. 428 (1821).

Exsice. Bohl. n. 87 ; Cromb. n. 43 ; Johns. n. 227.

Closely allied to $P$. canina, intermediate stages occurring between the two species, but in general it is more reddish in colour, and the margin of the lobes are crisper. It differs also in habitat.

Hab. Among mosses on shady rocks, and the stumps of trees in maritime and mountainous districts.-Distr. Rather rare throughout the British Isles.-B. M. Guernsey; Penzance, Cornwall; Totnes. Deron ; Cirencester, Gloncestershire; Gopsall, Leicestershire ; Hafod, Cardiganshire; near Kendal, WVestmoreland; New Galloway, Kirkcudbrightshire; Airds, Appin, Argyll ; Achmore, Killin, Perthshire; near Fort William, Invernessshire; Rossearbery, Cork; Clare Islamd. Mayo.

Var. prætextata Nyl. Syn. Lich. i. 1) 325) (1860).--Varies in the isirliferous or minutely squamulose margins of the thalline lobes. Form pratextata Cromb. in Journ. Linn. Suc. xvii. p. 57t (18sio) \& Monogr. i. p. 2\$9. P. ranima var. limbate Mudd Man. 
p. 8:3 (1861) (non Del.); form crispa Leight. Lich. Fl. ed. 3, p. 102 (1859) (non Ach.); form lepirloptiora Cromb. in Grevillea xv. p. 77 (15s7) (non Nyl.). Peltidea ulorrhize var. pretentutre Floerke ex Sommerf. Suppl. Fl. Lapp. p. 123 (1826).

Exsicc. Bohl. n. 30 ; Johns. n. 363 ; Larb. Lich. Hb. n. 46 ; Leight. n. 262 pro parte; Mudd n. 60.

Well marked by the densely isidioid margins of the thallus.

Hab. Among mosses on shady rocks, etc., generally in moist places. -Distr. Throughout the British Isles, more frequent than the species. - B. M. Rozel, Jersey; Bocconoc, Cornwall; Lustleigh and Widdi. combe, Devon ; near IVorcester; Barmouth and Dolgelly, Merioneth; Easby, Sowerdale and Baystale, Cleveland, Yorkshire; Teesdale, Iurham; Windermere and near Kiendal, Westmoreland; Tieswick, Cumberland; Airds, Appin, Argyll; Glen Lochay, Killin and Glen Fender. Blair Athole, Perthshire; Craig Cluny, Braemar, Aberdeen. shire; near Fort William, Invernessshire; I. of Slive; Killarney, Tierry; Glendalough, Connemara, Galway; Clare Island, Mayo.

\section{Thallus pulverulent, granular or scabrid above.}

4. P. malacea Fr. Lich. Eur. p. 44 (1831). - Thallus moderate in size, thickish, smooth or obsoletely pulverulent, pale-greyishbrown when moist, bright-brown or greyish when dry, beneath tomentose, dark-brown at the centre, becoming lighter and almost colourless towards the margin, without nerves. Apothecia moderate in size, orbicular, adnate, lrownish-red, crenulate at the marcrin ; spores elongate-fusiform, 3-5-septate, 58-7t $\mu$ long, 5-6 $\mu$ thick.-Cromb. in Journ. Bot. lvii. p. 147 (1874) ; Leight. Lich. Fil. ed. 3, p. 102 pro parte. Peltiden malurea Ach. Syn. Lich. p. 240 (1814) pro parte; var. micrololu Nyl. ex Ianny in Bull. Soc. Bot. xxv. p. 378 (1878) ; Cromb. Monogrr. i. p. 는.

Exsice. Johns. n. 362.

Distinguished by the almost continuous brown tomentum of the under surface. Apothecia are occasionally formed on the under side of the thallus, but in that case not at the extreme margin as in Nephromium (Bitter in Ber. Deutsch. Bot. Ges. xxii. p. 248 (1904)).

$H a b$. Among mosses on rocks and about the roots of trees in mountrinous regions.-Distr. Lare in hilly or mountainous regions in W. Fingland and Highlands of Scotland.-B. M. Gravesend, lient; Bridgnorth and Hope Thowdler, Shropshire; Inverury, Argyll ; Glen Lochay and Dunkeld, Perthshire.

5. P. scutata Koerl). Syst. Lich. (ierm. p. 60 (1855).-Thallus divided into moderate-sized loles, more or less minutely sramular or furfuraceous, the lobes undulate, (renate, (risp) and bluish-greysorediate (marely naked) at the margins, greyish-grcen when moist, pale tawny-hown when dry, beneath with a pale brown tomentum, whitish interspaces and whitish rhizine, the nerves and rhizina both becoming diuker. Apothecia ratres small, roundish, on short atsermeling lobes, the margin crenate and 
intlexed; spores usually :3-septate, 44-60 $\mu$ long, $4-5 \mu$ thick.Leight. Lioh. Fl. p. 110 ; ed. 3, p. 104. P. polydactyla var. sentate Fr. Lich. Eur. p. 47 (1831); Cromb. Lich. Brit. p. 29. P. canina var. sentata Mudd Man. 1). 83 (1861). Lichenoides sulfuscum, peltis horizontalibus flamis Dill. Hist. Musc. p. 205, t. 28, fig. 104 c (17t1). Lichen scututus Dicks. Pl. Crypt. fasc. 3, p. 18 (1793) (non Wulf.); With. Arr. ed. 3, iv. p. 71 ; Engl. Bot. t. 1834. Peltideu scutatu Ach. Meth. Lich. p. 285 (1803); S. F. Gray Nat. Arr. i. p. 427 ; Hook. Fl. Scot. ii. p. 60 \& in Sm. Engl. Fl. v. p. 21 .

Exsice. Cromb. n. 44 ; Johns, n. 126 ; Leight. n. 262 pro parte.

Somewhat similar to $P$. polydactyla var. collina in the form of the lobes, but characterized by the furfuraceous thallus and nearly always by the sorediate margins.

Hab. Among mosses on the trunks of trees, rarely on turf-walls in wooded districts.-Distr. Not frequent in S.W. and N. England, in Wales and in Scotland, and in N.E. and S.IV. Ireland.-B. M. Tregawn, Cornwall ; near Plymouth, Becky Fall, Elburton, Tingsbridge, Ivy Bridge, South Brent and near Harberton, Devon; Shanklin, I. of Wight; Up Park and near Hastiogs, Sussex; near Oswestry, Shropshire; near Edwinsford, Caemarthenshire; Hafod, Cartiganshire; Dolgelly and Llyn Bodlyn, Mericneth; Hoggarts TTood, Cleveland, Yorkshire; Ambleside, Westmoreland; Lamplugh and lieswick, Cumberland; New Galloway, Kirkcudbrightshire; Collinton Woods, near Edinburgh; Inverary and Barealdine, Argyll; The Trossachs, Glen Lochay and Schiehallion, Perthshire; near Fort William, Invernessshire; Glenferness, Nairnshire; Killarney, Kerry; near Belfast, Antrim.

6. P. scabrosa Th. Fr. Lich. Aret. p. 45 (1S60).-Thallus moderate in size, subcoriaceous, finely and minutely areolatescabrid, roundly lobed, pale-brown or greyish, beneath whitish, subreticulate with nearly confluent nerves, pale towards the periphery, blackish towards the centre. Apothecia moderate in size, roundish, at length revolute, brownish-red or dark-brown, the margin subcrenulate; spores 3 - or more-septate, $68-80 \mu$ lons, or longer, $4-5 \mu$ thick.-Cromb. in Journ. Bot. xxiii. p. 195 (1885).

Allied to $P$. rufescens but differs in the scabrid thallus and in the long narrow spores. There is no specimen in the British herbarium.

Hab. On turf-covered walls between Corriemulzie and Inverey, Braemar, Aberdeenshire.

\section{Thallus naked, shining above.}

7. P. polydactyla Hoffin. Deutschl. Fl. ii. p. 106 (1795)).Thallus thinnish, smooth and shining, frequently digititer-loleted and ascending at the margins, especially when fertile, slaucuusgreen when moist, hrownish-grey or tawny-lnown when dir, covered below with a brown tomentum or reticulate with white 
interspaces and wide brown reins, which are often blackish towards the centre, and with or without concolorous rhizinie. Apothecia moderate in size or small, generally somewhat oblong, reddish-brown, the margin irregularly crenate; spores thinly 3-7-septate, 60-80 $\mu$ lomg, 1-5 $\mu$ thick.-Mndd Nan. p. 83; Cromb. Lich. Brit. p. 29 (excl. var. seututu); Leight. Lich. Fl. p. 109 ; ed. 3, p. 103 (incl. var, hymenina); f. microcarpa Cromb. Monogr. i. p. 291 (1894); var. leymenina Cromb. loc. cit. p. 292. Lichenoides cineremen polydactylon Dill. Hist. Mluse. p. 207, t. 28, fig. 107 (1741) \& Lielemoides membranarenum pellucirlam, peltis digpitatis geminutis p. 208, t. 28, fig. 108. Lichen ymlydretilom Neck. Meth. Musc. p. 85 (17 7 ) ; With. Arr. ed. 3, ir. p. 69. L. aninus var. polydactylon Lightf. Fl. Scot. ii. P. 846 (17Ti); vars. $\gamma \& \delta$ Huds. Fl. Angl. ed. 2, p. 547. Peltidere polyductyla Ach. Meth. Musc. p. 286 (incl. var. pelluridu); S. F. Gray Nat. Arr. i. p. 428 ; Hook. Fl. Scot. ii. p. 61 \& in Sm. Engl. Fl. v. p. 216 ; Tayl. in Nackay Fl. Hib. ii. p. 154 ; var. microcerpa Ach. Lich. Univ. p. 520 (1810). P. lıymenina Ach. Meth. Musc. p. 284 (1803).

Exsice. Bohl. nos. 56, 71 ; Cromb. n. 148 ; Johns. nos. 27,28 ; Larbal. Lich. Hb. (without number); Leight. n. 172; Mudd n. 61 .

Distinguished by the smooth upper surface, the brownish tomentum below and the incurving of the narrow fertile lobules and apothecia and by the septation of the spores. The reining below due to stretching growth raries; in some specimens or parts of specimens it is less evident and the tomentum is almost continuous (var. hymmina), in others the process is more marked. Sometimes the tomentum is blackish towards the centre. The apothecia and thallus may be small (f. microcarpa) or of fairly large dimensions. When the apothecia are two together it is referred to by I)illenius as geminate (rar. pellucida Ach.). The pycnidial spores are $7-12 \mu$ long, 3-1 $\mu$ thick.

Hab. Anong mosses and short grass in maritime and inland districts.-Distr. General and mostly common throughout the l3ritish Isles.-B. M. Guernsey; near Penzance, Bocconoc and Withiel, Cornwall; near Totnes and Dartmoor, 1)eron; Nutley, II Ints; Danny, Sussex; High liocks, Tumbridge Wells, Fient; Epping Forest, IEsex; Gogmagog Hills, Cambridgeshire; near Worcester and near Matrern, Woreestershire; Hatboro' Magna, Witwickshire; Ludlow, Jridgnorth and near (iver Caradoc, Shrophine; Aberdorey and near Dolgelly, Merioneth; Anglesen; Kildale, (leveland, Yorkishire; Emestone, Jurhan; Windermere, Westmoreland ; Lamplugh, Alston and near Whitehaven, Cumberlamd; Xew Galloway, lirkeudbrightshire; Anchindenny Wooxh, near Edinburgh; Kemmure, near (ilasgow, Lantulshire; Inverary, Appin and Batealdine, Argrll ; (ilen Lochay, Glen Fender, Killin and Jien Lawers. Perthshive; Purris, Kincardineshire; (orriemulzie, Bratemar, Aberleenshire; Lochaber. Invernessshire; near Forres, Elginshire; Applecross, liossshire; Cromaglown, Killarney, Kerry; Kỵlemore, Galway; near Westport, Maỹo.

Form collina Nyl. Lich. Acand. p. !0 (1N61)._C'haracterized by the smaller loher, which are eri-p) at the margins (ef. n. 5).- 
Cromb. in Journ. Bot. xiv. p. 360 (1876). Var. collina Leight. Lich. Fl. ed. 3, p. $10+$ (1879). Lichen collinns Ach. Lich. Siuec. Prodr. p. 162 (1798).

Exsicc. Johns. n. 309.

Hab. On decayed mosses on the ground and on old walls in upland districts.-Distr. Rare in N. England, among the Grampians, Scotland, and S.W. Ireland.-B. M. Cumberland; Glen Lochay; Killin, Perthshire; Glen Cluny, Braemar, Aberdeenshire; Killarney, Kerry.

Var. lophyra Nyl. Jich. Scand. p. 90 (1861),-Thallus lobes rounded. Apothecia small, roundish, oblong or transversely oblong. Cromb. Lich. Brit. p. 29. Peltiden horizontulis var. lophyyra Ach. Lich. Univ. p. 516 (1810).

Acharius' description of the lobes as being elevated and crisp at the margins might rather refer to f. collina. Acharius cites as synonymous Withering's Lichen mfescens and $L$. rufus, which are quoted under $P$. rufescens. There is no specimen of this variety in the British herbarium. shire.

Hab. On decayed mosses on boulders at Finlarig, Killin, Perth-

8. P. horizontalis Hoffm. Deutschl. Fl. ii. p. 107 (1795).Thallus rather large and spreading, smooth and somewhat shining, sometimes with frequent dents or hollows, the lobes sinuate and slightly undulate at the margins, dull or brownishgreen when moist, pale-glaucous or brown when dry, beneath brownish at the circumference, becoming brownish-black towards the centre, reticulate with white interstices, and with few scattered dark rhizinæ. Apothecia usually abundant and large, round or elliptical, plane, reddish-brown, becoming darker, the margin subcrenulate; spores $6-8$ in the ascus, rather broadly fusiform, 3-septate, 30-42 $\mu$ long, 6-7 $\mu$ thick.-Mudd Man. p. 84 ; Cromb. Lich. Brit. p. 29 ; Leight. Lich. Fl. p. 110 ; ed. 3, p. 10t. Lichenoides subfuscum, peltis horizontulibus plunis Dill. Hist. Mlusc. p. 205, t. 28 , fig. 104 A, B (1741). Lirlen horizontalis L. Mant. p. 132 (1767) ; Huds. Fl. Angl. p. 543 ; Lightf. Fl. Scot. ii. p. 849 ; With. Arr. ed. 3, iv. p. 72 ; Engì. Bot. t. 888. Peltidea horizontalis Ach. Meth. Lich. p. 288 (1803); S. F. Gray Nat. Arr. i. p. 427 ; Hook. Fl. Scot. ii. p. 60 it in Su. Engl. Fl. v. p. 215 ; Tayl. in Mackay Fl. Hib. ii. p. 15.3.

Exsicc. Bohl. n. 37 ; Cromb. n. 45 ; Dicks. Hort. Sicc. fase. xvi. n. 24 ; Johns. n. 228 ; Larb. Lich. Hb. n. 249 ; Leight. n. 108 ; Mudd n. 62.

Characterized by the large thallus and the round apothecia which remain horizontal, and also by the size and septation of the spores.

Hab. Among mosses and rocks, trees and walls, mostly in upland districts.-Distr. General though not common in hilly ilistriets of Great Britain and Ireland.-B. M. Pentire, ('ornwall; 1)irtmoor, Ilsham Walk and near Totnes, Devon; New Forest, Hants; Fridge Rocks, Ardingly and near Hentield, Sussex; I3etehworth, Surey; 
Leigh Toods near Bristol. Gloncestershire; Barion Hill and Charnmool Forest. Leicestershire; Milrem. Worcestershire; near Simmond's Iat. Mommouthshire; Aberdorey and Barmouth, Merioneth; Bettrs-r-Coel, Carnurvonshire; Osmestry and Thitcliff Rochs, Shropshire; Stogdale, Cleveland, Yorkshire; near Iiendal, Westmoreland; Iiesmick. Cumberland; The Cheriots, Northumberland; New Gallomay. Firliculbrightshire; Swanston near Edinburgh; Bowling Bay, Dumbartonshire; Dumoon and Barcaldine, Argyll; Loch Fiatrine, near Callander, Fienmore, Craighall and Dunkeli, Perthshire; Sidlaw Hills. Forfarshire; Craig Clunr, Braemar, Aberdeenshire; Lochaber, Inrernessshire; near Forres, Elginshire; Fillarney, Tierry; Louisburgh, Mayo.

Tar. muscorum Schleich. ex Schrs. Enum. p. 21 (1850).Thallus lobes and apothecia constantly smaller. Cromb. in Journ. Bot. xiv. p. 360 (1876); Leight. Lich. Fl. ed. 3, p. 105; f. muscorum Cromb. MIonogr. i. p. 294 (1894).

Exsice. Johns. 12. 229.

Hab. Among mosses at the roots of old trees in upland districts.Distr. Rave in S.TW. and N. England, S. Grampians, Scotland, and N.IT. Ireland.-B. M. Paignton, Deron; Formbr, Iancashire on sandhills); near Thiteharen, Cumberland; Glen Lochay. Perthshire ; Killarney, Kerry ; Kylemore, Connemara, Galway.

\section{§ ii. Peltidea Wain. Lich. Brés. i. p. 179 (1890).}

Algal cells bright-green (Drctylococcu*); cephalodia present.

9. P. aphthosa Willd. Fl. Berol. p. 347 (1787).-Thallus broadly membranaceous, thin or somewhat thickish, smooth and shining above, bright-green when moist, dull-brownish when dry, dotted with darker-coloured tubercle-like epigenous cephalodia. Apothecia roundish, moderate in size or rather large, about $8 \mathrm{~mm}$. in diameter, adnate on the ends of rather narrow thallus segments, reddish-brown, slightly lacerate at the edges; spores fusiform, 3-7-septate, colourless or pale-brown, $50-90 \mu$ long, 5-6 $\mu$ thick.-Mudd Man. p. 81: Leight. Lich. Fl. p. 107 ; ed. 3, p. 101. Lirhenoides digitntnm leetevirens, ermucis nigris notufum Dill. Hist. Musc. n. 207, t. 228, fig. 106 (1741). Lirhen (cpththosus L. Ap. Pl. p. 1148 (175:3) : Lightf. Fl. Scot. ii. p. 847; Huds. Fl. Angl. ed. 2, p. 547 ; With. Arr. ed. 3, iv. p. 70 ;

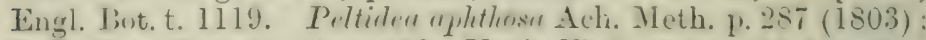
S. F. Gray Nat. Arr. i. 1. 428: Hook. Fl. Sout. ii. p. 60 d in Sm. Engl. Fl. v. p. 215; Tayl. in Mackay Fl. Hib. ii. p. 153 ; Cromb. Lich. Brit. p. 28 \& MLonogr. i. p. 278.

Exsicc. Croall n. 491 ; Cromb. n. 147 ; Johns. n. 306 ; Leight. n. 321.

Chiefly di-tinguished by the presence of cephalodia, as small dark tubercles inttint on the surfice of the thallus. Supposed to resemble spots cantised by ". thrmish," hence the name aphlhess. It is more generally fruitful in morthern localities.

Hab. Anong momes on rocks and boullers, as also on turf-walls 
in moist shaded upland localities.-Distr. Rather rare in WT. and $N$. England and S. Scotland; more plentiful in the Grampians; rare in Ireland.-B. M. Stout's Wood, Gloucestershire; Craigforda, Herefordshire; Llyn Bodlyn, Merioneth; Llanberris, Carnarvonshire; Buxton, Derbyshire; Walla Crag, Cumberland; Teesdale, Durham; The Cheviots, Northumberland; Falls of Clyde, Lanarkshire; near Inverary and Barcaldine, Argyll; Ben Lawers, Craig Calliach, Glen Lochay, Killin, Blair Athole and Den of Reichip, Perthshire; Clova and Sidlaw Hills, Forfarshire; Craig Cluny, Invercauld, Blair Athole and Craig Coinnoch, Braemar, Aberdeenshire; Glen Lochy and Loch Linnhe, Invernessshire; near Belfast, Antrim; Connemara, Galway.

Var. leucophlebia Nyl. Syn. Lich. p. 323 (1860)._-Thallus usually smaller, more opaque and whitish beneath, with distinct whitish nerves. Apothecia rare (not seen in Britain); spores 3-septate, 52-66 $\mu$ long, 4-6 $\mu$ thick. Peltirler aphthosa var. lencopletelia Nyl. in Not. Sällsk. Faun. \& Fl. Fenn. Förh. v. p. 117 (1866); Cromb. Monogr. i. p. 278.

Exsice. Johns. n. 83 ; Mudd n. 58.

Hab. Among mosses on shady rocks or on the ground in upland districts.-Distr. Rare in S.IV. and N. England, in S. Scotland and in the Highlands, not seen from Ireland.- $B$. M. Dartinoor, Devon; White Force, and on moors, Teesdale, Durham; near Kendal, West. moreland; New Galloway, Trirkcudbrightshire ; Dalmahoy Hill, near Edinburgh; near Inverary, Invernessshire; the Ochills, Blair Athole, Rannoch and The Trossachs, Perthshire.

10. P. venosa Hoffm. Pl. Lich. i. p. 31, t. 6, fig. $2(1790)$.Thallus rather small, up to $2 \mathrm{~cm}$. across, the fronds ascending, roundish, entire or somewhat lobate, smooth and shining, brightgreen when moist, greyish or greyish-brown or fawn-coloured when dry, beneath white with dark-brown branching nerves radiating from the base. Cephalodia somewhat globose, glaucousgreen, becoming dark-coloured, hypogenous, seated on the brown tomentose nerves. Apothecia roundish, moderate in size or rather larger, up to about $5 \mathrm{~mm}$. in diameter, plane, adnate, dark-brown or blackish, the proper margin somewhat crenate, eranescent; spores 6 to 8 in the ascus, fusiform, 3 -septate, colourless or pale-brown, 30-45 $\mu$ long, $7-8 \mu$ thick.- Indd Man. p. 84, t. 1, fig. 23 ; Leight. Lich. Fl. p. 111 ; edl. 3, p. 105. Lichenoinles partum virescens, peltis nigricantilus planis Dill. Hist. Musc. p. 208, t. 28, f. 109 (1741). Lichen venosus L. Sp. Pl. p. 1148 (1753); Lightf. Fl. Scot. ii. p. 84t; Huds. Fl. Angl. ed. 2, p. 546; With. Arr. ed. 3, iv. p. 69; Engl. Bot. t. 887. Peltide a venosa Ach. Meth. Lich. p. 28.2 (1803); S. F. Gray Nat. Arr. i. p. 427; Hook. Fl. Scot. ii. p. 59 \& in Sm. Engl. Fl. r. p. 215 ; Cromb. Lich. Brit. p. 28 \& Monogr. i. p. 279.

Exsicc. Cromb. n. 42.

Differs from the precerling species in the much smaller size of the thallus and in the hypogenous cephalodia. 
Hab. On turf walls and on the ground in fissures of rocks in upland and mountrinous situations.-Distr. Pare in the hilly regions of WV. England, Wales, X. Ireland and S. Scotland, more frequent in the (irampians.-B. M. Whitcliff Rocks, near Ludlow, Shropshire ; Glyder Fawr, Carnarronshire; Kirkmichael and near Moftat, Dumfriesshire; Habbies How, Pentland Hills near Edinburgh; Menstrie Glen, near Stirling; Stronachlachar, Finlarig, Killin, Ben Lawers, Glen Lyon and Piss of Killiecrankie, Perthshire; Reeky Linn and Clova, Forfarshire; Belfast, Antrim.

33. NEPHROMIUM Nyl. in Mém. Soc. Ści. Nat. Cherb. r. p. 101 (1857) d Syn. i. p. 318 (1860). (Pl. 33.)

Thallus foliose, horizontal, corticate on both surfaces, the uncler surface sometimes tomentose. Algal cells Nostoc. Apothecia marginal, roundish, adfixed on the lower surface of the thallus, finally directed upwards by the turning back of the fertile lobes, without a thalline margin; paraphyses simple, septate; spores fusiform-oblong, usually brownish, 1-3-septate. Spermogones with septate sterigmata and small straight somewhat dumbbell-shaped pleurogenous spermatia.

The associated genus Nepleroma which contains bright-green gonidia is not represented in the British Isles; the species are mostly found in cold regions.

1. N. resupinatum Dalle Torre it Sarnth. Die Flechten Tirol, (ic. p. $80(1902)$. - Thallus suborbicular, lobate or laciniateiobate, smooth or thinly tomentose, dull-glaucous or brown, paler beneath, densely tomentose and dotted with white granules (the merlulla white, $\mathbf{K}-$ ). Apothecia moderate in size, rerldishbrown, unequal and crenulate at the margins; spores colourless or brownish, $20-24 \mu$ long, $6-7 \mu$ thick. $-N$. tomentosum $N$ rl. in IÉm. Soc. Sei. Nat. Cherb. v. p. 101 (1857); Carroll in Journ. but. iii. p. 28s (1865); Cromb. Lich. Brit. p. 28 ; Leight. Lich. Fl. p. 105 (incl. var. ramenm; ed. 3, p. 99 : subsp. rameum Cromb. Monogr. i. p. 283? (non Scher.). Lirhen resupinatus L. Sp. Pl. p. 1148 (1753) fide Wainio in Med. Suc. Faun. it Fl. Fenn. xiv. p. 6 (1856). L. tomentosus Swartz Prodr. Fl. Ind. p. 147 (178s). Prlligera tomentosa Hoffm. Deutschl. Fl. ii. p. 108 (1795). Nephroma resupinatu Ach. Lich. Univ. p. 522 (1810); S. F. (iray Nat. Arr. i. p. 426; Hook. Fl. Sicot. ii. p. 61 d in Sm. Engl. Fl. v. p. 216 ; Tayl. in Mackay Fl. Hib. ii. p. 154.

A specinen from Robt. Brown marked subsp. rancum agrees with the species, and is from the same locality. loth species and "subspecies" are sprinkled with white dots (psemdocyphellie) on the under surface. The subspecies differs, however, in the longer nurrower lobes and somewhat thimmer texture of the thallus. There does not seem to be any anthentie record of its oceurrence in the British Isles.

IIah. On the trunkis of old trees in rocky upland situations.B. M. Craig Cluny, Braemar, Aberdeenshire. 
2. N. Iævigatum Nyl. in Mém. Suc. Sci. Nat. Cherb. v. p. 101 (1857).- Thallus suborhicular, smonth above, chestnut- or dull-brown, the lobes sinuate-crenate at the margins, beneath glabrous and slightly wrinkled, pale (medulla white, $\mathbb{K}-$ ). Apothecia small or moderate, reddish-brown, crenulate, unequal at the margin, depressed and granulate at the back; spores 20-24 $\mu$ long, 6-7 $\mu$ thick.-Cromb. Lich. Brit. p. 28; Leight. Lich. Fl. p. 104; ed. 3, p. 99. Lichenoides saxatile fuscum, peltis in aversa foliorum superficie locatis Dill. in Ray Syn. ed. 3, p. 7T, n. 91 (17.4). Lichenoides fuscum, peltis posticis ferrugineis Dill. Hist. Musc. p. 206, t. 28, fig. 105 ^ (1741). Lichen resupiaatus Huds. Fl. Angl. p. 45;) (1762)? Light. Fl. Scot. ii. p. 843? With. Arr. ed. 3, iv. p. 71? Nephirome læavigatum Ach. Syn. Lich. p. 242 (1814); Mudd Man. p. 81?

Evidently a rare lichen everywhere; there is no specimen in the British herbarium. The original habitat as given by Acharius is "in mountainous places," and it is extremely doubtful to which species Dillenius and others quoted above refer, though Crombie has determined the specimens in the Dillenian herbarium collected in Sussex and Shropshire as $N$. lavigatum.

$H a b$. On the trunks of old trees and on mossy boulders in mountainous places.

Var. subtomentellum Nyl. in Not. Sällsk. Faun. \& Fl. Fenn. Förh. v. p. 116 (1866).-Thallus dark-brown, beneath wrinkled, obsoletely and slightly tomentose, brown (medulla waite, $\mathbf{K}-$ ). Apothecia moderate in size, dark-red, wrinkled at the back or thinly areolate-granular; spores similar to the species.-Leight. Lich. Fl. ed. 3, p. 99.

Exsicc. Cromb. n. 149.

Resembling the species in the wrinkled backs of the apothecia. The thallus is generally darker and there are vestiges of a tomentum on the under surface. According to Crombie the spermatia are $2 \cdot 5 \mu$ long and $1 \mu$ thick, those of the species being $3 \cdot 5-4 \mu$ long.

$H a b$. On the trunks of old trees in mountainous regions.-Distr. Local and searce in N. Wales and among the S. Grampians, Scotlind. -B. M. Head of Loch Awe, Argyll; Glen L Lochay, Kíllin, P'erthshire.

Var. parile Nyl. Syn. Lich. i. p. 320 (1860).--Thallus lobes more or less crisp and bluish-grey sorediate at the margini, beneath naked, wrinkled, pale or sometimes rlark-coloured. Apothecia rare: spores as in the species.-Cromb. Lich. brit. p. 2s; J Jeight. Lich. Fl. p. 105; ed. 3, p. 99. N. parile Nyl. in

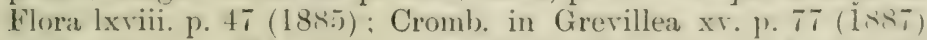

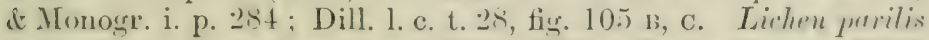
Ach. Lich. Suec. Prodr. p. $164(1798)$ : Engl. Bot. t. 2:3ti). Nepleromer purite Ach. Lich. Univ. p. 522 (1810) pro parte; S. F. Gray Nat. Arr. i. p. 427; Hook. in Sm. Engl. Fi. v.

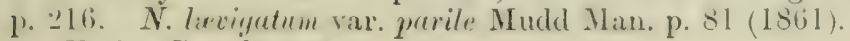

Exsice. Cromb. n, 41. 
Though sometimes given specific rank, evirlently only a sorerliate though well-marlier variety of N. lavigatum. Bitter (Jahrb. Wiss. Bot. xxxvi. p. 454 (1901)) has recorded the occurrence of both species and variety in close proximity; the former on the branches of a tree bore apothecia and no soredia, while var. parile, abundantly sorediate, grew in a more damp situation among moss and grass on the ground. The soredia are mostly marginal, though sometimes scattered over the surface. 'They become dark in colour in older plants. None of the British specimens are fertile.

$H a b$. On mossy rocks and boulders and about the roots of old trees in wooded districts.-Distr. Rather rare in S. and IV. England, Scotland and Ireland.-B. M. Ivy Bridge, Hennock, Bovey Tracey, Totnes, and near Devonport, Devon; Cound Moor and near Oswestry, Shropshire; Dolgelly and Twll Du, Merioneth; Windermere, Westmoreland; Braithwaite, Cumberland; Pentland Hills, near Edinburgh; - Barcaldine, Argyll; Craig Cailliach, Glen Lochay and Pass of Killiecrankie, Perthshire; Craig Cluny, Braemar, Aberdeenshire ; Caledonian Canal, Invernessshire ; near Dunkerron, Kerry.

3. N. lusitanicum Nyl. in Flora liii. p. 38 (1870). - Thallus suborbicular, lobate, smooth and somewhat shining, the lobes rounded, crenate, crisp or undulate at the margins, chestnut- or clark-brown, beneath glabrous, somewhat wrinkled, pale (medulla yellow, $\mathrm{K}+$ purplish). Apothecia varying in size up to $1 \mathrm{~cm}$. across, sometimes confluent, reddish-brown, incurved, sometimes crenate at the edges, somewhat depressed and minutely areolate at the back; spores 20-24 $\mu$ long, $6-7 \mu$ thick.-Leight. in Ann. Mag. Nat. Hist. ser. 4, v. p. 41 (1870) \& Lich. Fl. p. 106 ; edl. 3, p. 100. N. Trvigatum f. lusitanirum Cromb. Lich. Brit. p. $2 S$ (1870). Iichen resupinatus Sm. Engl. Bot. t. 305 (1796) (non L.); var. 2 With. Arr. ed. 3, iv. p. 71 (1796). Nepleroma lusitanicum Schær. Enum. p. 323 (1850).

Exsice. Croall n. 99 ; Dicks. Hort. Sicc. fasc. xri. n. 23; Johns. n. 226 ; Laro. Lich. Hb. n. 288 ; Leight. n. 23.

Distinguished from other species by the smoother, more shining surface and by the usually yellow medulla.

Ifal. On the trunks of old trees, and on mossy rocks and boulders in wooded districts.-Dist. General and not uncommon throughout the British Isles.-B. M. Islands of Bréchon and Guernsey; Scilly Islands; nenr liespring, P'enzance, Lislienrd and St. Austell, Cornwall; Okchampton, Torcuay, Iustleigh Cleeve and near Totnes, Devon; New lorest, Hants ; Eridge liocks, Jett Beach and Ardingly, Sussex; Romney Marsh and Tyydi, Fient; Irattield Forest, Essex; Malvern, Worcestershire; near Oswestry, Shropshire; Barmouth, Dolgelly and Aberdovey, Merioneth; Capol Curig and Bettws-y-Coed, Camnarvonshire; Baysdale, Cleveland, Yorkshire; Egrolestone, Durham; Mardule, Westmoreland; Keswick and Jassenthwate Lake, Cumberland; New Galloway, hirkeudbrightshire; near Moflat, Dumfriesshire; d)mubarton Castle. 1)umbartonshire; Jitrealdine, Inverary and Head

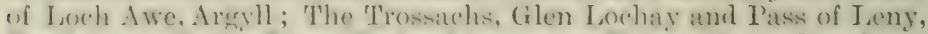

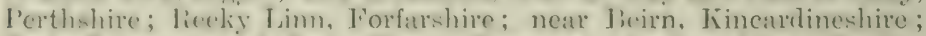
Craig Comnoch am Craig Cluny, Iracmar. Aberdeenshire; Cawdor 
Woods, Nairnshire; Glen Nevis, Loch Linnhe, Fort George and Falls of Foyers, Invernessshire; Applecross, Rossshire; Luggelaw, Wicklow; Fillarney, Kerry; Derryclare, Connemara, Galway; Fairhead, Antrim.

Form panniforme Cromb. in Grevillea xv. p. 77 (187i) \& Monogr. i. p. 286.-Thallus of small deeply cut closely imbricate lobes, dark in colour above and below.

Hab. Similar to the species.-Distr. Rare in S.IV. England and TV. Highlands of Scotland.-B. II. Tear Penzance, Cornwall; Barcaldine, Argyll; Glen Lochay, Perthshire; Loch Limuhe, Invernessshire.

Tar. hibernicum Nyl. ex Leight. Lich. Fl. ed. 3, p. 100 (1879).-Differs from the species in the white medulla $(\mathrm{K}+$ purple) and in the smooth back of the apothecia.

Hab. Similar to the species.-Distr. Rare in IV. England, WV. Highlands of Scotland and X.W. Ireland. - B. M. Neai Launceston, Cornwall; near Walkingham, Deron; near Douglas, I. of Man; Barcaldine, Argyll; Doughreagh, Connemara, Galway.

\section{SOLORINA Ach. Lich. Univ. p. 27 (1810). (Pl. 34.)}

Thallus foliose, fragile, the upper surface corticate, the under surface partly nervose and rhizinose. Algal cells bright-green, Dactylococcus, rarely blue-green, Nostoc. Apothecia superficial, or urceolate and sunk in the upper surface of the thallus, irregularly scattered, reddish- or dark-brown, without a thalline margin; paraphyses thickish, septate; spores 2 to 8 in the ascus, fusiform-oblong or ellipsoid, 1-sepate, brownish or reddishbrown. Spermogones unknown.

The cephalodia in this genus occur as groups of Nostoc cells with surrounding hyphæ, embedded in the medulla, on the lower surface or: in squamules. The apothecia are developed before the cortex covering them is thrown off, hence the term "veiled apothecia."

1. S. crocea Ach. Lich. Univ. p. 149 (1810).-Thallus orbicular, membranaceous, thickish, appressed, smooth or roughish on the surface, lobed and crispate, dark-green when moist, reddish or brown when dry, the medulla and lower surface deep crange or saffron-coloured, with sulbreticulate nerves and rhizinie. Apothecia moderate in size or rather large, up to $1 \mathrm{~cm}$. in diameter, rather tumid, clark-reddlish-brown ; paraphyses stoutish, septate; spores 6-8 in the ascus, oblong or somewhat fusiform, 1-septate, $35-45 \mu$ long, $10-12 \mu$ thick.-S. F. Gray Nat. Arr. i. 1). 429 ; Hrok. Fl. Scot. ii. 1) 36 it in Sm. Engl. Fl. v. p. 214; IIudd Man. 1) 85 ; Cromb. Lich. Brit. p. 29 ; Leight. Lich. Fl.

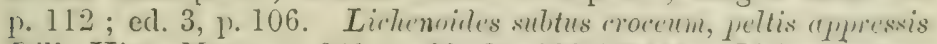
Dill. Hist. IIusc. p. 221, t. 30, fig. 120 (17+1). Lirhen irocens L. Sp. Pl. p. 1149 (175:3): Lightt. Fl. Acot. ii. 1. 8.76: Huls. Fl. Angl. ed. 2, p. 548; With. Arr. ed. 3, iv. 1. 68; Engl. lisut. t. 498 . 
Exwir Croall n. 489 ; Cromb. n. 46 ; Dicks. Dried Plants n. 50 .

Easily distinguishel by the hyphe of the medulla which are encrusted with saffron-coloured crystals ( $K+$ violet).

There are two types of algie which function as gonidia: an upper bright-rreen layer of Dactylococcus cells which rises into the cortex in tooth-like projections or prramids, beneath this a narrow band of loose hyphe, and lower still an interrupted stratum of Nostoc cells. Hue (I'́m. Soc. Sci. Nat. Cherb. xxxriii. p. 10 (1911)) states that the first gonidial association is with the Dactylococcus, that alga alome being present at the extremity of the young lobes. The Nostoc layer is subdiscontinuous, and is rarely present below the apothecium. It replaces in $S$. croced the endogenous scattered cephalodia of the other species.

Hab. On the ground and in fissures of rocks and boulders in alpine places.-Distr. Rather local and scarce on the tops of Irish and Scottish mountains; plentiful on Ben Lawers.-B. M. Ben Lomond. Stirlingshire; Ben Chalum, Ben More, Benteskerney and Ben Lawers. Perthshire; Clora Mts., Forfarshire; Lochnagar, Morrone, Ben-naboord and Ben Macdhui, Aberdeenshire ; Ben Neris, Invernessshire; Brandon MIts., Kerry.

2. S. saccata Ach. Lich. Univ. p. 149 (1810).-Thallus widespreading, orbicular, submembranaceous, rather smooth, occasionally white-pruinose, the lobes rounded or slightly crenate, lobate, bright-green when moist, redrlish-brown when dry, beneath whitish, tomentose, with scattered long rhizinæ. Apothecia roundish, dark-brown, scattered, deeply sunk as if urceolate in the thallus; paraphyses stoutish, septate; spores 4 in the ascus, ellipsoid or oblong, reddish-brown, 1-septate, 32-50 $\mu$ long, 18-27 $\mu$ thick.-S. F. Gray Nat. Arr. i. p. 429 ; Hook. Fl. Scot. ii. 1. 36 \& in Sm. Engl. Fl. v. p. 214; Tayl. in Mackay Fl. Hil. ii. p. 153 ; MLudd Man. p. 85, t. 1, fig. 24; Cromb. Lich. Brit. 1. 29 ; Leight. Lich. Fl. p. 112 ; ed. :3, p. 106. Lichenoides lichenis farie, pultis acetabulis immerwis Dill. Hist. Musc. p. 221, t. 30, fig. 121 (17+1). Lichen surcutus L. Fl. Suec. p. 419, n. 1102 (1755) : Lightf. Fl. Scot. ii. 1. 8.5); Huds. Fl. Angl. ii. p. 548; lingl. Bot. t. 288 ; With. Arr. ed. 3, iv. p. 67.

Exsicc. Bohl. 12. 4; Croall n. 391 ; Cromb. 11. 47 ; Johns. n. 225 ; Leight. 1.111 ; Mudd n. 63.

Easily known by the sunk apothecia with the rather wile-spreading thatlus. Cephatodia containing Nostoc cells are enclosed in the lower medullit, sometimes causing it slight protuherance on the under surface.

Huh. (In the orrouml ondecasen mosses, in erevices of rocks, rarely on the mortar of old walls in moist shady places in upland and subalpine district. - Vistr. (ieneral but not common in 11 . and $\mathrm{X}$. England, in N. Wales and N. Scotland, rare in S.W. and N.

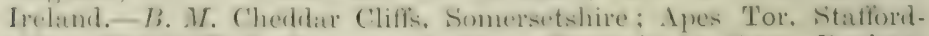
shire; Whiteliff liocks near Lublow, Shropshire: Cwn Bychan, Merioneth; (ritm, Derbyshire; Island of Anglesea; near Buxton. Derhahire; Ingleborongh, Whernside and bulton Woods. Yorkshire; 
Kentmere, Westmoreland ; Alston, Cumberland ; Teesdale, Durham; Loch Awe and Island of Lismore, Argyll; Killin, Finlarig, Ben Lawers, Craig Tulloch and Blair Athole, Perthshire; Canlochan Glen, Forfarshire; Craig Clunr, Carr Rochs and Morrone. Braemar. Aberdeenshire; Bandon Hill, Kerry; Ben Bulben, Sligo ; Colin Glen near Belfast, Antrim.

3. S. spongiosa Carroll in Journ. Bot. iii. p. 288 (1865).Thallus fragile, suborbicular, of small suberect squamules, minutely crenate, becoming partly granular-crustaceous, dark-green when moist, brown when dry. Apothecia round, sunk in the thallus or becoming plane, dark-reddish-brown, surrounded by squamules or shreds of the thallus; spores 4 in the ascus, ellipsoid, brownish, 30-50 $\mu$ long, 18-23 $\mu$ thick.-Cromb. Lich. Brit. p. 30. S. limbata Mudd Man. p. 85 (1861); Leight. Licb. Fl. p. 113 ; ed. 3, p. 107. Lichen spongiosus Sm. Engl. Bot. t. $137 t$ (180t). Collema spongiosum Ach. Lich. Univ. p. 661 (1810) ; Hook. in Sim. Engl. But. v. p. 214; Tayl. in Mackay Fl. Hib. ii. p. 111. Pulychidium sprongiosum s. F. Gray Nat. Arr. i. P. 102 (1821). Lerrnora limbrta Sommerf. Suppl. Fl. Lapp. p. 105, t. 3 (1826).

Exsice. Johns, n. 30T.

Differs from the preceding in the much less dereloped thallus, and in the less deeply urceolate apothecia. The cephalodia of this species are in the form of minute green squamules, often attached to the apothecium.

$\mathrm{Hab}$. On the ground among rocks and on turf walls in uplizn? districts.-Distr. Rare in N. England and N.E. Ireland, more plentiful among the Grampians.-B. M. Buxton Dale, Derbyshire; Thermside and Guisboro' Moor, Cleveland, Yorkshire; Teesdale, Durham; near Kendal, Westmoreland; Finlarig, Killin, near Tummel Bridge and Craig Tulloch, Perthshire; Glenariff, Antrim.

4. S. bispora Nyl. Syn. i. p. 331, t. 8, fig. 42 (1860).-Thallus orbicular, small, thickish, fragile, wrinkled, lobate, somewhat crenate, pale-greyish or brownish-green, white-pruinose, whitish beneath. A pothecia round, sunk in the thallus, small or moderate in size, brown or dark-brown, bordered generally by the broken thallus; spores 2 in the ascus, ellipsoid, reddish-brown, 65-58 $\mu$ long, 33-42 $\mu$ thick.- Stirton in Grevillea ii. p. 60 (187:3): Leight. Lich. Fl. ed. 3, p. 107.

Differs from the preceding in the white-pruinose thallus, the 2-spored asious. and in the larger spores. Groups of Nostoc form cephalodia on the under surface of the thallus.

$H a b$. On the ground in alpine districts.-B. M. Ben Lawers. 


\section{ORDER IX. STICTACE无.}

Thallus foliose, horizontal or somewhat ascending, corticate on both surfaces, heneath more or less tomentose. Cyphelle (minute cup-like hollows) or pseudo-cyphelles (openings in the cortex) constant on the under surface in Stictu. Cephalodia present in certain species. Algal cells blue-green (Nostoc) or bright-green (Palmellacee). Apotheecia marginal or scattered, scutellate and shortly stalked or sessile; paraphyses simple, septate; spores elongate, 2-pluri-septate, colourless or brown. Spermogones with septate sterigmata and short straight pleurogenous spermatia.

Resembling Peltigeracex in that both types of gonidia, blue-green and bright-green, are represented, and in the frequent presence of cephalodia in those species with bright-green algal cells. Crphellæ are small cup-like empty pits with a distinct rim that occur amongst the tomentum of the lower surface; pseudo-cyphellie are less definitely marginate and are filled with loose hyphæ.

Two genera are represented in Great Britain :-

Thallus with cyphellæ or pseudo-cyphellæ on the under surface ...........................................

Thallus without these structures ........................ 36. Lobaria.

35. STICTA Schreb. L. Gen. Pl. ii. p. 768 (1791). (Pl. 35.)

Thallus foliose, variously lobate or laciniate, horizontal, sometimes slightly ascending or stalked and upright, cortex on both surfaces plectenchymatous; beneath cyphellate or pseudocyphellate and pale- or dark-brown-tomentose, with single or fasciculate hyphre. Algal cells Nostoc or Palmellacee. Cephalodia rarely present. Apothecia marginal or scattered, with or without a thalline margin; paraphyses simple, septate; asci 8 -spored, the spores elongate, fusiform or acicular, $1-\bar{T}$-septate. Spermogones with septate sterigmata anrl pleurogenous spermatia, short and slightly thickened at each end.

The genus is distinguished among foliose lichens by the minute round openings in the tomentose under-surface the to the presence of cyphellæ or pseudocyphellæ.

It is dividerl into two sections, distinguished hy the character of the algx:-

Thallus with blue-green algæ $($ Nostoc)..................... i. Stictina.

Thallus with briglit-green algie (Palmellaceat ........... ii. Eustreta.

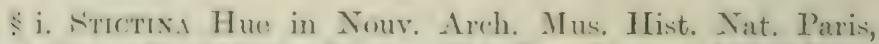
ser. 4. iii. 1. 81 (1901). Stittina Ny. Syn. Lich. 1. $3: 33(1860)$; Cromb. Monogr. i. p. 265 ; Leight. Lich. Fl. p. 114.

Algal cells blue-green. 


\section{Thallus with cyphellæe on the under surface.}

1. S. fuliginosa Ach. MLth. Lich. p. 2800 (1\&03).-Thallus usually rather small, ahout :3-5 $\mathrm{cm}$. in cliameter to $10 \mathrm{~cm}$. or more, submonophyllons, often several lobes from one centre, somewhat rigid, smoothish or somewhat wrinkled, light or darkbrown, the lobes broadening outwards, rouncled, usually thickly sprinkled with clark-brown coralloid isidia, beneath pale-brown, tomentose, with whitish or pale cyphelle. Apothecia small, scattered, rery rare, plane or slightly convex reddish-brown, with a crenate thalline margin: spores fusiform, colourless, 1-3-septate, $2 \bar{T}-40 \mu$ long, $7-i \mu$ thick. -S. F. Gray Nat. Arr. i. p. 431; Hook. Fl. Scot. ii. p. 59 it in Sm. Engl. Fl. v. p. 206; Tayl. in Mackay Fl. Hib. ii. p. 152; Mudd Man. p. 88. Lichensides fuliginosum et pulverulentum, scutellis rubiginosis Dill. Hist. Musc. p. 198, t. 26, fig. $100 \mathrm{~A}(17+1)$. Lichen fuliginosus Dicks. Pl. Crypt. fasc. i. p. 13 (1785); With. Arr. ed. 3, iv. p. 70 ; Engl. Bot. t. 1103. Stictinr fuliginasa Nyl. Syn. i. p. 347 (1860) ; Cromb. Lich. Brit. p. 30 d MLonogr. i. p. 267 ; Leight. Lich. Fl. p. 116 ; ed. 3, p. 109.

Exice. Cromb. n. 133 ; Johns. n. 24; Larb. Cresar. n. 61 ; Leight. n. 142.

An easily distinguished species from the dull-brown colour and the sprinkling of still darker isidia. These eridently function as the principal organs of propagation, apothecia being very rare.

Hab. On mossy trunlis of old trees and on rocks in moist shady places.-Distr. General and fairly common, especially in western districts.-B. $M$. Jersey ; Jerbourg, Guernsey ; Annet Island, Scilly ; Bocconoc, Camelford, Withiel and near Penzance, Cornwall; Walkhampton, Iry Bridge, near Lustleigh, Moreton, Dewerstone Rocks, Becky Fall, near Ashburton and Rirer Teign, Deron; I. of Wight; Lydd, Kent; Malvern, Worcestershire; Whitcliff Pocks, near Ludlow, Shropshire; Hafod, Cardiganshire; Dolgelly, Aberdover and Cwm Bychan, Merioneth; Bettrs-y-Coed, Trefriw, Capel Curig, Aberglaslyn, and near Bangor, Carnarvon; Anglesea; Windermere and near Rydal, Testmoreland: Feswick and Ennerdale, Cumberland; New Gallowar, Tirlicudbrightshire; Falls of Clrcke, Lanarkshire; Bowling Bay, Dumbartonshire; Inverary, Appin and hear of Loch Awe, Argyll ; Pass of Leny, Glen Lochay and Glen Lyon, Perthshire; Craig Cluny, Bracmar, Aberdeenshire; Applecross. lioss hire; Killarney, Rerry; near Tylemore, Galway; Clare Island, Maro.

2. S. sylvatica Ach. Meth. Lich. p. -2\&l (1803).-Thallus: larese and spreading, rather rigid, sometimes shining and with irregular, slightly indicated pits, tawny-or dull-brown and more or less isidiose, the isilia dark-coloured, more develoned along the lines of the shallow depressions, the lobes deeply cut, laciniate, variously rounded or crenulate, lifid or trifid towards the extremities, the anrls ohtuee: loeneath tomentoes, dark-hrown,

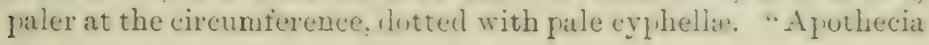


small or moderate in size, scattered, plane or slightly convex, the margin naked, spores as in S. fuligiuosu." - S. F. Gray Nat. Arr. i. p. 431; Hook. Fl. Seot. ii. 1. 59 it in sm. Engl. Fl. r. p. 207 ; Tayl in Mackay Fl. Hib. ii. p. 152 ; Mudd Man. p. 87. Lichenoirts pollysthides villosum of serburum, pelt is partis Dill. Hist. Mlusc. p. 199, t. 27, fig. 101 (1741). Lichen syleaticus Huds. Fl. Angl. 1. 453 (1762); Lightf. Fl. Scot. p. 848; With. Arr. ed. 3, iv. p. 71 ; Engl. Bot. t. 2298. Stictina syluatica Nyl. Syn. Lich. i. p. 348 (1860): Cromb. Lich. Brit. p. 30 \& Monogr. i. p. 268; Leight. Lich. Fl. p. 116 ; ed. 3, p. 109.

Exsier. Croall n. 487; Cromb. n. 134; Larb. Lich. Hib. n. 209 ; Leight. n. 109.

Closely allied to the preceding but differing in the more developed thallus, the very different form of the lobes and the darker under surface. The isidia may be crowded as in S. fuliginosa, but generally they are less abundant and outline the shallow depressions. The apothecia are evidently very rare, the British specimens in the herbarium being all sterile.

Hab. On mossy rocks, old walls and about the roots of trees in shady moist places.-Distr. Plentiful in the western districts of Great Britain and Ireland.-B. M. Bocconoc and near Penzance, Cornwall; Lidford, Widdecombe, Meary, Lustleigh, Cleeve and Bigbury, Devon; near Oswestry, Shropshire; Hafod, Cardiganshire; Aberdorey, Dolgelly, Barmouth and Phewgreidden, Merioneth; Conway Falls, Carnarronshire; Anglesea; Mardale, Westmoreland; Keswick, Cumberland ; Egglestone, Durham ; The Cheviots, Northumberland; New Galloway, Kircudbrightshire; Beld Craig, Moffat, Dumfriesshire; Falls of the Clyde, Lanarkshire; Callender rocks near Stirling; Inverary, Appin and Barcaldine, Argyll; Falls of Leny, Falls of Mones's, Glen Lochar, Finlarig, Kíllin, Aberfeldy and Brackliun Bridge, Perthshire; Reeky Linn, Forfarshire; Craig Cluny and Craig Coimoch, Braemar, Aberdeenshire; S. of Fort William and Rothie. murchns. Invernessshire; Cawdor Woods, Nairnshire; Blackwater Bridge and Killarner. Kerry, near Kiylemore and Derryelare, Comnemara, Galway; near Carrickfergus, Antrim.

:) S. Dufourii Del. stict. p. is, t. 6, tig. $2.2(18: 23-25)$.. Thallus rather small, thin, smooth, glaucous-green or -brown, mostly smouth and somewhat shining, the lobes laciniate, erisp) at the edges and minutely fimbriate, often also coralloid-isidiose on the marmins and on the surface of the thallus, beneath slightly tomenterse, often reticulately wrinkled, pale-to dark-brown, with paler cyphellae. Apotheedia unknown. S. riliutu Tayl. in Mackaty

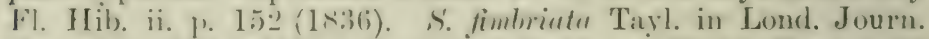

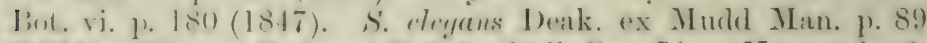

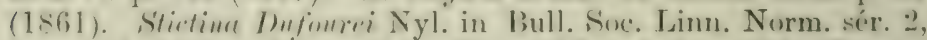
ii. p. .00 (1Sfis) ; Leight. Lieh. Fl. p. 117 ; ed. :, p. 110 : Cromb.

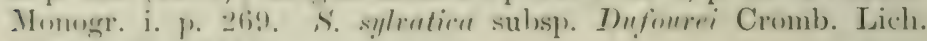
brit. p. 30 (1871).

Exsice. Cromb. 11. 135 ; Leight. 1n. 173. 
Easily recognized by the thinner lighter-coloured thallus and fimbriate margins, though occasionally it is darker, with the margin more entire.

Hab. On mossy rocks and trees.-Distr. Rather rare in S.TV. England, N. Wales, WV. Highlands of Scotland and S.IV. Ireland.B. M.-Pentire, Penzance, near the Lizard and Liskeard, Cornwall; near Totnes, Lidford and Torquay, Devon; Ty Gwyn, Dolgelly, Merioneth; Tongland, Kirkcudbrightshire; Barcaldine, Argyll ; Askew Wood and Hyde's Cottage, Killarney, Kerry.

4. S. limbata Ach. Neth. Lich. 1. 280 (1803).-Thallus moderate in size, monophyllous, but deeply lobate, smooth or slightly pitted, somewhat shining, dull-glaucous or pale-brown, the lobes broad and rounded, sprinkled with soralia towards the periphery, the margins densely sorediate; beneath pale-brownishtomentose, dotted with lighter coloured cyphellæ. Apothecia unknown.-S. F. Gray Nat. Arr. i. p. 431 ; Hook. Fl. Scot. ii. p. 59 \& in Sm. Engl. Fl. v. p. 206 ; Tayl. in Mackay Fl. Hib. ii. 1. 152; Mudd Man. 1. S'. Lichenoirles fuliginosum et pulvemlentum, scutrllis rubiginosis Dill. Hist. Musc. p. 19s, t. 26 , fig. 100 B, C. Lirle'n limbatus Sm. Engl. Bot. t. $1104(1 \leq 02)$. Stictina limbutre Nyl. Syn. Lich. i. 1) 346 (1860); Leight. Lich. Fl. p. 115 ; ed. 3, p. 1 U8 ; Cromb. NIonogr. i. p. 268. S. finliginuse subsp. limbata Cromb. Lich. Brit. p. 30 (1870).

Exsicc. Cromb. n. 35 ; Larb. Caesar. 1. 15 ; Johns. n. 190.

Distinguished from the preceding by the sorediate thallus and the absence of isidia. The sorectia are grevish or dull bluish-grey. Buellia Parmeliarum Oliv. is frequently found on the thallus.

Hab. On mossy trunks of trees and on shady rocks among mosses. -Distr. General and fairly common especially in the western counties of Great Britain and Ireland, rare in the Channel Islands.-B. M. Rozel, Jersey ; Jerbourg, Guernsey ; Bocconoc, Withiel, near the Tavy and near Penzance, Cornwall ; Shaugh, Torquay, Okehampton, Dartmoor, Clovelly, Kiestor near the Teign and near Exeter, Devon; near Ryde, I. of Wight; Lyndhurst, New Forest, Hants; Ardingly and Tilgate, Sussex; Lydd, Kent; Malvern, Worcestershire; near Pembroke; Hafod, Cardiganshire; Hay Coppice, Herefordshire; Dolgelly and Barmouth, Merioneth; Bettws-y-Coed; Capel Curig and near Bangor, Carnarvonshire; Anglesea; near Stavely, Kendal, Westmoreland; Thornthwaite, Cumberland; Teesdale, Durham; The Cheriots, Northumberland; New Galloway, Kirkeudbrightshire; Beld Craig, Moffat, Dumfriesshire; Falls of the Clyde, Lanarkshire; Turfin Hill, near Edinburgh; Invorary, Barcaldine and Appin, Argyll; Loch Fiatrine, Pass of Leny and Glen Lochay, Killin, Perthshire; Clova, Forfarshire; Craig Cluny, Braemar, Aberdeenshire; Glen Tevis, Invernessshire; I. of Skye; Aghada, Cork Harbour and Castlebernarel Park, Bandon, Cork; Cromaglown, Killarney, and Old Dromore, Kerry; near Belfast, Antrim.

Thallus with pseudocyphella on the under surface.

5. S. intricata Del. var. Thouarsii Mudd Man. 1. 90 (1\&61).Thallus coriacenus, spreading, sinuate and shortly lobed, smmewbat 
shining, greenish-bruwn when moist, reddish-brown when dry, the lobes somewhat crumpled and crowded, sprinkled over the surface with roundish or irregular grevish-white soralia or with masses of isidia becoming sorediate, the margins of the lobes also frequently white-sorediate ; beneath densely tomentose, darkbrown, paler towards the circumference, with a few pseuclo. cyphellie. Apothecia not seen rightly dereloped. S. Thoucrsii Del. Stict. p. 90, t. \&, fig. 29 (1823-25). Stirtina intricate rar. Thonnsii Nyl. Syn. i. p. 335 (1860): Leight. Lich. Fl. p. 114; ed. 3, p. 108; Cromb. Monogr. i. p. 266.

Exsice. Cromb. n. 33.

A tropical or subtropical lichen. Neither species nor rariety occurs in Europe except in the British Isles, where the variety is widely distributed though not common. It is easily distinguished from the other species by the character of the soredia and by the pseudocyphelli, which are midway betreen cyphellie and pseudocyphellæ.

Hab. On mossy rocks and boulders and on the trunks of old trees. - Distr. Local and rare in the S. IV. and N. districts of Great Britain and Ireland.-B. MI. Near Borer Tracey, Dartmoor, Deron ; near Dolgelly and Barmouth, Nerioneth; New Galloway, Kirkcudbrightshire; Inverary, Falls of Brander, Barcaldine and Oban, Argyll ; Loch Taj, Perthshire; S. of Fort William, Invernessshire; Cromaglown, Derrycunihy and Killarney Woods, Fierry Maam, Torc Mts., Galway; Fenagh, Carlow; Glonarm, Antrim.

6. S. crocata Ach. Neth. Jich. p. $27 T$ (1803). - Thallus of moderate size, opaque or somewhat shining, generally reticulatepitted, the lobes rather broad, crenate, dark-olive-green or dullbrown, the medulla usually citrine-yellow, the surface and the ridges between the pits rellow-sorediate; beneath densely tomentose, with a few small yellow pseudo-cyphelle. Apothecia scattered or nearly marginal, moderate in size, dark-coloured, the marrin crenate, at length nearly excluded; spores oblongfusiform, brown, 1-septate, $-20-32 \mu$ loug, 9-10 $\mu$ thick.--Hook. Fl. Scot. ii. p. 58 it in Sm. Engl. Fl. r. p. 205 ; S. F. Gray Nat. Arr. i. 430; Tayl. in Mackay Fl. Hib. ii. p. 151 ; Mudd Man. 1. 89. Lirhen rocutus L. ML̃ant. iii. 1. 310 (1771); Dicks. Pl. Crylt. fatse ii. 1. 22; With. Arr. erl. 3, iv. p. 52; Engl. Bot. t. -110. Stirtinu crocuta Nyl. Syn. i. p. 338; Cromb. Lich. Brit. p. 31 it Monogr. i. p. 266 ; Leight. Lich. Fl. p. 114 ; ed. 3 , p. 108.

Exsicc. Cromb. n. 34 ; Dicks. Hort. Sicc. fasc. iv. 1. 24.

Easily recognized by the greeni-h-yellow soredia and psento. cyphellir; the latter occur sparingly and irregularly in the form of minute pustules.

Hab). Among morses on trees and rocks in shady places, frequently in ravines.-Distr. Iocal in S.W. Fingland and s. Scotland, more frepnent in the W. Ifighlands; scarce in S., W. and N. Irelant.L. M. Carn Galven, near l'enzance, Commall; Taristock, Walkham 
Tirer and near Tixen Tor, Dartmoor. Deron; Dalmahoy Hill, near Edinburgh; Inverars, Oban and Head of Loch Ame, Argyll; rarine at foot of Ben More, Glen Falloeh and Aberfeldr, Perthshire; Glen Iorriston, Invernessshire ; Renmare, Tierry; Cushendall, Antrim.

§ ii. Eusticta Wain. Lich. Brés. i. p. 191 (1890). Algal cells bright-green.

\section{Thallus with cyphellæ on the under surface.}

7. S. damæcornis Ach. Meth. Lich. p. 276 (1803).--Thallus smooth, slightly shining, pale glaucous or reddish-brown, widespreading, laciniate-lobate, the lobes sinuate, elongate and narrow or rery broad, the margins mostly entire, dichotomous and truncate at the ends. Apothecia scattered or chiefly marginal, reddish-brown, with a lighter coloured entire or slightly crenulate margin; spores fusiform, 1-3-septate, 26-36 $\mu$ long, 8-11 $\mu$ thick. - Cromb. Lich. Brit. p. 32 ; var. macrophylla Nyl. in Mém. Soc. Sici. Nat. Cherb. v. p. 102 (1857); Mudd Man. p. 88; Leight. Lich. Fl. p. 119 ; ed. 3, p. 112 ; form latior Cromb. in Grevillea xv. p. 76 (1887) \& Monogr. i. p. 273. S. macrophylla Burr. in Engl. Bot. Suppl. t. 2697 (1831) (non Bory ex Del.); Hook. in Sm. Engl. Fl. v. p. 205 (1833); Tayl. in Mackay Fl. Hib. ii. p. 150.

Exsicc. Cromb. n. 38.

An exotic species confined to S. and S.W. Treland, the only European locality. There is no real distinction between $S$. damacornis and var. macrophylla.

Hab. On shads rocks in maritime and upland districts.-Distr. Tery local but plentiful in S. and S. W. Ireland.-B. M. Cromaglown and Torc Cascade, Killarney, Kerry.

\section{Thallus with pseudocyphellæ on the under surface.}

8. S. aurata Ach. Meth. Lich. p. 277 (1803).-Thallus horizontal, moderate in size, opaque or slightly shining, broadly and deeply lobed, tawny- or reddish-brown when dry, the lobes crisp and crenate undulate, usually bright-yellow-sorediate at the margins, beneath with a dense dark-brown short tomentum at the centre, becoming lighter-coloured and bare at the periphery, and sprinkled with bright-yellow pulverulent pseudocyphellie. Apothecia very rare, large, marginal or submarginal, reddishblack, the margin thin, incurved; spores fusiform, 3-septate, brownish, 21-24 $\mu$ long, and $6-7 \mu$ thick, or 19-21 $\mu$ long, and 7-8 $\mu$ thick.-S. F. Gray Nat. Arr. i. p. 430; Hook. in Sm. Engl. Fl. r. p. 205 ; MIudd Man. p. 90 ; Cromb. Lich. Brit. p. 31 ; Leight. Lich. Fl. p. 119 ; ed. 3, p. 112 ; form subglancescens: Cromb), in Grevillea xv. p. 76 (18si) \& Monogr. i. p. 274. Lichenoides lucunosum rutilum marginibus flacis Dill. 
Hist. Musc. p. 549, t. 84, fig. $12(17+1)$. Lichen auratus Sm. Engl. Bot. t. 2359 (1811).

Exsicc. Cromb. n. 39 ; Larb. Cresar. n. 16 ; Leight. n. 261.

Distinguisbed by the bright-rellow colour of the sorediate margins of the lobes. Form subglaucescens, collected at Lyme Regis, differs only in being bright-green when moist. The British plants are sterile. Cephalodia are sometimes formed on the under surface.

Hat. On trees, rocks, heather, etc., in maritime localities.-Distr. Local and scarce in the Chammel and Scilly Islands and in S.W. England.-B.M. Near the Eperquerie, Sark; Jerbourg, Guernsey; Fresco. St. Mary's and Bryer Islands, Scilly; coasts of Cornwall; Undercliff, Lyme Regis, Dorset; near Shanklin, Tentnor and Pyde, I. of Wight.

36. LOBARIA Sichrel,. L. Gen. Pl. ii. p. 768 (1791); emend. Wain. Lich. Brés. i. p. 193 (1890). Lobarina Nyl. in Flora lx. p. 233 (1871) ; Cromb. Monogr. i. p. 270. Ricaselin De Not. in Giorn. Bot. Ital. ii. p. $178(1+46)$; Leight. Lich. Fl. p. 120; Cromb. MIonogr. i. p. 274. (Pl. 36.)

Thallus broadly foliose, horizontal or partly ascending, cortex on both surfaces of plectenchyma, tomentose below, with the hyphal filaments single or in strands. Algal cells Nostoc, Cystococus or Protorucus. Cephalodia sometimes present. Apothecia at first almost closed, then discoid, marginate, generally with gonidia in the margin; paraphyses simple, septate; spores 8 in the ascus, elongate, 1-9-septate, colourless or brown.

Distinguished from Sticta by the absence of cyphellie or pseudo. crphella on the lower surface. The British species of Lobaria are classified in two sections:-

Thallus with blue-green gonidia................. i. LoBARINA.

Thallus with bright-green gonidia................ ii. Ricasolia.

ş i. Lobarina Wain. Lich. Brés. i. p. 193 (1890).

Algal cells blue-green (Nostoc).

1. L. scrobiculata I)C. Fl. Fr. ii. p. 40: (180.) $)$ - - Thallus widle-spreadling, rigirl, somewhat opaque, irregularly reticulatepitterl (scroliculate), grevish-green, sprinkled especially at the margins with white or bluish-grey soralia, the lobes rounded, undulate more or less erenate at the margins, beneath pale- or dark-brown-trmentrose, with scattered naked white blister-like devations eorresponding to the depressions of the upper surface. Apothecia very small, seattered. red or brownish-red, the margin thick, inflexed, entire, sometimes sorediate: spores fusiform,

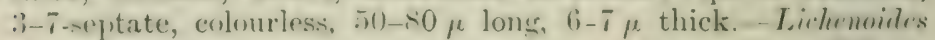

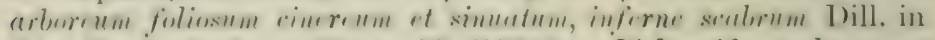
Ray Syn. ed. 3, p. 75, n. 77 (1724). Lirhementes pulmomenm

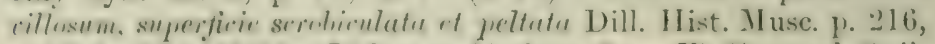

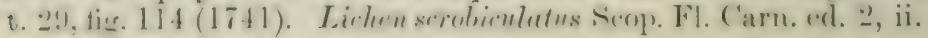


p. 384 (1772); Lightf. Fl. Scot. ii. p. 850 : With. Arr. ed. :3, ir. 1. 59) : Engl. Bot. t. 497. L. verrucosus Huds. Fl. Angl. ed. ㄹ, p. 545 (1778). Stirtu scrobiculatu Ach. Lich. Univ. p. 453 (1810) ; S. F. Gray Nat. Arr. i. p. 430 ; Hook. Fl. Scot. ii. p. 59 d in Sm. Engl. Fl. v. p. 206 ; Tayl. in Mackay Fl. Hib. ii. p. 1.51; Mudd Man. p. 87, t. 1, fig. 26. Stictina serobiculate Nyl. Lich. Scand. p. 94 (1861); Cromb. Lich. Brit. p. 30 ; Leight. Lich. Fl. p. 117 ; ed. 3, p. 110. Lobarina serobienlater Nyl. in Flora lx. 1). 233 (1877); Cromb. in Grevillea xv. 1). 76 (1877) \& Monogr. i. p. 270.

Exsicc. Cromb. n. 36 ; Johns. n. 223 ; Larb. Cæsar. n. 14 \& Lich. Hb. n. 325 ; Leight. n. 201 ; Mudd n. 65.

A species well-marked by the grevish-green colour and the scrobiculose sorediate surface. The apothecia are rather rare and are frequently blackened by the parasitic fungus Celidium Stictarum.

$\mathrm{Hab}$. On the trunks of old trees and on moist shady rocks chiefly near streams and lakes.-Distr. General and common in most parts of the British Isles.-B. M. La Coupe, Jerser; Jerbourg, Guernser; Bryer Islaud, Scilly; Helmen Tor and Liskeard, Cornwall; South Brent, Iry Bridge, Okehampton, near Totnes and Dartmoor, Devon; New Forest, Hants; Quarn Wood, Ryde and Ventnor, I. of Wight; Eridge Park and Hastings, Sussex; Tunbridge Wells and Lydd, Kent; Malrern. Worcestershire; Llanbedr, Carder Idris, near Dolgelly and Bamouth, Merioneth; Capel Curig, Trefriew and Bettws-y-Coet, Carnarronshire; Anglesea; Oggerar Gill, Cleveland, and near Halifax, Yorkshire; Teesdale, Durham; Mardale, Westmoreland; Keswick and Calder Abber, Cumberland; New Galloway, Kirkcudbrightshire; Beld Craig, Moffat, Dumfriesshire; Turfin Hill, near Edinburgh; near Inverary, head of Loch Awe, Appin and Barcaldine, Argyll; Loch Katrine, Pass of Leny, Loch Comn, Loch Pannoch, Glen Lochay, Glen Falloch, Finlarig and Fillin, Perthshire; Clova, Forfarshire; Craig Coinnoch, Invercauld and Loch MIuick, Aberdeenshire; S. of Fort William, Invernessshire; Hill of Doon, Nairnshire; Muckross, Killarney, Kerry; Kylemore and near Renryle, Connemara, Galway.

\section{§ii. Ricasolia Wain. Lich. Brés. i. p. 196 (1890). Algal cells bright-green (Protococcus).}

2. L. laciniata Wain. in Természetrajzi Füzetek xxii. 1. 30 T (1899).--Thallus horizontal, wide-spreading, rigid, smooth or somewhat wrinklerl, sinuate-lobate, the lobes elongate, broadly aud elegantly crenate, gliucous-green, becoming greyish-white or pale-brown, beneath pale, with brownish tomentum or fasiculate rhizine $(\mathrm{K}+$ yellowish, except the medulla, $\mathrm{Ca} \mathrm{Cl}-)$. Apothecia at first almost closed then large, concave or plane, reddishbrown with a thin inflexed entire or granulate margin; spores elongate-fusiform, 1-3-septate, colourless, :32-60 $\mu$ long, $6-i \mu$.

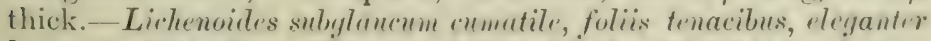
luriniatis Dill. Hist. Musc. p. 197, t. 26, fig. 99 (1741). Lirluen larimiatus Huds. Fl. Angl. p. 469 (176-). L. amplissimus Sopp. Fl. Carn. ed. 2, ii. 1. 386 (1772). L. glmuliferus Lightf. Fl. Scot. ii. 
p. $853(177$ ): With. Arr. ed. 3, iv. p. 57 ; Engl. Bot. t. 293. Parmelin plommlifern Ach. Meth. Lich. p. 218 (1803) ; S. F. Gray Nat. Arr. i. p. 436 ; Hook. Fl. Scot. ii. p. 52 it in Sm. Engl. F1. v. p. 198. Stirtu glomenlifere Del. Stict. p. 129 (1S2:3-25); Mudd Man. p. 91. Ricasolia amplissima De Not. in Giorn. Bot. Ital. ii. p. 179 (1846); Leight. Lich. Fl. p. 120 (1871); ed. 3, p. 112: Cromb. Monogr. i. p. 275. R. glomnliferc Nyl. in Act. Soc. Liun. Bord. sér. 3, i. p. 300 (18:56); Cromb. Lich. Brit. p. 32.

Exsice. Cromb. n. 138 ; Johns. n. 25 ; Larb. Ceesar. 11. 62 ; Leight. n. 110.

Generally recognized by the presence of massed groups of clarkgreen coralloid cephalodia, which have been sometimes described as a seprarate plant, Dendriscocaulon bolacinum (Nyl. in Flora lxviii. p. 299 (1855); ('romb. Monogr. i. p. T7). It is one of our largest lichens and is of a rigid coriaceous texture; the somewhat imbricate lobes are elegantly crenate. Apothecia are rare; spermogones are more frequent, with spermatia about $5 \mu$ long and $1 \mu$ thick.

Hat. On the trunks of old trees, chiefly ash and onk, rarely on rocks in maritime and inland districts.-Distr. Chiefly in the western tracts of Great Britain, rare in S.TY. and N. Treland and in the Channel Islands.-D. M. Near Iozel, Jerwey; Jerbourg, Gnemsey; Chatenu Point, Sark; Bocconoc, near Launceston, Comwall; Chagford, Mamaton NIoor, Brent Tor and Iry I3ridge, Devon; New Forest, Hants; I. of Wight; Eridge Park, Sussex; Llanforda, near Oswestry, Shropshire; Hafod, Cartiganshire; near Dolgelly, Barmouth, Aberdorey and Llanbedh, Merioneth ; Sedburgh and Windermere, Westmoreland; Keswick, Cumberland; Horslerhope Denes, Durham; New Galloway, IRirkeudbrightshire; Minto Crags, Roxburghshire; Mugdock Castle, Stirlingshire; Loch Long, near liosenenth, Inverary and Barcaldine House, Argyll ; Loch Katrine, Gilen Lochay and Kenmore, Perthshire; Lochaber, Invernessshire; I)inish Island, Rillaney, Kerry.

3. L. lætevirens A. Zablbr. in Engler of Prantl Nat. Pllanzenf. i. 1\%, p. Is (1906).-Thallus orbicular', spreading, smooth or wrinkled, often shining, green when moist, pale-brown when dry, the lobes somewhat laciniate, rounded, sulierenate and undulate, heneath corered with a pale tomentum, and with pale rhizine ( $\mathrm{K}-, \mathrm{CaCl}-$ ). Apothecia small or large, generally crowded towards the centre of the thallus, reddish, the margins rather granulate, inflexed; spores fusiform, 1-sepate, becoming palebrown, 26-4.4 $\mu$ long, 9-11 $\mu$ thick.-Lirlemendes arturewin cinereo-

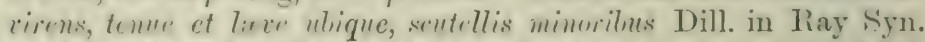
exl. 3, p. 73, n. (it (17:-4). Lirhenoides larterirens, scutellis fulvis 1)ill. Hist. Muse. 1). 195, t. 25, fie. 98 (1741). Lichen lecteriens Lichtf. Fl. Seot. ii. p s.) (18T ed. 3, iv. p. 58. L. herbaceus Huds. Fl. Angl. ed. 2, p. 544

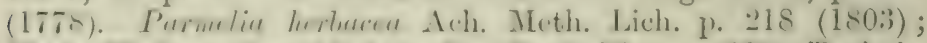

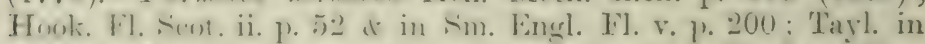

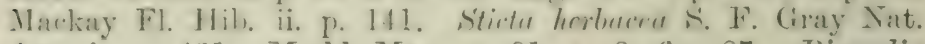
Arr. i. p. 431; Mudd Min. p. 91, t. 2, fig. 27. Ricasolia 
Terbacea De Not. in Giorn. Bot. Ital. ii. p. 1\&0 (1\&46); Cromb. Lich. Brit. p. 32. R. læteriens Leight. Lich. Fl. p. 121 (1871); ed. 3, p. 113.

Exsice. Cromb. n. 40; Dicks. Dried Plants, n. 23; Johns. nos. 81, 82; Larb. Lich. Hb. n. 326 ; Leight. n. 75.

Somewhat resembling the preceding but with a thinner less coriaceous thallus. Apothecia and spermogones are generally present. Sereral specimens (Johns. 11. 82, etc.) bear apothecia in which the margins have become partly and minutely laciniate.

$H a b$. On the trunks of old trees, occasionally on mossy boulders.Distr. General and mostly common throughout the British Isles.B. M. Island of Bréchou; near Tozel, Jersey; Bryer Island, Scilly; Boconnoc and St. Minver, Cornmall ; Iry Bridge, South Brent, near Totnes, Becky Fall and near Harberton, Devon; New Forest, Hants; Shanklin and Appuldurcomb, Isle of Wight; Ardingly and Charlton Forest, Sussex; Charnwood Forest and Bardon Hill, Leicestershire; Dyneror Castle, Carmarthenshire; near Dolgelly, Aberdorey and Barmouth, Merioneth; Bettws-y-Coed, Carnarvonshire; Anglesea ; Derbyshire; Baysdale, Cleveland, Yorkshire; near Egglestone, Durham; Windermere and near Stoclgill, Westmoreland; Testrick and Calder Abber, Cumberland; New Galloway, Kircudbrightshire; Largs, Ayrshire; near Inverary, Barcaldine and Appin, Argrll; The Trossachs, Glen Lochay, Craighall and Bracklin Falls, Perthshire; Lochaber, Invernessshire; Cawdor Woods, Nairnshire; Applecross, Tossshire; Tillarney and Cromaglown, Kerry; near Tílemore, Galway; Clare Island, Mayo.

4. L. pulmonaria Hoffm. Deutschl. Fl. ii. p. 146 (1795).Thallus wide-spreading, rigid, shining, pitted-reticulate, with narrow rather sinuate truncate lobes at the margins, generally sorediiferous on the ridges, more rarely bearing isidia, olive-green when moist, tawny- or dark-brown when dry, beneath unequal, bullate or blistered opposite the pits on the upper surface, whitish with a reddish-brown tomentum between the bullate swellings. Apothecia moderate in size, marginal or submarginal, light-red or clark-brown, the margin thin, entire or becoming crenulate, at length excluded; spores 1-3-septate, 18-30 $\mu$ long, 5-9 $\mu$ thick.-Cromb. in Grevillea xr. p. 76 (1887). Lichenoides peltatum arborenm maximum Dill. in Ray Syn. edl. :3, p. 76, n. 86 (1724). Lichenoides pulmoneum reticulutnin vulgare, marginibus peltiferis Dill. Hist. Musc. p. 212, t. 29, fig. 113 (1761). Lichen pulmomarius L. Sp. Pl. p. 1145 (1753); Huds. Fl. Angl. p. 449 ; Lightf. Fl. Scot. ii. p. 831 ; With. Arr. ed. 3, iv. p. 54 ; Engl. Bot. t. 572 . Purmelia pulmonuere Ach. Meth. Lich. p. 220 (1803). Stirfle pulmonecen Ach. Lich. Univ. p. 449 (1s10) (incl. var. plenecurpu); S. F. Gray Nat. Arr. i. p. 430 ; Mudd Man. p. 8T, t. 1, fig. 25; Cromb. Lich. Brit. 1. 31 ; Leight. Lich. Fl. p. 118; var. ay!reyutu Del. Stict. p. 14:, t. 17, fig. 62 (18:5). S. julmoneriu Hook. Fl. Scot. ii. p. 5s (18.21) \& in Sur. Engl. Fl. v. p. 206 ; Tayl. in Mackay lil. Hib. ii. p. 151: Leight. Lich. Fl. ed. 3, p. 111. Tree lungwort. 
Eusire. Carroll Lich. Hib. 11. 1; Croall n. 486 : Cromb. nos. 37,137 (as var. pleurocarpa); Johns. n. 22t; Leight. n. 74 ; Mudd n. 64.

The thallns is attached to the substratum more or lesw centrally and spreads free on all sides, sometimes attaining very large dimensions when the laciniate character is less erident. Soredia are frequent on the margins ant ridges though the surface nay be wholly or partly naked and shining. Isirlia are not uncommon mixed with the soredia.

The apothecia are occasionally blackened and rentered abortive by the parasitic fungus Celidium Stictarum (var. pleurocarpa). Cephalodia-or cephaloid tubercles-have been described as sometimes occurring on both surfaces, and as being simple or aggregate, reddish or dark-coloured (f. aggregatu Cromb. in Grevillea xv. p). 76 is Monogr. i. p. 273). The single British specimen from Inverary determined as f. aggregata by Crombie bears somewhat deformed apotheca only. Immersed cephalodia have been found by Hue in var. tenuior from Japan.

Hal. On the trunks of trees, especially old oaks, rarely on mossy rocks in inland and maritime districts.-Distr. General and not uncommon throughout the British Isles. $-B$. M. Guernsey; Bryer Island, Scilly; Bocounoc, St. Minver and near Penzance, Cornwall; Lidford, Totnes, Newton Bushell, Okehampton and Buckfastleigh, Devon; New Forest, Hants; liyde and Appuldurcomb, I. of Wight; near Balcombe, Eastham and Ardingly, Sussex; near Lrdd. lient; near Loughton, Essex; Cherworth Woods near Cirencester, Gloucestershire; Bagley Wood, near Oxford; Charnmood Forest, Leicestershire; near Ludlow, Shropshire; Hafod, Cardiganshire; Carler Idris. Cwm Bychan, Rhewgreidden, Aberdorer, Barmouth and Dolgelly, Merioneth; Bettws-y-Coed, Bangor, Conmay and Deril's Mridge, Carnarvonshire; Anglesea; Kildale. Cleveland. Torkshire; Egglestone, Durhan; Cheviots. Northumberland; Windernere and near Grasmere, Westmoreland; Patterdale and Calder Abber. Cumberland ; New Galloway, Kirkeudbrightshire; Ayrshire; near IIofliat. Dumfrieshire; Turfin Hill, near Edinburgh; Inverary, Heat of Loch Awe, Barealdine and Appin, Argyll ; The Trossachs, Loch Katrine, Fillin and Pass of Lenr. Perthshire; Den of Airlie. Reeky Lim. Lunile Craigs and (ilen Dole, Forfarshire; Dunottar Castle, Kkincardineshire; Craig Cluny and Corriemulzie. Britemar, Aberdeenshire; near Fort Williatn. Invernessshire; Citwdor Wood, Nairnshire; Applecross, Ilossshire; Dinish. Tonayne's Islands and C'romaglown, Killarney, Kerry ; Lough Inagh, Galway.

Form hypomela Cromb, in Grevillea xr. p. 76 (1887)... Thallus with a hrownish-black tomentum on the under surface hetween the bullate swellings: upper surfine frequently isidionil.

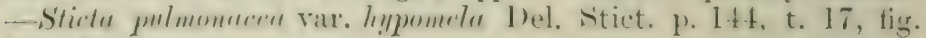
$64(1825)$.

Wxsice. Cromb. n. 136.

IIah. Sinilar (n the species.-J)is/r. Seon in at chatracteristic state only from S. W. Fingland. X. Wiales and the S. and W. Grampians.

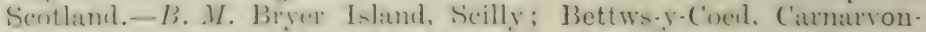
shere; Inverary and Barahline. Aryyll; Glen Lochay, I'erthshire; Loch Linnhe, Invernessshire. 


\section{ORDER X. PARMELIACE Æ.}

Thallus foliose, horizontal, decumbent, sometimes partly ascending or fruticose, corticate on one or both surfaces, beneath with rhizine or naked. Algal cells Pleurucocens. Apothecia sessile or shortly stalked, with a thalline margin; asci 2-8spored or rarely many-spored; spores colourless, simple. Spermogones with pleurogenous or more rarely acrogenou. spermatia.

The following genera are British:-

Thallus rhizinose, squamulose or foliose. Apothecia superficial.

Thallus squamulose; asci many.spored ........... 37. Candelaria.

Thallus foliose ; asci 2-8-spored.................. 38. Parmelia.

Thallus scarcely rhizinose, foliose or fruticose. Apothecia marginal.

39. Cetraria.

37. CANDELARIA Massal. Mem. Lich. p. 46 (1853). Lerenora subg. Combleluice Nyl. in Flora lxiv. p. 45t (1881); Cromb. Monogr. i. p. 366 pro parte. (Pl. 37.)

Thallus minutely foliose or squamulose, corticate on both surfaces, yellow above, beneath almost colourless, rhizinose. Apothecia sessile, scattered, discoid, with a thalline margin; paraphyses discrete, simple or rarely branched, septate and clavate upwards; asci many-spored; spores simple, colourless, sometimes bi-guttulate and pseudo-septate. Spermogones in small tubercles, with acrogenuus ellipsoid spermatia.

Differs from Parmelia in the squamulose thallus and the manyspored ascus. The yellow colour of the thallus is due to stictaurin, which gives no reaction with potash.

1. C. concolor Wain. Lich. Brés. i. p. 70 (1\&90).-Thallus suborbicular or spreading, the lobes small, laciniate-crenate, subimbricate or crowding over each other, the margins crisp, isidiose, granular or sorediose, bright-greenish-yellow ( $\mathrm{K}-$ ). Aputhecia small, sessile, dull-brownish-yellow, the thalline margin entire or granulate; spores numerous, ellipsoid, simple, uften bi-guttulate, $6-1+\mu$ long, $4-6 \mu$ thick. - Lichen candelurius L. Ap. Pl. p. 1141 (1753) nomen vayum; Hurls. Fl. Angl. p. 444? Lightf. Fl. Scot. ii. 1) 810 pro minore parte; Engl. Bot. t. 1794 (1807). L. concolor Dicks. Pl. Crypt. fasc. iii. p. 18, t. ix.

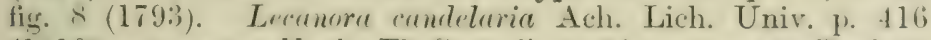
(1.10) fro parte: Hook. Fl. Sicot. ii. p. 51 pro parte: Tayl. in IIackay Fl. Hih. ii. 1. 139 ; Cromb. Lich. Brit. 1) 48 ; Leight. Lich. Fl. p. 182 (incl. var. gramulosu); ed. 3, p. 167 (incl. var. yranulosu). Parmelin parietima var. latiniesn Duf. ex Fr. Lich.

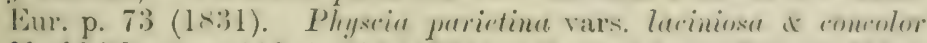

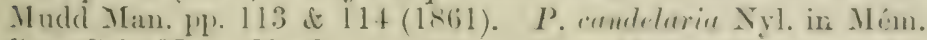
Soc. Sci. Nat. Cherb. p. 106 (1857); Mudd Man. p. 114. 
Psoroma comelelarim S. F. Gray Nat. Arr. i. p. 445 (1821). Squamuriu candelaria Hook. in Sm. Engl. Fl. v. p. 194 (1833). Lecenure luriniusu Nyl. in Flora lxiv. p. 45t (1881); Cromb). Monogr. i. p. 36 $\boldsymbol{T}$, fig. 62 .

Exsicc. Larb. Lich. Hb. n. 53 ; Leight. n. 12.

Hab. On trunks of trees and on old palings, rarely on walls.Distr. General throughout Great Britain, rare in Ireland and the Channel Islands.-B. M. St. Lawrence, Jersey; Vale Castle, Guernsey; near Penzance, Cornwall; near Tor'quay, Devon; Lyndhurst, New Forest, Hants; Hurst and Hassocks, Sussex; Penshurst Park, Tient; Walthamstow and Epping Forest, Essex; Windsor Park, J3erkshire; Storwell Park, Gloucestershire; Cherry Hinton, near Cambridge; Berwick near Shrensbury, Shropshire; near Barmouth, Merioneth; Stokesley, Yorkshire; Levens Park, Westmoreland; near Tieswick, Cumberland; Doune Castle and Killin, Perthshire; Durris, Tineardineshire; Abergeldie, Braemar, Aberdeenshire; Fort William and Rothiemurchus, Invernessshire; Blackrock, near Cork ; Killarney and Dunkerron, Kerry; near Limerick.

38. PARMELIA Ach. Neth. Lich. p. 153 emend De Not. in Mem. R. Acad. Sci. Torino ser. 2, x. p. 378 (1849). (Pl. 38.)

Thallus foliose, horizontal, rarely ascending, lobate or laciniate or linear, variously coloured, generally somewhat shining, cortex more or less distinctly plectenchymatous; soredia and isidia frequent, beneath rhizinose or almost naked, usually darker in colour, the rhizine of fasciculate hyphæ, frequently mucilaginous at the tips. Apothecia scattered, sessile or shortly stalked, often becoming rather large, round, with a thalline margin; hypothecium colourless, with gonidia underneath ; paraphyses usually branched and septate, involved in mucilage; asci 2-8-spored; spores ellipsoid or subglobose, simple, colourless. Spermogones scattered, becoming prominent, blackish, with septate sterigmata, the minute pleurogenous spermatia cylindrical or fusiform or thickened at each end.

The genus is divided into subgenera as follows:-

Thallus normally without rhizine, lobes narrow.... Thallus without rhizinæ, lobes broader, pierced with holes.

i. Hypogimina.

Thallus more or less rhizinose, lobes various.

ii. Menegazzia. iii. Eupasinet.s.

Sulygenus i. Hrposimsa Nyl. in Flora lxiv. p. 537 (1881). Thallus normally without rhizine, attached by dises or haustoria, or by rhizine formed as the result of friction; lobes generally narrow. Spores small.

1. P. physodes Ach. Meth. p. 250 (1803) (excl. var. vittuta).Thallus very variable in size, often very wide-spreading, sub. stellate, smooth, litciniate-lobed, glancous-irrey, the lobes multifid, linesu-sinuate, crenulate or blunt, dilated, and sometimes sorediate and recurved at the somewhat swollen apices, beneath 
generally brownish-blick, paler towards the circumference, shining, somewhat wrinkled, with occasional rhizine or haustorial dises where it is attacherl (cortices $\mathrm{K}+$ yellow, $\mathrm{CaCl}-$, merlulliz $\mathrm{K}(\mathrm{CaCl})+\mathrm{red})$. Apothecia rare in Britain, subpedicellate, moderate in size, becoming large with age, brownish-red, the margin entire; spores subspherical, $6-8 \mu$ long, $5-6 \mu$ thick; margins of the apothecia rarely sorediate.-Hook. Fl. Scot. ii. p. 56 it in Sm. Engl. Fl. v. p. 204 ; Tayl. in Mackay Fl. Hib. ii. p. 149 ; Mudd Man. p. 96 ; Cromb. Lich. Brit. 1).36 (incl. var. labrosa, excl. var. vittata); Leight. Lich. Fl. p. 125 ; ed. 3, p. 116 (incl. var. recurva); var. labrosa Ach. Lich. Unir. p. 493 (1810). Lichenoides ceratophyllum obtusins et minus ramosum Dill. in Ray Syn. ed. 3, p. 76, n. 85 (1724) it Hist. Musc. p. 15t, t. 20, fig. 49 A, B, c (17t1). Lichen pliysodes L. Sp. Pl. p. 1144 (1753); Huds. Fl. Angl. p. 447 ; Lightf. Fl. Scot. ii. p. S22 ; Engl. Bot. t. 126 pro parte; With. Arr. ed. 3, iv. p. 32. Physcia physerles S. F. Gray Nat. Arr. i. p. 436 (1821).

Exsicc. Bohl. n. 13 ; Croall n. 98 ; Cromb. nos. 31, 144; Johns. nos. 123, 304 (f. pauculu), 305 ; Larb. Lich. Hb. n. 290 ; Leight. nos. 48, 389 ; Mudd n. 70.

One of our commonest lichens, and, though rariable, easily recog. nized by the narrow lobes and generally dark, bare undersurface; no rhizinse are produced on the free parts. As the plant becomes older, wide soralia develop at the apex of the lobes; the lobes tend to rise up and become recurved, a condition known as vars. labrosa and recurva. Form paucula, recorded by Johnson, is, he concludes, a dwarf form with narrow lobes and eroded at the tips. The thallus is more or less appressed, the sorediate lobes being somewhat ascending. This lichen is attached in various ways to the substratum: rhizinxe are occasionally developed as the result of friction. Spermogones are frequent as clusters of black points.

Hab. On trees, heather, old walls, sometimes on sandy ground, etc., in maritime and inland districts, more generally fertile in mountainous regions. - Distr. General and common throughout the British Isles.-B. M. Quenvais, Jersey; Guernsey; Withiel and Penzance, Cornwall; Hay Tor, Dartmoor, Devon; New Forest, Hants; Mraresfield, Pondlye and Ardingly, Sussex; Mill Hill, Middlesex; Boreham, Wralthamstow and Epping Forest, Essex; Sandy, Bedfordshire; Brandon, Suffolk; Lickey Hills, Worcestershire; Charnwood Forest, Leicestershire; Church Stretton, Stiperstones, Wrelin Hill and Haughmond Hill, Shropshire; Stormy Down, Glamorganshire; Bedıl. gelert, Crwm Bychan, Cader Idris, Garth, near Barmouth, and near Dolgelly, Merioneth; Llanberis, Bettws-y-Coed aud Carnedd Dafycld, Carnarvonshire; Anglesea; near Matlock, Derbyshire; Lounsulale, Cleveland, Yorkshire; Windermere, Westmoreland ; Emerdale, Ashgill Woods (f. paucula) and Gateshead Fell, Cumberland; Dalry and New Galloway, Kirkcudbrightshire; near Glasgorn; Swanston Wood, Edinburgh ; Inverary, Argyll ; Crianlarich, Tỉllin, Loch Tay, Ben Lawers, Hammoch, C'raig Tulloch and Moncriefie Hill, Perthshire; Sidlaw Hills, Baldovan and Deerhill Wood, Forfar; Durris, Kincardineshire; Invercauld, Castleton, Morrone, Glen Derry and Glen Candlich, Braemar, Hill of Ardo and Countess Wells, Aberdeenshire; 
Tiothiemurchus and Glen Morriston, Invernessshire; Forres, Elginshire; Lairg, Sutherland; Unst, Shetland; near Cork; Dunkerron, Kerry.

Var. tubulosa Mudrl Nan. p. 97 (1\&61)...Thallus lobes tubular, erect, ascending, turgid and sorediate at the tips.Var. Talrosa Cromb. Lich. Brit. p. 36 pro parte; Leight. Lich. Fl. p. 126 ; edl. 3, p. 117 ; f. tululosa Cromb. Monogr. i. p. 259 (1894). P. cerctopluylla var. tubulosa Schar. Enum. p. 42 (1850). Lichen physodes Engl. Bot. t. 126, lower fig. (1793).

Eisice. Johns. n. 124 ; Leight. n. 48 pro parte; MIudd n. 70 pro parte.

Well marked by the cylindrical hollow lobes, which branch out from the substratum. It is more confined to hilly districts than the species. Apothecia are rarely found.

$H a b$. On trees and stone walls in maritime and upland districts.Distr. Fairly general and common in Great Britain.-B. M. Near Penzance and Withiel, Cornwall; Lustleigh Cleeve, Devon; Leith Hill, Surrey; Malvern Hills, Worcestershire; Sweeny, Shropshire; near Monmouth; Rhewgreidden, Nerioneth; Bettws-y-Coed and Beddgelert, Carnarvonshire; Kildale MLor, Baysdale and Lounsdale, Cleveland, Yorkshire; near Kendal, Westmoreland; Asby, Cumberland; New Galloway, Kirkeudbrightshire; Ben Lawers, Killin and Abernethy, Perthshire; Park and Hill of Ardo, Aberdeenshire; Rothiemurchus Woods, Invernessshire; Lairg, Sutherland.

Var. platyphylla Ach. Meth. Lich. p. 251 (1803).-Lobes rather wide, wrinkled and plicate, rounded and rather deeply crenate at the circumference, more or less sorediate at the tips, generally towards the centre. Apothecia not common.-Leight. Lich. Fl. p. 126 ; ed. 3 , p. 117.

Exsicc. Larb. Lich. Hb. n. 329.

The crowded wrinkled sometimes almost tuberculose thallus distinguishes the variety. The whole plant hats an undivided nonophyllous appearance.

17ub. On old palings and stone walls in maritime and hilly districts. -Distr. General though not common throughout the British Isles.B. M. Monlay Bay, Jersey; New Forest, Iramphire; Brading, I. of Wight; Lydd, Kent; ILuboro' Magna, Warwickshire; near Barmouth, Merioneth ; Killin, ('raig Tulloch, Ben Lawers, Trossachs and Aberfeldy, l'erthshire; Guthrie, Forfarshire; near Nigg, Kincardineshire; liothiemurchus, Invernessshire.

Form fuscescens Cromb. Monogr. i. p. 260 (1894).-Differs from var. pllolyphliglli in the brown-colonured thallus and in the

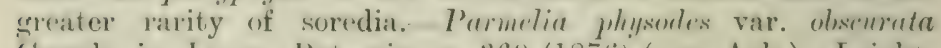
Cromb. in Journ. lint. xiv. 1) 360 (18-6i) (non Ach.) : Leight. Lich. Til. ed. 3, p. 118.

Crombie sugrests that the colour of the thallus may be due to the liabitat by the sea.

Hab. On old palings in maritine districts.-Distr. Loral in S.E. 
England and N.E. Scotland.-B. M. Lydd, Tient; near Cove, Kincardineshire.

2. P. vittata Nyl. in Flora lviii. p. 100 (1875).--Thallus horizontal, of rather elongate narrow sparsely branching hollow lacini:e, loosely adherent to the substratum, smooth and of ten shining, sometimes sorediate at the tips, glaucous-grey, beneath senerally shining-black, the dark colour spreading round and forming a margin to the lobes, the lower cortex pierced here and there by round holes $(\mathrm{K} \pm$ yellow, $\mathrm{Ca} C l-)$. Apothecia stalked, rather large, brownish-red, the margin thin, entire or inflexed; spores very small, $4-6 \mu$ long, almost globose, $3-4 \cdot 5 \mu$ thick.Cromb. in Grevillea xv. p. 76 (1887). Parmelia phiysodes var. vittute Ach. Meth. Lich. p. 251 (1803); Mudd Man. p. 96 pro parte; Cromb. Lich. Brit. p. 36 pro parte; Leight. Lich. Fl. p. 126 ; ed. 3 , p. 117 pro parte.

There is a somewhat doubtful specimen in Herb. Crombie, collected on firs, Ben Lawers; the dark margin of the lacinie is not well marked nor are the holes on the under surface very clear. There is no other specimen.

Hab. On mossy stones, on bark, or on the ground in mountainous regions. $-B$. $M$. Ben Lawers, Perthshire?

3. P. encausta Ach. Meth. Lich. p. 202 (1803).-Thallus suborbicular, appressed, composed of numerous elongate branching lacinie, generally rather hroader and spathulate, crenate at the circumference, the more central lobes very narrow and subcylindrical, sometimes of almost radiate structure, the tips somewhat turgid, silver-grey or greenish or very dark in colour, often dotted with the hlack spermogonia, beneath black, rather wrinkled $(\mathrm{K}+$ yellow, $\mathrm{CaCl}-)$. Apothecia adnate, moderate in size or rather large, plane, becoming flexuose, reddish-brown, with a thin crenulate margin ; spores ellipsoid, small, $7-10 \mu$ long, j-7 $\mu$ thick.-F. F. Gray Nat. Arr. i. p. 441 ; Hook. Fl. Scot. ii. p. 54 it in sm. Engl. Fl. v. p. 203 pro parte; Mudd Man. p. 97 (incl. var. cendefacta, excl. var. styyioides); Cromb. Lich. Brit. p. 36. Parmelia physodes var. candefacta Ach. Lich. Univ. p. 490 (1810); var. encausta Fr. Lich. Eur. p. 64 (1831); Leight. Lich. Fl. p. 127 ; ed. 3, p. 117. Lichen encaustus Sm. in Trans. Linn. Soc. i. p. 83, t. 4, tig. 6 (1791).

An ilpine species found only at the top of our lighest mountains.

Huh. On granite boulders-Disti. The Grampians, Scotland.B. M. Jen Lawer's, I'erthshire; Ben-naboord and Cairntoul, Jraenar, Aberdeenshire.

t. P. alpicola Th. Fr. Lich. Arct. p. it (1860). Thallus orbicular or expanded, appressed or adnate, of narrow, rugroseplicate or toruluse laciniate, crowded and imbricate (1) colerent in the centre, more free at the circumference and crenate. nodulnse 
or incurved at the tips, dark-olivaceous or blackish, beneath very black ( $\mathrm{K} \pm$ sellwwish, $\mathrm{CaCl}-$ ). Apothecia moderate in size or small, $2-4 \mathrm{~mm}$. across, becoming slightly convex, blackish, with a thin entire margin; spores subglobose or ellipsoid, $7-12 \mu \times \overline{5}-9 \mu$. Cromb. in Journ. Bot. x. p. $35 \tau(187 \cdot 2)$; Leight. Lich. Fl. ed. 3, p. 118. P. encoustu var, styyjuides Linds. in Trans. Roy. Soc. Edinb. p. 224 (18.9); MLdd Man. p. 97. P. Momprotii f. discreta Nyl. Syn. Lich. i. p. 392 (1861). P. stygia f. minor Nyl. ex Carroll in Journ. Bot. iii. p. 285 (1865): Cromb. Lich. Brit. p. 3\%. P. disereta Cromb. Lich. Brit. p. 36 (1870). P. pluysurles var. discretu Leight. Lich. Fl. p. 127 (1871). Lirhen encaustus Sm. Engl. Bot. t. 2049 (1809) (non Ach.).

Exsicc. Cromb. n. 32 ; Dicks. Hort. Sicc. fasc. ii. n. 25.

Differs from the preceding in the more compact wrinkled growth of the thallus, which is generally darker in colour and more shining. Apothecia are frequent. The spermogones are minute and black, with spermatia $7 \mu$ long, $1 \mu$ thick.

$H a b$. On granitic and quartzose boulders in alpine places. - Distr. Local and scarce on the Grampians, Scotland; rare in N. W. Treland. B. MI. Ben MIore and Cairn Gowar, Perthshire; Clora MIts. Forfarshire; Cairn Drochit, Morrone and Ben-naboord, Braemar, Aberdeenshire; Ben Nevis, Invernessshire; Mayo.

Subgenus ii. Mexegazzia A. Zahlbr. in Engler \& Prantl Nat. Pflanzenf. i. 1*, p. 212 (1907). - Thallus without rhizine, attached by haustoria or mucilage; lobes perforate above. Spores large.

5. P. pertusa Scher. Lich. Helv. Spicil. p. 457 (1840).Thallus orbicular, spreading, appressed, glabrous and shining, dotted with round holes, frequently sorediate, whitish or brownish, the lobes narrow, with palmate sinuate branching, somewhat convex, wider, crenate and brown at the tips, beneath black, naked, wrinklerl $(\mathrm{K}+$ yellow, $\mathrm{CaCl}-)$. Apothecia moderate in size up to $4 \mathrm{~mm}$. across, or smaller, reddish-brown, the margin entire or crenulate, prominent; "spores $2-4$ in the ascus, very large, $45-60 \mu$ long, $22-28 \mu$ thick." - Cromb. Lich. Brit. p. 36 ; Leight. Fl. p. 129 ; ed. 3, p. 120. P. rintrym Ach. Meth. Lich. p. 2.51 (180:3); Hook. Fl. Scot. ii. 1. 56 it in Sm. Engl. Fl. v. p. 204, Tayyl. in Mackay's Tl. Hib. ii. p. 150. P. terebruta Mudd Man. p. 97 (1861). Lichen pertusus Schrank Baier. Fl. ii. p. 519, n. 1513 (1789). L. diutr!nms Ach. Lich. Suec. Prodr. 1. 116 (179s): Sm. Engl. Bot. t. 12.48. Lubaria terebrata

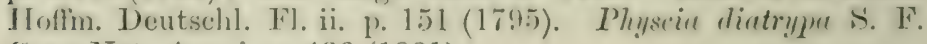
Gray Nat. Arr. i. p. 436 (1821).

Eirsire. Cromb. n. 145; Larb. Ciesar. n. 66 ; Leight. n. 264.

A liehen with a rery neat regular appearance. Soredia borne at the apex of suall upright branchlets are not uncommon. The upper cortex only is purforated; the lower cortex has mostly split from the upuer so that the lobes are hollow, the hyphe belonging to the 
under part of the thallus are dark brown. The whole thallus is closely attached to the substratum. British specimens are sterile.

$H a b$. On rocks among mosses and on the trunks of trees in maritime and inland districts.-Distr. Rare, though widely distributed throughout the British Isles.-B. M. Bonne Nuit, Jersey; Land's End, near St. Austell and near Penzance, Cornwall; Bolt Head and Valley of Rocks, Lynton, Devon ; New Folest, Hants; Hendremynech, Cardiganshire? Cwm. Bychan, Barmouth and Dolgelly, Merioneth; foot of Snowdon, Carnarvonshire; New Galloway, Kirkculbrightshire; Roseneath, Barcaldine and Ballachulish, Argyll; Keimaniegh Pass, Cork; Cromaglown, Glenmore Lake and Dunkerron, Kerry; Cushen. dun, Antrim.

Subgenus iii. Euparmelia Nyl. ex Hue Add. Nor. Lich. Eur. p. 39 (1886).-_Thallus lobes narrow or wide; beneath more or less rhizinose.

\section{A. Rlizinæ very scanty.}

6. P. pubescens TWain. in Medd. Soc. Faun. \& Fl. Fenn. xir. p. $22(18<6)$. - Thallus of rounded or somewhat flattened slender filaments, spreading, decumbent, dichotomously and intricately branched, olive-brown or brownish-black, somewhat shining, beneath paler, attached to the rock by short stoutish discoid hold-fasts or by short rhizina (?) $(\mathrm{K}-, \mathrm{CaCl}-)$. Apothecia seated on the thallus or terminal, moderate in size, plane or courex, concolorous with the thallus, the margin subentire or grauular; spores $7-11 \mu$ long, 6-8 $\mu$ thick. $-P$. lanata Wallr. Fl. Crypt. Germ. i. p. 529 (1831) (non Linn.); Mudd Man. p. 101 ; Cromb. Lich. Brit. p. 35 ; Leight. Lich. Fl. p. 124. Usnea crespitoser exilis, capillacen, atra Dill. Hist. Musc. p. 66, t. 13, fig. 9 (17 11 ). Lichen pubescens L. Sp. Pl. p. 1155 (1753); Engl. Bot. t. 846 (middle tig.). L. scaber Huds. Fl. Angl. ed. 2, p. 562 (1778). Cornicularia lanutu Ach. Meth. Lich. p. 304 (1803) ; S. F. Gray Nat. Arr. i. p. 405 ; Hook. Fl. Scot. ii. p. 69 \& in Sm. Engl. Fl. v. p. 229 ; Tayl. in Mackay Fl. Hil. ii. p. 87. Alectoria lanata Leight. Lich. Fl. ed. 3, p. 80 (1879).

Exsicc. Croall n. 498.

Frequently referred to the radiate fruticose lichens, but the habit is decumbent, the structure is partly dorsiventral, the gonidia being more or less massed on the upper side of the central medullary strand, and the plint is anchored to the substratum by disc-like hold-fasts. Th. Fries records the presence of rhizinx (Lich. Scund. 1). 126). Spermogones are frequent and give a somewhat nodulose character to the filaments.

Hab. On rocks and boulders, rarely on gravelly soil in subalpine and alpine localities.-Distr. Rare in S.IV. and N. Englind ami in N. Wales and S.W. Ireland; more frequent on the Grampians, seotland.-B. M. Dartmoor Tors, Devon; Cader Idris and Aran Mawdilwy; Mevioneth; Llangollen, Dembighshire; Snowdon, Carnaronshire; Teesdale, Durham; New Galloway, Firkcudbrightshire; Glen Tilt, Ben More, Matel Girdy and Jen Lilwers, I'erthshire; Clovia Mts. aud 
Tiatelaw, Forfarshire; Loch Phadrig, Lochnagar, Morrone, Cairngorm and Ben-maboord, Braemar, Aberdeenshire; len Neris, Invernessshire; Hills of Applecross, Rossshire; Lemnabad, Caithness; Mangerton, Fillarney and Macgillicuddy's Reeks, Kerry; Doughruagh Mts., Connemara, Galway.

Var. reticulata A. L. Sm.-Thallus with shorter branching, forming a kind of reticulation especially at the circumference, the tips very shortly furcate. Apothecia frequently ciliate at the margins. $P$. lancetr var. reticulata Cromb. in Grevillea xii. p. 72 (1884); var. subriliatu Npl. in Flora li. p. 346 (1868); Cromb. in Journ. Bot. vii. p. 50 (1869) \& Lich. Brit. p. 35; Leight. Lich. Fl. p. 125. Coralloilles temuissimum nigricans, mundi muliebris instrer textum Dill. Hist. MLusc. p. 113, t. 17, fig. 32 (1741). Lirhen pubeseens Lightf. Fl. Scot. ii. p. 893 (1777) (non Limn.) ; Huds. Fl. Angl. ed. 2, p. 562? With. Arr. ed. 3 , iv. p. 48. L. reticulatus Wulf. in Jacq. Coll. ii. p. 187, t. 13, fig. 6 (1788). Alectoria lanatu var. parmetioirles Cromb. in Journ. Bot. x. p. 233 (1<72) ; Leight. Lich. Fl. ed. 3, p. 81 (incl. f. subciliata).

Distinguished by the shorter more profuse branches, and by the subciliate apothecia which are more frequent than in the species.

$H a b$. On rocks and boulders in alpine localities.-Distr. Plentiful on some of the higher Grampians, Scotland.-B. M. Ben Lawers, Perthshire; Clova Mts., Forfarshire; Cairngorm, Glen Callater, Morrone and Invercauld, Braemar, Aberdeenshire.

7. P. corniculata A. L. Sm.-Thallus of narrow, roundly compressed stiff fronds $1-2 \cdot 5 \mathrm{~cm}$. high, crowded and suberect, sparingly brancherl, the branches tapering, olive-brown or brownish-black and somewhat shining, base attached by a hold-fast $(\mathrm{K}-, \mathrm{CaCl}-)$. Apothecia plane, becoming convex, concolorous with the thallus, with an entire or fimbriate margin ; spores $s-11 \mu$ lomg, $4-6 \mu$ thick. $-P$. tristis Wallr. Fl. Crypt. Germ. 1. 52s (1831); Nyl. in Act. Linn. Soc. Bord. sér. ;, i. p. $30+(1856)$; Cromb. in Grevillea xii. p. 71 (1884). Corclloides comirulatum, furi temuines farie Dill. Hist. MLusc. p. 11s, t. 17, fig. 37 (17+1). Lichen rormirnlutus Lightf. Fl. Scot. ii. p. S8.5 (17Ti) (e deseript.). L. radiatus Huds. Fl. Angl. ed. 2, p. 5.9 (176s). L. tristis Wel. spicil. p. 209 (17Ts); With. Arr. ed. .3,

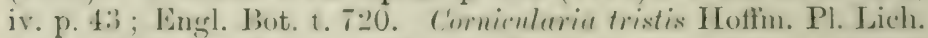
ii. p. 36, t. 34, fig. 1 (1794); S. F. Gray Nat. Arr. i. p. 404

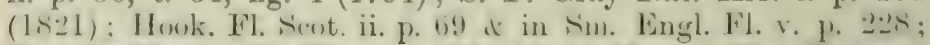
Tayl. in Matckay Fl. IIil, ii. p. 86 ; Mudd Man. I. 76. I'lot!ysmu triste Nyl. Syn. Lich. i. p. 307 (1<60): Cromb. Lich. Brit. p. 26; Leight. Lich. Fl. p. 99 ; ed. 3, p. 94.

Exsicc. Croall n. 497 ; Dicks. Hort. Sice. fase. ix. 11. 25 ; Jolins. 11. 70 .

I nomutain species, necurring either in dense swards or in indiated tufts on the roclis. Though largely fruticose in habit, the structure 
is dorsiventral, with the gonidial layer almost touching each marriin, and rising in pramid-lilie projections towarls the upper cortex. 'The apothecia, which are frequent, are subterminal. Spermogones are numerous and prominent. with spermatia $5 \mu$ long and $1 \mu$ thick.

Lightfoot's description leaves no doubt as to the identity of Lichen corniculutus, which antedates both Hurtson's and Weber's names.

Hab. On rocks and boulders in mountainous districts.-Distr. Tiather rare in $\mathrm{W}$. and $\mathrm{X}$. England and $\mathrm{N}$. Wales; more frequent in the Scottish Highlands; rare in S.W. Ireland.-B. M. Dartmoor, Deron; Malvern Hills, Woreestershire ; Sugar Loaf MIt., Monmouthshire; Cader Idris, Merioneth; The Glyders, Snowdon and Moel Siabod, Carnarroushire; Llangollen, Denbighsbire; Crickley Scar, Yorkshire; Egglestone, Durham; The Cheviots, Northumberland; Mardale, Testmoreland; Ennerdale, Cumberland; New Galloway, Tirkeudbrightshire; Ben More, Ben Lawers, Ben Trachie and Aberfeldy, Perthshire; Clova Mts., Head of the White Water and Iítelaw, Forfarshire; near Invercauld, Craig Coinnoch, Morrone, Glen Callater, Glen Dee and Ben-naboord. Braemar and Hill of Ardo, Aberdeenshire; Ben Neris, Invernessshire; Applecross, Rossshire; Dunkerron, Kerry.

8. P. stygia Ach. Meth. Lich. p. 203 (1803).-Thallus orl)icular, appressed, somewhat shining, smooth, olive-brown or blackish, the lobes narrow, with spreading palmate branching, somewhat convex and incurved at the apices, beneath pitchblack but paler towards the edge, with few stoutish rhizina ( $\mathrm{K}-, \mathrm{CaCl}-$ ). Apothecia becoming large and flexuose, dark olire-lorown or black, with a dark-coloured crenulate margin : spores small, 8-10 $\mu$ long, 6-T $\mu$ thick. -S. F. Gray Yat. Arr. i. p. 441 ; Hook. Fl. Scot. ii. p. 54 it in Sm. Engl. Fl. v. p. 202 ; MIudd Man. p. 100 ; Cromb. Lich. Brit. p. 35 ; Leight. Jich. F]. 1. 124 ; ed. 3, p. 116 . Lichen sty!nius L. Sp. Pl. p. 114:3 (1753); Dicks. Pl. Crypt. fasc. iii. p. 16 ; With. Arr. ed. 3, iv. p. 30 ; Engl. Bot. t. 2048.

Exsice. Dicks. Hort. Sicc. fasc. ii. n. 25 pro parte.

Night be confused with Platysma fuhlunense on account of the partly shining thallus, but it is blacker, and the lobes thicker and more convex. It is generally fertile. Spermogones are frequent, with spores $5 \mu$ long, $1 \mu$ thick.

$H a l$. On granitic and quartzose rocks and boulders in subalpine and alpine regions.-Distr. Local and rare among the Grampians, Scotland.--B. M. Ben More, Perthshire; Lochnagar, Ben-naboord and Jen Macdhui, Braenar, Aberleenshire; Ben Nevis, Invernessshire.

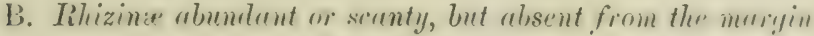 (Amphigymia).}

\section{a. Thallus glaucous-grey.}

9. P. perlata Ach. Meth. Lich. 1. 216 (1503). ..Thallus horizontal, wide-spreading, somewhat orbicular in wntline, smoth, glancous greyish-white, lobate, the lobe's rounded, ascending, 
undulating, crisp and often with turgid soralia at the margins; heneath brownish-black, with short scattered or crowded rhizine, paler and without rhizinx towards the circumference ( $\mathrm{K}+$ +rennese. $\mathrm{CaCl}-)$. Apothecia very rare, moderate in size or beeoming rather large, reddish-brown, the margin thin, entire, incurved; spores ellipsoid, 11-17 $\mu$ long, 7-10 $\mu$ thick.-S. F. Gray Nat. Arr. i. p. 437 ; Hook. Fl. Scot. ii. p. 52 it in Sm. Engl. Fl. v. p. 200; Tayl. in Mackay Fl. Hib. ii. p. 148; Mudd Nan. p. 92; Cromb. Lich. Brit. p. 33 ; Leight. Lich. Fl. p. 128 ; ed. 3, p. 119. Lichenoirles glancum prolutum, subtus nigrum et cirrosum Dill. Hist. Musc. p. 147, t. 20, fig. 39, ., B, D, E (1741). Lichen perlatus Huds. Fl. Angl. p. 448 (1762); Lightf. Fl. Scot. ii. p. 839 ; With. Arr. ed. 3, iv. p. 68 ; Engl. Bot. t. 341 .

E.csicc. Johns. n. 23 ; Larb. Lich. Hb. 11. 291 ; Leight. nos. 76,392 .

Usually about 4 to 6 inches across. Though the turgid marginal soredia are a characteristic feature, they are sometimes absent; the species being recognisable by the smooth thallus, and the orange colour profluced on the upper surface on the application of potash.

Hab. On the trunks of old trees, and on rocks in maritime and inland tracts.-Distr. General and plentiful throughout the British Isles.-B. M. Island of Guernsey; Bocconoc, near Penzance and Withiel, Cornwall; Torquay, near Lilford, South Brent, Dartmoor and Ilfracombe, Devon; New Forest. Hants; Isle of Wight; St. Leouarls Forest, Fairlight Glen, near Hastings; Mrurk Cross, near Brighton, Henfield and Arundel, Sussex; Lydd, Kent; Little Waltham, St. Ossyth, and near Messing, Essex; Cheltenham, Gloncestershire; Gopsall Wood and Twreross. Leicestershire; Wrighton I'arli, Herefordshire; Haughmond Hill, Shropshire; Llanbedr, Fammouth and Dolgelly, IIerioneth; Bousdale Gill. Cleveland, Forkshire; Starely, liendal and Windermere, Westmoreland; New Galloway, Tirkeudbrightshire; Swanston Wood, near Vilinburgh; near Inverary and 13arealdine, Argyll; Loch Kintrine and Fillin, Perthshire; S. of Fort William, Invernessshire; Applecross, liossshire; near Cork; Dunkerron, Kerry; Achill Island and Clare Island, MIayo.

Var. ciliata Scheer. Enum. p. 3t (1S.70).- Thallus similar to that of the species, with rounded crenate lobes, erisp and ciliate at the margins and with turgid soralia. Apothecia rare.-Leight. Lich. 11. 1. 12!); ed. 3, p. 1:0. Subsp. riliutu Nyl. in Flura lxi.

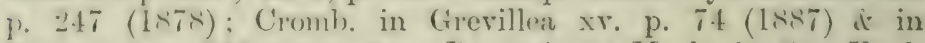

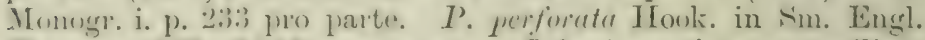

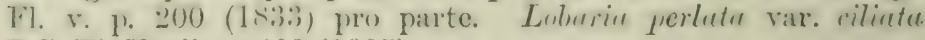
DC. F]. Fr. ii. p. 403 (1805).

1)istinguished by the presence of cilia on the margins of the lobes;

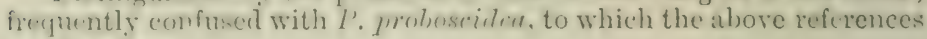
partly refer.

Heh). ()n the trumks of trues, amd on rocks and houlders in matime

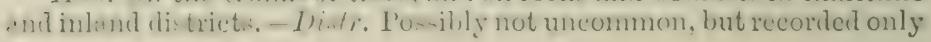


in the southern and western counties of Great Britain and Ireland.B. M. Helmen Tor, Cornwall; Hay Tor, Dartmoor, Deron; I. of Wight; Barmonth, Merioneth; Eskilale, Cumberland; Helensburgh, Dumbartonshire; Inverary and Barcaldine, Argrll ; Clave Island and Achill Island, Mayo.

\section{b. Thallus greenish-yellow.}

10. P. caperata Ach. Meth. Lich. p. 216 (1803).-Thallus spreading, lobate, wrinkled; sometimes pulverulent-sorediate towards the centre, the lobes broad, rounded, narrowly sinuate and crenulate, pale-yellowish-green or pale ochraceous, beneath blackish, rhizinose, brown and naked at the circumference $(\mathrm{K}+$ yellowish, $\mathrm{CaCl}-)$. Apothecia moderate in size, brownishred, the margin crenulate and often sorediate; spores $17-20 \mu$ lons, 7-10 $\mu$ thick.-S. F. Gray Nat. Arr. i. p. 437 ; Hook. Fl. Scot. ii. p. 52 it in Sm. Engl. Fl. r. p. 198; Tayl. in Mackay Fl. Hib. ii. p. 146 ; Mudd Man. p. 101, t. 릉 fig. 30; Cromb. Lich. Brit. p. 32 ; Leight. Lich. Fl. p. 122; ed. 3, p. 114. Lichenoides crusta foliosa, catinerco et luteo virescente superne, inferne migra et lati Dill. in Ray Syn. ed. 3, p. 73, n. 62 (1724). Lichenuides caperntum, rosacee expunsum, e sulpluteo virens Dill. Hist. MIuse. p. 193, t. 25, fig. 97 (1741). Lichen enperatus L. Sp. Pl. p. $11+7$ (1753) : Hudls. Fl. Angl. ed. 2, p. 543 ; With. Arr. ed. :3, iv. p. 58 ; Engl. Bot. t. 654 .

Eesice. Bohl. n. 123; Cromb. n. 140 ; Johns. n. 220 ; Larb. Cæasar. n. 63 \& Lich. Hb. n. $2 \varepsilon 9$; Leight. n. 77 ; Mudd n. 73.

Also a wide-spreading species, it is well distinguished by the colour and the wrinkling of the thallus. The apothecia are somewhat rare, and are chiefly central. Spermogones are minute and brown, with spermatia $6-7 \mu$ long, $1 \mu$ thick.

Hab. On the trunks of old trees, palings and boulders.-Distr. General and fairly abundant throughout the British Isles, though rare in N. Scotland.-B. M. St. Brelade's and Boulay Bay, Jersey ; Guernsey; St. Mary's, Scilly; Bocconoc, Penzance aud Withiel, Cornwall; Iry Bridge, Bolt Head, Newton Bushell, Totnes and Dartmoor, Devon; Lrme Regis, Dorset; Lyndhurst, Hants; Carisbroolse and Ryde, Isle of Wight; Lewes, Hastings, Pondlye, and near Brighton, Sussex; near Tunbridge Wells, Tient; Walthamstow, Hainault Forest anil near Bocking, Essex; Stonehenge, Wilts; Elstree, Herts; near Malrem, Worcestershire; Gamlingay, Cam. bridgeshire; Charnwood Forest and Twyeross, Leicestershire; Haurhmond IIll, Shropshire; Hafoll, Cardiganshire; Cwm Brchan and near Barmouth, Merioneth ; Llanberis, Carnarvonshire; Anglesea ; Buxton, Derbyshire; T'eesdale, Durham; near Hexhan, Torthumberland; Stavely, Windermere, Westmoreland; lieswick and Asby, Cumberland; New Galloway, Tirkeudbrightshire; livelstone and Tentland IIills, near Edlinburgh ; Airds, Appin, Argyll; Ilairdrummond, Aberfoyle, liemmore and Jien Lawer's, l'erthshire; Jen Nevis, Invernessshire; liostellan, Corls; Dunkerron, lierry; Achill Island, Mrayo. 


\section{c. Thallus olivaceous or brownish.}

11. P. subaurifera Nirl. in Flora 1vi. p. 22 (1873).-Thallus orbicular, thin in texture, closely appressed. crumpled and lobate, olive- or unber-brown, with a yellowish medulla, generally glalmrous at the circumference, isidiose towards the centre and more or less sprinkled with yellowish sorerlia, the lobes rounded and crenate, beneath blackish, shortly fibrillose, lighter coloured and hare at the edge $(\mathrm{K} \mp$ rellowinh, $\mathrm{CaCl}=$ rehli-h $)$. Apothecia small, dark chestnut-coloured, the margin subentire, often yellowsorediate ; spores 11-13 $\mu$ long, $T-s \mu$ thick.-Cromb. in Journ. Linn. Soc. xvii. p. 572 (1880) \& in Grevillea x. p. 25 (18si). Lichennides olivecenm, seutellis læevibus Dill. Hist. IIusc. p. IN2, t. 24, fig. 77 c $(17+1)$. Lichen oliveceus var. 3 With. Arr. ed. 3, iv. p. 35 (1796) (fide Crombie Monogr. i. p. 252).

Exsicc. Larb. Lich. Hb. 210.

Differs from allied species in the rellow medulla and scattered soredia, a character more distinctly marked in northern specimens (cf. I'. Mongeotii). Apothecia are extremely rare; they occur on only one of our specimens, collected at Penzance. Spermogones are also very rare; spermatia $5 \mu$ long, $1 \mu$ thick.

$H a b$. On the trunks of trees, chiefly oaks and firs, also on branches of shrubs.-Distr. Rare in N. Wales, the Highlands of Scotland and N.W. Ireland.-B. M. Near Penzance, Cornwall; Henfield, Sussex; Lydd, Kent; Gopsall Park, Leicestershire; Wimpole Park, Cam. bridgeshire; Tiempsey, Worcestershire; Abertover, Merioneth; Bettws-y-Coed, Camarronshire; Ayton, Cleveland, Yorkshire; Hindburndale, Lancashire; Windermere, Westmoreland; Glen Lochay, Perthshire; Durris, Fincardineshire; near Banchory. Aberteenshire; Applecross, Rossshire; Irylemore. Galway.

12. P. Mougeotii Schar. Enum. Lich. p. 16 (1к.)0).-Thallus rather small, orbicular, appressed and closely arinate, generally. darker and subareolate in the centre, greenish or greyish-yellow towards the outside, usually sprinkled with small yellowish-white soralia, the laciniae narrow, linear, multifid, slightly convex and spreading at the apices, frequently transrersely cracked, beneath brownish-black, with very short rhizine, smooth at the edges $(\mathrm{K}+$ yellowish, $(\mathrm{aCl}-)$. Apothecia rare, minute, reddishbrown, the marein pulverulent: spores $8-10 \mu$ lone, $5-6 \mu$ thick.-Mucld Man. p. 102; Croml. Lich. Jirit. P. 34. I. cmspersa f. Mougeotii Leight. Lich. Fl. p. 136; ed. 3, p. 125. Lirlern imerrus sm. Engl. Bot. t. 1375 (1804) pro parte. (non Pers.).

Exsicc. Cromb. n. 143; Larb. Lich. Hb. nos. S7, 251; Leight. n. 143 ; Mudd n. 74 .

1)intingnished los the linear appressed lobes and by the rellowish soredia. It has freygently been considered as allied to $l^{\prime}$. comsporsa, but the smooth enlges of the under surface place it in this section. 
The spermogones are rather rare, minute and brownish-black; the spermatia are $5-6 \mu$ long and $1 \mu$ thick.

Hab. On rocks and boulders, chiefly granite and gneiss in maritime and upland districts.-Distr. Local and rather scarce, in Great Britain and Ireland; most frernent perhaps on the Grampians, Scotland.-B. II. Withiel and Bormin, Cornwall; Charnwood Forest, Leicestershire; near Barmouth and Capel Arthog, Merioneth ; Bettwsr-Coed, Carnarronshire; Battersby and Ingleby, Cleveland, Yorkshire; Teesdale, Durham; near Kendal. Westmoreland; New Galloway, Kirkcudbrightshire; Achosragan Hill, Appin, Argrll; Ben Lawer's and Craig Tulloch, Perthshire; Durris, Kincardineshire; Glen Dee, Braemar and C'rathes, Aberdeenshire; Curraghmore, Wraterford; Dunkerron, Kerry; Connemara, Galway.

Form dispersa Cromb. in Grevillea xv. p. 7. ( 1887 ). Thallus of seattered narrow short laciniat, sparingly sorediate. Apothecia not seen.

Hab. On schist rocks in shady situations in subalpine tracts. B. M. Achosragan Hill, Appin, Argyll.

13. P. olivetorum Nyl. in Not. Sillsk. Faun, it Fl. Fenn. Fïrh. $\vee$ p. 180 (1866). - Thallus horizontal, roundly lobed, smooth, greyish-green becoming yellowish-brown and shining when dry, the lobes somewhat ascendling, crisp, incurved, thickened and sorediate at the margins, beneath blackish, brownish at the circumference, wrinkled, very sparingly rhizinuse $\left(\mathrm{K} \pm\right.$ sellow, $\left.\mathrm{CaCl} \mp{ }^{\mathrm{red}}\right)$. Apöthecia moderate in size $(5-10 \mathrm{~mm}$. across), shortly pedicellate, brownish-red, the excipulum and margin smooth, becoming sometimes sorediose; spores $14-18 \mu$ long, 7-12 $\mu$ thick. Leight. Lich. Fl. p. 130 ; ed. 3, p. 121. P. perlata var, olicetoruin Ach. Lich. Univ. P. 458 (1810).

Distinguished from $P$. perlata by the almost complete absence of rhizinze and by the thin lines of marginal soredia. The British specimens are sterile. The spermatia are cylindrical.

Hab. On trunks of trees and on rocks in mooded maritime and mountainous districts.-Distr. Rare in S. England, N. Wales and S.W. Highlands of Scotland.-B. M. Drews-y-nant, Merionetll; Barcaldine, Argyll.

14. P. cetrarioides Del. ex Nyl. in Flora lii. p. 290 (1869). -Thallus large, orbicular or irregular, roundly lobed, smooth, generally wrinkled, the lobes broad, crenate, somewhat ascending, crisp and sorediate at the margins, beneath blackish, brownish at the circumference, wrinkled, very sparingly rhizinose $\left(\mathrm{K} \pm{ }^{\text {yeliow }}, \mathrm{CaCl}-\right.$, medulla $\mathrm{K}$ ( $\mathrm{CaCl}$. f. + reddish). Apothecia moderate or large, brownish-red, the margin entire, becomine sorediose; spores $14-16 \mu$ long, $11-12 \mu$ thick. Croml). Lich. Brit. p. 34 ; Leight. Lich. 1F. 1. 128 : ed. :3, 1. 119. P. perlutu var. cetrarioides Duby Bot. Gall. ii. p. 601 (1830). 
Very sinditu to the preceding. lut distinguished by the reactions and by the form of the spematia which are ligeniform /broadly clavate). The apothecia are rare.

Hab. On the trunks of old trees, rarely on rocks in wooded maritime aml upland regions.--Distr. liather rare; the Channel Islands, S. and S. WV. England, N. Witles, and hilly regions of Seotland. - I;. .1. liozel, rersey; Helmen Tor, Cornwall; Dartmoor and Jickleigh Vale. levon; New Forest, Hants; Dolgelly, Aluerdorey and neatr liarmonth. Merionoth; New (ralloway, Kirliendirightshire; Appin. Arryll: Inch Katrine. Perthshire; Joch Limmbe, Invernessshire.

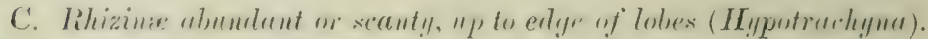

\section{a. Thallus whitish or grey-coloured.}

\section{Isidia and Soredia absent.}

15. P. tiliacea Ach. Meth. Lich. 1. 215 (180:3). Thallus 1) rbicular, rather thin, laciniate-lobed. appiessed. smonth or partly winkled or subpruinose, pale greyish-glancous, the lobes subimbricate, deeply divided and crenate, bensath brownishblack, rhizinose to the margin ( $\mathrm{K} \pm$ sellowish, $\left.\mathrm{CaCl} \mp_{\text {red }}\right)$. - Apothecia moderate in si\%. rowdred when present, concave or nearly plane, brownishrerl, the mar.in heroming crenulate: spores ellipoid, small, $7-11 \mu$ long, $5-7 \mu$ thick. - s. F. (tray Nat. Arr. i. p. 438; Ilook. in sm. Engl. lil. r. p. 200 : Nudd

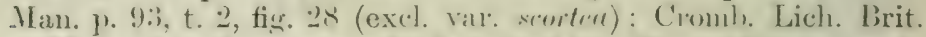
p. :3:3 (exrl. subsp. sortere): Leight. Lich. Fl. 1. 1:3l pro parte (incl. var. rugosula); ed. :, 1'. l:2l poro parte (incl. val. mesusula).

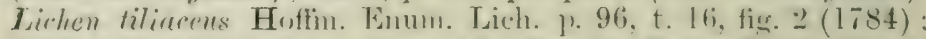
licks. Pl. Crypt. fisse iii. p. lii: sm. in Trams. Linn. soce. p. 83 (1791); With. Arr. ed. 3, ir. I. :31.

Exsice. Larb. Lich. H1). n. 292.

bistimenished by the more closely appressed thallus with narowly simnate and slosely contignons lobes. (renate at the matrin and sometines wrinkled and prumose. 'The apothecial are chiefly central ; the spemogemes are prominent and hownis $h_{1}$ with spermatiat $7 \mu$ long, $1 \mu$ thick.

Hah. (In the trmolis of troes, rarrly on rockis in maritime and inland districts.-. I)istr. liather rave in the ('hammel Isliands, S. and X. Encrland, X. Witles and Wr. Seotland, not ret reeorded for Ireland.

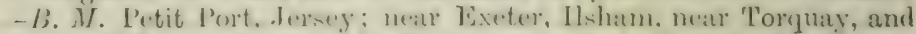
(hatgforl, Jevon) Lymington. Hants: near Iiyde 1. of Wight: Lewes.

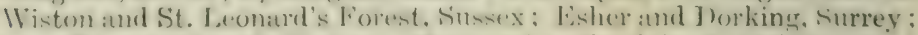

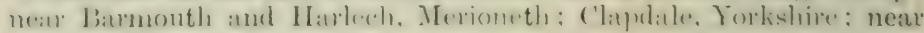
lienilal. Westmorelnnil.

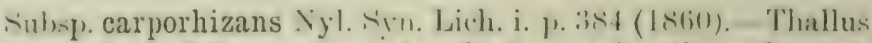
sintal to that of the species. Ipotheriat oceasionally perforated, 1.110 rxejumlum blackish and hlark-setulene. Cromb. in Grevillea xv. p. Tis (1887). P'armelia carportizans 'Tayl. in Hook. Joum. 
Bot. vi. p. $16: 3$ (1ヘ47); Cromb. in Joum. Bot. xx. 1. 272 (1882). Lichen tiliaceus Sm. Engl. Bot. t. 700 (1800).

Distinguished from the species by the darti setulose under surfuce of the base of the apothecium. The dark fibrils are not always easily seen. In Engl. Bot. t. 700 they are omitter, though quite clearly indicated in one of Sowerby's unpublished drawings, and present in the specimen of Lirhen tiliacmes preserved in the British Inseum.

Hab. On the trunks of trees in wooded districts.-Distr. Not uncommon in the Channel Islands and s. Englind.-B. M. Terbourg, Gnernsey; Chagford, Ashburton. Cornworthy, and near Torquaty, Devon; 1) unster 'Tower, Somerset; I, rimington, Hunts; near Rrvie. I. of Wight.

\section{Isidia or Soredia on surface of lobes.}

16. P. scortea Ach. Lich. Univ. p. 461 (1810).-Thallus orbicular, spreading, coriaceons, whitish, more or less densely covered towards the centre with darker isidia, the lobes short, rounded-crenate; beneath densely black rhizinose to the margin $\left(\mathrm{K} \pm\right.$ sellowish, $\left.\mathrm{CaCl} \mp_{\text {reildish }}\right)$. Apothecia moderate in size, scattered, reddish-hrown, the margin subentire; spores $7-11 \mu$ long, 5-7 $\mu$ thick.- Hook. in Sim. Engl. Fl. p. 199. P'. tiliacea var. scortea Mérat Nouv. Flor. envir. Paris ed. 4, i. p. 393 (1836); Mudd Man. 1. 9:3: Leight. Lich. Fl. p. 1:31: ed. 3, p. 12.2. Subsp. scortea Cromb. Lich. Brit. 1. 33 (1870). Lichen scorteus Ach. Lich. Suec. Prodr. p. 119 (1798); Engl. Bot. t. 2065.

Exsicc. Larb. Caesar. n. 18 ; Leight. n. ST.

Differs from $I^{\prime}$. tilincer in the slightly thicher isirliose thallus. A specimen from Bolt Head. Devon, with small congested lobes, hats been described as f. concrescens Cromb. Monogr. i. p. 240 (1894).

Hab. On trees and old pillings, ralrely on rockis in maritine and inland districts.-Distr. Rire in the Channel Islatels, England and Wales, S. and W. Scotland and S. W. Ireland. - I3. M. L'Etacq. Tersey ; Sarts; Bolt Heal, Deron ; Shanklin, I. of Wight; Jes lorest, Hants ; Stonehenge, Wilts; near Lewes and Henfield. Sussex; Harboro' Magna and Newbold-on-Avon, Warwickshire; 'Twyoross, Leicestershire; Little Stretton, Shropshire; Holylind, Pembrolieshire ; Ilinforda and near Bamouth, Meriometh; Stoliesley, ('leveland, Yorkshire; near Egglestone, Durham; near Kendil. Westmorelind;

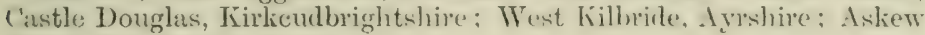
Wood, Dunkerron, Kerry.

17. P. proboscidea Tilyl. in Mackay F1. Hib. ii. p. I 13 ( $18: 36$ ) (non Allioni ex Ach. Lich. (Thiv. 1) 458 (1s10)). Thallus moderate in size or wide-spreading often bearing isidia changing into soredia over the surfice, slancous- or whitish-grey, the: lobes imbricate, crisp and renate or often finely disiected at the margins, cilia present on the margins and experally associated with the isidia on the surfice; benenth black, densely rhirinose, sonerally naked and brown at the edere ( $\mathrm{K}+$ yellow, then red). 
Apothecia rare, subpedicellate, rerldish-brown, the outer wall rugose, areolate and isidiose; margins incurved, crenate and often becomine sorediate; spores ellipsoid, $23-33 \mu$ lons, 15-17 $\mu$. thick (fide Hue) with a thick epispore.-P. perlata var. ciliatn Cromb. Lich. Brit. p. 33 (1870) (non Scher.). P. pilosellu Hue in Journ. Bot. Fr. xii. p. 247 (1898). Lirken perforatus Sm. Engl. Bot. t. 2423 (1812) (excl. mid. fig.).

Exsicc. Cromb. n. 30 ; Johns. n. 68 ; Larb. Cresar. n. 17 \& Lich. Hb. n. 86 ; Leight. n. 112.

The absence of marginal soralia, the superficial cilia, and the large spores distinguish the species from $P$. perlata var. ciliatr. Some. times the sorediose isidia form scab-like excrescences ( $P$. pilosellin f. excrescens Arn. ex Hue tom. cit. p. 249). Apothecia are rare; the spores in a specimen from Anglesea were smaller than the recorderi size, measuring from $20 \mu$ in length.

Hab. On trees, rocks and boulders in shady situations.-Distr. (ieneral, though not common throughout the British Isles.13. M. Jersey; Guernser; St. Mary's Isle, Scilly; near Penzance. Cornwall; Lustleigh Cleeve and near Bolt Head, Devon; St. Leonards, Sussex; Tunbridge Wells, Tient; Malrern, Worcestershire ; Barmouth and Dolgelly, Merioneth; Anglesea; near Kendal, Westmoreland; Keswick, Cumberland; New Galloway, Kirlicudbrightshire; Barcaldine, Argyll; the Trossachs and near Loch Tay, Perthshire; S. of Fort William, Invernessshire; Applecross, Ross. shire; Dunkerron, Denis and Derryeunihy, Kerry; Killery 13ay, Connemara, Galway; Clare Island, Mayo.

18. P. saxatilis Ach. Meth. Lich. p. 204 (1803).-Thallu. thin, spreading or suborbicular, laciniate-lobate with reticulate lines or markinuss, or even reticulate-lacunose, frequently more or less isidose, greyish white or glaucous-grey, the lobes grenerally rather narrow, sinuous, crenate and truncate or retuse at the

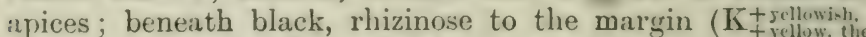

CaCl.-). Apothecia moderate in size or rather large, the excipulum and margin thin, crenulate or often isidiose, the dis. reddish-brown; spores ellipsoid, $14-18 \mu$ long, $7-9 \mu$ thick, with an epispore 1-1 $5 \mu$ thick.-S. F. Gray Nat. Arr. i. p. 440: Hork. Fl. Scot. ii. 1) 5.3 \& in Sm. Engl. Fl. v. p. 199; 'Tayl. it Mackay Fl. Hib. ii. p. It4; Mudd Man. p. 94 (excl. vars. Iencorheren and ompledodes); Cromb. Lich. Brit. p. 34 (excl. vars. sulcrate and omplutolos); Leight. Lich. Til. p. 137 (excl. vars. sulcutu and omplentortes, incl. var. punniformis); ed. :3, p. 126.

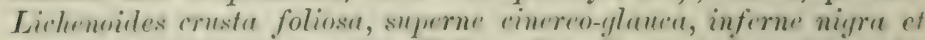
rimosa, sentellis nigricuntiluns Dill. in Ray Myn. ed. 3, p. 7:2, n. 61

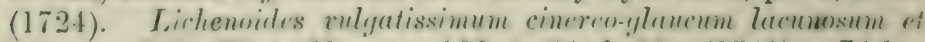
cirrosum Dill. Ilist. Mu<c. p. 188, t. 24, f. 833 a (1741). Lichen

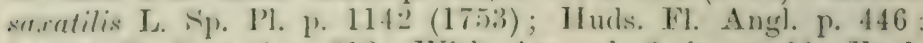
Lightf. Fl. Sicot, ii. 1. S16; With. Arr. ed. 3, iv. 1). 333; Engl. Bot. t. 603.

Exsicc. Cromb. n. 27 ; Leight. n. 203 pro parte. 
A very common species, easily recognized by the reticulate lines on the thallus which are mostly whitish, though sometimes becoming larker, and sometimes marked by isidia. Apothecia are very rare. - permogones are minute with spermatia about $7 \mu$ long and $1 \mu$ thick. There is a sterile form with very narrow crowded lacinice which are sometimes isictioid (f. panniformis Cromb. in Grevillea, xv. p. 7.j (1887)).

Hal, On trees, walls, rocks and boulders in lowland and upland districts. - Distr. General throughout the British Isles.-B. M. Island of Guerusey; near Penzance, Cornwall; Dartmoor, Deron; New Forest, Hants; Sussex; Malvern Hills, Worcestershire; Lambeth. s. Wales; Dolgelly, Merioneth; Starely, Westmoreland; Ayrshire; Appin, Argyll; Finlarig, Ben Lawers, Glen Falloch, Abernethy, Invertrosachs, Black Wood of Rannoch and Ben Vraclie, Perthshire; Cortachy, Forfarshire; Portlethen, Kincardineshire; Corriemulzie, I Hramir, Aberdeenshire; Hen Nevis, Invernessshire; Clare Island and Achill Island, Mayo.

Form furfuracea Schitr. Lich. Helv. Sipic. p. 455 (1846).Thallus spreading, greyish white, generally densely covered with sreyish-brown isidia which frequently obliterate the lobes except it the circumference, otherwise similar to the species. Var. fiurfuracea Mudd Man. p. 95 (1861) ; Leight. Lich. Fl. p. 138 ; .rl. 3, p. 127. Parmelia horrescens Tayl. in Mackay Fl. Hib. ii. p. 144 (1836) pro parte. Lichenoides vulgatissimum cinereo!lanenim lacunosum et cirrosum Dill. Hist. Musc. p. 188, t. 24, fig. $83 \mathrm{c}, \mathrm{D}(1741)$.

Exsice. Bohl. n. 11 ; Johns. n. 187 ; Larb. Lich. Hb. n. 211 ; Leight. n. 46 pro parte.

More frequent than the species with which it is connected by cvery stage of isidiose derelopment. Frequently fertile, and the apothecial margins rough with isidia.

Hab. (On rocks, walls and trees, chiefly in upland districts.7)istr. General and common in many parts of the British Isles.B. M. Alderney; near Penzance and Helminton, Cornwall ; Throwley 1)own and near South Brent, Devon; Basingstoke and New Forest. Hants; Maresfield Common, Eridge Rocks and Ardingly, Sussex; - iavernake Forest, Wilts; Charnwood Forest, Leicestershire; Malvern, Worcestershire; Lambeth, S. Wales; Barmouth and near Dolgelly, Merioneth; Capel Curig, Carnarvonshire; Anglesea; The Wrekin, Shropshire; Chatsworth and near Buxton, Derbyshire; Cleveland. Yorkshire; Rentmere, Westmoreland; Kieswick, Cumberland ; New (ialloway, Firkcudbrightshire; Dalmahoy Crags, near Edinburgh; near Helensburgh, Dumbartonshire; Appin, Argyll; Trossachs, Jien Litwer's and near Dunkeld, Perthshire; Clova and Cortachy, Perthshire; Glen C'alliter, Morrone, Ben Aron and Craig Coinnoch, Braemar and (rathes, Alerdeenshire; Glen Nevis, Invernessshire; Applecross, Iiossihire; Lambay Island, near Dublin; near Cork; Dunkerron, Kerry ; livlemore, Galway ; ('lare Island and Achill Tsland, Mayo.

19. P. sulcata Tayl. in Mackay Fl. Hib. ii. p. 145 (1836).-Thallus orbicular, sprearling, laciniate-lobate, the lobes sinuate, hranched, irregularly imbricate, subtruncate at the apices, 
greyish or glaucous white and more or less marked with reticulate lines, the reticulations frequently changing to furrowed oblong o1. linear white-marginel soralia; beneath blackish, rhizinose ( $\mathrm{K}_{\text {f yellow, then red, }} \mathrm{CaCl}_{-}^{-}$). Apothecia and spores as in P. saxutilis, or rather smaller.-Cromb. in Grevillea xv. p. 75 (1887). P. sacutilis var. Inuderoa Wallr. Fl. Crypt. Germ. i. p. 49! (18.31) ; Mudd Man. p. 94; var. sulcate Cromb. Lich. Brit. 1. 34 ; Leight. Lich. Fl. p. $1: 38$; erl. 3, p. 126. Lirhenoirles vulyatissimum rinereo-ylaucum, lacunosum of rivesum Dill. Hist. IIuse. p. 188, t. 24, fig. 83 в (1741).

Exsicc. Cromb. n. 28 ; Dicks. Hort. Sicc. fase. xiv. 11.22 ; Johns. n. 69 ; Leight. n. 203 ; Mudd n. 66.

Distinguished from the precerling by the absence of isidia and by the furrowed soralia which are often abunlant on the thallus and along the margins of the lobes, giving the whole plant a rough scabrous appearance.

Hub. On trees and old walls in maritime and inland districts.Distr. General and common throughout the British Isles; fertile chiefly in the Highlands of Scotland.-B. M. Guernsey; Penzance and Withiel, Cornwall; Beerling and Newtimber, Susmex; New Forest, Hants; near Cirencester and Sapperton. Ciloncestershire: near Malden, Epping and Hainault Forests, Essex; Harboro' Magnit. Warwickshire; Aberdorey, Merioneth; Ludlow, Shropshire; Haddon Hall and 1)arley, Derbyshire; Ayton and Ingleby, Clevelaud. Forkshire; near Hexham, Northumberlund ; Dalry, Firkeudbrightshire: Ireghom and Craiglockart, wear Edinburgh; Jarcaldine. Argrll: Joch Katriue and Fillin, Perthshire; Jaldovan, Forfarkhire: near Jraemar and Den of IIurtle, Aberdeenshire; near Fort Willian. Invernessshire; Applecross, liossihire: Rostellan. ('ork: Imuliernou. Kerry; Clare Island and Achill Island, Mayo.

20. P. dubia fichare. Enum. Lich. p. 4.) (16.)(1).-.Thallus sulurlicular, thimish in texture, apjeressed, lobate, sumoth w slishtly winkled, glatucous-grey or pale-whitish-grey, the surfine more or less thickly sprinklerl with small round soralia, the loles rather broad, rounder, sinuate, the erlges freyuently sorerliate: beneath almost black, wrinkled, sparingly rhizinose ( $\mathrm{K}+$ yellom.

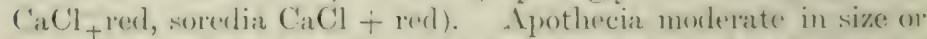
latger, hownish-red, the maresin alevated, inflexed: spores 11-15 $\mu$ long, $8-11 \mu$ thick.-P. Boreri Turn. in 'Trans. Linn. Soc. ix. p. 148, t. 13, fig. 2 (1808); S. F. Gray Nat. Arr. i. 1. 4:37: Howk. in Nu. Engl. Fl. v. p. l!9! : Tayl. in Mackay Fl.

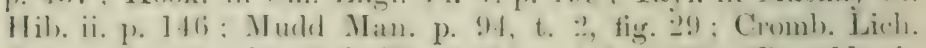
Brit. p. 3.1; Leight. Lich. Fl. p. 133 ; ed. 3, p. 122. P. reddendu

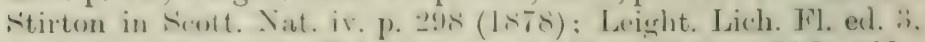
p. 119 ; Cromb. in Grevillea x. p. 26 (1851). Lichenoides:

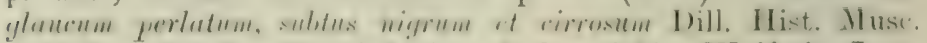
p. 147, t. 20, fig. $39 \mathrm{C}(1741)$. Lichen dubius Wulf. in Jacp. Collect. But. iv. 1. 275, t. 19, tig. I (17!) ). L. Burreri Tum. in Sim. lingl. Bot. t. 1780 (1807). 
Exsice. Larb. Cresar. n. 20 ; Leight. n. 231.

Somewhat similar to $P$. sulcata, but difiering in the ioru of the soredia and in the thalline reactions. Apothecia are rare in British specimens, they are chiefly central and become perforate with age. spermatia are lageniform (broadly clavate), $-4 \cdot 5 \mu$ long, $1 \mu$ thick.

$H a b$. On trunks of old trees, rarely on rocks in wooded districts. -Distr. General in the Chamel Islands and in S. and TV. Englanil. rarer in Scotland and Ireland.-D. M. Tozel, Jersey; near Jerbourg. Guernsey; near l'enzance and IVithiel, Cornwall; Basingstolie and Tyndhurst, Hants; Tiyde and Shanklin, I. of Wight; near Brighton, Henfield, Haywarl's Heath, Angmering Park, Hurstpierpoint. Hastings and near St. Leomards, Sussex ; Naidstone, Kent ; Walthamstow, near Maldon and Great Totham, Fssex; Femble and Sipperton. Gloucestershire; near Oxford; Harboro" Magna, Warwichshire; Hindlip and Malvern, Torcestershire ; 'Treross, Leicestershire: Barmouth and 1)olcrelly, T[erioneth; I)yneror Castle, Citermarthenshire; near Fendid, II stmoreland; New (ialloway, Kirleudbrightshire; West Kilbrile, Arrshire ; Riverstown, Cork; neir I.imerick; Dunkerron, Kerry; Westport and Achill Island, Mayo.

21. P. ambigua Ach. Meth. Lich. 1). 207 (1803).-Thallus orbicular, closely adnate, straw-colourerl or glaucous-grey, sprinkel with sulphur-colonred soralia, the lobes narrow, somewliat pinnatifid, plane, widening outwalds: beneath brownish-black, lighter towards the circumference with a few scattered stoutish rhizina almost to the edge $(\mathrm{K}-, \mathrm{CaCl}-)$. Alxthecia small, with a rather prominent entire or crenulate margin; spores ublong or ovoid-oblong, often slightly curved, $7-11 \mu$ long. $2 \cdot 5-3 \cdot 5 \mu$ thick.-Borr in Engl. Bot. Fuppl. t. 2796 (two lower figs.). Hook. Fl. Scot. ii. p. 55 \& in Sm. Engl. Fl. v. p. 203 ; Leight. Lich. Fl. p. 127 ; ed. 3, p. 118. P. diffusa Mudd Man. p. 103 (186I) (non Web.). Lichen ambigus WVulf. in Jacq. Coll. Bot. iv. p. 239 (1790). P'anmeliopsis ambigma Nyl. in Not.

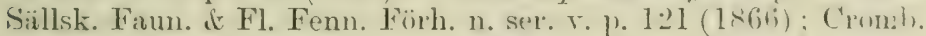
Lich. Birt. p. 37 \& Monogr. i. p. 263.

Exsice. Cromb. n. 146 ; Johns. 1n. 222; Leight. n. $37: 3$; Nudd n. 75.

Well distinguished from $P$. Mougentii, which it resembles in the rellow soralia by the more dereloped thallus, by the mbrolien lobes. the absence of reaction, and the form of the atscospores and sirermatia. 'The latter are long, slender and arcuate, about 18.25 $\mu$ long, $5 \mu$ thick. Jiecatnse they differ from those of other Promelia, this sperien and $P$. aleurites, in which they also occur, have been placed by several writers in a separate genus, l'armeliopsis.

$\mathrm{Hab}$. On the trunks of old fir trees near the roots and on old fir

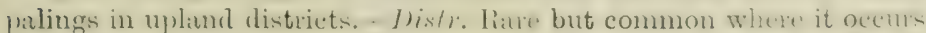
throughout England and Central Highlands, Scotland.- B. M. Ightham, Kent; 'I'wycross and Gopsall Park, Leicestershire; neat

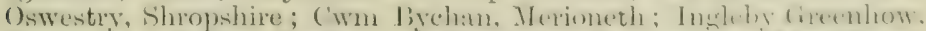

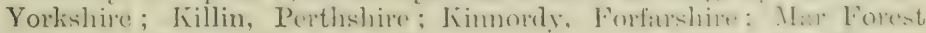
and Glen Derry, Braemar, Aberteenshire; Larig Guie, Janfishire; Rothiemurchus, Invernessshire. 
22. P. hyperopta Ach. Syn. Lich. 1. 208 (1814); (in Hb. Ach. fide Wainio in Termesz. Fiiz. xxii. p. 280 (1899)).-Thallus orbicular, closely appressed, sreyish-white, with whitish pulverulent soredia, the lobes narrow, spreading, not much branched: benenth brownish-black, with scanty rhizinat to the edge ( $\mathrm{K}^{+}+$yellww, $\mathrm{CaCl}_{-}^{-}$). A jothecia very long, small or nearly moderate in size, brownish or reddish-brown, concave or becoming plane, the margin thin, slightly crenulate; spores oblong or fusiformollong, usually somewhat curved, 11-12, $\mu$ long, 3-4 $\mu$ thick.Mudd Man. p. 98 ; Leight. Lich Fl. ed. 2, p. 478; ed. 3, p. 119. P. umbigner Borr. in Engl. Bot. Suppl. t. 2796 (1835) (two upper figs.). Parmeliopsis aleurites Nyl. in Flora lii. p. 445 (1869) (non Ach.); Cromb. Monogr. i. p. 263.

Distinguisher from the precerling by the white sorediat, and by the reaction with potash. There is considerable confusion in nomenclature between this species and Cetraria (aleurites) diffusa. The latter is isiliose, brown beneath. while $P$. Tiyperoptr is sorediose and black beneath.

$H a b$. On the trunks of old firs near the roots, and on fir palings in mountainous districts.-I istr. Rare in the N. Grampians, Scotland. - B. M. Glen Dee, Braemar, Aberdeenshire; Larig Guie, Banffshire; A viemore, Invernessshire.

\section{Soredia on tips or margins of lobes.}

23. P. cetrata Ach. Syn. Lich. p. 198 (1814); Wain. Lich. Irés. i. 1) 40 (1890).--Thallus suborbicular, lobate, smooth, minutely reticulate-rimulose, glaucous or whitish, the lobes irregular, rather deeply crenulate and ascending at the circumference, more deeply divided towards the centre, occassionally black ciliate, frequently sorediate on the tips or the margins, more rarely on the surface; beneath blackish towards the centre, dark-brown at the edges: rhizina over the entire lower surface or reduced to papille towards the elge ( $\mathbf{K}_{+}^{+}$jellow, nen real. $\mathrm{CaCl}-$ ). Apothecia very rare, typically pedicellate, brown, the margin entire, generally perforate at the centre when mature; spores 14-15 $\mu$ long, $7-8, \mu$ thick. $P$. jerformatas. F. (iray Nat. Arr. i. 1. $4: 37$ (1821)? Nyl. Sym. Lich. i. 1. 377 (1860) pro parte (nou Ach.) (incl. var. whute), p. 37s: Itook, in Sm. Engl. Fl. v. 1. 200 pro parte. Cromb. Lich. Brit. 1. 32: Leight. Lich. Fl. 1. 134; edl. 3, 1. 12:3. I', rtimlutu Tayl. in Mackay Fl. Hib. ii. p. 148 (18:36). P. prelutu var. cilintu Mudd Man. p. 92 (1861).

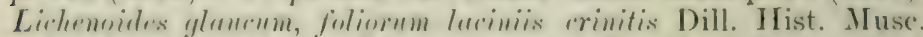

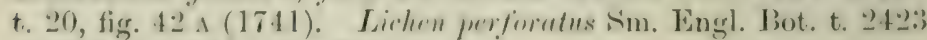
(mid. fig.) (1812) (non Jacq.).

Exsice. Cromb. n. 29 ; Larb. Lich. Hib. n. 250.

Jistinguished by the faint mosaic of minute cracks on the mplere surface, and by the presenee of rhizinar or papillas right up to the edge. It has heen comfuserl with $l$ '. profuratu, also an Acharian species, but 


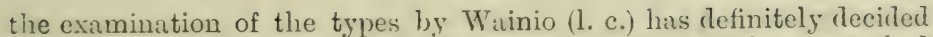
the point of nomenclature. In $P$. perforatu Ach. the lobes are nalied at the edge of the under surface.

$\mathrm{Hat}$. On mossy rocks and the trunks of old trees chiefly in mariime districts.-Dist). Rather uncommon in the Southern and Vestern counties of the British Isles.-B. M. Rozel, Jersey ; Alderney; Penzance and Withiel, Cornwall; South Brent, Devon; Lyme liegis, Dorset; Carisbrooke, I. of Wight; Nannau, Dolgelly and Tan-y-Croes, Merioneth; Barcaldine, Argyll; Dunkerron, Kerry; near Kylemore, Connemara, Galway.

24. P. lævigata Ach. Syn. Lich. p. 212 (1814).-Thallus suborbicular, horizontal, lobate, the lobes sinuate at the axils, multifid, narrow or rather broad, spreading (divaricate), partly imbricate, often with turgid soralia at the apices, glaucous-white "ll whitish; beneath blackish, densely rhizinose up to the margin i $\mathrm{K} \pm$ sellow, $\mathrm{CaCl}_{-}^{-}$, medulla $\mathrm{K}$ (CaClf) + red). Apothecia moderate in size or large, reddish-brown, the marcrin becoming crenulate or sorediate ; spores $6-8$ in the ascus, $17-23 \mu$ long, $10-14 \mu$ thich witl a stout epispore.-S. F. Gray Nat. Arr. i. p. 443 ; Hook. Fl. Scot. ii. p. 5.) d in Sm. Engl. Fl. r. p. 200 ; Tayl. in Mackay Fl. Hib. ii. p. 148 ; Cromb. Lich. Brit. p. 33 ; Leight. Lich. Fl. 1. 139 ; ed. 3, p. 12s. P. simose var. lævigata Scher. Enum. 1. 43 (1850); Mudd Man. p. 95. Lichen levigatus Sm. Engl. Bot. t. 1852 (1808).

Exsicc. Cromb. n. 141 ; Larb. Casar. n. 64 \& Lich. Hib. n. 124 ; Mudd n. 69 .

Distinguished by the sinuous rounded axils and the rather blunt -yuare tops of the lacinite. The apothecia are very rare and imperfect. "The spore sizes have been talien from Nylander's description (Sym. Jich. p. 384), there being no material wherenith to verify them. ipermogones are more frequent; they are minute, blackish with spermatia about $5-7 \mu$ long, $1 \mu$ thich.

Hab. On rocks, boulders, and trunks of trees, chiefly in maritime and mountainous districts. - Distr. General and not uncommon in the Southern and Western districts of the British Isles.-B. $M$. .Tersey; Guernsey; Penzance and near Withiel, Cornwall ; Okehamptrm, Iustleigh Cleeve, Dartmoor, Lynton and Bolt Head, Devon; New Forest and Bournemouth, Hants; near Dolgelly, Aberdorey, :nd Bimouth, Merioneth; Llanberis and Beddgelert, Carmarron- hire; Jeaumaris, Anglesea; Asby, Cumberland; Inverary and Bar"aldine, Argyll ; Trossachs, Perthshire; Ben Nevis, Invernessshire ; (ilen Ach-na-Shilloch, Rossshire; Gougaumbara, Cork; Killarney. Kerry; Connemara, Galway; Achill Island, Mayo.

Var. dissecta Olis. Lich. d'Eur. i. p. 189 (1907).-Thallus yellowish, small, deeply dissected and isidiiferous; beneath with -hort rhizinat: (medulla $\mathrm{K}(\mathrm{CaCl})+$ red). Apothecia unknown.-Parmelia Aisserta Nyl. in Flora lxv. P. 451 (1SS2); Cromb) in Grevillea xr. p. 75 (1887) \& Monogr. i. p. 247.

liecorderl by Nylander as a saxicolous lichen rate in Treland. A

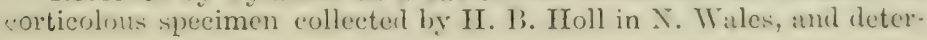


mined by Chombie as $l$ '. Aissecta, has an orbicular thallus of sinnous narrow pinnatifid lobes, like a very fine $I^{\prime}$. sinuosa. Here and there isidia are developed on the surface.

Hab. On rocks or trunks of trees.-B. M. Cwm Bychan, Nerioneth.

25. P. revoluta Florke Deutsch. Lich. i. p: 11 (1815).Thallus orbicular, moderate in size (usually $2-3$ inches across), smooth, narowly sinuate-lobate or liciniate, glaucous-white of whitish, the lobes slightly hooded-revolute and sometimes with turgid soralia at the tips, the sorecliate area spreading over the lobes; beneath blackish, rhivinose up to the brownish margin, but often becoming naked ( $\mathrm{K} \pm$ min. $\mathrm{CaCl}$ ₹redclish). A pothecia rather small, brownish-red, the margin entire or crenate; spores 6-8 in the ascus, 11-19 $\mu$ long, 7-12 $\mu$ thick.-Cromb. in Grevillea xv. p. $75(1887)$. $P$. tiliacea vars. revoluta and sublievigatre Leight. Lich. Fl. p. 132 (1871); var. sublavigata ed :i. p. 122 (1879) (? Nyl.). I'. lievigutre vars. revolute and sulsimuson Leight. op. cit. ed. 3, p. 129.

Exsicc. Johns. n. 186 ; Larb. Lich. Hib. n. 293 ; Leight. 11. 202 (as P. Fosteri Borr), n. :ist (as P. ruyguse Tayl.); Mudrl n. 68 .

A smaller plant than l'. Jartigntr. which it resembles in the sinnous branching and rounded axils, lut is distinguished by the slightly revolute tips of the lobes.

$H a b$. On rocks and trees among mosses in maritime and mountainous districts. - Distr. (reneral, but not (ommon in S. $\mathrm{W}$. and $\mathrm{N}$. Fingland, rare in the ('hannel Islands. S. Seotland and TV. Highlands. and W. Irelund.-13. M. Jat ('oupe, Jersey: St. Breock, Withiel and P'enzance, ('ornwall: Ilsham, E'llacombe, Dartmoor and I, ynton. Jeron; I. of Wight: near Lyndhurst and liournemouth, IIants: St. I.eonard's Forest, Jirilge liocks amd Ardingly, Sussex: Carder. Idris, near Bamouth, near Dolgelly and Aberiovey, Merioneth ; Anglesea; liedale, Yorkshire; near liendal, Nestmorelund; New

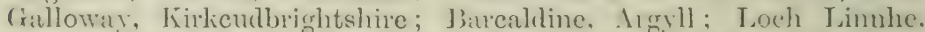
Invemesshire; ('istlebermard P'ark, lamblon, ('uk; Killarney. Kerry: Letterfrack, Connemara, Galwar.

Var. rugosa Cromb. in Grevillea xr. p. 75 (1887) (incl. f. jumniformis). -Thallus more expanded, the lobes hroater, often bulging at the centre and rugose en tuluereulate-rusose. A pothecial

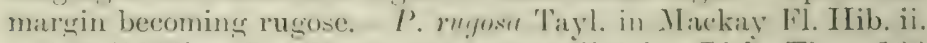
p. 145 (1836). P. tilincen var. mugosa Leight. Lich. Fl. p. 13:3 (1871). P. laveigutre var, mugose Leight. op. cit. ed. 3, p. 128 (1879).

'The lobes are more crowded in the centre and somewhat less revolute at the tips. and soredia are less frequently developer than in the species. Form jumnigurmis is cromsled with short lobes, evident? an growth condition.

Hab. On rocks, boulders, railings, ete, in maritime and inland districts.-Jistr. Less frequent but mostly coextensive with the

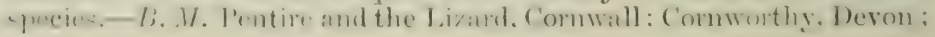


Bramber, Sussex; Bummonth, Dolselly :mel Abertorey, Merioncth: Llanberis, Carnarvonshire; Barcaldine, Argyll.

Var. concentrica Cromb. in Grevillea xr. p. 75 (1887). An erratic globular form, the lobes growing in concentric layers. Apothecia not seen.-P. suratilis var. monentricr Leight. in Exsicc. n. 232 (1856), ef. Berk. in Gard. Chron. 1856, pp. 84 \& 172. $P$. simosa var. erratica Linds. in Trans. R. Soc. Edin. xxii. 1, p. 218 (1859); var. conentricu Mudd Man. p. 96 (1861). P. læevigata var. concentrica Cromb. Lich. Brit. p. 33 (1870). P. tiliacea var. concentrica Leight. Lich. Fl. p. 132 (1871); ed. 3, p. 122.

Exsicc. Leight. n. 232.

This curious variety has been collecter in two different localities. It was first found unittached on the downs of Melbury Hill. Crombie points out that there is no reason to suppose the lichen was at first free, but it had become detached and subsequently globular in form (Journ. Bot. x. 1) 307 (1872)), an observation confirmed by Paulson and Somerville Hastings (Knowledge xxxrii. p. 319 (1914) ).

Hab. On upland downs.-B. M. Melbury Hill near Shaftesbury, Dorset; downs near Seaford, Sussex.

26. P. endochlora Leight. Tich. Fl. 1) 140 (1\&il). - Thallus horizontal, moderate in size, sinuate-lobate rather of it thin texture, the lobes imbricate, blunt at the ends sometimes with turgid soralia, whitish or glaucous-white ; medulla sulphur-yellow : beneath black, rbizinose up to the edge ( $K+$ yellow). Apothecia moderate in size or large, brownish-red, the amphithecium verrucose, margin incurved, verrucose-crenate; spores $6-x$ in the ascus, 16-19 $\mu$ long, $8-11 \mu$ thick. - Leight. op. cit. ed. 3, p. 130. P. Mc Millanu Stirton in Grevillea iii. p. $7 !(1 \times 74)$. P. renthomyel Nyl. in Flora lvii. p. 306 (1sit): Cromh. in Journ. Bot. xii. p. 360 (1876) \& Monogr. i. p. 236.

Altogether a slightly smaller plant than $P$. lavigata, and distinguished by the yellow medulla ; the soredlia become dark-colomred with age.

Hab. On rocks and boulder's in shady mosslind distriet..... I)istr. J weal and scarce in X. Wales, Scottish Highlands and W. Irelinnd.B. MT. Dolgelly, Merioneth; Barealdine, Iplpin, and (ilen ('roe. Argyll; Askew Wood, Dunkerron, Terry; Kylemore, commemanta. Galway.

\section{b. Thallus greenish-yellow.}

27. P. conspersa Ach. Meth. Lich. 1) -205 (1803).- Thallu. orbicular, spreadling widely, appressed, laciniate-lohate, somewhat smooth and shining, the lobes plane, sinuiste, remate. yreenish-straw-roloured ; heneath brown, with short black rhizina mostly up to the edge ( $\mathrm{K}$ +yellow, then $\mathrm{red}, \mathrm{CaCl}$ ). Aputheciar generally central and numerous, dark-brown, with an mitire. inflexed margin : spores $\$-12 \mu$ long, $5-8 \mu$ thick. \&. P. lirily 
Nat. Arr. i. p. 44:; Hook. Fl. Scot. ii. p. 5is in Sm. Engl. Fl. v. p. 199 ; Tayl. in Mackay Fl. Hib. ii. p. 143 ; Mudd Man. p. 102 ; Cromb. Lich. Brit. p. 34 ; Leight. Lich. Fl. p. 134: ed. 3, p. 124. Lichenoides imbricatum riridans, scrutellis badiis Dill. Hist. Muse. p. 180 , t. 24, fig. 75 a (1741). Lichen centrifurges Huds. Fl. Angl. p. 445 (1762) (non Linn.); Lightf. Fl. Scot. ii. p. 814; With. Arr. ed. 3, iv. p. 32 pro parte. L. con*persus Ehrh. ex Ach. Lich. Suec. Prodr. p. 118 (1798); Engl. Bot. t. 2097.

Exsicc. Cromb. n. 26 ; Jolıns. n. 303 ; Larb. Crsar. n. 65 ; Leight. n. 78 .

The thallus is normally orbicular, but it may spead extensively and become more irregular in outline. Towards the centre the lobes are frequently more dirided and somewhat convex, and tend to become isidiose. The spermogones are black and irregularly scattered, with spermatia $5-6 \mu$ long, and $1 \mu$ thick.

Hab. On the trunks of old trees or palings, and on boulders.Distr. General and common throughout the British Isles, especially in mountainous districts.-B. M. Jersey; Sark; near Penzance and Helminton, Cornwall; Dartmoor, Iry Bridge and Temple Noor, Devon; Westerham, Kent; IIalvern Hills, Worcestershire; Charnwood Forest, Leicestershire; near Oswestry, Shropshire; Llanbedr, Barmouth, and Cader Idris, Merioneth ; Beddgelert and Bangor, Carnarronshire; Llandysssil, Cardiganshire; Benumaris, Anglesea; Teesdale, Durham; near Kendal, Westmoreland; New Gallowar, Tirkcudbrightshire; near Moffat, Dumfriesshire; Ayrshire; lî̀ng's Park, Stirling; Inverary, Criman Canal and Appin, Argyll; Loch Ard, Ben Lawers and Aberfeldr, Perthshire; Glen Cluny, Braemar, Aberdeenshire; Applecross, Rossshire; Dunkerron, Rerry; Louisburgh, Mayo.

Form isidiata Leight. Lich. Fl. p. 135 (1871).-Thallus wered with densely crowded isidia except towards the circumference.-Leight. Lich. Fl. ed. 3, p. 125. Tichenoides isc. Dill. 1. c. fig. 75 B. Imbricaria conspersa f. isidiata Anzi Catal. Lich. Sondr. p. 28 (1860).

Firirc. Bohl. n. 110 : Johns. n. 221 ; Leight. 11.79 pro parte.

1)iffers ehiefly in the densely isidioid thatlus, the lobes being often scarcely distinguishable. It is usually sterile.

IIal. On rocks and bonlders in mpland regions.-Distr. Rather rave in S. W., W. and N. Fingland, Wales, and S. Scotland aud N.W. Jreland, more frequent in the s. and W. Highlands, - B. . W. Withiel. lioscorea, and near Penzance, Cornwall ; Dartmoor, 1)evon ; Maresfield. Sinsex; Herefordshire Jencon. Mralrern, Woreestershire; Bardon Hill, Leicestershire; Coed Coch, Denbighshire; near Dolgelly and liamouth, Merioneth; Snowdon, Carnarvonshire: near liendal, Westmoreland: New (iallowity, hirkeudbrightshire: King's Park. Stirling; Aphin, Aryll ; near Aberfeldy, hen Lawers and hamoch. J'rethshire; near Cortachy, Forfarshire; ('rathes, Aberdeenshire.

Var. stenophylla Ach. Meth. Lich. 1. 206 (180:3).-Thallus lobes narrower, more divided, erowderl and imbricate. Apothecia

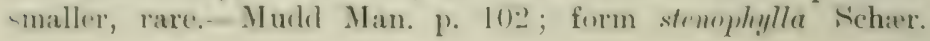


Enum. Lich. 1) 46 (1850); Cromb. Lich. Brit. p. 34: Leight. Lich. Fl. p. 135 ; ed. 3 , p. 124.

Exsicc. Johns. n. 121; Leight. 1n. 79 pro parte.

Distinguished by the form of the lacinie, which are also oceasionally crowded and panniform. The thallus is normally smooth, but sometimes isidiiferous.

Hab. On boulders and old walls in upland districts.-Distr. Rare in S., Central and W. England, N. Wales, S.W. Highlands and S. Grampians, Scotland, rare in S.W. and TV. Ireland.-B. M. Near' Penzance, Cornwall; Bardon Hill, Leicestershire; near Oswestry, Shropshire; Rhewgreidden, Llanbedr, Barmouth and Dolgelly, Merioneth; near Kendal, Westmoreland; Wastdale, Cumberland; Inverary and Appin, Argyll; Ben Lawers, Perthshire; Dunkerron, Kerry; Corraun Mit., Mayo.

28. P. sinuosa Ach. Syn. Lich. p. 207 (1814).-Thallus suborbicular, rather small, laciniate-lobed, widely sinuate, smonth, the lobes narrow, pinnatifid, dilated and often sorediate at the apices, yellowish-green; beneath blackish and densely rhizinose, usually to the edge, sometimes lighter in colour and bare at the tips $\left(\mathrm{Kf}\right.$ + yellow, then reel, $\mathrm{CaCl}_{-}^{-}$). A pothecia central, rare, moderate in size or small, reddish-brown, the margin thin, entire; spores 11-20 $\mu$ long, 8-12 $\mu$ thick. -S. F. Gray Nat. Arr. i. p. 442; Hook. Fl. Scot. ii. p. 54 \& in Sm. Engl. Fl. v. p. 203 ; Tayl. in Mackay Fl. Hib. ii. p. 149 ; Mudd Man. p. 95 pro parte; Cromb. Lich. Brit. p. 33 ; Leight. Lich. Fl. p. 136 ; ed. 3, p. 125. Lichen sinuosus Sm. Engl. Bot. t. 2050 (1809).

Exsice. Larb. Lich. Hb. n. 8.

Somewhat resembling $P$. Tavigata in the sinuous branching, but differing in the narrower lobes and the colour of the thallus, and in the thalline reaction.

$H a b$. On trunks of trees and on boulders in maritime and upland districts.-Distr. Rather rare in the Channel Islands, S. and IV. England, S. and W. Scotlaud, and S. and TV. Ireland.-B. M. Guernsey; Ullacombe, Devon; Barmouth, Ty Gwn, near Dolgelly, Merioneth; Anglesea; Brodrick Castle, Arran; Appin, Argyll; Glen Nevis, Invernessshire; Applecross, Rossshire; near Macroom, Cork ; Cromaglown and Dunkerron, Kerry ; Connemara, Galway.

29. P. multifida A. L. Sm.-Thallus orbicular or irregularly spreading, narrowly laciniate, greenish-straw-coloured or paleochraceous, sometimes dark-greenish-brown towards the centre and sometimes with large tuberculose sulphur-coloured sotalia, the lobes narrow, convex, rather gnarled, incurved at the apices; beneath dark-coloured with short crowderl black rhizinie ( $\mathrm{K}_{-}^{-}, \mathrm{CaCl}_{-}^{-}$). Apothecia small, reddish-brown, the margin subentire; spores 8-1 $2 \mu$ long, 5-6 $\mu$ thick. $P$. recurvu Ach. Meth. Lich. 1. 201 (1803); S. 1T. Graly Nat. Arr. i. p. 4.2; Hook. Fl. Scot. ii. p. 54. P. incurva Fr. Nov. Sched. Crit. p. 31 (1826) ; Hook. in Sim. Lingl. Fil. r. p. 202; Tayl. in Mackay 
Fl. Hil, ii. 1) 149: Mudrl Man. p. 10:; Cromb. Lich. Brit. p. 34 \& Monogr. i. p. 249 ; Leight. Lich. Fl. p. 140 ; ed. 3, 1. 129. Lichen imultifidms l)icks. Pl. Crypt. fasc. iii. p. 16, t. ?) fig. 7 (1793). With. Arr. ed. 3, iv. p. 28. L. incurvus Pers. in Ust. Ann. Bot. vii. p. 24 (179t).

Distinguished from allied speeies in the incurverl apices of the lobes, and grenerally in the guarled and twisted aspect of the whole plant. Apothecia are rare, but spermogones are frequent, with spermatia 5-7 $\mu$ long, $1 \mu$ thick.

$\mathrm{Hab}$. On granite rocks and boulders in subalpine and alpine plices.-1)istr. Local and rate in S.T. Treland and S. Scotland, more frequent among the Grampians.-D. . M. New Galloway, Kirkoudbrightshire; ('rier Coinmoch, Ben-naboord. Morrone and Upuer Crlen Dee, Braemar, Aberteenshire.

\section{c. Thallus dark-green, olivaceous or brown.}

30. P. acetabulum Duh. Bot. Gall. ii. p. 601 (1830).-Thallus orbicular, coriaceous-membranaceous, smooth or wrinkled, iobate, dark-green or dull-olivacenus, the lobes imbricate, rounded, ippressed at the circumference, ascending, erumpled or undulating in the centre; beneath pale-brown, sparingly rhizinose $\left(\mathrm{K}_{+}^{-}\right.$sellowish, then res, $\left.\mathrm{CaCl}_{-}^{-}\right)$. Apothecia becoming rather large, lorownish-red, the margin crenulate, inflexed; spores $12-16 \mu$ Jong, 8-10 $\mu$ thick.-Mudel Man. p. 99; Cromb. Lich. Brit. p. 35 ; Leight. Lich. Fl. p. 136 ; ed. 3 , p. 125 . P. corrugata Ach. Meth. Lich. p. $215(1 \times 03)$ : S. F. Gray Nat. Arr. i. p. 438:

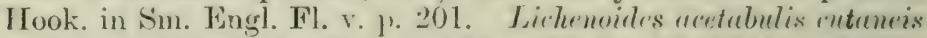
"t ruyposis I)ill. Hist. Muse. p. 185, t. 24, fig. 7!9 (17+1). Lichen "cetribulum Neck. Delic. (iallo-Belg. p. 506 (176s). L. corrugutus: Sm. in Trans. Linn. Soc. i. p. 83, 1791 \& Engl. Bot. t. 1652.

Exsice. Cromb. n. 142 ; Leight. n. 362.

Distinguished by the dull dark green or brown colour of the corrugate thallus. Apothecia are rather rare; spermogones are abundant, with spermatia about $7 \mu$ long, $1 \mu$ thick.

ITab. On the trunks of old trees in woods and partis in lowland districts.-Disfr. Not gencral nor common throughout Fngland. rare in Seotland, not seen from [welind. 13. Mr. Okelsamptom, Devon:

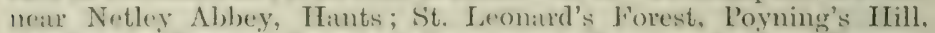
Hayward's Heath, Jiamber ('istle amd Beceding l'riory. Sussex; Matdstone and Broome l'ark, lient: neat ('helusford and Epping lorest, Essex: Somerford hiryne, Wiltshire: near ("irenoester and I'airford, Gloueretershire; near the Ketch, Worcestershire; Remblam and near liury, Suflolk; Harboro' Marna. Warwickshire; near Buckinghan: Nesseliff. Sluopuhire: Ayton and Stokesley. Cleveland, Yorkshire; Auldbar, liorfarshire.

:il. P. olivacea A(h. M(+1h. H. 213 (1S(1;)). Thallus orbicular, appresieal, lobate, wrinkled, olive or derp umber-brown, the lobes plane romberl and crenate: lumeath dark-brown, sparingly 
rhizinose ( $\mathbf{K}$. C $\mathbf{C}^{\prime} \mathrm{C}_{-}$). Apothecia moderate in size, darknmber-brown, the margin entire or subentire: spores $11-19 \mu$ long, 7-10 $\mu$ thick.-Cromb. Lich. Brit. p. 35 pro parte d in Grevillea x. p. 24: Leight. Lich. Fl. p. 122 pro parte; ed. ;3, p. 114 pro parte. Lirhensides olirucerm, sentellis lavilues. Dill. Hist. Musc. p. 182, t. 24, fig. 77 a (1741). Lichen olivacous L. Sp. Pl. p. 1143 (1753).

A northern species found in the British Isles only in N. Scotland. Lichen olivaceus and Parmelia olivacea of earlier British authors refer to other specie's. It may be realily recognized by the wrinkled thallus.

Hab. On the trunks of trees, birch and alder, in wooded upland districts.-Distr. Local and rate in the $\mathrm{N}$. Grampians. Scotland.B. M. Banks of the Cluny, Braemar, Aberdeenshire.

:).2. P. exasperata Carroll in Journ. Bot. iii. 1\% 28: (186.5).

'Thallus orbicular or sprearling irregularly, closely appressed, lobate, more or less thickly sprinkled with minute roundish papilla with an opening abore (breathing pores), olive-brown, the lobes variable, generally obliteriated towirds the centre, sometimes pinnatifid, rounder and crenate at the circumference; beneath somewhat paler and rhizinose to the edge $\left(\mathrm{K}_{-}^{-}, \mathrm{CaCl}_{-}^{-}\right)$. Apothecia generally moderate in size, or rather large, ul, to nearly 1 cm. across, brownish-red, the margin raised, and generally thickly papillose with breathing pores: spores 9-1:2 $\mu \operatorname{long}, 7$ -

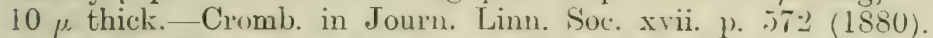
P. olivacee S. F. (Tray Nat. Arr. i. p. 438 (1821) (non Ach.): Hook. Fl. Scot. ii. p. 5.2 it in Nm. Engl. Fl. v. 1). 200: Tayl. in Mackay Fl. Hib. ii. 1. 14:3: Mudd Man. p. 99 pro parte; subsp. rasperata Nyl. Syn. Lich. i. p. 396 (1\$60) : Cromb. Lich. Brit. p. 35); var. exasperatu Leight. Lich. Fl. 1) 1.33 (1871): ed. 3, p. 115. Lichenoide's rmsta foliosa seutrllata, mellum Dill. in Ray Syn. ed. 3, 1). 72, 11.60 (1724). Lirhenoides olivarem, scutellis amplioribus vermesis Dill. Hist. Musc. P. 18t, t. 24, fig. 78 (17+1). Lichen olieacens Huds. Fl. Angl. p. 446 (1762) (non L.); Lightf. Fl. Scot. ii. p. $\$ 19$ pro larte; With. Arr.

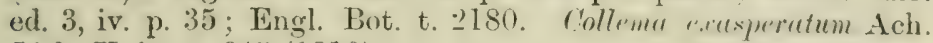
Lich. Univ. p. 645 (1810).

Exsicc. Larb. Lich. Hb. n. 327 ; Leight. 110s. 263, 356 ; Nudd n. 72 .

liesembles 1 . fuliginosa var. latevivens in colour and habit. but is well distinguished by the constantly papillose thallus - not isidiose. and in the absence of thalline reactions. 'T'he spermogones are immersed in the thallus, towards the circumference of the thalline:

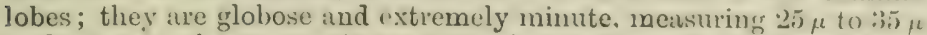
in diameter : the spermatia are someryat fusiform, $8-10 \%$ lomer almut $1 \mu$ thick.

Hul). (On the trumks of old trees in maritime and upland distriets. - Distr. (iencral and common in the $S$. and WV. eomnties of (ire:te 
Britain and Ireland.--D. M. Withiel, Cornwall ; New Forest, Hants ; Danny and Tilgate, Sussex; Gad's Hill, Kent; Cricklade, Wiltshire; Pembridge, Herefordshire; Crowle, Worcestershire; near Dolgelly, Merioneth; Island of Anglesea ; Ayton, Cleveland, Yorkshire; Eggle. stone, Durham; near Kendal, Westmoreland; New Galloway, Kirkcudbrightshire; Largs, Arrshire; Pentland Hills, near Edinburgh; Appin, Argyll: Gleu Calliach and Glen Lochay, Perthshire; S. of Fort William, Inrernessshire; Kilrarock, Nairnshire; Applecross. Rossshire; Glencar and Mangerton, Kerry; Killery Bay, Connemara. Galway.

33. P. omphalodes Ach. Meth. p. $20 t$ (1803).-Thallus orbicular, sometimes widely spreading, rather smooth and shining, laciniate-lobate, the lobes generally narrow, crowded variously subtruncate or retuse at the apices, dark-brown to purplishblack, often with whitish dotted reticulations; beneath densely black-rhizinose $(\mathrm{K}+$ sellowish, then red, $\mathrm{CaCl}-)$. Apothecia often numerous, moderate in size or large, up to about $2 \mathrm{~cm}$. across. dark reddish-brown, the amphithecium and margin thin and light-coloured; spores $12-16 \mu$ long, $6-7 \mu$ thick.-S. F. Gray Yat. Arr. i. p. 440 ; Hook. Fl. Scot. ii. p. 53 \& in Sm. Engl. Fl. ৩. p. 199; Tayl. in Mackay Fl. Hib. ii. p. 145; f. cresio pruinosa Nyl. ex Stiz. in St. Gall Nat. Ges. 1876, p. 206 ; Cromb. in Journ. Bot. lxv. p. 272 (1882) \& Monogr. i. p. 214. P. sacatilis var. omplualodes Fr. Lich. Eur. p. 62 (1831); Mudd Man. p. 95 ; Cromb. Lich. Brit. p. 34 ; Leight. Lich. Fl. p. 138: ed. 3, p. 127 ; var. lævis Nyl. Syn. Lich. i. p. 389 (1860). Subsp. omplatodes f. cæsio-pminnsa Nyl. ex Norrl. in Not. Siillsk. Faun. \& Fl. Fenn. Förh. xiii. p. 324 (1873). P. sulcata var. lævis Cromb. in Journ. Bot. Iviii. p. 140 (1875) \& Monogr. i. p. 242. Lichenoides sacatile tinctorim, foliis pilosis yurpureis: Dill. in Ray Syn. ed. 3, p. 74, n. $70(1724)$ \& Hist. Musc. p. 185. t. 24, fig. 80 (1741). Lichen ompluelodes L. Sp. Pl. p. 114:3 (1753); Huds. Fl. Angl. p. 446 ; Lightf. Fl. Seot. ii. p. 818: With. Arr. ed. 3, iv. p. 34 ; Engl. Bot. t. 604.

Exsicc. Bohl. n. 18 ; Croall nos. 389, 390 ; Dicks. Hort. Sicc. fase. xvii. n. 22; Johns. n. 188 ; Larb. Cassar. n. 19; Leight. n. 7 ; Mudd n. 67 .

Closely allied to $I^{\prime}$. ser.xatilis, of which along with $I$ '. suleata it is frecuently classified as a variety. It differs in the more shining generally muel darker thallus, less marked reticulations, and in the entire absence of soredia or isidia. P. sulcata var. lavis is similar. but somewhat lighter in colom. Occasionally the thallus is bluishwhite as if puinose (f. casiopruinosu). It often spreads extensively. covering large boulders. Spermogones are not uncommon.

Hal). ()n rocks, boulders, ete., in maritime, upland and alpine regions.-I)istr. Wirtely distributed and common throughout the. british Isles, especially in hilly regions.-D. I/. (inernsey; Alemey; frevey; neatr l'enzatnee, Camelford, T'emple Moor, and Helminton. ('ornwall; J,ynton, Dartumor, Hay 'lor and Lustleigh ('leeve. bevon; Matrem IFills, Worecstershire; Bamonth, lihewgreidden. 
:mel Carler Idris, Merioneth ; Conway MIt.. Cwm Idwal, and Llanberis, (imarvonshire; Holyheal and Anglesea; near Mralloch. Derby; Cleveland, Forkshire; near Egglestone and Teesdale, Durham; Fentmore. Westmoreland; C'umberland; Cheriots, Northumberland; Moffat, Dumfriesshire; New Galloway, Kirkeudbrightshire; Dalmahoy ('rags near Edinburgh; Appin. Argyll; Killin, Ben Laners, Ben Chroin, the Trossachs. Ramnoch, Abernethy and near Dumkeld. Perthshire; Canlochan and Clova. Forfarshire; Durris, Kincurdineshire; near Invercauld, Morrone. Glen Dee, Braemar, near Aviemore and Jien Nevis. Invernessshire; Applecross. Rossshire; Dunkeron and Caher, Kerry; Corraun and Achill Island, Mayo.

Var. panniformis Ach. Meth. p. 204 pro parte. -Thallus mure or less spreading, divided into narrow laciniæe which are crowdedly imbricate. Apothecia as in the sprecies.-Cromb. in (irevillea Xv. p. 75 (18Ti) incl. ff. glomulifere and subconcentrice w Monogr. i. p. 244. P. suxutilis var. panniformis Cromb. Lich. Brit. p. 34 (1870); Leight. Lich. Fl. ed. 3, p. 128; var. cmeplealorles ff. subconcentrien and glumulifera Cromb. in Journ. Bot, x. p. 307 (187:-) ; form glomulifur Leight. Lich. Fl. ed. 3, p. $126(1879)$.

Exsicc. Johns. 11. 189.

A densely imbricate form; very rarely the lobes crowd over each i) ther in many lavers (f. subconcentrica). On specimens from Cwu Iiwal, Carmarronshire, and Morrone, Aberdeenshire, there are galllike formations of upright massed isidioid outgrowths (f. glomulifira). some rare growth condition rather than a true form.

Hab. On rocks and boulders in upland and subalpine regions.J istr. Somewhat rare, though plentiful where it occurs in S.TV. and N.W. England. N. Wales. S. Scotland, on the Grampians and in WT. Ireland.-B. M. Tear Penzance and Helminton, Cornwall ; Hay. 'Tor, Dartmoor and Didsworthy, Deron; Stiperstones Hill, Shrop-hire; Llyn Gwrionydd, Merioneth; Cwm Idwal, Carnarvonshire; Cumberland; New Galloway, Kirkeudbrightshire; Ben Cruachan. Argyll; Ben More and Ben Lawers, Perthshire; Morrone, Braemar and Ben-naboord, Aberdeenshire; Ben Neris, Inreruesshire; Corraun MI. and Achill Sound, Mayo.

:34. P. prolixa Carroll in Journ. Bot. iii. p. 2xs (186j).-Thallus suborbicular, appressed, narrowly lobate, the lobes imbricate, crowded, convex and wrinkled, crenate, scarcely. dilated at the apices, very dark-olive or blackish-umber, somewhat shining; beneath blackish, sparingly rhizinose all "ser $\left(\mathrm{K}_{-}^{-}, \mathrm{CaCl}_{-}\right)$. Apothecia small or moderate in size. eroloured like the thallus with an entire or subentire margin: spores 9-12 $\mu$ long, $5-(j \mu$ thick.-Crumb. in Grevillea x. p. 2.5 (18s1). P. dendritica Pers. in Ann. Wetter. Ges. ii. p. 16

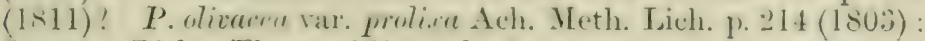
Leight. Lich. Fl. p. 122; ed. 3, p. 115; var. dendritica Leight. 1. c.

Exsicc. Leight. 11. 365 (as $P$. stygia). 
Distinguished from $P$. olivacea by the narrower lobes, the dark coloux, and by the habitat.

Hab. On rocks in maritime and upland districts.-Distr. Rarre in WV. England and Wales, in S. Scotlaud aud the N. Grampians, and in W. Ireland.-B. M. Malvern Hills, Woreestershire; Caer Camadoc. Shropshire; Llandegley Rochis, Rathnorshire; Notl-y-grolfa, Montsomeryshire; Douglas Head, Isle of Man; Nex Galluwat, Firk"udbrightshive; Port Lethen, Tïncarlineshire; Critigr (inie, Jirannar. Aberdeenshire.

Subsp. Delisei Nyl. in Bull. Soc. Linn. Norm. sér. 2, vi. 1. 303 (187\%). - Thallus larger, and paler in colour, light-brown, the lobes broader at the circumference $(\mathrm{K}(\mathrm{CaCl} \mp \mathrm{f}$. reddish $)$ ).

Cromb. in Journ. Bot. xi. p. 133 (1873) it in Grevillen x. p. :-). P. olivace var. Detisei Dub. Bot. Gall. p. 602 (1830); var. aquilordes Linds. in Trans. Roy. Soc. Edin. xxii. p. 236 (18.5) : Mudd Man. p. 99. P. Delisei Leight. Lich. Fl. ed. 3, p. 1:? (1879).

Exsicc. Bohl. n. 109 pro parte; Larb. Lich. Hb. n. 328 ; Leight. n. 291 pro parte.

To this subspecies refer also the citations Lichen olivaceus pro parte and Parmelia olivacea pro parte of various British authors alreary. quoter. In old plants the apothecia are rather larger and crowded.

$H a b$. On rocks and boulders in maritime and upland districts.Distr. Local in the Channel Islands, s. and W. England, N. Wales, Central Scotland and S. Ireland.-B. M. Rozel and La Moye, Jersey; Jerbourg, Guernsey; Helminton and near Penzance, Cornmall; Wembury, Devon; Shanklin, I. of Wight; Barmouth, Merioneth; Anglesea ; Douglas, I. of Man; near Kiendal. Testmoreland; Ioch Creran. Argyll; King's Park, Stirling; Mizzen Head, Cork.

Var. isidiascens Nyl. ex Cromb. in (irevillea x. p. 25 (18:1). -Thallus more or less sprinkled with conglomerate stoutish concolorous wart-like isirlia, which become sometimes whitisll-

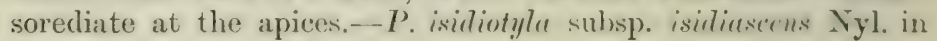
Flora lviii. p. 8 (1875).

Eisice. Bohl. n. 109) pro parte ; Leight. n. 291 pro parte.

Evidently a distinct variety, as the subspecies is entirely snooth. The isilia are generally more cromed towarls the centre of the thallus.

Hab. The same as the subspecies.-Distr. Local and searce in the ('hannel Islamds, S. Fingland. S. Wales and C'entral sicotland.1). M. Island of Sirk; the Lizard, lioche liocks, near Penzance and Helninton, ('ornwall; ne:ar l'lymouth, levon ; lifield, WVilts; Batlmouth, Merioneth; Anglesen; Kingr's l'ark, Stirling; Iongh I lan, Wicklow.

35. P. fuliginosa Nyl. in Flora li. 1. 346 (1sis). Thallus. orlicular or spreading irregularly, membranaceous, appressed, Inbate, errenish or hlatkish-brown, crowded with rather elongate eylindrial or irregularly formed brownish-black isiclia, the lobes when bare smenth, shinine, mather plane and crenate : beneath 
blackish, rhizinose to the margin $\left(\mathrm{K}_{-}^{-}, \mathrm{CaCl}_{\mp}^{-}\right.$rell $)$. Apothecia small or moderate in size, scattererl, rather dark-coloured, with a thickish, slightly crenulate margin; spores 9-12 $\mu$ long, $5-6 \mu$ thick.-Cromb. Lich. Brit. p. 36 ; Leight. Lich. Fl. 1). 13t; ed. 3, p. 123. P. olivacra F1. in Duby Bot. Gall. p. 602 (1830); f. furfuracea Scher. Enum. Lich. p. 47 (1850); var. furfuracea Mudd Man. p. 100 (1861). Lichenoides olivaceum, sutellis lrvibus Dill. Hist. Musc. p. 182, fig. 77, B (1741).

Exsicc. Croall n. 591 ; Johns. n. 122.

Characterized among brown Purmelia by the chemical reaction and by the dense covering of almost black isidia, sometimes only isolated lobes being visible. The apothecia and spermogrones are rare, especially on saxicolous specimens.

$H a b$. Chiefly on rocks and stones, also on old palings and on trees, in maritime and upland districts.-Distr. General though not common throughont the British Isles.-B. M. La Move, Jerser; Penzance and near. St. ]3reock, Con 11wall; Runnrmend, Surrey; North Hill and Herefordshire Jeacon. Malvern, Worcestershire: Hatughmond Hill and Stiperstones, Shropshive; Hafod-Morfa and Borthwynom near Dolgelly and Phew-greidlen, Merioneth; Trefriw aud Bettws-yCoed, Carnarronshire ; near Ayton, Cleveland. Yorkshire; near Kendal, Westmoreland. Cumberland; New Galloway, Fircudbrightshire; Head of Loch Awe, Argrll ; Glen Lochar, Falls of Tummel and Blair Athole, Perthshire; Glen Shee, Forfarshire; Portlethen and Durris, Fincardineshire; Hill of Ardo and Castleton of Braematr. Aberdeenshire; S. of Fort William, Invernessshire; near Abernethy, Elgin; Darros River, near Kylemore, Connemara, Galmay ; Clare Island and Achill Island, Mayo.

Var. Iætevirens Nyl. in Bull. Soc. Linn. Norm. sér. 2, vi. p. $272(1872)$. - Thallus orbicular or spreading, lohes large and colour lighter than in the species, with generally fewer, lightercoloured isidia (medulla CaCl + red, fugitive). Apothecia similar to the species.-Cromb. in Grevillea x. p. 28 (1881). Form olivace Leight. Lich. Fl. ed. 3, p. 123 (1879). P. Borreri f. olivacen Leight. Lich. Fl. ed. "2, p. 479 (1871). Imbricaria olivucen var. lixtevirens Flot. in Uebers. Schles. Ges. Breslau, 1850 , p. 131 (1851).

Exsicc. Bohl. n. 86 ; Johns. nos. 248, 249.

Though lighter in colour and largely different in habitat there are transition forms between this and the species. In some species the isidia are crowded and dark coloured, in others they are very sparingly formed (f. demulata Cromb, in Grevillea x. 1). 71 (1857)). Frequently the isidlia are abraded, giving the thallus a white-punetate appearance.

Hab. On old trees and palings, rarely on walls in maritime and upland districts.--Distr. Not uncommon throughout Great liritain and Ireland.-13. M. Ardingly, Sussex; North Hill, Malvern, Worcestershire; Devil's Bridge, Cardiganshire; near Dolgrelly and lihewgreidden, Irerioneth; Capel Curig and Bettws-y-Coed, ('armarvonshire; IIopton, Suffolk; near Guishoro, ('levelant, Yorkshire; Fendal and Leven's l'ark, Westmoreland; heswick. C'unberland; Appin and head of Loch Awe, Argyll ; Craig Calliateh, Loch Ard and ciles. 
Jochar, Ierthshire; Durris, Kinciudineshire; Morone. Bramar, Aberdeenshire; Cromaglown, Killarney, Ferry; Derrelare and near Fylemore. C'onnemara, Gilway : Westport and Achill Island, Mayo.

36. P. sorediata Th. Fr. Lich. Arct. 1. 56 (1860). -Thallus suborbicular, generally small, lobate, appressed, greenish- or umber-hlack, sprinkled with small, greyish-white, round soredia, the lobes narrow, contiguous, rather plane, multifid and slightly dilated at the apices; beneath rhizinose generally to the edge $\left(\mathrm{K}_{-}^{-}, \mathrm{C}_{\mathrm{ilCl}}^{-}\right.$). Apothecia very rare, subconcolorous with the thallus. concave, the margin entire; spores more or less oblong, 10-12 $\mu$ long, 5-6 $\mu$ thick.-Parmeliu stygin var. sorerliute Ach. Lich. Univ. p. 471 (1810). P. prolixa subsp. sorediata Cromb. in Journ. Bot. xx. p. 273 (1882) \& Monogr. i. p. 253.

The rescription of the apothecium is taken from Th. Fries 1. c. There are no apothecia present on the Jritish specimens. The smallness of the plant, with the flatter lobes ard the presence of soredia, distinguish it from $P$. prolixa.

Hab. On rocks in upland mountainous ristricts.-Distr. Tare in WV. England and among the Central and N. Grampians, Scotland.B. M. North Hill, Malvern ; Craig Tulloch. Blain Athole, Perthshire; Craig Guie, Braemar, Aberdeenshire.

39. CETRARIA Ach. Meth. Lich. p. 29:- (180:i). Cornicularia Schreb. Linn. Gen. Pl. ii. 1) 768 (1791); emend. Ach. Meth. Lich. p. 300 (180:i) pro parte; S. F. Gray Nat. Arr. i. p. 404 pro parte: Mudrl Man. 1).76 (1861) pro jarte. Platysma Nyl. in Mém. Sor. Sici. Nat. Cherb. v. 1\% 100 (1857) pro parte: Cromb. IIonogre i. 1). 21\%. Lrburir sect. Platisma Hoffm. Deutschl. Fl. ii. p. 138 (1795) pro parte. (Pl. 39.)

Thallus foliaceous (Platysimu), partly horizontal or ascending, or fruticose (Cetraria), with the fronds compressed, rarely cylindrical, sparingly rhizinose or attached at the hase and soon loose from the substratum, corticate on both surfaces, the cortex mostly of sunall-celled plectenchyma, the under surface shining, (oneolorous with the upper surfiues or darlier; pseudo-eyphellar present in some species. Apothecia marginal or sulmarginal, sessile or shortly stalked, round, with a thalline marchin; hypotherium light-coloured ; paraphyses simple or rarely branched, septate: asci 6 -8-spored : spores colourless, simple, very small. spermogones in marginal tuhereles or thurn-like prepilie, with pleurogronous spermatia, varying in form.

\section{A. Thallus folinceons, more or less horizontal (Platysma).}

\section{Thallus grey in colour.}

1. C. glauca Ach. Meth. Lich. p. 296 (1803).-'Whallus foliacerus, willesprealing. lobate, loosely attached, the lobes

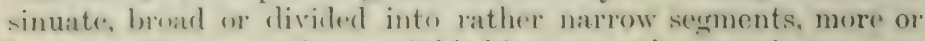
loss asemeline, smonth or wrinkled-laumose, the margins renate 
or lacerate and often sorediate, glaucous-grey or darker coloured, beneath blackish, brown at the circumference and shining, very sparingly rhizinose $(\mathrm{K} \pm$ sellwwish, $\mathrm{CaCl}-$ ). Apothecia rare, marginal, moderate or rather large, reddish-brown, the margin thin, evanescent; spores ellipsoid, 6-9 $\mu$ long, 3-5 $\mu$ thick.S. F. Gray Nat. Arr. i. p. 433 ; Hook. Fl. Scot. ii. p. 37 it in Sm. Engl. Fl. v. p. 220 ; Tayl. in Mackay Fl. Hib. ii. p. 154: Mudd Man. p. 79, t. 1, fig. 20. Lichenoinles Endivia follis crispis et splendentilus, subtus nigricantibus Dill. Hist. Musc. p. 19-2, t. 25, fig. 96 (17+1). Lichen glancus L. Sp. Pl. p. 1148 (1753); Huds. Fl. Angl. p. 453 ; Lightf. Fl. Scot. ii. p. 838 ; With. Arr. ed. 3, iv. p. 53 ; Engl. Bot. t. 1606. Platysmen glancum Nyl. in Act. Soc. Linn. Bord. sér. 3, i. p. 295; Cromb. Lich. Brit. p. 27 it MLonogr. i. p. 225 ; Leight. Lich. Fl. p. 102 ; ed. 33, p. 97 (incl. f. sorediosa).

Exsicc. Bohl. n. 79 ; Croall n. 395 ; Leight. n. 44 ; Mudd n. 54 .

Distinguished from I'armelia by the thin texture and the naked under surface of the lobes. It often forms large patches. The British plants are rarely fertile; spermogones, when present, oceur in tuberculose marginal papillie, the sterigmata are 2-4-septate and the spermatia $7 \mu$ long, $1 \mu$ wide.

When attacked by the parasitic lichen Buellia Parmeliarum (Abro. thallus) bullate swellings may be found on the lobes, a condition recorded as a distinct species by early writers;-Lichenoides saxatil. finctorium foliz latioribus non pilosis, vesirulas proferens Dill. in Ray s.rn. ed. :3, p. 74, n. 71 (1724). Lichenoides tinctorium glalume cesiculosum Dill. Hist. Musc. p. 185, t. 24, fig. 82 (1741). Lichen ampullacens L. Sp. Pl. p. 1146 (1753); Huds. Fl. Angl. p. 450; With. Arr. ed. 3, iv. p. 61. Platysma glaucum f. ampullaceum Cromb. in Joum. Linn. Soc. xvii. p. 572 (1880) \& Monogr. i. p. 227. There is no specimen in the British herbarium.

$H a b$. On trunks of trees, walls, rocks, and on the ground, more "ipecially in maritime or upland situations.-Distr. General throughwut the British Isles, more abundant in mountainous districts; not rery frequent in Ireland.-B. M. Boulay Bay, Jersey; Lamoma and ILlminton, Cornwall; Hay Tor and Lustleigh Cleeve, Dartmoor. l Bovey Tracey, Meavy and Lynton, Deron; New Forest, Hants; Tunbridge Wells, Kent; Thorndon Hall and High Beech, Epping Forest. Wssex; near Sprouston, Suffolk; Sale, Norfolk; Mralvern, Woreester. shire; near Oswestry and Wrekin Hill, S'hropshire; Barmonth, I)olgelly and Aran Marrddwy, Merioneth; Capel Curig, Cammonshire: Charnwoorl Forest and Gopsall Park, Leicestershire; near Matlock. Derbyshite; Kildale Moor, Cleveland, Iorkshire; Teesdale and (Honkley Fell, Durham; Stavely Head. Westnoreland; Ashgill. ('umberland; New Galloway, Kirkeudbrightshire; near Loeh Skene. Moffat. Dumfiesshire; Pentland Hills and swanston Wood, Misllothian; neatr Inverary and Loch (reran, Argyll ; Killin. Sien Latwert. Loch Earn and Birnim Hill, Dunkeld, Perthshire; Baldovan, liossit. Ioor and Deerhill Wood, Forfarshire; Countesswells Worr, neal. Aberdeen, (ilen ('allater and Lion's F'ace, Jhrannar, Aberdeenshire: liothiemurehus, (ilen Nevis, Loch Emnich and Invermoriston. Inver. 
nessshire; netr Forres, Elginshire; Hills of Applecross, liossshire; Loch Shin, Sutherland; Killarney, Lough Brui and Fimchey Bridge, Kerry.

Var. fallax Ach. Lich. Tnir. 1. 509 (1尺10).-Thiallus white beneath or only partially black, often fimbriate or coralloid at the margins.-Hook. Fl. Sent. ii. p. 57 is in Sm. Engl. Fl. v. p. 220 ; Mudd Man. p. s0. Lichenoides membranacenu, tuba Fullopione ammlmm Dill. Hist. Muse. p. 165, t. 22, fig. 58. Lichen fallax Web. Spicil. Fl. (ioett. p. 244 (17 אA) : Dicks. Pl. Crypt fasc. i. p. 13 ; With. Arr. ed. 3, iv. p. 53; Engl. Bot. t. 2:373. Platysma glauer f. fallar: Nyl. Syn. Lich. i. p. 314 (1sfio) : Leight. Lich. Fl. p. 103 (incl. f. roralloidea) : erl. 3, p. 98 (incl. f. coralloidea); Cromb. Monogr i. p. 226 ; var. fallax Cromb. Lich. Brit. p. 27 (1871).

Exsice. Mudd n. 55.

Distinguished by the partially white colour of the under surface aud more or less by the fimbriate margins of the lobes. Perhaps more a gromth form than a varietr, as it senerally oceurs in moist or shady conditions.

Hab. On the trunks of old trees in shady woods, rarely on moist rocks in upland districts.-Dist). Local and scurce in S. IT. and $\mathbf{N}$. Fnglani, central Scotland and S. WT. Ireland.-D. M. Helminton, Cornwall; Dartmoor, Deron; Tunbridge Wells, Fent; Garth, Dolgelly, Merioneth; Ingleby Park, Cleveland, Yorkshire; Alston, Cumberland; near Inverary, Argyll ; Glen Falloch, Glen Lochay and Finlarig, Fillin, P'erthshire; Sirllaw Hills and Deerhill Wood. Forfarshire; Glen Nevis. Invernessshire.

Var. tenuisectum A. L. Sm. - Thallus darker in colour, the lacinie short, narrow, much divicled and crowded in a panniform manner. Plutyssmu glanem f. temisertum Cromb. in Grevillea xv. p. 49 (1886) nomen; var. Irnuisectum Cromb. Monogr. i. p. 227 (1894).

1)istinguisted by the much divided lobes. ('rombie surerests that the darker colour may be due to the habitat.

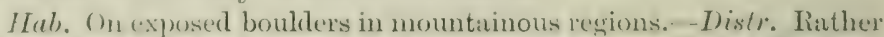
locinl, thourh not uncommon in the momtainous lewrons of Engrand

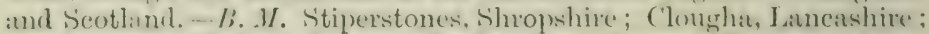
('reanlatrich and ben Tatwers, Perthshire: Thorome, lisacmar, Aberdeenshire; Glen Nevis, Invernessshire.

2. C. Lacunosa Aeh. Meth. p. 295 (1803). -Thallus broadly follitceous-lobate, reticulate-lacunose, whitish-or bluish-grey, the lobes crenate-tundulate, incised, rounded at the apices; beneath

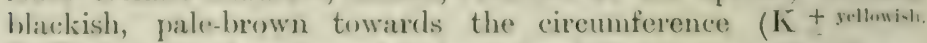
( $: \mathrm{Cl}=$ ). Apothecia prominent, moderate in size or rather large, rechlish-brown, the margin entire; spores ellipsoid, (i-8 $\mu$ long,

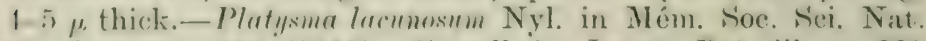
('leeb) v. P. 100 (1857); Carroll in Journ. Bot. iii. p. 288 (1<65); (Cromb. Lich. Brit. 1\%. 27; Leight. Lich. Fl. p. 10:3; ed. 3, p. 98. 
1)istinguisher from the preceding by the reticulate winkled upper. surface. Sometimes the thallus is isidiiferous, especially when growing in damp localities. On dry exposed rochs it is of a dark chestnut colour. Apothecii have not been found in this country; spermogones are similar to those of $C$. glaucum.

$H a b$. On rocks in subalpine districts.-Distr. Local among the (rampians, Scotland.-D. M. Glen Falloch, Ben Lawers and Craig Calliach, Perthshire; Craig Cluny and Morrone, Braemar, Aberteenshire; near Fort William, Invernessshire.

3. C. diffusa A. L. Sm.-Thallus orbicular, closely appressed, tinely and densely isidiose in the centre, the lobes naked at the circumference, sinuate, narrow, rounded and crenate at the apices, greyish- or brownish-white, beneath pale-brown with a few long rhizine ( $\mathrm{K}+$ deep yellow, $\mathrm{CaCl}-$ ). Apothecia marginal, rather sinall, reddish-brown, the margin crenulate and sorediate ; spores ellipsuid, (6-9 $\mu$ long, 5-6 $\mu$ thick.-Lichen diffusus Dicks. Pl. Crypt. fasc. iii. p. 17, t. 9, fig. 6 (1793) (IVeb. ?); With. Arr. ed. 3, iv. p. 32. L. aleurites Ach. Lich. Suec. Prodr. p. 117 (1798); Engl. Bot. t. 858. Parmelia wleurites Ach. Meth. Lich. p. 208 (1803); Hook. Fl. S'cot. ii. p. 54 \& in Sm. Engl. Bot. v. p. 203 ; Mudd Man. p. 98; Leight. Lich. Fl. p. 130, P. diffusa S. F. Gray Nat. Arr. i. p. 442 (1821). P. horrescens Tayl. in Mackay Fl. Hib. ii. p. 144 (1836); Cromb. in Grevillea vii. p. 98 (1879). Purmeliopsis uleurites Cromb. Lich. Brit. p. 37 (1870). Platysun diffusum Nyl. in Flora lv. p. 247 (1872); Cromb. in Journ. Bot. x. p. 234 $(1872)$ \& in Monogr. i. p. 222 ; Leight. Lich. Fl. ed. 3, p. 95.

Exsice. Dicks. Hort. Sice. fase. xi. n. 23 ; Leight. n. 47 ; IIudd n. 71 .

Not unlike Parmelia hyperopta (P.aleurites), with which it has been often confused. The lobes are frequently almost obliterated by the isidia, described by older writers as "firrinose." The apothecia are rather rare, but when present are numerous and crowded. The spermogones are marginal and prominent, with spores $\& \mu$ long and $1 \mu$ thick.

There is some uncertainty as to the identity of Weber's Lichen liffusus (Spic. Fl. Goett. p. 250), described as "firinose and blick below:" Dickson's specimen and description of $L$. diffinsus, how"Ver, give priority over $L$. aleurites Ach. for this specie's, which name' has been adopted by Wainio and some others.

$\mathrm{Hab}$. On old palings, rarely on trumks of trees or among. mosses in rocks in wooded lowland and uplind districts.-Distr. Here and Shere in Fingland, and in the Highlands of s'ontland; rare in Ireland. -B. M. Wakehurst, Ardingly, Jurton Park, Wridge Park and Imbersham, Sussex; Woolner Forest, Inants; near Windsor, lerkis; Stolie l'ark ind Sotterly P'ark, Jincks; ('roft C'istle and near ILereford, Iferefordhire; Gopsall, Le ieestershire; near Osmes'ry and Ellesnere,

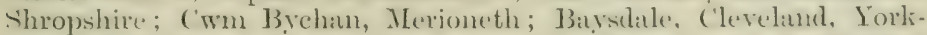
hire: Barealdine, Argril; Inverarnan and Crianlatich, P'erthshire; Glen Dee, Bratennar, Aberdeenshire; Rothiemurehus, Insemessidner; Dunkerron, líerry. 


\section{Thallus bright-yellow.}

4. C. juniperina Ach. Meth. Jich. p. 298 (1803) (excl. val. pinastri). -Thallus of crowded ascending lobes, crisp and deeply crenate at the upturned margins, generally marked with browin papillat, citrine or greenish-yellow, rather paler beneath, the: medulla more deeply coloured $(\mathrm{K}-, \mathrm{CaCl}-)$. Apothecia marginal on the upper surface of the lacinie, rather small, reddish or brown, with narrow corrugate or denticulate margin; spores ellipsoid, 6-9 $\mu$ lons, $t-6 \mu$ thick. --S. F. Gray Nat. Arr. i. p. 432 ; Hook. in Sm. Engl. Fl. v. p. 220 : Mudd Man. p. 79. Lichen juniperimus L. Sp. Pl. p. 1147 (1753): Huds. Fl. Angl. p. 452? Platysma jnniperimum Nyl. in Aet. hoc. Linn. Bord. sír. 3, i. p. 295 (1857) ; Cromb. Lich. Brit. 1. 27; Leight. Lich. Fl. 1. 10:2 ; ed. :3, 1. 96 (excl, var. pinastri).

The few authentic specimens in the herbarium are less highly. developed than those collected in higher altitudes. (Only one of the specimens (from Teesdale) is sparingly fertile. The spermatia ar. elongate and slightly thicker at one end; they measure $7 \mu$ long. $1 \mu$ thick. Hudson's Lichen juniprrinus according to Smith (Engl. Fl. t. 194) as well as Lightfoot's plint (F'. Scot. ii. p. 836) are formof Xanthoria parietina.

$H a b$. On the trunlss of old pine trees in mountain woods.Distr. Extremely local and rave in N. Fngland and among the N. Grampians, Scotlund.-D. IT. Near High Force Inn, Teesdalı, 1) mhan ; Clova, Forfarshire ; Rothienutrehus Woods, Invernessshire.

5. C. pinastri S. F. (Eray Nat. Arr. i. p. $4: 32$ (1821), -.-Thalluappressed, the lobes roundish, plane and sometimes imbricate, sreenish-yellow, the margins intensely yellow-pulverulent. the medulla also deeply coloured; beneath concolorous ( $\mathrm{K}-, \mathrm{CaCl}-$ ). Apothecia as in the preceding species, very rare-C - juniferimu var. piunstri Ach. Meth. Lich. p. 298 (1803): Hook. Fl. Scot. ii. p. 57 it in Sm. Lingl. Fl. v. p. 220; Mudd Man. p. 79. Lichen

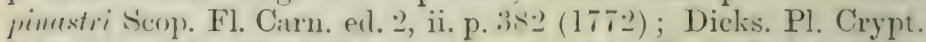
fiesce iii. 1) 18 ; With. Arr. ed. :, iv. 1, 51 ; Engl. Bot. t. 2111. Plutysun pinastri Nyl. in Flora lii. 1) 442 (1869); Croml. Monogr. i. p. 225. I'. juniprrimm subsp. pimustri Cromb. Lich. Brit. p. 27 (1870) \& in Journ. Bot. x. p. 234 (1872); var. pinastri Leight. Lich. Fl. p. 102 (1871); ed. 3, p. 97.

A smaller plant than the preceding, but with broader lobes;

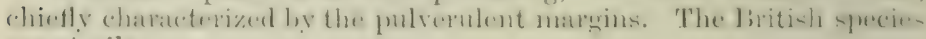
are sterile.

$H a b$. On the trunks of old firs and on larch palings in uplame wooded distriets.-Distr. Local and rare in E. and N. England and

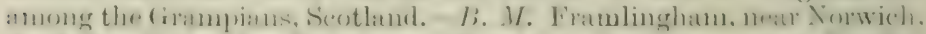

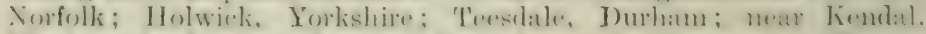

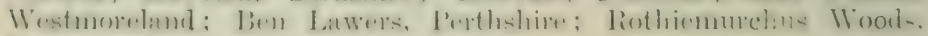
Invernessshire. 


\section{Thallus brown.}

6. C. sepincola Ach. Meth. Lich. p. 297 (1803).-Thallus decumbent or ascending, of small plane lacinize, short or slightly elongate, with undulate-sinuate or crenate margins, olive- or chestnut-brown, beneath paler. Apothecia adnate on or near the margin of the lobes, moderate in size, dark-brown, shining, the margin thin, crenate; spores ellipsoid, 6-10 $\mu$ long; $5-6 \mu$ thick. - Lichen sepincola Ehrh. Beitr. ii. p. 95 (1788); Engl. Bot. t. 2386, fig. 2. Platysme rapincolum Nyl. in Act. Soe. Linn. bord. sér. 3, i. p. 295 (1857) (excl. varr. ulopleyllum); Cromb. Lich. Brit. p. 26 pro parte; Leight. Lich. Fu. p. 100 (excl, varr. uloplyylla); ed. 3, p. 94 (excl. var. ulopluylla).

A small plant, with the lobes closely packed or sometimes effuse. It is rarely fertile in Great Britain. Spermogones, when present, have spermatia $6 \mu$ long, $1 \mu$ thick.

$H(a)$. On branches of trees, mostly firs, and on old palings in mountainous districts.-Distr. Local and rare in N. England and in the N. Grampians, Scotland.-B. MI. Teesdale, Durhann; Glen Quoich and Glen Dee, Braemar, Aberdeenshire.

7. C. chlorophylla Wain. in Act. Soc. Faun. \& Fl. Fenn. xiii. 1. 6, p. 7,1896 (1897). - Thallus moderate in size, greyish- or reddish-brown, smooth or slightly wrinkled and lacunose, broadly or narrowly laciniate and branched, the margins sinuateundulate and crisp, sometimes isidiose, generally whitejulverulent. Apothecia rather small, with subcrenulate or entire margin; spores $6-10 \mu$ long, 5-6 $\mu$ thick. $-C$. sepincolı var. ulophyylla Ach. Meth. Lich. p. 297 (1803). C. sapincolı ऽ. F. Gray Nat. Arr. i. p. 432 (1821) (non Ach.). C. sepincolu Hook. Fl. Scot. ii. p. 57 (1821) and in Sm. Engl. Fl. p. 220; Mudd Man. p. 80. Lichen chloropleyllus Humb. Fl. Frib. p. 20 (1793). L. sepincola Dicks. Pl. Crypt. fasc. iii. p. Is (1793) (non Ehrh.); With. Arr. ed. 3, iv. p. 73 ; Engl. Bot. t. 2386, tigr. 1. Platysma ulophyllum Nyl. in Flura lii. p. 44: (1869); Cromb. Monogr. i. p. 2-21. P. sepincolum var. ulopleyllum Nyl. in Mém. Soc. Sci. Nat. Cherb. v. p. 101 (1857); Leight. Lich. Wl. p. 100 ; ed. 3 , p. 95 .

Exsicc. Croall n. 593 ; Leight. n. 45 ; Mudd n. 56.

Differs from the preceding in the larger size of the lobes, and the (risp) isidiose or generally white pulverulent margins. It is rery rarely fertile.

Iful. On old palings and on fir's, rarely on boulders in mplimd and mountainous districts.-Dist). (ieneral, though not common in Jingland; more frequent in the mountainous districts of Seotlind; not

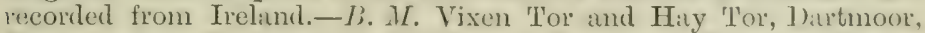
Jevon; near St. Leonards, Ifield and Balcombe. Sussex; 13atdon IIill and Gopsall, Leicestershire; ()teley Piark, Fillesmere, Shropshire: Cwm Bychan, Merioneth; between Yirmouth and Caistor, suffolk: Teesdale, Durham; Ingleby P'ark, Cleveland, Torkishire; Skiddaw 
and Ashgill, Cumberland; New Galloway, Tirkcudbrightshire: Gren Falloch, Killin, Ben Lawers, Glen Lyon, Crianlarich and Falls of Bruar, Perthshire; Deerhill iVood, Kinnoul Wood, Clova and liossie Moor, Forfarshire; Ballochbuie, Morrone, and Linn of Quoich, Bricmar, Aberleenshire; Glen Nevis, Loch Ennich, lothiemurchus Woods and Invermoriston, Invernessshire.

\section{Thallus almost black, lobes very narrow.}

8. C. hepatizon Wain. in Termesz. Fuz. xxii. p. 22-8 (1899).Thallus suborbicular, appressed, imbricate, dark-reddish-brown or brownish-black, the lacinise rather narrow, multifid, sinuate, smooth, somewhat grooved, the margins slightly raised, with marginal papilke, rounded and crenate at the apices; beneath blackish with a few rhizine at the circumference ( $K \mp$ yellowist. $\mathrm{CaCl}^{-}$). Apothecia moderate in size, generally about 2 or $3 \mathrm{~mm}$. wide, reddish-brown, the exterior plicate and wrinkled, the irregularities continued as stoutish granules on the margins; spores ellipsoid, $5-11 \mu$ long, $4-6 \mu$ thick.-Lichenoirles tinctorium atrum, foliis mimimis crispis Dill. Hist. Muse. p. 188, t. 24, f. 81 (1841). Lichen Tepatizon Ach. Lich. Suec. Prodr. p. 110 (1798). L. fahlunensis Lightf. Fl. Scot. ii. p. 819 (17\% $)$ ? Huds. Fl. Angl. ed. 2, p. 53:2 pro parte (1778); With. Arr. ed. 3, iv. p. 30 pro parte; Sm. Engl. Bot. t. 653 (descript. only). Parmelia fahlunensis S. F. Gray Nat. Arr. i. p. 441 (1821) (non Ach.); Hook. Fl. Seot. ii. p. 53 pro parte \& in Sm. Engl. Bot. v. p. 202: Mudd Man. 1) 100 pro parte. Platysma fallunense Nyl. Syn. Lich. i. p. 309 (1860); Cromb. Lich. Brit. p. 27 \& Mlonogr. i. p. 222 ; Leight. Lich. Fl. p. 101 ; ed. 3, p. 95.

Exsice. Croall n. 97.

Limnalus's type specimens of Lichen fahlunensis belong to the: following species, which was delinited by Nylanter and given the. specific name "commixtum." The species are very similar in appearance and are easily confused. The spermogones in both species are borne in the marginal papilla, with short simple sterigmata and clongate or ellipsoid spermatia.

ITal. On rockis and houlders in alpine abd subalpine districts.Distr. Ineal and senere in S.WV. England, N. England and N. Wales; more freduent amomg the (itampians, scotland; recorded from Ireland.- B. M. IIay Tor, 1)artmoor. Devon; Carler Idris, Merioneth; the Cheviots. Northmulerland; Ben Lawers, Perthshire; Cloval Mrts..

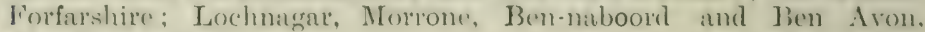
Aherdeenshire.

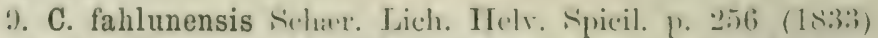

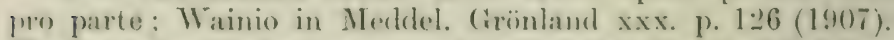
Thallus suburbicular, appressed, imbricate, dork reddish-brown or blackish, the larciniar somewhat ascending, narrow, multifid, the scomonts freduently entangled, almost plane, the margins rrisp, wfen with papillas : beneath concolorons with a few rhizinar 
near the circumference ( $\mathrm{K}-, \mathrm{CaCl}-$ ). Apothecia moderate in size or rither small, the exterior smoothish, and the margin entire or partly crenulate; spores ellipsoid, $5-11 \mu$ long, $\downarrow-6 \mu$ thick. -. Lichen fuhlunensis L. Sp. P1. p. 1143 (1753) (cfr. Wainiu in Medd. Soc. Faum. \& Fl. Fenn. xiv. p. 4 (1886)) (non Ach. Lich. Suec. Prodr. p. 110 (1798)) ; Engl. Bot. t. 653 (fig. only). Platysmu commixtmm Nyl. Śyn. Lich. i. 1. 310 (1860); Carroll in Journ. Bot. ir. p. 22 (1866); Cromb. Lich. Brit. p. 27 ( Nonogr. i. p. 22:); Leight. Lich. Fl. p. 101; ed. 3, p. 96; t. temisectrm Cromb. in. Grevillea xv. p. 49 (1S86) \& Monogr. i. 1'. 221. Cetraria rommixta f. temuiserta Th. Fr. Lich. Scand. p. 109 (1871).

Exsice. Cromb. n. 25 ; Dicks. Hort. Sicc. fasc. 14, n. 23.

Often confused with ( . Jrpati:on, but differs in the more ascending lobes, and in the almost entire margins of the apothecia; the latter are senerally numerous and they become large with age; they are chiefiy horne on the central lobes. In f. trmisecte the lobes are generally narrower.

Hab. On rocks and boulder's, chiefly in alpine localities.-Distr. Iiare in N. Wales, S, and W. Scotland, but more plentiful among the Grimpians. $-B$. M. Carnedd Llewelyn, Camarvonshire; New Galloway, Kirkeudbrightshire; Ben More, Ben Lawers and hills near Amulree, Perthshire; Katelaw, Forfarshire; Ben-naboord, Morrone, :mul Lochnagar, Aberkenshire; Ben Neris, Invernesshire; Island of Mirll, Argyll.

10. C. polyschiza Lett. in Hedwigria lii. 1. 221 (1912). 'Thallus orbicular, the lobes short, crowled and imbricate, narrow, rather raised at the margins and slightly grooved, thickish and smooth, rounded crenate at the apices, greyish or dark-olivebrown, beneath generally paler ( $\mathrm{K}-, \mathrm{CaCl}-$ ). Apothecir morlerate in size, brownish-red, externally wrinkled, with a stout rugose margin; spores ellipsoid, 5-11 $\mu$ long, $4-6 \mu$ thick. Platysina polyschizum Nyl. in Flora xlr. p. s2 (1S62); Cromb. in Journ. Bot. xx. p. 272 (1882) \& Monogr. i. p. 223.

Distinguished from the preceding by the crowded panniform habit of growth and the lighter colour of the under surface.

Hab. On rocks and boulders.-B. M. Ben-naboord, Braemar, Aberdeenshire (the only British locality).

\section{B. Thallus ascending, more or less fruticose (Eucetraria). Thallus pale-yellowish.}

11. C. cucullata Ach. Meth. Lich. p. $293(1803)$. - Thallus in uits, ascencling, sinuate-laviniate, branching, the fronds flat or uenerally connivent at the very undulate margins, slightly recurved at the apices, pale-yellowish or straw-colomed. Apre thecia very lare, subterminal, almate to the back of the lobes, pale flesh-colourerl, up to about 1 cm. across, the margin thin, renulate, or at length excluded: spowes $\bar{\tau}-10 \mu$ lomer, i $\mu$ thick. 
- Murld Man. 1. 78. Lichenoides lacunosum cuntidum, ete. : var. $\beta$ cum marginibus coruntibus ut velut tubulosa, etc. Dill. Hist. Musc. p. 162 , t. 21, fig. 56 в (1741). Lichen cucullatus Bellardi Osis. Bot. p. 54 (1788); Sm. in Trans. Linn. Soc. i. p. st, t. 4, fig. 7 (1791). Platisma cucullatum Hoffim. Pl. Lich. iii. p. 17, t. 66, fig. 2 (1801). Plutysmate cullatum Nyl, in Act. Soc. Linn. Bord. sér. 3, i. p. 295 (1857) ; Cromb. in Journ. Bot. viii. p. $96(1870)$ : Leight. Lich. Fl. p. 99 ; ed. 3, p. 94.

Exsice. Cromb. n. 132.

Somewhat resembling $C$. nivalis in the colour of the thallus, but differing in the narrower (up to about 5 (mil. wide) connivent fronds. and in the position of the apothecia. In Great Britain it is sterile and occurs only in small seattered tufts.

Hab. On the ground among mosses, etc., in alpine places.-Distr. Recorded only from the summits of the higher Scottish Grampians.$B$. $M$. Cairntoul and Cairngorm, Braemar, Aberdeenshire.

1.. C. nivalis Ach. Meth. Lich. p. 294 (1803).- Thallu. pale-straw-coloured or yellowish-white, ascending, branched, sinuate-laciniate, the lacinice wide and foliaceous or narrow, with the margins somewhat connivent, irregularly reticulate-lacunose, the margins crisp, crenate and dentate at the apices. Apothecia acinate towards the tips of the lacinia, becoming rather large (about $1 \mathrm{~cm}$. across), somewhat brownish-flesh-coloured. with a crenulate margin ; spores small, $7-9 \mu$ long, 4-5 $\mu$ thick.S. F. Gray Nat. Arr. i. p. 433 ; Hook. Fl. Scot. ii. p. 57 \& in Sm. Engl. Fl. v. p. 221 ; Mudd Man. p. 78 . Lichenoides lurmesnm

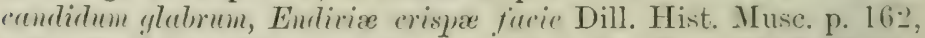
t. 21, fig. 56 A (17+1). Lichen niculis L. Sp. Pl. p. $1145(17.53)$ : Dicks. Pl. Crypt. fasc. iii. p. 17 ; With. Arr. ed. 3, ir. p. 60: Engl. Bot.t. 1994. Platysma nicale Nyl. in Act. Soc. Linn. Bord. sér. 3, i. p. 295 (1857); Cromb. Lich. Brit. p. 26 i Monogr. i. p. 220 ; Leight. Lich. Fl. p. 99 ; ed. 3, p. 93.

Exsias. Croall n. 394 ; Cromb. n. 2t: Leight. n. 43 : Mudil n. 53.

This beatiful species, characteristic of alpine and Aretic region. often forms widely spreacling dense tuit.. British plants are mostly sterile, though spermogones are necasionally present; they occur an black marimal papillar with simple or septate sterigmata and spermatia 6-7 $\mu$ long, $1 \mu$ thick.

Hab. On the ground among mosses and bave detritus in moun. tainous plitees...-I)is/r. I'lentiful among the Seottish Grampian-. sspecially in Jraemas. 13. M. Ben Lawers. P'erthshire; Jasssies and

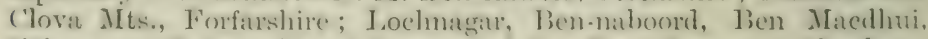
Cairngom, Cairntoul, and Sources of the Dee. Bratemat, Aherdenshire; Jen Nevis, Invernessshire.

Thallus pale to darto-brown; psendociphliella present.

1:i. C. islandica Ach. Meth. Lich. p. 29!3 (180:3).- Thalluaserndine, branched, strapslaped and narrow of subfoliaceons, 
somewhat rigid, pale-chestnut or dark-brown, alike on both surfaces, often stained a blood-red colour at the base, the fronds more or less regularly bordered with small spines and generally incurved, the lower side frequently dotted with white impressed (lecorticated spots (pseudo-cyphelle). Apothecia adnate on the upper surface of the apices, large or moderate in size, with a thin entire or crenulate disappearing margin ; spores $7-11 \mu$ long, 4-6 $\mu$ thick.-S. F. Gray Nat. Arr. i. p. 433; Hook. Fl. S'cot. ii. 1) is of in Sm. Engl. Fl. r. p. 221; Tayl. in Mackay Fl. Hil. ii. 1. 155 : Cromb. Lich. Brit. p. 2.) ; Leight. Lich. Fl. p. 96 ; ed. 3, 1. 91. Lichenoides righidum, Eryngii foliu referens Dill. in Ray Syn. ed. 3, p. 77 , n. 90 (1724) \& Hist. Musc. p. 209, t. 28, f. 111 A. Lichen islundicus L. Sp. Fl. p. $1145 \alpha$ (1753); Huds. Fl. Angl. p. 448 : Lightf. Fl. Scot. ii. p. 829 ; Engl. Bot. t. 1330.

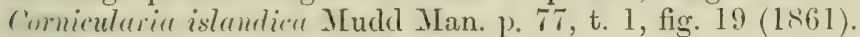

Exsicc. Leight. n. 42 ; Mudd n. 51.

A northern lichen, well known as Iceland Moss, and famed for its edible and medicinal qualities. The fronds vary in width from 1-2 mm. to several cm. The marginal spines are ustally occupied by spermogones, but sometimes they develop as haptera and anchor the plant to the smrounding regetation. The white spots on the under surface are described by Wainio as pscuclo-cyphella. (Ark. Bot. viii. 4, p. 20 (1909)).

$H a b$. On the ground in heathy or stony places in upland or alpine *ituations.-Distr. Somewhat uncommon in the mountainous districts of the British Isles though plentiful among the Grampians, Scotland. - B. M. Wootton Common and King's Lynn, Norfolk; nen Scarhorough, Lowthorpe 1Ioor, Stockton Forest, Langwith Moor and itenshall Common, Yorkshire; Snowdon, Carnarvonshire; Pentland Hills near Edinburgh; Ben Lomond, Stirlingshire; Ben More, Ben Lawers, Mrael Graedha and Ben-y-Gloe, Blair Athole, Perthshire; Clova IIts. and Sidlaw Hills, Forfarshire; Ben-naboord, Lochnagar, Ben Macdhui, Morrone, Britemar and Countess Wells, Aberdeenshire.

Form platyna Fr. Lich. Eur. p. 37 (1831).-Fronds broad, ibout 2 to $3 \mathrm{~cm}$. wide, sparingly branched and less constantly spinulose at the margins. Apothecia large, abont $1 \mathrm{~cm}$. in (liameter, submarginal, rather rare--Leight. Lich. Fl. p. 96; ed. 3 , p. 91 pro parte. C. islandica f. dilatulu Norrl. in Medd. Sillsk. Faun. \& Fl. Fenn. i. p. $16(1876)$; Cromb. in Journ. Linn. suc. Bot. xvii, p. 575) (1880). Lichenoides rigjidum, Erymgii folin rferens. Dill. Hist. Muse. 1. 209, t. 28, fig. 111 в (17+1).

Differs chiefly in the wider fronds ; there are numerous intermediate stages.

Hab. On the ground among heaths in alpine places.-1)istr. Confined to the higher Grampians.-B. M. Lochnagar, Ben-naboord. Cairngorm, and Cairntoul, Braemar, Aberdeenshire.

Var. tenuifolia Wain. in Ark. Bot. viii. 4, p. 2l (1909). Fronds caspitose, crowded, narrow, erect or depressed, the margins spinulose and comnivent, the apices flattened out, white naked spots frequently present on the lower surface. - Cetrurin 
islendien var. wisum Ach. Lich. Triviv. p. 513 (1810): Cromb. Lich. Brit. p. 206: form subtululusa Fr. Lich. Eur. p. :37 (1831): form crispu Leight. Lich. Fl. p. 97 (1871); erl. 3, 1. 92; subs]'. (rispa Crowb). in Grevillea xii. p. 7:3 (1884). C. erixpa Lamy in Bull. Soe. Bot. Fr. xxv. p. 36-2 (1878); Cromb. IInnogr. i. p. 216 (incl. f. subtulutusa). Lirhenosides Eryngii foliu referens, temioribus et crispioribus folios Dill. Hist. II usc. p. 닐. t. 28 . fig. 112 (1741). Lirhen islandirns var. tenuifolius Retz. Fl. Scand. Prodr. 1) 227 (1779) ; var. $\beta$. Lightf. Fl. Scot. ii. 1. 8.30 (1777) : Huds. Fl. Angl. ed. 2, p. 5399; With. Arr.ed. 3, ir. p. 54. Cormicularia islendier var. erispe MLudd Man. p. TT (1861).

Exsicr. Croall 11. 493 ; Leight. 11. 42 (in some specinens): Mudd n. 52.

Distinguished from the species by the narrower, generally connivent frouds. The form of the branching fronds gives it a somewhat crisp curled appearance.

$H a b$. On the ground among mosses mostly in mountainous districts.-Distr. Rare in N. Wales, N. England, and in S.W. and N. Ireland, more plentiful among the Grampians, Scotland. $-B$. M. Snow ron and Carnedd Llewellyn, Carnarronshire; Mael Graedha, Ben Lawers and Pannoch, Perthshire; Katelaw and Clova, Forfarshire: I.ochmagar, Morrone, Ben-naboord and Cairntoul, Braemar, Aberdeenshire; I3en Nevis, Invernessshire ; Mangerton, Ierry ; Slieve Donart. Down.

14. C. hiascens Th. Fr. Lich. Scand. p. 58 (1871)..-Thallus of erect densely crowiled narrow fromels, plane or partly connivent, repeatedly lianched towards the apex, sparingly spinulose at the margins, pale- or (ark-brown, often yellowish-hrown at the base, the lower sirle freruently dotted with impressed decorticated white spots (pseudo-cyphellie). Apothecia adnateto the upper surface of the fronds, elevated, moderate in size. the disc subencolorous, the margins sometimes denticulate: spores $7-11 \mu$ long, $4-6 \mu$ thick. C. aruleutu var. hiurserns. Fr. Lich. Eur. p. 36 (1831). C. islandica var. Delisei Bory ex Sicher. Enum. p. $16(1850)$. (: Dtlisei Th. Fr. in K. Srensk. Vet.-Akad. Handl. vii. n. 2, 1. 11 (1867); Croml), Lich. Brit. p. 26 ; Leight. Lich. Fl. p. 97 ; ed. 3, p. 92.

The British species are sterile. Th. Fries and Crombie give chemical reactions as $\mathrm{K}-$, medulla $\mathrm{Ca} \mathrm{Cl} f+$; Wainio, however, could get no reation with any of his specimens (Ark. Sot. viii. n. 4, p. 22).

Hab. Among mosses on the ground in nlpine places.-Distr. Extremely are on the summits of the loftier (ivampians, scotland.li. M. Lochnagar and Ben Macdhui, Aberdeenshire.

Thallus dark-chestmut-broun, without pseudo-cyphellax.

15. C. aculeata Fr. Fyst. (1).h. Vem. p. 239 (18.5). Thallus riscid. of narrow shinines shrubhy rounded or slishtely compressed 
fronds, sometimes lacunose, almost hollow, intricately and irregularly much loranched, chestnut- or dark-brown, the branches divergent, forked, more or less spinulose. Apothecin rare in Britain, rather small, lateral or subterminal, concolorous, the marrin spinuluse-denticulate: spores small, $5-9 \mu$ long, $3-t \mu$ thick.-Cromb. Lich. Brit. p. 26 ; Leight. Lich. Fl. p. 97

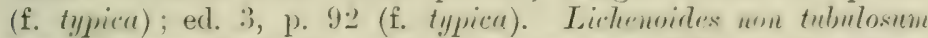
ramosissimm frutemli specie, rufo-nigrescres Dill. in liay Syn. ed. :3, p. 66, n. 10 pro parte (1724). Corallowides fintiruli sperie fuscum spinusum Dill. Hist. Musc. p. 11 . pro parte $(17+1)$. Lichen

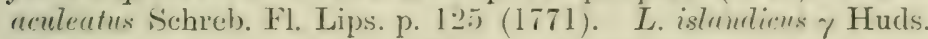
Fl. Angl. ed. 2, p. 539 (1778). Comicularia aculeate Ach. Meth. Lich. p. 302 (1803) ; S. F. Gray Nat. Arr. i. p. 405 ; Hook. Fl. Sicot. ii. p. 69 \& in Sm. Engl. Fl. v. p. 2.-s; 'Tayl. in Mackay Fl. Hib. ii.p. 86 ; Mudd Man. p. 76 (incl, var. . Incaula):

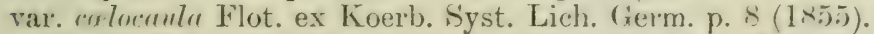

Exsire. Croall n. 198; Johns, n. 60 ; Larb. Lich. Cantab. n. \& ; Leight. n. 3 ; Mudd n. 50.

I distinct though somenhat variable specie-, the branches are round, or compressed more exiecially at the axils. It always grows in interlaced clumps. The spermogones, which are rare, are seated in the tips of the spines; the spermatiat measure $4 \mu$ long and $1 \mu$ thick.

Hab. On the ground in sandy and gravelly places anongr grasses and heath of moorland in upland localities. - Distr. Fairly common on heathlands, etc., throughout the British Isles.-H. M. Qunenvais, Jersey; 1)artmoor, Devon; Studland, I)orset; Lrindhurst Common, Hants; near Chehmsford, Essex; Thetford Warren, Suffolk; Malvern Hills and Hartlebury Common, Worcestershire; Charnwood Forest and Bardon Hill, Leicestershire; Haughmond Hill, Shropshire; Nant Ffrancon, Curnarvonshire; Lleniestyn, Anglesen; near Over, Cheshire; Farndale and Ayton Moor. Cleveland, Yorkshire; Gateshead, Durhan; F Filhope Law and West Allen Carrs, Northumberland; New Galloway, Kirkcudbrightshire; Pentlind Hills, near Edinburgh ; Glen Lochay, Birnam Hill and Ben Lawers, Perthshire; Baldovan Woods, Sinllaw Hills and Clova, Forfarshire; Lochnagar, Aberdeenshire; Glen Nevis, Invernessshire; Culbin, Elginshire.

Form hispida Cromb. Monogr. i. p. 218 (1894).-Thallus smaller, more slender and intricate, densely caspitose, the crowded branches more or less spinulose, senerally darker in colsur than the species. Apothecia numerrus, dilated, the disc lighter-coloured than the thallus. - Var. hispirlı Cromb. in Journ.

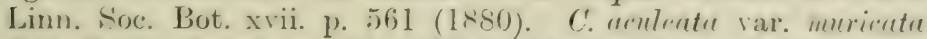
Nyl. Lich. Scand. p. 80 (1861) : Cromb. Lich. Brit. 1). 루;

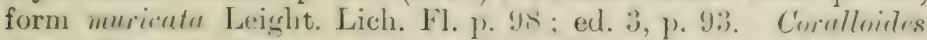

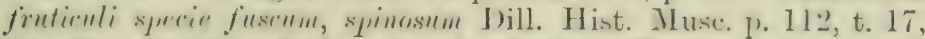
tig. 31a (1741). Lerdern hispielus Lightf. Fl. Sicot. ii. p. se3 (1777); With. Arr. erl. 3, iv. 1. 43; Engl. Bot. t. 45:. L. muricatus Ach. Lich. Suec. Prodr. p. 214 (1798). Cornicularia spadicea Ach. Meth. Lich. p. 301 (1803). C. aculeata var, spadicea Hook. II. Scot. ii. p. 69 (1821). 
Exsicc. Jolıns. n. 61 ; Larb. Lich. Hb. n. 163 ; Leight. n. 4 ; Mudd n. 49.

Forms low dense tufts up to about $3 \mathrm{~cm}$. in height. Though a fairly well-marked form, it is very closely connected with the species. and is sometimes spinous lilie the more dereloped f. acanthellu.

Hab. On the ground on moorlands in upland districts. - Dist). Frequent in moorland and hilly districts of Great Britain, rave in Irelind.-B. . M. Scilly Islands; Rough 'Tor, Cornwall; I) iutmoor. Devonshire; Lewes, Sussex; Lydh, Kent; Hatinault Forest, Essex; Wolinghau Heath, Buchs; Malvern, Worcestershire; Haughmond Hill, neal Oswestry, and Longmynd, Shropshire; Cwm l3ychan. Merioneth ; Breidlen, Montgoneryshire; Hlack Edge, near Buxton, and Chatsworth, Derbyshire; North Wootton, Norfolk; near Beverly, Hainworth Moor, Battersby Moor and Ayton, Cleveland, Yorkshire; Swinhope Fell, Northumberland; near Kendal, Westmorelamd; Asby :ınd Lamplugh, Cumberland; New Galloway, Krirkcudbrightshire; 1)almahoy Hill and Pentland Hills, near Edinburgh; Ben Lawers. Craig Tulloch and Rannoch Moor, Perthshire; Sidlaw Hills, Montrose links and near Cortachy, Forfarshire; Glen Dee and Glen Mruick, Braemar, Aberdeenshire; Hills of Applecross, liossshire; Tillarney, Tierry; Mrt. Errigal, Donegal.

Form acanthella Nyl. Lich. Scancl. 1) \&u (1861). - Thallus similar to that of the species, but beset with denticulate spines and generally very dark in colour. Apothecia rare, lighter in colour than the thallus.-Leight. Lich. Fl. p. 98: ed. 3, p. 93. Var. acenthella Nyl. in Mém. Soc. Sci. Cherb. v. p. 100 (1857) : Cromb. in Journ. Bot. viii. p. 96 (1870). Corclloides fruticuli specie fuscum, spinosum Dill. Hist. Musc. p. 112, t. 17, fig. 31ı

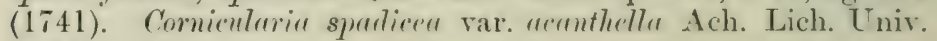
p. $612(1810)$.

Exsicc. Johns. n. 62.

Distinguished by the more spinous branches; it is well-matred. though possibly a form due to growth couditions of greater illumination.

Hab. On the ground, sand dunes, ete., among mosses in matritime and upland districts.-Distr. Pather uneommon throughout Great Britain.-D. M. Harting Combe, Sussex ; Godalming, Surrey ; (Clifton, Gloucestershire; Dolgelly, Merioneth; Fandile. Yorlishire; Prestwich Carr and West Allen ('urrs, Northumberland; Baldovan Woods, Sidlaw IIills and C'lora Mts., Forfarshire; s. of Lochnagar. Aberdeenshire; Gilen Nevis, Invernessshire; Findhom, Islginshire.

16. C. odontella Ach. Syn. Lich. p. 230 (1814).-Thallus densely caspitose, the fronds short, plane, rather narrow and palmately liranched, spinulose at the margins, chestnut-or clarkhrown, paler at the base or sometimes red. A I otheciat teminal. concolorous, the margin denticulate : sporess $7-10 \mu$ long, $4-5 \mu$ thick.-Croml). in Journ. Bot. xx. 1. 272 (1882). Lirtien odontellus Ach. Lich. Suec, Prodr. p. 213 (1788).

Distinguished by the small size and by the llattened fronds. The only British specinen is sterile.

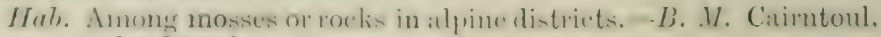
Brnemsr, Aberdeenshire. 


\section{ORDER XI. USNEACE正.}

Thallus fruticose, elongate, filamentous or strap-shaped, branched, attached at the base, usually radiate in structure: strengthening hyphre generally present. Algal cells Protococeus, within the inner cortex. Apothecia roundish, sessile or shortly stalked, marginate; asci 1-8-spored; spores colourless or rarely hrown, simple or septate. Spermogones immersed; sterigmatil simple, sparingly septate, with acrogenous or pleurogenous spermatia.

Distinguished by the generally upright or pendulous elongate thallus, with basal attachment. Transition stages between the foliaceous and fruticose types occur in the genus Evernia, in which the structure is only subradiate and the thallus, though usually with a single penetrating foothold, may form secondary basal sheaths. Cerania (Thamnolia) is doubtfully included in the Order. The British genera are as follows:-

'Thallus strap-shaped, narrow or broad.

Structure subdorsiventral, with under surface of different colour ............................. 40. Evernia.

Structure radiate, alike on both surfaces ....... 41. Ramalina.

Thallus filamentous.

Medulla with central chondroid strand.......... 42. Usnea.

Medulla of loose arachnoid hyphæ................ 43. Alectoria. Thallus stalk-like.

Fronds hollow, tapering upwards

44. Cerania.

40. EVERNIA Ach. Lich. Univ. p. 84 (1910). (Pl. 40.)

Thallus erect or pendulous or somewhat decumbent, strapshaped, divided or repeatedly branched, rather soft and flaccid, attached by a basal sheath, occasionally by a few rhizina; differently coloured above and below. Algal cells Protococcus. Structure subdorsiventral ; cortex on both surfaces of gelatinous cells; gonidia mostly confined to a layer below the upper surface. Apothecia lateral or almost terminal, with a thalline margin; paraphyses stoutish, simple; spores $\delta$ in the ascus, small, ellipsoid, simple. Spermogones lateral, immersed, with pleurogenous straight acicular spermatia.

1. E. prunastri Ach. Lich. Univ. p. 442 (1810).-Thallus at first ascending then more or less decumbent or pendulous, the fronds irregularly strap-shaped, wrinkled-lacunose or somewhat furrowed, greenish-grey above, white beneath, becoming brownish and concolorous in herbarium, repeatedly divided and branched, especially towards the apex, usually about $5-10 \mathrm{~cm}$. long, frequently sorediate at the margins or on the wrinkles ( $K+y$ yeliow. $\mathrm{CaCl}_{-}^{-}$). Apothecia riure, on a short stout pedicel, chiefly lateral. moderate in size, the dise reddish-brown, the margin inflexed: spores $7-10 \mu$ lons. $4 \cdot \bar{j}-6 \mu$ thick. $\rightarrow$. F. (rma Nat. Arr. i. 
p. 425 ; Hook. Fl. Scot. ii. p. 61 \& in Sm. Engl. Fl. v. p. 224 : Tayl. in Mackay Fl. Hib. ii. p. 84; Mudd Man. p. 72 ; Cromb. Lich. Brit. 1) 24 (incl. f. sorediifera); Leight. Lich. Fl. p. 90; erl. 3, p. 82. Lichensides arboreum remostm majus et mollins rolore candicante Dill. in Ray Syn. p. 75, n. 80 (1721). Lichenoides cornutum bromrliale molle subtus incamum Dill. Hist. Musc. p. 160, t. 21, fig. 55 A (1741). Lichen prunastri L. Sp. Pl. p. 1147 (1753) ; Huds. Fl. Angl. p. 452 ; Lightf. Fl. Scot. p. 835; With. Arr. ed. 3, iv. p. 52 ; Engl. Bot. t. 859.

Exsice. Bohl. n. 64; Croall n. 396 ; Johns. n. 22 ; Larb. Lich. Hb. n. 246 ; Leight. n. 36 ; Mudd n. 41.

A variable species according to age and habitat, but always readily. distinguished by the white under surface. Though the structure is on the whole dorsiventral, groups of algre frequently occur on the lower side, especially near the tips. Apothecia and spermogones are rare. The latter have spermatia 6-7 $\mu$ long, $\cdot 5 \mu$ thick.

$H a b$. On the trunks and branches of trees, or on hedge bushes, in orchards, woods, ete.-Distr. General and usually plentiful in most parts of the British Isles; more frequently fertile on the Grampians, Scotland. - B. M. Islands of Jrrsey and Guernsey; near Penzance and Withiel, Cornwall; Cllacombe near Bovey Tracey, Devon; New Forest, Hants ; St. Leonarls Forest, Eridge l'ark, near Tilgate, near Hapstead and Bolnore, Sussex; Lydd, Kent; Shiere, Godalning, Surrey ; Langford, Epping Forest and Walthanstow, Essex; Cirencester, Gloucestershire; Broadwas and Malvern, Worcestershire; Oswestry, the Wrekin and near Shrewsbury, Shropshire; Madingley near Cambridge ; near Cromer, Norfolk; Welbeck Park, Notts; Cwm Bych:n, Merioneth; Anglesea, Cheshire; near Matlock, Buxton and near Bank House, Derbyshire; Lounsdale and Ayton, Cleveland, Yorkshire; near liendal, Westmoreland; Hale Mlill and Alston, Cumberland; Gibsicle Woods, Durham; New Galloway, Kirkend. brightshire; Currie, near Elinburgh ; near Glasgow; Appin, Argrll ; Fillin, Abertelty and Blaeberry Hill, Perthshire; Deerhill Wood, Sidlaw Hills, Guthrie, and Kinnordy, Forfarshire; Countesswells Woods, Durris Woods, and Ballochbuie Forest, Braemar, Aberdcenshire; Invernoriston and Rothiemurchus Woods, Invernessstire; Cawior Woods, Naimshire; Lairg, Sutherlandshire; near Cork; Achill Island, Mayo; near 13elfast, Antrim.

Form retusa Cromb), in Journ. Jinn. Soc, xrii. p. 569 (1880). - Thallus of short crowded erect fronds which are retuse and emarginate at the apices. Apothecia not seen.-Lichemides

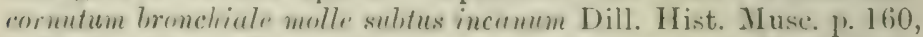
t. 21, fig. 5. n. Parmelin prumastri var. retusa Ach. Meth. Lich. p. 257 (1803).

(irows in dense tuft alout 1 or 2 ('m. in height, and often spreads extensively. It is more or less sorediiferous.

Ifah. On old palings chiefly larch, in lowland or upland districts. - Distr. Seen only from a few localities in S. England, E. and N. Seotlanl. - 33. M. l'ark, near Aberdeen and Jurris, Aberdeenshire.

Vitr. stictoceros Hook. in sin. Engl. Fl. v. p. 2.21 (1;.3:3) (non Ach.). - Thallus perdulous or prostrate, subcompressed, ereenish- 
sulphur-coloured, mostly similarly coloured on hoth surfaces, the fronds rather narrow, attenuate upwards, frequently dotted with dark-coloured tubercles. Apothecia very rare.-Mudd Man. p. 72 ; Leight. Lich. Fl. 1. 91 ; ed. 3, p. 83 (incl. var. gracilis). Var. gracilis Ach. Lich. Univ. p. 442 (1810)? Cromb. in Journ. Bot. x. p. 233 (1872) ; form stictocera Cromb. Lich. Brit. p. 25 (1870). Lichenoirles comiculutum candidum. molle, scgmentis ungustis Dill. Hist. Musc. p. 159, t. 21, fig. 54 (1741). Lichen prunustri $\beta$ Huds. Fl. Angl. ed. 2, p. 541 (1778); Witb. Arr. ed. 3, iv. p. 53 pro partè. Lichen stictoceros Sm. Engl. Bot. t. 1353 (1804).

Exsicc. Larb. Cresar. n. 59.

Distinguished by being generally concolorous on both surfaces. It̀ approaches the genus Letheria, but there are no chondroid strands. in the pith and the algre of the lower surface are very seanty. The structure otherwise is sinilar to that of the species. The darkcoloured tubercles are of hyphal nature; they arise at points where the lichen fronds are attached to other branches.

$H a b$. On bare sandy soil, and on heather in maritime regions, rarely on the trunks of old firs in mountainous districts. $-B$. $M$. Qnenvais, Jersey; Dawlish and Exmouth Downs, Devon; Lydd Beach, Kent; Stronachlachan Woods, Killin, Perthshire; Decrhill Wood, Forfarshire ; Findhorn, Elginshire.

2. E. furfuracea Mann Lich. Bohem. 1) 105 (1825).-Thallus ascending, pendulous or decumbent, of long narrow fronds repeatedly dichotomously branched, incurved at the margins, attenuate upwards, greyish or greyish-green at becoming dark grey; beneath black, naked, attached by a rhizinose basal sheath ( $\mathrm{K}^{-}$sellunish, $\mathrm{CaCl}_{-}^{-}$). Apothecia moderate in size or large, subpedicellate, brownish-red, the margin thin, inflexed; spores $7-10 \mu$ long, 4-5 $\mu$ thick.-Mudd Man. p. 71 ; Cromb. Lich. Brit. p. 24; Leight. Lich. Fl. p. 90 ; ed. 3, p. 82; form mulks Cromb. Monogr. i. p. 231 (1894). Lichenoides cormutum amurum superue cinerem, inferne nigrum Dill. Hist. Muse. p. 157, t. ㄴ1, fig. 52 (1741). Lichen furfuraceus L. Sp. PI. p. 1146 (1753) Huds. Fl. Angl. p. 450 ; Lightf. Fl. Scot, ii. p. 832: With. Arr. ed. 3, iv. 1. 56. Parmeliu furfuracen Ach. Meth. Lich. p. 25t; Tayl. in Mackay Fl. Hib. ii. p. 144. Borreme fuifurecere Ach. Lich. Univ. p. 500 (1810) (incl. var. mulu) ; S. F. Gray Nat. Arr. i. p. 435 ; Hook. Fl. Scot. ii. p. 56 it in sm. Engl. Fl. v. p. 223 .

Eisier. Croall n. 494 ; Johns. 11. 302: Leight. n. :37; Mudel n. 60 .

1)ifiers from the preceding in the black under surficee. It has been sometimes chassified as a l'armelia, but though the strueture is mainly dorsiventral, it is freguently radiate for some distance (abont -5 cm.) beluw the tips. 'The fronds are frecunently attached to carch other by haptera, and to the support by a secondiry stolon-like sheath which forms a new base for further fronds. 
Hab. On the trunls of trees, old palings, walls or rocks in upland districts.-Distr. General and somewhat frequent in upland districts of Great Britain; apparently rare in Ireland.-B. $M$. Helminton, Cornwall; Dartmoor and South Brent, Deron; New Forest, Hants ; Eridge, Sussex; Twycross, Leicestershire; near (Oswestry, Caer Caradoe and Wrekin IIill, Shropshire; Dolgelly, Bamouth and Cwu Bychan, Merioneth; Camedd Dafydd, Carnarvonshire; Anglesea ; Chesterfield and near I3uxton, Derbyshire; Iarndale, Yorlsshire; Figglestone, Durhan! ('hillingham Park, Northumberland; New Galloway, Kirkculbrightshire; Swanston Wood near Edinburgh ; Glen Falloch. Argyll; Blaeberry Hill, Glen Lochay, Killin, Crianlarich, Pass of Leny and Glen Lyon, Perthshire; Deerhill Wood and Rossie 1Loor, Forfarshire; Durris, Kincardineshire; Invercauld, Auchindryne and Castleton. Braemar, Aberdecnshire: Glen Neris. Invernessshire.

Form scobicina Cromb. Lich. Brit. p. 24 (1870). - Fronds frequently broader, darker in colour, densely isidiose and fibrillose; otherwise as in the species.-Leight. Lich. Fl. p. 90. Parmelia furfurucen var. senlicinu Ach. MIeth. Lich. P. 25.5 (1803).

Exsicc. Johns. n. 66.

A growth form of very pronounced character and frequently associated with the smoother species. It is rarely fertile and the apothecia may be isidiose on the receptacle and on the margin.

$H a b$. On the trunks of trees, old palings and stone walls in upland districts.-Distr. Tather local, though plentiful in IV. and Central England; but chiefly in the (irampians, Scotland.- J. M. Weald Hall, Essex; Chesterfield and Chatsworth, Derbyshire; Gopsall Park, Leicestershire; MIalvern, Worcestershire ; Arkindale, Yorkshire ; Langley, Northumberlaud; Killin and ]3en Lawers, Perthshire; Johnston Hill, Forfarshire; Morrone and Castleton. Braemar, and Countesswells, Aberdeenshire ; lothiemurchus, Invernessshire.

Form ceratea Cromb. in Grevillea vi. p. 21 (1877).-Thallus decumbent, fronds narrow, convex and subcylindrical, acuminate, isidiose or subglabrous. - Prrmelia furfurecen var. erreten Ach. Meth. Lich. p. 255 (1803).

Exsicc. Cromb. 1. 139; Johns. n. 67.

Distinguished by the narrow fronds. The British specimens are barren, though Acharius (Lieh. ('nir. p. 501) sitys the apothecia chicfly occur on this form.

Hah. On rocks and old walls in uplamd districts. - Distr. liare in various distriets of Eingland and seotland-L. M. Helminton, ('ornwall; IIunter 'Tor, Dartmoor. Deron ; near Juxton, Derbyshire; ne:tr. Kendal and Windermere, Westnoneland; Alston. C'unberland; P'entland Irills. near Edinburgh ; (ilen Filloch. P'erthshire: near Countesswells, Aberdeenshire.

11. RAMALINA Ach. lich. Univ. 1'p. 12.2 d 598 (IS10). (11. 41.)

Thallus of ereet or partly pendulous fronds, branched, 
compressed and strap-shaped or narrow and almost cylindrical, attached by a basal sheath or by penetrating hyphie; structure radiate, the medulla generally of loose hyphar, the gelatinous cortex formed of shortly branched thick-walled coaleseing hyphe, growing in a direction vertical to the long axis of the thallus; inner cortex of longitudinal strengthening hypha in a ring or as separate strands, which are rarely absent; soralia not infrequent; air-pores occurring as breaks in the thallus. Algal cells Profocorcus. Apothecia terminal or lateral, sometimes on the angle of bent fronds (geniculate), marginate; hypothecium colourless; paraphyses simple, concrete: spores 8 in the ascus, ellipsoid, colourless, 1-septate, straight or slightly curved.

\section{Thallus corticolous, without soredia.}

1. R. calicaris Fr. Lich. Eur. p. 30 (1831) pro parte (incl. f. canaliculata); emend. Nyl. in Bull. Soc. Linn. Norm. sér. 2, iv. p. 131 (1870).-Thallus erect, compressed, the fronds narrow or sometimes rather broader, often longitudinally lacunose and (avaliculate, pale glaucous- or greyish-green (medullir $\mathrm{K}-$ ). Apothecia subpedicellate, marginal, generally rather crowded near the tips of the frond, frequently on a bent angle (geniculate), small or moderate in size, the disc pale flesh-coloured or greenish, the receptacle wrinkled below; spores ellipsoid, straight, 10-1 i $\mu$ long, 5-7 $\mu$ thick. - Iudd Man. p. 72 pro parte; Cromb. Lich. Brit. 1. 25 pro parte; Leight. Lich. Fl. p. 92 (incl. f. conaliculat, excl. hi. furinace and thrensta); ed. :3, p. *:3. R. fustigiata var. mlicuris Ach. Syn. Lich. p. 297 (1\&lt); Hook. Fl. Scot. ii. p. 68 ; Tayl. in Mackay Fl. Hib. ii. p. 85. Lichenoides artorenm ramosum, engustioribus cinereovirentilus rumulis Dill. in Ray syn. ed. 3, p. 75 n. 81 (1724). Licherusides corclliforme rostratum if cencliculutum Dill. Hist. Muse. p. 170, t. 23, fig. 62 A (17+1). Lichen caliarris L. Ap. Pl. p. 1146 (1753) pro parte; Huds. N1. Angl. 1. $\$ 51$ pro parte; Lightf. Fl. S'cot. p. 834 pro parte: With. Arr. ed. 3, iv. p. 51 pro parte. L. fastigiatu. Sim. Engl. lint. t. 890 (upper tig.) (1801) (non Pers.). Lobarin aldiraris Hoffm. Deutschl. F]. ii. p. 139 (1795) pro parte.

Exsicc. Cromb. n. 21 ; Johns. n. 16; Mudd n. 44.

Lichen calicaris L. is a mixture and referable partly to the above. partly to $I$, siliqunse. Established custom has restricterl it to corticolons forms. It is distinguished by the arboreal habit anil the rather narrow chamnelled thallus. The fronds vary in height and in branching: short erowded narruw out rrowths arise at right angles to the mitin frond on some specimens. Spermogones are fairly. common, with minute spermatia $3-4 \mu$ long, $1 \mu$ thick. The strengthening tissue forms a ring within the cortex, and here and there projects into the medulla ; the cortex is formed of irrerular branching thick-walled cells which pisss ont at right angles to the longitudinal axis. The algx lie in groups. 
Hab. On trees.-Distr. General and common in the British Isles. rare in the Channel Islands.-B. $M$. St. Aubin's, Jersey; near Tiespring and Penzance, Cornwall; mear Totnes and Torquar, Deron; New Forest. Hants; Lavington Common, Sussex; Lydd, Kent; Old Tindisor, Berlishire; Pyle, Glamorganshire; Drneror Castle, Carmarthenshire; Anglesea; Airyholme Woods. Cleveland, Yorkshire; near Stavely. Westmoreland; Wastdale, Cumberland ; Pentland Hills, near Elinburgh; Barcaldine and Appin, Argrll; Killin, Kenmore and Abernethy, Perthshire; Deerhill Wood and near Arbroath. Forfarshire; Countesswells Woods and Abergeldie. Aberdeenshire; S. of Fort Trilliam and Invermoriston, Invernessshire; Loch Shin, Sutherland; Achill Island, Mayo; Antrim.

Var. subampliata Nyl. in tom. cit. p. 132.-Lacinire broader than in the species. Apothecia mostly subterminal; spores as in the species.-Leight. Lich. Fl. p. 471 ; ecl. 3, p. 84.-Lichenristes coralliforme rostratum ef renuliculatum Dill. Hist. MLusc. p. 170 , t. 23 , fig. 62 в (1741).

Exsicc. Mudd n. 42.

The thallus is intermediate between the species and that of R. fraxinca, but the straight spores indicate the true relationship.

Hab. On the trunks of trees in maritime and upland districts.Distr. Local and scarce in England, Wales and S.W. Scotland.B. M. Penzance, Cornwall; New Forest, Hants; Beeding Priory and Tunbridge Wells. Sussex; Malvern, Vorcestershire; Aberdovey, Merioneth; Arton, Cleveland, Yorkshire ; Staveley, Westmoreland ; Barcaldine, Argyll.

Var. subfastigiata Nyl. l. c.-Lacinie broader, subequal in length. Apothecia terminal; spores as in the species.-Leight. Lich. Fl. ed. 2, p. 471 ; ed. 3, p. 84.

The thallus approaches that of $R$. fastigiata in form, but the spores conform to those of the above species.

Hal). On trees in maritime and upland districts.-Distr. S.W. England, S. Wales and the S.W. Highlituds of seotland.-D. MI. Near Penzance, Cornwall; Appin, Argyll.

2. R. fraxinea Ach. Lich. Univ. 1) (002) (1\$10). -Thallus partly upright or suhpentulous, the fronds compressed, narrow or broarl, generally mareowing upwards, longitudinally and partly transversely wrinkled or nerved, sreyish-wren. Apothecia abundant, marginal and superticial, peeticellate, moderate in size or large, the dise reddish-flesh-colourerl or greenish, the reeptacle umerpually wrinkled: spores ublong-ellipsoid, curved, 10-12 $\mu$

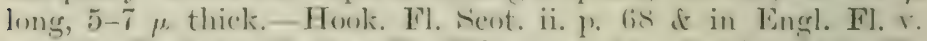

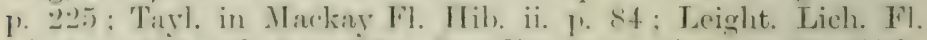
ed. 2, p. 472 ; ed. 3, p. 85. R. calicaris var. fraxinea Fr. Lich. Eur. 1. :30 (15:31): Mudd Man. p. 73: Cromb. Lich. Brit. 1. 25: form fiaxinen Leight. Tich. Fl. 1. 94. Lichenoiles arbireum

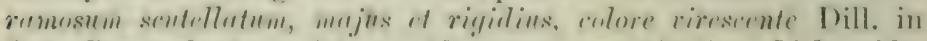
Ray Syn. ed. 3, p. 75, n. 79 pro parte (1724). Lichenoides 
Tongifolium ruyosan rigirlum Dill. Hist. Musc. p. 165, t. 22, fig. 59 A, B (1741). Lichen fruxineus L. Sp. Pl. p. 1146 (175::); Huds. Fl. Angl. p. 451 pro parte; Lighte. Fl. Scot. ii. 1. 835 ; With. Arr. ed. 3, iv. p. 56 ; Engl. Bot. t. 1781.

E.xsicc. Croall n. 495 ; Bohl. n. 21 pro parte; Dicks. Hort. sice. fase. xii. 11. 24 ; Johns. n. 17 ; Larb. Lich. Cantab. n. 5 ; Leight. n. 38 pro parte; Mudd n. 42.

A variable species in the length and width of the fronds. On the wider lacinix the apothecia tend to become superficial on both surfaces, more especially on the better-lighter portions. The outer cortex is composed of thick-walled confused hyphæ; the strengthening hyphre occur in irregular strands. There are longitudinally ellipsoid breaks in the thallus of this species which function as breathing-pores.

$H a b$. On trees in open places or in forests in lowland and upland districts.-Disti. General and fairly common throughout the British Isles.-B. M. Near Penzance, Cornwall; New Forest, Hants; Brading Downs and Bembridge, I. of Wight; Amberley, Shoreham and near (ilynde, Sussex; Epping Forest and Ulting, Essex; Cirencester, Gloucestershire; Harboro Magna, Warwickshire; Clungunford and near Shrewsbury, Shrophire; Cleveland, Yorkshire; Teesdale, Durham; Windermere, Westmoreland; Alston, Cumberland; near I3erwick-on-Tweed; New Galloway, Kirkcudbrightshire; near MIoffat, Dumfriesshire; Roslin and near Edinburgh, Midlothian; Barcaldine and near Oban, Argyll ; Blair Athole, Perthshire; Reeky Linn, Baldovan Woods and Rossie Moor, Forfarshire; Countesswells Wood, Invercauld, Craig Coinnoch and Glen Clunie, Braemar, Aberdeenshire; Glen Nevis, Invernessshire; Killarney, Kerry.

Var. ampliata Ach. Lich. Univ. p. 603 (1810).-Lacinixe very broadly developer, tapering or blunt at the tips, longitudinally and transversely nerved and wrinkled.-Cromb. in Grevillea vii. p. 141 (1879) (incl. f. monophylla); form amplintu Leight. Lich. Fl. ed. 2, p. 473 ; ed. 3, 1. 86 . Lichenoides lim!ifulium rugrosum rigidum Dill. Hist. Musc. p. 165, t. 22, fig. $59 \mathrm{c}$ (1741). Parmelin firanea var. ampliata Ach. Meth. 1. 259 (1803).

E.exicr. Bohl. n. 21 pro parte; Johns. n. 18 ; Larb. Lich. Hb n. 286 ; Leight. n. 38 .

Connected with the species by intermediate forms, though wellmarked in extreme specimens. The apothecia are usually abundant and sometimes very large.

$H a b$. On old trees, chiefly oak and ash, in wooded upland districts. -Disti. Father local and not plentiful in the British Isles.-B. M. Jartmoor, Devon; New Forest, Hants; Amberley, Sussex; Epping Forest, Essex; Bartonbury, Gloucestershire ; Gopsall Park, Leicestershire; Alfrie, Worcestershire; Oswestry, Shropshire; Barmouth and Aberdovey, Merioneth; Island of Anglesea; near Willington, Cheshire; Darley, Derbyshire; Ayton, Cleveland, Yorkshire; East Allendale. Northumberland; New Galloway, Kirkcurbrightshire; 13lair Athole, I'erthshire; Abergeldie, Braenar, Aberdeenshire; Fort Augustus, Invernessshire.

Var. calcariformis Nyl. in Bull. Soc. Linn. Norm. síx. 2, iN. 1. $136(1870)$. - Laciniae long and rather narrow, attentuate 
upwards, wrinkled and nerved. Apothecia marginal and subterminal.Cromb. in Journ. Bot. xx. p. 272 (1882).

Exsice. Johns. n. 183.

Distinguished by the persistently narrow fronds somewhat similar to those of $R$. calicaris, from which it diflers in the curved spores.

Hab. On the branches of trees in upland situations.-Distr. Rather rare in S.IV., W. and N.E. England and N. Wales.-B. $M$. Dartmoor, Devon; Pickeridge, near Taunton, Somer'set; near Barmouth, Merioneth; near Kendal, Westmoreland ; Lamplugh, Cumberland; Teesdale, Durham.

3. R. fastigiata Ach. Lich. Univ. 1. 603 (1810) pro parteThallus erect, rather rigid, of short crowded subequil fastigiate fronds, generally compressed, sometimes hollow, smooth or longitudinally wrinkled and nerved, greyish-green (medulla, K -). Apothecia numerous, terminal, on a broad base, plane or becoming convex, generally small or moderate in size (5 $\mathrm{mm}$. and under), wrinkled beneath, the disc pale greyish-green; spores oblong, ellipsoid, curved, 9-17 $\mu$ long, 5-7 $\mu$ thick.-S. F. Gray Nat. Arr. i. p. 406 ; Hook. Fl. Scot. ii. p. 68 \& in S'm. Engl. Fl. v. 1. 225; Tayl. in Mackay Fl. Hib. ii. 1. 85 ; Leight. Lich. Fl. ed. 2, p. 473 ; ed. 3, p. 86. R. calicaris var. fastigiatı Fr. Lich. Eur. p. :30 (1831) ; Mudd Man. p. 73 ; Cromb. Lich. Brit. p. 25; form fastigiatı Leight. Lich. F1. p. 94 (1871). Lichenside's cormutum bronchiale molle, subtus imanum Dill. Hist. Musc. p. 160, t. 21, fig. 55 B (1741) \& Lichenoides coralliforme, rustratum of canaliculatum, p. 170 , t. 23 , fig. 62 c. Lichen populinus Ehrh. Exs. n. 276 (1793), ined. L. fustigiatus Pers. in Ust. Ann. Bot. xii. p. 256 (1794); Engl. Bot. t. 890 (lower fig.). L. allicaris Huds. Fl. Angl. p. 451 pro parte; Lightf. Fl. S(*ot. ii. 1). $8.3 !$ pro parte.

E.rsirc. Croall n. 496 ; Bohl. n. 22 ; Larb. Lich. Ciesar. n. 60 : Lich. Hb. n. 287 \& Lich. Cantab. n. 6: Leight. n. 39 ; Mudd n. 43 .

Distinguished by the compact growth of the generally short lacinice, which tend to widen at the tipss into the base of the apothecia. Spermogones are rare, with minute spermatia about $3 \cdot 5 \mu$ long and $1 \mu$ thick.

Hal). On trees in wooded districts.-Distr. General and common in Great Britain, rare in the fir wooks of the Highlands, in Ireland and the Chamnel Islands.- $L$. II. Jersey; Cinernsey; near Penzance and Withiel, ('ornwall; near 'Toryuay, l)evon; New Forest, Hants; near liyde, I. of Wight; lieeding I'riory, Lewes, IIurstpiexpoint and Shoreham, Sussex; ('hiselhurst and P'enshurst, lient; near Croylon and Iieigate Hill, Surrey; Hainault Forest, Epping Forest and ('opthall Green, Issex; ('ireneester, Gloucestershire; Malvem aul Broadwas, Woreestershire; Causeway, Warwickshire; Aberdorey. Merioncth; Anglesen; Brome, near Oswestry and Shrewsburi. Shropshire; near Over, Cheshire; Frerselen Wood, Cambridgeshire; Charnwood Forest, Leicestershire; Cleveland, Yorkshire; Teesdale, l)urhan; near liendal, Westmoreland; Lamplugh, Cumberland : 
Nerv Galloway, Kirlicudbrightshire; Roslin and Bonally, Nidlothian; Bowling Bay, Dumbarton; Barcaldine, Argsll ; Loch Tay, Blaeberry Hill and Blair Athole, Perthshire; Guthrie and Tealing, Forfarshire; Den Fenella, Kincardineshire; Abergeldie and Craig Coinnoch, Braemar and Countesswells Wood, Aberdeenshire; Glen Nevis and Invermoriston, Invernessshire ; near Strathpeffer, Rossshire ; Lairg, Sutherland; Derriquin, Kerry.

Form minutula Cromb. in Grevillea vii. p. 141 (1879).Thallus of short slender much branched fastigiate lacinite. Apothecia not seen.- Ramalina farinacea var. mimutula Ach. Lich. Univ. p. 606 (1810); Th. Fr. Lich. Scand. i. p. 37 (1871). Lichenoides serymentis aryutioribus, ad margines verrucosis et pulverulentis Dill. Hist. Musc. p. 172, t. 23, fig. 63 \& (1741), firle Cromb. in Journ. Linn. Soc. xvii. p. 570 (1880).

Considered by Crombie and others to belong to the present species, of which it is probably a young and barren state.

$H a b$. On palings, chiefly larch, in wooded districts.-Distr. Local and scarce in S. England and in Scotland; probably overlooker.B. M. New Forest, Hants; Swanston near Edinburgh; Park, near Aberdeen; Lairg, Sutherland.

4. R. dilacerata Wain. in Medd. Soc. Faun. \& Fl. Fenn. xiv. pp. 14 \& 21 (1886).--Thallus small, in rounded cushion-litie groups, the lacinire soft, rounded or compressed longitudinally, nerved, subpellucid, branched, attenuate, pale straw-coloured (medulla $\mathrm{K}-$ ). Apothecia numerous, small, terminal, plane $\mathrm{or}^{*}$ convex, yellowish flesh-coloured or glaucous, smoothish beneath; spores oblong or fusiform-oblong, straight, 9-15 $\mu$ long, 4-6 $\mu$ thick.-R. calicaris f. minuscula Nyl. in Not. Sällsk. Faun. \& Fl. Fenn. v. p. 114 (1866). R. minuscula Nyl. in Bull. Soc. Linn. Norm. sér. 2, ir. p. $16+$ (1870); Cromb. in Grevillea xii. p. 142 it Monogr. i. p. 200. Lobarin dilacerate Hoffm. Dentschl. Fl. p. 140 (1795) (excl. syn. Dill.).

Of the same habit as the preceding, but distinguished by the small soft thallus and straight spores. The cortex is narrow, with a narrow ring of strengthening longitudinal hyphie; the medulla is loose and arachnoid.

$H a b$. On the branches of conifers and erratic on rocks in mountainous districts.-B. M. Craig Clumy, Braemar, Aberdeenshire (the only British record).

j. R. geniculata Hook. ¿ Tayl. in Lond. Journ. Bot. iii. p. 65:) (1844). - Thallus rather short, the lacinia smooth, longitudinally nerved, subcompressed, fistulose and frequently jer'forated, subfastigiately branched, ending in numerous narrow divaricate points, pale or pale straw-coloured (medulla $\mathrm{K}-$-). Apothecia moderate in size, sometimes rather larege, pale fleshcoloured, smooth or wrinkled below; spores oblongr or fusiformoblong, straight or slightly enreel, 9-15 $\mu$ lone, t-7 $\mu$ thick. 
Cromb, in Journ. Bot. xir. p. 360 (1\&76); Leight. Lich. Fl. ed. 3 , p. 90 .

An exotic species described first from $N$. Zealand; British specimens are confined to W. Ireland.

$H a b$. On stems of shrubs (thorns) in maritime districts. $-B . M$. Killery Bay, Connemara, Galway.

\section{Thallus corticolous, sorediate.}

6. R. farinacea Ach. Lich. Univ. p. 606 (1810) (incl. forms phaterata it pendulina, p. 607).- Thallus of rather narrow attenuate, generally compressed fronds, stiff or somewhat flaccid and pendulous, irregularly lacunose or obsoletely nerverl, pale greenish-glaucous, the marrins beset with roundish-ellipsoid soralia. Apothecia rare, pedicellate, small, terminal and lateral, smooth beneath, the disc greenish or pale reddish-brown; spores fusiform-ellipsoid, straight, $\$-16 \mu$ long, $4-7 \mu$ thick.-S. F. Gray Nat. Arr. i. p. 407 ; Hook. Fl. Scot. ii. p. 68 it in Sm. Engl. Fl. v. p. 225; Tayl. in Mackay Fl. Hib. ii. p. 85; Leight. Lich. Fl. ed. 2 , p. 472 ; edi. 3, p. 84 ; f. phateruta Cromb. in Grevillea vii. p. 141 (1879) \& f. pendelina op. cit. xv. p. 47 (1886). R. calicaris var. farinace Mudd Man. p. 73 (1861); Cromb. Lich. Brit. p. 25; f. farinarea Leight. Lich. Fl. p. 93 (1871). Lichenoides setmuentis anyustioribus, ad maryines verrucosis et fulcerulentis Dill. Hist. Musc. p. 172 , t. 23 , fig. 6.3 13, c, D, E (17 14 ). Lichen farinuceus L. Sp. Pl. p. 1146 (1753) ; Huds. kl. Angl. p. 451 : Lightf. Fl. Scot. ii. p. 833 ; With. Arr. ed. 3, ir. p. 50; Engl. Bot. t. 889. Parmelia farinacen Ach. Meth. Lich. p. 264 (1803) (incl. vars. pendulina \& pluterata).

Exsice. Cromb. 11. 22 ; Johns. nos. 57, 58; Leight. n. 40 ; Nudd n. 45 .

The thallus raries greatly, and may be very luxuriant in somewhat damp localities (f. pendulina) or short and stunted when opposite conditions prevail (f. phaterata). The strengthening hyphe occur in strands within the cortex, which is formed of shortly branching thickwalled hyphæ; the algæ lie in groups.

Ifab. On trunks and branches of trees in wooded districts.-Distr. (ieneral and usually plentiful in the Jritish Isles.-B. M. Boulay liay, Jersey; Penzance and Withicl, Cornwall ; New Forest, IIants; ('irisbrooke, I. of Wight; Iavington Common and Glynde, Sussex; I.ydd, lient; Shiere, Surrey; near (Yucnilon, near Loughton and Ifatfield Poverel, Essex; 1)yrievor Castle, Carmarthenshire; Anglesea ; liettws-y-Coed, Camarvonshire; Malvern and Broadwas, Woreester- hire; near ()swestry and Shrewsbury, Shropshire ; Newton, Cleveluml. Forkshire; Eorglestone, Inuham; Staveley, near Kental, Westmone. lund; Alston, Cumberland: New Galloway, Kirkcudbrightshire; near Elinburgh; Apuin, Argrll ; Loch Katrine, linlarig, Craig Calliach, Bhebery I Iill and Balthayock Woods, Perthshire; Baldoran Wood and liecky I,imm, lorfarshire; (Comtesswells Woods and Invereauld, Brachu, Aberdenshire; (ilen Veris and Invermoriston, Inverness. 
shire; Applecross, Rossshire ; near Cork; Dunkerron, Kerry; Glengarry Wood and Dugort, Achill Island, Mayo.

Subsp. intermedia Cromb. in Grevillea xv. p. 47 (1886).Lacini:e much branched, crowded, short, smooth, the ultimate branchlets slender, otherwise as in the species. $-\boldsymbol{R}$. minuscula subsp. intermedia Del. ex Nyl, in Bull. Soc. Limn. Norm. sér. 2, iv. p. 166 (1870). Li. intermedia Nyl. in Flora lvi. p. 66 (1873); Cromb. in Journ. Bot. xi. p. $1: 33$ (1873); Leight. Lich. Fl. ed. 3, p. 90 .

\section{Exsice. Larb. Lich. Hb, n, 248.} thallus.

Distinguished from the species by the smoother and more slender

Hab. On branches of shrubs in maritime districts.-Distr. Local and searce in the Channel Islands, S. IV. England, IV. Scotland and N.IT. Ireland.-B. M. Sark; Annet Island, Scilly; near Penzance, Cornwall; Killery Bay, Connemara.

7. R. pollinaria Ach. Lich. Univ. p. 608 (1810) - Thallus suberect, slightly shining, pale straw-coloured or glaucous-green, the lacinire compressed, elongate, often rather wide and somewhat flacid, very much branched, longitudinally and unequally wrinkled and lacunose, the edges often crispate or lacerate, soredia whitefalinose, scattered over the surface. Apothecia rare, subterminal, concave, moderate in size; spores oblong, straight or slightly curved, 10-15 $\mu$ long, 4-6 $\mu$ thick.-S. F. Gray Nat. Arr. i. p. 407 ; Hook. in Sm. Engl. Fl. v. p. 225 ; Tayl. in Mackay Fl. Hib. ii. p. 85 pro parte; IIudd Ian. p. 74 ; Cromb. Lich. Brit. p. 25 ; Leight. Lich. Fl. p. 95 ; ed. 2, p. 475 ; ed. 3, p. 87. Lichenoirles lacnuosum lacerum, latius et angustius Dill. Hist. Musc. p. 163, t. 21, fig. 57 D, E (1741). Lichen pollinarius W estr. in Vet. Acad. Handl. xvi. p. 56 (1795) ; Engl. Bot. descr. pro parte of t. 1607. L. farinaceus var. 3, With. Arr. ed. 3, iv. p. 51 (1796).

Exsicc. Cromb. n. 130 ; Mudd n. 46 pro parte.

Distinguished from $R$. farinace by the scattered soredia and by the generally wider fronds, from $R$. cernioiles by the longitudinal ribbing. It agrees with the latter species in the compact structure of the medulla and in the gelatinized firm cortex, but it is also further strengthened by some strands of hyphre within the cortex.

Hab. On old trees, rarely on rocks in wooded tracts.-Distr. General and common in S. and TV. England, local in N. Wales and the Chamnel Isliunds, rare in $\mathbf{S}$. Scotland and Ireland.- $/$. $.1 \%$. La lioche. Jersey; Sark; Treseo Island, Scilly; P'entire, The Lizard and neax Penzance, Colnwall ; Plymouth and streat, Devon; New Forest, Hants; near livile, I. of Wight; Henfield and near Lewes, Sussex; near Maidstone, Tient; Waltham Abbey, Essex ; Stowe P'ark, Bucks; Twyeross, Leicestershire; Haughmoni Hill, Shropshire; Inglely;. Cleveland, Yorkshire; Teesilale, Durham; near Iexhan, North. mmberland; near Skelton, Cumberland; New Galloway, Kirkeudbrightshire; Salisbury Crags, Edinburgh. 
Form humilis Cromb. in Journ. Bot. x. p. 73 (1872).Laciniar short, congesterl and complicate, often flexume; soredia large, often confluent. I jothecia very rare.-- Leight. Lich. Fl. ed. 2, p. 475 ; ed. 3, p. 88 . Var. lumilis Ach. Lich. Univ. p. $608(1810)$.

Exsicc. Larb. Lich. Hb. n. 208 ; Leight. n. 41 pro parte.

Distinguished from the species by the dwarfed, pulvinate habit of growth, and by the occasionally abundant soredia. Apothecia not seen on British specimens.

Hab. On trees, palings, etc., occasionally on rocks anil stones in maritime and upland regions.-Distr. Local though plentiful where it occurs throughout England, rare in Scotland.-B. $M$. Near Penzance, Cornwall ; Taunton, Somerset; near Lyndhurst, New Forest, Hants ; Penshurst, Kent; Gopsall, Leicestershire; Lakenham, Suffolk; Salisbury Crags, Edinburgh.

8. R. evernioides Nyl. in Act. Suc. Linn. Bord. sér. 3, i. p. 29:3 (1856).-Thallus greyish or greenish straw-coloured, suberect, of rather large plane irregular lacinia, variously branched and licerate, crowdedly reticulate-wrinkled and scrobiculitte (not longitudinally nerved), with scattered roundish superficial or marminal soralia frequently on the lines of the reticulation. Apothecia rare, marginal, moderate in size, wrinkled beneath ; spores oblong, slightly curved, $10-15 \mu$ long, :3-5 $\mu$ thick.Cromb. in Journ. Bot. x. p. 73 (1872) (incl. f. memophylla): Leight. Lich. Fl. ed. -2, p. 475; ed. 3, p. 88. Lichenoides lacunosum lucernm, latius et angustius Dill. Hist. Muse. 1). 163,

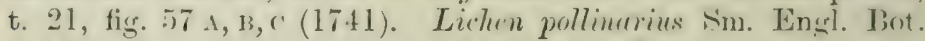
t. 1607 , fig. et descr. pro parte (1806) (non Westr.).

Exisier. Cromb. n. 131 ; Leight. n. 41 pro parte; 11 urlin n. fti pro parte.

Easily distinguished by the scrobiculate thallus from all forms of li. pollinuria with which it mainly anrees in the internal structure except for the strengthening strands, which are absent in this sprecies. The thallus, which varies greatly in the form and wirth of the lacinia. is rather flaceid. Crombie's f. monopliyllu is merely a growth form. R. evernioides is, in Europe, found only in the West.

Hab. On old trees, chiefly oaks, in wooded upland districts.listr. General and eommon in $\rightarrow$. and $\mathrm{W}$. Lingland and $\mathrm{S}$. and $\mathrm{J}$. Ireland; rare in the (hannel Islands, not seen from Scotland.--13. $M$. Endellion and 'T'intagel, ('omwall; Islington, s. Jeron; 'l'estwoor? Park and near byndhurst, New lorest, IImts; Pembridge, I. of Wight; Earnley, Eriche and Worthiner Sussex; near lieigate. Surrey; Braxted Pardi, Essex; Stowe P'ark, Jueks; Bourton-on-

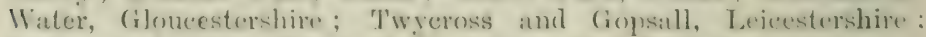
Anglesen; Juglehy, Cleveland, Yorkshire; near Jelfast, dutrim.

\section{Thallus saxicolous, withont sorediu.}

?. R. siliquosa A. L. sim.- Thallus upright, rimirl, smish-or yellowish-green, the fronds rather shining, varying in length. 
more or less compressed, smoothish or longitudinally furrowed and lacunose, generally rather narrow, branched and attenuate (medulla $\mathrm{K}+$ yellowish, then rusty-red, reaction often uncertain). Apothecia subpedicellate, marginal and subterminal, moderate in size, becoming convex, pale-reddish or glaucous; spores oblongellipsoid, straight or slightly curved, 1-2-19 $\mu$ long, $4-6 \mu$ thick.R. scopulom Ach. Lich. Univ. p. 604 (1810) (incl. vars. "uspidata \& cornuta); S. F. Gray Nat. Arr. 1. p. 406 (incl. var. cornuta, p. 407) ; Hook. Fl. Scot. ii. p. 68 \& in Sm. Engl. Fl. v. p. 225 ; Tayl. in Mackay Fl. Hib. ii. p. 85 ; Mudd Man. p. 74 ; Cromb. Lich. Brit. p. "25 \& Monogr. i. p. 196 (incl. var. incrussata); Leight. Lich. Fl. p. 91 ; ed. 2, p. 476 ; ed. 3, p. 88 (incl. var. incrassata). $R$. cuspidatı Nyl. in Bull. Soc. Linn. Norm. sér. 2, iv. p. 158 (1870) (incl. var. crassa, p. 159 ; Cromb. in Journ. Bot. x. p. 74 (1872); op. cit. xii. p. 147 (1874) (incl. var. rrassa) \& Monogr. i. p. 197 (incl. var. crassa) ; Leight. Lich. Fl. ed. 2 , p. 477 ; ed. 3 , p. 89 (incl. var. crassa, p. 90). Coralloides fasciculare verrucosum et veluti siliquosum Dill. Hist. Musc. p. 119, t. 17, fig. 38 (1741). Lichen siliquosus Huds. 1il. Angl. p. 460 (1758); With. Arr. ed. 3, iv. p. 40. L. scopulorum Retz. Obs. Bot. iv. p. 30 (1786); Dicks. Pl. Crypt. iii. p. 1s; With. tom. cit. p. 57 ; Engl. Bot. t. 688 .

Exsicc. Bohl. n. 112 ; Johns. nos, 59, 218: Larb. Lich. Hb. nos. 247,324 ; Leight. n. 2 .

The two species $R$. scopulorum and $l$. cuspidutu, which are here united under R. siliquosa (a name of older date), were differentiated by Nylander (l. c.) solely on account of the chemical reaction. Continued experience proves the extreme uncertainty of the test, as it seems to be associated with a varied exposure to sea water (M. C. Knowles in Sci. Proc. Roy. Dublin Soc. xiv. (N.S.), no. 6 (1913), jp. 87 and 88). With these should also be included $R$. armorica (Nyl. in Flora 1x. p. 562 (1877)) with the medulla $\mathrm{K}+$ yellow, recorded as a variety by M. C. Knowles (tom. cit. p. 123). A distinction recorded between spores is also misleading, as in both "species" they are straight or slightly curved, and black spots sometimes on the tips of the fronds are not confined to $R$. "uspidata. The vars. incrassata and crassa of the two "species" are also alike morphologically. The distorted form characteristic of them has been proved by Zopf (Ber. Deutsch. Bot. Ges. xxv. (1907) p. 233) to be due to insect action.

The lichen is provided with a stout band of longitudinal strengthening hyphx which projects irregularly into the medulla. The outer cortex is narrow and very gelatinous.

Hab. On rocks and boulders in maritime districts, rarely at at distance from the sea.-Distr. General and common on rocky coasts of the British Isles.-B. $M$. Guernsey; La Moye, Mount Orgueil and Grisnez Common, Jersey ; St. Mary's, Scilly ; St. Michael's Mount, Land's I'nd, Lamorna Cliff, 'l'intagel, The Lizard, St. Ireock, l'entire. Fowey and l'enzance, Cornwall; near Plymouth, Leigh Tor, Durtmoor, Bolt Head, Wembury and 'Torquay, Devon; I. of Wight: Tenby, Manortier and near Fishguar, l'embrolieshire; Aberistrith. 
Cardiganshire; ]3armouth, Aberdovey, Dolgelly and Harlech Castle, Merioneth; Pwllheli, Camarronshire; South Stacks, Anglesea; Port Soderick, Isle of Man; Holy Island and Dunstanborough, North. nmberlind; St. liees and near Whitehaven, Cumberland; Solwas. Firth, Firkeudbrightshire; Ailsa Craig and I. of Cumbrae, Firth of Clycle; Immerkip. Lienfrewshire; Tsle of May, Rivelston and Cramond near Edinburgh; Island of Mull and Airàs, Appin, Arryll; Westwater, Fifeshire; Kinnoul Hill, Perthshire; Banlss of the Tay and Turin Hill, Forfarshire; Portlethen, Fincardineshire; near Peterhend, Aberdeenshire; Invermoriston, Invernessshire; Applecross, Tiossshire ; Orkney Islauds ; Great Island, Cork ; Renoyle, Connemara ; The Bills, Clare Island, Achill Island and near Westport, Mayo; Ardglass, Down.

Form minor A. L. Sm. Thallus small, erect, with slender sparingly branched attenuate fronds. Apothecia small. - R. cuspielate t. minor Nyl. in Bull. Soc. Limn. Norm, sér. 2, iv. p. 159 (1870); Croml), in Grevillea vii. p. 141 (1879) \& Monogr. i. p. 198.

A much dwarfed condition about 1 inch in height.

Hab.- On dry exposed rocks in maritime districts.-Distr. Plentiful though local in the Channel Islands, S. and W. England and N.E. scotland, and probably elsewhere.-B. 1 . The Vale, Guernsey; Fower and near Penzance, Cornwall; Wembury, Deron; near Tenby, Penbrokeshire; Aberystwith, Cardiganshire; St. Bees, Cumberland; Portlethen, Kincardineshire.

Sulspp. breviuscula i. L. Sm.-Thallus of short lacinie, firm, congested, variously difform (medulla $k-$ ). Apothecia small or submoderate, the margin of the receptacle subcrenateR. polymorpher Tayl. in Mackay Fil. Hib. ii. p. 84 (15:36) pro parte; Leight. 1. 92 ; ed. 2, 1. 474 pro parte; ed. 3, p. 86 pro parte; Cromb. Lich. Brit. p. 25 pro parte; form depressi Cromb. in Journ. Bot. x. 1). 72 (15i2). R. scoputorum var. polymoryha Mudd Man. p. 74 (1861) (non Ach.). R. cuspidteta f. breciusenla Nyl. in Bull. Soe. Limn. Norm. sér -2, iv. p. 159 (1870); subsp. Irrinseula Nyl. ex. Cromb. in Grevillea vii. p. 141 (1879) it Monogr. i. p. 198.

Exsicc. Leight. n. 73 ; Mudd n. 47.

A very deformed-looking plant not unlike vars. crassa and incrassnta. In some of the snatler states it is closely appressed to the substratum.

Hab. On rocks in maritime districts and on mountains.-Distr. Iather mare in the Chamnel Islands, S. II. and N. England, N.T.

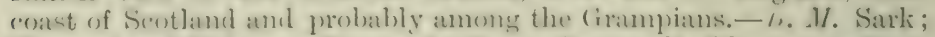
'I'intuge.l and Polperro, Cornwall ; (iowere l'eninsula, Glanorganshire;

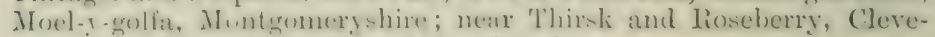
land, Yorkshire; Portlethen, Kincardineshire.

Fum gracilescens A. L. Sm.- Thallus small, congesterl fulvinater fhe laciniar shortly mueh divided at the apices which are often incurved, or revolute and curled.-- Li. conspidata subsp. 
Treviuscula f. gracilescens Cromb. in Grevillea vii. p. $1+1$ (1879) \& Monogr. i. p. 199.

The Irish specimens listed below have the characteristic growth of this form; they give the reaction hi + yellow, medulla becoming red. The lierry specimen was collected three miles from the sea.

$H a b$. On rocks, etc., at or near the sea.-Distr. Rather rare in the Channel Islands, S. England and E. and WT. Ireland, probably overlooked elsewhere.-B. M. Guernsey; Sark; near Brighton; Cloghane, Kerry; Achill Island, Mayo.

10. R. Curnowii Cromb. ex Nyl. in Flora lviii. p. 441 (1875). -Thallus subrigid, slender, rounded or slightly compressed, sparingly branched, pale greyish-green, blackish at the base (medulla K-). Apothecia marginal-geniculate and terminal, rather small, becoming convex, smooth below; spores ellipsoirl, straight, 11-15 $\mu$ long, 4-6 $\mu$ thick.-Cromb., in Grevillea iv. p. 180 (1876) ; Leight. Lich. Fl. ed. 3, p. 90.

Exsice. Cromb. n. 129 ; Larb. Crsar. n. 13.

Very near the preceding species. Though the medulla is unaffected, the cortex, at least in some specimens, takes a red stain with potash. The apothecia and spermogones are frequently numerous; the latter are blackish, thus, according to Nylander, suggesting affinity with $R$. carpathica, a Hungarian species in which the margin of the apothecium is black. The spermatia measure $3 \mu$ long, $1 \mu$ thick.

Hab. On rocks in maritime districts.-Distr. Common in the Channel Islands, S.TV. England and WV. Ireland.-H. 1\%. Grisnez Common, Jersey; St. Mary's, Scilly ; St. Michael's Mount, near Land's End, and Penzance, Cornwall ; Clare Island, Mayo.

\section{Thallus saxicolous, sorediate.}

11. R. subfarinacea Nyl. in Flora lvi. p. 66 (1873).-Thallus erect or subpendulous, pale-greenish or greenish-grey, formed of tufts of crowded branched rather narrow compressed lacinia, smooth or slightly channelled, attenuate and often nuch divided upwards.; soralia numerous, ellipsoid or roundish, marginal (medulla and soredia $K+$ yellowish, then rusty-red). Apothecia rare, small, marginal or subterminal, hecoming convex; spores oblong, straight, $12-15 \mu$ long, $4-6 \mu$ thick.-Cromb. in Grevillea xv. p. 47 (18r6i). R. culicuris vas. thranstu Mudd Nan. 1) 7:3 (1861) (non Ach.) ; Leight. Lich. Fl. 1.94 juo parte. Ii. seopularum var. sul, farinacen Nyl. ex Cromb. in Journ. Lot. x. p. 74 (1872) ; Leight. Lich. F1. ed. 2, p. 476 ; ed. 3, p. 89.

Exsicc. Cromb. 1. 23 ; Johns. 1. 19 ; Larb. Lich. Hb. n. 323.

A stonter plant than li. jarinaren, which it partly rescubles in habit and structure, more especially in the form and position of the soralia. It differs in the well-marked reaction with potash and in the saxicolous habitat. It oceurs in small tufts or occisionally forms extensive swards. 
Hub. (On rockis amd old walls in maritime and upland districts.1)istr. General and common where it occurs on rocky shores or momntainons tracts of the Jritish Isles.-P. M. Alderney; La Coupe, Tersey; Ammet Island, Scilly; Land's End, The Lizard and near Penzance. Cornwall ; near Plymouth, Iry Bridge and Dartmoor, Deronshire; Malvern Hills, Worcestershire; Long Mrnd, Shropshire; near Dolgelly and Harlech Castle, Merioneth; Moel-y-golfa, Montgoneryshire; Iieddgelert and Snowdon, Carnarvonshire; Langbraugh, Cleveland, Yorkshire; near. Hexharn, Northumberland; near Staveley, Westmoreland; Peuruddock and St. Bees, Cumberland; Airds, Appin. Argyll; Killin, Perthshire; Portlethen and Crathes, Fincardineshire; Banchory-Devenick and Morrone. Braemar, Aberdeenshire; Applecross, Rossshire.

12. R. polymorpha Ach. Lich. Unir. p. 600 (1810) pro parte. -Thallus rigid, compressed, irregularly lacunose and longitudinally nerved, rather short ( $5 \mathrm{~cm}$. or less), pale-greenish, the margins and surface of the lacinia dotted with granular ellipsoid soralia $(\mathrm{K}-$ ). Apothecia very rare, marginal or subterminal, concave, small, wrinkled or smoothish below; spores oblong, straight or almost straight, 11-16 $\mu$ long, 4-5 $\mu$ thick.-Croml. Lich. Brit. p. 25 pro parte; Leight. Lich. Fl. ed. 2, p. 474 pro parte ; ed. 3, p. 87 (incl. f. ligulata). Lichen polymorplus Ach. in Tet. Acad. Handl. xviii. p. 270 (1797) pro parte.

Distinguished from allied rock forms ly the soralia. British specimens are sterile. Strands of strengthening hyphe lie within the outer cortex.

$H a b$. On exposed alpine or maritime roclis. .' I. . M. I'ortlethen, Kincardineshire (the only British locality).

Var. emplecta Ach. Lich. Univ. p. 601 (1810).-Lacinia: more slencler, very much branched and tapering.-Cromb. in (rrevillea xv. p. +7 (1886) ; f. emplecta Leight. Lich. Fl. ed. ¿2, I. +75 pro parte: ed. 3, p. 87 pro parte. P'armelia polymorplua var. emplecta Ach. Meth. Lich. p. 267 (1803).

Hal. On rocks and boulders in mountainous resions.-Distr. Local and scarce in the N. Grampians, Seotland.- I3. M. Nenr Loch Callater, Braemar, Aberdeenshire.

13. R. capitata Nyl. in Bull. Suc. Limn. sér. .2, vi. p. 2.5̇ (1872). -Thallus short, mlaucous or pale-green, the lacinia compressed, much branched, esprecially near the tips, wrinkled longitudinally and lacunose; soralia globose, singly or more on the olituse apices. Apothecia very rare, terminal or subterminal, the receptacle becoming wrinkled on the under side; spores oblong, straight or slightly curved.- R. polymorphu var. copitulu Ach. Lich. Univ. 1) Gol (1810) (incl. Var. strepsilis): subsp. caprituta Syl. ex Cromb. in (irevillea vii. p. 141 (1879): Cromb. Monogre. i. p. 19:i. Ii. pulymerplua Hook. in sm. Engl. Fl. v.

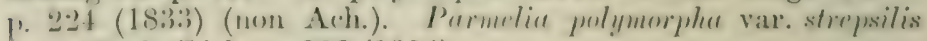
Ach. Meth. Lich. p. 266 (1803). 
Differs from the preceding in the position of the soralia and in the consequent short fronds. The anatomical structure is practically the same; the strong strands of strengthening hyphse sometimes meet, forming a bridge across the medulla.

$H a\}$. On rocks, in mountainous regions.-Distr. Local and scarce in N. England (?) and in the N. Grampians, Scotland.-B. M. Bennaboord, Aberdeenshire.

42. USNEA Dill. Hist. Nusc. p. 56 (1741) pro parte; Adans. Fam. Pl. ii. p. 7 (1763). (Pl. 42.)

Thallus filamentous, upright or pendulous, generally cylindrical, variously branched, often scabrid, greyish-green or yellowish, attached at the base by a sheath or by a penetrating holdfast; structure radiate with a firm chondroid central axis, or very rarely hollow, the cortical layer thin. Algal cells Protococcus. Apothecia mostly rather large, lateral or terminal, peltate, the dise usually rather light-coloured with a thalline, generally ciliate margin; hypothecium colourless, with underlying gronidia; paraphyses concrete, branched and septate; asci 8 -spored; spores small, ellipsoid, simple. Spermogones lateral, immersed or slightly protuberant, light or dark coloured with sparingly branched sterigmata and acrogenous spermatia.

Our species of Usnea occur chiefly on trees in forests, and the pendulous forms may attain a length of $1 \mathrm{ft}$. or more; occasionally they grow on rocks. Nearly all are sorediate, and in some species the soredia develop on the parent plant as lateral branchlets. Fleshcoloured tubercles-called pseudo-cephalodia-are frequently formed, and are irregularly scattered over the filaments. They are composed of dense hyphæ which rise from the gonidial tissue; no gonidia are enclosed in these tubercles, which are only abortive apothecia.

1. U. florida Web. in Wigg. Prim. Fl. Hols. p. 91 (1780).Thallus erect, one or several main stalks rising from the base, repeatedly forked, terete, about $1.5 \mathrm{~mm}$. in cliameter, finely verruculose, sometimes becoming bare and almost smuoth, secondary branches more slender, patent, both primary and secondary generally beset all round with short or elongate horizontal fibrils, and frequently scabrid with soredia, palegreyish or greyish-green. Apothecia plane, moderate in size or large up to about $1 \mathrm{~cm}$. in diameter, geniculate or apparently terminal, the margins bordered with long slender cilia which are occasionally branched and sparsely fibrillose; spores shortly ellipsoid, 7-11 $\mu$ long, 6-7 $\mu$ thick.-S. F. Gray Nat. Arr. i. p. 403 (incl. var. rubiginer); Hook. Fl. Scot. ii. p. 70 \& in sim. Engl. Fl. v. p. 226 ; Cromb. in Journ. Linn. Soc. xvii. p. 55j (1880); var. rubiginea Ach. Lich. Univ. p. 621 (1810)? L. ceratina var. seabrosa Ach. Lich. Univ. p. 6:0 (1810)? Cromb. in Journ. Bot. $\mathrm{xx} .1$. $272(1582)$ it Monogr. i. p. 206 pro parte (imel. f. ferruginasens Cromb. in Trans. Essex Field Club, iv. 1. (jo (1885) jor parte. U. bubuta var. foride Fr. Lich. Fur. p. 1s 
(1831): Mudd Man. p. 69, t. 1, fig. 15: Cromb. Lich. Brit. p. 23 ; ff. floristn and rubiginen Leight. Lich. Fl. pp. $83 \& 86$ (1871) ; ed. :3, pp. 7.5 it 77 pro parte. U. Mirate var. fluride Tayl. in Mackay Fl. Hib. ii. p. 86 (18:36). U. intexta Stirt. in Scott. Nat. v. p. 102(1880). U. mbicmula Stirt.1. c. U. subluridu Stirt. 1. c. Ti. crmetsifula Stirt. op. cit. vi. 1) 109 (1<81). U. sul).

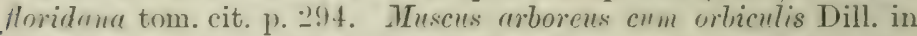
Pay Syn. ed. :3, p. 65, n. 6 (1724). Usinen vulgatissima tenuion it brevior, chim wromelis Dill. Hist. Muse. p. 69, t. 13, fig. 13) (17£1). Lichen fluridus L. Sp. Pl. p. $115 t$ (17.53) : Huds. Fl. Angl. p. 463 ; Lightf. Fl. Scot. ii. p: 897 : With. Arr. erl. 3, iv. p. 50 ; Engl. Bot. t. 872 .

E.rsirr. Cromb. 11. 16 ; Johns. n. 21 ; Larb. Lich. Hb. n. 285.

Distinguished by the constantly erect habit, the well-dereloped apothecia, and by the generally crowded horizontal fibrils; these are mostly smooth, but occasionally they tend to become verrucose like the main stem, and eren sorediate, forming a transition to the more constantly sorediate var. 7ivte. Both the species and the rariety are ocersionally tinged red; a condition indicated in the varieties and forms rubiginca, ferruginascens and mbicunda. The new British species described in Stirton's papers are based on various chemical reactions.

$\mathrm{Hab}$. On the branches of trees, rarely on rocks, in woods and forest..-Distr. General and not uncommon throughout Great Britain, rare in the Channel Islands.-B. M. Island of Guernsey; Iboulay Bay, Jerser ; Boconnoc and near l'enzance, Cornwall ; Lydford, near Totnes, Olichampton and Becky Falls, Devon; New Forest, Hants; near Tunbridge Wells and near Hastings. Sussex ; near Lydd, Iicnt; Haslemere, Surrey; Hay Coppice and Whitfeld, Herefordshire; Dynevor Castle, Carmarthenshire; Conway Falls, Hafod and Ijettws-y-Coed, Carnarronshire; Anglesea; Gibside Woods, Durham; Ambleside, Westmoreland; New Galloway, Firkcudbrightshire, Pentland Hills near Edinburgh; Appin and near Inverary, Argrll; Craig Calliach and Stronachlachan Woods, Killin, Perthshire; Durris Woods. Tincardineshire; Ballochbuie Forest, Braemar and Countess. wells Woods. Aberdeenshire; Invernoriston, Invernessshire; Clare Island, Mayo.

Tar. hirta Ach. Meth. Lich. p. 309 (180:3).-.-Thallus rather short, nearly arect, carespitose', crowdedly branched and fibrillose, the fibrille and secomilary branches slender, frequently long, forked and curving, and generally more or less beset with soredia. Apotheria very rare, wather small : spores $(6-8 \mu$ long, $4-6 \mu$ thick. Ir. livitu Ifuffin. Dentschl. Fl. 1. $1: 33$ (1795) : Cromb. in Journ. Linn. Soc. xvii. p. 555 (1880) \& Monogr. i. p. 203.

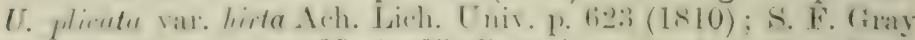
Nat. Arr. i. p. 404; Hook. Fl. Scot. ii. p. 70 \& in Sm. Engl. F1. v. p. 226 ; Tayl. in Mackay Fl. Hib. ii. p. 86 . U. barbut vax. hirta Fr. Lich. Lux. p. 18 (1831); Mudd Man. p. 69; f.

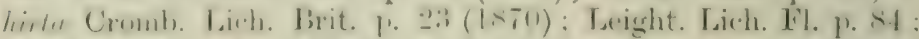
ed. 3, p. 76. U. subpectimulu stirt. in Scott. Nat. v. p. 10 s 
(1880). Usmea velyutissima tennior et brevior, sine arbiculis Dill. Hist. Musc. p. 67, t. 13, fig. 12 (17+1). Lirhen hirtes L. SP. PI. p. $1155(1753)$ : Huds. Fl. Angl. p. 46:; Lightf. Fl. Scot. ii. p. 895 ; With. Arr. ed. 3 , iv. p. 46.

\section{Exsice. Leight. n. 1 pro parte; Mudd n. 35.}

Smaller and more entangled than the species and more commonly; sorerliate. It is perhaps more a growth form due to moist conditions than a variety, as though fairly well marlied, there are intermediate stages. As in so many sorediate lichens, apothecia are rare. The specimens with reddish tinted thallus belong partly to the species and partly to the variety.

Hab. On old palings and on the branches of trees in wooded neigh. bourhoods.-Distr. General and fairly abundant throughout the British Isles.-B. M. Guernsey; Rozel, Jersey; near Penzance and Withiel, Cornwall; Coryton and Becky Falls, Devon; New Forest, Hants; near Ryde, I. of WVight; near Hastings, St. Leonards Forest, near Balcombe, Maplehurst and Haywards Heath, Sussex; near Writtle, Messing and Hainhault Forest, Essex; neal Sapperton and near Cirencester, Gloucestershire; Gopsall, Leicestershire; Stiperstones, near Oswestry and Haughmond Hill, Shropshire, Cemmes Road, Montgomeryshire; Nannau, Dolgelly, Merioneth; Conway Falls and Bettws-y-Coed, Carnarvonshire; Anglesea; Ayton and Ingleby, Cleveland, Yorlishire; near Hexham, Northumberland; Ashgill and Calder Abbey, Cumberland; New Galloway, Trirkendbrightshire; near Moffat, Dumfriesshire; Pentland Hills, neav Edimburgh; Inverary and Appin, Argyll; Killin, Perthshire; Rossie Woods, Forfarshire; Muchalls, Trincardineshire; Park, near Aberdeen, and Mar Forest, Braemar, Aberdeenshire; Rothiemurchus Woods, Invernessshire; Lairg, Sutherlandshire; Asliew IVood, Kerry; Achill Island, Mayo; near Belfast, Antrim.

Var. mollis Hue in Nouv. Arch. Nus. Hist. Nat. Paris sér. 4, i. p. 35 (1899).-Thallus pale-grey, erect, with a stout base, with rather long branchlets and the central axis very slender.-Usnea mollis Stirt. in Scott. Nat. vi. P. 109 (1881). Specimen not seen.

Collected near New Galloway, Kirheulbrightshire; recorded also from Brazil, Japan and Africa.

2. U. cornuta Kuerb. Parerg. Lich. p. ¿2 (1 859$)$. - Thallus piale, erect, crespitose, stiff, distinctly articulate, scircely branched, rough with minute papille or soralia, the apices sorerliate, incurved. Apothecia pallid, small or moderate in size, the margins ciliate; spores small, simple, 9-11 $\mu$ long, $7-9 \mu$ thick.Sitirton in Scutt. Nat. vi. p. 10:) (1880). Specimen not secu.

Hab.-On rocks. Recorded by Stirton from S. Ingland and S. Scotland.

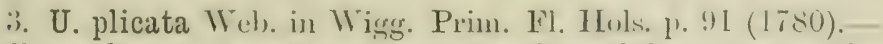
'Thallus suberect, becoming elongate and pendulous, terete, the cortex becoming ringed and rerrucose-sorediate, sparingly fibrillose and varionsly hanched, the bronches patent, dillise, often 
entangled, verrucose and sparingly fibrillose, pale greenish-grey or yellowish. Apothecia rare, moderate in size or rather large, concolorous, sometimes pruinose, the margins with long cilia: spores $7-9 \mu$ long, $5-7 \mu$ thick. -S. F. Gray Nat. Arr. i. p. 403 (incl. var. comose? ): Hook. Fl. Scot. ii. p. $70 \&$ in Sm. Engl. Fl. p. 226. U. ceratina Ach. Lich. Univ. p. 619 (1810); Cromb. in Journ. Linn. Soc. xvii. p. 554 (1880) \& Monogr. i. p. 205 (incl. var. seabrosa pro parte). U. barbata var. plicata Fr. Lich. Eur. p. 18 (1831); Mudd Man. p. 69 ; Cromb. Lich. Brit. p. 23 pro parte; f. plicata Leight. Lich. Fl. p. 85 (1871) ; ed. 3, p. 76 pro parte; var. ceratina Schær. Lich. Helv. Spicil. p. 505 (1840); Cromb. in Journ. Bot. x. p. 232 (1872) ; f. ceratinu Leight. Lich. Fl. p. 85 (1871); ed. 3, p. 77. U. scubrata Nyl. in Flora lviii. p. 103 (1875). U. comosa Stirt. (? Ach.) \& U. nitida Stirt. in Scott. Nat. vi. p. 294 (1882)? U. dasypoga var. scabrutu Cromb. in Grevillea xv. p. 48 (1886) \& Monogr. i. p. 205. Muscus arborcus: Usnea officinarum Dill. in Ray Syn. ed. 3, p. 64, n. 1 (1724). Usnea valyaris loris longis implexis Dill. Hist. Muse. p. 56, t. 11, fig. 1 (1741). Lichen plicatus L. Sp. Pl. p. 1154 (1753); Huds. Fl. Angl. p. 461 ; Lightf. Fl. Scot. ii. p. 889; With. Arr. ed. 3, iv. p. 50 ; Engl. Bot. t. 257 ?

Exsicc. Johns. n. 20; Leight. n. 1 pro parte; Mudd nos. 34,36 .

$U$.plicata is synonymous with $U$. ceratina and includes forms partly upright and others entirely pendulous. It is characterized chiefly by the long frequently entangled branches and branchlets which soon begin to hang down, and by the fewer and more seattered fibrils than in the previous species. The amnular breaks in the cortex and the coarsely verrucose character of the thallus though generally evident are not sufficiently or obviously typical, hence the varying and conflicting descriptions of this plant.

Hal. On the trunks and branches of trees, occasionally on rocks. -Distr. General and somewhat common throughout (ireat Britain. - B. M. Annets Island, Scilly; Roughton and Boconnoc, Comwall; Ivy Bridge, Arton, Lydford, near Totnes, near Becky Falls and Hunter's 'Tor, Dartmoor, Devon; I. of Wight; Woodeote Wood and Lyndhurst, New l'orest, Hants; Ardingly and Bexhill, Sussex; Lydd, Kient; near Malvern, Worcestershire; Haughmond Hill, shrop. shire; Nannau, near Dolgelly and Harlech, Merioneth; Hafod, Cardignnshire; Anglesen; Ayton Moor amd Ingleby P'ark, Cleveland, Yorkshire; Ashgill and Lamplough, Cumberland; New Galloway, Kirkcudbrightshire; Appin, Argyll ; Stronachlachan Woods and Ben Iawers, Perthshire; Ballochbuie Forest, Jirnemar, Aberdeenthire; Rothiemurehus, Invernessshire; Cawdor Woods, Naim, Niginshire.

4. U. barbata W(b. in Wiggs. Prim. Fl. Ilols. p. 91 (1780).'Thallus rather slender, pendulous, elengate, branched, scabrous with minute verruea, the branches long, divergent, generally with short patent crowded fibrils, greenish or pale-sreyish. A pothecia rare, usually small, pale or thesh-coloured with ciliate margins; 
spores ellipsoid, 9-11 $\mu$ long, 6-7 $\mu$ thick.-S. F. Gray Nat. Arr. i. p. 404 pro parte; Hook. Fl. Scot. ii. p. 70 pro parte; var. lasopoga Schær. Enum. p. 4 (1850); Mudd Man. p. 69; f. dasypoga Cromb. Lich. Brit. p. 23 (1870); Leight. Lich. Fl. p. 81 (1871); ed. 3, p. 76 . U. plicata var. dasopoya Ach. Meth. Lich. p. 312 (1803). U. dasypoya Stiz. in Verh. St. Gall. Nat. Ges. p. 202 (1876) ; Cromb. in Journ. Linn. Soc. xvii. p. 555 (1880) \& Monogr. i. p. 203. Usnea barbata, loris tenuibus fibrosis Dill. Hist. Musc. p. 63, t. 12, fig. 6 (1741). Lichen barbatus L. Sp. Pl. p. 1155 (1753)? Huds. Fl. Angl. p. 461 (1762); Lightf. Fl. Scot. ii. p. 890. L. articulatus Sm. Engl. Bot. t. 258, tig. 2 (1795).

Exsicc. Johns, n. 219.

Distinguished among pendulous species by the more slender minutely scabrous branches and by the crowded horizontal fibrils on the older parts of the thallus.

$H a b$. On the trunks of trees, chiefly firs, in wooded upland regions. -Distr. Rather rare in England, commoner among the Grampians, Scotland.-B. M. Rhewgreidden, Merioneth; Teesdale Forest, Durham; Ingleby, Cleveland, Yorkshire; Stronachlachan, Killin and Ben Lawers, Perthshire; Deerhill Wood, Forfarshire; Mar Forest, Aberdeenshire; Rothiemurchus Woods, Invernessshire.

Var. pendula Heb. Howe Class. Fam. Usn. Amér. Nord. Paris, p. 14 (1912).--Thallus smooth, irregularly branched, the branches very sparingly or not fibrillose, the ultimate branches very slender.-U. plicata Ach. Lich. Univ. p. 622 (1810); Tayl. in Mackay Fl. Hib. ii. p. 86. U. barbate var. plicute f. pendula Scher. Enum. p. 4 (1850). U. dasypoya var. plicata Cromb. in Grevillea xr. p. 48 (1886) \& Monogr. i. p. 204 pro parte. Lichen plicatus Ach. Lich. Suec. Prodr. p. 225 (1798) (non Linn.); Engl. Bot. t. 257.

A variety somewhat doubtfully referred to this species, owing to the rather dense branches which are, however, almost destitute of horizontal fibrils. The references of English authors refer partly to this variety and partly to Usnea plicata, under which they are quoted.

Hab. On the branches of trees, chiefly larch, in wooded mountainous regions.-Distr. Rare in Wales, N. England.-B. M. Craig (alliach, Perthshire; near Corriemulzie, Braemar, Aberleenshire; Dulcie by the Findhorn, Elginshire.

5. U. articulata Hoffin. Deutschl. Fl. ii. p. 13:3 (1795).Thallus pendulous, elongate, nearly smooth, flaceil, much branched, the older primary tilaments constricted at intervals, the articulations variously inflated, sometimes very large, and apart on the central axis, the branchlets slender, sparsely and finely fibrillose and entangled, occasionally sorediate, pale greyishgreen or pale tawny-yellow. Apothecia rare, small, pale, 
sparingly ciliate; spores $8-10 \mu$ long, $5-6 \mu$ thick.-Cromb. in Journ. Linn. Soc. xvii. p. 554 (1880). U. barbate var. articulate Ach. Meth. Lich. p. 313 (1803) ; S. F. Gray Nat. Arr. i. p. 404 (1821); Hook. Tl. Ścot. ii. p. 70 \& in Sm. Engl. Fl. v. p. 227 : IIudd Man. p. 69 ; f. articulate Cromb. Lich. Brit. p. 23 (1870); Leight. Lich. Fl. p. 85; ed. 3, p. 77 ; var. intestiniformis Ach. Lich. Uriv. p. 625 (1810); f. intestiniformis Cromb. in Grevillea xv. p. 48 (1886) \& Monogr. i. p. 207. U. Jarbata Hook. in Sm. Engl. Fl. v. p. 226 (1833) pro parte. $U$. constrictula Stirt. in Scott. Nat. v. p. 109 (1880)? Mincus arboreus nodosus Dill. in Ray Syn. ed. 3, p. 65, n. 4 (1724). Usnea capillacea ct nodosa Dill. Hist. Muse. p. 60, t. 11, fig. 4 (1741). Lichen witiculatus L. Sp. Pl. p. 1156 (1753); Huds. Fl. Angl. p. 462: With. Arr. ed. 3, is. p. 48, inol. var. barbatus; Engl. Bot. t. 258 , fig. 1 .

Exsicc. Cromb. n. 17 ; Dicks. Hort. Sicc. fasc. 14, n. 24.

Distinguished by the ringed and constricted inflations of the cortex of the primary brauches. In form intestiniformis these are slightly exaggerated in size. Apothecia have not been found in this country, though abortive fruits are occasionally produced.

$H a b$. On the trunks of old trees in shady woods and forests in upland districts.-Distr. Fairly general though becoming local and scarce with the disappearance of the old forests.-L.M. Liskeard, Cornwall; Exmouth Warren, near Exeter, Arton, Braunton Down and Becky Falls, Devon; Appuldurcomb and Ventnor, I. of Wight; Boldrewood and Lyndhurst, New Forest, Hants; Charlton Forest. Sussex; Enfield Chace, Herts ; near Stokenchurch, Oxford; Cwm Bychan, near Barmouth, Merioneth; Denbighshire; Hafod, Carli. ganshire; Burnley, Lancashire; Stronachlachan Woods, Rillin and Brachlin Falls, Perthshire; Deerhill Woorls, Forfarshire; Portmarnock, near Dublin.

43. ALECTORIA Ach. Lich. Univ. p. 592 (1810) pro parte: emend. A. Zahlbr. in Engler it Prantl Pflanzenf. i. 1*, p. 21! (1907). (Pl. 43.)

Thallus filamentous, erect or pendulous, branched, cylindrical or partly compressed, attached by a basal sheath; structure radiate, the merlulla of loose hypha or partly hollow, the cortical layer fibrous, formed of hypher parallel with the long axis of the plant. Algal cells Protorocens. Apothecia lateral on bent or straight branches, marginate, the margin rarely ciliate, the dise brown or blackish: hypotherium colourless with underlying sonidia ; paraphyses branched ; spores $4-8$ in the ascus, ellipsoid. simple, colourless or hrownish. Apermogones in small lateral tubercles; sterigmata sparsely branehed, with plemrogenous short spermatia slightly thickened at each end.

A genus of upland or momntain plants. Occasionally the thallus hecomes free from the substratum by decity of the lower part of the thallus, growth still continuing at the tips. 


\section{Thallus mostly light in colour.}

1. A. ochroleuca Nyl. in Mém. Soc. Ści. Nat. Cherb. v. p. 9s (1857).-Thallus erect, caspitose, the main branches stoutish, rather flattened, soraliate and impressed-lacunose, the ultimate branchlets numerous, spreading, more cylindrical, slender and attenuate, ochroleucous or whitish straw-coloured, the apices recurved and usually blackish ( $\mathrm{Kf} \pm$ vellowish, $\mathrm{CaCl}=$ ). Apothecia rare, rather large, sessile, brownish-red or blackish, the margin stoutish and inflexed or almost excluded; spores becoming brown, 28- $42 \mu$ long, 14-24 $\mu$ thick.-Mfudd Man. p. 70 ; Cromb. Lich. Brit. p. 24 ; Leight. Lich. Fl. p. 87; ed. 3, p. 79. Lichen ochroleucus Ehrh. Beitr. iii. p. 82 (1788); Dicks. Pl. Crypt. fasc. iii. p. 19 ; With. Arr. ed. 3, iv. p. 46 pro parte ; Engl. Bot. t. 2374. Cornicularia orholeuce Ach. Lich. Univ. p. 61t (1810); Hook. Fl. Scot. ii. p. 69 \& in Sm. Engl. Fl. v. p. 228.

Exsicc. Cromb. n. 126.

The dark colour is confined to the apices in British specimens, though in the Arctic regions it extends over the greater part of the thallus. Apothecia are borne on the thicker branches.

$H a b$. Among mosses and gravelly soil in alpine places.-Distr. Confined to the higher Grampians, on or near their summits. $-B . M$. Cairngorm and Cairntoul, Braemar, Aberdeenshire; Clova MIts., Forfarshire.

Form tenuior Cromb. in Journ. Bot. x. p. 232 (1872).Thallus smaller, decumbent, the branches more slender and somewhat entangled. Apothecia small, pale reddish-brown.-Leight. Lich. Fl. ed. 3, p. 79. Lichen sarmentosus Sm. Engl. Bot. t. 2040 (smaller fig.) fide Crombie.

This form has been considered by Crombie as belonging to the above species rather than to $A$. sarmentosa. In one single specimeu there is only a slight trace of dark colour at the apices. It is not to be confused with $A$. crinalis Leight. which is a synonym of $A$. ochero. leuca var. cincinnata.

Ha). On sterile ground in alpine places.-B. M. Ben Luighal, Sutherlandshire, the only locality.

Var. cincinnata Th. Fr. Lich. Arct. p. 27 (1860).-Thallus lecumbent, sparingly branched, entangled, cylindrical or unipually compressed, impressed-lacunose, pale greenish sulphurcoloured, generally with an apical tuft of slender branchlets which are sparingly blackish, the whole thallus often tinged here and there bluish-black. - Leight. Lich. Fl. p. s8 ; ed. 3, p. 79 ; t. rincinnutre Cromb. Lich. Brit. p. 24 (1870); var. surmentuse Cromb. Lich. Brit. p. 24 (1\$70); var. crinalis Le inht. Lich. Fl. p. So (1\$il). A. sumentrese S. F. Ciray Nat. Arr. i. p. 40s (18:-1): IIouk. Fl. Serot. ii. p. 6r di in sm. Engl. Fl. v. p. 2.27; Mudd Man. 1. T0; var. riucinuatu Nyl. in Flora lii. 1) 444 (18199): Cromb. in

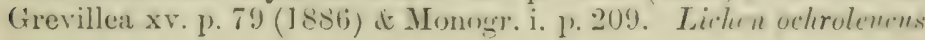


With. Arr. ed. 3, iv. p. 46 (1796) pro parte. L. sarmentosus Sm Engl. Bot. t. 2040 (1809) (larger figure).

Exsicc. Croall n. 398 ; Cromb. n. 18.

More closely akin to A. ochoroluca than to A. sarmentosa in the colouration and in the type of branching, though of more straggling habit than the species.

Hab. On the ground in alpine places creeping loosely over mosses. (.tc.-Distr. Local though plentiful on the higher Grampians, Scotland. - B. M. Summit of Morne, Ben-naboord, Ben Macdhui, Cairngorm, Morrone and Invercauld, Braemar, Aberdeenshire; Ben Luighal, Sutherlandshire.

2. A. sarmentosa Ach. Lich. Univ. p. 595) (1810).-Thallus pendulous or decumbent, remotely branched and entangled, more or less impressed-lacunose, compressed at the axils, the apices long and attenuate, whitish straw-coloured. Apothecia small, lateral, the disc dark reddish-brown; spores 2 to 4 in the ascus, becoming brown, $15-36 \mu$ long, 14-30 $\mu$ thick.-Cromb. in Journ. Bot. xiii. p. 140 (1875). A. ochelenea var. samentesa Nyl. Syn. Lich. i. p. 282 (1860); Leight. Lich. Fl. ed. 3, p. 79. Usnea Inris longis dichotomis, extremitatibus tennioribus Dill. Hist. Muse. p. 59, t. 11, fig. 2 (1741)? Lichen sarmentosus Ach. in Vet. Akad. Handl. 1795, p. 212, t. 8, fig. 2.

The thallus of this species is long and straggling and without the tufted apical branches of the preceding species, from which it also differs in the uniformly light colour.

Hab. Among mosses on the ground.-H. M. ('airngorm, Braemar, Aberdeenshire.

3. A. thrausta Ach. Lich. Univ. p. 596 (1810).-Thallus slender, pendulous or prostrate, subcylindrical, occasionally compressed, especially at the axils, smooth, shining, pale strawcoloured; branching frequent, the hranchlets slender, tapering, often soraliate at the tips (medulla $\mathrm{K}-$ ). Apothecia unknown.Ramalina colleoris var. throusta Fr. Lich. Eur. p. 30 (1831); ILudd Man. p. 7:3? subsp. throusta Cromb. Lich. Brit. p. 25 pro parte; f. throustn Laight. Lich. Fl. p. 94 (1S71). Ti. thraustu Nyl. in Bull. Soxe Linn. Norm. sér. 2, ir. 1. 116 (1N70); Leight. Iich. Fl. ed. 2 , p. 470 ; ed. 3, p. 8.3 of in Amm. Mag. Nat. Hist. sér. 4, ix. 1. 126 (1872); Cromb. in Joum. liot. x. p. 71 (1872) d Monogr. i. p. 187.

Of uncertain systematic position in the absence of apothecia, lut the structure of the cortex is that of Alectoria, being composed of thick-walled branching hyphat parallel to the long axis of the plant. The alge lie in groups.

Hal. On trees or on rocks or sandy soil in northern recrions on high altitudes. - 3. M. Bay of Nigrg, lineardineshire, the only British locality but now extinct. 
4. A. implexa Nyl. ex Norrl. in Med. Soc. Faun. \& Fl. Fenn. i. p. 14 (1876).-Thallus pendulous, elongate, slender, much branched and entangled, greyish-yellow or greyish, soralia very rare $(\mathrm{K} \pm, \mathrm{CaCl}-)$. Apothecia and spores as in $A$. jubata, very rare.-A. jubate var. cana Ach. Lich. Univ. p. 593 (1810). A. cana Leight. Lich. Fl. p. 88 (1871). A. capillaris Cromb. in Journ. Bot. x. p. 233 (1872) ; Leight. Lich. Fl. ed. 3, p. 79. Usnea implexa Hoffm. Deutschl. Fl. ii. p. 134 (1795). Parmetia jubata var. capillaris Ach. Meth. Lich. p. 273 (1803).

Similar in habit to $A$. jubata, but more slender and of a lighter colour and with a positive reaction with potash. British specimens are sterile.

Hab. On the trunks of old firs in mountainous districts.-Distr. Local and rare in N. England and the Grampians, Scotland.-B. M. Killin, Perthshire; Deerhill IVood, Forfar; Glen Derrie, Braemar, Aberdeenshire; Rothiemurchus Woods, Invernessshire.

Thallus mostly dark in colour.

5. A. nigricans Nyl. Lich. Scand. p. 71 (1861).-Thallus caspitose, rigid, erect or ascending, cylindrical or somewhat compressed, dichotomously and intricately branched, impressed. lacunose at the axils, and more or less deflexed and slender at the tips, rather dull chestnut-black, paler towards the base $(\mathrm{K}+$ medulla yellow at base, $\mathrm{CaCl}+$ medulla reddish). Apothecia lateral, rather large, chestnut-brown, the margin thin, at length excluded; spores colourless, 21-35 $\mu$ long, 15-20 $\mu$ thick.-Carroll in Journ. Bot. iii. p. 287 (1865); Cromb. Lich. Brit. p. 24 ; Leight. Lich. Fl. p. 87 ; ed. 3, p. 78 . Corniculariu "chroleuca var. nigricans Ach. Lich. Univ. p. 615 (1810).

Exsice. Cromb. n. 19.

Similar in habit to A, ochrolenca, but differs in colour. Herbarium specimens are generally easily recognized by the reddish tinge given to the paper on which they are mounted. Spermogones occur towards. the apices, but apothecia have been found only in Labrador and Arctic America. A specimen in the Sowerby Herbarium is said to have been collected by Harriman at Teesdale, Durham.

Hab. Among mosses on the ground and on rocks in alpine and cubalpine localities.-Distr. Somewhat local, but usually plentiful on the higher Grampians, Scotland; very rare in Wales, doubtful in $\mathrm{N}$. England.-B. $M$. Cwm Bychan, Merioneth; The Glyders, Carnarvonhire; Teesdale, Durham? ] Ben Lawers, Mael Girdy, Ben-y-Gloe and Cain Gowar, Blair Athole, Perthshire; Ben-naboord and Ben Macdhui. Braemar, Aberdeenshire; Ben Nevis, Invernessshire.

6. A. bicolor Nyl. in Act. Śoc. Linn. Bord. sér. 3, i. 1) ¿291 (1856).-Thallus cespitose, erect, cylindrical, irregularly and lensely branched and intricate, the branchlets patent, short, sender or subfibrillose, the apices usually somewhat curved, black "r. brownish-black. Apothecia lateral, small, very rame, blackish; 
spores ellipsuid, colourless, small, 7 -r $\mu$ long, j-6 $\mu$ ihick.-IIudd Man. p. 70 ; Cromb. Lich. Brit. p. 2:3; Leight. Lich. Fl. 1). 86 ; ed. 3, p. 78. Muscus comlloides lone nigrex instar saxis urliserens Dill. in Ray Syn. ed. 3, p. 65, n. 3 (1724). Usne' lanæ nigræ instar saxis adhærens Dill. Hist, M[use. p. 66, t. 1:, fig. S (1741). Lichen bicolor Ehrh. Beitr. iii. 1) 82 (1788) ; Engl. Bot. t. 1853. L. lanatus Huds. Fl. Angr. p. 461 (176.) (non L.) : Jightf. Fl. Scot. ii. p. 892 ; With. Arr. ed. 3, iv. p. 47. Cormi'mlaria bicolor Ach. Neth. Lich. p. 304 (1803); S. F. Gray Nat. Arr. i. p. 405 ; Hook. Fl. Scot. ii. p. 69 \& in Sm. Engl. Fl. r. p. 228 .

Exsicc. Cromb. n. 127 ; Mudd n. 39.

Allied to $A$. jubata, but differs in the persistently darker colour and generally saxicolous erect or prostrate habit. The apothecia have been gathered only in the Himalayan Mits. The spermogones are minute, with spermatia $8 \mu \mathrm{long}, \cdot 05 \mu$ thick.

Hab. On rocks and boulders among mosses in upland and sub. alpine regions.-Distr. Frequent and sometimes abundant in hilly regions of $\mathrm{WV}$. and N. England, N. Wales and the Highlands of scotland, rare in N.E. Ireland.-B. M. Helminton, Cornwall ; Hay Tor, Bovey Tracey, Dartimoor, Lustleigh Cleeve and Walkington. Devon; Capel Arthog, Llyn Bodlyn and Cader Idris, Merioneth: Anglesea; Farndale, Yorlishire; Teestale, Durham; Kentmere, Westmoreland; New Galloway, Kirkcudbrightshire; Ben-A'an, near Taymouth, Corrie, Uachlar, Ben Lawers, Ben More and Rannoch, Perthshire; Canlochan, Forfarshire ; Lochnagar, Aberdeenshire: Craigellachie, Banffshire; Ben Luighal, Sutherlandshire; Antrim.

7. A. divergens Nyl. Syn. Lich. p. 278 (1860) pro parte: Lich. Scand. p. 71 (1861).-Thallus rigid, erect or prostrate. frequently branched, cylindrical or subangular, shining, brownish chestnut-coloured, the branches dichotomous, diverging $(\mathrm{K}-, \mathrm{CaCl}$ medulla + red). Apothecia very rare, bright-brown, the margin usually crenulate or rough; spores 8 in the ascus, colourless, ellipsoid, small, $8-10 \mu$ long, $4 \cdot 5-5 \cdot 5 \mu$ thick.- Cromb. in Journ. Bot. xi. p. 133 (1873) ; Leight. Lich. Fl. exl. : p. 78. Comirulurin diveryens Ach. Meth. Lich. p. 30:3, t. (i, fig. 1 (1803).

Not unlike cetrariu aculeata in outward appearance, but the thallus is generally stouter and never spinulose. It reaches it:highest rlevelopment in Aretic regions. Apothecia have not been found on British speeimens; they are recorded only from N.F. Asia.

Hab. On the ground among mosses in alpine places.-B. MI. (itimgom, Bracmar, Aberteenshire, the only british locality.

․ A. jubata Arh. Jieh. T'niv. 1. 59:2 (1810) pro parte'Thallus filiform, penduluus, subeylindrical, slightly compressed at the axils, smowth, much branched, more or less soraliate. olive-isown or brownish-erey to -hlack, the branches wary. contangled. Apothecia rare, small, innate, plane or convex, the 
wargin entire, at length excluded, the disc dull subfuscous; spores small, colourless, 6-9 $\mu$ long, $4-5 \mu$ thick.-S. F. Gray Nat. Arr. i. p. 408 ; Hook. Fl. Seot. ii. p. 67 \& in Sm. Engl. Fl. v. p. 227 ; Tayl. in Mackay Fl. Hib. ii. p. 86 ; Mudd Man. p. 70 pro parte; Cromb. Lich. Brit. p. 24 ; Leight. Lich. Fl. p. 88; ed. 3, p. 80. Muscus corcellimus saxutilis foniculacens Dill. in Ray Syn. ed. 3, p. 65 (1724). Usnea jubata nigricans Dill. Hist. Yusc. p. 64, t. 12, fig. $7(17+1)$. Lichen jubatus L. Sp. Pl. p. 1155 (1753) pro parte; Huds. Fl. Angl. p. 461 pro parte; Lightf. Fl. Scot. ii. p. 891 pro parte; With. Arr. ed. 3, iv. p. 46; Engl. Bot. t. 1880 pro parte.

Exsicc. Bohl. n. 83 ; Croall n. 397 ; Cromb. n. 128 ; Johns. n. 247 ; Leight. n. 72 ; Mudd n. 37.

Erect when young, but becoming pendulous and often very much tangled. The colour varies very considerably. Small prominent rimmed soralia are frequent on the stouter branches. Spermogones are rare; they are enclosed in scattered thalline tubercles; the spermatia minute, $6-7 \mu$ long, $\cdot 05 \mu$ thick.

$H a b$. On the trunks and branches of old trees, chiefly pine and larch, more rarely on boulders among mosses, in wooded upland and subalpine regions.-Distr. General and sometimes abundant in hilly and mountainous regions-B. M. Roughton, Cornwall; Hay Tor and Vixen Tor, Dartmoor, Devon; New Forest, Hants; Tunbridge Wells, St. Leonards, Balscombe and Pond Leigh, Sussex; Charnwood Forest, Leicestershire; Phewgreidden, Dolgelly and near Barmouth, Merioneth; Anglesea; near Kingley, Warwickshire; near Oswestry, Shropshire; Malvern, Worcestershire; Chatsworth, Derbyshire; Baysdale and near Great Ayton, Yorkshire; Teesdale, Durham; Keswick and Alston, Cumberland; The Cheviots, North. umberland; New Galloway, Kirlicudbrightshire; Beld Craig, Moffat, Dumfriesshire ; Pentland Hills, near Edinburgh ; Appin, Argyll ; Glen Falloch, Tillin, Ben Lawers and Knock of Crieff, Perthshire; Deerhill Wood and Rossie Moor, Forfarshire; Ballochbuie Forest, Ballater, Craig Cluny, Mar Forest and Morrone, Braemar and Countesswells Wood, Aberdeenshire; Rothiemurchus Woods, Glen Nevis and Glen IIoriston, Invernessshire ; Cawdor, Nairnshire; Lairg, Sutherland.

Var. lanestris Ach. Lich. Univ. p. 593 (1810).-Thallus smaller, decumbent, rather soft, sparingly soraliate, the branches numerous, short, slender, densely entangled.-Form lanestris Cromb. in Journ. Bot. x. p. 233 (1872); f. tenerima Cromb. in Grevillea xv. p. 48 (1886).

A small prostrate variety to which Crombie has referred the upper tigure in Engl. Bot. t. 1850. Form tenerrima is still shorter and more tangled, somewhat resembling Ephecbe in appearance. No fructification has been observed.

Hab. On fir palings and trunks of birch trees.-Distr. liare in upland distriets.-B. M. Helsby Hill, Cheshire; Killin, I'erthshire; J Sallochbuie Forest and Morrone, Bruemar, Aberteenshire.

Subsp. subcana Nyl. ex Cromb. in Journ. Bot. xiv. 1) 360 (1876).-Thallus pendulous, slender, of moderate length, much 
branched, greyish; soralia numerous, rather prominent. Apothecir not seen.

More slender and less entangled than the species, and of a lighter colour. The numerous soralia and the absence of reaction with potash distinguish it from $A$. implexa.

$H a b$. On the branches of old firs in wooded mountainous regions. - Distr. Local and rare among the Grampians, Scotland-B. $M$. Ben Lawers, Perthshire.

Subsp. chalybeiformis Th. Fr. Lich. Scand. p. 25 (1871).Thallus decumbent, flexuose, stouter and more rigid than the species, olive- or brownish-black, the branches short, remote sometimes a little paler at the apices; soralia rather rare. Apothecia not seen.-Cromb). in Grevillea xr. p. 48 (1886). Var. rhalybeiformis Ach. Lich. Univ. p. 593 (1810); Hook. Fl. Scot. ii. p. 57 d in Sm. Encl. Fl. v. p. 227 ; Mudd Man. p. 70 ; Cromb. Lich. Brit. p. 24 ; Leight. Lich. Fl. p. 89 ; ed. 3 , p. 80. A. chalybeiformis S. F. Gray Nat. Arr. i. p. 408 (1821). IIuscus raule rigido, instar fili chalibei Dill. in Ray Syn. ed. 3, p. 65 n. 2 (1724). Usnea rigida horsum vorsum extensa Dill. Hist. Husc. p. 66, t. 13, fig. 10 (1741). Lichen chalybeifomis L. Sp. Pl. p. 1155 (1753); Huds. Fl. Angl. p. 462 ; Lightf. Fl. Scot. ii. p. 892 ; With. Arr. ed. 3, iv. p. 47.

Exsice. Larb. Lich. Hb, n. 245 \& Lich. Cantal), n. 7 ; Mudrl n. 38 .

Sometimes regarted as a species, but too closely akin to Alectoria jubuta to be worthy of separate specific rank. Neither apothecia nor spermogones have been found on British specimens. A. jubata generally grows on trees, while this subspecies is uniformly a rock plant.

Hub. Among mosses on rocks and boulder's in upland and mountainous districts.-Distr. General and not uncommon in Iinglind and $\mathrm{x}$. Wales, plentiful among the Grampians, Scotland; not re. corded from Ireland.-B. M. Templemore, Deron; Eridge rocks near Tunbridge Wells, and Ardingly rocks, Sussex; Herefordshire Jieacon near Malvern; Cader Idtris, II erioneth; Snowlon, Carnarronshire; Anglesen; Thetford Wirren, Norfolk; Battersby Cleveland, Yorkshire; Gatesheal Fell, Durhann; Suldale, Vestmoreland; Ben ('ruachan. Argyll; Jen More and lien Liwers, Perthshire; Cloval Mts., l'orfarshire; Craig Coinnoch. (ilen Cluny, Lochnagar, 13ennaboord, Craig Guie and Morrone, Bracmar, Aberdeenshire : Ben Nevis and Loch Ennich, Invernessshire; Hoy, Orkney.

44. CERANIA S. F. (iray Nat. Arr. i. 1. 413 (18:1). Thamnolia Ach. in litt. ex Scher. Enum. p. 243 (1850). (Pl. 44.)

Thallus of upright stalk-like fromds, cylindrieal, sparingly hranched, tapering upwards: the contex of small cells : medullia of parallel hypher, hollow in the centre. Algal cells Plenrocorens. Apothecia not rightly known. Spermogones immerserl, in small 
warts, with pleurogenous short cylindrical straight or slightly bent spermatia.

The position of the genus is uncertain in the absence of definite knowledge as to the reproduction of the plant. Massalongo (in Flora xxxix. p. 232) and Th. Fr. (Lich. Arct. p. 161) represent the apothecia as terminal and immarginate somewhat like those of Cladonia, with simple colourless spores. According to Minlis (in Flora lvii. p. 337) the fruits are pyrenocarpous and are united in lateral stromata.

1. C. vermicularis S. F. Gray 1. c.-Thallus erect or mostly prostrate, fronds simple or sparingly branched, smooth or somewhat grooved, somewhat solitary or in dense tufts, chalky-white ( $\mathrm{K}+$ yellow). Apothecia doubtful.-Thamnolia vermicularis Scher. Enum. p. 243 (1850); Mudd Man. p. 68 ; Cromb. Lich. Brit. p. 23 ; Leight. Lich. Fl. p. 83 ; ed. 3 , p. 75. Lichen vermicularis Swartz in Linn. fil. Meth. Musc. p. 37 (1781); Dicks. Pl. Crypt. fasc. ii. p. 23, t. 6, fig. 10 ; With. Arr. ea. 3, iv. p. 41 ; Engl. Bot. t. 2029. Cladonia vermicularis DC. Fl. Franc. ii. p. 355 (1805); Hook. in Sm. Engl. Fl. v. p. 234; ILudd Brit. Clad. p. 34. Cenomyce vermicularis Ach. Lich. Univ. p. 566 (1810); Hook. Fl. Scot. ii. p. 65.

Exsice Croall n. 399 ; Cromb. n. 13.

Easily recognized by the form and habit resembling small white worms. The pycnidia are very rare with spermatia, 4-5 $\mu$ long, $1 \mu$ thick.

$H a b$. On the ground among mosses and heaths in alpine and mountainous regions.-Distr. Very local and rare on the mountains of N. Wales, N. England and Scotland.-B. M. Cader Idris, Merioneth; Skiddaw, Cumberland; Ben Lawers, Craig Calliach and Ben Vrackie, Perthshire; Clova IIts. and Canlochan, Forfarshire; Lochnagar, Morrone, Miltown of Invercauld, Ben-naboord and Cairntoul Braemar, Aberdeenshire; Ben Nevis, Invernessshire; Hills of Applecross, Rossshire.

Var. taurica A. L. Sm.-Thallus more turgid, suberect recurved, cornute and pointed at the apices.-Lichen tauricus Wulf. in Jacq. Coll. ii. p. 177, t. 12, fig. 2 (1788). Thamnolia vermicularis var. taurica schær. Enum. p. 244 (1850); Cromb. in Journ. Bot. xxiii. p. 195 (1885) \& Monogr. i. p. 185.

Differs from the species in the stouter thallus.

Hab. On the ground in alpine places. $-B$. M. Near the summit of Cairngorm, Braemar, Aberdeenshire.

\section{ORdER XII. PHYSIACEÆ.}

Thallus fruticose, foliose, squamulose or crustaceous, yellowcoloured, grey or brown. Structure various. Algal cells Protococcus. Apothecia discoid, marginate or rarely immarginate; 
spores colourless or brown, 1 -septate, with thick outer walls and septum, the latter generally pierced by a longitudinal canal (polarilocular), rarely simple or 3-septate. Spermogones chambered, the sterigmatia cellular (arthrosterigmata), with short pleurogenous spermatia.

The genera in this order are distinguished in most cases by the peculiarly septate spores. The median septum develops by an ingrowth from the outer wall, and though occasionally a narrow band, it sometimes broadens to such an extent that the lumen of the cells is reduced to a small space. A few species with simple or with is-septate spores are included in the genera, owing to other typical characters, such as the form of the spermogones, \&c.

Parietin, a rellow acid which rields an immediate purple or crimson colouration on the application of potash, is characteristic of several of the genera : of all those with yellow-coloured thalli except Candclariella, The latter genus is howerer included in the order as the spores, though mostly simple, often become septate and polarilocular.

The British genera are :-

Parictin present (yellow lichen acid coloured crimson or purple with potash).

Spores colourless, usually 1 -septate.

Thallus fruticose, yellow

Thallus foliose, yellow

45. Teloschistes.

Thallus squamulose or crustaceous, mostly yellow

46. Xanthoria.

47. Placodium.

Parietin not present.

Spores colourless, at first simple, often many in the ascus.

Thallus crustaceous

48. Candelariella.

Spores brown, usually 1 -septate. Colour various.

Thallus foliose, rarely fruticose or sub. fruticose......

49. Physcia.

Thallus squamulose or crustaceous ...... 50. Rinodina.

15. TELOCHISTES Norm, in Nyl. Mag. Naturvid. Christ. vii. 1. 228 (1852) excl. I'hyllothalle ice. Burrera Ach. Syn. Lich. 1). 200 (1814) pro parte: S. F. Gray Nat. Arr. i. p. 434 pro parte; Hook. Fl. Scot. ii. p. 56 d in Sin. Engl. Fl. v. p. 222 pro parte. Physcin Sichel). (ien. Pl. ecl. 8, ii. p. 768 (17!) 1) pro parte: Nurld Man. p. 111 pru parte: Cromb. Lich. Brit. p. 37 d Monoge. i. p. 294 pro parte: Leight. Lich. Nl. p. 141: ed. :3, p. 130 pro parte. (Pl, 45.)

'Thallus frutionse, brightly coloured, yellow, upright or partly decumbent, the frourls brancherl, eylindrical or compressed, attacherl at the hase: structure racliate, the cortex of longiturlinal hyphar (tihrous). Aleal rells Protomerens. Apothecia 
discoid, with a thalline margin; hypothecium colourless; paraphyses simple, or shortly branched at the apices, septate; spores 8 in the ascus, colourless, polarilocular, 1-septate, rarely moreseptate.

This and the following genus have been includer in Plyyscia by recent British authors. It is distinguished by the fruticose character of the thallus, and by the colour of the spores; the fibrous cortex gives the necessary support to the fronds.

1. T. flavicans Norm. 1. c.-Thallus erect or almost decumbent, yellow or orange-yellow, the fronds narrow, cylindrical or somewhat compressed, branched and entangled, often minutely nodulose, and fibrillose at the apices; yellowish-white soralia

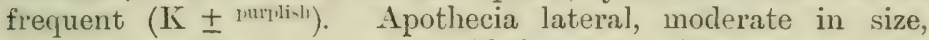
becoming plane or convex, reddish-yellow, the margin thin, subcrenulate; spores polarilocular, $12-18 \mu$ long, $7-11 \mu$ thick.-Inscus arborcus an'eus segmentis capillaceus brevibus Buddle Hort. Sicc. fol. 9, n. 7 in Herb. Sloane. Muscus unreus tenuissimus: Dill. in Ray Syu. ed. 3, 1. 65), n. \& (1724). Usnea rapillacea citrina, fruticuli sperie Dill. Hist. Muse. p. 7:3, t. 13, f. 16 (1741). Lichen vulpinus Huds. Fl. Angl. p. 462 (1762) non Linn.; Lightf. Fl. Scot. ii. p. 896 ; With. Arr. ed. 3, iv. p. 49 . L. flavicans Siwartz Fl. Ind. Oecid. iii. p. 1908 (1788); Engl. Bot. t. 2113. Parmelia flaticans Ach. Meth. Lich. p. 268 (1803); Tayl. in Mackay FI. Hib. ii. p. 147. Borrera flavirens Ach. Lich. Univ. p. 504 (1810); Hook. Fl. Scot. ii. p. 57 it in Sm. Engl. Fl. v. p. 224 ; var. læte Ach. Syn. Lich. p. 225 (1814). Physcia flaticans DC. Fl. Fr. vi. p. 189 (1\$15); Mudd Man. p. 112, t. 2, f. 3.3 ; Cromb. Lich. Brit. p. 37 ; Leight. Lich. Fl. p. 141 ; ed. 3, p. 130. Borreru lata S. F. Gray Nat. Arr. i. p. 435 (1821).

Exsicc. Carroll Lich. Hib. nos. 5, 6 ; Cromb. n. 48 ; Larb. Cresar. n. 21 ; Leight. n. 169 ; Mudd n. 84.

Though usually of a beautiful golden colour, it varies in becoming it dull green in the shade and is sometimes paler on one surface. The apothecia are very rare in l3ritish specimens; the spermogones are more frequent.

Hab. On trees and shrubs, sometimes on rocks or walls, chiefly in maritime (listrict..-1)istr. Esually plentiful where it occurs, in S. and W. Scotland, N. Wales, S. Freland and fornerly in S.WF. Scotland (Ailsa Craig). B. M. Sark; Alderney; Guemsey; Jersey; bioconnoc, Penzance, Withiel and liede, Cornwall; near Totnes. Jiutmoor. Becky Fialls, Lydford, Widldicombe, South lirent and Torquay, Devon ; Boldrewood and Hrockenhurst. New Forest. IIants; near Ventnor, Shanklin. Appuldureombe and livde, I. of llight; Arlingly, Up Park. St. Leonards Forest, near Hastings, Fanilight (ilen and Lewes, Sussex; Dungeness and Lydd, lient; Malvern Hill. Worestershire; Aberdovey and Hamouth, Merioneth; Jholyheal. inglesen; Killarney, liery; Whiting liuy, Witerford; near ('orli.

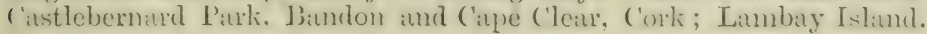
Dublin. 
2. T. chrysophthalmus Th. Fr. Gen. Heterolich. Eur. p. 51 (1861). - Thallus short, rigid, growing in tufts, bright greenishyellow, the fronds narrow, compressed, plane or channelled, much-branched and fibrillose at the tips and sometimes on the margins $\left(K \pm{ }^{\text {rurplish }}\right)$. Apothecia rather large, terminal or subterminal, concave then almost plane, deep orange-coloured with a ciliate or sometimes entire margin; spores 11-17 $\mu$ long, 6-10 $\mu$ thick.-Lichenoides pulmonarius minimus subluteus, receptaculis florum coronatis, mali aurantii coloris Dill. Hist. Musc. p. 74, t. 13 , f. 17 (1741). Lichen chrysophthalmus L. Mant. ii. p. 311 (1771) ; Engl. Bot. t. 1088. Borrera chrysoplethalma Ach. Lich. Univ. p. 502 (1810); S. F. Gray Nat. Arr. i. p. 435 ; Hook. in Sm. Engl. Fl. v. p. 223 ; Mudd Man. p. 11.2, t. 2, fig. 31 (incl. var. Dickieana). Physcia chrysophthalma DC. Fl. Fr. ii. p. 401 (1805); Cromb. Lich. Brit. p. 37 (incl. var. Dickieana) \& Monogr. i. p. 296 (incl. f. Diclieana); Leiglit. Lich. Fl. p. 141 ; ed. 3 , p. 131 (incl. f. Dickieana). P. villosa var. Dickieana Linds. in Trans. Roy. Soc. Edin. xxii. p. 254 (1859).

Exsicc. Bohl. n. 122 ; Carroll Lich. Hib. n. 3 ; Larb. Cæesar. n. 22 ; Leight. n. 394.

Easily distinguished from the preceding by the shorter, more strap-like fronds. The thallus is often greyish-green and sometines almost white (var. Dickicana), an effect of habitat and degree of exposure to light, \&c. Apothecia are usually abundant.

Hab. On trees, rarely on old palings, in maritime districts.Distr. Rather local and scarce in the Channel Islands, S. Englaud, W. Scotland and S. and N. Ireland.- M. M. Rozel and St. Peter's Valley, Jersey; Sark; Guernsey ; near Torduay, Devon; near Ryde, I. of Wight; near Brighton, Shoreham and Lewes, Sussex; Kilbritain and near Cork; Nucrone, Kerry; Newcastle, Down.

46. XANTHORIA Th. Fr. Lich. Arct. p. 66 (1860); emend. Lich. Scand. p. 144 (1871) (excl. X. concolor). Plyssciu Schreb. Gen. Pl. ed. 8, ii. p. 768 (1791) pro parte; Mudd Man. p. 111 pro parte; Cromb. Lich. Brit. p. 37 \& Monogr. i. p. 294 pro parte; Leight. Lich. Fl. p. 141 ; ed. 3, p. 130 pro parte. (Pl. 46.)

Thallus foliose, horizontal, or partly ascending, lobate, brightly colourerl, sometimes sorediate, beneath more or less rhizinose and generally paler; cortex on both surfaces of plectenchyma. Apothecia seattered, discoirl, moderate in size, with a thallıne margin ; hypothecium colourless; paraphyses discrete, septate, shortly branched at the clavate apices; spores s in the ascus, 1-septate, polarilocular.

Differing from Treloschistes in the character of the thallus and iu the cortical structure.

1. X. parietina 'Th. Fr. Lich. Aret. P. $67(1860)$ pro parte if Lich. Siemd. p. 115) (1871).-Thallus suborbieular in ontline. yellow, the lobes apluressed imbricate, somewhat wrinkled, 
rounded and crenulate at the circumiference $(K+$ vinlet-purplish). Apotbecia moderate in size, numerous and crowded towards the inntre of the thallus, "oncave, hecoming plane, subconcolorous, with a thin entire margin: spores $12-16 \mu$ lone, $7-9 \mu$ thick. -

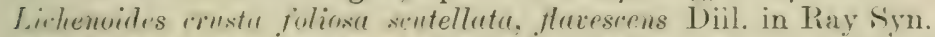

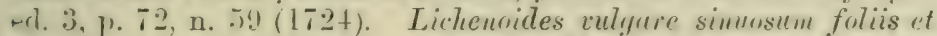
arntrllis luteis Dill. Hist. IIusc. 1) 180, t. 24, fig. $76(1741)$. Lirhen umietims L. SI. Pl. p. $11+3$ (1753); Huds. Fl. Angl. 1. 447: Lightf. Fl. Secot. ii. p. 822 ; Engl. Bot. t. 194; With. Arr. ed. :3, iv. 1. :34; Relh. Fl. Cantab. 1. 428. L. juniperinus. Hurk. Fl. Angl. 1. 452 (176-2) (non Linn.): Lightf. Fl. Scot. ii. 1. *:36. Parmelia parietiua Ach. Meth. Lich. p. 213 (180:3): $\therefore$ F. Gray Nat. Arr. i. p. 438 ; Hook. Fl. Scot. ii. p. 52 it in Sim. Engl. Fl. v. p. 204 ; Tayl. in Mackay Fl. Hib. ii. p. 141. Plipsria parictima De Not. in Mem. R. Accarl. Torino ser. 2. x. 1.. Ax (1849): Mudul Man. 1. 113; Cromb. Lich. Brit. p. 38 it

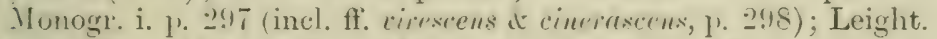
Livh. Fl. 1. 14:2 ; ed. 3, 1. $1: 31$ (incl, var. polyeurpa f. cineruscrns); f. viridescens Cromb. in Journ. Linn. Soc, xvii. p. 572 (1880).

Exsicc. Bohl. n. 12 ; Johns. 11. 84; Larb. Lich. Hb. n. 9 d Lich. Cantab. n. 10; Leight. n. 10; Mudd 11. 85.

I brilliantly coloneal lichen where illunination is good, but green a. grey when shaled from direct light. The change in colour has -iven rise to the forms rirscens and cinerescens now includerl in the - Hecies), which also grive in fainter reaction with potash owing to the small production of the colouring crystals of parietin. In such inecimens there are always some traces of brighter colour in the thallus, and the apothecial dises are more or less orange.

Hab. On trees, palings, walls and rocks, sometimes on peaty soil. 4...t frequently in maritine districts. - Disis. (ieneral and plentiful in the British Isles.-W. M. Ilsham Valley, Torquay, Deron; Lym-

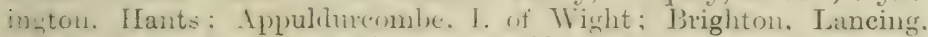
St. Leonards and Lewes, Sussex; Lydd, near Dover and Higham, nar craverend, Kent; Haling, near Croydon. Surrey : Gostield Ifall. Fisex; Eigmare, Middlecex; Windsor, Derlis; ('irencester. 1, mo-tershire: near Worceter am Mralrern, Worcestershire: Harlum Magna. Warwickshire; (irimsuny (ireen, Northamptonshire: WTyms. Leicestershire; Matlock. Buxton and Haddon Ifall, Derly.

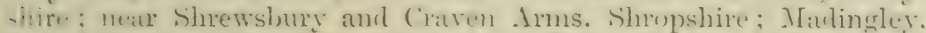

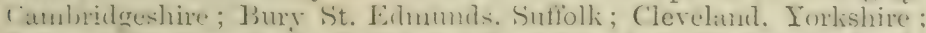

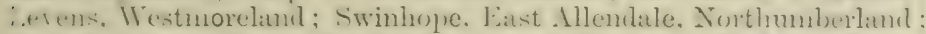
$\because \cdots$ Callowar, Kirhculbrightshire; near Stirling; Finlarig. Killin.

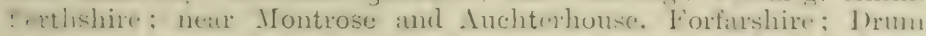

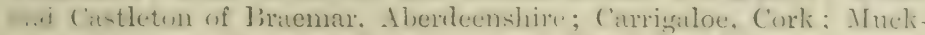
zoss, Killarney, Kerry; Achill Island and The Bills, Mavo.

Var. aureola 'Th. Fir. Lich. Aret. 1\%,67 (1860).-Thallus whicular, wntrifugally plicate-wrinkled, smetimes granular. wrecially towarls the rentre, the lobes dilated and flinate"enate at the alpices, semerally deep goldentyellew. Aputherial

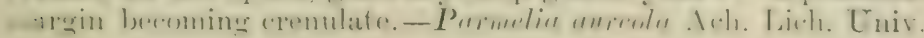


p. 487 (1810). Plyseia parietina var. aureola Nyl. Syn. i. p. $411(1860)$; II dul Min. 1). 113: Leight. Lich. Fl. 1) 143;

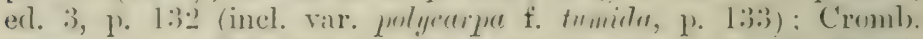

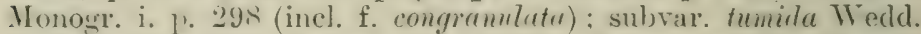

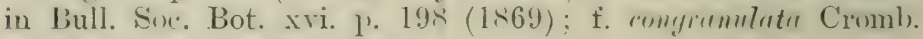
in Grevillea xv. p. 78 (1887).

Exsice. Johns. n. 85 ; Larb. Lich. Hb. n. 212.

Distinguished by the submonophyllous wrinkled thallus, which is often more or less granular. Thallus and apothecia are generally deeply coloured. Form congramulata is more densely granular.

Hab. On trees and walls in maritime and upland districts.Distr. Rather rare throughont England, S. Wales and in E. Scotland.--13. M. St. Ninver and Withiel, Cornwall; near Riyde, I. of Wight; Llting, Essex; Twyeross, Leicestershire; Tenby, l'embrolieshire; Great Comberton, Worcestershire; Buxton, Derbyshire ; near King's Lynu, Norfolk; Tendal, Westmoreland; Harris Moor, ne:tr Whitehaven, Cumberland; Weardale, Durham; Swinhope, East Allendale, Northmmberland; Cramond, near Edinburgh; near Cove ind Portlethen, Kincardineshire; near Aberdeen.

Var. ectanea Oliv. Lich. LiOrne, I. 8.3 (188\%).-Thallus of narrower imbricate lobes, plane or unequal, with raised margins; (leep) tawny-or reddish-yellow. Apothecia small or moderate in size, the margin generally entive.-Tuscus crustu . . adnascens Havus Buddle Hort. Sicc. ii. fol. 6, n. 4 in Herb. Sloane. Permelin purietina var. ectonen Ach. Lich. Lniv. 1). 464 (1S10). Physcia parirtina var. cetanen Nyl. in Let. Soc. Linn. Bord. sir. 3, i. p. 306 (18.56); Mudd Man. p. I13; Leisht. Lich. Fl. 1). 143 ; ed. 3 , p. 132 ; Cromb. Monogr. i. p. 299 ; var. aureola Cromb. Lich. Brit. p. 38 (1870) (non Nyl.).

Exsice. Johns. n. 86 ; Larb. Lich. Cesar. n. 67.

Closely approaching the species, though more irregular in outline. more broken up, and generally more ilecply coloured. ('rombic (Monogr. i. p. 299) suggests that Lirhen fulius D)ieks. (1'l. (rypt. fasc. iii. p. $16(1793))$ may be referable to this variety.

Ifal). (On diry rocks in maritine, rarely in momntainous districts.-Distr. Local, though plentiful where it occurs in S.W. and $\mathrm{N}$. Englamd, S. and N. Walles. F. Sicotland and S.W. Ireland.-B. M. fersey; Sink: (inemser: P'enzance, Commall; Jolt Head, Devon: Tenby, I'enholieshire; King's stanley, (ilonecetershire; Ilanymy. nech, Alontemershire; Bamouth. Aferioneth: I. of Man; St. Jiees. C'muberland; Fern Islands. Northumberland; ('ramond, near Eddin.

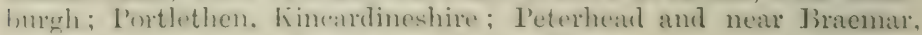
Aberdeenshire ; near Blackwater Brilge, Kerry.

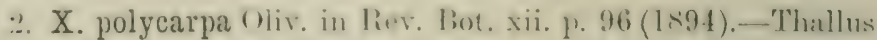

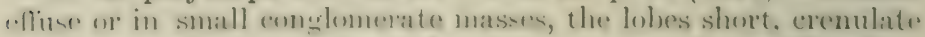
at the margine, sometime almost crustaceous, grentish-yellow (k+purple). Apothecia numernus, crowded, almest rovering the thallus, rather small, with turevil entire margin : spores 


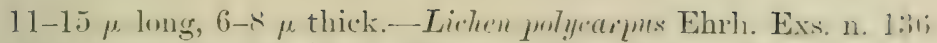
(1791) nomen; Sm. Engl. Bot. n. 1795 (1807). Psoromu julycorpum S. F. Gray Nat. Arr. i. 1. 445 (18:1). Lercenore cumit-

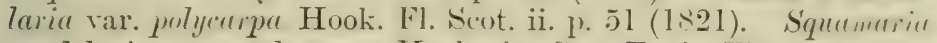
candelaria var. prilyerarpe Hook. in Sm. Engl. Fl. v. 1. 194 (18:33). Physeia porietina var. polygrurpe Mudd Man. 1'. 11:3 (1861); Cromb. Lich. Brit. 1. 38; Leight. Lich. Fl. 1. 14t: ed. 3, 1. 133. P. polycerpu Nyl. ex Lany in Bull. Soc. Lut. Fr. xxv. p. 381 (1878).

Exsicc. Johns. n. 8i ; Larb. Lich. Hb. n. 47 \& Lich. Cantab. n. 11 ; Leight. n. 265 ; Mudd n. 86 pro parte.

The thallus is much less dereloped than in the previous species. and the spores rather smaller. It frequently occurs in roundish pulvinate patches.

Hub. On palings aml trees, chictly larch, in maritime and uplaml distriets.-Distr. Here and there throughont England and scotland. not recorded for Ireland,- D. W. St. Leonarl's Forest, Su'sex; liemble. Wilts; Langford, Essex; ('herry Hinton and Gogmagog Hills. Cambridgeshue: Twreross. Leicestershire; near Oswestry. Shrop. shire; lierlcur, ('levelint, Yorkshire; near Hexham, Northumberland : Finlarig and nenr Latwers Inn. Tillin. Perthslive; Jurris. Kuncardineshire.

Form lobulata A. L. Sm.-Thallus reduced, effuse, lobes short, roundly crenate. Apothecia numerous, small: spores's at in the species. Leranora lobulata Flïrke Deutsche Lich. i. 1. 10 (181.5). Physein parietine var. Iobulutu Mudd Man. 1. 11:3

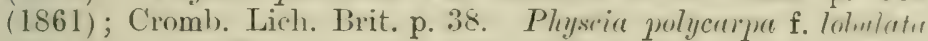
Cromb. in Grevillea xv. p. 78 (1887) \& Monogr. i. p. 300.

Exsicc. Johns. n. 88 ; Mudd n. 86 pro parte.

Considered by Crombie to be possibly only a depauperate forni: of the species with which it often grows associated.

I a ch. On palings in upland districts.-Distr. Tare in X. Finulani and in the S. and X.E. Grampians, Scotland.--B. M. liedcir, (levelind, Yorkshire; Wark-on-Tyne, Northumberland; near Killin. Perthshire; Durris, Kineardineshire.

3. X. lychnea Th. Fr. Lich. Acand. i. 1. I 146 (1871). -Thallas spreating. lobates the lohes small, crowderl, plane and imbriate. or ascentins, decerly cut, with upturned sranular-pulverulent

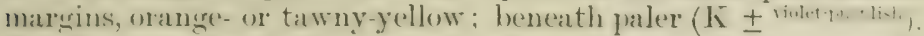
Alotheria moderate in size, rather rame, scattered, concolorme, the margin entire or crenate; spores $11-17 \mu$ long, $7-11 \mu$ thick. - Lichen concolor Dicks. fase. iii. p. 18, t. ix. f. 8 (1793) pro

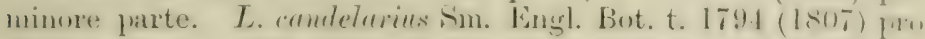
minore parte. Parmelia candeluria var. lychnea Acb. Meth. p. 187 (1803). Physcia parietina var. lygchea MLudd Man. p. 114 ; Leight. Lich. Fl. p. 143 ; ed. :3, p. 132; subsp. lychnen 
Cromb. Lich. Tirit. 1) :38 (1870). Physria lychnea Nyl. ex Carroll in Journ. Bot. iii. j). 2\&s (1865) : Cromb. Monogr. i. p. 300.

Exsire. Johns. n. 89 ; Larb. Lich. H1. n. 16: ; Leight. n. 11.

The generally upright lobes with pulverulent margins distinguish this'species from the two preceding. It is generally sterile, and the apothecia when present are more plane and less crowded than in X. polycarpa.

Ha7). On trees, palings, rocks and walls in maritime and upland districts. - Distr. Rather rave throughout Great Britain and Ireland.B. M.- Near Penzance and St. Austell, Cornwall; Cirencester, (iloncestershire, Windsor I'axk, Berks; Whentfield Park, Oxfordshire; Colwall, Herefordshire; near Shrewsbury, Shropshire; Malvern, Worcestershire; Wark-on-Trne, Northumberland; Teesdale and Redworth, Durham; Blackford Hill, Edinburgh ; Ben Lawers. P'erthshire; Findhaven Hill, Forfarshire; Durris, Kincardineshire; Lairg, Sutherlandshire.

Var. perfusa Oliv. Exp. Syst. i. p. 171 (1897).-Thallus of very minute crowded laciniæ. Apothecia rather small, scattered.Pleyscir lyclener f. perfusa Nyl. ex Lamy in Bull. Soc. Bot. Fr. xxv. p. 382 (1878); Cromb. Monogr. i. p. 301.

The lacinie are packed so closely that the thallus lias the appear. ance of a granular crust.

$H a\}$. On granite walls in maritime and upland districts. -Distr. liare anong the X. Grampians and in N.E. Scotland.-B. M. Portlethen. Kincurdineshire; Crathie, Braenar, Aberdeenshire.

Var. pygmæa Oliv. Lich. LOOne, 1) 83 (1882).-Thallus small, in cleterminate patches, the lacinia erect, narrowly divided or rounderl. Apothecia moderate in size: spores 10-14 $\mu$ longr, 7-9 " thick. - Borrern pyymen Bory ex Fr. Lich. Eur. p. T:

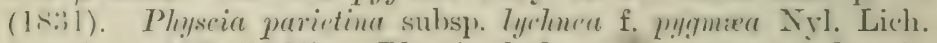

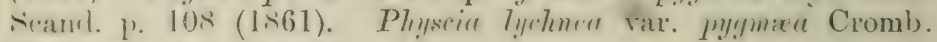
Monogr. i. p. 301 (1894).

Difters from the species in the seattered almost nothlar thallus. otherwise not easily distinguished.

IIah. On expossed sranite walls in an upland distriet.-IS. IT. IBen Lawers, Perthshire, the only British locality.

ii. PLACODIUNI DC: F. Fr. ii. 1). 377 (180.) pro parte:

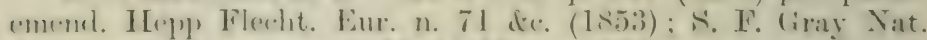
Ar. i. 1. I fli pro parte: Muld Man. p. 1:30 poro parte: Cromb. Brit. Lich. p. 45 pro parte; Leight. Lich. Fl. p. 175; ed. 3,

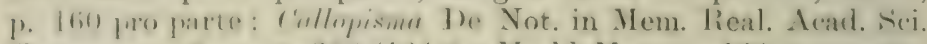
Torino, ser. … x. p. 3isis (184!9); Mudd Man. p. 1:30 pro parte.

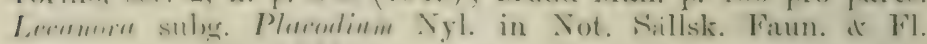
Fenn. v. p. 126 (1866) pro parte; Cromb. Monogr. i. p. 357 pro parte. (P1. 47.)

Thallus -rpanulere with a delinite somewhat circular ontline

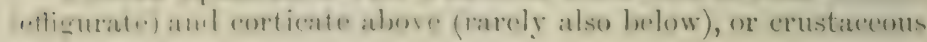


and effuse, the prevailing colour yellow, but also whitish, grevish or very dark-grey. Algal cells Protocuerns. Apothecia brightly, rarely dark coloured, generally with a thalline margin, in some species with the margin excluded or with a proper margin only: paraphyses slender, nearly always broader and septate and often shortly branched at the tips, the epithecium generally deeply suffused with parietin granules: spores 8 in the ascus, colourles: 1 -septate (very rarely simple), polarilocular.

The lichen acid parietin is produced in more or less abundince in the thallus of most of the species of this genus, and in the apothecia of all except $P^{\prime} l$.refellens, which is probably an imporerished form. The spores are polarilocular in nearly all; they are simple in $1 \%$ mupestve and imperfectly polarilocular in a few others.

The name Placorlium was given by Hill (History of I'lants, p. 96 (1751)) to a raried series of lichens, smme of which are undoubted Placodium species as now understood. De Candolle limited the cremus to species with a squanulose effigurate thallus. It was further. limited by Hepp to species with polarilocular spores (Euplacodium). and at the same time extencled to those with it crustaceous thallu. having the same type of spores (Callopisma) and to biatorine speciesi.e. apothecia without a thalline murgin (Blasteniu). The same comprehensive riew of the genus is taken by modern continental lichenologists, who have however generally adopted the more recent name Caloplace (Th. Fr. Lich. Arct. p. 118 (1860); ement. Iich. Scand. p. 167 (1871)).

The species are arranged in three sections, the more highis developed being placed first :-

Apothecia with a thalline margin.

Thallus squamulose.

i. Euplacodius.

Thallus crustaceous

ii. Callopisja.

Apothecia without a thalline margin.

Thallus crustaceons.............. iii. BLastenia.

$\$$ i. Euplacodium Stizenb. in St. Gall. Ber. Nat. Ges. iii. p. $172(1862)$.

Thallus squamulose and more or less ettigurate or fartly crustaceous, yellow-eoloured: the spores are polarilocular except in Placodium fulgens.

\section{Spores simple or imperfectly septate.}

1. Pl. fulgens S. F. Gray Nat. Arr. i. p. 447 (1821).Thallus orloicular: radliating, submonophyllous or imbricate at the contre, often tuberculose, prale- or citrine-yellow, somewhat, pulverulent, the laciniar arenate, deeply eut and envex at the mangins, closely appressed to the substratum ( $K+$ ileep violet). Apothecia small, generally plane, the thalline margin thin, disnplearius, deep orange-coloured: paraphyses slender, concrete, simple or forked upwarls, inspersed with yellow sranules; spores ellipsoirlonate, simple, with the antents massed towateds the. 
poles, $7-13 \mu$ long, 3-5 $\mu$ thick.-Mudd Man. p. 131; Cromb. Lich. Brit. 1. 45: Leight. Lich. Fl. 1. 17 s; erl. 3, p. 16t. Lirhen fulgens swatz Nor. Act. Upsal. iv. 1). 246 (1784); Dicks. Pl. Crypt. fasc. iv. 1. 24 ; Engl. Bot. t. 1667. Lecamora fulgens Ach. Lich. Univ. p. 437 (1810); Cromb. Monogr. i. p. 357. Sirpurmaria fulgens Hook. in Śm. Engl. Fl. v. p. 195 (183:3).

Exsice. Cromb. n. 155 ; Larb. Lich. Cresar. n. 27 \& Lich. Hb. ก. 296.

The spores of the species are simple, but they appear to be poorly developed; there is sometimes an appearance of reptation, with (nttuli: at each pole. The thallus resembles other Placorlia in the Iresenee of parietin. which gives the vellow colour to the thallus. When dry it is whitish suffused, becoming more brightly coloured when moistened. The spermogones are like others of the order with spermatia $3 \mu$ long, $1 \mu$ thick.

Hal). Creeping orer the mosses of cilculleous soil, shell-sand and erevices of rocks in maritime districts.-Dist $\%$. Not uncommon in a fer localities of the ('hamel Islands. S. England and S. Wales.B. M. Quenrais, Jersey; Guernsey; Hray Hill, St. Minver and IVithiel, Cormwall; Freshwater Bav, I. of Wight; Newhaven and liottingrdean Cliffs, Sussex; Stackjole court and I,ydstep. Pembrokeshire.

\section{Spores polarilocular.}

\section{Thallus entively lobate.}

․ Pl. callopismum Mér. Nour. Fl. Env, Paris, ed. 2, i. 1. Int (18:2). Thallus robicular, radiate-stellate, closely adnate, the lubes of the circumference dilated, contigunus, plane, lightuf orange-yellow, more or less pruinose, the centre cracked-areolatr, often deeper in colour or brown $(\mathrm{K}+$ jurplish $)$. Apothecia Hanr, becoming conrex, the disc reddish-yellow, the margin fialer, thexuose or subcrenulate; spores very wirle, lemon-shaperl, $10-16 \mu$ long, (i . $10 \mu$ thick. - Mudd Man. 1) 13:3, t. 2, fig. 42: Gromb. Lich. Brit. p. 45 ; Leight. Lich. Fl. p. 176 ; ed. 3,

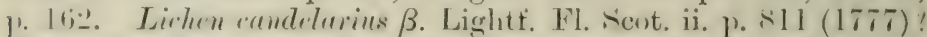
J. mmanm sin. Engl. Bot. t. 2157 (up)er fig.) (1810). L.romorn cullopismu Ach. Lich. (Thiv. 1) 4:37 (1810) (non Hoftim.); Cromb. MIonogr. i. p. 362 (excl. subsp. sympagea). 11. $11: 3$.

Exsicc. Johns, n. 405 ; Larb. Lich. Hb. n. 164; Leight.

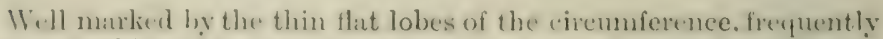
there is a white zone near the edge. It is also distingnished by the broak eitriform spores.

Hab. On rocks and the mortar of walls in maritime and inland

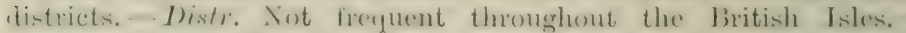

B. M. Guernsey; PJymouth and men Torquay, Deron; near Ciren-

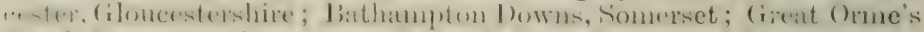

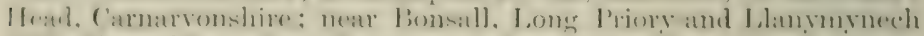

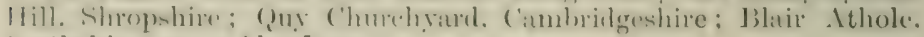
l'erthshire; near' Aberileen. 
Var. brevilobatum A. L. Sn.-Differs from the sprecies in the reduced thallus, the lubes of the circumference being short, rather scattered or absent, the centre cracked-areolate or verrucose. Apothecia and spores as in the species.-Leconorn brevilobata Nyl. in Flora lxvi. 1). 99 (188:3). Lecanora cellopisma subsp. sympatgea var. lnevilobata Cromb. Monogr. i. p. 363 (1894).

Hab. On schistose rocks in maritime and inland districts.-Distr. Very rare in N.W. England and X.E. Scotland.- B. M. Tear Alston. Cumberland; Portlethen, Trincardineshire

3. Pl. flavescens A. L. Sim.-Thallus orbicular, closely adnate, bright-yellow, shining, pruinose or naked, the lobes of the circumference narrow, turgid, crenulate $(K+$ purplish). Apothecia concolorous or brownish-red, the margin entire, disappearing: spores very wide at the septum, lemon-shaped, 8-14 $\mu$ lons, 6-10 $\mu$ thick. - Pl. rallopismem rar. plicutum Leight. Lich. Fl. p. 177 (1871); ed. 3, p. 163. Lichenoides crustosum, orbiculis et scutellis flavis Dill. Hist. Musc. p. 136, t. 18, fig. A. Lichen flecescens Huds. Fl. Angl. 1. 4t5 (1762) pro maj. parte. Amphiloma Heppiannm Mïll.-Arg. in Mém. Suc. Physs. Hist. Nat. Gen. xvi. p. $379(1862)$. Leetenora murerm var. plicutum Wedrl. in Bull. Soc. Bot. Fr. xri. p. 200 (1869). L. callopisma var. symparea Nyl. in Bull. Soc. Linn. Norm. sér. 2, vi. 1'.30+ (1872) (non Ach.); subsp. sympager Cromb. in Grevillea xviii. 1. 45) (1889) \& Monogr. i. p. 362.

Exsice, Johns. n, 31; Larb. Lich. Hb. 11. 15; Mudd nos. 94,96 .

Closely allied to the preceding, there being slight connecting stages though distinct in the extreme forms. in which the lacinite are turgid and convex like those of $\mathrm{Pl}$. murumu. 'l'wo other names have been used for the plant, based on Luchen aurantius Pers. (Ust. Ann. Bot. xi. p. 14 (1794)), and L. sympageus Ach. (Lich. Suec. Prodi. p. 10.5 (1798)), but both those plants are probably only forms of $P l$ callopismum, as the lacinire are described as plane.

The Dillenian deseription refers to four species. which hatve been verified after examination as follows:-those under fig. $18 \mathrm{~A}$ are Pl. flavescens; under $18 \mathrm{~B} \mathrm{Pl}$. citrinum and Candelaria concolor; under $18 \mathrm{c} P$. muromm.

Hab. On rocks and mortar of walls, chiefly in maritime, but also in inland districts.-D Jish. Not unconmon throughout the liritish Isles.-B. M. Vale Castle, Guernsey; Alderney; St. Austell and st. Maws, ('ormwall ; Torquaty and North Lrnton, Deron ; near ligde. I. of Wight; Glynde and Pensemarsh, S'ussex; Manorbeer, near t'enby, l'(mb)rokeshire; near Southerndown, (Hlanorganshire; Aberitover, Merioneth; Llanmenech IIill, Shropshire: Juxton and

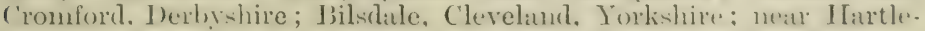
pool, Jurhan ; Arubarrow, Westmoreland; St. Bers. ('mulerlind;

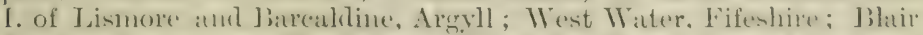

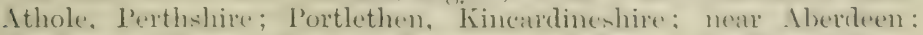

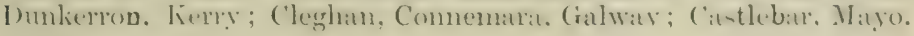




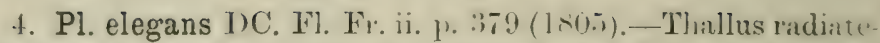
stellate and normally orbicular, formerl of subdiscrete narow elongate laciniae, branched, torulose and crenate at the aprices. orange or dark unge-red, paler below $\left(\mathrm{K}-p_{\text {morplish }}\right)$. A pothecia rather small, nearly plane, concolorons, the marsin entire: spreres ellipsoid or ovoid, 11-16 $\mu$ long, 1;-9 $\mu$ thick- Mudd Ifan. 1. 131, t. 2, fig. 41 ; Cromb. Lich. Brit. 1. 45 : Leight. Lich. F. p. 178 ; ed. 3 , p. 163 . Lichen elegans Link in Ann. Naturg. i. 1. 37 (1791). Lecenora elegans Ach. Lich. Tnir. 1. 435 (1810, Hook. Fl. Scot. ii. p. 50 ; Cromb. in (irevillea xriii. p. 44 (1S.s! it Monogr. i. p. 358. Squamaria elegans Hook. in Sm. Engl. F. v. p. 195 (1833) pro parte.

Distinguished by the non-contiguons narrow deeply coloured lacinie. It is an alpiue or northem plant very rave in this comtry: the British citations may possibly refer to sone other species. Thi thallus is corticate on both surfices and lonsely aftixeel. so that it is easily detached. The spores vary from being broadly ovoid to ellipsoid.

Hab. On granite rocks in alpine situations.-Distr. Sparingly

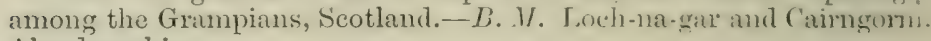
Aberdeenshire.

Tar. tenue Nyl. Lich. Scand. 1) 1:37 (1N61). - Thallus mu.h reduced, the lacinise narrow and scattered. Apothecia small.Tar. discreta Much Man. 1. 1:31 (1N61). Lichenoides temixsimum, sentellis exignis minirtis Dill. Hist. Muse. 1) 175. t. -21. fig. 68 (1741). Lichen eleguns var. temuis Wahlenb. Fl. Lalp'. p. 417 (1S12). Lecanora elegans var. tenmis Ach. Syn. Lich. p. 183 (1814); Cromb. Monogr. i. 11. 355. Parmelia detyans var. discreta Schrer. Enum. p. 52 (1850).

$H a b$. On calcareous and other rocks in subalpine situations:Distr. liare in S. Wales, X. England and the Grampians, Seotland.13. M. Whimbold liocks, near liadnor; J'ast Alleminle. Northumber. land; Craig Guie, Braemar, Aberdeenshire.

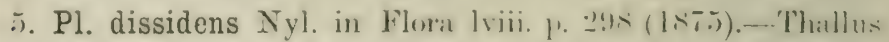
orbieular, mederate in size, stellate-radiate, the lacinia (onves. narrow, often free at the circunference, (renate at the tips, dull resklish-yellow $(\mathrm{k}+$ purplish $)$. Apotheria numerous, concolorme. the thalline marein crenulate; speres $916 \mu$ long, $5-i \mu$ thices.

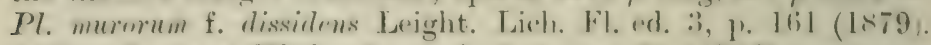

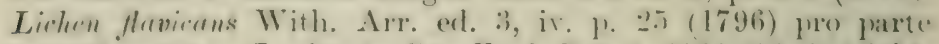

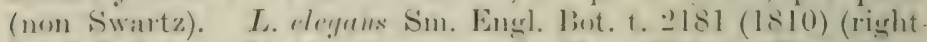

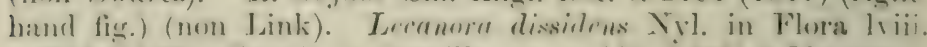

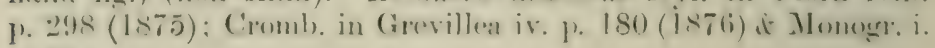
p. 361 .

\section{Warsic. Johns, n. $25 \%$.}

Agreeing in outline and colour with states of Xinthoria purietimu.

The lacinise are somewhat similar in form to those of the pre.

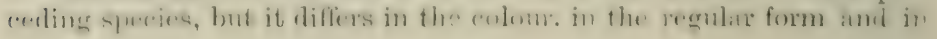


the crenulate margin of the apothecia. The thallus is corticite (m) both surfaces, and, though elosely appressed, is easily detached.

Hab. On slate roofs and on brick walls in inland districts.Distr. Found only here and there in England, probably overlooker. -B. M. Near Groombrilge. Sussex; near Stroud and King's Stanley. (Hloncestershire; Cropsall, Leicestershire; Avton, Cleveland, York. shire; Brigsteer, Westmoreland.

6. Pl. murorum DC. Fl. Fr. ii. p. 378 (1805).-Thallus orbicular, stellate-radiate, the lacinic closely adnate, continuour from the centre, contignous and somewhat turgid and crenate at the circumference, egg-yellow or citrine, usually whitish-suffuserl ( $\mathrm{K}+$ purplish). Apotbecia concolorous, plane, becoming convex. the thalline marsin entire: spores ellipsoid or ovoid, 9-15 $\mu$ long, 4-7 $\mu$ thick. S. F. Gray Nat. Arr. i. p. 447 pro parte; Mudd Man. 1. 132 pro parte; Cromb. Lich. Brit. 1. 45 pro parte: Leight. Lich. Fl. 1. 175 ; ed. 3, p. 160 pro parte. Lichencides mustosum, artriculis of scutrllis fluvis Dill. Hist. Musc. p. 136, t. 18, fig. $18 \mathrm{c}(17 \pm 1)$. Lichen flavescen.s Huds. Fl. Angl. 1) 445 (176:) pro minore parte. L. murorum Hoffm. Enum. Lich. p. 63 (1784) ; Engl. Bot. t. 2157 (lower fig.). Lecanora murum Ach. Lich. Unir. p. 433 (1810); Hook. Fl. Scot. ii. p. 50 pro parte: Tayl. in Mackay Fl. Hib. ii. p. 140 pro parte; Cromb. Monogr. i. p. 359 .

Exsice: Johns. nos. 97, 405.

Distinguished from allied species by the turgid lacinix. by the more continuous lobate centre, which is often brown-coloured, and to some extent by the white pruina. It has frequently been confused by older writers with $P$. callopismum, a species well defined by spore characters. Though normally in flat orbicular rosettes effigurate at the circumference, it may be considerably broken up and oceur in stunted crowded lobulate patches (Physcia muromm var. pulvinata Massal. Symm. Lich. p. 13 (1855)).

Hab. On calcareous rocks and mortar of walls in maritime and inland districts.--Distr. P'robably general throughout the British Isles.-B. M. Anstey's (ove, Tormay, 1)evon; Glynrle, Sussex; near ('irencester, Gloucestershire; Anglesea; Great Orme's Head, Camilrronshire; Teesdale. Durham; Warkworth ('astle, Northumberlind: Iforningside near Edinburgh; Appin, Argyll; near Aberdeen; ('late" Island, Mayo.

Furm corticicolum Oliv. Lich. Eur. p. 90 (1909).-Thallus in pulvinate patches, reddish-yellow or greyish-green. Apothecia

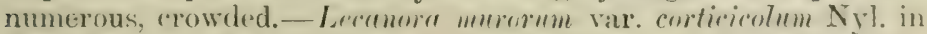
Bull. Sor. Bot. Fr. xiii. p. 3fic ( 1 \&66) : Cromb. in Grevillea rviii. p. $44(1889)$ \& Monogr. i. p. 359.

Exsice. Larb. Lich. Hb, n, 52.

Hab. On trunks of trees or on old timber in inland districts. Jistr. Apparently rare in S. and E. Fongland -Ji. M. Windsor (ireat l'ark, Berks ; Great Wilbrahnm, Cambridgeshire. 
Vas. pusillum Flacs. Lich. Fr.-Comti: p. 2:31 (18x(i).-Thallus sualler, the lacinite short, plicate-radiate at the circumference, uten absent, more broken up into lobules or separate small spuammles at the centre, naked or white-suffused, vitelline or paleyellw, Apotheria small, becoming plane or convex, covenlorous : sprures as in the spereses or somewhat smaller.-Plurorlium miniatum Leight. Lich. Fl. ed. 3, p. 162 (1879) pro parte. Pl. mnimum var. miniutmm Mudd Man. p. $13+(1: 261)$ pro parte : C'roml. Lich. Brit. p. 45 (1870) pro parte: Leight. Lich. Fl. 1. 175. Lirlern mirratux Hoffim. Enum. Lich. 1. 6i: (1784)? L. trunluris Ehrh. Exs. 11. :304 (1785) nomen nudum. L. degans Sim. Engl. Bot. t. 2181 (two left-hand figs.) (1810) (non Link). śfuamarir miniatı Hook. in Sin. Engr. Fl. v. p. 195 (15:33)? jo parte. Pliyscin jusill, Massal. in Flora xxxv. p. jfit (1852). Leronora olderascen. Nyl. in Flora lxvi. 1).99 (188:3); Cromb. in .Journ. Bot. xxiii. 1' 19.) (1<85). L. muromm subsp. tegularis Nyl. in tom. cit. P. 106 : Cromb. Monogr. i. p. 360 (incl. var. olbliterascens).

Exsice. Johns. nos. 71, 98; Larb. Lich. Hb. n. 51 ; Leight n. 207 : Iludd 11. 9\%.

With a non-raliate less developed thallus then the species, and (donely approaching the pulvinate form; the lobate character is (onstant. The colour varies from citrine-yellow to brownish-rerl. hence the ambignons term miniatum. The anothecia are generally rrowded, and tend to become convex. with the thalline margin lisappearing (var. obliterascens).

Hab. On rocks and walls, rarely on old timber, in maritime and inland situations.-1)istr. Thather rave throughout (ireat Jritain and the Chamnel Islands.-13. M. Ro\%el. Jersey; near Glynde, Sussex; hemble. Gloncestershire; Weston, Oxfordihire; J.lingmynech IHill. Shrmshire; Ayton. C'levelant, Jorkshire: Jroughton Castle, West. noreland; Bassenthwaite, ('umberland ; near Callander, the 'Trossitchn and C'raigr Tulloch. Perthshire; Will's ]hries, Forfurshire; Cove. lincardineshire.

Form Arnoldi 1. 1. An. - Thallus very small, the thalline lobules seattered or contiguous, not racliate, cimabarine. Apo-

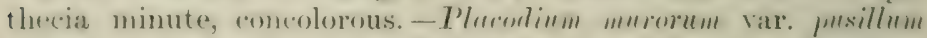
Crmul), in Journ. Lot. viii. 1).97 (1870)! (nos Massil.). Lecemorn miniml, Tayl. in Markay Fl. Hil, ii. 1). 110 (1s:36i) (? Hoflm.). L. Arnoldi Wedd. in Bull. Soc. Bot. Fr. xxiii. p. 96 (1876).

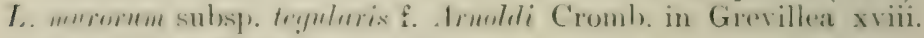
P. $45(1889)$ it Monogr. i. 1). 361.

Sencely differing from the varicty except in the minute thallus and apothecia and in the constantly cinnabarine colour.

Hab. On dry calcareous roeks in inland districts.-Distr. late in X.E. England, the Grampiaus, Scotland and S.W. Ireland.-B. M.

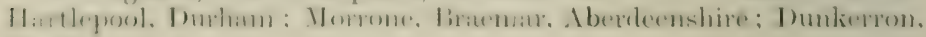
kierry. 
Thallus gramlar in the centre, sometimes sorectiate.

7. Pl. granulosum Hep' Flecht. Eur. n. 908 (1:6i). Thallus normally arbicular or sometimes spreading, closely adnate, stellate-radiate, the laciniat of the circumference oblons. nurrow, convex, rugulose, the centre granular-areolate, compresi of upright separate isidiose like granules, sometimes divided $\mathrm{cm}$ (renulate, deep reddish-yellow ( $\mathbf{K}+$ purplish). Apothecia rare. small, concolorous, the thalline marsin entire, becoming subcrenulate; spores 10-16 $\mu$ long, $6-\delta \mu$ thick.-Amphilomu framulosum Mïll.-Arg. in Mém. Soc. Phys. Hist. Nat. Geneve xri.

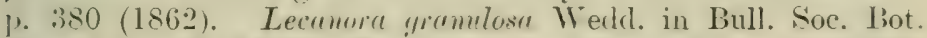
Fr. xxiii. p. 9s (1876) : Croml. in (irerillea xriii. p. 4.j (1ss!) it Monogr. i. p. 365.

Exsicc. Johns, n. 258.

Not unlike $P$. cirrochroum, but the central granules are more compact and not sorediate. The thallus of the specimen in $\mathrm{Hb}$. Johns. has no radiate lacinie.

Hub. On rocks, chiefly calcareons, in maritime and inland districts. -Distr. Not common in W. England and E. Ireland.- $-B . M$. Cherlar Cliffs. Somersetshire; St. Bees. (immerland; Howth neai Dublin.

\&. Pl. scopulare Olir. Lich. Eur. 1. 96 (1909).-Thalluirbicular, rather small, closely adnate, stellate-radiate, the lacinie narrow, contiguous, convex, warted-areolate in the (entre, redclish-yellow $(\mathbf{K}+$ purplish $)$. A pothecia small, numerous. ylane, the thalline margin entire; spores 9-17 $\mu$ long, i- 7 " thick. Lecanora scopularis Nyl. in Flora lxvi. p. 105 (18x.3): ('romb. in Journ. Bot. xxiii. 1. 195 (1885) \& Monogr. i. p. 364.

$H a b$. On schistose rocks in a maritime district.-B. M. Portlethen, Kineardineshire.

9. Pl. decipiens Leight. Lich. Fl. l' 176 (1871). Thallus ummally orlicular, often irregularly developed, laciniate-radiate at the circumference, the lacinia rather narrow, turgicl, contiguous, incised-crenate at the tips, the centre granulate-areolate. “enerally furfuraceous, velluw, or citrine, with concolorous soredi: ( $\mathrm{K}+$ purplish). Aprothecia small, the thalline margin heemint sulurenate; spores whlong-ellipsoid, sometimes slightly curved. 10-16 $\mu$ long, $4-8 \mu$ thick.-Leight. Lich. Fl. ed. 3, p. 161. Physcia decipiens Arn. in Flora 1. p. 562 (1867). Lecenoin

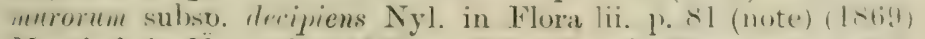

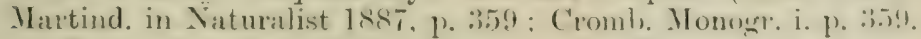

Exsice. Johns. n. 256 ; Larb. Lich. Hb. n. 90 (as var. cemboricum).

Differs from $l l$. murorum in the somewhat narrower lacinice and in the granular sorediate centre of the thallus. Nrlunder has 
sugrested (Flora lxvi. p. 106 that this plant may be the origina? Lichen murorum Hoftim.

Hab. On walls in lowland districts.-Distr. Local in S.W. and E. Englant.-B. M. Shorcham, lient; near Cirencester, Gloucentershire; Milton Church, Cambritgeshire; Anglesea.

10. P1. cirrochroum Hel', Flecht. Eur. n. 39s (15.5)..Thallus small, orlicular, closely arlnate, often imperfect, radiatrstellate, the larinie narrow and convex or somewhat wider and more contiguous, (renulate at the tips, bright orange-yellow. crustaceous-areolate and sometimes darker and poorly developed at the centre, bright orange-yellow, citrine within and dotted with citrine soralia ( $\mathrm{K}+$ purplish). Apothecia minute, orangeyellow, the thalline margin sulentire; spores oblong-ellipsoid, 13-18 $\mu$ long, 5-6 $\mu$ thick.-Cromb. in Journ. Bot. xii. p. 147 (1574); Leight. Lich. Fl. ed. 3, p. 161. Lerenosa rirroclerou Ach. Syn. Lich. p. 181 (1814); Cromb. Monogr. i. p. 363. L. linearios Tayl. in Machay Fl. Hib) ii. 1) 260 (18:36) (yommer state?).

Exsice. Johns. n. 99.

Characterized by the suall round citrine soralia lotted over the thallus. The British plants are sterile. The spores are long in relation to their wirlth, though I have not been able to see any up to 1s $\mu$. The paraphyses are sleniler. but more or less clivate and septat. at the tips.

Hab. On rocks, mostly calcareons, in maritime and iuland districts. -Distr. Rather rare throughout the British Isles, though commoner. in western districts.--B. M. Anster's Core, Torpuly and sidmoutl. Veron; Yatton and Weston-super-Mare. Somerset; Great Orme's Hear, Carnarvonshire; Silverdale, Laneashire; Lovedale, Derbyshire; Arnbarrow, near Fiendal and Iilnthorpe, Westmoreland: Alston, Cumberland; I. of Lismore, Argyll ; (raig Tulloch, 13lair Athole, Perthshire; Dunkerron, Kerry.

Var. obliterans 1. L. Sin.-Thallus smaller, less distinctly raliate, or the lacinia sometimes ohsolete, varying in colour from ochraceous to drepl) tawny-yellow, the soredia citrine or somewhat tawny-yellow, less eflise than in the species. Placulium allitrains Nyl. in Flora lvii. p. $7(1874)$. Specimen not seen.

Nylanter las sueresesterl the varietal aflinity of this plant. It atrees with the species in the presenee of sorecian, a rather unusun] character in this genus.

Hab. On schistose rocks, Caithness.

Thallus or bicular, entirely leprose.

11. Pl. xantholytum Nyl. Jich. Env. Pari, P. th (lis!hi).-

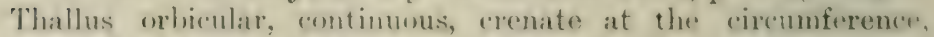
(verywher lopuse, soldur. yollow or greenish-yellow, white within

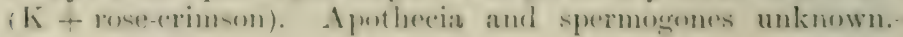




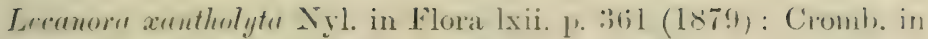
Grevillea viii. p. 112 (1880) \& Monogr. i. p. 366.

Exsice. Johns. n. 407 .

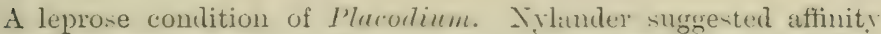
with Pl. cimochroum. but Crombie (1. e.) noint out that it differfrom that species in being internally white.

Hub. On shady calcareous rocks in maritime and upland district.. -Distr. Local though plentiful where it occurs in S. IF.. ('entral and N. England, N. Wales and the Central Highlinds, ticotlimi.--D. M. sidmouth and Anster's ('ore. Toryuay, Devon; Bithimpton Downs. Simetset; Tiew Eilge. Stolie'say, Sinopshire: Great '(Mme's Hearl. Carnarronshire; Silverdile, Lancashire: Seout Scar. Westmoreland: Craig Tulloch, Blair Athole, P'erthshire.

\section{Thallus not effigurate, efjuse.}

1:). Pl. lobulatum A. L. Sin.--Thallus effuse, irregulatr, thin, smooth, sub-areolate, or composed of minute contiguous slightly. conves lobules, accasionaliy with small lacinia at the circunferenc bright-yellow or wrange-red $(K+$ purplish). Ipotheria small, numerous, plane or convex, concolorous, the margin entire: spores ellipsoid, 10-1+ $\mu$ long, j-6j $\mu$ thick. Pl. mumum var. lohmlatmm Hepl' Flecht. Eur. 11. il (185:)): Mudd Man.

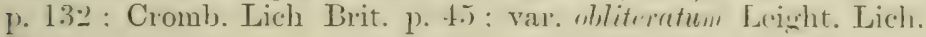
Fl. p. 176 (1871) ; ed. 3, p. 161. Lichen obliterutus Pers. in Ust. Anu. Bot. xi. 1). 15 (1794)? Lecunorce lobulatu Sommerf.

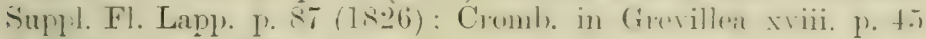
it Nonogr. i. P. 363.

Exsice. Cromb. 11. 156: Johns. 11. 72; Larb. Ciesal. 11. 71 (f Lich. Hb. n. 295 ; Leight. n. 268.

A brightly coloured maritime species, which differs from $I$. mmor,m in the alnuost complete abrence of peripheral ratii. It ma!

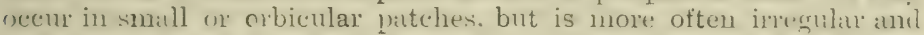
wide spreading. P'ersoon's species, Lichen obliteratus, is of prior

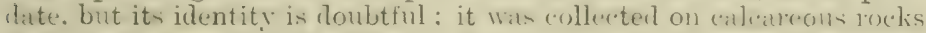
and is not recorded as maritime.

Hub. On rocks in maritime districts,-Distr. liather common round the coasts of the 13ritish Isles.- $B$. $M$. Jersey; Guernsey: Alderney; St. Maws, Cormwall; Ilsham, and Meadfoot, Torquay. Devon; North Cliff, 'lenby, Pembrokeshive; Souther'n Down.

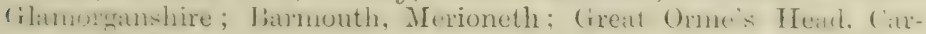
narvonshire; Anglesea; Douglas, Isle of Man; Arnbarrow; West-

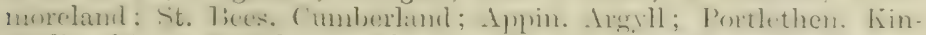
cardineshire; I'eterhear, Aberdeenshire; Applecross, Rossshire;

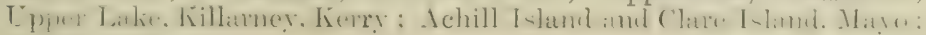
Ardglass. Down.

1.. Pl. miniatulum ()liv. Livh. Eur. 1. !) (1!)!1!. Thallu-

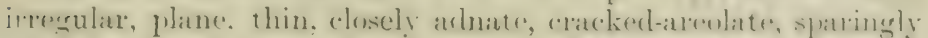

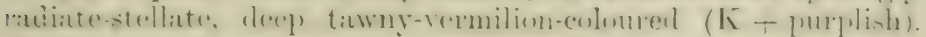
Apothecia minute, concolorous, the thalline margin entire: 
spores small, broadly ellipsoirl, $\lceil-10 \mu$ long, $4-5 \mu$ thick.

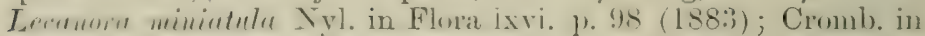
Jonrn. Bot. xxiii. p. 195 (1883) \& Monogr. i. p. $36 t$.

The thallus forms a thin expansion following the inequalities of the rock; the radiate lacinix are only scanty. Nylander has suggester that it may only be a variety of $P$. murorum var. pusillum, but the apothecia and spores are smaller.

Hab. On quartzose roeks in a subalpine district.-B. Mr. MLorrone, liraemar. Aberdeenshire.

3ii. Callopisia A. L. Sm. Cullopisma (as genus) De Not in Mem. Reale Acad. Sci. Torino, ser. 2, x. p. 388 (1849) pro parte; Mucld Man. p. 134 pro parte.

Thallus entirely crustacerus: apothecia with a thalline margin, sometimes disappearing; spores polarilocular except in $P$ l. nicule, in which they are simply septate.

\section{Thetlus yellow or yreenish-iyellow $(K+$ purple $)$.}

14. Pl. citrinum Help Flecht, Eur, n. 394 (1857).-Thallus rfluse, furfuraceous, granular-areslate, citrine- or greenish-yellow $(\mathrm{K}+$ purplish $)$. Ipwthecia orange-yellow, plane, sometimes hecoming convex, with the thin thalline margin disappearing: spres ellipsoid, often rather wide at the centre, 10-15 $\mu$ long, its pthick.-Leight. Lich. El. p. 177 ; ed. 3, p. 163. Pl.murmm var. citrinum Flot. in Uebers. Schles. Ges. Vat. Cult. 1849, 1. 119: Murk Man. 1. 1:32 (incl. var. steropenm ?); subsp. ritrimm

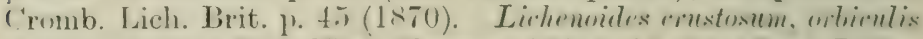
-t sentellis derris Dill. Hist. Muse. p. 136, t. 18, fig. 18 B. Lirhen

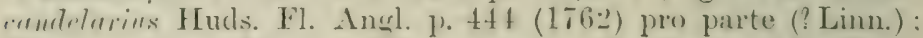
With. Arr. ed. 3, iv. p. 27 pro parte. 'L. citrimes Ach. Lich. suec. Prodr. 13. 73 (17!s) : Engl. Bot. t. 1793 (three lower figs.). Verrncusine citrina Hoffm. Deutschl. El. ii. p. 198 (1795).

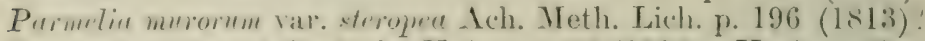
Leernume citrinn Ach. Lich. [niv. 11. 402) (1810): Hook. in Sm. lingl. Fl. ₹. p. 192; Tayl. in Mackay Nil. Hib. ii. p. 138: Cromb. Mlonogr. i. p. 371 .

Easice. Johns, n. 73 ; Larb. Lich. Hb. n. 129 ; Leight. 1 . 86.

Thy. furumerous thallus sureats extensively, covering mortan. mosses, ete. ; it is often sterile, though generally well fertile. The whom varies fwom brisht citrine-vellow to greenish or greenishrellow, the changes being due to light or shade conditions.

Hab. On mortar of walls, more rarely on rocks, trees, mosses, ctc., fhirfly almut fowns and villages in matione and inland localitios. -

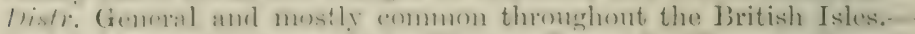

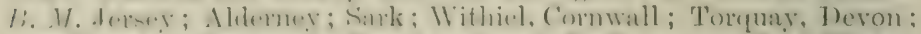

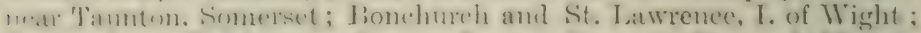
lintfinglean, lirighton and mene Tewes, Sussex; Stansted Mount-

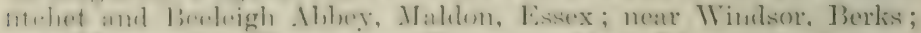

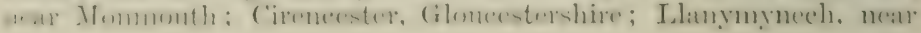


Oswestry and near Shrewhurr, Shropshire; Idinfairfechan. Cimnalvonshire; Anglesea; Twycross, Leicestershire; Wimpole Park. Cambridgeshire; Norwich, Norfolk; near Arton, ('levelaud. Yorlishire; Brougham Castle, Westmoreland; Iximplough, Cumberland: Ifexham, Northumberlanu; near Edinburoh; (rourock, lienfrew: shire; Cupar, Fife; Kingr's Park, stirling; Will's liraes, Forfur'she: Nigg, Kincardineshire; near Aberdeen; Tnmlerron. Kierry; Clare Island and Achill Sound, Mayo.

Form flavocitrinum A. L. Sm.-.Thallus indeterminate: minutely squamulose, thinnish, the squamules nore or loss pulverulent.-Lecanora flavocitrina Nyl. in Flora lxix. p. 461 (1886) \& Cromb. Monogr. i. p. 372. Specimen not seen.

Determined by J3ouly de Lestain (Lich. H)unk. 1). 130 (1910i t as a form of C'aloplace ritring rar. maritimn, the spuamulose character. being due to the attaclis of acarine and molluses. He proved the jilentity of his new plants with an original specimen from Stareley: Westmoreland.

Hab. On schistose walls in an upland situation, Staveley near Kendal, Westmorelasd.

Form depauperatum A. L. sm.-Thallus cfluse, the granuls's minute, scattered. Apothecia small, wherwise as in the type.Lecunora ritrina f. depanperata Cromb). in (irevillea xviii. 1. 1.) (1889) \& Monogr. i. 372.

Exsicc. Johns. n. 408 ; Larb. Lich. Hb. n. 128.

A very poorly developed condition of the species.

$H a b$. On granitic rocks in maritime regions.-Distr. Rare in the Channel Islands, N.E. and N. W. England and W. Ireland.-B. $M$. Alderney; Kylemore, Connemara, Galway.

15. Pl. phloginum A. L. sm.-Thallus ettise, thin, minutely: granular-leprose, in crowded areolate masses or sparsely scattered, citrine or greenish-yellow ( $\mathrm{K}+$ jurplish). Aprothecia small, plane, beconing convex, golden-yellow at first, with it scarcely perceptible thalline margin ( $\mathrm{K}+$ crimson); slumes ellipsoid-oblong, 11-15 $\mu$ long, $5-9 \mu$ wide (usually about $10 \times 5 \mu)$. Parmelia citrina var. phlogine Ach. Meth. Lich. p. 1ベ() (ISO:i). Lecenora phlogina Nyl. in Mém. Soc. Sci. Nat. Cherk. v. p. 112 (1857); Cromb. in Journ. Bot. ix. p. 178

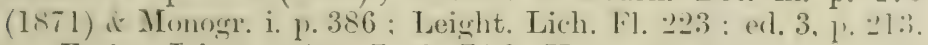

\section{Exsicc. Johns. n.75; Larb. Lich. Hb, 11, 57 \& Cantab. n. 7.}

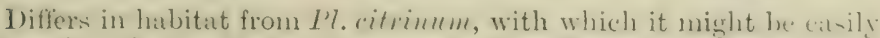
confused. 'The thallus is however less brightly coloured and less luxmiant, and the atprothecia smaller, with the thalline mathin thin and becoming excluded.

Hab. On the trunks of old trees, generally ash or elm, rarely on old wood in matime or inland districts.-Distr. Thare in the Channel

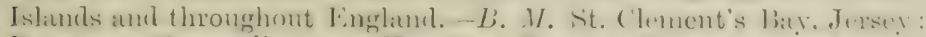

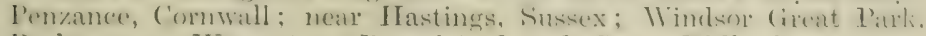
Berks; near Woreester; l'ampisforl and Great Wilbraham, Cam1bridgeshire; Alston, Cumberland. 
Form luteum i. L. Sin.-Thallus very thin, pulverulent, pale greenish-yellow or grey. A potheria minute, orange coloured. Lecider eprirunthe var. luter Ach. Lich. Univ. p. 209 (1§10). Lecenorn phlenginu var. luten Nyl. Lich. Scand. p. 142 (1861): Cromb. Monogir. i. p. 386.

Differing in the generally more reduced growth, which is probably The to the substratum.

Hab. On regetable detritus in maritime districts.-Dislr. liare in $\therefore$ England and S.W. Highlands of Scotland. $-B$. M. Luecombe (ove, I. of Wight; Tottingdean, Sussex; Airds, Aplin, Argyll.

16. Pl. incrustans A. L. Sm.-Thallus effuse, crustaceous, thickish, areolate or reduced to scattered granules, pale- or ureenish-yellow ( $K+$ purplish). Apothecia plane or slightly convex, orange-yellow, sometimes pruinose, the thalline margin entive or becominn crenulate; spores ellipsoid, polarilocular, $\therefore-13(-18) \mu$ long, $4-8 \mu$ thick.-Lecamera in.vustens Ach. Lich. [niv. p. 405 (1810); Cromb. in Grevillea xriii. p. 4.) (1889) it Monogr. i. p. 372.

Sometimes regarded as a variety of $P l$. murorum; the paraphyses :tre branched above and often capitate, and their septation upwards well-marlied as in those of that species. The description is partly taken from bouly de Lesdain (Lich. Dunk. p). 13:3), who gires spore length up to $18 \mu$.

$H a b$. On schistose walls in a maritime district.- $B . M$. Portlethen, Kineardineshire.

17. Pl. aurantiacum Hepp Flecht. Eur. n. 19s (1853).Thallus subdeterminate, thickish, or somitimes very thin, with a sprearding grey hypothallus not always visible, thinly membranaceous, continuous or areolate, pale citrine, sreyish- or greenish-yellow ( $\mathrm{K}+$ purplish). Apothecia small or moderate in size, plane, with a thin entire or crenulate margin, becoming convex and immarginate, deep orange or reddish: paraphyses detvite, septate and hranched upwards; speres broatly ellipsoicl, varying in size and development of sepitum, 11-16 $\mu$ long, (6-9) $\mu$ thick. Lielen flacormbeseftes Huds. Fl. Angl. P. 443 (1762)?: With. Arr. erl. :3. iv. p. 15? L. andunturess Lightf. Wl. Seot. ii.

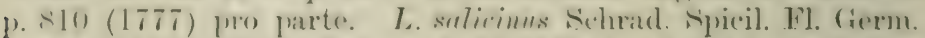

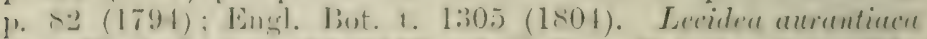

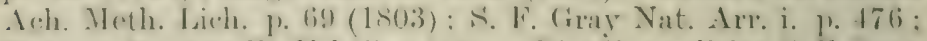

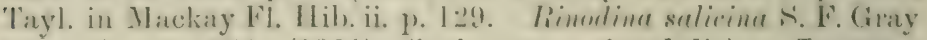
tom. cit. p. 456 (1821) (incl. var. microthelia). Lecanorn

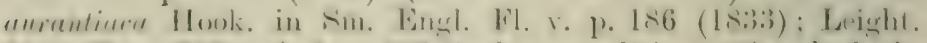

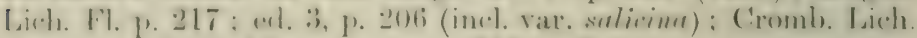
Brit. p. 46 is Monogr i. p. 373. Callopisma aurantiucum

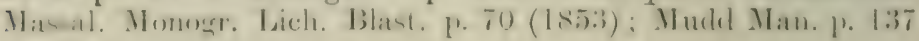
(incl, var. salicinum). 
Exsice. Bohl. n. 118; Carroll Lich. Hib. n. 37 ; Johns. и. 322 ; Leight. n. 212 ; Mudd n. 99.

A variable lichen in the form and colour of the thallus and in the form of the spores. The apothecia are numerous and chiefly central. Spermogones are frequent, especially in the absence of apothecia: they occupy the tips of papillie (I'urmetia microthelia Ach. Meth. Lich. 1). 176 (1503)). Hudson's plant is somewhat doubtful, as it haonly a greenish leprose thallus. Lightfoot's description refers to vir. fluvorufescens as well as to this plint, as he gives habitat "sometimes upon rocks."

Hab. On the trunks of trees, chiefly poplars, willows and ash, and on old palings in maritime lowland and upland situations. - Dist $:$ General throughout the British Tsles.-B. M. Guerusey; Cornwall; near I'lymouth and Ilsham Talley, Torquay, Devon; St. Helen's and Bembridge, I. of Wight; Buckhurst Park, Willingham, Erirlge Park. Frant and Woolstonbury, Sinssex; Halsterd, Kent; Stansted Mountfitchet Park, Mark's Hall and Walthamstow, Issex; Windsor Great Park, Berks; Malvern and near Crowle, Worcestershire; Oswestry and Shrewsbury, Shropshire; Gam, Denbighshire; Anglesea; Twrcross and Gopsall Park. Leicestershire; Ayton and Cleveland, Yorkshire; Levens, WVestmoreland; Newton Riggs, Cumberland; Teesdale, Durham; Hexham and Wansbeck, Northumberland; New Gallow:y, Kirkendbrightshire ; Largs, Avrshire; near Edinburgh ; near Tuverary and Comel Ferry, Argyll; Finlarig, Killin, Perthshire; Abergeldie. Braemar, Aberdeenshire ; Clonmel, Tipperary; Ballynegard, Limerick : near Belfast, Antrim.

Var. flavovirescens Hepp 1. c.-Thallus etruse, thin, plane and areolate, or in minute lobulate granules, greenish- or orangreyellow ( $K+$ crimson). Apothecia generally rather small, plane, with a thin thalline entire, rarely crenulate, margin, becoming convex, the disc orange-yellow, the margin lighter coloured.-L. flavorirscens Wulf. in Schrift. Ges. Naturf. Fr. 1) 122 (17xis). L. erythellus Ach. Lich. Suec. Prodr. p. t:) (1798); Engl. Bot. t. 1993. Lecenora erythrlla Ach. Lich. Unir. 1) 401 (L\&10): Hook. Fl. Scot. ii. p. 49 \& in Sm. Engl. Fl. v. p. 186. L. aurantiaca var. erythrella Nyl. in Act. Soc. Linn. Bord. sir. :3, i. 1. 322 (1856); Cromb. Lich. Brit. 1) 46 ; Leight. Lich. Fl. p. 217 ; edl. 3, p. 207 : subsp. erythella Nyl, ex Croml, in Grevillea xviii. 1). 45 (1889) \& MLonogr. i. 1). 374. Rinulinu cryttirella S. F. Gray Nat. Arr. i. p. 456 (1821). Leciden rytherlla Tayl. in Mackay Fl. Hib. ii. p. 1:30 (18:36). ('allopismu muratireum var. Jlurovireseens Massal. Monogr. Lich. Mlast. p. 70 (1853) ; Mudd Man. p. 137.

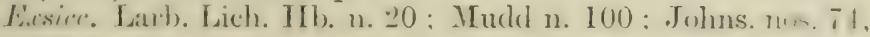
$102,103$.

1)iffering from the species in the habitat and generally in the sure brightly coloured thallus and smaller apothecir.

Hab. On rocks and old walls in maritime and inland localities.Distr. Fairly general throughout (ireat liritam, rare in lrelumit.

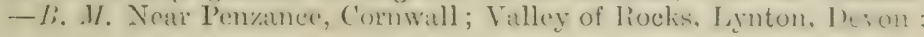


Hastings, Sussex; North Hill. Malvern, Worcentershire; J3lack Nomut, Aberearemur, Nommouthshire; Craig-Y-Tihiw. Oswestry and J.langurnech Hill, Shropshirs; Suowdon and Beddgelert. Ciunarvonhive; Roseberr, ('levelanr, Yorksbire; Brigsteer. Westmoreland: Aliton and Egremont, Cumbertand; Appin abd Glen Orehy, Argril ; Killin, Jien Itawers, Kinnoul Hill and Blair Athole, Perthshire; Lumlir Craigs. Forfarshire; Castleton of Bratemar and Morrome. Aberdeenshire; Kylemore Lake, Connemara, Galway.

Var. inalpinum Anzi Catal. Lich. Sourlr. 1). 42 (Relio). Thallus thir, pale-yellow or whitish. Apothecia redrlish,

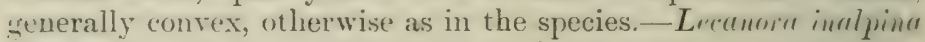
Ach. Lich. Univ. p. 388 (1810). L. aurantiaca var. inalpinn

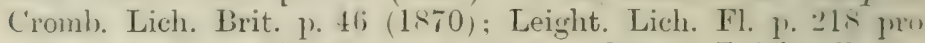
parte; ed. 3, p. 207 pro parte; var. rubescens Leight. 11. c. : subsp. erythella var. inulfiun Cromb. in Grevillea xriii. 1. 4.) (18ig) \& Monogr. i. p. $37+$ (incl. f. rubeserns). Lrecider aniantiven var. rubescens Ach. Meth. Lich. p. 69 (1803). Callopisma anrantiacum var. inalpinum Mudd Man. p. 137 (1861).

Exsicc. Johns. n. 101.

Jistinguished by the thinner thallus and the deeply coloment apothecia.

Hab. On schistose rocks in upland districts.-Distr. liare in $\mathrm{N} . \mathrm{W}$. Fingland and the S. Gramplans, Scotland.-li. M. Harris Moon. Whiteharen, Cumberland; Glen Lochay amd Ben Latwers. Scotlamt.

Subsp. irrubescens A. I. Sim. -Thallus etluse, thin, scattererl. tawny-yellow. Apothecia minute, becoming convex and immalgrinate, concolotous with the thallus. - Leriden rigthrelle var.

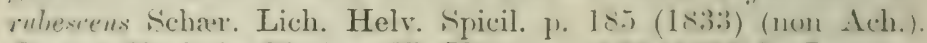
L. prirtu Tayl. in Mackay Fl. Hib. ii. p. 130 (15:3(i)? Ledunuin

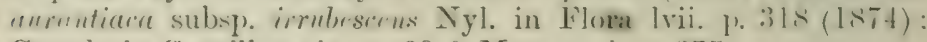
Cromb. in Grevillea xix. p. 60 \& Monogr: i. p. 375.

The only British specimen (in Hb. Salwey) is similar to Anzi's

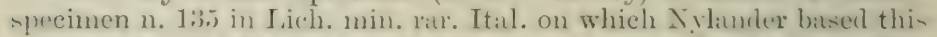
subspecies. The thallus consist of mimute scattered red sciales. The specimen was wrongly mamed Lecidea pictn 'I'ayl. by Salwey (cf. Placodium pyraccum f. pictum).

Hab. On schistose rocks.- li. M. Near 13mmonth. Merionetl.

18. Pl. crenulatelium A. L. Sm.-Thallus effuse, thin, mequal, craclied, at times almost ubsulete, citrine-rellow $(\mathrm{K}+$ purple). Aputhecia morleme in size, plane, with it thek prepere matgin, and fincly erenulate thalline matrgin, concolumens with the thatlus (K+ jurple) : spores ellipsoid, 15-20 $\mu$ long.

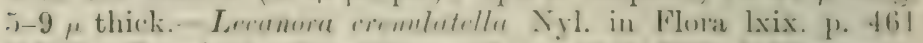

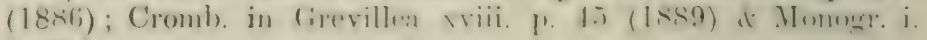
p. 375 .

Wasice. Johns. n. :365. 
Considered by Nylander as near to $\mathrm{Pl}$. aurantiacum var. flavowivescens, but differs in the form of the apothecium (zeorine). It wats originally collected at Arnside, Westmoreland, on quartzose roclis.

$\mathrm{Hab}$. On rocks in maritime and inland districts.-Distr. Rare in N. W. England.--B. M. Cumberland (on limestone).

\section{Thallus greyish-white $(K+$ jurple $)$.}

19. Pl. cerinum Hepp Flecht. Eur. 11. 20:3 (1853).-Thallus thin, scurfy or granular, greyish-white, a bluish-black hypothallus sometimes visible (If + crimson). Apothecia numerous, often crowded, moderate in size or rather large, up to $2 \mathrm{~mm}$. across, bright-or dull-yellow, with an entire persistent whitish thalline margin $(\mathbf{K}+$ crimson $)$; paraphyses slender, knobby and septate and sometimes branched at the tips; spores generally small, subglobose to ellipsoid, $8-16 \mu$ long, 5-9 $\mu$ thick, polarilocular. but the central tube indistinct.-Lirhern cerims Hedw. LaubMoose ii. p. 77, t. 21, 13 (1788): Dicks. Pl. Crypt. fasc. iii. p. 14 (1793); With. Arr. ed. 3, iv. 1) 24; Ensl. Bot. t. 627. Patelluriu

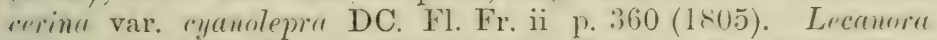
rerina Ach. Lich. Lniv. p. 390 (1810); Hook. in Sm. Lngl. Fl. v. p. 190: Tayl in Iackay 11. Hib. ii. p. 1:30: Cromb. Lich. Brit.

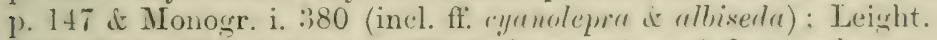
Lich. Fl. p. 220; ed. 3, p. 209 (inel. var. fuser de f. cymolepru); ff. cyanolepra it albiseda Nyl. Lich. Scand. p. 144 (1861). Rinethan cerina S. F. Gray Nat. Arr. i. 1.456 (1821). Callopisme reriur De Not. in Mem. Lieale Acarl. Nici. Torino ser. 2, x. p. 38y (1849): Mudd Man. 1\% 13:3; var, fuscum Massal. Sched. Crit. Lich. p. 130 (1855).

Exsicc. Cromb. n. 60 ; Johns, n. 34; Larb. Lich. Hb. nos. 21, 167; Leight. n. 83; Mudd n. 97.

A rarien species as to the development of the thallus; it is some. times almost evanescent, though the apothecial margin always persists. Occasionally the hypothallus is predominant (f. cyanolepra). s. that the thallus is represented by a blackish stain, rarely it is ilmu-t white (f. albisedra), the apothecial margin also being white. A munler of rarieties bave been recognized depending on colour changes in apothecia and thallus.

Hull. (n the trunks of trees anil on old palings, ete., in maritime. inlame and uplimd districts.-Distr. General and fairly common thronghout the British Isles.-B. M. Jersey; Guemsey; Sark; Trefritwn. Withiel and Truro, Conwall; P'lynouth and Exeter, 1)evon: near Shanklin, I. of Wight; New Forest, Hants; Hassocks Giate and Lewes. Sussex; Maidstone, Kient; near Colchester, Clting and Widdington, Essex; near Cirencester, Gloncestershire; Oswestry. and near Shrewshury, Shropshire; Angleseat; Cherry Hinton and near (Quy, Cambridgeshire; Jilsdale, Yorkshire; Derwent Water and Gainford. Durhan; Wansbeck, Northumberland; nenr hendal. Wentmorelund; Largs, Ayshire; Jlair Drmmond and ('raig T'ulloch, blair Athole, Perthshire; near Cork; Inunkerron and libllame?. lierry; Adare, Limerick. 
Var. stilicidiorum Hepl Flecht. Eur. 11. 406 (1857).Thallus very thin, leprose, greyish-white; bypothallus not risible. Apothecia rather small, the dise sreyish, or dark olivegreen and pruinose, the margin sreyish-white, often flexuose. Lichen stilicirlierum Hornem. in Fl. Dan. t. 10653, figs. 2 (1792). L. rhlorolenrs Sm. Engl. Bot. t. 1:37:3 (180:5). Lecanora rhloroleme Ach. Syn. Lich. p. 160 (1814); Hook. Fl. Scot. ii. 1) 48 \& in Sm. Engl. Fl. v. p. 190. L. cerina var. stilicidiorum Nyl. in $\mathrm{Mcm}$. Soc. Sci. Nat. Cherb. v. p. 112 (1857); Cromb. Lich. Brit. 1. 4 \& Monogr. i. p. 381 ; Leight. Lich. Fl. p. 221 ; el. 3, p. 210. Rinodina stilicidiorum S. F. Gray Nat. Arr. i. p. 456 (1821). Callopisma cerinmin var. stilicidionum Massal. Monogr. Lich. Blast. p. 86 (1S53) ; Mudd Man. p. 136.

Exsice. Johns. n. 107.

Differs from the species in the habitat, the leprose thallus, colour of apothecia, etc.

$H a b$. Inerusting mosses on calcareous rocks in inland and upland situations.-Distr. Somewhat common in Great Britain, not recorded from Ireland.- - B. M. Dartmoor, Devon; Dovedale, Derbyshire; Igrglestone, Durham; Cunswick Scar, Westmoreland; near Stretton, Cumberland; Achosragan Hill, Appin, Argyll; Ben Lawers and ('raig Tulloch, Perthshire; Craig Guie and Morrone, Braemar, Aberdeenshire.

Var. chlorinum Anzi Catal. Lich. Sondr. p. 41 (1560).Thallus effuse, granular, areolate, dull dirty-green. Apothecia dull-orange, the margin greyish-white.-Zeora cerimu var. chlorina Flot. in Uebers. Schles. Ges. Vat. Cult. p. $126(1850)$. Callopisma crinum var. rhlorinum Murd Man. p. 136 (1861). Lecenona

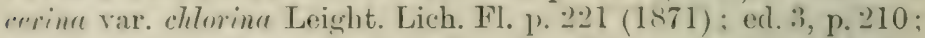
supsp, rhlorinu Lamy in Bull. Soe. Bot. Fr. xxy. p. 505 (1878): Cromb. in Grevillea xviii. p. 46 \& Monogr. i. p. 381.

Faxsice. Johns. n. 192; Larb. Lich. Ilb. n. 22.

1)istinguisher from the species by the thicker and darker thallus.

Irab. ()n shacly rocks in upland situations.-Distr. Taue in $\mathrm{N}$. Fugland and W. Ireland.-13. M. Newton, Clereland; Lerens l'ark, Westmorelime ; Chollerford. Northumberland; Lough (orrib, Galway.

Form cyanopolium A. L. Sm. Thallus subleprose, thickish, cuarsely areolate, dull-grey or bluish-grey. Apothecia moderate in size, the dist mance, the margin bluish-grey, flexuose, at

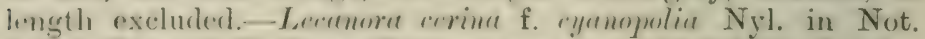
Sillsk. Faun. d Fl. Fonn. Füh. n, ser. v. p. 120 (1866); Leight. Lich. Fl. ed. 3, p. 211 ; Cromb. Monogr. i. p. 382.

Alnost exally similar to the variety, but with slinht differenees in thallus and npothecia.

Hab. On wet stones in upland districts.-Distr. Rare in $\mathrm{N}$. Enoland and IV. Irelami.--1). 1/. C'lollerford, Northumberland: between Lough Feagh and Iongh Much. Comnentara, Galway. 
20. Pl. pyraceum Anzi Anal. Lich. p. 10 (1858).-Thallus effuse, thin, granular-leprose or -areolate, greyish-white, with a whitish hypothallus, often disappearing ( $\mathrm{Kf}+$ reddish). Apothecia numerous, generally very small, orange-yellow ( $\mathrm{K}+$ crimson), with a thalline margin, becoming plane, with only the paler proper margin prominent: paraphyses clavate, sometimes branched and septate at the tips, the cells thickwalled; spores oblong-ellipsoid, 11-16 $\mu$ long, 5-7 $\mu$ thick. Parmelin cerina var. pyrarel Ach. Meth. Lich. p. 176 (1803). Lecanora pyracea Nyl. in Not. Sällsk. Faun. \& Fl. Fenn. Förh. n. ser. v. p. 129 (1866) : Cromb. Lich. Brit. p. 47 pro parte d Monogr. i. p. 383 ; Leight. Lich. Fl. p. 221 ; ed. 3, p. 211 pro parte.

Exsice. Johns. n. 108; Leight. n. 118; Mudd n. 101.

Allied to $I \%$. crimum. but differs in the more scanty thallus and smaller apothecia, which scarcely show a thalline margin. It is constantly associated with other crustaceous species, and may seem to have a thallus different from its own.

$\mathrm{Hab}$. On rocks and stones, rarely (in our country) on trees in maritime and upland regions.-Dists. Here and there throughout the British Isles, probably often overloolied.-I. M. St. Merryn, Cornwall; near Borey Tricer; near Ryde, I. of Wight; Hastings, the South Downs and Beeding Downs, Sussex; near Cirencester, Gloucestershire; Barmouth, Werioneth ; near Newton, Ingleborough. Langbraugh and near Easby, Clereland. Yorkishive; Wark-on-Tyne and Chollerford, Northumberlind: Staveley near Kendal, Westmoreland; Ballachulish, Argrll; Ben Lawers, Perthshire; near Fort Tilliam, Invernessshire; Ballynahinch, Comnemari, Galway ; West. port, Mayo.

Form submersum A. I. Sm.-Thallus thin, dark, becoming coar.ely areolate, otherwise resembling the species.-Lecanora Iyracer f. submersa Nyl. in Flora Ixviii. p. 43 (185.) ; Cromb. Monogr. i. p. 384. Specimen not seen.

$\mathrm{Hab}$. On stones in streams.-Distv. Found only in W. Ireland (near Kylemore, Connemara, Galway).

Var. pyrithromum A. L. Śm.--Thallus paler, generally obsolete. Apothecia more convex, deep-rellow or rusty-red : spores oblong or broadly ellipsoirl, 10-13 $\mu$ long, $t-10 \mu$ thick.-Leristen rupestris var. pyrithroma Ach. Lich. Univ. p. 206 (1s10). Lerenora pyracen f. pyrithema Nyl. in Bull. Suc. Bot. Fr. xiii. 1.:267 (1866) ; Cromb. Lich. Brit. p. 47 ; var. p!yrithroma Cromb. in Grevillea xviii. p. 46 (1889) \& Monogr. i. p). 38.4 (non Leight.).

Exsice. Larb. Lich. Hb. n. 335 \& Lich. Cantab. n. 25.

Diflers chicfly in the absence of thallus and in the shorter, sonnctimes broaler spores. It is generally mixed up) with other lichens with the apothecia parasitic on their thallus.

Hah. On rocks, walls and tlints in lowland and upland recrions.Distr. Rare from E. and N. England, the Grampians and N.E. 


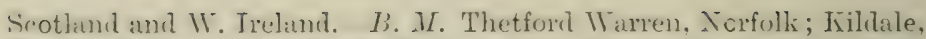
Clevelaud, Forlishire; Craicr Tulloch, Blair Athole, Perthshire; Crairr Guie, Brimmar and I'ark. Aberdeenshire; Longh Inagh, Connenarat, Galway.

f. pictum A. L. Sm.-Thallus thin, greyish, evanescent. - Ipothecia brightly yeliow-pruinose. with a thickish reflexerl froper margin.-Lecirlea picte Tayl. in Mackay FJ. Hib. ii. 1. 130 (18:36). Leranora pyracen vir. 1"!rithromur Leight. Lich. Fl. p. 22 (1871) (non Ach.); ed. 3, p. 212; f. picta Cromb. in (irevillea xriii. 1) 46 (1889) it Monogr. i. 1) 334.

Exsice. Johns. n. 366 ; Larb. Lich. Hb. n. 55.

Distinguisher by the bright-rellow prina of the apothecia, which. however, tends to disappear in herbaria.

Hall. (On schistose rocks in mountainous regions.-Distr. liare in X. Wales, the Scottish Grampians and in W. Ireland.-B. M. Garth Road. Anglesea; lien Lawers and Craig Calliach, I'erthshire; Craig IIt., Rerry; Lettemore and Longh Inagh, Connemara, Galway.

Var. lacteum A. L. Sm.-Thallus thin, chalky-white. Apothecia small, orange-red, becoming convex. - Callopixima Inteoullum var. lucteum Massal. Sched. Crit. Lich. p. 13:3 (15:5i)). Lecenora pyracen var. Inctea Stizenb. Lich. Helr. 1.98 (188.); Cromb. Monogr. i. p. 384.

Exsice. Johns. n. 40 ?.

Distingnished by the whitish thallus. The apothecia are contre. gate in small groups in our specimens.

Hul, On calcareous rocks in maritime districts.-1)istr. Fery ritu in X.E. and N.W. England.-13. M. Hartlepool. T)urham ; Egremont. Cumberland.

Var. holocarpum Anzi l. c. Thallus scanty, greyish. or obsolete. Apothecia erowrlerl, orange-yellow: spores broadly

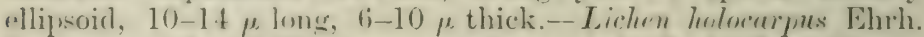

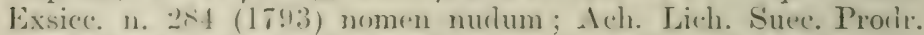

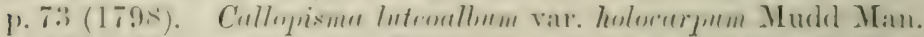

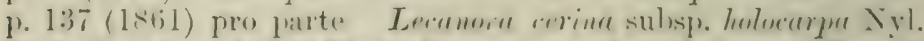

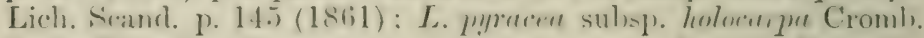
Lich. Brit. p. 47 pro parte; var. holocarpa Leight. Lich. I1. p. 222 (1871) pro parte ; ed. ", p. 211 pro parte.

Exsirc. Johns, 11. 35; Larb. Tich. Hb. 11. 132.

Crombine and others lowl that the wrey thallus does not belone to the lichon: the aprothecia in that wase would be saprophytie on the timber. etc., or" on other lichens.

Hab. On old timber, rarely on rocks, generally in upland situations.-Distr. Father rave in N. England and in the Highlands of

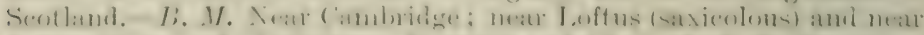

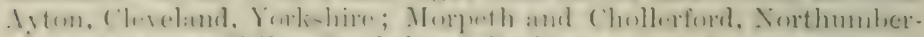

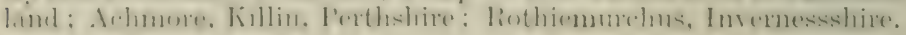


21. Pl. chalybæum Naeg. ex Hepp Flecht. Fur. n. 0t (1853).-Thallus thickish, spreading, or tencling towards a definite outline, closely adnate, depply cracked areolate, whitishor greyish-lead coloured, the outer areolations sometimes crenulate. generally limited by a black hypothallus ( $K+$ pale-violet). Apothecia small or moderate in size, immersed or adnate, plane. the disc black, dull-brown when moist, nakerl (or pruinose?), the thalline margin, when visible, entire, whitish ( $K+$ slightly paleviolet in section); paraphyses clavate, luranched and septate upwards, brown at the tips; sprores ellipsoid, 11-15 $\mu$ lons. 6-8 $\mu$ thick, polarilocular.- Iudd 11 an. 1. 13t; Cromb. Lich. Brit. p. 46 ; Leight. Lich. Fl. p. 179 ; ed. 3, p. 165 . Parmelia chalybrea Fr. Lich. Eur. p. 125 (1831). Lecanora chalybea Scher. Enum. 1) 60 (1550); Cromb. in Grevillea xviii. ए. Iti (1889) \& Monogr. i. p. 390.

Exsicc. Cromb. n. 59 ; Johns, n. 314.

Easily recognized by the colour and by the regular deep areolition of the limited thallus. There is only it very faint violet retetion in the apothecium with potash, but spores and pariphyses are chara.teristic of Placodium.

Hab. On calcareous rocks in maritime and hilly regions.-Distr. Rare in S.IV. and N. England, N. Wales and the Grampiaus, scot. land.-B. 1\%. Jabbicombe, Devon; Llinymynech Hill, shropshire: Great Orne's Head, Carnarronshire ; Penhill, Yorkshire; Burnhoye, Weardale, Durham; Whitbarrow, Westmoreland; Craig Tulloch. Blair Athole, Perthshire.

22. Pl. variable Nyl. Lich. Scand. 1) 138 (1861). -Thialluthinnish, determinate, limited l,y a black hypothallus, crackectareolate, dark- or brownish-grey ( $\mathbf{K}+$ pale-violet). Apothecia somewhat prominent, rather suall, plane or convex, the dise brown or blackish, generally densely bluish-grey pruinose, the thalline margin prominent, entire, whitish: paraphyses suhclavate, septate upwards: spores ellipsoid, $13-16 \mu$ long, $7-10 \mu$ thick (epithecium $\mathrm{K}+$ pale-violet).-Cromb. in Journ. Bot. viii. p. 97 (1870); Leight. Lich. Hl. p. 179 ; ed. 33, p. 165. Lichen rariululis Pers. in Ust. Ann. Bot. vii. p. $26(1794)$. Lecenorn

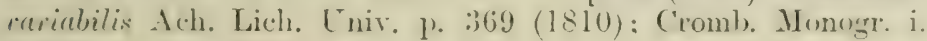
p. 391.

Closely allied to the preceding, of which it might be only a variety. It differs in the darker colour of the thallus, the superticial apothecia and the pruinose dise.

$H a b$. On calcareous rocks in hilly districts.-Distr. Rather rare

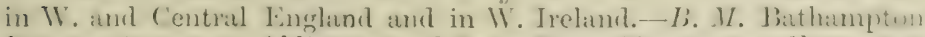

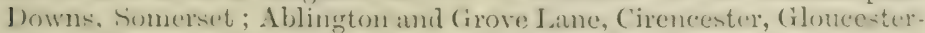

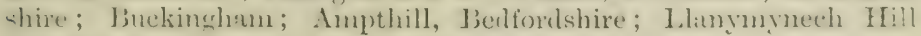
Shropshire; Cunning Dale, Buxton, Derbyshire.

Var. ecrustaceum Nil. tom. (it. 1. l:3!. -Thallus immersoi in the rock, scircely visible. Apothecia small, subinnate, the 
thalline marrin thin, disappearing, otherwise like the species.Pl. Aguillinmum Hepp Flecht. Eur. n. 40 T (15.5) (non Ach.) : Leight. Lich. Fl. ed. 3, p. 165. Lecanora variabitis var. mostrese Nyl. ex Cromb. in Grevillea xviii. 1. 46 (1889) “ MLonogr. i. p. 391.

E.csicc. Johns. n. 131.

Owing to the scanty derelopment of the superficial thallus the :ppothecia are almost non-marginate. They are less corered with fminin than in the species, and are sometimes semi-immersert.

Hal. On calcareous rocks in maritime and mpland districts.Distr. Tare in S.W. and N.W. England and S. Wales.-B. M. Anstey's Cove, Torquay; Jathampton Downs, Somerset; Tenbi: Pembrokeshire; Silverdale, Laneashire; Lamplugh, Cumberland.

\section{Thallus greyish-white $(\boldsymbol{K}-)$.}

23. Pl. phæocarpellum A. L. Sim.-Thallus effuse, thin, meyish-white, often evanescent $(\mathrm{K}-)$. Apothecia small, plane, with a thin proper margin, or couvex, the dise brown or darkbrown ( $\boldsymbol{K}+$ crimson becoming purple); paraphyses slender, hranched upwards and septate at the tips; spores ellipsoid,

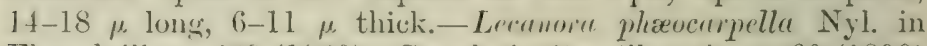
Flora lxiii. 1. :iss (1880); Cromb. in (xrevillea xix. p. 60 (1890)

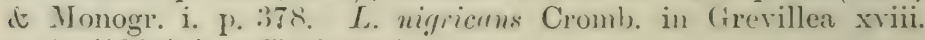
p. 45 (1889) (non Tuckerm.).

The eolonrs of the apothecia distingruish this species from all others. The epithecium is erowder with smill cells budded off from the pariphyses, and deeply suffused with hown lichen-acid, which becomes crimson with potash.

$\mathrm{Hab}$. On the trunk of a tree in a mountainous region.- B. Mr. Craig Cluny, Jraemar, Aberdeenshire.

21. Pl. refellens A. L. Sm. - Thallus thin, unequal, continuous: ur furfunceous, greyish $(\boldsymbol{K}-)$. Apotheciil small, plane, paleredelish, with a thin thalline margin, somewhat pulverulent, at length disappearing ( $\mathrm{K}^{-}$) ; paraphyses thickish, slightly clavate and septate upwarels; spores distinctly polatilocular with central

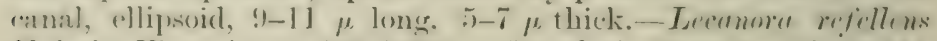

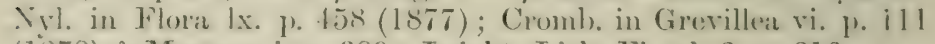
(1878) \& Monogr. i. p. 389 ; Leight. Lich. 1il. ed. 3, p. 213.

E.xsicc. Iarb. Lich. Hi, n. 24.

An abnormal species lacking the presence of prietin both in thallus and apothecial. It is possihly an imporerished development of $P l$. cerinum.

Hub. On the trunks of poplars.- B. M. Cleghan, Connemara, Galway (the only locality).

2.). Pl. erythrocarpum A. L. Sin. Thallus sululeterminate. 'pustaresus, thin, forfuraceous, granulat amb areolate or some- 
times imperfectly lobed or crenate at the circumference, bluishsrey or greyish-white $(\mathrm{K}-)$. Aprothecia plane, round of irregular in form, orange- or tawny-red ( $K+$ deel' purple $)$, the thalline margin thickish, sometimes flexuose; spores broadily ellipsoid, 12-16 $\mu$ long, 8-9 $\mu$ thick.-Lichen arenarius Pers. in Ust. Ann. Bot. vii. 1). 27 (1794) (nom Retz.); Dicks. Pl. Crypt. fasc. iv. p. 23, t. 12, fig. 2. L. cæsiorufus Sin. Engl. Bot. n. 10t1) (1802) (non Schrad.). Patellaria riythreacipa Pers. in Ann. Wett. Ges. ii. 1. 12 (1810). Lrcider rythrocarpia Ach. Lich. Enir. p. 205 (1810). Lecanara tricholytu Ach. tom. cit. p. 425 : Cromh. in Grevillea xviii. 1) 45 (1889) \& Monogr. i. 1). 365. L. rubricosa Ach. Syn. p. 162 (1814) pro parte. Lecanora renaria Cromb. Lich. Brit. p. 46 (1870): Leight. Lich. Fl. 1. 23:3 : ed. 3, p. 21:. Rinorlina rubricosa S. F. Gray Nat. Arr. i. p. 1.5.2 (18:1). Callopisma arenarimm Mudd Man. p. 138 (1861).

Exsice. Larb. Lich. Hb. 11. 26.

Distinguished by the thick furfuraceous thallus and by the habitat. Often confused with $P l$. casio-rufum, but differ's, anuons other characters, in the absence of thalline reaction with potash.

Ha7. On sandstone rockis and walls, rarely on bricks in maritin. and inland districts.-Distv. Iiather rare in the Channel Islitnds, S.I. . and $\mathrm{WV}$. England and in S. Wales.-B. M. Jersey; I. of Wight; , ihoreham, Fairlight near Hastings. I'ulborough and Midhurst. Sussex; near Hereford; near Moumouth; near Lyndstep, I'embrokeshire; Bury St. Edmund's, Suffolk; Strumpshaw, Norfolk; Wislect! and Waterbeach, Cambridgeshire.

Thallus whitish; reaction with potash various.

26. P1. Lallavei Oliv. Lich. Eur. 1). 99 (1909).-Thallus reterminate, thickish, smooth, tartareous, cracked-areolate, chalky-white $(\mathrm{K}-)$. Alothecia subimate, with a thin thalline margin, becoming immarginate, bright-rusty or blood-red ( $\mathrm{I}+$ dark crimson); spores ellipsoid-oblong, 8-12 $\mu$ long, $4-7 \mu$ thick.

- Lecider Lrallacei Clem. Ensayo, p. 29.) (1807). Lecanom Lallavei Nyl. in Ném. Soc. Sci. Nat. Cherb. v. p. 112 (18.ri): (roml). Lich. Brit. 1\% t6 \& Monogr. i. 1\% :366: Leight. Lich. 11. p. 223 ; ed. 3 , p. 212 pro parte.

Allier to the precenting species, but differs in the structure of the thallus, innate apothecia and smaller spores.

$H a b$. On calcareous rocks and walls in maritime districts, - Distr: liare in S. WV. and S. Fngland and S.E. Irelaud.--13. M. I. of Wight: Lower Glanmire Road, Cork.

27. Pl. albolutescens 1. T. Tul. Thallus thin and furturareous, or thickish and areolate, whitish, of evanescent (k- ). Apothecia moderate in size or small, dark-olange, with a paler prominent persistent proper marem (K + crimson) : paraphyses

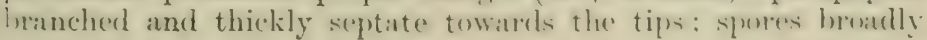




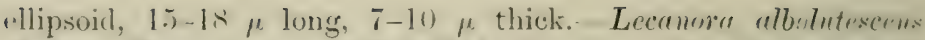
Nyl. in Flora lxiv. 1) 177 (lNel): Cromb. in Grevillea x. 1. 2.2 (1881) \& Nonogr. i. p. 379.

Exsice. Johns. nos. 129, 130 (as form ecrustacea).

The apothecia are sometine large and irregular in form ; they are sublecanorine, gonidia being present below the hypothecium. The thallus also sometimes spreals upwards round the outside. The spores vary in form, the polar loculi may be fairly small, or very large, with the median septum correspondingly thin.

$H a b$. On granitic rocks in upland regions,-Distr. Very sparingly in X. England. - B. M. Trneside, Bịwell. Northumberlind; scalegill. Cumberland.

28. Pl. nivale Tuckerm. Syn. N. Amer. Lich。 i. p. 176 (188*). - Thallus effuse, minutely granular, whitish or greyish ( $\mathrm{K}+$ purplish). Apothecia small, adnate, at first plane with intire proper margin, becoming convex, orange-coloured $\omega$ brownish ( $K+$ crimson); paraphrses septate at the tips; spores oblong-fusiform, simple, hecoming septate, $24-38 \mu$ long, $5-7 \mu$ thick. Zeora nivalis Koerb. in Denkschr. Schles. Ges. Vat. Kult. p. 231, fig. 2(1853). Leromora niralis Carroll in Journ. But. iii. p. 208 (1865): Cromb. Lich. Brit. p. 48 \& Monogr. i.

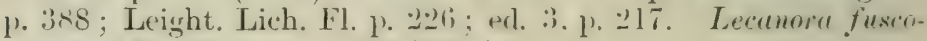
luteolina Mudd Man. p. 153 (1861).

Generally deseribed as having a thin thalline margin, but that is scarcely visible at any stage; in sections there is a strong band of gonidia abutting on the lower part of the proper margin. In some of the spores there is a distinet thickening of the median septum, which. combined with the presence of parietin, plices it in this genus. The apothecia are numerous and crowded.

Hal. On decaved mosses on rocks and boulders in alpine loculities. -1)istr. Spaningly among the S. (immpians, Scotlant.-1;. 1/. Jien lawers and Ben Cruachan, l'erthshire.

\section{Thallus derli-coloured; reaction with potash cerions.}

29. P1. hæmatites A. L. Sin.-Thallus subefiuse or determinate, continuons and wrinklerl, or areolate, dark-grey, with a hish hypothallus ( $\mathrm{K}+$ rrimson). I pothecia morlerate or small. the dise rusty-red, the thalline marein ererish-white, persistent: faraphyses stender, rarely hrandhed and septate upwards: spores oblong- or broadly-ellipsoid, 12-18 $\mu$ long, 6-11 $\mu$ thick.-

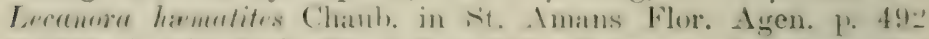

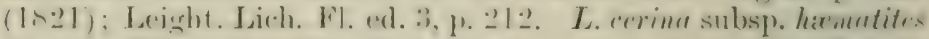
Nyl. in Mćm. Soc. Sci. Nat. Cherb. v. p. 112 (1857); Cromb. llonogr. i. p. 38\%.

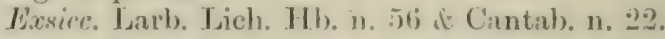

Distinet mot mly in the mhlour of thatlus and apentheeia, but in the hahitat. The aprotheria am gemerally crowded; the spore hocoli aw very small. 
Hab. On smooth bark.-Distr. Kare in S.E. and W. England.li. M. Ilshim, Toryuay; Cherry Hinton and Bottisham, Cumbridgeshire; near Worcester.

30. Pl. cæsiorufum A. L. Sm.-Thallus crustaceous, thichish. crackerl-arcolate, light-or dark-grev (If + purplish). Apothecia molerate in size, often crowded, hecoming jlane, rusty-red ( $\mathrm{K}$ purple), the proper margin prominent, lighter-coloured, oft(1) fiexuose and subcrenulate; paraphyses rather stout and the hypothecium dense, with a laver of sonidia beneath: spores ellipsoid, 14-17 $\mu$ long, $7-9$ is thick. - Lirhen casiorufus Ach. Lich. Suec. Prodr. 1). 45) (1798). Leciden "resinrufa Ach. Meth. Lich. p. 71 (1803) ; S. F. Gray Nat. Arr. i. p. 478 (?). Lecanora

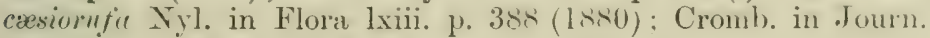
Bot. xx. p. 273 (1882) \& Monogr. i. p. 378.

Exsice. Johns. n. 323 (as val' grandis).

Somewhat similar to $P l$. firmgincum in appearance, but difiering in the structure of the bypothecium, which is of small-celled somewhat obscure plectenchyma and with an molerlayer of gonidia. The. thallus is generally rather thick and dark-coloured.

$H a b$. On siliceous rocks in maritime and inland districts. Distr. Rare throughout the Dritish Isles, perhaps not often identifich. B. M. La Ioye, Jersey; Chateau Point, Sark; The Lizard, Cornwall; near Malvern, Worcestershire; Chollerforl, Northumberland: St. Bees and near Penrith, Cumberlami ; Ayton, Cleveland, Yorkshire; Renwich. Kirlicudbrightshire; near Ellinburgh ; I. of Lismore. Argyll ; Kilkee, Clare; Achill Island, Mayo.

31. P1. fuscoatrum A. L. Sm.-Thallus effuse, blackish, cracked-areolate $(K+$ purple). Apothecia very small, dark rustyred, with a clistinct eutire thalline margin; paraphyses slender, branched, septate and capitate at the tips; spores ellipsoid,

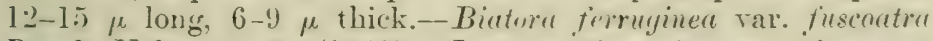

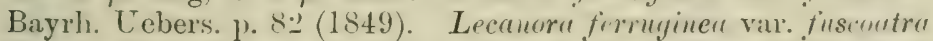
C'ruml). Lich. Brit. p. 47 (1870); Leight. Lich. Fl. p. 2).20; ed. 3, p. 209. L. fuscoatre Nyl. in Bull. Soc. Linn. Norm. sér. 2, vi. p. 260 (1872); Cromb. Monogr. i. p. 377.

A rare lichen, but well distinguished by the darli thallus ant the structure of the apothecium.

Hah. On schistose rocks-Distr. liare in N.W. England, S.II: Highlamis and N.F. Seotland.-13. M. Nonth of l)ouglats, I. of Min: Barcaldine, Argyll.

3:. Pl. concilians A. I. Sm.-Thallus subeffuse, thickisl, coascly areolate, dark-grey or hlackish (K-). Apothecia morlerate in size, with a thalline marsin, becoming plane or convex, and the margin disaplearing, lewwnish black when dry, lark rusty-recl when moist (K + dark-purplish); lamiahyse branched amel septate at the tipse formins a dense ephthecium:

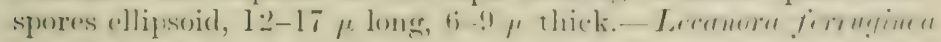


i. anciliums Xyl. Lich. Suand. p. 143 (18if1); var. conciliuns Crmml, in Journ. Bot. viii. 1). 97 (1870); Leight. Lich. Fl. 1. 2.-2); ed. 3, 1. 209. Lermora diphyodes Cromb. in Journ. lint. xi. p. 133 (1873) (non Nyl.); Leight. Lich. Fl. ed. 3, p. 2li3. L. romilirens Nyl. in Flora lxiii. 1). 388 (1880) ; Cromb. Monogr. i. p. 377 .

1)istinguished by the rery dark thallus and apothecia. Gonidia :we abundant bencath the hypothecium and in the margin of the apothecium.

Hab. On schistose rocks in a maritiue region.-D. M. Near Portlethen. Kincardineshire.

\$ iii. Buastexid Stizenb. in St. Gall. Ber. Nat. Ges. iii. 1. 171 (186:) po parte ; Blasteniu Massal. in Flora xxxv. p. 57; (1852) (as genus).

Thallus crustaceous: apothecia without a thalline margin; spores polarilocular except in $P l$. rupestre.

\section{Thallus yellowish $(K+$ purple $)$.}

i3. Pl. ochraceum Anzi Catal. Lich. Sonchr. 1) 44 (1\&60).Thallus determinate, thinly felted, continuous, ochraceous-yellow ( $\mathbf{L}+$ erimson). Apothecia small, sessile, concave then plane, tawny-saffion or orange-yellow, the proper (?) margin ochraceous, thin, prominent; spores variable, ellipsoid or elongate, 1-septate, usually polauilucular, 1ㄹ-15 $\mu$ long, $5-7 \mu$ thick.-Lecirlea ochracea Schre, in Nat. Anz. 1818, p. 11. L. icterica Tayl. in Lond. Journ. Bot. vi. p. 150 (1847) fide Jeishton. Callopisina orhracenn Massal. Monogr'. Lich. Blast. 1). S! (18.53) ; Mudd Man. I). 13:, t. 2, fig. 43 (1861). Lerrmorl arharen Nyl. "x C'romb. Lich.

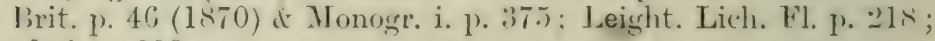
ed. 3, p. 208 .

The marrin of the apothecium is practically withont algate, so that it is more biatorine than lecanorine. Apt to be confused with the following species.

Hab. On crlcareons roclis in moritime and inland districts.-

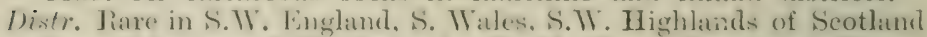
and possibly from $\$$. WT. Ireland.- J). M. Hope ('ore, near lingsbridge, Devon; I. of Lismore, Argyll.

:if. Pl. tetrastichum 1. L. Fin.-Thallus sululeterminate, thinly folted, rontinums, rarely areolate, ochraceous-yellow or yollow ish-grey (K+rimsm). Apothecia small, sessile, concarve then plane, tawny-satlion or orange-yellow, the proper (?) margin lightr.p in colour, prominent ( $\mathrm{K}+$ purplish) : spores broadly (ellipsoid or uhlong, 1-septate, pularilorolar, the cell-contents masserl in the. polar loculi, and drawn out in a wide tube almost to the septum.

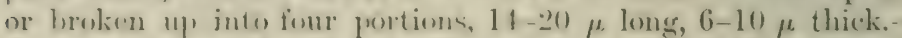

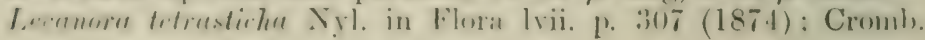


in Journ. Bot. xiv. p. $360(1876)$ it MLonogr. i. p. :3×9: Leightt. Lich. Fl. ed. 3, p. 224.

Closely allied to the preceding, of which it may ouly be at form. but with larger, peculiarly developing spores. They are, however. truly polarilocular, and carefnl eximnination has failed to establish the 4-celled condition. Considered by Nylander to be related to Lex'enor't Brebissonii, a S. American plant.

$\mathrm{Hab}$. On calcareous rocks in maritime and inland situations.Distr. liare throughout Fngland and S. WV. Highlands of Scotland. B. M. Near Plymonth, Chudleigh, Ilsham and above Anster's C'ove. Devon; Cunning Dale, Buxton and near Bonsall, Derbyshire; Malham Tarn, Yorkshire; Levens, TVestmoreland; I. of Lismore. Argyll.

35. P1. vitellinulum A. L. Sm.-Thallus effuse, thin, sometimes faintly areolate, yellowish ( $\mathrm{Kf}+\mathrm{purplish})$. A pothecia very small, numerous, orange-yellow ( $K+$ crimson), the proper margin prominent or at length excluded ; spores oblong-ellipsoid, small, 9)-12 $\mu$ long, $4-6 \mu$ thick. -Lecenora vitellimula Nyl. in Flora xlvi. p. 305 (1863); Cromb. in Journ. Bot. xx. p. 273 (1882) \& Monogr. i. p. 385.

Distinguisher by the colour of the thallus and by the sunall spores. The paraphyses are slender, but often two or more large cells are separated off at the tips.

Hab. On calcareous rocks in maritime and hilly districts.-Distr. Tather rare, but widely distributed throughout the British I-les. B. M. Noirmont, Jersey; Sidmouth, Devon; Yatton, Somerset; Beethwaite, Westmoreland; Overend, Egremont. Cumberland; Lismore, Argyll; Carrigogunnel, Limerick.

\section{Thallus greyish-whtite; reaction with potash various.}

36. Pl. ferrugineum Hepp Flecht. Eur. 11. 400 (1857).-Thillus: effuse, very thin or thickish, and unequal or areolate, greyish or whitish, sometimes evanescent ( $\mathbf{K}+$ purplish). Apothecia small (1) moderate in size, plane, becoming convex, bright rusty-red ( $\mathrm{I}+$ purple), the proper margin thin, rather lighter in colour, prominent, sometimes flexuose; paraphyses septate and branched upwards, and capitate; spores broadly ellipsoid, 11-16 $\mu$ lons.

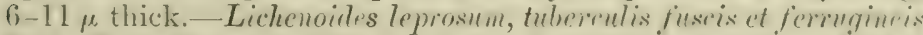
Dill. I Iist. Muse. 1) 126, t. 18, fie. $4(17+1)$ pro parte. Beihen

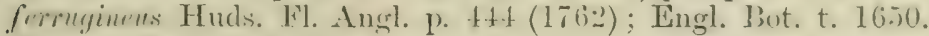
L. vernalis Lightf. Fl. Scot. ii. p. 805 pro parte. Lecanora

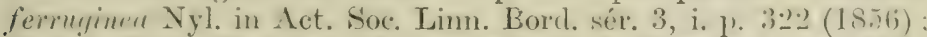
Cromb). Lich. Brit. p. 46 (corticolous) it Monogr. i. 1'.376:

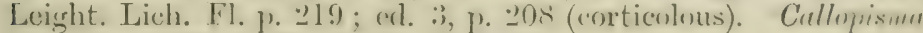
fermgineum Mudd Man. p. 139 (1861).

Exsicc. Bohl. n. 108 ; Larb. Lich. Hb. n. 95.

The thallus is variable, but the species is well clistingnished by the persistent runty-red colour of the apothecia. Oecatsionally the thallus 
grows up around the apothecin, or) that they ahmost appear to hatre a thalline margin.

Hab. On trunks of trees in maritime and inland districts.Distr. General in wooded districts of most parts of the British Isles.-B. M. Gnernsey ; Boconnoc, Cornwall ; near I'lymouth, Devon: New Forest. Hants; Shanklin and near Rrde, I. of Wight; Hurst. it. I,eonard's Forest, Lewes, Jrighton. Shoreham, Newhaved. Maywards Heath, Waliehurst ant I) Imy, Sussex; Epping Forest. Widlington, Langford, Stansterl and Mountfitchet, Essex; Cirencester. (iloncestershire; ()swestry, Shropshire; Bamouth, Merioneth ; Tre. frix, Cammonshire; Anglesea; ('leveland. Torkshire; Teesdale. Jurhan; Levens and Windermere. Westnoreland; Largs, Arrshire: near Stirling; Finlarig, Kemmore and Aberfeldy, I'erthshire; Cork; Kienmare and Glenmore Lake, Tien'y ; Ti ylemore, Connemara.

Var. festivum A. L. Sin. - Thallus thin, continuous or areolate. light-or dark-grey, often evanescent. Apotlecia small. often convex, the proper margin becoming flexuose and crenulate or disappearing,-Lichen ciemularius With. Arr. ed. 3, iv. p. 405 (errore L. crenulatus, p. 22) pro parte. Lecidea cresio-rufa var. iestive Ach. Syn. Lich. p. 4 t (181t). Leecenen ferminea var. fexticu Nyl. Lich. Scand. 1'. 143 (1861); var. cemularia it f. fistiven Cromb. Lich. Brit. 1) 47 (1870): ff. survenlu, festivu Jeeight. Lich. Fl. pp. 219, 2.20 (1871): ed. :3, pp. 208, 209. Culloprimu fervunineum var. festivum Mudd M[an. p. 139 (1861).

Exsice. Johns. nos. 104, 312 ; Larb. Lich. Hb. n. 165 ; Leight. n. 85 ; Mudd n. 102.

Differs chiefy in habitat from the species. The thallum gives rery little reaction with potash, and when dark-grey gives none at all. The apothecia may be seattered or very cromeleil. Withering s name L. crenularius refers to a plant on trees as well as rocks.

Hub. On rocks, chiefly siliceous, in maritine and upland district.. -Dis/1. Sonewhat rentral thronghout the British Isles.-13. M. Iersey; Alderney; Silrk; St. Austell, St. Minver and near P'enzance. ('ormwall; Kingsbridge and Torquay, Deron; Jeerling. Sussex: Haughmond Hill, Shropshire ; Llandysil. Cardiganshire ; Aberdorey. Merioneth; Ilolyhear MIt, Anglesea, Jettws-y-Coed. Carnarvonshire : Malvern. Woreestershire; near Roseberry, Cleveland, Yorkshire:

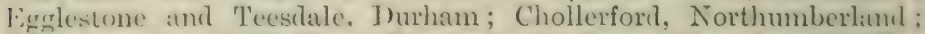
Whitehaven and st. liees, cumberland; Barealdine. Argyll; The. Trosiachs, Perthshire; Immie Craigs and West Water, Forfarshire: l'ortlethen, lincardineshire; near lballiter, Aherdeenshire; near Inniscarra, Cork; Saltees, Wexford; Kilkee, Clare; Iiylemore. Galway; Clare Island and Achill, Mayo; Glenam, Antrim.

Form ferruginascens 1. L. sin. Thallus efluse, whiti-h, thin or evanerent. Apotheria rery small, plane and with a proper marein, beeomine convex, taw ny ferruginous $(K+$ purple $)$ : spore-

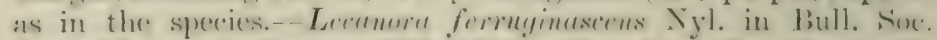

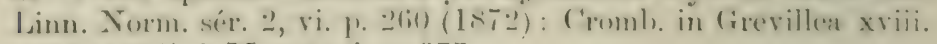
p. 45 (1889) \& Monogr. i. p. 37 \%

Exaice. Jolins. 11. 105. 
Though made a species by Nylander, it is very closely related to var. festivum. The spores of our specimens are very distinctly polarilocular and measure about $15 \mu$ long and $7 \mu$ thick. As in the variety the thallus gives little or no reaction with potash.

$H a b$. On schistose rocks in an upland situation.-B. M. Near liendal, TVestmoreland.

37. Pl. cerinellum A. L. sm.-Thallus thin, sorclid-greyisl, scarcely risible ( $K+$ yellowish). Apothecia minute, subbiatorine, bright-vellow ( $K+$ jurplish): spores $r, 12$ or 16 in the ascus. ellipsoid, polarilocular, small, 9-12 $\mu$ long, 5-6 $\mu$ thick. Letruora rerinella Nyl. in Bull. Soc. Bot. Fr. xiii. p. 370 (1866) \& in Bull. Soc. Linn. Norm. sér. 2, vi. p. 260 (1872); Cromb. in Journ. Hot. xx. p. 2-7:) (188:2) \& Monogr. i. p. :38:. Specimen not seen:

Described by Nylander as resembling a minute $P l$. cerinum, but it difiers in the number of spores in the acus. It has been freunently. recorded on the Continent.

On branches of trees in lowland districts.-Distr. E. England, near Cambridge.

3ร. Pl. luteoalbum Hepp Flecht. Eur. n. 202 (15.5:3). - Thallus effuse, thin, furfuraceous, grevish-white, sometimes evanescent $(\mathrm{K}+$ ). Apothecia generally numerous and erowded, small, at first imnte, then superficial and plane, with a thin paler proper. margin, becoming convex, deel) orange-yellow ( $\mathrm{K}+$ crimson): hymenium rather narrow; parajhyses slender, septate and rather. swollen at the tips, sometimes clistinctly capitate; spores ellipsoid, small, the polar loculi very distinct, but the median septum thin, 9-11 $\mu$ long, 4-5 $\mu$ thick.-Lichen luteoalbus Turn. in Trans. Linn. Soc. vii. p. 92, t. 8, fig. 3 (1804); Engl. Bot. t. 1426. Patellaria ulmicola DC. Fl. Fr. ii. p. 358 (1805). Lecidea luterulba Ach. Lich. Univ. P. 207 (ISIO); S. F. (iraty Nat. Arr. i. p. 475 ; Hook. Fl. Scot. ii. p. 40. L. ulmicola Borr. ex Hook. in sos. Engl. Fl. v. p. 185) (18:33). Cellopisma luteorllum Massal. Monosr. Lich. Blast. p. \$0 (185:3); Mudd Min. p. 136. Lecunoru

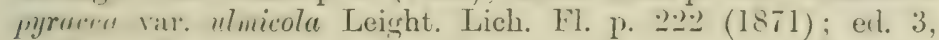
p. 211. L. Tuteoalba Nyl. ex Lamy in Bull. Soc. Bot. Fr. xxv. p. 398 (1878); Cromb. Nonogr. i. p. 385.

Exsicc. Bohl. n. 76 ; Cromb. n. 61 ; Larb. Lich. Hb. n. 168 \& Cantab. n. 19; Leight. n. 84; Mudd n. 98.

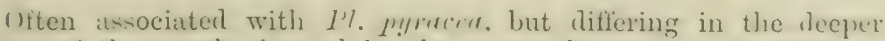
colour of the apothecia and in the spore characters. (ionidia atre mesent in at broad band below the liypotheeimu, but mot in the margin.

Hab. On trees, chietly elun, and on old wood.-Distr. Fairly general throurhout the british Isles.-1;. M. Near Ventnor and near Shanklin, I. of Wight; I.ewes. (ilynde. Washington, I)anmy I'ark and Woodmancote. Sussex; Eynsforl. Kient; near . Mill Hill, Mirlllesex; El-tree, Herts; Stowe I'ark. Jurk-: Wimlsor (ireat l'ark, Jierks;

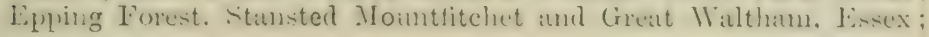


Derlforthire: near Cirencestrr, frloucester hice; near Worcester and North Malveru, Woreester-hire: Wimpole: Park and Marlingley, (ambridseshire; Twyerois, Leicestershire; near Masham, Yorkshire; Levens Bridre, Testmoreland; Telion Park, Tansheck Talley, Torthmberland; 1)oun Cintle, Stirlingahire; P'itfour, Aberleenshire ; Tostellitn, Cork : Imnisfallen, Fillarney, Kerry ; Castle Comnell. Limerick.

Form rupestre A. L. Sw.-Thallus whitish, grey ish or obsolete, fenerally in scattered granules. Apothecia minute, scattered or rrowded.-Leridra ulmirola Tayl. in Mackay Fl. Hib. ii. p. 129 1836). Leanura cerim subsp. murcen f. mpestris Nyl. Lich. s.ancl. 1). 14.; (1\&61). L. Intencellue f. rupestris Cromb. Monogr. i. p. $386^{\circ}(1894)$.

Exsicc. Johns. n. 313 ; Leight. n. 213 ; Mudd n. 146.

The structure of the apothecium, spores, ete., is similar to that of the species; it differs chieffy in the habitat which has influenced the iluearance of the thallus. It is symonymous with f. calcicola Arn.

$H a b$. On limestone, mortar or arenaceous stones mostly in upland districts.-Distr. Rare in S. and N. England and S. WV. Irelind. - B. M. Newton Abbot, Deron; Ingleby, Cleveland, Yorkshire; Bolam, Durham ; Dunkerron, Kerry.

39. Pl. xupestre Branth if Rostr. in Bot. Tidskr. iii. 1. 206; (1869).-Thallus thin, determinate, cracked-areolate, dirty-whitish ur -reyish $(\mathrm{K}-$ ). Apothecia arluate, small or moderate in size, plane or convex, not marginate, yellowish-or dull-red $\left(K+\mu^{n}{ }^{\prime} p l e\right)$; paraphyses slender, swollen and septate at the tips, conglutinate: spores ellipsoid or ovoirl, simple, 9-15 $\mu$ lons, j-s $\mu$ thick.-. Lichen mpestris som. Fl. Carn. erl. -2, ii. p. 36:3 (1772); Engrl.

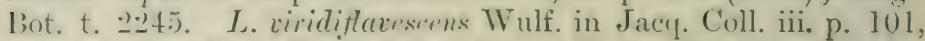
t. 2, fic. 1 (17S!). Vermentiu infescens Hoffm. Pl. Lich. i. p. so, t. 17, ties. 1 (1790). Leridea musestris var. imuluta Ach. Lich. Unir. 1\%. ofof (1s10); var. viridifucesens MIudd Man. 1). 191 (1,61). L. irmbutı Ach. Sym. Lich. p. 40 (1s1.t); Hook. in sin. Enst. Fl. v. p. 18:3; Tayl. in Mackay Fl. Hib. ii. p. 128.

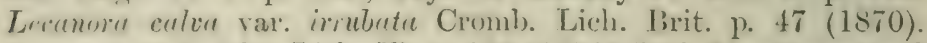
L. rupestris Leight. Lich. Wl. p. 190 (1871) (incl. f. rufeseens and t. vividiflaceserns): ed. 3, 1). 204. L. imbluta Nyl. ex Norrl.

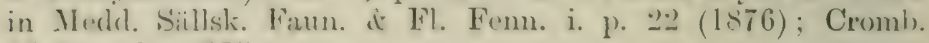
IIonogr. i. p. 387.

Ersire. Johns. nos. 194, 20(5 (?), 110; Larb. Lich. IIb. n. 101); Leight. 11. 119 ; Mudd n. 161.

Cienerally elassified muder Lividen Seret. Biatora, on account of the simple spores, but belongs to Jlurolium (Siect. Blastenia), not only in account of the spermogrmes, which have septate sterigmata and pl-urosmous spernatia, but also the presence of parietin, the lichen areid which is parent mly in lichens of this order. It can easily be reognized and placed by the reaction with potash. The anothecia breomes a darker red with are (f. rufesechs), and the spores have menerally thicliened walls. though rately any indication of central 
septation. Tohnson's Lirsice. n. 268, seems to belong here lut our specimen is imperfectly developed.

Hab. On calcareous rochs, mortar. sandstones, ete. in maritime and inland localities.-Distr. Not uncommon throughout Great Britain and Irelant.-B. IT. Tear P'enzance, Cornwall; Anstey's Cove. Torpuaty and Commorthy, Devon; Beachy Head, Duncton aurl Beelling Downs, Sussex; Shiere, Surer; Windsor Great Park, Berks; Jathampton Dorns, Sonterset; Norton, near Norcester: Llanymynech and Whitcliff Roclis. near Lullow, Shropshire: Bilsclale and near Carlton, Cleveland, Jorkshire; Beamish, Durham: Leren's Park, Testmoreland; Chollerford, Northumberland ; Appiu. Argyll ; Craig Tulloch, Perthshire ; Kirkland, Fife ; Killarney, Kerry ; Ben Bulben, Sligo; neur Krylemore, Connemara, Galway; Mallaranny. Achill Sound and Clare Island, Mayo.

Var. calvum A. L. Sm.-Thallus effuse or determinate, thichish or immersed in the stone, whitisb. Apothecia small or moderate in size, subimmersed in the thallus or in the rock, rerldish-yellow ( $\mathrm{K}+$ purple); jaraphyses thickish.-Lichen ralums Dicks. Pl. Crypt. fasc. ii. p. 18, t. 6, fig. $\frac{1}{2}(1790)$; With. Arr. ed. 3. ir. 1) 1t; Engl. Bot. t. 948. Lecirlen vu extris Ach. Lich. Unir. 1). 206 (1810); S. F. Gray Nat. Arr. i. 1) 472 ; Hook. Fl. Scot. ii. 1). 39 it in Sm. Engl. Fl. v. p. 183; Tayl. in Mackay Fl. Hib. ii. 1\% 128; Mudd Man. ए. 19:3. Lecenora calea Nyl. Lich. Scand. 1). 147 (1561); Cromb. Lich. Brit. p. 47. Lecanora ruputic $\mathrm{f}$. alua Leight. Lich. Fl. p. 191 : ed. 3, 1. 203: Cromb. in Grevillea xii. p. je. Leranora imuluta subsp. culcu Lamy in Bull. Soc. Bot. Fr. xxx. p. 378 (1883); Cromb. Monogr. i. p. 387 .

\section{Exsicc. Bohl. n. 73 (drawing only); Johns. n. 195.}

Differs from the species in the thallus. which is not areolate, an! in the apothecia immersed at the base and leaving pits in the rock (foveolate). They are generally larger than in the species.

Hab. On calcareous rocks, rarely on flints in maritime and momntainous district-.-Distr. More restricted than the species thongh common where it occurs in Great Britain, not scen from

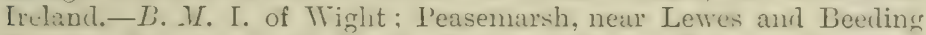
lhwns, Sussex; I, rdil beach, lient; Iieigate, Surrey; Compton Bi-hol, Sonerset; Craig-y-Ihliw, Oswestry. Shropshire; Llangollen. lonbighthire ; Angleser ; Egrglestone. Durhan ; Jeven's I'ark, West moreland; Brwell. Northunberlind; King's Park, Edinburgh : Achoragin Hill. Appin and near Jen ('ruachan, Argyll; Craig Trulloch. I'erthshire; C'raig Guie and Momone, Bratemar, Aberteenshire.

Finn incrustans A. L. Tim.-Thallus thin, white, mostly immerserl in the rork. Apothecia small, plane ur slightly comvex.

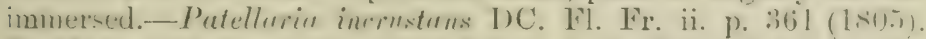

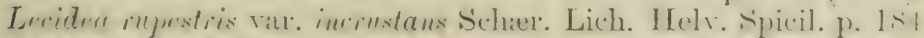

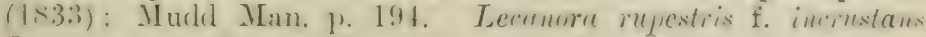
Leight. Lich. F1. p. 191 (1871); ed. 3, p. 203. L. irmuatu

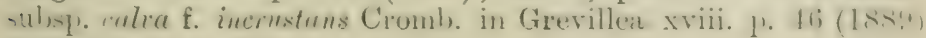
i. Monogr. i. p. 388. 
1)iffers from the variety only in the somewhat smaller apotheciat, which sumetimes remain entirely immersed (forcolate), though other fruits in the specimen become prominent.

Hab. On calcareous rocks in maritime and inland regions.Distr. Rare in S.W. England, the Grampians and TV. Scotland.I). M. Bathampton Downs, Somerset; Lismore, Argyll.

Suhsip. Siebenhaarianum A. L. Sm.-Thallus effuse, thickish, in small patches, cracked-areolate or of scattered rranules. - Ipothecia rather large, aclnate, convex, at first orange-coloured becoming dark-olive or blackish; hypothecium yellowish-brown; spores as in the species. - Biatora Siebenhaariana Koerb. Sisst. Lich. Germ. p. 207 (1855). Lecanma imbate subsp. Sirbenlearrianu Cromb. in .Joum. Bot. xxiii. 1). 195) (1885) it Monorge. i. P. 388 .

An alpine lichen, distinguished by the dark apothecia. 'Th. Fries (Lich. Siand. p. 425) says that the lyypothecium is in young stage:s violet-ruse in colnur, becoming more and more brown. "I hive been mable to rerify that on our specimens; the hypothecium is some shade of yellow in the younger fruits.

Hab. On mica-schist rocks.-Distr. Rare in the S. Grampians, Sicotland.-B. M. Summits of Ben Lawers and Craig Calliach, Perthshire.

Thathes blurlish; reartion with jotash, crimson-purple or mone.

40. P1. atroflavum A. L. Sm.-Thallus effuse or determinate. blackish, very thin or with small raised smooth warts on a black lypothallus $(\mathrm{K}-$ ). Apothecia small, plane, becoming convex, shining, reddish-yellow, the proper margin rather lighter coloured (K + crimson): paraphyses slightly thicker and luanched and septate at the tips: spores ellipsoid, 9-11 $\mu$ lons, $\overline{-}-6 \mu$ thick.-Lecidea atroflava 'Turn. in Trans. Linn. Soc. ix. p. 14:, t. 11, fig. 2 (1808); Hook. in Sm. Engl. Fl. v. p. 185. Lichen atro-

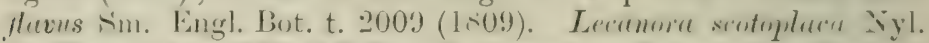

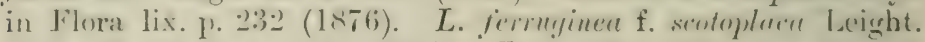
Lich. Fl. ed. 3, p. 209 (1879). L. atroflave Nyl. ex Kwackh Lich. Heiclelb. p. 83 (1883) ; Cromb. Monogr. i. p. 379.

Distinguished by the very dark thin smooth thallus, which is however sometimes obsolete. The apothecia are sometimes very crowded, suggesting 1 l. pyraceum val. holocarpum.

Hab. On siliceous rocks, usually exposed flints, mostly in unaritime regions.-1)istr. Local and scarce in S. and E. Englaud. N. Wales and N.W. Ireland.-B. M. Ryde, I. of Wight; Beachy Head and the Downs, Sussex; Lydd Beach, lient; Barmoutl, Merioneth; Iiylemore, Connemara, Galway.

11. Pl. Turnerianum A. I. Sur.- Thallus thin or thickish,

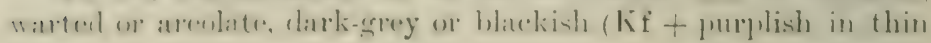


section). Apothecia small or moderate in size, with a frreper margin, flexuose in the larger a prothecia, orange-reddish or brown. the margin lighter in colour ( $K+$ erimson); paraplyses slender. lranched and septate at the tips: spores lovadly ellipsoid, 11-16 $\mu$ long, 7-10 $\mu$ thick.-Lecidea Turneriana Ach. Lich. Univ. p. 206 (1810). Lecanora Turneriana Nyl, ex Cromb. in Journ. Bot. xiv: p. 360 (1876) \& Monogr. i. p. 379.

Exsice. Jolns. 1. 106 : Larb. Lich. Hb. (without a number).

Allied to $\mathrm{Pl}$. atroflavum, but with a thicher thallus; the spores are sometimes almost globose. perhaps owing to compression in the aseus.

Hab. On rocks in maritime districts.-Distr. Rare in S. Wales. N.W. Eugland and IV. Ireland.-- B. M. St. David's, I'embrolieshire; Barrowmouth, Cumberland ; Killery Bay, Comnemara, Galway.

48. CANDELARIELLA Müll.-Ar.s. in Bull. Herb. Boiss. ii. App. i. p. 47 (1894). Lecanora subgen. Candelaria Nyl. in Flora lxir. p. fit (1851) pro parte: Cromb. MLonogr. i. 1. :266. (Pl. 48.)

Thallus crustaceous, sranular, sometimes lobed at the circunference, yellow-coloured $\left(\mathrm{K}^{-}-\right)$. Algal cells Protocorens. Apothecia sessile, yellow, with a thalline margin $(K-)$; hrpothecium colourless : paraphyses unbranched, occasionally septate. and wider towards the apex; spores 8 or many in the ascus, colourless, ellipsoid, simple or 1-septate. Spermogones minute, with septate forked or brancherl sterigmata and acrogenous. spermatia.

The yellow thallus characteristic of the species in this gemus contains no parietin, but though in that and in other respects resemblimg Leconnra, there are undoubted aftinities with the Plirsiaceie, as the spores tend to become septate and, occasionally, polarilocular. It has been suggested that this genus may form the base of the polarilocular series. There is also aftinity with the genus Candrlaria (Parmeliacex).

\section{Thallus lobate at the circunference.}

1. C. crenata A. L. Sm.--Thallus orbicular, the lobes of the circunference effigurate, short, divided and crenate, convex. yellow $(\mathbf{K}-)$. Aprothecia moderate in size, plane, citrine. or livid yellow, the thalline margin granular-crenate; spores many in the ascus, ellipsoid-ololong, simple ot obscurely septatte, !- 15 il long, $1-7 \mu$ thick.-Lichen murormm var. remulatus IVahlenh. Fl. Lapp. 1). H6 (181:) (non Dicks.). Letrnore "renuta Nyl. in Sot.

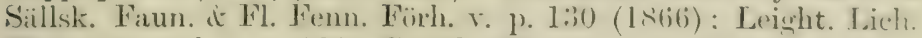
Fl. p. 180 ; ed. 3, p. 166 ; Cromb. Monogr. i. p. 367.

Not unlike Placodium murorum in the form of the thallus. But dilfering in the absence of parietin and in the sprore chatactex. I 
-pecimen recortul from Anglesea has 8 spores in the ascus and belongs to $C$. medians.

Hul. On rocks in a maritime district. - B. M. Portlethen, Kincilldineshire.

‥ C. medians A. L. Sm.-Thallus orbicular, often irregular, libate at the circumference, the lobes rather flattened or narrow and convex, the centre granular-areolate, orange- or citrinevellow, or sreyish in the centre $\left(\mathrm{K}^{-}\right)$. A Apothecia rather sinall, ilull-brown or yellow, the thalline margin entire or crenulate: suores \& in the ascus, oblong-ellipsoid, occasionally 1-septate: $11-17 \mu$ lons, 4-6 $\mu$ thick.-Purmelia jurietina var. gramlatu Schere. Enum. p. .0 (1850). Plarortimm mertians Nyl. in Bull. Six. lint. Fr. ix. p. 262 (1862). Lecanora mertirns Nyl. in Bull. Foce. lint. Fr. xiii, p. 367 (1866); Leight. Lich. Fl. p. 20.5 : erl. :3, p. 189 ; Cromb. MIonogr. i. p. 370.

Exsicc. Larb. Lich. Hb. n. 59.

The lobes of the circumference resemble those of Placorlium murorum, but it is easily distinguished by the absence of reaction with potash.

Hab. On calcareous rocks and walls in lowland and upland districts.-Distr. Rare in Central and IV. England.- B. IT. I'inlsury Lark, Cirencester, Gloncestershire; Llanmymech Hill. Shropshire; Denny Abbey, Cambridgeshire; Beaumaris, Ánglesen.

\section{Thallus gramular.}

¿. C. vitellina Mïll.-Ar'g. 1. c.-Thallus eftuse, thickiklı. arimalar, the granules small, roundish, exowded, dividerl intu areoler, bright or clull orange-yellow (vitelline). Apothecia sissile, plane, tawny- or dull-yellow, the thalline matrin entine 11. sranular-crenulate: spores many in the ascus (1.2-20.1-320), - llipsoid-oblong, sometimes slightly curved, becoming 2-cedled.

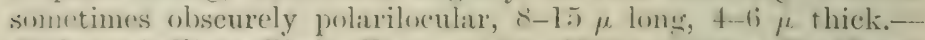
Lidh" vitellims Ehrh. Exs. 11. 15.) (175.)) : Dicks. Pl. Crypt.

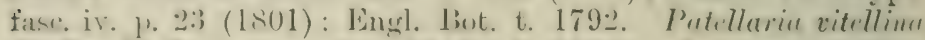

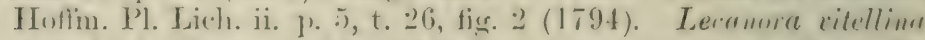
Ach. Lich. Univ. 1) 41):3 (1810) (incl. val. arruscuns): Hook. Fl. sont. ii. p. 19 d in sm. Enel. Jil. r. p. 1!) ; Tayl. in Mackay El.

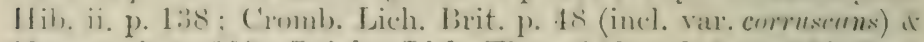
Monogr. i. 1. 368; Leight. Lich. Fl. p. 180 ; ed. 3, p. 166 (incl. var. corruscans).

Exsire. Bohl. n. is; Johns. n. 32; Larb. Lich. Hb. nos. 214, $297,298$.

The thallus forms a dense crust of fine granules divided into

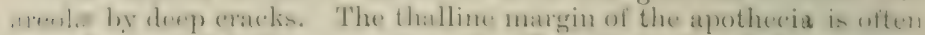
anmalar-eremblate (sare corrusedus). ('rembie states that matitime specimens give a brownish-red reaction with potash, the result probably of being sprayed with sea-water. 
Hab. On rocks, walls and earth, also on trees and old palings.Distr.-General and common throughout the British Isles.- L. M. Tersey; Gruernsey; Sark; Launceston and St. Yinver, Cornwall: Lustleigh Cleeve, Devon; Broonfield, Beeleigh and Tralthamstom. Essex; Madingley, Cambridgeshire; Ankerdine Hill and Malreme. Worcestershire; Longmynd, Shropshire; Bannouth, Merioneth: Anglesea; Buxton. Derbyshire; near Arton, Clereland, Forkshire: Stockifield and Swinhope, Tirst Allendile, Northumberland; near Fiental, Testmoreland; Alston, Cmmberland; C'rigleith, near Filinburgh; Appin. Argrll; Fillin. Ben Lawers and Criag Tulloch, Hlair Athole, Perthshire; Will's Jraes, Forfarshire; Portlethen, Kincardineshire; Bridge of Gitirn, Ballater, Aberdeenshire; Rothiemurchn-. Invernessshire; Kylemore, Connemara, Galmay.

Var. aurella A. L. Sin.-Granules of the thallus scattrorerl. wften almost disappearing. Apothecia minute, otherwise liks. the species.--Virmarir "micllu Hoffun. Fl. Deutschl. ii. 1'. 19:(1795). Leroura ritellina var. aurellu Ach. Lich. Univ. p. \&11 $\frac{1}{4}$ (1sio); Cromb. Lich. Brit. p. 4s it Monogr. i. 1) 369 ; Leight. Lich. Fl. p. 181 ; erl. 3, p. 167.

Exsicc. Johns. n. 100.

Hab. On rocks and walls in maritime and upland districts.I) istr. Rare in the Channel Islands, X. England and Highlands oi Ścotlanr.-B. I. Sark; East Allendale, Northmuberlank; Appin. Argyll; Tillin, P'erthshire.

Var. xanthostigma A. L. Sm. -Thallus thin, more leprone than in the species, sometimes rery scanty. Apothecia minut.. -Lichen citrinus Sin. Engl. Bot. t. $1793^{\circ}$ (1807) (non Ach.) ficle. Crombie. Lecanora citrina var. canthustigma Pers. ex. Ach. Lich. Univ. p. 403 (1810). L. vitwllina sulssp. wanthostigma Iyl. in Not. Siillsk. Faun. it Fl. Femm. Fürh. v. I. 130 (1866): Cromh. Monogr. i. p. 369. L. anthestigma Cromb. in Journ. But. Xx. p. $273(1882)$.

Hur. On the trunks of old trees in wooled districts.-Disti. (12il: recorded from S. and E. England.-B. M. Glyude, Sussex; Wialtium. stow, Essex; near IBradford, Wilts; Windsor Great Park, Berli-.

t. C. epizantha A. L. Sm.-Thallus effuse, thin, glanule... scanty or almost disappearing, orange-yollow or greyish ( $\mathrm{K}-$ ). Apothecia mumsous, small, with a thin pale-yellow subrenuiat. margin, plane, becoming convex; spores 8 in the ascus, nblunt or ellipsoid, simple, sometimes becoming septate and polarilorular.

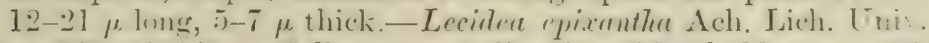

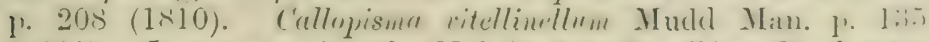

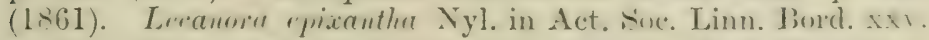
p. 62 (1864); Cromb. in Grevillea xviii. p. 45 \& Monogr. i. p. 370 ; Leight. Lich. F1. p. 206 ; ed. 3, p. 213 . L. vitellina var. epixanthe Cromb. Lich. Brit. p. 48 (1870) (incl. var. octospora); Leight. Lich. F1. p. 181 ; ed. 3, p. 167.

The thallus is much more scanty than in $C$. vitcllina and the

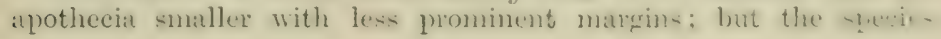


-ibitly diflers in the munber of the syores with and their more pronounced polarilocular character.

$H a b$. On rocks and walls in maritime and upland situations.Jistr. Thare in S. England. Wales amd S. Ireland.-- D. M. Hastings, sustex; Chedlat, Sorrerset; Inlandyssil. Cardiganshire; Ciant:Stairs, Cork.

4!) PHYSCIA schrel, Gern. H. ed. s, ii. p. T6i (1791): emend Th. Fr. Lich. Aret. p. 60 (1860). Borrera Ach. Lich. Inir. 1). $496(1<10)$ pro parte: S. F. Gray Nat. Arr. i. p. 434 fro parte: Hook. El. Scot. ii. 1. 56 pro parte; Mudd Man. p. 103. (Pl. 49.)

Thallus rarely ascending and fruticose, more generally foliose and horizontal, grevish, whitish or brown, attached by haptera or hy rhizoids. Structure various, radiate, subrarliate or dorsirentral. Apothecia discoid, sessile or shortly stalked, with a thalline margin, the disc dark; hypothecium colourless, brownishyellow or dark: paraplyses septate, simple or branched near the alpices and tipled with brown: spores $s$ in the ascus, dark-brown. more or less distinctly polarilocular.

There is considerable rariation in the thallus; a few species are wholly surounded by a cortex which is formed of hyphe parallel with the long axis of the frond, termed fitrous. This type of cortex in some is confined to the upper surface, in others to the lower; while in other's agrain it is replaced by a cortex of plectenchrma. Thore species with a filrous upper cortex have been placed by some anthor's in a separate genus Anaptyrhin (Loerb. Syst. Lich. Germ. 1. $49(18,55))$. The spoles have neatly ilways a well-matied polarilocular structure, lut the apices of the spores rather than the septa are the most thickencil portions, and the cell-lumens are thus pliced near the median wall.

\section{A. Cortex fibrous above or on both surfaces.}

Thallus fruticose or partly ascendiny.

1. Ph. intricata Scher. Enum. 1) 11 (1850). - Thallus

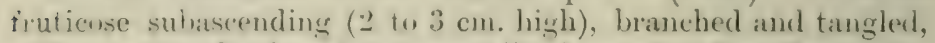
with routing hyphas, but erencmally hecoming free from the -ubstratum at the hase : fomds narow, rather compressed and . lannelled, fulleserent and uneren. (onnected together by haptera, iles ultimate hranchlets often sherty fimbriate, gregish-erlateous (h-). Apullereia rare, latcral, stssile, rather small, convex, with a thin entio ereg marerin: spores dank-brown, ls-20 $\mu$ long, 11-15 $\mu$ thick.-Cromb. Lich. Brit. p. 37 ; Leight. Lich. [1. p. 144; ed. 3, p. 13:3. Lichenoides subhirsulum teres, scutellis purvis niyris Dill. Hist. Musc. p. 157, t. 2l, f. 51 (1741). Lichen intricatus Desf. Fl. Atl. ii. 1) 420, t. 258, f. 3 (1800).

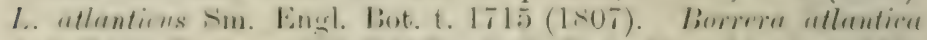

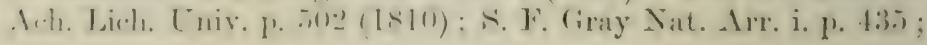


Hook. in S'm. Engl. FI. v. 1. 223. B. intriente Mudd Man. p. 104 (1861).

Exsice. Cromb. n. 49, Mudd n. 76.

The ouly British species of the genus that has a radiate structure and wholly fruticose habit. The cortex is composed of filament parallel with the long axis (fibrous); these hyphe send out short branches on the surface which give the plant a soft pubescent appearance. It somewhat resembles $P h$. villosa, a southem lichen, but is not hairy and differs in the apothecia.

Hab. On rocks, sand and trunks of old trees in maritime districts. -Distr. Local in S. England.-B. M. Brackleshram near Selsey, near Portfield and near Chichester and Barnham and clifls near Hastings, Sussex.

2. $\mathrm{Ph}$. ciliaris DC. Fl. Fr. ii. p. 396 (180.5)...-Thallus spreading, of elongate rather narrow branching imbricate lacinie, subascending or generally decumbent, greenish-grey or rlark-coloured, the under surface pale, hollowed sut, the margin: beset with long grey or partly brown fibrils or cilia which often form haptera at the tips, attaching the frond to other parts of the lichen and to the substratum $(\mathbf{K}-)$. Alothecia large: stalkerl, the dise brownish-black, often bluish-grey-pruinose, the margin prominent, entire or generally crenate, becoming proliferous; spores ol)hong, 30-50 $\mu$ long, 18-24 $\mu$ thick. -Cromb. Lich. Brit. p. 38 : Leight. Lich. Fl. p. 14t: ed. 3, p. 133 (incl. ff. actinota and verrucosa). Lichenoides arboreum foliosum rinereum, srutellis niyris, foliomm extremitretibus hispridis et pilosis: Dill. in Ray Syn. ed. 3, p. 73, n. 67 (1724). Lichenoides hispidum majus et rigidius, s'ntellis migris Dill. Hist. Musc. p. 150 , t. 20, f. 45 (1741). Lichen ciliaris L. Sp. Pl. p. 1144 (1753) ; Huds. Fl. Angl. p. 44s : Lightf. Fl. Scot. ii. 1. 82 : With. Arr. ed. 3, iv. p. 55; Engl. Bot. t. 1352. Parmelia riliaris Ach. Meth. Lich. p. 255 (1803) (incl. var. actinota). Boriern riliaris Ach. Lich. Lniv. p. 496 (1-10) (incl. vars. urtinete and verrncosa); S. F. Gray Nat. Arr. i. 1. 434 : Hook. Fl. sent. ii. p. 56 ; Honok. in sm. Engl. Fl. v. p. 를 : Mudd Man. p. 105.

Exsicc. Bohl. n. 38 ; Cromb. 11. 50 ; Dicks. Hort. Sicc. fase, vii. n. 24; Johns, nos. 90, 91 ; Larb. Carsar. n. 6i it Lich. Hb. n. 125 ; Leight. n. 364 ; Mudd n. 77.

The thallus of the upper surface and slightly round the elige icarticate, the cortex being composed of long parallel hyphe which branch out from the margin at intervals to form the stout cilia ; the under surface is non-corticate. The colour raries with the habitat. but is constantly greenish when moist and often whitish- or greyish. pulverulent when dir. The apothecia are generally abundant; the ilenticulations of the margin nay grow out into short linciniar if $\operatorname{arlinota}$. The spermogones are often very muminent (f. crrm. $\cos a)$; the spermatia are cylindrical, $4-5 \mu$ long, $1 \mu$ thick. 
Hut. On trunlss of old trees, chiefly oaks and elms in cultivater aistricts.-I)istr. (ieneral and plentiful in Fugland, scarcer elsewhere throughout the British Isles.-B. $M$. Jersey; Sark; Guernsey; Fiburton and Newton IBushell, Deron; Winchester, Hants ; near Ryde, I. of Wiglat; IIurstpierpoint, Danny and Glynde, Sussex; Tooting Common and Dorking. Surrey; Hrthe, Kent; 'Llting. near Colchester and Tralthanstow, Lssex; near Farringlon and Windsor, Berkis; near Swindon, W"ilts; near Cirencester, (rloneestershire; Twycror.. Leicestershire; (Overthorpe, Northamptonshire; Malvern and BroathWits. Worestershire; Moor Park, Herefordshire; Clungunfort, Shropshire; Hopton, Cheshire; Anglesen; Sutiollk; Scoulton Mcr. and Norwich, Norfolk; near Ayton, Cleveland and Dillhy, Yorkshire; Mirldleton, Teesdale, Durham; near Hexham and Wark, Northmberland; near Kendal, Westmoreland; Rosslyn Woods, Midlothian; I3lackness, Linlithgowshire; Finlarig, Fillin, I'erthshire; Foulis, Baldoran, . Auldbar and Melgund Castle, Forfarshire; Midmar Castle, Aberdeenshire; Oakpark near Carlow.

Form melanosticta Olir. Exp. Syst. Lich. i. p. 17.j (1897). -.-Thallus frequently wide-sprearling: lacinice narrower, more appressed, greenish- or dark-l)rown, with dark cilia. Aputhecia not pruinnse.-Plıyscia ciliaris ras. saxirola Nyl. in Mérn. Soc. A.ci. Nat. Cherb. v. p. 106 (1857) it Syn. Lich. i. p. $+14(1860)$ : Carroll in Joum. Bot. v. p. 254 (1867); Cromb. Lich. Brit. 1. 38 \& Monogr. i. p. 303; form sudiola Leight. Lich. Fi.

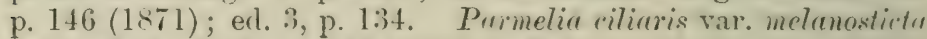

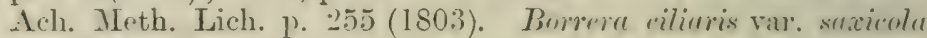
Mudd MIan. p. 105.

Distinguisherl by the colour of the thallus and hy the habitat. There are connecting stages with the species.

Hab. On rocks and walls, rarely on sandy soil in maritime and momntainous regions.-Distr. Local and scarce throughout the J British Isles-I). M. (Juenvais and St. Brelade's, Jersey; Withiel, ('ornwall; near Malvern, Worcestershire; Buxton. i)erbyshire; Holyheal, Anglesea: near Langbraugh, C'leveland, Iorkshire ; ('raig Tulloch, B3lar Athole, l'erthshire: Morrone, Bratmatr, Aberdeenshire: Sybil Heal, Kerry.

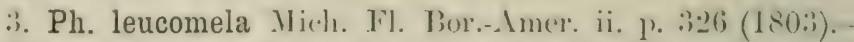
Thailus spreading. with narrow hranching lacinia, tapering or forked at the alwex. White or sreyish-white and smosth, thr margins beset with long slender fiequenty lomehing black cilia which attach the plant to the sulstratum hy eoiling round grass, moss, ete., w by haptera : breneath white, and furfuraceous

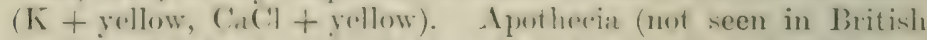
slecenens) lateral. perdicollate, rather large, plane, bluish-erey-

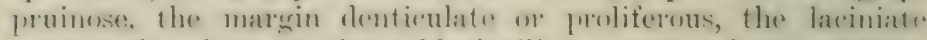
culerowths alsu sometimes blackeriliate: spores large, oblons-

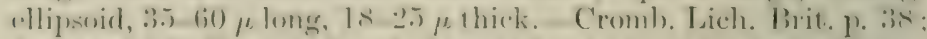

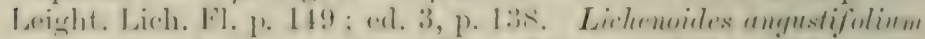
plenum, crinibus migris Dill. Hist. Musc. p. 156, t. 21, f. 50 (1741). Borrera lenomeln Ach. Lich. Univ. p. 499 (1810); 
S. F. Gray Nat. Arr. i. p. 431; Hook. in Sm. Engl. Fl. v.

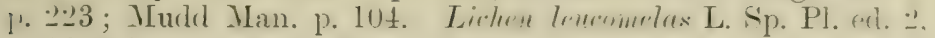
1). 1613 (1763); Engl. Bot. t. 2548.

Eisicc. Carroll Lich. Hib. n. 2: Cromb. n. 150: Johns. 11. 402 ; Larb. Caesar. 11. 69 ; Leight. n. 168.

J)istinguished from $P /$. ritimis by the more straggling thimnt ${ }^{2}$ thallus and by the lonirer black cilia." The fronds ale almars dor-iventral; the upper cortex is composed of hyph parallel witi: the lom axis of the fronds, the under surface is non-corticate. It is a continental plant which only reaches the Southern Coast.

$\mathrm{Hab}$. On the ground among mosses and short grasses, rarely on mossy trunks of trees in or near maritime districts.-Distr. S. Englimil and Channel Islauds.-I). M. (Yuenvilis, st. Brelade's and st. Orven's Bay, Jersey; Sark; Alderney; Bryel and Trescoe Islands, Scilly; The Lizard and liynance Core, (ormwall; Dartmonr. bolt Head, Torquay and Babbicombe, Devon; Bathwick Down. Somerset; Ballawl Domm. Swanime. Dorset; St. Leomards Fortet. Sussex; Ballycotton and Cape Clear Island, Cork.

\section{Thallus horizontal.}

4. Ph. fusca A. L. Sm.-Thallus suborloicular, tlat, the lacini: "rarrow, irregularly branched and imloricate, appressed, becominn wirler, digitate and more sprearling at the circumference, with the tips somewhat crenate, chestnut-hown: beneath paler with sprarsely scattered greyish or blackish rhizina $(\mathrm{K}-$ ). Aputhecia sinall to moderate in size, often numpous and clowded, the dis: blackish, the margin prominent, crenate: spores oblong, lirown.

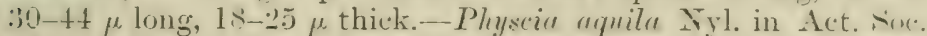
Limn. Borrl. sér. 3, i. 1) :309 (1856): Cromb. Lich. Brit. I. 39 ، Monogr. i. p. 310 ; Leight. Lich. Fl. p. 1503 ; ed. 3, p. 142. Lirlemoides anyustifulintm fusrum, sint,llis jullis Dill. Hist. MIuse. p. 175, t. 24, f. 69 (1741). Livlen pullus Liglite. Fl. ścot. ii.

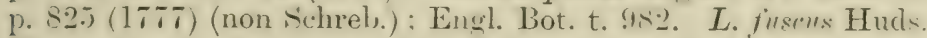
F1. Angl. ed. 2, p. 533 (1778). L. obscurus With. Ar. ed. "3, iv. p. 28 (1796). L. aquilus Ach. Lich. Suec. Prodr. p. 109 (179八). Parmelia anuila Ach. Meth. Lich. 1. 201 (1803); S. I. Gray Nat. Arr. i. p. 441 ; Hook. Fl. Scot. ii. p. 54 \& in Sn. Engl. Bot. v. p. 203 ; Tayl. in Mackay Fl. Hib. ii. p. 143.

Exsice. Bohl. n. 111; Dicks. Hort. Sicc. fasc. v. n. 25: Jobns. 11. 29 ; Larb. Cresar. n. 23 ; Leight. 1.144.

A well-nurked species both in form and colour. The manches at the circumference sometiuns grow out in at straggling mamner or thi.y. may be partly corrorled (var. stippan Ach. 1. c.). The cortical structure differs from that of the merious species in being imentan? fibrous on both surfaces.

Hab. ()n rocks in maritine distriets, rairely an hills some distance. firm the sca,-Distr. Cieneral and fariry errnmon on most of the reke coasts of the british Isles; expecially abumlant in N.I. 
Scotlani.-B. M. Jersey; Guernsey; nea Lawannick, Newlyn, l'enzance. Temple Moor, Stoneyford, Roche liocks and Helminton, Cornmall; Torpury, Bolt Heal, Hay Tor, Dartmoor, near the Teign, ncar. (1) Jehampton and Ilfracombe, Devon; Tilgate, Sussex; Stone. hense, Wilts; near Oswestry, Shropshire; near Tenby, Pembrokeshir:; Tarmouth and Harlech Castle, Merionethshire; Llanberis and P'wllheli, Camiuronshire; Holyhead, Anglesea; Jouglas Head, Isle of Min ; Jarrownouth, Cumberland ; Holy Island, Northumberl:ınil: New Galloway, Kirkendbrightshire; King's P'ark and Turfin Hill near Fdimburgh; Barcaldine, Argyll; Glen Tilt, Perthshire; Montrose, Forfarshire; Cove and Portlethen, Kincardineshire; near l'eterhear. Aberdemshire; Ballyeotton and Mizen Head, Cork; Kenmare River, Kerry; Ardglass, Down.

․ Ph. speciosa Nyl. in Act. Soc. Lim. Bord. sćr. 3, i. p. 307 (1856).-Thallus laciniate-lobed, somewhat digitate, spreading, the lacinire blunt and retuse at the apices or often with raised apical soralia, oceasionally whitish-or blackish-eiliate; beneath whitish to bluish-grey towards the base, adhering by stout whitish "r black rhizina or liy cilia ( $\mathbf{K}+$ yellow). Apothecia rare, sessile, moderate in size or rather larse, brown, the margin incurved, intire or sometimes crenate: spores oblong, larre, 25-36 $\mu$ long, 12-19 $\mu$ thick.-Cromb. Lich. Brit. p. 38; Leight. Lich. Fl. 1). 151 ; ed. 3, p. 138. Lichen speciosus Wulf. in Jacq. Coll. iii. 1. 119, t. 7 (1789) : Engl. Bot. t. 1979 (upper fig.). Parmelia spurose Ach. Meth. Lich. p. 198 (180:3) : s.. F. Gray Nat. Arr. i. 1) 4 t2; Hook. Fl. Neot. ii. p. 5.) \& in Sm. Engl. Fl. r. 1. 201 ; Tayl. in Mackay Fl. Hil, ii. p. 1t!) pon parte. Bemere speriose Müdd Man. p. 107.

Distinguished by the apical soralia and ciliate margins. The folse's may he closely crowited and imbricate or scattered, especially if growing among mosser. Though apothecial are sometimes present in continentarl specinens, they have not been fomn in Britain. The curtex of both surfaces is composed of hyphar more or less parallel with the long axis of the lacinize.

Hat). ()n mosies, rockis and trees, chictly in mirritine districts.--

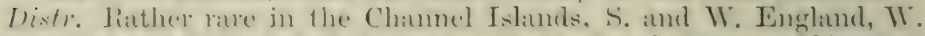

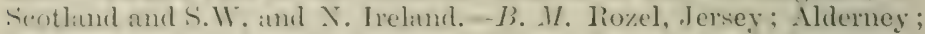
Guemsey; The Lizard, liynance Cove, Bodmin and Roughton, Cornwall; J3olt Head, Valley of the liocks and Lyuton, Devon; St. Leonards l'onest. Sursex; Jammouth, ('wu Bychan and Llyn liodlyn, Merioneth; near Inverary. Appio, Parealdine and ballachu. lish, Argyll; (ilen liblloch, Perthshire; ('loghame, J)unkerron aud lillarney, lierry.

Var. hypoleuca Nil. Sin. i. 11. 117 (1:660).--Thallus appressed,

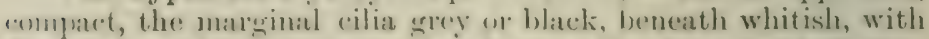
dersely hranchines rhizina. A pothecia rather large, with thekly lateiniate-sorediate margins; spores rather larger than in the

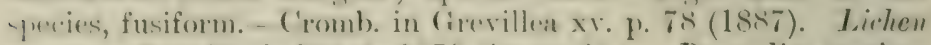

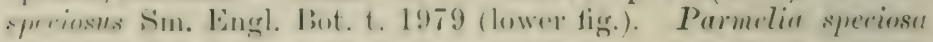


var. hypoleurer Ach. Srn. Lich. 1. 211 (1814): Tayl. 1. c. pr" parte.

An exotic variety, sometimes given specific rank, which has become naturalized in S.W. Ireland. The apothecia when prenent are crowded and rather large.

$H a b$. On rocks in shady sicuations, $-B$. M. Dunkerron, Tierry.

\section{B. Cortex fibrous on lover surface, plectenchymatous above.}

6. Ph. pulverulenta $\mathrm{Nyl}$, in Act. Soc. Linn. Bord. sér. 3, i. 1) 308 (1856).-Thallus suborbicular, of appressed somewhat stellate contiguous multifid firm opaque lacinie, ohtuse and incised-crenate, pale-greyish or greyish-brown, greenish when moist, more or less white-pruinose ; beneath black, covered with rather long stiff black rhizine which bristle with short branchlet, $(\mathbf{K}-)$. Apothecia sessile, moderate in size or becoming large. the dise brownish-black, greyish-pruinose or naked, the margin taick, entire, sometimes crenate or scantily yroliferous : spores large, 20-36 $\mu$ long, 12-20 $\mu$ thick...-Cromb. Lich. Brit. p. 38: Leight. Lich. Fl. p. 146 ; ed. 3, p. 135 ; f. punniformis Cromb. in Journ. Linn. Soc. xvii. p. 571 (1880) \& Monogr. i. p. 306 ; f. demimuta Cromb. in Journ. Bot. xx. p. 273 (188\%) \& Monogr. i. p. 306. Museus licheniformis viridis de. Buddle Hort. Sicc. ii. tol. 6, 12. 10 in Herb. Sloane. Lichenoides arboreum, arustu folinsin virescente sc. Dill. in Ray Syn. ed. 3, p. 74, n. 73 (1724). Lichenoides glaurum orbindare, segmentis latinseulis, scutellis nitgi. Dill. Hist. Muse. p. 177 , t. 24, fig. 71 A, D (1741) pro parte. Lichen pulverulentus Schreb. Sivic. Fl. Lips. p. $128(1771)$. Lichen stellaris var. Huds. Fl. Angl. 1. $448(176-2)$ : With. Arr. ed. 3, iv. 1. 31. Parmelia pulcerulenta Ach. Meth. Lich. p. 210 (1<0:i): S. F. Gray Nat. Arr. i. p. 443 ; Hook. Fl. Scot. ii. p. 55 \& in Sm. Eagl. Fl. v. p. 201 ; Tayl. in Mackay Fl. Hib. ii. p. 141. Borrera pulcerulenta Mudd Man. p. 110 (1861).

Exsice. Bohl. n. 69 ; Johns. nos. 127, 404; Larb. Lich. Hb. n. 10 \& Lich. Cantab. n. 12 ; Leight. n. 49 ; Mudd n. 82.

Generally recognized by the white pruina on the thallus and apothecia which is chietly visible in the dry condition; the lacinia. are rather thick and of at illl green when moist. Both thallus and apothecia are variable; the lacinitr are inpresser and contiguous at the circmuference, but towards the centre are often imbricate with minute proliferations mostly from the extges of the lobes. The allied forms panniformis and deminutu have small :pothecia and small lobes, crowded and imbricate in the former, rather sparsely scatterent in the latter, evidently growth conditions. The upper cortex is indistinctly plectenchymatous and granulose, the lower is tibroun, of dark-brown hyphe parallel with the long axis of the lobes.

$H a b$. On trunks and branches of trees and on palingrs, ravely on stone walls, chiefly in cultivated lowland ame mplaned districts... Distr. General and usually common throughout the liritish Isles.-

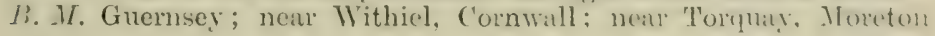


Mamp-tear and Wembury. I)cron: Appuldurcombe, Shanklin aml near Tivile. I. of Wight: Glynde. Shorehan, Hurstpierpoint and

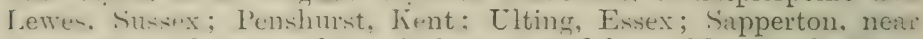
('irencester. (iloneentershive: Irilton. Oxforlshire; Moor Park, Hereforlshire; (rowle. Worester-hire; Clungunford, Lyth Bank ame

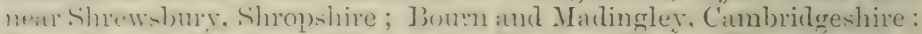
bolgelly and Ahertorey, Merioneth: Harhoro' Magna. Warwichshire: Twycross. Leicestershire; Angleseat Ayton and Cleveland, Yorkshire: livoughan ('atle and Kiendal. Westmoreland; Middleton, Tecsiale. Durhan; (reetown, Kirliculbrightshire; Largs, Ayrshire; neat. Eclinburgh ; Applin. Argrll : Fillin and Craig Tulloch, Blair Athole l'erthshire; Montrose, Strathmartin, ('amperdurn and Jaldoviul. Forfarshire: ('nlt; and Alurgelilie Castle, Aberleenshire; Applecross. liosshire: Carriguloe and Anharla. Conk: Ballynegarde, Limerick: Dunlierron, Kerry; Westport, . Гayo.

Form argyphea Cromb. in Joum. Linn. Suc. Bot. xrii. 1). ji 1 (1880).-Thallus and apothecia entirely white pruinose. the larinia rather dilated at the circumference; margins of ilothecia sometimes crenulate.-Dill. 1. c. t. 71, D. Parmelin puleerulcnta var. argyphea Ach. Lich. Ưniv. p. 474 (1810).

Exsice. Johns. n. 40 5.

The abundant furuina gives a white velvety appentauce to thr. thallus.

Hul). ()n trumks of treen in maritime and upland districts-Disti. Rare in X. England (Johmson Firsir.), the central Grampians. Scotland, and S.W. Ireland.-B. M. Craig Tulloch, Blair Athole. Perthshire; Adare, Limerich.

Tar. subpapillosa Cromb. in Journ. Bot. xx. 1. 273 (185:-). Thallus dersely unequally papillate, greyish-or hownish-pruinuse. I pothecia pruino:e with turgid subpapillate mar.gins.

Hat). On trunks of trees.-Jistr. Rare in F.and X.E. England.l. . W. Jinry St. Fdmund.s. Suffinlk; Jellingham. Northumberland.

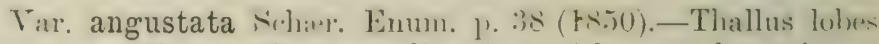
mareww, sometimes rather spreading, brownish, searcely pruincse? heneath densely rhimines. Apothecia small, with stontish

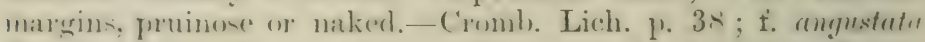
Leight. Lich. 11. p. 147 (1871); ed. 3, p. 135. Lichen rengustatus Hoffm. Enum. 1. 77, t. 11, fig. 2 (1784). Borreru julerulenta var. angustata Mudd Man. p. 110 (1861).

The narrow discrete lacinite are in some specimens very long, in other's short and more crowied.

Hab. On the trunks of trees in upland districts.-Distr. Rare in $\therefore$ and X. Fongland. and in 4.11 . ceotland. - R. M. Nembury, Nevon: Appuldurcombe, I. of Wight; Glynele and St. Leomards lioest.

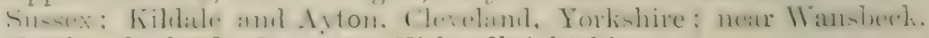
Aorthumberland; Creetown, Iirkencibrightshire.

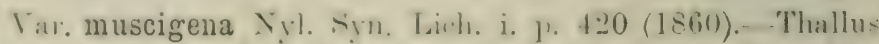

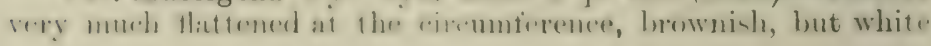


with the pruina. Apothecia rare, the margin erenate. - Leight. Lich. Fl. ed. 2, p. 479 ; ed. :3, p. 136 (form); subsp. musrigfrum Cromb. in Grevillea xv. p. Ts (1887) \& MLmogr. i. p. 309. Parmelia muscigena Ach. Lich. Univ. p. 472 (1810).

A very rare variety in this country, only one imperfect specimen having been gathered. The habitat rither suggests that the form of the licinie may be due to the more moist conditions. The spores are on the whole smaller than in the species, measuring $24-30 \mu$ long. 11-15 $\mu$ thick.

Hab. On decayed mosses on the ground. $-B$. M. Craig Tulloch, Blair Athole, Perthshire.

Var, venusta Oliv. Exp. Syst. Lich. p. 179 (1897).--Thallus of somewhat narrow incised lobes, brown- or brownish-grey, slightly or not pruinose. Apothecia with proliferous margins.Cromb. Lich. Brit. 1) 39 ; f. wmiste Leight. Lich. Fl. p. It7 (1871) (excl. Syn. Engl. Bot.) : ed. 3, p. 136 ; subsp. ienusta Syl. ex Lamy in Bull. Soc. Bot. xxr. p. 383 (1तis); Cromb. in Grevillea xv. p. 78 \& Monogr. i. p. 308. Parmelia venusta Ach. Meth. Lich. p. 211, t. 8, fig. 5 (1803).

Differs chiefly in the less pruinose or naked thallus and in the coronite apothecia. The latter character is sometimes absent, and very occasionally is present in the species.

Fab. On trunks of old trees in rooded situations.-Distr. Rare in the northern districts of England and S. TV. Scotland and Ireland. - B. . . Nenr Ayton, Cleveland, Yorkshire; New Galloway, Kirlicurlhrimhthire; liemnore. Perthshire; near Fort IVilliam, Invernessshire; Carrigaloe, Cork; Ballynegarde, Limerick.

Form subvenusta ()liv. 1. c.-Similar to var. conuster but with the thallus more distinctly pruinuse.-I'lysere pulverulentu val:

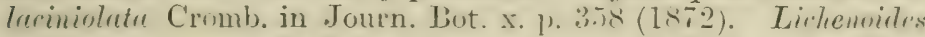

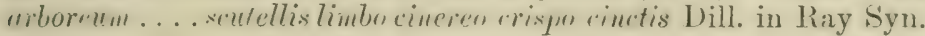
ed. 3, p. 75, n. 75 (1724). Lichen stellaris var. Lightf. Fl. Ścot. ii. p. 824; Huds. Fl. Angl. ed. 2, p. 534 ; With. Arr. ed. 3, iv. p. 31. L. pulverulentus Sm. Engl. Bot. t. 2063 (1809) (non Schreb.).

Exricc. Johns. 11. 250.

Similar to rar. venusta but generally pruinose; as in the variety, some of the apothecia have occasionally entire margins.

Hat. On the trunks of old trees in maritime and upland districts. -Distr. Loeal and rave in England, Scotland and Ireland.-B. M.

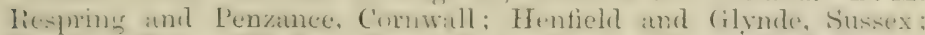

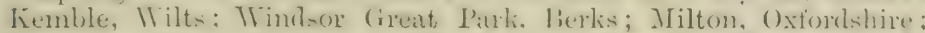

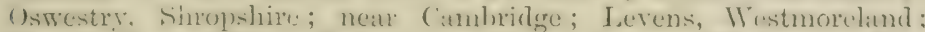

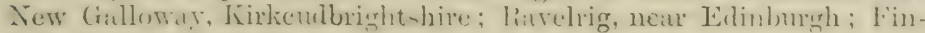
larig, Killin, Perthshire.

7. Ph. grisea A. Kahlbr, in Amm. K. K. Naturhist. Hofmus.

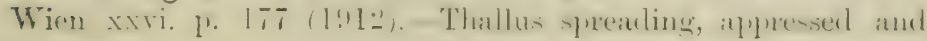


adnate, wrinkled, laciniate, crenate at the circumference, sreyishpruinose, creyish-white or light-brownish, densely solediate on the margins, especially towards the centre of the thallus: beneath dark and rhizinose $(\mathrm{K}-)$. Apothecia small or moderate in size, the margins hecoming lacerate-sorediate; spores $24-28 \mu$ lons, 15-18 $\mu$ thick.-Ph. pulevelenta var. pityrea Cromb. Lich. Brit. p. 39 ; Leight. Lich. Fl. p. 146 ; ed. 3, p. 135 ; subsp. fitmin Nyl. ex Lamy in Bull. Sonc. But. Fr. xxv. 1) 383 (1878); ('roml), in Grevillea xr. p. Ts is Monogr. i. p. 30s. Lichenointes

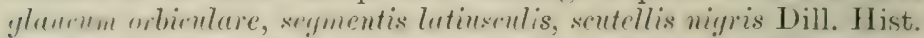
Musc. p. 177, t. 24, fig. 71 c (1741). Lichen griseus Lamarck Enevol. Méth. iii. p. tít) (1789). I. pityreus Ach. Lich. Suec. Prodr. 1). $12 t$ (1798); Engl. Bot. t. 2064. Parmelia pityrea Ach. Lich. Univ. p. 183 (181U); Hook. in Sm. Engl. Fi. v. p. 201. Borvera fulverulenta var. grisea Mudd Man. p. 111 (1861).

Exsire. Cromb. n. 51 ; Johns. 11. 128; Larb. Lich. Hb. 11. 48 ; Leight. n. 370; Mudd n. 83.

Similiu to $P$ \% pulevelenta in the pruinose thallus, but thinner in texture, and along with the margins of the apothecia, densely sorediate. The sorerlia. which at first line the margins of the lobes, sometimes spread over almost the whole centre of the thallus.

Hab.-On the trunlss of trees, rarely on old walls, in maritime, lowland and upland districts.-Distr. General and common in England, raver in the Chamnel Islands and scotland, not yet recorded from Irelaud. -13.M. Guemsey; Basingstolie and Lymington. Hants; livde and Appuldureombe, I. of Wight; Shoreham, Glynde, Wakehurst Park and Wolstonluny, Sussex; Ifythe, Kent; Edgware and Harefield, Middlesex; Jiphing Forest and Hraxted I'ark, Essex; near Elstree. Herts; near ('heltenhan, near ('ireneester and linurton-onthe.Witer, (iloncestershire; Windsor, Herks; Milton, ()xfortshire; Valvern and near Tembser, Woreestershire; Harboro' Magna, Wiuwickshire; Ludlow I'ark, Shomplire; Abertorey. Merioneth; Carlton. ('leveland, Yorkshire; Windermere. Westmoreland; Apuin, Arerll; Jlairlrummond near. Stirlingr (ilen Ample, P'erthshire; Drum near Aberdeen.

$\therefore$ Ph. stellaris Nyl. in Act. Soc. Linn. Burl. sil. :3. i. p. $30 \pi$

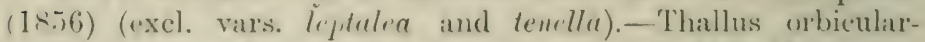

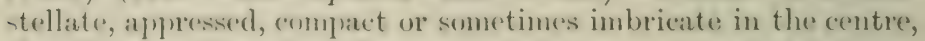
thr. lolues at the rireumference contiguous, somewhat envex, more on less defply ineised and crenate, greyish or wrevish-white, Eenerally datkere towards the contre: beneath whitish, with grey

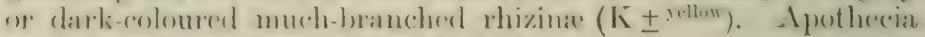
rather small, sesile, the lise blakish, ereyish-pruinese on naked, the margin entire or crenulate; spores $16-2+\mu$ long, $8-11 \mu$

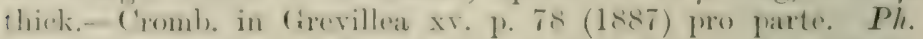
retropresse Stirton in 'lrans. Glaseg. Soc. Nat. p. 85 (1875); Leight. Lich. Fl. ed. 3, p. 138. Lichen stellaris L. Sp. Pl. p. 1144 (1753). Parmeliu stellaris Ach. Lich. Univ. 1) 47.6 
(1810); Hook. Fl. Scot. ii. p. 55 \& in Sn. Engl. Fl. v. p. 201.

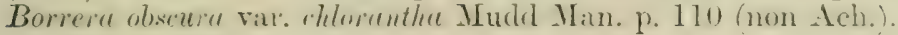
Exsice. Mucld n. 81.

A rariable plant, but distinguished by the absence of pruins on the thallus and by the light-colonred under surface. The cortes of the mple surface is somewhat obscmely plectenchymatom-. with small cells; that of the lower is fibrous. The rhizing vary from light grey to black; generally they are greyish or brownish.

Hab. On trees by roukides. etc.., in lowlind and upland district. -Distr. Seen only from a few localities in $N$. England and the Grampians, Scotlind.--B. M. Near Ayton. Cleveland. Yorkshire: Achmore, Killin aud lien I,awers, Perthshire; Monaltric Honles. Ballater and Countesswells. Aberdeenshive.

Var. aipolia Nyl. Lich. Scand. p. 111 (1861).-Lacinice of the circumference more plane than in the species, lientith whitish or grey (K+yellow).-Physcin reipula Nyl. in Flora liii. p. 58 (1870) : Croml. in Journ. Bot. viii. 1). 97 (1870), in Jourı. Linn. Soc. Bot. xvii. p. 571 (1880) (incl. f. arritu) \& Monosr. i. p. 313. Ph. stelluris rar. arritu Cromb. Lich. Brit. p. 39 (18тu). Lichenoides rinerenm, segmentis argutis strllatis, scutollis nirgris Dill. Hist. Musc. p. 176. t. 24 , f. 70 A, B $(1761)$. Livlen stelluris Huds. Fl. Angl. p. $448(176-2)$ (nom L.) tide Crombie. L. ripmins Ach. Lich. Suec. Prodr. p. 112 (179S).

Exsice. Croall. n. 592.

Distinguisined from the species by the more Hattened thallus. which in age becomes wrinkled in the centre; but chiefly by the reaction of the melulla with potash, which gives a faint-lemon vellow.

Hub. On trees. rarely on calcareons $\pi_{i}$ lls, iu maritime and inlant districts.-Distr. Rather rave throughout the British Isles. - L. M. Penzance, Cornwall; Ilsham Valley, Torepuay, and Linton. Ineron: Shanklin, I. of Wight; near Lemes. Sussex; Haforl, Cardigan-hire: Dolgelly, Merioneth; neat lieudal, Westmoreland; Appin. Aroyll: Killin and Ben Lawers, l'erthshire ; Castleton of Braemar. Aberile'n-

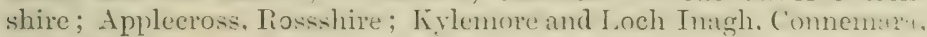
Galway.

Form anthelina Nyl. Jich. Fiand. p. 111 (1sijl). Thallus witl narrower lacinia which are more apart, longr. rathereonsex. and with more developed black rhizinia, heneath srevish-hruwn $(\mathrm{K} \pm$ sellow $)$. $-P l$. aipolice var. anthelina Cromb. in Grevillen xr. p. 78 (1857). Lichen anthelinus Ach. Lich. Suec. Prodr. 1. 11] (1798).

This form is identical with Lichen ambigums Ehrh. P'. Crypt.

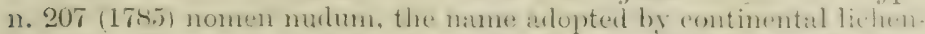
ologrists. Ifereat in species and varieties the matring of the apothecimn becomes cremblate with age. The reaction with potash allies it with var. aipolia.

Hab. On trees in maritime and inland distriets.-Distr. liare in

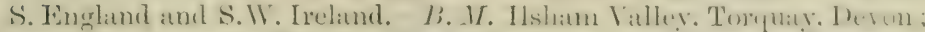
near Ryde, I. of Wight; Henficld, Sussex; Mfuchuss Demesine, Killarney, licry. 
Var. cercidia 'Th. Fr. Lich. Arand. i. 1) 1:39 (1871)..-Thallun sreyish-white, the lacinice short. contiguous, somewhat convex 11 . wrinkled, croweded and partly imbricate in the centre, broader. at the cireunference. Aputhecia mostly juinose, sometimelarger:-Physice stellaris Cromb. Cich. Brit. p. 3!) (1870) pure parte; Leight. Lich. Fl. p. 151 ; ed. 3, p. 140. Pl. aipolia var.

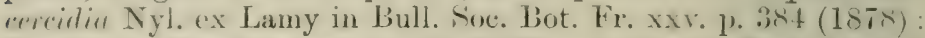

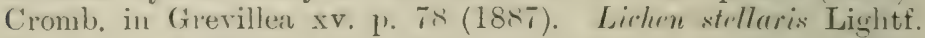
Fl. Scot. ii. p. 824 (1777) ; With. Arr. ed. 3, iv. p. 31 pro parte. Promelia aipolia vas. cercintio Ach. Lich. Univ. p. 478 (1810). P. stellaris 'layl. in Mackily Fl. Hib. ii. p. 142 (1839) (? A(r.). Borrera stellaris Mudd Man. p. 109 (1861).

Exsicc. Carroll Lich. Hib. n. 7 ; Johns. n. 251; Larb. Lich. Hb. 1. 161 \& Lich. Cantab. 1. 13 ; Leight. n. 6; Mudd n. 79.

A coarser plant than the species, resembling $\mathrm{M} h$. pulcerulentu in the irregular difform wrinkled growth. The short rhizina are rrowded, much branched and berome datrere in eolomr. The apothecis are often uumerous and crowded.

Hab. On old trees, rarely on calcitreous walls, in cult ivated district .

D)istr. General and plentiful in most parts of the Britisle Isles. I). M. Gnemsey; Withiel and L'enzance, Cornwall; near Higle. I. of Wight; Glynde, Fairlight near Hastings, and Henfield. Suscex: licigate. Simrey; Elgware, Midhlesex; Elstree, Herts; Winlsor. lierks; [thing. Esisex; nenl Natlsworth, Gloucestershire; P'ixharm and North IIalvern, Woreestershire; I.landrindod. Tamborate: I.lanymyech, Clungunford and near Shrewsbury. Shopshire; Aberdovey, Iferioneth; Malew, I. of Man ; Madinerley I'ark, ('ambridgr. shire; Twyeross. Jeicestershire; near Ayton, ('levelind. Yorkshire: near Ifexham, Northmmberland; Kendill and II indermere, IV estmone. land; Alston, Cumberland ; Xew Galloway, Kirlicudbrightshire: near Melrose, Loxhmohshire; near Eilinhmegh ; near Inverary and Appin. Argyll ; Blair Drummond, near Stirling ; Finlatig, Killin, l'erthshire:

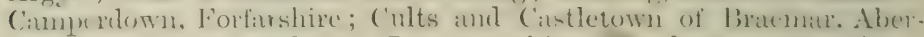
deenshire; Tort IVilliam, Invernessshire; Applecross, liossshire; near Cork; Dumlierron, Kerry.

9. Ph. melops Duf. ex Nyl. in Flora lvii. p. 16 (1874).-

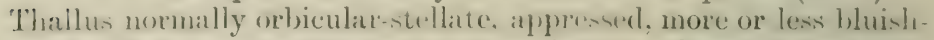
mey with natrow entignous comrex laciniae; heneath blownish

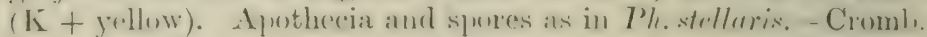
in Journ. Bot. xxiii. p. 195) (188.)).

The thallus of our single specimen is of scattered almost isolater branching lacinise, and recalls vas. aipolia $\mathrm{f}$. antheline of the pre-

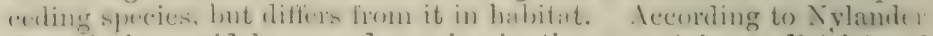
(1.c.) it is a widely spread species in the mountainous distriets of liurope.

Hab. On a ealcrireons wall among mosses.-B. M. Appin, Areryll. the only British locality.

10. Ph. hispida 'Iuckerm. Syn. N. Amer. Lich. i. p. Ti

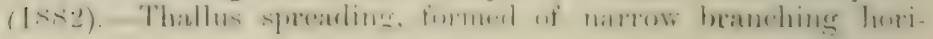


zontal or asconding straggling lacinie, beset with marginal spey or brownish cilia, generally pale-grey, becoming rarker, whitish beneath, with few grey rhizine ( $\mathrm{K} \pm$ yellwi-h). Apothecia small or moderate in size, the dise pruinose or naked, the margin entire, sometimes becoming crenulate; spores oblong, 15-.23 long, S-11 $\mu$ thick.-Ph. stellaris var. temelle Nyl. in Mém. Soce Sci. Nat. Cherb. v. p. 107 (1857); Cromb. Lich. Brit. p. 39 ; Leight. Lich. Wl. p. 151 ; ed. 3, p. 141 ; var. leptalea Nyl. Srrn. Lich. p. 425 (1860) : Cromb. Lich. Brit. p. 39 \& Monogr. i. p. 311 ; Leight. Lich. Fl. p. 151 ; ed. 3, p. 140 ; subsp. tenella Nyl. ex Cromb. in Grevillea xv. p. $78 .(1887$ ) \& Monogr. i. p.:312. Musens parrus cinereus maryinibus pilosis Buddle Hout. sicc. ii. fol. 6, n. 7 in Herb. Sloane. Lichenoides hispirlum minus st tenerrius, scutellis nigris Dill. Hist. Muse. p. 152, t. 20, f. 46 (1741). Lichen hispidus Schreb. Spic. Fl. Lips. 1) 126 (1771). L. tenellus Scop. Fl. Carn. ed. 2, ii. 1) 394 (1772); With. Arr. ed. 3 , iv. p. 56 ; Engl. Bot. t. 1351. L. ciliaris var. Lightf. Fl. Scot. ii. p. 828 (1777) ; Huds. Fl. Angl. ed. 2, p. 538. L. leptalrus Ach. Lich. Suec. Prodr. p. 108 (1798). Parmerlir tencllu Ach. Meth. Lich. p. 250 (180:3); Tayl. in Mackay Fl. Hib. ii. p. 147 . Borrera tenell A Ach. Lich. Univ. p. 498 (18́lo): S. F. Gray Nat. Arr. i. p. 434 ; Hook. Fl. Scot. ii. p. 56 \& in Fin. Fngl. Fl. v. p. 222. B. Trispid, Mudd Man. p. 106 (1\&61) (incl. var. tenella).

Exsice. Bohl. ‥ 20 ; Carroll Lich. Hib. n. 8; Cromb. n. 151 Johns. n. 92 ; Larb. Lich. Hb. n. 330 ; Leight. n. 174 ; Mudd 11. 78 .

Somewhat similar in habit and appearance to $P h$. ciliaris, but of slighter structure throughout. The two plants, Lichen tenellus and $L$. leptale'us, now united under $P$ 's. Fispirla, lo not differ except in the hooded tips, frequently sorediate, of the lacinia in subsp. tenclla. These are caused by a mite which eats away the cortex and stimulates it formation of gonidlal tissue (Bouly de Lesclain, Lich. Dunk. 1, 68). The upper cortex is plectencliymatous and densely gramulose; the lower cortex is fibrous with here and there rhizinz; the lacinise are mainly attached by the cilia.

Hab. On trees, rarely on oid walls or boulders in maritime and inland districts. - Dist). Common throughont the Jivitish Islem. L. M. Lat Moye, Jersey; Guernsey; I'enzanee, Withiel and St. Minter. ('ormwall; Bolt Heal and Plymouth, Devon; Lymington, Hitnt: : Shanklin and Jiarling, I. of Wight; St. Leonaris Forest, Wolstonhury, lolney and Hurstpierpoint, Sussex; IIolnwood. Survey; Ulting an? Walthimstow, Lssex; near ('irencester, Gloueestershere; 'Tweros and bardon Hill, Leicestershire; (rimsbury Green, Northanjotonshire: Malvern, Woreestershire; Ilimymynech ame ()swestry, Shropshime: 'Tenby, Yembrokeshire; Aberdovey and 1)olselly, Merioneth; Anshsean; Bury St. Edmunds, Suffolk; Latou and Farshan, Norfuils: 13uxton. IIatlock, D)irley, Dyan and (romford, 1)erbyshire; Artum.

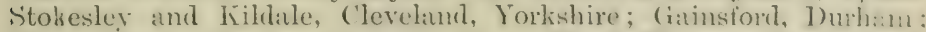
Holy Islant, Vorthumberlanul; ('roft Heat. Westmoleland: new

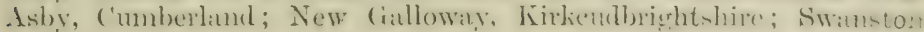


Foor and neal Erlinhurgh; Wormit Bay, Fife; Appin, Argrll: lien Lawers. Killin and Blair Drumuond, l'erthshire; T'ealing,-Inchterlinnse and IIontrose, Forfarshive; Castleton of Braemar and cult-. Aberteenshire; Cirrigaloe, Cork; Dromoreland, Clare: C'ushleckir and Dugort, Achill Island, Mayo.

Form exempta A. L. Sm.-Lacinie shorter and broader. sumetimes crowded and imbricate, sparingly and shortly ciliate. - Mhyscia stellaris subsp. tenella f. erempta Cromb. Monogr. i. p. 313 (1894). Borrerce tenella var. exemta Ach. Lich. Univ. 1. 499 (1810). Parmelia tenellu var. remptu Tayl. in Mackay Fl. Hib. ii. p. 147 (1S36).

Exsice. Johns. n. 93.

$\mathrm{Hab}$. On the trunks of trees and on palings.-Distr. Rare in ․ Eugland and S.WW. Ireland, probably overlooked.--B. M. Wark-(3!1Tyne, Northumberland; Ballynegarde, Limerick.

Form subobscura A. L. Sm.--Thallus rather darker and cilia Marker. Pl. stellaris var. subolscurn Nyl. in Bidr. Finl. Nat. iv.

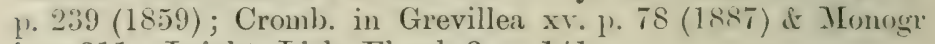
i. p. 311 ; Leight. Lich. Fl. ed. 3, p. 141.

Exsice. Larb. Lich. Hb. (without a number).

The darker colour of thallus and eilia may possibly be due to the exposed habitat of the form.

Hat. On rocks and wall-tops.--Distr. Liare in the Channel Isliumls. 1. England, Highlands of Scotland and W. Irelamel-- B. M. La Move. Jursey; Rildale, Cleveland, Yorkshire; Craig Tnlloch. Jhair Athole. Perthshire; Leenane, Galway.

11. Ph. astroidea Nyl. in Act. Soc. Liun. Bord. sćr. 3, i. p. $308(1856)$.- Thallus irregularly orbicular, thin, clonely :1ppressed, the lacinie of the periphery narrow or rather hroul, crenate at the tips, the centre of the thallus granular, isidiose or becoming wholly pulverulent-sorediose, whucous- or whitish-erey : beneath whitish, with numerous short slightly brownish rhizina $(\mathrm{K}+$ yellow, CaCl + yellow). Aputhecia ratre, small, the dise lnownish-black, naked or pruinose, the margin inflexed, leeoming rrenulate; spores ellipsoid-oblong, 17-20 $\mu$ lomes, s-11 $\mu$ thick.

Carroll in Journ. Bot. iii. 1. -88 (1 +6.5$)$; Cromb. Lich. Brit. p. 39 ; Leight. Lich. 11. p. 153 ; ed. 3, p. 139. Pamelia astruider Cleu. Ensayo, p. :302 (1\$07). P'. C'lementi 'Turn. in

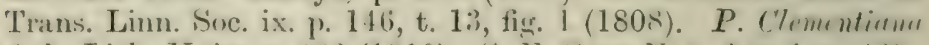
Ach. Lich. Univ. 1) As:3 $(1810)$; S. J. Graly Nat. Am. i. 1) f:3! :

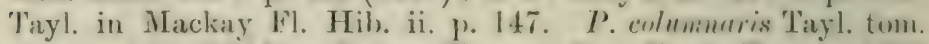

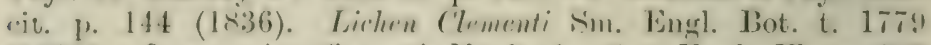
(1807). Squamariu ('lementi Hook. in sim. Fingl. Fl. 1. I!)(i (1833). Borrera astroidea Mudd Man. p. 108, t. 2, fig. 32 (1861) (incl. var. Clementi)

Exsice. Leight. n. 324.

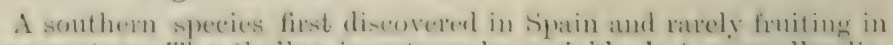

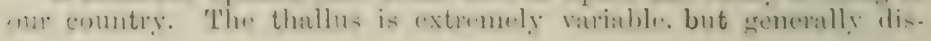


tinguished by the extensive sorchial development, the whole centre of the thallus frequently becoming leprose; occasionally it is more isidiose (Parmctia columnaris). The upper cortex is plectenchymatous, the lower is indistinctly fibrous, being formed of rather thicli-willed branching hyphe subparallel to the long axis of the lobes.

$H a b$. On the trunks of trees, often in orchards, and on tiled roofs in maritime and inland districts.-Distr. Somewhat rare in the Channel Islands, S. and Central Englind, N. Wales, S. and W. Ireland, not seen from Scotland.-B. $M$. Rozel and St. Martin's, Jersey; Guernser; Penzance, Cornwall ; near P'lymouth, Devon; near Southampton, Hants ; Ryde, I. of Wight; Brighton, Henfield, Sedlescombe, Glynile, near Lewes and Hurstpierpoint, Sussex; near Maidstone and Tunbridge Wells, Kent; Saffron Walden and Epping Forest, Essex; West Haddon and Inuckly Folly, Northamptonshire; Twycross, Leicestershire; Barmouth, Merioneth; Carigaliue near Cork; Dunherron, Kerry; Tervoe, Limerick; Hylemore Lake, Comnemara, Galway.

Form elegans Cromb. Monogr. i. p. 317 (1894).-Thallus slaucous-white, the lacinise long and narrow, branched and spreading, frequently isidiose at the margins.-Var, eleyans $\mathrm{Nyl}$. ex Leight. Lich. Fl. ed. 3, p. 139 (1879).

Exsice. Larb. Lich. Hb. n. 88.

$H a b$. On rocks in a maritime district. $-B . M$. S. of Kylemore Lake, Connemara, Galway (the only British locality).

12. Ph. cæsia Nyl. in Act. Soc. Linn. Borrl. sér. :3, i. p. 308 (1s:6).-Thallus normally orbicular-stellate, closely adnate, formed of narrow dividing radiating lacinire, convex, contiguous, and spreading at the tips, light- or dark-grey, sprinkled with round whitish-grey soralia; beneath pale, with brown rbizina ( $\mathrm{K}+$ yellow). Apothecia rare, chiefly central, rather small, naked or pruinose, the margin prominent, entire or crenulate: spores oblong, 16-2:3 $\mu$ long, 9-13 $\mu$ thick.-Cromb. Lich. Brit. p. 39. Ph. stellaris var. 'æsia Leight. Lich. Fl. p. 152 (18T1); ed. :", 1. 141. Lichenoides cinereum, segmentis aigutis stellatis, soutellis niyris Dill. Hist. Musc. p. 176, t. 24, fig. 70 c (1741). Li.lien resius Hoffm. Enum. Lich. p. 65, t. 12, fig. 1 (1784); Eingl. Bot. t. 1052. Lichen Psore Dicks. Pl. Crypt. fasc. iii. 1. 17 (1793) ; TVith. Arr. ed. 3, iv. p. 26. Parmelia cresia Ach. Iteth. Lich. 1. 197 (1803) ; N. F. Gray Nat. Arr. i. p. 443; Tayl. in Mackay 11. Hib. ii. p. 147. Squamaria 'æexia Hook. in Śn. Engl. Fl. v. 1) 196 (1833). Borrera cæsin Mudd Man. p. 107 (1861).

Exsicc. Johns. n. 252 ; Leight. n. 323.

Distinguished by the stellate outline and by the presence of soralia, though in some specimens one or other of these characters is rbscure. The lower cortex is fibroms formed of brownish iregularly parallel hyphre, with occasional cell formatiou.

Hat). On walls, roofs and boulders in lowlend and upland districts. 7)ists. General though not common throughout the liritish Isles, 
-B. M. Guernsey; Tithiel and near Penzance, Coruwall; Porchester, Ifants; Chestlam and Harstpierpoint, Sussex; Richmond House, Surrer; Y'lting and Walthamstow, Essex; near Oxforl and ('ilthorpe, ()xfordshire; near Jrarboro' Magna, Warwichshire; Twy(ross and Jitrlon Hill. Leicestershire; near Oswestry, Shropshire; Jinnouth. Merimeth ; Juxton, Derbyshire ; Ayton, Cleveland. Yorkshire: Teestale, I)urhinn: near Hexham, Northumberland; near Kendal. Westmoreland; New Galloway, Firlicultrightshire; Tirlfield, Ianalislire: near Edinburgh ; Appin, Argrll; Dunblane, lien Lawer's and Craig Tulloch, I3lair Athole, Perthshire; Crathie. Braemar, Aberdeenshire.

Form teretiuscula Cromb. Monogr, i. p. 31s (1894)...-Lacinia narrower and somewhat convex, less contiguous but crowled and partly imbricate.-Parmelin resin var. terefinserla Ach. Lich. Univ. p. 479 (1810).

Distinguished only by the chameters of the lucinix ; intermediate states are not wanting. British specimens are sterile.

Hab. On rocks in maritime and inland districts.-Distr. Collected only in Wr. England and S.W. Ireland.-B. M. Penzance, Cornwall; Malvern, Worcestershire; Dunkerron, Kerry.

13. Ph. elæina A. L. Sm.-Thallus rather small, thin, orljicular, of narrow imbricate-stellate lacinice, multiticl at the circumference, dull greenish-grey, closely adhering to the substratum, frequently breaking wp in the older parts and becoming romghened on laprose or sorediate; beneath light-colomerl or brownish, attached by few dolieate rhizine ( $\mathrm{K}-$ ). Apothecia rather raxe, small, the disc brownish-black, the marsin entire. prominent: sproles ellipsoid, $14-21 \mu$ lomer, 8-10 $\mu$ thick, or sumallex.-Ph. arlylutimutu Yyl. in Flor:a xiv. 1. :5:) (186:) : Cromb. Lich. Jirit. 1). 40 \& Monogr. i. p. :"20): Leight. Lich. Fl. ed. 3, p. 137. Ph. obscura var. adglutinata Leight. Lich. Fl. 1. 14! (1871). Lichen rlariums sun. Engl. Put. t. elise (1810).

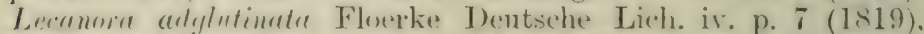

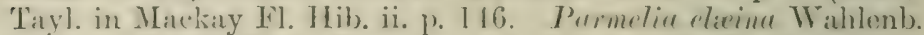

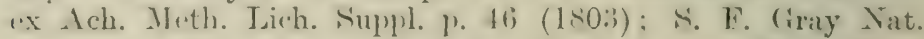
Arr. i. p. 439. Squamaria claxina Hook, in Sm. Engl. Fl.v. ). 197 (1833).

Lirsire. Cromb. n. 152: Larb. Lich. Trb. n. 49.

The thallus is extremely thin, aud is closely agrolutinate to the support. The lower cortex is formed of a marrow band of hyphace parallel to the lomer avis forme whech hyphar singly, or in rhisinese

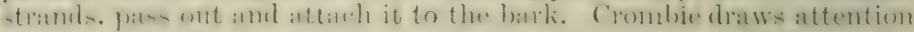
to the unusual spermogones which are olive-brown with aciculn. spermatia, about $18 \mu$ long, and senrecly $1 \mu$ thick.

Hab. On the trunks of trees, rarely on walls in maritime and

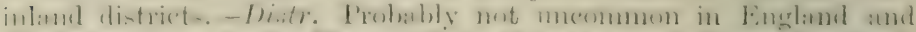

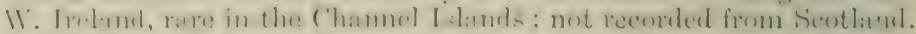
-13. M. Guernsey ; Penzance, Cornwall; Lymington, Hants ;

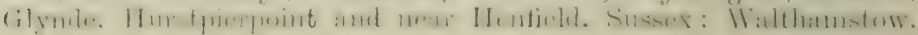


Essex; neur Cirencester. Gloncestersbire: Gamlingar, Cambrilgeshire; Arton, Clereland, Yorhshire; near Fendal, Westmorelind; Killaloe, Clare; near Letterfrack, Connemara, Galway.

Form sorediata A. L. Sm.-Lacinice broader, dilated at the tips, closely appressed, the margins and centre almost entirely. leprose-sorediate, greyish-sglaucous. Apothecia not seen. Pl. uilglutimatu f. sorediatu Nrl. ex Leight. Lich. Fl. erl. 3, p. 138 (1879); Cromb. Monogr. i. p. 321.

Exsice. Larb. Lich. Hb. n. 127.

Paler in colour than the speeies, and more entirely sorediate.

Hab. On walls and trees in upland districts.-Distr. Rare in W. Ireland-B. M. Letterfrach and Mweolan, Connenutra. Galway.

\section{Cortex plectenchymatous on both surfaces.}

14. Ph. erosa Leight. Lich. Fl. p. 152 (1871).-Thallus subrrbicular, moderate in size, composed of mostly short crowderl imbricate lacinie, minutely crenate or notcherl, as if eroded at the margins, light-grey, often ascending and powery-sorediate. beneath whitish-yellow, sparingly rhizinose $(\mathrm{K}+$ yellow, $\mathrm{CaCl}+$ yellow). Apothecia rather small, dark-brown, pruinose or naked, the margin subentire: spores oblong-ellipsuid, 14-20 long, 7-10 $\mu$ thick.-Cromb. in .Journ. Bot. x. J. 3.5 (1872): Leight. Lich. Fl. ed. 3, p. 139. Ph. resiel var. "7luiura Cromb. Lich. Brit. 1). 39 (1870) (non Ach.). Squamaria erasa Borr. Enerl. Bot. Suppl. t. - 2807 (1807). S. trithacir Hork. in Sm. Engl. Fl. v. p. 19t (183:3). Bowera casin var. allinen Mudd Man. p. 108, t. 2), fig. 31 (1861) (non Ach.).

Erirr. Larb. Ciesar. n. 24 it Lich. Hb. n. 2y4: Leight. n. 266.

Clonely allied to $I^{\prime} h$. tribacia, but differing in the more delicate textme and with fewer rhizini. In both species the cortex of the lower surface, like the upper, is of suall-celled indistinct plectenchyma.

Hah. On trees, walls and rocks in matime and upland districts. -Disti. Not general nor common throughout the British Islands.-B. M. St. Mary's, Scilly; Rozel, St. Owen's and Lit More. Tersey: Jerbourg and Moulin Huet. Guernsey; Penzance and Withiel. Cornwall; Plymouth and Wembary, Devon; Porchester, Hant: : Jexhill and Ifashiugton, Sussex; near Swindon, Wilts; Kingston. Somerset; Malvern, Worcestershire; Nimnau. Dolgelly, Bamuouth and Abertorer, Merioneth; near Ayton, Cleveland, Torkshire; neat Staveley. Westuoreland; Tew Galloway, Kirkeulbrightshire; Burcaldine, Argyll ; Invermoriston, Invernessshire.

15. Ph. tribacia Nyl. in Flora vii. p. 307 (18Tt). -Thallumoderate in si\%, irregularly orthcular, the lobes short, party imbricate, crente at the edges, greyish-white. sprinkled with small subglobose concolorous soralia which mat coalesce intu sorediate pustules: bencath brownish-white, with few concolorus. rhizina. Apothecia moderate in size, blackish, the thalline 
margin sulentire or crenulate: spores oblong, 15-20 $\mu$ long, S-11 $\mu$ thick.-Cromb. in Grevillea xv. p. 78 (1887). Pl. tribacoides Nyl. 1. (. ; Cromb. in Grevillea iii. p. 22 (187t) dt Nonogr. i. 1. :315: Leight. Lich. Fl. ed. 3, p. 140. Lecanora tribacia Ach. Lich. Univ. p. 415 (1810). Psoroma tribacinm S. F. Gray Nat. Arr. i. p. 445 (1821). Borrera cxsia var. tribreia Mudd Mian. p. 107 (1861).

$P h$. tribacoides is similar to $P$, tribacia except in the reaction with potash; both turn yellow in the cortex and soredia, but the former rives a somewhat stronger colour in the medulla. Apothecia are extremely rare; there are none present in any of our specimens; the description of spores, etc., is taken from Crombie (Monogr. i. p. 315$)$.

Hab. On trees in maritime districts.-Distr. Local and rare in the Channel Islinnds and S. England.-D. M. St. Tohn's and St. Martin's, Jersey; near Penzance, Cornwall ; Lymington, Hants.

16. Ph. subdetersa Nyl. in Flora lxi. p. $3+4$ (1878) (note)... Thallus spreading, formed of rather wide appressed lobes, pale greenish-lorown, sparingly sorediate on the surface of the lobes, the soredia and medulla yellowish (medulla $\mathbf{K}+$ slightly yellow); beneath brown, rhizinose. Apothecia unknown.

Distingruisher by the colour of the medulla and soredia. Upper and lower cortices are plectenchymatous.

IIab. Among mosses on rocks in subalpine regions.-Distr. Very rare in W. England and S. Grampians, Seotland.--B. M. North Hill, Malrern, Worcestershire; Ben Lawers, Perthshire.

17. Ph. orbicularis Dalla Torre \& Sarnth. Die Flechten Tirol, etc. p. 165) (1902).-Thallus spreading, closely aplressed, cracked and almost crustaceous or laciniate, the lacinia narrow, often overlapping, sprearling in all directions, suberenate or (ntire at the tips, dark-or greyish-lorown: beneath rery black, with erowded short simple or hranched rhizine ( $\mathrm{K}-, \mathrm{CaCl}-$ ). Apothecia rather small, generally numerous, the disc blackishbrown, the margin prominent, (ntire; spores ellipsoicl-oblong,

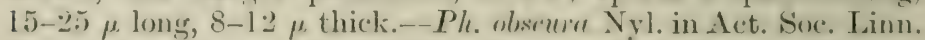
Borel. ser. 3, i. p. :30!) (1856). Cromb. Lich. Jrit. p. 39 (incl.

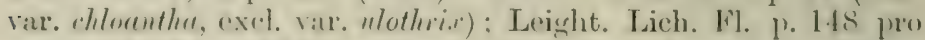
parte, ed. 3, p. $1: 36$ pro parte (incl. var. chlorentha). Lichen orlicularis Nerk. Moth. Muse. 1). Asi (1761). L. obsenus Ehrh.

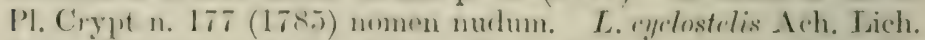
Suec. Prodr. p. 113 (1798); Engl. Bot. t. 1942. Parmelia ryclostelis Ach. Meth. 1,ich. p. 1!!9 (1803) : S. F. Gray Nat. Arr. i. p. 4tt pro parte; Hook. in Sm. Engl. Fl. v. p. 202

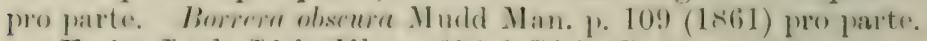

E.xsier. Larb. Lich, Hb. 11. 252 \& Lich. Cantab. n. 1.t.

A dull-colourer plant with an orbicular or irregular outline, fiendently sminkled with sorediate-like dots. which seem to be 
nibblerl or abraded portions; occasionally the rhizin:e grow horizon:tally from the margins of the lacinie. The lower cortex is a rather broud layer of very dark plectenchyma. Apothecia are fairly froquent; spermogones are still more numerous with spermati:t. i) $\mu$ long, about $1 \mu$ thick. The variety (Parmelia chloantha Ach. sin. I.ich. p. 217 (1814)), distinguished by a lighter-colomed thislu: does not occur in the British Isles.

Hab. On trunks of trees in inland districts.-Dist. Rare in Englind and the s. Grampians, seotland.-B. I. Brockenhurst. New Forest, Hants; Beeding, Sussex; near Ledbury, Herefordshire: Malrern, Worcestershire; Newmarliet, Cambridgeshire; Penylun. Denbighshire; Finlarig, Killin, Perthshire.

Var. ciliata Dalla Torre \& Simuth. Die Flechten Tirol, etc. 1. $166\left(190^{\circ}\right)$. - Thallus sinilar to that of the species; beneath lark-rhizinuse, the rhizina frequently growing straight from the margin of the lobes, like rigid cilia. Apothecia rather larger, numerous, the under side freguently furnished with stiff orey wr dark cilia.-Physcin ulothrix Nyl. in Flora lviii. p. 360 (1\&75): Cromb. in Journ. Linn. Soc. xxii. p. 571 (1RS0) \& Monogr. i. p. 319. Ph. obscura var. ulothrix Cromb. Lich. Brit. p. 39 ; Leight. Lich. Fl. p. 149 ; ed. 3, p. 137. Lichenoides viride, segmentis ungustis distortix, sentellis pullis Dill. Hist. Musc. 1. 17., t. 2t, tig. 72 A (1741). Lichen cilialus Hoftin. Enum. Lich. p. 69 , t. 14 , fig. 1 (1784); Dicks. Pl. Crypt. fasc. iii. p. 16? With. Arr. ed. 3, iv. p. 30. L. stellaris var. 4 With. tom. cit. 1. 31 (1796). L. ulothirix Ach. Lich. Suec. Prodr. p. 113 (1735). L. virellus Sm. Engl. Bot. t. 1696 (1807) lower fig. Purmelin uluthrix Ach. Meth. Lich. 1. 200 (1803); Tayl. in Mackay Fl. Hib. ii. p. 146. Borrere olsecure var. ulothrie Mudd IJan. p. 110 (1861).

Exsice. Johns. n. 210 ; Leight. n. 80.

Though given specific rank by Acharius. Crombie and others. this lichen can only be considered a viriety, as the ciliate character of the lobes, due to the horizontal rhizina of the margin, is also a fenture of the species, though to a less marlied cxtent, and the brush-like cilia of the apothecia are not constant eren in the same specimen. The cortex of the muder surface is like that of the species. The identity. of Lirhen ciliatus with Physcia ulothrix was detemined by Wrinin (Medd. Soc. Faun. \& Fl. Fenn. xiv. p. 14 (1886)).

Hab. On the trunks of trees, rarely on palings and walls in maritime and upland districts.-Distr. liather uncommon throuri:ont Great Britain ani Ireland.-13. M. Near Penzance, Cormwall; Tortuat, Devon; Bolney, Brighton and Aldbourne, Sussex; Cltin:lissex; Cirencester, Gloucestershire; Gopsall, Leicestershire: na.r. Worcester: Juxton, J)erbyshire; Ashgill, Cumberland: New (iallo. way. Kirkublbrghtshire: Appin, Argill; Finlarig, Killin and (ilen Fender, Blair Athole, Perthshire; Carrigaloc, Cork.

Var. virella Dalla Torre of tiunth. J)ie Flechten Tirol, ite.

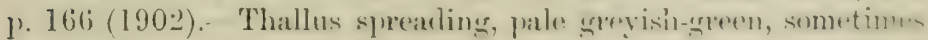


disteri with small roundish soralia. Apothecia small or moderate in size, ranely ciliate on the under side.--Pliyscin obscura var.

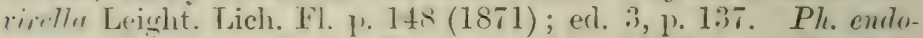
corerue Cromb. in Journ. Bot. x. p. 359 (187.) (non. Kórb.) : Seight. Lich. Fl. ed. 3, 1) 14\%. Ph. nlothric var. virclla Cronsh.

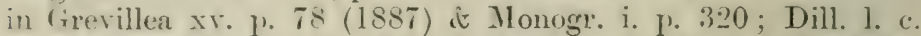
tig. 7. 13. Lirhen virellus Ach. Lich. Suee. Prorlr. 1. 108 (179s): Ensl. IBnt. t. 1696, two upprer figs. Parmelia virclla Ach. Meth Lich. 1. 201 (1803) : Hook. in Sin. Engl. Fl. v. p. 202. Burreru obscura var. virella Mudd Man. p. 110 (1861).

Exsicc. Larb. Lich. Hb. n. 126 \& Lich. Cantab. n. 15 ; Mudd n. 80.

Distinguished by the lighter colour, bright-green when wet, light. brown when dry. Some of the specimens like those of the species are dotted with small abrader or nibbled spots, others are abundiantly sorediate. The lobes are rhizinose-ciliate aud oceasionally the apothecia. Toth species and rarieties, more especially rar. rimpln. are frequently associated with Janthorir parietina, and are thus liable to be suffused with parietin, which give a vellow tone of

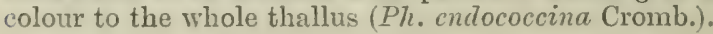

Hab. On trunks of old trees, rarely on walls in maritime and inland districts.-Distr. Not uncowmon in England, rarer in Wales. Scothanl and Ireland.-B. .T. Near Penzance, Cornwall; Ilsham. 'T'oryiay, Deron ; Tirde, I. of Wight; near Jirighton, Henfield and 1):nnv, Sussex; Epluing Forest and Ulting, Essex; near Cirenceste'l and Honerbourne, Gloucestershire; Broadwas and Norton, Worecstershive; Gogmagog Hills and near Nermarket, Cambridgeshire: Alerilorer, Merioneth; Durler. Derbyshire: Ayton, Cleveland, Iork- hive: Airds, Appin. Argyll: Finlarig. Fillin and Gilen Fender. Perthslive; Tilllaloe, Cork; Lyons near Dublin.

. I. Pl. lithotea Nyl. in Flora lx. p. 3.j.t (187T).-- Thallus sul,orlicular, romposerl of short plane subimbricate multifid lacinias, light-ur crencrally dark-hown, beneath black, the rhizine black. munerous, oceasionally extending from the margins ( $\mathbf{L}-$, $\mathrm{CaC}^{\mathrm{C}}$-). Apothecia rare "central, blackish: spores as in the

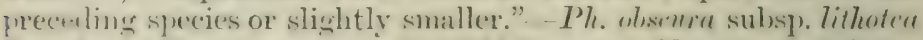

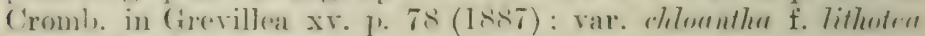

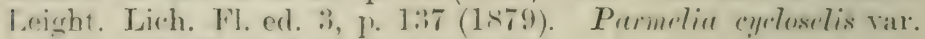
lithoter Ach. Metb. Lich. p. 199 (1803).

Exisice. Larb. Lich. Hl). (without a number).

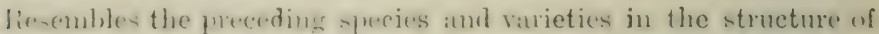

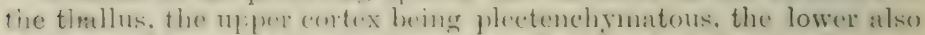

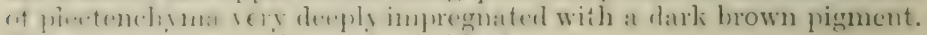
The older specimens beconte roughly furfuraceous.

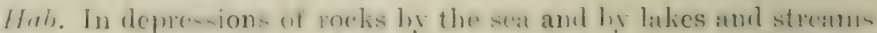
in mountainous districts.-Distr. Loenl and scarce in N. England, ‥ Wales. S. Grampians, Scotland, and N.W. Ireland.-B. M. Near

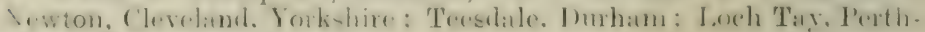
thire; Connemara, Gulway. 


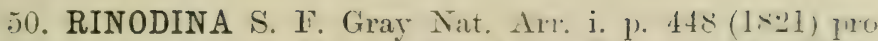
minima parte; emend. Massal. Ric. Lich. Crost. p. 14 (1852): Mudd Man. p. 14\%. Lecanora sect. IRimolina Ach. Lich. Unir. p. 344 (1810) pro minore parte. (Pl. 50.)

Thallus crustaceous, rarely symamulose, non-corticate except in highly developed species. Algal cells Piofncocus. Apothecia dark-coloured, generally with a prominent thalline margin : paraphyses slender, broader, septate, brown and often shortly branched at the tips; spores s in the ascus (rarely more) 1 -septate, more or less distinctly polarilocular, brown.

The spores of this genus, as in Physcia, are nearly always distinctly polarilocular with the cell-lumens rather near the median. wall. The thallus in most species is colowerl some tinge of grey, in: others it becomes very dark. The genus is distinguished from Burlliu by the thalline margin of the apothecium and also by the more or less distinctly polarilocular spores. The same type of spores occurin Bucllia discolor, B. interpolata, B. biloculata and $D$. polosporn (Brit. Lich. ii. p. 168). The first two species have a colourless hypothecium, and are clearly allied to linorlina; the two litter having a dark hypothecium are more truly lecicleine.

\section{Thallus isidioid-squamulase.}

1. R. isidioides Olir. Lich. Eur. fasc. 2, p. 186 (1909). Thallus effuse, consisting of somewhat coralloid isidia-like jucesses, scattered or rarely united into a spuamulose structure. simple or sometimes rivided unerenly, eylindrical or slightly compressed, whitish or pale greyish-green ( $\mathrm{K}+$ rellowish, $\mathrm{CaCl}-1$. Apothecia small or moderate in size, plane, the disc blackish. the thalline margin entire or crenulate-isiclioid; praplysseslightly clavate, septate and brown at the tips; spores fusiformellipsoid, sometimes constricted in the middle, colourless then

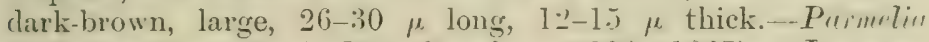
isidinirles Borr. Engl. Bot. Suppl. t. -2808 (1837). Lirunorer isidivides Nyl. in Mlém. Soc. Sci. Nat. Cherb. v. p. 11j(1Ej̃): Cromb. Lich. Brit. 1. 49 \& Monogr. i. p. f02 : Leight. Lich. Fl. p. 2.24; ed. 3, 1. 214. Borrete isidivide's Mudd Man. 1. 106 (1861).

In endemic species well characterized by the peeuliar thallus; it hats recently been rediscorered in the New Forest by R. Panlion. The structure of the minute "radiate" thillus is almost wholly. cellular with the gonidia massed towarth the centre: there is in refinite cortex.

$H a b$. On mossy and naked trupks of trees in inland or upland districts.-Dist . Pare in N. Wales and s. Fingland.-D. M. Cauln:m. New Forest, Hants; Cwm brehan and I)olymellynen. Meriometh.

\section{Thallus crustaceous, grey or whitish.}

On trees or wood.

$\therefore$. R. polyspora Th. Fr. Lich. Aret. I. 121; (1N6(0). -Thallu-

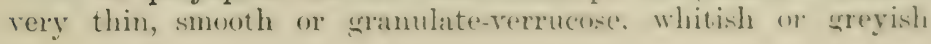


( $\mathrm{K}-, \mathrm{CaCl}-$ ). Apothecia minute, arlnate, the disc brownish or blackish, at first plane and then with a thin rather paler margin, becoming convex and immarginate; paraphyses somewhat comglutinate, slightly thicker, knobbed and brown at the tips, and often shortly brancherl and septate; spores $12-24$ in the ascus, oblong-ellipsoid, straight or slightly curved, 13-16 lons, $5-\$ \mu$ thick. $-R$. vophliontrs Massal. Ric. Lich. Crost. p. 14 (18.2) (non A(h.); Muckl Man. p. 142. Lerenore polyspore Nyl. in Not. Sillsk. Faun. it Fl. Fenn. Fïrh. 11. ser. viii. p. 1K2 (1871): Cromb. in Grevillea xriii. p. 47 (1889) \& Monogr. i. 1). 402 .

Tistinguished by the number of spores in the ascus. There is no British specimen in the herbarium.

Hab. On smooth birk of trees in mountainous regions.-Distr. Only very sparingly at Craig Calliach, Perthshire.

3. R. sophodes Th. Fr. Lich. Arct. p. 125 (1860) (non Massal.).-Thallus determinate or subleterminate, often suborbicular, rather thin, verrucose-areolate, grey or greyish-brown, with a black hypothallus ( $\mathbf{K}-$ ). Apothecia small, usually crowded in roundish patches, brownish-black, the thalline margin entire, sometimes becoming crenulate; spores ellipsoid, $12-20 \mu$ long, 6-8 (or -10) $\mu$ thick.-Rimorlina exigue var. horiza Mudi Man. p. 143 (1861). Lichen sophodes Ach. Lich. Suec. Prodr. p. 67 (1798); Engl. Bot. t. 1791. Leeranora sopleodes Ach. Lich. Univ. p. $356(1810)$; S. F. Gray Nat. Arr. i. p. 450 pro parte: Hook. in sim. Engl. Fl. v. p. 1 sis pro parte: Cromb. Lich. Brit. 1. 49 pro parte d MLonogr. i. p. 394 ; Leight. Lich. Fl. p. 2.24: ed. 3, p. 214 pro parte. Lecanora subfusca var, horiza Ach. Lich. Univ. p. 394 (1810)?

Exsiec. Mudd n. 109.

The thallus, though mostly circunseribed by the black line of the hypothallus, is sometines effine, and generally erowded with upothecia. These owe the dirk colour of the dise to the parapliyses, which are brown orer the tips; they are slightly wider and septate upwards, sometimes encling in several short branchlets. The spores have thickened walls, fach cell with it restricted lumen, which show: frepuently a projection towards the meilian septum. Massalongo:

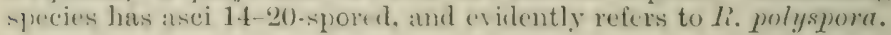

Hah. On trunks of trees, especially nsh, in wooded localities. Distr. Local and rare in S..W. and N. England and S. Wales.B. A. Near Anstey's Cove, 'Torquay, Devon; near Lyndhurst, New Forest, Hants; near Cuclimere, Sussex; Kemble, Wilts; Llanymy-

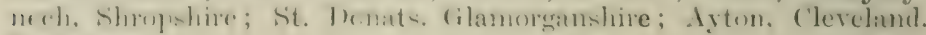
Yorkshire.

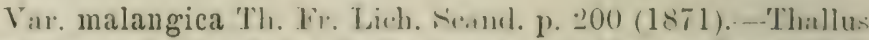
rllin:e, contrely arenlate, furfuranesus on the surface, dark

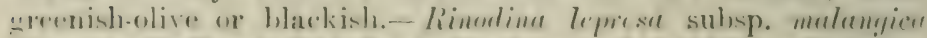

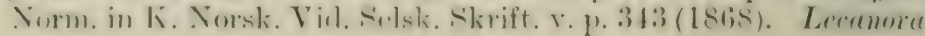




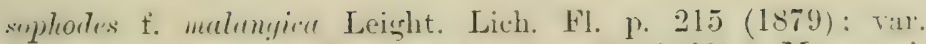
merlengira Cromb. in Grevillen xviii. po $46(1889)$ it Monost. $\mathrm{i}$. p. 394. Specimen not seen.

The B. M. specimen recorded as var. malangica is Buellia myrioaripu. It was collected by Leighton on Haughmond Hill. Shropshine.

Hat.-On trunks of trees. - Distr. Sparingly in IV. England?

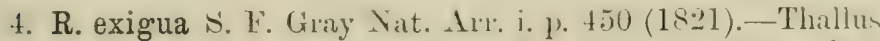
phise, thin, membranaceuns and continuous or areulate, often granular and scattered, whitish or pale- to dark-grey, hypothallus black, but ravely distinct $(\mathrm{K}-$ ). Apothecia small, plane, the clise blackish, with a thin thalline margin, entire or crenulate. lecoming convex with the margin excluded ; paraphyses nar'owly clavate, septate and brown at the tips: spores fusiform-ellipsoid, 11-18 $\mu$ long, 6-8 $\mu$ thick.-Mudd Man. p. $1+2$ pro parte (incl. rar. 1miclea). R. peridere s. F. Gray Nat. Arr. i. p. $4+9(18-1)$ pro parte. Lichen evigums Ach. Lich. Suec. Prodr. p. 69 (1798): Engl. Bot. t. 1849 pro parte. L. perirleus vim. Engl. Bot. t. 1850 (1808) (non Ach.). Leecenome periclen Honk. in Sn. Engl. Bot. v. p. 187 (1833) ; Tayl. in ILackay Fl. Hib. ii. p. 133. L. exigua Hook. in S̈m. Engl. Fl. v. p. list (1833) pro parte : Cromb. MIonogr. i. p. 395 pro parte. L. sophodes var. rivigua Cromb. Lich. Brit. 1). $49(1870)$; f. exigna Leight. Lich. Fl. p. 224 (1871); ed. 3, p. 214.

Exsicc. Larb. Lich. Hb. nos. 169, $26 \%$.

Not easily distinguished from li. sophodes, but the thallus is usually more spreading and thinner, and the apothecia are smalle ind less persistently marginate; the spores also are slightly smaller.

$\mathrm{Hab}$. On trees, or more frequently on palings in maritime and inland districts.-Dist. Fairly common thioughout the Channel Islaukls and England, evidently rare in Scotland and Ireland.-B. $M$. Noirmont, Jersey; Lyndhurst, New Forest, Hants; Hurstpierpoint. Snssex; Epping Forest, Essex; near Bristol, Somerset; ITeston. ()xfordshire; near Morda. Oswestry, Shropshire; near Worcester : Suffolk; Yarmouth, Norfolk ; Ayton, Cleveland, Yorkshire.

Var. lecideoides Th. Fr. Lich. Scand. p. 20:3 (1R71).-Thallus srey, seanty or absent. Apothecia small, thin, plane, with at errevish thalline margin becoming crenulate $\mathrm{ol}^{\circ}$ disappearing spores oblong, 16-20 $\mu$ long, S-11 $\mu$ thick.-Leconora soplearles:

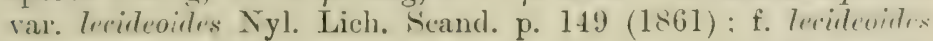
Leight. Lich. Fl. p. 225 (1871); ed. 3, p. 215 pro parte. L. revigure var. lefirlevides Cromb. in (irevillea xriii. p. 46 (1-29) E Monogr i. p. 396.

Though with somewhat larger spores, resembles li. arigun in th." habitat and in the subentire margin of the apotheciun, which generally becomes excluded.

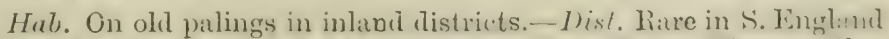

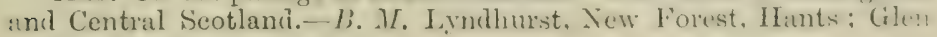
Lochay, Killin, Perthshire. 
$\therefore$ R. roboris Am. in Flora lxiv p. 197 (1881): Oliv. Exp. syt. Lich. 1. 252 (1897),- Thallus determinate or subeftuse, thinnish, continuous and somewhat winkled or superficially are late or furfuraceous, whitish or greyish-white ( $\mathrm{K}+$ yellow) ; hyputhallns black, visible only occasionally as a nariow black line. Apothecia moderate in size or rather large, prominent, thickly scattered, the disc blackish, the margin persistent, leconing crenulate; paraphyses septate, irregularly brancherl and hrown upwards; spores ellipsoid, $15-18 \mu$ lons, 6-9 $\mu$ thick. - Lerentra robmix Duf. ex Nyl. in Móm. Soc. Sci. Nat. Cherb. ii. I. $826(1854)$ : Cromb. in Grevillea xviii. p. $46(1889)$ it ILonogr. i. 1. 397. L. sophodes var. roboris Nyl. Lich. Scand. 1. $149(1861)$ : f. roluris Leight. Lich. Fl. p. 225 (1871) : ed. 3, p. 215.

Ersice. Johns. n. 36 ; Iarb. Lich. Hb. n. 260.

Distinguished by the more developed lighter-coloured thallus, by the reaction with potash, and by the whitish-margined apothecia.

Hab. On trunks of trees with rugged bark, rarely on stems of heather in maritime and inland localities.-Dist. Father common in the liritish Isles except Scotland, where it has not yet been reported. - B. M. East Coast of Jersey; D'Ixeart, Sark; Launceston and l'enzance, Cornwall; Ilsham, Torquay, Devon; New Forest, Hants; Tilg:ate and Danny, Sussex; Epping Forest, Langford, Maldon, Danbury and Thorudon Hall. Jrentford, Esisex; Savernake Forest. Wilts: Harboro' Margna, Warwichshire; near Worcester; Charnwoorl Forest. I.eicestershire; Yimmonth, Suffolk ; Cwm Brchan, Merioneth ; Trefriw, Carnarronshire; Teesdale, Durham; Felton Woods, Northumberlind; Leveu's Park. Westmoleland: Calder Abber, Cumberlaml: Comigaloe, near Cork; I) oughruagh Mrt.. Comnemara, (ialway.

\section{On roclis, slates, tiles, etc.}

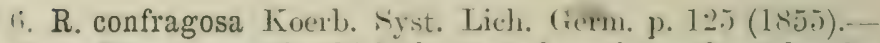
Thallus efluse, itenerally thickish, warted-arcolite, the tubereles onnetines rather sparse, greyish or dirty-white ( $\mathrm{K}+$ yellow), lyjwthallus black, often not visible. A prothecia morlerate in size wit rather small, the dise blackish, the thalline margin prominent, becoming crenulate: praraphyses sender, septate and brown at the tips, and slightly (nlareed ; spores ellipsoid, 1.2-2:3 $\mu$ long. 7-1:3 p. thick. - Parmelin anfretemsa Ach. Meth. Tich. Suppl.

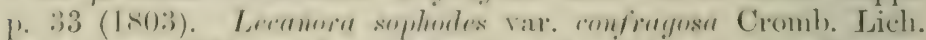
lirit. 1. 49 (1870). L. comfirmuse Nyl. ex Lamy in Bull. Sere. But. Fr. xxv. p. 404 (187S); Leight. Lich. Fl. ed. 3, p. 222 ; Cromb. Monogr. i. p. 397.

Exsice, Larb. Ciesar. 11. 28 \& Lich. Hb. 11. 301.

Dearly allied to li. roluenis. but with a generally thicker. duller flallus. The apothecia are numerous and prominent. The plant

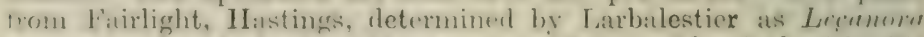

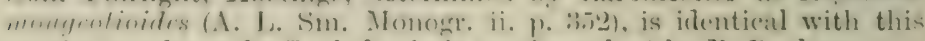
species, as shown by Larbnlestier's specimen lent by R. Paulson. 
Hab. On granitic and schistose rocks in maritime and inland localities.-Dist. Rare throughout the British Isles.-B. M. La Coupe, Jersey ; The Lizard, Cornwall ; neal Hastings, Sussex; Portlethen, Kincardineshire: rear ('rookharen, Cork; Donghuagh

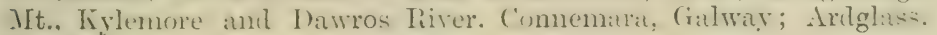
Down.

7. R. atrocinerea Kioerb). Syst. Lich. (icrm. 1) 125) (1,55). -Thallus effuse or determinate, thickish, whitish- or darkwrey, senerally of rounderl smooth rerucas, continums and crowed or scattered, with a black hypothallus ( $K+$ rellow. $\left(\mathrm{C}_{1} \mathrm{Cl}+\mathrm{recldish}\right)$. Apothecia at first minute and imnate in th.. verucu, becoming plane, at length convex, the disc dark-brown or blackish, the thalline malgin rather thin, entire, becoming obliterated : spores ellipsoid, 17-2.5 $\mu$ long. 10-12 $\mu$ thick.-Mudd Man. p. 14t, t. 2, fig. 49. Lirlern atroninerens Dickis. Pl. Crypt. fasc, iii. p. 14, t. 9, fig. 2 (1793); With. Arr. ed. 3, iv. 1. 19 : Engl. Bot. t. 2096. Lerilea atrorineren Hook. in $5 \mathrm{~m}$. Engl. El. v. P. $174(1833)$. Lecmora mitrind Tayl. in Machay Fl. Hib. ii. p. 134 (1836) pro parte (non Tahl.). I. atrorineren Nyl. in Flora liii. 1. 38 (1870): Cromb. in Jumn Bot. viii. 1. 97 (1870) \& Monogr. i. p. 398 ; Leight. Lich. Fl. p. 226 ; ed. :3, p. 216 .

\section{Exsicc. Leight. n. 146.}

Differs from allied species in the reaction with $\mathrm{CaCl}$; but the light-colourerl rerrucit on the hlack liypothallus also give at distinctive tessellated appearance to this plant. Crombie has given spore sizes up to:30 $\mu$ long and $16 \mu$ thick, but I have not been able to verify these large measurements. Sipemogones are not infrupent with spermatia $7-9 \mu$ long, 1-2 $\mu$ thick.

Hul,. (On rocks in maritime and moland districts.-Dist. Here and 1here throughout the British Isles-B. M. Guernsey; near l'enzance, Cornwall ; Crown Hill, Plympton, Deron; Lyth Hill, shropshire; Bamouth. Merioneth ; Holyhead. Anglesea ; Jiucaldine. Argyll; Portlethen, Kincardineshire; near Cork; Cliffs of Moher. Clare; Dunkerion and Carig Mt., Kerry.

8. R. subexigua Oliv. Lich. Eur. fase. 2, p. 181 (1909).Thallus cfluse, smouth, crackerl-arcolate, gale-greyish or dull. rellowish (K.). Apothecia minute, plane, the dise blackinh.

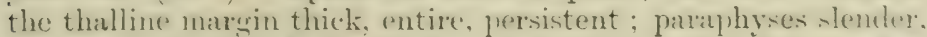
sometimes branched, lonobberl and brown at the tips: sporm

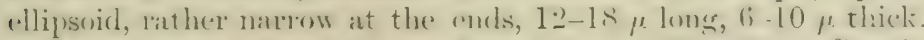

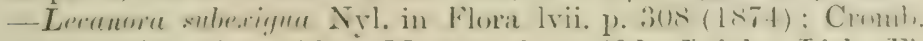
in Grevillea iii. p. 22 i Nonogr. i. p. 396 ; Leight. Lich. Fl. ed. 3, p. 220 .

The thallus is somewhat thicker than in li. cxigua. The spores vary, but do not differ in size.

Hab. On granitic rocks in meritime listricts.--Dist. liue in S.IV. England and E. Ireland.-B. M. Near Penzance, Cornwall. 
9. R. demissa Arn. in Floria Iv. p. $34\left(187^{\circ}\right)$. -Thallus thin, efluse, granulate or leproe or alnost wanting, brownish or dullstey, with a concolorous or darker hypothallus. Apothecia numerous, croweded or scattered, minute, the disc blackish. hecoming convex and prominent, the thalline margin thin, entire, Inersistent or disappearing: paraphyses clitvate, septate and brown at the tipss ; spores oblong-ellipssid, sometimes constricted in the middle, $10-16 \mu$ long, 5-9 $\mu$ thick. - Lirlen rigyns Sin. Engyl. lint. t. 18.t9 (1808) pro parte (nom Ach.). $R$. metubolicu var: demiswn Linerb. Syst. Lich. Germ. p. 124 (1855). Lecommu exigur f. demissu Stiz. in St. Gall. Nat. Ges. 1881, p. 359: Cromb. in Grevillea xviii. p. 46 (1\&89) \& MIonogr. i. p. 396. L. sophtules var. Texciguta Cromb. Lich. Jirit. 1) 4!) (1870) (non

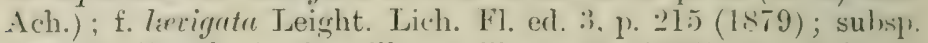
leverigata Cromb. in Grevillea xviii. 1). 46 (1889) (non Stiz.) it Monogr. i. p. 395.

Exsicc. Johns. nos. 196, 367 ; Larb. Lich. Hb. 11. 261 ; Mudd n. 107.

Ender this species have been groupert the speeinens that were renarderl as saxicolous forms of li. crigue. It is distinct in halbitat and in the dark, sometimes very scant or absent thallus. also in the more convex development of the apothecium.

Hab. On various rocks, sandstone, granitic, slate, etc., in mitritime and inland district.-Dist. Not meommon thronghout the British Isles.-B. M. Chateau Point, Jersey; Vale, Guernsey; Iuccombe and Shanklin, I. of Wight; Hentield. Sussex; IItingr. lissex; near Cirencester and Charfield, Gloncestershire: Jammonth. Nerioneth; near Jranton, Suffolk; Aber-Ty-(ilyn, X. Willes; near Ayton, Cleveland, Yorkshire; Port Sorlerick, I. of Minn ; St. liees. Cumberland; I. of Lismore, Argrll ; Portlethen, Fincardineshire: Carrigaloe. Cork; I'ortmarnock. Dublin: ('leghan. Commemata, Galway.

10. R. æquata Oliv. Lich. Lur. fase. 2, p. 177 (1909).-Thallus effuse, thin, smooth, oreyish-white, often searcely visible or obsolete (Kf + yellow). Apotheciat small, thinly marminate, becoming convex, llackish or dark-lorown, whitish within: spores broudly ellipoid, 16-20 $\mu$ lomg, 10-11 $\mu$ thick: hymenial gelatine deep blue with iodine---Lerriden romiops var. exquetu Ach. Lich. Univ. p. 171 (1810). L. exquetu Nyl. ex ('romb. in Jomm. Bot. xii. p. 149 (1874). Lecenore sequeitn Nyl. in Flora lxvii. p. 392 (1884); Cromb. Monogr. i. p. 101.

The above description is taken from (rombie. The only specinuen

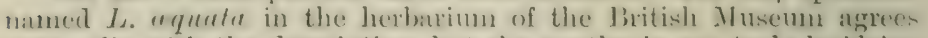
sutwardly with the deseription. but the apothecia are truly leceidein. into which $n 0$ gonidiat have entered. and with a dark-brown hypothe.

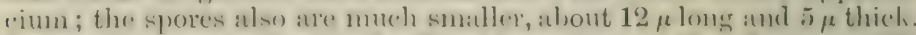

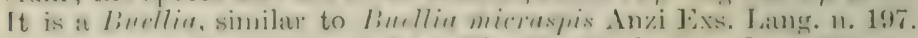
That species has been cited by T'H. Fr. (Lich. Scand. p. 601) at: synonynous with 13 . seratilis; lut the latter has a much more 
ieveloper thallus. It may however be a lepunperate condition of that species.

Hab. On granitic rocks in maritime and inland regions.

11. R. Bischoffii Koerb. Parerg. Lich. p. 75 (1859).- Thallus thin, effust, continuous and farimose or thinly areolate, greyish or brownish, often inlistinct $(K-)$. Apothecia very small, plane, with a thin entire thalline margin, becoming convex and immarginate, dark-brown; paraphyses with clavate lranched septate and brown apices: spotes broadly ellipsoid, 15-20 $\mu$ long, 7-12 $\mu$ thick.-Psora Bischoffii Hepp Flecht. Eur. n. 81 (1853). Lecenora Bischoffii Cromb. in Jomm. Bot. xiii. p. 141 (1875) d Monogr. i. p. 399 ; Leight. Lich. Fl. ed. 3, p. 220. thallus.

Distinguisher by the minute plane apothecia and the thin scurfy

$H a b$. On calcareous rocks in upland situations.-Distr. Rare in IV. England and the Central (rrampiaus, Scotland.-B. M. Rodmarton, Eloucestershire; Ennertale, (umberland; Craig Tulloch, Blair Athole, Perthshire.

Tar. immersa Koerb. 1. c. -Thallus immersed in the rock, risible as whitish spots. Apothecia immersed-foveolate, minute, the brown thalline margin somewhat prominent, otherwise as in the species.-Leconom Bischofii var. immersa Cromb, in Journ. But. Nir. p. 360 (18T6) it Monogr. i. 1) 400 ; Leight. Lich. Fl. ed. 3, p. 221. Lecidea alociza Cromb. in Journ. Bot. ix. p. 178 1NTl) (nom Massal.) pro parte; Leight. Lich. Fl. p. 310 pro varte. Lecilea alorizuides Leight. Lich. Fl. ed. 3, p. 325 (1879) pro parte. Buellia alocizoides A. I. Sm. MIonogr. ii. p. 167 (1911) pro parte.

Confused with auother minute lichen Bucllia alocizoiles, as the thalline margin is obsenre ant the sport-characters are not always well marked.

Hab. On calcareous rocks and walls in maritime and upland Ristricts.-Distr. Rare in S.W. and N. England and in Wales.B. II. Torqual, Deron; Yatton and Weston-super-Mare, Somerset; Eglwyseg rockis, Denbighshire; Buxton, Derbyshire.

l.). R. subarenaria 1. L. Sm.--Thallus thin, smooth, continuous and somewhat uneven or of scattered minute areolie : hyothallus blackish-brown, underlying the areolix or bordering the thallus. Apothecia minute, about $0 \cdot 3-\cdot 4 \mathrm{~mm}$. in (iiameter, adnate, plane or concave with a prominent noper matrin, the thalline marwin not risible. but a gonidial layer present below the colourlesis hypothecium; paraphyses slenrler, clavate, eptate, bown and often branched at the tips: asci clavate: symes $x$ in the ascus often moleveloped. broadly ellipsid, polariocular, and sometimes swollen in the midclle, the two leculi 
neill the centre and conerally commected, large, mostly alout $27 \mu$ long and $12 \mu$ thick, but also :30 $\mu$ long and 15 $\mu$ thick.

Allied to Rinodina arenaria Fr. a northern or mountainous continental species. but dillering in the form of the spores and in other chatracteristics. The spores are freurently shrivelled and of -mall woportions, which may be due to inundation of the specinens, but there is no indication that they were collected in or near water.

Hab. On hard rocks.-Distr. Tare in S. and W. Treland-B. M. Near Cork; Lettermore, Connemara, Galway.

\section{Thallus dark-grey or blackish.}

On trees.

1:). R. colobina Th. Fr. Lich. Scand. 1). 205 (18T1).-.Thallus (rifuse, thin, pulverulent, grey or greyish-black $(\mathbf{K}+$ purplish). - Ipothecia minute, plane, the disc blackish; the thalline margin thickish, entire, light-grey ; paraphyses slender, septate, slightly thicker or capitate and bluish-brown at the tips (epithecimm $K+$ deep violet); spores ellipsoid, sometimes slightly constricted, 16-20 $\mu$ lons, $7-9 \mu$ thick.-Lerenora colobina Ach. Tich. Univ. p. 358 (1810); Cromb. in Jomm. Bot. xx. p. 27:; (1882) \& Monogr. i. p. 400.

Exsice. Larb. Lich. Hb, n. 91.

Distinguishat by the bluish epithecium and the unusual reactions with potash.

Hab. On the trunks of old trees. $-B . M$. Entrance to Icliworth Park, Suffolk (the only British locality).

\section{On rocks, walls, etc.}

14. R. teichophila Jatta Syll. Tich. Ital. 1) 276 (1:100)... Thallus subdeterninate, thickish or sometimes rather thin, aranular, deeply cracked-ireolate, dark greenish-grey (K - ). Apothecia numerous, rather small, plane, blitek, the thalline marein thickish, mostly ontire, not prominent, paler than the thallus; spores ellipsoid, blunt at the ends, 18-27 $\mu$ long, 11-16 $\mu$ thick. - R. exigun var. metabolica Mudd Man. p. 143

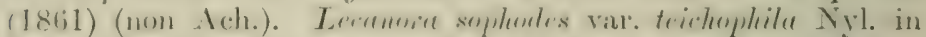

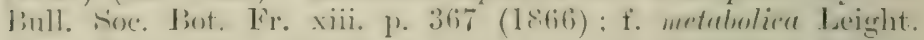
Lich. Fl. p. 225 (1871); ed. 3, p. 215. L. teichophila Nyl. ex Lamy in Bull. Soc. Bot. Fir. xxv. p. 405 (1878); Cromb. Monogr. i. p. 399.

E.r.sirr. Johns. n. 235: Mudd 11. 108.

Very variable but distinguished by the large thick spores, and illso by the dark deeply cracked thallus.

Hab.-On rocks and walls in maritime and upland situntions.-

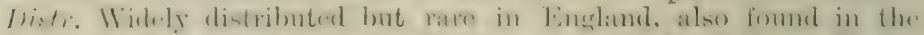
Scottish Grampians and in W. Ireland.-13. M. Ulting, Lissex; 15:thampton lowns, Somment: Cirencester, (ilonestershire; Holly 
Bush Hill, Malvern, Worcestershire; near Ayton, Cleveland, Yorkshire; St. Bees, Cumberland; The Trossachs, Perthshire ; Connemara, Galway.

15. R. milvina Th. Fries Lich. Arct. p. 124 (1860).-Thallus effuse, thickish, granular- or warted-arelolate, unequal, brownish, or dark-coloured $(\mathrm{K}-$ ) ; hypothallus thin, black. Apothecia rather small, plane, the dise brownish-black, the thalline margin entire; spores ellipsoid, 14-20 $\mu$ long, $7-12 \mu$ thick.-Parmelia milvina Wahlenb. ex Ach. Meth. Lich. Suppl. p. 34 (1803). Lecanora milvina Ach. Lich. Univ. p. 358 (1810); Borr. Engl. Bot. Suppl. t. 2662, fig. 1; Hook. in Sm. Engl. Fl.v. p. 187 ; Mudd Man. p. 144 ; Leight. Lich. Fl. ed. 3, p. 216 pro parte; Cromb. Monogr. i. p. 398.

Exsicc. Larb. Lich. Hb. n. 25 ; Johns. n. 197.

Marked by the dark thallus and the small flat apothecia sometimes obscurely margined.

Hab. On rocks in maritime and upland districts.-Distr. Rare in the Channel Islands, S.IV. and N.E. England, S.IV. Highlands and N.E. Scotland.-B. M. Vale Castle, Guermsey; near Penzance, Cornwall; Barcaldine, Argyll; S. of Bay of Nigg, Kincardineshire; Maam Turk Mts., Galway.

16. R. umbrinofusca Oliv. Lich. Eur. fasc. 2, p. 187 (1909).Thallus determinate, thinly crustaceous, continuous or areolate, purplish-brown or -black, with a radiating dendroid blackish liypothallus $(K-)$. Apothecia minute, plane, adnate, black, the margin brownish, obscure; paraphyses clavace, septate and brown at the tips ; spores small, shortly ellipsoid, blunt, 10-11 $\mu$ long, 6-7 $\mu$ thick.-Lecanora mbrinofusca Nyl. in Flora lxiii. p. 389 (1880) ; Cromb. in Grevillea x. p. 23 (1881) \& Monogr. i. p. 401 .

In outward appearance very like a Lecidea species, but the structure of the apothecium is wholly lecanorine. The spores only occasionally show the characters associated with Rinodina. It forms small dark spots on the white flint; it was considered by Nylander to approach Lecanora griseo-fusca, a Finland plant.

Hab. On flints in an inland district.-B. M. Thetford Warren, Norfolk, the only locality.

17. R. coniopta A. L. Sm.-Thallus thick, smooth, unequal, deeply cracked-areolate, purplish-grey or dark-purple-brown $(\mathrm{K}-, \mathrm{K}(\mathrm{CaCl})+$ reddish $)$. Apothecia moderate in size, at first plane, with a thin thallino margin, the disc dark-brown, becoming convex and immarginate, white within; palraphyses thickish, slightly thickened, septate, knobby and brown at the extreme tips, rarely shortly branched; spores ellipsoid, darkbrown, 15-20 $\mu$ long, 8-10 $\mu$ thick.-Lecanora conionta Nyl. in 
Floria lvi. p. 19 (1873); Cromb. in Grevillen i. p. 141 \& Monogr. i. p. 399 ; Leight. Lich. Fl. ed. 3, p. 216.

Exsicc. Cromb. n. 158.

Included by several systematists in Burllia, but the apothecium is rather more lecanorine than lecideine in structure: there are traces of the thallus enclosing the apothecium and the subhymenial layer is rery thick and colourless and contains a few scattered gonidia; the spores are of the Rinodina type with contracted contents, though that character seems also to occur in some Buellin specimens. Generally compared with Buellin coniops, but the thallus more nearly resembles some states of Lecidea vivulosa.

IIab. On siliceous rocks in maritime districts.-Distr. Here and there on the coasts of the British Isles.-B. M. Jersey; Alderney; Sark; St. Merryn and near Penzance, Cornwall; near Portlethen, Kincardineshire; Kinsale, Cork; Connemara, Galway.

\section{On turf, etc.}

18. R. Conradi Koerb. Syst. Lich. Germ. p. 123 (1855).Thallus effuse, thin, granular-leprose or minutely warted, grey or greyish-brown ( $\mathrm{K}-$ ). Apothecia small, plane, dark-brown, the thalline margin entire or somewhat wrinkled; paraphyses conglutinate, slightly clavate, branched, septate and brown at the tips; spores ellipsoid-fusiform, 1-septate, but the two loculi frequently constricted in the middle giving the appearance of septation, or their cell contents much broken up, dark-brown, large, 20-35 $\mu$ long, 10-15 $\mu$ thick.-Lecanora pyreniosporu Nyl. in Vet. Ak. Förh. 1860 , p. -97 , note? Cromb. Lich. Brit. p. 49 ; Leight. Lich. Fl. p. 230 ; ed. 3, p. 22.2. L. Miplinthia Nyl. in Act. Soc. Sci. Fenn. vii. p. 444 (186:3)? Leight. 1l. c.; Cromb. Monogr. i. 1. 401. L. Cunradi Nyl. in Not. Saillsk. Faun. et Fl. Fenn. Förh. xi. p. 182 (1871); Cromb. Monogr. i. p. 400.

Exsicc. Larb. Ciesar. n. 78 \& Lich. Hb. nos. 263, 302.

Distinguished by the habitat and by the large and somewhat peculiar spores. They have been deseribed as 4 -celled, but it is merely that the lumen of cach cell is constricted in the middle. Our specimens of Lecanora diplinthia agree with the above; I have not seen Nylander's plant.

1Ful. On decayed turf, on mossy ground, on exerements of sheep, r.te., in maritine and inland districts.-Distr. liare in ('hannel Islands, E. England and S. Wales.-B. M. La Moye, Jersey; Eperquerie, Sark; Lrandun I'urk, Suffolk; Thetford Warren, Norfolk.

\section{(IRDiR XIII. LECANORACE王.}

Thallus crustacenus or squamulone, variously coloured. Sitrueture more or less stratose, corticate above or non-corticate, attareherl by hyphas to the substratum. Algal cells Chlorophyceese. Apotheria superfieial or at first immersed in the thallus, cliseoid, 
normally with a prominent thalline margin; spores usually 8 , rarely many in the ascus, colourless, simple or variously septate.

of world-wide distribution. Distinguished from the somewhat parallel Order, Lecideacer, by the character of the apothecia, in the development of which the thallus takes part, and forms a protective margin round the disc.

Phialoysis (Lecanora mbra Ach.) belongs to Gyalecta, and the species of Lccanora sect. Sarcogyne have been placed in Biatorella (see Appendix). Psoroma is placed under Pannariaceæ (p. 89).

The following British genera are included in the Order :-

Spores simple.

Spores 8 or few in the ascus

51. Lecanora.

Spores many in the ascus................... 52. Acarospora. Spores septate.

Spores elongate-ellipsoid, 1-2-septate........ 53. Lecania.

Spores elongate-fusiform, 1-3-septate ........ 54. Icmadophilus

Spores elongate-acicular, pluri-septate....... 55. Hæmatomma.

51. LECANORA Ach. Lich. Univ. p. 77 (1810) pro parte. (Pl. 51.)

Thallus squamulose or variously crustaceous, rarely somewhat minutely fruticose, mostly of stratose structure, the cortex of the upper surface of decomposed hyphæ, or wanting. Algal cells, Protococcus. Apothecia generally superficial, sometimes immersed at first; spores usually 8 in the ascus, colourless, simple, mostly ellipsoid. Spermogones with acrogenous or rarely pleurogenous spermatia.

In the genus, as here understood, are included the species with simple colourless spores, generally 8 in the ascus (up to 32 in L. Sambuci). The sections Ochrolechia and Aspicilia are frequently regarded as distinct genera, the former on account of differences in paraphyses and spores, the latter because of the late development of the thalline margin. The species are grouped in the following sections :-

Thallus squamulose

$\S$ i. Squamaria.

Thallus crustaceous or indistinctly squamulose.

Apothecia superficial from the first.

Spores small or moderate in size (less

than $40 \mu$ in length) ................... \& ii. Eulecanora.

Spores very large, with a thick epispore \$ iii. OcHnolecHi..

Apothecia immersed at first................... § iv. Asricilia.

§ i. Sqquamaria DC. Fl. Franc. ii. p. 374 (1805) pro parte (as the genus Squammaria); Hook. in Sm. Engl. Fl. v. p. 192; Mudd Man. p. 127; Cromb. Lich. Brit. p. 44 ; Leight. Lich. Fl. p. 171 ; ed. 3, p. 157. Lecanora subg. Squamaria Nyl. in Not. Siallsk. Faun. \& Fl. Fenn. Förh. v. p. 125 (1866); Cromb. MIonogr. i. p. 350. Squamaria subg. Placopsis Nyl. in Ann. Sci. Nat. xv. p. 376 (1861). Lecenora subg. Placopsis Cromb. Monogr. i. p. 355 (1894). 
Thallus squamulose, the squamules imbricate, or appressed and more or less effigurate at the circumference. Apothecia superficial ; spores moderate in size or rather small.

\section{Thallus of imbricate squamules.}

1. L. cartilaginea A. L. Sm. (non Ach.).--Thallus squamulose, the squamules thickish, cartilaginous, imbricate or loosely appressed to the substratum, roundly crenate, pale- or darkbrown, corticate above, beneath non-corticate, dark-coloured, attached by stoutish roughened hyphe (K - ). Apothecia moderate in size, concave or plane, becoming irregularly convex, reddish-brown, the margin thinnish, almost entire, disappearing; paraphyses conglutinate, slender, septate and slightly widenerl upwards, the epithecium of dark-brown granules; spores oblongellipsoid, 11-15 $\mu$ long, 4-6 $\mu$ thick.-L. crassa Ach. Lich. Unir. p. 413 (1810); Hook. Fl. S'cot. ii. p. 51 ; Cromb. Monogr. i. p. 351 ; var. melaloma Ach. tom. cit. p. 414 ; f. melaloma Cromb. in Grevillea xviii. p. 44 (1889) \& Monogr. i. p. 35\%. Lichenoides cartilagineum, scutellis fulvis planis Dill. Hist. Musc. p. 179, t. 24, fig. 74 (1741). Lichen cartilagineus Lightf. Fl. Scot. ii. p. 815 (1777); With. Arr. ed. 3, iv. p. 29. L. crassus Huds. Fl. Angl. ed. 2, p. 530 (1778); Engl. Bot. t. 1893. Squamariu crassa DC. Fl. Fr. ii. p. 375 (1805); Hook. in Sm. Engl. Fl. v. p. 193 ; Mudd Man. p. 127 ; Cromb. Lich. Brit. p. 44 ; Leight. Lich. Fl. p. 171 ; ed. 3, p. 157. Psoroma crassum S. F. Gray Nat. Arr. i. p. 444 (1821).

Exsice. Bohl. n. 2 ; Cromb. n. 157 ; Dicks. Hort. Sicc. fasce. vi. n. 24 ; Larb. Cæsar. n. 73 \& Lich. Hb. n. 333 ; Leight. n. 5 ; Mudd n. 91 .

Not unlike Lecidea (Psora) Turila, but distinguished when sterile by the larger lighter-coloured squamules; they vary from glaucousgreen to chestnut-brown, often white-edged, and oceasionally whitepruinose. The apothecia are abundant, scattered orer the squamules. The form melaloma differs only in the dark edges of the squamules.

Lightfoot's name Lichen carlilagincus has priority, though $L$. crassus has been almost universally alopted; it must not be confused with Lichen carlilagineus Ach., which refers to the fullowing plant.

I $a$ ab. On the ground, sprealing over mosses, etc., and on rocks, chiefly calcareous, in maritime and inland districts.-Distr. General and common throughout the British Isles, more especially in the sonthern counties.-B. M. (Quenvais, Jersey; Herm; Guernsey; St. Merryn, Cornwall; Berry Ifead and J habbicombe, I)evon; near Needles, I. of Wight; Newhaven Cliffs, B3innor, and IIurstpierpoint, Sussex; ('leeve Ifill and Cheddar Clifl's, Somerset; 1)urdham Down, Leigh Woods, and St. Vincent's liocks, liristol, (iloneestershire; P'ort Eynon. (ilamorganshire; near Tenby and Stackpole Court, Pembrolicshire; Aberdovey, Merioneth; Snowdon and (ireat Orme's Head, Carnarvonshire; Iliangollen, I)enhighshire; P'ufin Island, Anglesen; Oswestry, Shropshire; near Juxton and Dowedale, Derbyshire; Ulverston, 
Lancashire; Ingleborough, Clapham, Yorks; Egglestone, Durham; Whitbarrow, Westmoreland; Arthur's Seat, Edinburgh; Black Isle and Lismore, Appin, Argyll ; Mornington, Meath; Killarney, Kerry.

2. L. Achariana A. L. Sm.-Thallus spreading or pulvinate, the squamules rather narrow, or dilated and deeply crenate at the circumference, somewhat shining, pale greenish-yellow; beneath whitish $(\mathrm{K}-)$. A pothecia numerous, concave, then rather large and plane, and irregularly lobed, reddish-flesh-coloured, the margin entire or crenulate; spores oblong or ellipsoid, 11-16 $\mu$ long, 5-6 $\mu$ thick. $-L$. cartilaginea Ach. Lich. Univ. p. 415 (1810); Cromb. in Grevillea xviii. p. 44 \& Monogr. i. p. 553. Lichen cartilagineus Ach. in Vet. Acad. Handl. xvi. p. 133, t. 5, tig. 4 (1795) (non Lightf.). Squemaria cartilaginea DC. Fl. Franc. ii. p. 376 (1805); Borr. Engl. Bot. Suppl. t. 2802 ; MIudd Ian. p. 128 ; Cromb. Lich. Brit. p. 44; Leight. Lich. Fl. p. 172 ; ed. 3, p. 158.

A rare British lichen, differing from $L$. cartilaginea (Lightf.) in the form of the squamules and in the colour. It is a northern plant.

$H a b$. On rocks in maritime and upland localities. $-B$. M. Above Barmouth, Merioneth. Reported by Leighton (l. c.) from Yorkshire.

\section{Thallus appressed, radiate-efigurate at the circumference.}

3. L. lentigera Ach. Lich. Univ. p. 423 (1810).-Thallus orbicular, of thickish closely appressed coherent squamules, wrinkled and tuberculose over the surface, undulate, crenate and effigurate at the circumference, whitish or very pale brownishgreen, subpruinose, white beneath $(\mathrm{K}-)$. Apothecia rather small, crowded, the disc pale brown, concave then convex, the thalline margin entire, thickish, becoming thinner; parapliyses slender, concrete, slightly clavate; spores ellipsoid, 9-12 $\mu$ long, about $5 \mu$ thick.-Cromb. in Grevillea xii. p. 61 (1882) \& Monogr. i. p. 352. Lichen lentigerus Web. Spicil. Fl. Gœtt. p. 192 (1778): Relh. Fl. Cantab. p. 435 with fig.; Dicks. Pl. Crypt. fasc. i. p. 11 ; Engl. Bot. t. 871 ; With. Arr. ed. 3, iv. p. 27. Squamaria lentigera DC. Fl. Fr. ii. p. 376 (1805); Hook. in Sm. Engl. Fl. v. p. 195 ; Mudd Man. p. 128 , t. 2, fig. 40 ; Cromb. Lich. Brit. p. 44 ; Leight. Lich. Fl. p. 172; ed. 3, p. 157 . Placodium lentigerum S. F. Gray Nat. Arr. i. p. 447.

Exsicc. Larb. Lich. Cantab. n. 27.

Smaller, more appressed and lighter in colour than $L$. carlitagince.

Hab. On cretaceous soil in maritime and inland places.-I)istr. Sparingly in S., I. and Central England.-B. M. I. of Wight; Newhaven, Sussex; Thetford Warren, Suffolk; Gogmagog Hills and Newmarket Heath, Cambridge.

4. L. chrysoleuca Ach. Lich. Univ. p. 411 (1810).-Thallus thickish, almost continuous, wrinkled and crenate-lobate at the 
circumference or of imbricate squamules, pale-yellowish strawcoloured; sometimes pruinose; beneath pale towards the centre, bluish-black towards the edges $(K-)$. Apothecia moderate in size, the disc reddish-flesh-coloured, the margin thin, entire or becoming crenate and flexuose; spores ellipsoid, 9-12 $\mu$ long, 4-6 $\mu$ thick.-Cromb. Monogr. i. p. 35:. Lichen chrysolencus Sm. in Trans. Linn. Soc. i. p. 82, t. 4, fig. 5 (1791). Squameriet chrysoleuca Leight. Lich. Fl. ed. 3, p. 158.

Considered by Crombie as doubtfully British; it has not again been colleeted at Ben Brecht. It occurs both in Scandinavia and the Alps.

$H a b$. On granite and schistose rocks in alpine districts.-Distr. Recorded by Leighton (l. c.) from Ben Brecht, Argyll.

5. L. pruinosa Chaub. in St. Am. Fl. Agen. p. 495 (1821).Thallus orbicular, continuous, effigurate at the circumference, whitish and subfarinaceous, the outer squamules plicate and crenate $(\mathrm{CaCl}+\mathrm{red})$. Apothecia small, the dise brownish and grey-pruinose, the thalline margins prominent, entire or subcrenulate ; spores ellipsoid, $10-13 \mu$ long, $5-6 \mu$ thick.- $L$. pruinifera Nyl. in Bull. Soc. Bot. Fr. xiii. p. 368 (1866) note; Cromb. in Journ. Bot. xx. p. 274 (1882) \& Monogr. i. p. 355.

Differs from $L$. lentigera in the farinaceous surface and in the pruinose apothecia. The surface "powder" is largely composed of crystals of oxalate of lime.

$H a b$. On calcareous rocks. $-B . M$. Cleve Hill, Somersetshire (the only British locality).

6. L. gelida Ach. Lich. Univ. p. 428 (1810).-Thallus normally orbicular, up to $5 \mathrm{~cm}$. or more in cliameter, often somewhat irregular, closely appressed, cartilaginous, areolate in the centre, sometimes with greenish soredia, effigurate at the circumference, the radii narrow, branched, widening outwards and crenate at the tips, dull-white to cinerous-rrey ( $\mathbf{K}+$ yellow, $\mathrm{CaCl}+\mathrm{red}$ ), cephalodiiferous, the cephalodia forming small brownish or flesh-eoloured orbicular radiate patches seatterel

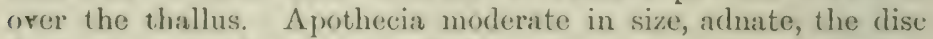
flesh-coloured, the margin thick, entire; paraphyses slenter, branched and septate at the tips ; spores ellipsoid, 1.t-18 $p$ long,

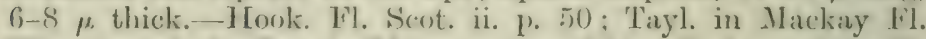
Hib. ii. p. 140; Cromb. Monour. i. p. 3.5. Le Lichen gelielus L. Mant. p. 183 (1767); Dicks. J'l. Crypt. fase. ii. p. 19; With.

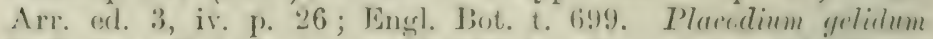
S. F. (iray Nat. Arr. i. p. 41S (1.201). Symameria yplida Ilook. in Sim. Enisl. Fl. v. p. 195) (18333); Mudd Man. p. 12!); Cromb. Lich. Brit. p. 45 ; Lecight. Lich. El. p. 176 ; ed. 3, p. 159 (incl. f. dispersa). 
Exsicc. Dicks. Hort. Sicc. fasc. vii. n. 25 ; Larb. Lich. Hb. 11. 50 .

Owing to the presence of cephalodia placed in Squamaria subg. Placopsis by Nylander in Amn. Sei. Nat. xv. p. 376 (1861). Lecanoin subg. Placopsis Cromb. Monogr. i. p. 355 (1894).

Often sterile, but well marked by the prominent cephalodia. which contain Stigonema and Nostoc algie. A young stage with scattered thalli and small cephalodia has been described as fo clispers" Cromb. in Grevillea i. p. 171 (1873).

$H a b$. On siliceous rocks in maritime, upland and subalpine districts.-Distr. In the rocky or hilly regions of England, Scotland and Ireland.- - B. M. St. Austell, Cornwall ; Cader Idris, Dolgelly and Llyn Bodlyn, Merioneth ; Nant Ffrancon and Cwm Glyders, Carnarvonshire; Egglestone and Teestale, Durham; near Kendal, Westmoreland; Knock Mortom Screes, Cumberland, New Galloway. Kirkeudbrightshire; Loch Arve, Argyll ; Craig Calliach, Ben Chaluna. Ben Lawers and Craig Tulloch, Perthshire; Clova and Caulochan. Forfarshire; Glen Cluny, Invercauld and Glen Caudlic, Braemar, Aberdeenshire; Rothiemurehus, Ben Neris and Fort Augustus, Invernessshire; Hills of Applecross, Rossshire; Dunkerron and Connor Cliffs, Dingle, Kerry; Letterfrack and Recess, Connemara, Galway ; Belclare and Clare Island, Mayo ; Carnlough, Antrim.

7. L. muralis Scher. Enum. Lich. p. 66 (18.50).-Thallus normally orbicular, often wide-spreading, pale-brownish or greenish-straw-coloured, appressed, imbricate or areolate-crustaceous in the centre, radiate-squamulose at the circumference, the squamules contiguous, narrow or rather broad, flat or subplicate, crenate at the apices, sometimes white at the margins. Apothecia up to $2 \mathrm{~mm}$. in diameter, crowded, generally plane, the dise yellowish-brown, the thalline margin thin, Hexuous or crenulate, rather light-coloured; paraphyses irregular, slightly thicker upwards, the epithecium a brownish grumous layer: spores ellipsoid, 9-16 $\mu$ long, 4-7 $\mu$ thick.-L. saxicola Acb. Lich. Univ. p. $4: 31$ (1810); Tayl. in Mackay Fl. Hib. ii. p. 140; Cromb. Monogr. i. p. 353 (incl. subsp). albomurginuta); var. albomarginatu Nyl. ex. Norrl. in Süllsk. Faum. \& Fl. Fenn. Förh. viii. p. 181 (1871). Lichen muralis Schreb. Spicil. Fl. Lips. p. 130 (1771), tide Arn. in Flora lxvii. p. 311 (1884); Dicks. Pl. Crypt. fasc. i. p. 11 ; With. Arr. ed. 3, iv. p. 29. L. saxicola Poll. Hist. Pl. Pal. p. 2.5 (1775); Engl. Bot. t. 169.). Placorlinum saxicolum S. F. Gray Nat. Arr. i. p. 447 (1821). Squemarin saxirolı Howk. in sin. Engl. Fl. r. p. 197 (1833) ; Mudd Man. p. 129: Cromb. Lich. Brit. p. 44 ; Leight. Lich. Fl. p. 173 ; ed. 3, 1. 15 (incl. var. albomerginuta) : subsp), albonerginuta Cromb), in Journ. Bot. xii. p. 147 (1874).

Exsicc. Bohl. n. 55 ; Johns. n. 191 ; Larb. Lich. Hb. n. 213 d Lich. Cantab. n. 24 ; Leight. 1. 145; Mudd n. 92.

A variable plant, which may form very large patches, with the centre often broken away; if sterile the lobes are crowiled and imbricate, when fertile the centre of the thallus may be entirely. 
corered by the apothecia which become irregular from pressure; sometimes the squamules are white-margined in part, or over the whole thallus (subsp. albomarginata).

Hab. On rocks, boulders, walls, etc., rarely on oak palings in maritime and iuland districts.-Distr. General though not common throughout the British Isles.-B. M. Fliquet Bay, Jersey; Vale Castle, Guernsey; Sark; near Penzance, Cornwall; near Ryde, I. of Wight; near Lewes and Midhurst, Sussex; Penshurst, Kent; near London, Middlesex; Chelmsford, Essex; Yarmouth, Norfolk; Bedfordshire; Ross, Herefordshire; Malvern Hills, Worcestershire; Bridge of Ludlow, Haughmond Hill, Oswestry and Caer Caradoc, Shropshire; Twycross, Leicestershire; Dolgelly, Barmouth and Cader Idris, Merioneth ; Llandyssil, Cardiganshire; Anglesea; Clifirigg, Cleveland, Yorkshire; near Egglestone and Teestale, Durham; near Kendal and Brougham Castle, Westmoreland; Wark and Gunnerton Crags, Northumberland; New Galloway, Kirkcudbrightshire; Arthur's Seat and Dalmahoy Hill, Edinburgh; Kyles of Bute; Burntisland, Fifeshire; near Connel Ferry, Argyll; Ben Lawers, Perthshire; Castleton of Braemar, Aberdeenshire; Kileully near Cork; near Belfast, Antrim.

Tar. diffracta Schrer. 1. c.-Thallus almost entirely cartilaginous-areolate, greyish-green or generally dark-coloured. Apothecia dark-reddish, with lighter thin disappearing margins. -L. saxicola var. diffracta Cromb. in Grevillea xviii. p. 44 (1889) \& Monogr. i. p. 354. Liehen diffractus Ach. Lich. Suec. Prodr. p. 63 (1798). Squamaria saxicola var. diffracta Nyl. Lich. Scand. p. 133 (1861); Cromb. Lich. Brit. p. 45 ; Leight. Lich. F1. p. 173 ; ed. 3, p. 159. Var. areoluta Leight. ex Mudd Man. p. 129 (1861).

Exsicc. Leight. n. 81 ; Mudd n. 93.

The squamulose character is generally obseure, though the plant is occasionally lobate at the circumference.

$H a\}$. On rocks in upland and subalpine situations.-Distr. Locul and searce in England and the Grampians, Seotland.- B. M. St. Minver, Cornwall ; IIaughmond Hill, Shropshire; near Ayton, Cleve. land, Yorkshire; Jen Lawers, Perthshire; Craig Guie, Bracmar. Aberdoenshire.

Var. versicolor Tuckerm. Sinn, N. Amer. Lich. p. 185 (188:2). -Thallus generally reduced, light-coloured, white-sufiused. Apothecia with frominent white crenulate margins.-L. saxicolu var. rrsiotor Cromb. in Grevillea xviii. 1. 4t (1889) d Monogr. i. p. 35.t (incl. f. dispersa). Lichen remiculor P'ers. in Ust. Ann. Bot. vii. 1. 24 (1794). Squemerie sertirolu var. versicolor Nyl. Lich. Seand. P. 1833 (1861) ; Leight. Lich. Fl. 1. 174; ed. :3, p. 159 (incl. var. albomarginata $\mathrm{f}$, dispersa).

Exsice. Johns. 11. 311.

The thallus may be rery reduced and the apothecia scattered or mited in pulvinate groups (i. disporsa). The powlery-white appearance is most characteristic in the prominent thalline margins of the apothecia. 
$H a b$. On calcareous and schistose rocks in maritime and upland regions.-Distr. Rather rare in W. England, WVales and Scotland.B. M. St. Darid's, Pembrokeshire; Chance's Pitch, Malveru, IVorcestershire ; Burmouth, Merioneth; Great Orme's Head, Carnarvonshire; I. of Lismore, Argyll ; Craig Tulloch, Blair Athole, Perthshire.

8. L. subimbricata A. L. Sm.-Thallus orbicular, closely adnate, crustaceous-areulate in the centre, effigurate at the circumference, the outer radii contiguous, narrow and convex, or slightly broadening out and becoming plane and crenate at the tips, whitish or cinerous-grey ( $K+$ yellow, then red). Apothecia numerous, rather small, innate, then plane, lorown or dark-brown when moist, almost black when drr, the thalline margin thin, entire; paraphyses slender, constricted-septate; spores broadly ellipsoid, 10-15้ $\mu$ long, 6-8.5 $\mu$ thick. - L. circinata Ach. Lich. Unir. p. 425 (1810)? Hook. Fl. Scot. ii. p. j0; Cromb. Lich. Brit. p. 49 \& Monogr. i. p. 403 ; Leight. Lich. Fl. p. 195) ; ed. 3, p. 179 ; subsp. subcircinata Cromb. in Grevillea xviii. p. 47 (1889). L. subcircinata Nyl. in Flora lvi. p. 18 (1873). Lichen subimbricatus Relh. Fl. Cantab. p. 427, with fig. (1785). L. circinatus Pers. in Ust. Ann. Bot. vii. p. 25 (1794?) ; Engl. Bot. t. 1941. Placorlium circinatum S. F. Gray, Nat. Arr. i. p. 448 (1821). Squamaria circinata Hook. in Sm. Engl. Fl. v. p. 196 (1833); Mudd Man. p. 130.

In this species the paraphyses are septate and constricted, appearing almost like rows of conidia. In this respect both Continental and British species are alike, as is also L. circinatula. According to Nylander there is a difference in the reaction to potash between Continental and British specimens, the former failing to give the red colouration. I have found that a Continental specimen turns red, while some of our specimens remain yellow. Nylauder did not consider that the reaction in this case was a specific distinction. In some specimens the apothecia and thallus have a reddish tinge (Parmelia circinate rar. mymlina Fr. Lich. Eur. p. 124 (1831). Lscanora circinata f. myrmina Cromb. in Grevillea tom. cit. p. 47). The colour is, however, accidental, being caused by suffusion of peroxide of iron or by uxine. Spermatia are recorded as 6-7 $\mu$ long, $1 \mu$ thick. An old specimen from Clare Hall Bridge, Relhan's original locality, is in the herbarium of the British MIuseum.

Hab. On rocks and walls, often on bridges, in lowland and upland ristriets.-Distr. Not common in the Channel Islands, England and Wales, reported from S.W. Scotland, not seen from Ireland-B. MI Guernsey; near Staple Fitzpaine, Somerset; near Stroud, Gloucestershire; Hale's End, Malvern and Pershore Bridge, Worcestershire; Oversley Bridge, Warwichshire; near Congerstone, Leicestershire; Conway Castle, Denbighshire; Bamard Castle, Egrlestone, and Teesdale, Durham; Kirkby Lonsdale, Westmoreland.

Var. circinatula A. L. Sm.-Similar to the species in form, lout rather rlarker and with smaller spores, $7 \mu$ lone, $5 \mu$ thick.-L. circinutula Nyl. in Flora lxvi. p. 100 (1883); Croml, in Grevillea xii. p. 89 (1884) \& Monogr. i. p. 404. 
I have been unable to find spores in our specimens. The darker colour may be due to more direct exposure. Spermatia are recorded as $3 \cdot 5-4 \cdot 5 \mu$ long, $\cdot 5 \mu$ thick.

Haz. On flints in a maritime district.- $B$. M. Beachy Head, Sussex (the only locality).

9. L. melanaspis Ach. Lich. Univ. p. 427 (1810).--Thallus suborbicular, adnate, areolate-verrucose in the centre, the lobes of the circumference branched, convex, cinerous-grey and greyish-pruinose $(\mathrm{K}-, \mathrm{CaCl}-)$. A pothecia rather small, plane, dark-coloured, the thalline margin thickish, entire; spores ellipsoid, 10-14 $\mu$ long, $6-10 \mu$ thick ; hymenial gelatine bluish then wine-red with iodine.-Leight. Lich. Fl. ed. 3, p. 201 ; Cromb. Monogr. i. p. 403. L. alphoplaca var. melanaspis Stirt. Scott. Nat. iv. p. 28 (1877). Parmelia melanaspis Ach. Meth. Lich. p. 196 (1803). Specimen not seen.

A rare lichen; it differs from $L$. alphoplaca, a Continental plant, in the absence of any reaction with potash.

$\mathrm{Hab}$. On rocks in a mountainous region. Recorded only from Ben Brecht, Argyll.

10. L. exomila Stirton in Scott. Nat. v. p. 217 (1880).Thallus dull-cinereous or also blackish, squamulose-rugulose (if proper?). Apothecia appressed dark-brown or brownish-black, plane, up to $1 \mathrm{~mm}$. across; the margin prominent, crenate or in i young state somewhat wrinkled, cærulescent or pale cærulescent; hypothecium colourless; paraphyses slender, not well discrete, conglutinate at the brown apices; spores 8 in the ascus, colourless, ellipsoid, simple, often binucleate, 9-11 $\mu$ long, $6 \cdot 5-8 \mu$ thick; hymenial gelatine blue then tawny with iodine. Specimen not seen.

Stirton is not sure if the thallus belongs to this "curious and singular Lreanora," as it grows associated with Bilimbia aromatica, which has " a thallus of a corresponding character. In every instance the margin is truly cxrulescent."

IIab. On rocks. Collected by Stirton at Glas Miel, Perthshire.

§ ii. Eulecaxora Th. Fr. Lich. Aret. p. 99) (1860), pro parte (as subgenus); Cromb. Monogr. i. p. 371, pro parto (as subgenus).

Thatlus varionsly crustaceous. Apothecia superficial; spores moderate in size or rather small.

For convenience of reference, this large section has been divided into a series of groupls markical either by thalline or apothecial characters.

A. Sulfusea yroup. - Thallus cinereous-erey or whitish ( $\mathrm{K}+$ yellowish or yellow). Apothecia moderate in size, the disc reddish-brown, rarely pale brick-red, or brownish-black. 


\section{Apothecia reddish-brown.}

11. L. subfusca Ach. Lich. Univ. p. 393 (1810) pro parte (incl. var. argentata). - Thallus thinnish, opaque, developed beneath and above the bark, effuse or determinate, slightly wrinkled, unequal or occasionally granular, whitish or ash-grey ( $\mathrm{K}+$ yellowish). Apothecia moderate in size, ravely up to $2 \mathrm{~mm}$. across, scattered or crowderl, rather prominent and attached by a narrow base, rounderl, the disc plane or generally convex, brownish-red, the thalline margin rather thin, not prominent, entire or sometimes slightly crenulate; paraphyses slender, subdiscrete, more or less distinctly septate, straight or flexuose, variously formed at the tips, sometimes slightly clavate or swollen, and tinged with a bright-brown colour or embedded in a brown gelatinous epithecium; spores oblong-ellipsoid, 11-16 $\mu$ long, $7-9 \mu$ thick, but occasionally larger ; hymenial gelatine blue, the asci dark tawny-coloured, with iodine.-Hook. Fl. Scot. ii. p. 47 pro parte and in Sm. Engl. Fl. p. 189 pro parte; Mudd Man. p. 146 pro parte: Cromb. Lich. Brit. p. 51 pro parte (incl. f. argentuta) it Monogr. i. p. 409 ; fig. 65; Leight. Lich. Fl. p. 201 ; ed. 3 , p. 185 (incl. f. argentata). Lichen subfuscus L. Sp. Pl. p. 1142 (1753) pro parte.

Exsicc. Johns. n. 110 ; Larb. Lich. Hb. n. 217.

The species and varieties are distinguished by the thin thallus, best scen towards the margin, as in time it may become piled up and thickish towards the centre. The apothecia in the species have a prominent disc, the margin is thin and normally entire, but occasion. ally becomes crenulate. Spermogones in this and allied species are black at the opening, with mostly curred spermatia about $16-20$ or $-24 \mu$ long.

There is a group of "forms," "varicties," or "species " intimately. associated with Lecanora subfusir, and rarionsly designated by different workers, probably all of then included under Lichen subfuscus L. A large series of these from diffurent collections have been examined by Hue (Bull. Soc. Bot. Fr. 1. p. 22), and the results obtained by him have been verified on our British specimens. 'There are differences among them in the development of the thallus and of the ipothecial margin, which are not sufticiently constant to be specific. The microscopic characters are also variable to some extent, but the differences there seem to be largely due to agre. They include the form of the tips of the parapliyses which are slender and flexuose in all, and more or less conglutinat"., but in some are slirhtly calpitate or clavate, in others of equal wilth throughout. In the liatter case they are colourless; the wider types are often brown, generally the epitheeium is a brown gelatinous licyer and gramulose or non-mamnlose. Steiner (Verh. K.K. \%ool.-Jot. Cies. lxi.) diflerentiated the typical species as having cappitate paraphyses, but that character apuears, though rarely, in several of the forms; he also considered the insperserl granulose conclition as specific. but that character also is mitrustworthy and seens to be at growth condition. The reation with iodine, which Nylimeler relied on to determine species, is practically the same for them all: with a very dilute solution, the hymeuimm 
turns a delicate blue, in more concentrated solution, the asci generally become vinous or tamny-red, and a violet tinge is frequently produced in trinsition, or remains when the other tints have faded away, depending evidently on the presence of small quantities of the vinouscolouring substance.

In the absence of any true microscopic distinctions, the macroscopic characters have been accepted as of varietal importance. Plarcintia cpicymatia. Wint. is frequently parasitic on the thallus of this and of allied species.

Hab. On trunks of trees, rarely on old palings in maritime and lowland districts.- Rare in E., S. and W. England, though probably overlooked.-B. M. Lyndhurst, New Forest, Hants; Churchhill, near Worcester ; near Cambridge; N. England.

Form muscicola Wheld. \& Wils. Lich. Perth. p. 37 (1915).-Thallus thin, grey $(\mathrm{K}+$ deep yellow, $\mathrm{CaCl}-)$. Apothecia moderate in size, concave or plane, shining, deep reddish or hlackish brown, the thalline margin entire ; spores $12-14 \mu$ long, $7-8 \mu$ thick.

"This form is probably a state due to the peculiar habitat, which is similar to that of L. epibryon. It differs from that, which is a more alpine plant, in haring a more dusky thallus, apothecia about half the diameter, and shorter spores."

Hab. Creeping over mosses (Tortula and Grimmia) on walls, near Pitlochry, Perthshire.

Var. chlarona Ach. Syn. Lich. p. 15s (1814); Hue in Bull. Soc. Bot. Fr. l. p. 72 (1903).-Thallus thin, smoothish or somewhat wrinkled-unequal, or thinly granulate, whitish or greyish. A pothecia rather small, plane or slightly convex, the dise generaliy flesh-coloured or pale-lirown, the thalline margin thicker and more prominent than in the speeies, entire at first but soon becoming crenulate and the receptacle more or less furrowed: spores rather smaller than the species !)-15 $\mu$ (rarely $17 \mu$ ) long, 5-9 $\mu$ thick.-I. sulfusce var. distens and var. glabrate MLudd Man. pu. 146, 147 (1861) (non Ach.); f. chluronu Stizenlo, in

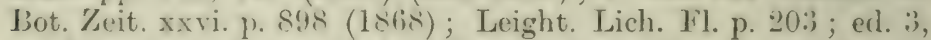
1). 18s. I. distinete var. chleromu Ach. Lich. Univ. p. 397 (1810). L. allella f. hlarmu Cromb. Lich. Isrit. p. 51 (1870). L. rogosa sulssp. chlarona Nyl. in Flora lxvi. p. 107 (1sis:); Cromb. Monogrr. i. 1. 41:. L. fhlurma Croml), in Frevillea xviii. p. 68 (1890). Lichen distans Pers. ex Ach. 1. c.

E.csirr. Larh. Lich. I1h, n. 25i : Leight. 11. 115; Mudh n. 112, 113 (pro parte).

In this variety the apotheciat are rather small and scattered; it differs from the species in the planere lighter-eoloured disc and the more prominent margin, entire at first but soon crenulate. 'The furrows of the receptacle are not easily seen and they also necur occusionally in other varieties. Wheldon and Wilson (Journ. Limm. Soc. xliii. p. 114 (1515)) have refereed a specimen from Clatburn. 
S. Lancashire, to L. chlarona var. lecideina Oliv. Syst. Lich. i. p. 274 (1897), on account of its disappearing margin.

Hab. On smooth bark of trees, occasionally on palings.-Distr. Fairly common throughout the British Isles.-B. M. Withiel, Cornwall; neal Torquay, Devon; near Ryde, I. of Wight; Eridge Park, Henfield, Withyam, near Lewes, and Glynde, Sussex; Holmwood and Shiere, Surrey; Wrotham, Kent; Epping Forest, Gosfield Hall and White Colne, Essex; Hawkridge, Somerset; near Cirencester, Gloucestershire; Ampthill, Bedfordshire ; Babraham, Cambridgeshire; Gopsall Park and Twycross, Leicestershire; Aberdovey, Merioneth; Wrekin Hill, Shropshire; Cliffirigg and near Ayton, Cleveland, Yorkshire; Teesdale, Durham; Wastdale, Cumberland; near Glasgow; Appin, Argyll ; Finlarig, Killin, Perthshire; Glen Cluny, Braemar and Countesswells Wood, Aberdeenshire; Loch Linnhe, Invernessshire; Upper Lake, Killarney, Kerry; Mallaranny, Dugort and Glandarry, Achill, Mayo.

Form geographica Hue in Bull. Soc. Bot. Fr. l. p. 81 (1903). -Thallus similar to that of var. cllarona, but limited and dissected by black lines. Apothecia small, the margin at first prominent, entire, then crenulate.- $L$. subfusca var. geographica Massal. Ric. Lich. p. 6 (1852). L. chlarona var. geographica Nyl. ex Cromb. in Grevillea xviii. p. 68 (1890). L. rugosa subsp. chlarona var. geographica Cromb. MLnogr. i. p. 414 (1896).

Exsicc. Johns. n. 260 ; Mudd n. 113 pro parte.

Evidently only an accidental form of growth which occurs also in other Lecanorre. As noted by several observers, the black "geographical" lines are constantly, if not always, due to an accompanying growth of Lecidea parasema, though they are occasionally present without any apparent Lecidea thallus. In some specimens of var. chlarona a dark margin is developed, but it seems to be composed of brown hyphomycetous hyphæ.

Hab. On somewhat smooth bark of trees.-Distr. Not common throughout the British Isles.-B. M. Ullacombe, near Bovey Tracey, Deron; New Forest, Hants; St. Leonard's Forest, Sussex; near Gravesend, Kent; Bathampton and Hawkridge, Somerset; Desford, Iseicestershire ; Malvern, Worcestershire ; Clitfingg, Cleveland, Yorkshire; New Galloway, Kirlicudbrightshire; Airds, Appin, Argyll; Finlarig, Killin, Perthshire.

Var. pinastre Schrer. Enum. p. 74 (1850).-Thallus effuse or subdeterminate, generally thin and subleprose, sometimes rather thicker and finely warted-areolate, greyish-white. Apothecia small, plane or convex, scattered or erowded, the dise reddishor dark-brown, the thalline margin rather prominent, at first entire, becoming slightly crenulate; paraphyses as in the species; spores broadly ellipsoid, $9-15 \mu$ long, generally $7-9 \mu$ thick.Mudd Man. p. 146. I. rugosa subsp. chlerona t. pinustre Cromb. MIonogr. i. p. 413 (1894).

Differing from the species in the more developed margin of the apothecia and in the generatly smaller spores. From var. chlarone it is separated by the almost constantly entire apothecial margin. 
Hat. On firs and fir palings in upland regions.-Distr. Rather rare in England, more frequent in sicotland.-B. $M$. Near Penzance. Cornwall; near Leith Hill. Surrey; Buxton, Derbyshire; Ayton Moor, Cleveland. Yorkshire ; Staveley, Westmoreland; West Lomond Hill. Fifeshire; Achmore, Fillin, Ben Lawers, Blair Athole and Blacberry Hill, Perthshire; Durris, Kincardineshire; Countesswell. Wood, near Aberdeen; Rothiemurchus, Invernessshire; Applecros:. liossshire.

Tar. allophana Ach. Lich. Unir. p. 395 (1810); Hue in Bull. Suc. Bot. Fr. 1. p. 55 (1903).-Thallus thin, wrinkledunequal, or becoming thick and warted at the centre loy new growth layers, mostly effuse, sometimes limited, whitish or greyish. Apothecia moderate in size, hecomingr rather large and irregular in form, seattered or often hecoming crowded against each other, and then angular and difform, the disc brownish red, hecoming often very dark or almost black, the thalline margin rather thicker than in the species, entire, then irregularly crenulate or furrowed: spores generally about 14-16 $\mu$ long and $7-9 \mu$ thick, but varying from $6 \mu$ to $11 \mu$ in width and 10-2. $\mu$ in length.-L. sulfusere var. atrynea Mudd Man. p. 147 (1861) pro parte ; f. allophlana Cromb. Lich. Brit. p. 51 (1870); Leight. Lich. Fl. 1. 200 ; ed. :3, p. 15.5. L. allopham Nyl. in Flora 1v. p. 250 (1872) note; Cromb. Monogr. i. p. 411. Lichenoides crustaceum et leprosum scutellis sulfuscis Dill. in Ray Syn. ed. 3, p. 71, 11. $45(1724)$ pro parte of Hist. Muse. 1. 134, t. 1s, fig. 16 (1741) (fide Crombie). Lirhe'n sulfuscus Huds. Tl. Angl.p. 444 (1762); Engl, Bot. t. 2109.

Exsicc. Bohl. n. 35 ; Johns. nos. 37 pro parte, 317 ; Larb. Lich. Hb. nos. 58, 256 it Lich. Cantal). nos. 18, 21 : Leight. n. 116 pro parte.

Not unlike the previous variety in the early stages, but the thallus becomes thicker towards the centre, the apothecia become large. often densely crowded and lobed and durker in colour; the margin is eritire and prominent for some time, then irregularly crenate, and ptrshed back by the turgitl irregular disc. Occasionally only a few of the larger apothecia are left on a thick verrucose thallus.

Hab. On trunks of trees, rarely on old palings.-Distr. Not unconmon thronghout the British Isles.- Ij. M. Instleigh, Devon; Lyndhurst, Aew Forest. II ints; Shanklin and Jrading, I. of Wight: Mfount ITarre, near Lewes, Damny, Glynde and St. Leonard's Forest, Suscex; Uling and Walthanstow, Fssex; Windsor Great Park. Berks; Bourton-on-the-Water, Gloncestershire; Gopsall and 'Twyrross. Leicestershire; Jronlwas and near Worcester; near Shrewsbury, Shrophire; Barmouth and Aberdovey. Merioneth; Cherry Hinton, Stapleford and (1)er. ('ambridgeshire; Bury St. Jdmunds. Suftolk; Jommslale and Artun, ('levelant, Yorkshire; l'iereebrilge. T) nhan; ('hollerford, Wark-on-Tyme and Wansbeck, Northumberland; Cleator MIor, ('mulerlanl; New Galloway, Kirkeudbrightshire: Inverary, Argyll ; Finlarig, Killin, I'erthshire; Camperdown Woods. Furfurhire; T'ullagreen, Corli; Cantle Connel, Imorick; Achil! Island, Mayo. 
Form parisiensis Hue in Bull. Soc. Bot. Fr. 1. p. 65 (1903). -Thallus definitely limited, generally somewhat obicular, thin towards the margin, thicker and verrucose towards the centre. Apothecia as in the variety.- $L$. sulfusea var. lioriza Ach. Lich. Univ. p. 394 (1810)?; f. parisiensis Leight. Lich. Fl. p. 201 (1871) ; ed. 3, p. 185 . L. parisiensis Nyl. in Bull. Soc. Bot. Fr. xiii. p. 368 (1866) ; Cromb. in Journ. Bot. ix. p. 178 (1871) \& Monogr. i. p. 412.

Exsicc. Leight. n. 116 pro parte.

The original description of $L$. parisiensis makes the determinate thallus a distinguishing characteristic of this plant, which does not otherwise differ from the variety. In both, the apothecia tend to become large and turgid with age. The variety horiza Ach. is generally classified under Rinodina sophodes.

$H a b$. On trunks of trees in maritime and upland tracts.-Distr. Not uncommon in England; rare in Ireland; not recorded for Scotland.-B. MI. Ilsham, Torquay and near Bovey Tracey, Devon; Lyndhurst, New Forest, Hants; near Worcester; near Shrewsbury, Shropshire ; near Ayton, Cleveland, Yorkshire; near Cork.

12. L. fuscescens $\mathrm{Nyl}$. in Flora lv. p. 552 (1872) note.Thallus effuse, of thickly scattered minute greyish granules on a thin blackish hypothallus ( $\mathrm{K}+$ yellow). Apothecia small or submoderate in size, adnate, plane, brown or blackish, the margin thin, disappearing; paraphyses subdiscrete, slightly wirlened and brownish at the apices; spores globose-ellipsoid, small, 6-9 $\mu$ long, 4-7 $\mu$ thick.-Cromb. in Journ. Bot. xiii. p. 141 (1875) \& Monogr. i. p. 423 ; Leight. Lich. Fl. ed. 3, p. 201. Lecideu fuscescens Sommerf. Suppl. Fl. Lapp. p. 161 (1826).

Along with the specimens from Morrone there is a second minute lichen, Bilimbia Nitschlieana. The apothecia of both are penetrated by the torulose brown hyphæ of a fungus.

$H a b$. On trunks of birch in mountainous districts.-B. M. Morrone, Braemar, Aberdeenshire.

13. L. rugosa Nyl. in Flora lv. p. 250 (1872) note.-Thallus senerally determinate, thickish up to the margin, wrinkledsranulate or warted, unequal, whitish or grey (K + yellowish). Apothecia scattered or crowded, moderate in size, somewhat frominent, closed then open, the dise brown or reddish-brown the thalline margin thick, crenulate, the receptacle furrowed and wrinkled; paraphyses slender, septite, scarcely thickened upwards, ending in a brown epithecium ; spores ellipsoid, generally about $12-15 \mu$ long, 6-5 $\mu$ thick, sometimes rather larger; hymenium blue with dilute ioline, the asci dirty wine-red in stronger solutions.-Cromb. in Grevillea xviii. p. (is $(1 \$ 90)$ \& IIonogrr. i. p. 412. L. sulyiusere f. rugose Nyl. Lich. Scand. p. 160 (1861); Cromb. Lich. Brit. p. 51 ; Leight. Lich. Fil. p. 201, 
ed. 3, p. 186. Lichen rugosus Pers. ex Ach. Lich. Univ. p. 394 (1810) (? Linn.).

Exsicc. Johns. n. 37 pro parte, 111.

Frequently classified as a variety of $L$. subfusca, and closely allied to var. allopituma, but the thick thallus and thalline margin are distinctive, though the thallus varies somewhat with the condition of the bark on which it grows. The apothecia are usually reddish-brown. L. rugosum L. (Sp. Pl.p. 1140) and early British authors is doubtful ; Limnæus gives a citation from Dillenius which Crombie has identified with the fungus Dichrna.

Hab. On trunks of trees, rarely on old palings.-Distr. General and fairly common throughout the British Isles.- $B$. $M$. Ilsham, Torquay, Devon; Glynile, Sussex; Ulting. Essex; near Cirencester, Gloucestershire; Gopsall, Leicestershire; Hollybush Hill, Malvern, Worcestershire; Bakewell, Derby shire; Levens Park, Westmoreland ; Calder Abbey and Alston, Cumberland; Chollerford, Northumberland; Pennycuik Glen, near Edinburgh; near Glasgow; Barcaldine, Arg. ll ; Blairdrummond, near Stirling; Killin, Perthshire ; Rostellan, Cork; Old Dromore and Tillarney, Kierry; Tervoe, near Limerick; Derryclare and Lough Inagh, Galway; Westport, Mayo.

14. L. epibryon Ach. Syn. Lich. p. 15 5 (1814).-Thallus subdeterminate, granulose-concrescent or warted, white $(\mathrm{K}+$ yellowish). Apothecia moderate in size, plane, scattered or crowded, the dise brown or reddish-brown, the thalline margin thin, entire, rarely flexuose or crenulate; paraphyses slender, indistinctly septate, rather broadly clavate and brown at the tips; spores $14-19 \mu$ long, $6-11 \mu$ thick ; hymenial gelatine blue, the asci becoming wine-red, with iodine.-Cromb. in Grevillea xviii. p. 68 \& MIonogr. i. p. 411. L. sulfusca var. epiltryon Mudd IIan. p. 147 (1861); f. epilrya Cromb. Lich. Brit. p. 51 (1870); Leight. Lich. Fl. p. 203; ed. 3, p. 187. Lichen hypn nrum Wulf. in Jacq. Coll. iv. p. 233, t. 7, fig. l (1790) (non Vahl in Fl. Dan. t. 956 (1787) \& non Dicks.). L. cpiluryon Ach. Lich. Suec. Prod. p. 79 (1798).

A northem or alpine plant, characterized by the white granulose continuous thallus, by the constantly larger spores, and by the character of the paraphyses.

IIab. On decayed mosses on the ground in mountainous regions. - B. M. Ben Lawers, Perthshire.

15. L. intumescens Kórb. Syst. Lich. Germ. p. 143 (1855). -Thallus determinate, thin, smooth or becoming wrinkled, whitish $(K+y e l l o w i s h)$. Apothecia thickly scattered, prominent, small or moderate in size, the disc light or dark reddishbrown, plane or convex, sometimes slightly dull-pruinose or beeming blarkish, the thalline margin thick, inflexed, generally entire, but sometimes flexume and crenate, white; paraphyses somewhat conglutinate, slencler, septate, sometimes branched and irrechular towards the tips, colonrless, the epithecium of brown 
granules ; spores ellipsoid, 12-18 $\mu$ long, 6-8 $\mu$ thick; hymenial gelatine blue with iodine.-Cromb. in Grevillea xii. p. 60 (1884) \& Monogr. i. p. 417. L. sulfusca f. intumescens Stizenb. in Bot. Zeit. xxvi. p. 893 (1868) ; Leight. Lich. Fl. p. 202 ; ed. 3, p. 186. Lichen pallidus Dicks. Pl. Crypt. fase. ii. p. 19 (1790) (nom Schreb.). Parmelia intumescens Rebent. Prodr. Fl. Neom. 1. 301 (1804).

Exsicc. Dicks. Hort. Sicc. fasc. ix. n. 23 ; Johns. n. 318.

Distinguished chiefly by the tumid white margins of the apothecia. when these are crenulate, they are somewhat like the fruits of L. rugosa. Spermogones have the spermatia up to $30 \mu$ long (fide Crombie Monogr. i. p. 417).

Hab. On smooth bark of trees in wooded maritime and inland districts.-Distr. Rather rare in England and Scotland and S.W. Ireland.-B. M. Ullacombe, Bovey Tracey, Devon; New Forest. Hants ; Shiere, Surrey ; Cirencester, Gloucestershire ; Rhiwgreidden. Merioneth; New Galloway, Kirkcudbrightshire; Barcaldime, Argyll; Finlarig, Killin and Craig Calliach, Perthshire; Momone, Braemar. Aberdeenshire; Loch Linnhe, Invernessshire; Terroe, Limerick.

16. L. chiarotera Nyl. in Flora 1r. p. $550(1872)$ note.Thallus determinate or subdeterminate, thickish, finely wartedgranulate, sometimes cracked-areolate, whitish or greyish ( $\mathrm{K}+$ yellow). Apothecia moderate in size or rather large, the clisc generally plane or irregular, pale-reddish; the thalline margin thick, crenulate or flexuose; paraphyses slender, septate, with long and often bent colourless tips, the epithecium gramular, brown; spores ellipsoid or oblong, small, 9-11 $\mu$ long, $7-9 \mu$ thick; hymenial gelatine blue with iodine-Leight. Lich. Fl. ed. 3, p. 182 ; Cromb. Monogr. i. p. 417.

Exsicc. Johns. n. 261.

The thickish pale warted thallus and the pale-reddish apothecir distinguish this species from other's of the subfusca group. In the British specimens the apothecia are rather large and irregular and occasionally pruinose owing to the abjointed tips of the paraphyses.

Hub. On trees in upland districts-Distr. Rare in N.E. Englant, IV. Seotland and S. Ireland.-B. M. Northumberland; Glen C'rerin. Barcaldine, Argyll ; Letterfrack, Connemara, Galway.

17. L. campestris L. de Lest. Lich. Dunk. p. 16: (1910). Thallus often limited by a whitish hypothallus, continumusly warted-granulate or sramular-areolite, whitish or cinereous-grey ( $\mathrm{K}+$ yellowish). Apothecia sattered or smerally comwed. especially towards the centre of the thallus, moderate in size. plane, becoming somewhat convex, brown or redrlish-brown when wet, or darker when dry, the thalline marerin thin, mostly entire lut sometimes more or less cremulate; paraphyses more couglutinate in old specimens, slender, distinctly branched and sejuate. variously elavate and lrown at the tips; spores ellipsoid, 9-15 $\mu$ long, 6-8 $\mu$ thick; hymenial gelatine blue, the asci faint?y wine- 
red, with iodine. L. smbfusca Hook. Fl. Scot. ii. p. 47 (saxicolous) \& in Sm. Eng]. Fl. Y. p. 189 (saxicolous); var. campestris Scher. Enum. 1) 75 (1850); Mudd Man. p. 14i; Cromb. Monogr. i. p. 410 ; f. campestris Cromb. Lich. Brit. p. 51 (1870); f. argentatu Leight. Lich. Fl. p. 201 (1871) pro parte (non Ach.); ed. 3, p. 186 pro parte ; var. spodophacoides Cromb. in Grevillea i.p. 171 (1872). L. spodophseoides Nyl. in Flora 1r. p. 250 (1872) note; Cromb. Monogr. i. p. 410 . Lichen punctatus Dicks. Pl. Crypt. fasc. iii. 1). 15 (1793)? (? Scop. and others) Engl. Bot. t. 450 ? With. Arr. ed. 3, iv. p. 19.

Exsicc. Johns. nos. 77, 324; Larb. Lich. Hb. n. 99.

Frequently classified as a saxicolous variety of Lecanora subfusca, but differs in the thallus-partly, no doubt, due to the habitat-and also in the paraphyses, which are more constantly clarate than in that species, and brown at the tips. 'The figures and descriptions of Lichen yunctatus by authors previous to "English Botany" are, in the absence of specimens, too rague for identification. The "English Botany" specimen is doubtful, so the species name campestris has dbeen retained (cf. L. Prevostii f. melanocarpa).

$\mathrm{Hab}$. On rocks and walls, rarely on the ground, from maritime to upland districts. - Distr. General and common throughout the British Isles.-B. M. St. Ouen's Bay, Jersey; The Vale, Guernsey; Withiel. near Penzance and Wadebridge, Cornwall ; Ilsham Walk, Torquay, Teron; Shanklin, I. of Wight; Hastings, Sussex; Barnsley Park, Cirencester, Gloucestershire ; Stormy Down, Glamorganshire; Llandyssil, Cardiganshire; Greeba Mt., I. of Man; Malvern, Worcestershire; near Ayton, Cleveland, Yorkshire; near Tiendal and Helsington, Westmoreland; Whitehaven and St. Bees, Cumberland; Ravensworth Fell and Egglestone, Durham; Chollerford, Northumberland ; Braid Hills, Edinburgh, West Water, Fife; Achosragan Hill, Appin, Argyll ; Glen Almond, Glen Lyon and Glen Fender, Perthshire; Cove, Fincardineshire; near Aberdeen; Cork Harboux and Kinsale, Cork; near Kilkee, Clare; Ballynahinch, Dawros Bridge and Lettermore, Galway; Louisburgh and Achill Island, Mayo.

\section{Apothecia brownish-black or black.}

18. L. coilocarpa Nyl. ex Norrlin in Merld. Siillsk. Faun. \& Fl. Fenn. i. p. 23 (1876). - Thallus suldeterminate, unequal, wartedof granular-areolate, whitish or greyish ( $\mathrm{K}+$ yellowish). Apothecia small or occasionally up to $3 \mathrm{~mm}$. across, the disc concave then plane, hrownish-hlack, the thalline margin entire, often becoming flexuose or cromulate; paraphyses slender, septate sertrerly widened upwards, the epitherimn dark- or sometimes erenish-lorown; spores ellipsoid, 12-18 $\mu$ long. $6-9 \mu$ thick: humenial gelatine hue with iodine.-Cromb. in Grevillea xriii.

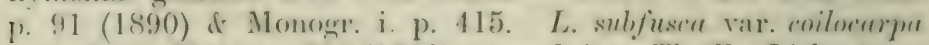
Arh. Lirh. Univ. 1, :393 (1810) ; var. lnimed Th. Fr. Lich. Aret. 1. 11). (1860); Mudd Man. p. 147 ; f. lainea Cromb). Lich. Jirit.

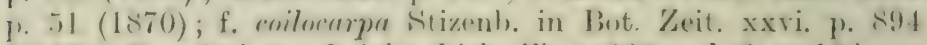

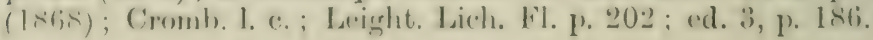


Exsice. Bohl. n. 59 ? Johns. n. 325 ; Larb. Cæsar. n. 77 ; Leight. n. 52; Mudd n. 111.

In the apothecia of this species there is nearly always a trace of brown, more easily seen when they are moistened. The tips of the paraphyses are also brown, though occasionally there is a trace of dull olive-green, more apparent after treatment with potash. In this and the following species the spermogones are frequently immersed in the apices of thalline warts. The species was originally described as corticolous, and on the Continent occurs both on trees and on rocks. Our specimens are all saxicolous except f. pulicaris.

Hab. On rocks and walls (sometimes on trunks of trees) in maritime and upland districts.-Distr. Fairly common throughout the British Isles.-B. M. Boulay Bay, Jersey; Helmenton, Cornwall; Mearfoot, Torquay, Devon; Ardingly Rocks, Sussex; Rusthall Common, Kent; Malvern, Worcestershire; Trellick, Monmouthshire ; Barmouth, Merioneth ; Cwm Ffynnon Llugy, Carnarvonshire ; Haughmond Hill, Shropshire; Ayton, Cleveland, Yorkshire ; Staveley, Westmoreland; Alston, Cumberland; Dalmahoy Hill, near Edinburgh; Appin, Argyll ; The Trossachs, Perthshire; Baldovan, Forfarshire; near Portlethen, Kincardineshire; Hill of Ardo, Aberdeenshire Lambay Island, Dublin.

Form pulicaris Cromb. in Grevillea xviii. p. 68 (1890).Thallus very thin or obsolete, whitish. Apothecia numerous, small, the disc black, plane, becoming convex, the thalline margin thin, entire, becoming crenulate-Cromb. Monogr. i. p. 416. L. pulicaris Ach. Syn. Lich. p. 336 (1814). Patellaria pulicaris Pers. in Ann. Wetter. Ges, ii. p. 13 (1810) fide Ach. 1. c.

The few British specimens are lignicolous and without a thallus. The epithecium resembles that of the species in the dark brownishblack colour, differing in this respect from $L$. subfusca var. allophana and from $L$. atrynea, with which it might be confused.

$H a b$. On old fir palings in upland districts. - Distr. Rare in the Scottish Grampians.-B. M. Blair Athole, Perthshire; Crathie, Braemar, Aberdeenshire.

19. L. gangaleoides Nyl. in Flora lv. p. 354 (1872).-Thallus subdeterminate, generally thick and coarsely warted-areolate, greyish ( $K+$ yellow). Apothecia moderate in size, mostly crowded, the disc plane, black, the thalline margin rather prominent, sometimes inflexed, entire or becoming slightly furrowed or crenulate, occasionally sometimes flexuose; paraphyses slender, septate, scarcely widened upwards though sometimes slightly clavate and coloured at the tips, the epithecium dark-or greenishbrown; spores ellipsoid, $12-17 \mu$ long, 6-9 $\mu$ thick, or rather larger; hymenial gelatine blue with iodine.-Cromb. in Journ. Bot. xiv. p. 360 (1876) \& Monogr. i. p. 416 ; Leight. Lich. El. exl. 3, p. 189. L. sulfusen f. gangalen Leight. Lich. Fl. p. 20.2?; ed. 3, p. 187? (non Ach.) ; f. meluecerpa Leight. op. cit. ed. 3, 1. 187. L. atrynea var, melacarpa Cromb. in Grevillea i. p. 171 
(I 873) (? Nyl.) \& Monogr. i. p. 415 . L. plymatula Johns. Exsice. n. 368 .

Exsicr. Johns. n. 198,368 (as L. plymatula); Larb. Lich. Hb. n. 19.

Tery closely allied to the preceding species, but distinguished by the thicker more warted thallus, and by the almost constantly black apothecia, thus resembling $L$. atra; the latter is, however, easily recognized by the violet colour of the hymenium. The paraphyses are more constantly dark-greenish than in $L$. coilocarpa.

$H a b$. On rocks and walls in maritime or mountainous regions.J) istr. liare in N. England, the Scottish Highlands and W. Ireland. -B. M. Llandbedrog, Carnarronshire; N. Derbyshire; Bearmoor, Northumberland; Wastdale, Cumberland; New Galloway, Kirkcudbrightshire; Achosragan Hill, Appin, Argyll; Craig Tulloch, Blair Athole, Perthshire ; Letter Hill and Ballinaliill, Connemara, Galway; Belclare near Westport and Clare Island, Mayo.

Subsp. schistina Nyl. in Flora lv. p. 429 (1872).-Thallus determinate, smooth, wrinkled or areolate, glaucous-white. Apothecia grenerally rather small, sometimes becoming large and irregular, the disc plane then convex, black; the thalline margin thickish, incurved; spores ellipsoid, 11-14 $\mu$ long, 6-8 $\mu$ thick. -Cromb. in Grevillea xviii. p. 68 it Monogr. i. p. 416. $L$. schistina Nyl. ex Cromb. in Journ. Bot. xx. p. 274 (1882).

Differs from the species in the less warted thallus. The paraphyses are sometimes stouter and the spores are also persistently smaller.

Hab. On rocks and walls in maritime and upland districts.-Distr. Sparingly in the Scottish Highlands and in W. Ireland.-B. M. Barcaldine, Argyll; Craig Tulloch, Blair Athole, Perthshire; Clare Island and Achill Island, Mayo.

20. L. atra Ach. Lich. Univ. p. 344 (1810) (excl. vars. imfragosa and expansa). - Thallus determinate, thickish towards the centre, granulate or of crowcled irregular warts, clear grey or greyish-white, with a thin blackish hypothallus ( $\mathrm{K}+$ yellow). A pothecia molerate in size (up to $2 \mathrm{~mm}$. across or more), crowded, the disc plane, black, the thalline margin prominent, persistent, often flexuose, entire or hecoming crenulate ; paraphyses coherent, septate, violet in colour, the tips dark-brown, the whole hymenium vinlet, appearing almost black in at thick seetion; spores ellipsoid, (1)-15) $\mu$ long, 6-8 $\mu$ thick; hymenial golatine blue with iodine. -Honk. Fl. Sout. ii. p. 47 it in Sm. Engl. Fl. v. p. 186 ; Tayl. in Mackay Fl. Hil), ii. p. 1:33; Murke Man. p. 145 pro parte;

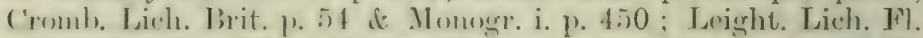

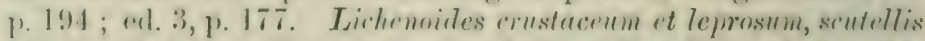
nigrierntilus majorilus of minurilus 1)ill. in Ray syn. ed. 3, p. 71, 11. 4:3 (1729) pro parte of II ist. Muse. p. 133, t. 18, fig. 15. (1741). Lirhen ater IIuds. Fl. Angl. i. p. Af.i $(1762)$; Lightf. Fl. Sent. 
ii. p. 813 ; With. Arr. ed. 3, iv. p. 18 ; Engl. Bot. t. 949. Rinodina atra S. F. Gray Nat. Arr. i. p. 449 (1821).

Exsicc. Johns. n. 119 ; Jarb. Lich. Hb. nos. 16, 54.

Distinguished from other Lecanora with a black disc by the violet paraphyses which tend to become brown with age; the whole hymenium is blackish in thick sections. The apothecia are generally numerous and crowded. Spermogones are frequent with long slender somewhat straight spermatia, 18-26 $\mu$ long.

$H a b$. On rocks, walls and trees from maritime to subalpine regions. - Inistr. General and common throughont the British Isles.-B. M. Sark; St. Minver, Cornwall; Ilsham Walk, Torquay, Devon; New Forest, Hants; Hastings, Sussex; Lydd Beach, Kent; Reigate Hill, Surrey; Langford, Essex; Cirencester, Gloucestershire; IVoodfield. Monmouthshire; Tenby, Pembrokeshire; Worcester and Malvern Hills, WVorcestershire; Oswestry, Shropshire ; Aberdovey and Dolgelly, Merioneth; Anglesea; Cheveley Park and near Newnarliet, Cambridgeshire; near Yarmouth, Suffolk; Staveley Head, Westmoreland; St. Bees and Alston, Cumberland; near Glasgow; Barcaldine and Appin, Argyll; West Water and near Balmerino, Fifeshire; Loch Tay, Craig Tulloch and Kinnoul Hill, Perthshire; Denfenella and near Portlethen, Kincardineshire; Hill of Ardo, Aberdeenshire; near Cork; Killaloe, Clare; Dawros, Connemara, Galway; Achill Island and Clare Island, Mayo.

Var. grumosa Ach. Lich. Univ. p. 345 (1810).-Thallus more finely granulose and cracked-areolate. Apothecia somewhat sunk in the thallus, small.-Cromb. Monogr. i. p. 451 . Lichen grumosus Pers, in Ust. Ann. Bot. xiv. p. 36 (1795).

Exsicc. Johns. n. 139.

Differs from the species in the granulose thallus. Another variety (var. subbyssoidea) also with a granulose thallus has been recorded by Stirton from Blair Athole, Perthshire, in Trans. Glasg. Nat. Hist. soc. p. 85 (1S75). He describes it as having a blackish thallus, effigurate at the circumference, with a white subbyssoid hypothallus. ('rombie (Monogr. i. p. 451) suggests that it may be a form of L. gangaleoides.

Hab. On rocks and walls in maritime and upland districts.Distr. Rare in S. Wales, N.W. England and probably N.E. Scotland (Cromb. 1. c.).-B. M. Woodfield, Mommouthshire; Brougham Castle, IVestmoreland.

b. Hageni group. - Thallus thin or scanty, whitish or greyish ( $\mathrm{K}-$ ). Apothecia small, the dise generally dull- or vellowishbrown; ascus 8- or poly-spored (L. Sambuci).

\section{Ascus 8-spored.}

21. L. Hageni Ach. Lich. Univ. p. 368 (1810).-Thallus efluse, thin, minutely granular, cinereous-white, often searecly visible $(K-)$. Apothecia mostly small (less than $1 \mathrm{~mm}$. acescs). often crowded, the dise plane or becoming turgid, pale to diarkbrown of a dull tinge, sometimes greyish-pruinose, the thalline 
margin rather thin, entire or often crenulate and somewhat prominent, or sometimes almost obliterated by the swollen disc ; paraphyses slender or stoutish, irregularly septate and often uneven, colourless, or slightly clavate and brown at the tips, the epithecium of brown granules; spores ellipsoid, 9-12 $\mu$ long, 5-6 $\mu$ thick.-Leight. Lich. Fl. p. 208 ; ed. 3, p. 192 ; Cromb. Monogr. i. p. 425. L. albella var. Hageni Mudd Man. p. 168 (1851). L. umbrina var. Hageni Cromb. Lich. Brit. p. 51 (1870). Lichen Hageni Ach. Lich. Suec. Prodr. p. 57 (1798).

Exsice. Johns. n. 115; Larb. Lich. Hb. nos. 131, 219 \& Lich. Cantab. n. 20.

L. Hageni has been distinguished from L. umbrina by Nylander and others (Cromb. Monogr. i. p. 424) on account of the difference in length of the spermatia: those of the former measuring up to $15 \mu$, the latter 15-22 $\mu$. It is a character that is uncertain and difficult to rely on, as spermogones are frequently absent. It differs from species of the $L$. subfusca group in the less developed thallus, in the smaller apothecia and spores, the stouter paraphyses, the duller, more umberbrown of the dise, and in the absence of reaction with potash.

$H a b$. On trees, or often on old palings, linoleum, etc., more rarely. on soil or stones.-Distr. Not uncommon throughout the British Islands.-B. M. St. Aubin's Bay, Jersey ; near Penzance; New Forest, Hants; Ryde, I. of WVight; Lyrd, Kent; Langford, Hadleigh and Hockley, Essex; Windsor Great Park, Berks; Wellow near Bath, Somerset; Wimpole Park and Bottisham, Cambridgeshire; Brandon and Mendelsham, Suffolk; Ayton, Cleveland, Yorkshire; Ashgill Sicie and Ennerdale, Cumberland; Inverary, Argyll; Blair Athole and Achmore, Killin, Perthshire; Castlemartyr, Cork; Ballynagarie. Limerick.

Form Zosteræ A. L. Sm.-Thallus poorly developed, almost wholly covered by the apothecia. Apothecia generally crowderl, rather small, sometimes becoming large and irregular, the disc. dull-brown, the thalline margin white prominent, entire of subcrenulate; paraphyses stoutish, irregularly septate, sometimes bead-like towards the tips or irregularly clavate and brownish: spores as in the species; hymenial gelatine biue with iocline.L. sulvfusea var. Zostere Ach. Syn. Lich. p. 158 (1814). L. umbrina subsp. Zosterse Cromb, in .Journ. Bot. xii. p. 148 (1874) ; f. Zostera Leight. Lich. Fl. ed. 3, 1. 191 (1879). L. Zostera Nyl. in Flora lix. p. 577 (1876); Cromb. Monogr. i. p. 425.

Crombie gives spore sizes rather larger than those of the specie: $(11-14 \mu \times 6-7 \mu)$, but I have been umable to find spores so large in our specimens. In a weak solution of iorline the hymenimm remains blue. Fvirlently a transition stage to the following variety.

Hab. On old plants of Zostera marina.-Distr. Tare in the Channel Islauds, S.W. Fugland and S.W. Ireland.-13. M. Terser; Sark; Guerusey; Pentire and the Lizard, Cornwall; Kilkee, Clare.

Var. marina Th. Fr. Jieh. Arct. p. 106 (1860); Lesel. I,ich. I)umk. 1. 15:) (1910).-'Thallus scarcely visible. Apothecia rather 
large, generally more than $1 \mathrm{~mm}$. across, crowded and difform, the disc deep purple-brown, with a white prominent persistent marmin becoming crenulate.-Lecanora sarcopsis var. marina Wahlenb. ex Sommerf. Fl. Lapp. Suppl. p. 91 (1826).

Hab. On sea piles, etc.-B. M. Mersea Island, Essex (collected by P. Thompson).

Var. Crombiei Johns. Exsicc. n. 263 (1897).-Thallus whitishcinerous, granular, deeply cracked-areolate. Apothecia small, crowded, angular, the inargin prominent, entire, becoming crenulate.

Exsicc. Johns. n. 263.

Hab. On a decorticate stump.-B. M. Near Bolam, Durham (the only locality).

22. L. umbrina Massal. Ric. Lich. Crost. p. 10 (1852) pro parte; Nyl. in Bull. Soc. Bot. xiii. p. 369 (1866).-Thallus effuse, thinnish, granulate, unequal, greyish or dark $(\mathrm{K}-)$. Apothecia generally umber- or dark-brown, not pruinose, small, the thalline margin crenulate or entire, persistent; paraphyses slender, coherent, irregularly septate and slightly clavate or capitate, the epithecium of brown granules; spores ellipsoid, 8-12 $\mu$ long, 5-6 $\mu$ thick.-Carroll in Journ. Bot. v. p. 25 (1867) ; Cromb. Lich. Brit. p. 51 pro parte \& Monogr. i. p. 423; Leight. Lich. Fl. p. 207 pro parte; ed. 3, p. 191 pro parte; f. subdistans Nyl. ex Cromb. in Journ. Bot. viii. p. 97 (1870). L. Hageni f. calcigena Nyl. ex Cromb. in Journ. Bot. xiv. p. 361 $(1 \wedge 76)$ \& Monogr. i. p. 426 ; Leight. Lich. Fl. ed. 3, p. 192. Lichen umbrinus Ehrh. Crypt. exs. n. 245 (1793) nomen nudum.

Exsicc. Johns. n. 262 (as f. subdistans), 369 ; Larb. Lich. $\mathrm{Hb}$. (without a number).

Closely allied to L. Hagcni, differing only in the somewhat stouter more persistent apothecial margins and in the generally saxicolous habitat. The thallus is sometimes very dark owing to the development of dark-brown hypothallic filaments or to the presence of blue-green algæ.

Hab. On siliceous or calcareous rockis, rarely on the ground or on palings.-Distr. Wide-spreat but less common than the previous species.-B. MI. La Moye, Jersey; near Penzance, Cornwall; Bannerdown, Wilts; Aberdovey; Merioneth; Ayton, Cleveland, Yorkshire; Wastlale and St. Bees, Cumberland; Ravensmouth, Durham; Barealdine, Argyll; Bay of Nigg and Portlethen, Kincardineshire; Cliffs of Moher, Clare; Killery Bay and Lettermore, Connemara, Galway.

23. L. crenulata Hook. in Sim. Engl. Fl. v. p. 190 (18:33); Nyl. in Not. Sïllsk. Faun. d Fl. Femn. Fürh. 1866, p. 1s1.Thallus very thin, effuse, greyish-white, often searcely visible $(\mathrm{K}-)$. Apothecia small, seattered, the dise yollow- or dullbrown, sometimes pruinose, the thalline margin frominent, becoming deeply erenulate, white; paraphyses coherent, thickish 
or slenter, sepitate, colourless, sometimes slightly clavate or (a) itate at the tips, the epithecium of dense brown granules; spores ellipsoid, 10-16 $\mu$ long, $5-7 \mu$ thick (senerally about 12 $\mu$ long).-Cromb. MLonogr. i. p. 424. L. albella var. crenulata Mudd Man. p. 148 (1861). L. galactina var. disperso-areolate Mudd tom. cit. p. 149. L. umbrinu f. cremulata Cromb. Lich. Brit. I. 51 (1870); Leight. Lich. Fl. p. 207 ; ed. 3, p. 191 ; subsp. cremelata Cromb. in Grevillea xii. p. 59 (1883). Lichen cremulatus Dicks. Pl. Crypt. fasc. iii. p. 14, t. 9, fig. 1 (1793); Engl. Bot. t. 930 ; With. Arr. ed. 3, iv. p. 17.

Exsice. Johns. n. 38 ; Larb. Lich. Hb. n. 258.

A dainty species allied to $L$. Hageni, and recalling somewhat I. galactina subsp. dispersa or $L$. subluta var. perspersa. The spermatia have been recorded by Nylander (Cromb. MIonogr. i. p. 424) as 11-15 $\mu$ long, $\cdot 5 \mu$ thick.

Hab. On calcareous or sandstone rocks.-Distr. Rare in S.TW. and X. England, the Grampians, Scotland, and N.IV. Ireland.-B. M. Watcombe Bay, Devon; Alfrick, Worcestershire; near Ayton, Carlton Jank and Bilsdale, Cleveland, Yorkshire; Egglestone, Durham; Tamplugh. Cumberland; Egglestone, Durham; West Water, Fifeshire; Craig Tulloch, Blair Athole, Perthshire; Craig Guie, Braemar, Aberdeenshire; Oughterarde, Galway.

24. L. conferta Nyl, in Ann. Sci. Nat. sér. 3, vii. p. 313 (1:67) note.-Thallus effuse, thin, scanty, granulate, greyishwhite or sreenish-grey $(\mathbf{K}-)$. Apothecia rather small $(\cdot 3-\cdot 8 \mathrm{~mm}$. across), plane, crowded in small groups and subangular from pressure, pale brick-red, or darker, the thalline margin very thin, sometimes crenulate, disappearing; paraphyses slender, septate, a little wider or sometimes shortly branched and irrogular at the tiph, the epithecium brownish ; spores ellipsoid, 9-15 $\mu$ long, $5-i \mu$ thick: hymenial gelatine blue with iodine-Cromb. in (ivesillea xviii. p. 69 (1890) \& Monogr. i. p. 427. L. umbrina var. ronfreta Cromb. in Journ. Bot, viii. p. 97 (1870). L. Hageni var. comfertn Leight. Lieh. Fl. p. 20s (1871) note; ed. 3, p. 192. Patellaria conferta Dub. Bot. Gall. ii. p. 654 (1830).

A rare species allied to $L$. Hageni or to $L$. crenulata. In the solitary specimen in the herlourium the thallus has almost disilypeared and the reaction ('aCl + saffron-yellow recorded by Hue (Journ. de Hot. v. p. 258) is not to be seen.

$H a b$. On granitic stones of a wall. $-B$. M. Woodside, near Aberleen (the only British locality).

2.). L. Agardhiana A(h. Syn. Lich. p. 152 (1814); Nyl. Lich. Ficand. p. 138 (1861). Thallus efluse, thin, continuous, smooth "1 furfuraceous, sreyish (K-). Apothecia minute, at first in:ate, the dise brownish-black, the thalline mangin thin, whit ish, entire som whliterated, with the dise convex and sometimes sightly pruinose (epitherim IINO, + rosaceons); paraphyses

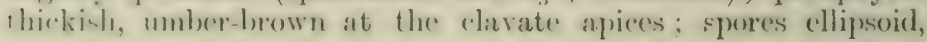


about $10-14 \mu$ long, $4-5 \mu$ thick ; hymenial gelatine blue with iodine.-Cromb. in Crevillea xviii. p. 69 (1890) \& IIonogr. i. p. 426.

Allied to L. umbrina, but the apothecia have a less prominent thalline margin; they appear lecideine when mature.

Hab. On calcareous rocks. - B. M. Great Orme's Head, Curnarronshire (the only British record).

\section{Ascus poly-spored.}

26. L. Sambuci Nyl. Lich. Scand. p. 168 (1861).-Thallus effuse, very thin, minutely granulate or pulverulent, or scarcely visible, whitish or greyish $(\mathrm{K}-$ or $\mathrm{f}+$ yellowish). Apothecia small, congregate or scattered, the disc pale- or reddish-brown. the thalline margin thin, entire or crenulate, persistent; paraphyses subdiscrete, septate, colourless, or brown and capitate at the tips; spores 12,16 or 32 in the ascus, ellipsoid, $8-12 \mu$ long, $5-7 \mu$ thick; hymenial gelatine blue with iodine.-Carroll in Journ. Bot. iv. p. 23 (1866) ; Cromb. Lich. Brit. p. 53 it Monogr. i. p. 443 ; Leight. Lich. FI. p. 186 ; ed. 3, p. 171.

Exsicc. Johns. n. 417.

Distinguished from allied species by the poly-spored asci.

The small apothecia with white crenulate margins recall Lccanor crenulata or L. Hageni. There is only a very faint yellow reaction with potash - or none.

Hab. On trees, often poplars or old elders, rarely on wood.-Distr. Very rare in N. England and W. Scotland.-B. M. Durham; Barealdine, Argyll.

C. Pallida group. - Thallus whitish, yellowish, or more rarely greyish (reactions various or none). Apothecia more or less pruinose.

\section{Thallus $K+$ yellow.}

27. L. pallida Scher. Enum. p. 78 (1850).--Thallus determinate, thin, smooth or sometimes becoming thicker and granulate, whitish ( $\mathrm{K}+$ yellow). Apothecia scattered or crowded, moderate or rather small, the dise plane or becoming slightitly convex, pale flesh-coloured, generally pruinose $(\mathrm{CaCl}-)$, the thalline margin entire, prominent or sometimes excluded by the growth of the disc; paraphyses generally conglutinate, rather slenter, sometimes flexuose, septate, not widened nor coloured at the tips, but the epithecium brown, granulose ; spores ellipsoirl, small, 10-12 $\mu$ long, 5-8 $\mu$ thick, sometimes larger; hymenial gelatine blue with iodine.-L. albella Ach. Lich. Univ. p. 369 (1S10); Hook. in Sm. Engl, Fl. v. p. 191 ; Mudd Man. p. 147 : Cromb. Lich. Brit. p. 51 pro parte it Monogr. i. p. the (incl. ff. perallella and subalbella); Leight. Lich. Fl. (ed. 3, 1. 206; : f. prrallulla Nyl. ex Cromb. in Journ. Bot. xiv. p. 361 (1876) ; t. sululbellu Hue in 
Rev. Bot. vi. p. 161 (1887-8). L. subfusca f. albella Leight. Lich. Fl. p. 204 (1871). L. peralbella Nyl. in Flora lv. p. 36.) (1872) ; Leight. op. cit. ed. 3, p. 206. L. subalbella Nyl. 1. (. Lichen pallidus Schreb. Spicil. Fl. Lips. p. 133 (1771). L. albcllus: Pers. in Ust. Ann. Bot. xi. p. 18 (1794) ; Engl. Bot. t. 2154. L. rosellus Sm. Engl. Bot. t. 1651 (1806) (non Pers.). Rinorlium albella S. F. Gray Nat. Arr. i. p. 453 (1821).

Exsicc. Bohl. n. 77 ; Mudd n. 113.

Distinguished by the whitish determinate thallus which forms orbicular patches on somewhat smooth bark, and also by the lightcoloured pruinose apothecia. The spermogones are light-colouret round the ostiole, thus differing from those of $L$. subfusca, which are dark-coloured (fide Hue Add. Nov. p. 84) ; the spermatia are 16-22 $\mu$ long.

Hab. On smooth bark of trees in wooded districts.-Distr. Rather rare but widely distributed in the British Isles. $-B$. $M$. Near Borey Tracey, Becky Falls, Devon; Netley Abbey and Lyndhurst, New Forest, Hants; Bainbridge, I. of 'Vight; St. Leonard's Forest. Sussex; Savernake Forest, Wilts; Epping Forest, Hockley and Hadleigh Woods, Essex; Hay Park, Herefordshire; Gopsall Wood, Leicestershire; Cliffrigg, Cleveland, Yorkshire; Barcaldine, Argyll ; Morrone, Braemar, Aberdeenshire; Killaloe, Clare; Killery Bay and Ballynahinch, Connemara, Galway.

28. L. carpinea Wain. in Medd. Soc. Faun. \& Fl. Fenn. xiv. p. 23 (1886).-Thallus determinate, thin, smooth or becoming unequally granulate towards the centre, greyish-white $(\mathrm{K}+$ yellow). Apothecia small or moderate in size, scattered or more often crowded and becoming angular, the dise pale- reddish-or dark-brown and more or less whitish-pruinose, plane, then often convex $(\mathrm{CaCl}+$ citrine-yellow $)$, the thalline margin thin, generally entire, sometimes crenulate or often excluded; paraphyses somewhat conglutinate, slender, sometimes flexuose, septate, not widened upwards nor coloured at the tips, but the epithecium dark-brown and granulose; spores ellipsoid, generally rather small, 9-16 $\mu$ long, $6-7 \mu$ thick: hymenial gelatine blue with iodine.- L. angulosn Ach. Lich. Univ. p. 364 (1810); Leight. Lich. Fl. ed. 3, p. 205 ; Cromb. Monogr. i. p. 419 (exel. var.

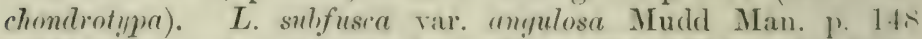
(1861); f. anyulos Leight. Lich. Fi. p. 204 (1871). L. albella subsp. angulosa Cromb. Lich. Hit. p. 5l (1870). Lichen rarpiurets L. Sp. PI. p. 1141 (175:3). I. angulosus Schreb. Spicil. Fl, Lips. p. $136(1771)$.

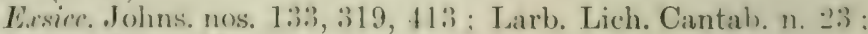
MIudd nos. 114, 115.

Closely allied to the preceding species, differing, however, decisively in the yellow reaction of the apothecial dise: with ehloride of lime. it oceurs usually in definite patches, with the apothecia crowded in the. centre. The reaction with ionline depends on the solution; moler a certain strength there is only a blue colour produced. This refors 
equally to f. subangulosa Johns. Exs. 1. 413 (1810); the change to wine-red is, however, much quicker in some specimens than in others. The specimens recorded under $L$. angulosa var. chondrotypa Cromb. Monogr. i. p. 420 (1894) belong to L. pallida and not to L. chondrotypa Ach. (Lich. Univ. p. 365 (1810)). Lichen glabratus Dicks., a herbarium name, is quoted by Nylander (Lich. Scaud. p. 162) as synonymous with $L$. cliondrotypa. The spermogones are black above with spermatia 14-18 $\mu$ long.

Hab. On trunks of trees, rarely on old palings, in maritime and inland districts.-Distr. Not uncommon throughout the British Isles. - B. M. Ullacombe, Bovey Tracey, Devon; New Forest, Hants; Shermanbury, near Lewes and near Hastings, Sussex; Holmwood, Surrey; Tunbridge Wells, Kent; Fpping Forest, Essex; near Cirencester, Gloucestershire; Nesscliff, Shropshire; Kempsey, Worcestershire; Bottisham, Cambridgeshire; between Staithes and Loftus, Ayton, and near Easby, Cleveland, Yorkshire; Catterleen, Cumberland; Appin, Argyll; Finlarig, Killin, Perthshire; Castleconnell, Limerick; near Belfast, Antrim.

29. L. sordida Th. Fr. Lich. Arct. p. 115 (1860) (excl. vars.). - Thallus subdeterminate, thickish, continuous, then wrinkled or cracked-areolate, rarely subfarinose, sometimes radiate at the circumference, with a white hypothallus not often visible, whitish or cinereous $(\mathbf{K}+$ yellow). Apothecia scattered or crowded, small or large, imnate or appressed, the disc plane, often becoming convex, dull-reddish or -brownish, generally bluish-black-pruinose $(\mathrm{CaCl}+$ yellow $)$, the thalline margin thin, acute or often deeply crenate and flexuose, or disappearing; paraphyses crowded, slender, colourless, septate, especially towards the apex, the epithecium granular, dull-olive-brown; spor's ellipsoid, 10-14 $\mu$ long, 6-7 $\mu$ thick. - L. glaucoma Ach. Lich. Univ. p. 362 (1810): Hook. Fl. Scot. ii. p. 48 \& in Sm. Engl. Fl. v. p. 189 ; Tayl. in Mackay Fl. Hib. ii. p. 135; Mudd Man. p. 153 ; Cromb. Lich. Brit. p. 50 \& Monogr. i. p. 420 (incl. subsp. suluradiosa Nyl. in Flora lv. p. 549 (1872)) ; Leight. Lich. Fl. p. 215 (incl. f. corulatu? and f. cinereopruinosa); ed. 3, p. 204 (incl. ff.). Lichen mipicola L. Mant. p. 132 (1767)? Lightf. Fl. Ścot. ii. p. 806 ? Huds. Fl. Angl. ed. 2, p. 525 ? With. Arr. ed. 3, iv. p. 13, t. 31 . fig. 2 (1796). L. sordidus Pers. in Ust. Ann. Bot. vii. p. 26 (1794). L. glancoma Ach. Lich. Suec. Prodr. p. 56 (1798): Engl. Bot. t. 2156. Verrucaria glanema Hoffm. Fl. Deutschl. ii. p. 172 (1795). Rinodina glaucoma S. F. Gray Nat. Arr. i. p. $453(1521)$.

Exsice. Johns. n. 112 ; Larb. Lich. Hb. n. 259; Leight. n. 5.) : Mudd n. 122 .

An extremely variable plant, both as regards thallus and apothecia. but the pruinose character of the disc, combined with the reaction to $\mathrm{CaCl}$, is a sure test. The apothecial margin is generally entire but may be deeply indented, with the dise flat or turgid. Spermogones are frequent, and like black points in the thallus. Thallus and apotheeia are the hosts of various parisites, the lattur of Arthonia varians. 
Several names have been emplored for this plant: Lichen rimosus ()ed. Fl. Dan. iii. t. 468, fig. 3 (1769) is altogether doubtful, though adopted by Schrerer (Enum. p. 71), aud Dickson's plant of that name is Thizocaryon calcureum. Withering's figure of $L$. rupicola almost certainly represents the plant, though the description is deficient anit the habitat "on calcareous rocks" is wrong; it is antedated by Lichen sortictus Pers., which has been generally accepted by competent and critical lichenologists, and of which the diagnosis and habitat accord with this lichen. L. glancoma subsp. bicincta Nyl. var. lecideina Cromb. Monogr. i. p. 422 (1894) was recorded as $L$. subcarnea rar. lecilcina Cromb. in Grevillea xriii. p. 68 (1890), and belongs to that species. It has a thinner, smoother thallus, gives a red reaction with potash, and no disc reaction witl $\mathrm{CaCl}$. L. glaucoma f. corulata Leight. seems also to be identical with that form.

Hab. On siliceous rocks, boulders and walls in maritime and mpland districts, chiefly mountainous.-Distr. General and common probably throughout the British Isles.-B. M. Jersey; Guernsey; Sirk; St. Minver and Penzance, Cornwall; Bolt Head, Deron; near Folkestone, Kient; Charnwool Forest and Bardon Hill, Leicestershire; Malvern Hills, Worcestershire; Aberdorey and Barmouth, Merioneth; I'wllheli, Carnarronshire; Anglesea; Long Mynd and Haughmond Hill, Shropshire; Ayton and Cliffrigg, Cleveland and Pibbledale, Yorkshire; Middleton-in-Teesdale, Durham; Swinhope, East Allendale, Northumberlaud; near Milnthorpe and Swindale, Westmoreland; Catterleen, Cumberland; New Galloway, Kirkoudbrightshire; Tiyles of Bute; Barcaldine, Argyll; Killin, Perthshire; near Dundee, Forfarshire; Portlethen, Kincardineshire; Craig Guie and Castleton of Braemar, Aberdeenshire; Tinsale, Cork; Lambay Island and Howth, Dublin.

Form decussata A. L. Sm.-Thallus marked with black lines, probably due to the presence of some other lichen.-L. glaucoma t. decussatu Cromb. in ('revillea xviii. p. 68 (1890) it Monogr. i. p. 421 .

Hut. On rocks in maritime and upland districts.-Distr. Sparingly in the Chammel Islinds, X. England and E. Scotland.-B. M. Chateau l'oint, Surk; Gunuerton Crags, Northumberlaml; near Dundee, Forfarshire.

Form complanata A. L. Sm.-Thallus and apothecia in a uniform plane. Apothecia innate.-I. glauroma f. complanatu Leight. Lich. Fl. ed. 3, p. 205 (1879); Cromb. 1l.c.

Exsicc. Johns. n. 113.

Inat). On slate rocks in maritime districts.-Dist). Sparingly round the coasts of cireat Britain aml s. Ireland.-13. M. Near Towyn, I'embrokshire; near Jurwick-on-Tweed; Ballachulish, Arorll.

Form distans A. I. Ám. - Thallus thin, rather smooth, cracked. Aputhecia few, seattered, ratlue small.-- L. glancoma f. distans Johns. Exs. n. 414 (1910).

Exsice. Jolıns. n. 414 .

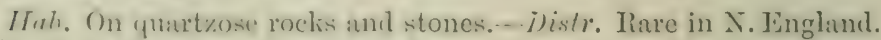
-B. M. Whitehaven, Cumberland. 
Var. Swartzii A. L. Sn.-Thallus thickish, deeply crackedareolate, somewhat radiating at the circumference. Apothecia plime or convex, aggregate-conglomerate- $L$. glauroina var. Swartzii Nyl. Lich. Scand. p. 159 (1861) ; Cromb. Lich. Brit. p. 50 \& MLonogr. i. p. 421 ; Leight. Lich. Fl. p. 216 ; ed. 3, p. 205. Lichen Suartzii Ach. in K. Vet. Acad. Handl. xr. p. 18.), t. 1, fig. 2 (1794); Dicks. Pl. Crypt. fasc. iv. p. 23.

Not easily defined in the absence of satisfuctory specimens. In the single British specimen, the apotheria are deeply crenate, a character that occurs in the species, and are often turgid and difform and with deeply indented margins. They are much larger than those in the figure by Acharius, which Crombie, howerer, says is not good.

Hab. On rocks in mountainous districts.-B. M. Ben Cruachan, Argyll.

Var. inflexa A. L. Sm.-Thallus deeply cracked-areolate. Apothecia generally crowded into cushion-like tubercles, rather lirge, the margin prominent, strongly crenate or flexuose, white. - L. glaucoma var. inflexa Johns. ex Cromb. ll. c.

Exsicc. Johns, n. 114.

A well-marked plant, more or less connected with the preceding vilriety, but the apothecia are more crowded into tuberculate masses, and the thallus is more cinereous.

$H a b$. On quartzose rocks.-B. M. Alston, Cumberland (the only locality).

30. L. cenisia Ach. Lich. Univ. p. 361 (1810).-Thallus of warted granules contiguous or scattered, subglobose or forming in areolate crust, whitish or greyish ( $\mathbf{K}+$ yellow). Apothecia uften rather large, up to $2 \mathrm{~mm}$. across, yellowish- or dull-brown lwcoming darker, sometimes almost black, greyish-pruinose, the thalline margin prominent, entire, then becoming flexuose and rrenulate; paraphyses slender, crowded, often undulate, scarcely widenerl upwards, septate near the tips and colourlest, the "pithecium brown ; spores broadly ellipsoid, $1 \cdot 2-19 \mu$ long, $8-10 \mu$ thick; hymenial gelatine blue with iodine. $-L$. rtrynea var. inisic Lamy in Bull. Soc. Bot. Fr. xxv. p. 409 (1878); Cromb. in Grevillea xviii. p. 68 (1890) \& Monogr. i. p. 415.

Characterized by the warterl granules of the thallus and by the pruinose apothecia. The spores of the specimens examined measured only rurely up to $17 \mu$ in length. The apothecium has been described : ls zeorine, i.e., with a double margin, a character not easily demonstrated in this lichen.

Hab. On schistose rocks in a maritime district.-13. M. Near Portlethen, Kincardineshire (the only British record).

Var. atrynea Ifarm. Lich. Fr. v. p. 992 (191:3). Thallus more compact than in the species, granular- or warted areoglate, whitish or greyish ( $\mathrm{K}+$ yellowish). Apothecia generally rather small and scattered or often crowded, the dise lown and scarerly 
pruinose, becoming very dark, the brown colour only visible when moist, the thalline margin prominent, crenulate or subentire; paraphyses as in the species, the epithecium tending to become darker and olivaceous-brown; spores as in the species. $-L$. sulfusca var. atrynea Ach. Lich. Univ. p. 395 (1810); Mudd Man. p. 147 pro parte; f. atryner Cromb. Lich. Brit. p. 51 ; Leight. Lich. Fl. p. 20.3 ; ed. 3, p. 187. L. atrynen Nyl. in Flora lv. p. 250 (1872) note; Cromb. Monogr. i. p. 414.

\section{Exsicc. Johns, n. 78.}

Commoner than the species, and very closely allied in the specimens with lighter-coloured apothecia. In our specimens they are, however, less pruinose, and become rery dark. The specimen from Craig Tulloch recorded as L. atrynea var. mclanocarpa (Cromb. Monogr. i. p. 415 ) is, as far as can be judged from the single small gathering, identical both in thallus and apothecia with $L$. gangalcoides. No spores are present, but the paraphyses have the dark greenish tips of that species.

Hab. On rocks, rarely on trees or wood, in maritime and inland situations.-Distr. Rather rare in Great Britain and Ireland.-B. M. Shanklin, I. of Wight; Barmouth, Merioneth; Eastham, Cheshire; Buxton, Derbyshire; Carlton, Cleveland, Yorkshire; Teesdale, Durham; Killin, Perthshree; Cove, Kincardineshire; Dinish Island, Killarney, Kerry.

\section{Thallus $K+$ yellow, then red.}

:31. L. subcarnea Ach. Lich. Univ. 1) 365 (1810).-Thallus subdeterminate, with a white hypothallus, thin or thickish smorth and cracked-areolate, or in torn-like fragments, yellowish white $(\mathrm{K}+$ yellow, then deep red). Apothecia prominent, scattered or crowded, morlerate in size, the disc plane, becoming convex, flesh-coloured, rarely brownish-red, more or less whitishor l)luish-pruinose, the thalline margin thin, entire, undulate, or rarely crenulate, then almost excluded; paraphyses stoutish, septate, irregularly bent and knobbed at the tips, the epithecium wranulose, dark-brown in section ; spores ellipsoid, small, 10-J.4 $\mu$ long, 5-8 $\mu$ thick; hymenial gelatine violet-blue with iodine.Leight. Lich. 11. p. 216 ; ed. 3, p. 205; Cromb. Monogr. i. p. 422. L. glaneome var. sulicarnen Mudd Man. p. 153) (1861); Cromb. Lich. lirit. 1. 50). Lichen sulecarnens Swartz ex Westr. in Vet. Akad. Hand1. 1791, 1. 126. L. palleserns. With. Arr. ed. 33, iv. p. 21 (1796) pro parte. Lecidea subearnea Ilook. in Sm. Engl. til. v. p. 184 (1833).

Differs from the preceding in the flesh-coloured pruinose spothecia, and from $L$. sorrlidn in the lighter coloured thallus. As in $I$. $m$ r. forstera, the reaction with potiah is not eonstant. The thallus always turns yellow, but the red reaction does not always follow very ducisisely. The spermegones are black, with eurved spermatia $20-25 \mu$ long.

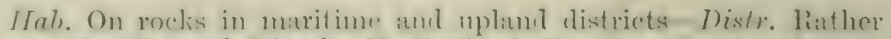
rare in the ('hamel Islands, N. Linglind, the Cirampians and N.E. 
Scotland-B. M. Boulay Bay, Jersey; Alderney; Valley of Tiocks, Lynton, Devon; Barmouth, Ierioneth; Keighley and Ayton, Yorkshire; Teesdale, Durham; Craig Tulloch, Blair Athole, Perthshire; Morrone, Braemar, Aberdeenshire.

:2. L. præpostera Nyl. in Flora lvi. p. 19 (1873).-Thallus whitish or pale yellowish, rather thick, crowdedly tuberculose or smooth and cracked into small areolis ( $\mathrm{K}+$ yellow, then red). Apothecia small or moderate in size, at first innate, often poorly developed, the disc brown, becoming dull-blackish, generally white-pruinose, the thalline margin thick, partly wrinkled or crenulate; paraphyses slender, septate, slightly coloured at the tips, but the epithecium dark greenish-brown and granulose; spores rather small, ellipsoid, 9-14 $\mu$ long, 5-6 $\mu$ thick; hymenial gelatine bluish with iodine.-Cromb. in Grevillea i. p. 141 (1873) \& Monogr. i. p. 418 ; Leight. Lich. Fl. ed. 3, p. 173 .

The reaction with potash gives a very distinctive character to this species, though in some of the specimens it is not very pronounced. The thick whitish thallus differentiates it from neighbouring species. Spermogones with straight or slightly curved spermatia about $16 \mu$ long.

IIab. On basaltic rocks.-Distr. Local and rare in the Channel Islands.-B. M. Jerbourg, Guernsey; Rozel, Jersey.

\section{Thallus $K$ -}

33. I. galactina Ach. Lich. Univ. p. 424 (1810).-.Thallus sulorbicular or spreading widely, crustaceous, areolate, the uranules when well developed crenulate and subsquamulose at the circumference, whitish or straw-coloured $(\mathrm{K}-)$. A pothecia crowded and often obscuring the thallus, rather small, plane, pale lorownish-red, white pruinose or naked, the thalline margin at tirst thickish, becoming thin, flexuose and crenulate: hymenium inspersed-granulose; paraphyses slender, septate, sometimes wirler at the tips; spores ellipsoid, 9-15 $\mu$ long, $\bar{\tau}-7 \mu$ thick; hymenial gelatine blue with iodine.-Mudd Man. p. 149 (exc). var. risperso-areolata); Cromb. Lich. Brit. p. 50 it Monogr. i. p. 404; Leight. Lich. Fl. p. 206 ; ed. 3, p. 189.

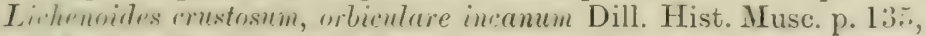
t. Is, fig. 17 B (17+1). Parmelure gralactina Ach. Meth. Lich. p. 190 (1803).

Eusir. Jolnss. n. $2: 36$; Larb. Lich. Cantab. n. 26 ; Leight. n. 400 ; Mudd n. 116.

A rery variable lichen in the grouping of the apothecia and in the alpuarance of the thallus. The latter begins in small orbicular patches, with the outer granules somewhat spreading and lobate, but it soon spreads and becomes irregular and indeterminate, and is often obscured by the namerous apotheeia, which becone angular from pressure. It is one of the few lichens that persists in the immediate neighbourhood of large towns. 
$H a b$. On walls and rocks (chiefly calcareous), or rarely in crevices of walls from maritime to upland districts-Distr. General and common in most parts of the British Isles.-B. M. Rozel, Jersey; Sark; Newlyn Cliff, Penzance and Withiel, Cornwall; I'easemarsh, Hastings, Shoreham and Brighton, Sussex; Holloway and Stanmore, Midllesex; Wickham Bishops and Ulting, Essex, Cleve Hill and Tathampton Downs, Somersetshire; Cirencester and Chalford, Gloucestershire; Great Malvern, Worcestershire; Shifnal and Oswestry, Shropshire; Milton, Cambridgeshire; near Matlock, Derbyshire; Anglesea; near Ayton, Cleveland, Yorkshire ; Rerrick, Kirkcudbright. shire; ILing's Park, Stirling; Ben Lawers and Craig Tulloch, Blair Athole, Perthshire; Portlethen, Kincardineshire; Craig Guie, Braemar, Aberdeenshire; near Fort William, Invernessshire; Ky lemore Lake, Connemara, Galway.

Form livida Leight. Lich. Fl. p. 207 (1871).-Thallus pale or reddish-white, cracked-areolate, the areolre scale-like. Apothecia sometimes immersed in the thallus, otherwise as in the species. -Leight. op. cit. ed. 3, p. 190. L. livida Ach. Lich. Univ. p. 375 (1810); Cromb. Monogr. i. p. 407. L. grelectima var. livida Nyl. ex Cromb. Lich. Brit. p. 50 (1870).

Exsicc. Johns. n. 237.

A rare form, differing from the species in the somewhat more ieveloped thallus and immersed apothecia, the latter character occurs sometimes in the species.

$H a b$. On calcareous walls in upland districts.-Distr. lare in X. England and W. Scotland.-B. M. N. England; Appin, Argyll.

Form verrucosa Leight. Lich. Fl. ed. 3, P. 190 (1879).Thallus in white dispersed convex verrucose pulviululi. Apothecia small, immersed, crowded.-Cromb. in Grevillea xviii. p. 67 \& MLonogr. i. p. 405. L. galuetine var, deminuta Cromb. in Journ. Bot. xxiii. p. 195 (1885) (non Stenh.).

Exsice. Johns. n. 109.

'The form is connected with the continental var. aliminutu, but differs in the more scattered pulvinate habit.

Ifab. (On calcareous rocks.-Distr. Tiare in Wales, X. Englamil and the Cirampians, Sicotland.-B. M. Mumbles, near Swansen. Glamorganshire; Great Orme's Head, Carnarvonshire; Ashy, Vlestmoreland ; Craig Guie, Braemar, Aberdecnshire.

Var. subluta Nyl. in Flora lix. p. 572 (1876).-Thallus cfluse, minutely granulose, whitish $(\mathbf{K}-)$. Apothecia small, crowded, difform from pressure, pale yellowish-red, otherwise as in the sprecies. - L. sulilutu Nyl. tom. cit. 1. 23:2; Cromb. in Grevillea v. 1. 106 (1877) it Monogr. i. 1) 407 ; Leight. Lich. Fl. ed. 3 , p. 190.

In one of the specinens from Dawos liver, (omentrata, the apothecia are latger and in pulvinate groups, and the thallus very scanty, with a reaction $\mathrm{K}(\mathrm{CaCl})+$ reddish-orange.

Hab. (In calcarcous rocks in mpland situations.-7)istr. Lame anong the (irampiatus, Seotland, and in W. Ireland.-J. W. Ben lawers, Perthshire; liecess and l)awros liver, Commemara, (ialwaly. 
Form perspersa Nyl. tom. cit. p. 572.-Thallus obsolete. Apothecia smaller and sciattered, otherwise as in the species.L. subluta f. persperse Cromb. in Grevillea v. p. 106 (1877) \& Monogr. i. p. 407 ; var. perspersa Leight. Lich. Fl. ed. 3, p. 190 (1879).

\section{Exsicc. Johns. n. 259.}

Hab. On rocks in upland situations. - B. MI. N. England; Dawros River, Connemara, Galway.

Subsp. dispersa Nyl. ex Cromb. in Grevillea xviii. p. 68 (1890) \& Monogr. i. p. 406. - Thallus scanty or entirely wanting. Apothecia small, more or less seattered, the dise flesh-coloured to dark-brown, the thalline margin white, entire or becoming crenulate; paraphyses and spores as in the species.--L. galactina var. dispersu Ach. Lich. Univ. p. 424 (1810); f. dispersa Leight. Lich. FI. p. 206 ; ed. 3, p. 190. Lichen dispersus Per's. in Ust. Ann. Bot. vii. p. 27 (1794).

Exsicc. Johns. n. 76.

Differs from the species in the general absence of thallus and in the small well-formed apothecia, usually with an entire margin. The apothecia may be widely and sparsely scattered or rather crowded.

$H a b$. On rocks and walls in maritime and inland districts.-Distr. Rather rare in Great Britain and Ireland.- B. M. Ryde beach, I. of Wight; Cirencester, Gloucestershire; near Oswestry, Shropshire; Hartlepool, Durham ; Bywell, Northumberland ; Cunswick Scar, Westmoreland; Achosragan Hill, Argyll; Craig Tulloch, Blair Athole and Glen Lochay, Killin, Perthshire; Morrone, Braemar, Aberdeenshire; Cliffs of Moher, Clare; Delphi, Connemara, Galway.

Subsp, dissipata Nyl. in Bull. Soc. Bot. Fr. xiii. p. 368 (1866). -Thallus in spots or spreading indefinitely, consisting chiefly of a blackish stain-like hypothallus. Apothecia minute, the dise dull-brown or blackish, or slightly whitish-pruinose, the thalline margin whitish, subentire; spores rather smaller than in the species, $8-12 \mu$ long, 4-6 $\mu$ thick.-Cromb. in Grevillea xviii. p. 67 (1890) \& Monogr. i. p. 405.

Exsicc. Johns. n. 315.

One of the few lichens of the London district, forming ink-like stains, thallus and apothecia being further blackened by smoke. Johnson's plant from Durham has a very distinct hypothallus like that of the London lichens.

Hab. On calcareous rocks, stones, composite walls, etc.-Distr. Rather rare in the more open London districts such as S. Kensington, etc., and N. England.-B. M. Notting Hill and Camden Town, London; near Brusselton, Durham.

3.4. L. urbana Nyl. ex Cromb. in Journ. Bot. xxiii. p. 195 (1885).-Thallus white, oparque, more or less pruinose or farinose, of rather stout massed granules oecasionally flattened and crenu- 
late (K-). Apothecia moderate in size, crowded or in pulvinate groups, the disc brownish, white-pruinose, the thalline margin frominent, entire or faintly crenulate; paraphyses stoutish, septate, very slightly widened at the apex; spores ellipsoid, $11-1+\mu$ lons, $5 \cdot 7 \mu$ thick.-Cromb. Monogr. i. p. 406 . L. galrectina subsp. urbana Nyl. in Bull. Soc. Bot. Fr. xiii. p. 368 (1866).

Exsice. Johns. n. 316.

Very closely allied to $L$. galactina, but with a thicker thallus and with slight differences in the apothecia.

Itu\}. On mortar of old walls near towns in lowland districts.Distr. Pare in England and S. Ireland.-B. M. Lewes, Sussex; Folkestone, Kent; Dorking, Surrey; Berwick-on-Tweed ; near Cork.

35. L. Andrewii B. de Lesd. in Bull. Soc. Bot. Fr. Ixi. p. 82 (1914). - Thallus indistinct. Apothecia numerous, crowded, up to $1 \mathrm{~mm}$. across, disc pallid or dull-brown, plane, margin white, thick, subentire or subcrenulate, persistent and flexuose ( $\mathrm{CaCl} \mathrm{f}+$ yellow, $\mathrm{K}(\mathrm{CaCl})+$ reddish-orange $) ;$ epithecium yellowish, granular; hypothecium colourless; paraphyses easily separating, slender, simple, scarcely wider above, not septate; asci clavate; spores ellipsoid, 11-13 (15) $\mu$ long, $6 \mu$ thick ; hymenial gelatine deep blue with iodine.

The description has been taken from de Lesdain, but examination of the co-type specimens shows that the apothecia are sometimes pruinose; the paraphyses are swollen and sometimes divided at the tips, thus differing slightly from those of $L$. galactina. Another pectliar feature is the reaction, which, however, occurs in a specimen of L. galactina var. subluta.

Hab. On siliceous rocks partly encrusted with lime.-B. M. Braid IHills near Edinburgh (the only record; collected by J. McAndrew).

1). Varia group.-Thallus greenish-grey (reactions various or none). Apothecia greenish or dull greenish-brown.

36. L. varia Ach. Lich. Univ. p. 37 (incl. f. pleorytis).-Thallus generally wide-spreading in a thinnish warted granular crust, the small warts rather unequal, crowded or sparse or almost absent, yellowish-grcen, straw-coloured or greenish-grey $(\mathbf{K}-)$. Apothecia numerous and often crowderl, olsscuring the thallus, fenerally about $1 \mathrm{~mm}$. in diameter, beeming sometimes laryer and irregular in form, the dise dull yellowish-brown or -green, sonetimes darker and sometimes slightly pruinose, the thalline margin thin, prominent, persistent, subentire, becoming flexuose and angular; paraphyses slender, somewhat colerent, not distinctly scptate, the apices slightly larger or irregular, the "pithecium of minute yellowish granules, dark-brown in thick section; spores oblonerellipsoid, 9-12 1 , long, 5-7 $\mu$ thick: hymenial gelatine blue with iodline. - Iook. in sm. Kingl. Fl. v. 
p. 190; Tayl. in Nackay Fl. Hib. ii. p. 137 pro parte: Mudd Man. p. 149 pro parte; Cromb. Lich. Brit. p. 52 pro parte \& Monogr. i. p. 430 (incl. f. pleorytis) ; Leight. Lich. Fl. p. 192 ; ed. 3, p. 176 wo parte. Lichen varius Ehrh. Exs. n. 68 (1785)) nomen nudum; Sm. Engl. Bot. t. 1666 (1807). Patellaria varin Hoffin. Pl. Lich. i. p. 102 (1790); var. pleorytis Ach. Meth. 1. 178 (1833). Rinotina variu S. F. Gray Nat. Arr. i. 1. 452 (1821).

Exsice. Bohl. n. 107 ; Johns, nos. 134, 135 ; Larb. Lich. Hb. n. 215 ; Leight. n. 51.

Characterized by the smooth rather hard granules, as distinguished from the leprose thallus of $L$. farinaria which is move of a shade lichen. The apothecia are numnerous and may be much enlarged witl very irregular indented flexuose margins (f. pleorytis), a character that appears in mans of the apothecia. Spcrmatia thread-lilie, 12-22 $\mu$ long, $0.75 \mu$ thick.

Hab. On old palings (rarely on trunks of trees, heather, etc.).Distr. General and common throughont the British Islands. - $B . M$. Guernsey; Bovey Tracey, Deron; Iyndhurst, New Forest, Hants; Shermanbury, Hastings and St. Leonurd's Forest, Sussex; Penshurst l'ark, Kent; Shiere, Surrey; Finchley, Middlesex; Walthanstow, Issex; Elstree, Hertfordshire; Gamlingay, Cambridgeshire; Yarmouth, Norfolk; Hay Park, Herefordshire; Battenhall, near Worcester; Harboro' Magna, Warwickshire ; Twyeross and Gopsall Park, Leicestershire; near Shrewsbury, Shropshire; Barmouth, Merioneth: Arton, Cleveland and Skipworth. Yorkshire; Wark-on-Tyne and near Hexham, Northumberland; Ben Lawers and Killin, Perthshire; 1) irris, Kincardineshire; Crathie and Glen Dee, Braemar, Aberdeenshire ; Lothiemurchus, Invernessshire; Carrigaline, Cork; Killarney. Kerry.

37. L. farinaria Bor?. Engl. Bot. ruppl. 1. 2-7:- (18:3:). Thallus effuse, thickish, pulverulent-leprose and generally cracker. ireolate or subleprose, pale yellowish-green ( $\mathbf{K}+$ yellow). Apothecia sparsely scattered, palc reddish, becoming hrownish or very dark when old, generally rather sunk in the thallus and the margin pulverulent; paraphyses somewhat coherent, sparingly septate, irrerular and sometimes divided at the tips; the epithecium a mass of gramules, brown in thick section; spores ellipsnil, $10-16 \mu$ loner, 4-5 $\mu$ thick: hymenial gelatine blue with iodine.

Cromb. in Grevillea vii. p. 142 (1879). L. expallens val: "mizaen Ach. Lich. Univ. p. 374 (1810). L. varia var. mmizin" Cromb. Lich. Brit. 1. 52 (1570); Leight. Lich. Fl. 1). 1!:?. L. comizea Nyl. in Filora lv. 1) 219 (1872); Cromb. in 'Trans. Essex Field Club is. [. lit (1585) it Monogr. i. p. 4:31. I. sar("1) subsp. hrommpis Croml). in Journ. Bot. xi. p. l:3:3 (157:3) (nom

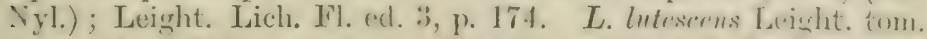

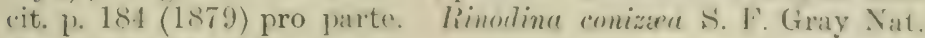
Arr. i. p. 454 (1821).

Exsicc. Cromb. n. 163 ; Johns. n. 79 ; Leight. n. 378. 
Close to the preceding species but differing in the thicker leprose thallus and in the pulverulent margins of the apothecia. It is frequently sterile, and in most of the specimens there is a yellow reaction with potash, sometimes turning to reddish-brown. As far as observed the spores are similar to those of L. varia, those of the latter species are, however, on the whole, larger and better developed.

Hab. On old palings and bark of old trees.-Distr. Not uncommon throughout England; rarely recorked from Scotland and not yet for Ireland, but probably overlooked.-B. M. Albourne, Sussex; Penshurst, Kent; Finchley, Middlesex; Reigate, Surrey; Epping Forest, Essex; Elstree, Herts; Stableford, Shropshire; Gopsall Park and 'Twycross, Leicestershire; Hevingham, Norfolk; Buxton, Derbyshire; Paldington near Manchester, Lancashire; Urpeth Valley, Durham; Asby, Cumberland; Corstorphine Hill, Edinburgh.

Var. conizæoides A. L. Sm.-Thallus generally less pulverulent than in the species. Apothecia with the margins often crenulate and inflexed but scarcely pulverulent, otherwise as in the species.-Lecanora comizavides Nyl. ex Cromb. in Journ. Bot. xxiii. p. 195 (1885) \& Monogr. i. 431.

Exsicc. Johns. n. 39.

Akin to $L$. farinaria, though somewhat resembling $L$. varia in the less leprose thallus which is sometimes sparingly developed. The same yellow reaction with potash is present as in L. farinaria. The spores are variable but attain the same size as in the species.

Hab. On the bark of old trees (beeches and pines) in wooder upland districts.-Distr. Only in a few localities of S., Central and N. England.- M. M. New Forest, Hants; nenr Buxton, Derbyshire; Egremont, Cumberland.

38. L. sublivescens A. L. Sm.-Thallus eftuse, thickish and granular-areolate or sometimes smooth as if rublued down, sordid yellowish-green $(K+$ yellowish-brown). Apothecia moderate in size, generally rather crowded when present, the disc dull-brown becoming rather convex and turgid and darker in colour, the thalline margin soon obliterated; paraphyses stoutish, uneven, irregularly septate, often branched, the epithecium of brown granules; sprores oblong-ellipsoid, 10-15 $\mu$ long, 4-5 $\mu$ thick; hymenial gelatine blue with iodine.- $L$. varia var. symmicta f. livescens Nyl. ex Cromb, in Joum. Bot. vii. p. 50 (1\$69) \& Lich. Brit. 1. 52. T. oresthe var. subliresens Nyl. in Floria lv. p. 248 (1872); Cromb. Mlonogr. i. p. 429.

More nearly allied to Lecanora farinevia var. coniza oides than to $L$. orosthea. It differs from the former chictly in the apothecial chnracters.

IIab. On bark of old trees (beech) in wonded distriets.-Distr. plentiful in a few localities in s. and E. Englamd.- B. M. Near I,yndhunst, New Forest, Hants; Hughbeech, Epping Forest, Lssex; IVindsor Great Park, Hants. 
E. Symmicfa group. - Thallus pale yellowish-grey, scanty (reactions various, or none). Apothecia generally small, mostly becoming turgid with the margin clisappearing, pale, then becoming dark.

\section{Apothecial margin disappearing.}

39. L. symmicta Ach. Syn. Lich. p. 340 (1814).-Thallus effuse, thin, finely granulate or subleprose, pale yellowish-green or whitish straw-coloured ( $\mathrm{K}+$ yellow, $\mathrm{CaCl}+$ orange). Apothecia small, rather scattered or crowded, the disc soon convex, pale Hesh-coloured, becoming darker or sometimes olivaceous, the thalline margin thin, soon disappearing; paraphyses stoutish, subdiscrete, septate, more or less widened and sometimes darker at the tips, the epithecium of brown granules; spores ellipsoid or oblong, $8-14 \mu$ long, $4-\overline{5} \mu$ thick.-Leight. Lich. Fl. ed. 3, p. 183 (excl. var. aitema); Cromb. IInnogr. i. p. 433. L. varia var. symmicte Ach. Lich. Univ. p. 379 (1810); Mudd Man. p. 150 ; Cromb. Lich. Brit. p. 52 pro parte; Leight. Lich. Fl. p. 193 pro parte.

Exsicc. Johns. n. 136, pro parte.

This species and the following, L. symmictera, are closely allied in habit and structure, the chief difference is in the orange reaction of the thallus with $\mathrm{CaCl}$. Both species tend to occur in pale thin pratches, with the anothecia more or less crowded and appressed, frecquently turgid and irregular in outline; possibly they might be regarded as growth conditions of one species.

$H a b$. On old palings and on fir trunks in maritime and inland districts.-Distr. Pare in S. and WV. England, N. Wales, W. Scotland and S. Ireland.--B. M. Lyndhurst, New Forest, Hants; Anglesea; Asby, Cumberland; Appin, Argyll ; Great Island, Cork.

Var. sæpincola Nyl. in Flora 1v. p. 249 (1872).-Thallus similar to that of the species. Apothecia becoming almost blackish; spores larger, $10-17 \mu$ long, $4-5 \mu$ thick.-Leight. Lich. Fl. edl. 3, p. 18:3 ; Cromb. Monogr. i. p. 434. L. varia var. s:epincola Nyl. Lich. Scand. p. 164 (1861); Cromb. Lich. Brit. 1. 52 ; Leight. Lich. Fl. p. 193. Leciden sappincola Ach. Syn. Lich. p. 35 (1814).

Exsice. Johns. n. 137.

Distinguished by the darker apothecia and the longer spores, and thus resembling those of $L$. symmictera var. aitema. There is an apparance of faint septation in some of the spores, and some are biguttulate.

Hab. On old palings in upland districts-Distr. Thare in $\mathrm{N}$. England and among the Grampians, Scotland.-B. M. ITart, Durham; Lamplugh, Cumberland; Kïllin, I'erthshire ; Crathie, Bracmar, Aberdeenshire.

40. L. symmictera Nyl. in Flora lv. p. 249 (1872). -Thallus effuse, finely granulate, sumetimes subleprose or almost obsolete, 
yellowish or greyish straw-coloured ( $\mathrm{K}+$ slightly yellow, CaCl - 1. Apothecia small or moderate in size, numerous, often crowled, irresular and confluent, the dise convex, turgid, pale flesh-coluned or becoming durk, the thalline margin excluded; paraphyses slender, conglutinate, septate, scarcely wider upwarls, the crithecium of brown granules; spores oblong, 10-15 $\mu$ long, :3-j phick: hymenial gelatine blue then tawny, the tips of the asci blue, with ioline.-Cromb. in Journ. Bot. xi. p. 133 (1873) ¿t Monogr. i. p. 434 ; Leight. Lich. Fl. ed. 3, p. 200.

Licsice. Johns. n. 415, 136 pro parte ; Larb. Lich. Hb. n. 130 : Mudd n. 117.

Included by most systematists under Lecanora, and here retained in that genus, though in the absence of gonidia from the margin it might seem to belong more to the biatorine Lecidea. There is vccasionally an appearance of a lighter-coloured margin, but that is due to the darker deposit of gritnules on the epithecium. The reaction with potash is sometimes scarcely perceptible.

Hat. On old palings and trumks of trees.-Distr. General in Great Irituin; not reported from Ireland.-- B. M. Beauport and St. John's, Tersey; near I'enzance, Cornwall; near Bovey Tracey, Devon; New Forest. Hants; Henfield and Shermanbury, Sussex; Millhill, Middlesex; Langford, Essex; near Minety, Wilts; Mendlesham, Suffolk; Gamlingay, Cambridgeshire; Thringstone, Leicestershire ; Dolgelly; Merioneth; Anglesea ; Ballasalla, I. of Man; near Ayton, Cleveland, Yorkshire; Levens, Westmoreland; New Galloway, Kirkeudbrightshire; Blairlrumuand near Stirling; Finlarigr, Killin and Ben Lawers, Perthshire: Nigg, Kincardineshire ; Crathie, Braemar, Aberdeenshire ; Louisburgh, Mayo.

Var. aitmea Nyl, in Flora lvi. p. 299 (1873).-Thallus slightly more developer than in the species. Apothecia more scatterecl, the disc blackish; spores similar to the species or rather larger.-Cromb. in (xrevillea xriii. p. 69 (1859) d

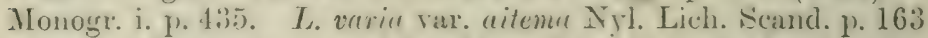
(1861): Mudd Man. p. 150 (1861): Uromb. Lich. Brit. p. 523; Leight. Lich. Fl. 1) 192; var. demigrete MIudd tom. eit. 1) 151 (1s61) (non Fr.). L. symuirtu var. aitma Nyl. in Flora lv. 1. 249 (1872) ; Leight. Lich. Fl. exl. :, 1. 183. L. trabalis Nyl. in Flora 1x. 2) 458 (1877); (romb. Monogx. i. p. 435. Lecidea ritrmen Arh. Lich. Unir. J. 1Ts (1810). L. sevincolu f. trabalis Ach. Syn. Lich. p. 35 (1814)?

Exsice. Cromb. n. 66 ; Johns. n. :370: Lath. Lich. 11b. n. 255 ; Mudd n. 118 .

(irowing feefuently in small patches: the apothecial dises are dark-brown or blackish, owing to the dirk-brown sramules of the epithecium.

[Iah. ()n old paling:s or on stmmps in upland districts,-])is(r.

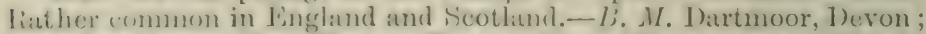
metr Lynihurst, New liorest, Hants: J. of Wight; near Millhill, Mirdllearex; near Gamlingay, Cambridgeshire; Battersby, Cleveland, Forlishire: Stanbope, Weardale, Jurham; Alston, Cumberland; 
Finlarig, Kenmore and Glen Lyon, Killin, and Glen Fender, Blair Athole, Perthshire; Crathie, Braemar, Aberdeenshire; Rothiemur. chus, Invernessshire.

41. L. subintricata Th. Fr. Lich. Scand. p. 265 (1871).Thallus very thin, finely granulose, pale-yellow or dull-greyish, or obsolete $(\mathrm{K}-)$. A pothecia simall, plane then convex, variable in colour, yellowish, reddish-brown or dark-olive-brown, the thalline margin thin, entire, soon excluded; paraphyses crowded and coherent, slender, branched, septate and scarcely wider upwards ; spores ellipsoid, small, 5-10 $\mu$ long, 3-4 $\mu$ thick.Cromb. in Journ. Bot. xi. p. 133 (1873) (excl. f. obscurior) \& Monogr. i. p. 440 ; Leight. Lich. Fl. ed. 3, p. 177. L. varia var. subintricata Nyl. in Flora li. p. 478 (1868).

Exsicc. Cromb, n. 162.

Resembling $L$. intricata in the varying colour of the apothecia. Nylander considered this species to be very near to $L$. symmicta var. sxpincola, but with much smaller spores. Crombie gives as thalline reaction $\mathrm{Kf}+$ yellowish. I have been unable to verify this, but the thallus in the British specimens is very scanty. Crombie also gives "spermatia thinly acicular, slightly arcunte, 6-7 $\mu$ long, $5 \mu$ thick."

$H a b$. On old palings in an upland district.-B. M. Glen Fender, Blair Athole, Perthshire (the only British record).

42. L. sarcopisioides A. L. Sm. - Thallus effuse, thin, minutely granular, whitish-grey, often disappearing $(\mathrm{K}+$ yellow $)$. Apothecia minute, numerous, sometimes aggregate, at first plane, hecoming convex, reddish then dull-brown or blackish, sometimes slightly pruinose, the margin thin, quickly excluded ; paraphyses conglutinate, septate, capitate or scarcely widened upwards, often dark over the apex, the epithecium and hymenium coloured darkbrown or blackish, often with a blue tinge ; spores oblong, $7-14 \mu$ long, 3-4 $\mu$ thick. - $L$. metaboloides Nyl. in Flora lv. p. 250 (1872) ; Cromb. in Journ. Bot. xx. p. 274 (1882); in Grevillea xviii. p. 69 (1890) (incl. f. obscurior) \& Monogr. i. p. 437 . Biatora sarcopisioides Massal. Ric. Lich. p. 128 (1852). Lecidea minutu var. sarcopisioides Cromb. Lich. Brit. p. 69 (1870) ; Leight. Lich. Fl. p. 266 ; ed. 3 , p. 264.

Exsicc. Johns. nos. 200, 416.

A well-inarked species, but easily mistalien for a Lecidea, as the thalline margin is only visible at an early stage. It differs from L. pimiprila in the character of the thallus and in the colour of the hymenium. T'he spores vary consilerably, but are usually elongate in our specimens as well as in those from Italy in our herbarium, though Jatta records the spore length as only $6 \mu \times 2 \mu$ (Fl. Ital. Crypt. iii. p. 316).

Nylander quoted as synonymous with his species (L. metuboloides) the one published earlier by Massulongo as Biatora surcopisioides, and cites as typical Anzi Exs. Lich. rar. Venet. 11. 61, a specimen with a more evident thallus, jrobably due to the weathered wood on which it grows. Another specimen, Anzi Exs. Minus rar. Ital. n. 175, 
also cited by Nylander (Flora lv. p. 250), bears less outward resemblance, as the apothecia are larger, more turgid and more persistently light-coloured, though internally it is the same.

At times the thallus is very dark (f. obscurior), owing to the presence of brown fungal hyphæe or of blue-green algæ.

Hab. On old palings and on decorticated stumps, rarely on stens of gorse, in maritime and inland wooded regions. $-B . M$. Ennerdale and Ravinglass, Eskdale, Cumberland; Achmore, Kenmore, Glen Falloch, Ben Lawers, Finlarig, Killin, Glen Fender and Pass of Killiecrankie, Perthshire; Glen Lochy, Invernessshire.

43. L. effusa Ach. Lich. Univ. p. 386 (1810). - Thallus effuse, granular or subleprose, yellowish-grey or dull-yeliow, sometimes almost evanescent ( $\mathrm{K}+$ yellow). Apothecia numerous, rather small, the disc plane, often becoming convex, brownish-red, the thalline margin thin, becoming subpulverulent or crenulate, sometimes excluded; paraphyses conglutinate, slender, septate, sometimes widened upwards and brown at the tips, the epithecium of reddish-brown granules; spores small, ellipsoid, $8-12 \mu$. long, $4-7 \mu$ thick; hymenial gelatine blue with iodine.-Cromb. in Grevillea vi. p. 21 (187t) \& Monogr. i. p. 441. L. varia var. sarcopis Ach. tom. cit. p. 378 ; Mudd Man. p. 150 ; var. apochrea Ach. tom. cit. p. 379 ; subsp. sarcopis Cromb. Lich. Brit. p. 52) (1870). L. sarcopis Ach. Syn. Lich. p. 177 (1814); Leight. Lich. Fl. p. 187 ; ed. 3, p. 174 ; Cromb. Monogr. i. p. 440. Lichen effusus Pers. ex Hoffm. Deutschl. Fl. ii. p. 174 (179.)). Parmelia sarcopis Wahl. ex Ach. Meth. Lich. Suppl. p. 40 (180:3). Rimorlina effusas. F. Gray Nat. Arr. i. p. 451 (1821). R. apochrin S. F. Gray tom. cit. p. 452 ? (? Ach.).

Exsice. Cromb. n. 161.

The apothecia are generally numerous and crowded, the discs are somewhat similar in colour to those of the $I$. subfusea group, but the different thallus and habitat and the smaller apothecia of $L$. cifust at once distinguish it. The two species, $L$. effusa and $L$. sareopis, differ only in the thallus, it being nore developed in the latter. evidently a growth condition, and not distinguishable cren as a variety.

1Fab. On old palings, rarcly on decorticated stmuns of trees.Distr. liather rave throughont the Chamel Islands, England and Scotlant, not recorted from Ireland.--B3. M. Jeaunort Bay, Tersey; near I'nzance, Conwall; Lundhurst, New Forest, Hants; near Tewes, Sussex; Bradon forest, Somerset; Norton and Fiempsey. Worcestershire; (iopsall P'ark, I, eicestershire; near Ayton and near Carlton, Cleveland, Yorkshire; Teestale, Durham; Levens, Westmoreland; Killin and Glen Lyon, l'erthshire; (ilen Dee and (rathie. Braemar, Aberdeenshire; Glen Morriston, Invernessshire.

\section{Apothecial margin persistent.}

11. L. piniperda Koerb. P’arers. Lieh. p. \&1 (I859)..-Thallus rfluse, sery thin, arachonol-leprese, whitish or with a tinge of 
yellow $(\mathrm{Kf}+$ yellowish). Apothecia minute, scattered or congregate, the disc plane, becomirg convex, flesh-coloured or brownish, slightly pruinose, the thalline margin thin, entire or subcrenulate, at first rather prominent; paraplayses conglutinate, septate, scarcely widened upwards, with a thin epithecium of brown granules; spores oblong-ellipsoid, $8-12 \mu$ long, $3-4 \mu$ thick. -Cromb. in Journ. Lot. xi. p. 133 (1873) \& Monogr. i. p. 455; Leight. Lich. Fl. ed. 3, p. 174 .

\section{Exsicc. Cromb. n. 160 ; Leight. n. 176.}

W'ell characterized by the thin and generally arachnoid or finelyfelted thallus and by the minute dainty apothecia, generally about $\cdot 3$ to $.5 \mathrm{~mm}$. in diame ter. The pruinose character is difficult to see in such minute objects except under a strong lens.

Hab. On trunks of fir trees, more rarely on old palings.-Distr. Rare in the British Isles, probably overlooked. $-B$. M. Millhill and Edgeware, Middlesex ; near Worcester ; Twyford, Shropshire ; Appin, Argyll ; near Loch Turnmel, Pertbshire; MIaam, Connemara, Galway.

Var. ochrostoma Koerb. 1. c.-Thallus similar to that of the species or almost obsolete. Apothecia generally numerous, becoming convex and the margin soon excluded, the disc more or less yellowish or rusty-red, not pruinose.-Leight. Lich. Fl. ed. 3, p. 174 ; Cromb. Monogr. i. p. 436.

Differs from the species in the colour of the apothecia. In the few British specimens the thallus has practically disappeared.

Hab. On old palings in wooded districts.-Distr. Rare in S. and W. England.-B. M. New Forest, Hants; Braydon Forest, Wilts.

Var. glaucella Koerb. 1. c.-Thallus more evident, greyishwhite. Apothecia bluish-grey-pruinose, the white thalline margin prominent, more persistent. - Subsp. ylaucella Nyl. ex Cromb. in Grevillea xix. p. 60 (1891) \& Monogr. i. p. 436.

Exsicc. Johns. n. 264.

Distinguished by the somewhat more developed thallus and by the darker pruinose apothecia.

Hab. On bark of pine trees.-Distr. Rather rare in N. and N.W. England.-B. M. Bantsdale, Yorkshire; Staveley, near Kendal, Westmoreland; Ennerdale Lake, Cumberland.

45. L. fugiens Nyl. in Flora lvi. p. 289 (1873).-Thallus efiuse, thin, minutely granulate or obsolete, whitish-grey or -yellow ( $\mathrm{K}+$ yellow, $\mathrm{CaCl}+$ orange). Apothecia minute, scattered, sessile, the disc dull-yellowish, the thalline margin whitish, prominent, entire or sometimes crenulate; paraphyses slender, subdiscrete, septate, irregularly swollen and sometimes yellowishbrown above; spores ellipsoicl-oblong, 9-13 $\mu$ long, 5-6 $\mu$ thick. -Cromb. in Grevillea ii. p. 89 (1873) \& Monogr. i. p. 436 ; Leight. Lich. Fl. ed. 3, p. 184.

Evidently a very rame lichen. The thallus is scatrecly evident except in the specimen from Commenara. Aylundor has regrarded 
it ats allied to $L$. piniperda. The reactions agree with those of L. symmicta, but are not always very pronounced. The spermogones have spermatia arcuate, $12-16 \mu$ long, $\cdot 5 \mu$ thick.

Hal. On roclis in maritime districts.-Distr. Rare in the Channel Tslands and in TV. Irelanil.-D. M. liozel, Jersey; Salrock, Councmara. Galway.

Vir. chlorophæoides A. L. Sin.--Thallus effuse, minutely granulate $(\mathrm{K}+$ yellow, $\mathrm{K}(\mathrm{CaCl})+$ orange-red $)$. Apothecia more numerous and slightly larger, otherwise similar to the species.I. chlorophroides Nyl. in Flora Ivi. p. 290 (1873); Cromb. in Journ. Bot. xii. p. 148 (1874) \& Monogr. i. p. 412 ; Leight. Lich. Fl. ed. 3, p. 184.

Exsicc. Larb. Lich. Hb. n. 98.

Thallus and apothecia are more abundant than in the species, from which it difiers in the reaction with $\mathrm{CaCl}$, possibly due to the more developed state.

Hab. On rocks in maritime districts.- B. M. Vale Castle, Guernsey.

F. Sulphurea group.-Thallus variously yellow (reactions various or none). Apothecia persistently light-coloured or becoming dark.

46. L. expallens Ach. Lich. Univ. p. 374 (1810) (excl. var. comiz:a).--Thallus effuse, thinnish, leprose-pulverulent, palesulphur-yellow ( $\mathrm{K}+\mathrm{ycllow}, \mathrm{CaCl}+$ orange-red or brownish). Apothecia few, small, subinnate, plane or slightly convex, paleyellow or flesh-coloured, the thalline margin thin, generally excluded; paraphyses coherent, stoutish, septate, the epithecium of brownish-yellow granules; spores cllipsoidloblong, $8-16 \mu$ long, 4-5 $\mu$ thick.-Leight. Lich. Fl. p. 199 ; ed. 3, p. 184; (romb). Monogr. i. p. 432. I. varia var. orosthea Mudd Man. p. 150 (1861). Lichen orosthens Su. Eumpl. Bot. t. 1549 (1806i) (non Ach.). Leprarin expullens Pers. ex Ach. l. c. Lecidea capullens liort. ex Hook. in Sm. Lingl. Fl. v. 1. 181 (1833) pro parte; 'Tayl. in Mackay TI. Hib. ii. p. 127.

Exsicc. Johns. n. 320 ; Larb. Lich. Hlo. n. 216.

Jistinguished from the expally leprose Ih jurimuria by the thinner paller thallus. Which recalls that of Jectiden lavidn. The renction with Cacl is not always very clear; often it is rellow changing to brownish. The apotheria tre seanty in the species, and the spores generally rather smatl; in the variety they are better developed and up to $16 \mu$ in length.

Hab. On trunks of trees dir and oaki sund on ohd palings in lowland and upland distriets.- Distr. Here and there throughout Fongland, X. Wales, S.W. and N.W. Ireland, not seen from Seotland.-.-B. M. Near lonseg Tratey and near Newton Albut, Deron; Glynde, Sussex; Colcahorue and Oakley l'ark. Cimenester, (iloucestershire; Tetsworth, (1) Remb hire; Ickworth, Suffulk; Thetforil, Norfolk; Cuton, Woreester. thire: Inolerlly, Merioneth; (iam Dingle, Denbighshire; Anglesea ; 
Airyholme Wood and Ripon, Yorkshire; St. Bees, Cumberlant; Ballynahinch, Connemara, Galway.

Var. lutescens Nyl. in Flora lv. p. 248 (1S72).--Thallus more granulate, scarcely pulverulent, and somewhat darker greenishyellow. Apotbecia more numerous than in the species, sometimes pruinose, the margins at first prominent then excluded. - Cromb. in Grevillea xviii. p. 69 (IS90) \& Monogr. i. p. 432. L. lutescens Dub. Bot. Gall. ii. p. 668 (18:30); Cromb. in Journ. Bot. xi. p. 133 (1873) ; Leight. Lich. Fl. ed. 3, p. $18 t$ pro parte. Lichen lutescens Hoffm. Enum. Lich. p. 3 (178t)? Patellaria lutescens DC. Fl. Franc. ii. p. 354 (1805). Rinodina lutescens S. F. Gray Nat. Arr. i. p. 453 (1821) pro parte.

Exsicc. Cromb. n. 65े; Johns. n. 116.

Bears the same relation to the species as var. conizceoides does to I. farinaria. Both may be only growth forms. The apothecia are generally numerous and crowded, in some places obscuring the thallus. Thallus and apothecial margins are firmer than in the species.

Hab. On trunks of trees and old palings (chiefly fir) in maritime and inland districts.-Distr. General in Great Britain; rare in the Channel Islands and S. Ireland.-B. M. Beaufort Bay, Jersey; Roche, Cornwall; near Torquay and Totnes, Devon; New Forest, Hants; Eartham, Sussex; Lydd, Kent; Ulting, Essex; near Ludlow, Herefordshire; Malvern, Worcestershire; Bettws-y-Coed and Trefriw, Carnarronshire; near Kendal, IVestmoreland; Ennerdale, Cumberland; New Galloway, Kirlicudbrightshire; Appin, Argyll; Craig Calliach and near Loch T'ummel, Perthshire; near Forfar; Durris, Kincardineshire; Countesswells near Aberdeen and Mar Forest, Braemar, Aberdeenshire; Rothiemurchus, Invernessshire; Applecross, Rossshire; Glenbower Wood and Castlebernard Park, Cork.

Var. smaragdocarpa Nyl. in Flora lv. p. 248 (1872) note.Thallus as in the species. "Apothecia bright emerald-green." -Cromb. in Grevillea xviii. p. 69 (1890) \& Monogr. i. p. 433.

Exsicc. Larb. Lich. Hb. (without a number).

The apothecia on our solitary specimen are now very dark, and the epithecium in section is a layer of brown granules; the paraphyses are stout, uneven and branched, the spores measure about $12 \mu \mathrm{long}$ and $4 \mu$ thick. It is reported from W. France on oak wood, and is recorled from Lamlash, Arran, by Wheldon and Travis in Journ. Bot. li. p. 251 (1913).

$H a b$. On a decorticated stump of oak.-B. M. Chiltern Hills, Oxfordshire.

Subsp. inversa Nyl. in Flora lxii. p. 361 (1879).-Thallus: nearly ats in the species. Apothecia with a more prominent, sul)entire margin; spores not seen.-Cromb. 1l. c.

There is only one specinen in our herbarium, originally labelled Lecanora albo-flavida 'Tayl. It is too scanty for examination. Nylander thinks that if the spores were linown it might be a new species. The reactions agree with those of $L$. expallens.

Hab. On branches of furze.-B. M. Fimnechy liver, lierry. 
47. L. orosthea Ach. Lich. Univ. p. 400 (1810).-Thallus spreading or determinate, thin, faintly or coarsely cracked-areolate, sometimes pulverulent, pale yellowish-coloured $(\mathrm{K}+$ yellowishbrown, $\mathrm{CaCl}-$ ). A pothecia small, rather rare, soon immarginate and convex or difform, coloured like the thallus or dull-blackish, subpruinose: paraphyses crowded, slender, septate, scitrcely thickened upwards, the epithecium colourless or sometimes blackish-brown ; spores ellipsoid-oblong, 9-16 $\mu$ long, $6-7 \mu$ thick, but mostly rather small; hymenial gelatine blue with iodine.Leight. Lich. Fl. p. 199 ; ed. 3, p. 183 ; Cromb. Monogr. i. p. 4-29. L. varia subsp. orosthea Cromb. Lich. Brit. p. 52 (1870). Lichen wrostheus Ach. Lich. Suec. Prodr. 1). 38 (1798). Lecirlea wrosthea Ach. Meth. Lich. p. 72 (1\&0:3) : s. F. Gray Nat. Arr. i. p. 470 .

Scarcely distinguishable from the preceding species, except in the smooth thinner rather lighter-coloured thallus. Crombie states that it grows chiefly on the smooth sides of perpendicular rocks, is very widely effuse, and generally sterile.

Hab. On siliceous rocks.-Distr. Tare in the British Isles, possibly often overlooked owing to the sterility of the thallus. $-B$. M. Ennerdale, Cumberland; West Water, Fife; Craig Calliach, Perthshire; Portlethen, Kincardineshire; Cloghane. Kerry; Vicklow; Irylemore, Connemara, Galway.

48. L. sulphurea Ach. Lich. Unir. 1'. 399 (1810).-Thallus a thickish smooth or sometimes cranular crust, deeply crackedareolate, the areola even or tumid, determinate, but the hypothallus indistinct, greenish-sulphur-columed $(\mathrm{K}+$ yellowish-hrown, $\mathrm{CaCl}-$ ). Apothecia numerous, up to $1.5 \mathrm{~mm}$. across, at first innate, hecoming prominent, plane or convex, the disc olive- or dull-black, more or less pruinose, the thalline margin searcely visible; paraphyses coherent, septate, slightly wider at the tips, the epithecium minutely granular, greenish-black; spores ellipsoid. 10-15 $\mu$ long, $5-6 \mu$ thick; hymenial gelatine blue with iodine. - Hudd Man. 1. 152; Cromb. Lich. Brit. p. 52 \& Monogr. i. 1. 428; Lucight. Lich. Fl. p. 198 ; ed. 3, p. 18.. Lichen sulphuren. IIoffm. Enum, p. 32, t. 4, fig. 1 (17\&) : Dicks. Pl. Crypt. fasc. ii. 1. 17 ; With. Arr. ed. :3, iv. p. 12; Engl. But. t. 11 s6 (upper fig.). Leriden sulplutere Wahlenl, Fl. Lapp. p. 47 (1812); S. F. Gray Niat. Arr. i. p. 470 ; Ilook. Fl. Scot. ii. p. 38 it in Sm. Engr. Fl. v. 1. 181; Tayl. in Mackay Fl. IIib. ii. p. 127.

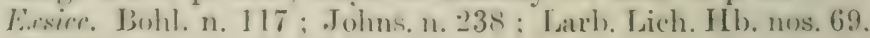
92 ; Leight. n. 114 ; Mudd n. 121.

I) istinetive in the colour of the thallus and the practically umnatr. ginate dark apotheein; they are often crowiled and become confluent. The spermogones ate punctiforn, inmersed, with spermatia $15-20 \mu$ long, $1 \mu$ thick.

Hab. (Jn rocks and walls in matitine, more rarely in momntainons renions.-J)ists. (iconeral and enmmom in (ireat liritain and Treland. 
rare in the Channel Islands.-B. M. Sark; St. Minver and Penzance, Cornwall; Bolt Head, Devon; Pulborough and Hastings, Sussex; Walthamstow and near Maldon, Essex; Malvern Hill, Worcestershire; Wrekin Hill, Shropshire; Chereley Park, Cambridgeshire; Bardon Hill, Leicestershire; Barmouth and Dolgelly, Merioneth; Anglesea; Tioseberry, Cleveland, Yorkshire; Staveley near Kiendal, Westmoreland; Egglestone, Durhan ; Wansbeck, Northumberland; Rerrick, Kirkcudbrightshive; Appin, Argyll ; Ben Lawers, Perthshire; Portlethen, Kincardineshire; Craig Guie, Braemar, Aberdeenshire; Glen Neris, Invernesshire; Killarney, Kerry; Letter Hill, Connemara, Galway; Lambay Island, Dublin.

49. L. epanora Ach. Lich. Univ. p. 377 (1810).--Thallus effuse, thickish, of crowded or scattered verrucose or subsquamulose granules, greenish-yellow, with citrine-yellow soredia, the hypothallus blackish or obsolete $(\mathrm{K}-)$. Apothecia sessile, plane, brownish-yellow, the thalline margin prominent, flexuose or subcrenulate : paraphyses coherent, slender, septate, scarcely widened at the tips, the epithecium brownish-yellow; spores ellipsoid, small, 8-11 $\mu$ long, $5 \cdot \tau \mu$ thick; bymenial gelatine blue with iodine.-Cromb. Lich. Brit. p. 53 it Monogr. i. p. 429 ; Leight. Lich. Fl. p. 205; ed. 3, p. 189. L. albottavidu Tayl. in Mackay Fl. Hil. ii. p. 260 (1836) ; Mudd Man. p. 155. Lichen epanorn: Ach. Lich. Suec. Prodr. p. 39 (1798).

Exsicc. Leight. n. 397.

Well distinguished by the yellow soredia which sometimes make large patches seem as if pulverulent. The hypothallus is scarcely visible in our specimens, which are also largely sterile.

HaZ. On siliceous rocks and walls.-Distr. Iocal in N. Wales, the Highlands, Scotland, and in S.W. Ireland.-B. M. Barmouth and Dolgelly, Merioneth; Ballachulish, Argyll; Glen Fender, Blair Athole, Perthshire; Dunkerron, Kerry.

50. I. polytropa Schær. Enum. p. 81 (1850) pro parte (incl. f. acrustacea).-Thallus effuse, rather thin, granulate- or crackedareolate or subsquamulose, or almost evanescent, pale sulphurcoloured or greyish-green, a black hypothallus sometinies visible (K + yellowish). Apothecia small or moderate in size, generally less than $1 \mathrm{~mm}$. across, closely adnate, at first plane, becoming convex, yellowish or reddish-flesh-coloured, the thin entire margin soon excluded; paraphyses rather slender, densely crowdrod and subconslutinate, sometimes widened and septate upwards, colourless, the epithecium a thin layer of hrownish granules; spores broadly cllipsoid, 9-14 $\mu$ long, 5-6 $\mu$ thick.Mudd Man. p. 151 (incl. var. "crustacen); Leight. Lich. Fl. p. 197 (incl. f. illuseriu); ed. 3, p. 181 ; Cromb. Monugr. i. p. 437. L. varin var. illusoria Ach. Lich. Univ. p. 3\$0 (1-10): var. polytropa Nyl. in Mèm. Sinc. Sci. Nat. Cherb. v. p. 114 (1857): Cromb. Lich. Jirit. p. i- (incl. f. Bllusaria). Lirhen polytropms Ehrh. Exs. 1. 294 (179:3) nomen nudum : Ach. Lich. Suec. Prodr. 
p. 72 (1798); Dicks. Pl. Crypt. iv. p. 22 ; Engl. Bot. t. 1264 (two lower figs.) (1804). Lecirlea polytropa Ach. Meth. Lich. p. 72 (1803) ; S. F. Gray Nat. Arr. i. p. 475 ; Hook. in Sm. Engl. Fl. v. p. 185. L. Ehrhartiana var. polytropa Ach. Syn. Lich. p. 47 (1814); Hook. Fil. Scot. ii. p. 40.

Exsicc. Johns. nos. 117, 265, 266 ; Leight. n. 179.

A species that varies considerably in the form of the thallus, which may be thickish, warted or reduced to small scattered granules or scales or almost absent (vars. acrustacen and illusoria). The apothecia are generally numerous, and may be small, regularly round and scattered, or much swollen and sometimes aggregate; the forms that follow represent extreme stages of condition that occur in the species.

$H a b$. On siliceous rocks, boulders and walls in maritime and mountainous districts.-Distr. More or less general throughout the British Isles.-B. $M$. Rozel and La Moye, Jersey; near Penzance, Cornwall; Bolt Head, Deron; Dolgelly and Aberdovey, Merioneth ; Lounsdale and Cliffrigg, Cleveland, Yorkshire ; Egglestone, Durham; Ennerdale, Cumberland; Appin, Argyll; Ben Lawers and Craig Tulloch, Perthshire; Portlethen, Kincardineshire; Bennaboord and Morrone, Braemar, Aberdeenshire; Ben Nevis, Invernessshire; Kinsale, Cork ; Derryquin and near Lough Caragh, Dunkerron, Kerry ; Doughruagh Mits., Connemara, Galway; Mallaranny, Achill, Mayo.

Form subglobosa Cromb. Monogr. i. p. 438 (1894).--Thallus effuse, generally rather thin, or obsolete. Apothecia numerous, rather small, convex and almost subglobose, yellowish or brownish, the margin excluded.-L. polytropa var. conglobata Murdd Man. p. 152 (186I) (non Flot.); f. conglubata Leight. Lich. Fl. p. 197 (1871) (non Sommerf.); ed. 3, p. 180 . L. varia var. polytropa f. conglobata Cromb. Lich. Brit. p. 52 (1870).

Exsicc. Johns. n. 118 ; Leight. n. 152 ; Mudd n. 120.

The same type of apothecium occurs in the species but not so uniformly.

Hab. Similar to the species.-Distr. Local in N. Wales, N. and W. England and in the Scottish Highlands.-B. M. Dolgelly, Mrerioneth ; Oswestry, Shropshire; Guisboro' Moor and Ayton Mfoor, Cleveland, Yorkshire; West Allen Carrs, Northumberland; Braithwaite and Alston, Cumberland; Craig Tulloch, Perthshire; Morrone, Braemar, Aberdeenshire.

Form alpigena Leight. Lich. Fl. 1. 197 (1871).-Thallus cracked-areolate, pale-yellow, or searcely visible. Apothecia large, plane or turgid and convex, appressed and very irregular the thalline margin thin, more or jess prominent or excluded.Leight. op. cit. ed. 3, p. 181: Cromb. MLnour. i. 4:38. L. ruriu var. alpigena Ach. Lich. Univ. p. 379 (1810).

Differing from the species in the large irregular apothecia, in our specimens they measure up to $4 \mathrm{~mm}$, across, with the thallus scarcely visible.

Hab. On schistose rocks in alpine regions.- B. M. Jien Jawers, Perthshire. 
Form efflorescens Cromb. Monogr. i. p. 438 (1894).-Thallus of minute scales on a dark hypothallus and sprinkled with paleyellowish round soralia. Apothecia small, somewhat convex and usually immarginate.

Crombie suggests that this unusual form may be due to the habitat. The hypothallus is formed of short-celled, very dark hyphe.

Hab. On shaded stones of a sehistose wall.-B. Al. Craig Tulloch, Blair Athole, Perthshire (the only record).

Var. stenotropa A. L. Sm.-Thallus effuse, thin, of yellowishgreen granules. Apothecia rather small, convex, immarginate, yellowish; spores thinner than in the species, about $7-12 \mu$ long, 3-4 $\mu$ thick. - L. stenotropa Nyl. in Flora lv. 1. 25) (1S7:2); Cromb. in Grevillea xviii. p. 6!) (18.0) \& MIonogr. i. p. 440.

A Scandinarian lichen which differs from the species in the slightly smaller thinner spores, otherwise not distinguishable.

$H a b$. On schistose stones of a wall, associated with Lrcidcr leucophera.-B. M. Craig T'ulloch. Blair Athole, Perthshire (the only British record).

51. L. intricata Ach. Lich. Univ. p. :380 (1810).-Thallus limited or effuse, thickish and cracked-ireolate, or composed of thin scales on a black hypothallus, whitish- or greenish-yellow or -brown ( $\mathrm{K}+$ yellowish). Apothecia numerous, mostly small. adnate or semi-immersed, becoming convex, dull-flesh-coloured or brownish becoming olive or blackish, the thalline matyin disappearing; paraphyses conglutinate, slender, rather wider and septate at the tips, the epithecium bluish-black; spores oblongellipsoid, 9-15 $\mu$ long, $5-7 \mu$ thick.-Tayl. in Mackay F]. Hib. ii. p. 137 (incl. var. romminuta?) ; Leight. Lich. Fl. p. 198; ed. :3, p. 181. L. comminuta Tayl. in Lond. Journ. Bot. vi. p. 160 (1847)? L. polytropa var, intricuta Schar. Enum. p. 82 (1880): Mudd Man. p. 152; var. alpigena Mudd Man. p. 152 (1861) (non Ach.); subsp. intricata Nyl. in Flora Iv. 1. 2.)1 (1872); Cromb. in Grevillen xviii. p. 69 is Monogr. i. p. 439. Lichen intricatus Schrad. Journ. Bot. v. p. 72 (1801) [Güttingen, 1802]. L. polytropus Sm. Engl. Bot. t. 1264 (two upper figs.) (1804) (non Ach.).

Exsicc. Johns. n. 40 ; Leight. n. 153 ; Mudd n. 119.

Closely allicd to the preceding species, of which it is sometines: considered to be a raricty or subspecies; it is distinguished by the darker more evident hypothallus, the darker apothecia, and the epithecium bluish-black in section. It is almost certain from the deseriptions that 'Taylor's $I$. romminuta belongs to this sperics.

The hypothallus of both species and variety is formed of rather stout hyphe with a bluish-bleck tinge of colom reculling the some. what similar hypothallus of Placynthium nigrum.

Hab. On rocks, boulders and walls, rarely on old palings, in maritime and mountainous districts.-Distr. I.ess frequent than the 
preceding in Wales, $\mathbb{\perp}$. England, the Highlands of Scotland and WV. Ireland.-B. M. Barmouth and Dolgelly, Merioneth; Llyn Geirionydd, Carnarvonshire; Borlbury Ring, near ('hurch Stretton, Shropshire; Ayton, Guishoru'. Fildale, Jaysidale and Ingleby, Cleveland, Yorkshire ; Swinhole, Northumberland ; Egrglestove, Durham ; Staveley, Westmoreland; Alston, Cumberland; Crianlarich, Ben Lawers, Killin (corticolous) and Craig Tulloch, Perthshire ; Portlethen, Fincardineshire; Morrone, Braemar, Aberdeenshire; Ben Neris, Invernessshire; Dunkerr.m, Kerry; Twelve Pins, Doughruagh MIts. and Kylemore, Conneınara, Galway.

Var. leptacina Stizenb. Lich. Helv. p. 117 (1882).-Thallus of crowded or scattered thin squamulose minutely crenulate granules, smooth, greenish-straw-coloured on a black hypothallus ( $K+$ yellowish). Apothecia numerous, moderate in size, the disc plane, olive or blackish, sometimes yellowish-pruinose, the thalline margin persistent, generally crenulate; paraphyses and spores similar to the species.-L. leptacina Sommerf. Suppl. F1. Lapp. p. 96 (1826). L. varia var. terrestris Nyl. ex Cromb. Lich. Brit. p. 52 (1870); Leight. Lich. Fl. p. 193 ; subsp. leptacina Cromb. in Journ. Bot. xi. p. 134 (1873) ; Leight. Lich. Fl. ed. 3, p. 177. L. polytropa subsp. intricata var. leptacina Cromb. in Grevillea xviii. p. 69 (1890) \& Monogr. i. p. 439.

Differing from the species in habitat and in the more brightly coloured thallus, very distinct agrainst the dark substratum.

$H a b$. On mosses (Grimmia and Autrwa), upon boulders in alpine regions.-Distr. Rare on the summits of some of the Seottish Gram. pians.-B. M. Ben Lawers, P'erthshire; Ben-na-boord, Braemar, Aberdeenshire.

52. L. frustulosa Ach. Lich. Univ. p. 405 (1810).-Thallus of scattered or contiguous large or small rounded warts which are seamed or cracked, especially at the edges, yellowish or whitish on a black hypothallus ( $\mathrm{K}+$ yellowish). Apothecia small or larese, the dise plane or rather convex, dark-brown or senerally black, the thalline margin entire or crenulate, generally rather prominent, sometimes disappearing; paraphyses coherent, wider and brown upwards, the epithecium dark brown; spores elliposid, 10-14 $\mu$ lon: $5-6$, thirk; hymenial gelatine blue with iodine.-IIowk. Fl. Sowt. ii. 1. 48 d in sm. Engl. Fl. v. p. 189: Muda Man. p. 145; Cromb. Lich. Lrit. p. 52 it Monogr. i. p. 442; Leight. Lich. Fl. p. 196 ; ed. 3, p. 179. Lurhen frustulesus Dicks. Pl. Crypt. fasce iii. p. 1:3, t. s, fig. $10(1793)$; With. Arr. ed. 3,

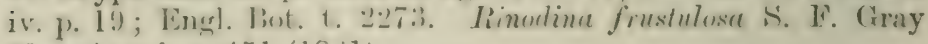
Nat. Arr. i. p. 451 (18:1).

Exsicc. Cromb. n. 165 ? Johns. 12. 80 ; Leight. n. 293.

An alpine or subalpine lichen, distingui-hed by the light-colnured smooth pelished rerrmea, which are finely seamul and cracked, especially at the eireumf rence, giving to the orge a cremulate appearance. 'The reaction with potash is much less marlied than in the 
preceding species, and the spores are smaller; these are present in very fer of our specimens, though the apothecia are fairly abundant.

$H u b$. On siliceous rocks in hilly regions.-Distr. Rare in N. England and among the Grampians, S'cotland.-B. M. Friar's Crag, Keswick; summits of Craig Calliach and Ben Lawers, Perthshire.

5:). L. argopholis Ach. Lich. Univ. p. 346 (1810).-.Thallus subdeterminate, thickish, granulate- or warted-areolate, the craumles contiguous, flattened or rounded, almost imbricate and (renate at the circumference, yellowish or whitish ( $\mathrm{K}+$ yellow). - Ipothecia moderate in size, the disc plane or convex, brownishblack, the thalline margin entire or crenate; paraphyses coherent, suarcely thickened and brown or greenish-black upwards; spores oblong-ellipsoid, 10-18 $\mu$ long, 5-9 $\mu$ thick; hymenial gelatine b) with iodine.-Hook. in Sm. Engl. Fl. v. p. 186 ; Cromb. Lich. Brit. p. 52 \& Monogr. i. p. 441 ; Leight. Lich. Fl. p. 196 ; ed. ", n. 180. Parmetia atru var. argopholis Ach. Meth. Lich. Suppl. p. 32 (1803).

\section{Exsicc. Johns. 11. 267.}

Irequently classified as i variety of $L$. frustulosa, but differs in the more contiguous rimose thallus, in the more pronounced reaction with potash, the crowded apothecia and the larger spores. It differs from $L$. gangalcoides in the colour and the somewhat scaly nature of the thallus and in the less prominent verrucæ.

Hab. ()n rocks in hilly maritime or mountainous regions.-Distr. liather rare but widely distributed in Great Britain and Ireland.B. M. Cleve Hill, Somerset; near Crosfaen, Mommouth; Trefriw, Ilanberis, Glyder Vahr and Carnedd Dafydd, Carnarvonshire; Gunnerton Craggs, Northmmberland; I'ugh Crag, Westmoreland; Bassen- thwaite, Cumberland; Achosragan Hill, Appin, Argyll; Ben Lawers, Perthshire; Ietter Hill and Dawros River, Connumara, Galway.

G. Badiu gronp.--Thallus dark-coloured $(\mathbf{K}-)$. Apothecia dull-brown or hlack, generally small; spores generally rather small.

54. L. badia Ach. Lich. Univ. p. 407 (1810).-Thallus widespreading, thickish, granulate or warted-areolate, sometimes ilmost subsquamulose, especially at the circumference, deep chestnut- or olive-bown, hypothallus black $\left(\mathrm{K}-, \mathrm{Ca}_{2} \mathrm{Cl}-\right)$. Apothecia generally numerous and crowded, small or moderate in size, the dise plane or rarely convex, dull-brown or brownishhlack, the thalline marerin persistent, entire or slightly crenulate, often becoming flexuse, not very prominent; paraphyses thickish, roherent, septate, uneven, often branched, slightly wider at the tips and deep-brown; spores fusiform, $10-16 \mu$ long, $4-6 \mu$ thick. -Mudd Man. p. 141, t. 2, tig. 50 ; Cromb. Lich. Brit. 1. 53 it Monogr. i. p. 451 ; Leight. Lich. Fl. p. 212 ; ed. 3, p. 198. I. squamulose Tayl. in Mackay Ti. Ilib. ii. 1. 13!) (18:36) pon 
parte (non Sm. Engl. Bot.). Lichen barius Pers. in Ust. Ann. Bot. vii. p. 27 (1794). Rinodina badia S. F. Gray Nat. Arr. i. p. $450(1821)$.

Exsicc. Johns. 120 ; Larb. Lich. Hb. n. 334 ; Leight. n. 206 : Mudd n. 110.

Easily recognized by the dark colour of the whole plant and by the fusiform spores. The asci are generally thickened at the apices. The spermogones are frequent, with pleurogenous spermatia, 7-10 $\mu$ long, $1 \mu$ thick. Crombie (Monogr. i. p. 452) remarks on the overlooking of this plant by early lichenologists, but there is one specimen from Teesdale in Sowerby's herbarium as Parmelia squamulosa.

$H a b$. On rocks and boulders from maritime to alpine districts.Distr. General and common throughout the British Isles. $-B . M$. Guernsey; La Moye, Gorey and Noirmont, Jersey; near Penzance, Cornwall; Bolt Head, Devon; Charnwood Forest, Bardon Hill and Thringstone, Leicestershire; Long Mynd, Shropshire; Barmouth and Dolgelly, Merioneth; Llyn Geirionydd, Carnarvonshire; Malvern, Worcestershire; near Buxton, Derbyshire; Cantley Spout and Roseberry, Cleveland, Yorkshire; Teesdale, Durham; Blacklot and Staveley Head, Westmoreland; Ennerdale, Cumberland; New Galloway, Kirlseudbrightshire; Appin, Argyll; Ben Lawers, Perthshire; Nigg and Portlethen, Kincardineshire; Cairu Ture and Morrone, Braemar, Aberdeenshire; Ben Nevis, Invernessshire; Mount Leinster, Carlow ; near Carnlough, Antrim.

Var. cinerascens Nyl. Lich. Scand. p. 170 (1871).-Thallus paler, hrownish-grey, otherwise as in the species.-Cromb. Lich. Brit. p. 54 \& Monosr. i. p. 452 ; Leight. Lich. Fl. p. 213 ; ed. :3, p. 198.

The difference in colour is very striking, and entitles the plant to varietal rank, though it may be the result of shaded growtl.

$H a b$. On shady schistose rocks and walls.-Distr. Local in Wales, the Central Grampians and N.F. S'cotland.-D. MI. Craig 'Tulloch. Blair Athole, Perthshire; P'ortlethen, Kineardineshire.

Subsp. picea Nyl. in Flora li. p. 478 (1868).-Thallus and apothecia black or blackish-brown; spores generally smaller.Cromb. in Journ. Bot. vii. p. 108 (1869); Lich. Brit. p. 54 dt Monogr. i. p. 452; f. picea Leight. Lich. Fl. p. 214; ed. 3, p. 199. Lichen yiceus Dicks. 11. Crypt. fase. iv. p. 222 (1801).

Charncterized by the darker colour. Crombie states that the sporss are smaller and oblong, but they vary even in the sime apothecium from being minute and ellipsoid to the fusiform eondition and size of the species.

Mab. On quartzose rocks in hilly distriets.-1)istr. liare in N. Wheland and among the Grampians, Scotlintl-D. M. W. Yorkahure; Hen Lawers, I'erthshire; Morrone, Braemar, Aberdenshire.

5i). L. austera Nyl, in Filora lvii. p. 309 (18T4).--Thallus sulveterminate, unergually thickish, almost scaly, dark tawnytrown, the hypothallus thin, black, scarcely evident (K-). 
Apothecia rather large, flexuous and deeply crenate-indented, sometimes proliferous with smaller apothecia growing on the margins, the disc dark-brown, the margin thickish, crenulate; paraphyses discrete, septate and uneren, scarcely thickened upwards; spores globose-ellipsoid, up to $9 \mu$ long, $7 \mu$ thick; tips of the asci blue, hymenium otherwise wine-red, with iodine. -Cromb. in Journ. Bot. xiii. p. 140 (1875) \& Monogr. i. p. 453 ; Leight. Lich. Fl. ed. 3, p. 199.

Considered by Crombie to be closely allied to L. Jadia, but differing widely in apothecial and hymenial characters; as in that species, there is a thick wall over the apex of the asci. Spermagones are recorded as frequent, with spermatia $4-5 \mu$ long and scarcely $1 \mu$ thick.

$H a b$. On weathered quartzose stones. $-B$. M. Summit of Ben Cruachan, Argyll (the only locality).

56. L. nitens Ach. Syn. Lich. p. 335 (1814); Nyl. in Flora lii. p. 298 (1869).- Thallus spreading, thickish, crackedareolate, the areolie of rounded granules or somewhat scaly, dullor dark-brown, the hypothallus black, little visible $(\mathrm{K}-)$. Apothecia moderate in size, numerous and crowded, appressed, the dise plane, brownish-black, the thalline margin thin, entire, paler; paraphyses coherent, stoutish, uneven, septate, brown upwards; spores oblong, $9-18 \mu$ long, $2 \cdot 5-4 \cdot 5 \mu$ long; the thickened tips of the asci persistently blue with iodine.-Cromb. in Journ. Bot. xx. p. $274(1882)$ \& Monogr. i. p. 454 . Patellaria nitens Pers. in Ann. Wetter. Ges. ii. p. 12 (181U).

Resembles $L$. badia, but the thallus of our sperimens is lighter in colour and the spores are different, generally they are about $12 \mu$ long and about 31 thick; I have not seen any so long as $18 \mu$. Spluinctrina kylemoriensis grows on this lichen.

Hub. On schistose rocks.-Distr. Local, but plentiful in one of the Channel Islands. $-B$. $M$. Chateau Point, Sark.

57. L. atriseda Nyl. in Act. Soc. Linn. Burd. sér. 3, i. p. 337 (1856) \& Lich. Scantl. p. 170.-Thallus of rounded contiguous or scattererl grauules or warts, reddish- or dull-brown $(\mathrm{K}-)$. Apothecia numerous, rather small, at first immersed in the granules, gradually widening and becoming plane and appressed, concolorous with the thallus, the marwin thin, entire; paraphyses coherent, ratber slender, septate, scarcely wider upwards, or slightly capitite, the epithecium brown; spores ellipsoid, $8-12 \mu$ long, 5-7 $\mu$ thick. - Cromb. in Journ. Bot. ix. p. 17s (1871) \& Monogr. i. p. 453. L. badia var, atrisuda Leight. Lich. Fl. p. 21:3 (18т1); erl. 3, p. 135. Parmeliu buliu rar. utriseda Fr. Nov. Sched. Crit. 182 i, p. 6 \& Lich. Eur. p. 149.

This lichen is always associated with Rhizorarpon gengruphicum. Ifalme (Bot. Centralbl. 1xiv. 1). 46 (1895)) describes the association as it cass of "antagonistic symbiosis," the Leconome gradually unvading and destroying the Rhizocarpon tissues. 
The apothecia may be so crowder as almost to obscure the thallus; the spermogones, which are sparingly present, are embediled in the verruce and blackish at the ostioles, with spermatia 18-20 $\mu$ long, $1 \mu$ thick.

An almormal specimen was described by Sommerfelt (Suppl. Fl. Tapp. p. 103 (1826) ) as Lecanora nephura, but as it refers to a "monstrosity" the name cannot be accepted.

Hab. On rocks in mountainous districts.-Distr. Rare in Wales, N. Englaud and the Grampians, Scotland.-B. M. Dolgelly, Merioneth; Finnerdale, Cumberland; Morrone, Braemar, Aberdeenshire.

58. L. torquata Nyl. in Act. Soc. Linn. Bord. súr. 3, i. p. 338 (1856). - Thallus thickish, generally smooth, cracked-areolate, brownish-mouse-grey $(K-)$; hypothallus black, limiting the thallus. Apothecia small, moderate in size or rather large, lrownish-black, the thalline margin paler; paraphyses thickish, diserete, sometimes branched, moniliform-septate, especially upwards, clavate and brown at the tips; spores varying from globose to ellipsoid when more mature, $5-10 \mu$ long, $3-5 \mu$ thick. -Cromb. in Journ. But. xii. p. 147 (1874) \& Monogr. i. p. 454 ; Leight. Lich. Fl. ed. :3, p. 200. P(tmelia torquata Fr. Syst. Orb. Veg. p. 284 (1825).

A somewhat rave lichen with a wide distribution in the Alps, P'vrenees, ete. The thallus is not unlike that of Lecidea rimosa. The apotheeia in the Alderney specimens are more appressed, with thinner sometimes flexnose and indented margins. The most charac. teristic features are the well-developed paraphyses with the upper cell or cells a clear rich brorvin colour. The spores are larger than the recorted sizes $(7 \mu$ long $)$, and in our specimens are tinged brown, possibly an effeet of age.

IIUT. On moist rockis.- I3. M. Alderney (the only British locality).

59. L. poliophæa Ach. Lich. Univ. 1).398 (1810).-Thallus subdeterminate, dreply cracked-areolate, the areolat composed of "losely packed elongate roundish papillie, greyish- or greenishbrown $(\mathrm{K}-)$. Apothecia numerous, small, adnate to the tips of the papillae, the dise plane, dull-hrown or blackish, the thalline margin thin, crenulate or papillate; paraphyses slender, septate, the tips almruptly davate, sonet imes divided, dark-brown especially over the apex : spores ellipsoid, simple, small, $7-13 \mu$ long, $4-6 \mu$ thick.-Cromb. Lich. Brit. 1, so d Monemg i. p. 40s; Leight. Lich. Fi. 1. 214 ; el. :3, p. 20). L. spentophlap" A.h. tom. cit. p. 385 :

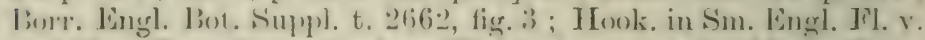

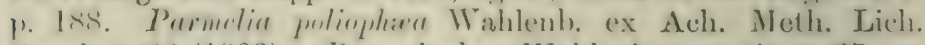

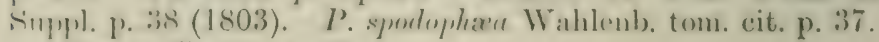

Exsier. Cromb. n. 62.

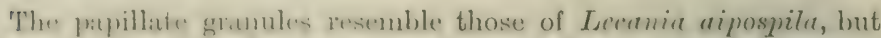
wre more slender. In moist situations the thallus is greenish

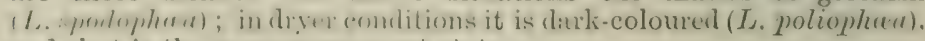
and that is the more permanent state. 
Hab. On granitic and schistose rocks in maritime districts.-Dist Local, though plentiful in the Channel Islands, S. IT. England and N.E. Scotland.-B. M. Le Fret, Jersey; Tolpedin Penwith, and nea: Penzance, Cornwall; Portlethen, Kincardineshire.

60. L. mammillifera Stirton in Trans. Glasgow Soc. Nat. 1875 , p. 85.-Thallus minutely cracked-areolate, dark- or brownish-grey, the areolie plane $(\mathrm{K}-, \mathrm{CaCl}-)$. Apothecia small, prominent, convex, black or brownish-black, internally pale-greyish, the margin (thalline?) obtuse, at length depressed ; paraphyses few, discrete, thickish, brownish at the clavate apices; hypothecium colourless; spores ellipsoid, 8-10 $\mu$ long, $7-8 \cdot 5 \mu$ thick; hymenial gelatine blue then tawny with iodine.-Leight. Lich. Fl. ed. 3, p. 201 ; Cromb. Monogr. i. p. 428. Specimen not seen.

$\mathrm{Hab}$. On rocks in a mountainous district; collected by Stirton at Ben-y-gloe, Blair Athole, Perthshire.

\section{(as genus).}

§iii. Ochrolechia Massal. Ric. Lich. Crost. p. 30 (1852)

Thallus crustaceous. Apothecia small or becoming very large, generally with a thick prominent margin; paraphyses long, slender, branched and intricate; spores $2-8$ in the ascus, usually very large. Spermogones with acrogenous straight spermatia.

This section is rery frequently regarded as of generic importance on account of the peculiar paraphyses and the very large spores.

61. L. tartarea Ach. Lich. Univ. p. 371, t. 7, fig. 3 (1810) (incl. var. grundinosa). - Thallus wide-spreading, thick, tartareous, unequal and corrugate on the surface, of crowded granules or warts, whitish or greyish ( $\mathrm{K}+$ faintly yellow, $\mathrm{CaCl}+\mathrm{red}$ ). Apothecia at first innate and closed, opening widely up to $1 \mathrm{~cm}$. acrosi, the disc generally plane, often wrinkled, pale yellowishred $(\mathrm{CaCl}+$ reddish), the thalline margin thickish, entire or corrugate; paraphyses slender, colourless, loosely coherent, very long, flexuous and branched; spores ellipsoid-oblong, very large, 40-72 $\mu$ long, 20-40 $\mu$ thick; hymenial gelatine blue with iodine.-Hook. Fl. Scot. ii. p. 49 it in Sm. Engl. Fl. v. p. 191 ; Tayl. in Mackay Fi. Hib. ii. p. 13s; Mudd Man. p. 156, t. 2-, fig. 51; Croml). Lich. Brit. p. 54 (incl. var. gromelinosu) it IIonergr. i. p. 45); Leight. Lich. F1. p. 187; ed. 3, p. 175 (incl. f. groudinosist). Lichenoides arustacen et leprosum, acrtabulis majorilns luteis, limlis argenteis Dill. in Ray Syn. ed. :3, p. 71, n. $46(1724)$ id Hist. Musc. p. 132, t. 18, fig. $13(1741)$. Lirhen tartureus L. Fin. Pl. p. 1141 (175:3); Huds. Fl. Angl. 1) 141: Lightf. Fl. Scot. ii. 1) 811 ; Engl. Bot. t. 156; With. Arr. col. :3.

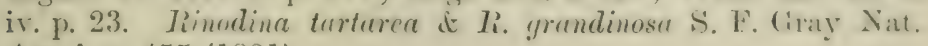
Arr. i. p. 455 (1821). 
Exsice. Bohl. n. 10 ; Croall n. 589 ; Cromb. n. 69 ; Jolns. n. 240 ; Leight. n. 128 ; Mudd n. 128.

A common lichen in upland districts which yields a purple dye (cudbear). The thallus which spreads widely and is frequently sterile is mostly rather thick and friable. The variety grandinosa Ach., with stoutish thalline warts, was founded on a specimen on gorse stems from Teesdale; it does not differ from other corticolous specimons. The apothecia when present are numerous and the disc is sometimes proliferous; the entangled paraphyses make a deep epithecial covering which is interspersed with granules. Specimens with a smooth thallus and with contorted apothecia, sometimes in crowded tubercles, were collected by the late WV. West in N. and W. Scotland. They resemble strongly Pertusaria gyrochrila in thallus and in apothecia. Spermogones are abundant, with minute oblong spermatia.

$H a b$. On rocks and old trunls of trees, rarely on the ground, chiefly in hilly districts.-Distr. General and abundant in Great Britain and Ireland, rare in the Channel Islands.-B. MI. Alderney; Lamorna near Penzance, Cornwall ; Bolt Head and Dartmoor, Devon ; New Forest, Hants; near Sheffield, Sussex; Hemel Hempstend, Herts; Clee Hill, Shropshire ; Cader Idris and Aberdorey, Nerioneth; Capel Curig, Carnarvonshire; Conway Falls, Denbighshire; Highcliff, Cleveland, Yorkshire; Egglestone and Teesdale, Durham; The Cheviots, Northumberland; Tientmere, Westmoreland; Alston, Cumberland; New Galloway, Kirkcudbrightshire; Ayrshire; Pentland Hills and Dalmahoy Hill, near Edinburgh; Kilmun, Ben Cruachan and Barcaldine, Argyll; Glen Falloch, Finlarig, Craig Calliach, Ben Lawers, Amulree, Ciaig Vinean and Craig 'I'ulloch, Blair Athole, Perthshire; Clova, Forfarshire; Portlethen and Nigg. Kincardineshire; Crag Coinnoch, Glen Callater, Morrone and Ben-naboord, Braemar, Aberdeenshire; Rothiemurchus Woods, Glen Nevis, Ben Nevis and I. of Harris, Invernessshire ; Forres, Nailnshire; Applecross, liossshire; Lairg, Sutherland; Ronas Hill, near Lerwick, shetland; Balta Sound, Unst; Doughruagh MIs., Comnemara, Galway; Corraun Mts. and Slievemore, Achill, Mayo.

Var. gronatodes Ach. Lich. Univ. p. 372 (1810). -Thallus in coralloid branches or clevations, or lobate-verrucose. Apothecia vare; spores $36-40 \mu$ lons, $25-2-27 \mu$ thick (fide Nylander Lich. Nov. Zeal. p. 145 (18sis)).-Cromb. in (irevillea xviii. p. 70 : f. gomatorles Leight. Lich. Fl. ed. 3, p. 176 (1879) (excl. 11. eit.). Lichen gonatodes Ach. Lich. Suec. Prodr. p. 89 (1798).

An alpine or subaretie lichen, distinguished ehiefly by the peculiar. thallus ; it is rathere a growth form or an exaggerrated state of the following variety.

Ifah. On deeayed mosse's on the ground in alpine sitnations. fi. 1\%. Summits of ben Aron, Bramar, Aberdeenshire (the omly British record).

Var. frigida Ach. Lich. Tniv. p. :3:2 (1810).-Thallus efinse. mather thin, eranulate. papillate or coralloisl. Apothecia smaller than in the speries (up to $4 \mathrm{~mm}$. arcosss), the thalline margin sometimes proliferous. - Much Man. po 156; Cromb. Jich. Jrit. 
p. 54 ; var. upsaliensis Hook. in Sm. Engl. Fl. v. p. 191 (1833); t. frigida Leight. Lich. Fl. p. 1 S8 (1871); ed. 3, p. 175; f. microcarpa Th. Fr. Lich. Scand. p. 234 (1871); Cromb. in Grcvillea xviii. p. 70 (1890); Hook. Wl. Scot. ii.p. 49 (as var. $\gamma$. ). Lichen frigidus Swartz Meth. Musc. p. 36, t. 2, fig. 4 (1781); With. Arr. ed. 3, iv. p. 22 ; Engl. Bot. t. 1879. L. upsaliensis Dicks. Pl. Crypt. fasc. i. p. 12, t. 2 , fig. 7 (1785) (non Linn.); Fingl. Bot. t. 1634. Rinodine frigida S. F. Gray Nat. Arr. i. p. 555 (1821).

Exsicc. Cromb. n. 70 ; Dicks. Dried Pl. n. 49.

An alpine variety with thinner granular or papillate thallus. A state with minute apothecia occasionally occurs (f. microcarpa Th. Fr. Lich. Scand. p. 234 (1871); Cromb. Monogr. i. p. 458).

Hah. On mosses on the ground of moorlands or mountains.1) istr. Local in E. England and N. Wales and Central Scotland; plentiful among the Grampians, not recorded from Ireland.-B. $M$. Bury St. Edmund's, Suffolk; Cwm Bychan, Merioneth; Ayton Moor, (leveland, Yorkshire; Teesdale, Durham ; Pentland Hills, near Edinburgh ; IBen Cruachan, Argyll; Ben Lawers, Ben Vrackie and Blair Athole, Perthshire; Katelaw and Clova Mits., Forfarshire; Morrone, IBen Macdhui, Glen Dee and Invereauld Mts., Braemar, Aberdeenshire; Ben Nevis, Invernessshire.

Subsp. subtartarea Nyl. in Bull. Soc. Linn. Norm. sér. 2, vi. p. $276(1872)$. - Thallus similar to the species but with sorediate justules or becoming wholly leprose. A pothecia rare, the margin sometimes leprose.-Cromb. in Journ. Bot. xx. p. 274 (1882) \& Monogr. i. p. 460. L. tartarea var. arborea Schær. Enum. p. 80 (1850)? MLudd Man. p. 156 ; subsp. pallescens f. leprosa Nyl. in Not. Siillsk. Faun. \& Fl. Fenn. Förh. v. p. 135 (1866); f. leprosa Leight. Lich. Fl. erl. 3, p. 175. Lichenoides tartareum farinaceum, srutellarum umbone fusco Dill. Hist. Musc. p. 132, t. 18, fig. 12 (1741). Patellaria tartarea var. arborea DC. Fl. Franc. ii. p. 364 $(1805)$ ?

Distinguished chiefly by the leprose thallus, a character not alluded to either by De Candolle or by Schærer.

IIab. On the trunks of old trees and occasionally on rocks in uplind and subalpine regions. -Distr. Probably common, though not often recordci.-13. 14. Roughton, Cornwall; Becky Falls, Devon; liridge liocks, Sussex; Lynn Gwernon, Merioneth; Rosedale, Yorkshire; New (ialloway, Kirkcudbrightshire; Roslin, neax Edinburgh: Barcaldine, Argyll; Ben Vrackie and Craig Calliach, Perthshire; Morrone, Bracnatr, Aberdeenshire; Ronayme's Island, Killarney, Kerry; Clommel, Tipperary; Leenane, Connemara, Galwaly.

62. L. gemimpara Th. Fr. Lich. Scand. p. 236 (1871).Thallus effise, formed of scattered warts or papille, which are roundish or somewhat angular, becoming sorediate, greyish-white ( $\mathrm{K}+$ yellowish-red ; soredia $\mathrm{CaCl}+$ reddish). Apotheeia on the apices of the papillie up to :) mm. across, the dise concare then 
Ilane, purplish-black, the thalline margin thick inflexed, crenate, persistent ; paraphyses conglutinate, intricately branched, brown at the apices; spores 2 in the ascus, ellipsoid, angular from pressure, colourless, becoming dark-coloured, - $-14 \mu$ long, $15-20 \mu$ thick.-Cromb. in Grevillea xviii. p. 70 it Monogr. i. 1. 463. L. leprothelia Nyl. in Flora lvii. p. 16 (1874) (a sterile form); Cromb. in Journ. Bot. xx. p. 274 (1882).

In the absence of fertile specimens it las not been possible to to more than transcribe Th. Fries's account of this plint. It is evidently rare, both here and on the continent.

Hal. On decryed mosses on the ground in alpine places. - B. M. Ben Lawers, Perthshire (the only British record).

63. L. parella Ach. Lich. Univ. p. 370 (1810) (excl. vars.).Thallus wide-spreading, generally determinate, thickish or thin, smooth and submembranaceous or deeply cracked-areolate, whitish or greenish-grey, the hypothallus white $(\mathrm{K}-, \mathrm{CaCl}-)$. Apothecia small or moderate in size, the disc concare then plane or becoming slightly convex, sometimes granular or wrinkled, pale flesh-red or whitish, generally covered with a white pruina $(\mathrm{K}(\mathrm{CaCl})+$ reddish $)$, the thalline margin thick, prominent, entire or wrinkled-crenulate : paraphyses subdiscrete, slender, unequal, flexuose, simple or branched, the tips budding off" small cells (the pruina); spores $4-8$ (rarely 2 ) in the ascus, ellipseid or somewhat globose, $45-88 \mu$ long, $25-50 \mu$ thick; hymenial gelatine blue with iocline. -Hook. Fl. Sent. ii. p. 48 it in Sm. Engl. Fl. v. p. 19] ; Tayl. in Mackay Fl. ILih. ii. p. 137 ; Cromb. Lich. Brit. p. 54 (incl. var. tumidulu, excl. vars. Turneri and upsaliensis) of Monogr. i. p. 461 (incl. f1. crenularia and porinoides); Leight. Lich. Fl. p. 188 pro parte: ed. 3, p. 201 pro parte. L. pallescens vars. purellu and tumidule Murdd Man. p. 155 (1861). Lirhenoides leprosum timbrorum, scutellis lapidium concri figurn Dill. IIist. Muse. p. 130, t. 18, fig. 10 (1741). Lichen purellus L. Mimt. p. 13르 (1767); Lightf. Fl. Scot. ii. p. \$14; ILuds. Fl. Angl. ed. -2, 1. 5:30; With. Arr. ed. 3, iv. I. 17 ; Engl. Bot. t. 727 (as L. perellus). L. tumirlulu. Pers. in Ust. Ann. Joot. xi. p. 1s (179.). Rinodima purella S. F. Gray Nat. Arr. i. p. 453 (1821). Pertusuriu inminatu Leight. in 'Trans. Linn. Soc. ser. 2, i. p. 241, t. 33, figs. 1-3 (1877) tf Lich. Fl. ed. 33, p. 235 (cf. Nyl, in Flora lxvi. p. 534).

Exsicc. Bohl. p. 60 ; Cromb. n. 166 ; Dicks. Hort. Sicc. fasc. x. n. 23 ; Johns. nos. 140, 141, 142, 144 ; Larb. Caesar. 11. 75 \& Lich. Hb. n. 300 ; Leight. 11. 8; Mudd n. 125.

One of the dye lichens known in early days as the l'irelle or (), seille

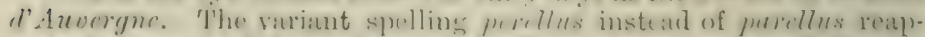
pears in several of the anthom cited. It is a very ermmon lichen on stone walls, ete., and grows well in a mothem asject. The apotheeia are sencrally abundant and are very variable in size; the thalline matgin is often very thiek (var. Inimidula) and prominent, flumgh ometimes ahnost lewel with the thallus; oceusionally the dise is 
almost entirely enclosed (f. porinoides Cromb. Monogr. i. p. 491 (1894)). A dense white pruina is generally present, but the rosecoloured dise is occasionally visible.

Hab. On roclis, walls, and trunlis of trees, ravely on palings, from maritime to mountainous regions.-Distr. General and common throughout the British Isles.-B. M. Boulay Bar, Jersey; Chateau Point, Sark; Penzance and St. Issy, Cornwall; Ilfracombe and Torquay, Devon; Lyndhurst, New Forest, Hants; Iiyde, I. of Wight; Wolstonbury, Walmer, Ardingly Rocks, Peasemarsh and near Hastiugs. Sussex; Greenwich Park and near T'mbridge Wells, Kient; Chelmer, Ulting and Langford, Essex; near Tenby, Penbrokeshire; Barmouth, Nerioneth; Llandyssil, Cardiganshire; Nant Francon and Capel Curig, Carnarvonshire; near Shrewsbury, Shropshire; Hale's End, Malvern, Worcestershire; Bardon Hill, Leicestershire; Silverdale. Lancashire; Arton, Cleveland, Yorkshire; Egrglestone, Durham; Tastdale and St. Bees, Cumberland; Chollerford and Wansbeck Talley, Northumberland; Arthur's Seat, Edinburgh; West Miater. Fife; Airds, Barcaldine, Lismore and Ballichulish, Argyll; Ben Lawers, Aberfeldy and Craig Tulloch, Blair Athole, Perthshire; Sidlaw Hills and Baldovan, Forfarshire; Portlethen and Cove, Fincardineshire; Norrone, Glen Callater and Glen Dee, Jiraemar, Aberdeenshire; Glen Nevis, Invernessshire; Applecross, Rossshire; Brandon Mt.. Kerry; Clare Island and Achill, Mayo.

Form nivea Cromb. Monogr. i. p. 462 (1894).--Thallus and thalline margin of the apothecia soft, snowy-white; otherwise as in the species.

A transition form evidently between the species and var. Turneri. It has only been collected once, but has probably been overlooked.

Hab. On the trunk of an old tree in an mpland situation.-B. II. Iillaloe, Clare.

Var. Turneri Nyl. in Mém. Soc. Sci. Nat. Cherb. v. p. 113 (1857).-.Thallus more or less leprose-pow wery, whitish or greenishwhite. Apothecia similar to the species but the thalline margin leprose.Cromb. Lich. Brit. p. 54 it Monogr. i. p. 462 ; f. Turneri Leight. Lich. Fl. p. 190 (1871); ecl. :, p. 203. L. Turneri Ach. Fyn. Lich. p. 70 (1814); Hook. in Sm. Engl. Fl. v. p. 191. L. palles"ens var. Turneri Mudd Man. p. 155 (1861). Lichen Tuneri Sn. Engl. Bot.t. 85T (1801). Rinodina Turneri s. F. Gray Nat. Arr. i. p. 454 (1821).

\section{Exsicc. Leight. n. 237 ; Mudd n. 127.}

A corticolous rariety distinguished by the powdery sorediate surface of the thallus. The margins of the apothecia. nsually entire, ate oceasionally furrowed, ns also in the species (f. subcrenate ('romb. in Grevillea xviii. p. 70 (1890) \& Monogr. i. p. 462).

Frb. On trunks of old trees in wookerl regions.-Distr. Iiather rare throughont the Iiritish Isles, - B. M. Cglorooke Park, C'lunleigh, Devon; Carisbronk and Jembridge, I. of Wight; New Forest. Iants ; Hurstpierpoint, Chichester and Jalcombe, Sussex; Holmwood, Surrey; Epping Forest and st. Osyth l'ark, lisex; Sarernale Forest. Wilts : 
near Barmouth, Merioneth ; near Ayton, Cleveland, Yorlsshire ; Egglestone, Durham; Loch Creran, Barcaldine and Inverary, Argyll; Morrone, Braemar, Aberdeenshire; Old Deer Park, Castlemartyr. Cork; Muckross, Killarney, Kerry.

64. L. pallescens Mudd Man. p. 155 (1861) (? Linn.) ; Nyl. in Bull. Soc. Linn. Norm. sér. 2, ii. p. 68 (1868).-Thallus rather thin and membranaceous or zonate at the circumference, becoming sometimes thickish and wrinkled-granular, whitish or greyish, bounded by a white hypothallus $(\mathrm{K}-, \mathrm{CaCl}-)$. Apothecia small or moderate in size, the disc concave then plane or wrinkled, faintly yellowish-pink, generally white pruinose $(\mathrm{K}(\mathrm{CaCl})+$ reddish), the thalline margin prominent, entire $(\mathrm{K}(\mathrm{CaCl})+$ reddish); paraphyses slender; spores 8 in the ascus, ellipsoid, up to $64 \mu$ long, 18-34 $\mu$ thick.-Cromb. in Grevillea xviii. p. 70 (1890) \& Monogr. i. p. 46:; var. tumidula Mudd Mian. 1. c. L. tartarea sulsp. pallescens Cromb. Lich. Brit. p. 54 (1870) pro parte. L. parella f. pallescens Leight. Lich. Fl. p. 189 (1871) pro parte; ed. 3, p. 202 pro parte. Lichen pallescens L. S.p. Pl. p. 1142 (1753).

Eirsic. Juhns. n. 1\$3 ; Larb. Caesar. n. T6 ; Mudd n. 126.

Generally with a thimner thallus and smaller apothecia than L. parella, from which it differs in the corticolous habitat, but chiefly in the reaction of the apothecial margin.

Hab. On trunks of trees.-Distr. Rare throughout the British Isles.-B. M. Jersey ; Lameeston, Cornwall ; near Lustleigh, Devon ; New Forest, Hants; Shanklin. I. of Wight; near Hastings, Sussex; Barmonth, Merioneth; Trefriw, Carnarronshire; near Easby, Clereland, Yorkshire; Barcaldine, Argyll ; Ben More, Perthshire.

65. L. upsaliensis Nyl. ex Norrl, in Not. Siillsk. Faun. \& Fl. Fenn. Förh. xiii. p. $332(1873)$. -Thallus effuse, continuous or of scattered rounded smooth granules, greyish-or yellowish-white $(\mathrm{K}-, \mathrm{CaCl}-)$. Apothecia rather small, the disc concave, becoming plane, generally densely gramular-pruinose, the thalline margin thickish, entire; paraphyses slencler; spores 4 to 8 in the asmus, $55-58 \mu$ long, $26-38 \mu$ thick.-Croml, in Grevillea xviii. p. 70 a Monogr. i. p. 1633 ; Leight. Lich. Fl. p. 192; ed. 3, P. 176 (excl. Syn. Engl. liot.). I. promella var. upsaliensis IIouk. Fl. Ścot. ii. p. 48 (1821)? Cromb. Lich. Brit. p. 54. Lielen upsalieme is T. Sp. Pl. p. 1142 (1753): S. F. Gray Nat. Arr. i. p. 454 (as the Upsal Rinodine)?

Diflers from $L$. parella in the halbitat and in the charneter of the thallus. It is possible that Hooker's and (iray's citations may refer to $L$. tarlarea var. frigilla.

Ilab. Inerusting mosies on the ground in alpine sitnations.- Disfr. Very rare on the (irampiams, Sicotland.-D. M. Craig Cilliatch. Perthshire; Morrone, Bracmar, Aberdeenshire. 
§iv. Aspicilia Massal. Ric. Lich. Crost. p. 36 (1852) (as genus); Mudd Man. p. 161.-Thallus variously crustaceous. Apothecia innate in the thallus then more or less emergent, the thalline margin persistent or disappearing, the proper margin often prominent; hypothecium nearly always colourless; paraphyses generally simple and densely septate; spores ellipsoid, large or small.

Aspicilia is frequently classified as a genus, as the early stages of apothecial development differ from those of Lecanora, being more alin to those of Lecidea, the thalline margin, which may be prominent and persistent, growing up with and around the apothecium as a later development. Lecanora Dicksonii and $L$. petobotrya are retained for convenience of reference, but they are more truly Lecidece.

There are two groups differing in the gonidia:-

A. EUaspicilia.

Algal cells Protococcacece.

B. Joxaspis ...................... Algal cells Trentepohlia.

\section{A. Euaspicilia-Algal cells Protoçoccus.}

\section{Thallus whitish or cinereous-grey, $K+$ yellow then red.}

66. L. cinerea Sommerf. Suppl. Fl. Lapp. p. 99 (1826).Thallus effuse or determinate, cracked-areolate, brownish- or whitish-grey ( $\mathrm{K}+$ yellow, then rusty red, $\mathrm{CaCl}-$ ). Apothecia rather swall, at first immersed and concave, hecoming sessile and plane, the dise black, the thalline margin entire; paraphyses coherent, septate, generally divided in moniliform fashion near the tips, the epithecium dark-brown; spores ellipsoirl, 8 or sometimes 6 in the ascus, 15-2:) $\mu$ long, 8-14 $\mu$ thick; hymenial relatine blue then wine-red with iodine-Cromb. Lich. Brit. p. 54 it Monogr. i. p. 466 ; Leight. Lich. F'l. p. 195 ; ed. 3, p. 172 (incl. ff. rimosn-areolata, diffracto-areolatu and vernecoso-areolata). Lichen cincreus L. Nant. i. p. 132 (176)? Huds. Fl. Angl. ed. 2, p. 525 ? Ach. Lich. Suec. Prodr. p. 32 (1798); Engl. Bot. t. 1751. Erepolaria cinerea Ach. Meth. Lich. p. 143 (1803); S. F. Gray Nat. Arr. i. p. 458; Hook. in Sm. Engl. Fl. v. p. 172 ; Tayl. in Mackay Fl. Hib. ii. p. 132. Aspicilia cinerea Korb. Syst. Lich. Germ. p. 164 (1855); Mudd Man. p. 162 pro parte.

Exsicc. Johns. n. 270.

A very variable plant as regards growth stages both of the thallus aur the apothecia, so that the reaction with potash is of great value in determining the different forms. The thallus spreads extensively though generally limited. The apothecia are abundant. Crombie has inchuder as it growth stage Lecanora calcarce f. ochracea Leight. Lich. Fl. (4l. 3, p. 193 (1879); as it is hased on Cmoluria cintrea var. ochracra sichar. Spicil. Fl. Helv. p. 72 (1826) it evidently belongs luere, but the British Aluseum specimen of f. ochracia (Leight. exs. 11. 292) is $I$. flavida. Another specimen libbelled Parmelin cincrea var. atrocinerea (Leight exs. n. 205) is imperfect but evidently a Lreidfa. Another very small specimen from Jersey (w)llected by 
Larbalestier and libelled $L_{\text {. }}$ errinea gives the same chemical reaction. but the spores are much smaller. The citations from Limuens and Hurlson are extremely doubtful. Aspicilia rincrea var. ocrlatu Mudd 1. c. is probably identical with Buellia verruculosa (Monogr. ii. p. 172). Spermogones are frequent with spermatia, 16-21 $\mu$ long. and $1 \mu$ thick.

According to Hue (Nouv. Aich. MIus. Paris sér. 5, ii. p. 35 (1910): the black hypothallus so frequently present belongs to some neighbouring species.

Hab. On rocks and walls in maritiue and mountainous districts.Distr. liather locul but widely distributed throughout the British Isles.-I3. M. Moulin Huet Bay and Viale Cistle, Guernsey; La Coupe, Jersey; Bray Hill, St. Minver and Lizard, Corntvall ; Lazonby, Cumberland; Cader Idris and Barmouth, Merioneth; Snomiton, Cirmarvonshire, Teesdale, Durlam ; near Edinburgh ; Barcaldine, Argyll; Ben Lawers and Glen Lochay, Killin, Perthshire ; Portlethen, Kincardineshire; Wicklow; Lambay Island, Dublin.

Form lepidota Leight. Lich. Fl. ed. 3, p. 173 (1879).Thallus brownish-grey, areolate, the areolie convex and wrinkled. Apothecia small, the thalline margins prominent, persistent.Lecanora cinerea var. lepridota Leight. in Grevillea iii. p. $116 \mathrm{j}$ (1875) ; Cromb. Monogr. i. p. 467.

Differs in the form of the thallus which is more squamulose ant darker.

Hab. On maritime rocks and by lakes in mountainous districts.-Distr. Reported only from the Channel Islands and N. Wales.-I. M. Beaufort, Jersey; Llyn Dinas near Beddgelert, Camarwonshire.

Subsp. epiglypta Nyl. in Flora lxiv. p. 4 (1S81)....'Thallus similar to that of the species. Apothecia becoming rather larece and prominent, the disc corrugate with pominent lines.Cromb. in Grevillea xix. p. 57 (1891) \& Monogr' i. 1. 467.

Characterized by the peculiar apothecia which have a somewhat gyrose appearanee. ITue has given it specific distinction (Nouv. Areh. AIus. Paris sér. 5, ii. p. 7 (1910) ). He found cephatodia within the: thallus and under the hymenium associated with filererpsa algie.

$\mathrm{Hab}$. On schistose rocks in mountainous districts.-Distr. Rave in N. Wales and W. Scotland.-13. H. ('ader Idris, Merioneth: Barcaldine, Argyll.

Var. olivascens A. I. Sm. Thallus thinner than in the species, smonth and somewhiat shinins, cracked-ineolate. Apothecia small, immersed or rather fuminent, the paraphyses dark blur. green at the tips, otherwise as in the species.

Differing form the spereies in the thimer more shining thallus and in the blare-green tips of the paraphyses. Ilhe contents of the spores in some cases are lorken np and look like two large globules. The differences may be due to habitat.

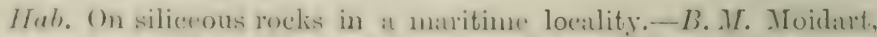
Insermesshire (the only recombl), collected by symers M. Maevicar. Jan. 1914. 
67. L. intermutans Nyl. in Flor: lv. p. 354 (1872).-Thallus (leterminate, deeply cracked-areolate, whitish- or brownish-grey ( $\mathrm{K}+$ yellow then rusty-red, $\mathrm{CaCl}-$ ). Apothecia immersed, the disc concave, blackish, the thalline margin prominent, entire, becoming inflexed; paraphyses slender, moniliform-septate upwards; spores usually 8 in the ascus, $23-34 \mu \operatorname{long}, 9-15 \mu$ thick; hymenial gelatine bluish then wine-red with iodine.Cromb. in Grevillea xix. p. 57 (1\$91) \& Monogr. i. p. 164.

Differs from the preceding species in the larger spores and, according to Nylander, in the smaller spermatia (7-9 $\mu$ long, $1 \mu$ thick). In the single specimen in the British Musem the spores measure about $20 \mu$ in length, and contain two large guttulie. The speeies is recorded from the Pyrenees and from N.W. France.

Hab. On schistose rocks in a maritime district.-B. MT. Near Kiylemore, Connemara, Galway.

68. L. alpina Sommerf. Suppl. Fl. Lapp. p. 91 (1826).Thallus indeterminate, deeply cracked into rounded or angular somewhat warted areola, grey or leaden-greyish on a black hypothallus ( $\mathrm{K}+$ yellow then red, $\mathrm{CaCl}-$, medulla $\mathrm{I}+$ blue). Apothecia numerous, immersed then superficial, the disc plane, redclish or black, the thalline margin prominent; paraphyses septate, clavate and brown at the tips, with a deep brown line over the apex: spores ellipsoid, 9-13 $\mu$ long, 6-8 $\mu$ thick; hymenial gelatine blue with iodine-Cromb. in Grevillea xix. 1. 57 (1831) \& IIonogr. i. p. 468 (non Leight. in Grevillea i. 1). 125 (1873)). L. cinerio-rufescens Cromb. Lich. Brit. p. 55 (1870) (non Nyl.); Leight. Lich Fl. p. 211 ; ed. 3, p. 197 (non Nyl. fide Cromb. Monogr. i. p. 468, note).

Differs from $L$. cincred in the much smaller spores and the blue reaction of the medulla with iodine, a peculiarity shared by $L$. cinereoinfescens. Spermogones hiwe spermatia $4-6 \mu$ long, and about $1 \mu$ thick. L. Myyrini Nyl. (Leight. Lich. Fl. ed. 3, p. 173) is not British.

Hab. On a mica-schist rock in an alpine situation.-D. M. Ben Lawers, Pertbshire (the only British record).

\section{b. Thallus white or whitish-grey, $K-$.}

69. L. calcarea Sommerf. Suppl. 11. Lapp. p. 102 (1826).Thallus effuse or distinctly determinate, often wide-spreading, smooth or farinose, continuous or cracked-areolate, chalky- or (rreyish-white, sometimes greenish at the circumference (K-, $\left.\mathrm{CaCl}^{-}\right)$. Apothecii generally crowded, immersed, small, irregular in form, becoming plane, the disc black, whitishpruinose, the thalline mawin entire or wrinkled; paraphyses lonsely coherent, slender, septate, more or less moniliform at the tips, the epithecium dark-brown; spores ellipsoid or subghohose, with a thick epispore, $18-30 \mu$ long, $14-27 \mu$ thick ; hymenial gelatine blue with iodine,-Cromh. Lich. Brit. p. 5t of Monogr. i. P. 473 ; Lcight. Lich. 11. P. 209 ; erl. :3, p. 192 (incl. f. concretı). 
Lichen calcareus L. Sp. Pl. p. 1140 (1753); Huds. Fl. Angl. p. 442 ; With. Arr. ed. 3, iv. p. 6 pro parte. L. tessellatus Sm. Engl. Bot. t. 533 (179s). L. multiqunctus Sm. op. cit. t. 820 (1800). Urcestaria crlicarea Ach. Meth. Lich. p. 142 (1803); S. T. Gray Nat. Arr. i. p. 459 ; Hook. in Sm. Engl. Fl. v. p. 172 ; Tayl. in Mackay Fl. Hib. ii. p. 132 ; var. concretu S'cher. Spicil. Lich. Helv. p. 73 (1826). U. tessellata Acb. l. c.; S. F. Gray tom. cit. p. 460. Aspicilia culcarea Kœrb. Parerg. Lich. p. 94 (1859); Mudd Man. p. 161, t. 3. fig. 55.

Exsicc. Johns. nos. 145, 146 ; Larb. Lich. Hb. n. 166 ; Leight. n. 13 ; Mudd n. 133.

Easily distinguished by the whitish thallus (except in var. Hoffmanni which is bluish-grey) and by the black apothecia at first immersed, then often with prominent margins. The typical condition of the plant with the areolie contiguous and angular has been described as var. concreta. Two figures in Engl. Bot. Lichon tessellatus and Lichen multipunctus evidently belong here. The former has been doubtfully cited under Verrucaria viridula (Monogr. ii. p. 284).

The spermogones, according to Crombie, are frequent and dark coloured, with spermatia 7-9 $\mu$ long, about $1 \mu$ thick.

$H a b$. On calcareous (rarely granitic) rocks and walls in maritime and upland regions.-Distr. General and common in limestone districts.-B. M. Near Penzance, Cornwall; Plymouth and Torquay, Devon; Bathampton Downs, Somerset; Mid-Sussex Weald; Folkestone, Kent; Cuddeson, Oxfordshire; Burgh Castle, Suffolk; Malvern Hills, Worcestershire; Llanymynech, Shropshire ; Barmouth, Merioneth; Llangollen, Denbighshirc; Great (Orme's Head, Carnarvon; Anglesea; Cunning Dale, near Buxton, Derbyshire; Lilsdale, Yorkshire; Egglostone, Durham; Lerens, Westmoreland; Lismore and Appin, Argyll ; Craig Tulloch, I3lair Athole. Perthshire; Morrone, Braemar, Aberdeenshire; Dunkerron and Killaruey, Kerry ; Maam, Connemara, Galway; Clare Island and Castlebar, Mayo.

Var. contorta Hepp Flecht. Eur. n. 6:9 (1860).-Thallus of scattered or contiguous squamule-like areole which are rounded or angular and crenulate, often raised in the centre, white or greyish-white. Apothecia immersed in the areole, small, spores ellipsoid or subglobose, somewhat smaller than in the species, up to abrut 25 $\mu$ lone, $17 \mu$ thick.-Cromb. Monogr. i. p. 474; f. comtonta Iseight. Lich. El. ed. 3, 1. 19:3 (1879). Vermeariu contorta Hoffin. Pl. Lich. i. p. 97, t. 22, figs. 3-4 (1790). Ureeolerie contorte. D)C. Fl. Erane. ii. P. 370 (1.805); Tayl. in Mackay Fl. Hib. ii. p. 1:32. Aspuritie calcuren var. contorte Mudd Man. p. 162 (1861).

Exsicc. Johns. n. 147 ; Leight. n. 322.

Distinguished by the sinttered and generally rounded thalline arcolx.

Ifab. On calcareons melis rhicfly in upland distriets.-Distr. Rather rare in (ireat, fritain and freland,-13. M. Near Kingskeswoll, Devon; Symond's Yat. Herefordshire; near Malvern, Woreester:hire; near (Jowrotry, Shropshire ; (Breat ()me's Ifead, C'arnarvon- 
shire ; Nerton, Cleveland, Yorkshire; Teesdale, Durham; Alston, Cumberland; The Ochills, near Stirling; Craig Tulloch, Blair Athole, Perthshire; Craig Guie, Braemar, Aberdeenshire; The O'Donoghue's Prison, Killarney, Kerry.

Form monstrosa Cromb. in Grevillea xix. p. 57 (1891) \& Monogr. i. p. 474.- Thallus of small scattered round areolie, somewhat convex and entire at the margins, white. Apothecia minute, undeveloped.- $L$. calcarea var. monstrosa Lamy in Bull. Soc. Bot. Fr. xxx. p. 392 (1883).

A very neat form, of small button-like white areolæ on a dark background of gelatinous algxe, etc. A central dark dot marks the position of the apothecia. Crombie has suggester that it may be only a young condition.

Hab. On calcareous stones of a wall.-B. M. Glen Fender, Blair Athole, Perthshire (the only British locality).

Var. Hoffmanni Sommerf. Suppl. Fl. Lapp. p. 102 (1826).-Thallus rather thick of squamule-like contiguous warts, or thinnish and cracked-areolate, whitish- or cinerous-grey. Apothecia generally prominent, the margin often crenulate; spores 21-34 $\mu$ long, 16-20 $\mu$ thick.-Cromb. Lich. Brit. p. 5t (excl. syn.) \& Mlonogr. i. p. 475 ; f. Holfmanni Leight. Lich. Fl. p. 209 ; ed. 3, p. 193. Lichen Hoffmanni Ach. Lich. Suec. Prodr. p. 31 (1798); Engl. Bot. t. 1940. Urecolaria Hoffmanni Ach. Meth. Lich. p. 145 (1803) ; S. F. Gray Nat. Arr. i. p. 459.

Exsicc. Johns. n. 148.

Near to the previous variety, but with more crowded, sometimes continuous thallus. Not unlike L. gibbosa in eolour, but differmg in the form of the thalline warts.

$H a b$. On rocks and walls, mainly calcareous, in maritime and upland districts.-Distr. Rare in Great Britain and W. Ireland.B. Ir. Meachy Heal, Sursex; Duffield, near Cirencester, Gloucestershire; Cnance's P'itch, Malvern, Worcestershire; IBuxton, Derbyshire; near Roseberry, Cleveland, Yorkshre ; Levens, Westmoreland ; Ben Cruachan, Argyll; Glen Fender, Blair Athole, Perthshire; Portlethen, Kineardineshire; Doughruagh Mts., Comemara, Galway.

70. L. pelohotrya Sommerf. Fl. Lapp. Suppl. p. 99 (1826).Thallus thickish, cumposed of large irlesular crowded warts rounded or plane, smooth, whitish $\left(\mathrm{K}-, \mathrm{C}_{2} \mathrm{Cl}-\right)$. Apothecia small or moderate in size, immersed or becoming -uperticial, the dise brownish-black, the thathe marrin inflexed; hypothecium brownish-black ; paraphyses long, sleuter, tlexuose, srptate and dark-brown near the tips; spores $4-5$ in the ascus, ellipsoid or oblong-ellipsoil, 2:3-35) $\mu$ long, 12-16 $\mu$ thick; hymenial gelatine blue with iodine -Leight. Lich. H1. ed. 3, p. 469; Cromb. Monogr. i. p. 469. Urceolaria pelubutrion Wahlenb. ex Ach.

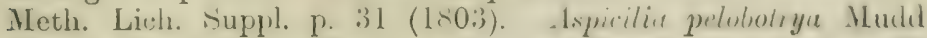

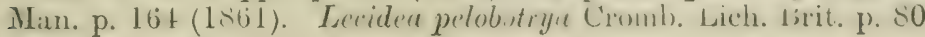
(1870); Leight. Lich. Fl. p. 298. 
liesembling Leemoru in the thalline margin, though frequently. placed in Lfrition on accomnt of the dark hypothecium. Warted scabrir pale-rectlish cephalodia, containing Glrocapsa gonirlia, are al)umlant on some of the specimens, but are absent from those growing in streams (f. rivularis Cromb. Monogr. i. p. 470).

IIah. On micr-schistose rocks in alpine places.-Distr. Rare on 2he Grumpians, Scotland.- B. .I. Loch-na-Gat, Ben Lawers, Perthshire.

\section{c. Thallus grey, of prominent or isidia-like warts, $K-$.}

71. L. verrucosa Laurer $\times x$ Sturm Deutschl. Fl. Krypt. ii. 2x, p. 6:3, t. 21 (18:35).-Thallus effuse, irregularly squamulosewarted, sometimes slightly pulverulent, greyish-blue-white $(\mathrm{I}-\mathrm{CaCl}-)$. Apothecin immersed, then prominent on the warts, small, the dise black with a narrow black rim surrounderl with a thickish thalline malgin; paraphyses coherent, slender, flexuose, submoniliform-septate and dark-brown above; asci large, with a thickish wall when mature, 8-spored ; spores large and thick-walled, bxoadly ellipsuid, variable in size, up to about (i.) $\mu$ long, and $30 \mu$ wide (often about $50 \mu \times 30 \mu$ ); hymenial selatine blue then quickly wine-red with iodine.-Cromb. Lich. lirit. p. js; in Grevillea i. 1) 17.2 \& Monogr. i. p. 475 ; Leight. Lich. Fl. 1). 214 : ed. 3, 1. 200. Urecolaria vermesa Ach. Lich. T'niv. p. 3:39 (1810). A.puirilir veimeosa Koerb. Syst. Lich. Germ. p. 167 (1855); Mudd Man. p. 164.

Exsice. Cromb. n. 73.

Well characterized by the large spores and by the habitat.

Hab. Incrusting mosses on rocks (chiefly calcareous), rarely on the ground in upland and subalpine situations.-Distr. Iiare in X. England and the Grampians, Sicotland.-B. M. Cunswick Scar. Westmoreland; Loch-na-Gat. Jien Jawers and C'raig 'Tulloch, Blair Athole, Perthshire.

72. L. poriniformis Nyl, in Flora xlviii. 13. 353 (1865).Thallus effuse, thinnish, membranacous and continuous or thicker and cracked, whitish-grey (K - ). Apothecia small, embedded in the thallus, then energing in rounded prominent verrucas either singly or : $\mathrm{t}$ to 1 in one verruca ; the dise rose-coloured or whitish, the thatline matgin thick, not prominent; paraphyses crowded, slemder, septate and hranched ; spores 6 to 8 in the ancens, collipsoid or wribl, large, with a thimnish wall, 50-80 $\mu$ long, 27 -5) $p$. thick : hymenial gelatine hue then tawny-yellow with iodine.-Carroll in Joum. lint. iv. p. 23 (1866); Cromb. Lich. Brit. 1) 56 ; in Cirerillea i. 1. 172 d Monugr. i. 1. 176; Leight. Lich. Fl. p. 190 ; ed. 3, p. 203.

Exsicc. Cromb. n. 74 ; Johns. n. 274.

In endenie species resemblins a l'erlusaria when mature, but ditiering in the catly tateres, the warts developing along with and as part of the apothecia. These are scattered or crowded. 
Hab. On siliceons rocks or walls, rarely incrusting mosses on trunks of old firs in maritime and subalpine districts.-Distr. Iiare in N. England (Cumberland and Westmoreland), and among th. Grampians and N.E. Scotliund.-D. M. X. Engliand; Hen Lawers and Craig Tulloch, Purthshire ; Portlethen, Ǩincardineshire.

73. I. leucophyma Leight. Lich. Fil. p. 205 (1871).Thallus of contiguous or scattererl smonth rounded or contorted warts or papillie, pale- or pinkish-grey, pale-yellow within $(\mathrm{K}-, \mathrm{CaCl}-)$. Apothecia moderate in size, the disc brownishred or black, the thalline margin prominent, entire, becomings flexuose; paraphyses slender ; spores broadly ellipsoid, thick. walled, very linge, 2:3-35 $\mu$ long, up to $20 \mu$ thick.-Leight. op. cit. ed. 3, p. 188 ; Cromb. Nonogr. i. p. 465.

Easily recognized by the papillas of the thallus. The apothecia inre rare, the spores vary greatly in size ; as $L$. arerptrnter Nyl. (near to L. complanala Kioerb.), it was deseribed in Flora lxii. p. 204 (1879) with spores $2: 3-27 \mu \times 11 \mu$. The above measurements are from Leighton's specimen. Spemogones are present with minute spernatia $1 \cdot 5 \mu$ long, $\cdot 5 \mu$ thick.

Hab. On micaceous rocks in alpine situations.-Distr. Rare among the Grampians, Scotland. $-\bar{B}$. $M$. Ben Lawers and Crair Calliach, Perthshire.

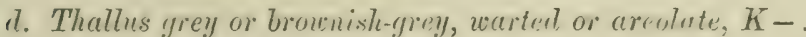

74. L. gibbosa Nyl, in Not. Siillsk. Faun. \& Fl. Fenn. Firh. n.s. v. p. 137 (1\$66).-Thallus determinate, thich, deeply crackerl, the areole warted or "gibbous," light- or dark-grey or dark greenish-brown on a black hypothallus $(\mathrm{K}-, \mathrm{CaCl}-)$. Apothecia rather small, immersed and concare, becoming plane, the dise brown then blackish, the thalline margin entire or slightly. (renulate, persistent: paraphyses coherent, long, subflexuose, rarely branched, thickly septate, moniliform towards the tips. which are generally brownish, or the epithecium dark-brown: spores $4-8$ in the asculs, ellipsoid or subslobose, large, with a distinct epispore, $21-38 \mu$ lona, 12-24 $\mu$ thick ; hynenial gelatine blue, then quickly wine-red with iodine.-Cromb. Lich. Brit. p. 55 pro parte of Monogr. i. p. 460 (excl. var. luser). Leight. Lich. F1. p. 210 (excl. fli. lurustris and punctata); ed. :3, p. 1!1.4 (incl. ff. cullyaris, pminoidea, squamatn). $L$. aspersu Borr. in Engl. Bot. Suppl. t. 2728 (18:32); Hook. in sm. Engl. Fl. ।. p. 188. L. tulerculosa IIonk. 1. c. (18:33). Lichen giblieses. Arh. Lich. Suec. Prodr. p. 30 (1798); Dicks. Pl. Crypt. firse. ii. p. 20. t. 6, fig. 5 (1790)? With. Arr. erl. 3, iv. p. 20? L. fillowsus sim. Engl. Bot. t. 173:- (1807). L. tuberculeses Sm. tom. cit. t. 17:3:i. Urceolaria giblusa Ach. Meth. Lich. 1) 144 (1<0:3); \$. F. (ima. Nat. Arr. i. p. 458 (incl. var. fimliniatu); Hook. in Sm. Engl. 1\%. v. p. 172. U. fimbriata Ach. tom. cit. p. 145. línodina tuber-

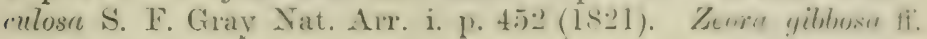


porimoidea \& squamata Flot. in Uebers. Schles. Ges. Vat. Cult. 1850, p. 128. Aspicilia giblosa Koerb. Syst. Lich. Germ. p. 163 (1855); Mudd Man. p. 162.

Exsice. Cromb. n. 167 ; Johns. n. 271 ; Larb. Lich. Hb. n. 220 ; Leight. n. 175 pro parte.

A very variable plant, hence the many different growth forms; it is "fibrose" or fimbriate when growing on bare flints, with the thalline areolis scattered over the dark radiating hypothallus. Occasionally these areolie swell into rounded warts ( $L$. tuberculosus), or they may, in moist conditions, become sorediate ( $L$. aspersu). Specimens with crenulate apothecia have been classified as f. porinoider. All or some of these different forms may occur on the same specimen. Spermogones are frequent on young plants, with spermatia 7-10 $\mu$ long, $1 \mu$ thick.

$H a b$. On rocks and stones (chiefly flints) in maritime and hilly districts.-Distr. Local, though plentiful in S.W. and N. England, rare in Wales and Scotland.-B. M. Chesil Beach, Portland Island. Dorset; Lyndhurst Mooi, Hants; Ryde, I. of Wight; Lewes, S. Downs, St. Leonards, Beachy Head and West Dearı, Sussex; I,ydd Beach, Kent; Hereford Beacon, Malvern, Worcestershire; Crossfaen. Monmouthshire; Cader Idris, Merioneth ; Caer Caradoc and Longmynd, Shropshire; Bury St. Edmund's, Suffolk; Cleveland, Yorkshire; Teesdale, Durham; Cumberland; Appin, Argyll.

Var. zonata Wain. in Medd. Soe. Faun. \& Fl. Fenn. vi. p. 168 (1881). - Thallus thin, cracked-areolate, determinate and zonate at the circumference with concentric lines and limited by a black hypothalline margin. Apothecia as in the species.-Cromb. in Grevillea xix. 1). 57 (1891) \& Monogr. i. p. 471. Sugedia zomutu Ach. in Vet. Akad. Handl. 1809, p. 16.5 \& Lich. Univ. p. 829 (1810).

A well-marked variety, evidently very rare. Crombie l. c. has suggested that $L$. gilbbosa var, squanatu 'Th. Fr. Tich. Seand. 1. 276 (non Flot.) may probably be an early stage of this variety.

$H a b$. On siliceous stones in maritime and upland situations.Distr. Very rare in S.E. England.-..1. M. Downs, Sussex; Lydd Beach, Kent.

Subsp. depressa Nyl. in Not. Sïllsk. Faun. of Fl. Fenn. n.s. r. p. 137 (1866) (incl. f. obsentuta).... Thatlus thickish, crackedareolate, dark-grey or blackish. Apothecia somewhat small, inmersed and thinly margined, then emergent, plane and immarginate; paraphyses slender, moniliform-septate and rlark-brown at the tips; spores ellipsoid, with a distinct epispore, 16-24 $\mu$ long, 8-14 $\mu$ thick; hymenial gelatine blue, the asci wine-red, with iodine.-Cromb. Lich. Brit. P. 5is it Monogr. i. p. 471; f. depressa Leight. Lich. bl. p. ㄴl0 (1871) (excl. syn. A(h.); ed. 3, p. 194 (excl. syn. Ach.).

Distinguished by the inmersed inmarginate apothecia. It has been givens specifie rank by II ue (Nour. Areh. Mus. Paris 1910, p. 82) 


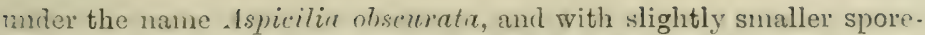
mu asurements than obtain in the British Museum specimen.

$H a b$. On a mica-schistose boulder in alpine situations.-B. $M$. Loch-na-Gat, Ben Lawers, Perthshire.

75. L. casiocinerea Nyl. in Flora lv. p. 69 (187:3).-Thallus thickish, unequally crackerl-areolate, bluish-grey, whitish or rather lark $(\mathrm{K}-, \mathrm{CaCl}-)$. Apothecia rather small, immersed then somewhat prominent, often confluent, the dise becoming plane, lilackish, the thalline margin entire or somewhat crenulate; laraplyyses moniliform-septate and dark-brown above; spores 1 - $-25 \mu$ long, $10-14 \mu$ thick; hymenial gelatine blue then quickly wine-red with iodine.-Leight. Lich. Fl. ed. 3, p. 194; Croml. Monogr. i. p. 472.

Exsice. Johns. n. 272 ; Larb. Lich. Hb. n. 60 ; Leight. n. 204.

Distinguished chiefly by the somewhat suffused-like velvety thallus, but otherwise scarcely differing from L. gibbosa, of which it might possibly be a growth form. Crombie gires the ascus as 8-spored, but vecasionally there are fewer. Hue (Nouv. Arch. Mus. Paris, sér. 5, ii. 1). 29 (1910)) finds larger goniclia and larger cortical cells thin in L. gibbosa.

Hab. On rocks mostly in mountainous districts.-Distr. Rather r.re throughout the British Isles. $-B$. $M$. Roughton and near Penzance. Cornwall; Llandyssil, Cardiganshire; Longmynd, Shropshire; Malvern Hills, Woreestershire; Lamplugh and Wastdale Lake-side, Cumberlaud ; Barcaldine, Argyll ; líng's Park, Stirling; near Portlethen, Kincardineshire; ILorrone, Braemar, Aberdeenshire; Kilcully neair Cork; Kilkee, Clare; Doughruagh IIts., Connemara, Galway; Black Mt., Antrim.

Form obscurata ityl. 1. c.-Thallus dark- or olive-greyish. Aputhecia as in the species.-Leight. Lich. Fl. ed. 3, p. 195; Cromb. 1. c.

Exsicc. Leight. n. 175 pro parte; Mudd n. 135.

scarcely to be distinguished from the two preceding species, there being transition forms in the colour of the thallus.

$[A a\}$. On rocks and boulders in upland and subalpine regious.lis ir. Rare in the British Isles.-B. M. Malvern Hills, Worcestershire: Cuer Caruloe, S'hropshire; Cliffrigg, Cleveland, Yorkshire; lieston ficur, Staveley, Westmoreland; King's Park, Stirling; Ben Lawers, Perthshire; Morrone, Braemar, Aberdeenshire.

7i. L. cinereorufescens Nyl. in Not. Siillsk. Faun. \& Fl. Fenn. Fork. n. ser. v. p. 1:37 (1866).-Thallus subdeterminate, crackedarenlate, pale ash-grey on a hlack hypothallus ( $\mathrm{K}-, \mathrm{CaCl}-$, medulla I + blue). Apothecia small or submoderate in size. immersed then somewhat prominent, the disc concave then plane. hrownish or dark-red, the thalline margin entire: paraphyses septate. clavate and brown at the tips ; spores ellipsoid, $12-24 \mu$ lons, $7-16 \mu$ thick.-Cromb. in Grevillea xix. 1) 57 (1891) ॥ Monogr. i. 1). 468. Treolaria cimerenufescess Ach. Lich. Iniv. 
p. 67 (1810). Aspricilia cinrea var. cinciempescen. Mudd Min. p. $163(1861)$ ?

1) ifiers from $L$. cineren in the colour of the apothecial dise, more brightly red when moist, and in the absence of reaction with potash. The species has not been recorded in our country, only the following form.

Form diamarta Nyl. l. c.--Thallus yellowish-red. Apothecia similar to that of the species, but the thalline margin or the contiguous thallus often somewhat crenate.-Cromb. Lich. Brit. p. 55 \& Monogr. i. p. 468; Leight. Lich. Fl. p. 211 ; ed. 3, p. 197. Lircularia diumerta Ach. Meth. Lich. p. 151 (180:3): s. F. Gray Nat. Arr. i. p. 458? Lichen riamertus Wahleni). Fl. Lapp. p. $114(1812)$. L. sinopicus Sin. Engl. Lot. t. 1776 (lower magnified fig.) (1807) (non Wahlenb.).

The rusty colour of the thallus is due to the large quantity of iron in the rocky substratum. The apothecia are abundant, but spermo. gones are few, with spermatia $4-\tilde{5} \mu$ long, $1 \mu$ thick (ficle Crombie).

$H a b$. On a miea-schist rock in an alpine situation.-- E. IT. Abore Loch-na-Gat, Ben Lawers, Perthshire (the only British recorl).

77. L. recedens Nyl. in Flora lxii. p. 351 (1879).--Thallus reterminate or effuse, mostly rather thick, deeply cracked-arcolate, ashy-grey $(\mathrm{K}-, \mathrm{CaCl}-)$. Apothecia rather small, often crowded, innate, the dise brownish-black, the thalline margin generally prominent; paraphyses long, thickly septate, almust moniliform especially towards the tips, the epithecium clark-brown; spore: broadly ellipisoid or subglobose, 10-12 $\mu$ in diam. or $14 \mu$ long, 9) $\mu$ thick: hymenial gelatine blue with iorline.-Cromb. in Grevillea xix. p. 57 (1891) \& Monogr. i. p. 469. L. subcineru Nyl. in Flora lii. p. S.2 (1त69): Cromb. in Journ. Bot. xiii. p. 140 (1875); Leisht. Lich. 11. ed. 3, p. 197. Levided recentens Tayl. in Mackay Fl. Hib. ii. p. 117 (1836).

Exsicc. Larb. Lich. Hb. n. 299.

1)iffers from $I$, rinerea in the form of the small spores and the absence of reaction with iodine in the meilulla. Larbalestier's specimen has a thimmer thallus than the others, but the mieroscopic details are identical.

IIab. On rocks in maritime and upland districts.-Distr. Tery rare in N. Wales, N. England, and s. and Wr. Ireland,-Di. M. Jarmonth, Merioneth; Jolwick Sear, Vorkshire; Dunkerron, Kerry: Derryclare, Connemara, Galway.

78. L. decincta Nyl. in Flora lxv. p. 452 (1582).-Thallus determinate, rather thick. smooth, eracked-iareolate, the areols often rounded, umber-grey on a black hypotballus ( $\mathrm{K}-$, $\mathrm{CaCl}-$ ). Apothecia rather small, semi-immersed then plane or convex, black, the thalline marsin thinnish, disaplearing: paraphyses 
discrete, stoutish (about ? $\mu$ thick), sparsely branched and septate, variously clavate or capitate at the tips and dark-brown. the pigment descending often 15-20 $\mu$; spores ellipsoid, small, 10-14 $\mu$ long, 6-\& $\mu$ thick; hymenial gelatine blue with iodine. -Cromb. in Grevillea xii. 1). $\$ 9$ (18\&4) \& MIonogre. i. 1. 480.

This species was placel by Nylander in a distinct section on account of the form of sterigmata and spermatia. The spermogones are very minute, the sterigmata are short tufted branches bearing at the tips minute rod-like spermatia about $3 \mu$ long, $1 \mu$ thick. It is allied, according to $N$ ylander, with L. intercinctr, a Portuguese lichen.

Hab. On schistose rocks in a hilly locality.-B. M. Red Screes, IVestmoreland (the only record).

\section{e. Thallus darti in colour, $K-$.}

79. L. Iusca Nyl. in Lull. Soc. Linn. Norm. sér. :-, vi. p. 28s (187:) note.-Thallus determinate, rather thin, and membranaceous at the circumference, wrinkled, cracked-areolate and thicker specially towards the centre, sometimes shining, olivaceous-grey, hypothallus scarcely visible $(\mathrm{K}-, \mathrm{CaCl}-)$. Apothecia rather small, immersed, often irregular in form, the disc black; paraphyses slender, long, subflexuose, moniliform towards the tips, which are brown, or the epithecium dark-brown; spores ellipsoid, $16-22 \mu$ long (rarely $24 \mu$ ), $10-12 \mu$ (rarely $16 \mu$ ) thick; hymenial selatine blue then quickly wine-red with iodine-Cromb. in Journ. Bot. xx. p. 274 (1882) (excl. spec. from Lazonby). L. gillosa subsp. lusea Cromb. in Grevillea xix. p. 57 (1891); var. Inser TWain. in Medd. Soc. Faun. \& Fl. Fenn. vi. p. 168 (1881); Cromb. Monogr. i. p. 471.

Described sometimes as a rariety of Aspicitin silvatica. It differ: from J. giblosa in the thimmer olivaceous thailus and smaller spores and in the longer spermatia, given as 16-21 $\mu$ long, but this has not been verifiable. The specimen from Lazonby belougs to $I$. cinerea.

Hab. On rocks in maritine and hilly regrons.-Distr. Rare though widely distributed in the Channel Islands and Great Britain.-D. MT. Chateau Point, Sark; Breiddon Hill, Montgomeryshire; Barmouth, Merioneth; Jattersby and Newton, Cleveland, Yorkshire; Ben Latwer: and Craig Calliach, Perthshire; Bay of Nigg, Kincardineshire.

80. L. subdepressa Nyl. in Bull. Soc. Linn. Norm. sér. :2, vi. p. $287(1872)$.- Thallus rather thin, plane, irregularly crackerl, smorth or somewhat wrinkled, cinereous or dark-grey (K-, $\mathrm{CaCl}-$ ). Apothecia rather small, scattererl, immersed then emergent, the disc and margin black, the thalline margin excluded; paraphyse's coherent, slender, often flexuose, septate, dark-brown above; spores cllipsoid, varjable in size, 18-32 $\mu$ long, 11-15 $\mu$ thick; hymenial gelatine faintly blue then quickly winered with iorline-- $I$. giblosa subsp. subdeqressa Lany in Bull. Soc. Bot. Fr. xxv. 1. 420 (1878); Cromb. in Grevillea xix. 1) ז 
(1891) \& Monogr. i. p. 472. Ureeoluriu mfescens Tayl. in Machay Fl. Hib. ii. p. 132 (1836) (non Turn.).

Differing from $L$. giblesa in the appearance of thallus and apothecia, which look as if washed smooth, and in the internal structure. The paraphyses are more sparsely septate and have not so constantly the bearl-like appearance upwards. Hue (Nouv. Arch. IIns. Paris, 1910, p. 34) has, however, described them as moniliform and greenish-black above.

S'permogones have spermatia $9-15 \mu$ long (or longer), $5 \mu$ thick.

$H a b$. On schistose rockis in mountrinous regions.-Distr. Local but plentiful where it occurs in Great Britain and Ireland. $-B$. $M$. Cader Idris and Camlan Valley, near Dolgelly, Merioneth; Snowdon. Carnarvonshire; Wintermere, ITestmoreland; Barcaldine, Argyll; Craig Calliach and Ben Lawers, Perthshire; Morrone, Braemar, Aberdeenshire; Cappamore. near Dunkerron, Kerry ; Maam Turk Mt.. Connemara, Galway.

S1. L. Bockii Th. Fr. in Bot. Not. p. 105 (1867).-Thallueffuse, plane, cracked-areolate or of minute scattered wart;, sometimes with sorediate spots, olive-brown or brownish-grey, on a thin black bypothallus $(\mathrm{K}(\mathrm{CaCl})+$ reddish $)$. Apothecia small, immersed or sessile, the disc black, irregular in outline, the thalline margin entire; paraphyses slender, septate, the epithecium brown; spores broadly ellipsoid, 16-21 $\mu$ lons, $8-11 \mu$ thick; hymenial grelatine blue, the asci wine-red, with iodine.-Cromb). in Journ. Bot. xx. p. 274 (1882) \& Monogr. i. p. 464. Parmelie. Bockii Rodig ex Fr. Syst. Orb. Veg. i. P. 285) (182.)).

Evidently a very rare lichen. The apothecia are minute. semi. immersed and often with a dot or fold on the disc. The Jritish specimens are poorly developed; the asci have a very thick tip amil the spores are smaller than the sizes given above (Th. Fr. Lich. Scind. p. 170); they measure frequently about $12 \mu$ in length.

Crombie (1. c.) quotes as a synonym Leranora sophortopsis Nyl. (Flora lix. p. 2:3 (1876) \& op. cit. p. 204 (1879)), in the diagnosis of which the spore sizes are given as 17-25 $\mu$ long, 11-15 $\mu$ thick.

Hab. (On a schistose wall in an upland district.-B. M. NenL Staveley, hendal, Westmoreland (the only liritish record).

82. L. complanatoides A. I. Sim.-Thallus rather thin, effuse, eracked-areolate, the areolas small (alont :3 mm. in diameter), smooth, sometimes sulsigumulose, with a hlack hypothallus

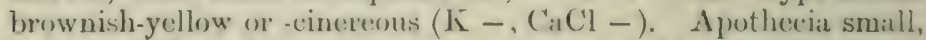
immerserl then plane, the margin searecly visible, the disc datkbrown; liypothecium colourless: paraphyses slender, coherent, flexunse, septate, the cells about is ploner, morcly branched behw, clavate and often shom ly banched above, the tips dark-brown. becoming green with potash: asri clanate up to $68 \mu$ longs. $10-12 \mu$ wide, not thickmed at the tipss spores 8 in the ascu-

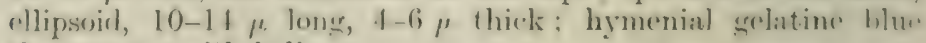
then tawny with iodine.

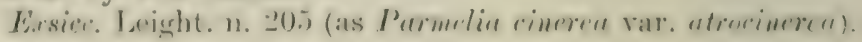


Nearly related to $L$. complanata Koerb., but differing in the more compact crustaccous-areolate thallus and in the almost non-marginate apothecia.

$H a b$. On siliceous rocks.-B. M. Lyth Hill, Shropshire.

83. L. superiuscula Nyl. in Flora lxii. p. 355 (1879).Thallus of small plane or slightly convex squamulose areolx, contignous or scattered, rounded or crenulate, brown or light brownish-grey $(\mathrm{K}-, \mathrm{CaCl}-)$. Apothecia minute, more or less immersed, blackish, the thalline margin thick and tumid; spores ellipsoid, 10-14 $\mu$ long, 5-8 $\mu$ thick; paraphyses subdiscrete, brownish at the apices.-Cromb. in Grevillea xiii. p. 112 (1880) it Monogr. i. p. 464.

Considered by Crombie as similar to, if not identical with, $L$. complanata Koerb., a lichen from the Tyrol, but the thalline margin of that species is thinner and crenulate. The spores are usually about $10 \mu \times 6 \mu$, the larger size has not been verified.

Spermogones are plentiful with arcuate spermatia $18-25 \mu$ long, - $6 \mu$ thick.

$H a b$. On a mica.schist rock in an alpine situation.- $B$. M. Above Loch-na-Gat, Ben Lawers, Perthshire (the only record).

84. L. morioides A. L. Sm.-Thallus reterminate, thin, composed of minute blackish-or reddish-grey areola on a black hypothallus ( $\mathrm{K}-\mathrm{CaCl}-$ ). Apothecia minute, immersed, solitary in the areolie, the disc black, the margin thin, scarcely prominent; paraphyses coherent, slender, septate, clavate at the dark coloured bluish-black tips; asci thickened at the tips; spores 7-9 $\mu$ long, $5 \mu$ thick; hymenial gelatine blue then wine-red with iodine.Aspiritia morioides Blomb. ex Arn. Lich. exsicc. n. 904 (1881); Arn. in Verh. Zool. Bot. Ges. Wien, xxxvi. p. 78 (1S86); Hue in Nouv. Arch. Mus. Paris, sér. 5, ii. p. 78 (1910).

Our single specimen in the Hugh Davies herbarium differs slightly from the above as described by Hue, though too nearly alike to be separaterl. The tips of the pariphyses are dark-brown, and the spores -very rarely developed as Hue also points out-are larger and somewhat oblong, they measure $7 \times 3 \mu$ or up to $12 \times 4 \mu$. The hymenial gelatine also remaius persistently blue with iodine. It was labelled Vermarin maura by Invies. The plant has been collected in Seandinavia, and in the 'Iyrol.

$H a b$. On siliceous rock.-B. M. N. Wales.

\section{f. Thathus varionsly coloned, thin and mostly continumes.}

55. L. levata Nyl. in Flora 1v. p. 364 (1872) ; "p. cit. Kiv. p. $18: 3$ (1851).--'Thallus determinate or effuse, thin, limgely continuous, cracked in places, especially towards the centre, smooth, shining, srey- or luown-olivaceous; hypotlaallus l)lack, often limitime the thallus $\left(\mathrm{K}^{-}-\mathrm{CaCl}-\right)$. Aprothecia minute, immersed, 
then becoming superficial, the clisc concave, black, the thalline margin rather prominent, entire or subcrenulate; paraphyses slender, coherent. flexwose, septate, moniliform upwards, the "pithecium dark-brown; spores ellipsoid, 15-2t $\mu$ long, 9-16 $\mu$ thick: hymenial gelatine bluish, then quickly wine-red with iodine,-Cromb. Monogr. i. p. 473. Sagerlin lievata Ach. Lich. Univ. p. 327 , t. 6, fig. 5 (1810).

Exsicc. Johns. n. 273.

Evidently a rare lichen, though of wide distribution on the continent and $\mathbf{N}$. America. According to Nylander (Lich. Fret. Behr. 1). :30, 1888) the spermatia measure $20-32 \mu$ long, $\cdot 5 \mu$ thick. I have been unable to find spermogones on our specimens.

Hab. On damp siliceous rocks in subalpine districts.-Distr. Rare in W. England and the Grampians, Scotland. $-B$. M. Wastdale Lake-side, Cumberland, Glen Callater, Braemar, Aberdeenshire.

86. L. lacustris Th. Fr. in K. Sr. Vet.-Akad. Handl, rii. "2, P. 24 (1867).-Thallus determinate or somewhat effuse, thin, firm, smooth, irregularly and finely cracked-areolate or continuous, pale-reddish or -yellowish $(\mathrm{K}-\mathrm{CaCl}-)$. Apothecia small, persistently immersed, the disc pale rose-coloured or brownish, the thalline margin tumid, of ten indistinct; paraphyses "oherent, slender, flexuose, septate, slightly thicker and more " Iosely septate at the tips, the epithecium brownish-or yellowishsranulose; slores ellipsoid, usually 13-18 $\mu$ long, 6-9 $\mu$ thick but sometimes larger ; hymenial gelatine blue then quickly wine-sed with iodine.-Leight. Lich. Tl. el. 3, p. 195 (excl. f. junctala); Cromb. in Grevillea xix. p. 5 \& (1891) (excl. rar. ryitaspis?) it Monogr. i. p. 477 . L. giblosa subsp. lacustris Cromb. Lich. Brit. 1. 55) (1870) (excl. var. punctata); f. lachstris Leight. Lich. Fl. p. 210 (1871) pro parte. Lichen lacustris With. Arr. ed. :3, iv. p. 21, t. :1, fig. 4 (1796). L. Acharii Westr. ex Ach. Licb. Suec. Prodr. 1) 33 (1798); Engl. Bot. t. 1087. Erceolarin Allurii Ach. Meth. Lich. p. 150 (1803) (excl. var. cyrtaspis) : S. F. Gray, Nat. Arr. i. p. 457 ; Ilook. Tl. Scot. ii. p. 47 (incl. var. cypterspis pro parte) of in Engl. Bot. v. p. 172 (incl. var. ryrtaspis pro parte); Tayl, in Mackay N1. Hib. ii. y. 1:32.

Exsicc. Cromb. n. 71 ; Johns. n. 275.

The thallus is nomally pale ochraceous or whitish, but may be rusty from infiltration of iron, as it grows on rocks subject to inumdat. tion. In some of our sprecimens the spores are langer than the sizes given above, measuring uj, to $24 \mu \times 12 \mu$. There is considemable cioubt as to the position of the variety cyrlaspis, the description of which in some cases agrees well with $L$. lacustris, and Lichen prunclatus, cited ats a smomym, is mobably a form of $I$. l'mestii.

IIal. On rocks in streans in upland and subalpine districts.Distr. Tocal though plentiful where it oecurs throughout the British Isles. J3.M. Withiel, (omwall; Tary Cleare and Dartmoor, Deron; Trndhurs Moor, New Forest, Hants; Namau, Dolgelly and Bar. 
mouth, Merioneth; Beddgelert, Trefriw Falls and Camedd Dafydd, Camarvoushire; Teesdale, Durham; Appin and Glencoe, Arg.ll ; neat the T'rossachs, G]en Falloch and Ben Lawers, Perthshire; Glen Callater, Traemir, Alerdeenshire; Invermoriston. Invernessshire; Jallaghbeanu G:tp, I)unkerron. and Connor Cliffs, Dingle. Kerry; Fallynakill ank Lough Inach, Connemara, Galway; Clave Island, Mayo.

87. L. Dicksonii Nyl. ex Carroll in Journ. Bot. iv. p. 25:) (1567).-Thallus thin, plane and smooth, finely ("acked-areolate, rusty of vellowish-red, with a thin black hypothallus (K-, $\mathrm{CaCl}-$ ). Apothecia small, innate, hecoming superficial, the disc concare, black, with a prominent hlack rim, the thalline margin very indistinct as an outer reddish covering; hypothecium rark-brown: Iaraphyses coherent, slencler, straight or flexuose, septate, the epithecium bluish-or brownish-black; spores ellipsuid, 11-14 $\mu$ long, 6-8 $\mu$ thick; hymenial gelatine hlue with iodine.-Cromb. Lich. Brit. p. 55 \& Monogr. i. p. 476 : Leight. Lich. Fl. 1). 211 ; ed. 3, p. 196. Lichen ciesins Dicks. Pl. Crypt. finsc. ii. 1'. 19, t. 6, fig. 6 (1790)? (non Hoffm.). L. Dicksmui Ach. Lich. Succ. Prodr. p. 76 (1798); With. Arr. ed. :3, ir. p. 20. L. Oeteri With. op. cit. p. 11 (1796) pro parte (non Web.) ; Sid. Engl. Bot. t. 1117. Lecidea Oederi Wablenb. Fl. Lapl. 1. 474 (1ミ12); S. F. Gray Nat. Arr. i. p. 465 ; Hook. Fl. Scot. ii. p. 38 \& in Sm. Engl. Fl. v. p. 178; Tayl. in Mackay FI. Hib. ii. 1). 12.2. L. melanoplisea Fr. in T et. Akad. Handl. 18.2.2, 1. 2.59; Mudd MIan. p. 206.

Exsice. Cromb. n. 72 ; Dicks. Hort. Sicc. fasc. ii. n. 24 ; Johns. n. 149 ; Leight. n. 127.

Of doubtful systematic position, with perhaps more afinity with Lecidea than with Lecanora. The apotheeis talie rise within the thallus and gradually emerge; ther are numerous and sometimes confluent, so that the disc may appear to be lined or dotted. The rusty colour is fairly constant, but, is in some other lichens, is generally considerel to be due to the infiltration of ferric hyllate, though, as has leen pointed out by Wheldon and Wilson (Lich. Perth. p. 42), the species sometimes grows on white yuarty where it exhibits the same bright colour. Specimens from Kerguelen Liand with a grey thallus have been recorded by Crombie as Lecider sineernla Nyl. (Limn. Soc. Jon11. Jot. XY. p. 190 (1877)). The species has been confused with Thirocaryon Oederi, but it differs in the prominent proper margin of the apothecium as well as in spore characters.

Hab. On rocks and walls chiefly schistose, in uplinnd or mountainous rergious.-Distr. Not uncommon in hilly districts of the British Isles.-D. M. Fingle Brirlge, near Chagford, Devon; Barmouth, Jlolgelly and Iihimgreidden. Merioneth; Jettws-y-Coed, Jenbighshire; Cwm Trefiry. Snowlon, Carnarvonshire; Anglesea ; Wrekin ILill, Shropshire; Staveler, Kendal, Westmoreland; Tam. plugh and Ennerdalc, ('umberland; Jien Lawer's and Critig T'ulloch. Blair Athole, Perthshire; (ilen Cillater am Morrone, Jitumar. Aberdeenshire; Applecross, liosshire; Crogham (?' Cloghrune) and Mangerton, Killarney, Kerry. 
Form atrata Cromb. Monogr i. p. 47i (1:94).-Thillus reduced to minute red portions here and there on the hlack hypothallus. Apothecia minute. -Gyalerta atratu Ach. in Tet. Akad. Handl. 1808, p. 229.

There are comnecting links betreen the rery reduced thallus of this form and that of the species.

Hab. On puartzose rocks in an alpine locality.-D. M. Morrone. Braemar, Aberdeenshire (the only British record).

88. L. flavida Hepp Flecht. Eur. n. 630 (1860).-Thallueffiuse, very thin, almost furfuraceous or thinly felted, scarcely cracked, with a ractiating dirty-whitish hypothallus, jalkochraceous or light-greyish $(\mathrm{K}-, \mathrm{CaCl}-)$. A pothecia very minute, immersed, the disc concave then plane, black, the thalline margin thin, entire ; paraphyses coherent, slender, septate, sulumoniliform upwards, the epithecium of brown granules; spores elliporid, $12-18 \mu$ long (or slightly longer), $7-11 \mu$ thick: hymenial gelatine blue with iodine.-Leight. Lich. Fl. ed. 3, p. 19.5; Cromb. Monogr. i. p. 478. L. gibbosa f. lacustris Leight. Lich. Fl. p. 210 (1871) pro parte. Aspicilin mhrucen Mudd Man. p. 163 (1861) (non Schær.).

Exsicc. Leight. n. 292 ; Mudd n. 136.

Hue (Nour, Arch. Mus. Nat. Hist. Paris, sér. 5, ii. p. 10.5) describe: the gonidia of this species as "chroolepoid." Some of them twe yellow, but they have not the large size of the Jonaspis group.

Hab. On rocks and stones in moist situations in lilly district.-Distr. Tare in N. England, - B. M. Cockishow Banli and Niton, Cleveland, Yorkshire.

89. L. fulvo-mellea A. L. Am.-Thallus eftise, very thin, smooth, in smaller or larger patches, contiguous or scattererl, yellowish or tawny-honey-coloured $(\mathrm{K}-. \mathrm{CaCl}-)$. Apothecia numerous, impressed in the thallus, minute, the disc about -2 mm. wide, yellowish flesh-coloured, becoming slightly brown, the thalline margin thickish, entire and rather prominent, often circumscissed from the thallus : paraphyses conglutinate, slender. sometimes flexuose, septate, submoniliform, the epithecium colourless or of rellowish-brown ranules: asci elongate-clavatt. about 40-50 $\mu$ long, 12 $\mu$ thick, s-spored; spores ellipsninl. colourless, small, s-le $\mu$ long, 4 -5 thick; hymenial gelatine searcely greenish-blue then wine-red with iodine.

The affunity of this lichen is with L. Irrastii, or possibly with

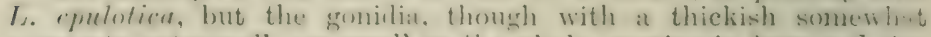
corrugate outer wall, are small on the whele, varying in form and $-i$.

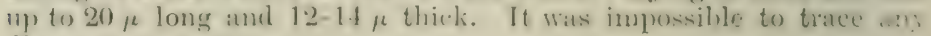
filamentous structurc. Holl).

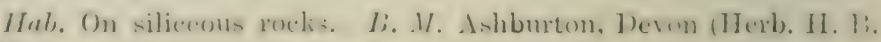


90. L. Prevostii Th. Fr. Lich. Scand, p. 288 (1871).-Thallus effuse, thin, continuous, generally tartareous, greyish or whitish or pale flesh-coloured $(\mathrm{K}-, \mathrm{CaCl}-)$. Apothecia minute, deeply immersed, often irregular in outline, concave, the disc pale fleshcoloured, the proper margin comnivent, surrounded by and distinct from the thalline margin ; paraphyses coherent, slender, septate ; spores ellipsoid, 14-22 $\mu$ long, 9-11 $\mu$ thick; hymenial gelatine blue then quickly wine-red with iodine.-Leight. Lich. Fl. ed. 3, p. 198 ; Cromb. Monogr. i. p. 47 \&. L. epulotica var. Prevostii Nyl. Lich. Scand. p. 189 (1861); Cromb. Lich. Brit. 1. 55 ; Leight. Lich. Fl. p. 212 . Gyulertu Prevostii Fr. Lich. Eur. p. 197 (1831). G. groicr Leight. Angioe. Lich. p. 87, t. 15, fig. 1 (1851) (non Wahlenb.).

Easily overlooked owing to the rather neutral colour of the thallus ant the inconspicuous apothecia, which are either immersed in pits or more rarely level with the surface.

Hab. On calcareous rocks in hilly or mountainous districts.Distr. Rare in W. and N. England and the Grampians, Scotland. -B. M. Bathampton Downs, Somerset; Ease Gill, near Leek, Lancashire; Levens, Westmoreland; Craig Tulloch, BHair Athole, P'erthshire; Craig Guie, Braemar, Aberdeenshire.

Form melanocarpa stizenb. Lich. Helv. p. 1:9 (1882).Apothecia becoming more prominent and darker, with the thalline margin obliterated.-Cromh. Monogr. i. p. 479. L. gibbosu subsp. Inu:ustris var. punctuta Cromb. Lich. Brit. p. 5.) (1870)? L. giblosa f. punctata Leight. Lich. Fl. p. 210 (1871)? ed. 3, p. 196 ? Lichen punctutus Sm. Enst. Bot. t. 450 (1798)? (Dicks.?) Urceolaria Acharii var. "yrtaspis Ach. Meth. Lich. p. 151 (1S03); Hook. in Sm. Engl. Fl. v. p. 172 pro parte. U. cyrtaspis S. F. Gray Nat. Arr. i. p. 458 (1821)? Aspicilir epulotica var. punctutre Mudd Man. p. 161 (1861). Hymenelice Prevostii var. melnuocarpe Krempelh. Fl. Layer. p. 167 (1861) nomen.

Sicarcely distinguishable from the species. Lichen punctatus, figured and described in English Botany from a specimen collected at Jurllow, scatcely accords with this variety, and Sowerby's specimen in HIb. 3rit. Mus. is from Teesdale, and hardly differs from the species (ef. L. eampestris: p. 274). Specimens from Somerset (Bathaunpton Downs) seem to be wholly Vemucaria integra Carroll.

$H a b$. On calcareous rocks in hilly or mountainous districts.Distr. Rare in X. Fngland and the Grampians. Seotland. - B. M. Teesdale, Inuham; ('raig Tulloch, Jlais: Athole, J'erthshire.

Var. affinis Nyl. ex. Stizenb. 1. c. --Thallus thin, somewlat similar to that of the species or redelish-flesh-coloured. Apothecia minute, becoming more prominent, the thalline margin persistent; spores similar to these of the species or more broarlly ellipsoid, 14-18 $\mu$ long, $9-1: 3 \mu$ thick,-Cromb. Mumenr. i. p. 479.9. 
Hymenelir affinis NIassal. Geneac. Lich. 1. 13 (1854) \& Symm. Lich. p. 23 (1855).

Distinguished by the very minute emergent apothecia.

$H a b$. On calcareous and associater rocks in subalpine regions.Distr. Fare in N. England and the Grampians, Scotlaud.--13. $M$. Teesilale, Durhan; Craig Tulloch, Jilair Athole, Perthshire; The Khoil, near Ballater, Braemar, Aberdeenshire.

\section{B. Jonaspis. Algal cells Trentepohlia.}

\section{a. Thallus thin, light coloured, $K-$.}

91. L. epulotica Nyl. ex Cromb. Lich. Brit. p. 55 (1870).-. Thallus subeffuse, tartareous, thin, continuous or faintly cracked, whitish or pale-reddish ( $\mathrm{K}-, \mathrm{CaCl}-)$. Apothecia small, innate, becoming somewhat superficial and circumcissed from the thallus, pale flesh-coloured, the thalline margin thickish; paraphyses coherent, slender, multi-septate, ahmost moniliform; spores broadly ellipsoid, 18-20 $\mu$ long, 10-11 $\mu$ thick, hymenial gelatine bluish then wine-red with iodine--Leight. Lich. Fl. p. 212 pro parte; ed. 3, p. 197; Cromb. Monogr. i. p. 479. Gyalecta 'pulotice Ach. Lich. Univ. p. 151, t. 1, fig. 7 (1810). Aspiciliu epulotica Mudd Man. p. 161, t. 3, fig. 54 (1861).

Closely related to L. Prerostii, but differing in the gonidia, a species of Trentrpollia, the filaments of which are mostly broken up into separate cells of a greeuish colour, but are ensily recognized by their large size, about $30 \mu$ long and $20 \mu$ thick. The British Musemin specimen of Johnson's exs. n. 150 does not belong here.

Hab. On calcareous and schistose rocks in upland and subalpine districts.-Distr. Rare in N. Wales, N. England and the Grnmpiuns, Scotland.-I3. M. Near Beddgelert, Carnarronshire; Nardale, West. moreland; Teesdale, Durham; Craig Calliach and Craig Tulloch, Iilair Athole, Perthshire; MIorrone, Jimemar, Aberdeenshire.

92. L. chrysophana Nyl. ex Stizenh. Lich. IIelr. 1. 12? (1882-3). - Thiallus effuse, thin, smoothish or faintly crackedareolate, dull or chestunt-reddish, becoming blackish-grey or -green when dry $(\mathrm{K}-, \mathrm{CaCl}-)$. Apothecia minute, concatve, blackish, the thalline margin thin, disappearing: paraphyses "onglutinate, slender, septate, dark blue-green, moniliform and clavate upwards; spores ellipsoid, about 9-12 $\mu$ long, $5-\tau \mu$. thick; hymenial gelatine bluish then quickly wine-red with iodine-Cromb. in Journ. Bot. xx. 1. 274 (185.) and Monogr. i.

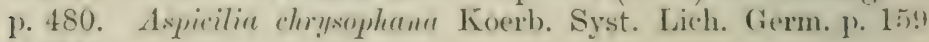
(1855).

Like the previons sprecies, distinguished by the very large gonidiat of the Trentrohlen algit. measuring usually abont $35 \mu$ by $28 \mu$, but recorded ats lawerer. The bhe-green eolour of the epithecium is not always prescnt.

Hab. On siliceons rocks and stones in alpine situations. Distr.

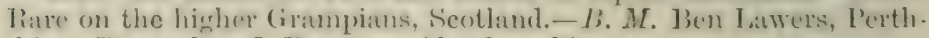
shire; Ben-naboord, Braemar, Aberdeenshire. 
52. ACAROSPORA Massal. Ric. Lich. Crost. p. 27 (185) : Mudd Man. p. 158. (Pl. 52.)

Thallus mostly squamulose and thickish, areolate, (n)rticate above or non-corticate, attacherl to the substratum by hypha. Algal cells Protococcus. Apothecia generally immerserl then plane, discoid, the thalline margin prominent or indistinct; hyprthecium colourless; paraphyses slender; spores many in the ascus. mostly ver'y small, colourless, oblong or ellipsoid. spermogrones with acrogenous elongate or almost globose spermatia.

Distinguisher by the plurispored asci. The species (L. pruinosn. L. simpler, etc.) classified under Sect. Sarcoryne Cromb. Jlonogr. i. p. 487, are without gonidia in the apothecia, and are described a: species of the lecideine genus Biatorella (see Appendix).

1. A. squamulosa Th. Fr. Lich. Scand. p. 21:3 (1Si1).Thallus squamulose, closely appressed, cracked-areolate, sometimes more continuous and the squamules rounded at the edge, tawny or dark reddish-brown, white beneath ( $\mathrm{K}-, \mathrm{CaCl}-$ ). Apothecia small or moderate in size, sunk in the thallus then emergent, the dise plane, dark reddish-brown, the thalline inargin entire; paraphyses discrete, septate, slightly clavate and reddishbrown at the tips; spores oblong-ellipsoid, $8-12 \mu$ long, 4-5) $\mu$ thick; hymenial gelatine blue with iodine.-1. rerrince var. squemulose MLudd Man. p. 158 (1861)? Lichen squamulosus: Sichrad. Samml. Crypt. Gew. n. 153 \& in Ust. Ann. Bot. xxii. p. S4 (1797). L. cervinus Pers. ex Ach. Meth. Lich. p. 181 (1su:3). Lecenore squamulose Nyl, in Bull. Soc. Linn. Norm. sér. 2, vi. p. 20 (1872); Leight. Lich. Fl. p. 18:3 pro parte: ed. :), p. 169 pro parte; Cromb. Monogr. i. 1. 48:. L. cervimu Cromb. Lich. Brit. p. 56 (1870) pro parte.

Distinguished by the comparatively large spores and by the appressed cracked thallus.

IIub. On calcareous rocks in mountainons districts. - D ist $r$. Rather rare in N. Wales, N.IV. Englund and on the Grampians, Scotland. B. M. Dolgelly, Merioneth; near Staveley, Kendal, Westmoreland: Craig Tulloch, Blitir Athole, Perthshire; Craig Guie and IIorrone. Braemar, Aberdeenshire.

Form albomarginata A. L. Sm.-Thalline squimules densely white-pulverulent at the margins, giving a mosaic effect. Lecenor"t

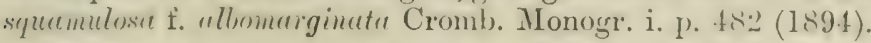

Hab). On calcareous rocks in a subalpine distriet. - I3, I. Crain Tulloch, Blair Athole, Perthshire (the only record).

2. A. Benedarensis Knowles in Sci. Proc. Roy. Dubl. Soc: p.131 (191:3).-Thallus globulose-squamulose, thick, the squamules discrete or sometimes confluent, $1-7 \mathrm{~mm}$. widle, abrut 5 to $1 \mathrm{~mm}$. thick, dark-lnown, pale beneath $(\mathrm{K}-, \mathrm{CaCl}-)$. Apothecia solitary or several in each squamule, at first completely inmersed and remainins innite, concave, concolorous with the thallus, 
reddish-brown when moist, the margin thick, entire, persistent; paraphyses slender, conglutinate, sparingly branched, yellowhrown at the apices; hypothecium sordid-grumous; ascus clavate, $\$ 0-100 \mu$ long, 1:-20 4 thick, myriospored; spores minute, :3-4.5 $\mu$ long, 1-2.5 $\mu$ thick; hymenial gelatine blue then winered with iodine. Spermogrones numerous, with spermatia $2 \cdot 5 \mu$ long, $1-1 \cdot 5 \mu$ thick.

$H a b$. On dry clayey soil on disintegrating fiue shales in sheltered sunny situations. $-\dot{B} . M$. Earlscliff, Howth coast, Dublin.

3. A. glaucocarpa Kór\}. Pareng. Lich. p. 57 (1559).--Thallus of small thickish squamules, scattered or rarely subimbricate, sometimes raised and crenate, yellowish- or dull-brown, white beneath $(\mathrm{K}-, \mathrm{CaCl}-)$. Apothecin moderate in size, the disc becoming plane, reddish-brown, sometimes bluish-grey-pruinose, the thalline margin thick, entire; paraphyses stoutish, coherent, septate, narrowly clavate and yellowish-brown at the tips; spores ellipsoid, 3-5 $\mu$ long, 1·5-2.5 $\mu$ thick; hymenial gelatine persistently blue with iodine.-Lichen glaucocarjus Wahlenb. in K. Vet. Acad. Handl. 1806, p. 143, t. 4, fig. 4. Lecanor a glaucorarpa Ach. op. cit. 1810, p. 151 ; Cromb. Lich. Brit. p. 56 \& MLonogr. i. p. 481 ; Leight. Lich. Fl. p. 182 ; ed. 3, p. 168.

Characterized by the form of the squamules. In our specimens, asci and spores are sparingly present; the latter do not measure more than $3-4 \mu$ in length.

Hab. On calcareous and schistose rocks in mountainous regions. -Distr. Rare in N. England and the Grampians. Scotland.--B. M. Craig-y-Rhiw, Oswestry, Shropshire; Teesdale, Durham; Ben Lawers and Craig Tulloch, Perthshire; Craig Guie, Braemar, Aberdeensbire.

Var. depauperata Jatta Syll. Lich. Ital. p. $23: 2$ (1900).Thallus almost obsolete. Apothecia varying in size, scattered or crowded, naked or pruinose, the margin more or less prominent. - A. rervina var. glancocurya f. depauperata Korb. Syst. Lich. (ierm. 1). 155 (1855). Lecenora gleucororpa var. depueperutı Cromb. in Journ. Bot. xi. p. $1: 34$ (1873) (incl. f. conferta) d Monogr. i. p. 4si (incl. ff. prminifern, demulutu Cromb). in Grevillea xix. p. $58(1891))$.

Minute portions of the thallus are occusionally visible round the apothecia, which, as in the species, may be pruinose or naked (ff. prinifora and demudata). It is elosely related, if not identical, with var. ronsprome Th. Fr. Lich. Aret. p. 88 (1860), but the deseriptions do not entirely agree.

Hab. On calcareons anul schistose rocks in mountainous regrions. Dislr. Sparingly in N. England and the Grampians, Scotland. . b. M. Near Inent. Yorlishire: Craig 'T'ulloch, 13lair Athole, Perthshire; Craig Guie and Morrone, Braemar, Aberdeenshire.

4. A. Lesdainii Marm. in litt.-C'hallus thickish, with an amorphous cortex, areolate-squamuluse, or the squamules ristinct. 
augregate, irregularly roundish or angular, flat or tumid, pale fawr-coloured above and below $(K+$ vellow then red $)$. Apothecia une or more immersed in the squamules, small or moderate in -ize, the disc reddish, becoming darker, the thalline margin not prominent; paraphyses rather slender, flexuose, dotted with minute guttule, not wiclening upward, agglutinate and colourless ir brownish at the tips; asci large, broadly oblong or ellipsoid, (1)-1.50 $\mu$ long, $24-38 \mu$ wide; spores innumerable, cylindrical, minutely guttulate at each end, $2-4 \mu$ long, $1 \mu$ thick; hymenial gelatine hlue then wine-red, the hyputhecium more persistently blue, with iodine.

Evirlently near to A. glaurocaryu, but differing in certain characters of thatlus and apothecia. There is considerable variation in thalline form: the specimen from Cumberland is flat and crached, in the others the spumules are alike tumid and generally roundish. The reaction with potash in one of the Forkshire specimens is not very distinct and the paraphyses are slightly clavate or irregular and sometimes branched, septate, or capitate. This may be only a growth form, as the otber characters are similar. The specimen was collected by Mr. Hebden and named br. Harmand in horour of his friend Dr. Bouly (1) I.esdain, of Dunkirk. Owiug to the wall, Hebden has been unable to secure Harmand's own description.

Hab. On rocks in upland districts.-Distr. Somerhat rave in N.:ınd X.W. Fngland.-D. W. Near Fieighley, Yorkshire; Buttermere, Cumberland.

$\therefore$ A. percænoides Jatta Syll. Lich. Ital. 1) $2: 31$ (1900).-Thallus thickish, warted-srquamulose, the squamules rather small, convex, scattered or imbricate, chestnut-brown, whitish-pruinose, white beneath $(\mathrm{K}-, \mathrm{CaCl}-)$. Apothecia minute, innate in the areolie, reddish- or dark-brown; paraphyses stoutish, very slightly clavate, brown and septate at the tips; spores ellipsoid, 3-6 $\mu$ long, $1 \cdot 5-2 \mu$ thick. - A. cervina var. percene Mudd Man. p. 159 (1sib)? Leridea peresua Ach. Syn. Lich. p. 29(1814)? Lectenora matunen f. percentuides Nyl. in Bull. Soc. Bot. x. p. 26:3 (186:3). L. percanoides Nyl. ex Wëdrl. op. cit. xvi. p. 202 (1869): Cromb. in Grevillea xix. p. 58 (1891) \& MLonogr. i. p. 482.

The squanules in the British specinens are white bordered; the anothecia are badly developed. Mudd's specimen of A. cervina var. pirca nu has been determined by Crombie as identical with this speeies. It is impossible to be sure as the squamules are sterile.

Ind. On calcareous rocks in upland situations.-Distr. liare in S. W. and X.F. Englant,-D. W. Near Yatton, Somerset; 'T'cesdale. 1) urham.

(i. A. fuscata Th. Fr. Lich. Scand. p. 21.) (1571) pro parte.-Thallus areolate-squamulose, the squamules crowded, angular and irregularly crenate-lobate, dull- or tawny-brown, blackish beneath ( $\mathrm{K}(\mathrm{CaCl})+$ reddish $)$. Apothecia minute, immersed, becoming partly superficial, the dise reddish- or dark-lnown, the thalline: 
margin thin, flexuose; paraphyses stoutish, subdiscrete, irregularly. septate and slightly larger at the tips; spores cylindrical, minute, $3-4 \mu$ long, $1-1 \cdot 5 \mu$ thick; hymenial gelatine blue then wine-red (more especially the asci) with iodine-A. cervina Massal. Ric. Lich. Crost. p. ¿- (185:2) : Murld Man. 1) I5S pro parte. Lichen fuscatus Schrad. Spicil. Fl. Germ. p. \&3 (1794). L. squamulosus im. Ensl. Bot. t. 2011 (male) (1-09) (non Sichrad.). Psoroma rervina S. F. Gray Nat. Arr. i. 1). 444 (18:1) pro parte. Lecrenore spuamulusa Hook. Fl. Scot. ii. p. 50 (1r.21) it in Sm. Engl. Fl. v. p. 187 pro parte (non sichrad.). L. rervina Cromb. Lich. Brit. 1. 56 $(1870)$ pro parte. L. fiesecata Cromb. 1. c. pro parte d Monogr. i. p. 483: Leight. Lich. Fl. p. 186 pro parte; ed. 3. p. 171 pro parte.

Exsice. Johns. 12. 276; Leight. 1. 24; Mudd n. 131.

Differs from $A$. squamulosa in the smaller spores, and also in the form of the squamules, which are often rather thin. The plant is often sterile.

Hab. On rocks, boulders and walls from maritime to upland situations.-Distr. Fairly common throughout Great Britain, rarer in Ireland.-B. $M$. La Moye, Jersey; Alderney; Guernsey; near Penzance, Commall; Morwell liocks, Devon; Pulborough and near Hastings, Sussex; Gorleston, Suffolk; Ankerdine Hill, Worcestershire; Charnwood Forest, Leicestershire ; Suclistone, near Monmoutl. and Crossfaen, Monmouthshire; Barmouth, Dolgelly and Aberdovey. Merioneth; Llyn Geironydd, Carmarronshire; Oswestry and IJaughmond Hill, Shropshire; Ayton and Guisboro' Moors, Cleveland, Yorkshire; Egrrlestone, Durbam ; near Hexham. Northumberland; Staveley. Kendal, Westmoreland; King's Park. Stirling; Ballachulish, Argyll : Craig Calliach, Perthshire; I'ortlethen, Nincardineshire; The Stocket near Aberdeen; Applecross, Rossshire; Dunkerron, Kerry.

7. A. reliscyphoides Oliv. Lich. Eur. fasc. ii. 1. 76 (1909).-Thallus of crowded somewhat crenate syuamules, (racked into areolar, pale tawny- or reddish-brown ( $\mathrm{K}(\mathrm{CaCl})+$ reddish $)$. Afothecia hecoming plane aud rather linge, the disc dark reddish-brown and granular-papillate, the thalline margin disappearing; paraphyses coherent, llexuse, irregular, many-septato at the tips: spores numerous, oblons-cylindrical, $3-6 \mu$ lons, $1-1 \cdot 5 \mu$ thick; hymenial gelatine blue then wine-red with iodine. -Lecomorre fuseatu var. pelisryplenides Nyl. in Flora lv. p. 364 (1872) ; Cromb. Monere i. p. 48. L. prliscyplaa Cromb. in Joum. Jiot. xi. p. 1:it (187:3) (non Nyl.) : Leight. Lich. Fl. ed. :, p. 172 (according to the locality).

I)ifiers from A. pelineyplan in the chemical renction similar to the : of $A$. fuscata, and in the larger apothecia.

Ilal). (In walls in a maritime district. I). M. Near I'ortletlen, Kincardineshire (the only British record).

․ A. smaragdula Maral. Tie. Lich. Crost. 1). 29 (1850)

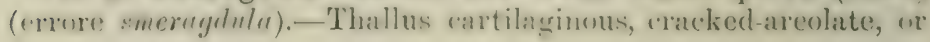


if squamules somewhat seattered and rounded, varying in colour frum yellowish- to rerldish-or dark greenish-lorown, dark beneath $(\mathrm{K}-\mathrm{CaCl}-)$. Apothecia small, immersed and concave, then sowewhat plane, solitary or sereral in each squamule; the disc lark-brown; paraphyses rather stout, variously septate, scarcely wiree at the tips, the epithecium lrown; spores minutely ellipsoid, ahout $3-4 \mu$ long, $1 \mu$ thick; hymenial gelatine blue then reddish-brown with iodine.-A, cervina vars. nufescen. smurugrlulu, privign! (non Ach.) Mudd Man. p). 159, 160 (1361). Enducarpon smaragdulum Wahlenb. ex Ach. Meth. Lich. Suppl. 1). 29 (1803): Howk. Fl. Scot. ii. p. 44 \& in Sm. Engl. Fl. v. 1. 1.3n; S. F. Gray Nat. Arr. i. p. 499; Leight. Angioc. Lich. p. Ir, t. 4, fig. (incl. var. rufociresens t. 4, fig. 4 d var. rufeerens). E. rufociresens Tayl. in Mackay Fl. Hib. ii. p. 100 (1836). Lichen smarugrlulus Sm. Engl. Bot. t. 1512 (1805). Errenluria rufescens Turn. ex Ach. Lich. Univ. p. 329 (1810): Honk. in Sm. Engl. Fl. v. 1). 173 ; Borr. in Engl. But. Suppl. 11. 2657 (Leridea rufesrens in text). Lecanora rufescens Nyl. in Flora K. p. 364 (1872) : Cromb. Monogr. i. p. 484. L. simeraydula Nyl. l. c.; Cromb. tom. cit. p. 486. L. fuscata var. smaragdula Cromb. Lich. Brit. p. 56. L. squamulosn f. smaragduln Leight. Lich. Fl. p. 184; ed. 3, p. 169.

Eicsice. Leight. n. 271; Mudd n. 132.

Fesenbles 1 . fusrutn in the dark undersurface, but differs in the sur. even thallus and in the absence of thalline reaction. Some. :inse the apothecia become papillate. L. rufescens and $L$. smaraydula differ only in the scattered squamules of the latter.

Hab. On rocks and walls in maritime and upland districts.list. Not common in maritine and hilly regions of the British 1-1es.-D. 1I. Island of Gnernsey; Redruth, Cornwall; Wichwar. (ilnacestershire; Jeeleigh and Langford. Essex; Cader Idris, DolF-1ly. and near Barmouth, Merioneth ; Gorlestou, Suffolk; Howden iill, Likildale Moor and near Ayton, Cleveland, Yorkshire; Teesdale. l)urham; near Hexham, Northumberland; near Tiendal, WestruoreInne: Barcaldine and Appin, Argyll ; Kring's Park, Stirling; Ben I. wwers, I'erthshire; Bay of Nigg, Tineardineshire; Derriquin, Sybil If a a and Dunkerron, Kerry; Kylemore, Connematra, Galway; ('iure I-Hend, Slieve Move Mt., Achill Island and Achill Sound, Mayo.

Var. sinopica Mascal. I. «-Thallus squamulose-areolate or th. -mall rounded syuamules somewhat scattered, rusty-red. A Futhecia minute, the dise dark-brown.--A. rercina var. sinopice Murtd Man. p. 160 (1861). Endormpon sinopimm Wahlenl. ex Ach. Meth. Jich. Suppl. p. 30 (1\$03) : S. F. Gray Nat. Art. i.

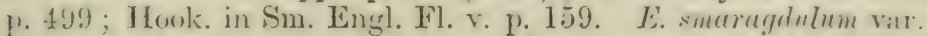
sinrpirnm Leightat. Angioc. Lich. p. 16, t. 5, fig. 1 (1851). Lichen simopirns Sin. Engl. Bot. t. 1776 (upper fig.) (1807). Lecrnomir fusereta var. sinopica Cromb. Lich. Brit. p. 56 (1870). 1. sgummlesa f. sinopira Leight. Lich. Fl. p. 184 (1871); ed. :3. 
p. 170. L. smaraydulı f. sinupica Nyl. ex Nürrlin in Not. Sïllsk. Famn. \& F]. Fenn. xiii. p. 332 (1874); Cromb. Monogr. i. p. 486.

Exsicc. Leight. 11. 285.

Diflers in the colour, which is due to the infiltration of ferric oxide. The thalline squamules are generally contiguous.

Hub. On rocks and boulders, chiefly schistose, in mountainous regions.-Distr. N. Wales and the Grampians, Scotland.-B. $M$. Dolgelly, Merioneth; Aber and Beddgelert, Carnarronshire; Angle. sea; Achosragn Hill, Appin, Argyll; Killin, Ben Lawers and Ben Vrackie, Perthshire; Glen Cluny, Braemar, Aberdeenshire; Glen Nevis, Invernessshire.

9. A. peliocypha Th. Fr. Lich. Alct. p. 89 (1860).-Thallus thickish, crackel-areolate, of crowded somewhat crenate squamules, tawny-brown, somewhat shining, blackish beneath $(\mathrm{K}(\mathrm{CaCl})-)$. Apothecia rather small, immersed then plane, reddish-brown, the dise granular-papillate, the thalline margin persistent, crenulate and flexuose; paraphyses stoutish, irregular, variously septate and clavate or ovoid at the tips; spores numerous, oblons-cylindrical, 3-5 $\mu$ long, 1-1.5) $\mu$ thick : Inymenial gelatine bluish then quickly wine-red with iorline.Parmelia peliocypha WVahlenb. ex Ach. Neth. Lich. Suppl. p. 40 (1803). Lecrnora peliorypha Nyl. in Not. Sïllsk. Faun. \& Fl. Fenn. Fürh. n. ser. v. p. 182 (1S66); Cromb. in Grevillea xix. p. 58 (1891) \& Monogr. i. p. 483.

Distinguished by the contrast in colour between thallus and apothecia and by the granular-papillate dises of the latter.

IYul. On mranitic rocks in alpine situations; recorted by Crombiu. from Bracriach, Braemar, Aberdeenshire.

10. A. rhagadiza Oliv. Lich. Eur. fasc. ii. p. 80 (1909).Thallus spreatling, unerual, variously and rleeply eracked, dark olive-greyish, dark beneath $\left(\mathrm{K}-\mathrm{C}_{\mathrm{aCl}}-\right)$. Apothecia small. imnate, concaves or plane, reddish-flesh-coloured; paraphyse: seuder ; spores oblong, narrow, abont $3 \cdot 5 \mu$ long, $1 \mu$ thick : hymenial gelatine tawny-wine-coloured with iodine-Lecanora rhanadizn Nyl. in Flora lxiv. p. 17s (1881); Cromb. in Greville: x. p. 23 (1881) \& Mlonogr. i. p. 485.

('onsidered by Nylander as nearly relited to "Ifennom rujesens." It differs in the colom of the thithus and of the spothecial dise, which may possibly be the effect of the damp habitat.

Mnb. On moist sumlstome rocks in a maritine locality.-B. M. Whitehaven, Cumberland (the only record).

11. A. discreta 'Th. Fries Lich. Ficancl. 1. 217 (1871).... 'J'hallus efluce, warted-or andular-aresolate, the areolar contiruous or dis rete, dark lowwn, dark leneath (K-CaCl-). Apothecia minute, impresserl, somewhat andular, dark-lorown, the thalline margin ubtuse or indistinet : paraplesses stoutish or slender, somewhat rlavate and generally redelish-hown at the extreme 
tips; spores oblong, 3-4 $\mu$ long, $1 \mu$ thick; hymenial gelatine blue then wine-red with iodine--Parmelia squamulosa var. Iiscreta Ach. Meth. Lich. Suppl. p. 41 (1803). Parmelia discreta Fr. Summ. Veg. Scand. p. 106 (1866). Lercunora admissa Nyl. in Flora 1. p. 370 (1867); Cromb. Lich. Brit. p. 57 \& Monogr. i. p. 485 ; Leight. Lich. Fl. p. 185. L. discreta Nyl. in Flora Iv. p. 364 (1872) ; Leight. Lich. Jil. ed. 3, p. 171 ; Cromb. Monogr. i. p. 485 .

Exsicc. Johns. n. 151.

Distinguished by the dark, angularly areolate thallus. A species collected by Harriman at Teesdale, with scattered areolin, belongs to A. smaragdula.

$H a b$. On exposed siliceous rocks in upland or mountainous regions.-Dist. Rare in N. Wales, N. England and the Grampians, Scotland.-B.M. Y Fegle Fawr, near Barmouth, Merioneth; Bywell, Northumberland; summit of Ben Lawers, Perthshire; summit of the Khoil, near Ballater, Aberdeenshire.

12. A. Heppii Koerb. Purerg. p. 61 (1859).-Thallus eftuse, very thin, continuous or partly obsolete, dirty-yellowish ( $K-$ $\mathrm{CaCl}-$ ). Apothecia small, the disc dark reddish-brown, the margin prominent, entire ; paraphyses coherent, slender, sometimes branched, septate, scarcely widened upwards, the epithecium dark-brown; spores whlong-ellipsoid, $4-4 \cdot 5 \mu$ long, 1-2 $\mu$ thick; hymenial gelatine blue with iodine-A. cervina var. Heppii Mudd Man. p. 160 (1861). MIyriospore Heppii Naeg. ex Hepp Flecht. Eur. n. 57 (1853). Lecanora Heppii Nyl. in Not. Sïllsk. Faun. \& Fl. Fenn. Fürh. n.s. v. p. 182 (1866); Cromb. Lich. Brit. p. 57 \& Monogr. i. p. 487 ; Knowles in Soc. Proc. Roy. Dubl. Soc. xiv. p. 131 (1913). L. squamulosa f. privigna Leight. Lich. Fl. p. 185 (1871) pro parte; f. Heppii op. cit. ed. 3, p. 170 (1879).

Exsice. Leight. n. 196.

An inconspicuous plant, with the thallus often scarcely visible. The apothecia are mumerous. The spores in the speeimens examined (Hepp exs. 12. 57 ard others) are smaller than the sizes cuoted from Th. Fries; they measure about $2 \cdot 5-3 \mu$ long, $1 \mu$ thick.

Hab. On siliceous and calcareous rocks in maritime and inland districts.-Distr. IRare in S. and N. Fngland, Wales and IS. Ireland. - B. M. Lyndhurst, New Forest, Hauts; South Downs and Hastiugs, Sussex; Bexley Hill, Kent; Great Ayton and Fasby, Cleveland, Yorkshire; Llandrindod, Radnorshire.

53. LECANIA Massal. Alc. Gen. 1). 12 (18.53); Mem. Lich. p. 120 (1853) ; Murld Man. p. 140 (1861) pro parte. (Pl. 5.3.)

Thallus squamulose, imbricate or lobed at the circumference and corticate alsure, or variously crustaceous. Algal cells: Protocorens. Apothecia reddish-brown or blackish, marginate when young, the margin often disaplearing; sporec erenerally is 
in the iscus (4-16 in $L$. syrinyen), colourless, more or less elongate and rather narrow, I-3-septate. Spermogones with pleurogenous or acrogenous arcuate or straight spermatia.

Lecania, as here understood, includes not only Lecania but Placolerania A. Zahlbr., which has a more distinctly squamuloseefligurate thallus anil pleurogenous spermatia. The apothecia in several of the species lose the thalline margin at an early stage, and look like Biatorince.

Thallus more or less squamulose §i. Placolecanta. Thallus variously crustaceous................ § ii. EuLecanid.

\$ i. Plicoledxia Stein. in S. B. Akad. Wiss. Wien. Math. Nat. Cl. crii. Alth. i. p. 106 (1898).-Thallus squanulose, the squamules effigurate at the circumference, imbricate, or becoming sranular.

1. I. candicans A. Zahlibr. in Oesterr. Bot. Zeitschr. lr. p. 61 (1905).-Thallus orloicular, adnate, squamulose, continuous or lobed or cracked-areolate in the centre, plicate-lobate at the circumference, grlaucous- or greyish-white, often pruinose $(\mathbf{K}-)$. Apothecia rather small. alout $1 \mathrm{~mm}$. across, the disc brownishblack, more or less pruinose, the thalline margin entire, persistent; paraphyses slender, wirler and brown at the tips; spores fusiform-ellipsoid, 1-septate, $7-14 \mu$ lons, $4-i \mu$ thick.-Lichen rundicans Dicks. Pl. Crypt. fase. iii. 1) 15, t. 9, fig. 5) (1793) : With. Arr. ed. 3, iv. p. 17 ; Engl. Bot. t. $1778 . \quad L$. epigeus Ach. Lich. Suec. Prodr. pr. 10.) (17.9s) (non Pers.). Lecrenora "priger Ach. Lich. Univ. 1) 422 (1\$10) : Hook. Fl. Suont. ii. p. 50. L. randirans Sicher. Enum. 1) $59(1<.00)$; Cromb. in Grevillea xviii. p. 46 it Monors. i. p. 390. Plandinm eprigeum S. F. Gray Nat. Arr. i. 1. 446 (1N-21) (nom Pers.). Pl. cundicans Dub. IBot. Gall. p. 661 (1\$30): Mudd Man. 1) 1333; Cromb. Lich. Brit. p. 4 ; Leight. Lieh. Fl. p. 17s: ed. 3, p. 16.t. Śqumuria

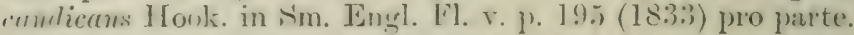

Exsicc. Johns. n. 411 ; Leight. n. 218.

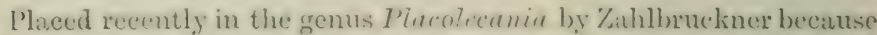
of the sepuamulose thallus; it is a very well-natried fichen which could only be eonfused with Buelliu conesirns, from which, however, it can be distinguished by the marginate apothecia and by the absence of reaction with potash. The ajnthecia are generally abundant, but the spores are rarely formed or are very imperfect.

Hob. On calcureous or cretaceous rocks in maritine and inland distriets. - Distr. Here and there in Fingland; rare in N. Wales and W. Scotland, not seen from Ireland.--li. ./. P'ortlamd Island and Swamage, Dorset: near Benchy IJeal. Sussex; Weston-super-Mare. Cleeve Hill and diathampton liowns, Somerset; Mal vern, Worcestershirw; Buxton and near ('ronford, Derbyshire; Llanymyech IIill,

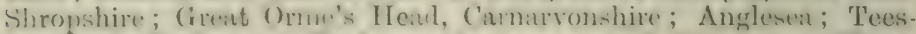

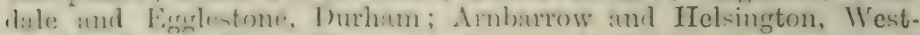
moreland; near Shean l'erry, Argyll. 
Var. Cesatii A. L. Sm.-Thallus densely white-pruinose, of more crowded growth, with the outer lobes niarrower. Apothecia pruinose, with a thick margin.- Ricusoliø Cesatii Massal. Mem. Lich. p. 47, t. 8, fig. 46 (1853). Plarorline Cesatii Leight. Lich. Fl. ed. 3, p. 164 (1879). Lecenora canticans var. Cesrtii Nyl. ex Cromb. in Grevillea xviii. p. 46 (1889) it Monogr. i. p. 390.

Hab. Similar to the species.-D., M. Sherbourne, Gloncestershire (the only British locality).

2. L. holophæa A. L. imm.-Thallus squamulose, subcontiguous or imbricate, dull- or chestnut-brown, the squamules thickish, rounded and erenate $(\mathrm{K}-, \mathrm{CaCl}-)$. Apotheciil small, adnate, plane, with an entire margin, becoming convex and immarginate, the disc dark-brown; paraphyses very slender, septate, with a brown subglobose or truncate head; spores oblong-fusiform, 12-18 $\mu$ long, 4-5 $\mu$ thick.-Parmelic holophre Mont. in Webb it Berth. Hist. Nat. Canar. iii. 3, p. 113 (1840). Lecidece sulburida Nyl. in Mém. Soc. Sci. Nat. Cherb. v. p. 337 (1857) (nomen nudum). Thalloidima subluride Mudd Man. p. 17: (1861). Lecunora holophxe Nyl. in Bull. Soc. Bot. Fr. viii. p. 755 (1861) ; Carroll in Journ. Bot. iv. p. 2:3 (1866) ; Cromb. Lich. Brit. p. 48 it Monogr. i. p. 392 ; Leight. Lich. Fl. p. 227 ; ed. 3 , p. 217.

Exsice. Leight. n. 380.

The thallus recalls that of Lecidere luridu, but it is easily distinguished by the apothecia. It is an Atlantic species that grows from the Canaries as far north as the British Islands. Carroll says it is not rave in crevices of rocks all round the Irish coasts. The spores in the British specimens, as far as observed, are about $14 \mu$ long and $4 \mu$ thick. The spermogones have short septate sterigmatia and straight short spermatia.

$H_{(u b}$. On the ground in crevices of rocks and walls in maritime, very rarely in inland, districts.-Distr. The Channel Islands, S. and W. Englind and s. and N.E. Ireland.-B. M. Moulin Huet Bay. (inernsey; Saltash and near Penzance, Cornwall; Bradstone and near P'rawle Point, Devon; Pulborough, Sussex; near Bridgenorth, Shropshire; Sybil Head, Kerry; Coast of Clare; Kiylemore, Connemara, Galway; Ardglass, Down.

Var. g'laucospora A. L. Sm.-Thallus paler, of sinaller squamules, becoming whitish-leprose. Apothecia with subentire persistent margin, otherwise as in the species.-Lerimera holophen var. gltenerospore Nyl. in Flora li. p. 164 (1868); Cromb. Lich. Brit. p. 40 it Monogr. i. p. 39:2 Leight. Lich. Fl. 1. '2.27; ed. :3, p. 218.

Exsice. Larb. Lich. Cresar. n. 79.

Differs very considerably in the aspeet of the thillns which often becomes granular or leprose, obscuring the squamules.

Ifah. On rocks in maritime districts.-Distr. Sparingly in the Chamnel Isliunds and S. W. Finglind.-1). If. Grosnez ('ommon, Jersey; Saint's lan, (inernsey: Alderner; near Endellion, Cornwall. 
3. L. leucospeirea A. L. Sm.-Thallus of minute sulscrenate: scattered or massed sfuamules, adnate, often somewhat granular, white $(\mathrm{K}-, \mathrm{CaCl}-)$. Apothecia minute, plane, the dise brown, the thalline margin entire; paraphyses slender, yellowish-brown at the apices ; spores oblong or ovoid-oblong, 1-septate, 11-13 $\mu$ long, about $3 \cdot 5 \mu$ thick.-Lecanora lencospeivere Nyl. in Flora li. 1. 473 (1त68); Cromb. Lich. Jirit. p. 48 it Monogr. i. p. 393 ; Leight. Lich. Fl. p. 227 ; ed. 3, p. 218.

Hab. On gravelly soil in maritime districts.-Distr. Rare in the Channel Islands and E. Treland. - B. M. Boulay Bay, Tersey; Howth, Dublin.

\$ii. Eulecasia Stizenb, in St. Gall. Ber. Nat. Ges. iii.p. 170 (1S62). - Thallus crustaceous. Apothecia frecuently beconning immarginate.

\section{Spores mostly 1-septate.}

Thallus determinate or subileterminate.

4. L. Ralfsii A. L.Sm.-Thallus subdeterminate, cartilarginonsareolate or gibbous, smooth, leaden-grey or dark olive-green $(\mathrm{K}-, \mathrm{CaCl}-)$. A pethecia small, rather lrominent, the dise plane, brownish or dark reddish-brown, the margin thin, disappearing; paraphyses subdiscretr, slender, septate, broader and brown at the apices; spores large, oblong-ellipsoid, sometimes slightly constricted at the septum, 18-2:3 $\mu$ long, 6-9 $\mu$ thick: hymenial gelatine blue then violet coloured with indine.Leridea Ralfsii sialw. in Ann. Penz. Nat. Hist. Sore. ii. 1) 145 (1853). L. Muddii Salw. ex Mudd Man. p. 179 (1861): Cromb. Lich. Brit. 1) 74 (1870): Leight. Lich. Fl. 1) 315. Bintorina Muddii Mudd Man. p. Ts (1861). Lecenoma Tialfsii Cromb. in Grevillea ii. p. 1:3 (1873) it Monogr. i. p. 39:3 ; Leight. Lich. Fl. ed. 3, p. 220 (excl. syn. L. actra).

Exsicc. Johns. 2. 132 ; Larb. Lich. Hb. n. 134.

Characterized by the dark-green thallus amd large spores; it is fit. quently associatrd with $I_{\text {. }}$ prosechoiles. Pinlorinu jojuma A. I. Sim. Monogr. ii. p. 114, with the synonyms Lecanora jejuna and Lecider sululiluke are perhaps identical with this lichen as stated by Crombie (1. c.), lut differ in the thinner thallus and light-eoloned biatorine apothecia.

$H a b$. On siliceons maritime rocks.-Distr. Rather rare round the Jibitish consts. li. 17. Jersey; St. Mary's, Seilly; the Lizat and nest P'enzance. ('onwall; liarrowmontl, Comberland; Barcaldine.

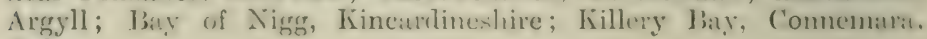
Galway.

5. L. actæa 13. de Lexd. Lich. Dunk. p. 178(1910).-Thallus determinate, mather thiek or thin, mequal, deeply erackerl. sereyish-teaden coloured, blush and thinly white fimbriate at the circumferenes (K-, CaCl-). Apothecia small, somewhat 
I) rominent, blackish, becoming convex; paraphyses thickish, septate, more or less coherent; epithecium dark-bluish; spores ellipsoid or subfusiform, 12-14 $\mu$ long, 1-5 $\mu$ thick; hymenial selatine llue, the asci at length violet, with iodine. - Lecunorn actra Nyl. in Flora lvi. p. 290 (1S73); Cromb. in Grevillea ii. p. 89 (187i) \& Monogr. i. p. 447 ; Knowles in Sci. Proc. Roy. Dubl. Soc. xiv. p. 130 (1913).

The specimens in the herbarium are too scanty to allow reexamination. Bouly de Lesdain describes a var. violacea (l. c.) with violet timbriate hypothallus, smoky-brown epithecium, capitate paraphyses, spores 9-15 $\mu$ long, $5-6 \mu$ thick, and shorter spermatia, 12-16 $\mu$ long. those of the species being 16-20 $\mu$ long. De Lesdain considers that spermatia may vary consilerably within the species, and he also suggests that $\dot{L}$. actieu, though seeming so different, may be a growth form of $L_{\text {. erysibe. }}$

Hab. On rocks in maritime listricts. -Distr. Tare in the Channel Islands and E. Ireland. $-B . M$. Boulay Bay, Jersey.

6. L. spodophæiza A. L. Sm.--Thallus in small determinate patches, areolate-warted, brownish, thinly white fimbriate at the (ireumference $(\mathrm{K}-, \mathrm{Ca} \mathrm{Cl}-$ ). Apothecia minute, the disc darkred, the margin stout, subentire; paraphyses rather stout, subeoherent, septate, irregular and generally brown at the tips; spores wblong- or fusiforv1-ellipsoid, sometimes slightly curved, becoming distinctly septate, $10-18 \mu$ long, 4-6 $\mu$ thick.-Lecenore sqodophasiza Nyl. in Flora lvi. p. 290 (1873) ; Cromb. in Grevillea ii. 1. 89 (187:3) \& Monogr. i. p. 447 ; Leight. Lich. Fl. ed. 3, p. 220; Knowles 1. c.

Differs from $L$. crysibe in the determinate thallus and in the apothecia, but rery closely related to some forms of that species. The spermatia are $18-25 \mu$ long, $\cdot 5 \mu$ thick.

Hal. On rocks in maritime districts.-Distr. Rare in the Channel Islands and E. Ireland.-B. M. Mont Orgueil, Jersey.

7. L. aipospila Th. Fr. Lich. Scand. 1. 293 (1871).-Thrallus suborbicular or spreading irregularly, composed in the centre of crowded angular or tuberculose papillie, which are scattered and are smaller or flattened out towalds the edge, greyish- or very dark-brown ( $\mathrm{K}-$ ), a dark hypothallus sometimes limiting the thallus. Apothecia small, innate in the papillae, dark-brown $\mathrm{cm}^{\circ}$ blackish, plane, becoming convex and immarginate; paraphyses wirlening upwards, thickly-septate, brown at the tips; spores ellipsoid, 9-14 $\mu$ long, 4-6 $\mu$ thick (or rather larrer up to $16 \mu \times 6 \mu$ ): hymenial gelatine bluish then dark-violet with iodine.- L. rrysilw var. aipuspila Mudd Man. P. 141 (186-1). Purmelia aipmpiln Wahlenb. ex Ach. Metb. Suppl. p. 36 (180):). Lecanora nipespila Ach. Lich. Univ. p. 385 (1\$10); Engl. Bot. suppl. t. 20662, tig. 2; Honh. in Sim. Engl. N1. v. p. 187 : Croml. Lich. Lirit. 
1. 49 \& Monogr. i. p. 407 ; Leight. Lich. Fl. p. 2228; ed. :, p. 219.

Exsicc. Cromb. n. 159.

I well-marked plant, closely allied to, if not identical with, L. Iabcnhorstii (Hepp) A. Zahlbr. It differs from L. crysibe in the rugged thallus and in the position of the apothecia at the tips of the papillis. Some of the specimens are almost black, due, according to Crombie, to a drier habitat. Spermogones occur near the edge of the thallus, with areuate spermatia $16-23 \mu$ long, $1 \mu$ thick.

$H a b$. On granitic and schistose rocks in maritime districts. $-D$ istr. Plentiful in the Chanuel Islands, S.W. and N.E. England, N.E. Scotland and S.W. Ireland.-B. M. Le Fret, Jersey; Jerbour, Guernsey; Tolpedn, Penwith, near Penzance, Land's End, and near the Lizard, Cornwall ; Holy Island and Staples Island, Northumberlaud; Portlethen and Cove, Kincardineshire; near Peterhead, Aberdeenshire; Glandore, Cork; Shirky Island, Kerry.

Var. maritima A. L. Sm.-Thallus granular, the granules more flattened than in the species, subcrenate at the circunference, greyish, sometimes dark-coloured. Apothecia on the granules, becoming immarginate.-Lecanora maritimu Sommeri. in Vet. Acad. Handl. 1823, p. 116. L. aipospila var, maritima Nyl. Lich. Scand. p. 158 (1861); Cromb. Lich. Brit. \& Mnnogr. i. p. 408 ; f. maritima Leight. Lich. Fl. p. 229 (1871) ; ed. 3. p. 219.

Hab. On granitic aud schistose rocks in maritine districts.--Dist $f$. Local and scarce in S.W. and T. England and X.W. Scotlani.B. M. Near Penzance, Cornwall; ])ouglas, Isle of Man; Portleth.?. Kincardineshire.

\section{Thallus effuse, variously areolate or granulose.}

8. L. albariella A. L. Sm.--Thallus effuse, thin, whitefarinose, or irregularly granular-areolate $(\mathrm{K}-, \mathrm{CaCl}-)$. $A_{l^{\prime}}$ thecia rather small, dark-coloured, becoming convex, with a thin white far inose disappearing margin : paraphyses discrete, septate, slightly thicker and hrown at the tips: spores ellipsoid, $8-1: \mu$. long, $3-5 \mu$ thick ; hymenial gelatine gutickly beeoming violet-

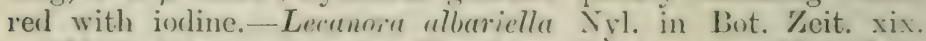
1. 338 (1861) note it in Act. Foe. Linn. Jined. xxv. p. 633 (1864): Jones in Nat. 14ist. Sone. Duhlin, 1864, p. 119; Cromb. Lich. brit. p. 50 ; Leight. Lich. Fl. p. 22!) ; ed. :3, p. 219. L. erysile subsp. alloriellu Nyl. in Flom lxiv. p. lit (1sis); Cromb) in

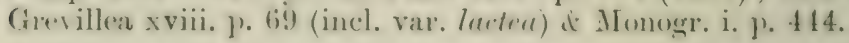

Distinguished by the whitish eream-colourerl thallus, more espre ially evident in the apothecial margins, and b,y the diserete paraphy -

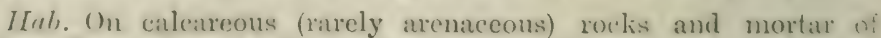
walls.-Distr. liare in s. England and in W. and N.1. Ireland. B. M. I. of Wight; neur Easthourne, Sussex; Clare Islaml, May : Glenarm, Antrim. 
9. L. prosechoides Oliv. Exp. Syst. Lich. Fr. i. p. 311 (1897).-'Thallus thin or thickish in places, uneyually or wartedareolate, whitish or dull-yellowish $(\mathrm{K}-, \mathrm{CaCl}-$ ). Apothecia rather small, plane, somewhat prominent, the disc hrown, beconing black, the thalline marsin subentire, partly disappearing; paraphyses somewhat concrete, thickish, septate, enlarged and brown at the tips; spores ellipsoid, simple,

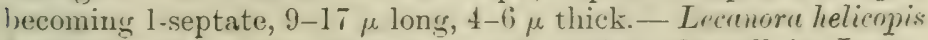
f. dilutior Nrl. Lich. Scand. p. 159 (1861); Carroll in Journ. Bot. iv. p. 25 (1866) ; Cromb. Lich. Brit. p. 50. L. umlriure subsp. prosechoides Nyl. ex Cromb. Lich. Brit. p. .)l (1870): t. prosechoides Leight. Lich. Fl. 1. 205 (1871); ed. 3, 1\% 191. L. jrosechoides Nyl. in Flora lr. p. 2.50 (187-2) (incl. f. sublutior (p. cit. lxv. p. 456 (is82)) ; Cromb. in (trevillea iii. p. 82 d Monorr. i. p. +26 (incl. f. sublutior). I. proserfle Leight. Lich. Fl. ed. 3, p. 224 (1879) (non Ach.).

E.csicc. Cromb. n. 67 ; Larb. Lich. Hb. n. 94.

I maritime plant, differing from $L$. crysibe in the stouter thallus and in the generally thicker spores. In the British specimens they measure usually about $8-12 \mu$ in length, the size given by Crombie. The thallus may be determinate and the apothecia are frernently the host of Arthonia varians. In some specimens the hymenium in the upper part is bluish-green. Sometimes the apothecir are lighter in colour (f. sublutior).

$H a b$. On schistore, rarely on cretaceons rocks or cement in muritime districts. - Distr. Fairly general round the coasts of the British Isles.-B. M. Noirmont, Jersey; Vale Bar, Guernsey; P'enzance. Cornwall; between Porlock and Lynton, Deron; Mamorbeer, Tenby, Pembrokeshire; Southerndown, Glamorganshire; The Mowldach and Dolgelly, Merioneth; Pwlheli, Carmarvousbire; Port Soderick, I. of Man; Barcaldine and Loch Creran, Argyll; l'ortlethen, IKincardineshire; Cnst, Shetland; Killiee, Clave; Letterfrack, Commemara, Galway; Ardglass, Down.

Var. melacarpoides Oliv. tom. cit. 1. 312.-Thallus bluishwhite. Apothecia black or bluish-black.-Lrenore prosechoinles subsp. melarerpoides Nyl. in Flora lxiv. 1) 7 (1881); var. melucurpoides Kuowles in S'ci. Proc. Roy. Dubl. Soc. xiv. p. 129 (1913). Specimen not seen.

Hab. On rocks by the shore. ('ollected on top of the seatwall at Sutton, Howth, Dublin, by M. C. IRnowles.

Var æruginascens (errore xrminusa) Oliv. 1. e.- Thallus leaden-white, limited by an acruginus dendritic hypothallus, also

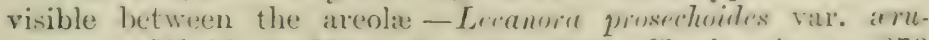

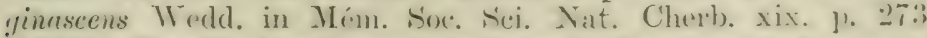
(1575); Knowles l. c. (ertore irmuinusu). Fipecimen not seen.

Irab. On rquart\% rocks by the shore. (ollected na: Neclles at Howth, Dublin, by M. C. Kinowles. 
10. L. spodomela A. L. Arm.-.Thallus effuse, thin, subleprose, areolate, greyish, or grevish-brown $(\mathrm{K}-, \mathrm{CaCL}-)$. Apothecia small, the disc blackish, the thalline margin light-grey, subcrenulate; paraphyses slender, brown and septate at the clavate tips, surmounted by a blackish epithecium, spores ellipsoid, 11-16 $\mu$ long, 6-7 $\mu$ thick; hrmenial gelatine blue with iodine.Lecanora sportomela Nyl. in Flora lix. 1. 572 (1876) and lxix. p. 101 (1886) : Cromb. in Grevillea v. p. 106 (1877) \& Monogr. i. p. 394 ; Leight. Lich. Fl, ed. 3, 221.

The thallus is obscured by a dark growth of blue-green alga; but apothecia are abundant and well developed. The paraphyses freguently show a dark line over the tip like those of $L$. proscchoidizr.

Hab. On maritime sandstone rocks.-Distr. Rare in Wr. Ireland.-B. M. Fillery Bay and Kylemore Lake, Connemara, Galway.

11. L. atrynioides Kinowles in Ści. Proc. Roy. Dublin Soc. xiv. p. $130(1913)$.- Thallus greyish, coarsely areolate, thin, effuse: hypothallus dark. Apothecia crowded and often angulose, - is to 1 mı. in diameter, the disc dark reddish-brown, hecoming convex, margined when young, the margin thin, whitish, entire or sul)crenulate, subpersistent; jaraphyses subriscrete, septate, clavate and blackish-brown at the tips ; spores ellipsoid, occasionally constricted at the septum, sometimes slightly curved, 10-14 $\mu$ long, $4-6 \mu$ thick; hrmenial gelatine decp blue then violet with iodine. Spermogones with slender arcuate spermatia borne on the tips of simple sterigmata.

With a general resemblance to Lecrenorn ofrynen ( $L$. crnisia rar. atrynea) and growing in similar situations.

Hal. On sehistose maritine rocks about high spring ticte-level, at Red Rocks, Howth, Dublin.

12. L. cæsia A. L. Sm.-Thallus subdeterminate, thinnish, tartareous, granulate and areolate-diffact, darkish cassious $(\mathrm{K}+\mathrm{CaCl}-)$; hyouhallus white. Apothecia moderate in size, depressed, plane or convex; epithecium dark resio-pruinose. the margin prominent, white-sorediate and flexuose-crenate : paraphyes slenrler, conglutinate, hranched : spores s in the ascus, colourless, ol)long-ellipsoirl, 1-septate: hymenial gelatine deep blue with iodine. Lerenora cessin Johns. exs. 11. :326 (1900).

Exsice. Johns. n. 326.

A maritime species. Johnson wats mathle to find the spernogones. There is only in small specinen, but it seens to show that the darti colour of the thallus is due to hlise-green algate. The gonidia are suall, about 7-8 $\mu$ in diameter. The primphyses are slender, very erowled and undulate, entirely oolnurles , lut the epithecimm of dark gramules. The spores are usually abunt $15 \mu$ long and $5-6 \%$ thick, but vary in

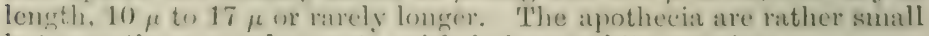
but sometimes conglomerate, with farinose white margins.

Hab. On arenneeous rocks. $-B$. $M$. Hudshend near Berwick-on'I'weed. 
13. L. prosechoidiza A. L. Sm.-Thallus thin, areolate, 1) lackish-wrey ( $\mathrm{K}-, \mathrm{CaCl}-$ ). A pothecia small, the risc blackish or brownish-black, the thalline margin thin, disappearing: paraphyses stoutish, mequal, rather cohering, septate, swollen at the tipss and hrown, with a dark-brown line over the trop: -jores ellipsoid, 9-14 $\mu$ long, 4-6 $\mu$ thick, simple then faintly septate: hymenial gelatine blue then tawny with iodine.Lecanore pirssechoirliñ Nyl. in Flora lxir. p. 3 (1881): Cromb. in Journ. Bot. xxiii. p. 195 (1885) \& Monogr. i. p. 427.

Closely allied to $L$. prosechoides or to $L$. crysibe but with a much thaker thallus and apothecia. The spores are so frequently simple that it might more truly be classified with Leranora, but its aftinity. is with Isecrnir. Sperwogones are rare with spermatia 16-22 $\mu$ long. $\cdot 5 \mu$ thick.

Hab. On schistose and calcareous rocks in maritime district.s.Iristr. Somewhat rare in W.. N.E. and N. Scotland and E. Ireland. -13. M. Barcaldine, Argyll; Bay of Nigg, near the Cove and l'ortlethen, Kincardineshire; Forse, Caithness.

14. L. erysibe Mudd Man. p. 141, t. 2, tig. 47 (1861) pro farte (incl. var. Rabenhorstii (non Hepp), excl. var. aipospila).-... Thatlus crustaceous, effuse, cracked-areolate or granulose, dull wrey or greenish-olive or brown, sometimes very thin $(\mathrm{h}-$ ). - lrothecia rather small, innate, with a slight margin, hecoming convex and immarginate, brown-or dull-red ; paraphyses coherent, stoutish, septate, slightly enlarged upwards and brown at the tips; spores ollong-ellipsoid, becoming 1 -septate, 10-15 $\mu$ long (rarely $19 \mu$ ), 3-5) $\mu$ thick; hymenial gelatine blue with iodine. Lichen erysibe Ach. Lich. Suec. Prodr. p. 50 (1798). Lecanora rysibe Nyl. in Mém. Soc. Sci. Yat. Cherb. v. 1) 114 (185i): Cromb. Lich. Brit. p. 53 \& Monogr. i. p. 443 ; Leight. Lich. Fl. p. 228 ; ed. 3, 218. L. pheoleurodes Nyl. in Flora lxii. p. 356 (1879); Cromb. in Grevillea viii.p. 112 (1880) \& Monogr. i. p. 445 (incl. subsp. proteiformis Nyl. in Flora lxiv. p. 5i38 (1881)?).

Exsicc. Johns. n. 371 (as Lecanora albariella); Mudd nos. $104,105$.

A rery ruriable plant in the form of the thallus, which is mostly manulate-areolate, and in the apothecia, which become prominent mul convex. Lecanora phooleucorles has been included as not being - pecifically distinct. Crombie has inadrertently giren its spermatiat medsurements (16-20 $\mu$ long) for those of the spores; they meatsure only up to $15 \mu$ in length. A specimen in Johnson's lixs. named 1. albariella has also been included ; the spores are very long, up to $19 \mu$, and occasionally an additional septum is formet in one of the cells. 13, de Lesdain records several instances of equally long spores (Lich. Dunk. pp. 174 and 175), and I have agreed with hin in including these long-sinred speeimens under 1 . crysibe. though possibly the alifferences atre specific. I form with a thin finely areolate thallus growing on limestone has been deseribed by Crombie as subsp. protri. fomis. It is evidently a poorly developed condition of the species.

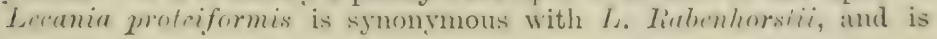


more nearly related to $L$. aipospile. L. Rabruhorstii (Hepl)) ]: ac Lesd. has not been found in Britain.

$H_{n}$ b). On rocks, very rarely on decorticated trees, in maritime : 1 il inland distriets.-Distr. Widely distributed throughout the British Isles.-D. M. St. Aubin's Fort, St. John's. Tiozel, Fliquet Jay, Noirmont and St. Brelade's (lignicolous), Jersey ; Sark; Guemsey; ne: Penzance, Cornwall ; near Torguay, Deron; Luccombe, I. of Wight; Rottingilean Cliffs, Sussex; Ulting, Essex; Bathampton Down. Somerset; near Painswick and near Cirencester, Gloucestershire; Goodwick Bay, Pembrolieshire; Abdon, Shropshire; Norton, Worcestershire; Rellear, neax Ayton and Coathan, C'leveland, Yorkshire; St. Bees, Cumberland; Lismore and Burcaldine, Argyll; Portlethen, Kineardineshire; Craig Guie, Briemar, Aberteenshire; Lower Glanmire Road, Cork; near Kilkee, Clare; Down.

Var. cinereofusca Mudd 1. c. t. 2, fig. 48.-Thallus effuse, very thin, leprose, greyish-green when moist, greyish-blown wher dry. Apothecia minute, scattered, numerous, the disc plane, dark-brown, slightly pruinose, at length convex; spores mort ellipsoid, indistinctly septate.-Lecanoia crysibe f. cincreofus. Cromb. in Grevillea xviii. p. $69(1890)$ \& Monogr. i. p. $444^{\circ}$

Exsicc. Mudd n. 106.

Considered by Crombie to be only a form of the species, but the very minute apothecia and indistinctly septate spores justify it varietal position.

$H a b$. On rocks and walls in maritime and inland districts. - Distr. Siparingly in S. W. and N. Englant.-B. M. Hastiugs, Sussex; Crowle near Worcester; near Ayton, Cleveland, Yorkshire.

Var. sincerior B. de Lescl. Lich. J)unk. y. 17i (1910)..Thallus whitish, granulate-areolate or of seattered srimules. Apothecia with a persistent thalline margin, the disc reddishbrown.-Lceanora rrysibe var. sincerior Nyl. in Flora lix. p. 5TT (1^76); Cromb. in Grevillea v. 1. 108 (1876) it MIonowr. i. p. 444: f. sincerior Leight. Lich. Fl. ed. 3, p. 219 .

E.esire. Johns. n. 138 ; Larb. Lich. IIh. without a number.

Differs from the species in the whiter colour of the thallus and th. persistently marginate apothecia. D. de Lesdain gives you sizes as 15 $-18 \mu$ lone, 5-6 $\mu$ thick. They are constantly $15 \mu$ long, $5 \mu$ thicl: in the british specimens, and they are very distinctly septate.

$H a b$. On rocks and walls in maritime locnlities.-Distr. Rare in the Chamnel Islands, S. and N. Enstimd, aml N.WV. Ireland.-D. M. Vale Castle, Gumnsey; Mastings. Sussex ; near Torpoint, Devon: North Tyne, Northmberland; it. Hees, ('umberland; Iettermon. Connemara, Galway.

15. L. Hutchinsia A. T. Sun.--Thallus effuse, thin, areolitı. smucwhat furfuraceous, or almost rlisappearing, pale rlull-browni-l.

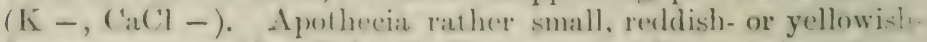
hrown, convex, the slight thalline marein disappearing at ats rarly stage; faraphyses subeliscrete, rather slemeler, septate. lightly clavate "lpwards, colnurless at the tips; spores oblon:- 
-llipsoid or fusiform, 10-12 $\mu$ long, 3-4 $\mu$ thick; hymenial selatine blue or partly wine-red with iodine.-Leranora Hutchinsia Nyl. in Flora 1. p. 326 (1867); Carroll in Journ. Bot. v. p. 25.) (1567); Cromb. Lich. Brit. p. 50 it Monogr. i. p. 445 (incl. var. arressitans); Leight. Lich. Fl. p. -226; erl. 3, p. 217. Lecider albucamea Nyl. in Flora lix. p. $234(1876)$ \& op. cit. lxii. 1). 361 $(1 \leq 79)$; Cromul. in Grevillea v. 1). $26(1 \times 76)$; Leight. Lich. Fl. arl. 3, p. 3!0 (incl. f. umbrosa). L. acressitans Nyl. op. cit. lix. p. $306(1876)$; Cromb. l. c. ; Leight. tom. cit. p. 260.

Eiexier. Cromb. n. 164 ; Larb. Lich. Hb. nos. 71, 72, 224, 269.

Allierl to $J$. crysibe. which it resembles in the appearance of the thillus, but differing in the early disappearance of the apothecial margin and in the more slender colourless paraphyses. It has not been recorderl on the Continent as a distinct species, but may have iveen overloolied or included as a form of $L$. crysibe. I. arcessitans differs only in the more scanty thallus. probably owing to the shady habitat.

Hal. On schistose rocks and walls in maritime and inland districts. Listr. liare in the Channel Islands, S. W. England and W. Ireland. -. L. M. Near Pozel, Jersey; Moulin Huet Bay, Gruernsey; St. John's. Devonport. Devon; near Penzance, Cornwall; Dawros, Renvyle, Glendalough, Irylemore and Doughruagh Mts., Connemara, Galway.

Form bellissima A. L. Sim.-Thallus thin, subgranulate. Afr,thecia usually in small groups, slightly pruinose.-Leconora - rysibe f. bellisime Leight. Lich. Fl. ed. 3, p. 217 (1879); Cromb. Monogr. i. 1. 446 ; var. angreyatilis Nyl. in Flora lxii. 1. 361 (1879); Cromb. in Grevillea viii. p. 114 (1880).

Hab. On shaty walls in a maritime district.-B. 1I. Cleghan, Connemara, Galway.

16. L. umbraticula A. L. Sin.-Thallus effuse, thin, subluprose, greenish $(\mathrm{K}-, \mathrm{CaCl}-)$. Apothecia small, rather plane, the margin disappearing, yellow; paraphyses conglutinate, rather siender, the epithecium colnurless ; spores fusiform, at first simple, hecoming l-septate, $8-16 \mu$ long, $-2-3 \mu$ thick : hymenial gelatine li?ue then wine-red with iodine.-Lecrnora nubraticula Nyl. in Filora lxii. p. 20:) (1879): Cromb. in Grevillea viii. p. 28 (1879) \& Monogr. i. p. 446.

Exsice. Larb). Lich. Hb. (without a number) as Leridea umbraticula.

Not unlilie a "Biatora," but with gonidia below the hypothecium. It is distinguished by the leprose thallus, the brightly coloured apothecia and the narrowly fusiform spores.

Ifal. On shady calcareous rocks in a maritime district.-I, $M$. Achnanure Castle, Galway.

\section{Spores 3-septate.}

17. L. Nylanderiana Massal. Sched. Crit. Lich. Ital. p. 152 (1 455$)$. - Thallus effuse, sranular, unequal, cracted-areolate, dull- 
cinereous or whitish ( $\mathrm{K}-, \mathrm{CaCl}-$ ). Apothecia rather small, at first plane, with a thin whitish-grey margin, becoming conrex and immarminate, the disc lorown or blackish, generally bluish. white-pruinose; paraphyses rather slender, coherent, septate, wider upwards and colourless, but the epithecium suffused with brown; spreres oblong or subfusiform, rarely curved, becoming 3-septate, $14-20 \mu$ long, $4-5 \mu$ thick; hymenial gelatine blue then wine-red with iodine.-- L. cœrulescens Mudd Man. p. 140, t. 2, firs. 46 (1861) (incl. var. reruleorubella). Lecanora athrorarpa f. comlescens Cromb. Lich. Brit. p. 5.3 (1870); Leight. Lich. Fl. p. 231 ; ed. 3, p. 223. L. Nylanderiana Nyl. ex Norrl. in Sällsk. Faun. \& Fl. Fenn. i. p. 24 (1876); Cromb. Monogr. i. p. 448 (inel, var. coruleorubella).

Exsicc. Leight. n. 294; Mudd n. 103.

Distinguished by the broken granular thallus and the pruinose apothecia.

Hab. On old walls in upland districts.-Distr. Local and scarce in W. and N. England.- B. .T. Preston, near Cirencester, Gloucestershire; near Stokesley, near Mrarsk and near Ayton, Cleveland, York. shire.

18. L. syringea Th. Fr. Lich. Scand. p. 290 (1871).-Thallus effuse, thinly furfuraceous or scarcely visible, greyish-white ( $\mathrm{K}-, \mathrm{CaCl}-)$. A pothecia small, numerous, the disc plane, hrownish or brownish-black, naked or pruinose, becoming convex, the thin entire thalline margin disappearing; paraphyses coherent, slender, sparsely septate, clavate and generally brown at the tips; spores $4-16$ in the ascus, ellipsoid, oblong or subfusiform usually somewhat curved, 1 -3-3eptate, $12-16 \mu$ long, $4-6 \mu$ thick : hymenial gelatine blue then wine-red or violet with iodine.L. fuscella Mudd Man. p. 140, t. 2, fig. 45) (1861) pro parte (non Massal.). Prermelia Hageni var. syringea Ach. Meth. Lich. p. 163 (180:i). P. prallita var. fuscella sichaer. Lich. Helv. Spicil. p. 39 r (1839). Lecenoma athrowarpa Cromb. Lich. Trit. 1) 5:3 (1870) (? Duby) (incl. var. fuscella); Leight. Lich. Fl. p. 23I pro parte; ed. 3, 1. 22:3 pro parte. L. syringea Lany in Bull. Soc. Bot. Fr. xxv. 1). 415 (187心); Cromb. in Cirevillea xriii. 1) T0 (1890) d Monogr. i. p. 448.

Exsicc. Johns. n. 269.

Apt to be mistaken for a species of Bilimlia, unless the thalline margin is specially looked for, ats at an early stage the apothecia becone convex. datta (I'l. Ital. Crypt. Yich. p. 402) retains L. athroocorpa Massal. as a separate speeies with persistent apothecial margin and smaller spores, and with it he associates $L$. fuscellu Matsial. as a synonym, so that the name $I$. symingea is correct for the above lichen.

Ihah. On trees, dhicfly poplar am maple in maritime and upland districts.-Dis/r. Jather rave in S. W. atnd N. Wingland. B. M. Ilsham, near 'Toryuay, Jevon; near lbming. I. of Wight; Lrockenhurst and near Stoney Gross, New forrst, Hauts; near the Beck, Malvern. Worcestershire; Stokesley, Cleveland, Yorkishire; Teesdale, Durban. 
Form metabolica A. L. Sin.- Thallus very thin. A pothecia ninute, convex, dark-brown or nearly black, the margin exclucled. - Lecenora metabolica Ach. Lich. Univ. p. 351 (1S10). L. athroocarpa viar. metabolica Cromb. Lich. Brit. p. 53 (1870); Leight. Lich. Fl. p. 232 ; ed. 3, p. 224. L. syringca f. metabolica Cromb. Monogr. i. p. 448 (1894).

Distinguished by the smaller more scattered and darlser apothecia.

Hab. On trees, chiefly maple, in maritime districts.-Distr. Very rare in the Channel Islands and S. England.-B. M. Trinity, Jersey; Brading, I. of Wight.

19. L. dubitans A. L. Sm.-Thallus a thin grey effuse rather irregular crust, sometimes almost obsolete (Kf + yellowish, $\mathrm{CaCl}-$ ). Apothecia minute, the disc pale- or dark-brown, the margin thin, soon evanescent; paraphyses somewhat coherent, irregularly widening, septate and brownish upwards; spores oblong-fusiform or ellipsoid, usually curved, 1-septate, 12-18 $\mu$ long, 4-6 $\mu$ thick.--Lecidea dubitrne Nyl. Lich. Scand. p. 207 (1861) fide Th. Fr. Lich. Scand. p. 294. Lecanora athoocarpa subsp. dimera Nyl. tom. cit. p. 169. L. dimere Nyl. ex Norr?. in Medd. Sällsk. Faun. \& Fl. Fenn. i. p. 24 (1876) incl. var. dubitans; Cromb. in Grevillea xviii. p. 70 (1890) \& Monogr. i. p. 449. L. Sambuci subsp. dimera Wheld. \& Wils. Lich. Perth. p. 40 (1915).

Distinct from the preceding in the form of the spores. Crombic states that the epithecium gives a pale rose-coloured reaction with potash. I have failed to obtain this.

$H a b$. On the smooth bark of trees in mountainous districts.Distr. lare in the Scottish Highlands. - B. $M$. Morrone, Braemar, Aberdeenshire.

20. L. curvescens A. L. Sm.-Thallus of minute scattered or congregate grey roundish granules or minutely squamulose and lark-brown. Apothecia moderate in size, rather prominent, becoming expanded and thin and slightly convex, the dise dark reddish-brown, the margin lighter coloured, disappearing; paraphyses coherent, very slender, more or less distinctly septate and variously widened upwards, pale yellowish-brown in the mass; asci broadly clavate, 6-8-spored; spores obtusely fusiform, slightly curved, 3-septate, 30-34 $\mu$ long, 1-6 $\mu$ thick.-Pannarin "urveseens Muld Man. p. 125, t. 2, fig. 38 (1861). Lecunore ruvescens Nyl. ex Carroll in Journ. Bot. iii. p. 288 (1865) emend. L. rhypariza f. arvescens Nyl. in Not. Sïllsk. Fiun. \& Fl. Fenn. Förh. 11. ser. v. p. 135 (1866); Cromb. Lich. Brit. p. 53 \& Monogr. i. p. 450 ; Leight. Lich. Fl. p. 214 ; ed. 3 , p. 199.

There is only one seanty specimen of this wery rare lichen in the herbarium of the British Mnseum, but an examintion of it has proved that the spores are listinctly "3-septate. The reaction with 
potash is giren for Lermora rhyparian as $\mathrm{K}$ + rellow, then bloor1"el. There was only a yellow reaction in our specimen of $L$. rur. rescens as tested now but there is a leep red stain on one of the apothecia, which was probably obtained when the specimen wats newly gathered.

Hab. Encrusting mosses (Andrea \& Grimmia) in an alpine situation.-B. M. Simmmit of ben Lawers, Perthshire; the only record.

54. ICMADOPHILUS Massal. Ric. Lich. Crost. 1). 26 (1852) : Mudd Man. p. 64. Bromyces Pers. pro parte. (Pl. 54.)

Thallus crustaceous, not corticated. Algal cells Protococcus. Apothecia sesisile or almost stalked, with a thalline margin at length disappearing; hypothecium colourless with gonidia partly lelow; paraphrses slender, simple, free; spores fusiform, 2-4celled colourlesis. Spermogones globose, immersed, with septate sparingly branched sterigmata. and cylindrical pleurogenous spermatia, which are slightly thicker at each end.

The genus is frequently included in Bromyces. but the structure and development of the apothecia are lecanorine.

I. ericetorum A. Zahllır. in Wiss. Mittheil. Bosn.-Herceg. iii. 1. 605 (1895).- Thallus effuse, closely granular, greenish or whitish ( $\mathrm{K}+$ yellow). Apothecia moderate in size or somewhat large, with a disappearing thalline margin, the dise soft, fleshcoloured, smoth or slishtly wrinkled (K + orange): asci ("ylindrical, 6- or 8-spored : the spores fusiform, 1-3-septate. $13-27 \mu$ long, $4-6 \mu$ thick: liymenial gelatine blue, the asci deep wine-red with iodine.-I. com yinosu Mudd Man. p. 64, t. 1, fir. 13 (1861). Lichen ricetonum L. Sip. Pl. 1. 11.t1 (1753): Huds. Fl. Angl. 1. 443 jmo parte: Engl. Bot. t. :372; var. $\beta$ Lightf. Fl. Scot. ii. 1). 80 !? L. seruginosus Scop. Fl. Carniol. ii.

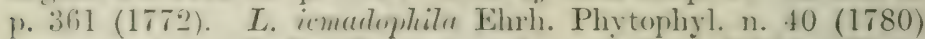
nomen nuclum; Hoftin. Enum. i. 1. :34, t. s, tig. l (178.1): With. Arr. ed. :3, iv. p. 15. Leridea imadoplita Ach. Ireth. p. 5s (180:3) : S. T. Gray Nat. Arr. i. p. 473; Hook. Fl. Secot. ii. p. 39 (t) in sm. Lngl. Fl. v. p. 184 : Tavl. in Mackay Fl. Hib, ii. p. 129.

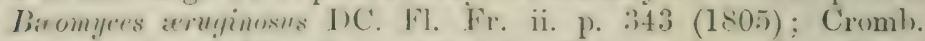
Monogr. i. p. 11:3. B. inmolophilus Nyl. in Act. Soc. Linn. Bord. sér. 8, i. p. 281 (1,56): Cremh. Lich. Brit. p. 16 : Leight. Lich. Fl. p. 54 ; ed. 3 , p. 52.

Exsicc. Croall n. 587 ; Cromb. n. 118; Johns. n. 47 ; Larb. Lich. Hb. n. 44 ; Leight. 1. 209 ; Mudd n. 32.

Thoush the apotherium is sometimes not altogether sessile, there is no true podetium as in the Clendoniocen. In shady localities it is a beatiful green colour. hut becomes yellowish in herbaria. The spermogones are enclosed in thalline granules.

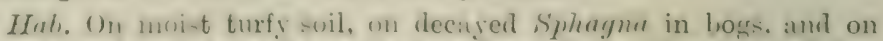
otten trunli- of trees in upland and smbalpine district... - / his/r. 
Local though plentiful where it occurs in Great Britain and Freland. -B. M. Ardingly, Sussex; Tumbridge Wells, Kent; Bagshot Heath, Surrey; Island of Anglesea; Jent and Guisboro' Moor, Cleveland, Yorkishe; 'T'eesdale, Durham; Alston Noor, Cumberland; New Galloway, Kirkendlorightshire; Pentland Hills and Swanston Hill, near Edinburgh ; Appin, Argrll ; blairdrummond near Stirling; Glen Falloch, Craig Calliach, Ben Lawers and Killin, Perthshire; Sidlaw Hills and Clova, Forfarshire; Glen Callater and Morrone, Bramemar, Aberdeenshire; Moidart, Pothiemurchus and Glen Nevis, Invernessshire ; near Lairg, Sutherland ; Pass of Keimaneigh and Gougancbarra, Cork; I) unkerron and Killaruer, Kerry ; Counemara, Galway; Slieve More, Achill, Mayo.

i.j. H出MATOMMA Massal. Ric. Lich. Crost. p. 32 (185.2): Mudd Man. p. 157. (Pl. 55.)

Thallus crustaceous, corticate on the upper surface or norcorticate. Algal cells Protococrus. Apothecia sessile or sometimes immersed; paraphyses discrete, slender ; spores 8 in the ascus, narrowly elongate, straight, bent or sometimes party coiled, :-many-septate, colourless. Spermogones with simple or hranched sterigmata and arcuate acrogenous spermatia.

1. H. ventosum Massal. Ric. Lich. Crost. p. :33 (1:5\%).Thallus determinate, thick, firm, crowdedly and irregularly warted, cracked-areolate, greenish-yellow or dark greenish-grey ( $\mathrm{K}+$ yellow). A pothecia sessile, small, morlerate in size, or rather large and often irregular (up to $3 \mathrm{~mm}$. across), the disc plane or convex, dark-crimson or blond-red ( $\mathrm{K}+$ blue-purplish), the thalline margin thin, often excluded ; paraphyses discrete, stontish, septate, scarcely wiclened upwards; spores irregularly elongate-fusiform, somewhat curved or contorted, 3-7-septate, 40-55 $\mu$ long, up to $5 \mu$ thick: hymenial gelatine blue with indine.-Mudd Man. p. 157, t. 2, fig. 5.2. Lichenoirles turfarenm Tivilum, scutellis mefis, margine exili Dill. Hist. Muse. p. 13:3, t. 18, fig. 14 (1741). Livhen ventosus L. Sp. Pl. p. 1141 (175:3) : lightf. Fl. Scot. ii. p. 806 : Huds. Fl. Angl. ed. 2, p. 527 : Engl. Bot. t. 906 : With. Arr. ed. 3, iv. p. 16. L. yetirlus Huds. tom. cit. p. Jes (1778) (non Linn.). Lecanora rentosa Ach. Lich. Univ. 1) 399 (1<10); Hook. Fl. Serot. ii. p. 48 i in Sim. Engl. Fl. v. 1. 189 ; (irev. Fl. Edin. 1) 332 : Tayl. in Markay li. Hib. ii. p. 136 ; Cromb. Lich. Brit. 1). 57 (incl. var. subfestivar) ¿t Monogr. i. P. 456 (incl. var. sulofestiva); Leight. Lich. Fl. 1. 23.3 ; ed. 3, 1. 2.25. Rimulina ventosa S. F. Gray Nat. Arr. i. 1). 451 (1821).

Exsire. liohl. n. 36 ; Croall n. 588 ; Dicks. Hort. Siere. fasse. v. n. 23 ; Leight. n. 9 ; Mudd n. 29.

Distingruished from other species by the thicker non-leprome thallus and by the generally darker apothecia, the deep colour of which tinges the covering pitper in herbaria. When very dark they have been reforred to var. lepardolemma (l'armelin erentesit var. lepu- 
rolemma Ach. Meth. p. 167 (1803)), and recorded by Willinson from Merioneth in Journ. Bot. xxxviii. p. 184 (1900). The apothecia of var. subfestica are small and badly developed, but otherwise it is similar to the species. Crombic records the spemogones as darkcoloured, with septate sterigmata and short rod-like spermatia.

Hab. On exposed siliceous rocks and boulders in upland or alpine situations.-Distr. Fairly common in upland districts of Englanit and Scotland, rare in Ireland.-B. M. Wistman's Wood and Pew Tor, Dartmoor, Devon; Epsom Downs, Surrey; Clee Hills, Shropshire; Moel-y-golfa, Montgomeryshire; Cader Idris, Merioneth ; Nant Francon, Penmaenmawr, Trefriw and Moel Siabod, Carnal: ronshire; Dent and Kildale Moor, Cleveland, Yorkshire; Leck, Lancashire; Teesdale, Durham; Gumnerton Crags, Northumberland; New Galloway, Kirkcudbrightshire; North Berwick Law, Berwickshire; Achosragan Hill aud Ben Cruachan, Argyll ; Ben Lawers, Ben Trackie and Birnam Hill, Perthshire: Katelaw and Clova, Forfar. shire; Lochnagar, Morrone and Glen Callater, Braemar, Aberdeenshire; Ben Nevis, Invernessshire; Hills of Applecross, Rossshire; Wicklow.

Form lævigatum A. L. Sm.-Thallus smooth, areolatecracked, yellowish straw-coloured. Apothecia small, depressed.Lecanora ventosa f. lrevigata Johns. ex Cromb. in Grevillea xix. p. 60 (1891) \& Monogr. i. p. 457.

Hab. On rocks in an upland district.-D. M. Bowness Kuolt. Ennerdale Lake, Cumberland (the only record).

2. H. coccineum Koerb. Syst. Lich. Germ. p. 15:3 (185.j).Thallus effuse, tartareous-farinose, generally thimnish, whitish or pale-sulphur-coloured, with a white hypothallus ( $K+$ yellow). Apothecia scattered, at first innate, gradually emerging and becoming sessile, small or rarely up to about 2 or $3 \mathrm{~mm}$. across. the disc plane or convex, crimson or reddish-brown $(K+$ violetpurple), the thalline margin thickish or insignificant, more or less crenulate, sranular or pulverulent; paraphyses coherent, slender, sometimes branched, sparsely septate, slightly and rariously widened at the tips; spores elongate-fusiform, 3-i. septate, 30-60 $\mu$ long, $5-7 \mu$ thick ; hymenial gelatine blue with iodine. Murld IIan. 1) 157. Lirhen cocineus Dicks. P1. Crypt. fasc. i. p. \&, t. 2, fig. 1 (17s.)); Engl. Bot. t. 223 ; With. Arr. erl. 9, iv. p. 16. L. hematomua Ehrh. Hannover Mag. 1786, 1. 285? Pers. in Ust. Ann. ljot. xi. p. 16 (1794) (incl. vat.

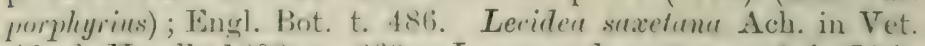
Akarl. Mandl. 1s08, 1). 269. Lectnora hiematemme Ach. Tich. Univ. p. iss (1810) (incl. vars. roceinea and porphyria) : Houk. Fl. Ścot. ii. p. 40 de in śn. Enerl. Fl. v. p. 190; Grev. Fl. Ediu. p. :33:"; 'Tayl. in Mackay El. ILib. ii. 1) 136; Cromb. Lich. Irrit.

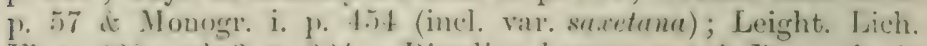

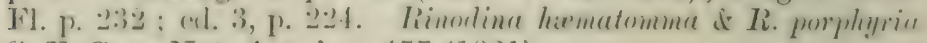
S. F. Gray Nat. Arr. i. p. 457 (18:21).

E.esicc. Bohl. n. 120; Dicks. Hort. Sicc. fasc. v. n. 24 ; 
Johns. n. 239 ; Larb. Lich. Hb. 11. 339 ; Leight. n. 214 ; Mudd n. 130 .

The spores according to Harmand (Lich. Fr. p. 1097) attain it length of $70 \mu$, in our specimen they are generally about $40 \mu$ long. The brightly-coloured apothecia contrast strongly with the white or yellowish thallus, which spreads widely on rocks and boulders. On tree-trunks, where it occurs occasionally (in the New Forest, Dorset and Suffolk), it is alway's sterile in our country. The recorded forms or varieties seem to be simply growth stages. The spermogones, according to Crombie (MIonogr. i. p. 45.5), are minute and look like young apothecia with which they are concolorous. I have been unable to verify this.

The purple reaction of the hymenium with potash is due to the presence of hymenorhodin (Zopf, Flechten Stofie, p. 320) ; it belongs to the same group of acid products as parietin.

Hab. On shaded perpendicular rocks and boulders, rarely on trees, in maritime and upland districts. - Disti. Not uncommon throughout the British Isles.-B. M. La Coupe and Rozel, Jersey; Guernsey; Brechou; Alderney; near Penzance. Cornwall; Ardingly and Withyam, Sussex; Beeleigh Abbey, Essex; Stonehenge, Wilts; Malvern, Worcestershire; Acton Burnell and Nesscliff Hill, Shropshire; Breiddon Hill, IIontgomeryshire; Barmouth, MIerioneth; Nant Francon and Carnedd Dafydd, Carnarronshire; Battersby, Cleveland, Yorkshire; Egglestone, Durham; Harlaw Hill, Northumberland; Cumberland; West Kilbride, Ayrshire; Roslin, near Edinburgh; Airds, Appin, Argyll ; Bowling Bay, Dumbartonshire; West Water, Fife; Blaeberry Hill near Perth, The Trossachs and Craig Calliach, Perthshire; Portlethen, Kincardineshire; Will's Braes, Forfarshire; Morrone, Braemar, Aberdeenshire; Glen Nevis, Invernessshire; near Belfast, Antrim; Western Blasquet Island, Kerry.

3. H. elatinum Koerb. Syst. Lich. Germ. p. 153 (1855).Thallus effuse, thin, granular-furfuraceous, whitish or paleyellowish-white ( $\mathrm{K}+$ yellow). Apothecia rather small, scattered, the disc plane, then convex, light brownish-red, the thalline margin thin, soon disappearing; paraphyses subdiscrete, slender, indistinctly septate, sometimes branched, slightly clavate, the epithecium of brownish-yellow granules; spores elongate-fusiform, 3-5-septate, usually curved, about $40-50 \mu$ long, 4-5 $\mu$ thick; hymenial gelatine blue with iodine-LLecenorce elatinu Ach. Lich. Univ. p. 387 (1810); Cromb. in Journ. Bot. viii. p. 98 (1870) \& Monogr. i. 1. 4.5); Leight. Lich. Fl. p. 2:31 ; ed. :3, p. 223.

Differing from either of the preceding species in the much thinner thallus, and in the absence of reaction with potash in the fruit. The asci are thick-walled, the spores lie in a half spiral. Though extremely rare in the liritish Islands it has a wide distribution, more especially in Scandinavia.

Hab. On the bark of old hollies.-B. M. Derrycuintry, liillarney, Kerry (the only British record). 


\section{()rma XIV. PERTUSARIACE正.}

Thallus crustaceous, effuse or determinate, attached by hypha: to the sulsstratum, corticate or non-corticate above. Algal cells Protococcus. Apothecia, one or several, immersed in thalline jrotuberances (verrucie or warts), the dises often compound, semi-enclosed, surrounded by a stout thalline margin ; paraphyses mostly branched and intricate; asci 1-\$-spored ; spores colourless or brownish, usually very large, oblong-ellipsoid, simple or 1-septate. Spermogones with simple or sparingly branched sterigmata and acrogenous long spermatia.

The affinity of the order is with Lecanoracese, more especially with the section Ochrolcchia, which has been included in Pertusariacea by some lichenologists. There are two British genera :-

Spores simple ......................... 56. Pertusaria.

Spores 1-septate........................ 57. Varicellaria.

5(i. PERTUSARIA DC. Fl. Fr. ii. p. 319 (1805). Variolaria Pers, in Ust. Ann. Bot. vii. p. 23 (1794); Hook. Fl. Scot. ii. p. 46 of in Sm. Engl. Fl. v. p. 168; S. F. Gray Nat. Arr. i. p. 490 ; Grev. Fl. Edin. p. 330 ; Tayl. in Mackay FI. Hib. ii. p. 112 ; Turn. \& Borr. Lich. Brit. p. 51 . Porina Ach. Lich. Univ. p. 60 (1810) ; S. F. Gray Nat. Arr. i. p. 495 ; Hook. Fl. Seot. ii. p. 45 ; Tayl. in Mackay Fl. Hib. ii. p. 101. (Pl. 56.)

Thallus continuous or cracked-areolate, thick and unequally warterl and wrinkled, or thinner and smoothish, generally superficial, rarely subcorticolous (hypophlwodal). Apothecia one or several immersed in the fertile protuberances (verructe or warts), more rarely impressed in the thalline areole, the dises appearing as minute ostioles or broadening out into lecanorine form ; hypotheciurn colourless; paraphyses long, very slender; spores 1-8 in the ascus, colourless or rarely blackish, simple, mostly very large, with a thick epispore, generally the asci alone are coloured deep blue with iodine.

The name Variolaria precedes that of Pertusaria, but it was founded solely on a non-essential eliancter-a sorediate thallus-and is therefore set aside. Iny some of the older writers Variolaria was classified along with somewhat indefinite genera, such as Spiloma. Certain species of I'arinlaria recorded in the older British Floras are now indeterninuble in the absence of specimens. Such are l'ario. laria cincrea S'm. Engl. Bot. t. 2411 (1812); IFook. in Sm. Engl. Fl.v. p. 170. V. tortu Tayl. in Mackay Fl. Ifib. ii. p. 114 (18:36). V.terricola Tayl. tom. cit. p. 115 is less indefinite, as a specimen in the Salwey herbarium labelled "from Dr. Tiylor" is a sterile thallus of linnmyces rosens. There are several species of fariolarin recorded by "Thrner and Borrer in "Lichenographia Britannica," such as i. vilitigo, I. grisen-rircus, ete., that ate of doubtful determination. It is notewnthy that thomgh the ahove work was published in 1839 
it had been widely circulated for many years previously, and is quoted as early as 1812 in Smith's "English Botany" (see Variolariu. griseo-vivens t. 2400).

The species of Pertusaria have been arranged according to the prevailing number of spores in the ascus, it is not a constant character.

\section{A. Spores one in the ascus.}

\section{Thallus non-sorediate.}

1. P. dactylina Nyl. in Act. Soc. Sci. Fenn. vii. p. 447 (1863) note 1.-Thallus thin, with crowded upright rounded stoutish papillæe about $1 \mathrm{~mm}$. in height, simple or rarely divided or coalescent, whitish ( $K+$ orange-yellow then red). Apothecia rather rare, immersed in the apices of the papillie, the disc hlackish, usually almost covered over; spores one in the ascus, 125-230 $\mu$ long, 65-85 $\mu$ thick.-Cromb. Lich. Brit. p. 60 it Monogr. i. 1. 493 ; Leight. Lich. Fl. p. 239 ; ed. 3, p. 230. Lichen ductylinus Ach. Lich. Suec. Prodr. p. 89 (1798). L. oculatus Sm. Engl. Bot. t. 1833 (1808) (non Dicks.). Rinorlina aculatr S. F. Gray Nat. Arr. i. p. 449 (1821) (non Dicks.).

Distinguished by the stoutish dactyloid papillie, and by the reactions with potash.

$\mathrm{Hab}$. On the ground or on decayed mosses in alpine regions.Dist. Confined to the summits of the Grampians, Scotland.-E. M. Ben Lawers, Perthshire; Morrone and Ben-maboord, Braemar, Aberdeenshire.

2. P. Hutchinsiæ Leight. Angriex. Lich. p. 30, t. 11, fig. 1 (1851). -Thallus effuse, thickish, unequally wrinkled or warted, whitish or cream-coloured $(\mathrm{K}-)$. Apothecia immersed in the verrucie, small or moderate in size, the disc well-exposed, depressed, brownish-black and greyish-pruinose, the margin thicker, somewhat torn; spores one in the ascus, 80-165 $\mu$ long (or more), $40-55 \mu$ thick.-Mudd Man. p. 277; Cromb. Lich. Brit. p. 59 \& Monogr. i. p. 493 ; Leight. Lich. Fl. p. 2243; ed. 3, p. 23:3. Thelotrema Hutchinsia Borr. Engl. Bot. Suppl. t. 2652 (1830): Hook. in Sm. Engl. Fl. v. p. 16:; Tayl. in Mackay Fl. Hib. ii. p. 103 ; Turn. \& Borr. Lich. Brit. p. 178.

An endenic: Irish species somewhat resembling Lreanora vermesu though with liurger thalline warts. Its nearest ally is Pertusuria. panyrger Th. F. Lich. Sciund. p. 308 (1871), in which the thallus tends to becone panillate. Crombie's spore lengih, 80-120 $\mu$, is too small, greatex lengths have been observed more nearly approaching the dimensions of $P$. panyrga $(110-220 \mu)$.

IIal. On the ground inclusting mosses and heiths,--J), M. Hills near Bantry, Cork.

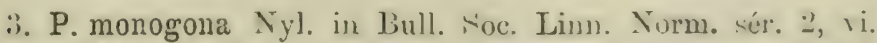
p. 289 (187:).-.'Thallus subdeterminate, thickish, wrinkled, 
cracked-arcolate and warterl, greyish-white $(\mathbf{K}+$ yellow then orange-red?). Apothecia imate in the somewhat flattened warts, the disc rather wide, uneven, brownish, white-pulverulent, the thalline marrin thick, entire or furrowed; spores one in the ascus, 150-235 $\mu$ long, $78-80 \mu$ thick.-Cromb. in Grevillen xix. p. 59 (1891) \& Monogr. i. p. 494.

Easily distinguished by the reaction with potash and by the singlespored asci. $P$. dealbata, with which it has been compared, has almost the sume reaction (less intensely red), is more generally isidiose and has a 2-spored ascus.

Hab. On schistose rocks.-li. M. Cader Idris, Merioneth (the only British record).

\section{Thallus more or less sorediate.}

4. P. bryontha Nyl. Lich. Scand. p. 178 (1861).-Thallus effuse, rather thin and spreading, or often consisting of subslobose fertile granules, which are sometimes sorediate, white or greyishwhite ( $\mathrm{K}+$ yellowish, soredia $\mathrm{CaCl}+$ redrlish). Apothecia at first closed, then with a plane open disc up to $2 \mathrm{~mm}$. across (in Brit. specimen), fawn-coloured, then cinereous-black, the thalline margin prominent, then almost excluded; spores one in the ascus, $120-230 \mu$ long, 40-70 $\mu$ thick, or sometimes smaller.Cromb. Lich. Brit. p. is \& Monogr. i. p. 492 ; Leight. Lich. Fl. p. 240 ; ed. 3 , p. 230 . P. macrospora Hepp Flecht. Eur. 1. 424 (1857); Mudd Man. p. 277. Prormetia subfuser var. bryontha Ach. Meth. Lich. p. 167 (1803).

One of our larest lichens. Reactions are sometimes given as $\mathrm{CaCl}+$ orange-red, but I have been unable to verify that on our specimen.

Hab. On the ground encrusting mosses and decared plants, in alpine places.-Distr. Local and scarce among the $\mathrm{N}$. Grampians, Scotland.-B. M. Cairngom and Ben-naboord, Braemar, Aberdeenshire.

5. P. ophthalmiza Nyl. in Flora xlviii. 1. 3it (1865).-Thallus effuse, thin, smooth or granulate, unequally wrinkled, lightcincreous-grey $(\mathrm{K}-, \mathrm{CaCl}-)$. Fertile verrucie small, seattered or generally (rowded, containing 1, rarely -2 -3, apothecia, the disc fairly open, blackish, the outer margin rugose or varely subleprose ; spores one in the ascus, 160 -205 $\mu$ loner, $80-100 \mu$ thick.- - Carroll in Journ. But. iv. 1. 2:3 (1866) : Teight. Tich. Fl. p. 24.2 ; ed. 8 , p. 233; Cromb. Monoms. i. 1). 496. P. eelata subsp. multipuneta

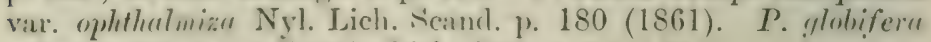
subsp. oplithalmizu Cruml. Lich. lirit. p. 59 (18т0).

Distinguished $\mathrm{l} y$ the thimnish thallus and the small Lecmore. like fertile vermeas. The spores in the (ilen Falloch specimens, evidently mature, measure only up to $175, \mu$ long, $55 \mu$ thick. ()therwise they correspond with Nylander's description. 
Hab. On the trunks of old pines in mountainous districts.-Dist. Tare in the Highlands, Scotland.-B. M. Glen Falloch and Black Wood, Rannoch, Perthshire.

6. P. velata Nyl. Lich. Scand. p. 179 (1861).-Thallus thinnish, determinate, smooth or unequally wrinkled, or sometimes cracked, with slight radiate folds towards the circumference, sreyish or white $(\mathrm{K}-, \mathrm{CaCl}+$ rose-red). Fertile verrucæ crowded, small, flat, sometimes sorediate at apices, the apothecia with open disc somewhat flesh-coloured, but "veiled" by a white layer of hyphr, mixed with oxalate of lime crystals, and surrounded liy a stoutish margin; spores one in the ascus, very large, 190310 $\mu$ long, 67-90 $\mu$ thick (or smaller).-Mudd Man. p. 274, t. 5, fig. 114; Cromb. Lich. Brit. p. 59 \& Monogr. i. p. 497 ; Leight. Lich. Fl. p. 241 ; ed. 3, p. 232 pro parte. Parmelia veluta Turn. in Trans. Linn. Soc. ix. p. 143, t. 12, fig. 1 (1808). Lichen velatus Sm. Engl. Bot. t. 2062 (1809). Varivlaria velate Ach. Tich. Univ. p. 319, t. 5, fig. 7 (1810); S. F. Gray Nat. Arr. i. p. 490 ; Hook. in Sm. Engl: Fl. v. p. 170.

The small lecanorine apothecia, the reaction with calcium hypo. chlorite, and the absence of definite soralia distinguish $P$. velata from other monosporous species. It is a subtropical plant, and occurs in Europe in the western regions. Lichen conspurcatus Sm. Engl. Bot. t. 964 (1801), and other citations have been quoted by Leighton as synonymous with $P$. velata. The small sterile fragments accompanying Smith's plate do not bear out the determination; but it is impossible to identify them (see also note to $\mathrm{n.} 11, P$. lactea).

Hab. On trees in wooded districts.-Dist. Pare in S. England, N. Wales and S. Ireland.-B. M. Ivy Bridge, Devon; Lulworth, Dorset; Quarn Wood, I. of Wight; New Forest, Hants; St. Leonard's Forest, Sussex; near Rusthall Common, Kent; Castlemartyr, Cork.

Form aspergilla Cromb. in Grevillea xix. p. 59 (1891).Fertile verruca scattered, rather large, prominent and whitesorediate $(\mathrm{K}-, \mathbf{C a C l}+$ rose-red).-Cromb. Monogr. i. p. 498. Lichen aspergillus Ach. Lich. Suec. Prodr. p. 28 (1798)? Vaviolaria aspergilla Ach. Meth. Lich. p. 13 (1803)?; Sm. Engl. Bot. t. 2401 (1812); Hook. in Sm. Engl. Fl. v. p. 170 ; Tayl. in Mackay Fl. Hib. ii. p. 112 ; Turn. \& Borr. Lich. Brit. p. 67. V. communis var. asperyilla S. F. Gray Nat. Arr. i. p. 491 (18:21).

Differs from the species in the prominent, generally sparsely scattered and densely sorediose verructe. It has been yuoted by Ifue (Full. Soc. Bot. xxxvii. p. 95) as synonymous with I'. multipuencta, and the continental plant which is saxicolous may possibly belong to that species, but the British specimens grive the same chemical reaction as $P$. velata.

1Iab. On trees and palings in inlamil situations.-Distr. Iiare in S. and Coutral England.-B. M. New Forest, Hants ; Sit. Leonard's Forest, Sussex ; Sevenoals, Kent; Shiere, Surrer; Quantoeli Combes, Somerset; Hay Park, Frerefordshire ; Ickworth, Suftulk. 
7. P. globulifera Nyl. in Mém. Soc. Sci. Nat. Cherb. v. p. $116(185 \pi)$. - Thallus suborbicular, thickish, somewhat memhranaceous and cartilaginous and with a zonate margin, generally wrinkled and plicate, sometimes granular-isidinid, crowded with large discoid soralia, greenish-grey $(\mathrm{K}-, \mathrm{CaCl}-)$. Apothecia enclosed in large corticate verruca, depressed, slobular and clused, then lacerate-deliscent and white sorediate; spores one in the ascus (rarely two), $207-276 \mu$ long, 50-80 $\mu$ thick.Mudd Man. p. 273 (excl. vars.); Cromb. Lich. Brit. p. 59 (errore globiferu) (excl. vars.) and Monogr. i. p. 495 ; Leight. Lich. Fl. p. 243 ; ed. 3 , p. 23:. Lirhenoirles candidum et farinarenm, scutell is fere planis Dill. Hist. Musc. p. 131, t. 18, fig. $11 \mathrm{~B}$, : (1it1). Lichen discoideus Sm. Engl. Bot. t. 1714 (1807) (non Pers.) \&: L. globuliferus t. 2008 (1809). Vurioluria globulifera Turn. in Trans. Limn. Soc. ix. p. 139, t. 10, fig. 2 (1808); S. F. Gray Nat. Arr. i. p. 490 ; Grev. Fl. Edin. p. 330 ; Huok. in Sm. Engl. Fl. v. p. 169; Turn. \& Borr. Lich. Brit. p. 59. V. dismidea Hook. in Sm. Engl. Fl. v. p. 269 (1833) (? Ach.) ; Tayl. in Mackay Fl. Hib. ii. p. 112 ? Turn. \& Borr. Lich. Brit. p. 61. V. faginea Tayl. 1. c.? (non Linn.).

Exsicc. Bohl. n. 96 ; Johns. n. 327 ; Mudd n. 2633 pro parte.

Though normally determinate, the thallus may spread indefinitely. lertile verucie are rare, generally they talie the form of densely powdery-white soralia (f. discoidea Cromb. in Grevillea xix. 1) 59 (1891) \& Monogr. i. p. 496). The spores examined are generally up to $220 \mu$ long, and frerpuently shorter than $207 \mu$. The citations from Taylor are doubtful. His $V$. faginen is not bitter to the taste, while $V$. discoidea, according to him, is so.

Hat. On trunks of old trees in wooder districts.-Distr. (iencral and common throughout the British Isles.-D. M. THoconnoc ani near Withiel, Cornwall; Chudleigh, Becley Fills and Borcy Tracey, Jevon; New Forest, Hants ; St. Leonard's l'orest, J)amy, Ardingly. Crawley and Jieeding Priory, Sussex; l'enshurst, lient; Shiere, Surrey; Liting and Epping Forest, Essex; Cirencester, Gloneestershire; Broalwas and Malvern, Worcestershire; Yannouth, Suffolk; Madingley, Cimluridgeshire; Jambeth, S. Wales; Jarmouth. Merioneth; Anglesea ; Craig-y-Hhiw and Haughmond Hill, Shropshire; Charnwood lorest and Gopsall. Leicestershire; near Arton. (Ceveland, Forkshire ; Iggrlestone, J)urhan ; Ifelensburgh, Dumbartonshire; Inverary and by Idoch ('wan, Argyll ; Caigforth, Stirling: (ilen Jochay, killin and J'lawbery Ifill near P'erth, l'erthshire; Den of Matus, forfurshire: Murtle, near Aberleen ; Loch Limhe, Invernessshire; Castlemartyr and Mareroon Denesde. Corli; Ashley I'arli. near Galway; Louisburgh, Mayo.

\section{P. faginea Leight. Lich. F. p. 24: (1871); Wain.} in Medd. Soc. Faun. \&: Fl. Fenn. xiv. 14, p. 24 (1888). Thallus determinate, thickish wr rather thin, wrinkled, gramulate and cracked, subzonate at the circumferene, srey, thickly covered with white soralial, hitter to the taste ( $\mathrm{K}-, \mathrm{CaCl}_{-}$).

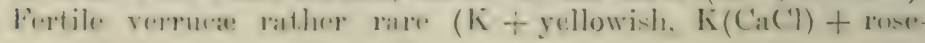


red or violet), apothecia small, solitary, with a wide white pulverulent dise and thin margin, becoming immarginate; spores one in the ascus, up to $150 \mu$ long, $40-50 \mu$ thick. - Leight. Lich. Fl. ed. 3, p. 232. P. globulifera var. surediatu Mudd Man. p. 274 (1861) pro parte (non Fr.) ; Cromb. Lich. Brit. p. 59 (1870)? (non Fr.). P. amara Nyl. in Flora lvi. p. 2:2 (1873); Cromb. in Grevillea xix. p. 59 it Monogr. i. p. 496. Lichenoides randidum et farinacen, scutellis fere planis Dill. Hist. Musc. p. 131, t. 18, fig. 11 c (1741). Lichen fagineus L. Sp. Pl. p. 1141 (1753); Huds. Fl. Angl. p. 443? Lightf. Fl. Scot. ii. p. 807? With. Arr. ed. 3, iv. p. 4 pro parte; Engl. Bot. t. 1713. Variolaria faginea Pers. in Ust. Ann. Bot. vii. p. 24 (1794); Turn. \& Borr. Lich. Brit. p. 64; Hook. in Sm. Engl. Fl. v. p. 169. V. amaru Ach. Lich. Univ. p. 324 (1810); Hook. Fl. Scot. ii. p. 46 ; Grev. Fl. Edin. p. 330 .

Exsice. Bohl. n. 26 ; Johns. n. 153.

1)istinguisher from allied monosporous species by the bitter taste (hence the trivial name amara) and by the chemical reaction. Crombie has given the spore sizes as 190-236 $\mu$ long, 50-70 $\mu$ thick. The above much smaller measurements are frow specimens in the herbarium. The spore walls are rather thin when mature.

Mudd has quoted, as synonyms of his var. sorediata, the species Variolaria griscovirens Turn. \& Borr. ex Sm. Engl. Bot. t. 2100 (1812), a specimen of which is preserved with the drawing; Turn. \& Borr. Lich. Brit. p. 54. It is a thin sterile thallus with small yellowish-green soralia, and might be a form of Lecunora farinaria Borr. Spiloma vitiligo (Ach. Meth. Lich. p. 10 (1S03) \& Sm. Engl. Bot. t. 2075 (1809)), quoted as syuonymous with Vuriolaria vitiligo Turn. \& Borr. tom. cit. p. 53 (1839), the powlery bodies of which are much darker, is equally indefinite.

Hub. On trunks of old trees, especially bech and elm in moorted iructs.-Distr. (ieneral and fairly common, though not seen from the Chamnel Islands.--B. 1 . Withiel and near Penzance, Cornwall; Lydford, Deron; Minety, Wilts; New Forest, Hants ; St. Leonard's Forest, Snssex; Lydd, Kent; Hainanlt Forest and near Gosfield, Wssex; Builiwas, Shropshive; Cwm Bychan, Merioneth; Anglesea; Gopsall anr Tothery 'I'emule, Leicestershire; Chatsworth, Derbyshire; Teestitle, Durham; Neldon Park, Northumberland; Wintermere, Westmoreland; Asby, Cumberland; near Glasgow, Lanarkshire; Craigforth. Stirling; Airds, Appin, Argyll; Finlirig, Killin, Perthshire; Applecross, Rossshire; Dunkerron, Kerry.

\section{P. multipuncta Nyl. in Flota Ixiii. p. 393 (1siro).-} Thallus irnerilly determinate, thinnish, indistinctly cracked-or wrinklerl-granulite, dotter with round flat white sorediate veruca, whitish or greyish-white (Kf + yellow, then sometimes red, $\mathrm{CaCl}-, \mathrm{I} \mp$ dark-biur). Apotheria one or several in each verucat, pale or brownish, with thinnish margin, the whole surface white-puwdery; spures one in the ascos, thick-walled,

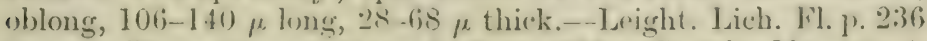

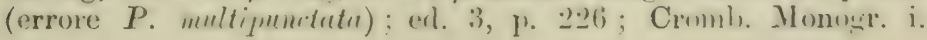


p. 494. P. globulifera var. multipunctat" Mudd Man. p. 274 (1861) ; Cromb. Lich. Brit. p. 59 (errore P. globiferc). P. sublartea Leight. in Ann. Mag. Nat. Hist. ser. 4, vi. p. $474(1870)$ \& Lich. Fl. 1. 245; ed. :3, p. 236 (saxicolous) fide Nyl. in Flora lxvi. p. 534 (1883). Variolaria multipuncte Turn. in Trans. Linn. Soc. ix. p. 1:i7, t. 10, fig. 1 (1808) : S. F. Gray Nat. Arr. i. p. 490 ; Hook. in Sm. Engl. Fl. v. p. 170 (errore V. multipunetata); Turn. \& Borr. Lich. Brit. p. 73. Lichen mulfipunctus Sm. Engl. Bot. t. 2061 (1809).

Exsicc. Johns. n. 152 ; Mudd n. 262.

Teadily identified by the neat white pustules and by the habitat on trees, very rarely on rocks, and then to be distinguished from $P$. lactea by the absence of reaction with calcium hypochlorite. There is a faint yellow reaction with potash which passes at once to reddish-brown or sometimes red, especially the medulla.

$H a b$. On trunks and branches of trees, rarely on schistose rocks, in maritime and inland districts.-Distr. Fairly common in England and Wales, less so in Scotland and Treland. $-\dot{B}$. M. Boconnoc. Cornwall; East Lynn, Devon; I. of Wight; New Forest, Hants; St. Leonard's Forest, Sussex; Shiere, Surrey; Cirencester, Gloucestershire; Barmouth and Cwm Bychan, Nerioneth; Conway Falls, Carnarvonshire; Brantsdale, Yorkshire; Teesdale, Durham; Asby, Cumberland ; Barealdine, Argyll ; Castlebernard, Cork ; Cromaglown and Tore MIt., Killarney, Kerry; Kylemore Lake, Connemara, Galway; Powerscourt, Wicklow.

Form lævigata Cromb. Monogr. i. p. 495 (1894).-Thallus thin, almost continuous and searcely wrinkled.--Tariolurin multipuncta var. lexigata Turn. \& Borr. ex Hook. in Sm. Engl. FI. v. p. 170 (18:33) \& Lich. Brit. 1) 73 (1839). V. constellatu Tayl. in Mackay Fl. Hib. ii. p. 113 (1836).

A thinner less developed thallus and apothecia thin in the species. possibly due to the habitat on smooth bark.

Hab. On smoothe bark of young trees.-Dislr. Found only in in ferw localities in S. England and S.IV. Ireland.-B. MI. Falmouth. ('ornwall; New Forest, Hants; St. Leonitrl's Forest. Hants; Asliew Wood, Kerry.

Form fastigiata Cromb. 1. c. Thallus of crowdecl coralloir fertile verruce, fastigiate and sorediate at the anices.- $P$. faslifficte Leight. in Ann. of Mag. Nat. Hist. ser. 4, vi. p. $474(1870)$ \& Lich. Fl. p. 245; ed. :3, p. "236. Isillinm menlutum var. fustigi afum Turn. if Borr. Lich. lirit. p. 103 (183!), fide Leight. 1. ('; var. $\beta$ Hook. in Sm. Engl. TI. v. p. 232. Tarielaria pelyflecia Tayl. in Mackay Tl. Hib. ii. p. 113 (1836).

A well murked form. 1). Taylor (l. e.) deseribes it as consplienous by the erowded and stalket apotheria placed in contact. like eertain basaltic columns.

Hal). On naked rocks and incrusting mosses in momtainous regions.--Disl. liecorded only trom S. and W. Ireland (Jantry. C'ork; Connemara, Galway).-B. $M$. D Dunkerron, Kerry. 
10. P. reducta Stirton in Scott. Naturalist, ir. p. 28 (187i). - Thallus thin, cracked-areolate, greyish or greyish-brown ( $\mathrm{K}+$ rellow, then deep red). Apothecia sessile, with open disc, 1 in Each thalline rerruca, brown or reddish-brown, bluish-greypruinose ; spores 1 in the ascus, 90-140 $\mu$ long, 30-40 $\mu$ thick. -Leight. Lich. Fl. ed. 3, p. 329 ; Cromb. MLonogr. i. p. 498. Specimen not seen.

"Closely allied to P. multipuncta Turn., younger spores with broadish epispore, mature ones with coarsely granular contents." The only plant of this section, except $P$. dactylina, with the marked reaction with potash. Wainio has recorded it from the Philippines (Phil. Journ. Sci. viii. p. 104 (1913)), in a sterile condition.

Hal. On trees in the S.IF. Highlands of Scotland (Ben Brecht, Argyll).

11. P. lactea Nyl. in Flora lxiv. p. 539 (1881)..-Thallus determinate, somewhat radiate and Placodium-like at the circumference, generally smooth, continuous or cracked-areolate, more or less dotterl with soralia, light- or cinereous-grey or whitish $(\mathrm{K}-, \mathrm{CaCl}+$ red, $\mathrm{K}(\mathrm{CaCl})+$ deeper red). Apothecia rare, small, solitary in the verrucre, the disc white, subleprose, the thalline margin irregular; spores $I$ in the ascus, $180-205 \mu$ long, $65-70 \mu$ thick. -Cromb. in Journ. Bot. xx. p. $274(1882)$ it Monogr. i. p. 498. P. lactescens var. lactea MIudd Man. p. 27.2 (1861). Lichen lactens L. Mant. p. 132 (1767); Huds. Fl. Angl. tel. 2, p. 526 ; With. Arr. ed. 3, iv. p. 5 ; Engl. Bot. t. 2410. Turiolaria lactea Pers, in Ust. Ann. Bot. vii. p. 24 (1794): S. F. Gray Nat. Arr. i. p. 492 ; Hook. Fl. Scot. ii. p. 46 \& in sin. Engl. Fl. v. p. 170; Grev. Fl. Edlin. p. 330; Tayl. in Mackay Fl. Hib. ii. p. 113; Turn. \& Borr. Lich. Brit. p. 62: Leight. Lich. Fl. p. 242 ; ed. 3, p. 232 (as synonym of $P$. velata). T. conspurrata Turn. \& Borr. ex Hook. in Sm. Engl. Fl. v. p. 168 (1833)? \& Lich. Brit. p. 57 (1839)?

The thallus may spread very widely and raries in thickness; it $i_{\text {. }}$ wenerally very light in colour, and may be easily distinguished from ither sorerliate species by the saxicolous habitat and by the chemical reaction. It is rarely fertile. The spore sizes are those given by Nylander. It is probable that Variolaria conspurcata Turn. is Borr. is a synonym of $P$. lactea, but it is impossible to be quite sure. Sureral specimens, labelled Variolaria conspurcata, on limestone or mortar from Shropshire and Derbrshire, give the same chemical reactions as $P$. lactea. They are sterile and indeterminable, but are probably abnormal forms owing to the unusual habitat.

Hab. On granitic and schistose rocks in mountainous regions.Distr. Somewhat rare throughout the British Isles.-D. M. Cbateau Ioint. Sark ; Lridge. Sussex; Aberdorey and CNm Ijychan, Merioneth: Auglesea ; Craig-y-lihiw, Shropshire?; Matlock, Derbyshire? ; near Mofhatt, Inumfriesshire; West Water, Forfarshire; Jen Lawers and Craig Calliach, Perthshire; Portlethen, Kincardineshire; (ilen Ey, Braemar, Aberdeenshire; Blackwater, Kerry. 
12. P. melanochlora Nyl. in Bull. Soc. Linn. Norm. sér. 2, vi. p. $289(1872)$.--Thallus effuse (or determinate), tartareous, thick, wrinkled and warted, subareolate, densely papillate, the papillie short, stout, rounded and sometimes sorediate at the apex, sreyish-white or greyish-smoke-colourerl $(\mathrm{K}(\mathrm{CaCl}) \mp$ violet-rosecoloured). Apothecia small, several (2-5) in the sorediate papilla; spores 1 in the ascus, $180-2.50 \mu$ long, $75-100 \mu$ thick.-Cromb. in (Arevillea xix. p. 59 (1891) it Monogr. i. 1). 493. Isidium melanochlorum DC. Fl. Fr. ii. p. 326 (1805).

The chemical reaction is distinct in Nylander's specimen from the I'rrenees; it is very slight in the one from Wales. The spores are very thick-wallerl and taper downwards, perhaps a development strge, and, so far as observed, measure from $45 \mu$ in width. The spermatia (fide Nyl.) measure about $4-5 \mu$ long, $1 \mu$ thick.

Hab. On quartzose and schistose rocks. $-B$. M. Barmouth, Merioneth (the only British record).

\section{B. Spores usnally two in the ascus.}

\section{Thallus non-sorediate; spores colourless.}

13. P. pustulata Nyl. in Act. Soc. Linn. Bord. sér. 3, i. 1. 441 (1856) (? Leight. Angioc. Lich. p. 30, t. 10, fig. 4 (1851)).'Thallus dereloped beneath or above the bark, determinate, thinnish, sinooth or finely granulate in parts, cream-coloured or greyishwhite $(\mathrm{K}+$ yellowish, $\mathbf{K}(\mathrm{CaCl})+$ slightly reddish $)$. Apothecia solitary or several in small convex seattered or congregate verrucx, the ostioles punctiform and dark, then hecoming lacerate and exposing a small flesh-coloured open disc; spores 22 in the ascus, $60-126 \mu$ long, $25-45 \mu$ thick.-MIudd Man. p. 25.5 pro parte: Cromb. Lich. Isrit. p. 60 pro parte of Monogr. i. 1). 504; Leight. Lich. Fl. p. 244 ; ed. 3, p. 234 pro parte. P. melalencu Dub. Jot. Gall. ii. p. 673 (1830); Leight. Angioc. Lich. p. 29, t. 10, fig. 4 \& Lich. Fl. 1. 240 ; ed. 3, 1. 230; Mudd Man. p. 275; Cromb. Monowr. i. p. 504. Porima pustulatre Ach. Lich. Univ. 1'.809 (1810). Lir.hen melulenens Sin. Engl. Pot. 1. 2461 (1813).

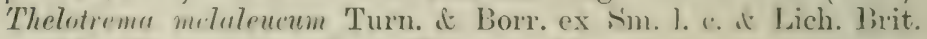
p. 183 ; Hook. in Sm. Engl. Fl. v. p. 161.

('hanaterized by the thin smoothish thallus and by the 2 -spored ascens. The reaction with potash is most easily secin in sections muler the microscope. with calcimm hypochlorite ander the thallus is gonerally tinged redelish. There is no specific distinetion between

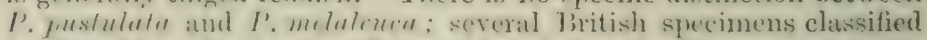
ly ('rombie and others as $I$ '. pustulala belong to I'. rommunis or to f. liviglaren. In a specimen from Dolgelly the verrusa are whitish on a grey thallus; it has been determined by Crombie as $\mathrm{f}$. super. pallcns Nyl. (Flora lxix. 1). 466 (1886)).

$H a b$. On trees in wooded districts.-Distr. Rather rare in the sonthern and midland comities of Jingland and in N. Walcs.- R. $M$.

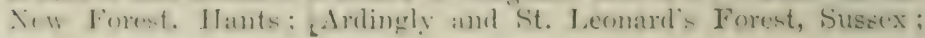


Whiere, Surrey; Epping Forest, Hadleigh and Hockley Woods, Essex; Burnham Beeches. Bucks; Dolgelly and Barmonth, Merioneth.

14. P. pertusa Dalla Torre \& Sarnth. Die Flecht. Tirol, p. 309 (1902)._Thallus determinate, warted-areolate or wrinkled, thick, or sometimes flat and thimnish, especially towards the concentrically marked margin, the fertile warts or verruce large and prominent, irregularly sub-globose, crencrially crowded, though sometimes thinly scattered, greyish or greenish-grey ( $\mathrm{K}+$ sellowi-h, $\mathrm{CaCl}-$ ). Aputhecia one or several in each verruca, punctiform, the disc minute, slightly depressed, blackish ; epithecium $\mathbf{K}+$ violet; paraphyses slender; spores 2 in the ascus (sometimes 1 or 3 or 4 ), $1: 30-205 \mu$ long, 4.5-80 $\mu$ thick: hymenial gelatine round the asci persistently blue with iorline. - P. communis DC. Fl. Fr. ii. p. 320 (1805) (incl. f. rupestris) ; Hook. in Sm. Engl. Fl. v. p. 160 ; Turn. \& Borr. Lich. Brit. p. 196 (incl. var. rupestris); Leight. Angioc. Lich. p. 27 \& Lich. Fl. v. p. 238 ; ed. :3, p. 229 (incl. f. rupestris) : Mudd Man. p. 275; Cromb. Lich. Brit. p. 58 \& MLonogr. i. p. 499 (incl. f. rupestris). P. rupestris Schar. Enum. p. 227 (1s50); Mudd Man. 11. 272 (incl. var. areolata! (non Clem.)). Lichrnoiles irrucosnm et rugosum, cinereum, glabrum Dill. Hist. Nusc. p. 12র, t. 1s, fig. ? (1741). Lichen pertusus L. Nant. p. 131 (1767); Lightf. Fl. Scot. ii. p. 802 ; Huds. Fl. Angl. ed. 2, p. 525: With. Arr. ed. 3, iv. p. 15 ; Engl. Bot. t. 677 . Porina pertusa Ach. Lich. Univ. p. 308 (1810) ; S. F. Gray Nat. Arr. i. p. 495) Hook. Fl. Seot. ii. p. 45; Grev. Fl. Edin. p. :354; Tayl. in Mackay Fl. Hib. ii. p. 102 .

Exsicc. Bohl. 11. วt; Johns. nos. 27s, 279, 122 (Brit. Mus. set as $P$. pustulatr) ; Leight. n. 71 (Brit. Mus, set as $P$. fallax) ; Mudd nos. 259 (f. rupestris), 264.

One of the commonest British lichens, eatsily known by the prominent verruce. The apothecia vary from one to many in each verruca, the narrowed dises are generally dark coloured, bit nay be whitish in shade conditions (f. leucostomu Sicher. Lnum. p. 229 (1850) ) when there is also no reaction of the epithecimm with $K$. The reactions of both thallus and apothecia, the latter characteristic of several other species, are sometimes rather fiaint. The thallus is frequently the host of Sphinctrina turbinata. Form rupestris differs only in habitat, it is rather uncommon.

Hab. On the trunks of old trees, rarely on palings or on roulis in lowland and upland regions.-Distr. General in the British Isles. B. M. Sark; Guernsey; Withiel, Cornwall; near l3orey Tracey and Lustleigh, Devon; Appuldureombe, I. of Wight; New Forest, Hants ; near Hastings, near Battle, St. Leonarl's Forest. Artingly, Henfield and Oftham, Sussex; I'enshurst, Kent; Shiere, Surrey; Hockley Wood, Hatfield Peverel and Epping Forest, Essex; near Jiuckinghan; Cirencester, Gloucestershire; Broadwas and near Malvern, Worcester. shire; Twyeross and Gopsall Park, Leicester; Infod, Cardiganshire; Barmouth and Dolgelly, Merioneth; Buildwas, Shropshire; Bettwsy-Coed, Denbighshire; near Conwa, Carnaronshire; Anglesen ; 
Church Stretton and Llanford, Shropshire; Enville, Staffordshire; Great Glenham, Suffoll; Millershale, Derbyshire; Kildale and near Ayton, Clevelund, Yorkshire ; Teesdale, Durham ; Windermere, West. moreland; Calder Abbey, Northumberland; Gilgarron and near Whitehaven, Cumberland; Nerv Galloway, Kirkeudbrightshire ; Roslin and Colinton Woods, Midlothian; near Glasgow; Barcaldine and I. of Lismore, Argyll; Glen Lochay, Killin, Aberfoyle and Balthayock Woods, Perthshire; Countesswells Woods, near Aberdeen and Craig Cluny, Braemar, Aberdeenshire; near Fort William, Invernessshire ; Applecross, Rossshire; Lairg, Sutherlandshire; Dunkerron, Kerry.

15. P. areolata Nyl. in Flora lxiv. p. 456 (1881).--Thallus (leterminate, thickish, more or less densely papillate, crackedareolate, light- or darkish-grey ( $\mathrm{K}+$ yellow). Apothecia with a minute blackish disc; epithecium $K+$ violet; spores 2 in the ascus (or sometimes more), $130-205 \mu$ long, $45-80 \mu$ thick.Cromb. in Grevillea xix. p. 59 (1891). P. communis subsp. areoluta Nyl. ex Hue Add. Nov. Lich. Eur. p. 118 (1886); Cromb. Monogr. i. p. 500. Thelotrema pertusum var, areolntum Clem. Ensayo, p. 300 (1807).

Though classified as a subspecies of P. pertusa by Nylander and others, there is a great difference in thalline characters, and in the much brighter reaction with potash. The British specimens are without apothecia; it has therefore been impossible to verify the spore characters.

$H a b$. On siliceous rocks and walls in maritime districts.-Distr. Among the Grampians, Scotland, and W. Ireland.-B. M. Craig Calliach and Craig Tulloch, Blair Athole, Perthshire; Morrone, Bratemar, Aberdeenshire; Hills of Applecross, Tiossshire.

16. P. ceuthocarpa Turn. ex Sm. Engl. Bot. t. 2372 (1821) note. - Thallus determinate, thickish, cracked-areolate and warted, the areolie convex, unequal, cream-coloured ( $\mathrm{K}+$ yellow, then deep-red). Apothecia in subglobose or irresularly conglomerate smooth verruca, decply immersed, the dises punctiform, blackish; spores 2 in the ascus, thick-walled, $150-175 \mu$ long, 40-60 $\mu$ thick.-Hook. in Sm. Engl. Fl. v. p. 160; Turn. ㄴ Borr. Lich. Brit. p. 200 : Leight. Angioc. Lich. p. 28, t. 9, fig. $t$ it Lich. Fl. p. 237 ; ed. 3, p. 22. ; Mudd Man. p. 271 ; Cromb. Lich. Brit. p. is it Monogr. i. p. 501. Lichen ceuthocarpus Sw. Engl. But. t. 2372 (1812). Porinu centhorerpa Tayl. in Mackay Fl. Hib. ii. p. 102 (1836).

Exsicc. Leight. n. 284.

There are only a few British Pertusmie with the alove strongly. marked potash reaction, and among then $l^{\prime}$. centhocurpen is distingnished by the thickish unerual thallus, by the large tumid fertile verruse, and by the saxicolous hathitat. On the continent it is classified along with $I^{\prime}$. corrontes, which is corticolons, while Smith's flint is sixicolons. Fries, however, records I'. centhoetrya as saxicolons: in Seandinavia und in Germany (Lich. Fur. p. $42 \%$ : 
$H a 7$. On roeks in maritime and mountainous districts.-Distr. Rare throughout the British Isles, though fairly plentiful where it occurs. $-B$. M. Jersey; Pentire, Kynance and Lamorna, Cornwall; Harlech, Barmouth, Aberdovey aud near Dolgelly, Mericneth ; Holyhead, Auglesea ; Airds, Appin, Argyll ; Craig Calliach, Perthshire; Lambay Island, Dublin.

Form microstictica Croml), Monogr. i. p. 502.-Thallus sprinkled with minute brownish papillee.-Lichen microsticticus Sm. Engl. Bot. t. 2243 (1811). Isidium mierosticticum Turn. \& Borr. ex Hook. Fl. Scot. ii. p. 66 (1821) \& Lich. Brit. p. 94; S. F. Gray Nat. Arr. i. p. 774 ; Hook. in Sm. Engl. Fl. v. p. 231.

Exsice. Leight. nos. 280, 342.

Scarcely to be considered as a true form, as the same type of small brown papill:e are occasionally present in P. concreta. Then they are abraded they leave a minute white dot on the thallus.

$H a b$. On rocks in maritime and mountainous regions.-Distr. Fare in the Channel Islands, N. Wales and S.W. Ireland (fide Crombie).-B. M. Barmouth, Merioneth.

Form variolosa Mudd Man, p. 271 (1861).-The thalline verrucæ sterile, sorediate.-Cromb. in Grevillen xix. p. 59 \& Monogr. i. p. 502.

Exsicc. Leight. n. 341.

The pulverulent verrucx are crowded and are more regular, as well as generally smaller, than in the species, but the affinity is easily recognized by the reaction with potash.

Hab. On rocks in maritime districts.-Distr. Tare in N. Wales and W. Ireland.-B. M. Dolgelly, Merioneth; Achill Island, Mayo.

17. P. concreta Nyl. in Mém. Soc. Sci. Nat. Cherb. v. p. 117 $(1857) \&$ in Flora lix. p. 233 (1876).-Thallus determinate, thickish, unequal or grenerally plane, cracked-areolate, whitish ( $\mathrm{K}+$ yellow, then red). Apothecia inmersed in the areols, the disc punctiform then somewhat exposed, flesh-coloured to blackish ; spores 2 in the ascus, $115-250 \mu$ long, $60-80 \mu$ thick.-Cromb. in Grevillea r. p. 25 (1876) \& Monogr. i. p. 505 ; Leight. Lich. Fl. ed. 3, p. 227.

Exsicc. Larb. Lich. Hb. n. 27.

Originally described from the Eastem Pyrenees, and considered by Nylander to be the specific form of Isidium Westringii. It differ's from $P$. chuthecripge in the absence of promounced verrucie, minute papillie are often present. Fertile specimens are very rare: in one from Clare Island the spores were barely mature, but the largest measured only $175 \mu \times 55 \mu$.

Ifrh. On rocks in maritime districts. - Distr. Local but somewhat abundant in WV. Ireland.-B. M. Tetterfrack, ('onnemara, Galway; Clare Island, Achill Islami and Mallatramy, Achill, Mayo. 
Form Westringii Nyl. in Flora lix. p. $234(1876)$. - Thallus thin or thickish, determinate, cracked-ireolate, more or less densely papillate, the papilla minute, then large, simple or brancherl.-Cromb. in Grevillea xix. p. j9 (1891) \& Monogr. i. p. 503. P. Textringii Leight. Lich. Fl. p. $2: 36$ (1871); ed. :3, 1. 2.27 pro minima parte (excl. syn. P. lartescens). Lichen Westringii Ach. in Vet. Acarl. Handl. xv. 1. 179, t. 6, fig. 1 (1794); Dicks. Pl. Crypt. fasc. iv. p. 20 ; Engl. Bot. t. 2204. Isidium Westringii Ach. Neth. Lich. p. 138 (1803) ; S. F. Gray Nat. Arr. i. p. 412 (1821) (excl. syn. Lichen qunctatus); Hook. Fl. Scot. ii. p. 66 \& in Sm. Engl. Fl. v. p. 231 ; Turn. \& Borr. Lich. Brit. p. 92.

Generally a thin plane thallus corered with papillit, but these may coalesce into a somewhat warted condition when it approaches $P$. ccuthocaryus in appearance. Leighton's description seems to refer largely to that species. It is a sterile form.

$H a b$. On rocks and walls in maritime and mountainous districts. -Distr. Rather rare throughout the British Isles.-D. M. Guernsey; Jersey; near st. Austell and P'enzance, Cornwall; Barmouth and Aberdover, Merioneth; Arkendale, Durham; Thornthwaite, near Keswick, Cumberland; Achosragan Hill, Appin, Argyll; Craig Tulloch, Blair Athole, Perthshire; Glen Callater, Braemar, Aberdeenshire; Kylemore, Connemara, Galway; Clare Island and Achill. Mayo.

\section{Thallus non-sorediate; spores olivaceous or blackish.}

18. P. lactescens Mudd Man. 1. 2-22 (1861) (excl. var. luctea).-Thallus thickish, smooth, unequal, becoming granulate or cracked-areolate ( $\mathrm{K}+$ yellow, then red). Fertile verructe scattered, flat, contorted and difform, the apothecia innate in the areole, with a somewhat open blackish disc; spores usually 2 (rarely 3-4), in the ascus, ellipsoid, becoming olivaceous or blackish ( $\mathrm{K}+$ violet), 90-130 $\mu$ long, $45-85 \mu$ thick.-Cromb, Monogr. i. p. 504. P. spilomenthodes Nyl. in Flora lxiv. p. 179 (1881); Cromb. in Grevillea x. p. 23 (1881).

Ersice. Mudd n. 260.

A purely British species so far as is yet known. In some of the specimens there are scattered sorediate or abraded small spots. P. spitomanthoutes was collected at Finnerdale, Cumberland, by the Rev. W. Johnson.

Hal. On rocks and walls in upland districts.-Distr. liare in N. Engrianil.-I3. M. Ayton Moor, Cleveland, Yorkshire; Ennerdale. Cumberland.

19. P. urceolaria Nyt in liull. Sue. Linn. Norm. p. 324 (1873) note.- Thallus rather thin, cracked-areolate, the surface scabricl with short papillar, whitish ( $\mathbf{K}+$ yellow, then red). Apothecia small, sunk in the areolin, the disc blackish, depressedurceolate, then becoming rather upen, with a stoutish minutely 
papillate marrin; spores 1-4 in the ascus, olivaceous or blackish (K + violet), 100-140 $\mu$ long, 50-75 $\mu$ thick.--Leight. Lich. Fl. ed. 3, p. 228 pro parte ; Cromb. Monogr. i. p. 505.

Exsicc. Larb. Lich. Hb. n. 28.

Occasionally confused with $P$. spitomantha, which, howerer, has a single large spore in the ascus. It approaches very closely the preceding species, the only real difierence being in the papillose thallus which may be simply a rarietal distinetion, but that can only be determined by the discovery of further specimens.

$H(u)$. On granitic stones of a wall in a maritime district. $-B . M$. La Moye, Jersey (the only locality).

\section{Thallus sorediate; spores colourless.}

20. P. coccodes Nyl. in Mém. Soc. Sci. Nat. Cherb. v. p. 116 (1857). - Thallus determinate or effuse, thin, following the inequalities of the bark, subfarinose or isidiose, areolate, occasionally warted, whitish ( $\mathrm{K}+$ yellow, then rusty-red). Apothecia one or several in scattered or congregate small subglobose verruce; the dises minute, dark-coloured; spores 2 in the ascus, 115-140 $\mu$ long, 40-60 $\mu$ thick.-Cromb. Lich. Brit. p. 59 \& Monogr. i. p. 502 (incl. f. bacillesa) ; form bacillosa Nyl. ex Lamy in Bull. Soc. Bot. Fr. xxv. p. 425 (1878). P. globullifera var. coccodes MIudd Man. p. 274 (1861). Lichen coccodes Ach. Lich. Suec. Prodr. p. 10 (1798); Engl. Bot. t. 1511. Isidium corcorles Ach. Meth. Lich. 1. 139 (1803); S. F. Gray Nat. Arr. i. p. 412 ; Hook. in Sm. Engl. Fl. v. p. 230 ; Turn. \& Jorr. Lich. Brit. 1) 89 (incl. var. phymatorles). I. phymatodes Ach. 1. c.?

Somewhat resembling the thallus of Lecanora purella var. Tumeri, but easily distinguished by the reaction with potash; occasionally the papillie are very luxuriant (f. bacillosa), and a sorediate form (f. variolaria) is recorded by Harmand (Lich. Fr. v. p. 1127 (1913)). In some specimens there is a pale reddish colour in parts (f. phymatodes). British plaints are sterile.

$H a h$. On trunks of old trees in inland districts.-Distr. Rare from S. to N. England.-B. M. New Forest, Hants; Albourne, Sussex; salperton, Gloucestershire; Hay I'ark, Herefordshire; near Quendon and Hainault Forest, Essex; near Norwich, Norfolk; Baysdale, Cleveland, Yorkshire.

21. P. dealbata Cromb. Lich. Brit. p. 59 (18т0) (excl. syu. $P$. lurferens). - Thallus effuse, occasionally with a definite margin, of crowiled unequal small granules or papille, generally rather thick, finely or coarsely cracked-areolate, whitish or ash-grey ( $\mathrm{K}+$ yellow (then frequently red), $\mathrm{CaCl}-$, medulla $\mathrm{I}+$ pale blue). Fertile verruce prominent, subglobose, containing several apothecia, white-pulverulent above; spores 2 in the ascus, very 
variable in size, $80-150 \mu$ long, 50-\$2 $\mu$ thick (or smaller).Cromb. in Grevillea xii. p. 59 of Monogr. i. p. 500 : Leirht. Lich. F]. 1. 238: exl. 3. 1. 228 pro parte. P. syucrepa Mudd Man. P. 27:3 (1861) (incl. var. drallata). Lirhen dralbatus Ach. Lich. sinee. Prodr. 1). 29 (1798). Vuriolaria denlbatu DC. FI. Fr. ii. p. 325 (1805) : Engl. Bot. t. 2519. V. corrlliua Ach. Lich. Univ. p. 319 (1-10); N. F. Cray Nat. Arr. i. p. 492 ; Tayl. in Mackay T.l. Hib. ii. p. 113. V. Florothece Tayl. tom. cit. p. 114 (18.36). Isirlinim pravartoxnm Turn. \& Borr. ex Hook. in Fim. Engrl. Fl, v. p. 231 (1833) \& Lich. Brit. p. 97.

Exsicc. Johns. n. 328 ; Leight. n. 320 ; Mudd n. 261.

Distinguished by the generally papillate thallus and the seattererl pustular verruce, which are frequently several-aggregate. The chemical reaction is very prononnced, and frequently the yellow colour changes to orange or red. The thallus is occasionally the host of Sclerococcum sphcerale Fr.

Hab. On rocks, boulders and walls in maritime and mountainous regions.-Distr. Fairly common throughout the British Isles.-B. MI. Sark; St. Austell, Cornwall; Dartnoor Tors, Devon; Barmouth. Aberdovey and Cwm Bychan, Merioneth; Nant Gwynant, Carnarvonshire; Anglesea; Oswestry and Caer Caradoc, Shropshire; Iildale Moor, Cleveland, Yorkshire; Teesdale, Durham ; Cumberland ; Ochill Hills, near Stirling; Lismore and Ben Cruachan, Argyll; The Trossachs, Crianlarich, Ben Lawers, Craig Calliach and Ben Vrackie. Perthshire; Sidlaw Hills and Clora, Forfarshire; Glen Callater and Morrone, Braemar, Aberdeenshire; Dunkerron and Finnehy River. Kerry; Dawros River, Connemara, Galway.

Forw corallina Cromb. Monogr. i. p. 501 (1894).-Thallus more densely papillate than in the species, with the papillat more elongate, simple or branched.- Var. corallina Cromb. in Grevillea xii. 1). 59 (1;8:3). P. syncarpa var. corallimu Mudd Min. p. 27:3 (186i1). Lirhen corullimus L. Mant. p. 131 (1767); Lightf. Fl. Ścot, ii. 1). 80 s : Huds. Fl. Angl. ed. 2, p. .526; Trith. Arr. ed. 3, iv. 1. 16; Engl. But. t. 1541. Isidium corallimm Ach. Meth. Lich. 1. 188 (180.3) ; S. F. Gray Nat. Arr. i. 1) 412 ; Hook. Fl. ricot. ii. 1) (i6!) \& in sm. Ensl. Fl. v. p. 231: Grev. Fl. Edin. p. 346 ; 'l'urn. \& Borr. Lich. Brit. p. 100.

I)iffering from the species in the more definitely branched coralloid papillar, though connecter with it by intermediate states. In our county, and in France, it is recorited as always sterile, but Yahlbruckner has issued a specimen from Saxony (Kirypt. exs. 11. 256) which bears apothecia.

Ifah. ()n rocks in maritine and upland situations. - Distr. Jocal and rare in Great Britain and [reland.-- B. M. Maresfield Common. Sinsex; I'ontnedelfyehutil, Brecknockshine; Jamouth, Merioneth; Anglesera Malrem, Woreestershire: Ayton Moor, Cleveland, Yorkhire ; Jegrlestone, Durham; Alston, Cumberland; Ben-y-gloe. l'erthshire; Sidlaw Hills and Jahlovan Woods, Forfarshire; Oban, Argyll; 'The Dargle River, Wicklow. 


\section{Spores usually four in the ascus.}

\section{Thallus non-sorediate.}

22. P. glomerata Śchur. Lich. Helr. Snicil. 1. 66 (18:3).-Thallus eftuse, thin, somewhat wrinkled, but consisting mestly of small subglobose crowded and sonctimes comfluent fertil. verrucas, white or faintly yellowish cream-colnured ( $\mathrm{K}+$ yellow. then blood-red, $\mathrm{CaCl}-$ ). Apothecia usually solitary, with punctiform or slightly open blackish dises; epitheciun $\mathrm{K}+$ violet: spores generally 4 in the ascus (sometimes 2 or up to 7 ). $72-125 \mu$ long, 28-44 $\mu$ thick. - Mudd Man. 1). 27.7: Carrull in Journ. Bot. iii. p. 289 (186.5) : Cromb. Lich. Brit. p. 60 d Monogr. i. p. 510; Leight. Angioc. Lich. p. 73 note it Lich. Fl. p. 237 ; ed. 3, p. 227. P. glomulifera Borr. ex Leight. Lich. kl. 1). 243 (1871): ed. 3, p. 234. Lichen glomerutus Schleich. Pl. Crypt. Cent. iii. n. 7\%, in Sehrad. Teu. Journ. Bot. i. 2. 1. 199 (1SO6) nomen nudum. Porina glomerata Ach. Lich. Univ. p. 310 (1810).

An alpine lichen, sufliciently" distinguished from other "moss" species by the number of spores and by the reaction with potash. The violet reaction of the epithecium is well markerl, suggesting affinity with $P$. Wulfinii. It is described and figured without a name in Leight. Angioc. Lich. p. 30, t. xi. fig. 2 (1851).

Hab. Encrusting dead mosses in momntainous places.-Distr. liare in the Scottish Grampians.-B. M. Craig Calliach and Ben Lawers, Perthshire.

23. P. leioplaca Scher. Lich. Helv. Spicil. 1. 66 (18:3). Thallus thin, developed above or within the outer periclermt layers, subdeterminate, smooth or with scattered unequal slight wrinkles and cracks, white or yellowish-white $\langle\mathbf{K}-$ or $\mathrm{i}-$ yellowish). Fertile verrucae numerous, scattered, prominent, smooth, the apothecia $1-5$ in each verruca, with pale or dark punctiform ostioles; spores normally 4, uniseriate in the ascus. sometimes varying in the same hymenium from 22 to $6 \mathrm{r}^{2}$ even :ollipsoirl, variable in size, $42-110 \mu$ long, $20-40 \mu$ thick.-Murd Man. 1. 276; Cromb. Lich. Brit. p. 60 \& Monogr. i. 1) $50 ! 1$ (incl. var. hesaspmor Nyl. Lich. Ścand. p. 18: (1N61)) : Leight. Lich. Fl. p. 244 ; ed. 3 , p. 234. P. communis var. leioplaca Turn. \& Borx. ex Schrer. 1. c. \& Lich. Brit. p. 197. P'minn leioplace Ach. in K. Vet. Acad. Handl. xxx. p. 1.)9 (1809) d Lich. Univ. p. 309, t. 7, fig. 2 (1810) (excl. vars.).

Exsicr. Johns. 11. 157 : Leight. n. 230 ; Mudd nos. 26.5. 267.

Distinguished by the thin, partly hyphophluodal, thallus and hy the normally 4 -spored ascus. Very ravely, there are s spores present, which are then smaller (var, ortospore Nyl. Lich. Sciund. 1) 1s.3 (1861: Wheld. (N 'Trav. in .Journ. Isot. Ii. p. 25) 1) (1919) ). 'The reatetion with

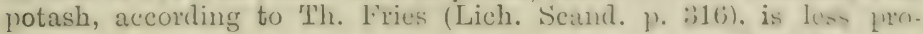


nounced in the lighter-colonred thalli. There is a doubtful specimen recorded from La Moye, J'r'sey, which is only spermogoniferous.

$H_{n}$ 7). On the trunks of trees from maritime to upland situations. -Distr. Farirly common in most parts of the British Islauds.-B. $M$. La Moye, Jersey ? TVithiel, Cornwall; Widdecombe, Lydford, Lustleigh and Torquay, Devon; Hinton Abbey, Somerset; New Forest, Hants; Shanlilin, I. of Wight; St. Leonard's Forest, Lindfield, Damny and Handeross, Sussex; Ightham, Kent; near Highbeach, Epping Forest, Hockley and Hadleigh Woods and near Bocking, Essex; near Cirencester, Gloucestershire; Woodbury Hill and Malven, Worcestershire; Gopsall Park and Twycross, Leicestershire; near Oswestry and Nesscliff, Shropshire; Gloddaeth, Carnarronshire; Bettws-y-coed, Denbighshire; Anglesea; Nervton Wood and Sowerdale, Cleveland, Yorlishire; Lamplugh, Cumberland ; Barcaldine, Argyll; Calliach and Falls of Moness, Aberfeldy, Perthshire; Moor of Morrone, Braemar, Aberdeen; Glen Nevis, Invernessshire; Enniskean, Cork; Kenmore, MI'Carthy's Island, Upper Lake and Dinish, Killarney, Kerry ; Renvyle Wood, Connemara, Galway ; Westport, Mayo.

24. P. xanthostoma Fr. Lich. Eur. p. 426 (1831).-Thallus effuse, thin, smooth, white, the fertile verruce scattered, subglobose $\left(\mathrm{I}-, \mathrm{CaCl}_{-}\right)$. Apothecia 1 to 5 in each verruca, the ostiole punctiform then opening to discoid form, pale yellowish Hesh-coloured; spores up to 6 in the ascus, 55-75 $\mu$ long, 30-40 $\mu$ thick.-Cromb. in Journ. Bot. xiii. p. 141 (1875); Leight. Lich. Fl. ed. 3, p. 235. Porina xunthostoma Sommerf. in Vet. Acad. Handl. 1823 [1824], p. 115.

The fertile veruce strongly resemble the apothecia of Lccanora normiformis or early stages of $L$. parella, but the plant can be distinguished by differences in thallus, etc.

IIub. On old stems of heather, etc., in alpine and subalpine localities.-Distr. Lare in the Grampiams and Highlands of Scotland. - B. M. Morroue, Braemar. Alerteenshire; near Lairg, Sutherland. shire.

\section{Thallus sorediate.}

2.). P. lutescens Lamy in Iiull. Soc. Bot. Fr. xxr. p. 427 (1578). Thallus subeftuse, thickish, unequal, warted or areolate, the thallus erenerally covered with sorecliate verrucie, sreenishyellow ( $\mathrm{K}(\mathrm{CaCl})+$ orange-yellow). Apothecia rare, the dise open, black, the margin tumid; spores rarely 8 in the ascus (usually $4-7$ ), about $60 \mu$ long, $36 \mu$ thick. Cromb. in Grevillea xix. p). 5? (1891) d Momorr. i. p. 507. P. fulla.e var. euriolose Fries Lich. Eur. p. 42:) (18:31); Mudd Man. p. 276. Liehen luteserens Hofm, Enmm. Lich. p. 3 (178.1). Lapmat lutesens Hoffm. Pl. Lich. p. 100, t. 23, ft: 1, 2 (1790). Lepraria luteserns Sim. Gingl. Bot. 1. 1529 (1806). Isidium luteseens Turn.

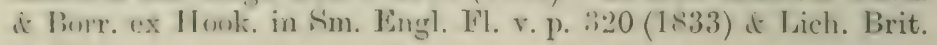
p. 87 . 
Somewhat similar to $P$. sulphure in colour, but diflering in the habitat and in the constantly furfuraceous thallus. All the specimens available for examination are sterile, though fruiting forms have been collected on the continent. The spore sizes are quoted from Harmand (Lich. Fr. v. p. 1138). He gives the hymenial reaction as $\mathrm{CaCl}+$ rose.

Hab. On the trunks of old trees, chiefly oaks.-Distr. Rare in S.IV. and N. England.-B. M. New Forest, Hants; Hurstpierpoint, Sussex; Ockham, Surrey, Epping Forest, Essex; Ickworth Park, Suffolk; Oswestry, Shropshire ; near Battersby, Cleveland, Yorkshire.

\section{Spores usually eight in the ascus.}

\section{Thallus non-sorediate.}

26. P. oculata Th. Fr. Lich. Scand. p. 307 (1<il).-Thallus effuse, mostly coralloid-papillate, the papilla rather slender, smooth, rounded at the tips, which are frequently occupied by dark-coloured spermogones, white or greyish $(K+$ yellow, then reddish). Apothecia immersed in the apices of the papille, the disc blackish, the thalline margin tumid, entire; spores $\delta$ in the ascus, ellipsoid, 18-30 $\mu$ long, 11-14 $\mu$ thick.-Liclen oculatus Dicks. Pl. Crypt. ii. p. 17, t. 6, fig. 5 (1790); With. Arr. ed. 3, iv. p. 7. Isidium oculatum Ach. Meth. Lich. p. 140 (1803): Turn. \& Borr. ex Hook. in Sm. Engl. Fl. v. p. 232 pro parte $\mathbb{E}$ Lich. Brit. p. 105 (excl. vars.). Lecunora oculuta Ach. Syn. Lich. p. 148 (1814); Hook. Fl. Scot. ii. p. 47 pro parte; MLudd Mian. p. 156 ; Cromb. Lich. Brit. p. 56 \& $M$ llonogr. i. p. 465 (incl. f. depressa) ; Leight. Lich. Fl. p. 200 ; ed. 3, 173.

Frequently classified under Lecanora. It looks like a miniature form of $P$. llactylina. It has been impossible, in the absence of apothecia in all available specimens, to verify the details as to spores, etc. Spermogones are more generally present.

Hab. On mosses on the ground, rarely on schistose roclis in alpine localities.-Distr. Rare on the summits of the Grampians, Scotland. -B. .H. Craig Calliach and Ben Lawers, Perthshire; Cairngorm, Cairntoul and Ben-naboord, Braemar, Aberdeenshire.

27. P. carneopallida Anzi ex Nyl. in Flora li.p. 478 (1868).Thallus developed under the bark (hypophlorodal) in spots, palte yellowish (in dried specimens) $(\mathrm{K}-, \mathrm{CaCl}-)$. Apothecia erumpent, small, not prominent, the dise flesh-coloured, covered at first, plane, then somewhat convex and naked with an irresular minutely sublobate margin; spores \& in the ascus, rather small. ellipsoid, 18-32 $\mu$ long, $11-20 \mu$ thick.-Cromb. in (irevillea xii. p. $60(1 \times 3)$ \& Mfonogr. i. p. 507. Lirhen anpularis With. Arr. ed. 3, iv. p. 22 (1796) (non Ehrh.) pro parte (hab. on trees) fide Crombie Il. e. Lecidea cumeupullidu Nyl. Jiot. Not. 15.i3, p. 183 \& Lich. Scand. p. 196, t. 1, fig. 9.

A Scandinavian plant not unlike fryulectu curneolutea; it has only once been collected in Great liritum. It was first recorded by 
fommerielt in F1. Lapp. Suppl. p. 8.j (1826) as Lecidca carneolutiol (non Turn.) with the name Lecivea protubrans Sommerf. in litt. in ihe symonymy. The first of these names was based on error, the second is a syonym which has been republished by Th. Fries in Lich. Aret. 1. 102 (1560) as Lecanora protriberans and in Lich. Scand. p. 305 as I'riusmin protuberans. Nylander's is the first authentic name.

Hul. (In the lark of alders in mountainous regions; recorded by Crombie from Appin, Argyll.

2.. P. Wulfenii DC. Fl. Fr. ii. p. 320 (1S0)).-Thallus effuse w. diterminate, thin and membranaceous or becoming thickish, wrinkled or areolate-cracked, whitish- or yellowish-grey ( $\mathrm{K}+$ rellowish, $\mathrm{I}(\mathrm{CaCl})+$ orange-yellow). Fertile verucie numerous. srmetimes confluent, of irregular form, with one or sereral apotbecia, at first with punctiform ostioles, then enlarging to a rlark-coloured (more rarely flesh-coloured) disc, with an irregular tumid crenate margin: epithecium $\mathrm{K}+$ violet; spores usually $\therefore$ in the ascus (sometimes fewer), $58-115 \mu$ long, $2-50 \mu$ thick.(romb. Lich. Lrit. p. 60 it Monogr. i. p. s05) (incl. var. glabrescens). P. fulla. Hook. in S sm. Engl. Fl. v. p. 160 (1833) : Leight. Angioc. Lich. p. 29 , t. 10, fig. 2 (18:1) \& Lich. Fl. 1. 240 pr larte: ed. 3, 1. 231 : Mudd Man. p. 276. Lichenoides vermcosum it sugu:um, cineremm, glalirmm 1)ill. Hist. Muse. p. 128, t. 18, fie. 9 fro parte $(17+1)$. Lirhen hymenius Ach. Lich. Suec. Prodr. 1. 80 (1798)? Engl. Bot. t. 1731. Thelotrema hymenium Ach. Meth. Lich. p. 133 (180:3)? Turn. « Borr. Lich. Brit. p. 18: f'w parte. Vervuraiu fullux Pers. ex Ach. Meth. Lich. p. 13:3 (1,03)? nomen nudum. Porina fallux Ach. Syn. Lich. p. 110 (1814): Tayl. in Mackay Fl. Hib. ii. 1. 10.2. P. hymenen S. F. Gray Nat. Arr. i. p. 495 (1821).

Eesice. Bohl. n. 100 ; Johns. nos. 154,156 (as var. difjacta) : Leight. n. 71 ; Mudd n. 266.

Similar to $I$. pertusa in habitat and in the peculiar reaction of the epithecinm with potash, but differing in the wide open disc, and in the number of the spores; these vary considerably in size according to the number in the ascus and to the stage of maturity; the sizes recorded in British Floras are too small. The thallus varies from a thin film with prominent verruce (var. glabrescens Nyl. in Bull. Soc. Linn. Torm. sé1. 2, vi. p. 290 (1572)), to a thick coarsely cracked. areolicte crust (rar. diffireta Johns. exs. n. 156). There are numerous intermediate stages, and they evidently depend on the type of bark ... which the plant grows. Thom nomally a corticolons species, it mas stras to other substruta; a specimen from a stone and mortal wall. collected at Belclare. Mayo. is typical I'. Whlfenii, and quite.

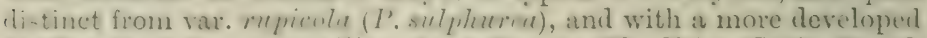
thallus than form spmestis. Aceording to Th. Fries (Lich. Seand. 1. 317), Lichen hymmius A(h. nore probahly represents a fon of

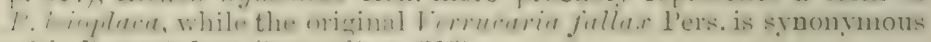
with $l^{\prime}$. pustulata (tom, cit. p. 313).

/hat. On trunlis of trees in patis and wookls (ravely saxicolous). -llior. Cencral and fairly comm!nn in the woblenl dietricts of the 
British Isles.-P. IT. Bocomnoc und Withiel, Cornwall; noar Totne:anl Lustleirh, Jeron; New Forest, Ifants; St. I wonarl's Forest. Tilgate and Chanritonlury, Sussex; Pensluurst, Kent; Eppiner and Hainault Forests, Hadleigh Woorls, Messing, Weald Hall and Mark's H:tl, Essex; Sotterly, Ugley and Yamnouth, Sufiolk; Jiatheaston, Sonnerset; Chamwori Forest. Iricestershire; Dolgelly and Aberdovey. Merioneth; Capel Curig and near Couway. Carnarvonshire; 'l'lefriw, Denbighshire; Oswestry and Llanrblodwell, Shropshire; Ingleby Park. Cleveland, Forkhire; Teestale, Durham; Calder Ahbey, Keswick and (ireenbank, Whitehaven, Cumbelland; Jarcaldine, Argyll ; Aberfeldy, Craig Calliach and J3lair Athole, Perthshire; I) nuris, Kincardineshire; ('raig ('luny, Braemar, Aberdeenshire; Castlebernard Park, Cork; Dinish, Killarney, Nerry; Belclare, Mayo.

Form carnea Fr. Lich. Eur. p. 424 (18.31).-Thallus as in the species. Aprothecial rise protruding, tumid and llesh-eriloured.Cromb. in Greviller xix. 1) 59 (1891) d Mnnogr. i. p. 506. Thelotseme leygurnitum var, cornene Turn. \& Borr. Lich. Brit. p. 185 (1839).

I'robubly only a growth condition, and perhaps due to extremely moist conditions.

Hab. On trees.-Distr. Locul and rare in S. England.-13. 1\%. New Forest, Hants; Erirge l'ark, Tunbridge Wells, Sussex; Toy's Hill, Canterbury, Kent.

Form sparsilis Cromb. Monogr. i. p. 506 (1s94). - Thallus very scinty or olsolete, whitish, the fertile verrucie scattered, otherwise as in the species.- P. fallur f. sparsilis Nyl. ex Leight. Lich. Fl. ed. 3, p. 232 (1879).

A peculiar growth condition, also probably depenting, as has been suggested, on the habitat.

Hab. On moist shady rocks. $-B$. M. Near Lough Inagh, C'onnemara, Galway (the only British locality).

Var. rugosa Nyl. in Bull. Soc. Linn. Norm. sér. 2, vi. p. -2!0 (1572); Johns. exs. 11. 15\%.-Thallus thick, coarsely warted: otherwise as in the species.

Exsicc. Johns. n. 155.

Perhaps suore a growth form than a variety. The thallus is very thisek and erowiledly warted; the ipothecia are numerous. Intermediate states are not wanting.

IIah. On old trees and rail-.-I;. 11. Cumberland (the only liritish record).

2!). P. inquinata Th. Fr. in Brot. Not. 1sfi, p. 10:- Thallus rather thin, continuous or cracked-apeolate, sonetimes wartedgranulate, dark, or pale-srey $(\mathrm{K}-, \mathrm{CaCl}-)$. Apothecia one or several in more or less prominent warts, the discs rather open, irregular, rounded or angular, with thin persistent paler marmin surrounding one or several confluent disces ; epitheriun hrownislo $(\mathrm{K}+$ dull purple or violet); spores $\mathrm{S}$ in the ascus, with thickish 
walls, 25-30 $\mu$ long, 14-18 $\mu$ thick.-Leight. Lich. Fl. ed. 3, p. 235; Cromb. Mlonogr. i. p. 508. Leerenora rourctate var. inquinata Ach. Lich. Univ. p. 353 (1810).

Exsicc. Larb. Lich. Hb. (without a number).

Easily distinguished by the several minute dark ostioles grouped in a conmon prominent dise. Both species and form are not unlike some forms of Lecanora (Aspicilia) cinerea.

Hab. On rocks in maritime and upland regions.-Distr. Scarce in X.E. England, W. Scotlind and W. Ireland.-B. MI. Barcaldine, Argyll ; Lettermore, Connemara, Ireland.

Form nolens Harm. Lich. Fr. v. p. 1133 (1913).-Thallus smonth, cracked-areolate. Apothecia one or more innate in the areolæe, depressed; spores 30-42 $\mu$ long, 15-22 $\mu$ thick. $P$. nolens: Nyl. in Flora xlvii. p. 489 (1864); Carroll in Journ. Bot. iii. p. 289 (1865) ; Jones in Proc. Nat. Hist. Soc. Drblin iv. p. 133 (1 1865$)$; Cromb. Lich. Brit. p. 61 \& Monogr. i. p. 50s; Leight. Lich. Fl. p. 245 ; ed. 3 , p. 235.

Frequently regarderl as synonymous with the species, but di-tinct in the depressed apothecia and the somewhat large spores. The epithecium gives the same reaction with potash.

$H a b$. On rocks in maritime districts.-Distr. Rare in W. and N.E. Ireland.-Distr. Glenarm, Antrim; Lough Feagh, near Lough Muck, Connemara, Galway.

\section{Thallus sometimes sorediate.}

30. P. sulphurea Schitr. Enum. p. 228 (1к50); emend Miısial. Ric. Lich. Crost. p. 187 (185\%).-Thallus efluse, thin or often rather thick, plane- or warted-areolate, sometimes seabroussorediate, sulphur- or greenish-yellow coloured $(\mathrm{K}(\mathrm{CaCl})+$ orange, or yellowish-red). Fertile verruce crowded, irregular, at tirst with punctiform dark ostioles, the dise widening, with a tumid crenate margin: epithecium $\mathrm{K}+$ violet : spores 8 in the ascus, variable in size, $50-80 \mu$ long, $25-30 \mu$ thick. $-P$. sulphuren var.

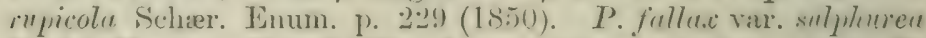
Murld Man. 1. 276 (1861); form sulplunrue Leight. Lich. Fl. ed. 2, p. 482; ed. 3, p. 231. P. Wulfenii var. rupicolı Nyl. in Bull. Suc. I imn. Norm. sér. 2, vi. p. 290 (1872); Cromb. in Grevillea xix. p. 5!) (1S!1) \& Monogr. i. p. 507. Eudurnom sulphurenm Tayl. in Matkay Fl. Hib, ii. p. 100 (1s:3(i); Leight. Angioc. Lich. p. 15, t. 3, tig. 4.

Frequently regarded as a variety of $J^{\prime}$. IInljomii, but differing in colour, habitat, in the presence of soreelia and in the spores. The sizes griven of these have been measured from seharer's sprecinen (exs. 11.595$)$. liritish specinens are mostly sterile and several of then are dotted with small round lishter-eolonred sorediose verruede, well seen in 'Taylor's specimen of Endurargon sulphurentu from Bunkerron. Though the latter represents the earliest trivial name. Scharer's later de-ignation is a coincidence merely and was not hased on 'Taylor's plant. 
Hab. On rocks in maritime and mountainous regions.-Distr. Rather rare in Wales, N. England, S.W. Highlands of Scotland ared S. and IV. Ireland.-B. M. Dolgelly, Merioneth; Anglesea; Inglehy Park, Cleveland, Yorkshire; Lismore, Argyll; The Trossachs, Perthshire; Dunkerron, Kerry; Belclare and Corraun Mt., Achill, Mayo.

31. P. gyrocheila Nyl. in Flora xlviii. p. 354 (1865).--Thallus effuse or determinate, unequally granulate, deeply cracked, srey $(\mathrm{K}+$ yellow, $\mathrm{CaCl}-)$. Apothecia in prominent tubercles, simple $(1)^{2}$ becoming subgyrose, with the disc labyrinthine (glypholeceine); spores 8 in the ascus, $6 S-70 \mu$ long, 36-50 $\mu$ thick; hymenial gelatine and asci bluish with iodine.-Carroll in Journ. Bot. iv. p. 23 (1866) ; Cromb. Lich. Brit. p. 61 \& Monogr. i. 1. 509; Leight. Lich. Fl. p. 241 ; ed 3, p. 232.

The above description is taken from Nylander. Of the two specimens in the British herbarium from rocks, Ben Lawers, determined as $P$. gyrocheila, one may be perhaps considered a co-type, as it presumably forms part of the original collection; the other, also froin Ben Lawers, was collected by Crombie. The material is too scanty to permit of exhaustive examination, but, as far as can be judged, they are very weathered exposed forms of Lecanora tartarea with exactly the same thalline reaction and the same size of spores as in that species. A series of somewhat similar specimens collected by the late W. West in Shetland and the Outer Hebrides were at first determined as Pertusuria gyrocheila, but finally were proved to be Lecanora tartarea, with transition stages from a normal open dise to a gyrose apothecium.

5i. VARICELLaRIA Nyl. in Mém. Soc. Sci. Nat. Cherb. r. p. 117 (1857); Lich. Scand. p. 182. (Pl. 57.)

Thallus thinly crustaceous, corticate. Apothecia in convex verruce, deeply immersed ; paraphyses slender, branched, intricate; isci 1-spored; spores very large, ellipsoid, 1-septate, colourless. Spermogones unknown.

According to Darbishire (Engl. Bot. Jahrb. xxii. 1) 631 (1897)) there is generally a cortex of plectenchyma about two cells thick both above and below. Strong hyphre traverse the internal tissue, uniting the two cortices, while from the lower cortex rhizine are producesl. which attach the thallus to the substratum.

1. V. microsticta Nyl. 11.c.-Thallus subdeterminate, une ųul, thin, smooth, sometines isidiose or leprose, whitish ( $\mathrm{I}-, \mathrm{CaCl}-$ ). Apothecia usually solitary in the fertile verruea, of which several maty be confluent, at first immersed then opening, the disc palereddish or flesh-coloured, generally white-suffised from the breaking down of the overlying tissues, the margins also suffused; spores very large, 225-350 $\mu$ long, 9.5-115 $\mu$ thick : hymenial gelatine and asei deep-blue with iodine.-Cromh. in Journ. liot. xx. p. 27.2 (1882) \& Monogr. i. p. 511.

Sufficiontly distinguished by the 2-celled cnomous spore, the largest linown in lichens. When poorly developed it resembles 
Protusurin. Th. Fries (Lich. Scand. p. :322) states that Pertusarin rholocuru fioerh. Syst. Lich. (iem. p. 384 (1855) is identical from an cxinnination of Foerber's plant; but the diagnosis does not enrre- pond, the spores being described as 1-celled, etc., so that Nylander's name must be retained.

IFrb. (In mosses on the ground in an alpine situation.-B. M. Ben Aron, Braemar, Aberdeenshire.

\section{ORDi: XT. THELOTREIMACE王.}

Thallus reustaceous, thin or thickish, mostly non-corticate. Alual cells Trentepolitir or Protococeus. Apothecia at first immersed and closed, then more or less open, with a proper margin senerally well developed, and usually surrounded by a (n)rerging thalline margin; paraphyses simple or branched; spores $1-\delta$ in the ascus, elongate-septate, or muriform, rather large, colourless or dirk-coloured. Śpermogones with acrogenous short, or long and curved, spermatia.

The immersed apothecia of the order recall those of Pertusariacene, though in the latter the proper margin is undereloped; it is also poorly represented in Phlyctis, while in Conotrema it is the thalline margin that tends to disappear. The paraphyses are of the lecanorine type. Conotrema is described in Monogr. ii. p. 1.

The British genera are as follows:-

Algal cells Trentepohtia.

Spores septate or muriform

58. Thelotrema.

Algal cells Protococcus.

(Spores elongate, multi-septate (see

Monomr. ii. p. 1) .....................

Spores muriform, colourless

Conotrema).

Sijores muriform, ditrk-coloured.

59. Phlyctis.

60. Diploschistes.

ז. THELOTREMA Ach. Meth. Lich. 1. 130 (1803): emend Lich. Univ. p. 312 (1810). (Pl. 58.)

Thallus crustacenus, superficial or partly developed beneatl the bark, non-corticate, or with an amorphous cortex, attached by hyphar. Algal cells Tirntrpoliliu. Apothecia at tirst immersed, then rmerging like small rerruce, the disc halfconcealed or opening out, the inner proper margin persistent. ermtinued or wanting helow the hypothecium, the outer thalline matrin prominent, werarching the dise: spores $1-8$ in the. ascus, oblong or fusiform, usually colourless, septate or irregularly inuriform.

The genus is charateri\%ed by the erater-like apothecia and by 13.e situte or muriform spores. it is poorly repuesenter in Europe. arearly all the species belomg to the wamere regrions of the erlobe.

1. Th. lepadinum Arh. Meth. Lich. p. 1:3: (180:3) \& Lich. I ni. 1. :31:2, 1. 1, fie. I (18/0). Thatlus rather thin, smonth or 
slightly wrinkled, somewhat shining, whitish or straw-colourer $(\mathrm{K}+$ reddish, $\mathrm{CaCl}-)$. A jothecia moderate in size (1-2) mm. across), numerous, prominent as a wart-like elevation, tho dise: semi-enclosed, dark-brown or blackish, pruinose or laked, the thalline margin thin, inflexed, even and sharp at the erlge; paraphyses massed, coherent, slencier, slightly clavate and often brown at the tips; spores $2-8$ in the ascus, oblong-fusiform, colourless, :35-70 $\mu$ long, 11-16 $\mu$ thick (or larger) ; septate and partly muriform; hymenial gelatine bluish with iodine.-Hook. Fl. Scot. ii. p. 45 \& in Sm. Engl. Fl. v. 1. 161 ; S. F. Gray Nat. Arr. i. 1. 494 ; Grer. Fl. Edin. 1. 3:30: Tayl. in Mackay Fl. Hib. ii. p. 102 ; Turn. \& Borr. Lich. Brit. p. 180 ; Leight. Angioc. Lich. p. 31 , t. 12, fig. 1 \& Lich. Fl...p. 247 ; ed. 3, p. 2is: Mudd Man. p. 278, t. 5, fig. 116: Cromb. Lich. Brit. p. (il d Monogr. i. p. jli. Lichen lepatimus Ach. Lich. Suec. Prodr. p. 30 (179s). L. inrlusus sm. Engl. Bot. t. 67s (1799).

Exsicc. Baxter's Stirp. Crypt. Ox. n. 20; Bohl. n. 29 ; Johns. n. 158 ; Leight. n. 121; MIudd n. 268.

The apothecia are mumerous and are very marliedly crater-like. The spore sizes given above are too small, as they measure not unfrequently up to 95 or $100 \mu$ long, $22 \mu$ thick; as in other instances, the size is relative to the number of spores in the ascus, sometimes they have a thick epispore.

Hab. On smooth bark of trees from maritime to upland districts.Distr. General and common in England, apparently rare in Scotland and Ireland.-B. M. St. Breock, Cornwall; New Forest and Southampton Common, Hants; St. Leonard's Forest, near Tumbridge Wells and Ardingly, Sussex; Ightham. Tent; Ugley, Walthamstow. near Ingatestone and Hockley Woods, Fssex; Bagley Wood, Berks: Leigh Woods near Bristol, Gloncestershire; Hollybush Hill, Malrern. Worcestershire; Hafod, Cardiganshire; Haughmond Hill, Church Stretton and Acton Burnell Hill, Shropshire: Charnwood Forest and Bardon Hill, Leicestershire ; Cwm Bychan and Barmouth, Merioneth ; baysdale, Cleveland, Yorkshire; T'eestale, Durham; Calder Abbey. Cumberland; New Galloway, Kirkcudbrightshire; Foot of Ben Lomond. Jumbitonshire; Appin, Argyll; Glen Filloch and Looh Katrine. l'erthshire; Morrone, Braemar, Aberdeenshire; Piverstone, Cork: Killarney, Kerry ; Achill Island, Mayo.

Var. scutelliforme Ach. Lich. Unir. 1. 31:3 (1810) \& Sirn. Lich. P. 115 (1814).- Thallus rather thick, unequal and some times sorediose, light-coloured. Apothecia crowded, the dis. more open, and the thalline marwin tumid and rugose.-Tayl. in Mackay Fl. Ifih. ii. p. 10:3 (1536); Cromb. in (sirevillea xix. 1. 60 \& Monogr. i. p. 514 (incl. f. rnustre) ; var. rupestor 'Turn. a Borr. Lich. Brit. 1) $1 \& 0$ (1\$39) ; Leight. Angioc. Lich. 1) :ï, Ł. 12, fig. 2- Mudd Man. p. 278: form rupestre Cromb. Lich.

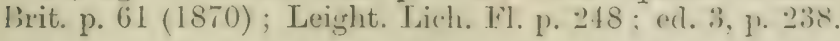

A well-marked variety in the extreme forms; the apothecia atr. generally very crowled and often in pominent groups. due apparently to inequalities of the substratum. 
Hab. On rugged bark of trees or on rocks in maritime and mplami districts.-Distr. Sparingly thoughout the British Isles.- B. M. New Forest. Hants; Namman, Lyn Bodlyn and Cammlan Valler. Merioneth; Garn, Denbighshire; Teestale, Durham; Wark, Northumberland; Lismore, Argyll ; Glenstale, Tipperary ; Kemmore Tioal anr Derrycuintry, Killarney, Kerry; Kiplemore and Doughruagh Mits.. Connemara, Galway.

2. Th. subtile Tuckerm. in Americ. Joum. Sci. Art. xxv. p. 426 (1858); Nyl. in Flora xlvii. p. 491 (1864) note.-Thallus thin, generally determinate, smooth or somewhat felted, sometimes shining, cream-coloured or whitish ( $\mathrm{Kf}+$ yellow, $\mathrm{CaCl}-$ ). Apothecia erumpent, small, the disc whitish, the proper margin prominent, often white-pulverulent: paraphyses slender, not widened upwards, buclding off small colourless cells at the tips: spores 8 in the ascus, narrowly elongate 9-12-septate, $40-50 \mu$ long, $8-10 \mu$ thick.-Carroll in Journ. Bot. iii. p. 289 (1865): Cromb. Lich. Brit. p. 61 it Monogr. i. p. 5l5); Leight. Lich. Fl. p. 248 ; ed. 3 , p. 239.

Exsice. Cromb. n. 169 ; Larb. Lich. Hb. n. 62.

An American species, the Europenn representatives of which are confined to our western shores. Nylander (l. c.) states that it: affinity is with $T h$. bicinctulum, an Australasian species. The specimen from Moidart was collected by the late Mr. W. West.

Hab. On smooth bark of trees in upland districts.-Distr. Rire in Scotland and V. Ireland.-B. M. Mooidart, Invemessshire; Tore MIt.. Cromaglown and Lough Inchiquin, Kerry ; Lough Derryclare, Holy Island and Lough Inagh, Connemara, Galway.

59. PHLYCTIS Wallr. Naturg. Flecht. i. p. 527 (18.25) emend Koerb. Syst. Lich. Germ. p. 390 (185.5). (Pl. 59.)

Thallus crustaceous, continuous or cracked, or pulverulent. develonerl above or beneath the bark. Algal cells Protocouris. Apothecia immersed, then scarcely emerging, the proper margin poorly developerl, the outer thalline margin irregularly dehiscent or indistinct; paraphyses slender, mostly unbranched ; spores $1-8$ in the ascus, elongate or ellipsoid, muriform, with a thin "pispore, colourless. Sipermogonei with simple sterigmata and short slender straight spermatia.

Though placer by some lichenologists in Lecanomeete, the immersed apotheria and muriform spores show the afthity with Thelotremaceas. In appearance the species are not unlike l'erlusmrin.

1. Phl. agelæa Koerh. Siyst. Lieh. Germ. p. 391 (1855).Thatlus eflitse or suldeterminate, thin, partly developed beneith the bark, sinooth or somewhat wrinkled, often pulverulent, white. or greyish-white (K+ yellow, then red). Apothecia small, one 11. sereral euclesed in rather flat pulverulent verrucar, the dise flesh-osloured then diark, the surrounding margin somewhat tumid and torn: spores 2 (or :3-4) in the aseus, ellipsoid, muriform. 
with an apiculus at each end $35-80 \mu$ long, 11-3:- $\mu$ thick. Iudd Man. p. 279, t. 5, fig. 118 ; Cromb. Lich. Brit. p. 61 it Monogr. i. 1. 512; Leight. Lich. Fl. 1. 246; ed. 3, p. 237. Lichen ugflæus: Ach. Lich. Suec. Prodr. p. 30 (1798) ; Engl. Bot. t. 1730. Thelotrema agelra S. F. Gray Nat. Arr. i. p. 494 (1821) pro parte. Variolaria agelea Turn. \& Borr. ex Hook. in Sm. Engl. Fl. v. p. 171 (1833) \& Lich. Brit. p. 78. V.constellute Tayl. in Mackay Fl. Hib. ii. p. 113 (1\$36) pro parte.

Exsicc. Leight. n. 282 ; Mudd n. 269.

The thallus is thin and often spreads widely over the bark. Apothecia are generally numerous and become dark with age, though for the most part covered over by the leprose thallus. This species and the following have recently been reported from Perthshire by Wheldon and Wilson (Journ. Bot. 1915, Suppl. p. 45).

$H a b$. On trunks of trees in maritime and inland situations.Distr. Fairly common throughout England, rare in S. Freland and Scotland. $-\dot{B}$. M. Arton near Totnes and Ilsham Walk, Torquay, Devon; Carisbrooke, I. of Wight; New Forest, Hants; near Lindfield. Glyude and Henfield, Sussex; Shiere, Surrey; Penshurst, Kient; Epping Forest, Quendon, Rickling, Hadleigh Woods and stansted Mountitchet, Essex; Bathampton Downs, Somerset; Cirencester, Gloucestershire; Forden, Montgomeryshire; Huglith, near Chureh Stretton and Oswestry, Shropshire; Barmouth and Aberdovey, Merioneth; Harboro' Magna, Warwickshire; Airyholm Wood and Hoggart's Wood, Cleveland, Yorkshire; Kitsboro", Riverstone and Castlebernard Park, Cork; Askew Wood and Dunkerron, Killarney, Kerry.

2. Phl. argena Koerb. Syst. Lich. Germ. p. 391 (1855).Thallus effuse, thin, smooth or wrinkled, pulverulent, silverygrey or cream-coloured ( $\mathrm{K}+$ rellow then deep red). Apothecia small, the disc blackish and pruinose; spores 1 in the ascus, oblong-ellipsoid, not apiculate, very large, 100-140 $\mu$ long, $\therefore 7-50 \mu$ thick. MIudd Man. p. 280 ; Cromb. Lich. Brit. p. 61 if Monogr. i. p. 513 ; Leight. Lich. Fl. p. 246 ; ed. 3, p. 237. Lichen urymus Ach. Lich. Suec. Prodr p. S (1798); Engl. Bot. t. 1923. Turiolarie argenu Turn. \& Borr. ex Hook. in Sm. Engl. Fl. v. p. 171 (1833) \& Lich. Brit. p. 75.

Differs from the preceding in the somewhat thinner more pulverulent thallus, ind in the non-apiculate spores. Fruiting specimen: are not common.

Hab. On the trunks of old trees in upland districts.-Distr. Fiather rare in S.W. and Central Englind, - B. M. Beckey Falls, Devon: Nerw Forest, Hunts; Shiere and Haslemere, Survey; Ightham, lient; Epping Forest, Gosfield Hall and Stansted Mountitchet, Essex: Burnham lieeches, Bucks; Charnwood liorest and Gopsall Wrood. Leicestershire; Broadwas and near Worecster; Barmonth. MIerioneth: Oswestry, Shropshire.

60. DIPLOSCHISTES Norm. in Nyt. Mag. Nat. Vidensk, vii. p. 232 (1853). Lrceolaria Ach. Meth. Lich. p. 141 (1803) pro parte (non Willd.) ; \&. F. Gray Nat, Arr. i. p. 457 pro parte; 
Grev. Fl. Edin. p. 330 pro parte; Hook. in Sm. Eng. Fl. v. 1. 171 po parte: Tarl. in Mackay Fl. Hib. ii. p. 13:- pro palte:

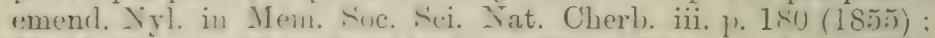
Murld Minn. p. 16i.): Jeight. Lich. Fl. p. 234: ed. 3, p. 239: Cromb. Monogr. i. p. 515. (Pl. 60.)

Thallus crustaceous, senerally areolate, rarely olsolete, nomcorticate or with an imperfect cortes. Algal colls Protoroccus. - Irothecia immersed-urceolate, with a well-developed proper marsin, and an outer persistent or disappearing thalline margin : praphyses slender: spores 4-8 in the ascus, muriform, darkroloureil. Spermogones with short cylindrical straight spermatia.

A small crenus not milike Throtrma in the form of the apothecia. but with different alcril cells. The name Lmenlarin was given by Willdenow tex ('othen. I)isp). Verr. Meth. p) 10 (1790i) to a genus of Pubiacer.

1. D. scruposus Norm. in Nyt. Mas. Nat. Virlensk. vii. p. 23.) (1.53).--Thallus determinate or effuse, thickish, uneven, rranulate- or warter-arenlate, deeply cracked, srey, greyishwhite or dark-grey ( $\mathrm{I}+$ yellowish, $\mathrm{CaCl}+$ red, I $\frac{\mathrm{g}}{+} \mathrm{blue}$ ). Aprothecia molerate in size, crater-like, the disc blackish, more ur less pruinose, the proper margin grevish black, comnivent, the thalline margin thickish, sometimes wrinkled or crenulate and werarching, or the dise wirlening, and the thalline margin thin, antire at the edge; hypothecium black; laraphyses slender, somewhat flexuose, brownish at the tips: spores ellipsoid. i-septate, the middle cells Iongitudinally divided, colourless then dark-brown, about 22-38 $\mu$ lone, 10-15 $\mu$ thick: hymenial selatine vellow with iodine.-Lichenoiles crustureum et leprosum, sutellis nigfieantilms majuritus of minorilus l)ill. Hist. Muse. 1. 1:33, 七. 18, fig. 1.5口 (1741). Lirhen semposts Sureh. Spicil. Fl. Lips. p. $13:$ (1771); Dicks. Pl. Crypt. fasce i. p. 11 : Engl. Bot. t. 266 ; With. Arx. ed. 3, iv. p. 19. Urceolaria scruposa Ach. Meth. Lich. 1. 147 (180:3) (incl. var. $)^{7}$ lumluru) : R. F. Gray Nat. Arr. i. p. 45!); Grev. Fl. Edin. 1. :3:31; Hook. in Sm. Fngl. Fl. . 1. 172: Tayl, in Mackay Fl. Hib. ii. p. 1:3: : Mudd Man. p. 165 ; Leight. Lich. Fl. p. 234; ed. 3, p. 239; Cromb. Monorer. i. 1. 516 (incl. f. plumber ). Lecaumu ecruposa sommerf. Fl. Lapp. Suppl. p. 10() (18:(i) : Cromb. Lich. Brit. p. 5s.

Eirsire. Croml, n. 7 ; : Johns. n. 1.99; Larl). Cantab. n. 35 \& Lich. Hb. n. 136 ; Leight. nos. 54, 379 ; Mudd n. 137.

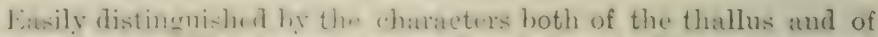
the apothecia. The formes raries, but in general it is thick and irregular: in sonw stmations it is atrier-coloured (f. plumbea). The rescetion of the medulla with iodine is fregnently indistinct. Lirhen

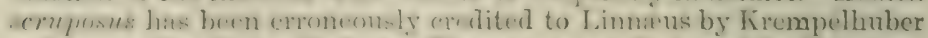

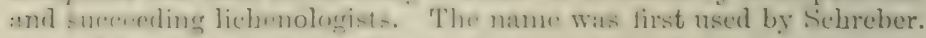

Mah. On rocks and walls. rarrly on old wood or on calcareous

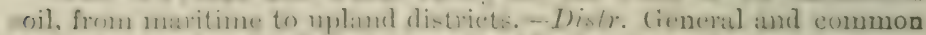

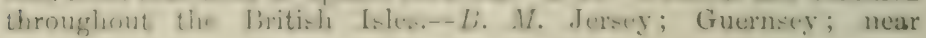


Penzance and near Padstow, Corinwall; near Shanklin. I. of Tienth: Shaston (Shaftesbury), Dorset; T3alton Mills, Maresieht. Wiest Hoathly, Danny and Pulborough, Sussex; Walthumstow (?), Esise: Kew Gardens, Surrey (179S); Jathampton Downs, Somerset; Migmore Church, Herefordshire; near Woreester, Pershore and Malrern. Worcestershire; Le:mington, Warwichshire; Ampthill, Bedfordshire; Gogmagog hill and Cheveley Park, Cambridgeshipe; Thetford Warren aud Livermore, Suffolk; Charnwood Forest and Barlon Hill. Leicestershire; Oswestry, Nemport, Grinshill, near Shrewshury and High liock, Bridgenorth, Shropshire; Barmonth, Merionctly; Bedl Gelert and Nant Ffrancon, Carnarvonshire; Anglesea ; Juxton, Derbyshire; Lounsdale, Cleveland, Yorkshire; Teesdale, Du'ham: Romin Wall, Chesters, Northumberland; Windermere and Staveler; Westmoreland; Alston and Bassenthwaite, Cumberland; New Gulloway, Kirlicudbrightshire; King's Park and Craiglochliart, Edinburgh; "West Water, Fifeshire; near I)unleld, Killin and Ben Trachie. Perthshire; Strathmartine and Den of Mains, Forfarshire: Morrone, Braemax, Aberdeenshire; near Fort William, Invernesshire ; Kilcully, Cork; Loughcooter, Galway.

2. D. bryophilus Zahlbr. in Hedwigia xxxi. p. 34 (1892)... Thallus effuse, rather thin and sometimes pulverulent or sometimes almost obsolete $(\mathrm{CaCl}+\mathrm{red})$. A pothecia generally numerou:, prominent, the disc opening widely, black, whitish-pruinose, the thalline margin often thin and entire or somewhat turgirl, wrinkled or creuulate; spores, etc., as in $D$. scruposus. Lichen bryoplitus. Ehrh. exs. n. 236 (1791) nomen nudun in Beitr. Naturk. vii. p. 102 (1792) (cf. Arn. in Flora lxiii. p. 554). Uropoluriu scrupose var. bryophila Schar. Lich. Helv. Spicil. p. 75 (1826); Mudd Man. p. 165; Cromb. Lich. Brit. 1. כ̃ ; f. bryophlilı Leight. Lich. Fl. p. 235 (1871); ed. 3, p. 240 ; sulssp. liyophilı Nyl. ex Nörrl. in Medd. Siillsk. Faun. d Fl. Fenn. i. p. 27 (1876); Cromb. Monogr. i. p. 517.

Exsicc. Johns. n. $2 \times 0$; Larh. Lich. Hb. nos. 63, 221 ; Leight. nos. 359,360 .

Generally regarded as a species, though possibly only a variety of D. scruposus, and differing chiefly in the habitat and in the more scanty thallus. The pulverulent condition has been recorded a Urccolaria scruposa var. dealbata Ach. Lich. Univ. p. "341 (1810). Not unfrequently it spreads to Cladonia squamules, where its own thallus often practically disappears, and the fruits which are freely produced are semi-parasitic on the Cladonia. The base of thi apothecium is embediled in the liost, the tissue of which is dis. coloured and injured immediately below. This contition has been recorded as Lecanora scruposa var. parasitica Sommerf. Fl. Lanp. Suppl. p. 100 (1826) pro parte (fide Crombie) and as subsp. bryophild f. ecrustacea Cromb. in Grevillea xix. p. 60 (1891).

Hab. Spreading over mosses, humus and Clutomin sruammles in maritime and upland regions.-Distr. Not uncommon in the Isritish Islands.-D. W. Quenvais, Jersey; St. Minver and l'enzance. C'ornwall; near 'Torgaay and Lustleigh Clecre, I)evon; Jathford IIill, Somerset; Wotton-under-Ldere and Pembury I'ark, ('irencester, Glon. cestershire; ('helmsford and lipping Forest, Jisex; Thet ford Wirren. Norfolk; Dolgelly and Barmouth, Merioneth; lligh Liocks, Jidige- 
north, Shrop-hire; Matlock. Derbyshire; Langbaurgh, Cleveland, Yorkshire; Egglestone, Durhan ; Lisnore and Appin. Argyll; Glen Lochay, 13en Lawers, Craig Tulloch and Blaeberry Hill, Perthshire; Morrone. J3raemar. Aberdeenshire; near Tilcully; Cork; Killarney, Kerry; Glen Inagh, Connemara, Galway; Deer Park, Belfast, Antrim.

3. D. gypsaceus Zahlbr. in Hedwigia xxxi. p. 35 (1892).Thallus thick, soft, continuous or crackerl, unequally wrinkled, more or less pulverulent $(\mathrm{K}-, \mathrm{CaCl}+\mathrm{rerl})$. Apothecia immersed in the thallus, the disc blackish, white-pruinose, small and enclosed or wiclening to about $2 \mathrm{~mm}$. across, the thalline margin scarcely perceptible or turgid; hymenium dark-brown; paraphyses slender, intricate, budding off small cells at the tips ; spores oblong-ellipsoid up to 8-septate, irregularly muriform, $23-42 \mu$ long, $9-17 \mu$ thick; hymenial gelatine faintly bluish then yellowish with iodine.Ureoluria srmpose var. albissima Ach. Meth. Lich. p. 147 (1803);

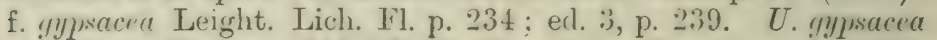
Ach. Lich. Univ. p. 338 (1810); Cromb. in Grevillea xix. p. 60 (1891) \& Monogr. i. p. 518.

Differs from D. scruposa in the whiter softer pulverulent thallus and in the spore characters. As to the latter, all measurements taken agree with the above sizes given by Hamnand, though Crombie has stated them to be up to $57 \mu$ long and 16-24 $\mu$ thick. Crombie also points out as a specific character that the medulla of the thallus does not turn blue with iodine.

Hab. On calcareous and cretaceous rocks in maritime and upland districts.-Distr. Recorded from few localities in S. and Central Englani. S. Wales and W. Ireland; probably overlooked.-B. MT. The Downs, Lewes, Sussex; Bathampton Downs, Somerset; N. Derbyshire; Alserdw liocks, Brecknockshire; Glencorbot, Comnemara, Galway.

4. D. actinostomus Zahblhr. in Hedwigia xxxi. p. 34 (1892). -Thallus subdeterminate, thickish, rather uniform and smooth, cracked-arenlate, the areolie more or less convex, light-grey ( $\mathbf{K}-$, $\left.\mathrm{CaCl}+\mathrm{recl}, \mathrm{I} \mp_{1, m_{m}}\right)$. A pothecia minute, one or several immersed in an areolia, the dise punctiform, enclosed, then opening and somewhat plane, l, lackish, whitish-grey-pruinose, the proper margin finely striate, the thalline margin thickish, not prominent; hypothecium narrow, lrown; paraylyges slender, intricate; spores rather broadly ovoid or ellipside, 5-6-septate and muriform, up to $35 \%$ long, $16-20$ thiek : hymenial gelatine slightly tinged, blue then yellow with imline.-Uirentuia actinustoma Pers. ex Ach. Lich. Unir. p. 20s (1s10); Cromb, in Journ. Bot. xxiii. p. 196 (1885) \& Monogr. i. p. 518.

The sprecies is not repreanted in our Islands, but nuly the following variet. The fouits in their enelosed stage are not unlike a Vermenria, and it was so mumed hy Achurims (I. e.). The striate character of the inner proper matrin is mostly obsemed by the overlying thatline margin; it is evidently due to tuft: of dark-lown hypha which are more or less apart, thus appearing as dark streaks. 
Var. cæsioplumbea A. L. Sin. - Thallus greyish leaden. colvured somewhat shining. Apothecia as in the species.-Ureplaria actinostome Far. exsin-plumbea Nyl. in Bull. Soce Linn. Norm. sér. 2, vi. p. 298 (lsi2) : Cromb. in Grevillea xix. p. 60 (1891) \& Monogr. i. p. 518.

Exsice. Johns, n. 160.

$H a b$. On rocks in maritime districts.-Distr. Sparingly in the Chamnel Islands and N.W. Englind.-B. MI. Chateau I'oint, Sark; St. Bees, Cumberland.

\section{ORDER XYA. CHRYSOTHRICACE}

Thallus byssoid, spongy, of branched loosely interworen hypher, not corticate. Algal cells Protococcacere or Trentepolitiu, generally in groups lodged among the hyphre (partly homoiomerous). Apothecia without a thalline margin, but with a double proper margin; spores colourless, simple or septate. ipermogones (seen only in one species), with simple sterigmata and small spermatia.

The Order was inadvertently omitted from the synoptical list of Cyclocarpinex (p. 26). It has been placed by Hue in a separate fimily "Intertexter" on account of the byssoid structure. It is not truly homoiomerous as the algie are mostly congregated near the surfice, a medullary stratum lying between the gonidial zone and the dark rhizoidal hyphæ of the hypothallus. Only one genus is represented in our country.

Thallus with algal cells, Protococcus ..... 61. Crocynia.

61. CROCYNIA Mansal. in Atti 1.st. Tenet. Sci. Lett. ed Art. ser. 3, v. p. 251 (1860). Leprolome Nyl. in Flora lxvi. p. 107 (1883); Cromb. Monogr. i. p. 348. (Pl. 61.)

Thallus of felterl intricate hypha, sprearling, noncorticate. Algal cells Protorocrus or Trentepohlia. Apothecia sessile or immersed, without a thalline margin, the disc red or blackish: paraphyses conglutinate, thickish, not branched : spores 6-8 in the useus, simple or 1-3-septate.

There is only one sterile sprecies recorded in our Islands, though in number of species also sterile lawe been found in Northern France. and may have been orerlooked here.

1. C. lanuginosa IIue in Mém. Suce Sci. Nat. Cherb. sér. 4. xxxrii. p. 229 (1909). - Thallus orbicular or effuse, adnate-lobate at the circumference, sranular-pulverulent at the centre, white or yellowish-white $(\mathbf{K}-)$ : hypothallus dark-brown, tomentose.

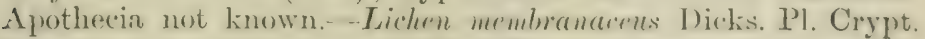
fasc. 2, p. 21, t. 6, fig. 1 (1790)? With. Arr. ed. 3, iv. p. 61? L. lannginosus Ach. Lich. Suec. Prodr. p. 1:20 (1798). Parmelin

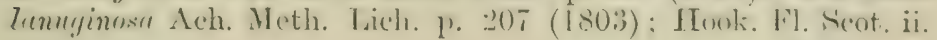


p. 53 : S. F. Gray Nat. Arr. i. p. 439 ; Tayl. in Mackay Fl. Hib. ii. p. 148. Squameria Tannginosa Hook. in Sm. Engl. Fl. v. p. 196 (183:3). Amphitona lanuginostem Nyl. in Mém. Since. Sci. Nat. Chorb. v. p. 110 (1857); Mudd Man. p. 126 ; Crom?. Lich. Brit. p. 44 ; Leight. Lich. Fl. p. 170 ; ed. 3, 156. Lepro Toma lenuginosum Nyl. in Flora lxvi. p. 107 (1883); Cromi. Nonogr. i. p. 348.

Eesire. Johns. n. 234 ; Larl). Lich. Hb. n. 332 ; Leight. n. 5.).

The plint is always sterile, though Dickson and Acharius both describe apothecin. It seems doubtful if Dickson were really dealing with this species. In Achariug' herbarium there are anthentic specimens, but according to Lïnnroth (Th. Fr. Lich. Arct. p. 79) thes are all sterile. The early records in our comntry are all describer as bearing apothecia, until Taylor, who says these bodies had not been seen in Ireland.

Hal. On decaring mosses on shaded rocks or soil in maritime and upland districts.-Distr. General and fairly common throughout the British Isles.-13. MI. Rozel, Jersey; Guernsey; Rioche Rock, Comwall; Vixen Tor, Dartmoor and Lustleigh Cleeve, Devon; Eridge Tiocks and High Roclis, Tunbridge Wells, Sussex; Longnyund Hill, Haughmond Hill and Craigford, Shropshire; Barmouth, Merioneth; Carnedd Dafydd, Carnarvonshire; Malvern, Worcestershire; Cham. wood Forest, Leicestershire; Ayton, Cleveland, Yorkshire; Iinleon Clints, Durham; Kentmere, Westmoreland; Wastdale, Cumberland ; Black Craig, New Galloway, Kirkcudbrightshire; Ben Lomont. Dumbartonshire; Achosragan Hill, Appin, Argyll; near Killin, Ben Lawers, The Trossachs and Craig Callinch, Perthshire; Canlochan. Forfarshire; Craig Cluny, Braemar, Aberdeenshire; Glen Neris. Invernessshire; near Lairg, Sutherlandshire; Bonane, near Dunkerron. Kerry. 


\section{APPENDIX.}

Tus Order's, senera and species described below had already been published by Crombie in his Monograph, Part 1, before the preparation of Part 2, in which they should have rightly been placed, was undertaken. The modern views of affinity accepted by lichenological students have necessitated the classification adopted. These Orders were left unnumbered in Part 2 ; but it is now possible to indicate the numerical arrangement, not only of those described here (marked by an asterisk), but of the remaining Orders of Subseries III. Graphiclinere, and of Series II. Pyrenocarpese, included in Part 2, to which references are duly given.

The completed list is as follows :-

Subseries II. CYCLOCARPINEDE-continued from $\mu .26$.

Order "XVI. Grropionacex, Part 2, p. 2; rescribed in whole.

"XYTT. Cladoniace., Part 2, p. 2; clescribed in whole.

XVIII. Coenogoniace.e, Part 2, p. 2.

*XIX. Lecideacex, Part 2, p. 4; described in part.

Subseries III. GRAPHIDINEZE.

(Tribe XIX. Graphidei, Part 2, p. 200.)

(Order 'XX. Dinumace, Part 2, I). 200 ; (lescribed in whole. *XXT. Rorcildires, Part 2, p. 200; described in whole.

XXII. Lecanactacese, Part 2, p. 201.

XXIII. Artioniacex, Part 2, p. 205.

XXIV. Graphidacese, Part 2, p. 220.

XXV. Chrodectonaces, Part 2, p. 258. 


\section{Series IT. PYRENOCARPINEE.}

(Tribe XX. Prrenocarpei, Part 2, p. 263.)

Order * XNVT. Prrenidiace.e, Part 2, p. 264; descrihed in part.

XXVII. Dermatocarpace, Part 2, p. 266.

., "XXVIII. Verrucariacer, Part 2, p. 275; (lescribed in part.

. *XXiX. Prrenulacei, Part 2, p. 31"2 : described in part.

. XXX. Thelocarpacee, Part 2, p. 345.

" XXI. Tripetheliace., Part 2, p. 347.

" XXXII. Mrcoporacex. Part 2, p. 348.

\section{ORDLR XVI. GYROPHORACE王.}

Thallus foliose, monophyllous or polyphyllous, corticate on both surfaces, attached by a central hold-fast or by rhizina Algal cells Protococcu. Apothecia sessile or almost stalked, with proper margin only (lecideine); the disc plane or furrower (ayrose) black: spores 1 to $S$ in the ascus, colvurless or clarkbrown, simple or muriform. Spermogones with septate sterismata and pleurogenous short spermatia (in British genera).

The Order is now classed with Cladoniacex and Lecideaceso on account of the lecideine fruit.

There are two British genera :-

Apothecia usually with gyrose disc; spores mostly simple, colourless.................................. Gyrophora. Apothecia with plane dise; spores large, murifom, brown ......

\section{Umbilicaria}

GYROPHORA A.h. Meth. Lich. p. 100)(1,0:3). Umblilingin ILofm. ex Schreh. (ien. Pl. ed. \&, ii. p. T(is (1791) pro parte: Leight, in Ann. Mag. Nat. Ilist. ser. 2-, sviii. 1. 2-13 (1s,56); Cromb. Lich. Brit. p. 40. (Pl. 62.)

Thallus monophyllous or polyphyllous, with plectenchymatous cortex above and below, attaclied by a central or suleentra! hold-fast and naked helow or rhizinose. Apothecial disc plane, or furrowes more or less concentrically with alternate fortile and sterile tissue: hypothecium dirk-coloureel: paraphyses sub. discrete: asci ellipsoid-cylindrical or hroatly ellipsoid, 8-spored: spores onc-celled (marely septate), rather small, ellipsoid, colnurless or becoming brownish.

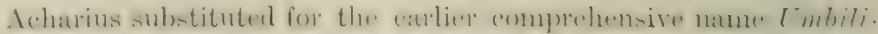

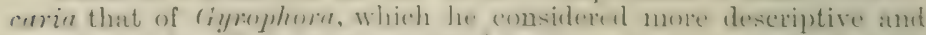

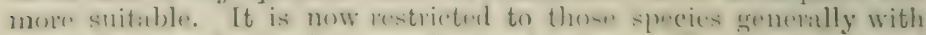

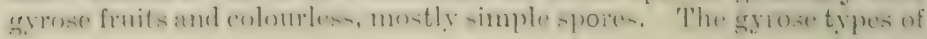


iructification were termed "tric " by Acharius (Meth. Lich. 1) xrii.l, and after him by some British lichenologists.

The species are classified in two sections:-

Apothecial dises plane.

i. AgYrophora.

Apothecial discs gyrose

ii. Eugyrophora.

§. Agrrophord A. Zahlbr. in Engler \& Prantl Pflanzenf. i. 1., p. 148 (1905). Umbilicaria subg. Agyrophora Nyl. in Flora 1xi.p. 247 (1878); Cromb. Monogr. i. p. 323.

Apothecial discs plane; spores simple, colourless.

1. G. leiocarpa Steudel, Nomencl. Bot. p. 194 (1824)._-Thallus moderate in size or rather large, monophyllous or deeply lobatepolyphyllous, rigid, the surface finely cracked- or wrinkledareolate, brownish-black, or reddish-grey and sometimes pruinose towards the centre both above and below, generally smoother or more finely areolate below $(\mathrm{K}-, \mathrm{CaCl}-)$. Apothecia rather small, prominent, stalked, plane, the margins thin, more or less irregular or crenulate; paraphyses colserent, the hymenium brown: spores oblong or elongate-oblong, 12-17 $\mu$ long, 4-6 $\mu$ thick.-G. "Gtro-pminosu Scher. in Meisner's Naturwiss. Anz. i. I. S (1817). Umbiticaria leiocarpa DC. F1. Fr. ii. p. 110 (1805). U. atro-pminosu Scher. ex Ser. NIus. Helr. Hist. Nat. p. 109, yl. 12 (18:1) pro parte; Cromb. in Jouru. Bot. p. $273(1882) d$ Monogr. i. p. 323.

Often confused with Lichen anthracimus Wulf., a plant referred by Acharius (Syn. Lich. 1). 63) to Gyrophora glabra. The spore descriptions are taken from Th. Fries (Lich, Scand. p. 166), as spores are wanting in all the specimens eximined, though apothecia are at undiant; these differ from those of other Gyroptiore in the plane disc.

Hal. On granitic boulders in exposed alpine situations.-Distr. hiare in the Grampians, S'cotland.-D. M. Summit of Cairntoul, Braemar, Aberdeenshire. plicate.

\$ii. Furnornond A. Zahlbr, 1. e. Apothecial dises gyrose-

The peculiar lines denoting alternate sterile and fertile tissue in the apothecium are due, according to Lindau (Schwendener, Lot. Cntersuch. 1899, p). 19-36), to the interrupted centrifusal development of the ascigerous tissue : a central area of paraphyes ilone is tirst formed, then surrounded by a fertile ascus zone, and the alternation of sterile and fertile areas is repeated as growth proceeds in irregularly concentric lines.

Thallus with fow or no rhizina or fibrils.

2. G. grisea 'I'urn. \& Borl. Lich. Brit. p. 236 (1839).'Thallus monophyllous: rather small (almut is cm. across), thin, 
minutely papillate or areolate, light grey or brownish-mousegrey; beneath darker, naked or scarcely rhizinose in the centre $(\mathrm{K}-\mathrm{CaCl} \mp$ res $)$. Apothecia rare, sessile, becoming convex and immarginate, the disc gyrose-plicate; spores 11-18 \% long, $s-10 \mu$ thick.-Mudd Man. p. 120 ; Cromb. in Journ. Linn. Sne. Bot. xrii. p. 57:) (1880) \& Monogr. i. p. 324 pro parte. G. murina Ach. Meth. Lich. p. 110 (1803) ; Engl. Bot. t. 2486 ; S. F. Gray Nat. Arr. i. p. 478 ; Hook. in Sm. Eng. Fl. v. p. 218. Lirhenoides saxatile fuliis minus divisis, cinereo-fuscis Dill. in Ray Syn. ed. 3, p. 73, n. 66 (1724). Lichenoides coriacenm cinereum, peltis atris compressis Dill. Hist. Musc. p. 219, t. 30, fig. 117 (1741) (excl. syn. Hb. Buddle). Lichen !risen!s Swartz ex Westr. in K. Vet. Aead. Handl. xiv. p. 52 (1793). L. Dillenii With. Arr. ed. 3, iv. p. 63 (1796) (excl. habitat St. Vincent's Rocks). L. murinus Ach. Lich. Suec. Prodr. p. 143 (1798). Umbilicaria frisea Hoffm. Deutschl. Fl. ii. p. 111 (1795); Leight. Lich. Fl. 1). 159 ; ed. 3, p. 147 . U. variu var. grisen Leight. in Ann. it IIag. Nat. Hist. ser. 2, xviii. p. 288 (1856).

A very rare plant in the British Islands; many of the citations are based on the mistaken identity by Dillenius of a plant from st. Tincent's Rocks, Bristol. According to Crombie (ll.c.), however. Dillenius certainly was dealing with this species, as the two specimens in his herbarium are typical, though both of them, of continental origin, were received from Celsius. The British specimen from st. Vincent's Rocks (Lichen petracus cincreus Anglicus Buddle Hort. Sicc. ii. fol. $36 \mathrm{in} \mathrm{Hb}$. Sloane) has proved on examination to be Der. imatocarpon miniutum. C'rombie and other's had evidently acceptent Dillenius' determination of the specimen without verification. Lichen deustus Huds. F1. Angl. p. 455 (1762) (non Liun.), though quoted by Crombie as a stmonym of the abore, is also a misidentification.

Hab. On roclss in maritime districts.-Distr. Rare in the Channel Islands and ? N. Wales.-B. M. Beanfort, Jersey; also a specimen marlacil Glyder Vawr (?) N. Wales, and a second small scrap, evidently collected by Hugh Davies (N. Wales).

A. G. proboscidea Ach. Meth. Lich. p. 105 (1 1 033).-Thallus small or moderate in size (generally ahout 5 $\mathrm{cm}$. in wilth), monophyllous, rather thin, lobed and crenate at the margins, the upper surface tubereulate or irregularly wrinklecl-reticulate, blarkish-brown, generally greyish-pruinose in the centre; beneath smosth, pale- or dark-greyish-brown ( $\mathrm{K}-\mathrm{CaCl} \pm$ realdish $)$. Aputhecia becoming immarginate and gyrose-plicate; spores oblong-ellipsoirl, 12-18 $\mu$ lmig, 6-8 $\mu$ thick.-Engl. Bot. t. 2184: $\therefore$ F. Cimy Nat. Arr. i. p. 476; Hook. Fl. Seot. ii. p. 41 if in Sm. Lingl. Fi. v. p. ㄹ17: Mudd Alan. p. 118; Cromh. Monugr. i. p. 325. Lichen prolumscillens L. Ny. Pl. 1. 1150 (1753); Ach. Lich. Suec. Prodr. p. 147 (1798). L. Arusfus Lightf. Fl. Sent. ii. p. sijl (17Ti) (excl, syn.) (nom Linn.) : With. Arr. erl. 3, iv. p. 63. Umbilireriu prolusciden DC. Fl. Fr. ii. p. $410(180.5)$ pro parte: 
C'romb. Lich. Brit. p. 40 ; Leight. Lich. Fl. p. 160 ; erl. 3, p. 147. U. curin var. reustu Leight. in Ann. Mag. Nat. Hist. ser. 2, xviii. p. 289 (1856).

Exsice. Croall n. 100.

Differs from other species of the genus in the wrinkled corrugate unner surfice, more marked towards the centre of the thallus, other parts of the thallus being frequently almost smooth; the lower surface is smooth and generally lighter in colour. The apothecia are usually abundant.

Tro of the specimens in the Linnean herbarium labelled Lichen p.rinscideus belong to $G$. cylindrica, a third is typical $G$. protsoscidea (tirle Wainio in Medd. Faun. \& Fl. Fenn. xir. p. 7 (1888)). Linnæus' descriptiou refers to the latter.

Ifat). On rocks and stone walls in uplaud and subalpine regions.I)ist,. The mountainous regions of $\mathrm{N}$. Wales, $\mathrm{X}$. Englund, S.W. and the Grampians, Scotland, reported also from E. and S.IV. Ireland.D. 1. Cader Idris, Merioneth; Snowdon, Carnarvonshire; Cardiganshive; Teestale, Durham; New Galloway, Kirkcudbrirthtshire; Ben Lawers and Ben More, Perthshire; Clova, Forfarshire; Craig ( oimoch, Lochnagar, near Invereauld, Ben-naboord, Glen Callater, Jen Machui and Glen Cluny, Bruemar, Aberdeenshire; Ben Nevis, Invernessshire.

Form corrugata Mudd MIan. p. 118 (1861) (incl. f. mesenterifurmis (non Wrulf.)).-Upper surface of thallus with deeply marked reticulate ridges or corrugations, otherwise as in the siecies-Var. exasperata Ach. Meth. Lich. p. 105 (1803): t. exesperata Cromb. Monogr. i. p. 326. G. densta var. comugatu and var. mesenteriformis (non Wulf.) Turn. \& Borr. Lich. Brit. 1'. 22 (1839). Lichen excesperatus Gumn. Fl. Norw. ii. p. 131 (176fi) fide Th. Fr. (excl. Syn. Dill.). Umbilicaria corrtgata Hothin. Pl. Lich. p. 65, t. 43, figs. $t-7$ (1794). U. varia var. deustu ff. corruguta, mesenteriformis Leight. in Ann. Mag. Nat. Hist. ser. 2, xviii. pp. 290, 291 (18.56). U. probroscinlea var. cousperata Cromb. Lich. Brit. 1) 40 (1870); ff. corrugate and menenterifomis Leight. Lich. Fl. pp. 160, 161 (1871); ed. 3, p. 148.

Connected with the species by intermediate stages; it represents an extreme northern or alpine form.

II, I. On rocks and houlders in alpine places. - B. MI. IBen-nuboord. Braemar, Aberdeenshire.

Form fimbriata Mudd Man. p. 118 (1861).-Thallus sparingly filrillose or rhizinose at the margin and occasionally on either surface; otherwise as in the species. - Cromb. Mronogr. i. 1r. 326 ; var. deplieans Cromb, in Journ. Bot. xx. p. 273 (18.2) (t Monogr. i. p. 326. G. deusta var. fimleriata Turn, \& Borr. Lich. Brit.

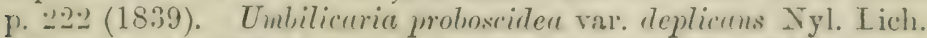
Scancl. 11. 116 (1861) ; f. fimlriata Leight. Lich. Fl. p. 160; ed. 3, p. 147. 
As in the plecies, the rugosities vary from well-nurked reticulations to an areolate-pustular surface (var. Arplicans). The marginal and superficial filres oceur iregnlarly, and may be very scanty or fairly abundant.

Hab. On rocks and stone walls in upland or alpine regions.7) istr. Similar to species.-J3. M. Swinhope Fell, Durham; Ben Lawers and Ben More, Perthshire; Clova, Forfarshire; Cairngrom, (ilen Callater, Then-naboord and Morrone, Braemar, Aberdeenshire; Ben Nevis, Invernessshire.

4. G. arctica Ach. Meth. Lich. 1. 106, t. 2, fig. 6 (1803).Thallus monophyllous, reaching fairly large dimensions in arctic regions, rather thick and coriaceous, slightly lobed, irenate and reflexed at the margin, the upper surface with crowded granulate wrinkles, sometimes rising to ridges, pale-grey to brownish or hackish-lyown, the centre lighter coloured and somewhat pruinose when dry; beneath almost smooth or finely wranulate papillose, paler in colour, l, lackish towards the centre ( $\mathrm{K}-, \mathrm{CaCl} \pm$ reelish $)$. Apothecia numerous, becoming convex; spores $12-16 \mu$ long, 6-8 $\mu$ thick (or frequently smaller).-Turn. is Borr. Lich. Brit. 1). 225 (locality doubtful); Engl. Bot. t. 2485 ; S. F. Gray Nat. Arr. i. p. 477 ; Cromb. Monogr. i. p. 3:31. G. prolioscidea var. arctice Wahlenh. Fl. Lapp. p. 48:3 (181:2); Hook. Fl. Scot. ii. p. 42 it in S'm. Engl. Fl. v. p. 217. Or. limpertoren var. artica Mudd Man. p. 117 . Lichenoides atrum, rovii Persici instur rxasperutum Dill. Hist. Musc. p. 2-200, t. :30, fig. 119 (1741). Imblilicaria enria var. aretion Leight. in Am. Mag. Nat. Hist. ser. 22, xviii. p. 28:3 (1856). U. arrtica Cromb. Lich. Brit. p. 40 (1870); Leight. Lich. Fl. p. 157 ; ed. 3, p. 145 pro parte.

A northern or alpine lichen near to G. hypperborea, rare in our country. A specimen quoted by Turnor and Borrer as collected in Durham seems of doubtful determination. T'he slightly pruinose character of the thallus may have sugrested to Jillenius its likeness to the skin of a peach.

IIul. On rocks in alpine situations, - B. II. Ben-utboord, Bracmur, Aberdeenshire.

5. G. hyperborea Ach. Meth. Lich. J. 104 (180:3).-Thallus monophyllous, moxlerate in size (generally about i) com. across), thin and toush, the surface pustulate-wrinkled and very unequal, more or less lacerate at the mareins, deep chestnut to blackishbrown; berseath smonth or finely aranulate-papillose, sublicunose, brownish-black (K -, (aCl + reddish). Apotheria sessile, appressed. irresular in form, elongate or triangular, heeming rounded and convex; spores clongate-ellipsoid, 12-16 p. longr,

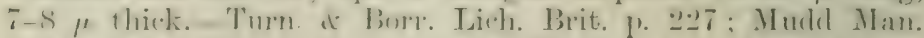
p. 117 (excl. var. arctica); Cromb. Monogr. i. p. 330. Lichen

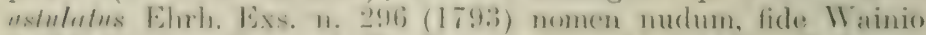

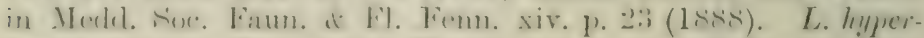
borens Ach. in Vet. Acad. Handl. xv. p. 89, t. 2, fig. 2 (1794). 
L. pullus Wulf. ex Jacq. Misc. ii. p. \&3, t. 9, figs. 3 (1781) (nom Schreb.); Dicks. Pl. Crypt. fase. ii. p. 23. L. Jucquini With. Arr. ed. 3, iv. p. 62 (1796)? (? Gmel.). Umbilinaria hyperboren Hoffm. Fl. Deutschl. ii. p. 110 (1795); Cromb. Lich. Brit. p. 41 : Leight. Lich. Fl. p. 157; ed 3, p. 145. U. varia var. Typperborea Leight. in Ann. Mag. Nat. Hist. ser. 2, xviii. p. 282 (1856).

Distinguished from G.probosciten by the small crowted contorter? pustules of the upper surface, which do not form into reticulate ridges as in that species. Gmelin (Limn. Syst. Veg. ii. p. 1374 (1796)) describes his species Lichen Jacquini as smooth on both surfaces.

Hab. On rocks and boulders in alpine situation:-Distr. Apparentlyconfined to the higher Scottish Grimpians.-B. MI. Clova, Forfarshire; Jien More, Perthshire; Lochnagar, Morrone and Jen-naboord, Braemar. Aberdeenshire; Ben Nevis, Invernessshire.

6. G. flocculosa Turn. \& Borr. Lich. Brit. p. 217 (1839).-Thallus small or moderate in size, thin, the upper surface smooth (1) partly flocculosely felted, in other parts beset with minute isidia-like elevations or with squamules, the margins often lacerate and reflexed, dull olive- or blackish-brown; beneath smooth, subconcolorous, lacunose-pitted $\left(\mathrm{K}-, \mathrm{CaCl} \mp_{\text {ret }}\right)$. Apothecia rery rare, sessile; spores oblong or oblong-ellipsoid, sometimes slightly "urved, 18-27 $\mu$ long, $7-9 \mu$ thick.-Cromb. in Grevillea $x \%$. p. 79 (1887) d Monogr. i. p. 3333. (1. deusta Ach. Meth. Lich. 1. 102 (1803) (non Limm.); Engl. Jut. t. 2483; \$. F. Gray Nat. Arr. i. p. 478 ; Hook. Fl. Scot. ii. p. $42 \&$ in Sm. Engl. Fl. v. 1). 218 ; Grev. Fl. Edin. p. 328. G. polyphlylla var. flocenlose Mudd Man. p. 116 (1861). Lichen flocculosus Wrulf. in Jacy. Coll. iii. 1. 99, t. 1, fig. 2(1789). Umililiraria flocculosa Hoffin. Fl. Dentschl. ii. p. 110 (1795); Cromb. Lich. Brit. p. 41 ; Leight. Lich. Fl. 1. 156 ; ed. 3, p. 144 . U. vuriu var. floceulosu Leight. in Ann. Mag. Nat. Hist. ser. 2, xviii. p. 280 (1856).

\section{E.ssice. Leight. n. 219.}

1)istinguished by the dull frequently matted or squamulose surfice and by the lacune of the smooth under surface, with the absence of tibrils or rhizine. The description of the spores is taken from Xylander (Lich. Seand. p. 119); it hat not been possible to verifs the letails. Lirhen deustus L. has been identified by Wainio (Medil. Soc. faun. \& Fl. Fem, xiv. p. 7 (1888) ) as probably synonymous with G. veticulata Th. Fr., which is not British.

Heb. On rocks and walls in upland and mountainous districts.I) istr. Father rare in Great Britain, not yet seen from Ireland._- B. M. ('aer Caradoe, Shropshire; Cater Idris and Cellfawr, near 13armouth, Merioneth; Whitwick Iocks, Jeicestershire; Finglestone, Jurlatm: New (iallowaty, Kirkeudbrightshire; Achosragan Ifill, Appin and Jien ('ruachan, Argrll ; Jen Lawers, I'erthshire; Cilen Callater, J3raemar. Aberdeenshire; Ben Nevis, Invernessshire.

7. G. polyphylla IJook. in sin. Engl. FI. v. p. 217 (I83:3).Thallus thin, polyplyellons or generally momplyyllous, but witl: 
crowded deeply divided lobes, which are rounded or sometimes lacerate, irresular in size, generally smonth, olive-reddish- or blackish-brown; beneath smooth, blackish ( $\mathrm{K}_{-}^{-}, \mathrm{CaCl}$. + reddish). Apothecia very rare, sessile, small, with few gyrose lines; spores 13-18 $\mu$ lons, $7-8 \mu$ thick. -Turn. \& Borr. Lich. Brit. p. 214 (incl, var. sulcata); MIuld Man. p. 116 (incl. f. Lacera, excl. var. florrulosu): Cromb. in Journ. Linn. Soc. xrii. p. $576(1880)$ it Monngr. i. p. 3:31. G. glubra var. polyplyylla s. F. Gray Nat. Arr. i. p. 476 (1\&21); Hook. Fl. Sieot. ii. p. 41 . Lirhenoides tenne pullum, foliis utrinque glabris Dill. Hist. MLusc. p. 225, t. 30, fig. $129(17+1)$. Lichen polyphyllus L. Sp. Pl. p. $1150(1753)$; Huds. Fl. Angl. p. 455: Lightf. Fl. Scot. ii. p. 863 ; With. Arr. ed. :3, iv. 1. 6.): Engl. Bot. t. 1282. Umbiticaria polyphylla Schrarl. Spicil. p. 10.2 (1794); Carroll in Journ. Bot. iv. p. 22 (1866); Cromb. Lich. Brit. p. 41 (incl. var. lacera); Leight. Lich. 1.1. p. 15.) : ed. 3, 1. 143 (incl. ff. Tacera, sulcuta). U. varia

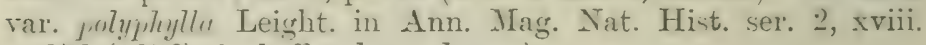
p. 278 (1856) (incl. ff. sulcata, lacera).

Eevier. Cruall n. 392; Johns. n. 364; Larb. Lich. Hl, n. 331 ; Leight. n. 313; Mudd n. 87.

Distinguished by the smooth somewhat shining surfice of the thallus, which, from being monophyllous, divides and branches into numerons orerlapping irregular lobes with a polyphyllons appearance, or sereral centres mar be present in one plant; all gradations are present, the extreme forms being lescribed below; the outer lobes may be torn (f. laccrata) and the outer epidermis is sometimes cracked, exposing the inner darker layer (f. sulcata). The colour reaction with calcium chloride is rather uncertain.

Apothecia are so rare, both in lome and foreign specimens, that it has not been possible to rerify details of spores, etc.

IIat. On rocks, boulders and walls in upland and mountainous districts.-Distr. Fairly general in the hilly parts of Great Britain, apparently rure in Ireland.-B. M. Nen St. Clear, Cornwall; Dart. noor. Itevon; Cader Idris and Cellfawr near Bamonth, Merioneth; Carnedel Idewelyn and Cwm Trefityn, Snowdon, Carnarvonshire; Charnwool Forest, Leicestershire; Ingleby and Battersby Moors. ('leveland, Yorkshire; between Hyshope and Wasterly, 1)urham; Fentmere, Westmoreland; nent Wullington. Northumberland; New Galloway, Kirkendlorightshire; Jen Lomond, Stirlingshire; Ben Lawers, near 'I'mumel bridge and ('raig-y-l'arns, Dunkeld. I'erthshire;

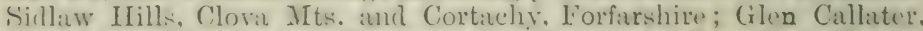
IIorrone and Lochmagar, Jmannar, Aberdeenshire; Ben Nevis, Inver. nessshire; Luggelaw, Wicklow (almost f. congregata).

Form glabra Cromls. Mlonogr. i. p. 39:2 (1894). - Thallus rather large, monophyllow, lobate or laciniate at the margin.F. glalion Ach. Meth. Lich. p. 101 (1त03) : S. F. (iray Nat. Arr. i. 1. Aiti: Hook. Fl. Sent. ii. 1. 41. Liche'n glelere Ach. in Vet. Acaul. J Iandl, xv. p. 31 (1794) \& Lich. Suece. T'role. p. 144 (1798). I. outhracinns Wulf. ex Jarp. Mise, ii. p, 84, t. 9, fig. $4(1781)$ (firle Ach.) : l)icks. Pl. Crypt. iii. p. 1!) (17!93); With. Arr. 
ed. 3, iv. p. 63. Umbilicaria vuria var. polyphlyglla f. monopleylle Leight. in Ann. Mas. Nat. Hist. ser. -2, xviii. p. 278 (1856)? U. polyphlılla f. monophlılla Leight. Lich. Fl. p. 155 (1871)? ed. 3, 1. 143 ; f. glabra Stizenb. St. Gall. Nat. Ges. 1876, p. 212.

Differ's from the species in the persistently monophyllous thallus. which is also somewhat stouter and firmel. Lichen anthracinus wa: included by Acharius (Syn. Lich. p. 63) under his Gyrophora glabru, with which the description agrees, and Dickson's plant seems also to be referable here.

$H a b$. On rocks and boulders in mpland or mountainous districts. -Distr. Collected only rarely in N. Scotlind and E. Ireland.-Zi. M. Ben Lawers, Perthshire; Lough Bray, near Dublin.

Form congregata Turn. \& Borr. Lich. Brit. p. -214 (18:39).Thallus of small crowded lobes, clustered and curled, with the wargins erect or reflexed, entire or crenate-lacerate.-Cromb. Monogr. i. p. 3332. Uimbilicaria varin var. polyphlylla f. congreyata Leisht. in Ann. Mag. Nat. Hist. ser. 2, xviii. p. 279 (1856). T. polyphylla f. conyreyata Leight. Lich. Fl. p. 156 (1871); ed. :3. p. 144 .

\section{Easicc. Leight. n. 65.}

Distinguished by the small ascending closely packed lobes, which 3nity have separate hold-fasts or may be parts of a single thiallus. It is connected with the species by intermediate stages."

$H a b$. On rocks in upland districts.-Distr. Rare in W. and N. England and E. Scotland.-B. M. Areoll Hill, Cier Carruloc and The Wrekin, Shropshire; Howden Gill, Cleveland, Yorkshire; Fincardineshire.

\section{Thallus with fibrils or rhizinæ.}

8. G. cylindrica Ach. Meth. Lich. p. 107 (1803).-Thallu.s inuderate in size (generally about $\check{\mathrm{cm}}$. across), subcoriaceous, mustly polyphyllous, sinuate-lobate, crenate or lacerate, greyishur black-fibrillose at the margins, the surface generally smooth, rull, greyish-brown above and sometimes pruinose; beneath often lishter and sometimes mottled with black, sparingly fibrillose and with one or more hold-fasts $(\mathrm{K}-, \mathrm{CaCl}-)$. Apothecia sassile becoming pedicellate, up to $2 \mathrm{~mm}$. across, thinly margined; spores rather small, 10-14 $\mu$ long, 6-S $\mu$ thick.-S. F. Gray Vat. Arr. i. 1, 477 ; Hook. Fl. Scot. ii. p. 42 it in Sm. Engl. Fl. v. p. 218 ; Tayl in Mackay Fl. Hib. ii. 1. 15.); Mudd Man. p. 119 ; Cromb. Monogr. i. p. 327 . G. proboscidea Turn. \& Limr. Lich. Brit. p. 219 (18:39) (non Linn.). Lichenuides conneum merginilus regenter fimbriatis Dill. Hist. Musc. p. 218, t. 29, fig. 116.1 (17+1). Lirhen cyliutrians L. Sp. Pl. 1) 114t (1753) (rexcl. Syn. 1)ill.); Ach. Lich. Suec. Prodr. p. Its (179s). $L$. rinitus Lightf. Fl. soot. ii. p. 860 (177T). L. mobriscidens Hucls. Fl. Angl. edl. 2, p. 5is (1778) (non Limn.); With. Arr. ed. :3, iv. 1. 65; ; Engl. Bot. t. 52.2 (two upper figs.). T'mbilicurin 
"uria var. puluscinlen Leight. in Ann. Mag. Nat. Hist. ser. -, xviii. 1). 291 (1856). U. rylindrice Cromb. Lich. Brit. p. 40 (1870); Leight. Lich. Fl. p. 161 ; ed. 3, p. 148.

E.isice. Cruall n. 196 ; Johns. n. 231 ; Leight. n. 95 ; Muda n. 88 .

Well marker by the densely fimbriate margins of the lobes. The fibrils are irregularly branched and vary in length and colour. The lobes arise by branching outgrowths from the main frond or frond and become crowded and overlapping. Apothecia and spermogones are numerous.

Hab. On rocks and boulders from upland to alpine regions.I) ist $r$. Rather rare in the hilly or mountainous regious of WT. England. Wales and Ireland, more abundant in Scotland.-B. M. Dartmoor, Ievon; Rhewgreidden, Dolgelly, Cwm Bychan and Aran Mowddwy. Merioneth; Cwm Trefarm and Glyder Vawr, Carnarvonshire; Cronkley Scarr, Yorkshire; Teesdale, Durham; Enmerdale, Cumberland; Ben Lawers and near Aberfeldy, Perthshire; Clova, Forfarshire; Bennaboord, Morrone and near Inrercauld, Braemar, Aberdeenshire: Ben Neris, Invermessshire; Mangerton and Brandon MIs., Kerry; C'onvalla, Cork; Doughruagh Comemara, Galmay; Sliere More MIts., Achill, Mayo.

Form denudata Mudd Man. p. 119 (1861).-Thallus lobe: almost clestitute of fibrils.-Cromb. Monogr. i. p. 328. G. prohosciden var. denudata Turn. \& Borr. Lich. Brit. p. 219 (1839). Umbiliraria varia var. probascidea f. denudata Leight. in Ann. Mag. Nat. Hist. ser. 2, xviii. p. 293 (1856). U. cylindrie var. demudata Cromb. Lich. Brit. p. 40 (1870): f. denudata Leight. Lich. Fl. p. 162 (1871); ed. 3, p. 149.

Though generally the lobes are almost naked, a few fibrils somewhat similar to those of the species are always present. The thallu. is probably affected by some growth conditions.

Hab. On rocks and boulders in subalpine regions.-Distr. liare in the mountainous districts of the British Isles.- $B . M$. Cader Idris. Merioneth; Pen Lawers, Perthshire; Ben-naboord, Braemar, Aberdeenshire; Brandon MIt., Kerry.

Form exasperata Mudd Man. p. 119 (1861).-Thallus polyphyllous, the lobes crowded, complicate, often small, ascending and crisp, somewhat rugose-uneven on the upper surface, smooth below, the fibrils spraringly produced on the margins or lower surfice.--Var. toructe Th. Fr. Lich. Scand. p. 157 (1871): Cromb. Monogr. i. 1\%. :329. G. tornatu Ach. Lich. Univ. p. 222.2. t. 2, figr. 1:3 (1810). G. probuscidea var. exasprentu Turn. \& liorr. Lich. Brit. p. 219 (153!). Umbilicaria var. meloseidea f. recsprotr Leight. in Ann. Mag. Nat. Hist. ser. 2, xviii. p. 2!) (186(i). U. rylimbriat t. rxasprata Leight. Lich. El. p. 16: (1871); ed. 3, p. 149.

Ficsice. Johns. n. 94.

Not milike the previons form lut difiering from it in the renerally smaller lobes and in the more or less uneven surface. 


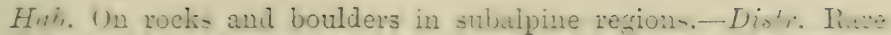
in D. Eugland and among the Glampians. Scotland.-D. M. Teesdile. Durham; Cairn Turc, Braemar, Aberdeenshire.

Tar. fimbriata Ach. Lich. Unir. 1) 2-2t (1510), - Lubes wi the thallus grenerally small, rounderl and finely and clensely Black-ciliate, vecasionally a $f \in w$ filorils rise on the under surface. —. F. Gray Nat. Arr. i. p. 47T: f. Riuluinta Cromb. Monogr. i.

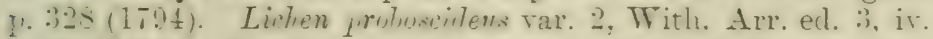

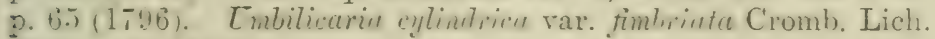
Brit. p. 40 (1S70).

The loves are more densely ciliute than in the species, and tide Alia are generally black, shorter and more slemitr. they sometinurise in little tufts on the surface of the thallus. Some of the specimens approach very near to the species.

Hul, ()n rocks and boulders in uplual and sabuinine rugious. Iiser. Coextensive with. though less common than. the shecien- -

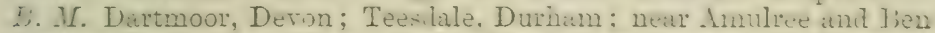
Inwer: Perthshire: Clora. Forfar-hire: dhove Inwreank. Morron. and Loch Phadrig, Braemar, Aberdeenshire.

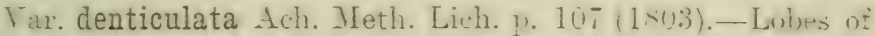
ih. thallus somewhat lacerate. coarstis fimbriate or denticulatr. thr fibrils lone, brual at the base. branched and tajering.-

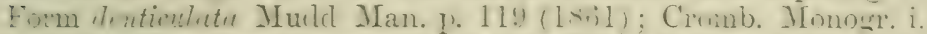

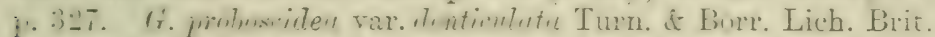
1. 219 (1839). Lichenoides trc. Dill. 1. c. fig. 116 B. Lichen

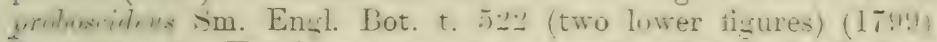

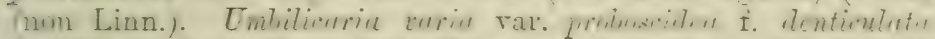

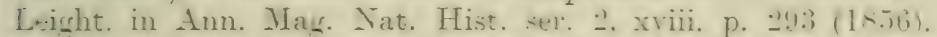

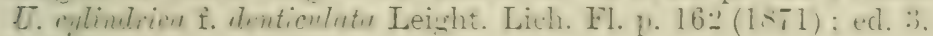
p. 149 .

Crombite call attention to the resmblance of the nur rinal ribril-

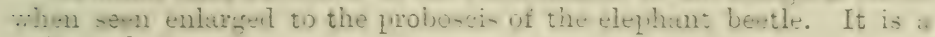
well-marked variety.

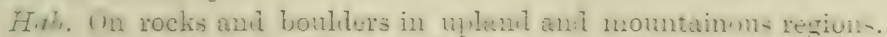
-Distr. Rather rare in $\mathrm{WT}$. and $\mathrm{N}$. England. Wales, the Scottish

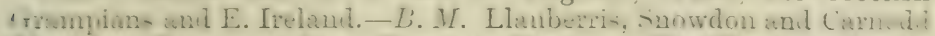
T.1ewelyn, Carnuronshire: Teeslale. Inubum: The Chevints. Nurth.

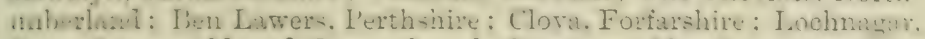

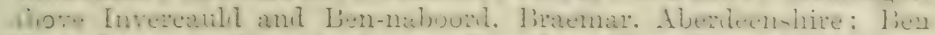

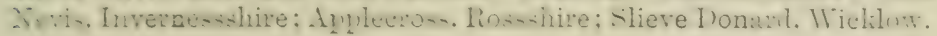

Var. Delisei Th. Fr. Lich. Saml. p. lis (1-T1).-Thallu-tuuter anil firmer, fibrils similar to thrse of the species, len abumlant wh the margins but senerally numerous on the under. surface. Aputhedia perlicellate, rather larse, crowdel. Cromb.

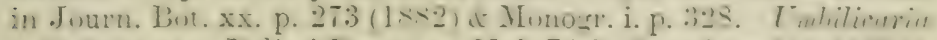

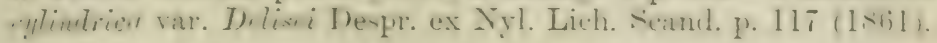

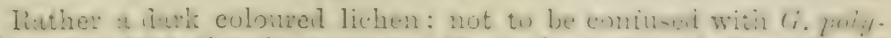

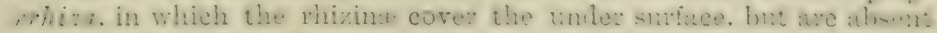
from the margins. The apothecia are beatifully gyrose. 
Hab. On rocks and boulders in alpine regions. $-B . M$. MIt. near Strathre. Perthshire; Ben-naboord, Braemar, Aberdecnshire; Ben Nevis, Invernessshire.

9. G. erosa Ach. Meth. Lich. p. 103 (1803).—Thallus moniphyllous, thin, rigid when dry, wrinkled areolate, laciniate and erose at the margins, olive-brown or blackish-brown; beneatl fincly sranulate-papillose in parts or smooth, and minutely subfibrilluse-scaly, pale-brown ( $\mathrm{K}-, \mathrm{CaCl}-$ ). Apothecia small, plane, then somewhat convex; spores $8-12 \mu$ long, $4-7 \mu$ thick.Cromb. in Grevillea xv. p. $79(1887)$ if Monogr. i. p. 329. Lirken crosus Teb. Spicil. Fl. Goett. p. 259 (1778)? Ach. Lich. Suec. Prodr. p. 145 (1798).

Exsice. Croall n, 393.

Constantly confused with or included under the following specie:. It is distinguished by the thin flat thallus with the lace-like margin. the small seale-like fibrils of the under surface, and by the absence of thalline reactions. The erosions in this and the following speciearise from the branching growth and subsequent anastomosis of narrow lacinize. The open spaces thus left are gradually bridged uver by converging growth of the meitulla from the inargins; the centre of the thallus is thus almost continuous in the lower parts of the thallus though breals persist in the gonidial and upper cortical layers for some time.

$H a b$. On rocks in alpine regions.-Distr. Rare on the higher Grampians.-B. MI. Loclnagar and Morrone, Braemar, Aberdeenshire.

10. G. torrefacta Cromb. in Grevillea xii. p. 74 (1884).Thallus monophyllous, coriaceous, crumpled, the surface rough: with irregular granulations or wrinkles, generally somewhat laciniate and erose at the margins, olive-brown or brownishblack; heneath pale-brownish, finely granulate-papillose in parts. lesset with perforations or often with filsils or with trabecule between the perforations $(\mathrm{K}-\mathrm{CaCl} \pm$ realikilh $)$. Apothecia as in

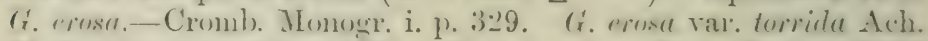
Meth. Lich. p. 104 (180:3). Yi. erose Sm. Engl. Bot. t. 206iti (livy) (non Ach.) : S. F. (iraty Niat. Arr. i. p. 47 : Ilouk. Fl. sest. ii. p. 42 is in sm. Enct. Jl. r. p.21s; Tayl. in Mackay Fl. IJib. ii. p. 15is: 'Turn. it Borr. Lich. Jirit. p. 229 pro parte: Muchl Man. 1. 117. Lichenoides rutusum durum fullum, preltis

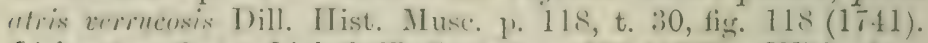

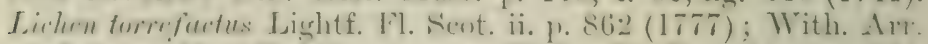

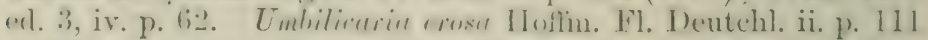
(1795) pro parte; (16mb). Lich. Brit. 1. 41 pro parte (incl. vat. torrida) Leight. Lich. Til. p. 158 ; ed. 3, p. 145 . U. varia var.

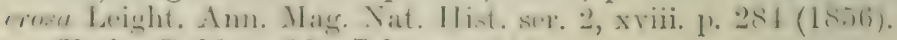

Exsice. Bohl. n. 19 ; Johns. n. 232.

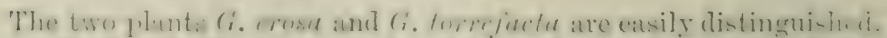

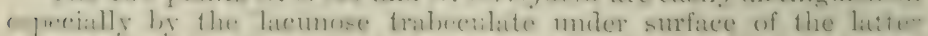

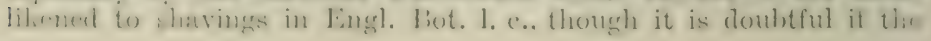


differences may not be due to some growth condition. In $G .10 \%$ facta the gonidial zone un to the darker cells of the cortex becomes a somewhat evaneseent rose-red, on the application of calcium chloride to the thallus sections, and is more marked in some specimens than in others; with potash there is no colour reaction. Occasionally the margins are lacerate $(G$. torritu f. subdividens Arl. ex Cromb. in Journ. Jjot. xx. p. 27: (1852)1.-The lacuna of the lower surface evidently arise by the brealing down of the tissue sud not from anastomising lacinix as at the margin.

Hab. On rocks and boulders in upland to alpine regions.-Distr. General and common in most of the upland or momntimous districts of Great 13ritain and Ireland.-B. II. Causand Beacon and Great Mis Tor, Dartnoor and Wallihampton. Deron; Carter Itris and near Barmouth, AIerioneth; (arnedd Dafydd, ('mm Trefarm. I) ywen and Snowdon. Cumarronshire; Sivinhoje Fell. Durham; The Cheriots and Test Allen Carrs, Northumberland; New Galloway, Kirlicudbrightshire; Goatfell, Arran; Ben Cruachan, Argyll; Ben More and Ben Lawers. Perthshire; Katelaw and Clova, Forfarihire; Lock Mruick, Craig Coinnoch and Ben-naboord. Bratemar. Aberdeenshire; Ben Neris. Invernessshire; Bennabad, Caithness; Killamer MIts. and Mangertou. Tierry; Doughruagh MIts., Comemara, Galway: Curslieve, Croagh Patrick, and Slieve More and Malaranns, Achill. Mayo.

11. G. polyrrhiza Koerb. Parerg. Lich. p. 41 (18.59).-Thallus monophyllous or very deeply and unequally lobed and suh)polyphyllous, moderate in size or small, crenate and undulate at the margins, more or less deeply reddish-brown, smooth and somewhat shining above; beneath very black, minutely papillate and almost everywhere densely rhizinose, the rhizine shortly and divaricately branched at the apex $(K-\mathrm{CaCl} \pm$ ine-rell $)$. Apothecia orbicular or irregular, plane, then convex and finely syrose; spores small, $8-11 \mu$ long, $4-5, \mu$ thick.-Mudd Man. p. 119 ; Cromb. Monogr. i. p. 333. G. prllita Ach. Meth. Lich. p. $108(1803)$; S. F. Gray Nat. Arr. i. p. tis; Hook. Fl. Scot. ii. p. 42 in Sm. Engl. Fl. v. p. 219; Tayl. in Mackay Fl. Hib. ii. p. 155) ; Turu. \& Borr. Lich. Brit. 11. 338. Lichenvides pullum

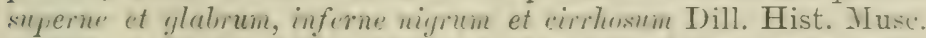
p. 226, t. 30, fis. 130 (1741). Lichen pulyithizas (errore prityrhizos) L. Sp. Pl. p. 1151 (175:3) : ILuds. Fl. Angl. 1. t5.): Lightf. Fl. Scot. ii. p. 864; With. Arr. ed. 3, iv. p. 64. L. cellews Huds. Fl. Angl. p. 454 (1762) (non Limn.). Lichen pellitus Ach. in Vet. Acad. Handl. xr. p. 95 (1794): Lingl. liot. t. 9:31. Umbilientin polyrolizos Fr. Lich. Eur. p. 358 (15.31): Cromb. Lich. Brit. p. 41 ; Leight. Lich. Fl. p. 159: ad, :3, 1. 146. Exsicc. Croall n. 197 ; Johns. n. 233 ; Mudd n. 89.

Distinguished by the cromited pamose matt d rhivina with apieat branching; they curl round at the margin and luwat through the the npper surface where any lieak oecurs in the thallus as small blact.

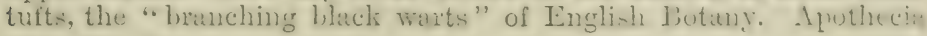
are very rare. 


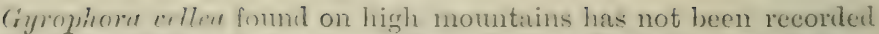
ior Jiritin; Hulsun's specimen frow Settle, Forkshire, unst hate becn wrongly deteminem. Lirhen vollous had been reported is

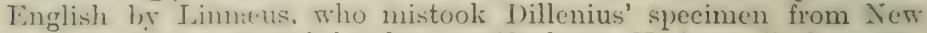
Tersey as from a liritish locility (ser. Tucherm. N. Amer. Lich. p. 88).

Thab. Saxicolous in upland and subalpine legions.-Distr. Rather wre in the mpland districts of England and Treland, more plentiful :mong the (Arampians, Scotland.-D. M. Helminton, Commall; Dartmoor. Devon; ('arlel [dris, C'wm Brolian and near Barmouth. Nerioncth; Arton Moor, Cleveland, Yorkshire; Teeslale, Durham; The Cheviot:. Northumberlund ; Emerclale, Cumberland; New Galloway. Firkeudbrightshire; Dalnahoy Hill near Erlinburgh ; Aberfeldy, I'its-s of Leny, Amulee and Glenshee, Perthishire; Cortachy and C'lora, Forfarshire; Lochnagar, Joch Phardig, Glen Callater, Glen Dee and Craig Coimoch, Bratemar, Aberleenshire; near Rothicmurchus, Jen Nevis and Ben Femog. Invemestshire; Applecross. Rossshire.

Form luxurians 'Th. Fr. Lich. Scand. p. Lof (1\$il). Thallus: much divided, the marmins lobulate, laciniate and crisp. Cromb. Monogr. i. p. 334. G. pellita var. luxurians Ach. Lich. Univ.

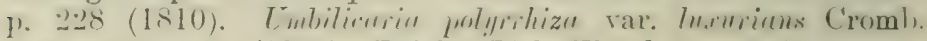
Lich. Brit. p. 41 (1870); Leight. Lich. Fl. ed. 3, p. 147.

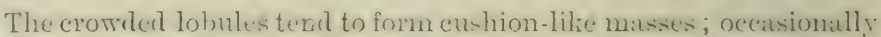
there are only few rhizins. Apothecia have not been seen on this form.

Hab. Saxicolous in upland or mountainous regions. - Distr. liare in S. WV. England and among the Granprians, Scotland-l3. $M$. Walkhampton and Sharpitor. T)eron; neal Killin. Ben Lawers and

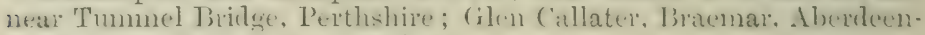
shire; Glen Neris, Invernessshire.

12. G. cirrosa Wain. in Medd. Soc. Faun. \& Fl. Fenn. xir. p. 2.9 (15.8.). Thallus monophyllous, rat her thick and coriaceous, smoth on the uppler surtice, and sumewhat pruinuse, irreunlarly but not dereply lobate, cinereous- on brownish-erey: beneath dark in colour, or erey in lates, granulate and rhizinose, the rhizina. frey or dark-brown, branched or simple, with simple tips $\left(\mathrm{K}-, \mathrm{CaCl} \pm{ }^{\mathrm{red}}\right)$. Apothecia sessile, up to $1.5 \mathrm{~mm}$. in diam.,

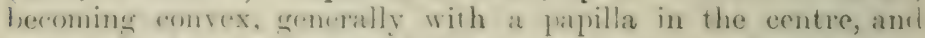
gyrose-plieate or w ith ireegular lines or asperities: spores rather

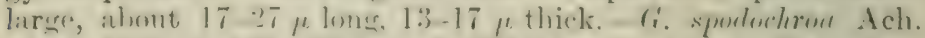
Ileth. Lielt. 1. I0s: Wilson at Whelelon in Journ. IBot. xlvii. pp. 431, $447(1909)$; A. L. Sm. Part 2, p. 332. Umbilicaria cirrosa Hoflin. Pl. Lich. P. 9, t. 2, figs. 3-4 (1790). Lichen syulowhroms Ehrh. exs. 11. 316 (179:i) nomen nurlum: Ach. Tich. Suec. Prodle. p. 149 (1798).

Not unlike $G$. vellea, an alyine or northem lichen, but of rather thimes texture and with batrer siones which are often brownisld. The specirs was foumd by Martirulale at Langdale, am was reportest

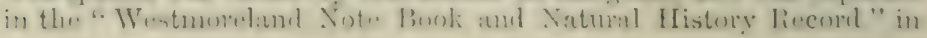


1859 fide Tilson of Theldon 1l. c. It was collected by Wilson $*$ Wheldon at the same locality in 1908.

Hab. Saxicolous in uplank or mountainous regions.- T. M. Lang. dale Pikes, Westmoreland.

UMBILICARIA Hoffin. ex Schrel, Gen. Pl. ed. 8, ii. p. 768 (1791). Subs. Lasallin Cromb. Monogr. i. p. 322 (1894). Lasullia Mérat. Nour. Fl. Paris i. p. 398 (18:36). (Pl. 63.)

Thallus rather lar'ge, coriaceous attached by a single central or subcentral holdfast, with plectenchymatous cortex above and below, without rhizina. Apothecia sessile, discoid, the disc mostly plane; hypothecium dark-coloured; paraphyses discrete ; asci ellipsoid, 1--2-spored ; spores ellipsoid, dark-coloured, muriform, with a thin epipspore.

Hofmamn first used the name Lmbilicaria in binomial combina. tion in his $\mathrm{Pl}$. Lich. i. p. 7, figs. 1-2 (1790). It was defined as a genus by Schreber the following year. The species included by Hoffman under Umbilicaria in Pl. Lich. and in Deutschl. Fl. ii (1795), are nearly all Gyrophore as now understood; but as Acharius at a later date instituted the name Giyrophora for species with mostly furrowed apothecia, the genus Umbilicarin is restricted to those with plane fruits and, more definitely, to those with dark muriform spores. The genera are closely allied, but are now well delimited.

1. U. pustulata Hoffm. Pl. Lich. ii. p. 13, t. 28, figs. 1-2 it t. 29, fig. 4 (1794).-Thallus normally orbicular, monophyllous, rather thin, attaining a large size (up to $18 \mathrm{~cm}$. across, or more), becoming irregularly torn and lobed, crowcled with pustulose swellings with corresponrling depressions (foveolie) on the under surface, pale-greyish or greyish-brown, with here and there compact groups of branching dark-brown isidia, both surfaces often densely pruinose and finely areolate, the lower surface dark-brown ( $\left.\mathrm{K}-, \mathrm{CaCl} \mp_{\text {reddish }}\right)$. Apothecia moderate in size or rather small, blackish, the dise plane or depressed, the proper margin crenulate-rugose; paraphyses discrete, septate, ratherwider and dark at the tips; spores one in the ascus, $28-70 \mu$ long, 18-3. $4 \mu$ thick (or sometimes larger); hymenial gelatine bluish then wine-rerl with iorline.-Hool. in Sm. Engl. Fl. v. p. 219: Leight. in Ann. Mag. Nat. Hist. ser. 2, xviii. p. 294 (1856) it Lich. Fl. p. 154; ed. 3, p. 14:3; Mudd Man. p. 115, t. 20, fic. 3.5.

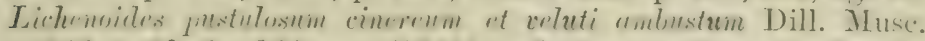

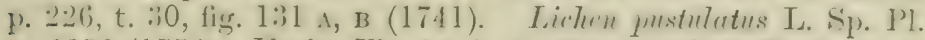
p. $1150(1753)$ : Iluds. Fl. Angl. p. 454: Lightf. Fl. Sicot. ii. p. 858 ; With. Arr. ed. 3, iv. p. 64; Engl. Bot. t. 1283. Gyrophere pustulute Ach. Lich. Univ. p. 206 (1810); S. F. Gray Nist. Arr. i. 1\% 178: Hook. Fl. Soot. ii. p. 42: Tayl. in Mackay

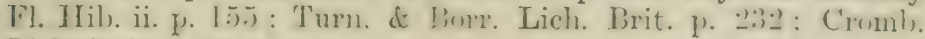
Lich. Brit. p. 40.

Exsicc. Bohl. n. 125 ; Cromb. n. 52 ; Johns. n. 230 ; Larb. Cresar. n. 25 ; Leight. n. 166. 
Easily known by the pustules, the development of which is due to unequal intercalary growth. The thallus is greenish when moist. Apothecia are rather rare in British specimens. It is chiefly a mountainous or northern lichen.

Hab. On rockis and boulders, rarely on old walls, in maritime or upland regions, - Distr. Not uncommon in rocky districts throughout the British Isles.-B. MI. La Moye and New Gorey, Jersey; Guernsey; Helminton. Cornwall; Blackstone Fock, near Borey Tracey, Hay Tor and Hunter Tor, Dartmoor, and near the Teign, Devon; Malvern Hills, Worcestershire; Charnwood Forest, Lcicestershire ; Nesscliffe Hill and Caer Caradoc, Shropshire; Cwm Bychan, Merioneth; Capel Curig and Nant Gwrnant, Camarronshire; Nepha, Westmoreland; Wastalle, Cumberland; New Galloway, Kirkcudbrightshire; Loch Corruisk, Skye; Ten Neris, Invernessshire; Sandy Loch, near Lerwick, Shetland; Mizzen Heal and Glengarift, Cork; near Dunkerron, Kerry.

\section{ORDER XVII. CLADONIACEZ.}

Thallus usually of twofold character: primary thallus crustaceons or squamulose, often evanescent, corticate or noncorticate, attached to the sulostratum by the hypothallus, by rhizinæ or oceasionally by a lorunching rhizoid ; secontary thallus or porletium upright, varying from a short apothecial stalk to a simple or branched usually tubular structure, corticate or noncorticate, tapering to a joint or opening out into a trumpetshaped scyphus. Algal cells Protorerens. Apothecia sessile on the tips of the podetia or on the margin of the scyphus, ravely on the primary thallus, immaloinate: paraphyses crenerally unbranched: spores simple wr variously septate. colourless. Sifermosones closely associated with or replacing the apothecia, with branching sterignata and acrogenous spermatiat.

The upright thallus, though mostly endogenous in origin, and recurter sometimes as an apothecial stalk, has lecome by metamorplosis an ormen of alsorption and asimilation and functions as a vegetative thallus.

The following British genera are included in the family:-

Podetia short, usually simple.

Podetia glabrous.

Thallus granular, spores 2-4-septate.......... Breomyces.

Thallus a gelatinizer crust, spores up to 1(0) - st pitate. Gomphillus.

I’odetia granular.

Thallus granular, spores simple .............. Pilophorus. Podetia usually well developed.

Podetia with a solid stalk, minutely squamulose, spores 4 -pluriseptate............................ Stereocaulon.

Podetia with a hollow stalk, spores simple........ Cladonia. 
B $20 M Y C E S$ Pers. in Ust. Ann. Bot. vii. p. 19 (1794); Nyl. Syn. Lich. i. p. 175 (1860) (excl. B. iematophilus). (Pl. 64.)

Horizontal or primary thallus crustaceous, granular, pulverulent or squamulose. Podetia endogenous in origin, rising from the inner tissue of the thalline granules, very short and with or without gonidia. Apothecia terminal, immarginate, lighteoloured; hypothecium pale; spores usually 8 in the ascus, ellipsoid or fusiform, simple or septate. colourless. Spermogones immersed in small tubercles, with septate sterigmata and acrogenous spermatia.

The podetia are very short, and originate generally, as do those of Cluctonia, within the thallus. Usually they are nakerl, though in some species they have a gonidial layer.

1. B. rufus DC. Fl. Fr. ii. p. 342 (1805).-Thallus effuse, thinnish, furfuraceous, whitish or bluish-green ( $\mathrm{K}+$ yellow). Podetia short, subcompressed, whitish, sometimes with gonidia. Apothecia small or moderate in size, plane or convex, reddish or brownish flesh-coloured ( $\mathrm{K}-$ ); paraphyses often slightly branched; spores 6 to 8 in the ascus, oblong-ellipsoid, siuple, small, $6-12 \mu$ long, $3-4 \mu$ thick ; hymenial gelatine not tingerl with iodine.-S. F. Gray Nat. Arr. i. p. 413 ; Hook. Fl. Scot. ii. 1. 65 d in Sm. Engl. Fl. v. p. 137 ; Cromb. Lich. Brit. p. 16 d Monogr. i. p. 109 ; Leight. Lich. Fl. p. 52 ; ed. 3, p. 50. B. rupestris Pers. in Ust. Ann. Bot. vii. p. 19 (1794); Tayl. in Mackiny Fl. Hib. ii. 78 ; var. lignorm Ach. Meth. Lich. p. 322 (1803). B. lignorum S. F. Gray 1. c. pro parte. B. byssoides - Cher. Enum. Lich. p. 18:3 (1850); MIudd Mian. p. 63. Lichenoides funfiforme terrestre, "rnpitulis fuscis Dill. in Lay syn. ed. :3, 1) $70,11.39$ (1724). Coralloides fungiforme saratile pullide fuscum Dill. Hist. Musc. p. 78, t. 14, fig. 4 (1741). Lichen rufu.: Huds. Fl. Angl. p. 443 (1762); With. Arr. ed. 3; iv. p. 14. L. lygsoides L. Mant. p. 133 (1767); Lightf. Fl. Scot. ii. 1. 809 ; Huls. Tl. Angl. ed. 2, p. 527; Engl. Bot. t. 37:). L. fungifumis Scop. Fl. Carniol. ed. 2, ii. p. 360 (1772); With. Arr. ed. 3, iv. p. 14.

Lxsice. Cromb. n. 12 ; Johns. n. 46 ; Larb. Cxsar. n. 6 \& Lich. Hb. n. 43 ; Leight. n. 178 ; Mudd n. 30.

Usually spreads extensively, and varies in thickness and colour ancumbing to sulstratum and exposure. The apothecia ane generally munerous, scattered or crowded, the stalk occisionally branched, aud when dry wrinkled and furrowed.

Hab. On sandy and gravelly soil, occasionally on rocks and stones, rarely on rotten wood in shady situations.-Distr. General and common, chiefly in hilly and mountainous regions.- B. M. Rozel, Jersey; Sark; Withicl and near Boconnoc, Cornwall; near South Brent and Dartmoor, Devon; I. of Wiuht; New Forest, Hants;

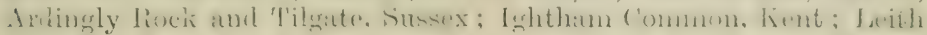
Hill and Hart Woorl, Surrey; Fornsey Wood, Middlesex; Epping 
Forest and Thorndon IIall, Essex; Ampthill, Bedfordshire; Malvern, Worcestershire; Charnmoorl Forest, Leicestershire; Meriden, War. wiclishire; Welshpool, Montgomeryshire; Barmouth and Dolgelly, Merionctlı; Bangor, Carnarvonshire; Ayton, Cleveland, Yorlishire ; Grayrigry Forest and Asby, Westmoreland; Reswick, Cumberland; Hexhans. Northumberland; Egglestone. Durham; New Galloway, Tirkcurlbrightshire; Leadhills, Lanarkshire; Pentland Hills, near Fdinburgh ; Ashburn, Gourock, Renfrewshire; Sidlaw Hills, Forfarshire ; Kilblane, Argyll ; Craig Calliach, Ben Lawers and Blair Athole, Perthshire; Invermoriston, Invernessshire ; Mangerton, Kerry ; Connemara, Galway ; Mallaranny, Achill, Mayo.

Var. subsquamulosus Nyl. in Flora lx. p. 46:) (1877).-Thallus usually orbicular, determinate, minutely squamulose more especially at the circumference. Aputhecia almost sessile, small, solitary or conglomerate, dark-brown.-Cromb. in Grevillea xv. p. 15 (1889) \& Monogr. i. p. 110. D. Tirnorum S. IT. Gray Nat. Arr. i. p. 413 (1821) pro parte. B. mfus vars. sessitis and carneus Nyl. Syn. Lich. p. 177 (1860); Cromb. Lich. Brit. p. 16. Var. corneus Leight. Lich. Fl. p. 53 ; ed. 3, p. 51 (incl. f. sessitis).

Exsicc. Larb. Casar. n. 7 ; Cromb. n. 116.

Not to be confused with $B$. carneus Floerke, a continental species, with a more squamulose thallus, and the reaction $\mathrm{K}+$ yellow then saffron-red.

$H a b$. On sandy and peaty soil, rarely on rotten wood in maritime and upland situations.-Distr. Rather rare in the Channel Islands, in S., S.W. and E. England, and among the Grampians, Scotland.B. M. Noirmont, Jersey; near Bodmin, Cornwall; Epping Forest, Essex; Menstrie Glen, near Stirling; Glen Lochay, Schichallion, Blair Athole and Rannoch, Perthshire; Braemar, Aberdeenshire; Killarney, Kexry.

Var. Prostii Harm. Lich. Fr. iii. p. 217 (1907).-Thallus granulose-warted, the warts often pulverulent. Apothecia large, convex sessile, difform or 2-4-comate and forming a mass reaching :3 mm. in cliameter.-Beomyses Prostii Duf. MS. in Herb. fide Harm. Specimen not seen.

Recorded by Wheldon and Travis in Journ. Linn. Soc. xlviii. p. 119 (19)5). from Iley slackis ('lough, J joulsworth Hill, Iancashire, May 1913.

2. B. roseus Pers. in Ust. Ann. Bot. vii. p. 19 (1794).Thallus gramular erustaceous, efhues on determinate, whitish (K + yellow). P'odedia rather short, terete, white. Apotheria

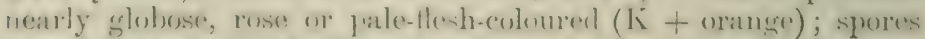
(i) or in the ascus, fusitom-nblong on fusiform, simple or some-

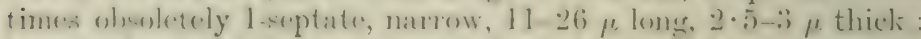

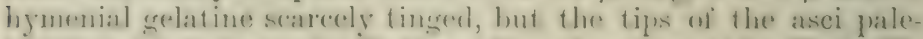

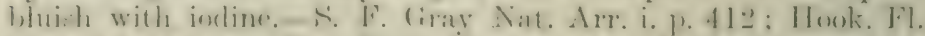

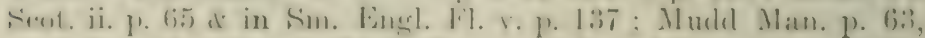
t. i. fig. 12; Cromb. Lich. Brit. p. 16 \& Monogrr. i. p. 111 ; 
Leight. Lich. Fl. 1. 53; ed. 3, 1. 51. Lichenoides funtiforme, crusta lemose comtide, caprintis et perticulis incurnatis Dill. in Ray Syn. ed. 3, p. 70, n. 40 (1724). Coralloides funyiforme carneum, basi lejosa Dill. Hist. IIusc. p. T6, t. 14, fig. 1 (1741). Lichen ericetormm Huds. Fl. Angl. p. 443 (1762) pro parte (non Limn.) ; Lightf. Fl. S'cot. ii. 809 (1777) (excl. var.) ; With. Arr. ed. 3, iv. p. 14. L. Bromyces Sm. Engl. Bot. t. 374 (1797). Variolaria terricola Tayl, in Mackay Fl. Hib. ii. p. 115 (1836).

Exsicc. Carroll Lich. Hib. n. 9; Cromb. n. 117 ; Johns. n. 171 ; Leight. n. 355 ; Mudd n. 31.

Distinguished from $B$. rufus by the longer porletia and by the colour of the apothecia. The thallus spreads extensively, and is often sprinkled with globose white or rosy-white granules. The apothecia are somewhat rare, but the rather large spermogones, which are blackish abore, are frequent; the spermatia are $5 \mu$ long and $1 \mu$ thick. Lichen ericetorum L. Sp. Pl. p. 1141 (1753) is B. (1ruginosus (Icmadophila ericetorum, p. 352).

Hab. On bare gravelly or turfy soil on moorland..-Distr. General in hilly or mountainous regions.- $D . M$. St. Breock Down and Tregawn, Cornwall; Uckfield, Lavington Common, Henfield stone and Tilgate, Sussex; Hurt Wool, Surrey; Toys Hill, near Sevenoaks, Tent; Epping Forest, Essex; Wapley Hill, Hereforlshire; Carder Idris, Crwm Bychan, Barmouth and Aberdover, M[crioneth; Montgomeryshire; Cleveland, Yorlishire; Cold Fell, Cumberland; The Cheriots, Northumberlaud; New Galloway, Kirkeudbrightshire; Leaihills, Lanarlshire; Achosragan IFill, Appin, Argyll ; Sheriffmoor, Stirlingshire; Glen Lochay, Ben More, Craig Tulloch and Ben Lawers, Perthshire; Baldoran Woods and Sidlaw Hills, Forfarshire; Glen Dee, Braemar, Aberdeenshire; Glen Neris, Invernessshire; near Clonmell, Tipperary.

3. B. placophyllus Ach. Meth. Lich. p. 323, t. 7 , fig. 4 (180:3).- Thallus membranaceous, ort)icular, squamulose, or partly crustaceous, the squamules adnate, wrinkled or plicate and subcrenulate, glaucous-green or whitish ( $\mathrm{K}+$ yellow). Podetia short, compressed, colourless, often divided at the apex. Apothecia rare, rather small, redclish or brownish-flesh-coloured (K - ) ; spores oblong-ellipsoid, simple, 10-15 $\mu$ long, $2-4 \mu$ thick : hymenial gelatine not tinged with iodine-Hook. in sim. Engrl. Fl. v. p. 137 ; Mudd Man. p. 63 ; Cromb. Lich. Brit. p. 16 ; Leight. Lich. Fl. p. 53 ; ed. 3 , p. 51.

In general aspect resembling, when sterile. Physerin grix a, though with a much thicker thallus.

$H a b$. On gravelly soil among heaths in moorland districts.Disfr. Locit and scarce in the momntainous regions of Great Britain.

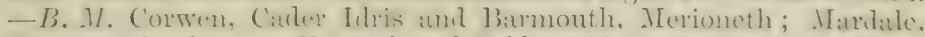
Westmordant; neatr lieswiek and Calder Abbey, cumberland; 'Teesdale, 1)urhan; Jew Gallowar, hirkembrightshire; Siullaw Hills, Forfarshire: Ijen Lawers and Falls of Bruar, I'ethishe: Momone. Braenar, Aberdenshire; Cilen devis, Invernessshire; Aeh-ma-lintim. Rossshire. 
GOMPHILLUS Nyl. in Bot. Not. $185: 3$, p. 165 \& in M[m. Soc. Sci. Nat. Cherb. iii. p. 186 (1855). (Pl. 65.)

Thallus effuse, of thick-walled agglutinate hypha and sparsely scattered gonidia, forming a thin gelatinized continuous crust. Apothecia one or several borne at the tip of a short stalk or pordetium rising from the horizontal thallus, dark-coloured, of a horn-like consistency; paraphyses slender, simple; spores \& in the ascus, filiform, pluriseptate; spermogones with simple short sterigmata, and minute acrogenous spermatia.

A monotypic genus nearly allieil to Bromyces; recorted also from France and Italy.

1. G. calycioides Nyl. in Act. Soc. Linn. Bord. sér. 3, i. p. 39: (1857).-Thallus effuse, thin or obsolete, greyish or greyish-green with a varnisherl appearance. Apothecia with somewhat slender short furrowed stalks, subglobose, dark or blackish; hypothecium colourless; paraphyses slender, conglutinate, the epithecium inspersed with brown colouring substance; asci cylindrical; spores 8 in the ascus, filiform up to 100-septate, $160-200 \mu$ or more long, about $2 \mu$ thick.-Carroll in Journ. Bot. iii. p. 287 (1865) ; Cromb. Lich. Brit. p. 15 it Monogr. i. p. 108 (incl. f. mirrocepllalus) ; Leight. Lich. lil. p. 52 (incl. f. microreplatus Nyl. Syn. i. p. 175 (1860)); ed. 3, p. 50. Bxomyces allycioides Del. ex I)ub. Bot. Gall. p. 636 (1\$30). B. microcephulus Tayl. in Mackay Fl. ILib. ii. I. 78 (18:36).

Exsice. Cromb. n. 115.

The form or variety microceplatus differs only in the specimens bearing slightly smaller apothecia.

Ifat). Inerusting decrying mosses on the ground, trees or boulders. -Distr. liare in N. Wales, WV. Scotland and in S. W. Ireland.-M. $M$. Barmouth, Merioneth; Barcaldine, Argyll ; Dinish, Tore M[t.; Muekross, Cromaglown and Dunkerron, herry; Letter Ifill, Connemari, Galway.

PILOPHORUS Th. Fr. Ster. Pil. Comm. p. 40 (185i). Sterencunlon, sect. Pilophimon Tucksm. Syn. Lich. New Ensl. p. 46 (1848). (Pl. 66.)

Primary thallus crustarerous, granular or minutely squamulose, non-corticate. Cephalorlia rresent. Podetia rloveloped from the njward grow th of the grimules (not endogenon:), ligid, cylindrical, simple or sparingly branched, beset with granules, nom-corticate, tubular or solid with a central strand of eompract parallel hyphate. Apotheria terminal on the porlet ia, single or in groups, subgholuse, immarsinate; hypothecium thick, dark-brown: paraphyses thickish, dith at the apriess ased clatsate, thickened at the

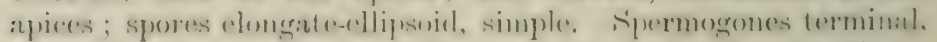

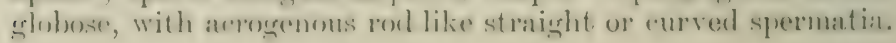


Tesembling Strocaulon in the nou-endogenons development of the portetium and in the presence of ceplaalodia, but differing in the more persistent primary thallus and the darker apothecia.

1. P. cereolus Stiz, in Verh. St. Gall. Nat. Ges, 1875, p. 198. -Thallus effuse, crustaceous, granulir, sometimes cracked into areolix, greyish-white, sprinkled with rather flat finely granular dark-olive cephalodia containing Stiqonema alge ( $\mathrm{K}+$ yellowish). Podetia short, erect, simple, greyish-white. Apothecia subglobose, black: spores ellipsoicl-fusiform, usually $16-20 \mu$ long, 5-8 $\mu$ thick.-Cromb. in Grevillea xv. p. 15 (1886) \& Monogr. i. p. 114. P. filula Th. Fr. Ster. Pil. Comm. 1) 40 (1857) : Leight. in Amn. Nacr. Nat. Hist. ser. 4, iv. p. 201 (1869) and Lich. Fl. p. 76, ed. 3, p. 69 ; Cromb. in Journ. Bot. viii. p. 96 (1870). P. strumatieus Nyl. ex Cromb. in Journ. Bot. xiii. p. 140 (1875) \& Monogr. i. p. 115. Lichen (Isidium) "ercolus Ach. Lich. Suec. Prorls. p. S9 (1798). Sterocaulon cereolus Ach. Neth. p. 316, t. 7, fig. 1 (1803) ; Borr. in Engl. Bot. Suppl. t. 2667 : Hook. in Sm. Engl. Fl. v. p. 233 ; Tayl. in Mackay FI. Hib. ii. p. 83. St. fibulum Tuckerm. Syn. Lich. p. 46 (1848). St. condensutum subsp. cereolinum Cromb. Lich. Brit. p. 17 (1870).

Exsicc. Leight. n. 383 ; Larb. Lich. Hb. n. 5.

Not unlike Sterocaulon pileatum, but easily distinguisher by the darker apothecia and by the more finely granular thallus. The spores of $P$. crreolus attain a larger size than the measurements given by Crombie $(16-22 \mu \times 4-5 \mu)$. Usually they reach about $17-20 \mu$ in length and $7 \mu$ in width; one abnormal spore measured $25 \mu \times 5 \mu$. In $I^{\prime}$. strumaticum the nomal size is the same, though rather thicker spores up to $9 \mu$ thick have been observed. In one specimen of that "species" the podetia are crowded and the apothecia contluent, which may have given the appearance of a strumose, deformed base in section. There is no other trace of it.

Hab. On moist shady rocks in uplated and subalpine situations. -Distr. Local and scarce in the mountainous parts of Great Britain and Ireland. $-B$. M. Llyn Gwernon, Cader Idris and Dolgelly, Merioneth; Glyder and Carnedd Dafydd, Carnarvon; Egglestone, Durham; New Galloway, Kirkeudbrightshire; Achosragan Hill, Appin and Ben Cruachan, Argyll; Criig Calliach, Glen Lyon, Kỉlin and Ben Lawers, Perthshire; Morone, Braemar, Aberdeenshire; Sligachan, Skye and Glen Nevis, Invernessshire; Applecross, Rossshire; Dunkerron, Kerry ; Kylemore, Connemara, Galway.

STEREOCAULON Schreb. Gen. Pl. ed. S, ii. p. 76s (1791): Nyl. Syn. i. p. 230 (1860). Leprocaulon Nyl. ex Lamy in Bull. Soc. But. Fr. xxv. p. 352 (1878); Cromb. MIonogr. i. p. 12.3. (Pl. 67.)

Primary thallus granular, or minutely squamulose, usually soon evanescent. Podetia erect or decumbent develojed from the "lpward growth of the: primary thallus (not endogenums) much branched, solicl in the centre, the exterior leset with minute wart: or valuously formed squamules which are more or less corticate. Cephalodia present usually on the porletia and ron- 
taining Nowter or Stigemenu. Apothecia terminal or lateral, usually dark-hrown, immarginate (rarely with a thalline margin); hypothecium colourless; paraphyses slender, discrete; asci cylindrical, 6-8-spored : spores elongate 4-pluri-septate, culourless. spermogones with filiform or cylindrical straight or hent acrogenous spermatia.

Along with l'itophorus differing from C'tndonia in the origin of the pordetium, but similar in the twofold character of the thallus and for that reason retained in the Cladoniacen.

\section{Primary thallus persistent.}

1. St. condensatum Hoffm. Deutsch. Fl. ii. p. 130 (1795).Primary thallus persistent, of coarse rounded granules sometimes flattened out into crenate squamules, glaucous or greyish-white. Cephalodia dark-greyish, rerrucose, intermixed with the thallus, containing Stigonemu. Podetia short or almost none, at first slightly tomentose then glabrous, the prodetial squamules often confluent, similar to those of the prinary thallus. Apothecia morlerate in size, terminal, plane, becoming convex, dark-reddishhrown; spores $3-7$-septate, fusiform-cylindrical, $20-36 \mu$ long, $1 \cdot 5-2 \cdot 5 \mu$ thick.-Nudd Man. p. 66 ; Cromb. Lich. Brit. p. 17 \& Monogr. i. p. 121 ; Leight. Lich. Fl. p. 79 ; ed. 3, p. 71.

Exsicc. Leight. n. 295; Mudd n. 33.

The primary thallus usually spreads extensively, forming a granular crust; the podetia are often scarcely dereloped, and the apothecia may be developed on the basal granules.

$H a b$. On the ground and on turf-covered walls in maritime and hilly regions.-Distr. General and common in the hilly regions of the British Isles, rare in the Channel Islands.-B. M. Near . Fildenhall, Suffolk; near Buxton, Derbyshire; Battersby and Baysdale Moors, Cleveland, Yorkshire; Teesdale, Durham; Housesteads, Northumberland; Doune, near Stirling; Auchterhouse, Forfarshire; Aberfeldy, P'erthshire; Portlethen, Kincardineshire; Craig Givie, Braenur, Aberdeenshire.

Var. condyloideum Nyl. Lich. S'and. p. 66 (1861).-Podetia rather more developed and branched, especially near the apex-Cromb. Lich. Lirit. 1) 17 it Monogr. i. p. 122 (as form); Leight. Lich. Fl. p. s0; ed. :3, p. 72. S. romdylevidenm Ach. Meth. Lich. p. 51 (1803); Hook, in Sm. Engl. Fl. v. p. 233.

Iful. On turf-covered walls in upland districts.-1)is/r. Loeal and

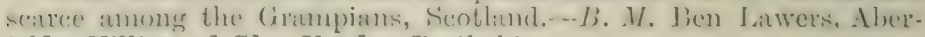
feldy, Kkillin and Glen Fender, Perthshire.

2. St. pileatum Ach. Lich. Inis. p. 5s.2 (1s/0).-P'rimary thatlus persistent, rfuse, formerl of rather rounded granules which tond to beerone squamulose or coralloid. Cophatodia dark-eslourel, in flattoned tubereules, not frequent, containing

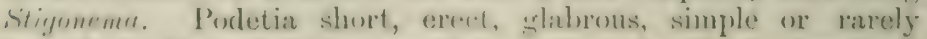
hrambed: the portetial squamules minute. Apothecia terminal, 
cap-shaped (pileate), plane then convex, brown or redclish-lıown ; spores 3-septate, narrowly ellipsoid, obtuse at the ends, $18-30 \mu$. lons, 4-5 $\mu$ thick.-Cromb. in Grevillea xi. p. 15 (1856) it Monogr. i. p. 12.. St. vereulus Borr. in Engl. Bot. Suppl. t. 2667 (1830) descr. pro parte; Touk. in sm. Enct. Fl. v. p. 23:3 pro parte. St. creolinum Kuerb. Nyst. Lich. Germ. p. 14 (1855); NIudd Man. 1). 67. St. comlensatum var. cercolinum Cromb. Lich. Brit. p. 17 pro parte; Leight. Lich. Fl. p. 79 ; ed. 3, p. 72.

Exsice. Larb. Lich. Hb. n. 6

Closely allied to the preceding but differs in the larrer porletia and in the coralline structure of the basal sfuamules. Th. Fries (Lich. Scand. p. 52) describes the cephalodia as oecurring towards the base of the podetia. In British specimens they oceur on the thallus as in the previous species.

$H a b$. On rocks in subalpine districts.-Distr. Rare and local in N. Wales, N. England, S.IV. Scotlind, the IV. Highlands and N.W. Ireland.-B. M. Cader Idris and Dolgelly. Merioncth; Wastdale, Cumberland; New Galloway, Trirkeudbrightshire; Jen Cruachan, Argyll; Glen Ogle and Glen Lochay, Perthshire; Connenura. (ialway.

3. St. nanum Ach. Neth. Lich. p. 315 (1803),-Primary thallus efluse, granular, powdery, the granules small whitish or bluish-green. Polletia crowded, slender, rather short, olsoletely arachnoid, simple or sparingly fastiglately bramed towards the apices $(\mathrm{K}-)$. Apothecia and spermogones unknown - S. IF. Gray Nat. Arr. i. p. 411 ; Mudd Nan. p. 67 ; Cromb. Lich. Brit. p. 17 ; Leight. Lich. Fl. 1).80; erl. 3, p. 73. Lichen nums Ach. Lich. Suec. Prodr. 1. 206 (179s). Lomorcenlen nanmm Nyl. ex Lamy in Bull. soc. Bot. Fr. xxv. p. 35. (1878); Cromb. in Grevillea xv. p. 15 (1836) \& Monogr. i. p. 123.

Exsicc, Larb. Lich. Hb. n. 284.

Frequently placed in a separate genus Leprocrulon on account of the leprarioid structure; it agrees with Strrencaulon in the trofold thallus and in the squamulose podetia. Th. Fries (Monogr. Ster. \& Pil. p. 65 (1858) ) describes ceplralodia as " conglomerate, plane, smooth, black" ; there are none present on the British specimens.

IIab. In crevices of rocks and walls in maritime and mountainous districts-Distr. Local, though plentiful where it oceurs, throughout the British Islands.-B. M. Joulay Bay, Jersey; Guemsey; Lanorna and Helmen Tor, Cornwall ; Loddiswell, Cawsand Bay, near Kingsbridge :und Totnes, Jevon; near Alfrick, Knightswick ind Worcester Beacon, Mahtrern Hills, Wreestershire; (Oswestry and Jlanymynech, Shropshire; Jettw-y-Cord, Carnarvonshire; Teesdale, Jurham; Bahnerino and Westwater. Fife; Gilen Jochay, I'erthishire; J)en of Balthayock and liecky Timn. Forfar-hipe; Falls of Lui, Mratemar, Aberdeenshire; Learmont, Derry.

\section{Primary thallus cvrnescent.}

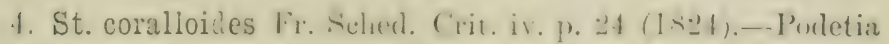
crespitose, erect, branched, the axis glabrous, the podetial 
syuanules coralline, disitately branched or subfibrillose, grey ish ( $\bar{K}^{+}$vellow). Cephaloclia on the podetia, somewhat spherical, oparque, rerrucose and minutely granular on the surface, grevish, containine stigonemu. Apothecia mostly terminal, moderate in size, globere, lurown or dark-recidish; spores :3- (rarely 5-7) septate, fusiform-cylindrical, 22-40 $\mu$ long, 2.5)-5 $\mu$ thick.Cromb. Lich. Jirit. p. 16 it MLonogr. i. p. 117 ; Leight. Lich. F1. 1. 77 ; al. 2, 1. 69. St. puschale Ach. Meth. Lich. p. 315 (180:3); S. F. Gray Nat. Arr. i. p. 411 ; Hook. Fl. Scot. ii. p. 66 \& in Am. Engl. Fl. v. p. 2.3.) ; Tayl. in Mackay Fl. Hib. ii. p. A3; Mudkl Man. p. 65 (incl. var. concllinum, t. 1, fig. 14); Cromb. Lich. Brit. p. 17 jro parte; Leight. Lich. Fl. p. 77 pro parte. Lichen parchalis Hucls. FI. Angl. p. 460 (1762) pro parte (non L.) : Lightf. Fl. S'cot. ii. p. A\&6 pro parte: With. Arr. ed. 3, iv. p. 44 pro parte; Engl. Bot. t. 28\%.

Exsicc. Bohl. n. 14; Croall n. 595 ; Ćromb. n. 119 ; Johns. n. 210 ; Leight. n. 148.

Distinguished by the coralloid pocesses into which the podetinl squamules are dividerl. and by the united bases of the podetia.

$H a 7$. On rocks, boulders and old walls in upland and subalpine districts.-Distr. General and common in the hilly districts of Great Britain, rare in Ireland.-B. M. Near I'enzance, between Arthur's bed and Wring ('heese and near Helminton, Cornwall; Okehampton, Devon; Abdon l3urf and near Oswestry, Shropshire ; Catler Idris and Dolgelly, Merioneth; Pen-y-Gwryd, Camarvonshire; Black Fige, Buxton, Derbyshire; near Stareler, Kendal and Ambleside, Westmoreland; Wastdale, Cumberland; Teestale, Durham; New Galloway, liirlieudbrightshire; Leadhills, Lanatkshire; Inverary and Appin, Argyll; Jen Lawers and Blair Athole, Perthshire; Sidlaw Ilills, Balgay Wood, Glen Isla and Strathmartine, Perthshire; Craig Nich, Glen Callater and Glen Dee, Braemar, Aberdeenshire; near Forres. Elginshire; Jen Nevis and Lochaber, Invernessshire; Hills of Aple Cross, Jiossshire; Killamey, Kerry; Comemara, Galway; Slieve More, Achill, Mayo.

5. St. Delisei Bury ex Bub. Bot. (iall. ii. p. 619 (1830).Podetia small, loosely ca'spitose, branched, the main axis thinly tomentrse or naked; porletial spuamules minute, rrenate or digitatcly divided, grouped near the apices, whitish and loecoming sorerliate: ( $\mathrm{K} \pm$ renluwi $)$. Apothecia unknown.-Cromb. in fourn. Bot. xxiii. p. 195 (1885) \& Monogr. i. p. 117.

linown only from W. France and X. Scotland. The gramules at the tipe of the podetia are whitish and almost entirely sorediate. Cephalodia are very rare, and similar to those of St. coralloides.

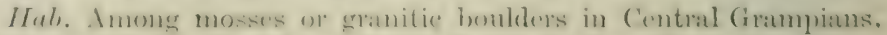
Scotland.-B. M. Near Loch Eagle, Ramnoch Moor, Perthshire.

6. St. evolutum (irawe ex Th. Fr. in liot. Not. (1s6.5) p. 181. P'orletia small or morlcrate in sizs, aispituse, frequently and

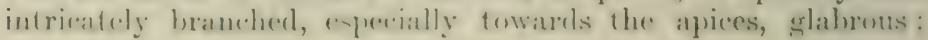


podetial squamules erowderl, swollen and branched, grevist. glaucous or whitish. Cephalodia rather scarce, somewhat spherical, minutely granular on the surface, sreyish, containing Stigonema. Apothecia terminal, at first thinly marginerl and pline, becoming convex and difform and often splitting, pale or dark-brown ; spores oblong-eilipsoid, obtuse, constantly 3-septate, 18- 28 long, $\overline{5}-7 \mu$ thick.-Cromb. in Journ. Bot. xiv. 1). 95.59 (1876) \&: Monogr. i. p. 118 ; Leight. Lich. Fl. ed. 3, p. 72.

Exsicc. Cromb. n. 120.

Intermediate between St, coralloides and St. paschale. The podetia are subdecumbent, the squamules stouter more brancherl and less distinctly palmate than in S. paschale, but not coralloid.

Ifab. On rocks and walls in maritime and hilly regions. - D istr. General and common in TV. and N. England, N. Wales. among the Grampians, Scotland and W. Ireland.-B. M. Hay Tor, Widliconbe, Wistmain's Wood and near Buckland on the moor, Deronshire; Plynlimmon, Cardiganshire; Cader Idris, Llyn Bodlyn, Dolgelly, near Barmouth and Garth, Merioneth; Beddgelert, Cirnarronshire; Teesdale, Durham; near Galloway, Kirkcudbrightshire; Appin, Argyll; Crianlarich, Ben Lawers and near Loch Eagle, Rannoch, T'erthshire; Ben Avon, Aberdeenshire; Loch Limnhe, Invernessshire: near Forres, Elginshire; Applecross, Rossshire; Cahir and Blickwater Bridge, Kerry; Connemara, Galway.

7. St. paschale Fr. Stirp. Femsj. p. 35 (18-25).-Podetia moderately high (about 3 to $9 \mathrm{~cm}$.), crowded or dispersed, erect or spreading, much branched, the axis slightly compressed, tomentose, becoming nearly glabrous; podetial squamules palnate or crenate, greyish white or whitish. Cephalodlia warted, containing Stigonemu. Apothecia terminal or subterminal, plane or convex, brown or dark-brown; spores usually 3- sometimes 5 -9-septate, fusiform-cylindrical, $18-40 \mu$ long, $3 \cdot 5-4 \cdot 5 \mu$ thick.Cromb. Lich. Brit. p. 17 pro parte ; in Grevillea xv. p. 15 (1:86) (1 Monogr: i. p. 118 ; Leight. Lich. Fl. p. 77 ; ed. 3, p. 70 pro parte. Lichen paschalis L. Sp. Pl. p. 115:3 (1753) pro parte.

A plant of northern or cold regions and very rare in this country. It has frequently been confused with St. coralloides, but differs in the form of the podetial squamules, which are smaller and are ne ver coralloid.

$H a b$. Among mosses on rocks and on the ground in alpine regions.-Dist). Rave in the northern regions of Scotland.-B. II. Upper Glen Dee, Braemar, Aberdeenshire; Morven, Caithness.

\section{․ St. denudatum Florke Dentsch. Lich. iv. p. 13 (1S19).-} Pocietia small or moderate in size, up to 5 ('nn. in height, attached below, nearly erect and branched above, attenuate and rarely sorediate at the apices, the axis glabrotis; podetial squamules whitish, sulupeltate, at first somewhat globose then flattened and depressed in the centre, with a crenulate margin, sometimes diseoid and erowderl often fewer towards the tips. Cephalodia 
walld, olive-brown, sumewhat shining, containing Stigmemer. Aputhecia very rare, small, lateral, plane or somewhat convex, hrownish: spores elongate-fusiform, :3-7-septate, 26-46 $\mu$ long, 3- i fl thick.-Cromb. Lich. Brit. p. 17 \& Monogr. i. 120 ; Leight. Sich. Fl. p. 78 ; ed. 3, p. 71 . S. pres.hale var. demulatum .ludd Minn. 1). 66 (1861). Lichenoiles non tubulosum, cinerenm ramosum totum ciustrcenm Dill. in Ray Syn. ed. 3, P. 66, n. 11 (1724) (sperimen in Buddle Hort. Sicc. ii. fol. 2, 11. 7, in Herb. Sloane).

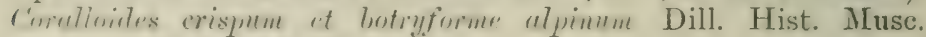
p. 114, t. 17, fig. 33 (1741).

Lisiec. C'roall n. 499; Julns. n. 211 ; Larb. Lich. Hb. n. 244.

liatily distinguished from other British species by the subpeltate -run:mules and by the thin squammlose podetia near the tips. When lar.er and wore robust it is f. valihum Laur. (ex Fr. Lich. Eur. p. 205) (1 -:31); Cromih). Monogr. i. 1). 120). Syuanules and podetia are rarely comewhat soreliate (f. capitatum Flot. ex Koerb. Syst. Lich. Germ. p. 13 (1855); Cromb. 1. c.).

ifol). On roeks and boulders in upland and alpine situations.j)isir. General and frequent in the more mountainous districts of Great Britain and Ireland.-B. M. Cawsand Beacon, Sharpitor Rock ant Mis Tor, Dartmoor, Deron; near Dolgelly and Cader Idris, Merioneth; Capel Curig, Pen-y-Gwryd, Moel Siabod, Llyn Idwal and Snnwlon, Carnarronshire; Aiglesea; Mrnydd-y-Myfyr, Shropshire; Falin Clints and Cronkley Scar, Teestale, Durham; Staveley Head, Trestmoreland; Ennerdale, Cumberland; near Gallowar, Firkendlrightshire; Ben Cruachan, Argrll; Ben Ledi, Ben Lawers and Iiamoch Moor. Perthshire; Sidlaw Hills and Clova, Forfarshire; Gilen Candlic, Craig Coinnoch, Cairn Drochit and Ben-naboord, Bratuar, Aberdeenshire; Ben Neris, Invernessshire; Hills of Apple. (ross. Tiossshire; Lairg, Sutherland; Killarney, Kerry; Kylemore, Connemara, Galway.

Tar. pulvinatum Th. Fr. Ster. \& Pil. Comm. p. 27 (1857).Purlestia densely caspitose, short, fastigrately and intricately lomanched, forming cushion-like growths, the spluamules turgid,

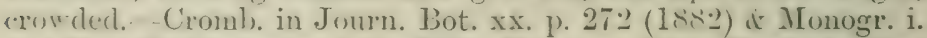

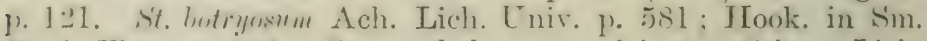

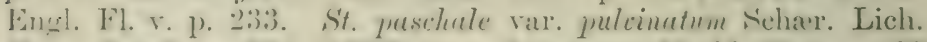

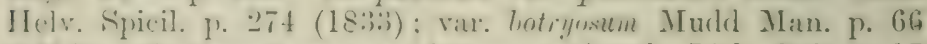

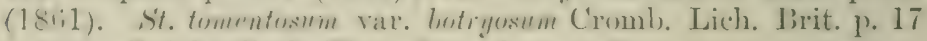
(1870); Leight. Lich. Tl. p. 78 ; ed. 3, p. 71.

Exsice. Johns. n. 212 ; Leight. n. 387.

liffers from the specios in the hort congested porletia and the somewhat confluent porletial squamules.

Hab. On rocks and boulders in mountainous regions.-Distr.

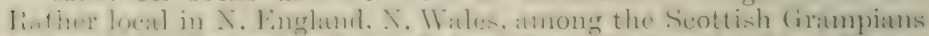

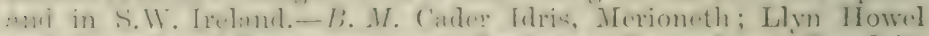

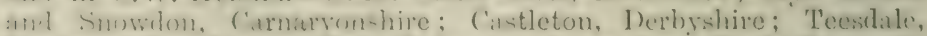

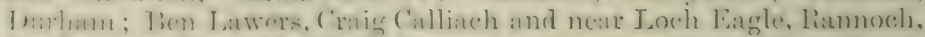

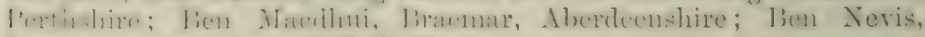
Invornessshire; Connor Clift's, Kerry. 
9. St. tomentosum Fr. Sched. Critt. iii. p. 20 (1;24) pro parte; Th. Fr. Ster. Pil. Comm. p. 29 (1857).- Podetia solitary or loosely caspitose, ascending or spreading, 3-9 $\mathrm{cm}$. hich, branched abore, the axis densely tomentose; porletial squamules. palmate-digitate, crowded above, scarcely any below, whitish or greyish-creen. Cephalodia minute, greyish or bluish-green, crntaining Nostoc. Apothecia small, terminal and lateral, concave, becoming suloglobose, brown or dark-brown; spores elongatefusiform, 3- rarely 5-7-septate, 22-:37 $\mu$ long, $2-3 \mu$ thick.Mudd Zian. p. 65 ; Cromb. Lich. Brit. p. 17 it Monogr. i. p. 119; Leight. Lich. Fl. p. 78 ; ed. 3, p. 70.

Exsicc. Dicks. Hort. Sice. n. 24 (as Lichen paschalis).

Distinguished from the preceding by the tomentum on the podetia. though that disappears somewhat with age. Apothecia are rather rare in British specimens; spermogones are more frequent, with spermatia $5-6 \mu$ long, $1 \mu$ thick.

Hab. Among gravel in stony places in maritime and subalyine districts.-Distr. Local and scarce in S.W. and N. England and in the hilly regions of Scotland.-B. M. Near Tavistock, Deron; Helvellyn, Cumberland; Sands of Barrie and Clova MIts., Forfarshire; Ben-naboord, Glen Dee, Glen Lui Beg, Braemar and Ben Macdhni. Aberdeenshire; Ben Nevis and Glen Feshie, Invernessshire.

10. St. alpinum Laur. ex Fr. Lich. Eur. p. 204 (1831).Podetia rather short, branched and densely congested, adherent to the substratum, the axis thinly tomentose ; podetial squamules abuve of conglomerate turgid granules almost obscuring the branches, more sparse below and subpalmate. Ceplialodia bluishgreen, containing Nostoc. Apothecia few, usually terminal and dilated, plane, becoming convex, dark-red or brownish-black: spores 3 - rarely $5-7$-septate, $22-37 \mu$ long, $2-3 \mu$ thick.-Cromb. in Grevillea xr. p. 15 (1886) \& Monogr. i. p. 119. S't. tomentown var. alpinum Th. Fr. Ster. Pil. Comm. p. 30 (1857); Cromb. Lich. Brit. p. 17 ; Leight. Lich. Fl. p. 78 ; ed. 3, 1. 71 . St. presshulle var. alpinum Mudd Man. p. 66 (1861).

Exsicc. Larb. Lich. Hb. n. 7 .

Distinguished from the preceding by character of the more erect congested podetia and the crowded turgid squamules.

Hal. On the ground and on boulders in subalpine district..Distr. Local ant scarce among the Scottish Grampians and TV. Irelant. - 13. M. Ben Trackie, Perthshire; Morrone. Braemar, Aberdem hive.

CLADONIA Hill Hist. Pl. p. 91 (1751) pro parte; Ifoffin.

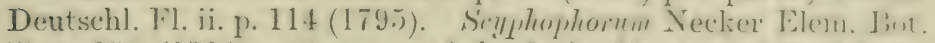
iii. p. 350 (1790). Cenemugre Ach. Lich. Unis. p. 10.) (1\$10):

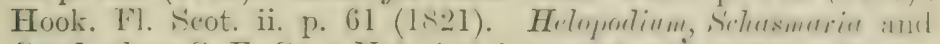
Scyphoplema S. F. Gray Nat. Arr. i. 1'p. $416,41 \%(18-1)$. Sizllerphorus IIook. in Sm. Engl. Fl. v. p. 2.36 (KR3:3). (Pl. tis.)

Primary thallus crustaceous, squamuloste on subfoliancents. 
sometimes evanescent; secondary thallus or podetia upright, simple or brancherl, tapering to a point or widening to form a shall iw cup or scyphus, inore or less corticate, pulverulent or beset with sfuamules, tubular and sometimes perforate at the axils or in the scyphi. Aputhecia terminal, at first somewhat plane or even marsinate, becoming convex; spores 8 in the ascus, "blong, simple, colourless. Spermogones usually terminal on the porletia, with cylindrical straight or curved acrogenous spermatia.

Characterized by the well-developed tubular porletia. There are three subgenera represented in the British Isles:-

Primary thallus crustaceous or squamulose soon evanescent; podetia mostly ascyphous...........

Primary thallus crustaceous, persistent; podetia ascyphous ....................................

Primary thallus squamulose, usually persistent; podetia scyphous or ascyphous.

\section{i. Cladina.}

ii. Pycnotheisa. iii. Cenojiyce.

Sulgenus i. Cladixa Leight. Lich. Fl. p. 72 (1871). Clatina Nyl. in Not. Sillsk. Faun. of Fl. Fenn. Förh. n. s. v. p. 110 (1866); Cromb. Monogr. i. p. 173.- - lasal thallus gramular or minutely syuamulose, som disappearing: podetia perishing at the base, with long continued apical growth and without podetial squamules.

The species of Cladina were considered to have no primary thallus, and though that has been disproved by careful observations for most of the species, the basal gramules or squamules disappear very soon. The limits of Xylander's genus have been followed. Wainio and some others have excluded Cladonia uncialis and $C$. amaurocrca, etc. (placing them under the subgenus Cenomyce).

\section{Podetia ascyploous, slender, cylindrical.}

1. C. rangiferina Wel. in Wigeger's Prim. Fl. ILols. W. 90 (17-21) por parte.-. Primary thallus of contiguous or scattered mimute erey ish granules som disaplesaring ; porletiat rising from the eranulue or from frasments of whler probletia, dying at the

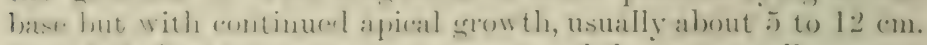
bong, hut shorter or sonetines very much longer, usually tomen-

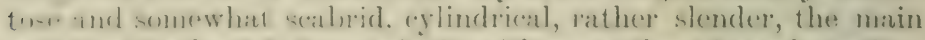

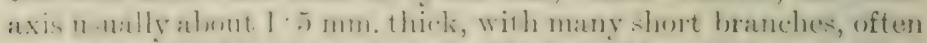
cilated and freforate at the axils, the branchlets shere, spreatinger

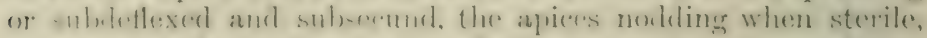

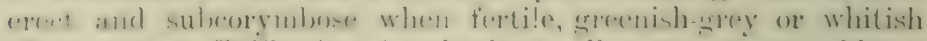
$(\mathrm{K}+\mathrm{yellow}, \mathrm{CaCl}-)$. Apothecia small, rare; spores oblongfusiform, 10-15 $\mu$ long, $: 5 \cdot 5 \mu$ thick.-S. 15. Gray Nat. Arr. i. p. 115; Hook. in Sm. Lingl. TI. v. p. 235; Mudd Man. p. 58 (exel. vars.) \& Brit. Clad. p. 24 (incl. f. major, p. 25, excl. other forms). Lichenoides tubulosum ramosissimum, fruticuli specie cendicens Dill, in liay Syn. ed. 3, p. 66, n. 14 (1724). Coral- 
Toinles montunum fruticuli specie, ubique comrlicans Dill. Hist. Muse. p. 107, t. 16, fig. 29 A-D (17+1). Lichen rangiferims L. Sp. Pl. p. 1153 (1753); Huds. Fl. Angl. 1. 458 (excl. var. $\beta$ ); Lightf. Fl. Scot. ii. p. 877 (excl. vars.); With. Arr. ed. 3, iv. p. 41 ; Engl. Bot. t. 173. Cenomyce rengiferina Ach. Syn. Lich. p. 277 (1814) (incl. f. giguntea); Hook. Fl. Scot. ii. p. 6.); Tayl. in Mackay Fl. Hib. ii. p. 79. Clatina rangiferina Nyl. in Not. Siillsk. Faum. ㄹ Fl. Feun. Fürh. n. s. v. p. 110 (1866); Leight. in Aun. Mag. Nat. Hist. ser. 3, xviii. p. 418 (1866) \& Lich. Fl. p. 74 ; ed. 3, p. 67 ; Cromb. Lich. Brit. p. 22 it Monogr. i. p. 174 (incl. f. gigrentea Lamy in Bull. Soc. Bot. Fr. xxv. p. 358 (1878)).

Exsicc. Croall n. 400.

This species is the well-known "Tein-deer Moss," and is distinguished from the following chiefly by the larger size and by the yellow reaction with potash. It grows in dense groups and sometimes in northern countries to a great height $\left(1 \frac{1}{2} \mathrm{ft}\right.$.). Usually it is tomentose and often covered with scurfy dots, or it is quite smooth and in older specimens tends to become greyish-brown. The apothecia are rare. but the spermogones are more frequent.

Hab. On the ground, usually in boggy places, mostly on high morlands.-Distr. Not general nor common in Great Britain; not seen from Ireland.-B. M. Trevello Carne, near Penzance, Cornwall; Charwood Forest, Leicestershire; Delamere Forest, Cheshire: snowdon, Carnarvonshire; The Cheriots, Northumberlind; Glen Lochay aud Ben Lawers, Perthshire; Clova MIts., Forfarshire; Craig Coinnoch and Glen Callater, Braemar, Aberdeenshire; Rothiemurchus Forest and Glen Nevis, Invernessshire.

․ C. sylvatica Hoffm. Deutschl. Fl. ii. p. 114 (1795).Primary thallus of contiguous or dispersed yellowish-green granules, soon evanescent; podetia branched, dying at the bare but with continued apical growth, mostly about $5 \mathrm{~cm}$. in length an: I slender, but attaining to $20 \mathrm{~cm}$. and the main axis stoutish, alsut $1 \cdot 5 \mathrm{~mm}$. thick, cylindrical, somewhat tomentose and scalnicl, sreenish-white, or pale-straw-coloured, the branches short, spreading or deflexerl, often dilated and perforate at the axils, the altimate branchlets short, subsecund, norlding when sterile, erect and subcorrmbose when fertile, greenish-grey or prale-stratwculoured ( $\mathrm{K}-, \mathrm{K}(\mathrm{CaCl})+$ vellow). Apothecia and spores ats

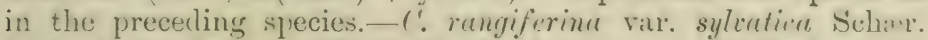
Lich. Helv. Spic. p. 38 (18:3), Mudrl Man. p. 5y it th. temuix,

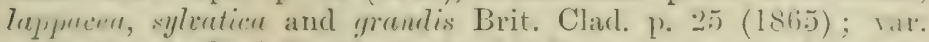

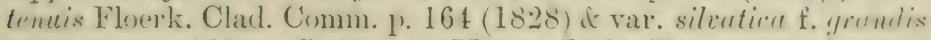
tom. cit. p. 169. C. impexa Harm. Lich. Fr. p. 232 (1907); A. L. Sm. Monogr. ii. p. 3551 (1911). C. ciliuta Stirt. in Scot.

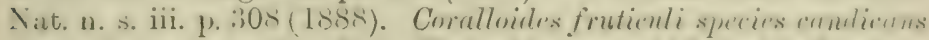

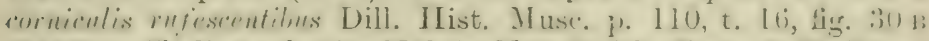

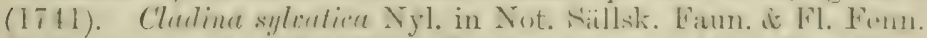
Forh. n. s. v. p. 110 (1Niffi): Leight. in Anu. Mats. Nat. Hist:

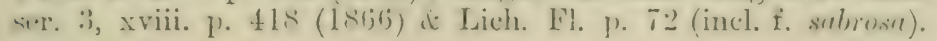


ed. :) p. (6t; ; C'ronn). Lich. Jirit. 1). 22 \& Monogr. i. p. 175) (incl. f. tenuis and var, grandis).

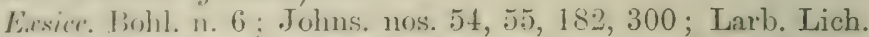
Hb. nos. 24:2, 24:3 of Lich. Cantab. 11. 4; Leight. n. 57; Mudd nos. 19, $20 \&$ Clad. nos. 57, 58, 60.

One of our commonest British Lichens; it differs little from the prececling species except in the absence of colour reaction with potash and in the generally smaller lighter-colourer and less tomentose podetia. Forms tenuis and grandis represent the somewhat more extreme developments. In f. lappacea the podetia are more crowiled and branched. Cladonia impexa is whitish and nlmost translucent in appearunce, but otherwise like the species; the translucent character appears occasionally both in this species and in the preceding. It is more than probable that Lichen rangiferinus of the older writers refers to this, the much commoner species.

Hab. On the ground in forests and moorlands.-Distr. General and common in Great Britain and Ireland, rare in the Channel Islands.-B. M. Tregawn, Cornwall ; Dartmoor, Devon; New Forest, Hants; Shanklin Downs, I. of Wight; Aldrington, Tilgate, Lavington and Crowborough, Sussex; Wimbledon, Surrey; Farnham Royal Common, Bucks; Epping Forest, Essex; Charnwood Forest, Leicestershire; Wyre Forest and Malvern, Worcestershire; Haughmond Hill, Shropshire; Barmouth and Thergreidden, Nerioneth; Thetford Warren, Suffolk; North Wootton Common, Norfolk; Ayton and Kildale Noors, Cleveland, Yorkshire; Windermere, Westmoreland; Alston, Cumberland; The Cheviots and West Allen Carrs, Northumberland; New Galloway, Kirkeudbrightshire; Pentland Hills, near Edinburgh; Ben Cruachan, Argyll; Ben Lawers, Kinnoul Hill and Moncreifie Hill, near Perth, Glen Lochay and Fannoch Moor, Perthshire; Sidlary Hills, Rossie Moor and Baldoran, Forfarshire; Mar Forest and Ben-naboord, Braemar and Countess Wells Wood, Aberdeenshire; Rothiemurchus and Ben Nevis, Invernessshire; Lairg. Sutherlandshire; Applecross, Rossshire; Kilminster Moor, Caithness; Arklow, Wicklow; Connemara, Galway; Mallaranny, Slieve MLor, Mt., Achil Island and Clare Island, Mayo; Kirkeubbin, Down.

Form lacerata Wain. Mon. Clad. i. 1) 29 (188i).-Porletia rather long and stoutish, very shortly hianched, perforate or lacerate at the axils.-Cenomyer sylention var. laseratu Del. in Duby 13ot. (iall. ii. 1. 6:21 (15:30). Cladina syluatica f. lacerata Cromb. in Grevillea xi. p. 115 (188:3) \& Monogr. i. p. 176.

Ifob. In moist sandy places amd on moorlands in maritine and inland districts.-Jistr. Scatree in the ('hammel Islands and in Great

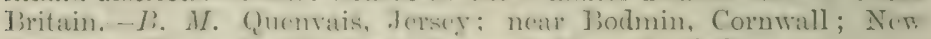

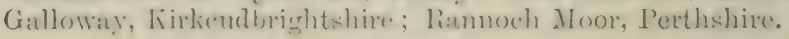

Viar. portentosa Wain. Mon. Claci. i. 1. 32.2 (1887).- P’odeti: steut and ratler inflated, difimm, tomentuse, seabril, sometime tmansluent, slustly hanched, denticulate-crispate at the apiceand sometimes also at the axils,-Corallina montana varietas

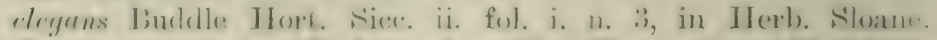

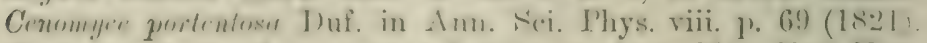

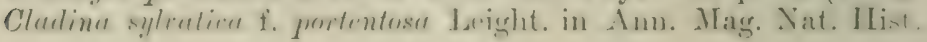


ser. 3, xviii. p. 419 (1866) \& Lich. Fl. p. 73 ; ed. 3, p. 67 ; Cromb. Lich. Brit. p. 22 \& Monogr. i. p. 176.

Fairly constant in appearance, though probably an abnormal growth form due to excessive moisture. It is rarely fertile.

Hab. In moist places on moorlands.-Distr. Rare in S. W. and Central England, S. Scotland.-B. M. Near Penzance, Cornwall; Hampstead, London (1Sth century); Charnwood Forest, Leicestershire; New Galloway, Tirkeulbrightshire; Moor of Pannoch, Perthshire; Glen Dee, Braemar, Aberdeenshire.

3. C. alpestris Rabenh. Clad. Eur. p. 11, fide Bausch in Verh. Nat. Ver. Carlsruhe, iv. p. 17 (1 869$)$.-. Porletia somewhat soft, with apical dense radiately spreading cymose branches forming a thyrsus, the main axis stoutish, that of the branches and branchlets rather slender, tips upright, usually light-strawcoloured $(\mathrm{K}-, \mathrm{K}(\mathrm{CaCl})+$ yellow $)$. Apothecia rare in Great Britain, minute, solitary or aggregate, brown or reddish-brown: spores fusiform or oblong, 10-1+ $\mu$ long, 3-3·5 $\mu$ thick, - C. ranfiferina var. alpestris Mudd Man. p. 59 (1861) \& f. rlpestris Brit. Clarl. p. 25 (1865). Coralloide's montanum fruticuli syecie, ubique candicans Dill. Hist. Musc. n. 107, t. 16, fig. 29 F, F. Lichen rangiferimes alpestris Linn. Sp. Pl. p. 1153 (1753). L. alpestris Huds. Fl. Angl. p. 458 (176:) ; Lightf. Fl. Scot. ii. p. 877. Clarlina sylvatica var. alpestris Nyl. in Not. Sällsk. Faun. \& Fl. Fenn. n. s. v. p. 176 (1866); Leight. in Ann. Mag. Nat. Hist. ser. 3, xviui. p. 419 (1866); Cromb. Lich. Brit. p. 22.2 it Monogr. i. 1). 177 ; f. alpestris Leight. Lich. Fl. p. 7:3; ed. 3, p. 66 .

\section{Exsicc. Larb. Lich. Hb. n. 85.}

So well-marked and constant in the form of the branching that it is now held to rank as a species. It is rarely fertile in the British Isles. The spermogones contain a rose-red colouring substance.

Hab. In moist places in woods and moorlands in upland and subalpine regions.-Dists. Rare in England and Ireland; wore frequent imong the Grampians, Scotland.-B. M. Phewgreidden, Merioneth; Gilen Lochay, Perthshire; Hill of Ardo, near Aberdeen and Benuaboord, Bricmar, Aberdeenshire; Glen Nevis, Invernessshire; Ballytore, Kildare; Kylemore and Roundstone, Galway.

Form pumila A. L. Sm.-Podetia shorter, very much branched, furming somewhat dense cushions, rather fragile.-Cenonyce

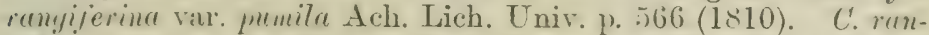
siferina f. lapparea Floerk. Clad. Comm. p. I6:2 (1828): Mudd Brit. Clad. 1. 2.5. Clarlina sylvatien f. pumila Leight. Lich. Fl. 1. 7:) (1871); edl. 3, p. 67; var. alyestris f. jumila Cromb. Lich. Brit. p. 22 $(1870)$ \& Mlonogr. i. p. 177.

Exsicc. Mudd Clad. n. 59.

Hab. In dry bare places or heaths, and on turf walls in upland districts.-Distr. Local and scarce in Great 13ritain, not seen from Ireland.-B. .I. Jroatwater Forest, Sussex: T.eith Hill, Surrey ;

I. 
Charnwood Forest. Leicestershice; lihewgreidden, Merioneth; Burton Heat, Cleveland, Yorkshire; Appin, Argrll; Rannoch. I'erthshire: Glen Dee, Jraemar. Aherdeenshire; Rothiemurchus, Invernes-shire.

Furm spumosa Norrl, ex Wain. Mon. Clad. i. p. 46 (1זsT). --Podetia shorter, more stragsling and irregularly branched, the main hranches soft and tomentose, whitish or greyish.

Without the dense apical branching of the species, but arreesing in the presence of red colouriug substance in the spermogones.

Collected by the late IV. IVest; determined by T. Hebden.B. M. Roundstone, Galway.

\section{Podetia ascyphous, tubular.}

4. C. uncialis Wel) in Wigg. Prim. Fl. Hols. p. 90 ( 1 - $x(y)$. Primary thallus of minute squamules, straw-coloured above, white beneath, scattered or aggregate, soon disalplearing; forletia rising from the margin of the squamules or mre frequently from the base of older memiers, increasing indelinitely at the apex, dying off below, ustally about $5 \mathrm{~cm}$. in heirht, but varying trom : cm. upwards and abnut - mm, thick less or more, subcylindrical, shortly and dichotomously brancherl, more or less perforated and often dilaterl at the axils, corticate and cuntinuous, areolate and verruculose, the ajpices erect, subulate or denticulate when sterile, radiately divided when fertile, sreenishstraw-coloured $\left(K-, K\left(C_{a r} C l\right)+\right.$ yellowish $)$ Apothecia small, pale or brown : snores oblong-fusiform, 8-12 $\mu$ lone, 3.5 $\mu$ thick. S. F. Gray Nat. Arr. i. p. 415 ; Hook. in Sm. Engl. Fl. v. 1. 234: Mudd Man, p. 5!) (incl. f. hnmilior): f. hmmilior Fr. Lich. Eur. p. 24t (18:31). ('. stellata Sichar. Lich. Heiv. Sipie. p. 1.2 (15:3) pro parte; Mudd Brit. Clad. p. 26 (incl. fï. mrinlis

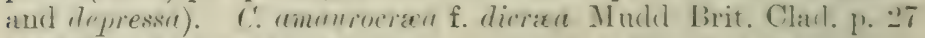

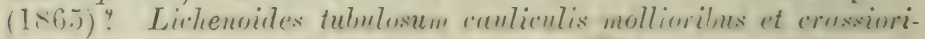
bus, minus Dill. in liay Syn. ed. 3, p. 67, n. 21 (17:24) (in

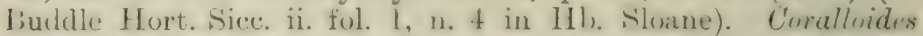
j"rofratum minus, molle of tenue Dill. Hist. Musce 1) 94, t. 16, fig. $22 \mathrm{~A}, \mathrm{C}, \mathrm{D}$, and fig. $27 \mathrm{~A}(174 \mathrm{l})$. Lichen uncialis L. Sp. Pl. 1. $11 \pi ; 3$ (175:3): Muds. Fl. Angl. 1) 45!! : Lightr. Fl. Ricot. ii.

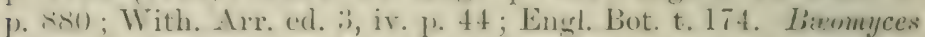

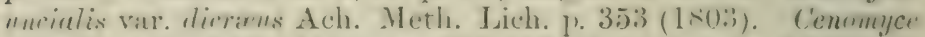
unciulis Ach. Lieh. Univ. p. jist (lslu) (incl. var. lmlatima); Hook. Fl. seot. ii. 3. 6t: Tayl. in Markaly Fl. Mhl. ii. 1). 99.

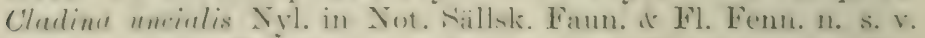
p. 111 (1866); Cromb. Lich. Brit. p. 22 \& Monogr. i. p. 178; Leight. Lich. Fl. p. 74 ; ed. 3, p. 67.

Exivec. Bohl, nos. 15, :11; Croall n. 596 ; Johns. n. 56.

The proletia vay fom stuooth to being areolate-rough in high

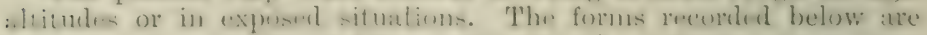
more nearly growth conditions, though the extreme stages are

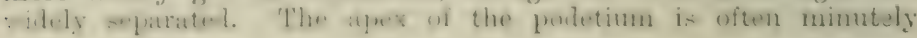


furcate-spinose or with sereral short points, but there are no true scyphi. It is usually sterile.

Hab. On the ground among mosses (frecuent in boggy places) on moorlands and mountains.-Distr. General and common throughout the British Isles.--P. M. St. Mary, Sicilly Isles; near Respring. Cornwall; Hay Tor, 1)artmoor, Devon; Tilgate, Sussex; near 'Tunbridge Wells, Kent; Charnwood Forest, Leicestershire; Hartlebury Common, Worcestershire; Barmouth and Rhervgreidden, Nerioneth; Snowdon and Capel Curig, Carnarvonshire; Ingleby Park and Ayton, Clevelind, Yorkshire; Alston, Cumberland ; Kirlshope Law, Swinhope Fell and The Cheriots, Northumberland; New Galloway, Kirkeudbrightshire; Ben Lomond, Dumbartonshire; Craig Canliach and Ramnoch Moor, Perthshire; Sidlaw Hills, Rossie Moor aud Clova, Forfurshire; Hill of Ardo, near Aberdeen; Glen Callater and Ben Macdhui, Braemar, Abcrdeenshire; near Rothiemurchus and Ben Nevis, Invernessshire; Hills of Applecross, Rossshire; Coitchford near Cork; Killarney, Kerry ; Kylemore, Galway ; Erris, Glandarry Mt., Slieve More Mt. and Mallaranny, Mayo.

Form bolacina Nyl. Lich. Scand. p. 5e (1N61). Podetia short, slender, usually very much and intricately branched.-C. stellate f. gracilis Mudd Brit. Clad. p. 26 (1865). Crumeger uncialis var. bolucina Ach. Lich. Univ. p. 559 (1810). Clutima uncialis var. bolacina Cromb. Lich. Brit. p. 22 $2(1870)$ \& f. bolucinu Monogr. i. p. 178 (1894). ก. 61 .

Exsicc. Johns. n. 301 ; Leight. n. 58 ; Mudd n. 17 \& Clad.

The extreme examples are very slenier, but there is a gradual transition to forms that more nearly approach the species. Generally the growth is more compact and pulvinate. It represents a form of the species in rery dry situations as f. chtior represents the srowth in more moist localities.

Hab. In dry places amcing mosses or moorlands in upland districts. -Distr. Chietly in N. England, N. Wales, among the Scottish (rrampians and in WT. Treland.-B. M. Hay Tor, Dartmoor, Devon; Ilaughmond Hill, Shropshire; Phewgreidicn, Merioneth; Farmale. Guisboro' anü Avton Moors, Cleveland, Yorkshire; Ramnoch, Perthshire; Morrone, Braemar, Aberdeenshire; Corraun Mt., Mayo.

Form elatior F1. Lich. Eur. p. 24t (1831) (incl. f. turyeserms). Podetia elongate, stout, sparingly branched, the branches subtiatigiate, subulate, furcate or sprealing-dentate at the aprices. usually sterile-Mudd Man. p. 59 (incl. fo turgescens); var. aduma S. F. Gray Nat. Arr. i. p. 415 (18-1) ; var. turgidu Fuhat. liveh. Helv. silicil. p. 4:) (18:3); Hook. in sm. Fingl. Fl. ฯ.

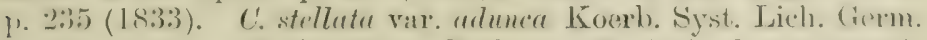
p. 37 (1855); Mudd Brit. Clad. p. 27 (incl. f. turgesecus).

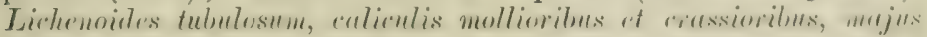
Dill. in Ray Syn. ed. 3, p. 67, n. 20 (1724). Cornlloides perforutum majus, molle et crassum Dill. Hist. Musc. p. 98, t. 16, fig. $21(17+1)$. Coralloides imperforatum corniculis brevissimis crispis Dill. tom. cit. p. 100 , t. 16, fig. 24. Lichen uncialis 
var. $\beta$. Tightf. Fl. Scot.ii. p. 880 (1777); Huds. Fl. Angl. ed. 2), p. 555; var. 2, With. Arr. ed. 3, iv. p. 44 (1796). Bæomyces udurus Ach. Meth. Lich. p. 35:3 (1803). Cenomyre nuralis var. obtusatu Ach. Lich. Univ. p. 5) 9 (1810); var. adunca Hook. Fl. Sicot. ii. 1. 64 (1821). Cludtina uncialis ff. turgescens and aluner Leight. Lich. Fl. p. 75 (1Si1); ed. 3, p. 68 (incl. f.

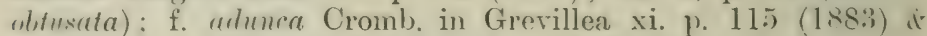
Monogr. i. p. 179 (incl. ff. turgescens and obtusata).

Exsicc. Johns. n. 217 ; Mudd n. 21 \& Clad. n. 62.

The portetia are sometimes very long (up to 4 inches) and stonter than in the species. In some instances they are short and swollen, with a deformed appearance (f. turgescens), or distorted and obtuse at the apices (f. obtusata); these forms are intimately connecter with f. elatior.

Hab. On the ground in damp places or on turf-walls (f. turgeseens) in upland moorlauds and hilly regions.-Distr. Probably general in Great Britain and Ireland.-B. M. Near Penzance and Withiel. Comwall; Dartmoor, Devon; Aldershot, Hants; Cwm Bycban, Merioneth; Battersby and Ayton Moors, Cleveland, Yorkshire; The Cheviots and Swinhope Fell, Northumberland; New Galloway, Kirk cudbrightshire; Ben Lomond, Dumbartonshire; Ben Cruachan, Argyll; Craig Calliach and Ben Lawers, Perthshire; Clova MIts. and Sidlaw Hills, Forfarshire; Hill of Ardo, near Aberdeen, Glen Candlic and Ben Macdhui, Braemar, Aberdeenshire; Glen Nevis, Inverness. shire ; Kilminster Moss, Caithness; Doneraile MIts., Cork ; Acharanagh. Wicklow ; Kylemore, Galway.

\section{Podetia occasionally scypliferous.}

5. C. amaurocræa Śchær. Lich. Helv. Spic. p. $3+(1 £ 23)$.Primary thallus soon evanescent; podetia elongate, slender or stoutish, variously branched, rarely perforate at the axils. smooth, the branches tapering or furcate, or becoming scyphiferous, the seyphi dentate-cristate or spinulose at the margins, often furoliferous, straw-eoloured or whitish-straw-coloured ( $K-$. $\mathrm{K}(\mathrm{CaCl})+$ rellow $)$. Apothecia rather small, brown or palereddish-hrown; spores oblong, 9-1:2 $\mu$ lon,$- 3 \cdot 5 \mu$ thick.-Mudel Brit. Clad. 1). 27 (incl. f. myriorrea) : var. myrioreme Flourk. Clad.

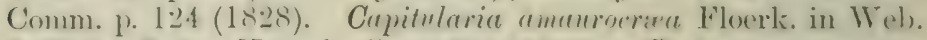
\& Molur Beitr. Naturk. ii. p. 33.1 (1\$10). Cladina amunrocraa Nyl. in Not. Siillsk. Faun. \& Fl. Fenn. 1. 111 (186i); Croml). Lich. Lrit. p. 2.2 \& Monome. i. 1) 180; Leight. Lieh. Fl. P. 71 : ed. 3, p. 67 .

E.rsire. Lapl). Tich. IIh, (without a number) : Muld ('laul. 11. 63.

Closely allimb to the precenling, hut distingnished by the oecurrence of seyphifbering porletia mixed with the suluble podetia. The serphi are reristate, amel resemble somewhat the blunt emb of a poiletium growing out on all sides.

Hab. On the grome in moist places amongrest henthe in mpland and sub-ulpine regions.-Distr. Liare in X. England. among the 
Grampians, Scotland, and in W. Ireland.-B. M. Guisboro' Moor, Cleveland, Yorkshire; Tannoch Moor, Perthshire; Ben-naboord and Glen Dee, Braemar, Aberteensbire; near Kylemore, Galway.

6. C. destricta Nyl. ex Wain. Mon. Clad. i. p. 252 (1887).Podetia rather short, from 3 to $6 \mathrm{~cm}$. in height, greyish-green or occasionally straw-coloured, corticate-areolate and rather warted, repeatedly branched, usually decumbent or of straggling srowth, ascyphous, or with scyphi when very well developed, the tapering branches lighter-coloured at the tips. Apothecia not seen ; spermogones blackish. - C. amaurocrze f. destricta Nyl. Lich. Scand. p. 59 (1861) ; f. 1epressa IIudd Brit. Clad. p. 28 (1.865). Cludinu amaniocrae subsp. destricta Nyl. ex Norrl. in Not. Sïllsk. Faum. \& Fl. Fenn. Firh. xii. p. 321 (187:3); Cromb. in Journ. Bot. xiv. p. 360 (1876) \& Monogr. i. p. 180.

Exsice. Mudd n. 18; Clad. n. 64.

Often regarded as a subspecies, or even a form of the preceding, but distinguished by the more slender warted entangled podetia and by the presence of dextrictinic acid, which gives a reddish tinge to the paper enclosing the lichen. According to Crombie (Monogr. i. p. 181) it often constitutes along with Lycoporlium. Silago, the scanty vegetation of granitic and schistose detritus.

Hab. On bare moolands and mountains from upland to alpine regions.-Distr. Tare in N. Wales, N. England and S. Scotland, more abundant among the Grampians. - B. M. Guisboro' and baysdale Moors, Yorkshire; New Gallowar, Kirkeulbrightshire ; Craig Calliach and Ben Lawers, Perthshire; Sidlaw Hills, Forfarshire; Morrone and Cairngorm, Braemar, Aberdeenshire; Ben Neris, Invernessshire.

siubgenus ii. Proxotnelia Leight. Lich. Fl. p. 55 (1871). Crnomyce Sect. Pycnothelia Ach. Jich. Unir. p. 571 (1810). Pyenothetia Duf. in Ann. Gén. Ści. Phys. viii. p. 45) (1821); S. F. Cray Nat. Arr. i. p. $42 \pm(18 \div 1)$ : Hook. in Sim. Engl. Fl. v. 1. 241 : Cromb. MLonogr. i. 124.-Primary thallus crustacerus, persistent; podetia short, like papille.

7. C. papillaria Huffm. Dentschl. Fl. ii. p. 117 (1795).Thallus crustaceous, granular, forming a crust, whitish or paleyellowish-ereen; podetia very short, papilla-like, clavate-cylindrical, inflated, very fracrile, glabrous, simple or rarely divicled. white or glaucous-green ( $\mathrm{K}+\mathrm{ycllowish}, \mathrm{CaCl}-)$. Aputhecia rare, small, torminal, solitary or ageremate, at first somewhat plane and malginate, hecoming envex, brown or reddish-brown,

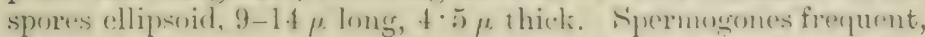
usually terminal, conical, with slichtly arcuate spores aroute at the ends.-Mudd Man. p. 59 \& Brit. Clad. p. 34. Coralloides

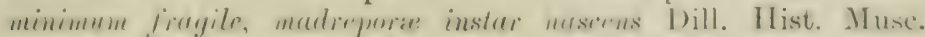
p. 107, t. 16, fig. 28 (1741). Lichen papillaria Ehrh. Phyt. נ. $100(1780)$; Jicks. PI. Crypt. fase. i. 1. 1:3 (1785); W ith. 
Arr. ed. 3, ir. 1. 4.5 : Engl. Bot. t. 907. Pynothelin papillaria Duf. in Ann. Gén. Áci. Phys. viii. p. 4t (1+21): \&. F. Gray Nat. Arr. i. 1. 4:4 (1 -1); Howk in Su. Engl. Fl. r. p. 241 ; Comb. Lich. Brit. p. 18 it Monogr. i. p. 124 ; Leight. Lich. Fl. $n 55$; ed. 3, p. 52. Cenomyce papillaria Ach. Lich. Univ. p. 571 (1810); Tayl. in Mackay Fl. Hib. ii. p. 82.

Exsicc. Cromb. n. 121 ; Croall n. 602; Leight. n. 208; IIudd n. 22 \& Clad. n. 80.

The crustaceous, perwistent thallus distingriwhes this specics from other Cladomix: the hollow, thin walled porletia somerrhat surgesest it minute ('. uncialis, they are nsually seattred, thomgh sometimes crowded.

Hal. On the ground in dry exposed places.-1)istr. (ienerat, but not common, mostly in the hilly and mountainous tracts of cireat Dritain and Ireland-B. M. St. Breock and Cirtinham, Cornmall; Dorset; Bournenouth, Hants; Ardingly Ilocks and Broudwater Forest, Sussex; Llandrindod Hill, liadnorshire; Iaysidile and Ayton. Cleveland, Yorkshire; Egglestone, 1)urham; New Gallowar, Lirkcudbrigitshire; Appin, Argyll; Ben Lawers and liannoch. l'erthshire; Clova, Forfar' Ben-naboord, Morrone and above Loch Callater. Braemar, Aberdeenshire; Ben Nevis, Invernessshire; Applecross. Rossshire; near Lairg. Sutherland; Doneraile Mts., Cork; Kilkee. Clare; Killarney, Kerry; Glendarry IIt., Corraun MIt., Cushlecka MIt., and Slieve More Mt., Achill, Mayo.

Var. molariformis Nyl. Lich. Scand. 1) j0 (1\&61).-Porletia touter, longer, and loranched towards the apices, the branches -ubfastigiate.-Suhsp. moluriformis Hoffm. Deutschl. Fl. ii. p. 117 (1795). Pyenothelia papillarin vas. moluriformis Cromb. Lich. Brit. P. 18 (1870); form moluriformis Croml). in Grevillea xi. p. 111 (1883) \& Monogr. i. p. 125.

A robust luxuriant variety with the podetia crowded and branched. and the horizontal thallus but little risible. Apothecia have not heen found on our specimens and spermogones are rare.

Hull. On the gromm anong rocks. plentiful where it necurs.B. $M$. Ardingly Roclis, Sussex.

Var, apoda Nyl, in Flora, xlviii. p. 211 (187s), note.-Thallus thinly crustacenus, white or whitish ; portetia small, or searcely formed. Apotheria sessile, small, of ten agoregate, immarginate,

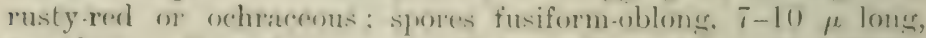

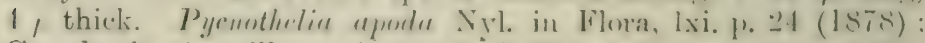
Cromb. in Grevillea, vii. p. $97^{\circ}(1879)$ \& Monogr. i. p. 125 ; Leight. Lich. Fl. ed. 3, p. 544. Specimen not seen.

bercribed as dithering in the redueced predetiat, instances of which

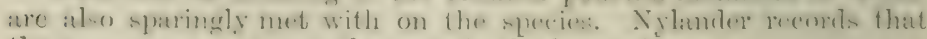
the spermogones commonly oceur in the lymenium.

IIab. On the ground in a maritine district in N.W. Ireland (Kylemore, Galwny). 
Suhgenus iii. Cenomyce Th. Fr. Lich. S'eand. p. 64 (1871). Cenomyer Ach. Lich. Univ. p. 105 (1810); Hook. Fl. Ścot. ii. p. 61 ; Grev. Fl. Eclin. p. 342 ; Tayl. in Mackay Fl. Hib. ii. p. 79. -Primary thallus squamulose or foliaceous, usually persistent; porletia mostl y well-rleveloped, scyphous or ascyphous. Aprithecia pale- or dark-brown, or red-coloured.

The Cladonie of the subgenus Cenomyce are found mostly on undistmbed mossy earth or on sandy soil on the ground or on rocks. A fer species grow by preference on old stumps or trinks of trees, as. for: instance, C. parasitica and $C$. macilenta. The species sprear widely, and are often intermingled. In certain conditions the superficial crimules or cortical areolie of the porletia grow out into squamules somewhat similar to those of the primary thallus, and thus many species have a squamulose variety or form.

In the following synopsis "large" squamules are from 1 to $3 \mathrm{~cm}$. in length. with less width; "medium" -sized are about $1 \mathrm{~cm}$. long or less; and "smill," about 2 to $5 \mathrm{~mm}$. The portetia when short are a few mm. in length, medium-sized 2 to :3 cm., and elongate or tall more than $3 \mathrm{~cm}$.

The species are arranged in two series according to the colours of the apothecia :-

Apothecia brown

A. Pheocarpeze.

Apothecia red

B. Coccifar

\section{Series A. Phizocarpex. Apothecia brown-coloured.}

I. Perlitia without perforations at tips or arils, mostly seyphifirous.

1. Podetia not or only partly corticate.

Basal squamules large, sometimes almost foliaceous.

\&. C. foliacea Willd. Fl. Berol. p. 363 (17-7) emend. Wain. Clarl. Univ. p. 384 (1894).--Syuamules of primary thallus crowrlexl rather large and rigid at the base, almost palmately divided, crenate and somewhat turned up at the tips, frequently blackish fibrillose at the margins, pale- or vellowish green above, beneath vellowish or white; podetia arising from the upper surface of the dacinia, often several from one frond, usually ratler shurt, simple, opening gradually to form irregular shallow scyphi, or sometimes ascyphous ( $\mathrm{Kf}+$ yellowish, $\mathrm{K}(\mathrm{CaCl})+$ deeper yellow). Apothecia terminal or marginal on the seyphi, convex, nodrate in size, reddish-brown; spores oblong, $8-1+\mu$ long, $-2+\mu$ thick.-C. aleicornis Floerk. Clad. Comm. 1'. 23 (18:-i). Cromb. Lich. Brit. p. 18 \& Monogr. i. 1. 127: f. pracilescens Cromb. in Grevillea xi. p. 111 (18s:3); Loright. Lich. Fl. p. 59: ed. 3, I. 56. C. onliviafolia var. alieormis Mudd Man.

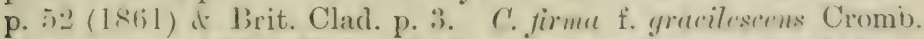
Monogr. i. 1) 128 (189-4). Lirlumides cortiluginosum, mbulis at pyxilulis exiynis Dill. in Ray Syn. exl. 3, p. 70, n. :3i (17:4).

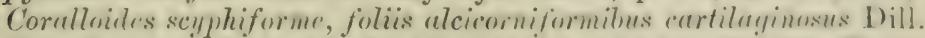

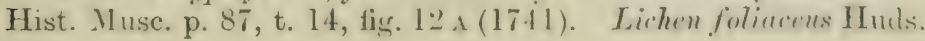


Fl. Angl. p. 457 (1762); With. Arr. ed. 3, iv. p. 35. L. alcicornis Lishtf. Fl. Ścot. ii. p. 872 (1777) pro parte; Engl. Bot. t. 1392. ('rnomyer alciarnis Ach. Syn. Lich. p. 250 (1\$14); Hook. Fl. sicot, ii. p. 62 ; (irev. Fl. Edin. p. 3t3. Sryphopherre alcicmuis s. F. Gray Nat. Arr. i. p. 418 (18:21); Hook. in Sm. Engl. Fl. v. p. 238.

Exsice. Jarb. Lich. Cresar. n. 56 it Lich. Cantab. n. 1 Leight. n. 15 ; Mudd Clad. n. 1.

Distinguished by the large yellowish-green congested squaumules and by the black rhizinose fibrillæ which are present though not abundant on any part of the plant possibly in response to contact. The spermogones are frequently sessile on the squamules. A rare plant with sleuder lobes (f. gracilescens), found only once in S. Wales, has been referred by Wainio (Monogr. Clad. ii. p. 393) to the species as a sport or growth form.

$\mathrm{Hal}$ ). In dry sandy places amongst mosses and heaths in maritime and inland districts.-Distr. Rather uncommon throughout Great Britain and the Chamnel Islands, rare in S.WW. Treland.-B. M. Quenvais, Jersey; Sark; L'Aneresse Bay, Guernsey; I. of Wight; Seilly Islands; Withiel, Cornwall; near Torquay, Deron; the Downs and near Brightou, Sussex; Romney Marsh, Lydd and West Wickham, Fient; Epping Forest, Essex; Charnwood Forest, Leicestershire; Hanghmond Hill, Shropshire; Barmouth, Merioneth; Lydistep, Pembrokeshire (f. gracilssems); Malrern Hills, Worcestershire; Aldgrove and Thetford Warren, Suffolk; Hunstanton, Norfolk; near Great Ayton, Cleveland, Yorkshire; Pentland Hills, Edinburnh; Lismore, Argyll ; Bay of Nigg, Fincardineshire; Findhorn, Elginshire ; Glengariff, Cork.

Var. firma Wain. Mon. Clad. Univ. ii. p. 400 (1894).Thalline squamules large, laciniate, crowded and suberect, crenate especially at the apices and occasionally filorillose, paleor yellowish-green above, pale-yellowish or whitish or rarely rosecoloured and white-suffused heneath; podetia small, scyphiferous. Apothecia more or less confuent, brown. - Cladonia alricornis var. firma Nyl. Syn. Lich. p. 191 (1860). ('. yirma Nyl. in liot Zeit. xix. p. 35. $(1861)$ pro parte; Cromb. Monogr. i. p. 128 (excl. f. gracilescens).

Exsicc. Cromb. n. 122; Larb. Cresar. 11. 57.

Diflers from the species in the more crowded upright growth o the less divided lacinise.

Ifah. On sandy soil and on the ground anong rocks in maritime districts.-Dist): Local and scarce in the Chamnel Islands and S. England.-B. M. Noirmont Waren and Quenvais, Jersey; Jerbonr Le cionffie and leart l'oint, (inernsey; Chatean Ponit, Sark; Start Point, l)evon: lis ighton Downs and Newhaven, Sustex; Lydd, Kent.

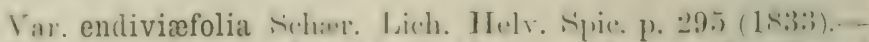
Thallus lohes large and rigid, divided into long rather loroal laciniar generally eremulate at the apiees, not filmillose, usually yellowish heneath : jollet ia suall, simple, rather rare. Apothecia 
and spores as in the species. $C$. endivicfolir Fr. Lich. Eur. p. 21.2 (1831); Mudd Man. p. 52 it Brit. Clacl. p. 22; Cromb. Lich. Brit. p. 18 \& Monogr. i. p. 127; Leight. Lich. Fl. p. 55 ; ed. :3, p. 53. Lichen Endivifolius Dicks. Pl. Crypt. fasc. iii. p. 17 (1793); With. Arr. ed. 3, iv. p. 60 ; Engl. Bot. t. 2361. Cenonnge endivirfolia Ach. Syn. Lich. p. 250 (1ऽ14); Hook. Fl. Scot. p. 62. Ścyphophora endiviafolia S. F. Gray Nat. Arr. i. p. 418 ; Hook. in Sm. Engl. Fl. p. 238.

Exsice. Dicks. Hort. Sicc. ix. n. 24.

Differs from the species in the very large spreading lacinite, which are turned up in dry weather, and in the absence of fibrillx.

Hab. On dry sanây (usually calcareous) soil among mosses and short grasses chiefly in maritime districts.-Distr. Local and scarce in a fer localities in N.E. and S. England.-B. M. Newliaven, Sussex; Banstead Downs, Surrey; Hemsby, near Yarmouth, Suffoll; Ayton Moor, Cleveland, Yorkshire.

9. C. strepsilis Wain. Mon. Clad. Univ. ii. 1. 40:3 (1894).Primary thallus of large or small squamules, sumewhat linear and sinusus, rather fragile, glaucous- or olivaceous-green above, beneath white or yellowish; podetia rising from or near the apices of the squamules, short, corticate, areolate, ascrphous, much lnanched above ( $\mathrm{K}+$ yellowish, $\mathrm{CaCl}+$ bright-green). Apothecia small, crowded on the tips of the podetial branches. - C. degrnerans subsp. coralloidea Nyl. Lich. Scand. 1. jt (1-61); Cromb. in (trevillea xr. 1). 4.) \& Monogr. i. 1) 148. C C. crialloidea IIudd Brit. Clad. 1). 5) (1865) (non Th. Fr.). C. furcatu subsp. corallridea Cromb. in Grevillea xi. 1) 113 (1;83). Banmyces strepsilis Ach. Meth. Lich. Suppl. p. 5: (1803). C'nomyee coralloidea Ach. Lich. Univ. p. 528 (1810).

Exsice. Mudd Clad. n. 4.

The cortex of the podetia is almost continuous, but uneren from the somewhat turgid areolie. The coralloid appearance is lue to the crowded apothecia.

$\mathrm{Hal}$. On the ground on wet heaths in mountainous districts.Distr. Rare in N. England and S. Grampians, Scotland.-B. M. Jaystale Moor, Cleveland, Yorkshire; Ben Lawers, Perthshire.

\section{Basal squamules medium-sized or small, thickish.}

10. C. pyxidata Hufliu. Dentschl. Fl. p. 121 (1795) pro parte: Fr. Nov. Sichel. Crit. 1. -2l (1826).-.-Primary thallus qquamulose, the squamules rather small, firm, thickish, variously incised of erenate, glaucous-ereen or sreyish, whitish beneath: jodetia mostly rather short, wine-glass to funnel-shaperl, sradually widening upwards to a rather broad scyphus, continumuly corticate or conrsely granular, the gramules frequently growing out in small syuamules, the scyphi sometimes proliferous, rarely spuamulose at the margins ( $\mathrm{K}-, \mathrm{CaCl}-$ ). Aprotheria moderate in size, 
brown or reclilish-hrown sometimes coalescing ; spores oblong-

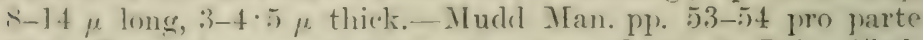
(incl. ff. simplex, murginulis, and var. urglecta) \& Brit. C'lad. lp. T-E pro parte (incl. 1t. weglerta, simpler, staphylea, synthetu and lophlyrre): C'romb: Lich. Brit. p. 18 pro parte (incl. var.

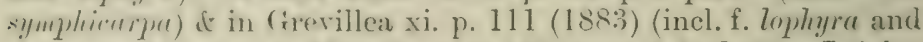
var. symplieraria) of Monogr. i. p. 12g (incl. f. lophlyra); Leight. Lich. Fl. p. 60 : ecl. :3, p. 56j pro parte (excl. vars., incl. f. costata);

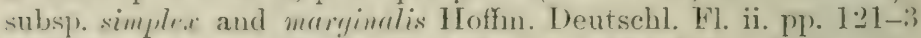
(17!) : var. costata Flocerk. Clad. Comm. p. 66 (1828). Lichemoides fululesmm pyxidutum rinerem Dill. in Ray Syn. ed. :3, p. 68, n. 2s

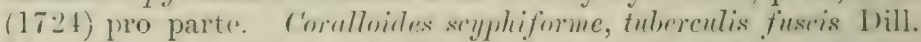
Hist. Musc. p. 79, t. 14, figs, $6 \mathrm{C}$ and I-M (1741). Lichen pyxirlutus Linn. Áp. Pl. p. 1151 (175:3) pro parte: Huds. Fl. Angl. 1. 456 : Lightf. Jl. Scot. ii. 1. x(i9 pro flarte: With. Arr. ed. 3 , iv. p. 36 (excl. var. 2); Engl. Bot. t. 1393. L. simplex Roth Tent. FI. Germ. p. 510 (1785)? L. symphicarpus Ach. Lich.

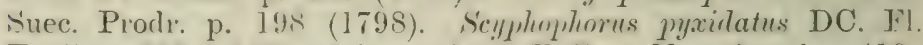
Fr. ii. p. :39) (180.) (excl. vars.) ; 今. F. Gray Nat. Arr. i. p. 419 :

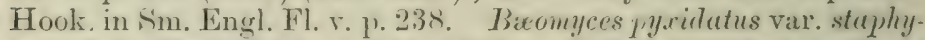
leus Arh. Meth. Lich. 1. 339 (1,03). B3. fimlurutus var. synthetus Ach. tom. cit. 342. Capitularia neglecta. Floerk. ex Web. \& Mohr Beitr. Nat. ii. p. 306 (1810). C'enomye 1!y.ridata Ach. Lich. Univ. p. 534 (1810) pro parte (incl. var. lophiyra, p. 535) : Hook. Fl. Scot. p. 62 ; Grev. Fl. Edin. p. 343. C. coccifera Tayl. in Nackay Fl. Hib. ii. p. 81 (1836) pro parte.

Edisire. Bohl. n. 320 : Johns. mos. 10, 213, 214; Leight. n. 407 : Mudid Clad. n. 6.

l)istinguisher by the rather short porletia which gradually widen out into a broar seypluns up to 1 (me. wide, and also by the coarse mamules with which nsually it is covered, especially on the inside of the scrphus. It is an extremely variable species with many forms and varieties, which are to be regarded rather as growth ioms since move than oue may be represented on the same sprecimen. Among those foms that have lieen obstreed in our country f. simpler. has very broal coarsely gramular seyplit bearing only perendiat; f. meglicta and f. symphicarpa lave confluent apothecia, but the formel has short gramulate-verruese porletia, these being smorther in f. symplicmpre; the apothecia are pedicellate and polletia long in f. staphyler; in f. syntheta the margins of the scyphi are proliferous. in f. lophlym they are fringed with small squimules, whil. in f. costata the podetium is decorticate and bare.

$H a b$. On the ground, old walls, rocks and about the roots of trees.

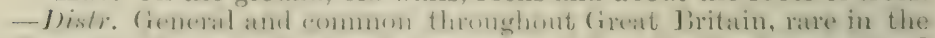
Channel Islands.-13. M. Guernsoy; St. Breock, St. Breward and

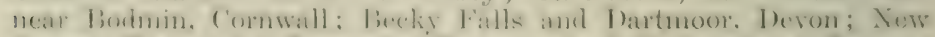

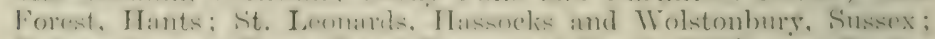

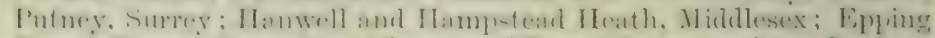

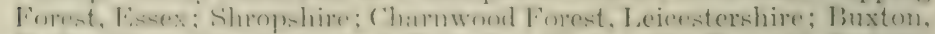

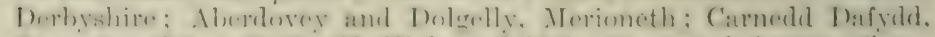

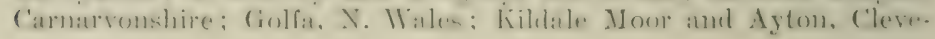


land, Yorkshire; Alston and Bassenthwaite Lake. ('umberland; Appun. Argrll; Killin, 13lair Athole and lienmore, Perthshire; 1)urris, lincardineshire; Countesswells aud Castleton of Braemar, Abertecnshirc; Rothienay House, Banffshire; near Fort William, Invernessshire: Lairg, Sutherland; Slieve Trore MIt., Achill Island, Achill Sound amul Clare Island, Mayo.

Form epiphylla Schatr. Enum. 1) 191 (1850).-Basal squanules present: podetia extremely reduced or wanting. Apothecia conglomerate, sulssessile on the squamules.--Mudd Man. p. 5:3: Cromb. Nonogr. i. p. 130 : var. epiptlylla Cromb. Lich. Brit. p. 18 (1S70); var. Ghomphen f. epiphylla Mudd Brit. Clad. p. \& (1865). Lichen epiphyllus Ach. Lich. Suec. Prodr. p. 185) (1798).

A curious and rare form of doubtful affinity. The apothecia are more or less sessile on the basal thallus. In the specimen collecterl by Mudd in Yorkshire the apothecia are scarcely visible.

$\mathrm{Hab}$. On the ground in inland places.-Distr. Rare in E. and N. England, not recently found.-B. M. Epping Forest, Essex; Ayton. Cleveland, Yorkshire (doubtful).

Var. pocillum Fr. Summ. Veg. p. 110 (1846).-Basal squamules decply crenate, firm, often closely appressed, greyish or usually greyish-tawny; podetia very short, closely granulate. verrucose-Cromb. Lich. Brit. p. $] 8$ \& Monogr. i. p. 130: f. preillum Mudd Man. p. 53 (1861) \& Brit. Clad. 1). 7. Breomyers pocillum Ach. Meth. Lich. p. 336, t. 8, tig. 6 (1803).

Exsicc. Johns. n. 286.

The basal thallus is occasionally orbicular and partly crustaccons. Apothecia are rare.

Hab. On bare soil on banks and heaths maritime and inland.Distr. Seen only from a few localities in the Channel Islands, England and scotland, but probably common.-B. M. The Vale, Gnemsey; near Bodmin, Conwall; Bathinnpton Downs. Somerset ; Charnwoorl Forest, Leicestershire; Barmouth, Merioneth; Redear and near Ayton, Cleveland, Yorkshire; Tongland, Kirkeudbriyhtshire; Fillin and Tiamoch, Perthshire; Jurris, fincardineshire; Countesswells and ('astleton of Braemar, Alserdeenshire; Glen Nevis, Inver. nessshire.

Var. chlorophæa Floerk. Clad. Comm. p. 70 (1828).-Basil squamules rather small, often pulverulent at the margins ; podetia rather long, mostly sranular below and becoming pulverulent upwards, greenish or sulphur-coloured, the scyphi usually narrow and often slightly contracted at the marein, sometimes proliforous. - Murdel Brit. Clad. p. \& (incl. fì. simplex, vulgaris, variu and infuscata) ; Leight. Lich. Fl. p. 60; ed. 3, p. 57. Cenomyce

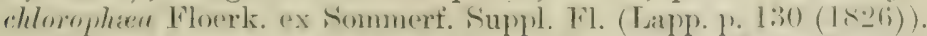

E.rsier. Johns. 11. 48 ; Larb. Lich. 1Ib. 11. 20t \& Lich. Cinntiat. n. 2 : Leight. n. 399 ; Mudrl Clad. nos. 7-10.

Differs from the species in the general breaking down of the gramules to at sorediose prowder on the uppere part of the prode timm. 
It might easily be confused with $C$. fimbriata, but the latter is pulverulent throughout.

Hab. Among mosses on the ground and on old walls.-Distr. General and common in Giveat Britain, rare in the Chamnel Islants, reported from Irehut.- B. .W. Guernsey; near P'enzance and near W'ithiel. ('ormwall; ne:t: Hunter Tor, Lustleigh Cleeve, Dartmoor, Devon: ('hislehurst, Kent; Ieith Hill, Surrey; Epping Forest, Jissex; Hale Find, Malrern, Woreestershire; Shrersbury, Shropshire ; Aberdovey and Dolgelly; Merioneth; Mildenhall, Suffolk; Wootton ('ommon, Norfolk; Arton, Newton and Kildale, Cleveland, Yorkshire; Morpeth, Northumberland ; Egremont, Cumberland; New Galloway, Kirlscuibrightshire; I'entland Hills, Edinburgh; Appin, Argyll ; near 'l'mmnel Bridge, Iimmoch and Blair Athole, I'erthshire; Durris, Kincardineshire; Countesswells, Aherdenshire; Loche I,imnhe, Invernessshire; Lairg, Sutherland.

Furm lepidophora Fherk. Clad. Comm. p. 75 (1א28).-Podetia densely coverel with minute crowderl crenate squamules, slaucrus grey. Cromb. in Grevillea xi. p. 111 (188:3) \& Monogr. i. 1. 131 : C. fimbrutu var. chloropheen t. phyllophora Koerb. Syst. Lich. Germ. p. 23 (1855); Mudd Brit. Clad. p. 9.

Somewhat resembling C. squamosa, but the vounger podetia are srimular-farinose like those of var. chlorophas. "I'robably a growth form due to excessive moisture.

Ituh. Ou old brick walls and thatched roofs in lowland districts.J)istr. Seen only from Central amd W. England, X. Wales and N.E. Seotlanil.--B. M. Lechlade, ()xfordshire; Conway, Cammarvonshire; Kinnordy, Forfarshire; Cults, near Aberdeen.

Form tuberculosa Murld Brit. Clad. p. 9 (186.)) (? Ioffm.). Porletia and seyphi more or less studded with short, often spermogoniferous, projections.

Exsicc. Mrudd Clad. n. 11.

A rery unusual form: the portetial stalks look as if dotter with mails. Mudd refers to ('oemans' ('laul. Belg. Exs. 11. 40, which [ have not been able to see.

Hab. In pastures.-B. M. Black Banks, Ayton, Clereland.

Form myriocarpa ('romb. in Carevillea xi. p. 111 (1883) d Inonese. i. 1) 1:31. Podetia rather short, the seyphi with numerous narrow gunlifirations tiplerel with small solitary or

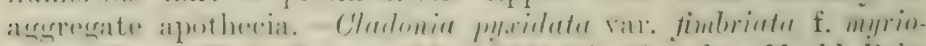

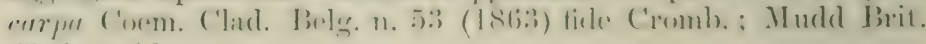
Clạd. p. 10.

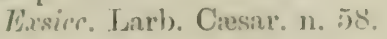

Distinguished by the prolifications of the seyphi in form like apothecial stalks.

Hab. On the groumd and on wall tops in maritime and inland siturtions.-Distr. Tocal and scarce in the Chamel Islands, IV. Englind and in S. and N. Scotlund.-B.M. St. Ouen's Bry, Jersey; 
Ogleworth Puk, (iluucestershive: Malveru and Jiemiler. Wrovestershire: Castle Ionglas. Kirkeulbrightshire: Achmore. Killin. l'erthshire; Glen Clumr, Braemar, Aberdeenshire.

11. C. fimbriata Fr. Lich. Eur. p. 222 (1831). — Basal syuamules rather small, srevish-ureen. White beneath. sumetimes evamescent: pudetia varying in leneth firm :3 mm. upwards. decorticate and finely julverulent, very rarely corticate and sometimes with minute syuamules near the base. seypliferous, the scrghi wiclening sumewhat abruptly, erect and rather regular in form, crenate or clenticulate or froliferons at the marcins $(\mathrm{K}-\mathrm{or}$ iantly rellow, $\mathrm{CaCl}-$ ). Apothecia moderate in size, sometimes coalesing, brown or redishliruwn: spores fusiform or oblong. A-14 $\mu$ long. 3-4.5 $\mu$ thick.-Cromb. Lich. Brit. p. 19 dE Monogr. i. p. 13t. C. prividate var. denticulutu Floerk. Clad. Comm. 1. 7.5. var. estutu, p. 66. and var. pteryguta, p. 69 (18:8).

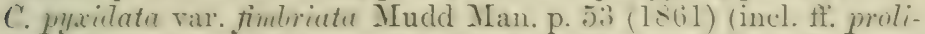

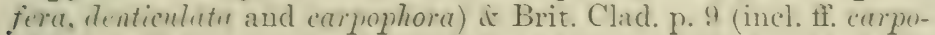

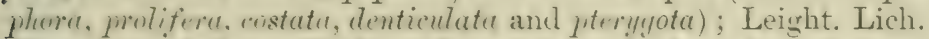
Fl. P. 61 : ed. 3. P. 57 (incl. f. costutu). Lichenodes tubulosum frolifermm, muminilus serratis Dill. in Ray sirn. ed. :3. p. 69, n. 30 (17:-4). Coralluides seypliforme tuberculis fuscis Dill. Hist. Musc. p. 79, t. 14, fig. 6 A. B $(17 t 1)$ \& Cur. sely lifurme gracile murginibus seriatis, p. A4. t. 14. fig. \&. Lichen fimloriutus L. .p. Pl. 1. 115. (17.53): Huds. Fl. Augl. p. 456; Lightt. Fl. rout. ii. 1) 870 ; With. Arr. ed. 3, iv. p. 57 ; Engl. Bot. t. 2438 ; var. prolifer Retz. Fl. Fand. 1). 23:2 (1779). Caprituluria curpe hora Floerk. in Berr. Mag. ii. p. 147 (1808). Cenomere fimloriute Ach. Srn. Lich. 1. 254 (1814) : Hook. Fl. Scot. ii. p. 6:- Tayl. in Mackay

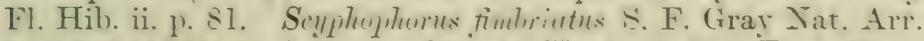
i. 1. $419(1,21)$ (incl. var. prolifira) : Hook. in Nm. Engl. Fl. v. p. 239 .

Exsicc. Bohl. n. 2t; Johns, nos. 11 and 172; Leight. n. 325 ; Mudd n. 8 \& Clad. nos. 15, 17, 18.

Differs from the precediug in thw more abruptly witening serphi. and from other Cladonix in the findr furturacous eorering of the podetia distinctive of all the rarieties and forms which rarely become sparsely squamulose. It is a rery variable species. hence the nmulner of arowth forms that have been recorded. Sometimes the porletia are denukate if. cestatal. or more than onee moliferons (f. molifina). If the seyphi are moredeuticulate than fimbriate it is fo denicillata. and when sumamules are formed on the marwin it is the somemlat ram f. ptomygutu. The apotheela are rare and usually sessile, but if th..y are borne on stalk-like projections it is focrpopinora.

Hul. ()n the gromud, roots of trees, and among mosses on wh

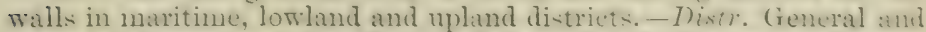
common thromghout the british Isles.-li, M. I)artmoor, Devon: Sherborne and New Forest, Hants; Hassereks. Sussex; Tumiridece

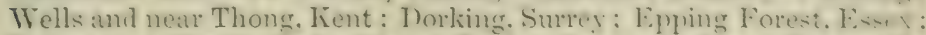
Tadmarton Heath, (Xxorlshire; Tenby. P'erubroke-hire: Bamonth. 
Merioneth: Aber, (amarronshire; Over, Cheshire; Newmarket Horth, Cambridgeshire; Ayton and Bilsdale, Cleveland, Yorkshire; Windermere. Westmoreland; Hale. Cumberland; Wark-on-Tyne, Northmmberland; New Gallowity, Kirkeudbrightshire; Royal Botanic Girrlens and Brair? Hills, Edimburerh; Barcaldine, Appin, Argyll; Killin and (ilen Lochay, Jilair Athole, Perthshire; Baldovan Woors, Forfarshire; Countesswells Woods, Aberdeenshire; liothienurchus, Invernessshire; Lairg, Sutherland; Kylemore, Galway.

Tar. simplex Wainio Monogr. Clad. Univ. ii. p. 256 (1894). -Porletia short or somewhat elongate, finely pulverulent, whitish or ureenish-grey, the stalks slender, cylindrical, the scyphi rather narrow, the margins entire or slightly crenulate or clenticulate, not proliferous.- - Var. tulueformis Cromb. Lich. Brit. p. 19 (IS10) it Mlonogr. i. p. 136 (incl. f. marra): var. conista and f. crigure Cromb. in Grevillea xi. p. 112 (188:3) \& Monogr. i. pp. 1:35, 1:36. C. l'y,ridata sulssp. exilis and tuluxformis Hoffm. Deutschl. Fl. ii. l'). $121,122(1795)$ : var. fimbriata ff. tubxformis and mucra IIudd Man. p. $5 t$ (1S61) it ti. macra, conista, tubxformis and megaphyllinu Brit. Clad. pp. 9, 10 (186.)); f. tuhreformis Leright. Lich. Fl. p. 62 ; ed. 3, 1. 5S. Coralloides scyplis. lumilibus, intus. fuscis Dill. Hist. Musc. p. 86, t. 14, fig. 11 (1741). Lichen filiformis Huds. Fl. Angl. p. $456(1762)$ ? var. ? With. Arr. ed. 3 , iv. 1. 39 (1796). L. l'yridatus var. simplex Weis Pl. Crypt. Fl. Gotting. 1). 84 (1770). L. py.xidatus var. exiffues Huds. Fl. Angl. ed. -2, p. 552 (1778). Capitularia pyxirlata rar. macra Floerk. in Web. \& Mohr Beitr. Nint. ii. p. 290 (1510). Cenomyce fimlriata var. conistu Ach. Syn. p. 257 (1814). Scyphophora conistr S. F. Gray Nat. Arr. i. p. 421 (1821) (incl. var. exilis).

Exsicc. Johns. n. 290; Leight. 11. 377; Mudd n. 7 \& Clad. nos. $12,13,14$.

In this variety the basal syuamules are well developed ; the podetia large in fo megajhyllima) are usually uniform in size and smaller; the sesphi are natrowex, with the margin entire or only slightly crenate; they are small and slemier (t. macro) and ocensionilly reddish-brown in the hollow of the cup (f. exigua). Apothecia are rare.

$H a b$. Similar to that of the species.-Distr. Not infrequent throughout (reat Britain, evidently raxe in Ireland. I. M. I amiret

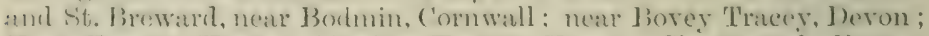
New Forest, Hants; Epping Forest, Issex; Charmood Forest, I. inestershire; near Worester ; Shrewshury, Shropshire; barmouth

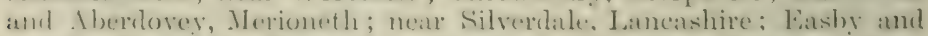

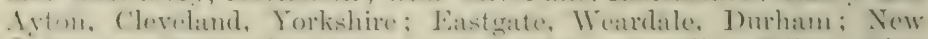

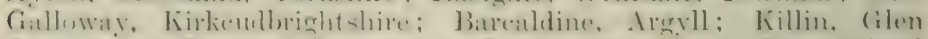

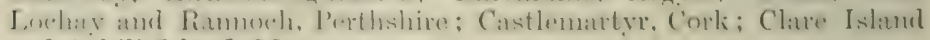
and Achill Island, MIayo.

Sulup. fibula Nil. ex Nirrl. in Merlel. Sillsk. Faun. it Fl.

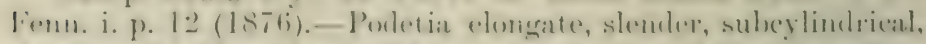
imple. with nartow serphi or ascyphoms, white-priberulent.

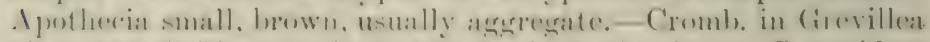
xi. p. 112 \& Monogr. i. 1. 137 (incl. f. abortiva). C. pyxidata 
var. cormute f. fibulu Mudd Brit. Clard. p. 1:) (Isis) ; var. fimbriate 1. rebrartiva Mudd tom. cit. p. 11. Lichen fibula Ach. Lich. Suec. Prodr. p. 19t(1798). Capituluria pyridata var. longijes f. abortiva Floerk. in Weh. \& Mohr Beitr. Nat. ii. p. 294 (1810). Scyphofleora finbriuta vars, aborticu and filularia S. F. (iray Nat. Arr. i. p. 420 (1821).

Exsicc. Johns. n. 173.

Distinguished from the species by the elongate podetia scarcely widening to form the seyphi and mixed $\pi$ ith ascrphous branches. In f. abortica the scrpli when formed are subcrenate or lacerate and the podetia are generally slightly stouter.

Hab. On decaying stumps and on the ground among mosses in wooded districts.-Distr. Hather rare in S. IT. England, S. S'cotland and the S. and S.W. Highlands.-B. M. Hunter Tor, Dartmoor. Devon; Lounsdale, Ayton and Broughton Bank, Clergland, Yorkshire: Moffat, Dumfriesshire; Barcaldine, Argyll.

Form nemoxyna A. L. Sm.-Podetia slender, elongate, scyphiferous, the scyphi narrow, irregularly racliate or the podetia with variously long subulate branches. Apothecia not seen.Var. subcornuta f. nemoxyna Nyl. ex Cromb. in Grevillen xi. p. 112 (1883) \& Monogr. i. p. 138. C. pyxidata var. cornuta. f. nemuxyna Mudd Brit. Clad. p. 13 (1865). Coralloidles scyphifurme cornutum Dill. Hist. Iusc. p. 92, t. 15 , fig. $16 \mathrm{~B}, \mathrm{D}, \mathrm{E}(17+1)$. Beomyces ratiatus var. nemoxymus Ach. Meth. Lich. p. $3+2$ (1su:3). s'yphophora fimbriate var. nemoxyna S. E. Gray Nat. Arr. i. p. $420(1821)$.

Differs from subsp. fibula in the slender straggling branches. It has been made a species by Zopf (Ber. Deutsch. Bot. Ges. xxvi. p. $110(1905)$ ) on account of the colourless nemoxrnic acid winch he extracted from it.

Hab. On the ground among heaths in upland districts.-Distr. Pare in E. and N. England and S. Grampians, Scotland. - B. MI. Epluing Forest, Essex; Arton Moor, Cleveland, Yorkshire; Killin. Perthshire.

Var. ladiata Cromb. in Grevillea xi. 1) 11:- (1883) \& MLmogr. i. 1. 1:3!)-Podetia elongate, subulate at the tips or usually scrohiferous, the scyphi narrow and radiate from the malyins.C. fimbriata var. radiata Cromb. Lich. Brit. p. 19 (1870).

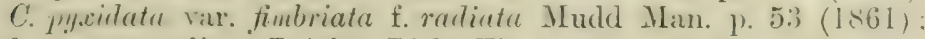
f. cormuto-radiata Leight. Lich. Fl. p. 62 ; ed. 3 , p. 58; พar. cornuta f. radiata Mudd Brit. Clad. p. 13 (1865). Muscus

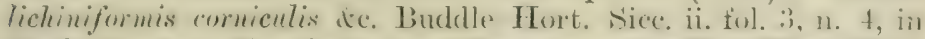

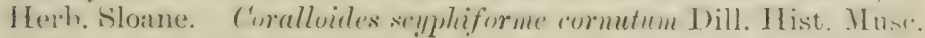
p. 92 , t. 15, figs. 16 c, F, G $(1740)$. Lichen radiatus Selueh.

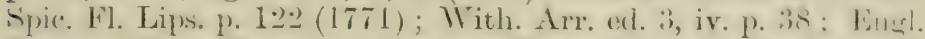

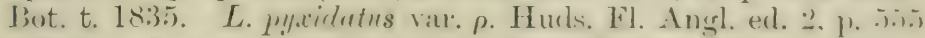
(1778). Cenomyce rartiata Ach. Lich. Univ. p. 547 (1810); 
Tayl. in Mackay Fl. IIh, ii. p. 81. Scyphoptenre fimbriatu vas:. radiata S. F. Gray Nat. Arr. i. p. 420 (1821).

Exsice. Bohl. n. 47 ; Johns. n. 175 ; Leight. n. 376 ; Mudd Clad. nos. 22, 24.

Diflers from the subspecies in the more or less elongate radiating branches arising from the margins of the seyphi and in these being oce:sionally somewhat expanded. Sipermogones only are present on the British specimens.

$\mathrm{Hat}$. On the ground in whland districts. - I) istr. Probalbly general in the hilly regions of Great Jritain and Ireland, though as ret recorded from comparatively few localities.-1). M. St. 13reock, ('ornwall; Hampstead, London (1Sth century); Essex; Malvern, Worcester-hire; Barmouth, Merioneth; Moel-y-golfa, Montgomeryshire; Westerdale. Kildale, Broughton Bank ani Iioseberry, Cleveland, Yorkshire; Tongland, Kirkeudbrightshire; Glen Lochity and liannoch, I'erthshire; Durris, Kincardineshire; Countesswells, Aberdeenshire; Aghalee bog, Lough Neagh, Londonderry; Killarney, Kerry.

Var. subcornuta Nyl. ex Cromb. in (irevillea xi. p. 11: (1883) it Monogre. i. p. 138 (incl. f. tortnosu).-Podetia usually slender, more or less elongate, ascyphous, simple or branched, horn-like, tapering upwards, almost entirely decorticate and finely furfuraceous, sometimes sparsely squamulose towards the base.C. pyxidata var. cornuta Fluerk. Clad. Comm. p. 59 (incl. f. dendroides, p. 60) (1828); Mudd Clad. 1. 12 pro parte (incl. ff. vnlgaris, untilopsea, tortuosa, cluvarioidea, subulata, isidiosa, dendroirtes, intricute and fastigiatu) ; var. fimbriate ff. cormute and dentroides Mudd Man. p. 53 (1561). Musms Tichiniformis cornimlis de. Buddle Hort. Sicc. ii. fol. 3, n. 5, in Herl). Sloane. Coralloides rix. rumosum, s'yplues obscuris Dill. Hist. II usc. p. 90, t. 15, fig. 14 v, d: (17+1). Lirlen suluulatus L. Sp. Plant. 1. 115:3 (1753) pro parte (secund. Herl). Limn. fide Wainio). L. curmutus var. $\delta$. Lightt. Fl. Sicot. ii. p. $876(1777)$; Engl. Bot. t. 18:36. Sryphophurn

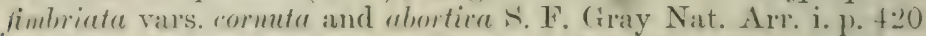

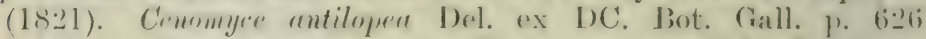

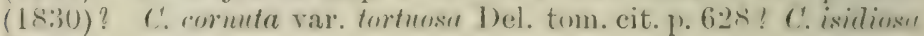
Del. 1. c.

Exsice. Bohl. n. 48 ; Croall n. 598 ; Johns. 1. 174; Mudd Clad. nos. 19, 20, 21.

Though in some instances alpmoaching very near to the subsl. filmele, distingnished by the constantly aseyphons condition of the podetia. 'The various forms recorded by Ifuld represent growth phases. In three of these the podetia are more or less squamulnse below:- f. tortuosa, unbranched and stout, the tips curved and

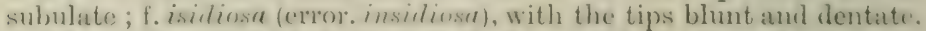
and fontilopur, which is branched ahove with the banches emred. The ronaining forms are natied or furfuracous: $-\mathrm{f}$. rlararividio. rather long and inflated upwark, hut the apex attenuated; f. suluelutu. short and subulate; f. dembrobles, long and variously branched athowe: f. intricalu, with branches enreel and entangled, and f. jastiginte. 
with short fastiginte branches towarts the tips. Wainio has adopter the Linnean name and records the above as C. fimbriatu var. subulatu (Clar. Unir. ii. p. 282 (1894)); the varietal name comute is confusert with $C$. cornuta.

Hat. On the ground among osses in upland districts.-Iristr. General but not common in Great Britain and Ireland.-B. M. Tilgate and West Grinstead, Sussex; Hampstead, London (1Sth century); Epping Forest. Essex; Charnwood Forest, Leicestershire; Loun-rlale. Kildale, Ayton and Barsdale, Cleveland. Yorkshire; Teesdale, Durham ; Hale, Cumberland; Letulhills, Lauarkshire ; Killin, P'erthshire; I) urris, Kincartimeshire; Morrone, Brammar, Aberdecnshire; near Cork; Blaris Bridge, Belfast, Antrin; Kylenore, Connemara, Galway; Achill Island, Mayo.

\section{Basal squamules minute and scattered.}

12. C. ieptophylla Floerk. Clacl. Comm. p. 19 (182s).Basal squamules small, rather scattered, round, entire or slightly crenate, pale-greenish; podetia rather rare, short, slender, glabrous, sometimes bificl, decorticate or partly corticate, ascyphous ( $\mathrm{K}-, \mathrm{CaCl}-)$. Apothecia turrid on the tips of the prodetia, brown; spores 10-12 $\mu$ long, :3-3) 5 $\mu$ thick.-Cromb. in Grevillea xi. p. 111 (188:3) \& MLonogr. i. p. 1:31. C. squamesa var. Trptopllylla Scher. Enum. p. 199 (1850): Mudd Man. p. 57. C'. cariosa var. leptoph!ll" Coem. Clarl. Belg. n. 22 (1863) ex Mudd Bit. Clat. p. 6 (1-6.5). C. py.rilutu subsp. leptopllylla Cromb. Lich. Bit. p. $18(1870)$ : var. leptophyll, Leight. Lich. Fl. p. 61 (1871); ed. 3, p. 57. Lichen microphyllus Sm. Eugl. liot. t. 17x.) (1807) (non Ach.). Heloparlinm leptopleyllum S. F. Gray Nat. Arr. i. p. 416 (1 1221$)$. Scypliophoms micropliyllus Hook. in Sm. Engl. Fl. v. p. 237 (1833).

Distinguished by the neat rounder squamules and the short aseyphons podetia, which are oftrin ribber or split, especially when dry, thus resembling C. cariosa.

Hal. In moist places among heaths in wooded inland tracts.Dist,. Hare in S. England and S. IV. Sicntland. - 73. M. Sussex; New Galloway, Kirkcudbrightshire.

\section{Podetia sometimes imperfectly corticate in parts; squamules medium-sized.}

13. C. ochrochlora Floerk. Clarl. Comm, p. 7.) (1s:s).f'rimary thallus of laciniately divided greenish squamules, white bencath; fodetia rather short or moderate in size, rarely up, to) 4 ('m. in hright, cylindrical, corticate and smooth below, greenish-grey, hecoming whitish-pulverulent above, obtuse and truncate at the appices, or with narow scyphi, dentate-radiate at the margins $\left(\mathrm{K}_{-}-\mathrm{C}_{2 \mathrm{C}} \mathrm{Cl}-\right.$ ). Apothecia small, sometimes confluent, fale-inown; pores fusiform or oblong, s-15 $\mu$ long, 3-4 $\mu$ thick (fide Wainio).-Cromb. in (irevillea xi. p. 11: d Monogrr. i. 1. 1 12. C. cormenle Mudd Man. p. $56(1 \leq 6 j)$ (non 
Fr.). C. fimlriate var. carneo-pullirla Nyl. Syn. i. p. 195) (1860); Cromb. in Grevillea xi. 1. 112 \& Monogr. i. p. 137. C. py.xidutu var. cerneprellide and var. ochrochlora Mudd Brit. Clad. pl. 11. 14 (1S6:)) (incl. forms). C. gracitis var. ochrochlorn Leight. Lich. F1. p. 6.3 (1871) ; ed. 3, p. 59. Capitularia pyxidata var. carneopallida Floerk. in Web. \& Mohr Beitr. Nat. ii. p. 304 (1810). Cenumyces fimbriata var. carneopallida Ach. Syn. Lich. 1). 258 (1814) pro parte. $25,26$.

Exwice. Johns. n. 291 (var. plyyllostrota); Mudd Clad. nos.

Considered by Wainio (Clad. Univ. ii. p. 319) as a variety of C. fimbriata. It resembles the subsp. fibula in the form of the podetia and also $C$. gracilis in being partly corticate. Here also squamules are occasionally formed on the podetia (var. phyllostrota Floerk. tom. cit. 1). 79; Mudd Brit. Clad. p. 15). Several forms recorded by Floerke (tom. cit. pp. 77 and 78) and cited by Mudd (tom. cit. pp. 14 and 15 ) as occurring in this comintry are: f. truncata with the podetia dilated above and trumente; f. orlontota with the seyphi. dentate at the margins; and f. paruphyonema with long porletia and proliferous scyphi. Mudd records two others, f. abnrtiva with somewhat deformed podetia and $\mathrm{f}$. rmosi glabrous and brancherl above.

Hab. On decaying trunks and turfy soil.-Distr. Tocal and scarce throughout England.-B. M. Near Bodmin, Cornwall; Becky Fialls. 1)evou; Amberley, Sussex; Snaresbrook, Epping Forest, Essex; Malvern, TVorcestershire; Dolgelly, Merioneth ; C'leveland, Yorkshire; Windermere, Westmoreland; Ashgill, Cumberland; New Galloway; Kirkeudbrightshire; Barcaldine, Argyll; Loch Iiatrine, Perthshire; S. of Fort IVilliam, Invernessshire.

Form ceratodes Floerk. Clarl. Comm. p. 77 (1828). Podetia short, rather swollen below, tapering upwards to subulate tips.Cromb. in Grevillea xi. p. 112 it Monogr. i. 1) 142. I'. pyridate var. ochechlora f. reratrides Mudd Brit. Clad. p. 14 (1\&65).

Exsicc. Johns. n. 292 ; Mudd Clad. n. 23.

I)iffers from the species in the ascyphous subulate porletia which are rarely branched, but sometimes squamulose.

Hab. On decariug trunks and turfy ground in shady localities.Distr. Appatently local and rare in S. 11 . and $\mathrm{X}$. Jinglind, and anong the Central seottish Cirampians. B. .K. Near Bodmin, Cornwall, Becky Fulls, 1)eron; Iommstale, ('levelunt, Yorkshire; Cum. berland ; liamoch, l'erthshire; Loch Limhe. Invernessshire.

14. C. pityrea Fr. Nov. Seherl. Crit. 1) -21 (18.)(i).-- Primary thallus squamulose, oftron evanereent: the squamules small, rather thin, moyish-green, white beneath; podetia with thin walls, rather short, corticate or entirely decortieate and granularsorerliate or with a fow squanules, grreyish-white, the si:yphi narrow, irresularly formed, funleriate and often poliferous at

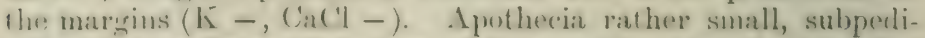

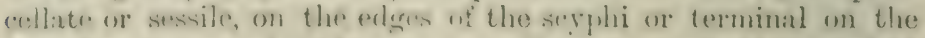
brameles, pale- or dark-lown ; paraphyas searecely thickened at 
the tips.-Cromb, in Grevillea xi. p. 112 \& Monogr. i. p. 1:32. C. pyxidate var. pityrea Nyl. ex Le Jolis in Mem. Soc. Sci. Nat. Cherb. vi. p. 241 (1858); Mudd Brit. Clad. p. 15 (incl. ff. scyphifert, fuscicularis, fimbriatula and phyllophoru); Leight. Lich. Fl. p. 60 ; ed. 3, p. 57 (incl. var. decorticata); var. symphicarpa Cromb. (non Ach.). \& subsp. pityrea Cromb. Lich. Brit. p. $18(1870)$. C. squemose var. deeorticate Mudd Man. p. 56 (1861) (? Scher.). C. Lamarkii Nyl. in Flora lviii. p. 447 (1875); Cromb. in Journ. Bot. xiv. p. 360 (1876) \& Monogr. i. p. 133 ; Leight. Lich. Fl. ed. 3, p. 54. Coralloides parum ramosum, tulerculis fuscis Dill. Hist. Muse. p. 97, t. 15, tig. 20 (1741). Capitularia pityrea Floerk. in Mag. Naturf. Fr. Berlin ii. p. 135 (1808). Cenomyces pityrea f. Aecorticata Ach. Syn. Lich. p. 254 (1814).

Exsice. Johns. nos. 287, 289 (f. Memudata) ; Larl). Ciesar n. 8; Nudd Clad. n. 16 pro parte, 27-29 and 38.

A viriable species with somewhat naked whitish podetia, it is not unlike a small form of C. squamosa in general habit, but frequently seypliferous. The podetia are usually narrow and more furfuraceous thin those of $C$. py.xiduta and more granular than $C$. fimbriatu. The apothecia are small and sessile, or subpedicellate and large. Joinson's specimen, $\mathrm{f}$. denudata, includes podetia very similar to those of C. pityrea with others that are sparsely squamulose. There is no specific difference between the two species C. pityrea and C. Lamariai exeept a slight reaction with potash recorded for the latter. The respective forms hololepis and Isignyi are also alike in being more squamulose than the species.

$\mathrm{Hab}$. On the ground among mosses and on dead stumps of tries.-Distr. Loeal and scarce throughout the British Isles.-B. M. Noirmont, Jersey ; Helmentor aud Bodmin, Cornwall ; Dartmoor, Devon ; New Forest, Hants; Chiddingly Wood and Tumbridge TVells, Sussex; Lounsdale, near Roseberry, Ayton Moor and Hlack Banlis, Clevelind, Yorkshire; Weardale, Durham; New Gallowas, Firlsudbrightshire; Apin, Argyll ; Rannoch, Perthshire; near Ballater, Aberleenshire; Loch Linnhe, Invernessshire; Kylemore, Galway.

Form hololepis Cxomb. in Grevillea xi. 1) 112 (1s83) \& Monogr. i. 1). 1:33.-Poletia short, squamuluse-furfuracenus, the squamules fracile and more or less pulrerulent. - Var. hololepis liloerk. Clad. Comm. p. \&3 (18:8). C. pyriutatu var. pitypeu it. hololepis and d' Insigmyi NIudd Brit. Clad. p. 16 (1865) (non exs. 1. :39). C. Lemarlaii t. Isigmyi Nyl. in Flora lviii. p. 4.47 (1875): ('romb. Monogrr. i. p. 1:34. Cenomyce Isignyi 1)el. ex Nyl. 1. e.

Exsicc. Johns. 1. 288; Larb. Lich. Hb. without a number.

$H a b$. On the ground among heaths or unosses in maritime and

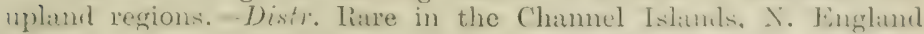
and the Grampians, Scotland.-B. M. Grisnez Common, Jersey; Tumer's Jill, Sussex: Tiastgate, Weardale, Dmham: near Falls of

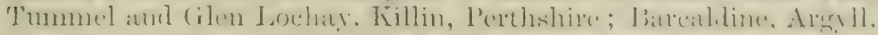

15. C. acuminata Norrl. in Medd. Siillsk. Faun. \& Fl. Fenn.

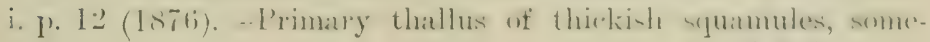


times large fut usually smoll, greenish-grey above, white beneath ; fodetia slender, elongate, rather cylindrical, simple or branched, ascylhous, irregularly branched, acminate at the apices, decorticatr and granular-furfuraceous; sreyish-white ( $\mathrm{K}+$ yellowish, ( $\mathrm{aCl}$-). Aprothecia terminal, small, brown; spores fu.iform or wrid, 10-16 $\mu$ lons, :3-4 $\mu$ thick.-Cromb. in Grevillea xi. p. 11:

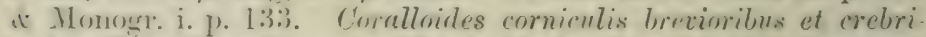
wilums 1)ili. Hist. Musc. p. 104, t. 16, fig. 27 E $(17+1)$. Cenomyce pityrea f. armminata Ach. ryn. Lich. p. 256 (1814). C. pyxiduta var. pityrea f. areminatu Mludd Brit. Clacl. p. 15 (1865).

Near to C'pityren, but distinct in the constantly pointed branches.

Hal,. On the ground aunong mosses in subalpine districts.-Distr. Jocal and searce anong the Grampians, Sontlind, and in X. W. Ireland I Galway).-B. M. Heat of Glen Callater, Braenar. Aberdeenshire.

\section{Podetia partly or entirely corticate, often ascyphous.}

\section{Basal squamules rather large.}

16. C. degenerans spreng. Syst. Veg. iv. p. $273(1827)$.Primary thallus rather scanty, the syuamules small, crenate at the margins, glaucous-green above, white heveath; podetia moderate in size, smowth at first then warted, uneven, and tomentose between the scattered corticate areole, rarely squamulose, whitish or pale-greenish, becoming black, especially at the base and then punctate (maculate) with the lisht-coloured areolas scyphiferous, the seyphi often radiate or proliferous at the margins ( $\mathrm{K}-, \mathrm{CaCl}-$ ). Apothecia rather large, lorown; paraphyses clavate at the tips: spores $10-11 \mu$ long, 3-5 $\mu$ thick. II udd Brit. Clad. 1. 17 (incl. ff. leaploten and enphorea); Cromsh. Lich. Brit. p. 19 (incl. var. Kaploten) \& Monogr. i. p. 146 (incl.

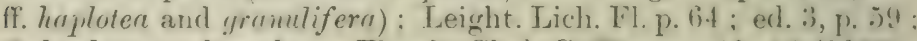

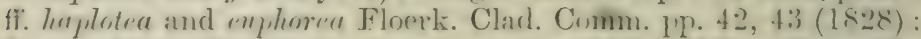

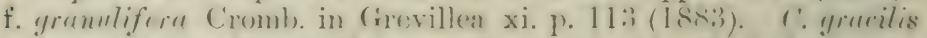

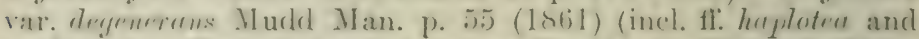

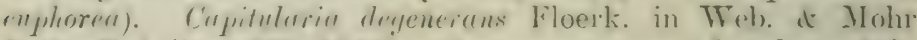

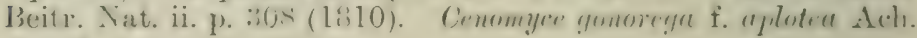
Syn. Lich. p. 258 (1814).

The distinguishing thoush sonetimes ol-eme eharacter of this and the following species is the blackening of the subeortial laver of

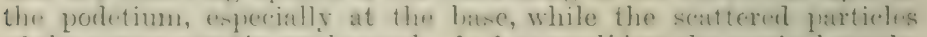

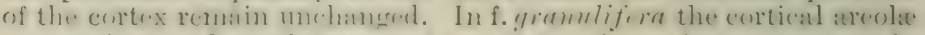
are swollen and partly spammlose, fiving the porletimn a comsely

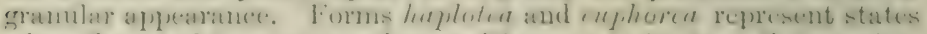
when the seyph are nore or lesen proliferous cr cristate at the matgins.

$H a b$. On the ground in alpine and subalpine regions.-Distr.

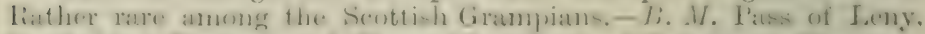

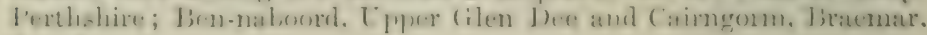
Aberdeenshire. 
Var. anomæa Cromb. Lich. Brit. 1. 20 (1870, \& Monogr. i. p. 147.-Podetia short, slender, usually more or less thickly beset with squamules: scyphi usually radiately divided. Apothecia sessile or pedicellate, dark-brown. - Form anomæa Fluerk. Clad. Comm. p. 4:i (18:8); Mrudd Brit. Clad. p. 1s ; Leight. Lich. Fl. p. 64 ; ed. :3, p. 60 ; ff. ply llophorre and phyllocephala Koerb. Syst. Lich. Germ. p. 20 (1855); IIudd 1. c. ; f. Meolepintin Nyl. Lich. Seand. p. 54 (1861); Cromb. Nonogr. i. p. 147. (. gracilis var. degenerans fi. anomæa and phyllophore IIudd Nan. p. 55 (1861). Lichen phigllophorus Ehrh. Pl. Crypt. n. 2287 (1793) (fide IV ainio Clad. Univ. ii. p. 151 (1894)). L. unomaeus Sm. Engl. Bot. t. 1867 (1808). Patellaria fusca var. degemerans f. phyllorephalum Wallr. Saulch.-Flecht. p. 130 (1829). Cenomyre anomred Hook. Fl. Sૈeot. ii. p. 63 (1821). Sryphophumus anomrus Hook. in Sm. Engl. Fl. v. p. 238 (1833).

Exsicc. Aludd Clach. n. :i2 (as $('$. pyxidutu var. pityren f. squamulosa).

Distinguished by the squamulose character, and not to be confused with $C$. squamosa, in which the podetia and squamules are somewhat furfuraceous and the scyphi perforated. The blackening of the portetia is not constant. Fom pleolepider, with small ascyphous squamulose porletia, dark-coloured and white-punctate, is evidently a growth form of the variety, thongh it has been referred by Wainio to $C$. squamosu (Clad. Univ, ii. p. 137).

Hab. On the ground in heaths, and on rotten wood.-Distr. Somewhat searce in S.W. and N. England, in S. and Central Scotland and among the Grampians.-B. MI. Near Hurstpierpoint, Sussex; Dartmoor, Deron; Nalveru, Worcestershire; Burton Head, Cleveland. Yorkshire; Pentland Hills, near Edinburgh; Sidlaw Hills, Forfarshire; Glen Quoich, Glen Callater and Morrone, Braemar, Aberdeenshire.

Subsp. trachyna Nyl, ex Nurrl. in Not. Sïllsk. Faun. if Fl. Fenn. Förh. xiii. p. 319 (1873).-Podetia slender, cylindrical, usually smouth, greyish-white, areolate and tomentose in the interstices, proliferous at the margins of the denticulate radiate scyphi, forming sereral tiers of short podetia. Apothecia minute, brown.-Cromb. in Grevillea xi. p. 113 \& Monogr. i. p. 147 ; f. trarleyme Floerk. Clad. Comm. p. 41 (18:8); Mudd Brit. Clad.

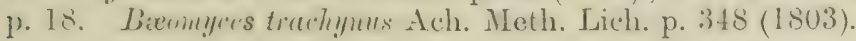

The blackening at the bass of the porietiat is searecly evident. but the corticate areolie with the tomentose interstices shor the atlinity with the species.

Hab. On heathy ground amongst moss in upland regions.-Distr. Rare among the Scottish Grampians. - 13. M. Cairntoul and Bennaboord, Braemar, Aberdeenshire.

Form subfurcata Nivl. ex Norrl. tom. eit. p. 3301). - P'oletia elongate. aseyphous, branched, fastigiate, the areoled giving a granular une"pual surface, brownish. Apothecia not soen. Cromb. in Grevillea xi. p. 113 (1883) \& Monogr. i. p. 148. 
The mamnliu-like areolir mark the difference between this fom and $C$. furcata to which it bears a strong resemblance.

$H a b$. On moist peaty ground in subalpine tracts.-B. M. Upper Glen Dee, Braemar, Aberdeenshire.

17. C. lepidota Nyl. in Not. Sailsk. Faum. ¿ Fl. Fenn. Förh. n. ser. $\vee .1 \% \cdot 176(1866)$ (non Ach.).--Prinary thallus of large, crenate sfuanules, pale-glaucous above, areolar more or less beset with large syuamules at the blackened pale-spotted base, the scyphi narrow, irregular, difform or cristate ( $\mathrm{K}+\mathrm{yellow}, \mathrm{CaCl}-$ ). Apothecia small, conglomerate brown : spores fusiform-oblong, 9-15 $\mu$ long, 3-4 $\mu$ thick.-Cromb. Monogr. i. p. 19.

Distinguished by the large squamules. The species has been recorded by Tramio (Clad. Lnir. ii. p. $159(18941)$ as C gracilescens. He includes Crnomyer gomorega f. le pidota Ach. Sin. Lich. p. 25 ? (1814) as a form of ( $\therefore$. degenerans (tom. cit. p. 15i3). The species hats not been recorterl in the British Isles, only the following form.

Form hypophylla Cromb. in Grevillea xi. p. 113 (1s83) \& Monogr. i. p. 14r.-Basal squamules rather langre, crowded, greyish-white or greenish-grey, white beneath, rising from a stalk-like base which is often black, with scattererl white spots; podetia short or long, more or less squamose, ascyphous but often irregularly branching, and foliaceous, the edgres studeled with brown oroid or subglobose pycnidia.- $C$. deyenerans f.

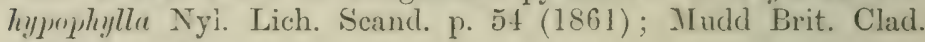
p. 18 .

Exsice. NIudd n. 9 pro parte \& Clad. n. 39.

A verry peculiar form, the podetia having the appearance of enlarged squamules. It approaches very near to some growth forms of $C$. cervicomis. IIndd's ('. cervicomis f. prorliga belongs possibly to this form (Brit. Clad. p. 4).

Hab. On the gromd anong rocks in mpland districts.-Dists. Not uncommon where it occurs in $S$. and $\mathcal{X}$. England and Wales, S. sicotland and among the Grampians.- I3. M. Intrinoor, Deron; Llanwtydd Wells, Brecknockshire; Plinlimmon, Cartiganshire: Dolgelly, lihewgreidlen and Maes-y-graruedd. Merioneth; Carnedd J)afydd and Bettw-y-Coed, Camarvonshire; J battershy, Ingleby and Ayton Moors, Cleveland. Yorkshire; Ennerdale, Cunberland; New Galloway, Kirliculbrightshire; Demnat, nerr Stirling; ('raig Calliach,

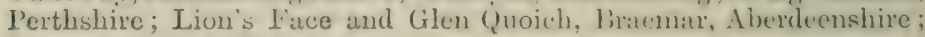
Slicve More, Achill Island, Mrayo.

18. C. cervicornis F(char. Eumm. p. 1!5 (18.50) pro parte.-

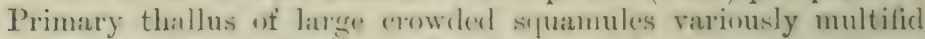
aserending, firm, renate, dark olive- or glancous-green above, whitish or hownish-linels beneath; puletiat short, corticate,

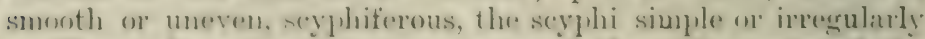
proliferous from the margins, more rarely from the centre of the s'yphus, somedimes squamulone (

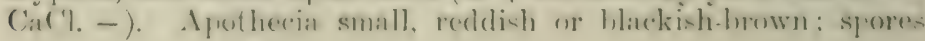


oblons-fusiform, 7-16 $\mu$ long, 3 $\mu$ thick.-Mudd Brit. Clard. p. 4 (incl. f. prodiga? excl. var. verticillatu); Leight. Lich. Fl. p. 57 ; ed. 3, 1. 54; Cromb. Monogr. i. 1. 14t; f. stipate Nyl. in Flora lix. 1) $239(1 \wedge 76)$; Cromb. in Journ. Bot. xiv. p. 360 (1876): Leight. Lich. Fl. ed. 3, p. 55. C. yracilis var. cervicumis Schare. Lich. Helv. Śpic. p. 297 (1833) pro parte; Mudd Man. p. It ; var. sololifere and subsp. revvirnmis Cromb. Lich. Brit. p. 19 (1871). C. verticillate var. soholifera Leight. in Ann. Mag. Nat. Hist. :er. 3, xviii. p. 411 (1866) \& Lich. Fl. p. 64; ed. 3, p. 59. C. snbolifera Nyl. in Bull. Soc. Linn. Norm. ser. 2, vi. p. 282 (1872); Cromb. in Grevillea xi. p. 113 (1883) \& Monogr. i. p. 144. Lichenoides 1mxidutum marginibus clegunter foliatis Dill. in Ray Syn. ed. 3, p.69, n. 33 (1724). Coralloides sryphiforme, marginibus raliatis ef foliatis I ill. Hist. Muse. p. 85, t. 14, figs. $9 \mathrm{~A}, \mathrm{~B}$ and foliis alcirornibus cartilayinosis p. 87, t. 14 , fig. 12 B (174l). Lichen cervicomis Ach. Lich. Suec. Prodr. p. 184 (1798); Engl. Bot. t. 2574. Cenomyce cervicornis Ach. Lich. Univ. p. 531 (1810) (incl. var. prodiga): Tayl. in Mackay Fl. Hib. ii. p. 81. C. clatomorpha var. sobolifera Del. in Duby Bot. Gall. p. $6: 31$ (1830). Scyphophorus cervicornis S. F. Gray Nat. Arr. i. p. 418 (1821); Hook. in Sm. Engl. Fl. v. p. 238.

Exsice. Croall 12. 597 ; Johns. n. 12; Larl). Lich. H1). n. 322; Leight. n. 14 ; Mudd n. 9 pro parte \&t Clad. n. 2.

Agrees with the following in the occasional central branching of the podetia, which are however shorter and more irregular in form and sometimes squammlose (f. prodiga). It differs in the more highly. developed primary thallus; the squamules vary in size and form and are sometimes very long and narrow (f. stipata). It is so frequently sterile that the more fertile condition in which the basal thallus is less pronounced has been sometimes considered a separate species (C. sobolifera).

Hal. On the ground and on mossy boulders and rocks in maritime and upland districts.-Distr. General in hilly and mountainous regions, rare in the Channel Islands. $-B$. M. Grosnez and Quenvais, Terser; Pleimmont, Guernsey; St. Breock, Helminton, Withiel, Penzance and near Wadebridge, Cornwall; Dartmoor and Bolt Head, Devonshire; Bathampton, Somerset; MIalvern, IVorcestershire; Rhewgreidten, Dolgelly and Aberdovey, Merioneth; Llanberis, Cardiganshire; near Capel Curig, Carnarvonshire; Anglesea; Buxton, Derbyshire; Ayton and Ingleby Moor, Cleveland, Yorkshire; Teestale, Durham; Windemere, Westmoreland; New Galloway, Kirkeudbrightshire; Moffat. Dumfriesshire; Pentland Hills, near Edinburgh; Barcaldine art Appin, Argyll; Glen Lochay, Ben Ledi, The Trossachs. Ramnoch and Craig Calliach, Perthshire; Ben-naboord, Braemar and Countesswells, Aberdeenshire; Glen Neris, Invernessshire; Apple. cross, liossshire; Lairg. Sutherland; latlyedmond, Cork; Killarmey and Carig Mt., Kerry; Kylemore, Gallway; Achill and ('lare Is]ands. Mayo.

19. C. verticillata Floerk. Clad. Comm, 1. 26 (1825:Primary thallus somewhat seanty, the squamules rather narrow 
crenate, dark-olive or greyish-green; podetia corticate, smooth, glancous- or brownish-green, seyphiferous, the seyphi regular, denticulate at the margins, repeatedly proliferous from the centre of the cups. Apothecia moderate, brown or reddish, spores oblong or rarely ovoid-oblone, $7-16 \mu$ long, $2-3 \mu$ thick.-Leight. Lich. Fl. 1) 63 ; ell. 3, p. 59 : Cromb. Ilonogr. i. p. 143. C. pyxidata subsp. verticillata Hoffm. Deutschl. Fl. ii. p. 122 (1795). C. gracilis var. verticillatn Fr. Lich. Eur. p. 219 (1831) pro parte; Mudd Man. p. 54. Subsp. verticillata Cromb. Lich. Brit. p. 19 (1870). C. cervicornis var. verticillate Flot. in Uebers. Schles. Ges. 1805, p. 105; Mudd Brit. Clad. p. 5. Lichenoides tubulosum pyxidutum proliferum Dill. in Ray Syn. ed. 3, p. 69, n. 29 (1724). Corullvides sryphiforme, tuberenlis fusctis Dill. Hist. Musc. p. 79, t. 14, fig. 6 D-II (1741). Lichen pywirlutus var. L. Sp. Pl. p. 1151 , n. 59 (1753); Huds. Fl. Angl. ed. 2, 1. 551; With. Arr. ed. 3, iv. p. :36. Scyphophora verticillutu S. F. Gray Nat. Arr. i. p. 418 (1821).

Exsicc. Mudd Clad. n. 3.

Easily recognized by the frequent central proliferations forming up to five tiers of podetia. British forms are rarely fertile.

Hab. On mossy rocks and boulders in maritime and inland districts.-Distr. Local and scarce throughout the British Isles.B. MI. Noirmont, Jersey, St. Breock, Cornwall ; Broadwater Forest, Tumbridge Wells and Maresfield Common, Surrey; near Shirley, Surrey; Delamere Forest, Cheshire; Ayton Moor and Baysdale and Farndale, Yorkshire; Glen Lochay, Killin, Perthshire; Moor of Morrone, Braemar, Aberdeenshire.

Form laciniolata Nyl. ex Cromb. in Grevillea xi. p: 112 (1883).-Primary squamules elongate and narrow; podetia with the scyphi squamulose at the margins; probably due to excessive moisture-Cromb. Monogr. i. p. 143.

Hab. On exposed rocks in moist places. - Distr. Found only spatringly in S.W. England and the S.W. Highllands of Scotland.B. M. Carn (ialva, P'enzance. Cornwall ; Jarealdine, Argyll.

\section{Basil squamules small, scanty, scattered.}

20. C. gracilis Willd. Fi. Merol. p. 363 (178T). - Primary thallus scanty, the synamules rat her small, olive-green or brownish above, whitish beneath. "ffen. cranescent; podetin usually numerous and crowderl, elongate, slender, rntirely corticate and smouth, simple or brancherl, segphiferums or tapering to a peint, the seyphi narmow or rarely dilated, torming a rather deep cup which is rlenticulate or proliforous at the margins, pale-greyish

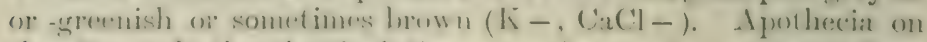
the tips of the denticulations rarely sesile on ascyphous

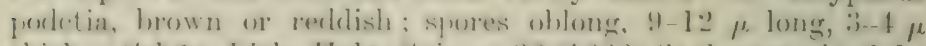

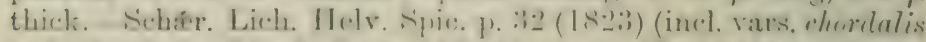
and ahontiva); linert). syst. Lich. Cierm. p. ls (15.55) (incl. var. 
vulyuris ff. ceratostetis and proboscidea); MIurdd Man. p. j4 (incl. f. chorlalis) \& Brit. Clad. p. 16 (incl. ff. cerutosielis, proboscideu, aburtiva and churdalis); Cromb. Lich. Brit. 1) 19 (incl. f. chordulis) \& Monogr. i. p. 139 (incl. subs]). gracillima); Leight. Lich. Fl. p. 6.2; ed. 3, p. 58 (incl. vars. chordatis and ahortiva). Corallina. montana tubulosa sc. Buddle Hort. sicc. ii. fol. i. nos. 10 \& 12 , in Herb. Sloane. Lirhenoides pyxidutum rinereum elatius, ramulis pyxidutim desinentilus Dill. in Ray sym. ed. :3, p. 69, 11. 3-2 (17.24). Corulloides scyphiforme serratum elutius, eculibus grarilibus glubris Dill. Hist. Musc. p. 8\&, t. 1t, fig. 1:3 c, D $(17+1)$. Lirhen grarilis L. Sp. Pl. p. 1152 (1753) ; Huds. Fl. Angl. p. 457 ; Lightf. Fl. Scot. ii. p. 87:3; With. Arr. ed. 3, iv. p. 37 ; Lngl. Brt. t. 1284. Capituluric yrucitis f. chordulis Floerk. in Web. \& Mohr Beitr. Ta.t. ii. p. 324 (1810). Crnmyer ecmenna Ach. Lich. Univ. p. 519 (1810) (incl. var. gracilis). C. gracilis Hook. Fl. śot. ii. p. 63 (1821); Tayl. in Mackay Fl. Hib. ii. p. 8:. Scyphophora ecmocyna (incl. var. gracilis) S. F. Gray Nat. Arr. i. p. 421 (1821).

E.crice. Johns. 11. 49 : Larb. Hb. 11. 20T it Liclı. Cantab. 11. 3 ; Leight. n. 296 ; Mudd nos. 10, 11 ; Clad. nos. 34-37.

Many varieties and forms of this lichen have been recorled ; chief among ilnen rar. chordatis with proliferous serphi, recognized by Floerke (1. c.) as probably a growth form and here included with the species; f. abortiva, a rather rare form, has the slender podetia terminated and oceasionally distorted by the apothecia; f. cratostelis is wholly ascrphous ancl sterile, a state of the podetia continually associated with those hearing seyphi. A very slenter form, issued by Norilin as subsp. gracillima (Hb. Lich. Fenn. ix. n. 424 (1882); Cromb. in Grevillea xi. p. 112 (1ss:3) of Monorr. i. p. 141) has been determined by Wianio (Monocr. ('lau. Lnir. iii. p. 251 (1s9s)) as a modification or growth form with much branched podetia.

As a rule the podetia of $C$.gracilis grow in crowded and often yuite extensire clumps; they are more or less slender and ulegant in form, about 5-10 cm. long; they tend to become blaclish and to die off at the base.

Hab. Among mosses on the ground and on rocks.-Dis/ 1 . General and common in most parts of Great Britain and Ireland; rare in the Channel Islands.-D. M. Guernsey; Sirk; near Penzauce, Cornwall; Dartmoor, Devon; Arlingly Pocks, Sussex; Lydd, Kent; High Down near Godalming, surrey; Hampstear, London (1Sth century); Wokingham Heath, Berks; Charnwood Forest, Leicestershire: Worecster l Beacon; Barnonth and b)olrelly, Nerioneth; Llanditona, Ancreser ; Hazelbeech, Northamptonshire; Epping lorrest, Essex: Thetford Wiaren, Suflolk; Wootton Common, Norfolk; ('hesterfiell. Derhyshire; Ingluy l'ark, Arto:l Mron and ITigheliffe, Clereland and Famblale, Yorkshire; Equrlestone, Durlum, The Cheriots, Northumberlimu; Samplugh, Cimberland; New Cialloway, Kirkendbrightshire; Manor Heant. Peethlentre: Harealdine, Argyll; (ilen

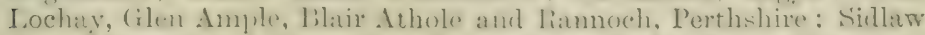

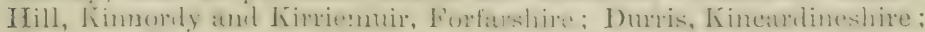

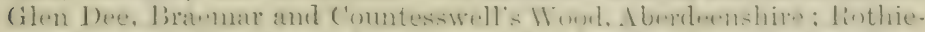

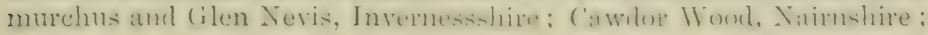


Forres. Flumshire; Apllecross, Tossthire; near Cork; Tore Mt. ant Killarney, Kerry; Ballynascreen Mts., Tyrone.

Form spinulifera Cromb. Monorr. i. p. 140 (1894).--Podetia slender, dark-brown, comewhat wrinkled, the stalks besct with short spinules; scyphi with the margins spinulose.

Hab. On moors.-B. M. Near Newton Abbot, Devon.

Var. hybrida Schær. Lich. Helv. Spic. p. 32 (1823).Puletia more or less elongate, robust, sparingly branched, usually scrphiferous, the seyphi narrow or dilated, simple or proliferous at the margins. Apothecia rare. - Mudd Man. p. 5.) (? incl. f. simplex) \& Brit. Clad. P. 17 (incl. var. macroceras); Cromb. Momogre i. p. 141 : var. marimeras Floerk. Clad. Comm. p. 38 (1828). (¿. Thlurida Hoffin. Deutsehl. Fl. ii. p. 119 (1798). C. arecilis f. Iongatu Croml). Lich. Brit. p. 19 (1870). Ceralloides scyphiforme etc. Dill. tom. eit. fig. 13 A, B. Lichen elongutus Jacy. Misc. ii. 1) 368, t. 2, fig. 1 (1781). C'apitnlariu !racilis var. maerorerus Floerk. in Weh. \& Molrr Beitr. Nat. ii. p. 330 (1810) (incl. f. elongata).

A rolnust plant, with the podetia unually scyphiferous. There is no sufficient reason for dividing the rarietr. as Wiainio has done, into

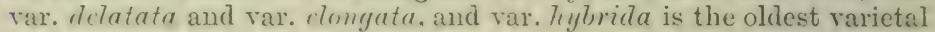
name.

$H a b$. On mossy rocks and among mosses on the ground in high or mountainous districts.-Distr. In upland regions of N. England and Sentland.-B. M. Arton Moor. Cleveland, Yorkshire; Sidlaw Hills. Forfarshire; Killin, Perthshire.

Tar, aspera Floerk. Clad. Comm. p. 40 (1:28).-Podetia rather slender, mostly ascyphous, more or less squamulose, the squanules crenate at the margin.-Form aspera Cromb. in Grevillea p. 112 (18s.) \& Monogr. i. p. 141. Capitularia yrurilis var. axyera Floerk. in Web. d Mohr lieitr. ii. p. 333 (1810).

Exsicc. Leight. n. 402.

Jiffers from the species in the presence of squamules on the podetia.

Hah. (On the ground in inland sitnations. - Distr. Local and scatree in Central und X. Fingland.--1). M. Charnwood Forest. Leicestershire; [nteby l'ark. ('levelind, Yorkshire; Windermere. Westmoreland.

21. C. cornuta Fr. Lich. Eur. p. 225 (1831).-Primary thathus of seatfered squamules or nome, the squamules small,

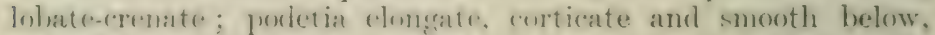
julverulent towards the apdice. tajering to a point or sometimess with narow scyphi (K - C C (Cl - ). A pothecia small, brown:

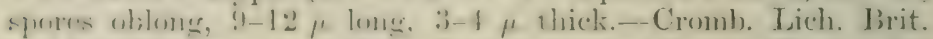
p. 19 d Monogrr. i. p. 141. Lichen cormutus L. Sp. Pl. p. 1152 (1753). 
Distinguished by the seanty squamules and by the semi-corticute podetia, which are to $10 \mathrm{~cm}$. high. Apothecia and spermogones are very rare in British specimens.

Hab. Among mosses on the ground, on heather, and in woods in upland tracts.-Distr. Rather: rare in N. Englaul and the Graupians, Scotland.-B. M. A yton Moor, Clevelind, Yorkshire; Sheriffmuir. Stirlingrhire; Tiannoch and Trilliecrankie, Perthshire; J3allochbuie Forest. Bramemar, Aberleenshire; liothienurchus, Invernessshire.

Form clavulus Fr. Lich. Eur. p. 225 (1831).-Podetia short, turorid, curved, granular-furfuraceous, corticate in small areas or near the base, without scyphi.-Cromb. Monogr. i. p. 142.

Hardly to be distinguisherl from "cornute " forms of $C$. fimlnintu except by the corticate areas. It is evidently a sterile form.

Hab. On turf walls in upland districts.-Distr. Local and scurce among the Central and N. Grampians, Scotland.-B. M. Rannoch. Perthshire; Glen Quoich, Braemar, Aberdeenshire.

\section{Podetia fissured or latticed.}

2.). C. macrophylla Stenh. in Öfvers. K. Vet. Akad. Fürh. 1865, p. 231.-Primary thallus of rather large squamules, glaucous-green above, whitish beneath, crenate at the margins: podetia moderate in size, cylindrical, rough with small squamulose vutgrowths from the areolae of the cortex, ascyphous or with narrow seyphi, becoming fissured ( $\mathrm{K}+$ yellowish, $\mathrm{CaCl}-$ ). Apothecia often rather large and confluent, brown; spores

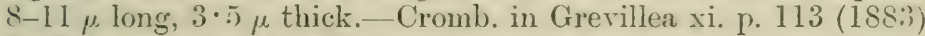
\& Monogr. i. p. 145. C. ventricosa var. macrophylla Schar. Lich. Helv. Spic. p. 316 (1833).

Approaches $C$. cariosa in the splitting of the podetia. It has been confounded with a continental species, C. decorticata, from which it differs in the character both of squamules and podetia.

Hab. On earth-covered boulders and ledges of rocks in wooded mountainous regions.-Distr. Rare among the Grampians, Scotland. -13. M. Head of Glem Quoich, Braemar, Aberteenshire (reconterl also from Craig Calliach, Perthshire).

23. C. cariosa Spreng. Syst. Veg. iv. p. 272 (1827).Sifuamules of primary thallus usually small (rarely large), rounded and crenate, scattered or crowded, greyish-crlaucous, white bencath; podetia rather short to medium length, simple or branched, smooth and partly denudate then sranular, white or greyish-graucous, becoming latticed and open as if carious, the scyphi when present dividing into subfastigiate branches ( $\mathrm{K}+$ yellow, CaCl - ). Apothecia turgid, overtopping the lomelses: hrown; sprores 9-1:3 $\mu$ lones, $4-5 \mu$ thick.-.lingl. Bot. Nuprl. $t$. 2761 ; Mudd Brit. Clad. p. 6 ; Cromb. Lich. Brit. p. 19 dt Monogr. i. p. 134; Leight. Lich. Fl. p. 57 ; ed. 3, p. 55. C! grarilis var. degemerans f. mriosa Mudd Man. p. 5.) (Isfil). 
Circalloides fungiforme fuscum, busi folincra Dill. Hist. Musc. p. 77 , t. 14, fig. 2 (1741). Lichen cariosus Ach. Lich. Suec. Prodr. p. 198 (1798). Cenmence cariosr Ach. Lich. Univ. p. 567 (1810); Tayl. in Mackay Fl. Hib. ii. p. 80.

Exsicc. Mudd Clad. n. 5 ; Johns. 11. 243? (possibly C. degenerans).

Distinguisher by the cancellate porletia and by the reaction. The basul stuamules are mostly very small, not unlike those of $C$. leptophylla.

Hab. On clayey and sandy soil in maritime and inland wooded districts.-Distr. Apparently local and searce in S. W. and X. Evgland, IV. Highlauds of Scotlind and S. W. Ireland.-B. M. Tile of Ecclesboume, Sussex; Horsemonden, Kent; Wyre Forest and Bewdley, Worcestershire; Arton, Cleveland, Torlishire; Barcaldine, Argrll ; Loch Katrine, Perthshire; Lochaber, Invernessshire.

\section{Podetia with perforations at the axils of branches, at tips or in scyphi.}

1. Podetia corticate, smooth, mostly ascyphous.

\section{Basal squamules rather large or medium-sized.}

24. C. turgida Hoffin. Deutschl. Fl. ii. p. 124 (1795).Primary thallus of rather large laciniate lobate squamules, entire or crenate at the margins, glaucous-green or whitish above, white beneath, sometimes few or evanescent: podetia one or more rising from the surface of the squamules, elongate, turgid or subcylindrical, sometimes sparsely squamulose, ascyphous or obsoletely scyphiferous, dentate-radiate at the margins, generally perforate at the tips, in the scyphi, or in the axils, smoothly corticate, glaucous or pale-green ( $\mathrm{Kit}+$ yellowish, $\mathrm{CaCl}-$ ). Apothecia rather small, brownish-red or pale : spores oblong or marely fu-iform-oblong, $8-1$ is $\mu$ long, :3-4 $\mu$ thick.-Cromb. Lich. Brit. p. 20 is Mommer. i. p. 149 : Lecight. Lich. Fl. p. 56 ; ed. 3, 1. .74. Lielern twrgidns Ehrh. Pl. ('rypt. n. 2997 (1793) nomen nudum.

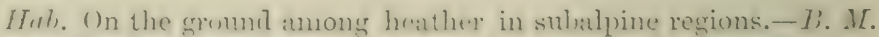
Head of Glen Quoich, Braemar, Aberdeenshire.

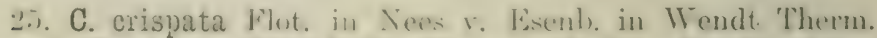
Warmi). Biretau, p. 43 (1:40). - P'rinary thallus of rather large or suall squamules, depely wenate or sublaciniate, ascending, Glaurous of hownish above. white helow, smotimes evanescent; pocketia mollerately long, often scrphiferons, rather turgicl, palecreyioh on hrownish. sometimes with souamules, corticate and

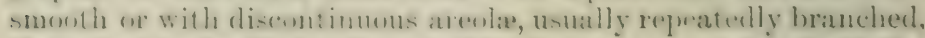
the apress amb axile pervioms, with the agertures cristate at the

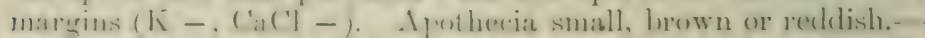

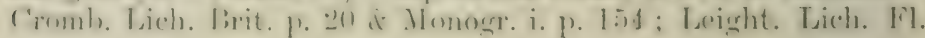


p. 65 ; ed. 3, p. 61. C. furcata var. crispata Floerk. Clad. Comm. p. 148 (1828); Murd Man. p. 57 \& Brit. Clart. 1. 22. Coralloides perforatum minus, mollo et temes Dill. Hi-t. Musc.

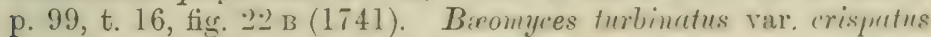
Ach. Meth. Lich. p. 341 (1803).

Exsicc. MLudd Clad. n. 45.

The denticulate-cristate margins of the seyphi and of the openings: both at the axils and tips of the porletia distinguish this species from all others. The spermogones contain red colouring substance.

$H a b$. On the ground among mosses in moorland districts.-Distr. Local and rare in X. Eugland and among the Scottish Grampians.I. AI. Fildare Moor and Lounsdale, Cleveland, Yorkshire; Ben-y-gloe, Perthshire; Ben-naboord and [pper Glen Dee, Braemar, Aberdeenshire.

Var. infundibulifera Wain. Clad. Univ. i. p. 3\$. $(1 \$ 87) .$. Podetia smonth, rather slender, repentedly branched, open at the axils but not cristate, scyphiferous, the scyphi dentate-cristate at the marsins. Subsp. furcutifurmis Cromb), in (irevillea xi. p. 113 (1R,3) (non Nyl.) \& Monogr. p. 155. ('. aranuirles $t$. infundibulifera Schær. Enum. p. 197 (1850).

Exsicc. Mudd n. 12.

Distinguished as in the species by the denticulate processes on the margin of the scynhi, though they are absent at the axils. Nylander's subsp. furcatiformis is, according to Wainio (tom. cit. p. 253), a form of $C$. amaurocrea.

Mab. On the ground among mosses in upland districts.-B. M. Ingleby Park, Cleveland, Yorkshire.

Var. cetrariæformis Wain. Clad. Univ. i. p. 392 (18:7).Podetia scyphiferous or scarcely dilated above but always pervious, the scyphi shortly dentate-1;idiate, rather darker in colour.Cenomyce yracilis f. cetrariæformis Del. in Du?. Bot. Gall. p. 6.2. (18:30). Coralloides scyphiforme serratum elatius, crulibus gracilibus glabris Dill. Hist. Musc. p. 88, t. 14, fig. $13 \mathrm{E}(17+1)$.

Referred by Wainio (l. c.) to this variety; the scyphi are less distinctly eristate than in the previous variety. A small specimen from the Dillenian herbarium is preserved in the British Mnseun. It has not again been collected in the British Isles.

Hab. In sterile shady places.- I3. 11. AIt. Stiperstones, Shropshire.

\section{Basal squamules small, soon evanescent.}

26. C. furcata Schrad. Spic. Fl. Germs. p. $107(1794)$.Primary thallus of small crenate laciniate syuamules, usually obsolete; porletia in tufts, elongate, rather slender, sulerlindrical, corticate, smoth or somew hat uneven, sometimes sparsely sorediose or with a few squanules especially towards the base. often with longitudinal fissures, glaucous-white or hrowni-hgreen, branched, usually perforate at the axils, the branchess somewhat erect, dichotomous or subradiate and corymbuse. 
attenuate-subulate, and spreading-furcate at the apices $(K-$, $\mathrm{CaCl}-$ ). Apothecia small, subglobose, brown; spores $10-13 \mu$ lone, 3-4 $\mu$ thick. $\rightarrow$ S. F Gray Nat. Arr. i. p. 414 ; Hook. in Sin. Engl. Fl. v. p. 2236 (incl. var. subulata); Mudd Man. p. 57 (incl. var. rucemosa f. erectu, and var. subulata, excl. var. crispreta) \& Brit. Clad. p. 21 (incl. var. subulata, with ff. cymosa, timucate (non Floerk.) and exilis); Cromb. Lich. Brit. p. 20 (incl. vars. corymbosn and temuissima) it MIonogr. i. p. 149 (incl. f. cxilis and var. corrymlios (t); Leight. Lich. Fl. p. 65 ; ed. 3, p. 60 ; ff. subulata, temuissima, and cymosa Floerk. Clarl. Comm. pp. 143, 1+t (1828). C. subulata Wigg. Prim. Fl. Hols. p. 90 (1780); i. F. Gray Nat. Arr. p. 414. C. reremosa Hoffin. Deutichl. Fl. ii. p. 114 (1795). C. arborea Stirton in Scott. Nat. ix. p. 121 (1885)? Lichenoirtes tubulosum cinereum, minus crustaceum minusque remosum Dill. in Ray Syn. ed. 3, p. 67, n. 17 (17:24).

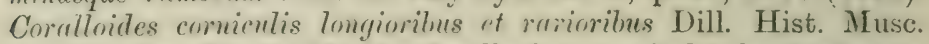
p. 102, fig. $26(17+1)$ \& Coralloides comiculis brevioribus et crebrioribus tom. cit. p. 104, t. 16, fig. $27 \mathrm{~A}$ ?, B pro parte, C. Lichen fuicrtus Huds. Fl. Angl. p. 458 (1762) pro parte \& L. sulum. latus, p. 459 (non L.); Lightf. FI. Scot. ii. P. 881 ; With. Arr. ed. 3 , iv. p. 42 . Cenomyer allotropa var. corymbosa Ach. i.ich. Eniv. p. 556 (1810). C. furcate Ach. Syn. Lich. p. 276 (1814) (incl. var. subulata); Hook. Fl. Scot. ii. p. 6t; Tayl. in Miackay Fl. Hib. ii. p. 80.

Exsicc. Bohl. n. 23 ; Leight. n. 401 ; Mudd n. 16 pro parte \& Clad. nos. 46, 50, 51, 53.

I) istinguished by the smooth corticate podetia and the fureate tips; differing from $C$. gracilis in the absence of sepphi. The variety known either as corymbesa, racemosa or subulata appears to be only it erowth form of the species occurring more frequently in lighter latitudes; it is rather stonter and less distinctly fureate. Hudson's Lirbern furcatus refers partly to this species and in a minor degree to the squamulose var. pinnata. A small rather dark erect form (f. wilis) grows in uplamd districts. On chalky soil the podetia are almost white (f. epermena Ach.).

The forms have been distingruished by Stirton (Sicott. Nat. ix.

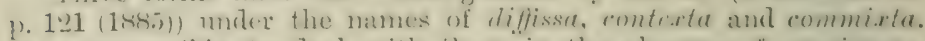
It is impussible to deal with then in the absonee of specimens. Amether specimen with larger apothecia has been described by the sume writer subsp. dispunsa (Scott. Nat. n. s. iii. p. 308 (1888)).

Hab. On the ground on moorlands, and on turfowalls in wooded mpland aistriets. - Dratr. I'robubly general and common throughnut

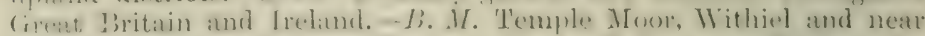

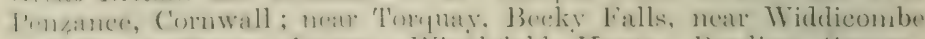

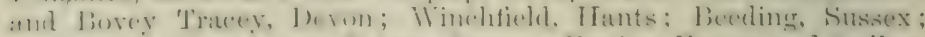

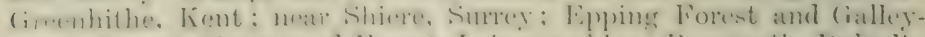

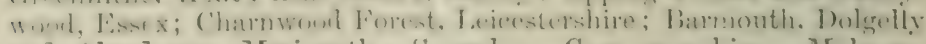
and Aberdovey, Merioneth; Snowdon, Carnarvonshire; Mnlvern,

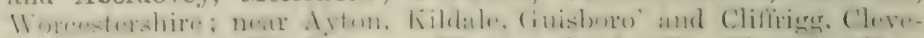

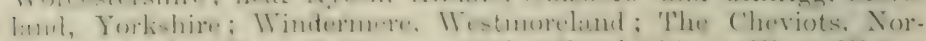

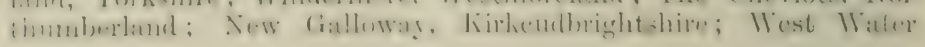


Fife; Baldovan, Sidlaw Hills and Clova, Forfarshire, Appiu, Argyll; Killin and Glen Lochay, Perthshire; Craig Cluny, Glen Dee anit Glen Callater, Braemar, Hill of Fare and Countesswells, Aberdeenshire; near Cork; Killarner, Kierry; Castle Connel, Limerick; Malaranny and Clare Island, Mayo.

Var. spinosa Leight. in Ann. Mag. Nat. Hist. ser. 3, xviii. p. 413 (1866) (? Hook.).-Podetia rigid, glabrous, decumbent, and often entangled, slender or stoutish, the branches curved and flexuose, here and there spinulose. Apothecia small, darkbrown.-Leight. Lich. Fl. 1. 6\%; ed. 3, 1) 60 pro parte ; Cromb.

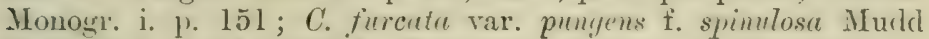
Brit. Clad. p. 2t(1865)? C'uralloides sparsum cuulibus tortuosis et spinosis Dill. Hist. IIusc. p. 101, t. 16, fig. 25 (1741). Lichen spinosus Huds. Fl. Angl. p. 459 (1762); Lightt. Fl. Scot. ii. p. 882 ; With. Arr. ed. 3 , iv. p. 45.

Distinguished by the rather lax irregularly branched and curved podetia, aud by the presence of the short erect or recurved spines. It is often very dark in colour.

Hab. On the ground in moorlands and on turf-walls in upland districts.-Distr. Fairly common throughout Great Britain and Ireland.-B. 1L. Dartmoor, Deron; Lavington Common and Lowns. Sussex; Epping Forest, Essex; Bardon Hill, Leicestershire ; Aberdorey, Merioneth; Anglesea; Newmarket Heath, Cambridge; Ingleby Park. Cleveland, Yorlishire; Harris Moor, Cumberlund ; The Cheriots. Northumberland; Craig Calliach and Rannoch, Perthshire; Baldovan and Sidlaw Hills, Forfarshire; Glen Muick and near Inverary, Braemar and Countesswells, Aberdeenshire; Glen Nevis, Invernessshire; Seymourhill Bog, near Belfast, Antrim.

Var. palamæa Nyl. ex Zwackh Lich. Heidell). p. 1:2 (1:8:3). - Podetia stoutish, curved, nodulose-rugose or smooth, usually. somewhat dilated and branched at the apices.-C. furcatu val. spuerliree Floerk. Clad. Comm. p. 146 (18.8); var. sululuta t. spadieren Mudd Brit. Clad. 1). 23 (1865); subsp. racemense t. pulamæe Cromb. in Grevillea xii. p. 91 (1884) \& MIonogr. i. 1). 152. Bæomyces spinosus var. palameus Ach. Meth. Lich. p. 359 (1803).

Exsicc. Mudd Clad. n. 52.

Not unlike var. spinosa but generally darlier in colour and destitute of spines. The cortex is subcontinuous and the areolie are swoll $=21$.

Hab. On the ground in upland localities.-Distr. Very rare in s. WV. and N. England.-B. M. Brighton Downs, Sussex; near Shiere. Surrey; Bathampton Downs, Somerset; Guisboro' Moor, Clevelaml. Yorkshire,

Var. pinnata Wain. Mon. Clad. Univ. i. p. 332 (1887).-. Podetia more or less thickly beset with squamules, elongate, stoutish, often fissured, the branches erect, furcate at the apices, verforate or clused at the axils. Apothesia minute, lorown.

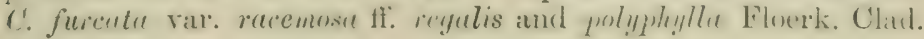


Comm. 川). 154, 15\% (1828): Mudd Brit. Clad. p. 22; var. sululuta $\mathrm{f}$. Ammeta Mudel tom. cit. 1). 23 ; var. racemosa Cromb. Lich. Brit. 1. 20 (1S70) (nom Floerke) ; Leight. Lich. Fl. p. 65; ed. 3. 1), 60) : sulssp. vacenesa Nyl. ex Norrl. in Not. Sïllsk. Faun. it Fl. Fenn. Förh. n. sex. x. 1\%.820 (187:); Cromb. in Grevillea xi. 1. 11:3 (18:.3) \& Momogr. i. 1. 151. Lirhenoides tubulosum cinurem, irmosius et crustareum Dill. in Ray Syn. ed. 3, p. 67, 11. 18 (17:4). Comalloill's corminulis brevioribus ef crebrioribus Dill. Hist. Musc. p. 104, t. 16, fig. 27 B (1741) pro parte. Liden furrutus Hurls. Fl. Ansl. ए. 458 (1762) pro parte; Lightf. Fl. Scot. ii. p. 881 ? With. Arr. ed. 3, iv. p. 45. Cenomyce rurmosa Hook. Fl. Ścot. ii. p. 64 (1821) (non Ach.). C. racemusa vir. primatu Floerk. in Schleich. Cat. Omn. Pl. p. 47 (1821) fide Wainio (Clad. Univ. i. p. 334).

Exsicc. Mudd Clad. nos. $47,48$.

Distinguished by the stoutish podetia which are sparsely suuanulose throughout their entire length with fairly large squamules.

$\mathrm{Hab}$. On the ground in moorlands. usually on damp peaty soil in upland districts.-Distr. Local and scarce in Great Britain and S. W. Ireland.--13. M. Becky Falls, Devon; Malvern, Worcestershire; Aberdorey. Dolgelly and Rhewgreidden, Merioneth; Guisboro' Moor and Ingleby Moor, Clevelaud, Yorkshire; New Galloway, Kirkeudbrightshire: Barealdine, Argyll; Glen Lochay and Ramoch. Perthshire; Glen Callater, Braemar. Aberdeenshire; Glen Nevis, Invernessshire; Killarney, Kerry.

Var. recurva Hofin. 1)eutschl. Fl. ii. p. 115 (1795).--Podetia lender, erect or curverl, often denuderl of cortex especially upwarls, scabrid and more or less beset with minute squamules, the branches divergent, often recurved and furcate at the apices. -...Mudrl Brit. Clarl. p. 2.2 (incl. f. thyrsoilfol); Leight. Lich. Fl. p. 65 ; ed. 3 , p. 60 ; var. adspersa Floerk. Deutschl. Lich. x. 1) 14 (1s21); Leight. tom. cit. p. 61 ; var. rucmosa f. surrecten Floerk. Clarl. Comm. 1) $154(18.25)$; f. rermon Mudd Man. p. is (1861) : var. sprimosn Hook. in sim. Engl. Fl. p. 236 (18:3) (non Iturls.) e descript.: Tayl. in Mackay Tl. Mih. ii. p. so e descript.; sulssp, ruremosil t. resuren Cromb). in Grevillea xi. p. 113 (1883) d Monogr. i. p. 15). (¿. remosu S. F. Gray Nat. Arr. i. p. 414

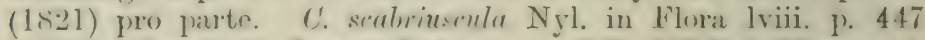
(1875); Cromb) in Journ. But. xiv. p. 360 (18T6) \& Monogr. i.

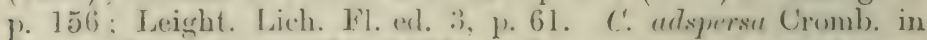

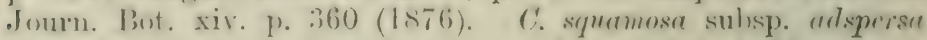
Nyl. ex Cromb. in Erevillea xi. p. 114 (188:3) it Monogr. i.

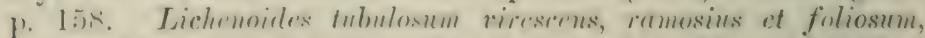
summitulilus antutis Dill. in liay syn. ed. :3, p. (i7, n. 19 (17:4).

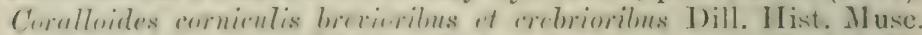
1. J1)4, t. 16, f. 27 1 $(1711)$. Lichen fureutus val. B. Lightf. Fl. seot. ii. p. $882(1777)$; var. 2, With. Arr. ed. 3, iv. p. 45. Cenomyer fureule var. adspersu likerk. Deutschl. Lich, x. 1) It 
(1827). C. scabriuscula Del. in Dub. Bot. Gall. ii. p. 623 (1830).

Eisice. Johns. n. 50: Mudd Clad. n. 49 (dark-brown form).

In some respects this rariety is a transition between $C$. furcatur and $C$. squamosu; it is characterized by the podetia being genmally scabrid and beset with minute squamules and by being fremuently decorticate, recurved or of somewhat tangled growth. The brimches vary from rery slender to rather stoutish. The reaction for $C$. scalrinscula is given as $\mathrm{K}+$ vellowish; but there is frequently in $C$. furcata sp. \& var. a slight yellowish reaction which quickly turus to fuscescent. (See Leight. in Ann. Mag. Nat. Hist. ser. 3, xriii. p. 413 (1866).)

Hub. On moorlands, mossy rockis and old turf-walls in maritime and upland districts.-Distr. Rather rare in the Channel Islands, England, Scotland and Ireland.-D. M. Noimont. Jersey; near Penzance, Cornwall; Shanklin Downs. I. of Wight; 13olt Head, Torquay. Becky Falls and Dartmoor, 1)eron; Hassocks Gite and Haymond's Heatl, Sussex; Epping Forest, Essex; Charnwood Forest, Leicestershire; Enmerdale Lalie, Cumberland ; Farndale Ioor, Cleveland. Yorkshire; New Galloway, Kirhculbrightshire; Barealdine, Argyll ; Rannoch, Perthshire; near Kincardine; Glen Mrich, Braemar and Countesswells, Aberdecushire; Loch Limhe. Inveruesshire; Kylemore, Galway.

27. C. rangiformis Hoflin. Deutschl. Fl. ii. p. $11 \pm$ (1795)).Primary thallus of rather small crenate squamules, soon evanescent; podetia slender, erect, much branched, repeatedly dichotomous, rarely sorediose, smooth, but the cortex areolate, greyishor sometimes brownish-white, the branches intricate. spreading, furcate and graclually attenuate at the apices which are often reddish-brown, closed or sometimes pertorate at the axils; ascyphous ( $\mathrm{K}+$ rellow, $\mathrm{CaCl}-$ ). A pothecia small, brownish; spores $10-13 \mu$ jong, $3-4 \mu$ thick. - C. punyens Floerk. Clad. Comm. 1. 156 (18:8) : S. F. Gray Nat. Arr. i. p. 415): Hook. in Sim. Engl. lil. r. p. 23.5; Leight. Lich. Fl. p. 56 ; ed. 3, p. 53 ; Cromb. in Grevillea xi. p. $11: 3$ it $M$ Ionogr i. p. 153 (incl. f. nirea); f. niver Koerl). Syst. Lich. (ierni. p. 35) (1855); Cromb. in (trevillea xr.p. tis. ('. furutu var. pungens Mucld Man. p. 58 \& Brit. Clach. p. 2:3 (incl. f. tenella): Cromb). Lich. Brit. p. 20. Lichenoirles tubulosum innosissimum, fruticuli spucie canticans, rormiculis rnfescentibus Dill. in Ray Syn. ed. 3), p. 67, n. 15 (17.24).

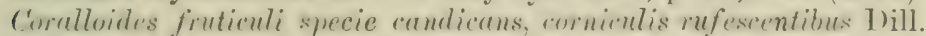
Hist. Musc: p) 110, t. 16, fig. 30 A (1711). Lichen Juntems Ach. Lich. Suec. I'rodr. p. 202(1798); Engl. Fl. t. 2444. L. rangiferimus var. $\beta$ Hurls. Fl. Angl. p. tis $(1762)$; Iightf. Fl. Scot. ii. p. S79 (fide Cromb. Monogr. i. p. 153); var. 2, With. Arr. ed. 3, iv. p. 4.2. Barmuges pmulens var. nims Ach. Meth, p. 35) (1>03). E.rsice. Cromb. n. 12:3 : Leright. n. 16: Mudd n. 16 pro parte \& Clad. nos. 54, 55.

Fasily eonfused with C. furealat on the one hand and C. sylcatica on the other. From the former it rifiters in the halbit of growth, due 
to the dichotomous branching forming densely congested somewhat thyrsoid tufts, in the lighter colour and in the distinctly yellow: reaction with potash. From C. sylvatica it is distinguished by the erect tips and other characters. The apothecia are generally rare, though sometimes abundant and conglomerate.

Hab. On the ground among mosses and short grass in maritime and inland situations.-Distr. Common in most parts of the Brilish Isles.-B. M. Island of Siuk; near Penzance and St. Merryn, Cornwall; Dartmoor, Deronshire; Isle of Wight; Shoreham, Sussex; Lrdd, Tient; Esher, Surrey ; Epping Forest, Essex ; Bretch, Oxfordshire; Charnwood Forest, Leicestershire; Aberdovey, Merioneth; Haughmond Hill, Shropshire; Delamere Forest, Cheshire; Dovedale and Buxton, Derbyshire; Tngleby Park, Ayton and Cliffrig, Cleveland, Torkshire; Windermere, Westinoreland, St. Bees, Cumberland; Barcaldine, Argyll ; Countesswells Wood, Aberdeenshire; Warrens. court and Macroon, Cork; C'lare Island and Achill Island, Mayo.

Var. foliosa Wain. Mon. Clad. Univ. i. p. 366 (1887).-Purletia erect or decumbent, slender, more or less sprinkled with sifuamules, rarely fertile, otherwise similar to the species.C. furretu var. pungens f. foliose Mudd Brit. Clarl. p. 54. C. punyers f. foliosa Leight. Lich. Fl. p. Jö; ed. 3, p. $5 t$ pro parte; Cromb. in Grevillen xi. p. 113 \& Monogr. i. p. 154. Corallina fuscu foliosa Buddle Hort. Sice. ii. fol. 1, n. 6, in Herb. Sloane. Coralloiles frutimli suecie ranticans, arniculis rufesentilus. Dill. Hist. Musc. 1'. 110, t. 16, fig. :30, c, D (17+1). Cenemyee rongiformis var, foliose Floerk. Deutsch. Lich. viii. p. 15 (182i).

Exsicc. Johns. n. 13 ; Leight. 1. 374 ; Mudd Clad. n. 56.

Hab. On the gromd in uplanl situations.-Distr. Somewhat local in England and Ireland.-B. M. Basingstolie, Hants ; Shicre. Surrey; Lydil. Kent; Hampstead, London (18th century) ; near Cheltenham, Gloucestershire; Cumberland; Tuam, Galway.

Var. muricata Arn. in Flora lxvii. 1) 88 (1884). - P'or!etia sonnewhat stout, the cortex often uneven from the turgid areola, obtuse, or shortly furcate at the apices, rather sparingrly

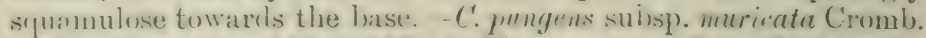

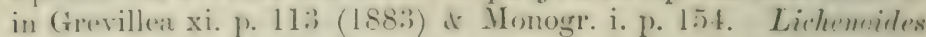
tululosum matjis romosum marime diforme bill. in hay siyn. ed. 3),

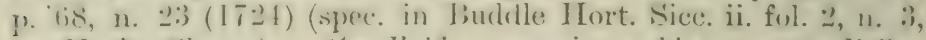

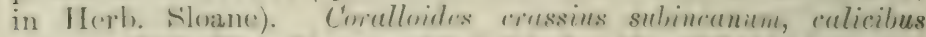
demtutus I)ill. IList. Musc. p. 9.), t. 1.5, fig. 1i, в (17.11) (dr.formed

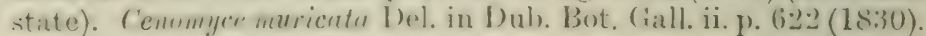

Exsice. Leight. n. 369.

I robunt variety, les branched than the species and accasionally difform. Not to be confused with $C$. furcata var. pinnata, from which it mat be listinguished hy the reaction ( $k+$ yellow).

Mab. (On the gromul in mpland situations. - Distr. liather rare in

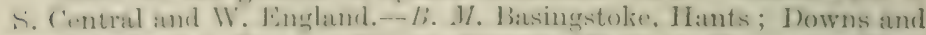

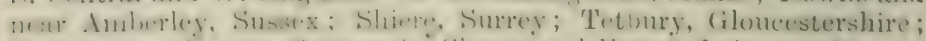

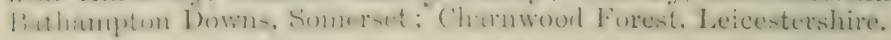




\section{Podetia mostly decorticate, usually scyphiferoms and generully pervious.}

\section{Basal rquamules small, often evanescent.}

28. C. cenotea Scher. Lich. Helv. Spic. 1) 35 (1823).Primary thallus of a few usually small lobate-crenate squanules, or evanescent; podetia of medium height, subcylindrical or irregularly turgescent, scyphiferous, repeatedly moliferous, the axils and scyphi pervious, whitish or greyish pulverulent throughout or partly corticate, and sometimes minutely squamulose at the base $(\mathrm{K}-, \mathrm{CaCl}-)$. Apothecia small, brown or pale; spores $2-8 . \mu$ long, $2 \cdot 5-3 \cdot 5 \mu$ thick. - Cromb. in Grevillea xi. p. 113 \& Monogr. i. p. 155. Bremyces renoten. Ach. Meth. Lich. p. 347 (1805).

The pulverulent podetia recall C. fimbriata, but it difiers from that species in the pervious scyphi and axils; the repeated rather dainty proliferations of the seyphus give a branched apperrance.

$H a b$. On putrid stumps of trees and on the ground in wooded uplind situations.-Distr. Local and scarce in N. England and mong the Grampians, Scotland, in the old Caledonian Forest.B. M. High Force, Yorkshire; Black Wood of Rannoch, Perthshire; Ballochbuie Forest, Ballater, Aberdeenshire.

Var. glauca Leight. in Ann. Mag. Nat. Hist. ser, :', xviii. p. $41+(1866)$. - Podetia rather long, somewhat glancous, rarely forming scyphi, the tips of the branches prolonged in subulate proliferations.-Cromb. in Grevillea xv. p. 4.5 \& Monogr. i. p. 155. C. glenuca Floerk. Clad. Comm. p. 140 (1828).

Wainio has included as a growth form C. py.ridrten var. fastigirta

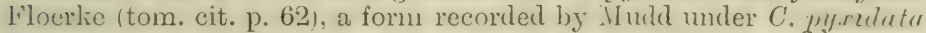
var. cornuta f. fastigiata (Brit. Clad. p. 13 (1e65)) as "podetia elongated, simple. the apex branched; branches short, attenuated. fistigiate," and he suggests that here also should be placed C. squamosit var. polychonia f. ferulacea Floerk. (tom. cit. 1. 1357), quoted by Murd as C. squamosa var. ventricosa, f. ferulacea (tom. cit. p. 20).

Hub. On decaying stumps among mosses in mountainous districts.

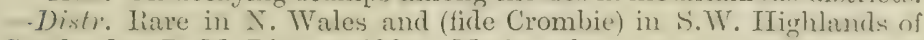
Scotland.-B. M. Rhewgreidden, Merioneth.

29. C. squamosa IIofhu. Deutschl. Fil. ii. 1. $1: 5$ (16!5). I'rimary thallus of short crenate somewhat wedge-shaped sifuamules, sreyish-white or pale above, white heneath, sometimes evanescent : podet ia subcy lindrical, usually seyphiferous, branched or proliferons, the seyphi and axils pervious, granulose and decerticate or unepuably warted, areolate-corticate, more or less covered with small sylammiles, the apices sometinses furate or eristate when fertile (K - CaCl - ). Apothecia small, pale- or rechlishbrown; spores $8-14 \mu$ long, 3-4 $\mu$ thick.-Mudd Man. p. 56

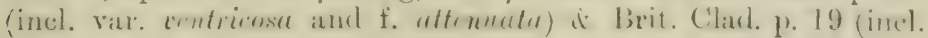


var. ventrirosu and ff. usperella, ferulacen? and polychonia); (romb. Lich. Brit. 1). 20 (excl. subsp. respritica) \& Monogr. i. p. 150 (incl. f. ventricosa) ; Leight. Lich. Fl. p. 66 ; ed. 3, p. 61 pro parte; var. resperella Floerk. Clad. Comm. p. 1:2 (1828); var. attemuntu Fr. Lich. Eur. p. 2:31 (1831) (non Hoffm.) ; var. rentivosa Fr. l. c. (non Huds.). C'. speciosa Cromb). in Grevillea xi. 1. $11+$ (1883). C. aspuella Cromb. Monogr. i. p. 159 (1894) (incl. f. pmlychomia). Bixemyers sparassus (incl. var. ventricususs) Ach. Meth. Lich, p. 3t7 (1803). Lichen sparassus Sm. Engl. Bot. t. 236.2 (1s11). Cenomyce spurassa Ach. Syn. Lich. p. 273 (1s14) Hook. Hl. Ścot. ii. p. 64; Tay]. in Mackay Fl. Hih. ii. j). 80. Schasmaria sparassa S. F. Gray Nat. Arr. i. p. 416 (1821).

Exsicc. Cromb. 11. 124; Johns. nos. 176 and 293; Larb. Cresar. n. 10 pro parte; Mudd n. 13 \& Clad. nos. 31, 40 (pro parte), 41,42 .

Distinguished chiefiy by the generally decorticate squamulose podetia, which rary in size from 1 to about is cm. in height. Though usually naked between the squamules, they are sometimes corered with a warted brown cortex spotted with white, like injured places. The podetia are sometimes stout and swollen. especially at the axils (f. ventricosa), or they may be narrow and almost without squamules (fi. attrmata, asperilla anil polychonia). The scyphi, when formed, are pervious and ragged-looling with the unequal proliferations. Stirton records a specimen, evidently of $C$. squamosu, as $C$. confirtula n. sp. in which he obtained a greenish-blue and nltinately a yollowish reaction with $\mathrm{CaCl}$ (Scott. Nat. n. s, iii. p. 308 (1888)).

Hab. Among mosses on the ground and on rocks in wooded, maritime and inland regions.-Dist). General and usually common where it oceur', chietly in the hilly regions of the British Isles, $-L . M$. Noilmont Bay, Tersey; St. Breock, Cornwall; Bovey Tracey ant near Becky Falls, Devon; Eritge, Sussex; Epping Forest, Essex; ('harnwood Forest, Leicestershire; Dolgelly and Aberdorey, MIerioneth; Coumay Falls, Carnarvonshire; Kildale Moor. Baysdale. Sitogiale. Westerdale, Jiroughtom, Guisboro' and Ingleby L'ark, C'lerelame, Sorkshire; Windermere. Westmoreland; Juminen Fell, T'eesdale. litrham; West Allen (arrs. Northmuberland; New Cialloway, Firlieulbright-

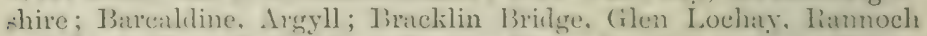
and Loch Tay, l'erthshire; louris, Kintandineshire; Craig Cluny,

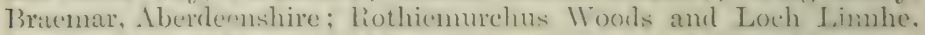
Invernessshire; Doneraile Mts.. ('ork; lillamey, Kery; Kylemore.

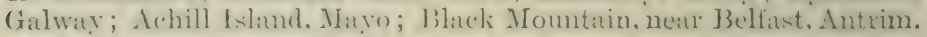

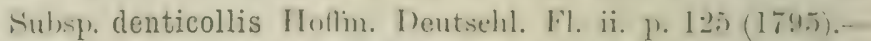
Siquamules of primary thallus and of poletia small or rather

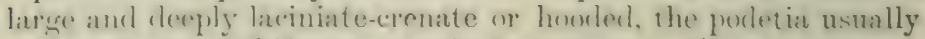
rather short, seyphiferous. uontly decorticate.-6!. sqummosa var.

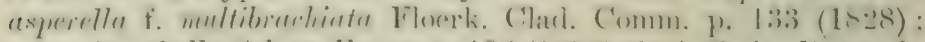

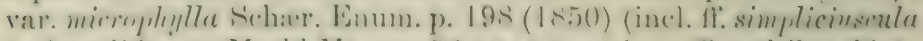

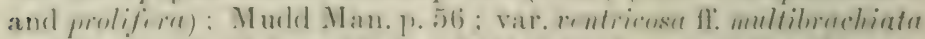

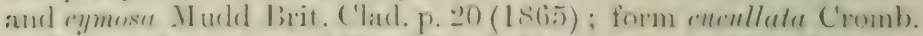

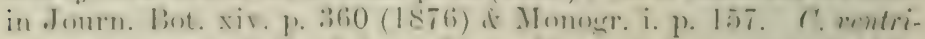

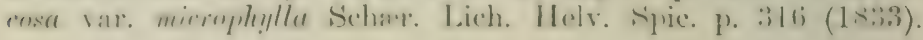


C. crispute t. ventricase ('romb) in Journ. Linn. Sive. xvii. p. ,560

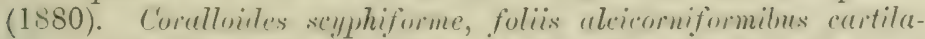

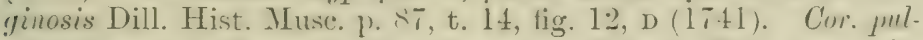
chrum, geniculis acetubulifumibus crispifoliosis Dill. tom. cit. p. 100, t. 16, fig. 2:3. Cenomyre cuculluta Del. in Dub. Bot. Gall. ii. 1. 620 (1830). C. crisprete var. ventricosa Del. in Dub. Bot. Gall. p. 627 (1830) firle Wian. Mun. Clad. Univ. i. p. 439 (1887).

Exsice. Mudd n. 14 \& Clad. nos. 30, 33 and 40 pro parte.

Perhaps more of a variety or form than a subspecies. It is frequently much branched above, but distinguisherl chiefly by the deeply and elegantly divided squamules, which teud to become hooder at the apices. Wainio has associated with the above C. Lamarkii f. Isignyi Nyl., included here under $C$. pityrea f. hololepis.

Hab. On mossy bonlders and decaring trunks of trees in wooted districts.-Distr. Rare in W. and N. Eugland, N. Wales, S. and W. Scotland and X.IT. Irelant.-B. M. Withiel, Cornwall; Balcombe. Sussex; Aberdovey and Dolgelly, Merioueth; Ingleby and near Battersby, Clereland, Yorkshire; Tongland, Tirkeudbrightshire; Appin and Barcalline, Argrll ; Loch Linnhe, Invernessshire; Leenane, near Kylemore, Galway.

30. C. subsquamosa Nyl. ex Cromb. in Journ. Linn. Soc. xvii. p. 560 (1880) \& MLonogr. i. p. 158.-Primary thallus of small crenate squamules, pale or greyish-green above, white below ; podetia usually rather short, branched, with or without scyphi, with axils and scyphi pervious, squamulose below, almost decorticate, granular upwards, furcate or radiate-cristate, the branches subcorymbose at the apices ( $\mathrm{K}+$ yellow, then crimson, $\mathrm{CaCl}-$ ). Apothecia small, solitary or aggregate, reddish-brown; spores obloug or fusiform-oblong, $8-1 \cdot 2 \mu$ long, $2 \cdot 5-3) \mu$ thick.-C. delicata var. sulsquamosa Nyl. ex Leight. in Amn. Mag. Nat. Hist. ser. 3, xviii. p. 407 (1866); Cromb. Lich. Brit. 1. 20; Leight. Lich. Fl. p. 59 ; ed. 3 , p. 55 .

Exsicc. Bohl. n. 16 ; Johns. n. 177 ; Larb. Cesar. n. 10 pro parte; Leight. n. 405; Mudd n.'14.

Differs from the preceding chiefly in the reaction with potash, a swit vivil yellow changing alter an interval to a chllish erinson. It is like ('. squamosa, a very variable plant, no two specinens being axactly alike. A number of forms chatacterized by some peculiarity of growth have been published by .J. Stirton (Scott. Nat. ix. p. 119 (1855)). These are ff. delututa, sublactere, deflctu and compressula. which I have not seen, and ff. furfurosa, phyclina, cristata and spilota, specimens of which have been loaned by J. MI'Andrew.

11ab. On decaying stmmps of trees and on mossy soil in maritime ard inland , listriets. - Dixh. Midely distributerl, thongh not eommen, throughout the british Is]es. I). M. Noimont bisy. Iorkey: neal

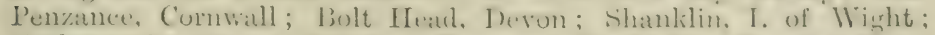

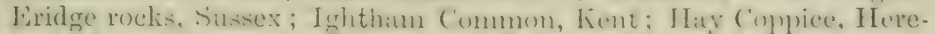
fordshire; Bamouth, Merioneth; Kiliale and Ingleby, Cleveland,

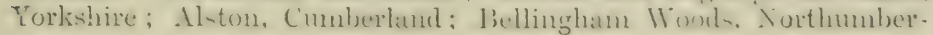


land; New Gallowiy, Kirliculbrightshire; Appin, Aroyll ; Rannoch, Perthshire; Sidlaw Hills, lorfarshire; Loch Limhe, Invernessshire; Kelly's Glen, near 1)ublin; Killaney, Kerry; Lecnane, Connemara. Galiway.

Form tumida Cromb. in Grevillea xi. p. 114 (1883) \& Monogr. i. p. 1.59.-Podetia turgid ventricose, the axils and apices dilated, infundibuliform.

$H a b$. On moist shady rocks among mosses in upland tracts.l)istr. Local and scarce in S. England, N. Wales, S. Scotland and in the S.W. Highlanis.-W. M. High Rocks, near Tmbridge Wells, lient; Jolgelly, Nerioneth; Xow Galloway, Firlicudbrightshire: Barcaldine, Argyll.

\section{Basal squamules small, persisient crouded.}

31. C. cespiticia Floerk. Clad. Comm. p. 8 (1828).-Primary thallus persistent, the squamules mostly crowder, rather small, irregular, somewhat laciniately divided or crenate, sometimes ascending, pale-green above, white beneath; podetia very short, naked, cylindrical, ascyphous, simple or divided ( $\mathrm{K}-, \mathrm{CaCl}-$ ). Apothecia conglomerate, sometimes apparently sessile on the leaflets, flesh-coloured or reddish; spores oblong, 8-16 $\mu$ long, 3-4 $\mu$ thick.-Cromb. in Grevillea xi. p. 14 \& Monogr. i. p. 159. (.. squamosa var. 'esprititia Nyl. in Act. Soc. Limn. Bord. sér. 3. i. p. 284 (18.56); Mudd Man. 1. 57 \& Brit. Clad. p. 21 ; subsp. raspiticia Nyl. Syn. Lich. p. 210 (1860) : Cromb. Lich. Brit. 1. 20. C. pyxidata var. cespriticia Leight. Lich. Fl. p. 60 ; ed. 3, 1. 57. Bromyces respiticius P'ers. in Ust. Ann. Bot. vii. 1. 155 (1794). Lichen respititins sm. Engl. Bot. t. 1796 (1807). Scyphophora crespiticia S. F. Gray, Nat. Arr. i. p. 417 (18:21): Hook. in Sm. Engl. Fl. v. p. 236.

Exsicc. Bohl. n. 72 ; Larb. Caesar. n. 9 ; Leight. n. 368 ; Mudd Clad. n. 44.

Approaches (', squumosn in the decorticate character of the very short porletimm. No seyphi are formed, and it is either pervious or closed at the apex and sumomed by the conglomerate spothecia. At times these are almost sessile on the hatsal squamules, which gives it the appearance of a Baomyces.

IIrb. Amoner mosses on the trunks of trees, on ricks on thatehed

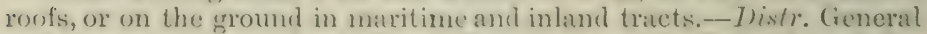
and common throughout fireat liritain, rare in Lreland and the

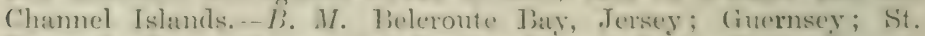
Brewarl, Cornwall; on the Ditrt and men 13ecky Falls, Devon:

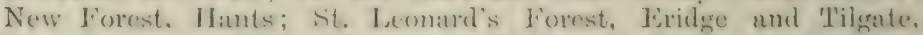
Sussex ; (balsey. Wilts ; Barmonth, Merioneth: Ludlow amd ritableford, Shropshire; Malvern, Womestershine; near Matlock, Derby-

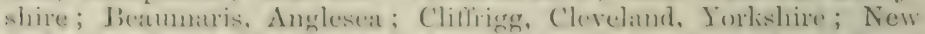

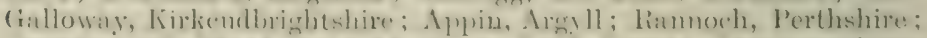

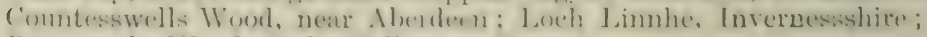
Dunscombe Woot, Cork; Killarney, Kery. 
3\%. C. parasitica Hoflim. Deutschl. Fl. ii. p. 127 (1795). Primary thallus of small narowvly erose-laciniate crowded squamules, sorediose at the margins and on the under surface, or becoming almost entirely a mass of soredia, greenish-white or brownish-grey above ; podetia short, slender, somewhat thickened upwards, simple or irregularly branched, and splitting or entire at axils and tips, ascyphous, non-corticate, furfuraceous, usually syuamulose $(\mathrm{K}+$ yellow, $\mathrm{CaCl}-$ ). Apothecia small, usually conglomerate, brown or pale ; spores oblong-fusiform, 10-15 $\mu$ long, $3 \cdot \bar{y}-4 \mu$ thick.-C. delicat Floerk. Clad. Comm. p. $T$ (18:8) ; Cromb. Lich. Brit. p. 20 (excl. var.) \& Monogr. i.p. 160 ; Leight. Lich. Fl. p. 5s ; ed. 3, p. 5j (excl. var.). C. squctmosa var. delicuta Fr. Lich. Eur. p. 231 (18:31); Mudd Man. p. 56 \& Brit. Clad. 1. 21. Lichen parasiticus Hoffm. Enum. p. 39, t. 8, fig. 4 (1784). L. Aelicatus Ehrh. Crypt. Exs. n. 247 (1793); Ach. Lich. Suec. Prodr. p. 199 (1798); Eugl. Bot. t. 2052. Cenomyce delicate Ach. Syn. Lich. 1. - $7+$ (1814); Tayl. in Mackay Fl. Hib. ii. p. 80. Helopodium delicutum S. F. Gray Nat. Arr. i. p. 416 (1821). Scyphophorus parasitiats Hook. in Sm. Engl. Fl.v. p. 237 (1833).

Exsicc. Leight. n. 382 ; Mudd n. 15 \& Clad. n. 43.

Agrees with $C$. subsquamosa in the chemical reaction with potash, but is distinguished by the crowted sorediose basal squanmles. In farourable situations it spreads extensively, and is generally fertile.

$H a b$. On rotten rails and stumps of trees, rarely on turfy soil in inland districts.-Distr. Somewhat scarce throughont England, rare in S. Scotland and S. aud W. Highlands.-B. M. Lyndhurst and Broclienhurst, New Forest, Hauts; St. Leonard's Forest, Sussex; Chelsfield, Kent; Thorndon Hall, Essex; Bagot's Park, Staffordshire; Aymestry, Herefordshire; Crown Fast Wood, near Worcester ; Llandrindod. Radnorshire; Easby Trood and Kildale, Cleveland, Yorkishire; Wastdale, Cumberland ; New Galloway, Kirkcudbrichtshire; Barcaldine, Argyll; Craig Calliach, Perthshire.

\section{B. Coccifere. Apothecia red-coloured.}

\section{Podetia scypliferous.}

\section{Basal squamules large.}

:3:. C. luteoalba Wils. \& Wheld. in Trans. Liverp. But. Fin. i. p. 7 (1909). - P'rimary squamules rather large (up to 1 em. long). irresularly crenate, incurved when dry, yellowish-green, luecuming darker above, pale sulphureous and pulverulent hencath ( $15+$ yellow, CaCl-). Pocletia rarely developed, very short, "3-5imm. high, eylindrical, rising from the surface of the leaflets, seyplaiferous, the seyphi narrow. Apothecia scarlet, minute, discrete

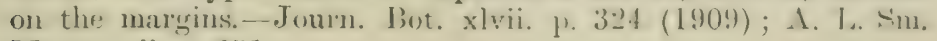
Monogr. ii. p. 351 . 
1)istingnisher by the rellow collow of the under side of the basal scpuamule which tilkes on if deep orange tint on the application of potash if followed by calcium chloride.

$H a b$. On old mosses in high altitudes.- B. M. Graygarth Fell, Lancashire (without podetia).

3.t. C. digitata Hr,fin. Deutschl. Fl. ii. p. 124 (1795)? Scher. 1. 2:- (1;:3).-- Primary stpuamules rather large, roundly lobed or crenate, rale-sreen above, beneath usually whitish and pulverulent; podetia subcylindrical, rarely branched, unequally corticate at the hase, white or yellow, pulverulent above, scyphiterous, the scyphi rather narrow with the margin incurved, irregularly divided and proliferous $(\mathrm{K}+$ yellow, $\mathrm{CaCl}-$ ). Apothecia small and scattered or confluent; spores $9-11 \mu$ long, $3 \cdot 5-4 \mu$ thick.-Cromb. Lich. Brit. 1). 21 \& Monogr. i. p. 166 (incl. f. brachytes); Leight. Lich. Fl. p. 6s; ed. 3, p. 63 (excl. var. macilenta); f. brachytes Nyl. Lich. Scand. p. 61 (1861). C. deformis f. digitutu-sarliuta Schaer. Enum. p. 188 (1850). C. roceifere vans. digifutı and digitato-radiatu Mudd Man. p. 61 (1861) \& Srit. Clad. p. :31. Coralloides crussius sulincrumu, calicilus dentatis Dill. Hist. Musc. p. 95, t. 15, fig. 18 a (not typical). Lirhen digitrtus L. Sp. Pl.p. 1152 (175:3). L. difformis Huds. Fl. Angl. p. 45E (1762). L. deformis Lightf. Fl. Heot. ii. p. 876 (nom L.) ; With. Arr. ed. :3, iv. p. 38. Bienmyces bacillaris f. brucluytes Ach. Meth. Lich. 1. 329 (1503). Sryphophora difitutu S. F. Gray Nat. Arr. i. p. 422 (1821).

E.esife. Johns. nos. 215, 216 and 295): Mudd Clad. 11. 76 (young stage).

Somewhat like $C$. deformis, but sufticiently distiuguished by the digitate branching, the nore slencler podetia (except in f. monsirosa). the incurved seyphi, and the pronounced rellow reaction with potash. In f. brachytes the podetia are slender with the basal squamules well developed.

$H_{a l}$. On decaying trumlis of trees amoug mosses in somerhat upland distriets.--D)istr. Iocal and rather scarce in the more hilly regrions of the British Isles.-I). M. S. Devon; Iihewgreidden and 13armonth, Mcrioneth; Malvern, Norecestershire; Kildale Moor, Ingleby l'ark and Jaysdale, Clexeland, Yorkshire; Windemere, Westrioreland; Wastalile and Asherill. Cumberland; Fenton IXill.

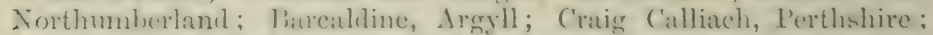

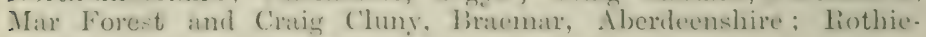
murchus Woods, Invernessshire, Achill Island, Mayo.

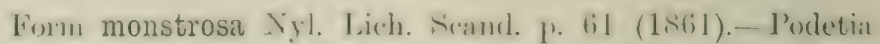
stont, irresularly rentriesere, sranular pulverulent. sometimes sfluamulese, the seyphi diftom and divided or proliferous, narruwer than the puletium. ('roml, in (irevillea xi. p. 114

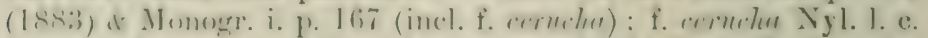

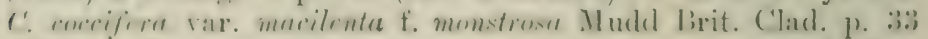

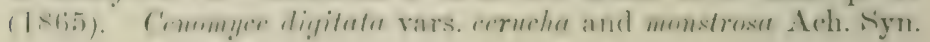




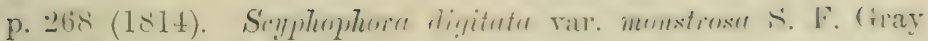
Nat. Arr. i. p. 422 (1821).

Exsice. Johns. n. 296 ; MIudd Clad. n. 69.

A turgid form of the species, rarely found fertile.

Hul. On decariug trunks of trees in wooled momntainous district. -Distr. Local and scarce in N. England, S. Scotland and the Grammitns, Scotlaud. - B. M. Battershy, Cleveland, Yorkshire; Winderinere, Westmoreland; Ashgill IToods, Cumberland; New Galloway, Kirkculbrightshire; Pen Lawers. Perthshire; Critigr Coinnoch and Craig Cluny, Braemar; Aberteenshire.

\section{Basal squamules moderate in size.}

3:). C. deformis Hoflm. Deutschl. Fl. ii. 1. 120 (1795).syuamules of primary thallus moderate in size or rather larre, crenate or lobate, ascending or aclpressed, pale-green above, whitish beneath: podetia elongate (up to about 3 inches long) turgid, simple, without squamules, or rarely with minute squamules towards the base. partly corticate or sulphuryellow-pulverulent, opening to a thin-walled serphus which is regular or difform. crenate-rlentate at the margins or irregularly prolifurous ( $\mathrm{Kt}+$ vellowish, $\mathrm{K}(\mathrm{C} \mathrm{C} \mathrm{Cl})+$ yellow). Arothecia separate or asgrergate; spores s-10 $\mu$ long, $;-4 \mu$ thick.-Cromb. Lich. Brit. p. 21 \& Monogr. i. p. 165 (incl. ff. goneche and pulvinata); Leight. Lich. F1. p. 68 ; ed. 3, p. 63 ; f. gonecha Nyl. srn. Lich. i. p. 22.2 (1860): Cromh, in (irevillea xi. 1) 114 ; f. pulvinata Nyl. Lich. Scand. p. 60 (1861); Cromb. in Grevillea-xv. p. 46. C. coccifere var. defomis Schar. Lich. Helv. Anpic. p. 283 (18:33); Murld Man. p. (il (incl. ff. lul formis and subuluta) \& Brit. Clad. p. :3) (excl. t. plenrotu). C. deformis f. subulata Schre. Enum. p. 188 (1850). C. crenulata var. tulieformis Koerb. Syn. Lich. (xerm. p. :30 (185.5) (fille Mudd). Lirlien deformis L. Sp. Pl. 1. 115:2 (1753) pro parte; Engl. Bot. i. 1394 (non Huds.). ('enomyce pulvinate Ach. Lich. Univ. 1. 514 (1810). C. deformis Ach. Syn. Lich. p. 268 (1814) : Ifrok. Fl. Acut. ii. p. 63. Seyphophora deformis s. F. Gray Nat. Arr. i. p. 422 (1821) ; Hook. in Sm. Engl. Bot. v. p. 240.

Exsice. Boll. 1.. 39 ; Croall n. 200 ; Johns. nos. 14 and 294 ; Leight. n. 275 ; Mudd n. 25 and Clad. n. 68.

Easily distinguished by the rather large, yellow-coloured poldetia ; srmetines they are bent at the tips, more or less fissured and partly corticate. In f. goncrlu the scyphi are somewhat more irregrular, amd in f. pulvinitu the sunamules and podetia are crowded together. The apothecia are rare in 13 ritish specimens.

Hah. On the gromal anong heaths in wooled uplamil districts.Distr. Not very general mor enmmon in 11 . and X. England, mome frequent in the Suttish Highlanis, not sech from Irekand. Is. M.

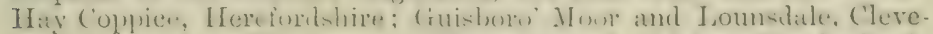

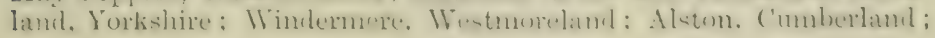


Egglestone, I)whann; Appin, Argsll; Craig Calliach, Rannoch and Craig-Y-Jarns. I)unkeld, l'erthshire; Jallochbuie Forest; Linn of lee, Ben-naboord and Loch Pharbich, Braemar, Aberdeenshire; Rothiemmehns Woods and Ben Ferrag, near Loch Ericht, Invernessshire; near Forres, Elginshire.

:36. C. coccifera Willd. Fl. Berol. 1) 361 (1787).--Primary thallus of melium-sizer or rather large firm squamules, lobate "r de'ply cut, greyish-green; porletia rather short, rarely divirled, coarsely sranular, the granules dispersed and sometimes sorediose or united into a verrucose cortex, occasindally squamulose "pening to a wide often irrogular scyphus which is sometimes proliferous from the margin, rarely from the centre (Kf + yeliow or,$- \mathrm{K}(\mathrm{CaCl})+\mathrm{y}(\mathrm{llow})$. Apothecia pedicellate or usually sessile and often confluent; spores oblong or oblong-ellipsoid, 9-11 $\mu$ long, 3-t $\mu$ thick ( $\mathrm{Kt}+$ yellow, $\mathrm{K}(\mathrm{CaCl})+$ yellow).Iucid Man. 1). 60, t. 1, fig. 11 (incl. var. comucopioides and f. extensa, excl, other vars. and forms) and Brit. Clad. p. 28 (incl. ff. cornucopioirles, ertensa, inuovata, asoter and phyllocoma) (excl. other vars. and forms); Cromb. in Grevillea xi. p. $116 \mathrm{~d}$ IIonogr. i. 1. 16] (incl. ff. asoted and rormecopioides); f. immorata and var. phyllowome Floerk. Clad. Comm. pp. 93, 94 (1828); f. cormuentioviles Br. \& Rostr. Lich. Dan. p. 4.2 (1869). C. cormucoprointes Fr. Lich. Eur. p. 236 (1831) ; Cromb. Sich. Brit. p. 21; Leight. Lich. Fl. 1. 66 ; ed. 3, 1. 6: (incl. fi. extensa and phliyllo-

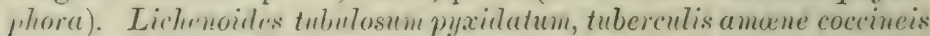
Dill. in Ray s'yn. ed. 3, 11. 35, 1). 69 (172+). Coralloides scyphiforme, tuberculis "oceine is Dill. Hist. Muse. p. 82, t. 14, fig. $7 \mathrm{~A}-\mathrm{M}$ (17+1). Lichen raccifirus L. Sp. Pl. p. 1151 (175:3) pro parte; Huds. Fl. Angl. ed. 2, p. 553: I ightf. Fl. Ficot. ii. p. 866 ; With. Arr. ed. 3, iv. p. 39 ; Engl. Bot. t. 2051. L. cornucopioides Huds. Fl. Ingl. p. 456 (1762) (non Linn. fide Wainio Mon. Clacl. i. p. 154) po parte ; Lightf. Fl. Seot. ii. p. 868 po parte : With. Arr. ed. 3, iv. p. 40 pro parte. Bexomyec's corriterus vars.

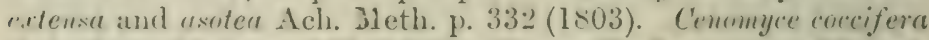
Ach. Lich. Univ. p. 537 (1810): Hook. Fl. Feot. ii. p. (i3 (incl.

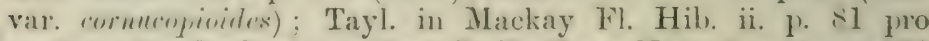
parte. Soypleopleora rocrifera S. F. Gray Nat. Art. i. 1) 423

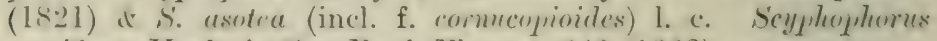

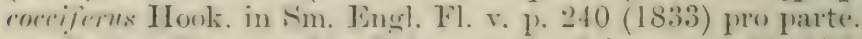

Esexice. Baxt. 11. (99 : Johl, 11. 40; Johns. nos. 51, 175. 179 and 1:0; Leright. nos. : 75 it and 401: Mudd n. 2:3 d Clad. nos. 65, 66 and 67 pro parte.

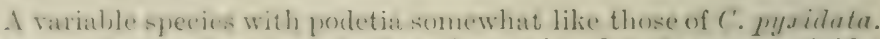

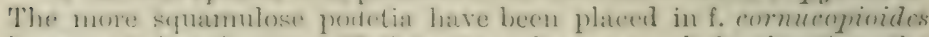
l,y some lirbenologists. If the squammles are mueh developed on the

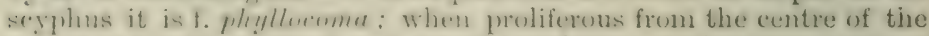
cup it is f. asolea; in $\mathrm{f}$. extensa the podetia are elongate; none of thes forms sem to be coms lant. and the rhaneters pass from one to the other: 
Hat). On the gresumd on moorlands and on turf walls from matime. to subalpine districts. - Distr. General and fairly common throughout the Brirish Isles.- P. . I. Le Goufire, Guernser; St. Jreward and near Wadebridge. ('ormwall; Hay Tor and Goodanoor, I)evon: Shanklin. Isle of Wight; Epping Forest. Fssex; Shotorer Hill. Berks; Charnwood Forest, Leicestershire; Wrekin Hill and Stiperstones. Shropshire; Woreester Beacon; Gower, P'embrokeshire; ('wm Brchan, Dolgelly and Aberdorey, Merioneth; Capel Curig, Carmarvonshire; 'Towthorpe Moor, Battursy Moor, Ayton Moor, Baysilale and Fildale, Cleveland, Forkshire; Alston. Cumberland; Teestalf. Durhan; The Cheriots, Northmberland; New Galloway, Firkentbrightshire; Ben Lomoud. Dumbartonshire: Apjoin, Argyll; Glen Lochar, near 'Tummel Bridge, and Fannoch Moor, Ierthshire; Clovir Mts. and Sidlaw Hills, Forfarshire; Countesswells and Scotstown Moor, near Aberdeen, Glen Clunie, Glen Callater and Ben-naboord. Braemar, Aberdeenshire; Ben Nevis, Invernessihire; Applecros:. Possshire; Lairg, Sutherlandshire; Doneraile Mts., Cork; Side Devis. near Belfast, Antrim; Kylemore, Galway; Achill, MLayo.

Var. incrassata Laur. in Sturm Deutschl. Fl, ii. Heft. 2829, p. $83(1835)$.- Primary thallus minutely squamulose; podeti: very short, verrucose-granulate, somewhat clarate, simple or sometimes divided above; scyphi absent or rarely developed. A pothecia small, crowded.-Cromb. in Grevillea xii. p. 92 (1884) d. Monogr. i. p. 16:. C. iurrassuta Floerk. Clarl. Comm. p. ㄹ1 (182R). C. coecifern f. epiphylla Cromb. in Journ. Linn. Suc. $x$ vii. p. $55 \pi(1880)$. C. macilente f. deminntu Cromb. in Grevillail xi. p. 115 (1883).

Included in $C$. coccifira on account of the grannlar podetia which very rarely become sorediose. The podetia are never more than $1 \cdot 5 \mathrm{~cm}$. in height, and the apothecia are numerous and confluent.

Hab. On peaty soil and decaying stumps of trees in mountainous districts.-Distr. Plare in S.W. and Central Highlands of Scotland.-B. M. Barcaldine, Argyll; Rannoch, Perthshire.

Subsp. pleurota Cromb. in Grevillea xi. p. 114 (1883) d Monogr. i. 1) 163.)- Podetia sranular sorediose or granularcorticate below and sorediose-julverulent above, yellowish-white or pale-greenish ; scyphi rather dilated, usually entire and rareiy. proliferous at the margins. Apothecia rare, solitary, suingerlicellate.-C. corcifera var. cromucrpioides f. pleurotu Mudd Man. p. 60 (1861) \& var. deformis f. plentota Brit. Clad. p. 30 (1565). C. cornucopionides subsp. pleurota Cromb. Lich. Brit. p. 2l (lsir): f. pleurotu Leisht. Lich. Fl. 1. 65: ed. 3, p. 6.2. C'apituluriu

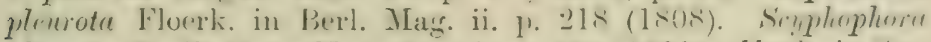

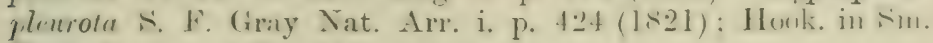
Engl. Fl. v. p. 240 (1833) pro parte.

Exsicc. Croall n. 600.

'This subspecies bears somewhat the same relation to the muene

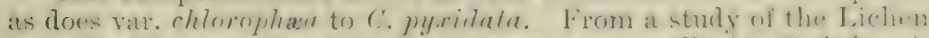

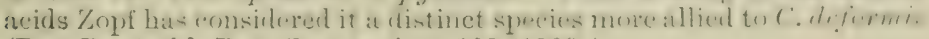
(Ber. Deutschl. Bot. Ges. xxvi. p. 109 (1908)). 


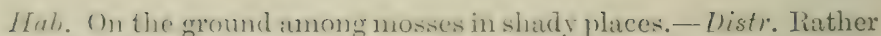
rute throughout the British Isles.-B. M. St. Breward and near Vardebridte, Cornwall ; Tilcrate. Anberley and Ardingly, Sussex; Hindhead and Plackwater. Surrey ; Ayton II oor, Cleveland, Yorkshire ; Ranuoch, Perthslire; (ilen .Inich, Aberdeenshire; Ten Ferrag by Loch Ericht. Invernesshire; Killarney, Kerry.

37. C. bellidiflora Sicher. Lich. Helv. Sipic. 1. ㄹ1 (1823).Primary thallus squimules moderate in size, rather firn, variously crenate or laciniate, often ascending, straw-coloured above, white beneath; podetia generally rather long, subsimple, cylindrical or somewhat ventricose, corticate and squamulose, scyphiferous or partly ascyphous, the seyphi narrow, sometimes imperfectly developed and divided, rarely proliferous $(\mathrm{K}-, \mathrm{CaCl}-)$. $\mathrm{A}_{1}$ othecia rather large, usually numerous and often conglomerate: spores 9-11 $\mu$ long, alout $3 \cdot 5 \mu$ thick. - Cromb. Lich. Brit. p. 21 (incl. fi. polycerthele and yrucilente) \& Monogr. i. p. 16:3 (incl. f. grucilenta); Leight. Lich. Fl. p. 72 ; ed. 3, p. 65; fï. ventricosu, poilycephale and gracilenta Floerk. Clad. Comm. pp. 97, 39 (1828); If, subuliformis and syncepleala Koerb. Syst. Lich. Germ. p. 29 (185.5). C. romifera var, bellidiflora Mudd Man. p. 60 (1861) do Brit. Clad. p. 29) (incl. ff. subulifurmis, gracilenta, ventricosa, synee1.luila and 1mlyceplutula). C. restitu Leight. in Ann. Mag. Nat. Hist. ser. 3, xix. p. 117 (1867) \& Lich. Fl. p. 67 ; ed. 3, p. 62 pro parte. Coralloniles via ramosum, scyplis olscuris Dill. Hist. Musc. p. 90, t. 15), fig. $14 \mathrm{~F}(1740)$ it Cor. scyphiforme, ossis femoris farir tom. cit. p. 91, t. 15, fig. 15. Lichen cormutus var. Lightf. Fl. Scot. ii. 1). $876(177 \pi)$. L. bellidiflorus Ach. Lich. Suec. P'rodr. p. 194 (1798); Engl. Bot. t. 1894. Cenomyge coccoceplata var. vestita pro parte and var. gracilenta Ach. Lich. Univ. 1'1. 541, 54: (1510). C. bellidiftora Ach. Syn. Lich. 1). 270 (181.4) (incl, vars. ventricosa and polycephala); Hook. Fl. Scot. ii.

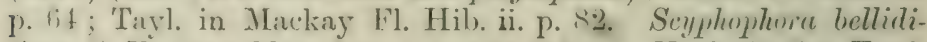
flora s. F. (iray Nat. Arr. i. 1. 424 (1821): Hook. in Sim. Engl. Fl. v. p. 240.

Exsice. Croall. n. 601.

Essentially an upland lichen, it is one of the most berutiful species of (')ulonia, with rather tall simple prodetia and brillinutly coloured matosive apotheria that generally (elowe up) the seyphus. It diflers from the preceding in heing corticite and more squannlose and in the marrower seyphit. The nome slender forms have been thesignated as f. gracilenta.

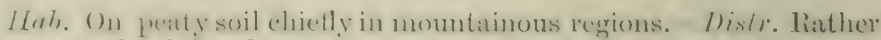
scarce in the hilly districts of Great Britain and Ireland.-B. M. Hustyn Down, Coruwall; Diffwys, near Barmouth, Merioneth;

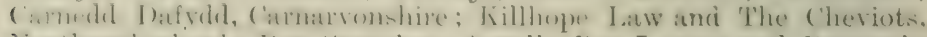

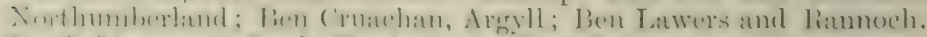

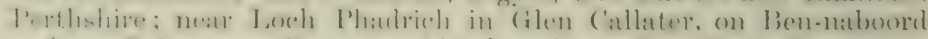

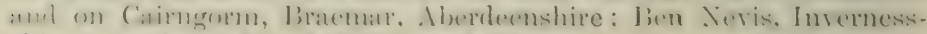
shire; Croghaun Mt., Achill Island, Mayo. 
Vax. Hookeri Nyl. Syn. Lich. i. 1) 221 (1860)-Pucl-tia clabrous, unequally corticate. withont squamules or only very itew ilereloped. Apothecin numerous, brinhty colourerl-Cromin, in Grevillea xi. 1. 114 i Monogr. i. 1) lit. C. Huoliri Tuck. in Proc. Amer. Acad. i. p. 247 (1847).

$H a b$. On the ground in subalpine moorlands.-Distr. Very rare among the N. Grampians, Scotland.-B. M. Glen Camblic. Britenna, Aberdeenshire.

3.. C. flabelliformis Wain. Mon. Cladl. Unir. i. p. 113 (1ssi). -Primary syuamules rather large or small. irregularly multifid and incised-crenate, pale-green or olive above, white helow or yellow towards the base; podetia of moderate length, somewhat widening upwards to the rather narrow scyphus, rarely ascyphous, often squamulose below, granular-pulverulent upwards, sometines brancher, the scyphus fringed by an irregular corona of proliferations of varying length ( $\mathrm{K}+$ orange-yellow, $\mathrm{CaCl}-$ ). Ipothercia small, discrete, or conglomerate and blockins up the scruhi: spores oblong-fusiform, 9-11 $\mu$ long.-C. pulydartyla Floerk. Clad.

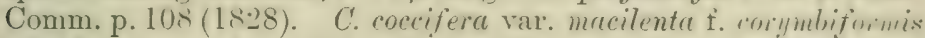
Mudd Man. p. 62 (1861) \& Brit. Clad. 1) 32 (incl. ft. tubrétormis, rorymbifurmis and f. phyllophora, p. 3.3). C. digitatu var. marilenta f. polydactyla Leight. Lich. Fl. p. 70: ed. 3, p. fit it fornumta,

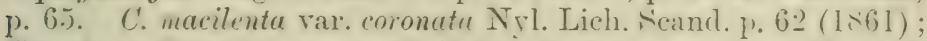
Cromb. in Grevillea xv. p. 46 (1R66) it Monogrt. i. J. 169 (incl. f. ventricosa, excl. f. carcata). Coralloides cormecrpioirles incrrmmin, seypleis cristutis Dill. Hist. Musc. 1). 94. 4. 15, fis. 17 1, 13, ( $(17+1)$. Lichen digitutus Huds. Fl. Angl. p. tiт (176-) (nom Limn. firle Cromb. Monogr. i. I. 166); Lightf. Fl. Sicot. ii. p. 874 ; With. Arr. ed. 3, iv. p. 39. L. ventricosus Huds. 1. c. ? Lightf. tom. cit. p. 875? With. tom. cit. p. 38? L. pyxilutus var. dimitatus Huds. Fl. Angl. erl. 2, p. 55t (17TS). C'apituluru flubelliformis Eluerk. in Jerl. Mag. ii. p. 216 (1S0s) fide $\mathbb{W}$ ainio 1. c. Bonmyres digitutus var. coronatus Ach. Meth. Lich. p. 3:3:) (180:3). ('rmmunger digitritu Hook. Fl. Scot. ii. p. 63 (18:21) (non Ach.). Siyphopluorus digitutus Hook. in Sm. Ensl. F1. v. p. 240 (18:33) pro parte.

Exsice. Bohl. nos. 7, 8 ; Jolnns. nos. 15, 299 ; Leight. nos. $27 t$ pro parte, 297 in some specimens; Mudd nos. 27. Clad. nos. 72 pro parte, 76, 79.

Sometimes described as a viriety of $c$. murilmtu, with which it is closely comnected, and with which it agrees in the white-pulvorulent podetia and the reaction with potash; but distinguished by distin.tly coronate seyphi. It is generally well-funited. Lichen intricenis doubtfully represents a form of this or of other species.

Hub. Among mosses on the gromnd, on boulders and alumit the roots of old trees. - Distr. Ciencral among the more hilly distriut of the British Isles. - B. M. Near Bodmin, Cornwall; Iry Jiriler and near Totnes, Devon; New Forest, Hants; Epping Forest. J...x : Chamwood Forest, Jeicestershire; Malrern, Woreestershire: liarmouth, Dolegelly and Aberdovey, Merioneth; Westerdale. I on:-iti: I. 
Inchlely and Kildale. Clereland, Torkshire; Ashgill, Cumberland; THinclimere, Testmoreland; Wark, Northumberland, New Galloway, Firliculbrightshire: IBarcaldine, Argyll; Glen Lochay, Falls of Bruar amul Joch liammoch. Perthshire; C'raig Cluny, Braemar, Aberdeenshile: Loch Linnhe and linthiemurchus Woods, Invernessshire; lillarney, lierry; Connemara, Galwaty; Slieve More Mt., Achill Island, MIayo; Devis MIt., Antrim.

Var. polydactyla Wain. tom. cit. p. 119.-Primary thallus fersistent or evanescent; podetia repeatedly proliferous from the margins of the scyphi, the proliferations scyphiferous or more rarely cornute.-C. coccifera var. macilenta f. polydractyla Iudd Man. p. 62 (1861) \& Brit. Clad. p. :32. Cenomyce polydactyla Floerk. Deutsch. Lich. x. p. 13 (1815).

Exsicc. Mudd n. 26 pro parte \& Clad. nos. 75, 77, 78.

Differing from the species in the more elongate scyphiferous proliferations. Possibly only a growth form, as there are many transition stages between the species and the variety.

Hab. Among mosses on the trunks of trees, etc.-Distr. Rather rare in S.IT. England, N. Wales and N. England.-B. M. Black Down and Treborough, Somerset; Dolgelly; Merioneth; Bilstiale, Baysdale and Ingleby, Cleveland, Yorkshire.

\section{Podetia ascyphous.}

$$
K+\text { yellow. }
$$

39. C. macilenta Hoffm. Deutschl. Fl. ii. p. 126 (1795).-Primary syuamules rather small, laciniate, lobate or crenate, slirucous-greenish above, white beneath; porletia cylindrical, : Hender, smple or divided at the apices, ascyphous or frequently finming at the apex an imperfect scyphus, everywhere whitishjulverulent ( $\mathrm{K}+$ yellow, $\mathrm{C}: \mathrm{Cl}-$ ). Apothecia small, terminal, sulitary or confluent: spores oblong or fusiform-oblong, $8-15 \mu$ long, 3-4 $\mu$ thick.-Cromb. Brit. p. 21 \& Monogr. i. p. 167

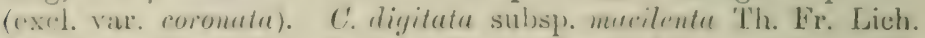
Scand. p. 68 (1871) ; Leight. Lich. Fl. p. 69 ; ed. 3, p. 63.

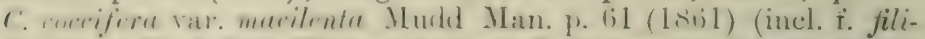

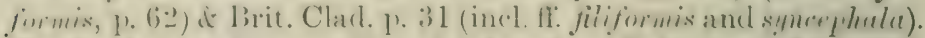

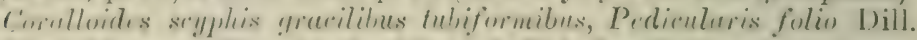

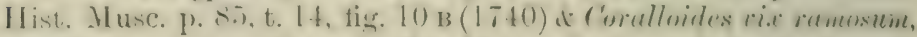

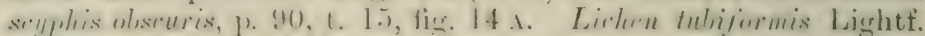
Fl. Scot. ii. p. 871 (1777) pro parte? L. filiformis With. Arr. orl. 3, iv. p. is (17!ni) (mon 11uds. and nmu Relh.); Ach. Lich.

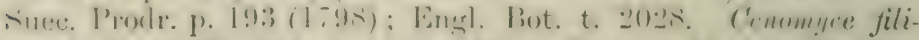

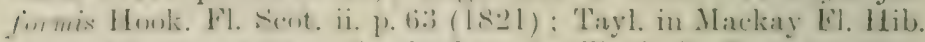
ii. p. 82 pro parte. Sycphophora bacillaris S. F. Gray Nat.

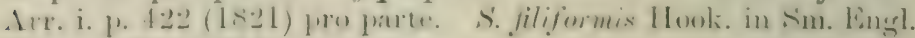
Fl. v. p. 233 (1833) pro parte.

Lxsicc. Johns: n. 297 ; Larb. Lich. Hb. n. 283 ; Aludd nos. 26 pro parte, 29 ، Clacl. 11.75 (in some specimens). 
Distinguished chietly by the rather small squanules, the slender white-pulverulent porletia and the yellow reaction with potash. The podetia taper towarts a blunt tip, which at times approaches very near to the seyplnus formation of $C$. flabelliformis. The apothecia are rarely well-developed.

Hab. Among mosses on old trunks of trees and on the ground in wooded districts.-Distr. General and not uncommon in most parts of the British Isles.-B. M. Jersey; Lustleigh and Bovey Tracey, Deron; New Forest, Hants; Epping Forest, Essex; Bradgate Park, Leicestershire; Cromford Moor, near Matlock, Derbyshire; Ayton and Ingleby, Cleveland, and Buckalan, Yorkshire; Windermere. Westmoreland; Ashgill, Cumberland; Sheriffunir, near Stirling; Barcaldine, Argyll ; Craig Calliach and Craig-y-Harns, near Dunkeld, i'erthshire; Craig Cluny, Braemar, Aberdeenshire; liothiemurchus Woods, Invernessshire.

Form clavata Cromb. in Grevillea xi. p. $114(1883)$ it Monogr. i. p. 168.-Podetia thickish, subventricose, unbranched, narrowing and cornute upwards, granular-pulverulent, sometimes minutely squamulose close to the base.-C. diyitatu subsp. macilenta f. clavatu Leight. Lich. Fl. p. 70 (1871) ; ed. 3, 1). 64. Coralloides vi.e ramosum scyplie olseuris Dill. Hist. Musc. p. 90, t. 15, tig. 14 B, C (1741). Lichen cornutus var. $\beta$ Lightf. Fl. scot. ii. P. $876(1777)$. Bitomyces defurmis var. clavatus Ach. Meth. Lich. p. 334 (1803) ?

Exsicc. Johns. n. 53 ; Leight. n. 403.

Tietained under $C$. macilenta rather than $C$. bacillaris, because of the yellow reaction with potash of all the specimens. It is merely a stouter subventricose form of the species. Apothecia are rare.

Hab. On the ground among mosses on heaths and on the deart stumps of trees in wooded upland districts.-Distr. New Forest. Hauts; Long Mynd, Shropshire ; Craig C'alliach aud Ramoch, P'erthshire; Mar Forest, Braemar, Aberdeenshire; Rothiemurchus, Inver. nessshire.

Form scolecina Nyl. Lich. Ficand. 1) 6: (1861) (incl. t. styru"clla).-Primary squainules crowded or scattered, rather thin, often more or less granular-sorediose when growing on woud: podetia small, tupering upwarch, white- or greyish-pulverulent. Aputhecia rave, minute, solitary or -2-3-angreate-Cromb. in Grevillea xi. p. 114 (1883) incl. f. stypacella \& Monogr. i. pp. Lis and 169; var. scolecine Cromb. Lich. Brit. p. 21 (1870).

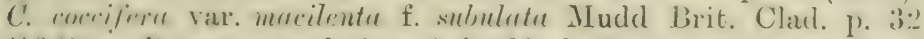

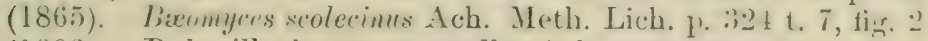
(1803). B. bacillaris var. styracellus Ach. tom. cit. p. 330.

Exsicc. Johns. nos. 52 and 244; Leight. n. 297 (in some specimens); Mudd Clad. n. 74.

A small form of the species approaching f. clarata on the one hand and vare astreater on the other, the specinusis on woul being particularly liable to soredial formation as in var. ostrcate.

Hal). (On mossy trunks of old trees or on decayiug wool. - I)is!r. Simewhat rave thoughout the liritish Isles. - S). M. Withiel, ('orn- 
Wall ; Bovery Tracey. I)ron; New Forest, Hants; Chichester. Sussex; Walthamstow, Essex; (iopsill Park, Lcicestershire; Nesscliff, Shropshire; I.oumstale, Clevelund. Forkshire; Whitehaven and Foremont, ('mmberland: Barcaldine, Areyll ; Loch Tummel, Perthshire ; Rothiemurchus Woods, Invernessshire, Torc Alt., Killarney, Kerry.

Tar. scabrosa Cromb), in Grevillea xii. p. 92 (1\&\&4) (incl. f. incrossatu) \& Mronogr. i. 169 (incl. f. intmesens).-Primary thallus of crowded granular squamules, greyish or glaucous, white bencath: podetia short or medium-sized, simple or variously divided, ascyphous, but blunt at the tips, covered with minute squamules or lough with granules. Apothecia small, sometimes conflunt. Form srabrosu Cromb, in Grevillea xi.

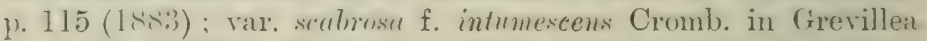
v. 1) 46 (1<56). I'Talonia corcifire var. macilente f. scabrose Mudd Brit. Clad. p. 32 (1865).

Exsicc. Johns. nos. 181 and 298 ; Mudd Clad. n. 73.

Somewhat similar to f. scolecina in the slighter forms, and gradually approaching to the more squamulose stouter condition if. intumescerns).

Hub. On decaving stumps and on turf-walls in wooded district:Distr. Local and scarce in S.W. and N. England, N. Wales and Ireland, frequent anoug the Scottish Grampians.-F. M. Near Bodmin, Cornwall; Ardingly. Sussex; near Graresend, lient; Malvern, Worcestershire; Dolgelly, Merioneth; Bridel Gill, Clevelaud, Yorkishire; Ashgill, Cumberlanil; Wark-on-Trne, Northumberland; New Galloway, Kirkeudbrightshire ; Barcalline, Argyll; Glen Lochay and Pannoch, Perthshire; near Inverey and Morrone, Bratenar, Aberdecushire ; liothiemurchus. Invernessshire ; Glandary and Dugort Road, Achill Island, Mayo.

Var. ostreata Nyl. Syn. Lich. i. 1). 225 (1860).-Primary squamules crowled, ascending or subimbricate, usually rather sorediose on the margins and under surfare; porletia short, stoutish. deasely sorecliose, obtuse at the apices. Aputhecia minute, very rare.-Cromb. in Grevillea xi. p. 115 (1S83) d Monocre i. 1'. 17. Cladonia digituta sulmp. macilenta f. asticatiformis Leight. Lich. 11. p. 70 (1871) ; ed. 3, p. 64.

Exsicc. Leight. n. 371.

The basal sifuanules are somewlat lilie those of Leridiu ostrintu. but larger, and with a cifferent reaction with potash. Terghtom has sugresterl that liden rmlifurmis sm. Eugl. Bot. t. 2112 (1810) might be the same as this variety. lut though the surumules bean some resemblame, the real "fruits" are rather those of some parasitic fungus. Houker refers to it doubthully as l'some ruthiformis $1.5 \mathrm{~m}$.

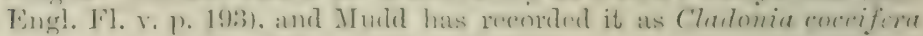
var. macilenta f. mubiformis (Man. p. 62).

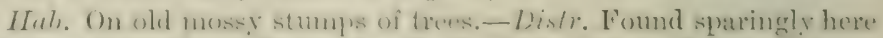

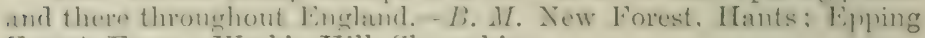
Forest, Essex; Wrekin Hill, Shropshire.

10. C. bacillaris Nyl. in Not. Sillsk. Faun. d Fl. F(nm, 11.s. 1. 1. 179 (lifiti). Diasal stpamules rather small, crenatle wr 
laciniate, glaucous or whitish above, white beneath; podetia slender, subcylindrical, simple or shortly divided above, subulate or rather blunt at the apices, greyish-white, granular-pulverulent ( $\mathrm{K}-, \mathrm{CaCl}-$ ). Apothecia small, sometimes confluent.Cromb. in Grevillea xi. p. 115 (1883) \& Monogr. i. p. 171. C. Floerlieana var. bacillaris Leight. in Ann. Mag. Nat. Hist. ser. 3, xviii. p. 417 (1866) pro parte \& Lich. Fl. p. 71 ; ed. 3, p. 65 pro parte; Cromb. Lich. Ijrit. p. 21 . C. roccifere var. macilenta f. clavata Mudd Brit. Clad. p. 32 (1865). Coralloirles vamulosum, tuberculis coccineis Dill. Hist. Musc. p. 96, t. 15, fig. 19 c (1741). Bæomyces bacillaris Ach. Meth. p. 329 (1803) pro minore parte. Seyphophora bacillaris S. F. Gray Nat. Arr. i. p. 422 (1821) pro parte.

Exsicc. Johns. n. 245 ; Mudd Clad. n. 70.

Distinguished from the preceding species by the absence of reaction with potash. The British specimens are rarely fertile.

$H a b$. On the ground or on turf-walls in inland situations.-Distr. Rare in S. and N. England, the Scottish Grampians and N.W. Ireland.-B. M. Wadebridge, Cornwall; Ayton Moor, Cleveland, Yorkshire; West Allen Carrs, Northumberland; Appin, Argrll; Glen Lochay and Rannoch, Perthshire; hills at Nigg, Kincardineshire.

Form pityropoda Nyl. ex Cromb. in Grevillea xi. p. 115 (1883). Podetia stoutish, rugose or minutely and crowdedly squamulose.-Cromb. Monogr. i. p. 172.

$H a b$. On the ground and on turf-walls in upland districts.-Distr. Rare among the Scottish Grampians and in N.TV. Ireland.-B. . K. Rannoch, Perthshire: Appin, Argyll ; Colin Glen, Antrim; Connemara, Galway.

Var. subcoronata Nyl. ex Cromb. in Grevillea xii. p. 92 (1884) \& Monogr. i. p. 172.--Podetia rather stoutish, very granulose or squamulose, simple or digitately branched towards the apices.-C. coccifera var. macilenta f. obtusa Mudd Man. p. 62 (1861) \& f. polycephala Mudd Brit. Clad. p. 32 (1865) pro parte. C. macilenta var. filiformis f. polycephala Flot. ex Koerb. Syst. Lich. Germ. p. 32 (1855). Coralloides ramulosum, tuberculis roccineis Dill. Hist. Mluse. p. 96, t. 15, fig. 19 A, B (1741).

Exsicc. Mudd Clad. n. 72 pro parte.

Approaches var. carcata of the following species, but still more closely allied to C. bacillaris in the longer and more finely pulverulent podetia. The British specimens are well fertile.

Hab. On the ground in upland moorlands.-Distr. Rather rare in S.W. and N. England, the S. Grampians, Scotland, and N.W. Ireland. - B. M. St. Breward, Cornwall ; near Hunter Tor, Dartmoor, Devon ; Sullington Heath and Ardingly, Sussex; Fildale Noor and Ingleby Park, Cleveland, Yorkshire; Glen Lochay, Perthshire; Connemara, Galway. 
41. C. Floerkeana Fr. Nov. Sched. Crit. p. 18 (1826).-Primary thallus of small seattered squamules, laciniate or crenate, sreenish-white ahove, white beneath, often scarcely visible; porletia short, cylinclrical, slencler, corticate entirely or in parts, only rarely sorediose, greyish-white or -green or brownish, often blackish at the base; mostly ascyphous, but rather wider at the obstuse alex, or fresuently shortly divided or branched $(\mathrm{K}-, \mathrm{CaCl}-)$. Apothecia moderate in size, usually conglomerate and hulging over the tips of the podetia; spores $8-10 \mu$ long, :) $\mu$ thick-Cromb. Lich. Brit. P. 21 pro parte \& Monogr. i. p. 172 ; Leight. Lich. Fl. p. 71 ; ed. 3 , p. 65 pro parte. C. corciferc var. Flowlienme Mudd Man. p. 61 (1861) \& Brit. Clad. p. 3:3 pro parte. Lirdien digitatus Sm. Engl. Bot. t. 2439 (1812) (non Huds.).

Exsice. Bohl. n. 80 ; Johns. n. 246 ; Mudd n. 24.

Differs from ('. Zncillaris in the shorter slender corticate rough porletia, rather like some of $C$. pilyrea, and in the abundant apothecia. Not unfrequently the podetia become roughly sorediose.

Hab. On peaty ground in uplaud moorlanits.-T/istr. Rather rare in the typically corticate condition in S., aud N. Englamd and among the Scottish Grampians.-B. 1. Inirtmoor, Devon; Ayton Moor, ('leveland, Yorkshire; Teesdale, lurhann; Achosmagn Hill, Aroyll ; Craig Calliach, Perthshire, Ben-naboord and Glen Callater, Braemar. Aberdeenshire.

Var. carcata Wainio Clarl. Univ. i. p. \&0 (18S7).-Podetia short or merlium-sizerl, multifir ahore, more or less verrucosesquamulose and often becoming surediese.--Form trachypoda Nyl. ex Cromb. in Joum. IBot. xiv. 1) 360 (1876) \& Monogr. i. 1. 17:3. C. macilenta var. currata Nyl. Lich. Scand. p. 62 (1861); Cromb. Lich. Brit. p. 21 \& f. carcuta Mlonogr. i. p. 171; C. concifora var. macilentu f. "arecutu Mudd Brit. Clad. p. 32

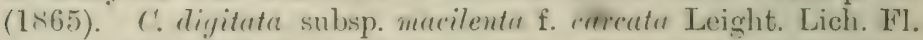
p. 70 (1871); ed. 3, p. 64 pro parte. Cenomyce carcata Ach. Lich. Univ. p. 568 (1810)?

Exsirr. Croall n. 599) : Latrb. Ti(ch. Hb. n. st; Leight. n. 56; Mudd Clad. nos. 67 pro parte and 71 .

Searecly distinguisher from the species exeejt by the squamules, "hich are usually rather scattered on the podetia ; the squanules or rerrucie may becone sorediose-pulverulent, and the apex is often multifid as in the speciess. ('enomyce carcata Ach. is of doubtful prosition, the description seems to refer nore ('losely to ('. bacillaris.

Hab. On peaty soil on the ground or on boulders in upland rerims. - llists. Xot mirequent throughout (iread 13ritain and Treland. Ji. M. Arilingly liocks, Sussex; Tunbridge Wells, Rent; Fsher (ommon and beith Hill, Surrex; Epping Forest, Fssex;

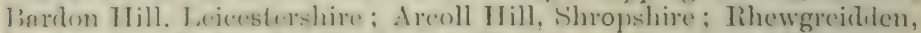
Merioneth; Battershy Bank and batysinle. ('leveland, Yorkshire;

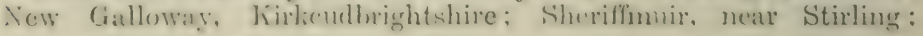


Achosragan Hill, Appin, Argyll; Craig Tulloch and Tannoch, I'erthshire; Canlochan Glen, Clovi, and Sidlaw Fills, Forfarshire; Cairnma Earn, Kincardineshire; Ben-naboord, Hill of Fare and Morrone, Braemar, Aberleenshire; Glen Nevis, Invernessshire; Applecross. Rossshire ; Lairg, Sutherlandshire; Doneraile Mts., Cork; Killarner. Kerry; near IKylemore, Connemara, Galway.

\section{Order XIX. LECIDEACEF. (Part 2, p. 2.)}

\section{GYALECTA Ach. (Part 2, p. 4.)}

\section{G. cupularis Schær. (Part 2, p. 5.)}

Var. marmorea Boist. Nouv. Fl. Lich. Fr. pt. 2, p. 178 (1902). -Distinguished from the species by the entire margin and by the habitat.- W. G. Travis, Lanc. Nat. iii. p. 82 (1910).

Recorded by IV. G. Travis on decayed moss. The condition of the margin seems, however, to be merely a growth phase that oceurs in plants on limestone as well as in those on mosses.

Hab. On mosses or mortar of an old limestone wall at Downlim. Lancashire.

4.1. Gyalecta rubra Massal. Ric. Lich. Crost. p. 146 (18.)2). Tharllus effuse, thin, powdery or granulose, whitish, the hylothallus whitish, scarcely visible $(\mathbf{K}-)$. Apothecia moderate in: size (rarely up to $1.5 \mathrm{~mm}$. across), at first closed then open and ('oncave, the disc rosy-red or reddish flesh-coloured, sometimes slightly pruinose, the outer unargin prominent, persistent, crenulate; paraphyses stoutish, septate, clavate and red at the tips: spores oblong-ellipsoid, 3-septate, 15-23 $\mu$ long, 5-8 $\mu$ thick.Mudd Man. p. 166, t. 3, fig. 58. Patellaria mbra Hoffm. PI. Lich. i. p. 81, t. 17, fig. 2 (1790). Parmeliu rubra Ach. Meth. Lich. 1. 170 (1803) ; Leight. Angioc. Lich. p. 86, t. 14, fig. 1. Leenora rubra Ach. Lich. Univ. 1) 389 (1810); Hook. Fl. Seot. ii. 1. 49 \& in Sin. Engl. Fl. v. p. 190 ; Cromb. Lich. Brit. 1. 58 \& Monogr. i. p. 457; Leight. Lich. Fl. r. 230 ; el. :3, 1. 222. Lichen Ulmi Sm. Engl. Bot. t. 2218 (1810). Rinodina rubru s. 1. Gray Nat. Arr. i. p. 457 (1821). Phiulopsis rubru Koerb. Syst. Lich. Germ. 1. 170 (1855); Mudd Man. 1) 165.

Exsicc. Cromb. n. 168; Leight. n. 236 ; Mudd n. 138.

Forming a thin willely effuse scurf on the substratun of bark on moss. The apothecia are numerous and prominent and well marlierl by the white crenulate margin and the rose-red disc.

Though classitied by various liehenologists under Lecenora, the structure of the thallus (with Trentepohlin gonidia), and of the apothecia, agree with the Gyalectiv. The species should be insurted after $G$.geoica. (Part 2, p. 7.)

Hab. On old trunlss of trees-oaks or elms, and on mosses on walls, de.-Distr. Lecal or ware in S., IV. and N. Fugrand and in the Sicottish Hirhlinels. - D. M. Jieeding l'riory, Sussex; Wignoms 
Castle, Herefordshire; Craig-y-Rhiw, near Oswestry, Shropshire; near Rieraulx, Bilsdale and Greta Bridge, Yorkshire; Craig Tulloch, Blair Athole, Perthshire.

"Phialopsis livida Mudd Man. p. 166 (1861).--Thallus effuse, thinnish, subtartareous, granulose-verrucose, becoming somewhat leprose, white. Apothecia small, not numerous, scattered, sessile, the dise dull- or bluish-black, slightly concave then plane, the margin thickish, smooth, polished, white; hypothecium dark-red, grumous; spores $\delta$ in the ascus, ellipsoid-oblong, irregularly 4-celled." Specimen not seen.

Mudd has stated that " this species somewhat resembles Lccanora (Aspicilia) verrucosa in its mode of expansion and outward appearance. It may be known by the colour of its hypothecium, stout paraphyses and by the internal organization of its spores." In the absence of specimens it is advisable to leave it where Mudd placed itnext to "Phialopsis rubra" - until the plant has been again collected.

$\mathrm{Hab}$. On the trunks of old trees, Killarney, Kerry.

LECIDEA Ach. (Part 2, p. 10.)

Species overlooked, or issued since the publication of Part 2.

"L. prostratula Stirt. in Scott. Nat. v. p. 218 (1880).'Thallus pale or pale-grey, thin, squamulose, the squamules adpressed, plane, scattered or contiguous with orcasionally crenulate margins, on a black hypothallus ( $\mathrm{K}-, \mathrm{CaCl}+$ reddish). Apothecia black, sessile, about $\cdot 6 \mathrm{~mm}$. wide, plane, marginate, becoming convex and almost immarginate; hypothecium brownishblack; paraphyses somewhat irregular, medium-sized, distinct, conglutinate at the black clavate apices; spores colourless, ellipsoid, simple, 9-12 $\mu$ long, 5-6 $\mu$ thick ; hymenial gelatine slightly bluish then wine-red with iodine.

From the squamulose thallus, the species should be placed near to L. Friesii (Part 2, p. 14).

Hab. On rocks, Craig Var, Kinloch Rannoch, Perthshire.

L. hypocyanea Stirt. 1. c.-Thallus pallid or pallid cinereous, rugulose, squamulose-congested. Apothecia brown or brownishblack, small $(\cdot 2-4 \mathrm{~mm}$. wide), convex, immarginate, aggregate or congested (12-30 glomerulate); hypothecium red, the subhymenial stratum thickish, bluish or intensely blue; paraphyses not discrete, conglutinato at the apices, not clavate nor inspersed : spores 8 in saccate asci, ellipsoid, simple, 9-12 $\mu$ long, $6-7 \mu$ thick.

Possibly akin to $L$. cnilocyanca Stirt. (1'art 2, p. 17). Stirton states that the blue colour is lacking here and there, and that nitrie acid applied gives at first a violaceous tint which ultimately vanishes.

$H a b$. On soil at the foot of Ben Lawers, Perthshire.

- Stirton's specimens have recently been sent for examination to the British Museum, where a set will be preserved. A revision of the species will be published in due course. 
23. L. coarctata Nyl. (Part 2, p. 22.)

Instead of thallus $\mathrm{CaCl}+$ deep-red insert :- $\mathrm{CaCl}$ - or + reddish; and after spores ellipsoid add:-when young often tinged with pale rose-colour and with large oil globules, 14-26 $\mu$ long. $7-12 \mu$ thick.

L. humigena Tayl. in Lond. Journ. Bot. vi. p. 150 (1847).Substratum of the thallus cuticular, gelatinous, whitish with scattered minute roundish brown verrucæ; gemmæ (gonidia?) granular, crowded, minute, oblong, subangular. Apothecia greenish, hemispherical, subpellucid, pale-brown, immarginate, the disc scabrid.

Probably near to or synonymous with $L$. vernalis (Part 2, p. 33). though Taylor says it can scarcely be confounded with that species.

Hab. On wet clay banks; Dunkerron, Kerry.

I. filamentosa Stirt. 1. c.-Thallus whitish or pallid, rugulose. sometimes dispersed-areolate. Apothecia small $(\cdot 2-\cdot 4 \mathrm{~mm}$. wide), brownish-black, plane, acutely marginate, becoming convex and scarcely marginate; hypothecium colourless; paraphyses slender, irregular, not well discrete, with sordid-brownish apices; spores 8 in the ascus, colourless, simple, oblong or oblong-ellipsoid, 11$16 \mu$ long, 5-6 $\mu$ thick: hymenial gelatine blue then yellow with iodine. p. 39).

Might be allied to L. albohyalina Nyl, in Sect. Biatora (Part 2.

Hab. On fallen or worked wood near Killin, Perthshire.

112A. L. petrosa Arn. in Flora li. p. 36 (1868).-Thallus thinly crustaceous, whitish or bluish-white, sometimes finely cracked-areolate or almost obsolete. Apothecia sessile or adnate, solitary or two or three together, at first plane, with a prominent margin, brownish-black; hypothecium black; paraphyses stoutish, conglutinate, the hymenium faintly blue-green or crerulescent, the epithecium dark, purplish-, bluish- or greenish-brown; spores ellipsoid, large, 16-30 $\mu$ long, 9-13 $\mu$ thick; hymenial gelatine blue with iodine.

Distinguished by the cxruleous blue colour in the hymenium and by the large spores. A variety albo-suffusa (L. cyaniza. Nyl. in Flora lv. p. 359 (1872) ) has been recorded by Th. Fries (Lich. Scand. p. 512) with pruinose apothecia.

We are indebted for the discovery and determination of this interesting species to $\mathrm{Mr}$. T. Hebden.

$H a b$. On calcareous rocks. $-B, M$. Malham, Yorkshire.

L. mersata Stirt. 1. c.-Thallus pallid or pallid-glaucous, sometimes reddish-ferruginous, thin, almost continuous, smooth, here and there rimulose-areolate $(\mathrm{K}-, \mathrm{CaCl}-)$. Apothecia 
adnate, black, large, plane, narrowly marginate, becoming "onvex and almost immaryinate, within cerulescent, especially apwarls; hypothecium thick, brownish-black; paraphyses dis('lete, filiform, 2-5-.) $\mu$ thick, the apices mostly blue, scarcely "lavate: spores colourless, simple, ellipsoirl or often fusiform4lipsoid, $2 \cdot 2-36 \mu$ lons, $8-11 \mu$ thick : hymenial gelatine intensely blue, the asci yellowish, with iodine.

Evidently closely allied to if not identical with Leciden jetrosa Irn.; but considered by Stirton as "near to L. cyanothalmu Nyl. ,Flora lv. p. 858 (1872)), which scarcely differs from L. contigua Fr." (lart 2, p. 67).

Hab. On submerged rocks in Loch Rannoch, Perthshire.

\section{L. albocœrulescens Ach. (Part 2, p. 69.)}

Var. smaragdula Knowles in litt.-Thallus continuous or rispersed, glaucous-white or white, with white hypothallus. - Ipothecia with slender, subcoherent paraphyses, clear-green or greenish-blue at the tips.

Differs from the species in the white hypothallus and chiefly in the clear green colour of the epithecium in section. These difference. may possibly be due to the submerged habitat.

Hah. On coarse granite rocks, completely submerged except in summer-P. M. Shores of Iough Nahanaghan (1377 ft.), Wicklow. Collected by M. C. Knowles, Sept. 1914.

129A. L. instratula Nyl. in Flora lxi. p. 24: (1878).'Thallus dark-grey, thin, smooth, plane, minutely cracked-areolate', with a black hypothallus. Apothecia minute, black, innate and immarginate; hypothecium colourless; paraphyses distinct, but very coherent, the epithecium blackish-green; asci swollen : spores ellipsoid, 9-12 $\mu$ long, 4-5 $\mu$ thick.--B. de Lesd. in Bull. Soc. Bot. Fr. liv. p. 444 (1907); Lillie in Scott. Bot. Rev. i. 1. $152(1912)$. Specimen not seen.

Evidently nearly allied to $L$. plan (Part 1, p. 76). The description is taken from Nylander and from B. de Lesdain.

Hab. On granitic rorks. Collected by D. Lillie at Canister Cairns. Caithness.

L. recensa Stirt. tom, (it. p. 219.- Thallus white or whitish, convex-areolate (areolie: contiguous or dispersed). Apotheciat sessile, black, flane, with a black margin (nargin mostly urdulate), small, often aggrenate; spores s in the ascus, colourl'ss, simple, oblong, curved or arcuate, $10-14 \mu$ long, $3 \cdot 5-4 \cdot 5 \mu$ thick; hypothecium colourless; paraphyses sometimes irregular, lhickish, with clavate brown tips; hymenial gelatine bluish with iodine.

Stirton sugrests that the above may be a form of $L$. rivulosa (lart 2, p. 87).

Hab. On rocks, Craig Var, Perthshirc. 
L. amphiplecta Stirt. 1. c.-Similar to L. furvella Nyl. (Part 2, p. 94), but with a colourless hypothecium, the paraphyses concrete and as if reticulate and the epithecium thick, conglutinate, brownish-black.

With potash the paraphyses become more distinct, as irregular. disjointed or nearly moniliform threads.

Hab. On rocks, Ben Lawers, Perthshire.

I. dasæa Stirt. 1. c.--Thallus brown or brownish-black, loosely adherent, soft, granulate-furfuraceous or isidioid, diffractareolate almost as in $L$. furvella $\mathrm{Nyl}$., but sometimes thinner and more scattered. Apothecia brownish-black or black, sinall $(\cdot 2-3 \mathrm{~mm}$. wide) concave, acutely marginate, becoming plane, with the margin depressed ; within reddish-brown ; hypothecium dark or redlish-brown; paraphyses irregular, not distinct, the apices concolorous, not clavate; spores 8 in the ascus, colourless, spherical, simple, $3 \cdot 5-4 \cdot 5 \mu$ in diameter; hymenial gelatine unchanged with iodine.

Considered by Stirton as alin to L. antiloga Stirt. (Part 2, p. 100).

Hab. On fallen wood, near Ben Lawers, Perthshire.

L. sanguinaria Ach. (Part 2, p. 105.)

Subsp. subsanguinaria Stirt. tom. cit. p. 218. - Similar to the species, but the thallus within continuously or here and there reddish $(\mathrm{K}-, \mathrm{CaCl}-)$. Spores occasionally 2 in the ascus, 70-120 $\mu$ long, 32-54 $\mu$ thick.

$H a b$. Corticolous, near Kinloch Rannoch, Perthshire.

\section{BIATORELLA De Not. (Part 2, p. 107.)}

§i. Eubiatorella Th. Fr. Lich. Scand. p. 397 (1874).Thallus evident or indistinct. Apothecia mostly soft and rather pale within (biatorine).

To include spp. 1-6 and also 4A B. campestris Th. Fr. (Part 2, p. 353).

$\S$ ii. Stlicogre Th. Fr. tom. cit. p. 405. Sarcogyne Flot. in Bot. Zeit. viii. p. 382 (1850). - Thallus superficial or immersed. Apothecia more or less carbonaceous, with prominent proper margins.

The following species of Biatorella were classified by Crombie under Lecanora (Monogr. i. p. 487). They are transferred to the lecideine genus because of the absence of gonidia in the apotheciun. They are numbered in succession to the Biatorella in Piurt 2.

\section{T'hallus evident.}

7. Biatorella pruinosa Mudd Man. p. 191, t. 3, fig. 74 (1861) (incl. var. reguluris).- Thallus thin, efluse, furfuraceous : 
greenish when wet, greyish-white when dry $(\mathrm{K}-, \mathrm{CaCl}-)$. Apothecia small or moderate in size, appressed, plane, reddishblack when moist, black, often bluish-grey-pruinose when dry, sometimes with a thin pseudo-margin; hypothecium pale; paraphyses slender, coherent, thickly septate, scarcely widened and brown towards the apices; spores many in the ascus, minutely ellipsoid or oblong, 3-5 $\mu$ long, about $2 \mu$ thick; hymenial gelatine bluish then tawny with iodine.-Lichen pruinosus Sim. Engl. Bot. t. 2244 (1811) (non Ach.). Lecidea pruinosa Hook. in Sm. Engl. Fl. v. p. 179 (1833) pro parte; Tayl. in Mackay Fl. Hib. ii. p. 125) pro parte. Lecanora pruinosi Cromb. Lich. Brit. p. 57 (1870) \& Monogr. i. p. 487, fig. 68. L. glancoctrin f. pruinosa Leight. Lich. Fl. p. 183 (1871); ed. 3, p. 168.

\section{Exsice. Johns. n. 420 ; Leight. n. 300 ; Murdd n. 160.}

Distinguished from allied species by the habitat and by the frequently pruinose disc of the apothecium. The thallus is sometimes immersed and scarcely visible.

Hooker (in Sm. Engl. Fl. l. c.) has quoted as a synonym Lichen pminatus Dicks. (errore L. pruinosus), published in Pl. Crypt. fasc. iii. p. 15, t. 9, fig. 4 (1793). According to the description, that species bas a ferruginous thallus and may possibly be a form of Lecidea confluens.

$H a b$. On calcareous rocks and mortar of walls from maritime to upland regions. - Distr. General and common in the British Isles.-15. 11. Near Penzance, Cornwall; Shanklin, I. of Wight; Lewes and Malling, Sussex; Shiere, Surrey; Cirencester, Gloucestershire; nen* Hereford; Harboro' Magna and P'olesworth, Warwickshire; near Malvern and Whittington, Worcestershire; near Corwen, Merioneth; near Shrewsbury, Shropshire; Ingleton and B3ilsdale, Cleveland, Yorkshire; near Gainford, Durham; Leven's l'ark and staveley. Westmoreland; Appin, Argyll ; King's I'ark, S'tirling; Craig Tulloch, Blair Athole, Perthshire; near Aberdeen; I) unkathal, Corls; White Park Bay, Antrim.

Form nuda A. L. Sm.-Thallus little visible or entirely immersed. Apothecia reddish-hrown, equinose. -- Lecanora fruinosa f. mula Nyl. ex Lamy in Bull. Soc. Bot. Fr. p. 423 (1878); Cromb. in (irevillea xix. p. 5s (1891) d Monogr. i. p. 488 .

Januy found this form abumlant on the granitie stones of old mildings, and remarks on the regular well-opened epruinose apothecia. It is often difficult to distinguish it from the species.

Hab. On rocks chictly calcareons, rarely siliceous and on mortar. of walls in upland regions.-D) istr. Widely distributed but rather rare in the Jiritish Isles.-B. M. Xeru linvey Traces, Devon; Egerton, Lient; Cirencester, Glowesterthire; Malvern, Worcestershire; Appin. Argell; Jen Lawers and Craig T'ulloch, Jiair Athole, Perthshire; Applecross, Rossshire.

Var. albocincta A. L. Sin.-Thallus immersed. Apothecia thinly fruinose or naked, with a white pruinose pseudo- 
margin.-Lecanorre pruinose var. albocincta Cromb. MIonogr. i. p. 488 (1894).

$H a b$. On the mortar of a wall in an upland district. $-B . M$. Mathon, Malvern Hills, Worcestershire (the only record).

8. B. hypophæa A. L. Sm.-Thallus effuse, thickish, unequally granulate, greyish- or dull yellowish-green $(\mathbf{K}-)$. Apothecia rather small, plane, dark-red or blackish, the proper margin unequal or subcrenulate, becoming exclucled; hypothecium pale or brownish; paraphyses rather stout, thickly septate, variously widened at the yellowish-brown apices; spores many, oblong, $5-6 \mu$ long, $1 \cdot 5 \mu$ thick; hymenial gelatine bluish then wine-red or tawny with iodine.-Lecanoru liypopliæa Nyl. in Flora liii. p. 34 (1870); Cromb. in Journ. Bot. viii. p. 97 (1870) \& Monogr. i. p. 489 ; Leight. Lich. Fl. p. 186 ; ed. 3, p. 172.

Differs from $B$. privigna, with which it is closely allied, in the presence of the superficial thallus and in the somewhat different spores; the paraphyses are exactly alike.

$H a b$. On granitic stones of a wall. - B. MI. Old MIachar Cathedral, Aberdeen (the only record).

9. B. flava A. L. Sm, ex Johns, in Naturalist 1917, p. 88.Thallus effuse, thickish, unequally granulate-cracked or scattered and furfuraceous, dull ochraceous-brown $(\mathrm{K}-$ ). Apothecia rather small (about $\cdot 5 \mathrm{~mm}$. in diam.), sessile or subinnate, sometimes circumscissed, plane or rarely convex, dark reddish-brown or black, the thalline margin inclistinct or disappearing; hypothecium and hymenium colourless; paraphyses slender, conglutinate above, Hexuose, sparsely septate except near the tijs which are slightly clavate and brisht-brown; spores many, minute, oblong-ellipsoid, about $3 \mu$ long, 1-2 $\mu$ thick; hymenial gelatine persistently blue with iorline.-Lecunora privigna var. flava Johns. in litt.

The thallus is not unlike that of $B$. hypophæa, but in the internal structure it differs from that species as also from B. privigna.

Hub. On limestone in a quarry.-B.M. Near the Church, Forest, Teesdale, Durham.

\section{Thallus not evident.}

10. B. clavus 'Th. Fr. Lich. Scand. p. 409 (1874).-Thallus very reduced, occasionally a few granules only risible below the apothecia. Apothecia large, often aggregate, attached at a central point, sometimes several connate in a common attachment, cuncave then plane, dark-reddish or almost black, with a prominent proper margin which is persistent and crenulate: hypotheciun thin, blackish-brown; paraphyses conglutinate, stoutisb, septate, scarcely widened at the tips, the epithecium dark-brown; spores many, oblong-ellipsoid 4-5 $\mu$ long, alout $2 \mu$ thick; hymenial selatine deep blue with iodine.-Patellario 
Alarus DC. Fl. Fr. ii. p. 348 (1805). Lecidea encarpa Nyl. in Bot. Not. 1853, p. 163. Lecanor eurecrue Stizenb. Lich. Helv. I). 134 (1881-2); Cromb. in (irevillea xix. p. 58 (1891) it Monogr. i. p. 48s. L. glancornrpa f. encarpn Leight. Lich. Fl. p. 183 (1871); ed. 3, p. 16s. Cathisinia concinna Stirt. in s'cott. Nat. iii. p. 307 (1888).

Distinguished by the large ayothecia with rugose margins.

Hab. On granitic rocks in maritime districts or by inland waters. -Distr. Rare in the Channel Islands and in Scilly, and among the Seottish Grampians.-B. MI. West Coast of Guernsey; St. Mary's, Scilly; Loch Rannoch, Perthshire.

11. B. privigna A. L. Sm.-Thallus indistinct or obsolete. Apothecia moderate in size, generally congregate, rounded or ancrular from pressure, the dise plane, reddish when moist, blackish when dry, brick-red under the outer black crust, the margin prominent, persistent, generally entire; hypothecium pale-coloured: paraphyses slender, conglutinate, thickly septate, reddish-brown upwards; spores many, minutely ellipsoid, $3-4 \mu$ long, $1 \cdot \pi / 4$ thick; hymenial gelatine blue then dull-greenish or tawny with iodine.-Licheu simplex Sm. Engl. Bot. t. 2152 (two right hand figs.) (1\&10) (non Dav.). Lecidea privigna Ach. Mroth. Lich. p. 49 (180:3): Hook. in Sm. Engl. Fl. v. p. 184. Endocarpon smaragdulum var. privignu Leight. Angioc. Lich. 1. 16 (1551). Lecanora fusiceta var. privigna Cromb. Lich. Brit. 1). 56 (1810). L. squamulese f. privigna Leight. Lich. FI. p. 185: ecl. 3, p. 170. L. privigna Nyl. in Bull. Soc. Linn. Norm. sér. 2, vi. p. 288 (1872); Cromb. Monogr. i. p. 489.

Exsicc. Johns. n. 277 ; Larb. Lich. Hb. n. 254.

Distinguished from $B$. clueus especially by the smaller apothecia and by the pale colour of the hypothecium.

Hat. On arenaceous and rranitie rocks in maritime and upland districts.-Distr. Hare but widely distributed in the British Isles.B. .1. Alderney; St. Jrelade's, Jersey; Shanklin, I. of W'ight; 13ywell, Northumberland; Bay of Nigg, lineardineshire; Woodside, near Aberdeen.

12. B. simplex Br. \& liostr. Lich. Dan. p. 115 (1869).Thallus deeply immersed. Apothecia minute, concave or plane, variously corrugate, black, the margin prominent, flexuose and irregularly crenate; paraphyses very slender, flexuose, sometimes luanched and septate, sliwhtly elavate and brown at the tips: spores many in the ascus, nimute, ellipsoid, :3-4 $\mu$ long, $1-2, \mu$ thick; hymenial grelatine blue then quickly wine-red with iodine. - Liehen simpled Dav. in Trans. Limn. Soc. ii. p. 285, t. 28 , fig. 2 (1794); With. Arr. ed. 3, iv. p. 5: Fingl. Bot. t. 2152 (two left hand figs.). L. simplex IIook, in ,in. Gngl. Fl, v. p. 179 (18.3:3) : Tayl. in Mackay W1. Hib. ii. P. 124. Rimedina privigna s. F. Giray Nat. Arr. i. p. 150 (1821). Acarospora cervina var. 
ximplex MIudd Man. p. 160 (1861). Lecanora simplex Nyl. ex Cromb. Lich. Brit. p. 57 (1870) it Monogr. i. p. 490 (incl. f. herpes) (1894). L. squumulose f. simplex Leight. Lich. Fl. p. 185: ed. 3, p. 170 .

Ersicc. Johns. nos. 418,419 ; Larb. Lich. Hb. without i number; Leight. nos. $272,273$.

The thallus is only rarely risible as a thin scurf; it is, however, present within the substratum. The species in this and other respects is nearly allied to $B$. pruinosa, though the apothecia are smaller and more irregular in form; is form with extremely winliled apotheci has been classified as Opegrapha Persoonii var. strepsolina Ach. (Lich. [niv. p. 247); if angulose and grrose-plicate it is Lecanora simplex. f. complicata Cromb. in Grevillea xix. p. 58 (1891).

Hab. On rocks chiefly schistose and calcareous in wuaritime and nountainous regions.-Distr. Not uncommon throughout the British Isles.-B. M. Lia More, Jersey ; Chateau Point, Sark; Tintagel, Withiel and Penzance, Cornwall; Buchfastleigh, Ashburton and Ilfracombe. Deron; Aberdorey, Barmouth and Dolgelly, Merioneth; Bangor. Cirmarvonshire; Anglesea; north of Douglas, Isle of Man; Hexhan and Bywell, Northumberland; Barcaldine, Ballachulish and Glencoe. Argyll; Craig Calliach, Ben Lawers and Craig Tulloch, Blair Athole. l'erthshire; Bay of Nigg, Kineardineshire; Craig Guie and Morrone, Braemar, Aberdeenshire; Dunkerron, Kerry; Gleucorbot, Connemara. Galway.

\section{BILIMBIA De Not. (Part 2, p. 133.)}

B. ilyophora TVheld. \& Wils. in Journ. Bot. liii. Suppl. p. 63 (1915).-Thallus black, sometimes gelatinous, thin. Apothecia black, small $(\cdot 2-\cdot 4 \mathrm{~mm}$. wicle), conrex, immarginate, at length hemispherical, rugulose, within entirely violaceous as in Leconor: atra ( $\mathbf{K}+$ bluish-green) ; hypothecium concolorous; paraphyses not distinct, sometimes irregrular; spores \& in the ascus, colourless, acute at one end, sometimes curved, 1-3-septate, 14-20 $\mu$ long, 4-5 $\mu$ thick; hymenial relatine dirty-blue with iodine.-Lecider ilyophora. Stirt. in Scott. Nat. v. 1. 220 (1880).

('onsidered by Stirton to be allied to Bilimbia (Lecilea) melam Amold, and from the description might be the same plant.

Hab. On dead wood, Kinloch Rannoch, Perthshire.

\section{BACIDIA De Not. (Part 2, p. 149.)}

8. B. latebricola Wheld. it Trav. in Journ. Limn. Soc. Bot. xhii. p. 127 (1915).-Thallus greenish-yellow, granular-leprose, effuse $(\mathrm{K}-, \mathrm{CaCl}-)$. Apothecia minute, mare, at first fleshcoloured, then livid, and blackish when old: epithecimm colourless; hypothecium almost colourless; hrmenimm colourless and not at first blue with iodine; asci cylindrical-clavate, 3.5-15 $\mu$ long; paraphyses clavate; spores narrowly lincar-clavate, mostly obtuse at one end, narrowing at the other, variously curved, 
rarely straight, very slender, with 5 to 11 thin septa, $26-43 \mu$ long, 1-2 $\mu$ thick.

Near to $B$. effusa and B. herbarum, but differing in the characters of thallus and apothecia; with the latter and with $B$. arceutina var. hypnaa it agrees in habitat, though it differs in the colour of the thallus and in other particulars.

Hab. Creeping over decayed mosses and thin dry humus on sancldunes or on broken sandy banks overhumg by herbage.-Distr. Rare in W. England (Lancashire) and X. Wales (Anglesea). - B. M. Formby, Lancashire.

\section{B. arceutina Branth \& Rostr. (Part 2, p. 157.)}

Form deminuta Th. Fr. Lich. Scand. p. 353 (1874).-Aputhecia small ; plane or concave and marginate.-Lecidea arceutinu f. deminuta Stirt. Scott. Nat. v. p. 220 (1880).

Stirton notes that the spores are $45-60 \mu$ long, 1-1.5 $\mu$ thick, and scarcely septate.

Form brevispora Wheld. \& Trav. in Journ. Linn. Soc. Bot. xliii. p. 127 (1915).-Differs from the species in the shorter more strongly curred spores; they measure $25-38 \mu$ long, $1 \cdot 2-2 \cdot 5 \mu$ thick, and are usually obscurely 7 -septate.

Hab. Incrusting decayed mosses on sand-dunes.-Distr. W. Englawrl (Lancashire).

17^. B. salicicola Wheld. \& Trav. tom. cit. p. 128.--Thallus scanty or evanescent. A pothecia rather small, varying from red to black, soon immarginate; hypothecium colourless; epithecium brown; spores cylindrical or fusiform, often attenuate at one end, generally curved, 29-35 $\mu$ long, $2-3 \cdot 5 \mu$ thick; hymenial gelatine blue then slowly wine-red with iodine.

Differing from $B$. arceutina in the shorter stouter spores and smaller apothecia, from B. Bcclilausii in the often fusiform spores aml other characters.

Hab. On deat twigs and exposed underground stems of Sulitr mpens on the enastal sand-hills.-Dis/r. Not uncommon on dunes in W. England.--B. M. Formby, Lancashire.

17в. B. epiphylla Wheld. \& Trav. 1. c.-Thallus almost eranescent, consisting of a few granules, green when fresh, cinereous when dry. Apothecia rery minute, black, sessile. flane then convex, soon inmarginate, colourless within; epithe. cium pale-hrown; paraphyses clavate, mostly colourless at the tips, slightly coherent; hylutherium pale yellowish-brown ; asci narow, $47 \mu$ long: spores slender, acicular, often curved at one end, multiseptate, $33-45 \mu$ long, $1-2 \mu$ thick.

Considered by the anthors to be akin to l, arecutina, but distinet in the smatler apothecia, the absenee of a red tinge, shorter spores and peculiar habitat. 
Hab. On fallen leaves of Sali.e repens on sand dunes.-Distr. Rare in W. England (Ainsdale, Lancashire).

\section{B. muscorum Mudd. (Part 2, p. 159.)}

Var. atriseda Wheld. \& Trav. tom. cit. p. 129.-Thallus effuse, granulose, the granules bright green when moist, cinereous when dry, scattered over a black hypothallus. Apothecia solitary or aggregate, at first pale-tawny, becoming black, with a thin ntargin soon disappearing, at length convex and difform ; epithecium blackish; hymenium brownish ; hypothecium reddish-brown; spores stright or slightly curved, acute at one, or both poles sometimes with an appendage, 30-39 $\mu$ long, $2-3 \mu$ thick.

Forming patches which appear blackish owing to the black hypothallus, it differs from the species in colour and habitat. (The appendages suggest germination of the spores.)

Hab. On decaying mosses and thin moist humus ou bare low Salir repens dunes associated with Cladonia pyxidata.

BUELLIA De Not. (Part 2, p. 165.)

Page 168. Under B. biloculata A. L. Sm. add:-synonym Lecanora biloculata Nyl. in Flora lxi. p. 248 (1878); Cromb. Nonogr. i. p. 383.

\section{RHIZOCARPON Ramond. (Part 2, p. 187.)}

3A. Rh. lotum Stizenb. ex Bausch Flecht. Baden, p. 152 (1859).- Thallus effuse, thin, pulverulent, pale ochraceous or cinereous-grey. Apothecia minute, scattered or congregate, black, with a persistent margin; hypothecium reddish-brown; paraIhysses coherent, the epithecium blackish-brown; spores halonate, sparsely nauriform, colourless then pale-brown, 18-22 $\mu$ long, $8-10 \mu$ thick. - B. de Lesd. in Bull. Soc. Bot. Fr. liii. p. 517 (1906); Lillie in Scott. Bot. Rev. p. 153 (1912).

Near to Rh, alboatrum (Part 2, p. 188).

Hab. - On granitic rocks. Collected by D. Lillie at Houstry, Dunbeath, Caithness.

\section{Order XX. DIRINACE王。(Part 2, p. 200.)}

Thallus crustaceous, attached by hypha, corticate on the upper surface, the cortex of closely packed upright hyphal branches disposed at right angles to the surface (fastigiate). Algal cells Trentepohliu. Apothecia discoid or somewhat elonsate, with proper and thalline margins; hypothecium and dise dark-coloured; spores elongate, septate. Spermogrones with simple sterigmata and acicular bent acrogenous spermatia. 
A small fimily represented in the British Isles by a single genus and species. It is classified under Graphidiuce on account both of thalline and apothecial characters, and is nearly allied to Roccellacer, us was pointed out by Crombie in Monogr. i. p. 491 (1894).

Spores fusiform, 3-septate, colourless.......... Dirina.

DIRINA l'r. Fyt. Orb. Veg. 1). $24+$ (1825). (Pl. 69.)

Thallus crustaceous, continuous or cracked. Apothecia discoir or somewhat irrerular or elongate, subimmersed in the areola or superficial, with a distinct thalline margin; hyputhecium thickish, hlack; spores 8 in the aseus, elongate-fusiform, 4-8-septate, colourless.

A maritine genus of few species but of wide clistribution in warn or subtropical regions.

1. D. repanda Nyl. in Mém. Suc. Ńci. Nat. Clerb. v. p. 116 $(18.57)$.- Thallus determinate and subeftigurate, thick, continuou: or areolate, generally uneyual and coarsely warted-granulate, greyish-white with a soft farinose surface and a white hyputhallus ( $\mathrm{Kf}+$ yellow, $\mathrm{CaCl}+$ rose-red). Apothecia moderate in size (up) ¿u 2 mmn. across), at first closed then plane, black, covered senerally with a white pruina, the thalline margin thick, obtuse, more or less inflexed; hypothecium thick, black: paraphyses simple, slightly wichened or irregular upwards; spores tusiform, often slightly bent, 3-septate, generally about $22 \mu$ lon 5) $\mu$ thick, but sometines smaller or larger; hymenial gelatine wine-red with iodine.-Cromb. in Journ. But. ix. 1. 178 (1871) a Mronor. i. p. 491, fig. 69; Leight. Lich. Fl. p. 2:35; ed. :", p. 226. Parmelia repanda Fr. Lich. Eur. p. 177 (1831).

Hxsice. Johns. n. 421.

A Mediterranean plant chiefly. The apothecia are often crowred wud become difform, with the margin flexuose. Spermogones are: abundant.

1Tab. (On roclis in martime (listriets. - J)istr. Thare in the Channe? Islamis, S. W. Fingland and $\mathrm{N}$. Wales.-13. M. Ia Coupe and Iiozel, . Iersey; J'ortlant Ishuml. 1)orset; Great Orme's Heal, Carnarronshire.

\section{(Ru: XXI. ROCCELIACE巴E. (Pant :, p. 200.)}

Thallus mestly fintie(se, of strap-shaped or rounded hranching frouds, attached to the substratum by a basal sheath, corticate, with a erentral merlullat enerally of bosely interwoven hyphat.

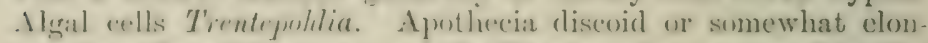
fate, nsually with proper and thalline margins; spores s in the. aseus, coloumles or rarely hownish, elongite, septate. Spermo. [-mmes wilh simple or slaningly hranched sterigmata and straight. ur curved acrogenous spermatia. 
With the exception of Rocella, the genera of Rocellacex contain few species. All of them inhabit mainly the sea-coasts of Wami countries. There is only one gemus represented in Europe.

Thallus eylindrical or strap-shaped, branched..... Roceella.

ROCCELLA DC. FI. Fr. ii. p. :3:34 (1805). (Pl. 70.)

Thallus fruticose of simple or branching fronds, greenish-or bluish-grey, mostly sorediate: cortex of closely packed hyphal branches disposed at right angles to the surface (fastigiate): medullary hyphre more or less parallel with the long axis; gronidia in a zone within the cortex. Apothecia lateral on the fronds, mostly discoid, with a projer margin, and with or without a thalline maryin ; hypothecium thick, black : paraphyses branched; spores elongate-oblong or fusiform, mostly 3-septate, colourless.

The species of Roccella have a wide distribution, but only two atre found as far north as the British Isles. They vield in more or less abundance a purple dye, the orseille or orchil of commerce. R. tinctoria, which is not British, is the best known and was one of the earliest recorded lichens.

1. P. fucoides Wain. in Welw. Cat. Afric. Plants, ii. ㄹ, 1'. 4:3:? (1901)._Thallu; of densely cat'spitos' thickly and repenterly branched fronds, rounded or slightly compressed, rather short. (generally about 3-.j cm. high), more or less sorediate, basil sheith sinall, light bluish-grey (outer cortex $\mathrm{CaCl}+$ orange-red, inn(s tissue and soredia -, medulla $T+$ blue). Apothecia small, somewhat prominent, black, without a thalline margin ; paratphyses uneven, rather wider, branched and dark at the tirs: spores oblong-fusiform, 3-septate, 12-16 $\mu$ long (or longer), :"t $\mu$ thick. - P. pleyeopsis Ach. Lich. Tuiv. p. 440 (1810) : S. F. Gray Nat. Arr. i. p. 426 ; Cromb. Lich. Brit. p. 22 d Monour. i. p. 18., tig. 37 ; Leight. Lich. Fl. p. \$1 ; ed. :3, p. 74. Li. tinctoria Hook. in Sm. Engl. Fl. v. p. 221 (1833) (non UC.): Mudd Man. p. 75 (incl. var. phymensis); Leight. I1. c. Lichen fucoirles Dicks. Pl. Crypt. fasc. ii. p. 22 (1790) it I. Rucr.llu (1)]. cit. fasc. iii. p. 19 (1793) (non Linn.); Engl. Bot. t. 211 ; With. Arr. ed. 3, iv. p. 42 (1796).

Exsicc. Cromb. n. 14; Larb. Cesar. n. 11 \& Lich. Hb. n. 122 ; Mudd n. 48.

A rather stunterl-looking bushy plant. abundantly sorediate and very raruly fertile. Sjemogones are occasionally present. with spermatia 1:3-16 $\mu$ long, $1 \mu$ thick. Jiy earlier liehenologists it was confused with Ifichen liorcella L. Sp. 1'. p. 115t, the well-linown tre

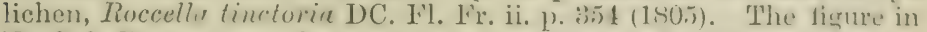
English 13otany was drawn from a specimen collected on l'ortland Island.

IIal. On rocks, rarely on Walls, in matritime locilities.-7)istr. Uncommon on the southern consts of the British Isles, very rare in 
the Clyde area, Scotland.-I3. .I. St. Brelade's Bay, La More and Noirmont, Terser ; Petit-Pot Bay, Guemsey; Sark; St. Mary's, Scilly Islands; The Lizard, Tintagel Castle, Lamorna, Pentire and St. IIinver, Cornwall; Kingswear, 13olt Head, Ilfracombe, Lynmouth and Lynton, Deron; Portland Island, Dorset; Bembridge and Godshill Church, I. of VVight; Millport, Cumbrae Island, Firth of Clyde.

Form tenuior A. L. Sm.-Thallus of longer slender fronds much branched at the apices. - R. phycopsis f. tenuior Nyl. ex Teight. Lich. Fl. ed. 3, p. 74 (1879) ; Cromb. MLonogr. i. p. 183. R. fuciformis (errore) f. temuior Cromb. in Grevillea xv. p. 47 (1886).

Differs in the long slender fronds, almost $10 \mathrm{~cm}$. high. Leighton, who first published this form, ascribed it to Larbalestier, by whom it was collected, but on the herbarium specimen Larbalestier has written f. tenuior Nylander, to whom it had evidently been submitted.

Hab. On rocks in a maritime situation.-B. M. La Moye, Jersey.

2. R. fuciformis DC. Fl. Fr. ii. p. 335 (1805).-Thallus of compressed short or long fronds narrow or wide, irregularly branched, frequently proliferate and more or less sorediate at the margins, the soredia solitary or in dense masses, glaucouswhite or -brownish ( $\mathrm{CaCl}$ surface and medulla - , soredia + rosered, medulla I+blue). Apothecia not uncommon, discoid, prominent, rather small, scattered or crowded, the disc black, at first pruinose, the thalline margin irregular in outline, at length almost excluded; paraphyses stoutish with brown tips, the whole hymenium deep brown in thick section; spores oblong-fusiform, 20-30 $\mu$ long, 4-6 $\mu$ thick.-S. F. Gray Nat. Arr. i. p. 426; Hook. in Sin. Engl. Fl. v. p. 222 ; Mudd Man. p. 76, t. 1, fig. 18; Cromb. Lich. Brit. p. 23 \& Monogr. i. p. 183 ; Leight. Lich. Fl. p. 82; ed. 3, p. 74. Lichenoides fuciforme tinctorium, cornicutis longioribus et acutioribus Dill. Hist. Musc. p. 168, tt. 22, 23, fig. 61 1-D (1711). Lichen fuciformis L. Sp. Pl. p. 1147 (1753); Dicks. Pl. Crypt. fasc. iii. p. 17 ; With. Arr. ed. 3, iv. p. 51 ; Engl. Bot. t. 728.

Eisicc. Cromb. nos. 15, 125 ; Larb. Casar. n. 12 \& Lich. Hb. n. 123 ; Leight. n. 171.

Generally found growing with the previous species, but very listinct in form and attaining a much larger size up to 6 inches in length, with the ribbon-like fronds from less than a line to nearly half an inch in width. Only the soredia in this species are stained with chloride of lime, the outer cortex and medulla are unafiected.

Hnb. On rocks in maritime districts.-Distr. Local though fairly plentiful on the southern coasts; rare in S.IV. and W. Ireland.I. M. St. Ouen's Bay, Sit. Brelanle's Bay and St. Martin's, Jersey; (ivernsey; St. Mary's, Scilly Islands; Logan Rocks, near Land's Lind, Tintagel, The Lizard, l'enzance and Lamoma Cove, Cornwall ; Bolt Head, Lynton and Ilfracombe, Devon. 


\section{Orter XXIII. ARTHONIACEZE. (Part 2, p. 205.)}

Arthonia Lilliei B. de Lesd. in Bull. Suc. Bot. Fr. lvii. (1910).-Thallus blackish, leprose, very slight. Apothecia black, minute, alrout $0 \cdot 1-0.2 \mathrm{~mm}$. in diam., round, persistently plane; liypothecium colourless; hymenium colourless or pale-brown; pararihrses closely coherent, the apices free and capitate, the epithecium olivaceous; asci ventricose; spores 8 in the ascus, crlourless, oblong or ellipsoid, 1-septate, scarcely constricterl and the loculi equal, 10-12 $\mu$ long, 4-5 $\mu$ thick; hymenial gelatine wine-red with iodine.-Lillie in Scott. Bot. Rev. i. p. 15:3 (191?). Specimen not seen.

Sometrhat difficult to place in the lack of information as to the gronidia; it seems to agree with $\S$ Lecideopsis (I'ert 2, p. 217) rather than with $\S$ Euarthonia (p. 211).

Hab. On siliceorns rocks. Collected by D. Lillie at Achastle. Caithness.

\section{Order XXVI. PYRENIDIACEÆ. (Part 2, p. 264.)}

PYRENIDIUM Nyl. in Flora xIviii. p. 210 (1865); Cromb. MInogro. i. p. 81 (1894); Leight. Lich. Fl. p. 36 (1871). (Pl. 71.)

Thallus minutely fruticose, rising from a crustaceous base, with a distinct plectenchymatous cortex. Algal cells Nostoc. Perithecia innate opening by a pore; spores oblong-ellipsoirl, brownish, septate.

A most interesting and unique lichen, being the only example of irnticose growth among the blue-green I'Jrenocarpei. Crombie has surrested that the fruits may be parasitic fungi; unfortunately the specimens in the herbarium of the British Museum seem to be sterile. There is no record of any recent collection of the plant.

1. P. actinellum Nyl. l. c.-Thallus adnate and crustaceous at the base, or sward-like with upright or semi-prostrate branching fromcls which are somewhat nodulose, but generally cylindrical, dark olive-brown in colour; cortex very distinct, one cell thick: goniclia in short chains or in groups scattered through the inerlulla. Perithecia "minute, scarcely prominent, almost entirely innate, the pyrenium entirely black"; spores 4 in the ascus (as figurect), "3-septate, brownish, 20-24 $\mu$ lon\&, 8-9 $\mu$ thick."Carroll in Journ. Bot. iii. p. 286 (1865); Croml). Lich. Brit. p. 10 if MIonogr. i. p. 81 ; Leight. Lich. F1. 1. 36 ; ed. 3, p. 37.

Hab. On cretaceous and calcareous peubles in unoist maritime ant upland districts.-Distr. liare in S. and S.W. England.-B. M. Anstey's Cove, Torquay, Devon; near Brighton, Sucsex; Bexley Hill, Kent; Shiere, Surrey. 
PYRENOCOCCUS Wheld. \& Wils. in Journ. Bot. liii. Suppl. p. 69 (1915).

Thallus none. Perithecia simple, coloured, subimmersed in the tissues of a host-plant containing Cyanophycer, opening by a pore; spores 8 in the ascus, ellipsoid, septate, fuscous.

Considered by the above authors as allied to Obryzum but differing in the shape and colour of the spores. It has been based on Endococcus exoriens Stirt., but the description suggests rather a parasitic fungus belonging to the genus Melanomma.

P. exoriens Wheld. \& Wils. 1. c.-Thallus none. Perithecia in the thallus of Pannariæ, semi-immersed, small, fuscous to fuscous-black; paraphyses none; spores ellipsoid, brown, 3-septate, 9-11 $\mu$ long, $6 \mu$ thick; hymenial gelatine wine-red with iodine.-Endococcus exoriens. Stirt. in Scott. Nat. v. p. 220 (1880). Specimen not seen.

Hab. Parasitic on the thallus of Pannarix, probably P. brunnea (P. pesizoides Leight.), Craig Var near Kinloch-Rannoch, Perthshire, the only record.

ORdER XXVIII. VERRUCARIACEÆ. (Part 2, p. 275.)

VERRUCARIA Pers. (Part 2, p. 276.)

3৯. V. Lorrain-Smithiæ Knowles in Sci. Proc. Roy. Dubl. Soc. xir. p. 138 (1913).-Thallus blackish-green, gelatinous, thin, continuous or sometimes almost evanescent. Perithecia excessively minute, about $120-180 \mu$ in cliam., scattered, hemispherical, shining, opening by a minute pore $15-20 \mu$ in diam., dimicliate; ascus elliptical, $20-25 \mu$ long, $10-12 \mu$ wide ; spores 8 in the ascus, simple, rod-like, oblong-elongate or slightly curved, 15-18 $\mu$ long, $2-4 \mu$ thick.

Characterized by the minute prominent perithecia.

$H a b$. On limestone rock, below neap-range or more abundant near low-water mark.-B. M. Balscadden Bay, Howth, Dublin. (M. C. Knowles, Sept. \& Dec., 1913.)

4. V. striatula Wahlenb. f. continua Knowles tom. cit. p. 137. -Thallus more continuous than in the species, sometimes radiate, with scattered small dots and ridges.

$H(a)$. On maritime rocks in more sheltered situations than the species.- B. M. Needles, Howth, Dublin. (M. C. Knowles, July, 1910.)

\section{THELIDIUM Massal. (Part 2, p. 297.)}

2^. Th. explicatum Wheld. \& Wils. in Journ. Bot. liii. Suppl. p. $70(1915)$. - Thallus pale or pale-grey, thin, often dispersed. Perithecia black, prominent, $\cdot 2-\cdot 35 \mathrm{~mm}$. wide, entire; para- 
physes wanting; spores $4-8$ in the ascus, colourless, ellipsoid or oblong-ellipsoid, sometimes larger at one end (gibbosulæ), 1-septate, 24-34 $\mu$ long, 10-13 $\mu$ thick; hymenial gelatine wine-red with iodine.-Verrucaria explicata Stirt. in Scott. Nat. v. p. 220 (1880). Specimen not seen.

Stirton suggests that this species may be identical with $V$. subrimulata Nyl., a Pyrenæan species.

$H a b$. On schistose rocks at the summit of Ben Lawers.

4A. Th. terrestre Wats. in Journ. Bot. Iv. p. 107, fig. B (1917). -Thallus thin, effuse, crustaceous or leprose, green or darker. Perithecia minute, black, scattered, semi-immersed, at length more or less sessile, dimidiate; outer wall dark-brown, inner pale-brown, the minute ostiole not depressed; hymenium without algal cells ; ostiolar filaments few or none ; paraphyses disappearing or absent; asci clavate; spores 8 in the ascus, colourless or greyish, granular, ellipsoid, one end usually narrower, 1-septate, lightly constricted in the middle, $16-28 \mu$ long, $7-11 \mu$ thick.

Closely allied to Th. Nylanderi. Watson considers it to be near. Th. Zwackliii Hepp, a saxicolous species, the spores of which are 1-3-septate.

Hab. On soil of hedge-bank among mosses. - B. M. Cheddon Fitzpaine, Somerset.

\section{POLYBLASTIA Massal. (Part 2, p. 300.)}

10A. P. mortensis Wats. in Journ. Bot. lv. p. 108, fig. A (191i).- Thallus thin, crustaceous, minutely granulose, effuse, continuous, greyish or greenish-grey or olivaceous, sometimes darker or evanescent, not gelatinous when moist. Perithecia small or moderate, semi-immersed with the upper third emergent, convex, shining; wall black at the base, thin and brown; ostiole slightly depressed; hymenium without algal cells; ostiolar filaments tew or none; asci clavate, somewhat inflated ; paraphyses few or none, mucilaginous; hymenial gelatine wine-red with iodine; spores oblong, 8 in the ascus, colourless, becoming brownish, muralilocular, with $7-14$ transverse rows of small cells, $40-50 \mu$ long, 16-20 $\mu$ thick.

$H a b$. On soil-cap of walls or on mortar, often on decaying mosses such as Tortula muralis near the sea.-B. M. Morte, Devon (December, 1913).

16. P. addubitans Wheld. \& Wils. in Journ. Bot. liii. Suppl. p. 71 (1915).- Thallus whitish, very scanty. Perithecia black, large, $\cdot 8-1 \cdot 4 \mathrm{~mm}$. wicle, prominent, round or often oblong, the peridium black, dimidiate ; paraphyses long, crowded, granularinspersed, tubular and filled with interrupted masses of protoplasm; spores 4-8 in the ascus, ellipsoid, colourless then brown, 3-5)-septate, with irregular longitudinal septa; hymenial gelatine 
not tinged with iodine.--Vermucurie addubitans Stirt. in Scott. Nat. v. p. $220(1880)$.

On decorticated wood near Kinloch Rannoch, Perthshire.

\section{MICROGL正NA Koerb. (Part 2, p. 308.)}

3A. M. nuda Wheld. \& Trav. in Journ. Limn. Soc. xliii. p. 132 (1915). - Thallus obsolete or reduced to a few cinercous granules at the base of the perithecia. Perithecia minute, black, superficial, dimidiate, with a distinct somewhat depressed ostiole; paraphyses subpersistent, visible until the spores are fully formed, branched, slender; asci subcylindrical; spores 8 in the ascus, irregularly arranged in the ascus, 2-3-septate and after a time sparingly and irregularly septate longitudinally, colourless or pale-greenish, oblong-ellipsoid, obtuse at both ends, the separate cells unequal, 16-20 $\mu$ long, $6-7 \cdot 5 \mu$ thick. Specimen not seen.

$H a b$. On half-buried gritstone pebbles in glacial drift on the banks of the Ribble at Chatburn (March, 1913).

3в. M. breadalbanensis Wheld. \& Wils. in Journ. Bot. liii. Suppl. p. 71 (1915). - Thallus pale citrine-yellow, smooth, broken into scattered or more contiguous subangular fragments, each hearing one or rarely two perithecia. Perithecia small, subglobose, slightly immersed at the base, black; peridium black, thick above, thinner towards the base where it forms a thin lorwn line; ostiole poriform, slightly protuberant but hardly parillieform; spores $6-8$ in the ascus irregularly biseriate, colourless, ellipsoid-oblong, obtuse at one or both ends, 6-7-septate with 1-3 longituclinal septa, $18-20 \mu$ long, $10 \mu$ thick. Specimen not seen.

Hab. On miea-schist rocks, growing amongst Lecilca contigur in larger or smaller patches. Collected by A. Wilson at Ben Cruichben, near Killin, Perthshire, June, 1913.

\section{Order XXIX. PYRENULACE互. (Part 2, p. 31:.)}

\section{ACROCORDIA Massal. (Part ^, p. 313.)}

4A. A. monensis Wheld. in Lane. Nat. viii. p. 196, Pl. 3 (1915).- Thallus greyish-white, thin, tartareous, pulverulent, or nearly ohsolete when it consists of a few granules round the base of the perithecia. Perithecia black, nearly globose, very small, prominent, slightly immersed at the base or sessile, smooth, scattered ; ostiole poriform ; jeridium entire, black, brown internally; paraphyses numerous, slencler, lax, distant; asci cylindrical, elongate, $99-120 \mu$ long; spores uniseriate or partly hiserizte, fusiform-ellipsoirl, colourless, 1-septate, constricted at 
the septum, rather large, 20-33 $\mu$ long, 6-10 $\mu$ thick. Specimen not seen.

Considered by Wheldon to be allied to $A$. Salweii, but distinct in the small perithecia and the large spores; these may have one cell rather larger than the other.

$H a b$. On mortar mixed with many fine quartz particles, on a wall in Glen Maye, I. of MIn, June, 1914. Collected by J. W. Hartley and J. A. Wheldon.

\section{ARTHOPYRENIA Massal. (Part 2, p. 315.)}

Page 32.3. For Arthopyrenia arenicola A. L. Sm., readA. argilospila A. L. Sm., and add to synonymy:-Verrucariu argilospila $\mathrm{Nyl}$. in Flora lvii. p. 15 (1874). Magmopsis argilospilu Nyl. ex Cromb. in Grevillea xv. p. 10 (1886) \& Monogr. i. p. 30.

An examination of the specimens placed in Magmopsis and from the same locality as "A. arenicola" leaves no doubt as to their identity. There is on the thallus the overgrowth of the blue-green algx, in the fruits the entire perithecial wall with the minute pore at the apex, and the arthopyrenial characters of paraphyses, asci and spores. In more developed fruits I have found spores measuring up to $26 \mu$ in length, and on one spore a third septum was formed near the base. Otherwise they are as described.

Magmopsis was placed by Nylander under the Tribe Pyrenidei (Flora lviii. p. 103 (1875)).

\section{ADDITIONAL SPECIES RECEIVED AFTER THE APPENDIX HAD BEEN PRINTED}

(Part 2, p. 7.)

5.. Gyalecta derivata A. L. Sm.-Thallus effuse, thin, finely furfuraceous, greyish or greenish. Apothecia small, urceolate, the disc pale-reddish, the margin whitish, thick, entire or broken here and there; hypothecium colourless; spores 8 in the ascus, 7-12-septate and sparingly muriform, $27-30 \mu \mathrm{long}, 5-6 \mu$ thick. - Lecidea derivata Nyl. in Flora xlviii. p. 603 (1865).

Nearly related to $G$. truncigena, but differing in character of the spores.

Hab. On tree trunks. - B. M. Naran, Meath. Collected by M. C. Knowles, August, 1915.

(Part 2, p. 297, after Verrucaria.)

Sarcopyrenia Nyl. in Maine it Loire Mém. Soc. Acad. iv. p. $69(185)$. - Thallus crustaceous. Algal cells Protococns. 
Perithecia simple, scattered, with a black peridium, opening by an ostiole; periphyses slender; paraphyses disappearing; asci elongate-clavate, soon disappearing, 8-spored; spores one-celled, colourless, cylindrical-vermiform, slightly flexuose or twisted in the middle, the ends clavately thickened.
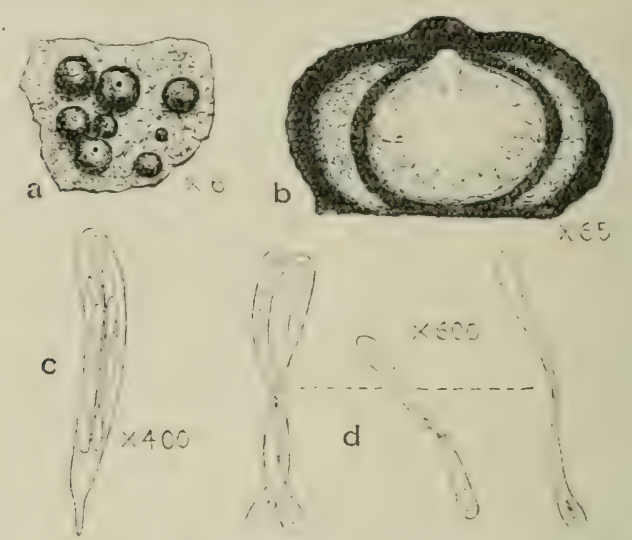

Sarcopyrenia gibba Nyl.-a, Plant on rock, with perithecia. b, Vertical section of perithecium. c, Ascus. d, Spores.

A monotypic genus recorded first from Constantine in Algiers, then from Switzerland, and from S.W. Germany. It is distinguished by the long vermiform spores. We are indebted to Rev. W. Johnson for this interesting lichen collected by him in November, 1880 ; it eseaped recognition until recently, and was sent to the British Museum for determination in December, 1917. In the system of classification adopted it should follow Verrucaria.

S. gibba Nyl. 1. c.-Thallus effuse, thin, yellowish-grey, mostly obsolete or immersed in the rock. Perithecia black, scattered or congregate, $\cdot 5 \mathrm{~mm}$. in diam. or less, hemispherical, with a minute papillate ostiole, or depressed and Lecidea-like, the outer peridium thickish, dimidiate but incurved at the base, the inner wall dark-brown; asci cylindrical fusiform, about $70 \mu$ long, $10 \mu$ thick, S-spored ; spores 30-40 $\mu$ long, $3-3 \cdot 5 \mu$ thick.-Verrucaria gibba Nyl. in Cherb. Mém. Soc. Sci. Nat. ii. p. 342 (1854).

In the specimen on sandstone from St. Bees the thallus is extremely scanty, Johnson, however, finds that it is "reddish or whitish-brown, thin, furfuraceous, occasionally cracked-areolate and mostly evanescent; hypothallus white or whitish." The spores secm to be almost flat at the centre where they are generally half-twisted over.

$H a b .-$ On arenaceous rocks. $-B$. M. St. Bees, Cumberland. 


\section{PART I., ADDENDA AND CORRIGENDA}

Page 9. Chænotheca melanophæa Zwackh, insert-

Var. flavocitrina Paulson in Journ. Bot. lv. p. 195 (1917).Thallus granular, effuse, varying in colour from cinereous-grey to deep-yellow. Apothecia numerous, similar in structure to those of the species.

This lichen was found spreading widely on oak and ash trees and also on dead iry stems where it showed as a deep-yellow film. The whole colouring was in places deep enough to suggest var. ferruginea, but the apothecia have longer stalks than in that rariety and the habitat "on trees" is different. The reaction with potash, as in the species, is purplish-red due to the presence of salazinic acid, and the woody tissues in contact with the lichen take the stain the most deeply. The hyphæ are generally unaffected.

Hab. On bark of trees. - B. M. Bricket Wood, near St. Albans, Herts. Collected by R. Paulson, May, 1917.

Page 23. For Sphærophorus globosus A. L. Sm., read S. globosus Wain. Exp. Antarct. Belge, Lich. p. 35 (1903).

Page 26.

After Order XV., insert XVA. CHRYSOTHRICACE

Page 35. Under Ephebe lanata, Hab., add rarely on trees. (Note supplied by W. Watson, Taunton.)

Page 42. Add 4. Psorotichia lugubris Dalle Torre \& Sarnth. Flecht. Tirol. p. 592 (1902). Lecidea l:sgubris Sommerf. Part 2, p. 16:

This species was doubtfully included under Lecidea. The late Mr. W. West, to whom a specimen was submitted, determined the gonidia as Gloeocapsa algæ.

Page 47. After Physma chalazanum, insert-

2A. Ph. chalazanellum A. L. Sm. Similar to Ph. chalazanum but with smaller thallus and apothecia, the latter $\cdot 2 \mathrm{~mm}$. in diam. and spores 12-19 $\mu$ long, 6-10 $\mu$ thick.-Collema chalazanellum Nyl. in Flora lix. p. 231 (1876); Wats. in Journ. Bot. lv. p. 109 (1917).

Hab. On limestone wall near Taunton, Somerset. 
Page 67. Insert-

3.. Leptogium andegavense Hy Lissai sur les Lich. d'Anjon, p. 28 (189:3) fide Harm. Lich. Fr. 1, p. 106 (1905). - Thallus lobate, turgid, sometimes obscured by the crowded apothecia. Apothecia scarcely $1 \mathrm{~mm}$. in diam.; hypothecium of stratified plectenchyma, the cells more crowded in the upper layer's; spores $25 \mu$ long or more, often narrower at one end, 4-5 septate, with a few longitudinal septa.-Collemodium andegavense Wats. in Journ. Bot. 1v. p. 110 (1917). Specimen not seen.

Similar to $L$. turgidum but less plicated and with the appearance of a small Collema pulposum.

$H a b$. On limestone walls near Taunton.

Page 74. Under Leptogium sinuatum, delete 3-septate.

Page 104. Under Solorina saccata, after spores reddish-brown, add with warted epispore.

Page 118. Under Candelaria concolor Exsicc., add Larb. Lich. Cantab. n. 16.

Page 157. Under Cetraria islandica Exsicc, add Johns. n. $4+1$ (Teesdale, Durham).

Page 223. Insert-

36A. Placodium Pollinii A. L. Sm.-Thallus thin, white then greyish, smooth, continuous or indistinctly cracked-areolate, with a darker hypothallus. Apothecia rather large, scattered or crowded, plane, becoming convex, at first brick-red with a brown tinge becoming blackish; hypothecium dingy-ochraceous; paraphyse.s slender, septate, slightly thicker at the tips; spores fusiformellipsoid, 15-16 $\mu$ long, 8-9 $\mu$ thick.-Blastenia Pollinii Massal. in Flora xxxv. p. 575 (1852). Lecanora Pollinii Massee in Grevillea xxi. p. 60, figs. $1-8$ and 5 (1882).

The thallus evidently gives no reaction with potash (Hepp Exs. n. 402). The apothecia have a distinct proper margin; the spores vary greatly in size from $9 \mu$ long upwards, and from $5 \mu$ thick.

Hah. On the bark of trees. - Specimen from Yorkshire in the Leighton Herbarium, Kew.

Page 233. Physcia fusca A. L. Sm., insert-

Var. cæsio-pruinosa A. L. Sm. Differs from the species in the bluish tinge of some of the lobes, chiefly towards the centre. - Ph. agnila var. cesso-pruinosa B. de Lesol. in Bull. Soc. Bot. Fr. 1vii. P. 31 (1910); I Lillie in sicott. Bot. Rer. 1, P. 149 (1912). Specimen not seen.

Noted by Lamy (Bull. Soc. Bot. Fr. xxv. p. 383 (1878)) as a growth form or aplearance only. Found by D. Lillie at E. Clyth, Caithness. 
Page 244. Insert-

12A. Physcia cæsitia Hue Add. Nor. Lich. Eur. p. 319 (1885).-Ph. cresia subsp. cæsitia Nyl. ex Norrl. in Not. Sillsk. Faun. \& Fl. Fenn. Förh. xiii. p. 326 (1873).

Differs from $P h$. cxsia in the thalline reaction ( $\mathrm{K} \pm$ yellow).

Originally described only from Lapland, it has been reported by Hue (l. c.) as occurring in Scotland.

\section{Pages 259 and 352. For ICMADOPHILUS, read ICMADO- PHILA.}

Page 291. For Lecanora farinaria Borr, read L. conizæa Nyl. (as the name of the species).

Page 311. For Lecanora gemimpara, read L. geminipara.

\section{Page 319. Insert-}

69.. Lecanora Lilliei Lillie in Scott. Bot. Rev. i. p. 151 (1912). - Thallus crustaceous, tartareous, cracked-areolate, white, yellow within $(\mathrm{K}-, \mathrm{CaCl}-)$. Apothecia minute, black, roundeddifform or elongate, immersed in the areolie; hypothecium colourless; paraphyses gelatinous-concrete, the epithecium olivaceous; asci narrowly clavate; spores $4-6$ in the ascus, ellipsoid, 13-15 $\mu$ long, 5-6 $\mu$ thick; hymenial gelatine deep blue with iodine.-Aspicilia Lilliei B. de Lesd. in Bull. Soc. Bot. liii. p. 515 (1906).

Considered by de Lesdain as very similar to Lecanor calcarea, but differing in the yellow colour internally and in the smaller spores.

Page 389. Insert-

1A. Gyrophora stipitata Branth in Meddel. Grønl. iii. p 491 (1887).-Thallus dark greyish-brown or sometimes paler, firm, crowdedly corrugate-tuberculose or rugose; beneath paler grey, subsmooth, on a short dark-brown stalk, 10-15 mm. high, almost the whole lower surface densely covered with pale-grey fibrils. Apothecia with a plane disc; spores 8 in the ascus, colourless, ellipsoid, 10-13 $\mu$ long, 8-9 $\mu$ thick. Lillie in Scott. Bot. Rev. i. p. 50 (1912). - Umbilicaria stipitata Nyl. Lich. Scand. p. $289(1861)$ is in Flora xlviii. p. 604 (1 $1 \times 65)$ note. Specimen not seen.

Recently this plant has been published by Zahlbruckner (Amm. K. K. Nat. Hofm. xxri. p. 170 (1912)) as a variety of $G$. mgiferu Ifue (Lich. Exot. p. 117 (1892)), a species placed under the seetion with gyrose dises, but Nylander notes that the irregularities are due to aggregation of apothecia (Syn. Lich. ii.p. 14 (1885)).

Recorded by D. Lillie from Ben-na-bad, Caithness. 


\section{N D E X}

The genera of lichens have undergone so many changes at the hands of systematists of divergent views, that the specific name has come to be recognized as the best clue to the plants. In preparing the Index, the aim has been to facilitate the tracing of any name that bas been used; specific names, along with those of orders and genera, \&c., are listed; varietal and well-established form-names are also included unless specific synonyms are recorded by which they can easily be idertified : redundant entries are thus avoided as far as possible. Synonyms are indicated by italics.

ACARospora Massal. 259, 333 accessitans Nyl. (Lecanora) 349 acetabulum Neck. (Lichen) 142 acetabulum Dub. (Parmelia) 142 Acharii Westr. (Lichen) 328 Acharii Ach. (Urceolaria) 328 aciculare Fr. (Calicium) 7 acicularis Zwackh (Chcnotheca) 6 acicularis Sm. (Lichen) 6 ACOLIUM S. F. Gray 20 ACROCORDIA Massal. 484 actiea B. de Lesd. (Lecania) 342 actaa Nyl. (Lecanora) 343 actinellum Nyl. (Pyrenidium) 481 actinostoma Pers. (Urceolaria) 384 actinostomus Zahlbr. (Diploschistes) 384 aculeata Fr. (Cetraria) 159, 180 aculeata Ach. (Cornicularia) 153 aculratus Schreb. (Tichen) 159 acuminata Norrl. (Cladonia) 435 addubitans Wheld. of Wils. (Foly. blastia) 483

arldulitans Stirt. (Vemucaria) 451 aulglutinata Floerk. (Lreanora) 241 algiutinata Nyl. (I'hysciat) 244 admissa Nyl. (Lecanora) 339 ads. rsa Cromb. (Cilutunia) 4.48 aquata Nyl. (Lecanora) 254 aquata Nyl. (Lecidea) 254 «quata Oliv. (Riuodina) 254 aruginascens Oliv. (Lecania var.) 345 æruginosa A. L. Sm. (Chænotheca) 8 cruginosa Mudd (Icmadophila) 352 aruginosum $\mathrm{Sm}$. (Calicium) 8 aruginosum S. F. Gray (Phacotrum) 8 (eruginosus DC. (Beomyces) 352 eruginosus Scop. (Lichen) 352 affinis Hook. (Squamaria) 85 affinis Dicks. (Lichen) 85 affinis Massal. (Hymenelia) 332 Agardhiana Ach. (Lecanora) 280 Agardhianum Hepp (Placodium) 215 agelæa Koerb. (Phlyctis) 350 agclaa S. F. Gray (Thelotrema) 381 agcla a Turn. \& Borr. (Tariolar.) 381 ageleus Ach. (Lichen) 351 aggregatum Nyl. (Collema) 63 aggregatus Th. Fr. (Synechobl.) 63 AGYROPHORA A. Zahlbr. 389 aipolia Nyl. (Physica) 239 aipolius Ach. (Lichen) 239 aipospila Ach. (Lecanora) 343 aipospila Th. Fr. (Lecania) 343 aipospila Wahlenb. (Parmelia) 313 aitemu Ach. (Lecidea) 294 albariella A. I. Sm. (Lecania) 344 alluariclla Nyl. (Licanora) 34, 347 albella Ach. (Lecanora) 281 albella S. F. Gray (Iimerina) 252 albellus Pers. (Lichen) 282 albocarnea Nyl. (Lecidea) 349 albocincta A. L. Sm. (Biatorella var.) 472 
albocœrulescens Ach. (Lecidea) 470 alboflavida Tayl. (Lecanora) 299, 301 albolutescens Nyl. (Lecanora) 218 albolutescens A. L. Sm. (Placodium) 217

ALECTORIA Ach. 182

aleurites Ach. (Lichen) 151

aleurites Ach. (Parmelia) 151

aleurites Cromb. (Parmeliopsis) 151

aleurites Nyl. (Parmeliopsis) 136

alcicornis Ach. (Cenomyce) 424

alcicomis Floerk. (Cladonia) 423

alcicornis S. F. Gray (Scyphoph.) 424

alcicornis Lightf. (Lichen) 424

allophana Nyl. (Lecanora) 270

alociza Cromb. (Lecidea) 255

alocizoides A. L. Sm. (Buellia) 255

alocizoides Leight. (Lecidea) 255

alpestris Rabenh. (Cladonia) 417

alphoplaca (Lecanora) 266

alpicola Th. Fr. (Parmelia) 121

alpigena Leight. (Lecanora var.) 302

alpina Sommerf. (Lecanora) 317

alpinum Laur. (Stereocaulon) 413

amara Nyl. (Pertusaria) 361

amara Ach. (Variolaria) 361

amaurocraa Floerk. (Capitularia) 420

amaurocraa Nyl. (Cladina) 420

amaurocræa Schær. (Cladonia) 420

ambigua Ach. (Parmelia) 135

ambigua Nyl. (Parmeliopsis) 135

ambiguus Ehrh. (Lichen) 239

ambiguus Wulf. (Lichen) 135

amplineum Ach. (Collema) 71

amphineum Nyl. (Leptogium) 71

amphiplecta Stirt. (Lecidea) 471

amplissima De Not. (Kicasolia) 114

amplissimus Scop. (Lichen) 113

ampullaceus L. (Lichen) 149

andegavense Wats. (Collemodium) 488

andegavense $\mathrm{Hy}$ (Leptogium) 488

Andrewii B. de Lesd. (Lecanora) 290

anglica Nyl. (Splinctrina) 4

angulosus Schreb. (Lichen) 282

angustatus Hoffm. (Lichen) 236

anomea Hook. (Ccnomyce) 436

anomaus Sm. (Lichen) 436

anomaus Hook. (Scyphophorus) 437

anthelinus Ach. (Lichen) 239

anthracinus Wulf. (Lichen) 394

antilopea Del. (Cenomyce) 432

Apothecia xiv aphthosa Willd. (Peltigera) 39

aphthosa Ach. (Peltidea) 95

aphthosus L. (Lichen) 98

apochroea S. F. Gray (Rinodina) 296

apoda Nyl. (Cladonia var.) 422

aquila Ach. (Parmelia) 233

aquila Nyl. (Physcia) 233

aquilus Ach. (Lichen) 233

arborea Stirt. (Cladonia) 446

arceutina Branth \& Rostr. (Bacidia) 476

Archilichenes $x$

arctica Ach. (Gyrophora) 392

arctica Cromb. (Umbilicaria) 392

arenaria Cromb. (Lecanora) 217

arenaria Fr. (Rinodina) 250

arenarium Nyl. (Calicium) 12

arcnarium MIudd (Callopisma) 217

arenarium Hampe (Cyphelium) 12

arenarius Pers. (Lichen) 217

arenicola A. L. Sm. (Arthopyrenia) 485

areolata Nyl. (Pertusaria) 366

areolatus Koerb. (Porocyphus) 27

argena Koerb. (Phlyctis) 351

argena Turn. \& Borr. (Variolaria) 381

argenus Ach. (Lichen) 381

argilospila A. L. Sm. (Arthopyrenia) 485

argilospila Nyl. (Magmopsis) 27,485

argilospila Nyl. (Vermcaria) 485

argopholis Ach. (Lecanora) 305

argyphea Cromb. (Physcia var.) 236

armorica Nyl. (Ramalina) 173

Arnoldi Wedd. (Lecanora) 202

Arnoldiana Nyl. (Collemopsis) 64

Arnoldiana A. Zahlbr. (Lemmopsis)

64

ARTHOPYRENIA MIassal. 485

ARTHONIACEE 387,481

articulata Hoffm. (Usnea) 181

articulatus L. (Lichen) 182

articulatus Sm. (Lichen) 181

asperella Cromb. (Cladonia) 452

asperellum Nyl. (Pterygium) 45

aspergilla Ach. (Variolaria) 359

aspergillus Ach. (Lichen) 359

aspera Floerk. (Cladonia var.) 442

aspersa Borr. (Lecanora) 31

ASPICILIA Massal. 315

astroidca MIudd (Borrera) 242

astroidea Clem. (Parmelia) 242

astroidea Nyl. (Physcia) 242 
ater Huds. (Lichen) 276

athrocarpa Cromb. (Lecanora)

350

atlantica Ach. (Borrera) 230

atlanticus Sm. (Lichen) 230

atra Ach. (Lecanora) 276, 475

atra S. F. Gray (Rinodina) 277

atriseda Wheld. \& Trav. (Bacidia var.) 477

atriseda Nyl. (Lecanora) 307

atrocinerea Nyl. (Lecanora) 253

atrocincrea Hook. (Lecidea) 253

atrocinerea Koerb. (Rinodina) 253

atrocinereus Dicks. (Lichen) 253

atroflava Nyl. (Lecanora) 226

atroflava Turn. (Lecidea) 226

atroflavum A. L. Sm. (Placodium) 226 atroflavus Sm. (Lichen) 226

atropruinosa Schær. (Gyiophora) 389 atropruinosa Schær. (Umbilicaria) 389 atrovirens Dillw. (Conferva) 35

atrovirens S. F. Gray (Girardia) 35

atrovirens Ag. (Stigonema) 35

atrynea Nyl. (Lecanora) 286, 346

atrynoides Knowles (Lecania) 346

atrata Ach. (Gyalecta) 330

aurata Ach. (Sticta) 111

aurantiaca Hook. (Lecanora) 208

aurantiaca Ach. (Lecidea) 208

aurantiacum Massal. (Callopisma) 208

aurantiacum Heṕp (Placodium) 208

aurantiacus Lightf. (Lichen) 203

aurantius Yers. (Lichen) 199

auratus Sm. (Lichen) 112

aurella A. I. Sm. (Verrucaria) 229

aureola Ach. (Parmelia) 193

auriculatum (Collema) 58

austera IJyl. (Lecanora) 306

\section{BACIDIA De Not. 475}

bacillaris Ach. (Bcomyces) 465

bacillaris Nyl. (Cladonia) 464

bacillaris S. F. Gray (Scyphoph.) 465

badia Ach. (Lecanora) 305, 307

badia S. F. Gray (Rinodina) 306

badius Pers. (Lichen) 306

B EOMYCES Pors. 402,403

Beomyces Sm. (Lichen) 405

baliolum Ach. (Calicium) 14

barbata Web. (Usnea) 180

barbatus L. (Lichen) 181

Beckhausii Koorb. (Bacidia) 476 bellidiflora Ach. (Cenomyce) 460

bellidiflora Schær. (Cladonia) 460

bellidiflora S. F. Gray (Scyphophora) 460

bellidiflorus Ach. (Lichen) 460

Benedarensis Knowles (Acarospcra) 333

BIATORELLA De Not. 333,471

biatorinum Nyl. (Collema) 66

biatorinum Nyl. (Collemodium) 66

biatorinum Leight. (Leptogium) 66

bicolor Nyl. (Alectoria) 185

bicolor. Ach. (Cornicularia) 186

bicolor Ehrh. (Lichen) 186

BILIMBIA De Not. 475

biloculata A. L. Sm. (Buellia) 477

biloculata Nyl. (Lecanora) 477

Bischoffii Cromb. (Lecanora) 255

Bischoffi Hepp (Psora) 255

Bischoffii Koerb. (Rinodina) 255

bispora Nyl. (Solorina) 105

BLASTENIA Stizenb. 197, 220

Bockii Th. Fr. (Lecanora) 326

Bockii Rodig. (Parmelia) 326

BORRERA Ach. 190, 230

Borreri Turn. (Lichen) 134

Borreri Turn. (Parmelia) 134

breadalbanensis Wheld. \& Wils.

(Microglæna) 484

Brebissonii Nyl. (Lecanora) 221

brevilobata Nyl. (Lecanora) 199

breviuscula A. L. Sm. (Ramalina subsp.) 174

brumnea Ach. (Lecanora) 86

brunnea Massal. (Pannaria) 86, 482

brunneola Müll-Arg. (Chænotheca) 8

brunneolum Ach. (Calicium) 8

brunneum S. F. Gray (Psoroma) 86

brunneus Swartz (Lichen) 86

bryontha Nyl. (Pertusaria) 353

bryophilus Zahlbr. (Diploschistes) 383

bryoplitus Elurh. (Lichen) 383

BUELLIA De Not. 477

Burgessii Ach. (Collema) 80

Burgessii Mont. (Leptogium) 79

Burgessii Lightf. (Lichen) 80

Burgessii S. F. Gray (Mallotium) 80

byssacea Nyl. (Stonocybe) 20

byssaceum Fr. (Calicium) 20

byssoides Schwr. (Baomyces) 403

byssoides Carring. (Ëphebe) 30

byssoides L. (Lichen) 403 
caruleo-badius Schleich. (Lichen) 85 cresia Mudd (Bomera) 243 cresia A. L. Sm. (Lecania) 346 casia Johns. (Lecanora) 346 casia Ach. (Parmelia) 243 cresia Nyl. (Physcia) 243, 489 cesia Hook. (Squamaria) 243 cæsiocinerea Nyl. (Lecanora) 323 cresioplumbea A. L. Sm. (Diploschistes var.) 385

cxsiorufa Nyl. (Lecanora) 219 casiorufa Ach. (Lecidea) 219 crsiorufum A. L. Sm. (Placodium) 219

casiorufus Ach. (Lichen) 219 casiorufus Sm. (Lichen) 219 cæsitia Hue (Physcia) 438 casizus Hoffm. (Lichen) 243 cresius Dicks. (Lichen) 329 cæspiticia Floerk. (Cladonia) 450 cospiticia S. F. Gray (Scyphop.) 456 caspiticius Pers. (Baomyces) 454 cospititius Sm. (Lichen) 454 crespitosum DC. (Sphærophorus) 25 ccespitosus Roth (Lichen) 25 calcarea Koerb. (Aspicilia) 318 calcarea Sommerf. (Lecanora) 318 calcarca Ach. (Urceolaria) 318 calcareum Th. Fr. (Rhizocarpon) 284 calcareus L. (Lichen) 318 calcarifurmis Nyl. (Ramalina var.) 167 calicaris L. (Lichen) 165 calicaris Huds. (Lichen) 168 calicaris Hoffm. (Lobaria) 165 calicaris Fr. (Ramalina) 165 C.ALICIACEL 2

CALICIUMI Pers. 4, 12 CALLOPISMA De Not. 196, 206 callopisma Ach. (Lecanora) 198 callopismum Mér. (Placodium) 198, 201

calva Nyl. (Lecanora) 225 calvus Dicks. (Lichen) 225 calycioides Del. (Bcomyces) 406 calycioides Nyl. (Gomphillus) 406 campestris Th. Fr. (Biatorella) 471 campestris B. de Lesd. (Lecanora) 273 CANDELARYA Massal. 117, 227 candelaria Ach. (Lecanora) 117 candelaria Nyl. (Physcia) 117 candelaria Hook. (Squamaria) 118 CANDELARIELLA Müll.-Arg. 227 candelarium S. F. Gray (Psoroma) 118 candelarius L. (Lichen) 117 candelarius Sm. (Lichen) 195 candelarius Huds. (Lichen) 206 candelarius Lightf. (Lichen var.) 198 candicans A. Zahlbr. (Lecania) 340 candicans Schær. (Lecanora) 340 candicans Dicks. (Lichen) 340 candicans Dub. (Placadium) 340 candicans Hook. (Squamaria) 340 canescens De Not. (Buellia) 340 canina Ach. (Peltidea) 91 canina Willd. (Peltigera) 90 caninus L. (Lichen) 91 cantherellum Ach. (Calicium) 12 cantherellum S. F. Gray (Phacotrum) 12

caperata Ach. (Parmelia) 127 caperatus L. (Lichen) 127 capillaris Cromb. (Alectoria) 185 capitata Nyl. (Ramalina) 176 capitatus Ach. (Lichen) 10 capitellatum Ach. (Calicium) 10 capitellatum S. F. Gray (Strongyl.) 10 carcata Ach. (Cenomyce) 466 cariosa Ach. (Cenomyce) 446 cariosa Spreng. (Cladonia) 443 cariosus Ach. (Lichen) 464 cameola MIudd (Cladonia) 433 carneolutea Boist. (Gyalecta) 373 carneolutea Sommerf. (Lecidea) 374 camco-pallida Nyl. (Cladonia var.) 434 cameopallida Nyl. (Lecidea) 373 carneopallida Anzi (Pertusaria) 373 carnosa Hook. (Lecanora) 88 carnosa Koerb. (Massalongia) 88 carnosa Leight. (Pannaria) SS carnosus Dicks. (Lichen) 88 carpathica (Ramalina) 175 carpinea Wain. (Lecanora) 282 carpineus L. (Lichen) 282 carpophora Floerk. (Capitularia) 429 carporhizans Tayl. (Parmelia) 130 cartilaginea A. L. Sm. (Lecanora) 260 cartilaginea Ach. (Lecanora) 261 cartilaginea DC. (Squamaria) 261 cartilagineus Lightf. (Lichen) 260 cartilagineus Ach. (Lichen) 261 CA'THISINIA Stirton 474 cenisia Ach. (Lecanora) 285 CENOMYCE Ach. 418 CENOMYCE Th. Fr. 414, 423 
cenotea Schær. (Cladonia) 451 cenoteus Ach. (Bceomyces) 451 centrifugum Nyl. (Pterygium) 45 centrifugus Huds. (Lichen) 140 Cephalodia xiii CERANIA S. F. Gray 188 coraniscum Nyl. (Collema) 49 ceranoides Mudd (Collema) 50 ceranoides Borr. (Collema) 57 ceratea Cromb. (Evernia f.) 164 ceratina Ach. (Usnea) 180 cercidia Th. Fr. (Physcia var.) 240 cereolinum Koerb. (Sterocaulon) 409 cereolus Ach. (Lichen) 407 cereolus Stiz. (Pilophorus) 407 cereolus Ach. (Stereocaulon) 407 cereolus Borr. (Stereocaulon) 409 cerina De Not. (Callopisma) 211 cerina Ach. (Lecanora) 211 cerina S. F. Gray (Rinodina) 211 cerinea Larb. (Lecanora) 316 cerinella Nyl. (Lecanora) 223 cerinellum A. L. Sm. (Placodium) 223 cerinum Hepp (Placodium) 211, 213 cervicornis Ach. (Cenomyce) 439 corvicornis Schær. (Cladonia) 438 cervicornis Ach. (Lichen) 439 cervicornis S. F. Gray (Scyphoph.) 439 cervina Massal. (Acarospora) 336 cervina Cromb. (Lecanora) 333, 336 cervina S. F. Gray (Psoroma) 336 cervinus Pers. (Lichen) 333 Cesatii Leight. (Placodium) 341 Cesatii Massal. (Ricasolia) 341 CETRARIA Ach. 117, 148 cetrariæformis Wain. (Cladonia var.) 445 cetrarioides Del. (Parmelia) 129 cetrata Ach. (Parmolia) 136 couthocarpa Turn. (Pertusaria) 366 ceuthocarpa Tayl. (Porina) 366 ceuthocarpus Sm. (Lichen) 366 CH ENOTHECA Th. Fr. 4 chalazanellum Nyl. (Collema) 487 chalazanellum A. L. Sm. (Physma) 487

chalazanodes Nyl. (Collema) 47 chalazanodes A. L. Sm. (Physma) 47 chalazanum Ach. (Collema) 47, 487 chalazanum Aru. (Physma) 47 chalybaca Schær. (Lecanora) 215 chalybca Fr. (Parmelia) 215 chalybæum Naeg. (Placodium) 215 chalybeiformis S. F. Gray (Alectoria) 188

chalybeiformis L. (Lichen) 188 cheilea Mudd (Massalongia) 82 cheilea Nyl. (Pannaria) 82 cheileum Ach. (Collema) 52 cheileus Ach. (Lichen) 52 CHIODECTONACEAE 387 chlarona Cromb. (Lecanora) 268 chlarotera Nyl. (Lecanora) 273 chlorantha Ach. (Parmelia) 247 chlorellum Turn. \& Borr. (Calicium) 6 chlorellum Koerb. (Cyphelium) 7 chlorinum Anzi (Placodium var.) 212 chloroleuca Ach. (Lecanora) 212 chloroleucus Sm. (Lichen) 212 chloromelum Mudd (Leptogium) 78 chlorophcea Floerk. (Cenomyce) 427 chlorophaoides Nyl. (Lecanora) 298 CHLOROPHYCEA viii $\times$ chlorophylla Wain. (Cetraria) 153 chlorophyllus Humb. (Lichen) 153 chlorothecia Tayl. (Variolaria) 370 chondrotypa Ach. (Lecanora) 283 chrysocephala Th. Fr. (Chænotheca) 5,13 chrysocephalum Ach. (Calicium) 5 chrysocephalum De Not. (Cyphelium) 5

chrysocephatum S. F. Gray (Phacotrum) 5 chrysocephalus Turn. (Lichen), 5 chrysoleuca Ach. (Lecanora) 261 chrysoleuca Loight. (Squamaria) 262 chrysoleucus Sm. (Lichen) 262 chrysophana Koerb. (Aspicilia) 332 chrysophana Nyl. (Lecanora) 332 chrysophthalma DC. (Physcia) 132 chrysophthalma Ach. (Borrera) 192 chrysophthalmus L. (Lichen) 192 chrysophthalmus Th. Fr. (Teloschistos) 192

CHRYSOTHRICACEX 385,487 ciliaris Ach. (Borrera) 231 ciliaris L. (Lichen) 231 ciliaris Ach. (Parmelia) 231 ciliaris DO. (Physcia) 231 ciliata Stirt. (Cladonia) 415 ciliata Schær. (Parmelia var.) 126 ciliata Dalla Torre \& Sarnth. (Physcia var.) 247 
ciliata Tayl. (Sticta) 108

ciliatus Hoffm. (Lichen) 247

cincinnata Th. Fr. (Alectoria var.) 183

cinerascens Nyl. (Lecanora var.) 306

cinerea Koérb. (Aspicilia) 315

cinerea Sommerf. (Lecanora) 315, 325,376

cinerea Ach. (Urceolaria) 315

cinerea Sm. (Variolaria) 356

cinereofusca MIudd (Lecania var.) 348

cinereo-rufescens Cromb. (Lecanora)

317

cinereorufescens Nyl. (Lecanora) 323

cinereorufescens Ach. (Urceolaria) 323

cinereum Pers. (Calicium) 7

cinereus L. (Lichen) 315

circinata Ach. (Lecanora) 265

circinata Hook. (Squamaria) 265

circinatula Nyl. (Lecanora) 265

circinatum S. F. Gray (Placodium) 265

circinatus Pers. (Lichen) 265

cirrochroa Ach. (Lecanora) 204

cirrochroum Hepp (Placodium) 204

cirrosa Wain. (Gyrophora) 400

cirrosa Hoffm. (Umbilicaria) 400

citrina Leight. (Coniocybe) 13

citrina Ach. (Lecanora) 206

citrina Hoffm. (Verrucaria) 206

citrinum Hepp (Placodium) 199, 206, 207

citrinus Ach. (Lichen) 206

citrinus Sm. (Lichen) 229

CLADINA Leight. 414

CLADONIA Hill 402,413

CLADONIACE EE 26, 387, 402

CLADOPHORA $x$

Classification $\mathrm{xxi}$

clavata Cromb. (Cladonia f.) 463

clavellum Turn. \& Borr. (Calicium) 15

clavellus Ach. (Lichen) 16

clavilucare Ach. (Calicium) 16

claviculare S. F. Gray (Phacotium) 16

clavus Th. Fr. (Biatorella) 473

clavus DC. (Patellaria) 476

Clementi Sm. (Lichen) 242

Clementi Turn. (Parmelia) 242

Clementi Hook. (Squamaria) 242

Clementiana Ach. (Parmelia) 242

coarctata Nyl. (Lecidea) 469

coccifera Tayl. (Cenomyce) 426

coccifera Ach. (Cenomyce) 458 coccifera Willd. (Cladonia) 458

coccifera S. F. Gray (Scyphophora) 453 cocciferus L. (Lichen) 458

cocciferus Hook. (Scyphophirus) 458 coccineum Koerb. (Hæmatomma) 354 coccineus Dicks. (Lichen) 354

COCCOCARPIA Nyl. 81 coccodes Ach. (Isidium) 369 coccodes Ach. (Lichen) 369 coccodes Nyl. (Pertusaria) 369 cochleatus Dicks. (Lichen) 78 CENOGONIACE IE 26, 387 ccerulescens Mudd (Lecania) 350 coilocarpa Nyl. (Lecanora) 274 COLLEMA Wigg. 46, 48 COLLEMACEAE 26, 46 COLLEMODIUM Nyl. 65 COLLEMOPSIS Nyl. 41 collinus Ach. (Lichen) 97 colobina Ach. (Lecanora) 256 colobina Th. Fr. (Rinodina) 256 columnaris Tayl. (Parmelia) 242 comminuta Tayl. (Lecanora) 303 communis DC. (Pertusaria) 365 comosa Stirt. (Usnea) 180 compacta A. L. Sm. (Thermutis) 28 compactum Nyl. (Gonionema) 29 compactus Leight. (Sirosiphon) 28 complanata Koerb. (Lecanora) 327 complanatoides A. L. Sm. (Lecanora) 326

complicatus Mudd (Synech.) 60 compressus Ach. (Spharophorus) 23 concentrica Cromb. (Parmelia var.) 139

concilians A. L. Sm. (Placodium) 219 concilians Nyl. (Lecanora) 220 concinna Stirt. (Cathisinia) 474 concinnum Flot. (Collema) 51 concolor Wain. (Candelaria) 117, 199, 488

concolor Dicks. (Lichen) 117, 195 concreta Nyl. (Pertusaria) 366 condensatum Hoffm. (Stereocaulon) 408 condyloideum Ach. (Stereocaulon) 408 conferta Nyl. (Lecanora) 280 conferta Dub. (Patellaria) 280 confertula Stirt. (Cladonia) 452 confertum Nyl. (Collema) 48 confertum A. L. Sm. (Physma) 48 confinis Ach. (Lichen) 44 
confinis Ag. (Lichina) 44 confluens Ach. (Lecidea) 472 confragosa Nyl. (Lecanora) 252 confragosa Ach. (Parmelia) 252 confragosa Koerb. (Rinodina) 252 conglomeratum Hofim. (Collema) 61 CONIOCARPINEA 1 CONIOCYBE Ach. 10 coniopta Nyl. (Lecanora) 257 coniopta A. L. Sm. (Rinodina) 257 conista S. F. Gray (Scyphophorus) 430 conizæa Nyl. (Lecanora) 291, 489 conizcea S. F. Gray (Rinodina) 291 conizcoides Nyl. (Lecanora) 292 conoplea Ach. (Parmelia) 85 CONOTREMA Tuck. 378 Conradi Nyl. (Lecanora) 258 Conradi Koerb. (Rinodina) 258 conspersa Ach. (Parmelia) 139 conspersus Ehrh. (Lichen) 140 conspurcata Turn. \& Borr. (Variolaria) 363 constellata Tayl. (Variolaria) 362, 381 constrictula Stirt. (Usnea) 178, 182 contigua Fr. (Lecidea) 470, 484 contorta Hepp (Lecanora var.) 318 contorta DC. (Urccolaria) 318 contorta Hoffm. (Verrucaria) 318 Corallina fusca foliosa Buddle 450 Corallina montana, etc. Buddle 416 corallina Ach. (Variolaria) 370 corallinoides A. Zahlbr. (Parmeliella) 81

corallinoides Hoffm. (Stercocaulon) 81 corallinum Ach. (Isidium) 370 corallinus L. (Lichen) 370 coralloidea Ach. (Cenomyce) 425 coralloidea Mudd (Cladonia) 425 coralloides Pers. (Spharophorus) 24 coralloides Frr. (Stereocaulon) 409, 411 Coralloides alpinum Dill. 23 Coralloides alpinum etc. Dill. 25 Coralloides cornic. etc. Dill. 124

Coralloides cornic. brev. otc. Dill. $436,446,448$

Coralloides cornic. long. rar. Dill. 446 Coralloides comucop. inc. cic. Dill. 461 Coralloides crass. subinc. ctc. Dill. 450,456

Coralloides crisp. Zotryf. ctc. Dill. 412 Coralloides cupressiforme, etc. Dill. 24 Coralloides frut. . . candic. Dill. 414
Coralloides frutic... cormic. vif. Dill. 415, 449, 450

Coralloides frut. spec. etc. Dill. 159, 160

Coralloides fungif. arb. etc. Dill. 13, 15

Coralloides fungi. carn. ctc. Dill. 405 Coralloides fungif. fusc. bas. fol. Dill. 444

Coralloides fungif. sax. Dill. 403

Coralloides imperforatum, etc. Dill. 419

Coralloides min. frag. etc. Dill. 421

Coralloides montanum frutic. ctc. Dill. 417

Coralloides parum ram. tuberc. fusc. Dill. 435

Coralloides perf. minus, etc. Dill. $418,419,445$

Coralloides pulchr. genic. etc. Dill. 453 Coralloides ramulosum, etc. Dill. 465 Corailloides scyphif. com. Dill. 431

Coralloides scyphif. fol. alcic, ctc. Dill. 423, 453

Coralloides scyphif. grac. Dill. 429

Coralloides scyphif. ossis fem. etc. Dill. 460

Coralloides scyphif. margin. rad. ctc. Dill. 439

Coralloides scyphif. serr. elat. ctc. Dill. $441,442,445$

Coralloides scyphif. tub. cocc. Dill. 458 Coralloides scyphif. tuberc. fusc. Dill. 440

Coralloides scyptrif. tub. fusc. Dill. 426,429

Coralloides scyphis gracil. etc. Dill. 462

Coralloides scyphis humil. ctc. Dill. 430

Coralloides sparsum caul. tort. spin. Dill. 447

Coralloides tenuiss. nigr. etc. Dill. 124 Coralloides . . veluti siliquosum Dill. 173

Coralloides vix ram. scyph. obsc. Dill. $431,460,462$

coronata Borr. (Lecidea) 86

coronata Hoffm. (Vemicaria) 87

corniculata A. L. Sm. (Parmelir) 124 comiculatus Lightf. (Lichen) 124 cornucopioides Huds. (Lichen) 458 cornuta Fr. (Cladonia) 442 
cornuta Koerb. (Usnea) 179

cormutus L. (Lichen) 442

cornutus Lightf. (Lichen var.) 460, 463

corrugata Ach. (Parmelia) 142 corrugata Hoffm. (Umbilicaria)

corrugatus Sm. (Lichen) 142

crassa Ach. (Lecanora) 260

crassa Nyl. (Ramalina var.) 173

crassa DC. (Squamaria) 260

crassum S. F. Gray (Psoroma) 260

crassus Huds. (Lichen) 260

crenata A. L. Sm. (Candelariella) 227

crenata Nyl. (Lecanora) 227

crenulata Hook. (Lecanora) 279, 281

crenulatella Nyl. (Lecanora) 210

crenulatellum A. L. Sm. (Placodium)

210

crenulatus Dicks. (Lichen) 280

cretaceum Hook. (Collema) 72

cretaceum S. F. Gray (Enchylium) 72

cretacoum Nyl. (Leptogium) 72

cretaceus Sm. (Lichen) 72

crispa Lamy (Cetraria) 158

crispa S. F. Gray (Pellidea) 93

crispata Flot. (Cladonia) 444

crispum S. F. Gray (Enchylium) 53

crispum Ach. (Collema) 56

crispus Ach. (Lichen) 57

crispus Sm. (Lichen) 50

cristatum Hoffm. (Collema) 55

cristatus Huds. (Lichen) 52

crocata Ach. (Sticta) 110

crocata Nyl. (Stictina) 110

crocatus L. (Lichen) 110

crocea Ach. (Solorina) 103

croceus L. (Lichen) 103

CROCYNIA Massal. 385

crccullata Del. (Cenomyce) 453

cucullata Ach. (Cetraria) 155

cucullatum Nyl. (Platysma) 156

cucullatus Bell. (Lichen) 156

cupularis Schær. (Gyalecta) 467

cupularis With. (Lichen) 373

Curnowii Cromb. (Ramalina) 175

curtiusculum Nyl. (Calicium) 16

curtum Turn. \& Borr. (Calicium) 16

curtum S. F. Gray (Phacotrum) 17

curvescens A. L. Sm. (Lecania) 351

curvescens Nyl. (Lecanora) 351

curvescens MIudd (Pannaria) 351

cuspidata Nyl. (Ramalina) 173 cyaniza Nyl. (Lecidea) 469

CYCLOCARPINE 1,25

cyclostelis Ach. (Lichen) 216

cyclostelis Ach. (Parmelia) 246

cylindrica Ach. (Gyrophora) 391,395

cylindrica Cromb. (Umbilicaria) 391

cylindricus L. (Lichen) 395

CYPHELIUM Ach. 4, 20

CYPHELIUNI MIUdd 4

Cyphellæ xiv

cyrtaspis Ach. (Lecanora) 328

CYSTOCOCCUS $\mathrm{x}$

dactylina Nyl. (Pertusaria) 357, 363, 373

dactylinus Ach. (Lichen) 357

damæcornis Ach. (Sticta) 111

dasæa Stirt. (Lecidea) 471

dasypoga Stiz. (Usnea) 181

dealbata Cromb. (Pertusaria) 358, 369

dealbata DC. (Variolaria) 370

dealbatus Ach. (Lichen) 370

debile Turn. \& Borr. (Calicium) 17

debile S. F. Gray (Strongylium) 18

decincta Nyl. (Lecanora) 324

decipiens Arn. (Physcia) 203

decipiens Leight. (Placodium) 203

deformis Ach. (Cenomyce) 457

deformis Hoffm. (Cladonia) 457, 459

deformis Lightf. (Lichen) 456

deformis L. (Lichen) 457

deformis S. F. Gray (Scyphophora) 457

degenerans Floerk. (Capitularia) 436

degenerans Spreng. (Cladonia) 436

delicata Ach. (Cenomyce) 455

delicata Floerk. (Cladonia) 455

delicatula Nyl. (Panmularia) 32

delicatula A. L. Sm. (Placynthium) 32

delicatum S. F. Gray (Helopodium) 455

delicatus Ehrh. (Lichen) 455

Delisei Th. Fr. (Cetraria) $15 \mathrm{~s}$

Delisei Th. Fr. (Gyrophora var.) 397

Delisei Leight. (Parmelia) 146

Delisei Nyl. (Parmelia) 146

Delisei Bory (Stereocaulon) 410

demissa Arn. (Rinodina) 254

dendriscum Nyl. (Leptogidium) 30

dendriscum Nyl. (Leptogium) 30

dendritica Pers. (Parmelia) 145

denticulata Ach. (Gyrophora var.) 397

denudatum Floerk. (Stereocaulon)

411

$2 \mathrm{k}$ 
depressa Nyl. (Lecanora subsp.) 322 derivata A. L. Sm. (Gyalecta) 485 dermatinum Ach. (Collema) 58 dermatinum Loight. (Leptogium) 58 DERMATOCARPACEZ 388 destricta Nyl. (Cladonia) 421 determinata A. L. Sm. (Massalongia var.) 89

deusta Ach. (Gyrophora) 393 deustus Lightf. (Liciren) 390 deustus L. (Lichen) 393 diamarta Ach. (Urceolaria) 324 diamartus Wahlenb. (Lichen) 324 diatrypa Ach. (Parmelia) 122 diatrypa S. F. Gray (Physcia) 122 diatrypus Ach. (Lichen) 122 Dicksonii Nyl. (Lecanora) 329 Dicksonii Ach. (Lichen) 329 difformis Huds. (Lichen) 456 diffractum Nyl. (Collema) 42 diffractum Krempelh. (Leptogium) 72 diffractus Ach. (Lichen) 264 diffundens Nyl. (Collemopsis) 42 diffundens Sydow (Psorotichia) 42 diffundens Nyl. (Pyrenopsis) 42 diffusa A. L. Sm. (Cetraria) 136, 151 diffusa Mudd (Parmelia) 135 diffusa S. F. Gray (Parmelia) 151 diffusum Nyl. (Platysma) 151 diffusus Dicks. (Lichen) 151 digitata Hook. (Cenomyce) 461 digitata Hoffm. (Cladonia) 456 digitata S. F. Gray (Scyphophora) 456 digitatus. I. (Lichen) 456 digitatus Huds. (Lichen) 461 digitatus Hook. (Scyphophorus) 461 dilacerata Hoffm. (Lobaria) 169 dilacerata Wain. (Ramalina) 169 Dillenii With. (Lichen) 390 dimera Nyl. (Lecanora) 351 diplyyodes Cromb. (Lecanora) 220 diplinthia Nyl. (Lecanora) 258 diploellum Nyl. (Calicium) 18 DIPLOSCHISTES Norm. 878, 381 DIRINA Fr. 478 DIRINACEIE 386,477 discoidea Hook. (Variolaria) 360 discoideus Sm. (Lichen) 360 discreta Th. Fr. (Acarospora) 338 discreta Nyl. (Lecanora) 339 discreta Fr. (L'armelia) 399 dispersa Nyl. (Lecanora) 289 dispersus Pers. (Lichen) 289 dissecta Nyl. (Pamelia) 137 disseminatum (Calicium) 18 dissidens Nyl. (Lecanora) 200 dissidens Nyl. (Placodium) 200 dissipata Nyl. (Lecanora) 289 distans Pers. (Lichen) 268, Distribution xix divergens Nyl. (Alectoria) 186 divergens Ach. (Cornicularia) 186 dubia Schær. (Parmelia) 134 dubitans A. L. Sm. (Lecania) 351 dubitans Nyl. (Lecidea) 351 dubius Wulf. (Lichen) 134 Dufourii Del. (Sticta) 108 Dufourii Nyl. (Stictina) 108

ecmocyna Ach. (Cenomyce) 441 comocyna S. F. Gray (Scyphophora) 441

Ecology xix

Economic uses $\mathrm{xx}$ ecrustaceum Nyl. (Placodium var.) 215

ectanea Oliv. (Xanthoria var.) 194 effusa Arn. (Basidia) 476 effusa Ach. (Lecanora) 296 cffusa S. F. Gray (Rinodina) 296 cffusus Pers. (Lichen) 296 elcina Wahlenb. (Parmelia) 244 elrina A. L. Sm. (Physcia) 244 claina Hook. (Squamaria) 244 elainus Sm. (Lichen) 244 classosporum Nyl. (Calicium) 9 elatina Ach. (Lecanora) 355 elatinum Koerb. (Hrmatomma) 355 elegans Ach. (Graphis) 20 clegans Ach. (Lecanora) 200 clegans Link (Lichen) 200 clegans Sm. (Lichen) 200, 202 olegans DC. (Placodium) 200 elegans Hook (Squamaria) 200 clegans Deak. (Sticta) 108 clongatus Jacq. (Lichen) 442 encausta Ach. (Parmelia) 121 cncaustus Sm. (Iichen) 121, 122 Enchylium S. H. Gray 48 cndiviafolia Ach. (Cenomyce) 425 endivirefolia Fr. (Cladonia) 425 cndiviafolia S.IF. Gray (Scyphophora) 425

endivifolins Dicks. (Lichen) 425 
endochlora Leight. (Parmelia) 139 epanora Ach. (Lecanora) 301 epanores Ach. (Lichen) 301

EPHEBE Fr. 34

EPHEBACE AE 26, 27

EPHEBEIA Nyl. 35

epibryon Ach. (Lecanora) 272

epibryon Ach. (Lichen) 272

epigea Ach. (Lecanora) 340

epigeum S. F. Gray (Placodium) 340

epigeus Ach. (Lichen) 340

epiglypta Nyl. (Lecanora subsp.) 316

epiphylla Wheld. \& Trav. (Bacidia) 476

epiphyllus Ach. (Lichen) 427

epixantha A. L. Sm. (Candelariella) 229

epixantha Nyl. (Lecanora) 229

epixantha Ach. (Lecidea) 229

epulotica Mudd (Aspicilia) 332

eprulotica Ach. (Gyalecta) 332

epulotica Nyl. (Lecanora) 330, 332

ericetorum A. Zahlbr. (Icmadophila)

352,405

ericetorum L. (Lichen) 352, 405

cricetorum Huds. (Lichen) 405

erosa Ach. (Gyrophora) 398

crosa Sm. (Gyrophora) 398

erosa Leight. (Physcia) 245

erosa Borr. (Squamaria) 245

erosa Hoffm. (Umbilicaria) 398

crosus Web. (Lichen) 398

erratica Linds. (Parmelia var.) 139

erumpens Tayl. (Peltidea) 92

erysibe Mudd (Lecania) 347

erysibe Nyl. (Lecanora) 347

crysibe Ach. (Lichen) 347

erythrella Ach. (Lecanora) 209

erythrella Tayl. (Lecidea) 209

crythrella S. F. Gray (Rinodina) 209

erythrellus Ach. (Lichen) 209

erythrocarpa Ach. (Lecidea) 217

erythrocarpa Pers. (Patellaria) 217

erythrocarpum A. L. Sm. (Placodium) 216

escharoides Sm. (Lichen) 82

EUASPICILIA 315

EUBIATORELLA Th. Fr. 471

eucarpa Stizenb. (Lecanora) 474

eucarpa Nyl. (Lecidea) 474

EUGYROPHORA A. Zahlbr. 389

EULECANIA Stizenb. 340,342
EULECANORA Th. Fr. 266

EUOPSIS Nyl. 37

EUPARMELIA Nyl. 123

EUPELTIGERA Hue 91

EUPLACODIUM Stizenb. 197

EUSTICTA Wain. 111

euspora Nyl. (Stenocybe) 19

eusporum Nyl. (Calicium) 19

eusporum Cromb. (Calicium) 20

eusportum Mudd (Stenocybe) 19

EVERNIA Ach. 161

evernioides Nyl. (Ramalina) 172

evolutum Græwe (Stereocaulon) 410

exasperata Mudd (Gyrophora f.) 396

exasperata Carroll (Parmelia) 143

exasperatum Ach. (Collema) 143

exasperatus Gunn. (Lichen) 391

Excretory products xix

exigua Hook. (Lecanora) 251

exigua S. F. Gray (Rinodina) 251, • 253,254

exiguus Ach. (Lichen) 251

exigures Sm. (Lichen) 254

exilis Lightf. (Lichen) 35

exomila Stirt. (Lecanora) 266

exoriens Stirt. (Endococcus) 482

exoriens Wheld. \& Wils. (Pyreno.

coccus) 482

expallens Ach. (Lecanora) 298

expallens Borr. (Lecidea) 298

expallens Pers. (Lepraria) 298

explicata Stirt. (Verrucaria) 483

explicatum Wheld. \& Wils. (T'helidium) 482

faginea Leight. (Pertusaria) 360

faginea Tayl. (Variolaria) 360

faginea Pers. (Variolaria) 361

fahlunense Nyl. (Platysma) ${ }^{\star} 154$

fahlunensis Schær. (Cetraria) 154

fahlunensis Lightf. (Lichen) 154

fahlunensis L. (Lichen) 155

fallax Web. (Lichen) 150

fallax Hook. (Pertusaria) 365, 374

fallax Ach. (Porina) 374

fallax Pers. (Vermearia) 374

farinacea Ach. (Ramalina) 170

farinaceus L. (Lichen) 170

farinaria Borr. (Lecanora) 291, 298, 361,489

fasciculare Ach. (Collema) 61

fasciculare S. F. Gray (Enchylium) 61 
fascicularis L. (Lichen) 61

fascicularis A. L. Sm. (Synech.) 61 fastigiata Leight. (Pertusaria) 362 fastigiata Ach. (Ramalina) 168 fastigiatus Sm. (Lichen) 165 fastigiatus Pers. (Lichen) 168 ferruginascens Nyl. (Lecanora) 222 ferruginea Nyl. (Lecanora) 221 ferrugineum Sm. (Calicium) 9 ferrugineum Mudd (Callopisma) 221 fermigineum S. F. Gray (Phacotium) 9 ferrugineum Hepp (Placodium) 219, 221

ferrugineus Huds. (Lichen) 221

festivum A. L. Sm. (Placodium var.) 222

fibrosus Sm. (Licien) 321

fibula Nyl. (Cladonia subsp.) 430, 432 fibula Ach. (Lichen) 431

fibula Th. Fr. (Pilophoron) 407 fibulum Tuckerm. (Stereocaulon) 407 filamentosa Stirt. (Lecidea) 469 filiforme A. L. Sm. (Pterygium) 45 filiformis Hook. (Ccnomyce) 462 filiformis Huds. (Lichen) 430 filiformis With. (Lichen) 462 filiformis Garov. (Parmelia) 45 filiformis Hook. (Scyphophora) 462 fimbriata Ach. (Cenomyce) 429 fimbriata Fr. (Cladonia) 429, 434 fimbriata Ach. (Gyrophora var.) 397 fimbriata Tayl. (Sticta) 108 fimbriatum Hoffm. (Collema) 76 fimbriatus L. (Lichen) 429 fimbriatus S. F. Gray (Scyphoph.) 429 firma Nyl. (Cladonia) 424

flabelliformis Floork. (Capitularia) 461

flabelliformis Wain. (Cladonia) 461 flaccidum Ach. (Collema) 63 flaccidum S. F. Gray (Lathagrium) 63 flaccidus Koerb. (Synech.) 63 flava A. L. Sm. (Biatorella) 473 flavescens Huds. (Lichen) 199, 201 flavescens A. L. Sm. (Placodium) 199 flavicans Ach. (Borrera) 191 flavicans Swartz (Lichen) 191 flavicans With. (Lichen) 200 flavicans Ach. (Parmelia) 191 flavicans DC. (Physcia) 191 flavicans Norm. ('Tolochistes) 191 flavida Hopp (Lccanora) 315, 330 flavocitrina Nyl. (Lecanora) 207, flavorubescens Huds. (Lichen) 208 flavovirescens Wulf. (Lichen) 209 flocculosa Turn. \& Borr. (Gyrophora) 393

flocculosa Hoffm. (Umbilicaria) 393 flocculosus Wulf. (Lichen) 393 florida Web. (Usnea) 177 floridus L. (Lichen) 178 fuviale S. F. Gray (Enchylium) 69 fluviatile Ach. (Collema) 68 fluviatile Nyl. (Collemodium) 69 fluviatile Cromb. (Leptogium) 68 fluviatilis Huds. (Lichen) 68 foliacea Willd. (Cladonia) 423 foliaceus Huds. (Lichen) 423 foliosa Wain. (Cladonia var.) 450 Fosteri Borr. (Parmelia) 138 fragile Tayl. (Collema) 67 fragile Nyl. (Collemodium) 67 fragile Nyl. (Leptogium) 67 fragilis Sm. (Lichen) 23 fragilis L. (Lichen) 25 fragilis Pers. (Sphrerophorus) 24 fragrans Ach. (Collema) 66 fragrans Tayl. (Collema) 72 fragrans S. F. Gray (Enchylium) 66 fragrans Cromb. (Leptogium) 65 fragrans Mudd (Leptogium) 72 fragrans $\mathrm{Sm}$. (Lichen) 66 fraxinea Ach. (Ramalina) 166 fraxineus L. (Lichen) 167 frigida S. F. Gray (Rinodina) 311 frigidus Swartz (Lichen) 311 frustulosa Ach. (Lecanora) 304 frustulosa S. F. Gray (Rinodina) 304 frustulosus Dicks. (Lichen) 301 fuciformis L. (Lichen) 480 fuciformis DC. (Roccella) 480 fucoides Dicks. (Lichen) 479 fucoides Wain. (Roccella) 479 fugiens Nyl. (Lecanora) 297 fulgens Ach. (Lecanora) 198 fulgens Swartz. (Lichen) 198 fulgens S. F. Gray (Placodium) 197 fulgens Hook. (Squamaria) 198 fuliginosa Nyl. (Parmelia) 146 fuliginosa (Pyrenopsis) 39 fuliginosa Ach. (Sticta) 107 fuliginosa Nyl. (Stictina) 107 fuliginosus Dicks. (Lichen) 107 fulvo-mellea A. L. Sm. (Lecanora) 330 
fulvus L. (Mucor) 11

fungiformis Scop. (Lichen) 403 furcata Ach. (Cenomyce) 446 furcata Schrad. (Cladonia) 445, 449 furcatus Huds. (Lichen) 446, 448 furcatus Lightf. (Lichen var.) 448 furfuracea Ach. (Borrera) 163 furfuracea Ach. (Coniocybe) 10, 13 furfuracea Mann (Evernia) 163 furfuracea Ach. (Parmelia) 163 furfuracea With. (Trichia) 10 furfuraceum Pers. (Calicium) 10 furfuraceus Tayl. (Bceomyces) 10 furfuraceus L. (Lichen) 163 furfuraceus L. (Mucor) 10 furfurea Nyl. (Pyrenopsis) 39 furfurella Nyl. (Collemopsis) 42 furfurella Boist. (Psorotichia) 41 furfurellum Nyl. (Collema) 42 furfureum Nyl. (Collema) 39 furvella Nyl. (Lecidea) 471 furvum Ach. (Collema) 59 furvum S. F. Gray (Lathagrium) 59 furvus Ach. (Lichen) 59

fusca A. L. Sm. (Physcia) 233, 488 fuscata Th. Fr. (Acarospora) 335 fuscata Cromb. (Lecanora) 336, 337 fuscatula Nyl. (Pyrenopsis) 38 fuscatus Schrad. (Lichen) 336 fuscella Mudd (Lecania) 350 fuscescens Nyl. (Lecanora) 271 fuscescens Sommerf. (Lecidea) 271 fuscoatra Nyl. (Lecanora) 219 fuscoatrum A. L. Sm. (Placodium) 219 fuscoluteolina Mudd (Lecanora) 218 fuscus Huds. (Lichen) 233

galactina Ach. (Lecanora) 287. galactina Ach. (Parmelia) 287 gangaleoides Nyl. (Lecanora) $277,286,305$ gelasinatus With. (Lichen) 3 gelida Ach. (Lecanora) - 262 gelida Hook. (Squamaria) 262 gelidum S. F. Gray (Placodium) 262 gelidus L. (Lichen) 262

gelidus Huds. (Lichen) 353

geminipara Th. Fr. (Lecanora) 311, 489

geniculata Hook. \& Tayl. (Ramalina) 167 geographica Hue (Lecanora var.) 269 geographicum DC. (Rhizocarp.) 307 geoica Leight. (Gyalecta) 331 gibba Nyl. (Sarcopyrenia) 486 gibbosa Koerb. (Aspicilia) 322 gibbosa Nyl. (Lecanora) 321 gibbosa Ach. (Urceolaria) 321 gibbosa Flot. (Zeora) 321 gibbosus Ach. (Lichen) 321 GIRARDIA S. F. Gray 34 glaber Ach. (Lichen) 394 glabra Ach. (Gyrophora) 394 glabratus Dicks. (Lichen) 283 glauca Ach. (Cetraria) 148 glauca Leight. (Cladonia var.) 451 glaucescens Hoffm. (Collema) 49 glaucocarpa Koerb. (Acarospora) 334 glaucocarpa Ach. (Lecanora) 334 glaucocarpus Wahlenb. (Lichen) 334 glaucoma Ach. (Lecanora) 283 glaucoma Ach. (Lichen) 283 glaucoma S. F. Gray (Rinodina) 283 glaucoma Hoffm. (Verrucaria) 283 glaucella Koerb. (Lecanora var.) 297 glaucum Nyl. (Platysma) 149 glaucus L. (Lichen) 149 Glebulentum Nyl. (Collemodium) 69 glebulentum Nyl. (Leptogium) 69 globiferus L. (Lichen) 24 " globosus Huds. (Lichen) 24 globosus A. L. Sm. (Sphcerophorus) 23 globosus Wain. (Sphærophorus) 487 globulifera Nyl. (Pertusaria) 360 globulifera Turn. (Variolaria) 360 GLOEOCAPSA $x$ glomerata Schær.(Pertusaria) 371 glomerata Ach. (Porina) 371 glomeratus Schleich. (Lichen) 371 glomulifera Ach. (Parmelia) 114 glomulifera Borr. (Pertusaria) 371 glomulifera Nyl. (Ricasolia) 114 glomulifera Del. (Sticta) 114 glomuliferus Lightf. (Lichen) 113 globuliferus Sm. (Lichen) 360 GOMPHILLUS Nyl. 402, 406 gonatodes Ach. (Lichen) 310 gonionema Nyl. 28 gracilescens Wain. (Cladonia) 438 gracilis Hook. (Cenomyce) 441 gracilis Willd. (Cladonia) 434, 440, 446

gracilis L. (Lichen) 441 
granatina Nyl. (Euopsis) 37 granatina Sommerf. (Lecanora) 37 granatina Nyl. (Pyrenopsis) 37 grandinosa S. F. Gray (Rinodina) 309 granosum Schær. (Collema) 57 granosus Scop. (Collema) 58 granulatum Hook. (Collema) 59 granulatus Huds. (Lichen) 56, 58 granulatus Sm. (Lichen) 59 granuliferum Nyl. (Collema) 56 granulosa Wedd. (Lecanora) 203 granulosum Müll.-Arg. (Amphiloma) 203

granulosum Hepp (Placodium) 203 grisea Turn, \& Borr, (Gyrophora) 389 grisea A. Zahlbr. (Physcia) 237, 405 grisea Hoffm. (Umbilicaria) 390 griseo-virens Turn. \& Borr. (Variolaria) 356,361

griseus Lamarck (Licheni) 238 griseus Schwartz (Lichen) 390 GRAPHIDACEA 386 GRAPHIDINE IE 1 grumosus.Pers. (Lichen) 277 grumulifera (Pyrenopsis) 38 GYALECTA Ach. 467 GYMNOCARPEA 1 gypsacea Ach. (Urceolaria) 384 gypsaceus Zahlbr. (Diploschistes) 384 gyrocheila Nyl. (Pertusaria) 310, 377 GYROPHORA Ach. 388, 401 GYROPHORACE E $26,387,388$ gyrosus Ach. (Lichen) 55

hamalea Nyl. (Euopsis) 37 hamalea Stirt. (Pyrenopsis) 37 hamaleum Sommerf. (Collema) 37 hamatites Chaub. (Lecanora) 218 hrmatites A. L. Sm. (Placodium) 218 hamatomma Ach. (Lecanora) 354 hamatomma Ehrh. (Lichen) 354 Hrmatomma Massal. 259, 353 hamatomma S. H'. Gray (Rinodina) 356 brmatopis Th. Fr. (Pyrenopsis) 38 Hageni Ach. (Lecanora) 277 Hageni Ach. (Lichen) 278, 281 IIELOPODIUM S. F. Gray 413 hemiphaum Nyl. (Calicium f.) 14 hemiphodium Nyl. (Calicium var.) 14 hopatizon Wain. (Cetraria) 154 hepatizon Lightf. (Lichen) 154 Heppianum Müll.-Arg. (Amphil.) 199
Heppii Koerb. (Acarospora) 339 Heppii Nyl. (Lecanora) 339 Heppii Naeg. (Myriospora) 339 herbacea Ach. (Parmelia) 114 herbacea De Not. (Ricasolia) 114 herbacea S. F. Gray (Sticta) .114 herbaceus Huds. (Lichen) 114 herbarum Arn. (Bacidia) 476 hiascens Th. Fr. (Cetraria) 158 hibernicum Nyl. (Nephr. var.) 103 Hildenbrandii Garov. (Collema) 79 Hildenbrandii Nyl. (Leptogium) 79 hirta Hofim. (Usnea) 178 hirtus L. (Lichen) 179 hispida Mudd (Borrera) 241 hispida Cromb. (Cetraria var.) 159 hispida Tuckerm. (Physcia) 240 thispidula Ach. (Cornicularia) 36 hispidula Nyl. (Ephebeia) 36 hispidulum S. F. Gray (Phacotmum) 6 hispidus Lightf. (Lichen) 159 hispidus Schreb. (Lichen) 241 Hoffmanni Sommerf. (Lecanora var.) 319

Hoffmanni Ach. (Lichen) 319 Hoffmanni Ach. (Urceolaria) 319 holocarpus Ehrl. (Lichen) 214 hololepis Cromb. (Cladonia f.) 435, 453

holophæa A. L. Sm. (Lecania) 341 holophaa Nyl. (Lecanora) 341 holophaca MIont. (Parmelia) 341 homœopsis Nyl. (Pyrenopsis) 38 Hookeri Tuck. (Cladonia) 461 Hookeri Hook. (Lecanora) 87 Hookeri Borr. (Lichen) 87 Hookeri Nyl. (Pannaria) 87 horizontalis L. (Lichen) 97 horizontalis Ach. (Peltidea) 97 horizontalis Hoffm. (Peltigera) 97 horrescens Tayl. (Parmelia) 133, 151 humigena Tayl. (Lecidea) 469 humosum Nyl. (Leptogium) 70 Hutchinsia A. L. Sm. (Lecania) 349 Hutchinsia Nyl. (Lecanora) 349 Hutchinsiæ Loight. (Pertusaria) 357 Hutchinsice Borr. (Thelotrema) 357 hyalinella Nyl. (Coniocybe) 12 hybrida Hoffm. (Cladonia) 442 hydrochara Ach. (Pammelia) 68 hymenia S. F. Gray (Porina) 374 hymenina Ach. (Peltidea) 96 
hymenium Ach. (Thelotrema) 374 hymenius Ach. (Lichen) 374

hyperborea Ach. (Gyrophora) 392 hyperborea Hoffm. (Umbilicaria) 393 hyperboreus Ach. (Lichen) 392 hyperellum Ach. (Calicium) 13 hyperellum S. F. Gray (Phacotrum) 13 hyperellus Ach. (Lichen) 13

hypergenum Nyl, (Collema) 55 hyperopta Ach. (Parmelia) 136, 151 hypnæa A. L. Sm. (Bacidia var.) 476 hypnorum Ach. (Lecanora) 90 hypnorum Dicks. (Lichen) 90 hypnomu Wulf. (Lichen) 272 hypnom Koerb. (Pannaria) 90 hypnorum S. F. Gray (Psoroma) 89 hypnorum Hook. (Squamaria) 90 hypocyanea Stirt. (Lecidea) 468 HYPOGYMINIA Nyl. 118

hypomela Cromb. (Lobaria var.) 116 hypophæa A. L. Sm. (Biatorella) 473

ICMADOPHILA Massal. 259, 352, 489

icmadophila Ach. (Lecidea) 352 icmadophila Ehrb. (Lichen) 352 icmadop7rilus Nyl. (Baomy.) 352, 403 icterica Tayl. (Lecidea) 220

ilyophora Wheld. \& WVils. (Bilimbia) 475

ilyophora Stirt. (Lecidea) 475

impexa Harm. (Cladonia) 415 implexa Nyl. (Alectoria) 185 implexa Hofim. (Usnea) 185, 188 inalpina Ach. (Lecanora) 210 incarnata Leight. (Pertusaria) 312 inclusus Sm. (Lichen) 379 incrassata Nyl. (Ramalina var.) 173 incrustans Acb. (Lecanora) 208 incrustans A. L.Sm.(Placodium) 208 incurva Fr. (Parmelia) 141 incurvus Sm. (Lichen) 128 incurvus Pers. (Lichen) 142 infundibulifera Wain. (Cladonia var.) 465

inquinans Trev. (Cyphelium) 21 inquinans Sm. (Lichen) 21 inquinata Th. Fr. (Pertusaria) 375 instratula Nyl. (Lecidea) 470 intermedia Nyl. (Ramalina) 171 intermutans Nyl. (Lecanora) 317 intestiniformis Ach. (Usnea var.) 182 intexta Stirt. (Usnea) 178

intricata NIudd (Borrera) 231

intricata Ach. (Lecanora) 303

intricata Arn. (Omphalaria) 40 intricata Schær. (Physcia) 230 intricata Nyl. (Synalissa) 40 intricatum Nyl. (Nematonostoc) 40 intricatus Desf. (Lichen) 230 intricatus Schrad. (Lichen) 303 intumescens Koerb. (Lecanora) 272 intumescens Rebent. (Parmelia) 273 inversa Nyl. (Lecanora subsp.) 299 imubata Nyl. (Lecanora) 224 irrubata Ach. (Lecidea) 224 irrubescens A. L. Sm. (Placodium subsp.) 210

Isidia xiii

isidioides MIudd (Borrera) 249 isidioides Nyl. (Collema) 49 isidioides Nyl. (Lecanora) 249 isidioides Borr. (Parmelia) 249 isidioides Oliv. (Rinodina) 249 isidiosa Del. (Cenomyce) 432 Isignyi Del. (Cenomyce) 435 islandica Ach. (Cetraria) 156, 488 islandica Mudd (Cornicularia) 157 islandicus L. (Lichen) 157

jacobcifolius Schrank (Lichen) 54 Jacquini With. (Lichen) 393 JONASPIS 332 jubata Ach. (Alectoria) 186 jubatus L. (Lichen) 187 juniperina Ach. (Cetraria) 152 juniperinum Nyl. (Platysma) 152 juniperinus L. (Lichen) 152 juniperinus Huds.(Lichen) 193

kenmorense A. L. Sm. (Pterygium) 45 lienmorensis Nyl. (Lichiniza) 46 kenmorensis Holl. (Synalissa) 46 kylmoriense Larb. (Calicium) 4 kylmoriensis Cromb. (Sphinctrina) 4, 307

labrosa Ach. (Parmelia var.) 119 lacer Sm. (Lichen) 75 lacerum Ach. (Collema) 75 lacerum S. F. Gray (Leptogium) 75 lacerus Liljeb. (Lichen) 75 
laciniata Wain. (Lobaria) 113 laciniatus Huds. (Lichen) 113 laciniosa Nyl. (Lecanora) 118 lactea Nyl. (Pertusaria) 363 lactea Pers. (Variolaria) 363 lacteus L. (Lichen) 363

lactescens Mudd (Pertusaria) 368 lacteum A. I. Sm. (Placodium var.) 214

lacunosa Ach. (Cetraria) 150 lacunosum Nyl. (Platysma) 150 lacustris Th. Fr. (Lecanora) 328 lacustris With. (Lichen) 328 lata S. F. Gray (Borrera) 191 latevirens Lightf. (Lichen) 114 lætevirens A. Zahlbr. (Lobaria) 114 latevirens Leight. (Ricasolia) 115 lætevirens Nyl. (Parmelia var.) 147 levata Nyl. (Lecanora) 327 levata Ach. (Sagedia) 328 levigata Ach. (Parmelia) 137 lavigatum Ach. (Nephroma) 101 lævigatum Nyl. (Nephromium) 101 levigatus Sm. (Lichen) 137 Lallavei Nyl. (Lecanora) 217 Lallavei Clem. (Lecidea) 217 Lallavei Oliv. (Placodium) 217 Lamarkii Nyl. (Cladonia) 435 lanata Leight. (Alectoria) 123 lanata Ach. (Cornicularia) 123 lanata Wain. (Ephebe) 35, 487 lanata Wallr. (Parmelia) 123 lanatus L. (Lichen) 35 lanatus Huds. (Lichen) 186 lanestris Ach. (Alectoria var.) 187 lanuginosa Hue (Crocynia) 385 lanuginosa Ach. (Parmelia) 385 lanuginosa Hook. (Squamaria) 386 lanuginosum Nyl. (Amphiloma) 386 lanuginosum Nyl. (Leproloma) 386 lanuginosus Ach. (Lichen) 385

IJASALLIA Mérat 401

LATHAGRIUM S. F. Gray 59 latebricola Wheld. \& Trav. (Bacidia) 475

Laureri Nyl. (Collema) 60

Laureri Flot. (Synech.) 60

T,ECANAC'TACEAF 387

lecanopsoides Nyl. (Collemopsis) 28,42 lecanopsoides Nyl. (Pyrcnopsis) 42 LECANIA Massal. 259, 339 IECANORA Ach. 259

\section{LECANORACEAE 26, 258}

LECIDEA Ach. 468

LECIDEACELE $\quad 26,387,467$

lecidioides Th. Fr. (Rinodina var.) 251 leiocarpa Steudel (Gyrophora) 389 lciocarpa DC. (Umbilicaria) 389 leioplaca Schær. (Pertusaria) 371 lcioplaca Ach. (Pcrina) 371 LEMMIOPSIS A. Zahlbr. 64 LEMPHOLEMMA Koerb. 46 lenticulare Ach. (Calicium) 16 lentigera Ach. (Lecanora) 261 lentigera DC. (Squamaria) 261 lentigerum S. F. Gray (Placodium) 261 lentigerus Web. (Lichen) 261 lepadinum (Thelotrema) 20 lepadinum Ach. (Thelotrema) 378 lepadinus Ach. (Lichen) 379 lepidophora Cromb. (Peltigera f.) 94 lepidiota Dalla Torre \& Sarnth. (Parmeliella) 83 lepidicta Stiz. (Pannularia) 83 lepidota Nyl. (Cladonia) 438 LEPROCAULON Nyl. 407 leprothelia Nyl. (Lecanora) 312 leptacina Sommerf. (Lecanora) 304 leptaleus Ach. (Lichen) 241 LEPTOGIDIUM Nyl. 30 leptogiella Nyl. (Collemopsis) 65 leptogiella A. L. Sm. (Lemmopsis) 65 LEPTOGIUM S. F. Gray 65 leptophylla Floerk. (Cladonia) 433, 444

leptophyllum S. F. Gray (Helop.) 433 leptophyllus Sm. (Lichen) 493 Lesdainii Harm. (Acarospora) 334 leucolepsis Wablenb. (Lichen) 87 leucolepsis Nyl. (Pannaria) 87 leucolepsis Hook. (Squamaria) 87 leucomela Ach. (Borrera) 232 leucomela Mich. (Physcia) 232 leucomelas L. (Lichen) 233 leucophlebia Nyl. (Poltigera var.) 99 leucophyma Leight. (Lecanora) 321 leucospeirea A. L. Sm. (Lecania) 342 leucospeirea Nyl. (Lecanora) 342

Lichen atro-ccruleus, laciniatus, etc. Hall 75

Lichen perpusillus nigricans, etc. Buddle 52

Lichen petr. cin. Angl. Buddle 390 lichenodeum Nyl. (Collema) 33 
lichenodeum Nyl. (Schizoma) 33

Lichenoides acetabulis, etc. Dill. 142

Lichenoides angust., ... crin. nigr. ctc. Dill 232

Lichenoides arb. cin.-vir. etc. Dill. 114

Lichenoides arboreum.... col. cand. Dill. 162

Lichenoides arbor., crust. fol. vir. etc. Dill. 235

Lichenoides arboreum fol. cin. etc. Dill. 231

Lichenoides arb. fol. . . scabrum Dill. 112

Lichenoides arboreum ramosum, etc. Dill. 165, 166

Lichenoides arbor. ... scut. limb. cin. etc. Dill. 237

Lichenoides atrum, cor. Pers. etc. Dill. 392

Lichenoides cand, et farin. etc. Dill. 360,361

Lichenoides caperatum, etc. Dill. 127

Lichenoides cartilagineum, etc. Dill. 260

Lichenoides cartilag. tub. pyx. exig. Dill. 423

Lichenoides ccratophyllum, etc. Dill. 119

Lichenoides cinereum polyd. Dill. 96

Lichenoides ciner. seg. arg. stell. ctc. Dill. 239, 243

Lichenoides cor. cin. . . . pelt. atr. etc. Dill. 390

Lichenoides coralliforme, etc. Dill. $165,166,168$

Lichenoides corneum margin ... fimbr. Dill. 396, 397

Lichenoides cornic.... segm. ang. Dill. 163

Lichenoides cormutum amarum, etc. Dill. 163

Lichenoides cornutum bronch, etc. Dill. 168

Lichenoides cornutum ... subt. in. can. Dill. 162

Lichenoides crusta . . cinerco-glauca, etc. Dill. 132

Lichenoides crusta . . flavescens Dill. 193

Lichenoides crusta foliosa, etc. Dill. 127
Lichenoides crust. . . limb. argent. Dill. 309

Lichenoides crust.orb. incan. Dill. 287

Lichenoides crust. orb. scut. flav. Dill. 199, 201, 206

Lichenoides crusta, . . pullum Dill. 143

Lichenoides crust. et lepr. etc. Dill, 382

Lichenoides crust.... scut, nigric. etc. Dill. 276

Lichenoides crust. . . . scut. subf. Dill. 270

Lichenoides digitatum . . fol. sin. Dill. 91,92

Lichenoides digitatum mescens, etc. Dill. 93

Lichenoides digit. . . verr. . . . notatum Dill. 98

Lichenoides Endiv. fol, crisp.etc. Dill. 149

Lichenoides foliis pilosis, etc. Dill. 52

Lichenoides fucif. tinct. etc. Dill. 480

Lichenoides fuliginosum, etc. Dill. 107

Lichenoides fuligin. et pulver. etc. Dill. 109

Lichenoides fungi. crusta lepr. ctc. Dill. 405

Lichenoides fungi. terr. etc. Dill. 403 Lichenoides fuscum, peltis, etc. Dill. 101

Lichenoides gelatinosum atro-virens, etc. Dill. 52

Lichenoides gelatinosum . . a auriculatum, etc. Dill. 58

Lichenoides gelatinosum . . fol. angustior. Dill. 68

Lichenoides gelatinosum ... fol. crist. Dill. 50,52

Lichenoides gelatinosum fol. imb. etc. Dill. 52

Lichenoides gelatinosum fol. . . . tuniform. Dill. 59

Lichenoides gelatinosum fuscum, etc. Dill. 54

Lichenoides gelatinosum ... granosum Dill. 68

Lichenoides gelatin. lobis, etc. Dill. 59

Lichenoides gelatinosum ... nigricans Dill. 62

Lichenoides gelatin. opunti. Dill. 68

Lichenoides gelatinosum palmatum, ctc. Dill. 63 
Lichenoides gel. ... purpur. Dill. 77 Lichenoides glaucum ... lac. crin. Dill. 136

Lichenoides glaucum orb., seg. lat. etc. Dill. '235, 238

Lichenoides glaucum perlatum, etc. Dill. 126, 134

Lichenoides granosum subglaucum, etc. Dill. 83

Lichenoides 7ispidum maj. rigid. etc. Dill. 231

Lichenoides hispidum... scut. nigr. Dill. 241

Lichenoides imbr. virid. etc. Dill. 140

Lichenoides lacunosum, etc. Dill. 111

Lichenoides lacun. Endiv. crisp. fac. Dill. 156

Lichenoides lacun, lacer. etc. Dill. 171,172

Lichenoides lacun., velut tubulosa Dill. 156

Lichenoides latevirens, etc. Dill. 114

Lichenoides lepros . . . cancri figura Dill. 312

Lichenoides lepr. tuber. fusc, ferr. Dill. 221

Lichenoides lichenis facie, etc. Dill. 104

Lichenoides longifolium, etc. Dill. 166, 167

Lichenoides membr. ... Fallop. amul. Dill. 150

Lichenoides membr. pell. etc. Dill. 96

Lichenoides non tubul. cin. etc. Dill. 412

Lichenoides non tubul. ramos. etc. Dill. 24

Lichenoides non. tubul. ramos. frut. etc. Dill. 159

Lichenoides non tubul. ramulis, etc. Dill. 23

Lichenoides olivaceum, etc. Dill. 128

Lichenoides oliv. . . . scut. leev. Dill. 143,147

Lichenoides oliv. . . . scut. verr. Dill. 143

Lichenoides parvum vircscens, etc. Dill. 99

Lichenoides pellucidum ... comic. Dill. 77

Lichenoides pellucidum, fol. crisp. Dill. 75,76
Lichenoides pelt. arb. etc. Dill. 115

Lichenoides peltatum... fol. div. Dill. 91

Lichenoides peltatum...rufescens Dill. 93

Lichenoides polyschides, etc. Dill. 108 Lichenoides pulm. retic. etc. Dill. 115 Lichenoides pulm.... subluteus, ctc. Dill. 192

Lichenoides pulm. villos, etc. Dill. 112 Lichenoides pullum superne, etc. Dill. 399

Lichenoides pustulosum, etc. Dill. 401 Lichenoides pyx. crn. elat. Dill. 441

Lichenoides pyx. margin. etc. Dill. 439

Lichenoides rig. Eryng. fol. ref. Dill. 157,158

Lichenoides rugosum durum, etc. Dill. 398

Lichenoides saxat. fol. min. etc. Dill. 390

Lichenoides saxatile fuscum, etc. Dill. 101

Lichenoides saxatile... nigrescens Dill. 62

Lichenoides sax. . . p pil. pur. Dill. 144

Lichenoides saxatile tenue, etc. Dill. 75

Lichenoides saxat., vesiculas proferens Dill. 149

Lichenoides seg. angust. etc. Dill. 170 Lichenoides seg. argut. etc. Dill. 169

Lichenoides subfuscum, peltis ... planis Dill. 95, 97

Lichenoides subgl. cumat. etc. Dill. 113

Lichenoides sublitrsutum teres, etc. Dill. 230

Lichenoides subtus croceum, etc. Dill. 103

Lichenoides tart. ... scutellis rufis, etc. Dill. 353

Lichenoides tart. . . umbone fusco Dill. 311

Lichenoides tenue et molle, etc. Dill. 83

Lichenoides tenue fol. depress. Dill. 74

Lichenoides tenue . . fol. surrect. Dill. 76

Lichenoides tenuc pullum, etc. Dill. 394

Lichenoides temuissimum, etc. Dill. 76 
Lichenoides tenuiss. scut. exig. min. Dill. 200

Lichenoides tinct., fol. min. crisp. Dill. 154

Lichenoides tinct. glabr. vesic. Dill. 149

Lichenoides tub. caulic. . . majus Dill. 419

Lichenoides tub. caulic.... minus Dill. 418

Lichenoides tub. cin. ram. crust. Dill. 448

Lichenoides tub. magis. ramos. Dill. 450

Lichenoides tub. prolif. Dill. 429

Lichenoides tub. pyx. cin. Dill. 426

Lichenoides tub. pyx. prolif. Dill. 440

Lichenoides tub. pyx. tuberc. cocc. Dill. 458

Lichenoides tubul. ramos. etc. Dill. 414

Lichenoides tub. ramos. Dill. 449

Lichenoides tub. viresc. Dill. 448

Lichenoides verr. et rug. etc. Dill. 365,374

Lichenoides viride... scut. pull. Dill. 247

Lichenoides vulg. cinereo-glaucum, etc. Dill. 132, 133

Lichenoides vulg..... fol. scut. lut. Dill. 193

LICHINA Ag. 21

LICHINACE DE 26, 43

LICHINIZA Nyl. 44

lignorum S. F. Gray (Bcomyces) 403, 404

Lilliei B. de Lesd. (Aspicilia) 489

Lilliei Lillie (Lecanora) 489

limbata Sommerf. (Lecanora) 105

limbata IIudd (Peltigera var.) 93

limbata Ach. (Sticta) 109

limbata Nyl. (Stictina) 109

limbatus Sm. (Lichen) 109

limosum Ach. (Collema) 49

linearis Tayl. (Lecanora) 204

lismorense Cromb. (Pterygium) 45

lithotea Nyl. (Physcia) 248

livida Ach. (Lecanora) 288

livida Mudd (Phialopsis) 468

LOBARIA Schreb. 112

LOBAPINA Nyl. 112

lobulata Flörk. (Lecanora) 195

lobulata Sommerf. (Lecanora) 205 lobulatum A.I. Sm. (Placodium) 205

lotum Stizenb. (Rhizocarpon) 477

lophaum Cromb. (Leptogium) 77

lophyra Nyl. (Peltigera var.) 97

Lorrain-Smithiæ Knowles (Verrucaria) 482

lugubris Sommerf. (Lecidea) 487

lugubris Dalla Torre \& Sarnth (Psoro-

tichia) 487

lurida Ach. (Lecidea) 260

lurida Ach. (Lecidea) 341

lusca Nyl. (Lecanora) 325

lusitanicum Schær. (Nephroma) 102

lusitanicum Nyl. (Nephromium) 102

luteoalba Wils. \& Wheld. (Cladonia) 455

luteoalba Nyl. (Lecanora) 223

luteoalba Ach. (Lecidea) 223

luteoalbum MIassal. (Callopisma) 223

luteoalbum Hepp (Placodium) 223

luteoalbus Turn. (Lichen) 223

lutescens Turn. \& Borr. (Isidium) 372

lutescens Leight. (Lecanora) 291

lutescens Dub. (Lecanora) 299

lutesrens Hoffm. (Lepra) 372

lutescens Sm. (Lepraria) 372

lutescens Hofim. (Lichen) 299, 372

lutescens DC. (Patellaria) 299

lutescens Lamy (Pertusaria) 372

lutescens S. F. Gray (Rinodina) 299

lychnea Nyl. (Physcia) 196

lychnea Th. Fr. (Xanthoria) 195

macilenta Hoffm. (Cladonia) 462

macrophylla Stenh. (Cladonia) 443

macrophylla Borr. (Sticta) 111

macrospora Hepp (Pertusaria) 358

MAGMOPSIS Nyl. 485

major Nyl. (Stenocybe) 19

malacea Ach. (Peltidea) 94

malacea Fr. (Peltigera) 94

malangica Th. Fr. (Rinodina var.) 250

MALLOTIUM S. F. Gray 65

mammillifera Stirt. (Lecanora) 309

marginale Hook. (Collema) 54

marginale S. F. Gray (Enchylium) 54

marginalis Huds. (Lichen) 54

marginatus Bernh. (Lichen) 52

marina Th. Fr. (Lecanora var.) 278

maritima Sommerf. (Lecanora) 341

maritimum Tayl. (Collema) 47

marmorea Boist. (Gyalecta var.) 467 
Martindalei Cromb. (Ephebeia) 36 MASSALONGIA Koerb. 88 MICMillana Stirt. (Parmelia) 139 medians A. L.Sm. (Candelariella) 228 medians Nyl. (Lecanora) 228 medians Nyl. (Placodium) 228 meizolobum Nyl. (Collema f.) 56 melacarpoides Oliv. (Lecania var.) 345 melæna Arn. (Bilimbia) 475 melcenum Ach. (Collema) 54 melaleuca Dub. (Pertusaria) 364 melaleucum Turn. \& Borr. (Thelotrema) 364

melaleucus Sm. (Lichon) 364 melanaspis Ach. (Lecanora) 266 melanaspis Ach. (Parmelia) 266 melanocarpus Swartz (Lichen) 23 melanocarpus Schær. (Sphæroph.) 23 melanochlora Nyl. (Pertusaria) 364 melanochlorum DC. (Isidium) 364 melanophæa Zwackh (Chænotheca) 9,487 melanophrea Fr. (Lecidea) 329 melanophaum Ach. (Calicium) 9 melanophaum Mudd (Cyphetium) 9 melantera A. L. Sm. (Parmeliella) 84 melantera Cromb. (Pannularia) 84 melantera Stirt. (Pannaria) 84 melops Duf. (Physcia) 240 MENEGAZZIA A. Zahlbr. 122 mersata Stirt. (Lecidea) 469 metabolica Ach. (Lecanora) 351 metaboloides Nyl. (Lecanora) 295 micraspis Anzi (Buellia) 254 microcephala Nyl. (Sphinctrina) 3 microcephala Koerb. (Sphinctrina) 4 microcephalum Tul, (Calicium) 3 microccphalum Ach. (Calicium) 4 microcephalum S. F. Gray (Phacotrum) 4

microcephalus Tayl. (Baomyces) 406 microcephalus Sm. (Lichen) 4 microloba Nyl. (Peltigera var.) 94 microphylla Hook. (Lccidea) 81 microphylla Müll,-Arg. (Parmeliella) 82 microphylla Massal. (Pannaria) 82 microphylla Stiz. (Panmularia) 82 microphyllum Ach. (Collema) 66 microphyllum Nyl. (Collemodium) 66 microphyllum S. F. Gray (Enchylium) 66 micropjuyllum Leight. (Leptogium) 65 microphyllum Hook. (Placodium) 81 microphyllus Sm. (Lichen) 81 microphyllus Swartz (Lichen) 82 microphyllus Hook. (Scyphophoms) 433

microscopicum Nyl. (Leptogium) 73 microthelia Ach. (Parmelia) 209 microsticta Nyl. (Varicellaria) 377 microsticticum Turn. \& Borr. (Isidium) 367

microsticticus Sm. (Lichen) 367 milvina Ach. (Lecanora) 257 milvina Tayl. (Lecanora) 253 milvina Wahlenb. (Parmelia) 257 milvina Th. Fr. (Rinodina) 257 miniata Hook. (Squamaria) 202 miniatula Nyl. (Lecanora) 206 miniatulum Oliv. (Placodium) 205 miniatum Th. Fr. (Dermatocarpon) 390

miniatum Leight. (Placodium) 202 miniatus Hofim. (Lichen) 202 minor Hook. (Lichina var.) 44 minuscula Leight. (Alectoria var.) 35 minuscula Nyl. (Ramalina) 169 minutellum Ach. (Calicium) 18 minutissimum Floerke (Collema) 72 minutissimum Fr. (Leptogium) 72 molariformis Nyl. (Cladonia var.) 422 mollis Stirt. (Usnea) 179 monensis Wheld. (Acrocordia) 484 monocarpum Duf. (Collema) 53 monogona Nyl. (Pertusaria) 357 monstrosa Nyl. (Cladonia) 456 Mooreii Hepp (Leptogium) 30 morioides Blomb. (Aspicilia) 327 morioides A. L. Sm. (Lecanora) 327 mortensis Wats. (Polyblastia) 483 Mougeotii Schær. (Parmelia) 128, 135 Mnddii Mudd (Biatorina) 342 Muddii Salw. (Lecidea) 342 multifida A. L. Sm. (Parmelia) 141 multifidum Schær. (Collema) 53, multifilus Scop. (Lichen) 54 multifidus Dicks. (Lichen) 142 multipartitum Sm. (Collema) 61 multipartitus Mudd (Synech.) 60 multipuncta Nyl. (Pertusaria) 359, 361,363

multipuncta Turn. (Variolaria) 362 multipunctus Sm. (Lichen) 362 
muralis Schær. (Lecanora) 263 muralis Schreb. (Lichen) 263 muricata Del. (Cenomyce) 450 murina Ach. (Gyrophora) 390 marinus Ach. (Lichen) 390 murorum Ach. (Lecanora) 201 murorum Sm. (Lichen) 198 murorum Hoffm. (Lichen) 201 murorum DC. (Placodium) 199, 201, 203, 227, 228

muscicola Ach. (Collema) 29 muscicola Swartz (Lichen) 29 muscicolum Fr. (Leptogium) 29 muscicolum S. F. Gray (Polychid.) 29 muscigena Ach. (Parmelia) 237 muscorum Mudd (Bacidia) 477 muscomum Tayl. (Lecanora) 88 muscorum Del. (Pannaria) 88 muscorum Schleich. (Peltigera var.) 98 muscorum S. F. Gray (Psoroma) 88 muscorum Hook. (Squamaria) 88 Muscus arboreus aureus, etc. Dill. 191 Muscus arb. cum orbic. Dill. 178 Muscus arboreus nodosus Dill. 182 muscus arb.: Usn. Officin. Dill. 180 MIuscus aureus tenuissimsus Dill. 191 Muscus caule rigido, etc. Dill. 188

Muscus corall. . . f fonicul. Dill. 187 Mruscus coralloides lance, etc. Dill. 186 Minscus crusta, etc. Buddle 194

MIuscus licheniformis, etc. Buddle 235 Mruscus lichin. cornic. etc. Buddle 431,432

IIuscus licheniformis . . nigricans Buddle 62

MIuscus parvus ... pilosis Buddle 241 MIYOPORACE 388

myriococcum Ach. (Collema) 47 myriococcus Ach. (Lichen) 47 MYXXOPHYCE $D E$ viii, $\mathrm{x}$

nanum Nyl. (Leprocaulon) 409 nanum Ach. (Stereocaulon) 409 nanus Ach. (Lichen) 409 nebulosa Nyl. (Pannaria) 87 nebulosa Hoffm. (Patellaria) 87 neglecta Floerk. (Capitularia) 426 nemoxyna Nyl. (Cladonia f.) 431 nephaca Sommerf. (Lecanora) 308 NEPHROMIUM Nyl. 100 niger Huds. (Lichen) 31 nigra Nyl. (Pannaria) 31 nigra Stiz. (Pannularia) 31 nigrescens Ach. (Collema) 62 nigrescens S. F. Gray (Lathagrium) 62 nigrescens Huds. (Lichen) 62 nigrescens Anzi (Synech.) 62 nigricans Nyl. (Alectoria) 185 nigricans Cromb. (Lecanora) 216 nignum Ach. (Collema) 31 nigrum Massal. (Lecothecium) 31 nigrum S. F. Gray (Placynthium) 31, 303

nitens Ach. (Lecanora) 307 nitens Pers. (Patellaria) 307 nitida Stirt. (Usnea) 180 nivale Tuckerm. (Placodium) 218 nivale Nyl. (Platysma) 156 nivalis Ach. (Cetraria) 156 nivalis Carroll (Lecanora) 218 nivalis L. (Lichen) 156 nivalis Koerb. (Zeora) 218 nolens Nyl. (Pertusaria) 376 NOSTOC $x$ Notarisii Tul. (Acolium) 22 Notarisii Zahlbr. (Cyphelium) 22 nuda A. L. Sm. (Biatorella f.) 472 nuda Wheld. \& Trav. (Microglæua) 484

Nutrition xviii

Nylanderi Krempelh. (Thelidium) 483 Nylanderiana Massal. (Lecania) 349 Nylanderiana Nyl. (Lecanora) 349

obliterans Nyl. (Placodium) 201 obliterascens Nyl. (Lecanora) 202 obliteratus Pers. (Lichen) 205 oblongans Nyl. (Collemopsis) 64 oblongans A. L. Sm. (Lemmopsis) 64 obscura Mudd (Borrera) 246 otscura Nyl. (Physcia) 246 obscurus With. (Lichen) 233 obscurus Ehrh. (Lichen) 246 ochracea Mudd (Aspicilia) 330 ochracea Nyl. (Lecanora) 220 ochracea Schær. (Lecidea) 220 ochraceum Massal. (Callopisma) 220 ochraceum Anzi (Placodium) 220 ochrochlora Floerk. (Cladonia) 433 OCHROLECHIA Massal. 309, 356 ochroleuca Nyl. (Alectoria) 183 ochroleuca Ach. (Comicularia) 183 ochroleucus Ehrh. (Lichen) 183 ochrostoma Kuerb.(Lecanora rar.) 297 
oculata Ach. (Lecanora) 373 oculata Th. Fr. (Portusaria) 373 oculata S. F. Gray (Rinodina) 357 oculatum Ach. (Isidium) 373 oculatus Sm. (Lichen) 357 oculatus Dicks. (Lichen) 373 odontella Ach. (Cetraria) 160) odontellus Ach. (Lichen) 160 Oederi Wahlenb. (Lecidea) 329 olivacea Ach. (Parmelia) 142 olivacea S. F. Gray (Parmelia) 143 olivacea Fr. (Parmelia) 147 olivascens A. L. Sm. (Lecanora var.) 316 olivaceus With. (Lichen var.) 128 olivaceus L. (Lichen) 143 olivaceus Huds. (Lichen) 143, 146 olivetorum Nyl. (Parmelia) 129 omphalodes L. (Lichen) 144 omphalodes Ach. (Parmelia) 144 ophthalmiza Nyl. (Pertusaria) 358 orbicularis Neck. (Lichen) 246 orbicularis Dalla Torre \& Sarnth. (Physcia) 246 orosthea Ach. (Lecanora) 292, 300 orosthea Ach. (Lecidea) 300 orostheus Sm. (Lichen) 298 orostheus Ach. (Lichen) 300 ostreata Nyl. (Cladonia var.) 464 ostreata Schær. (Lecidea) 464

palamæa Nyl. (Cladonia var.) 447 pallescens Mudd (Lecanora) 314 pallescens With. (Lichen) 286 pallescens L. (Lichen) 314 pallida Fr. (Coniocybe) 11 pallida Schier. (Lecanora) 281, 283 pallidum Pers. (Calicium) 11 pallidus Dicks. (Lichen) 273 pallidus Schrob. (Lichen) 282 palmatum Ach. (Collema) 77 palmatum Mont. (Leptogium) 77 palmatum S. F. Gray (Scytenizem) 77 palmatus Huds. (Lichen) 77

PALMIELLA $x$ PANNARIA Del. 80,84 PANNARIA ALudd 81 PANNARIACEAE 26, 80 pannaricllum Nyl. (Pterygium) 45 panniformo Cromb. (Nephr. f.) 103 PANNULARIA Nyl. 30, 81 papillaria Ach. (Conomyce) 422 papillaria Hoffm. (Cladonia) 421 papillaria Ehrb. (Lichen) 421 papillaria Duf. (Pycnothelia) 42 paradoxum Turn. \& Borr. (Isiäum) 370 paradoxum Bornet (Spilonema) 33 parasitica Hoffm. (Cladonia) 455 parasiticus Hoffm. (Lichen) 455 parasiticus Hook. (Scyphophorus) 455 parella Ach. (Lecanora) 312 parella.S. F. Gray (Rinodina) 312 parellus L. (Lichen) 312 parietina Th. Fr. (Xanthoria) 192 parietina Ach. (Parmelia) 193 parietina De Not. (Physcia) 193 parietinum Ach. (Calicium) 18 parietimus L. (Lichen) 193 parile Ach. (Nephroma) 101 parile Nyl. (Nephromium var.) 101 parilis Ach. (Lichen) 101 parisionsis Nyl. (Lecanora) 271 PARMELIA Ach. 117,118 PARMELIACE DE 26,117 PARMELIELLA Müll.-Arg. 80, 81 paschale Ach. (Stereocaulon) 410 paschale Fr. (Stereocaulon) 410 paschalis Huds. (Lichen) 410 paschalis L. (Lichen) 411, 413 peliocypha Th. Fr. (Acarospora) 338 peliocypha Nyl. (Lecanora) 338 peliocypha Wahlenb. (Parmelia) 338 peliscypha Cromb. (Lecanora) 336 peliscyphoides Oliv. (Acarospora) 336 pellita Ach. (Gyrophora) 399 pellitus Ach. (Lichen) 399 pelobotrion Wablonb. (Urccolaria) 319 pelobotrya Mudd (Aspicilia) 319 pelobotrya Sommerf. (Lecanora) 319 pelobotrya Cromb. (Lecidea) 319 PELTIDEA Ach. 90,98 PELTIGERA Willd. 90,91 PELTIGERACE \&E 26,90 percænoides Jatta (Acarospora) 335 percanoides Nyl. (Lecanora) 335 percanoides Ach. (Lecidea) 335 perellus Sm. (Lichen) 312 perforata Hook. (Parmelia) 126 perforata S. F. Gray (Parmelia) 136 perforatus Sm. (Lichen) 132, 136 periclea S. F. Gray (Rinodina) 251 Perithecin xiv perlata Ach. (Parmolia) 125 
perlatus Huds. (Lichen) 126 peronellum Ach. (Calicium) 11 petrosa Arn. (Lecidea) 469 pertusa Schær. (Parmelia) 122 pertusa Dalla Torre \& Sarnth. (Pertusaria) 365

pertusa Ach. (Porina) 365

PERTUSARIA DC. 356

PERTUSARIACE AE 26, 356

pertusus Schrank (Lichen) 122

pertusus L. (Lichen) 365

pezizoides Borr. (Lecanora) 87, 482 pezizoides Web. (Lichen) 86, 87 pezizoides Leight. (Pannaria) 86 phccocarpella Hyl. (Lecanora) 216 phæocarpellum A. L. Sm. (Placodium) 216

phaocephala Th. Fr. (Chanotheca) 6 phaocephalum Turn. \& Borr. (Calicium) 6

phcocephalum Koerb. (Cyphelium) 6 phococephalus Turn. (Lichen) 6 phæoleucodes Nyl. (Lecanora) 347 phlogina Nyl, (Lecanora) 207 phloginum A. L. Sm. (Placodium) 207 PHLXCTIS Wallr. 378,380 PHYCOLICHENES $\times$ phycopsis Ach. (Roccella) 479 phylliscella Nyl. (Pyrenopsis) 39 phyllophorus Ehrh. (Lichen) 437 Phylogeny $\mathrm{xxi}$ phymatodes Ach. (Isidium) 369 PHYSCIA Schreb. $190,192,230$ PHYSIACE E 26, 189

PHYSMA Massal. 46 physodes L. (Lichen) 119, 120 physodes Ach. (Parmelia) 118 physodes S. F. Gray (Physcia) 119 piceus Dicks. (Lichen) 306 pichneum Ach. (Collema var.) 78 picta Tayl. (Lecidea) 209, 214 pileatum Ach. (Stereocaulon) 407,408 PILOPHORON Tuckerm. 406 PILOPHORUS Th. Fr. 402, 406 pilosella Huo (Parmelia) 132 pinastre Schrr. (Lecanora var.) 269 pinastri S. F. Gray (Cetraria) 152 pinastri Scop. (Lichen) 152 pinastri Nyl. (Platsyma) 152 piniperda Koerb. (Lecanora) 296, 298 pinnata Wain. (Cladonia var.) 447,450 pityrea Floerk. (Capitularia) 435 pityrea Fr. (Cladonia) 434 pityrea Ach. (Parmelia) $23 \mathrm{~S}$ pityreus Ach. (Lichen) 238 placodiellum Nyl. (Leptogium) 72 PLACODIUM DC. 196 PLACOLECANIA Stein. 340 placophyllus Ach. (Bæomyces) 405 PLACOPSIS Nyl. 259, 263 PLACYNTHIUMI S. F. Gray 30 platyphylla Ach. (Parmelia var.) 120 PLATSYMA Nyl. 148 pleurocarpa Ach. (Lobaria var.) 115 PLEUROCOCCUS $\mathbf{x}$ pleurota Floerk. (Capitularia) 459 pleurota Cromb. (Cladonia subsp.) 459 pleurota S. F. Gray (Scyphophora) "459 plicata Web. (Usnea) 179 plicatile Sm. (Collema) 68 plicatile Nyl. (Collemodium) 68 plicatile S. F. Gray (Enchylinım) 68 plicatile Nyl. (Leptogium) 67 plicatus L. (Lichen) 180 plumbea Nyl. (Coccocarpia) 83 plumbea Ach. (Parmelia) 83 plumbea Wain. (Parmeliella) 83 plumbea Del. (Pannaria) 83 plumbeum Hook. (Placodium) 83 plumbeus Lightf. (Lichen) 83 plymatula Johns. (Lecanora) 276 pocillum Ach. (Bacomyces) 427 poliophæa Ach. (Lecanora) 308 poliophcea Wahlenb. (Parmetia) 308 pollinaria Ach. (Ramalina) 171 pollinarius Sm. (Lichen) 172 pollinarius Westr. (Lichen) 171 Polinieri Del. (Collema) 74 Pollinii Massal. (Blastenia) 488 Pollinii Massee (Lecanora) 488 Pollinii A. L. Sm. (Placodium) 488 polyanthes Bornh. (Lichen) 47 polyanthes Arn. (Physma) 47 POLYBLASTIA Massal. 483 polycarpa Nyl. (Physcia) 195 polycarpa Oliv. (Xanthoria) 196 polycarpon Koerb. (Collema) 60 polycarpum S. F. Gray (Psoroma) 195 polycarpus Ehrh. (Lichen) 195 polycarpus Dalla Torre \& Sarnth. (Synech.) 60

POLYCHIDIUMI S. F. Gray 27, 29 polydactyla Floerk. (Cenomyce) 462 polydactyla Floerk. (Cladonia) 461 
polydactyla Ach. (Peltidea) 96 polydactyla Hoffm. (Peltigera) 95 polydactylon Neck. (Lichen) 96 polymorpha Ach. (Ramalina) 176 polymorpha Tayl. (Ramalina) 174 polymorpluss Ach. (Lichen) 176 polyphylla Hook. (Gyrophora) 393 polyphylla Schrad. (Umbilicaria) 394 polyphyllus L. (Lichen) 394 polyrrhiza Koerb. (Gyrophora) 397, 399

polyrrhizos L. (Lichen) 399 polyrrizizos Fr. (Umbilicaria) 399 polyschiza Lett. (Cetraria) 155 polyschizum Nyl. (Platysma) $155^{\circ}$ polyspora Nyl. (Lecanora) 250 polyspora Th. Fr. (Rinodina) 249 polythecia Tayl. (Variolaria) 362 polytropa Schær. (Lecanora) 301 polytropa Ach. (Lecidea) 302 polytropus Ehrh. (Lichen) 301 polytropus Sm. (Lichien) 303 populneuin de Brond. (Calicium) 18 populinus Ehrh. (Lichen) 168 PORINA Ach. 356 poriniformis Nyl. (Lecanora) 320 POROCYPHUS Koerb. 27 porphyria S. F. Gray (Rinodina) 354 portentosa Duf. (Cenomyce) 416 portentosa Wain. (Cladonia var.) 416 præpostera Nyl. (Lecanora) 286 prætexta Nyl. (Peltigera var.) 93 Prevostii Fr. (Gyalecta) 331 Prevostii Th. Fr. (Lecanora) 328, 331,332

privigna A. L. Sm. (Biatorella) 474 privigna Nyl. (Lecanora) 474 privigna Ach. (Lecidea) 474 privigna S. F. Gray (Rinodina) 474 proboscidea Ach. (Gyrophora) 390 proboscideus L. (Lichen) 390 proboscidea Tayl. (Parmolia) 132 proboscidea DC. (Umbilicaria) 390 proboscideus Huds. (Lichen) 395 proboscideus Sm. (Lichen) 397 prolixa Carroll (Parmelia) 145 prosecha Loight. (Lecanora) 345 prosechoides Oliv. (Lecania) 345 prosechoides Nyl. (Lecanora) 345 prosechoidiza Nyl. (Lecanora) 347 prosechoidiza A.L. Sm. (Lecania) 347 Prostii Duf. (Bcomyces) 404 prostratula Stirt. (Lecidea) 468 PROTOCOCCUS $x$ protuberans Th. Fr. (Lecanora) 374 protuberans Sommerf. (Lecidea) 374 protuberans Th. Fr. (Pertusaria) 374 pruinatus Dicks. (Lichen) 472 pruinosa Mudd (Biatorella) 471,475 pruinosa Cromb. (Lecanora) 472 pruinosa Hook. (Lecidea) 472 pruinosus Sm. (Lichen) 472 prunastri Ach. (Evernia) 161 prunastri L. (Lichen) 162 Pseudo-cyphellæe xiv Psora Dicks. (Lichen) 243 psorellum Nyl. (Collema) 69 PSOROMIA S. F. Gray 80,89 PSOROTICHIA Massal. 36, 41 psotina Leight. (Pannaria) 32 PTERYGIUMI Nyl. 43, 44 pubescens Ach. (Cornicularia) 35 pubescens Nyl. (Ephebe) 35 pubescens L. (Lichen) 35, 123, 121 pubescens Wain. (Parmelia) 35, 123 pulicaris Ach. (Lichen) 275 pulicaris Pers. (Patellaria) 275 pulius Lightf. (Lichen) 233 pullus Wulf. (Lichen) 393 pulmonacea Ach. (Parmelia) 115 pulmonacea Ach. (Sticta) 115 pulmonaria Hoffm. (Lobaria) 115 pulmonaria Hook. (Sticta) 115 pulmonarius L. (Lichen) 115 pulposulum Nyl. (Collema) 51 pulposum Ach. (Collema) 50, 498 pulposus Bernh. (Lichen) 50 pulverulenta Mudd (Borrera) 235 pulverulenta Ach. (Parmelia) 235 pulverulenta Nyl. (Physcia) 235 pulverulentus Schrob. (Lichen) 235 pulverulentus Sm. (Lichen) 257 pulvinata Acb. (Cenomyce) 457 pulvinata Wain. (Euopsis) 37 pulvinata Schrr. (Lecidea) 37 pulvinatum Hoffm. (Collema) 76 pulvinatum Th. Fr. (Steroocaulon var.) 412

pumila S. F. Gray (Lichina) 44 pumilus Huds. (Fucus) 43 punctatus Dicks. (Lichen) 274 punctatus Dicks. (Lichen) 328, 331 pungens Floork. (Cladonia) 449 pungens Ach. (Lichen), 449 
pusilla Massal. (Physcia) 202 pusillum Floerke (Calicium) 17 pusillum Nyl. (Leptogium) 70 pusillum Flag. (Placodium var.) 202 pustulata Ach. (Gyrophora) 401 pustulata Nyl. (Pertusaria) 364, 365, 374

pustulata Ach. (Porina) 364 pustulata Hoffm. (Umbilicaria) 401 pustulatus L. (Lichen) 401 Pycnidia xvii PYCNOTHELIA Leight. 414, 421 pygmaa Bory (Borrera) 196 pygmra Ag. (Lichina) 43 pygmaus Lightf. (Fucus) 43 pyracea Nyl. (Lecanora) 213 pyraceum Anzi (Placodium) 213, 223 PYRENIDIACE E 388,481 PYRENIDIUM Nyl. 481 pyreniospora Nyl. (Lecanora) 258 PYRENOCARPEA 1

PYRENOCARPINE 388

PYRENOCOCCUS Wheld. \& Wils. 482

PYRENOPSIDACE E 26,36

PYRENOPSIS Nyl. 36, 38

pyrenopsoides Nyl. (Lecanora) 42 pyrenopsoides Forss. (Psorotichia) 42 PYRENULACE 2 388, 484

pyrithromum A. L. Sm. (Placodium var.) 213

pyxidata Ach. (Cenomyce) 426

pyxidata Hoffm. (Cladonia) 425, 458, 477

pyxidatus L. (Lichen var.) 440 pyxidatus L. (Lichen) 426 pyxidatus DC. (Scyphophorus) 426

quercinum Pers. (Calicium) 15

Rabenhorstii B. de Lesd. (Lecania) 347

racemosa Hook. (Cenomyce) 448 racemosa Hoffm. (Cladonia) 446 racemosa S. F. Gray (Cladonia) 448 radiata Ach. (Cenomyce) 431 radiatus Huds. (Lichen) 124 radiatus Schreb. (Lichen) 431 Ralfsii A. L. Sm. (Lecania) 342 Ralfsii Cromb. (Lecanora) 342 Ralfsii Salw. (Lecidea) 342 RAMALINA Ach. 161, $16 \pm$ rameum Cromb. (Nephromium) 100 ramulosa Fr. (Synalissa) 40, 50 ramulosum Hoffm. (Collema) 40 rangiferina $\mathrm{Ach}$. (Cenomyce) 415 rangiferina Nyl. (Cladina) 415 rangiferina Web. (Cladonia) 414 rangiferinus $\mathrm{L}$. (Lichen) 415 rangiferinus alpestris L. (Lichen) 417 rangiferinus Huds. (Lichen var.) $\mathbf{4 4 9}$ rangiformis Hoffm. (Cladonia) 449 recedens Nyl. (Lecanora) 324 recedens Tayl. (Lecidea) 324 recensa Stirt. (Lecidea) 470 recurva Hoffm. (Cladonia var.) 448 recurva Ach. (Parmelia) 141 reddenda Stirt. (Parmelia) $13 \pm$ reducta Stirt. (Pertusaria) 363 refellens Nyl. (Lecanora) 216 refellens A. L. Sm. (Placodium) 216 Reindeer Moss 415 repanda Nyl. (Dirina) 478 repanda Fr. (Parmelia) 478 resupinata Ach. (Nephroma) 100 resupinatum Dalle Torre \& Sarnth.

(Nephromium) 100

resupinatus L. (Lichen) 100 resupinatus Huds. (Lichen) 101 resupinatus Sm. (Lichen) 102 reticulata Th. Fr. (Gyrophora) 393 reticulata Tayl. (Parmelia) 136 reticulatus WVulf. (Lichen) 124 retinens Nyl. (Calicium) 19 retrogressa Stirton (Physcia) 238 revertens $\mathrm{Nyl}$. (Spilonema) 34 revcluta Floerk. (Parmelia) 138 rhagadiza Oliv. (Acarospora) 338 rhagadiza Nyl. (Lecanora) 338 RHIZOCARPON Ramond 477 rhodocarpa Koerb. (Pertusaria) 378 rhyparodes Nyl. (Leptogium) 69 RICASOLIA De Not. 112, 113 rimosus Oed. (Lichen) 284 RINODINA S. F. Gray 190,249 rivulare Ach. (Collema) 69 RIVULARIA $x$ roboris Duf. (Lecanora) 252 roboris Arn. (Rinodina) 252 ROCCELLA DC. 479

Roccella Dicks. (Lichen) 479

Roccella L. (Lichen) 479

ROCCELLACEA 387,478 roscidum Floerko (Calicium) 13 $2 \mathrm{~L}$ 
rosellus $\mathrm{Sm}$. (Lichen) 282 roseus Pers. (Bæomyces) 404 mubicunda Stirt. (Usnea) 178 rubiformis Sm. (Lichen) 464 rubiginea Ach. (Usnea var.) 177 rubiginosa Ach. (Parmelia) 85 rubiginosa Del. (Pannaria) 85 rubiginosus Thumb. (Lichen) 85 rubra Massal. (Gyalecta) 467 rubra Ach. (Lecanora) 467 rubra Ach. (Parmelia) 467 mibra Hoffm. (Patellaria) 467 rubra Koerb. (Phialopsis) 467 rubra S. F. Gray (Rinodina) 467 rubricosa Ach. (Lecanora) 217 rubricosa S. F. Gray (Rinodina) 217 rufescens Neck. (Lichen) 93 rufescens Ach. (Peltidea) 93 rufescens Hoffm. (Peltigera) 93 rufescens Turn. (Urceolaria) 337 rufescens Hoffm. (Verrucaria) 224 rufovirescens Tayl. (Endocarpon) 337 rufus DC. (Bæomyces) 403, 405 rufus Huds. (Lichen) 403 rugifera Hue (Gyrophora) 489 ruginosum Duf. (Collema) 78 ruginosum Nyl. (Leptogium) 78 rugosa Nyl. (Lecanora) 271 rugosa Tayl. (Parmelia) 138 rugosus Pers. (Lichen) 272 rupestre Branth \& Rostr. (Placodium) 224

mupestris Pers. (Bceomyces) 403 mepestris Leight. (Lecanora) 2.24 rupestris Ach. (Lecidea) 225 mupestris Scop. (Lichen) 224 mpestris Swartz (Lichen) 63 rupestris Schær. (Pertusaria) 365 rupestris A. L. Sm. (Synech.) 63 rupicola L. (Lichen) 283, 284

saccata Ach. (Solorina) 104, 488 saccatus I. (Lichen) 101

sapincola Ach. (Lecidea) 293 scepincolum Nyl. (Platysma) 153 salicicola Wheld. \& Trav. (Bacidia) 476 salicina ふ̀. F. Gray (Rinodina) 208 salicinus Schrad. (Lichen) 208 Salweii A. L. Sm. (Acrocordia) 485 Sambuci Nyl. (Lecanora) 281 sanguinaria Ach. (Lecidea) 471
SARCOGYNE Th, Fr. 471 sarcopis Ach. (Lecanora) 296 sarcopis Wahlenb. (Parmelia) 296 sarcopisioides Maskal. (Biatora) 295 sarcopisioides A. L. Sm. (Lecanora 295

sarmentosa Ach. (Alectoria) 184 sarmentosus Sm. (Lichen) 183 saturninum Ach. (Collema) 79 saturninum Nyl. (Leptogium) 79 saturninum S. F. Gray (Mallotium) 79 satuminus Dicks. (Lichen) 79 saxatilis L. (Lichen) 132 saxatilis Ach. (Parmelia) 132 saxetana Ach. (Lecidea) 354 saxicola Ach. (Lecanora) 263 saxicola Hook. (Squamaria) 263 saxicolum S. F. Gray (Placodium) 263 saxicolus Poll. (Lichen) 263 scaber Huds. (Lichen) 35, 123 scabrata Nyl. (Usnea) 180 scabriuscula Del. (Cenomyce) 449 scabriuscula Nyl. (Cladonia) 448 scabrosa Cromb. (Cladonia var.) 464 scabrosa Th. Fr. (Peltigera) 95 scabrosa Ach. (Usnea var.) 177 Schareri Cromb. (Collemopsis) 41 Schareri Massal. (Pannaria) 41 Schæreri Arn. (Psorotichia) 41 Schareri Nyl. (Pyrenopsis) 41 SCHASIIARIA S. F. Gray 413 SCHIZOMA Nyl. 27, 32

Schraderi Ach. (Collema) 73 Schraderi Nyl. (Collemodium) 73 Schraderi Nyl. (Leptogium) 73 Schraderi Bernh. (Lichen) 73 Schraderi S. F. Gray (Polychid.) 73 scolecinus Ach. (Bcomyces) 463 scopulare Oliv. (Placodium) 203 scopularis Nyl. (Lecanora) 203 scopulorum Retz. (Lichen) 173 scopulorum Ach. (Ramalina) 173 scortea Ach. (Parmelia) 191 scorteus Ach. (Lichen) 131 scoticum Nyl. (Spilonoma) 34 scotinum Fr. (Leptogium) 75 scotinus Acb. (Lichen) 75 scotoplaca Nyl. (Lecanora) 226 scrobiculata DC. (Lobaria) 112 scrobiculata Nyl. (Lobarina) 113 scrobiculata Ach. (Sticta) 113 scrobiculata Nyl. (Stictina) 113 
scrobiculatus Scop. (Lichen) 112 scruposa Sommerf. (Lecanora) 382 scruposa Ach. (Urceolaria) 382 scruposus Norm. (Diploschistes) 382 scruposus Schreb. (Lichen) 382 scutata Ach. (Peltidea) 95 scutata Koerb. (Peltigera) 94 scutatus Dicks. (Lichen) 95 scutelliforme Ach. (Thelotrema var.) 379

SCYPHOPHORUAI Neck. 413 SCYTENIUMS S. F. Gray 65 SCYTONEMIA $x$ sepincola Ach. (Cetraria) 153 sepincola Dicks. (Lichen) 153 sepincola Ehrh. (Lichen) 153 septata Leight. (Sphinctrina) 19 septata Rehm (Stenocybe) 19 septatum Leight. (Calicium) 20 sessile Pers. (Calicintm) 3, 22 Siebenhaariana Koerb.(Biatora) 226 siliquosa A. L. Sm. (Ramalina) 172 siliquosus Huds. (Lichen) 173 simplex Wain. (Cladonia var.) 430 simplex Nyl. (Lecanora) 475 simplex Hook. (Lecidea) 474 simplex Roth (Lichen) 426 simplex Dav. (Lichen) 474 simplex Sm. (Lichen) 474 sincerior B. de Lesd. (Lecania var.) 348

sinopicum Wahlenb. (Endocarpon) 337 sinopicus Sm. (Lichen) 324, 337 sinuatum Hoffm. (Collema) 74 sinuatum S. F. Gray (Lathagrium) 74 sinuatum Massal. (Leptogium) 74,488 sinuatus Huds. (Lichen) 74 sinuosa Ach. (Parmelia) 141 sinuosus Sm. (Lichen) 141 smaragdocarpa Nyl. (Lecanora var.) 299

smaragdula MIassal. (Acaros.) 336, 339 smaragdula Nyl. (Lecanora) 337 smaragdula Knowles (Lecidea var.) 470

smaragdulum Wablenb. (Endocarpon) 337

smaragdulus Sm. (Lichen) 337 SOLORINA Ach. 90, 103 sophodes Ach. (Lecanora) 250 sophodes Ach. (Lichen) 250 sophodes Th. Fr. (Rinodina) 250 sordida Th. Fr. (Lecanora) 283 sordidus Pers. (Lichen) 283

Soredia xiii sorediata Th. Fr. (Parmelia) 148 spadicea Ach. (Cornicularia) 159 sparassa Ach. (Cenomyce) 452 sparassa S. F. Gray (Schasmaria) 452 sparassus Ach. (Bceomyces) 452 sparassus Sm. (Lichen) 452 speciosa Mudd (Borrera) 234 speciosa Cromb. (Cladonia) 452 speciosa Ach. (Parmelia) 234 speciosa Nyl. (Physcia) 234 speciosus Sm. (Lichen) 234 speciosus Wulf. (Lichen) 234 Spermogones xvii sphærocephalum Wahlenb. (Calic.) 14 spharocephalum S. F. Gray (Phacotrum) 15

spharocephalus Web. (Lichen) 15 sphcerocephalus L. (Mucor) 15 SPHAROPHORACEAE 2, 22 SPHZROPHORON Ach. 22 SPH ÆROPHORUS Pers. 22 sphincterica Sowerb. (Spharia) 3 SPHINCTRINA Fr. 2 spilomanthodes Nyl. (Pertusaria) 368 SPILONEMIA Bornet 33 spinosus Huds. (Lichen) 447 spodochroa Ach. (Gyropiora) 400 spodochrous Ehrh. (Lichen) 400 spodomela A. L. Sm. (Lecanora) 346 spodomela $\mathrm{Nyl}$. (Lecanora) 346 spodophæa Ach. (Lecanora) 308 spodophcea Wablenb. (Parmelia) 308 spodophæiza A. L. Sm. (Lecania) 343 spodophceiza Nyl. (Lecanora) 343 spodophceoides Nyl. (Lecanora) 274 spongiosa Carroll (Solorina) 105 spongiosum Ach. (Collema) 105 spongiosum S. F. Gray (Polychid.) 105 spongiosus Sm. (Lichen) 105 spuria Hook. (Peltidea) 92 spuria DC. (Peltigera) 92 spurius Ach. (Lichen) 92 SQUAMARIA DC. 259 squamosa Hoffm. (Cladonia) 437, $449,451,454$ squamulosa Th. Fr. (Acarospora) 333 squamulosa Tayl. (Lecanora) 305 squamulosa Nyl. (Lecanora) 333 squamulosa Hook. (Lecanora) 336 
squamulosis Schrad. (Lichien) 333 squamulosus Sm. (Lichen) 336 stellaris Mudd (Borrera) 240 stellaris Huds. (Lichen) 235, 239 stellaris L. (Lichen) 238 stellaris Lightf. (Lichen) 240 stellaris Ach. (Parmelia) 238 stellaris Tayl. (Parmelia) 240 stellaris Nyl. (Physcia) 238 stellaris Cromb. (Physcia) 240 stellata Schær. (Cladonia) 418 stemoneum Ach. (Calicium var.) 8 STENOCYBE Nyl. 19 stenophylla Ach. (Parmelia var.) 140 stenotropa Nyl. (Lecanora) 303 STEREOCAULON Schreb. 402, 407 STICTA Schreb. 106

STICTACE RE 26, 106

Stictarum (Celidium) 116

Stictina Nyl. 106

stictoceros Sm. (Lichen) 163

stigonella Fr. (Trachylia) 22

stigonellum S. F. Gray (Acolium) 3 stigonellum Mudd (Acolium) 22 stigonellum Ach. (Calicium) 3,22 stigonellum Zahlbr. (Cyphelium) 22 STIGONEMA $\mathrm{x}$

stilicidionum Hornem. (Lichen) 212 stilicidion $\mathrm{S}$. F. Gray (Rinodina) 212

stipitata Branth (Gyrophora) 489 stipitata Nyl. (Umbilicaria) 489 strepsilis Ach. (Baomyces) 425 strepsilis Wain. (Cladonia) 425 strepsilis Ach. (Ramalina var.) 176 striatula Wablenb. (Verrucaria) 482 STRONGYLIUM S. E. Gray 4 strumaticus Nyl. (Pilophorus) 407 stygia Ach. (Parmelia) 125

stygia (Parmelia) 145

stygium Del. (Collema) 60

stygius L. (Lichen) 125

styracella Cromb. (Cladonia f.) 463 subalbella Nyl. (Lecanora) 282 subarenaria A. L. Sm. (Rinodina) 255 subareolata Nyl. (Pyrenopsis) 39 subaurifera Nyl. (Parmolia) 128 subcana Nyl. (Alectoria subsp.) 187 subcarnea Ach. (Lecanora) 286 subcamea Hook. (Lecidea) 286 subcarneus Swartz (Lichen) 286 subcinerea Nyl. (Lecanora) 324 subcircinata Nyl. (Lecanora) 265 subcornata Nyl. (Cladonia var.) 465 subcornuta Nyl. (Cladonia var.) 432 subdepressa Nyl. (Lecanora) 325 subdetersa Nyl. (Physcia) 246 subexigua Nyl. (Lecanora) 253 subexigua Oliv. (Rinodina) 253 subfarinacea Nyl. (Ramalina) 175 subfloridana Stirt. (Usnea) 178 subfusca Ach. (Lecanora) 267 subfiscus Huds. (Lichen) 270 subfuscus L. (Lichen) 267 subimbricata A.L.Sm. (Lecanora) 265 subimbricatus Relh. (Lichen) 265 subintricata Th. Fr. (Lecanora) 295 sublactea Leight. (Pertusaria) 362 sublurida Nyl, (Lecidea) 341 sublurida Mudd (Thalloidima) 341 sublurida Stirt. (Usnea) 178 subluta Nyl. (Lecanora) 288 sublivescens A. L. Sm. (Lecanora) 292 subobscura A. L. Sm. (Physcia subsp.) 242

subpectinata Stirt. (Usnea) 178 subplicatile Nyl. (Collema) 55 subrimulata Nyl. (Verrucaria) 483 subsanguinaria (Lecidea subsp.) 471 subsquamosa Nyl.i(Cladonia) 453, 455 subsquamulosus Nyl. (Bæomyces var.) 404

subtartarea Nyl. (Lecan. subsp.) 311 subtile Pers. (Calicium) 18 subtile Ach. (Collema) 71 subtile Nyl. (Leptogium) 71 subtile S. F. Gray (Polychidium) 71 subtile Tuck. (Thelotrema) 380 subtilis Schrad. (Lichen) 71 subtomentellum Nyl. (Nephr. var.) 101 subulata Wigg. (Cladonia) 446 subulatus L. (Lichen) 432 subulatus Huds. (Lichen) 446 sulcata Tayl. (Parmelia) 133 sulphurea Nyl. (Coniocybe) 11 sulphurea Ach. (Lecanora) 300 sulpluurea Wablenb. (Lecidea) 300 sulphurea Schær. (Pertus.) 373, 376 sulplucerclla Fr. (Coniocybe f.) 11 sulphureum Tayl. (Endocarpon) 376 sulphureus Retz. (Lichen) 11 sulphureus Hoffm. (Lichen) 300 Swartzii Ach. (Lichen) 285 
sylvatica Nyl. (Cladina) 415

sylvatica Hoffm. (Cladonia) 415, 449 sylvatica Ach. (Sticta) 107 sylvatica Nyl. Stictina) 108 sylvaticus Huds. (Lichen) 108 Symbiosis xviii

symmicta Ach. (Lecanora) 293, 298 symmictera Nyl. (Lecanora) 293

sympagea Nyl. (Lecanora var.) 199 sympageus Ach. (Lichen) 199 symphorea Nyl. (Synalissa) 40 symphoreum DC. (Collema) 60 SYNALISSA Fr. 40 synalissum Ach. (Collema) 40 syncarpa Mudd (Pertusaria) 369 SYNECHOBLASTUS Trev. 46, 59 syringea Th. Fr. (Lecania) 340,350 syringea Lamy (Lecanora) 350

tartarea Ach. (Lecanora) 309, 377 tartarea S. F. Gray (Rinodina) 309 tartareus L. (Lichen) 309 tasmanica (Pyrenopsis) 39 tauricus Wulf. (Lichen) 189 tegularis Nyl. (Lecanora subsp.) 202 tegularis Ehrh. (Lichen) 202 teichophila Nyl. (Lecanora) 256 teichophila Jatta (Rinodina) 256 TELOSCHISTES Norm. 190 tenax Sm. (Collema) 51 tenax S. F. Gray (Enchylium) 51 tenax Swartz (Lichen) 51 tenella Ach. (Borrera) 241 tenella Ach. (Parmelia) 241 tenellus Scop. (Lichen) 241 tenuissimum Ach. (Collema) 70 tenuissimum Koerb. (Leptogium) 70 tenuisimum S. F. Gray (Polychid.) 70 tenuissimus Dicks. (Lichen) 70 terebrata Hoffm. (Lobaria) 122 terrestre Wats. (Thelidium) 483 terricola Tayl. (Variolaria) 356, 405 terrulentum Nyl. (Collema) 48 tesselatus Sm. (Lichen) 318 tetrasporım Th. Fr. (Leptogium) 70 tetrasticha Nyl. (Lecanora) 220 tetrastichum A. L. Sm. (Placodium) 220

THAMNOLIA Ach. 188 THELIDIUM Massal. 482 THELOCARPACEA 388 'THELO'TREMA Ach. 378
THELOTREMACEAE 26, 378 THERIIUTIS Fr. 28

Thouarsii Del. (Sticta) 110 thrausta Ach. (Alectoria) 184 thrausta Nyl. (Ramalina) 184 tigillare S. F. Gray (Acolium) 21 tigillare Turn. \& Borr. (Calicium) 21

tigillare Ach. (Cyphelium) 20 tigillaris Ach. (Lichen) 21 tigillaris Fr. (Trachylia) 21 tiliacea Ach. (Parmelia) 130 tiliaceus Hoffm. (Lichen) 130 tinctoria DC. (Roccella) 479 tinctoria Hook. (Roccella) 479 tomentosa Hoffm. (Peltigera) 100 tomentosum Nyl. (Nephromium) 100 tomentosum Fr. (Stereocaulon) 413 tomentosus Swartz (Lichen) 100 tomata Ach. (Gyrophora) 396 torquata Nyl. (Lecanora) 308 torquata Fr. (Parmelia) 308 torrefacta Cromb. (Gyrophora) 398 torrefactus Lightf. (Lichen) - 398 trabalis Nyl. (Lecanora) 294 trabinella A. L. Sm. (Chænotbeca) 6 trabinellum S. F. Gray (Phacotrum) 6 trabinellus Sm. (Lichen) 6 trachelinum Ach. (Calicium) 14 TRACHYLIA Fr. 20 trachyna Nyl. (Cladonia subsp.) 437 trachymus Ach. (Baomyces) 437 trachyopum 'Tayl. (Collema) 31, 41 trajecta Nyl. (Stenocybe) 19 trajectum Nyl. (Calicium) 19 Tremella Roth (Lichen) 75 tremelloides Ach. (Collema) 78 tremelloides S. F. Gray (Leptogium) 78 tremelloides Lightf. (Lichen) 75 tremelloides Linn. fil. (Lichen) 78 TRENTEPOHLIA $\mathrm{x}$ tribacia Ach. (Lecanora) 246 tribacia Nyl. (Physcia) 245 tribacia Hook. (Squamaria) 245 tribacium S. F. Gray (Psoroma) 246 tribacoides Nyl. (Physcia) 246 trichiale Ach. (Calicium) 7 trichiale de Not. (Cyphelium) 7 trichialis Th. Fr. (Chænotheca) 7 triptoplyylla Nyl. (Pannaria) 81 triptophylla Stiz. (Pannularia) 81 
triptophyllum S. F. Gray (Lepidoma) 81

triseptata Nyl. (Pannularia) 32

triste Koerb. (Calicium) 18

triste Nyl. (Platysma) 124

tristis Hoffm. (Cornicularia) 124

tristis Web. (Lichen) 124

TRYPETHELTACEAE 388

tubaformis Cromb. (Cladonia var.) 430

tubæformis Massal. (Sphinctrina) 3

tuberculosa Hook. (Lecanora) 321

tuberculosa S. F. Gray (Rinodina) 321

tuberculosus Sm. (Lichen) 321

tubiformis Lightf. (Lichen) 462

tubulosa Mudd (Parmelia var.) 120

tumescens Tayl. (Parmelia var.) 86

tunaformis Ach. (Lichen) 59

turbinata Fr. (Sphinctrina) 3, 365

turbinatum Pers. (Calicium) 3

turgida Hoffm. (Cladonia) 444

turgidum Ach. (Collema) 67

turgidum Nyl. (Collemodium) 67

turgidum S. F. Gray (Enchylium) 67

turgidum Cromb. (Leptogium) 66, 488

turgidus Ehrh. (Lichen) 444

Turneri Ach. (Lecanora) 313

Turneri Sm. (Lichen) 313

Turneri S. F. Gray (Rinodina) 313

Turneriana Nyl. (Lecanora) 227

Turneriana Ach. (Lecidea) 227

Turnerianum A. L. Sm. (Placodium) 226

tympanella Fr. (Trachylia) 21

tympanellum S. F. Gray (Acolium) 21

tympanellum Ach. (Calicium) 21

Ulmi Sm. (Lichen) 467

ulmicola Borr. (Lecidea) 223

ulmicola DC. (Patellaria) 223

ulophyllum Nyl. (Platysma) 153

ulothrix Ach. (Lichen) 247

ulothrix Ach. (Parmolia) 247

ulothrix Nyl. (Physcia) 247

UMBILICARIA Hoffm. 388, 401

umbraticula A. L. Sm. (Lecania) 349

umbraticula Nyl. (Lecanora) 349

umbrina Massal. (Locanora) 279, 281

umbrinofusca Nyl. (Lecanora) 257

umbrinofusca Oliv. (Rinodina) 257

ambrinus Ehrh. (Lichen) 279 uncialis Ach. (Cenomyce) 418 uncialis Nyl. (Cladina) 418 uncialis Web. (Cladonia) 418, 422 uncialis L. (Lichen) 418, 419 upsaliensis Nyl. (Lecanora) 314 upsaliensis Dicks. (Lichen) 311 upsaliensis L. (Lichen) 314 urbana Nyl. (Lecanora) 289 URCEOLARIA Ach. 381 urceolaria Nyl. (Pertusaria) 368 USNEA Dill.

Usnea barbata, loris, etc. Dill. 181 Usnea cospitosa exilis, etc. Dill. 123 Usnea capillacea citrina, etc. Dill. 191 Usnea capill. et nod. Dill. 182 Usnea lance nigre, etc. Dill. 186 Usnea loris longis, etc. Dill. 184 Usnea jubata nigricans Dill. 187 Usnea rigida horsum, etc. Dill. 188 Usnea vulgaris loris, etc. Dill. 180 Usnea vulgatissima, etc. Dill. 178, 179 USNEACEAE 26,161 ustulatus Ehrh. (Lichen) 392

varia Ach. (Lecanora) 290 varia Hoffm. (Patellaria) 291 varia S. F. Gray (Rinodina) 291 variabile Nyl. (Placodium) 215 variabilis Ach. (Lecanora) 215 variabilis Pers. (Lichen) 215 varians Nyl. (Arthonia) 283 VARICELLARIA 356,377 varius Ehrb. (Lichen) 291 velata Turn. (Parmelia) 359 velata Nyl. (Pertusaria) 359 velata Ach. (Variolaria) 359 vellea Ach. (Gyrophora) 400 velleus Huds. (Lichen) 399, 400 volutina Th. Fr. (Thermutis) 23 velutinum Nyl. (Gonionema) 28 velutinum S. F. Gray (Polychi.) 28 velutinus Ach. (Lichen) 28 venosa Ach. (Peltidea) 99 venosa Hoffm. (Poltigera) 99 venosus L. (Lichen) 99 ventosa Acb. (Lecanora) 353 ventosa S. F. Gray (Rinodina) 953 voutosum Massal. (Hæmatomma) 353 ventosus L. (Lichen) 353 ventricosus Huds. (Lichen) 461 venusta Ach. (Parmelia) 237 vermicularis Ach. (Cenomyce) 189 
vermicularis S. F. Gray (Cerania) 189 vermicularis DC. (Cladonia) 189 vermicularis Swartz (Lichen) 189 vermicularis Schær. (Thamnolia) 189 vernalis Ach. (Lecidea) 469 vernalis Lightf. (Lichen) 221 VERRUCARIA Pers. 482 VERRUCARIACE AE 388, 482 verrucosa Koerb. (Aspicilia) 320 verrucosa Laur. (Lecanora) 320, 468 verrucosa Ach. (Urceolaria) 320 verrucosus Huds. (Lichen) 113 verruculosa Mudd (Buellia) 316 versicolor Pers. (Lichen) 264 verticillata Floerk. (Cladonia) 439 verticillata S. F. Gray (Scyplio.) 440 vespertilio Lightf. (Lichen) 62 vesita Leight. (Cladonia) 460 villosa Linds. (Physcia var.) 192 virella Ach. (Parmelia) 248 virellus Ach. (Lichen) 248 virescens Huds. (Clatirus) 10 viride Pers. (Calicium) 14 viridiflavescens Wulf. (Lichen) 224 viridula Ach. (Verrucaria) 318 vitellina Müll.Arg. (Candelariella) 228

vitellina Ach. (Lecanora) 228 vitellina Hofim. (Patellaria) 228 vitellinellum Mudd (Callopisma) 229 vitellinula Nyl. (Lecanora) 221 vitellinulum A. I. Sm. (Placodium) 221

vitellinus Ehrh. (Lichen) 228 vitiligo Ach. (Spiloma) 361 vitiligo Turn. \& Borr. (Variolaria) 356,361

vittata Nyl. (Parmelia) 121 vulgaris Thwaites (Synalissa) 40 vulpinus Huds. (Lichen) 191 Westringii Ach. (Lichen) 368 Westringii Leight. (Pertusaria) 368 Westringii Ach. (Isidium) 368 Wulfenii DC. (Pertusaria) 374, 376 xantholyta Nyl. (Lecanora) 205 xantholytum Nyl. (Placodium) 204 xanthomyela Nyl. (Parmelia) 139 XANTHORIA Th. Fr. 192 xanthostigma Cromb. (Lecanora) 229 xanthostoma Fr. (Pertusaria) 372 xanthostoma Sommerf. (Porina) 372 xylonellum Ach. (Calicium) 15 zonata Ach. (Sagedia) 322 Zosterce Nyl. (Lecanora) 278 Zwackhii Hepp (Thelidium) 483 


\section{INDEX OF PLATES}

Bæomyces roseus Pers. 64

Calicium quercinum Pers. 4

Candelaria concolor Wain. 37

Candelariella vitellina Müll.-Arg. 48

Cerania vermicularis S. F. Gray 44

Cetraria glauca Ach. 39

Chænotheca trabinella A. L. Sm. 2

Cladonia coccifera Willd. 68

Collema granuliferum Nyl. 24

Coniocybe furfuracea Ach. 3

Crocynia gossypina Nyl. 61

Crocynia lanuginosa Hue 61

Cyphelium inquinans Trev. 6

Diploschistes scruposus Norm. 60

Dirina repanda Nyl. 69

Ephebe lanata Wain. 15

Ephebeia hispidula Nyl. 16

Euopsis pulvinata Wain. 17

Evernia prunastri Ach. 40

Gomphillus calycioides Nyl. 65

Gyrophora proboscidea Ach. 62

Hæmatomma coccineum Koerb. 55

Icmadophila ericetorum A. Zahlbr. 54

Lecania syringea T'h. Fr. 53

Lecanora varia Ach. 51

Lemmopsis Arnoldiana A. Zahlbr. 26

Leptogidium dendriscum Nyl. 11

Loptogium sinuatum var. scotinum Koerb. 27

Lichina pygmæa Ag. 21

Lobaria pulmonaria Hoffm. 36

Massalongia carnosa Koerb. 30

Nophromium lusitanicum Nyl. 33

Parmelia caperata Ach. 38

Parmeliella plumbea Wain. 22
Pannaria rubiginosa Del. 29

Peltigera canina Willd. 32

Pertusaria pertusa Dalla Torre \& Sarnth. 56

Phlyotis agelæa Koerb. 59

Physcia stellaris var. aipolia Nyl. 49

Physma polyanthes Arn. 23

Pilophorus cereolus Stizenb. 66

Placodium murorum DC. 47

Placynthium nigrum S. F. Gray 12

Polychidium muscicolum S. F. Gray 10

Porocyphus areolatus Koerb. 8

Psoroma hypnorum S. F. Gray 31

Psorotichia Schæreri Arn. 20

Pterygium lismorense Cromb. 22

Pyrenidium actinellum Nyl. 71

Pyrenopsis phylliscella Nyl. 18

Ramalina fraxinea Ach. 41

Rinodina roboris Arn. 50

Roccella fuciformis DC. 70

Schizoma lichenodeum Nyl. 13

Solorina crocea Ach. 34

Sphærophorus globosus Wain. 7

Sphinctrina turbinata Fr. 1

Spilonema paradoxum Born. 14

Stenocybe septata Rehm 5

Stereocaulon coralloides Fr. 67

Sticta fuliginosa Ach. 35

Synalissa ramulosa Fr. 19

Synechoblastus nigrescens Anzi

Teloschistes flavicans Norm. 45

Thelotrema lepadinum Ach. 58

Thermutis volutina 'Th. Fr. 9

Umbilicaria pustulata Hoffm. 63

Usnea florida Web. 42

Varicellaria microsticta Nyl. 57

Xanthoria parietina Th. Fr. 46 


Plate 1
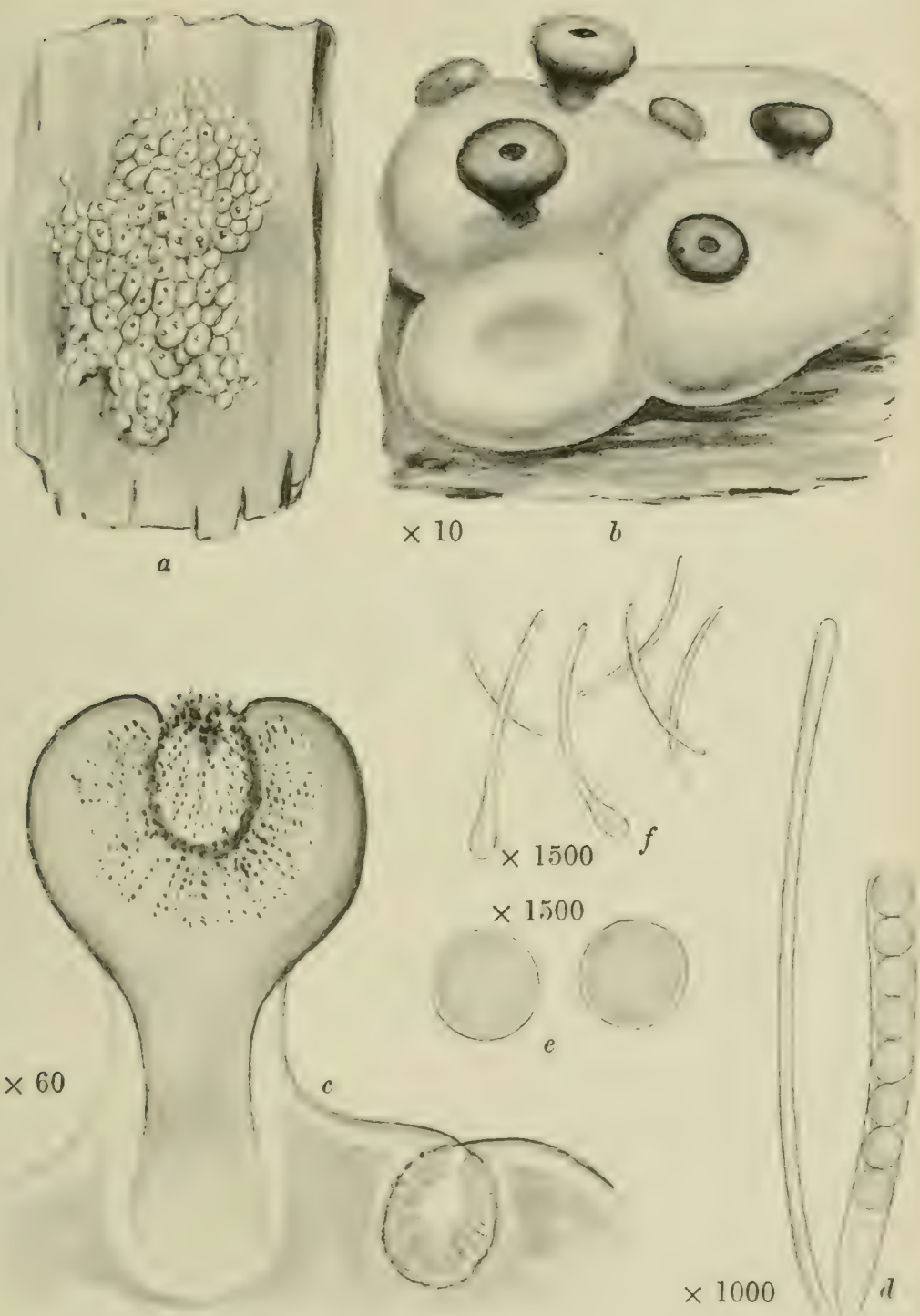

SPHINCTRINA TURBINATA Fr.

a. Plant on Pertusaria communis. b. Apothecia. c. Yertical section of apothecium and spermogone. $d$. Ascus and paraphysis. e. Ascospores. f. Spermatia. 

Plate 2
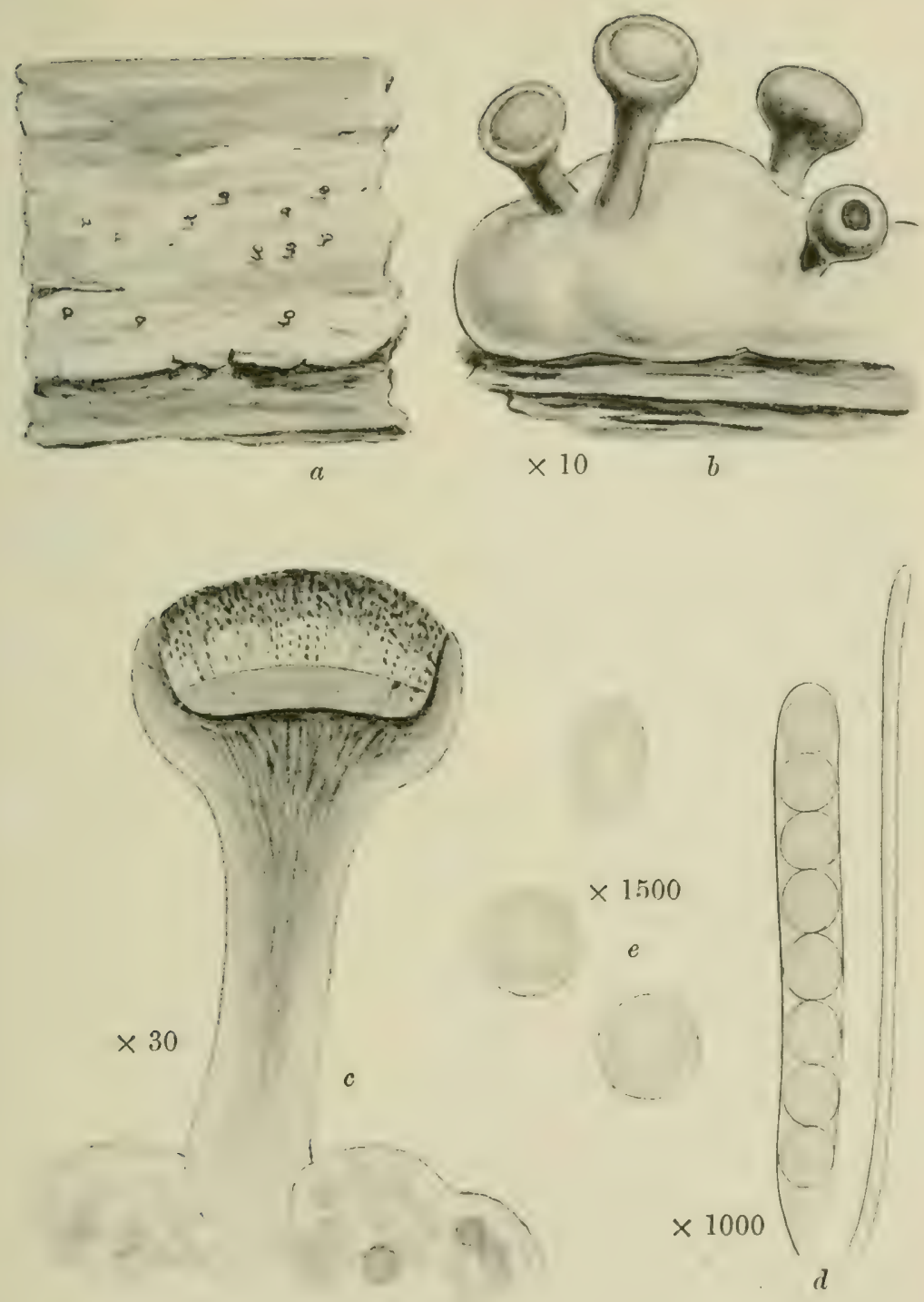

OHAENOTHECA TRABINELLA A. L. Sm.

a. Plant on wood. b. Portion of plant. c. Vertical section of apotherium. d. Ascus and paraphysis. e. Spores. 

Plate 3

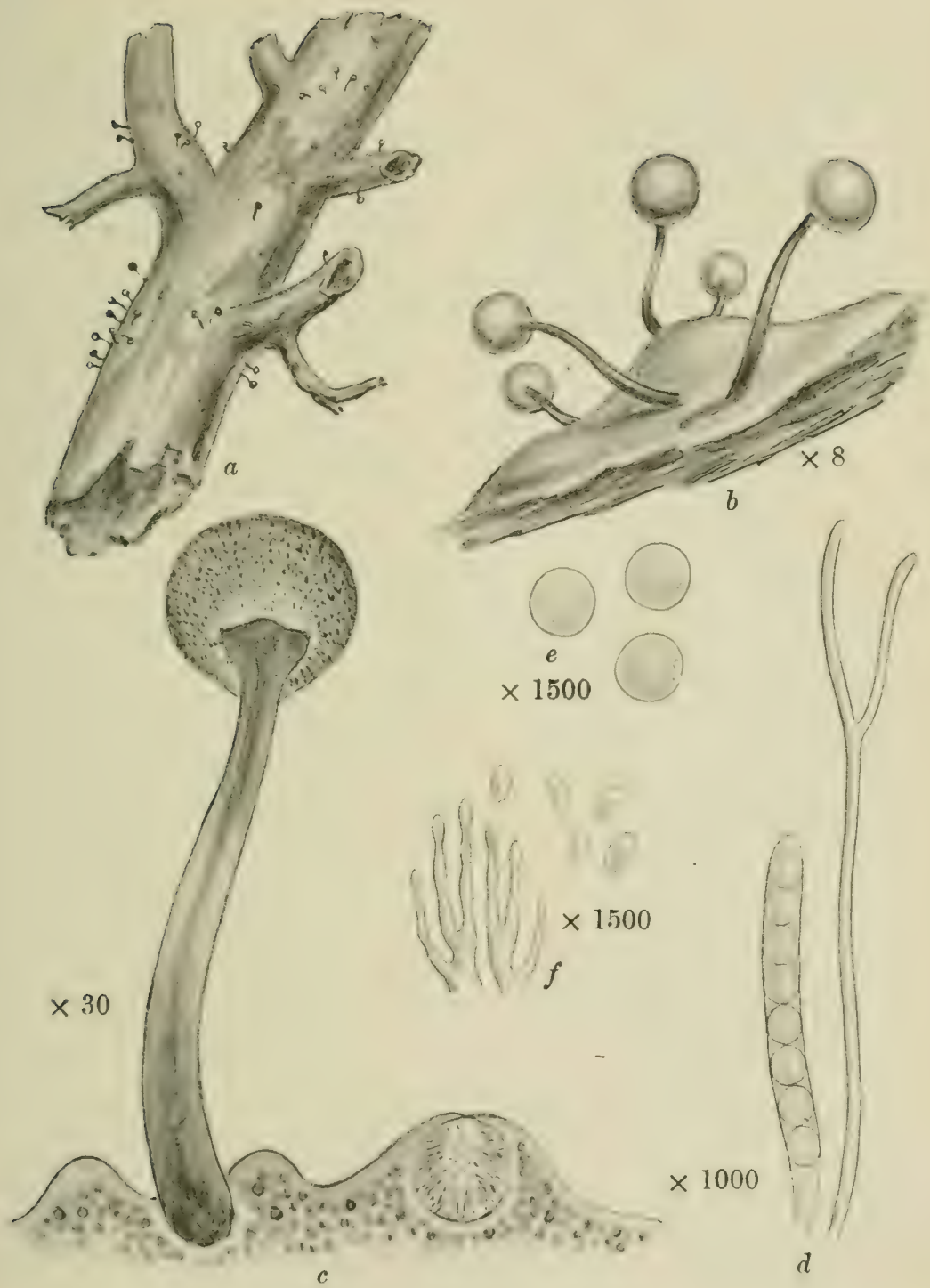

CONIOCYBE FURFURACEA Ach.

$a$. Plant on dead branch. b. Portion of plant. c. Vertical section of thallus, apothecium and spermogone. $d$. Ascus and paraphysis. c. Ascospores.

f. Sterigmatr and spermatia. 


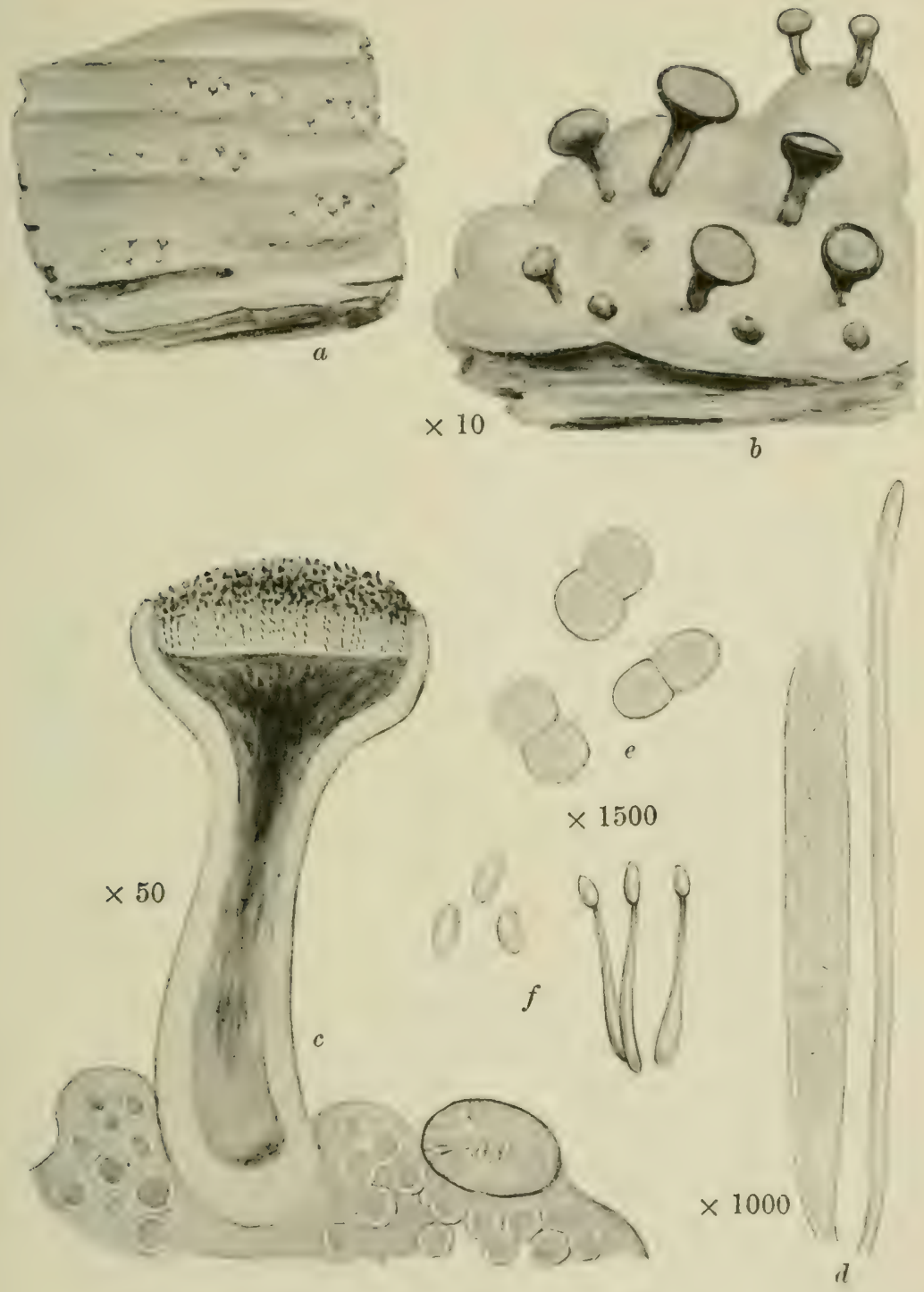

CALICIUM QUERCINUNI Pers.

a. Plant on old paling. b. Portion of plant. c. Vertical section of thallus, apothecium and spermogono. $d$. Ascus and paraphysis. e. Ascospores.

$f$. Sterigmata and spermatia. 

Plate 5
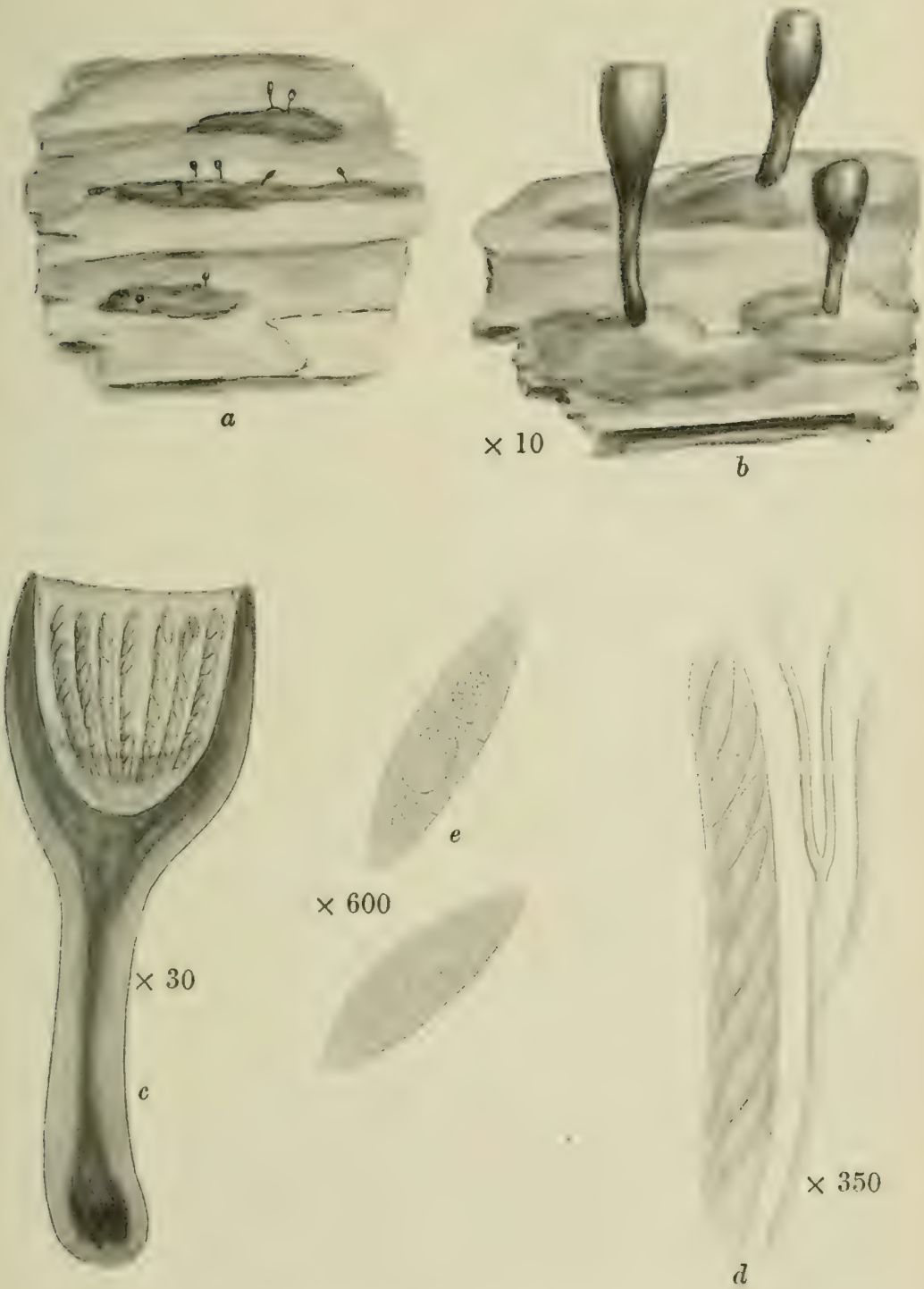

STENOCYBE SEPTATA Rehm.

a. Plant on bark. b. Portion of plant. c. Sertion of npothecium.

$d$. Ascus and paraphysis. $e$. Ascospores. 


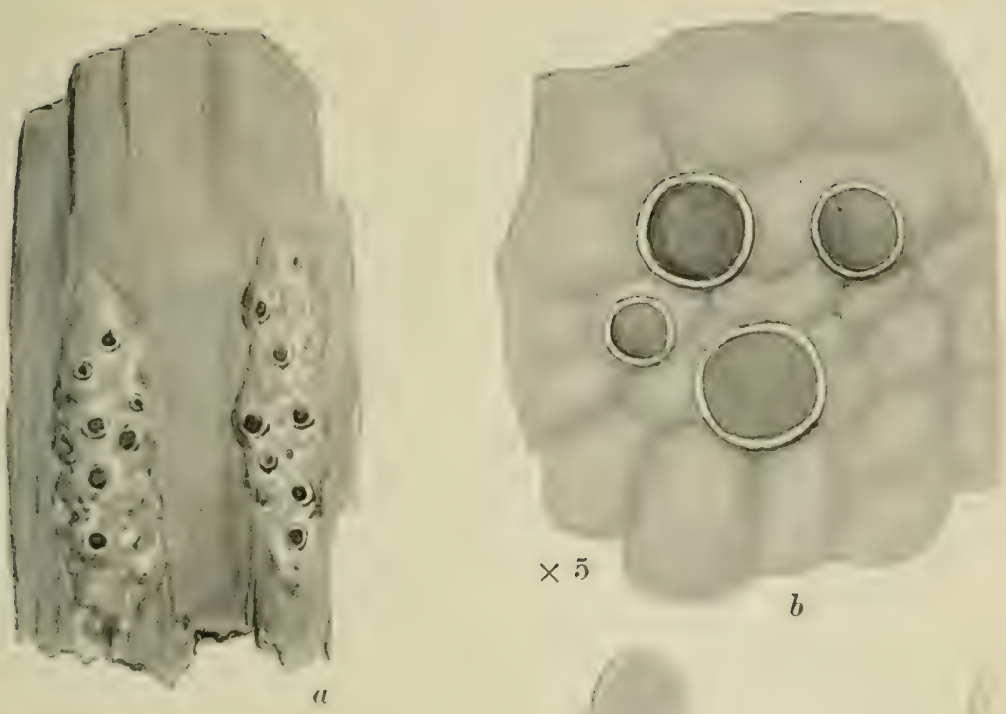

$\times 1500$

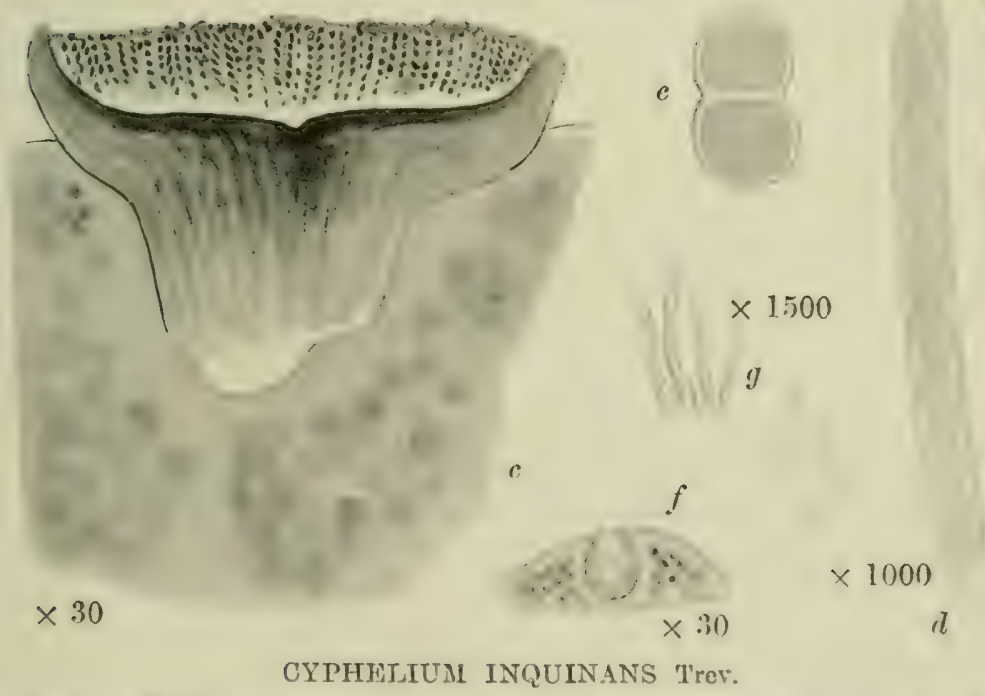

u. Plant on old wood. $b$. T'ortion of plant. c. Vertical section of thallus and apothecium. d. Ascus and paraphysis. e. Ascorpores. i. heetion of empty spermugone. g. Sterigmata and spermatia. 

Plate 7
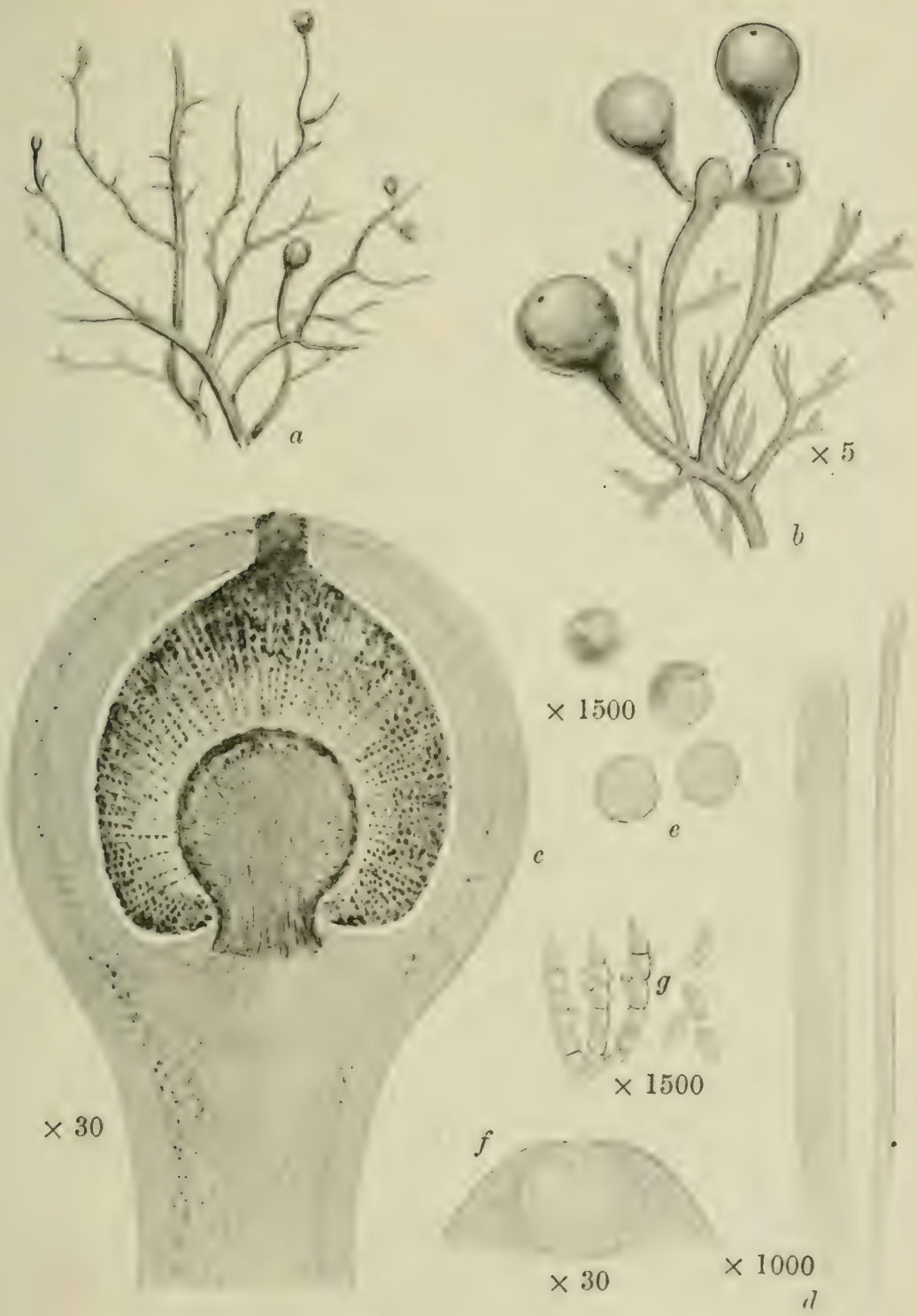

SPHAEROPHORUS GLOBOSUS A. L. Sm.

a. Plant. b. Portion of plant. c. Yertical section of apotbecium. d. Ascus: and paraphysis. e. Ascospores. f. Vertical section of spermogone. g. Sterigmata and spermatia. 


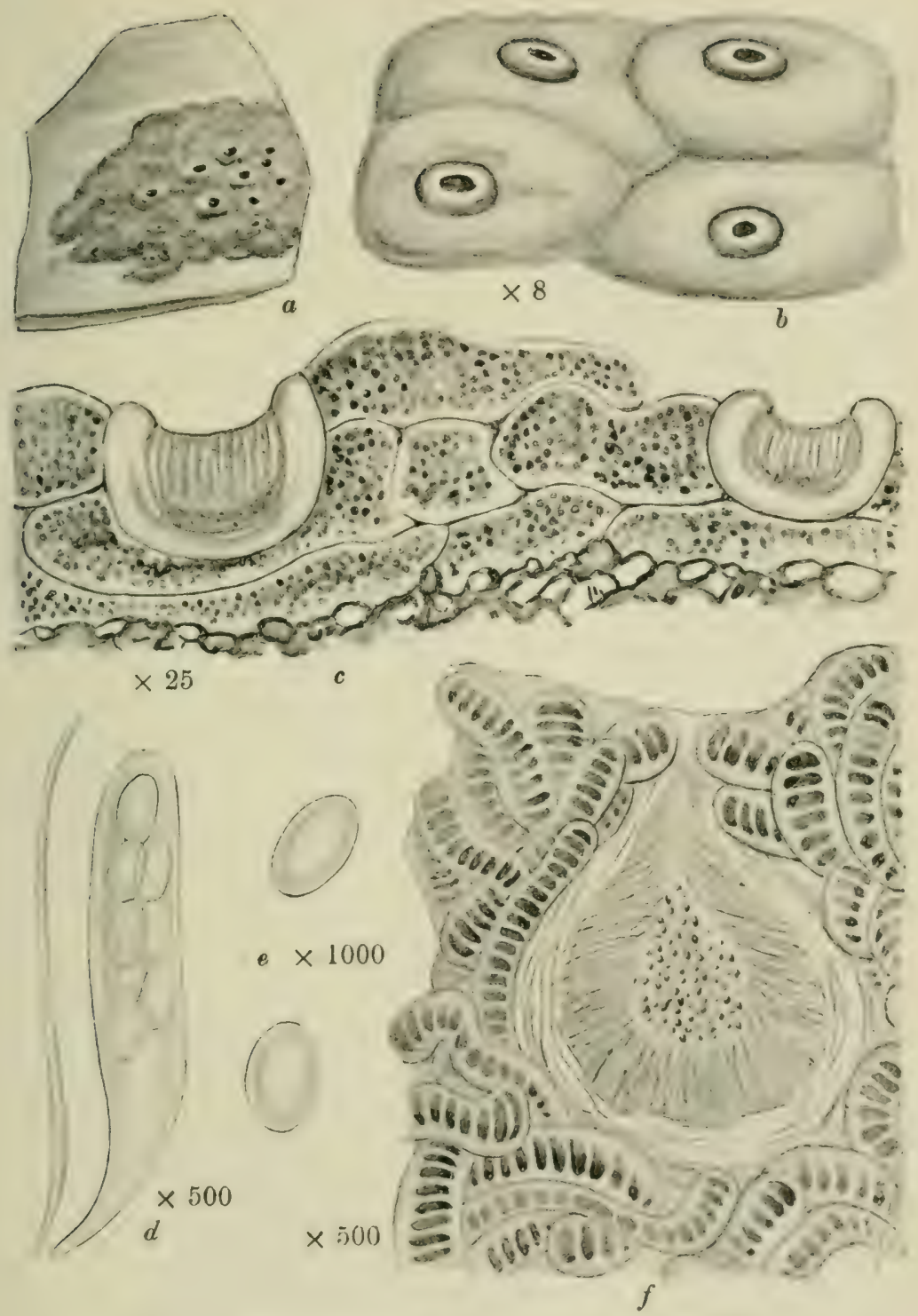

POROCYPHUS AREOLATUS Koerb.

a. Plant on rock. b. Portion of plant. c. Vertical section of thallus and apotbecia. $d$. Ascus and paraphysis. $e$. Spores. $f$. Vertical section of spermogone. 


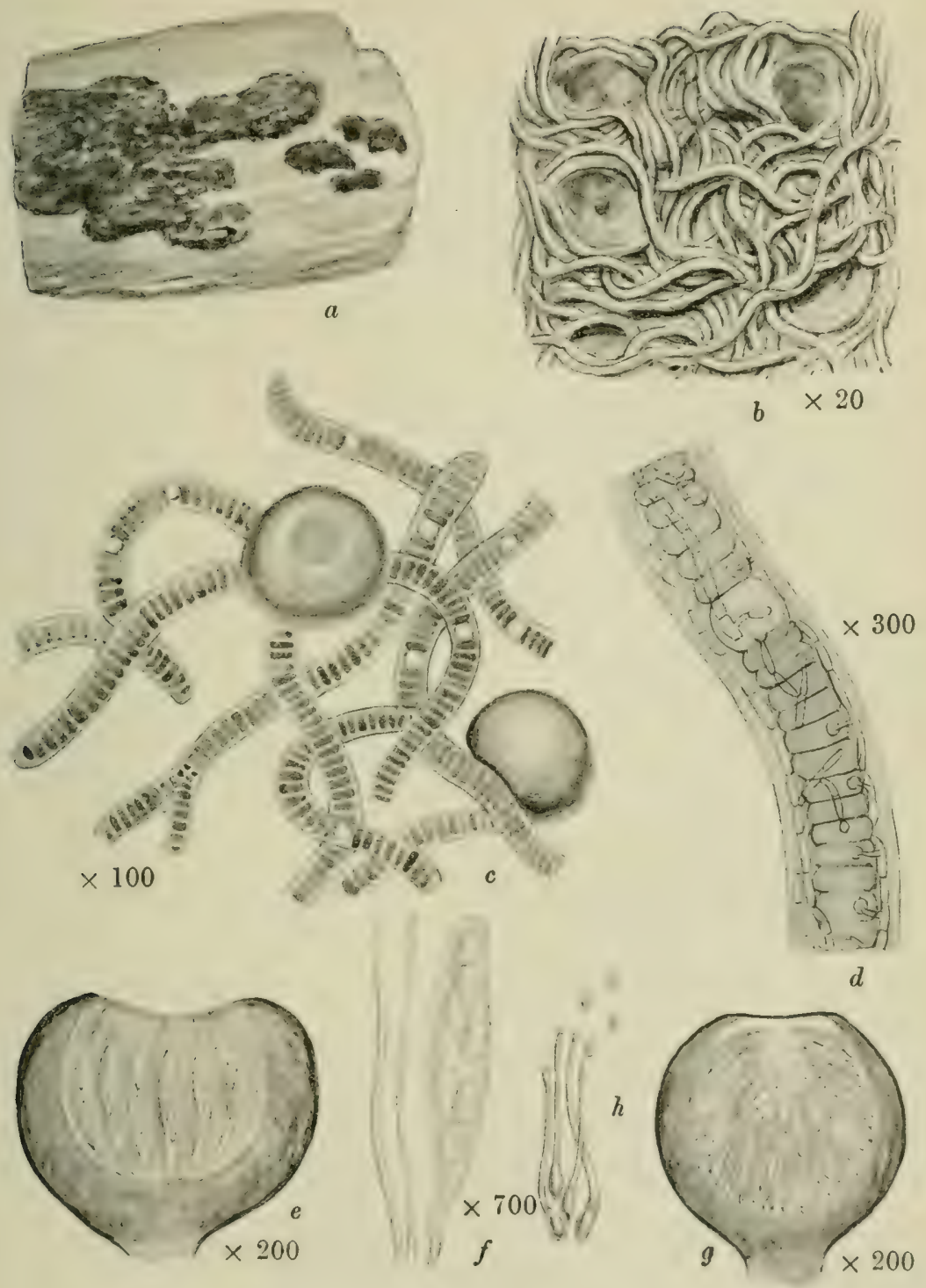

THERMUTIS VELUTINA Th. Fr.

$a$. Plant on rock. b. Portion of plant. $c$. Plant with apothecia. $d$. Portion of thallus. e. Vertical section of apothecium. f. Ascus and paraphyses. $g$. Vertical section of spermogone, $h$. Sterigmata and spermatia. 



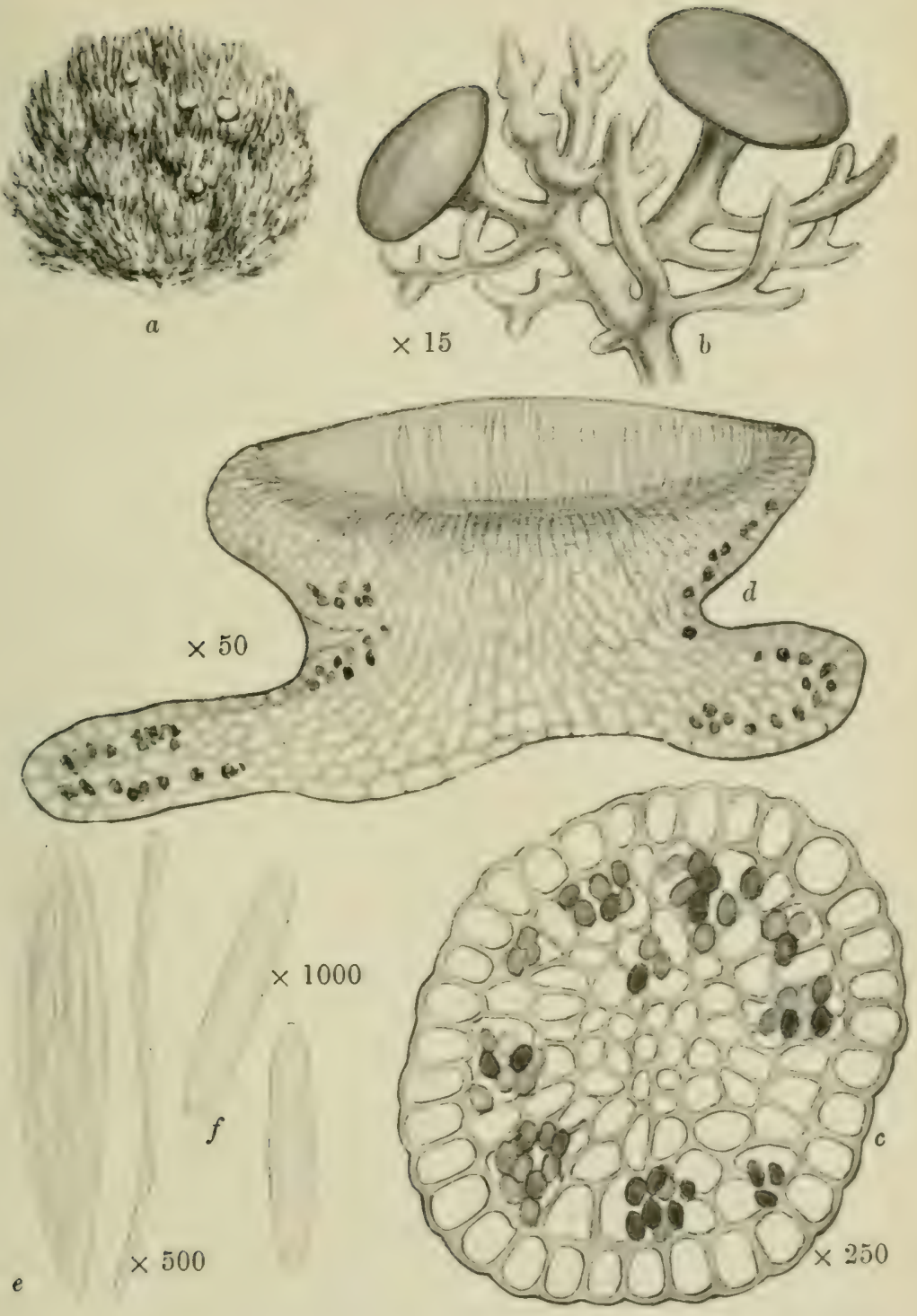

POLYCHIDIUA MUSCICOLUMI S. F. Gray.

C. Plant among mosses. b. Portion of Flant. c. Transverse section of thallus. $d$. Vertical section of apothecium. e. Ascus and paraphysis. f. Spores. 

Plate 11

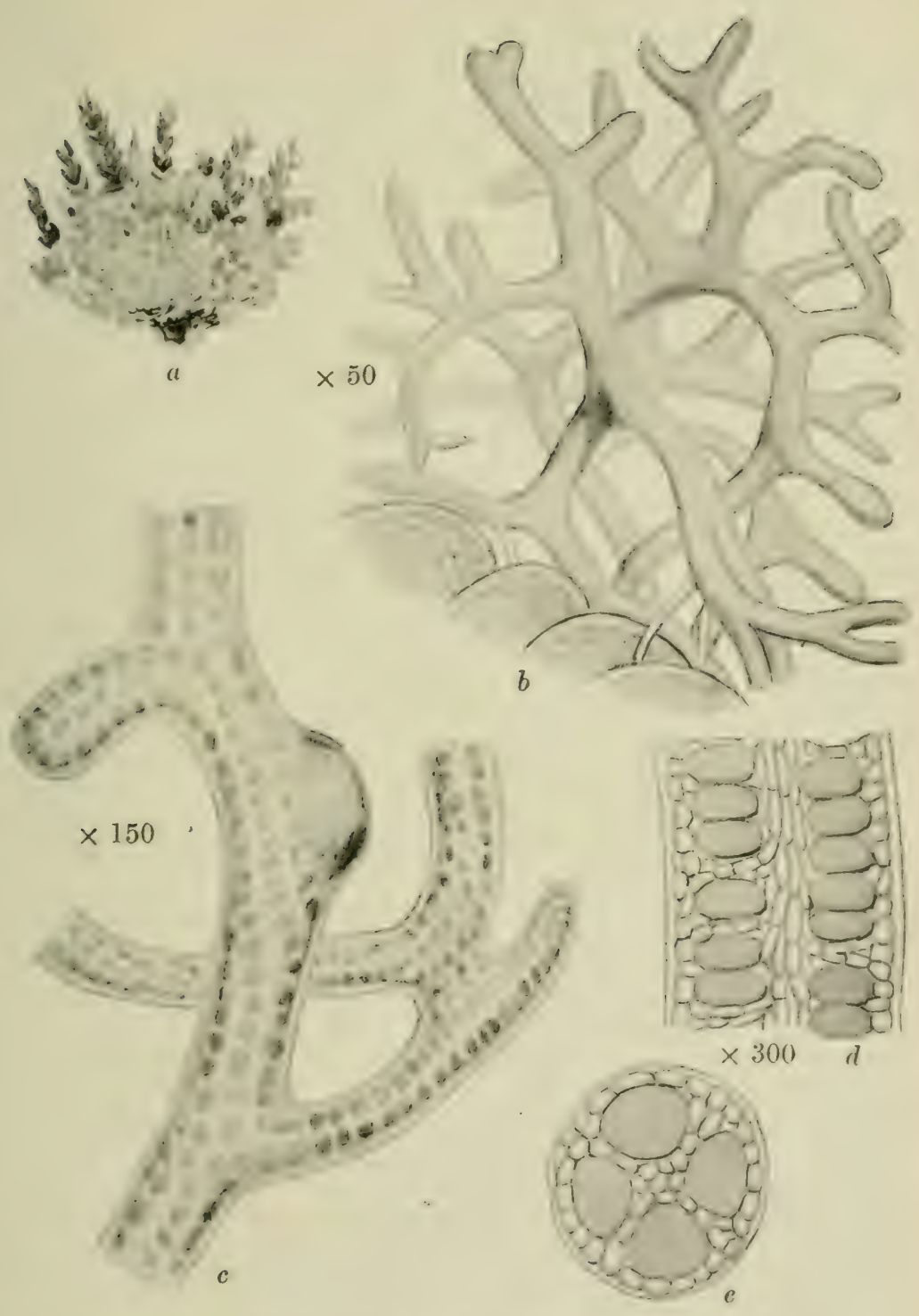

LEPTOGIDIUM DENDRISCUM Nyl.

a. Plant on moss. b. P'ortion of plant. c. Branching filament. d. 'Thallus in vertical section. $e$. Thallus in transverso section. 


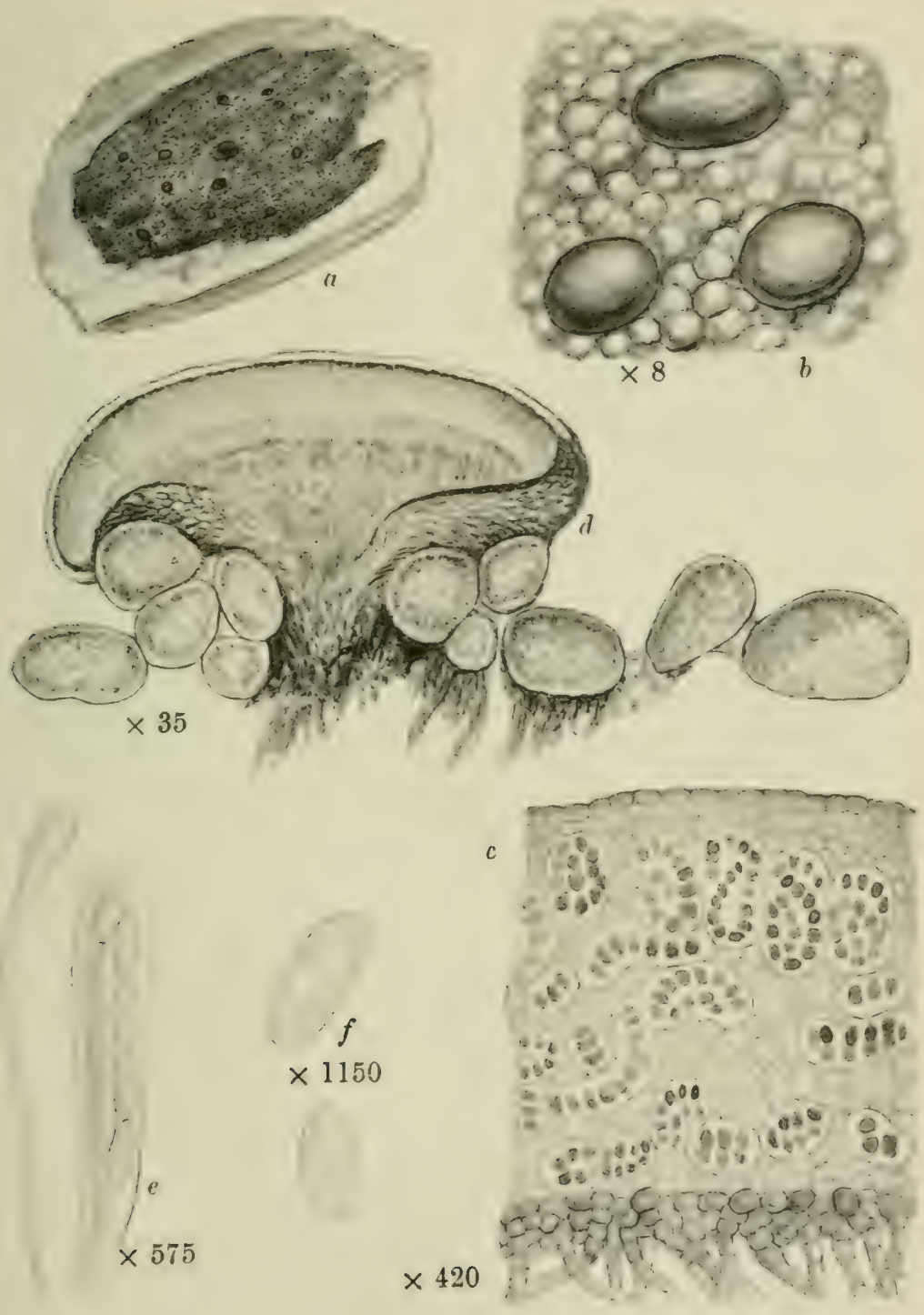

PLACYNTHIUM NIGRUM S. F. Gray.

a. Plant on rock. b. Portion of plant. c. Section of thallus. d. Vertical section of apothecium. e. Ascus and paraphysis, f. Spores. 


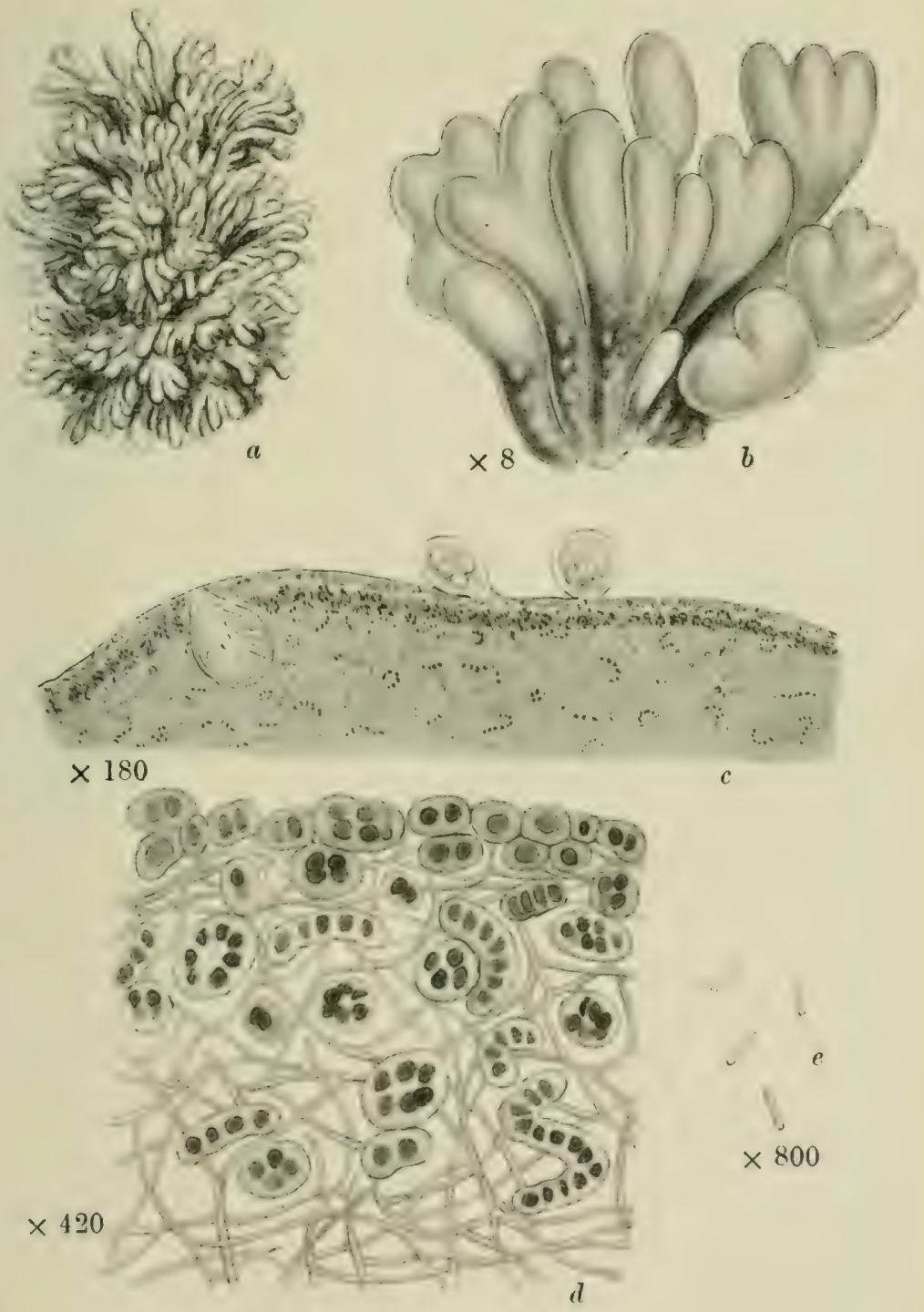

SCHIZOMA LICHENODEUM Nyl.

a. Plant on the ground. b. Portion of plant. c. Section of lobe and of spermogone. $d$. Section of tballus, e. Spormatia. 


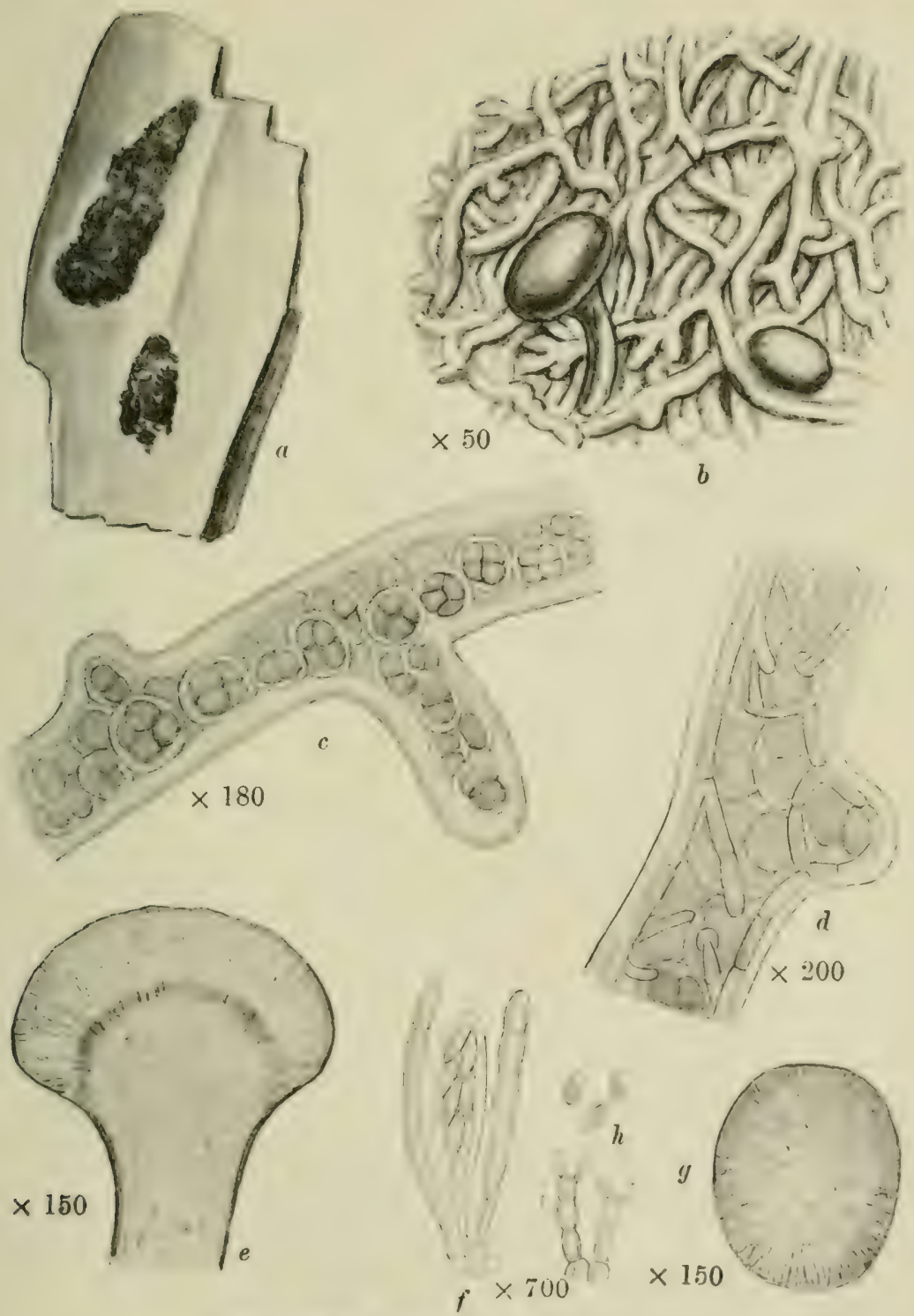

SPILONEMA PARADOXUM Born.

$a$. Plant on rock. b. Portion of plant. c. Portion of alga. $d$. Portion of thallus.

e. Vertical section of apothecium. f. Ascus and paraphyses. $g$. Section of spermogone. $h$. Sterigmata and spermatia. 



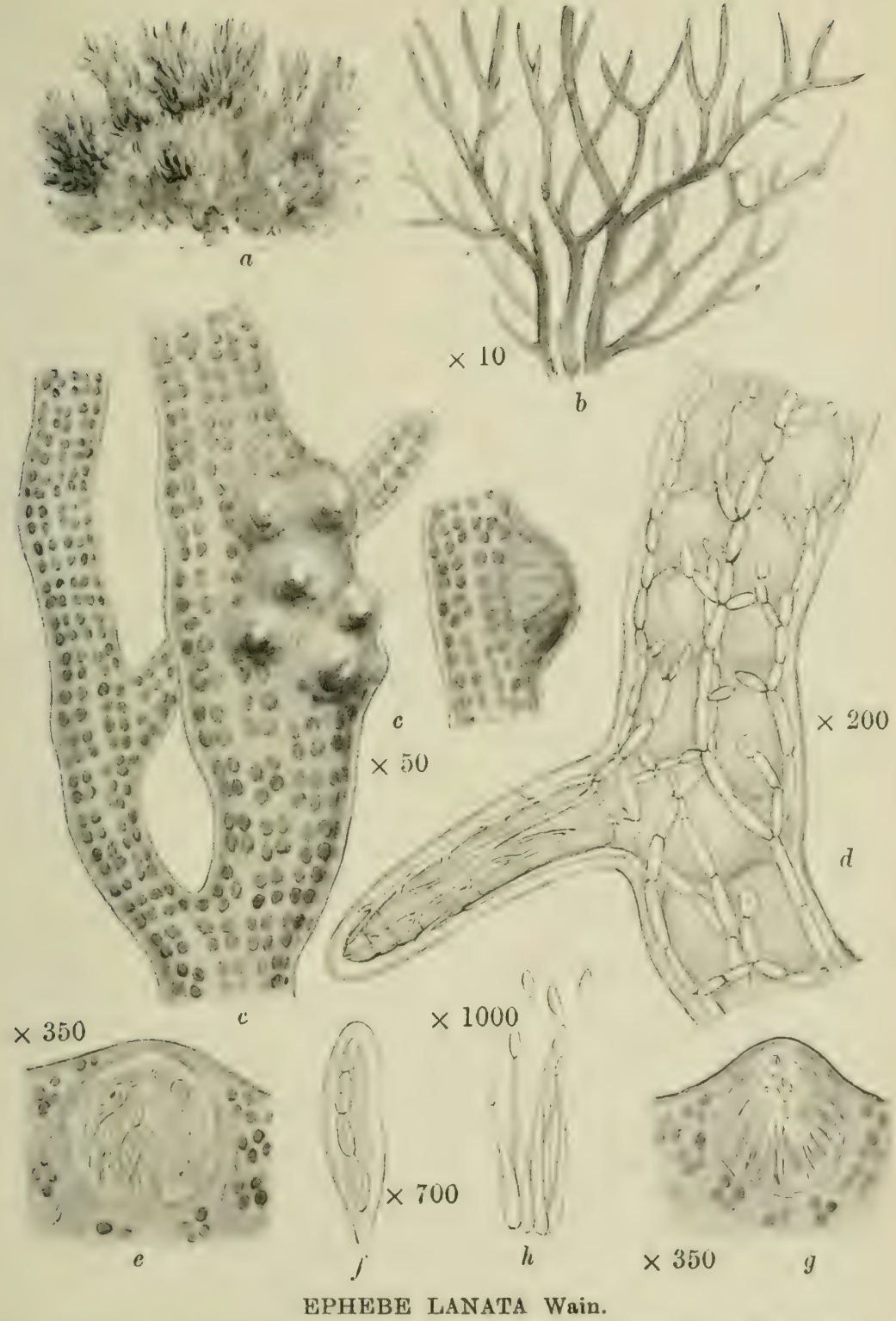

a. Plant on rock, $b$ and $c$. Portion of plant. $d$. Portion of thallus. $c$ Vertical section of apothecium. $f$. Ascus with spores. $g$. Vertical section of spermogone. $h$. Sterigmata and spermatia. 



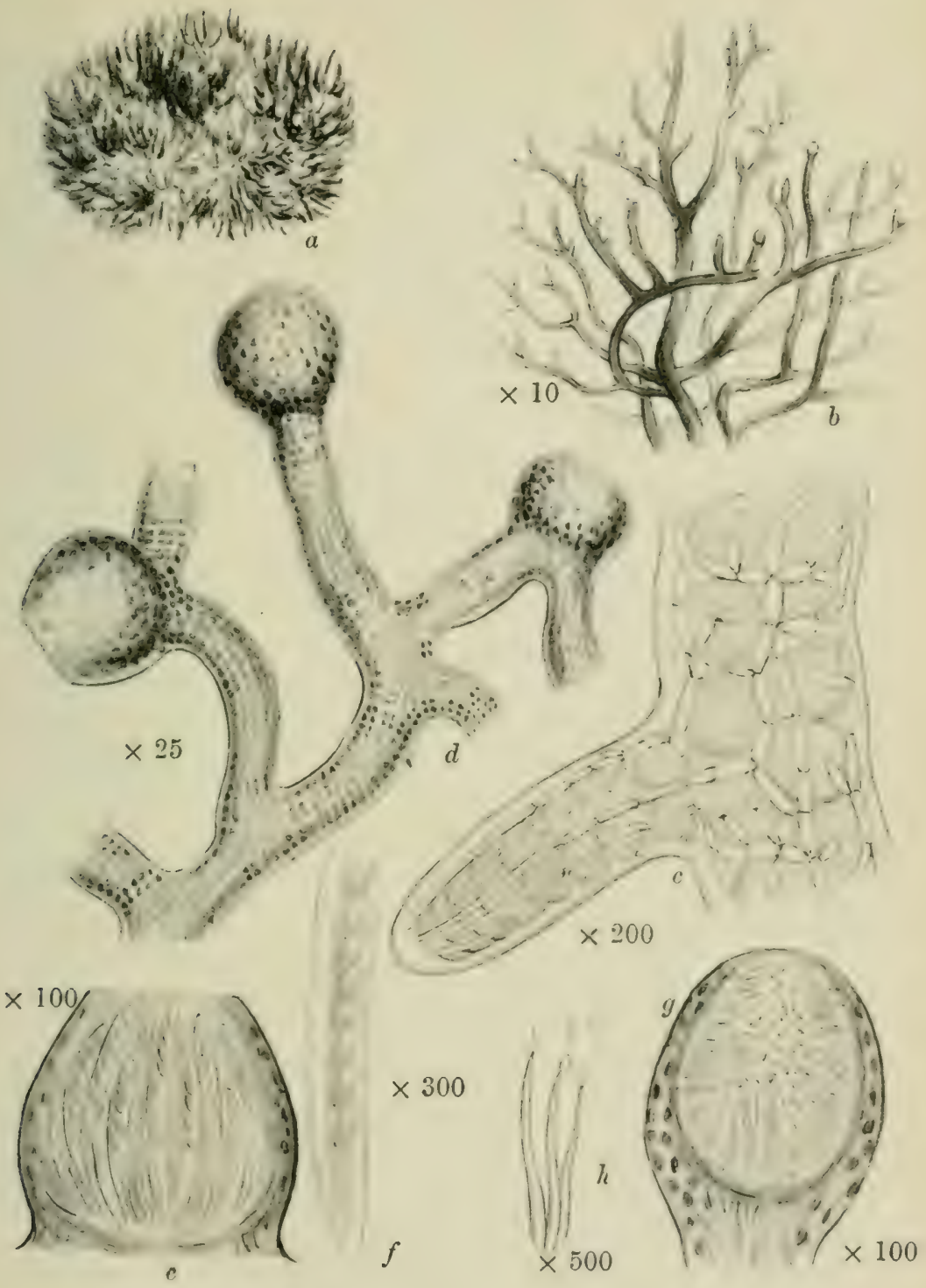

EPHEBEIA HISPIDULA Nyl.

a. Plunt on rock. b. Portion of plsnt. c. Thallus in verticul section. d. Fortile thallus. $c$. Vertical section of apothecium. $i$. Asets and paraphysis.

g. Vertical section of spermogone. h. Sterigmati and spermatia. 



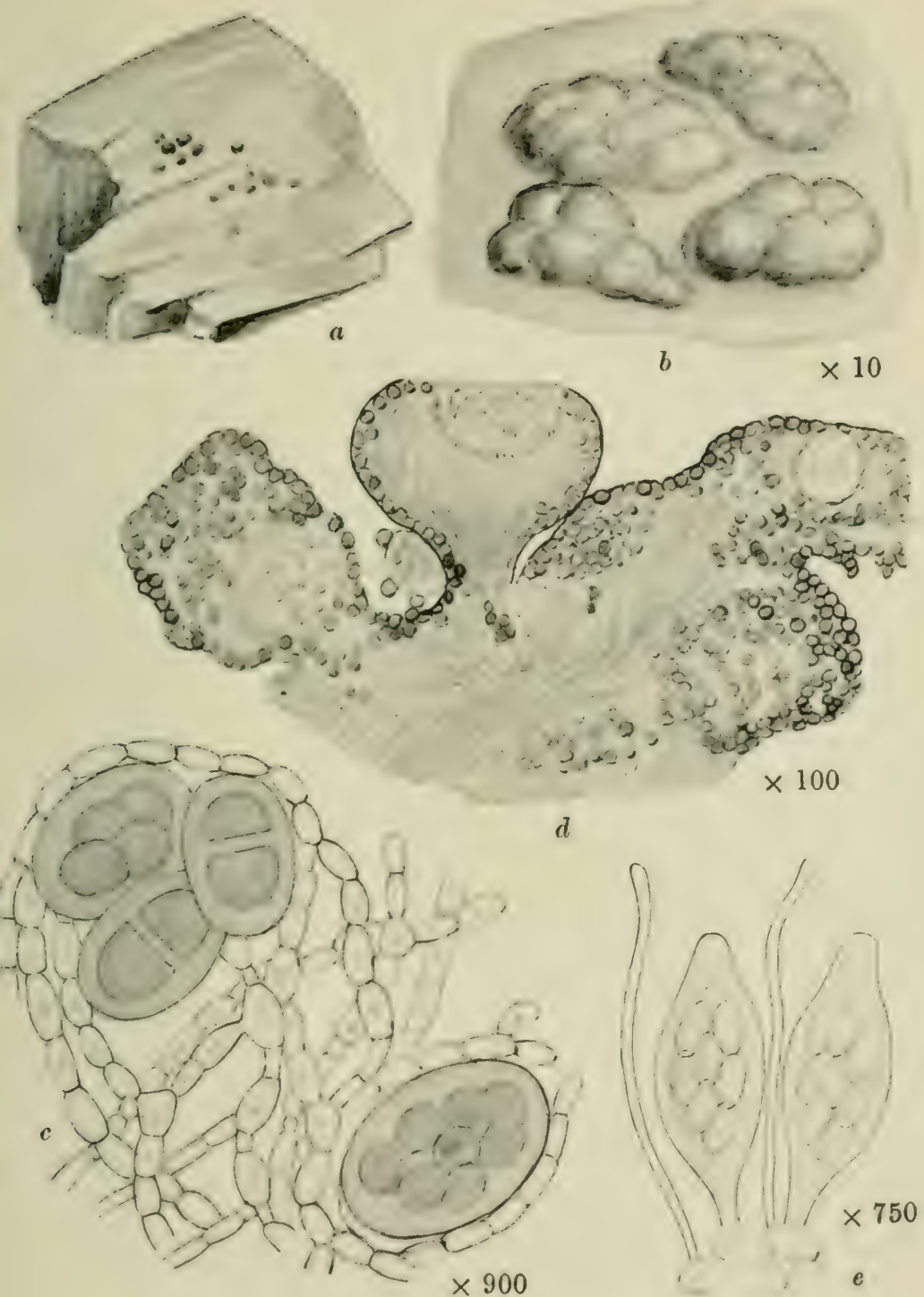

PYRENOPSIS PHYLLISCELLA Nyl.

a. Plant on boulder. b. Portion of plant. c. Section of thallus. d. Vertical section of thallus, with apothecium and spermogone. $c$. Asci with spores and paraphyses. 


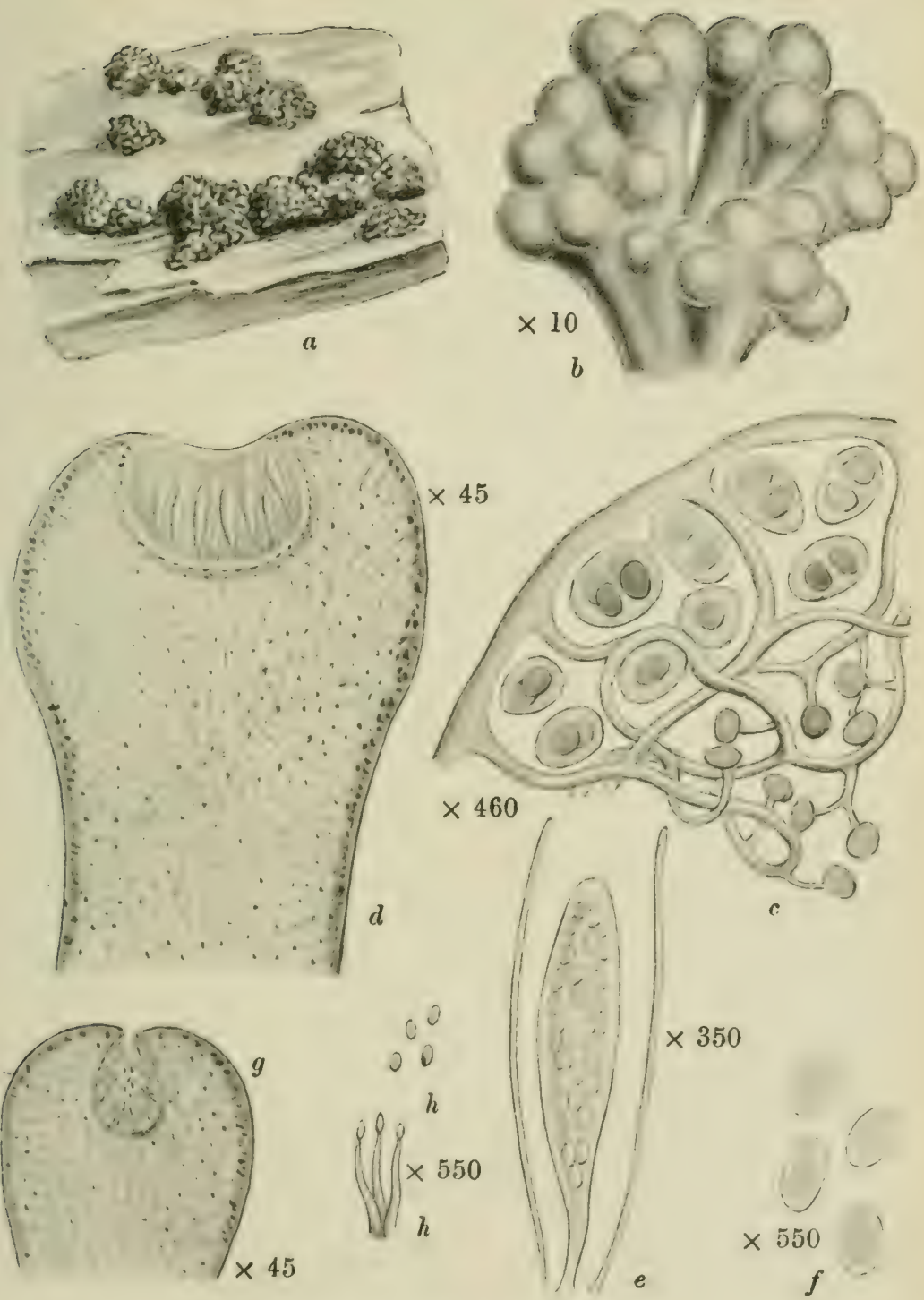

\section{SYNALISSA RAMULOSA Fr.}

a. Plant on rock. b. Portion of plant. c. Section of thallus, d. Vertical section of branch with apothecium. e. Ascus and paraphysea. $f$. Spores. g. Vertical section of spermogone. $h$. Sterigmata and spermatia 


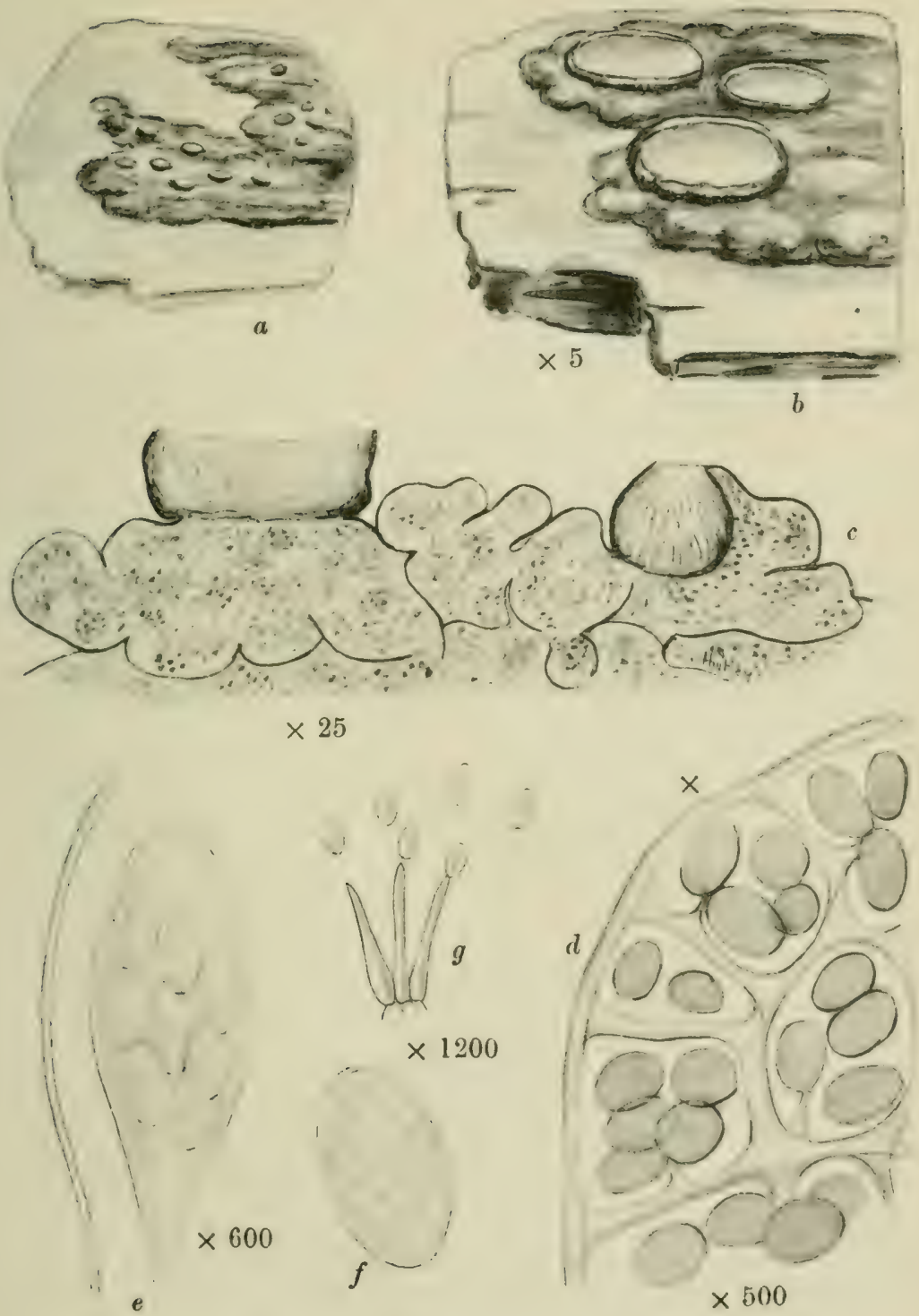

PSOROTICHIA SCHAERERI Am.

a. Plunt on rook. b. Portion of plant. c. Vertical section of thallus, apotheciam and spermogone. $d$. Sootion of thallus. e. Ascus and paraphysis.

f. Spore. g. Sterigmata and spermatia. 


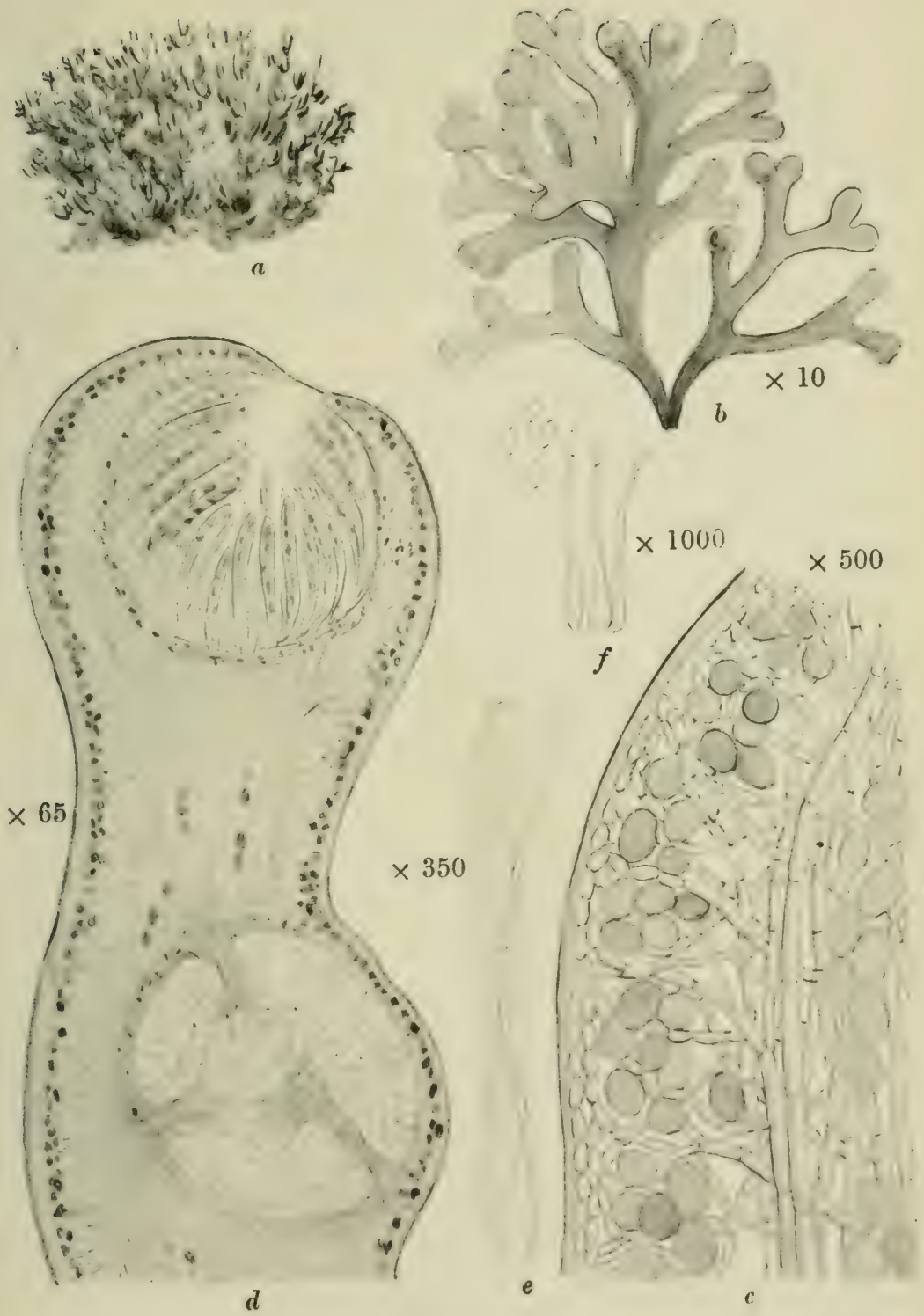

LICHINA PYGMAEA Ag.

a. Plant on rock. b. Portion of plant. c. Section of thallus. d. Section of fertilu branch with apothecium and spermogono, e. Asous with spores and paraphysis. $f$. Sterigmata and spermatia. 


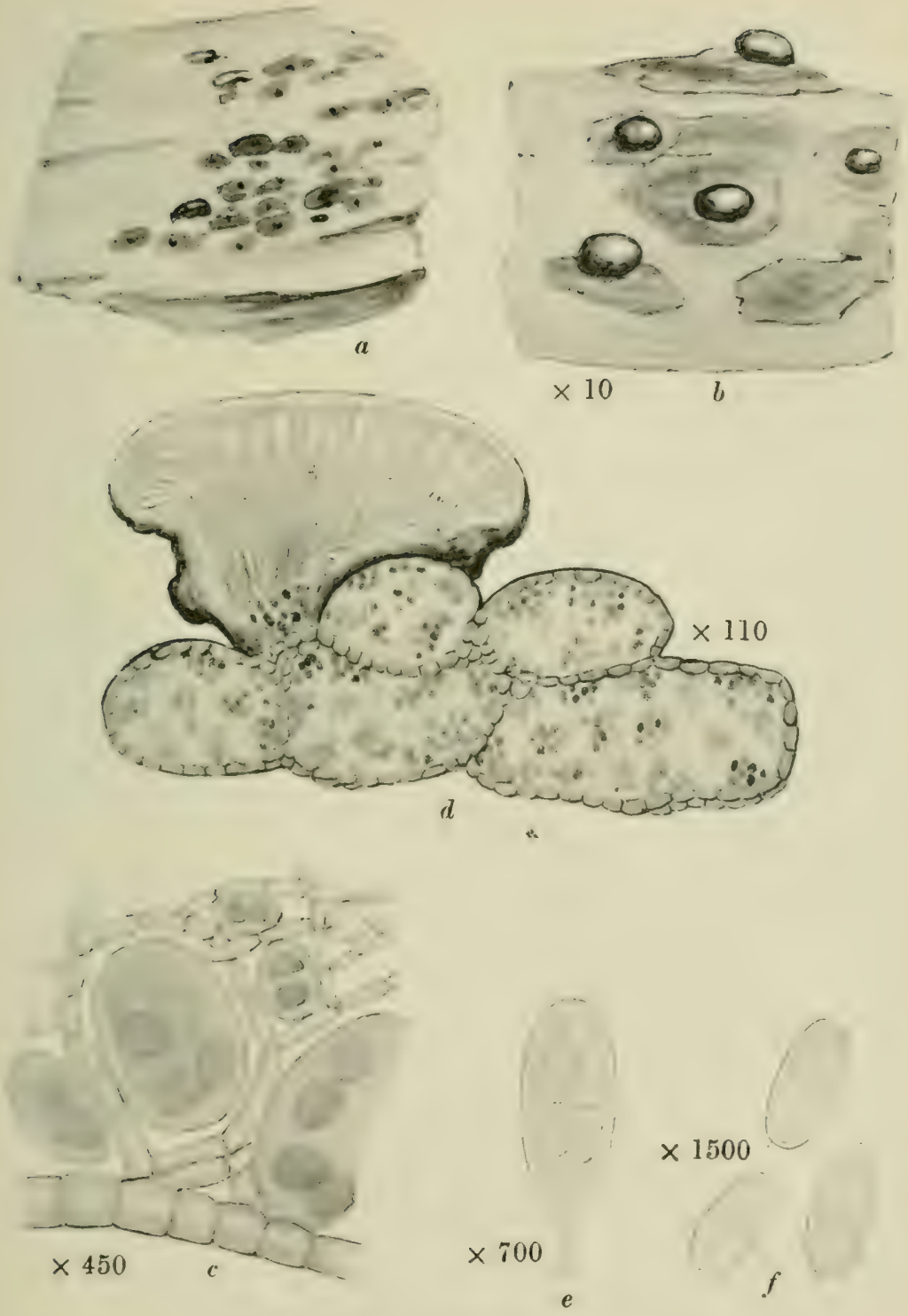

PTERYGIUM LISMIORENSE Cromb.

a. Plant on rock. b. Portion of plant. c. Section of thallus. d. Vertical section of thallus and apothecium. $e$. Ascus. $f$. Spores. 


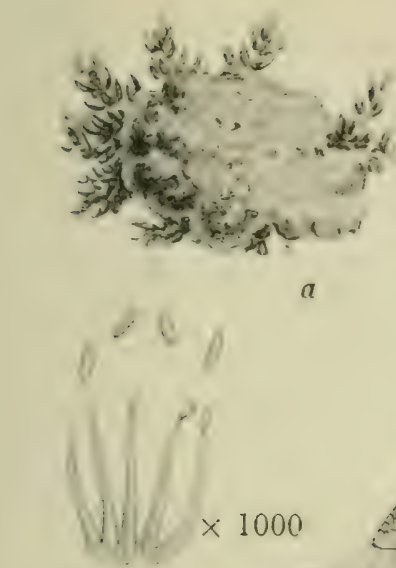

a
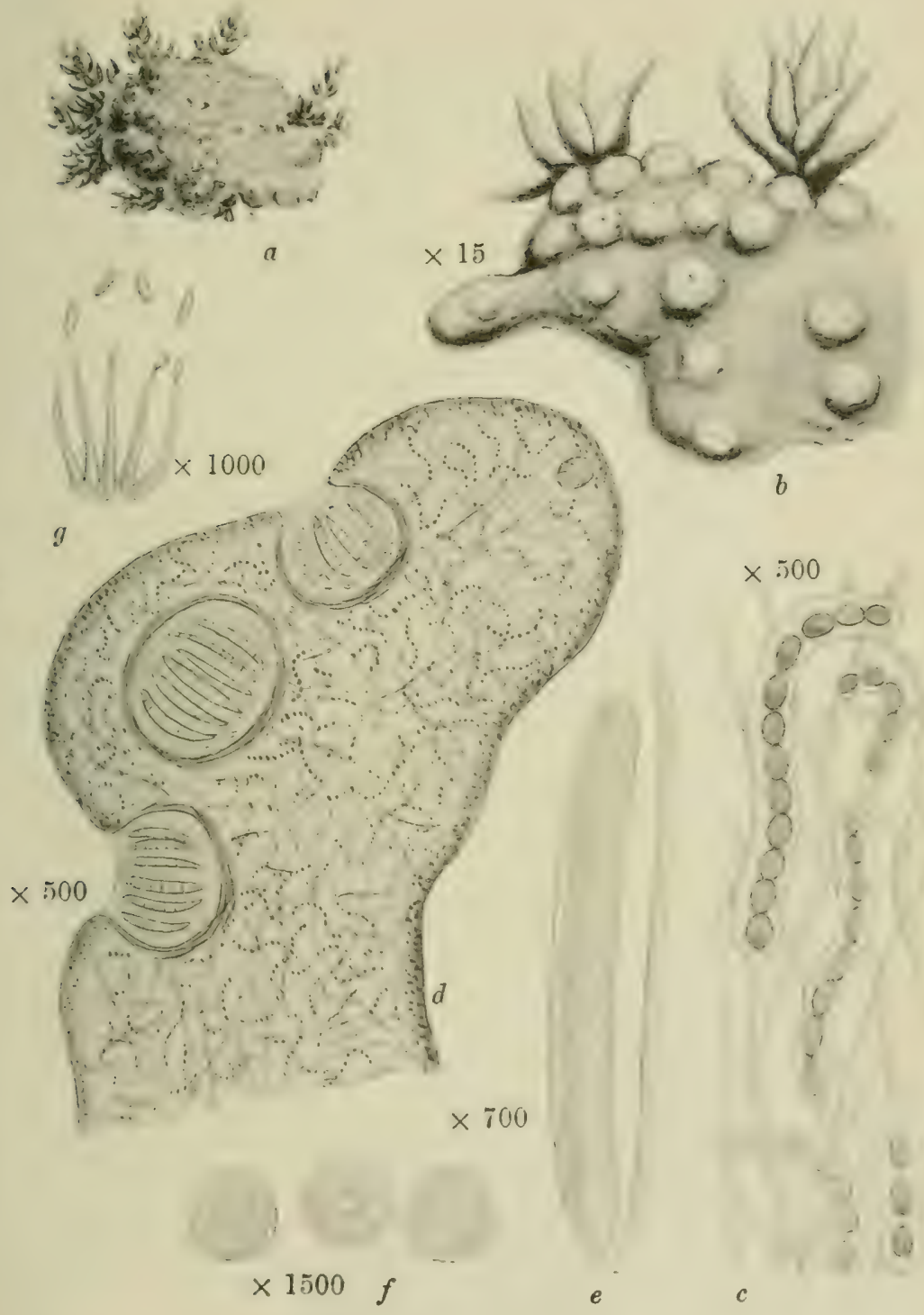

PHYSMA POLYANTHES Arn.

a. Whole plant. b. Purtion of plant. c. Section of thallus. d. Section of thallus with apotheciu. e. Ascus and paraphysis. f. Ascospores.

g. Sterigmata and spermatia. 



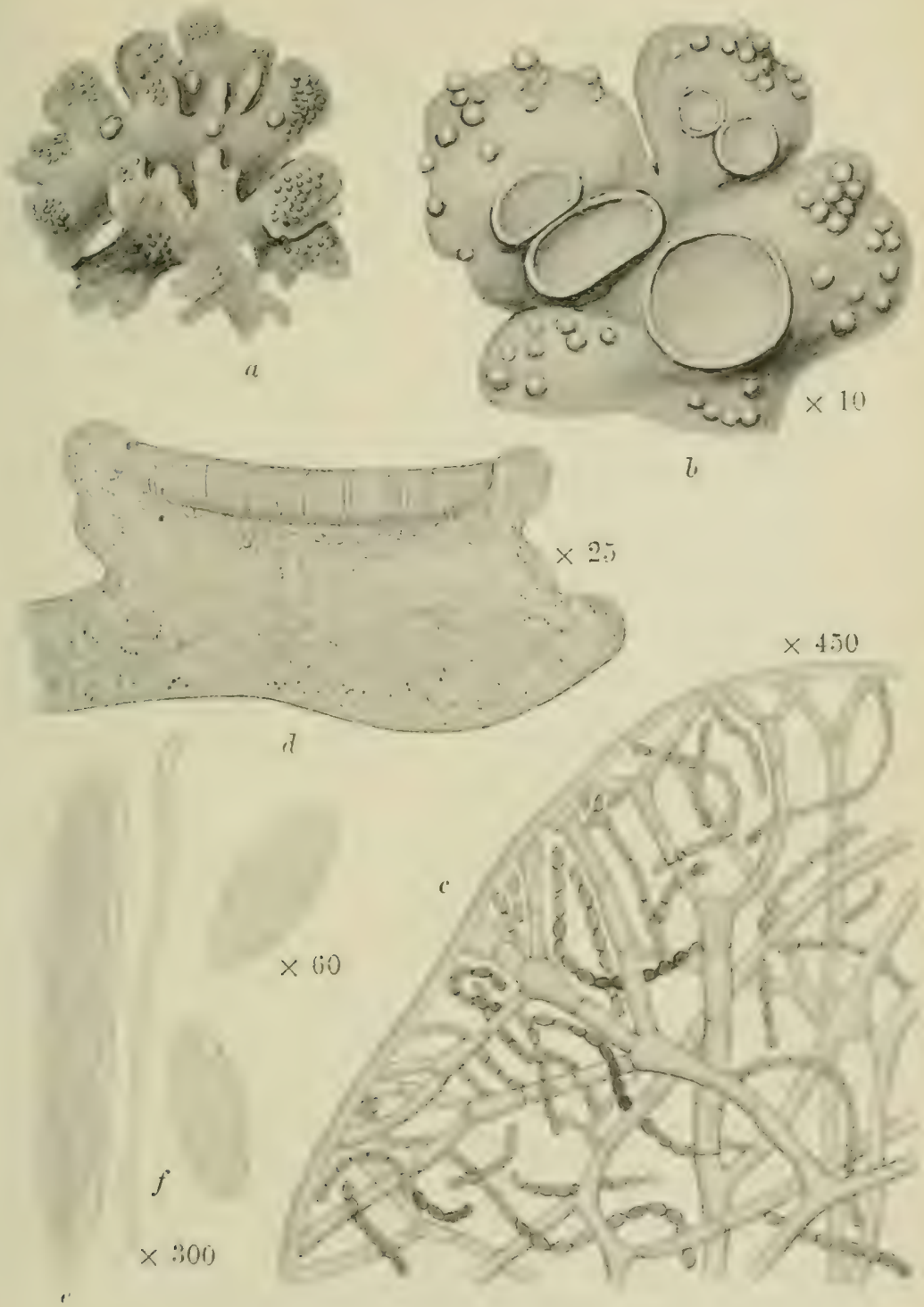

COLLEMA GRANULIFEIRM NYH.

4. Whole plant. b. Portion of plant. ¿. section of tballue. i. Vertinal section of apothecium. e. Ascus and paraphysis, $f$. Ascospores. 


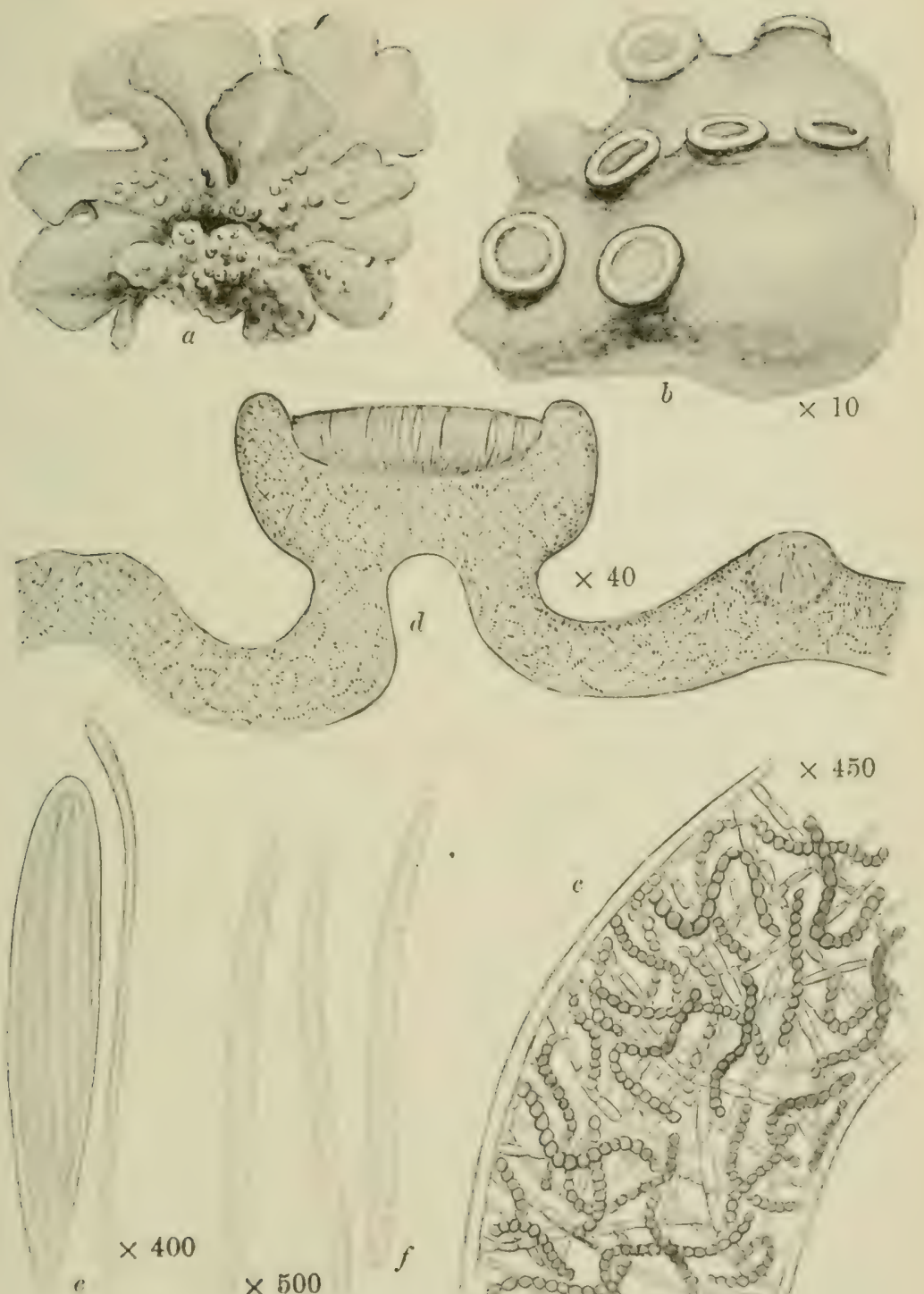

400

$\times 500$

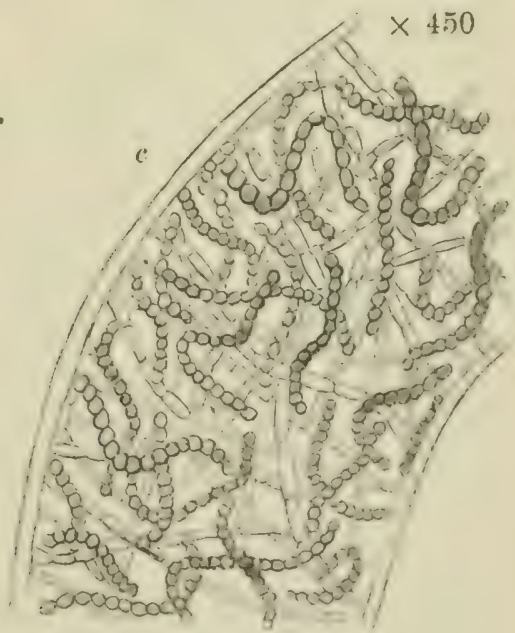

SYNECHOBLASTUS NIGRESCENS Anzi.

a. Plaut. b. Portion of plaut. c. Vertical section of thallus. d. Vertieal section of thallus and apothecium. $e$. Ascus and paraphysis. $f$. Ascospores. 



\section{Plate 26}

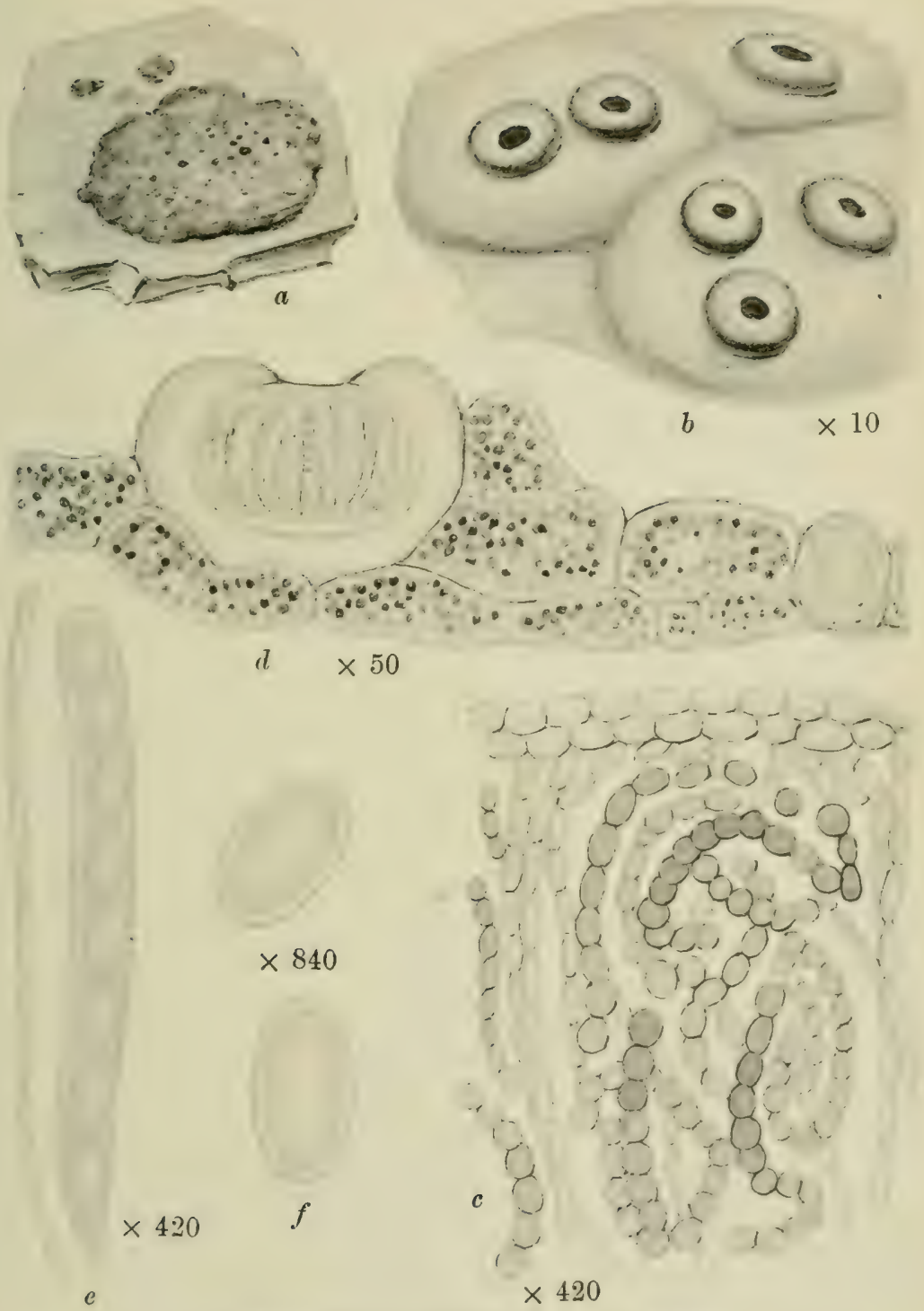

LEMMOPSIS ARNOLDIANA A. Zahlbr.

a. Plant on rock. b. Portion of plant. c. Section of thallus. d. Vertical section of thallus, apothecium and spermogone. $e$. Ascus and paraphysis. $f$. Ascospores. 


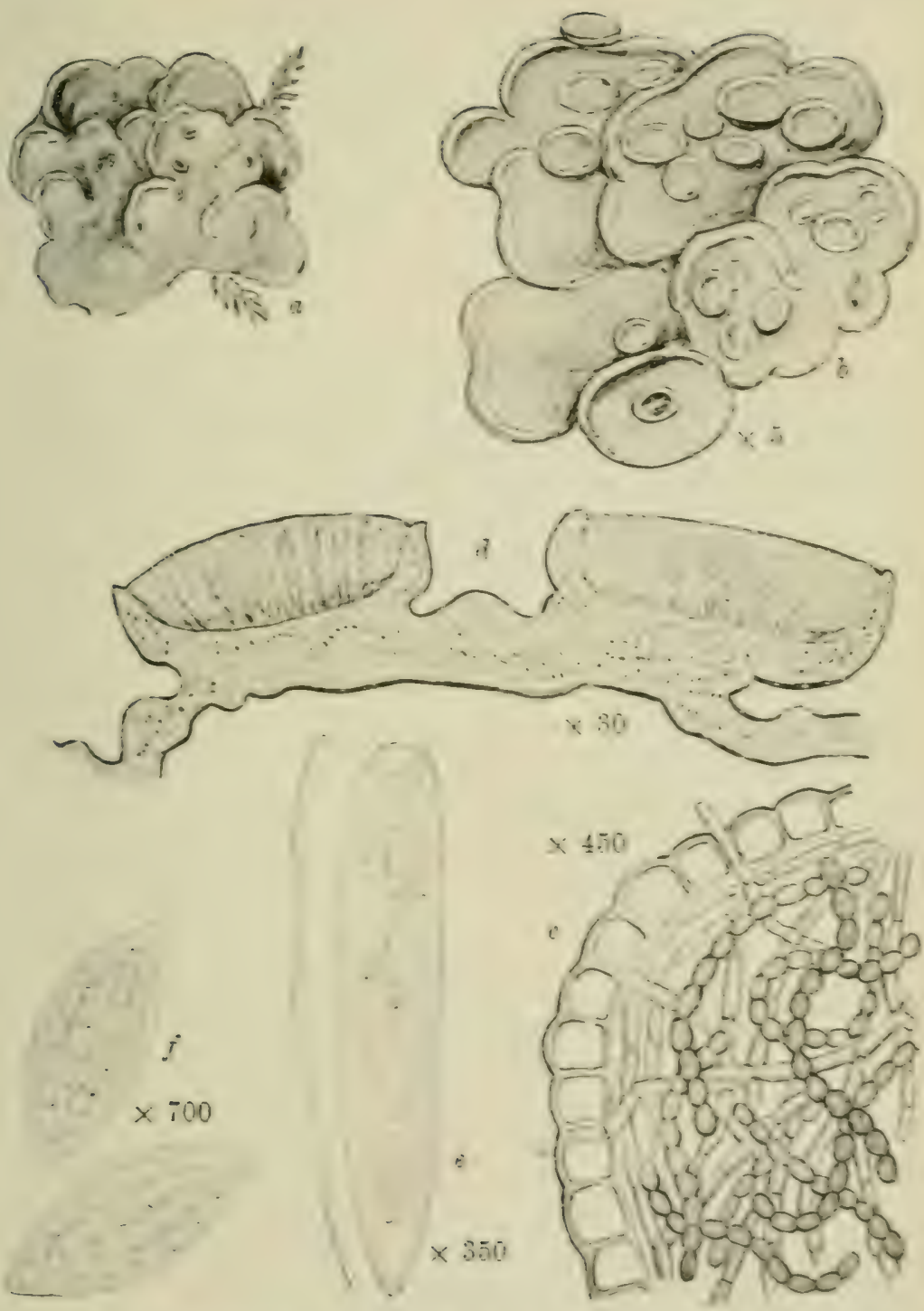

LEPTOGIUM STUUTLM TAR. SCOTNUM Ēerb.

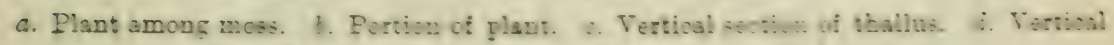
section of apothecis. e. Ascos and paraphysis. $f$. Aseospores. 


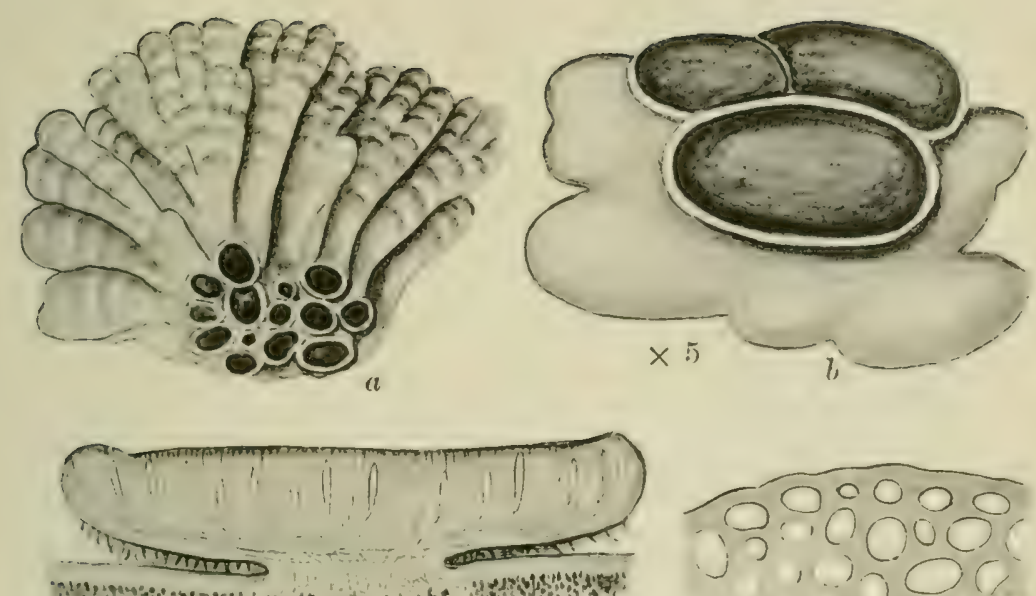

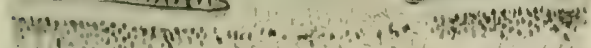
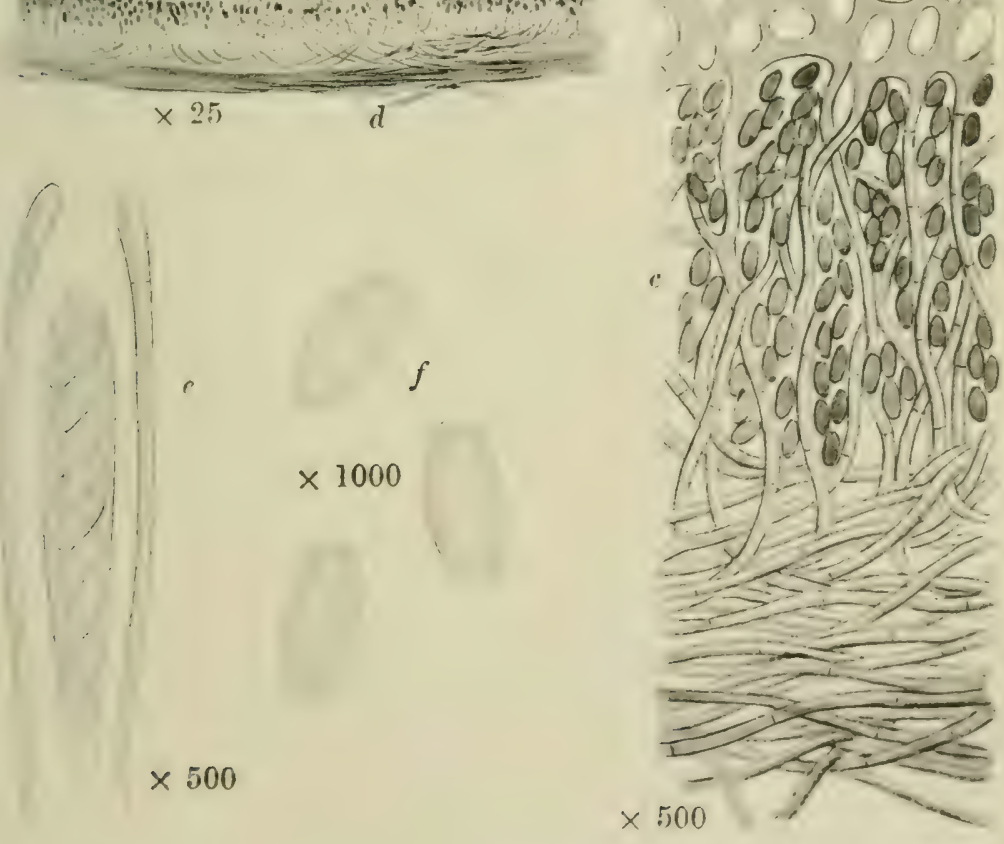

PARMETIFLLA PLUMBFA IVain.

a. Plant. b. I'ortion of piant. c. Yertical section of thallus. $d$. Vertical section of apothecium. e. Ascus and paraphyses. f. Ascospores. 



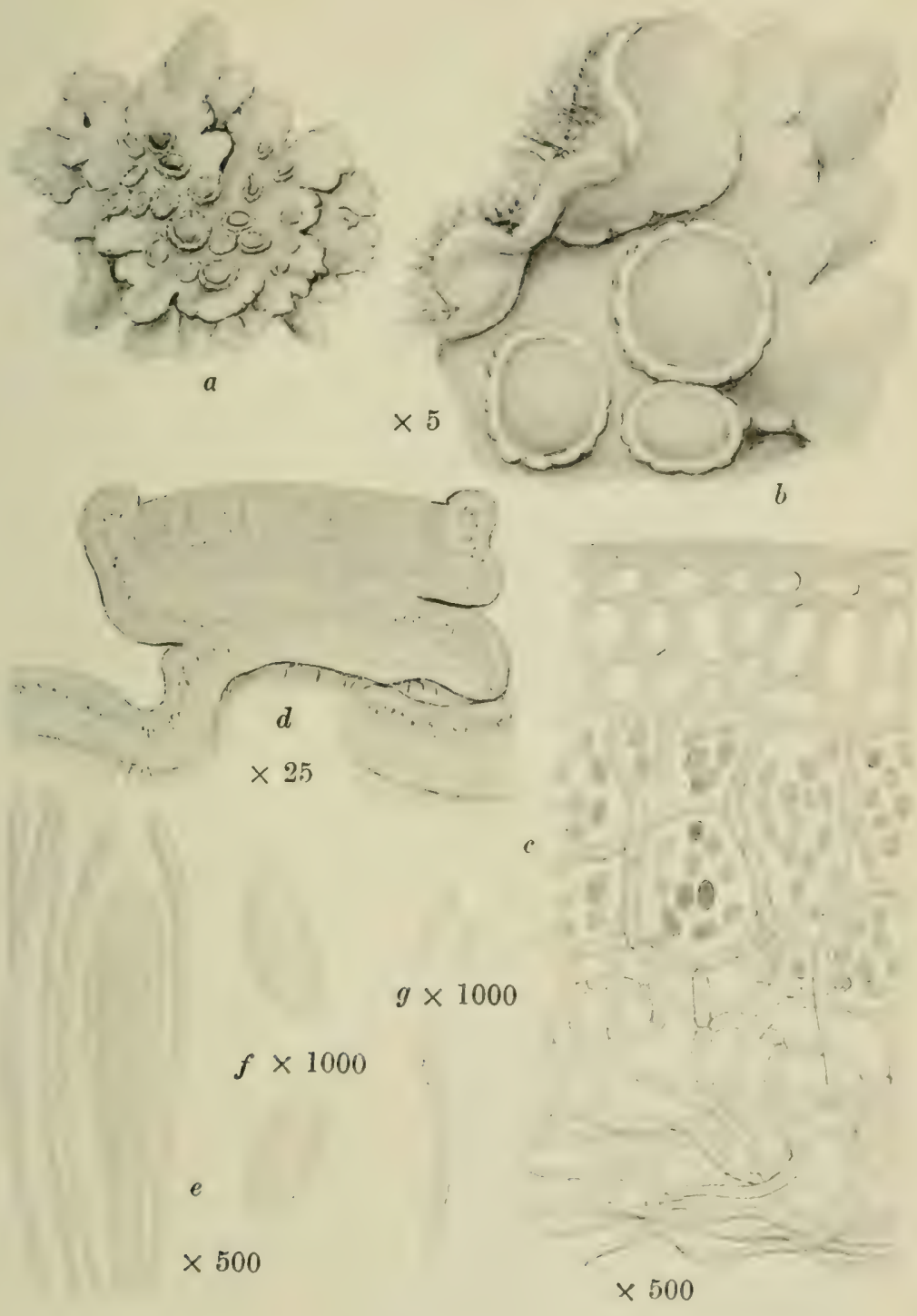

PANNARIA RUBIGINOSA Del.

$a$. Plant. b. Portion of plant. c. Vertical section of thallus. d. Vertical section of apothecium. c. Ascus and paraphyses, $f$. Ascospores. g. Sterigma and spermatia. 


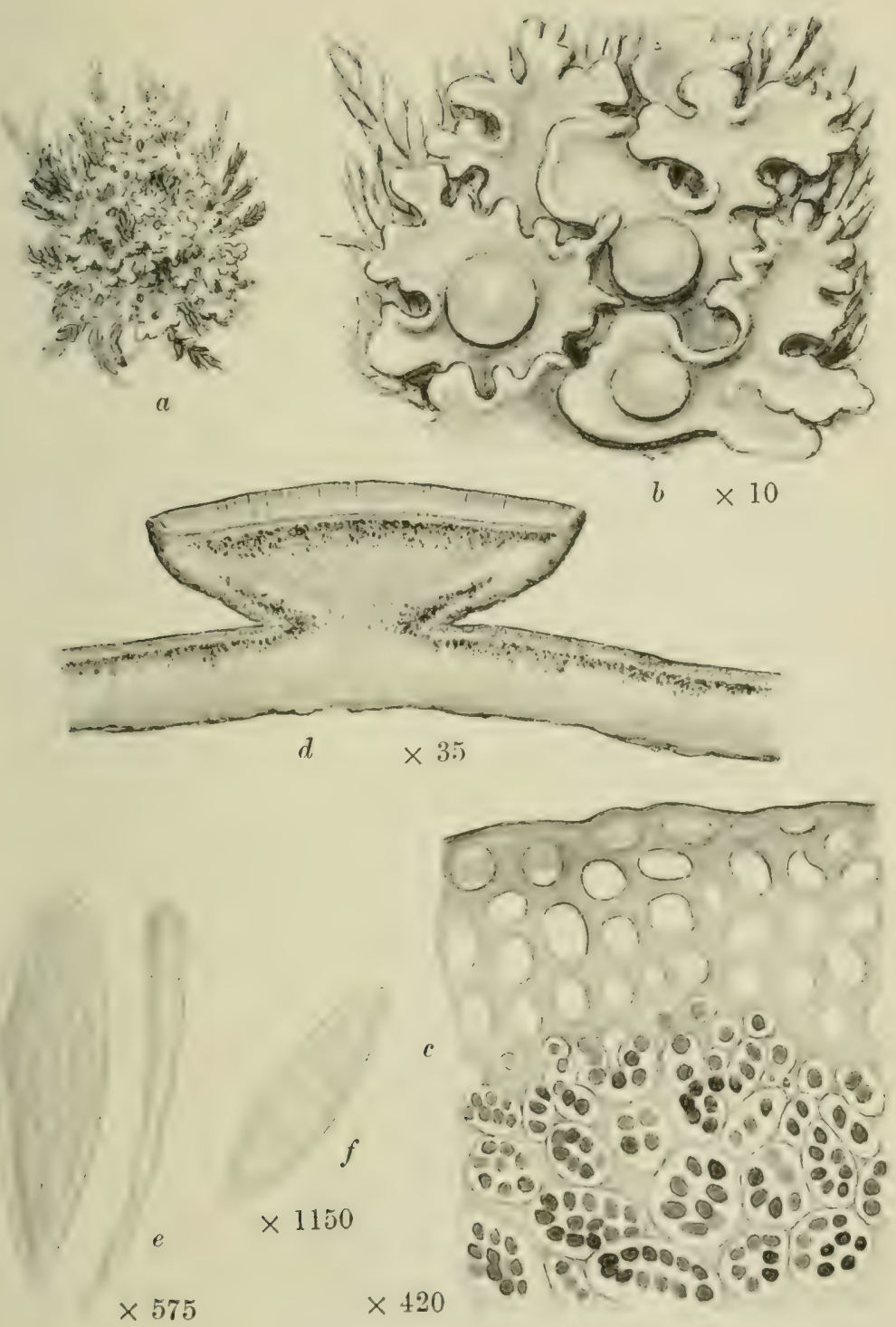

MASSALONGIA CARNOSA Koerb.

a Plant among moss. b. Portion of plant. c. Vertical section of thallus. d. Vertical section of apothecium. $c$. Ascus and paraphysis. $f$. Ascosporo. 


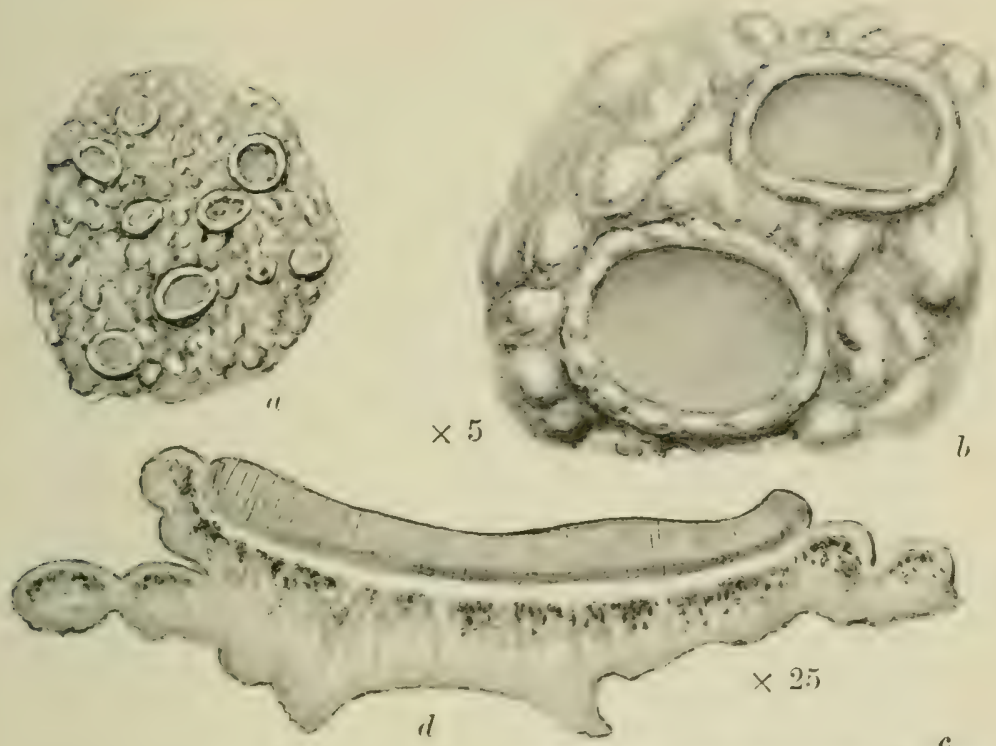

$\times$ 得

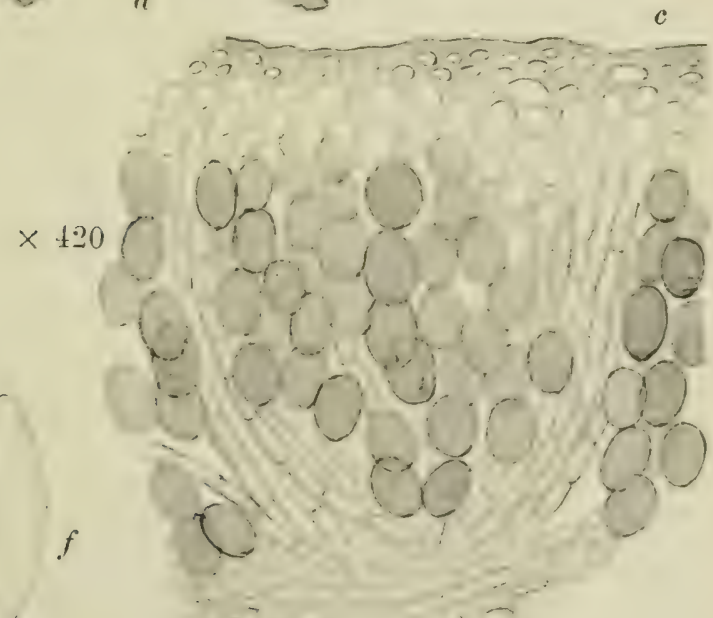

$\times 1150$

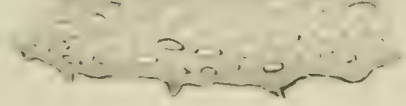

PSOROMA HYPNORUM S. F. Gray.

a. Plant. b. Portion of plant. c. Vertical section of thallus. d. Vertical section of apothecium. e. Ascus and paraphysis. f. Ascospore. 


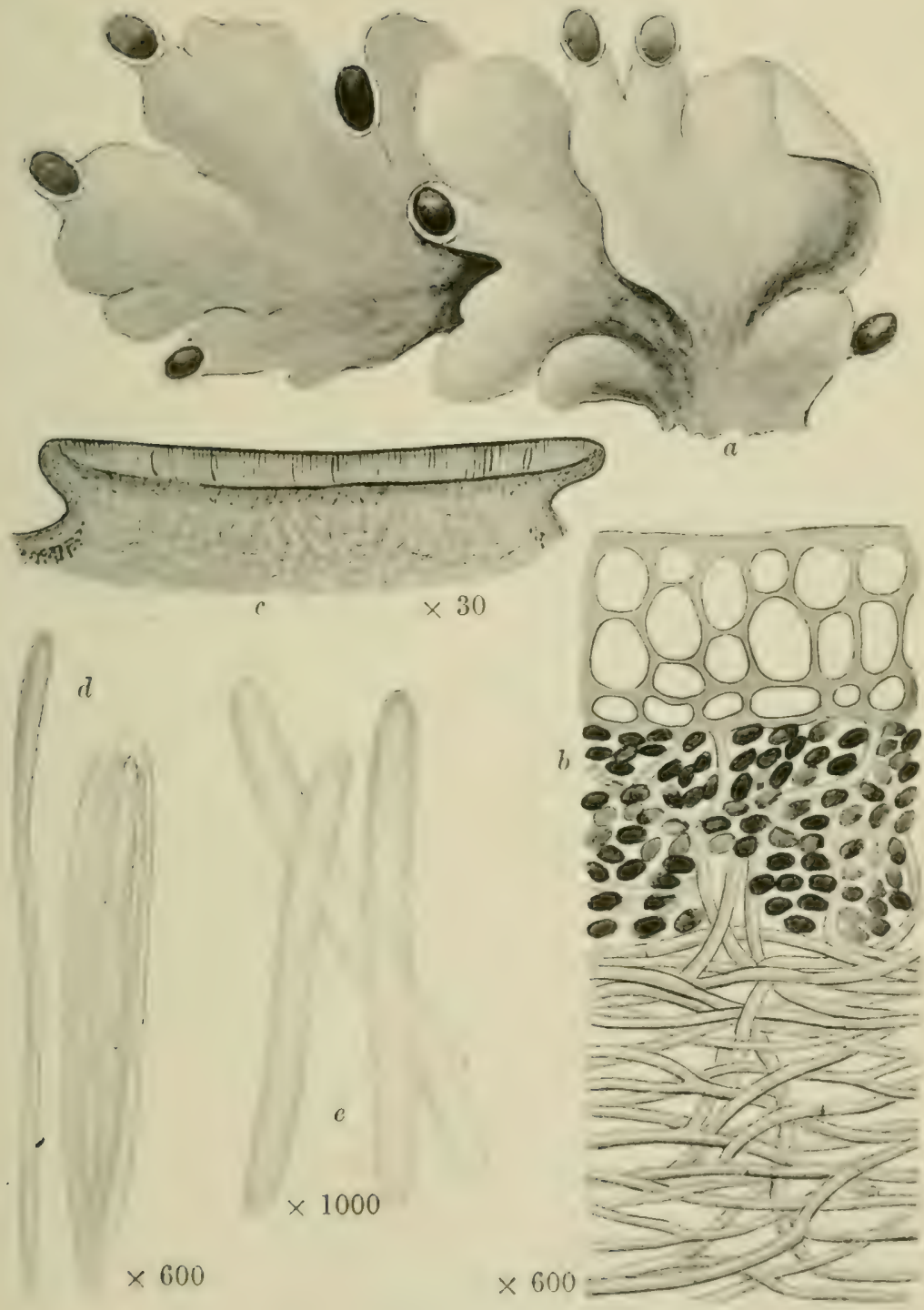

PELTIGEIRA CANINA Willd.

a. Portion of plant. b. Vertical section of thallus. c. Vertical section of apothecium. d. Ascus and paraphysis, c. Ascosporos. 


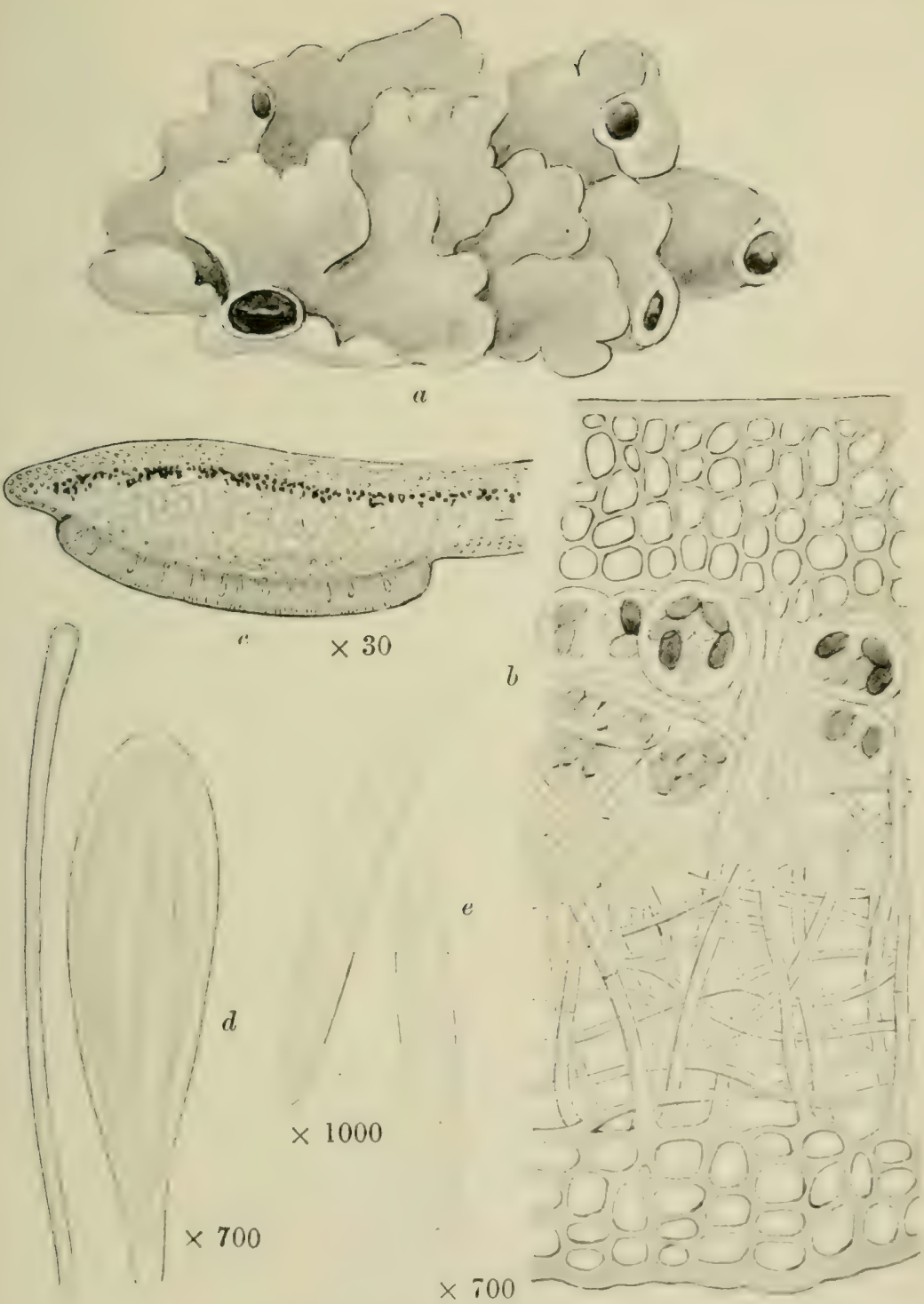

NEPHROMUM LUSITANICUM Nyl.

a. Portion of plaut. U. Vertical section of thallus. c. Vertical section of apothecium. $d$. Ascus and paraphysis. $c$. Ascospores. 


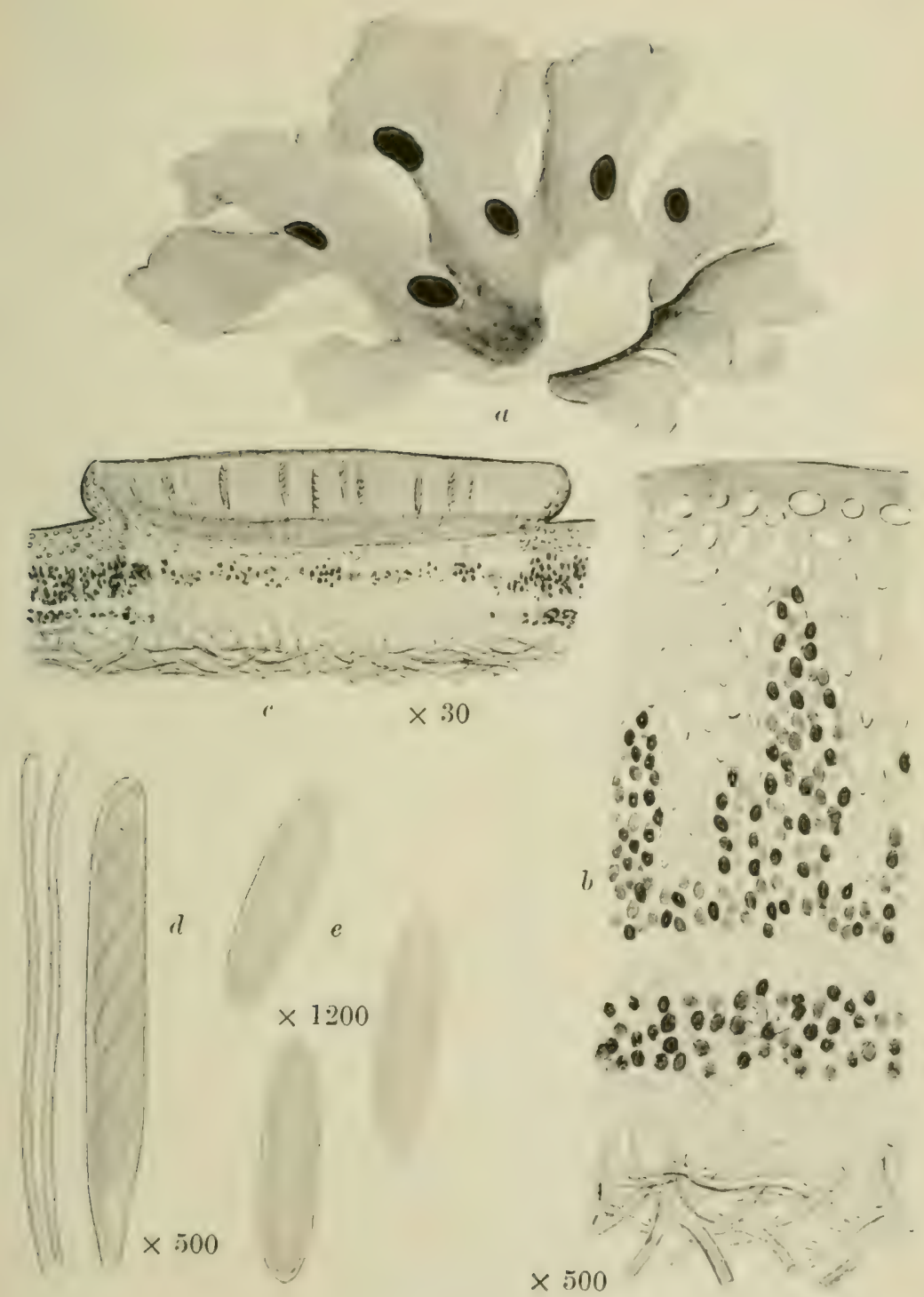

SOLORINA CROCEA Ach.

$a$. Portion of plant. b. Vertical section of thallus. c. Vertical section of apothecium. d. Ascus and paraphyses. e. Ascospores. 


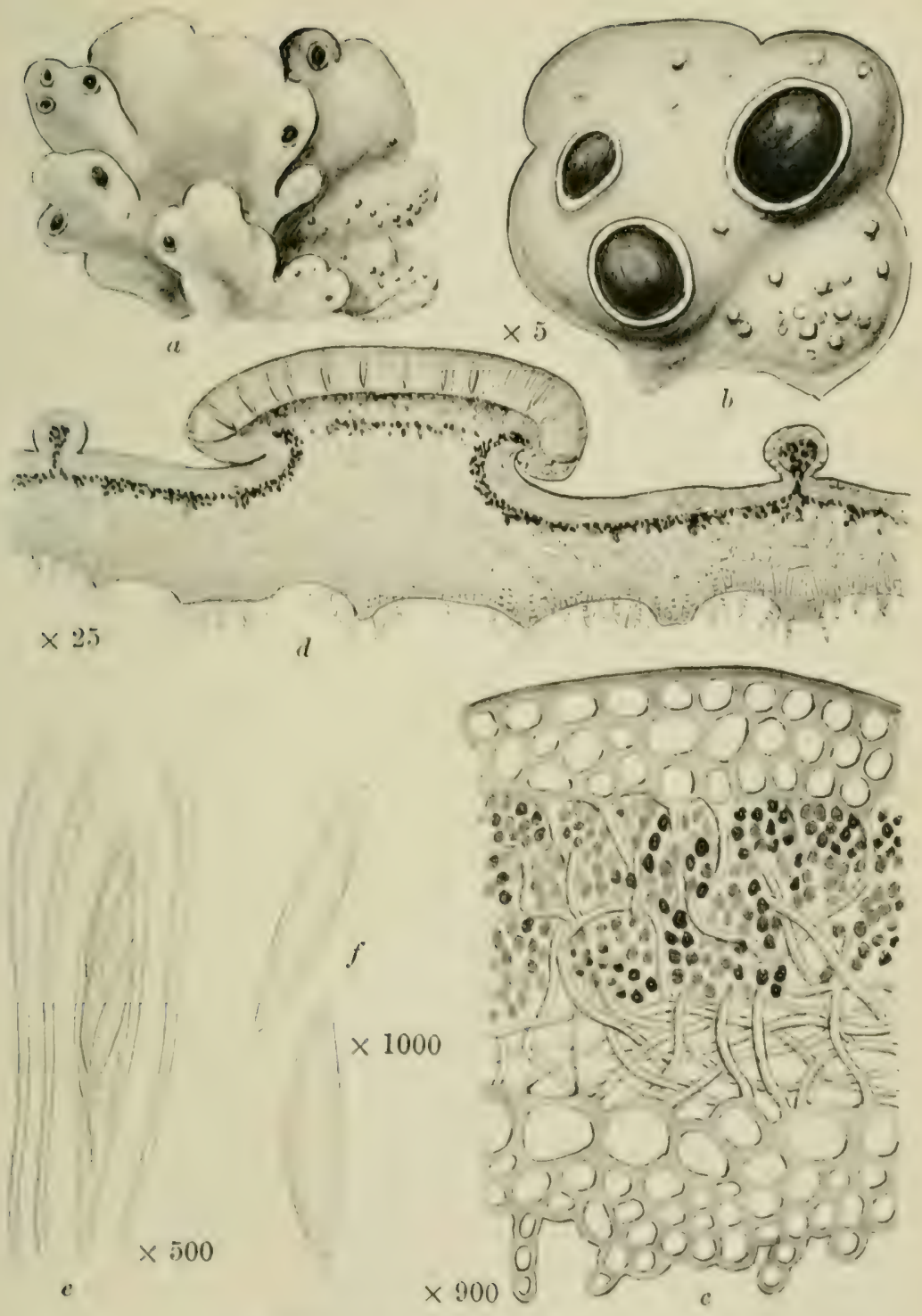

S'IICTA FULIGINOSA Ach.

1. Plant. b. Portion of plant. c. Vertical section of thallus. d. Fortical section of apothecium and thallus. e. Ascus and paraphyses. $f$. Spores. 


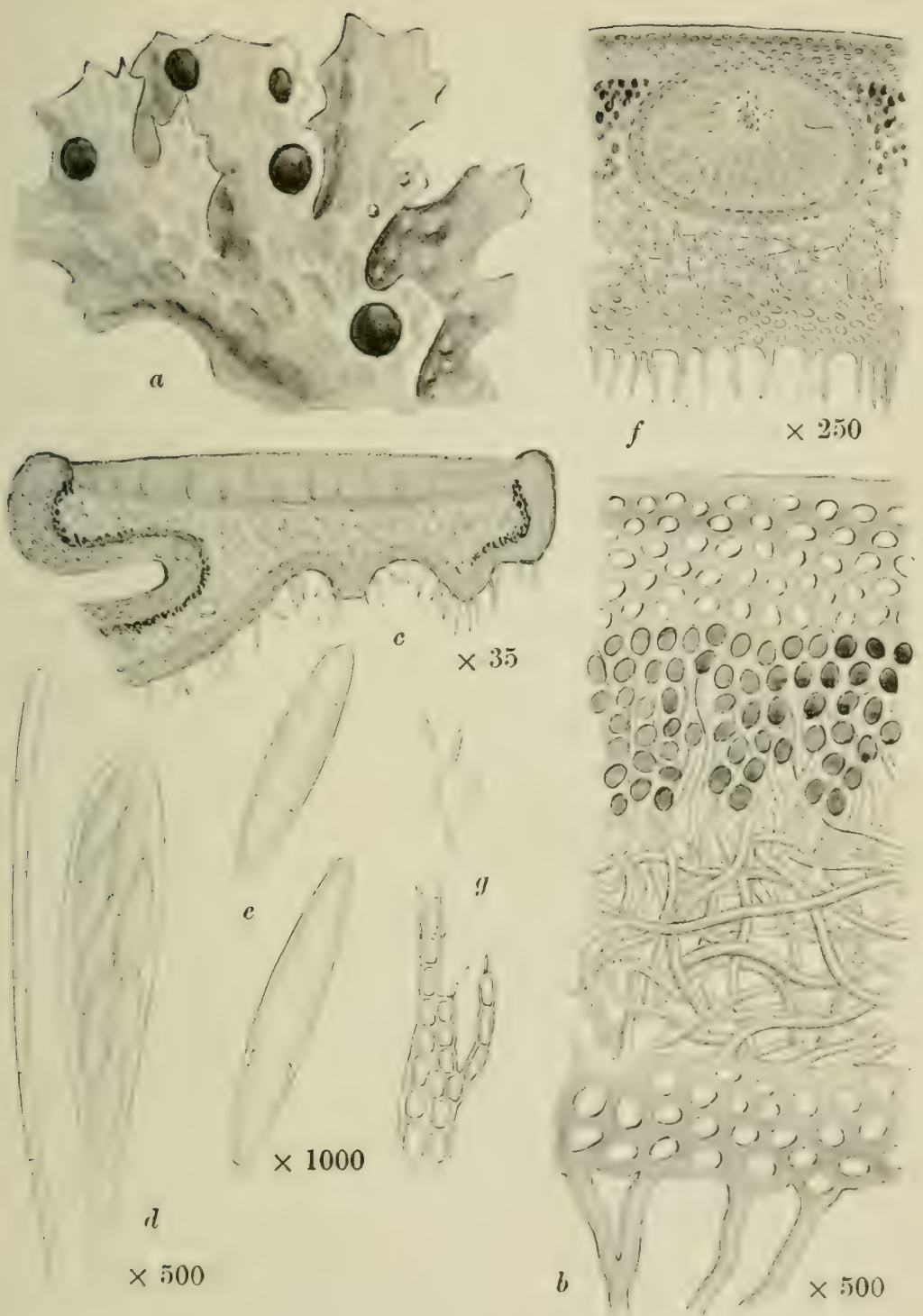

LOBAHIA PULMONARIA Hofim.

a. Iart of plant. b. Vertical section of thallus. $c$. Vertical section of apothecium. d. Ascus and paraphysis. $e$. Ascospores. $f$. Vertical section of spermogone. g. Sterigmata and spermatia. 


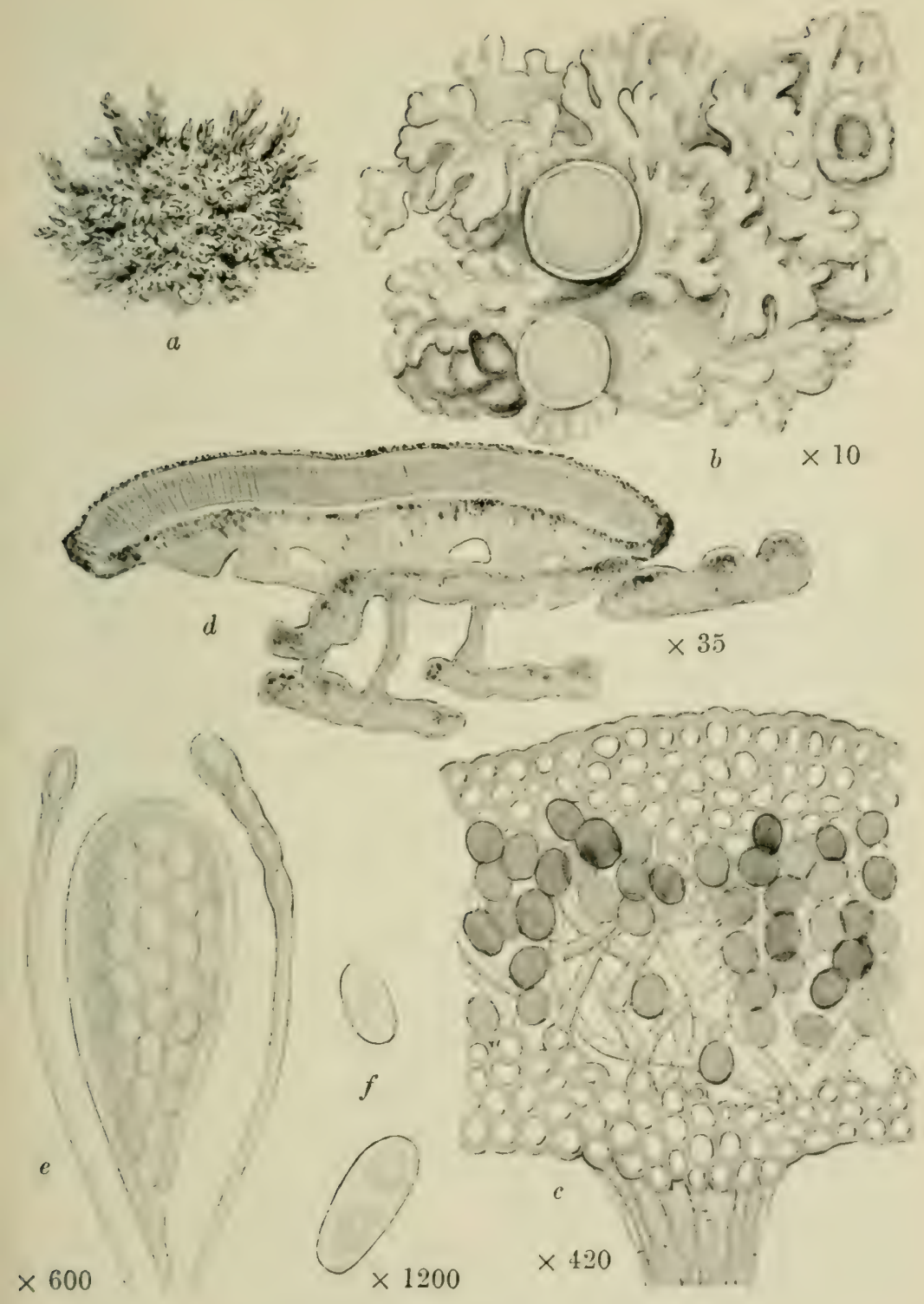

CANDELARIA CONCOLOR Wain.

a. Plant. b. Portion of plant. c. Vertical section of thallus. $d$. Vertical section of apothecium and thallus. $c$. Ascus and paraphysos. $f$. Spores. 


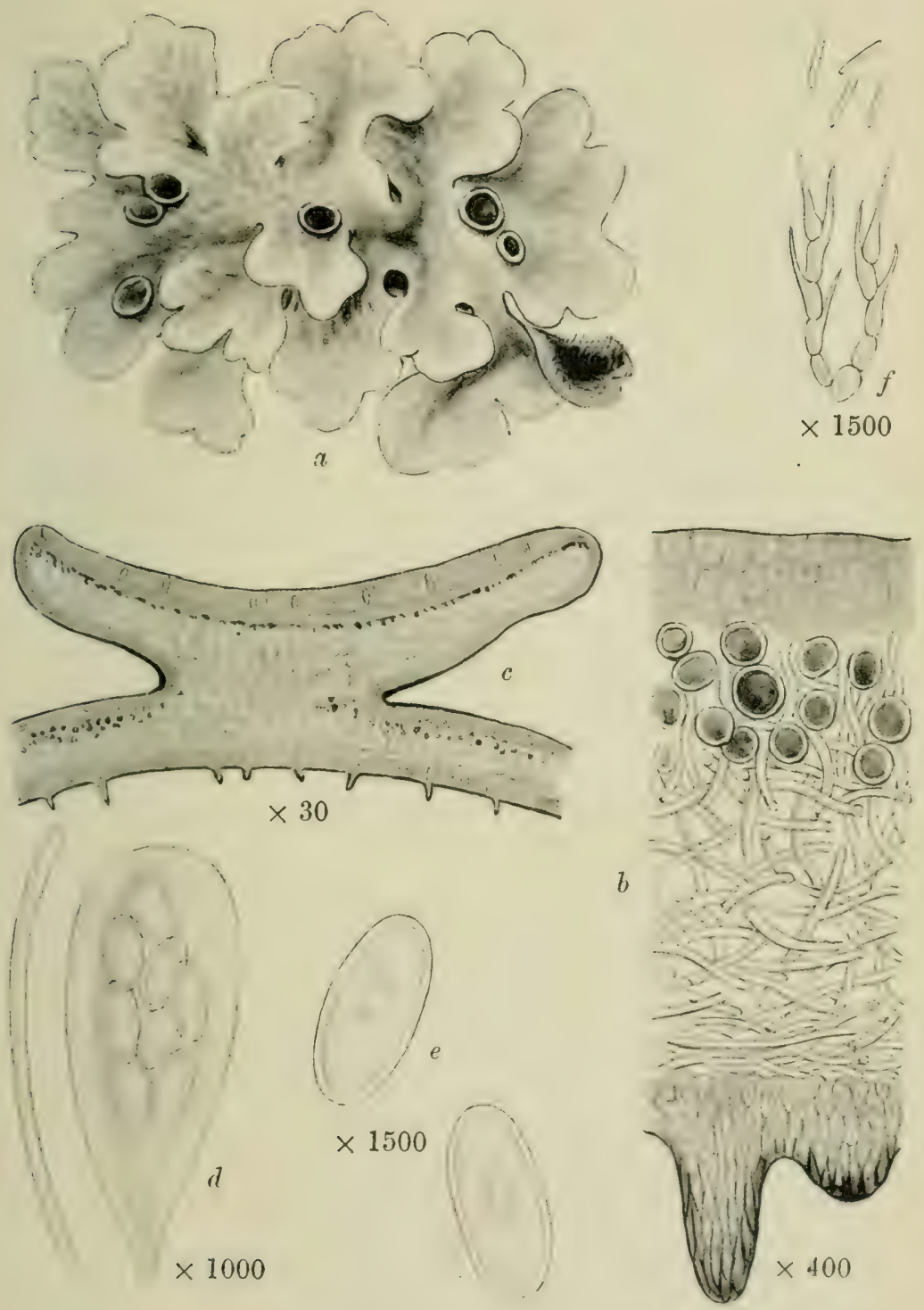

PARMELIA CAPERATA Ach.

a. Ylant. $b$. Yertical section of thallus. c. Yertical section of apothecium and thallus. d. Aseus and paraphysis. e. Spores, $f$. Sterigmatia and spermatia. 



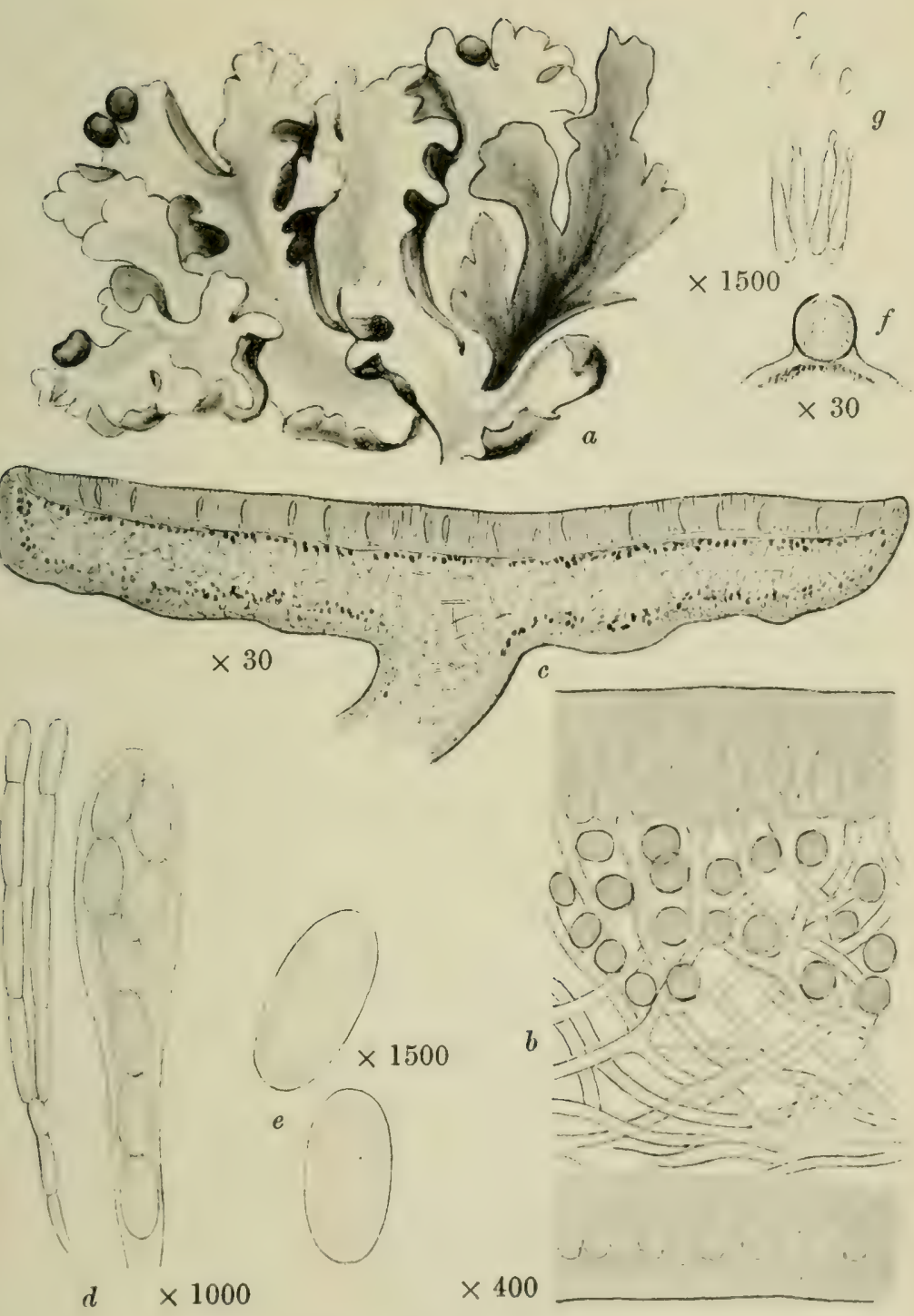

CETRARIA GLAUCA Ach.

a. Plant. b. Vertical section of thallus. $c$. Vertical section of apothecium. $d$. Ascus and paraphysis. e. Spores. $f$. Spermogone. g. Sterigmata and spermatia. 

PLATE 40

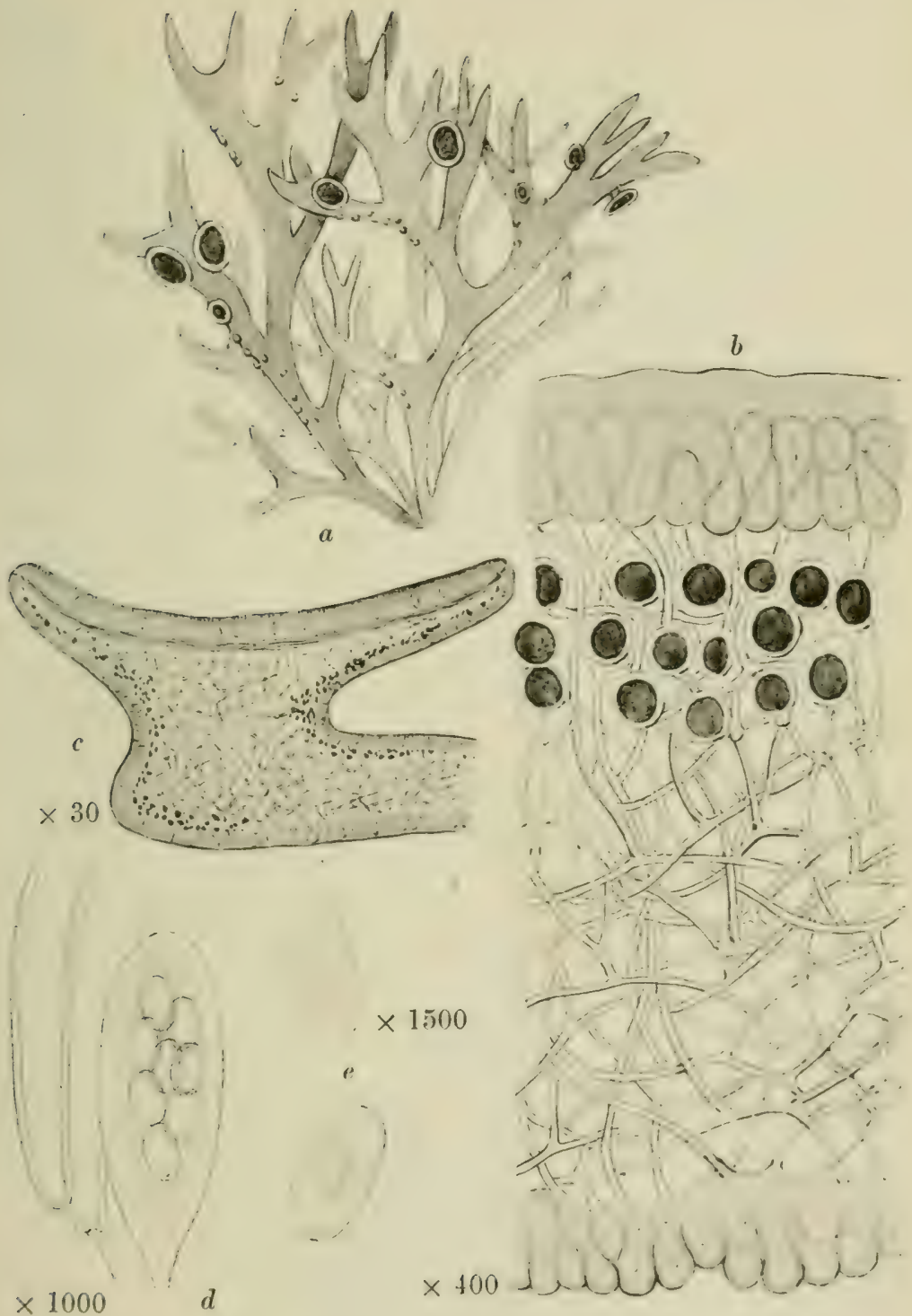

EVERNIA PRUNASTIR Ach.

a. Plant. b. Section of thallus. c. Vertical section of apothecium. d. Ascus and paraphyses. e. Spores. 



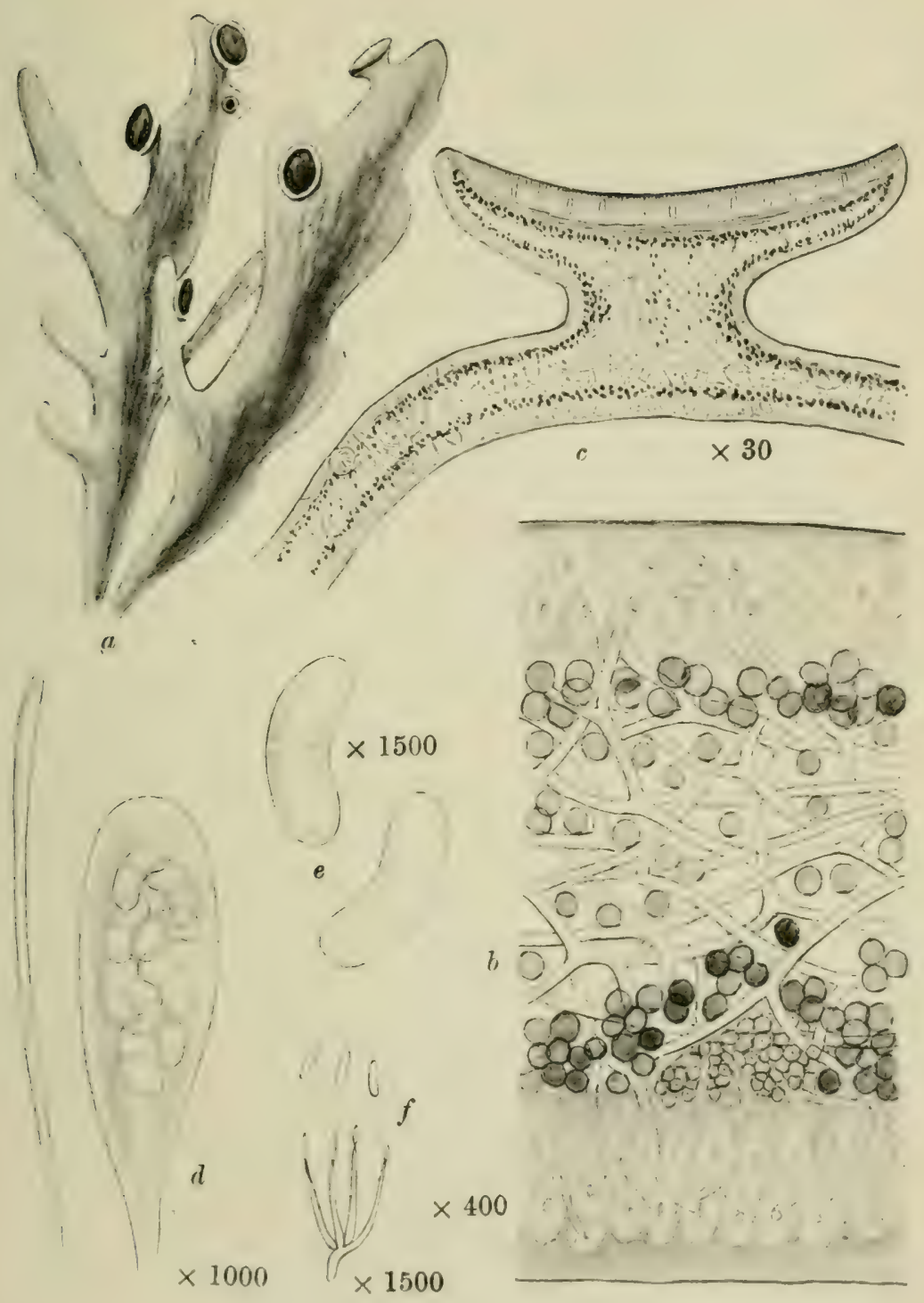

RAMALINA FRAXINEA Ach.

n. Portion of plant. 6. Transverse section of thallus. $c$. Vertical section of apothecium and thallus. d. Ascus and paraphysis.

c. Sporos. $f$. Sterigmata and spermatia. 



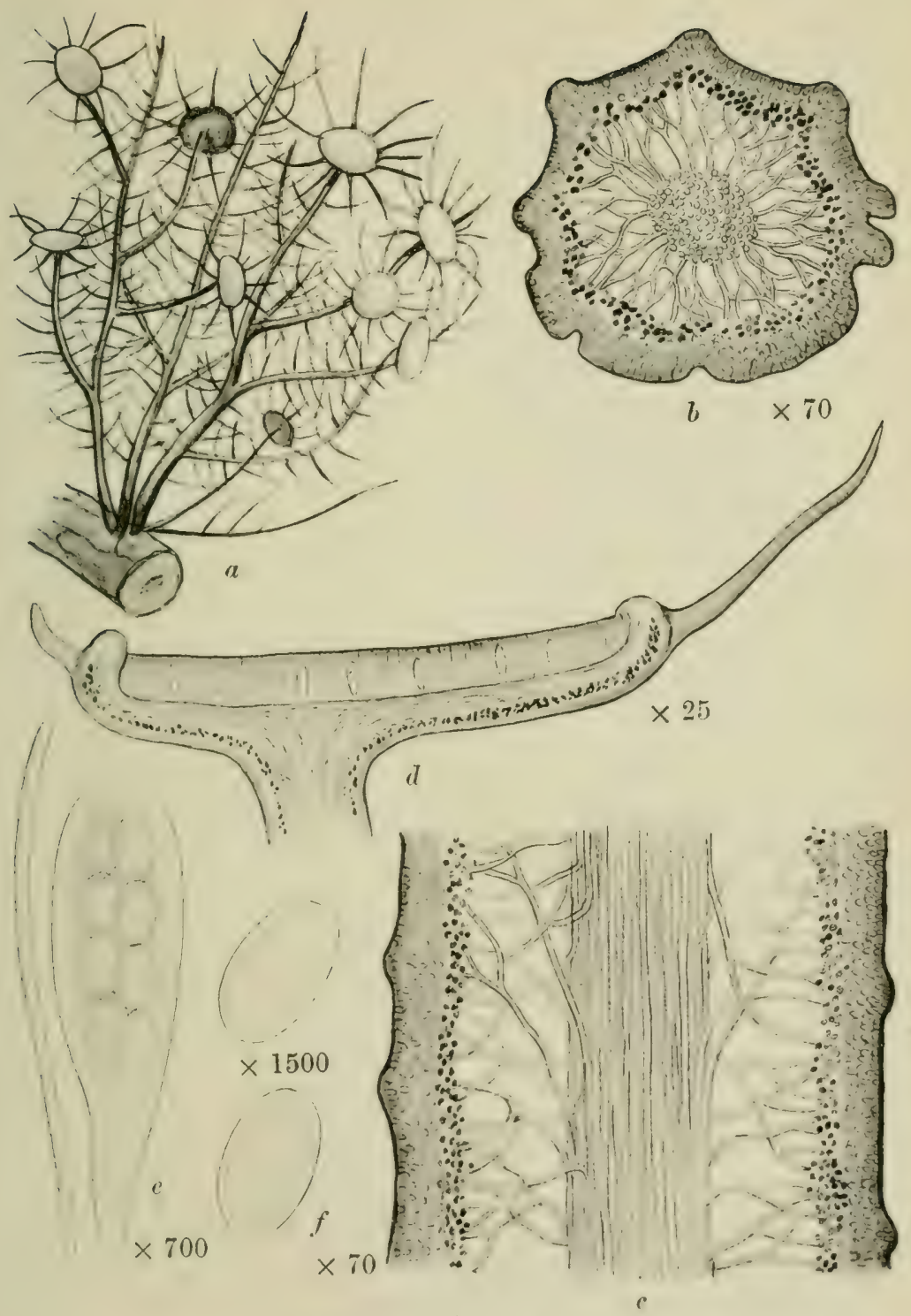

USNEA FLORIDA Web.

a. Plant on branch. $b$. Transverse section of thallus. $c$. Vertical section of thallus. d. Vertical section of apothecium. e. Ascus and paraphysis. $f$. Spores. 

Plate 43
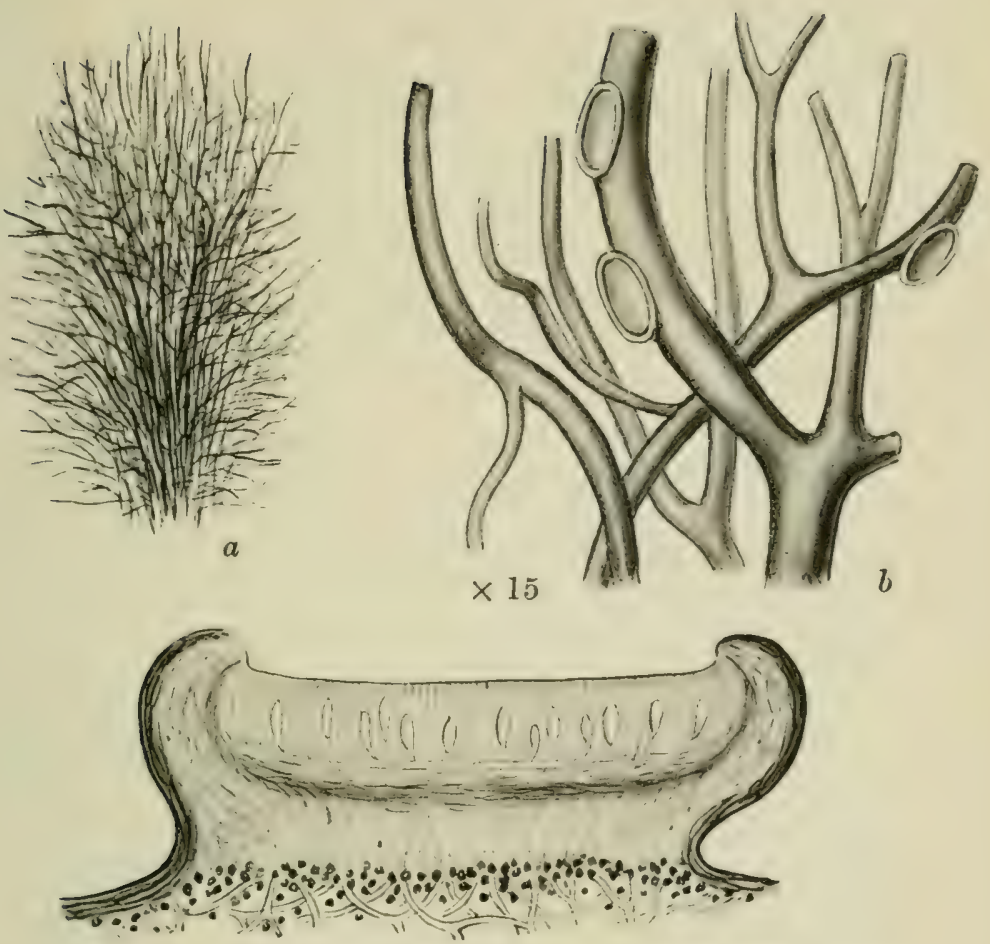

$\times 60$

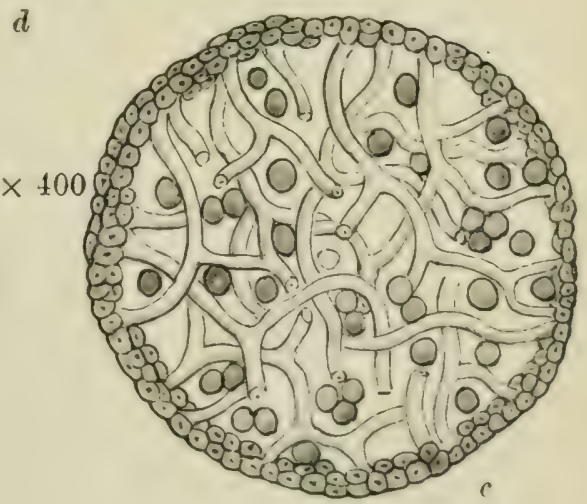

ALECTORIA JUBATA Ach.

a. Plant. b. Portion of plant. c. Transverse section of thallus. $d$. Vertical section of apothecium. c. Aseus and paraphysis. $f$. Spores. 



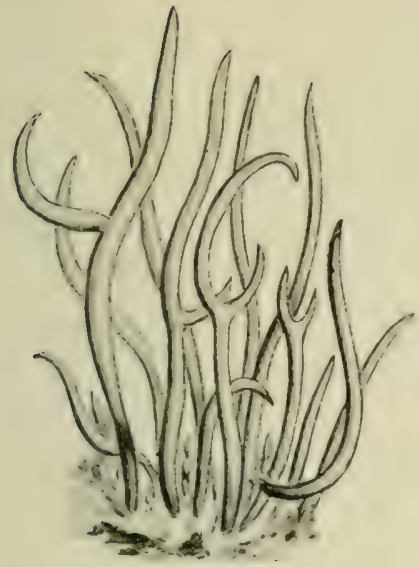

$a$
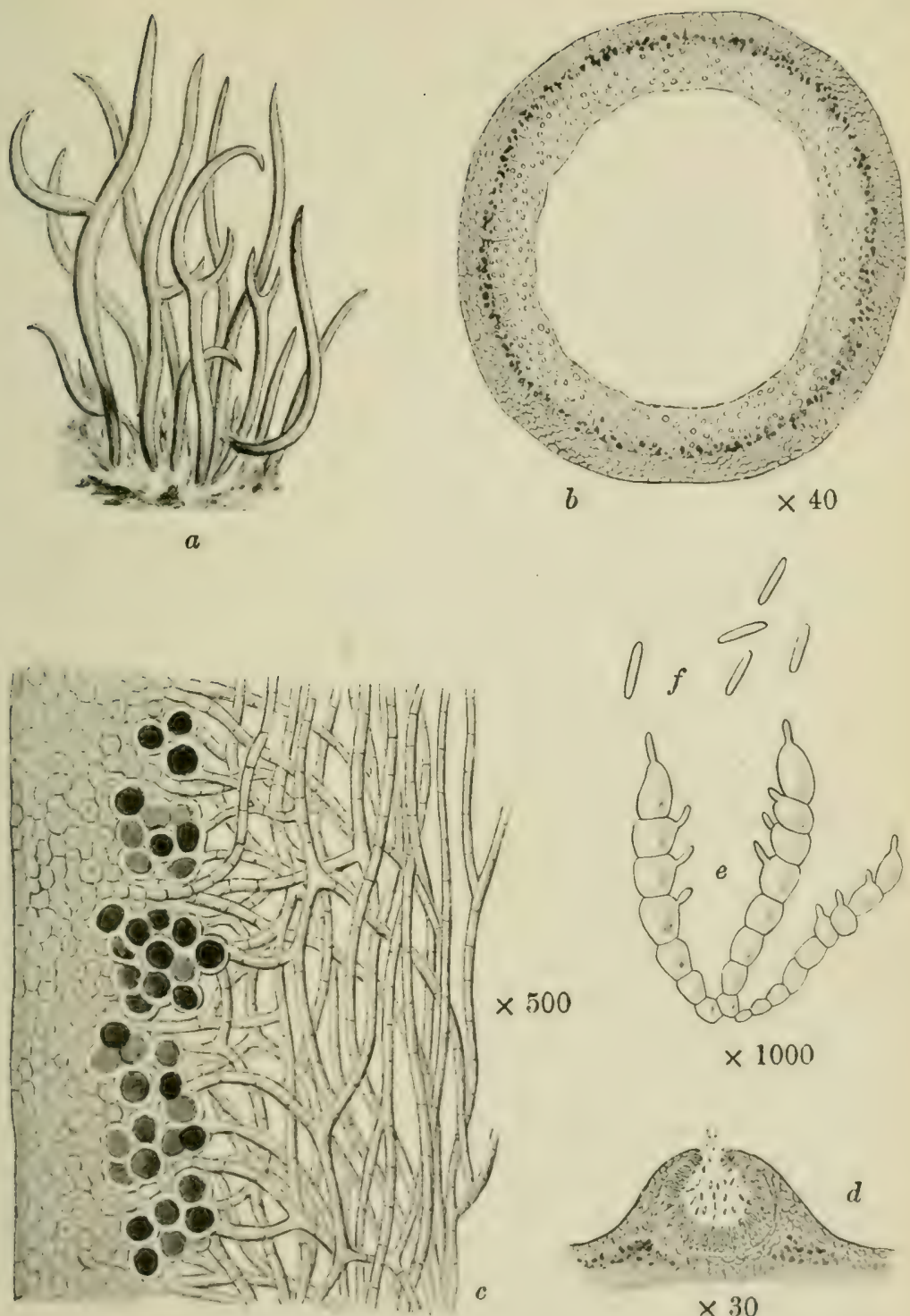

OERANIA VERMICULARIS S. F. Gray.

a. Plant on grounà. b. Transverse section of thallus. c. Vertica! section of thallus. $d$. Vortical section of spermogone. e. Sterigmata. $f$. Spormatis. 



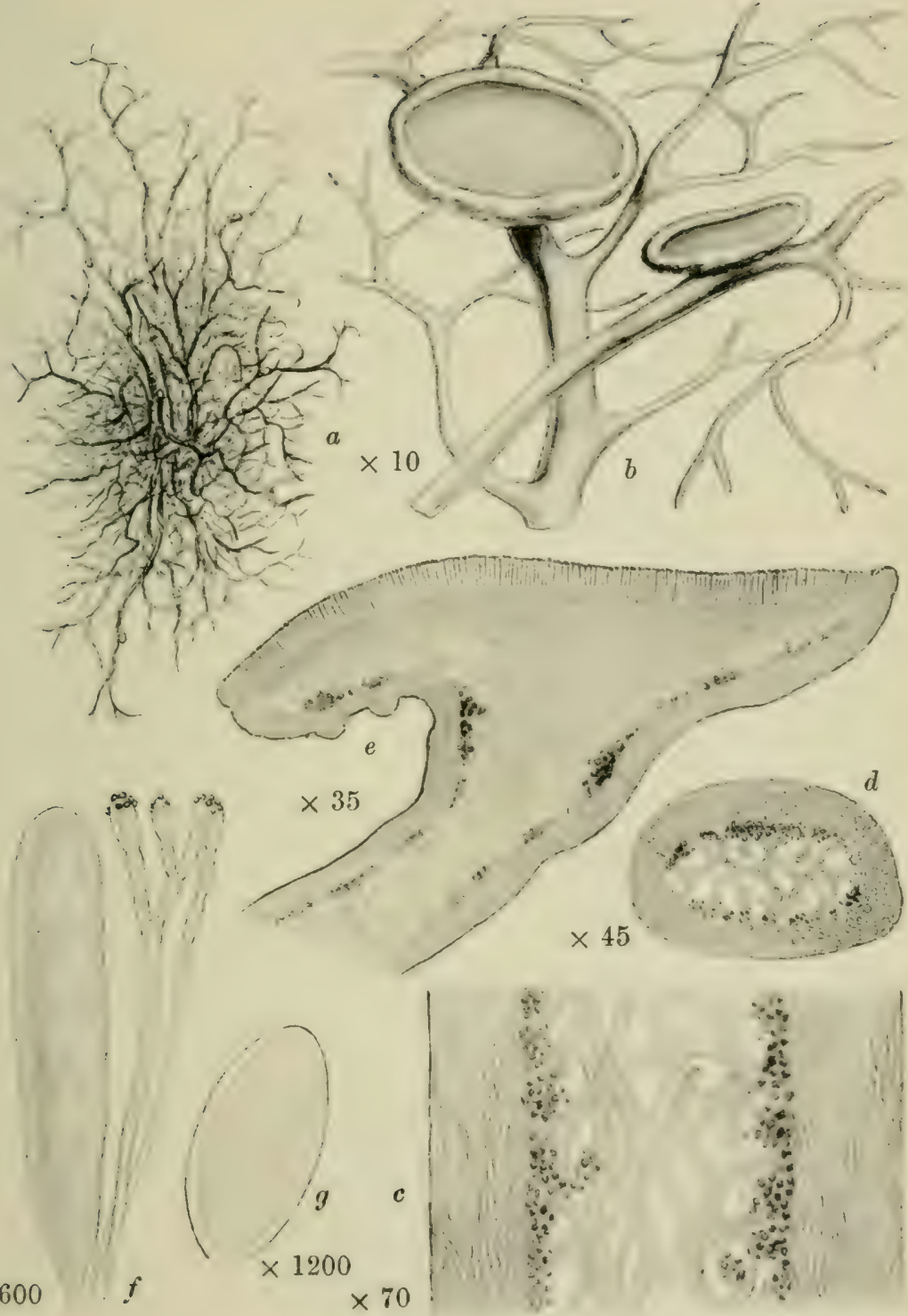

TELOSCHISTES FLAVICANS Norm.

a. Plant. b. Portion of plant. c. Longitudiaal section of frond. d. Transverso rection of frond. e. Vertical section of apothecium. $f$. Ascus and paraphyses. $g$. Spore. 

Plate 46
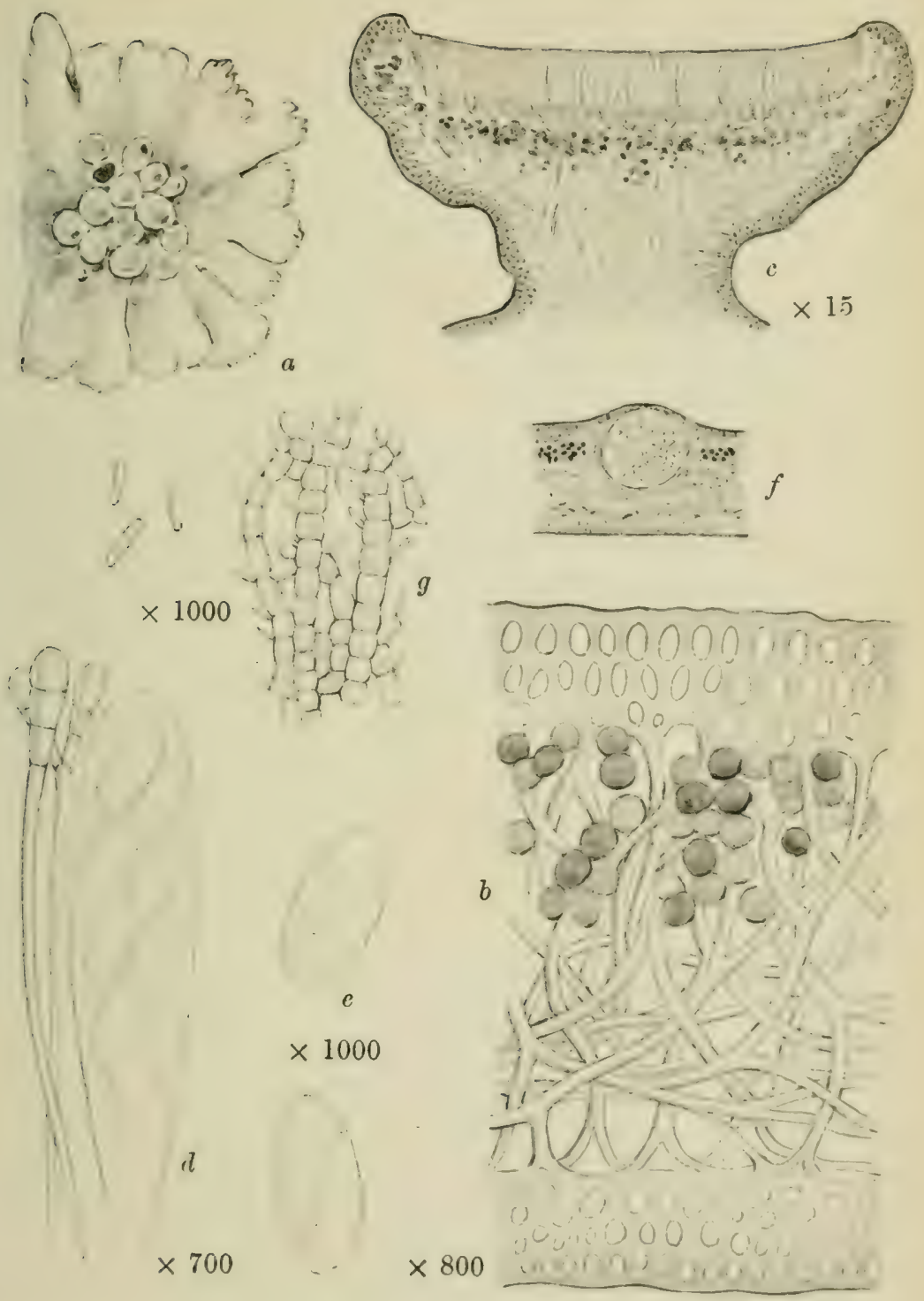

XANTHORIA PARIETINA Th, Fr.

$a$. Portion of plant. b. Vertical section of thallus. c. Vertical section of apothecium. d. Ascus end paraphyses. e. Spores. f. Vertical soction of spermogono. 

PLATE 47
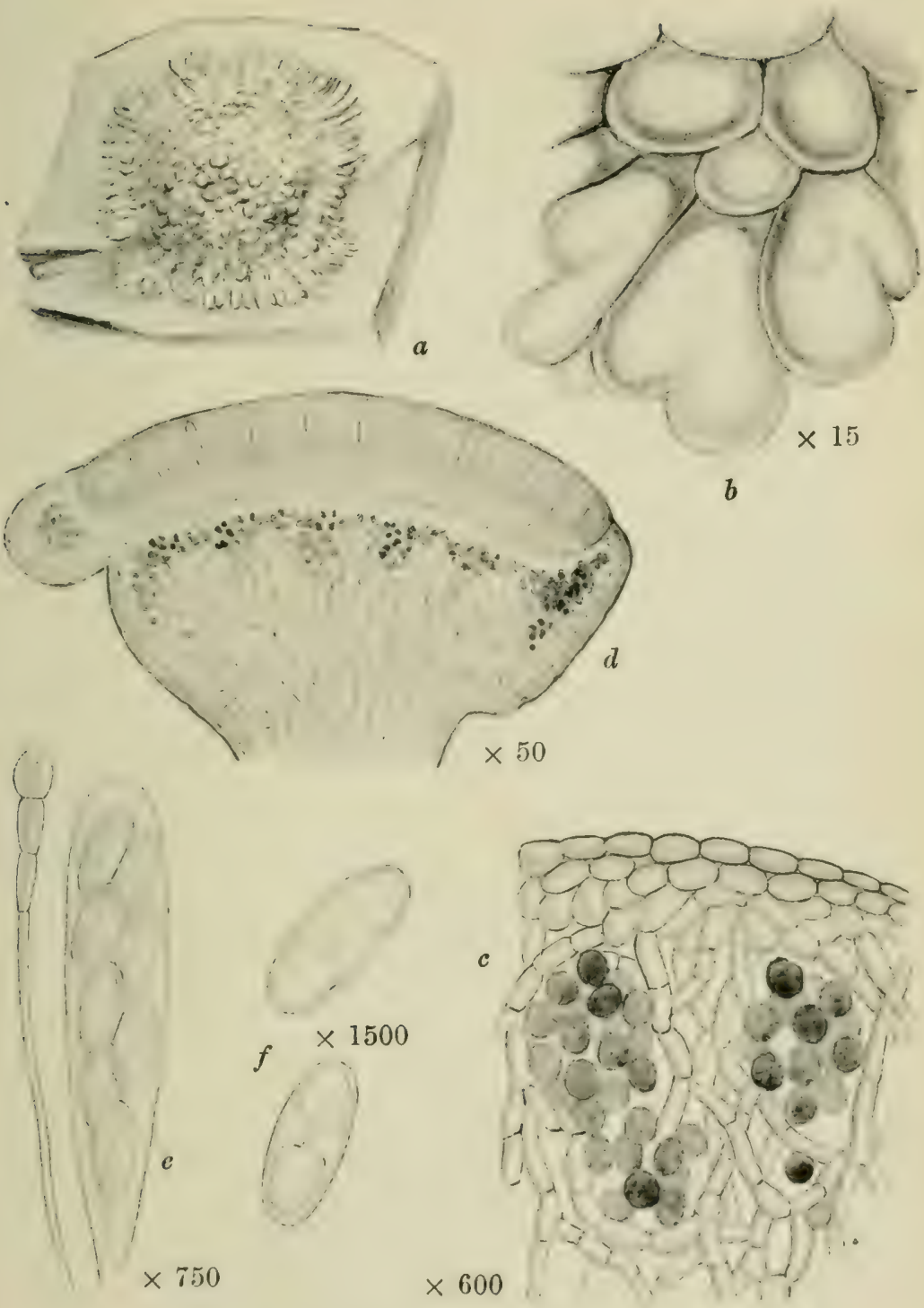

PLACODIUM MURORUM DC.

a. Plant on stone. b. Portion of plant. c. Vertical section of thallus. rl. Vertical soction of apothecium. e. Ascus and paraphysis, $f$. Spores. 


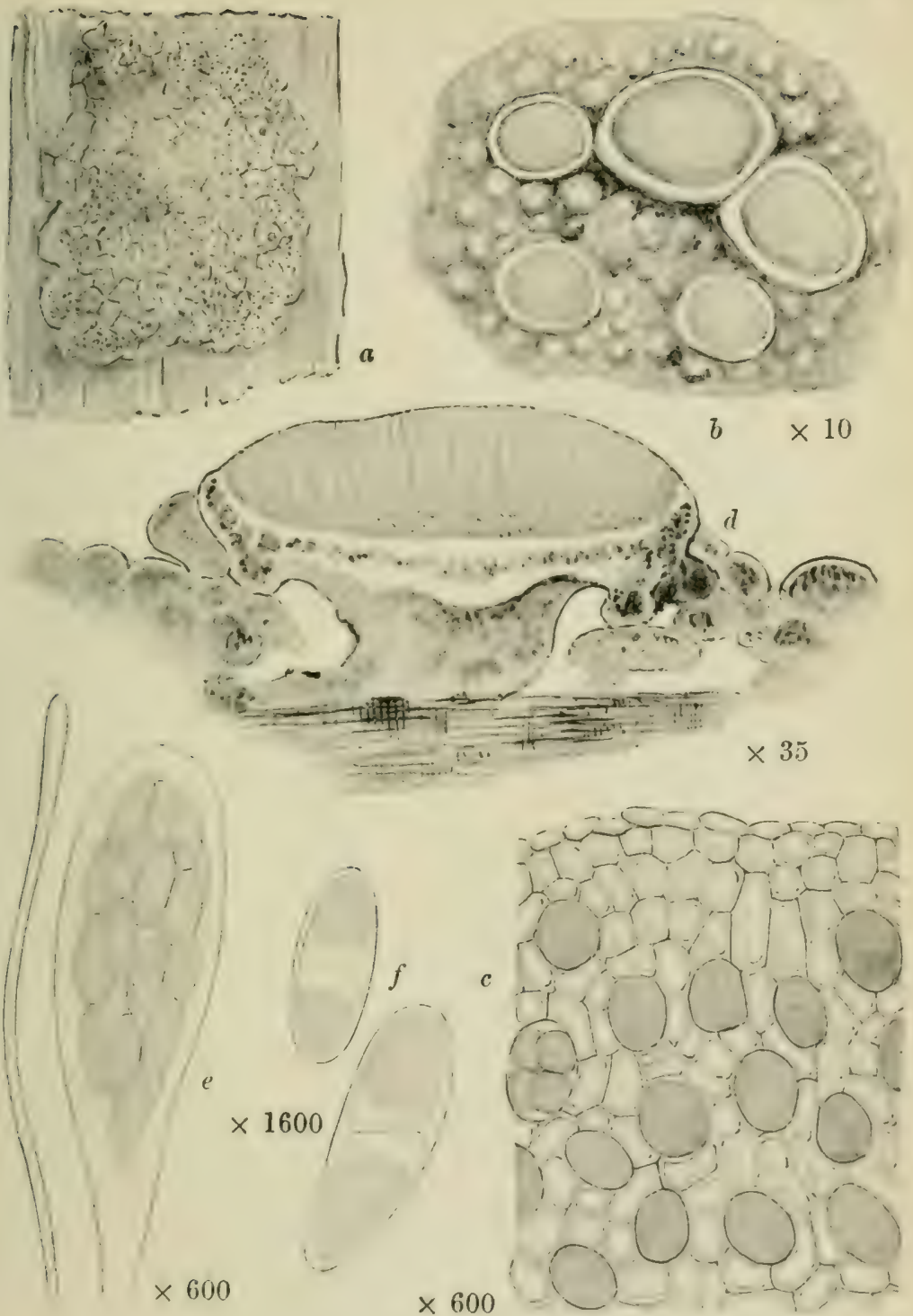

CANDELARIELLA VI'TELLINA Müll.-Arg.

a Plant on bark. b. Portion of plant. c. Vertical section of thallus. d. Vertical section of apothecium e. Ascus and paraphysis. f. Spores. 


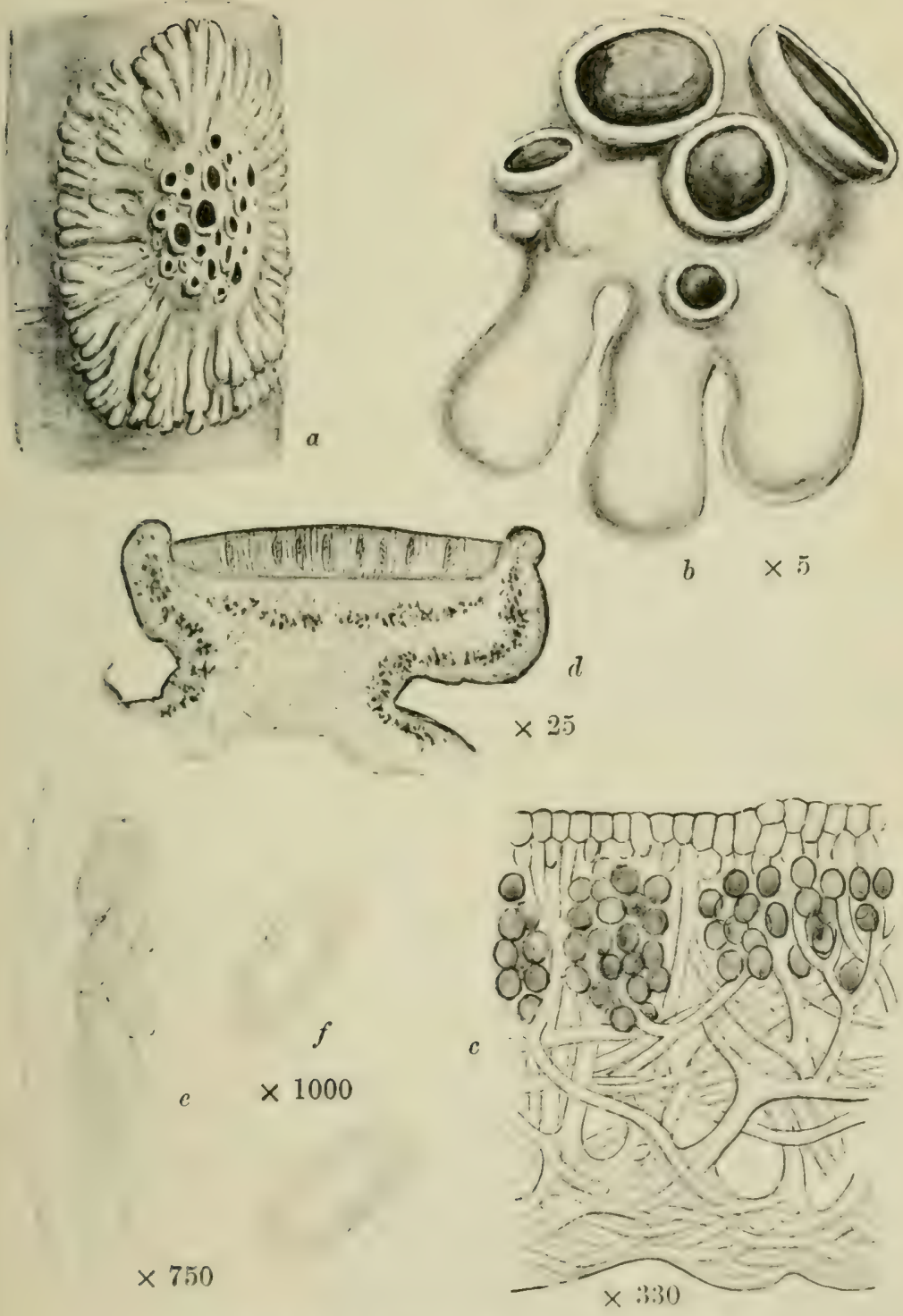

PHYSCIA STELLARIS Nyl. var. AIPOLIA Nyl.

a. Plant on bark. b. Portion of plant. c. Vertical section of thallus. d. Vertical section of apothecium. e. Ascus and paraphysis. f. Spures. 


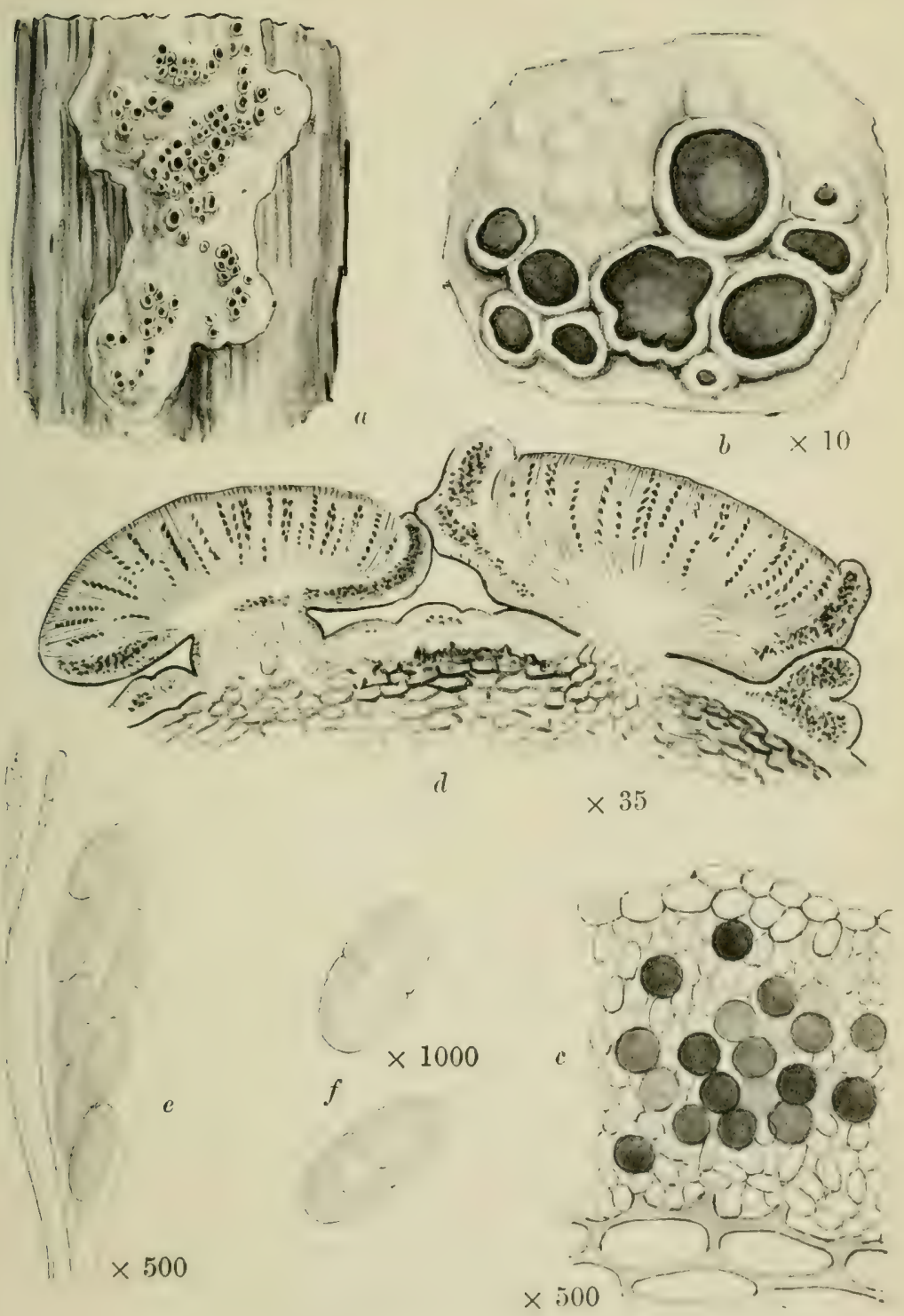

RINODINA ROBORIS Arn.

a. Plant on lark. b. Portion of plant. c. Vertical section of thallus. d. Vertical section of apothecium. e. Ascus and paraphysis. $f$. Spores. 


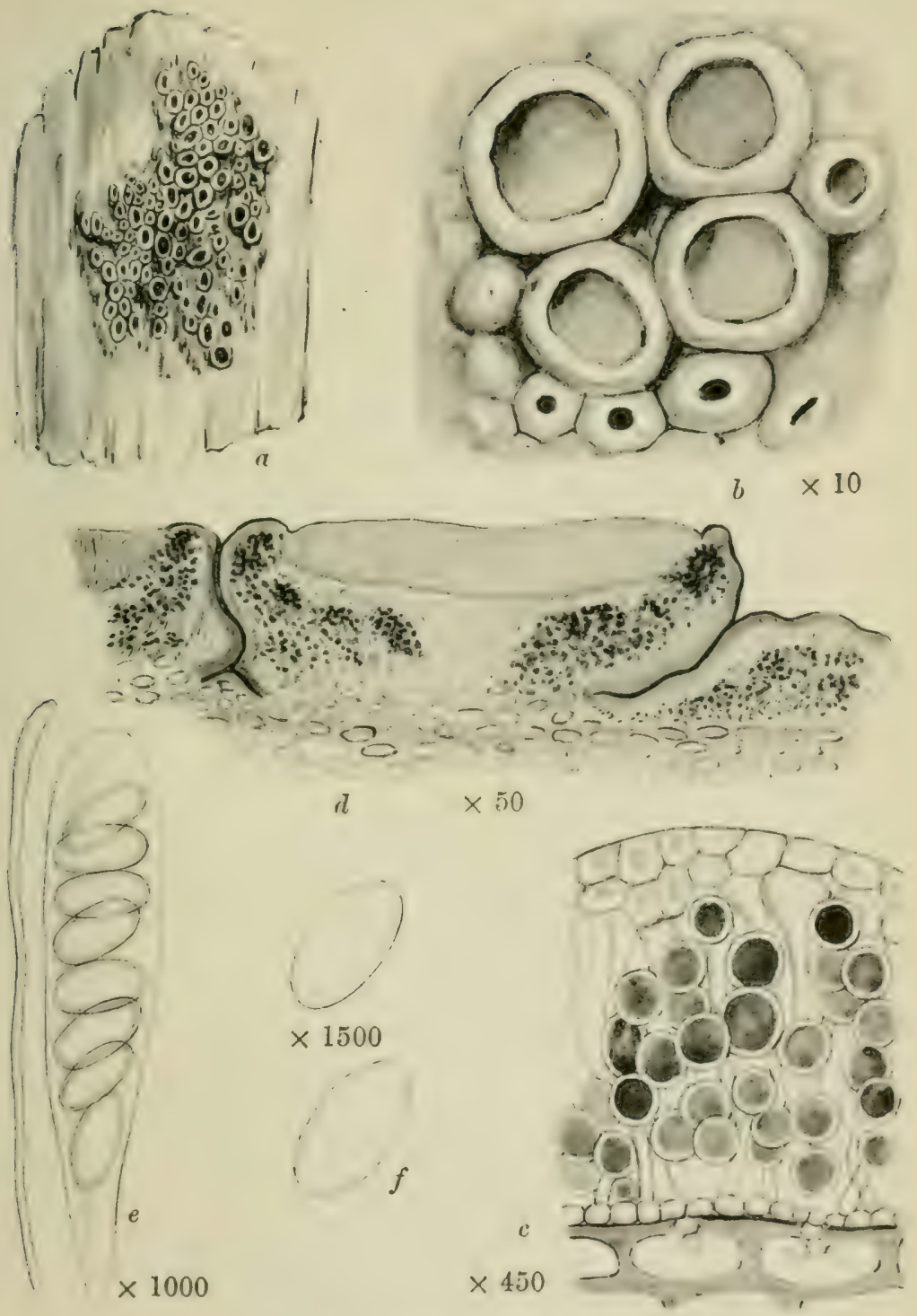

LECANORA VARIA Acb.

a. Plant on paling. b. Portion of plant. c. Vertical section of thallus. $d$. Vertical section of thallus and apothecium. $c$. Ascus and paraphysis. $j$. Spores. 


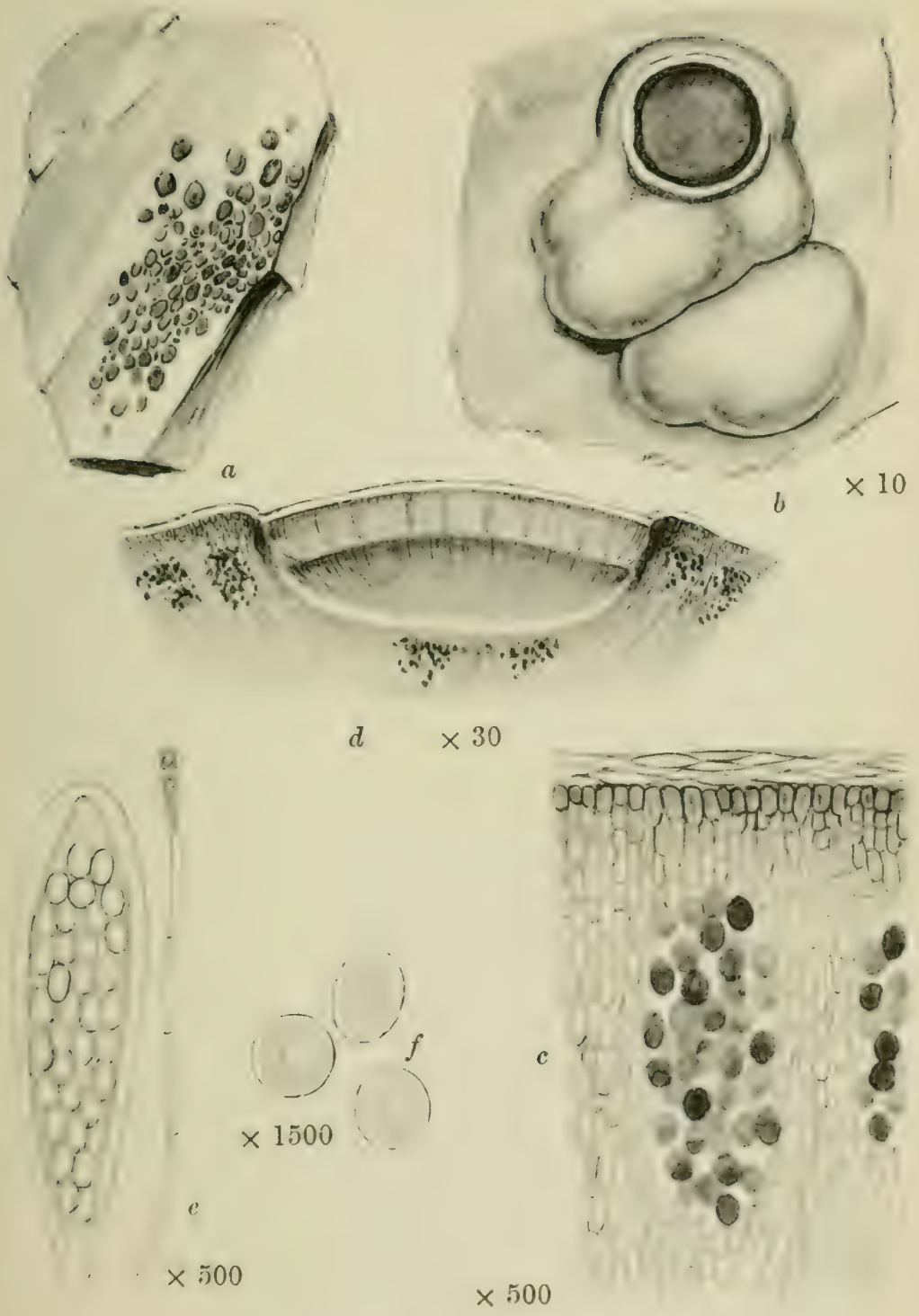

ACAROSPORA SQUAMULOSA Th. Fr.

a. Plant on rock. b. Portion of plant. c. Tertical section of squamule. d. Vertical sectiou of squamulo and apothecium. $e$. Ascus and paraplysis. $f$. Spores. 


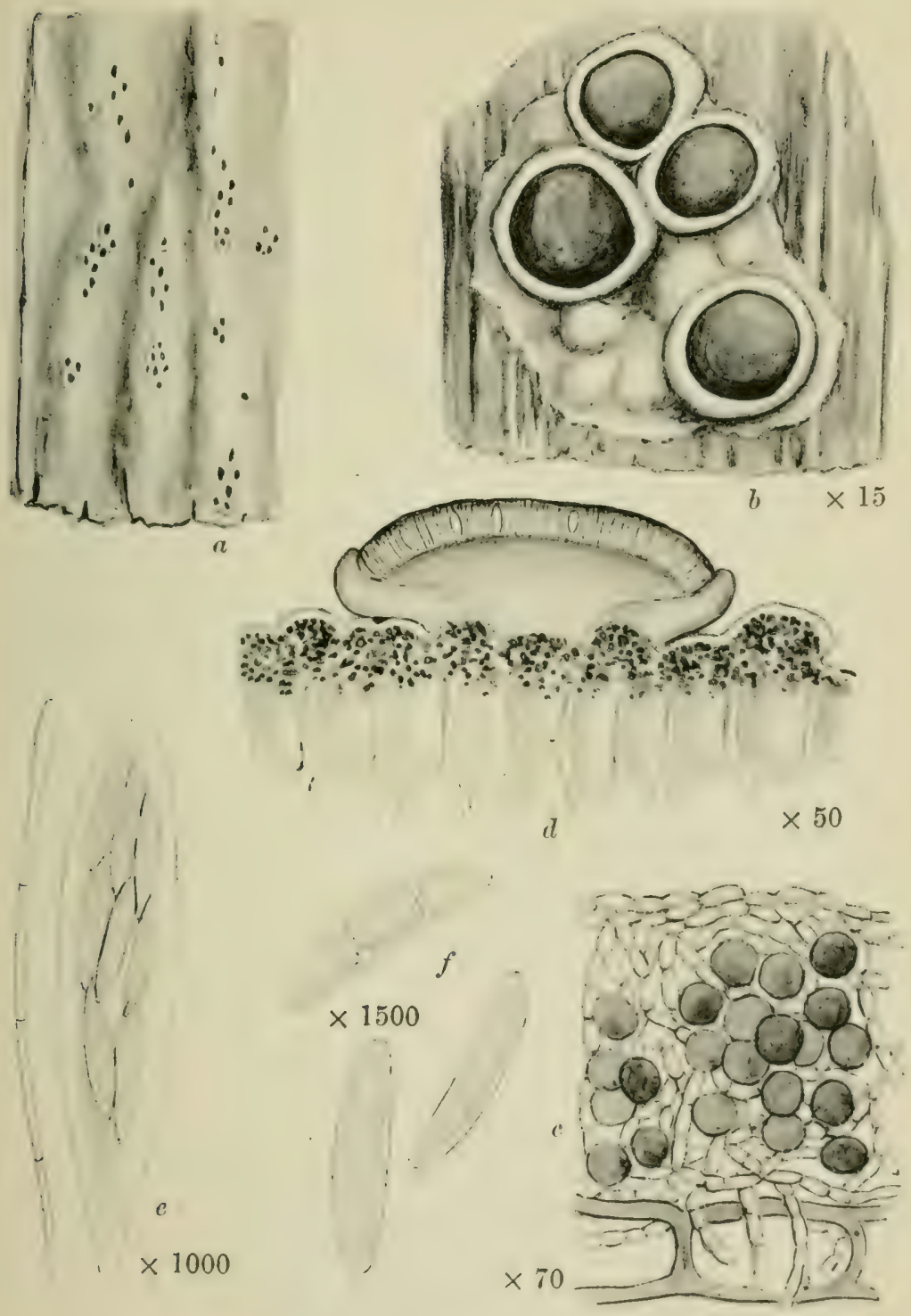

LECANIA SYRINGEA Th. Fr.

12. Piant on bark. 3. Portion of plant. c. Vertical section of thallus. d. Vertical section of thallus and apothecium. c. Ascus and paraplyysis. $f$. Spores. 


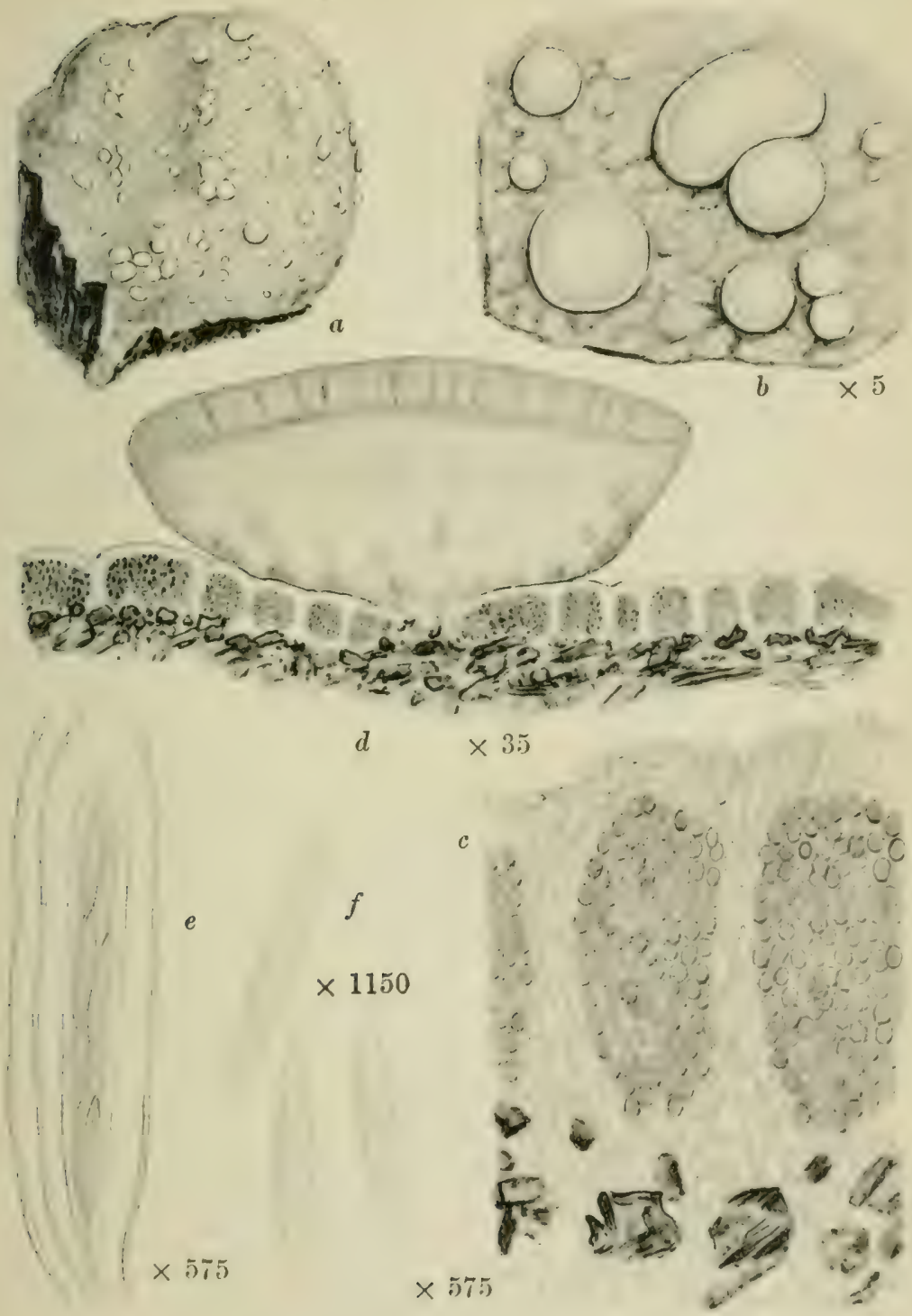

IOMADOPHILA ERICETOIZUM A. Zablbr.

a. Plant on soil. b. Portion of plant. c. Vertical section of thallus. $d$. Vertical section of thallus and apothecium. $e$. Ascus and paraphyses. $f$. Spores. 

Plate 55
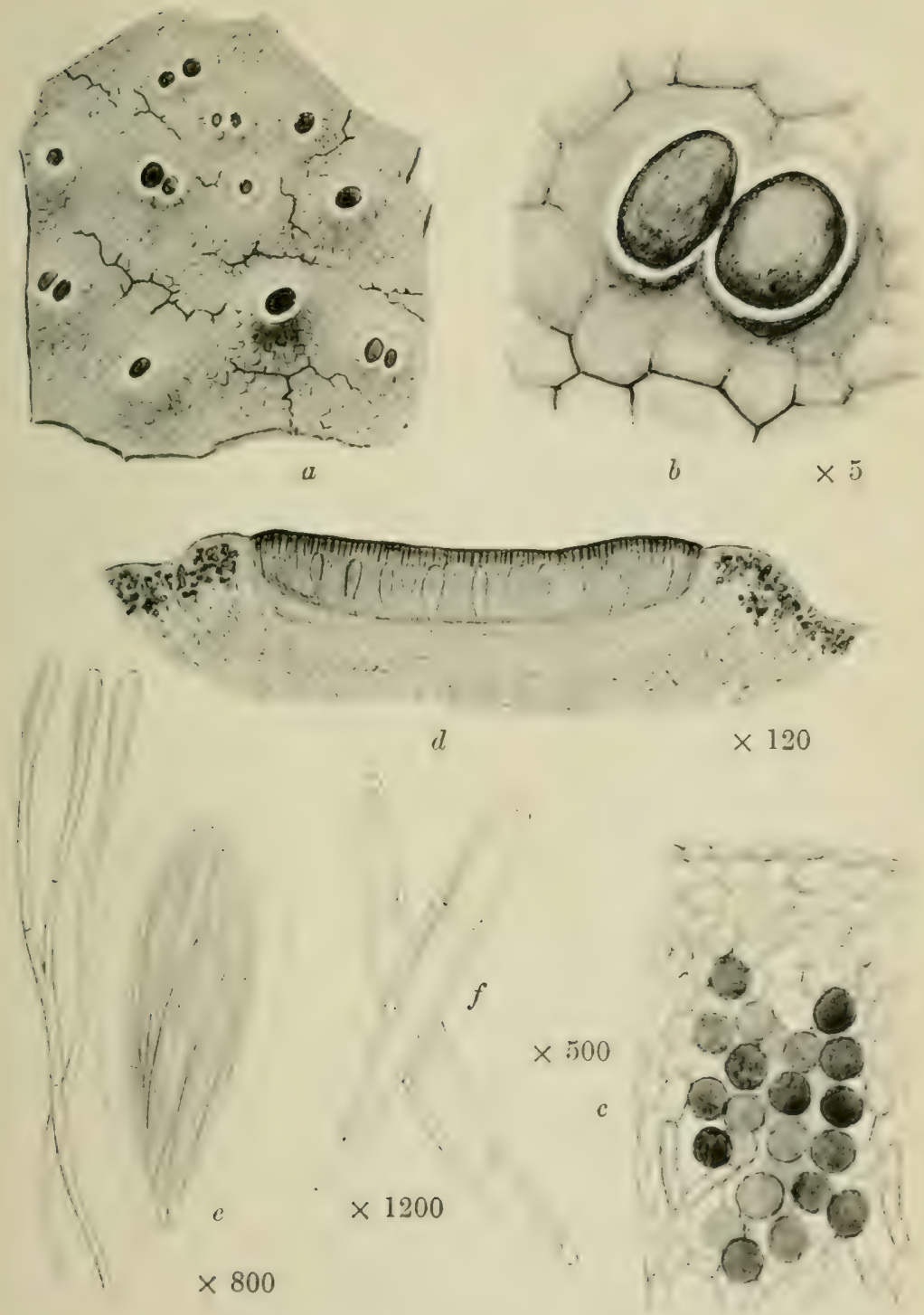

HFMATGMIIA COCCINEUM Roorb.

a. l'lant on rock. b. Purtion of plant. c. Vertical section of thallus. d. Vertical section of thallus and apothecium. $c$. Aicus and paraphyses. $f$. Sporos. 


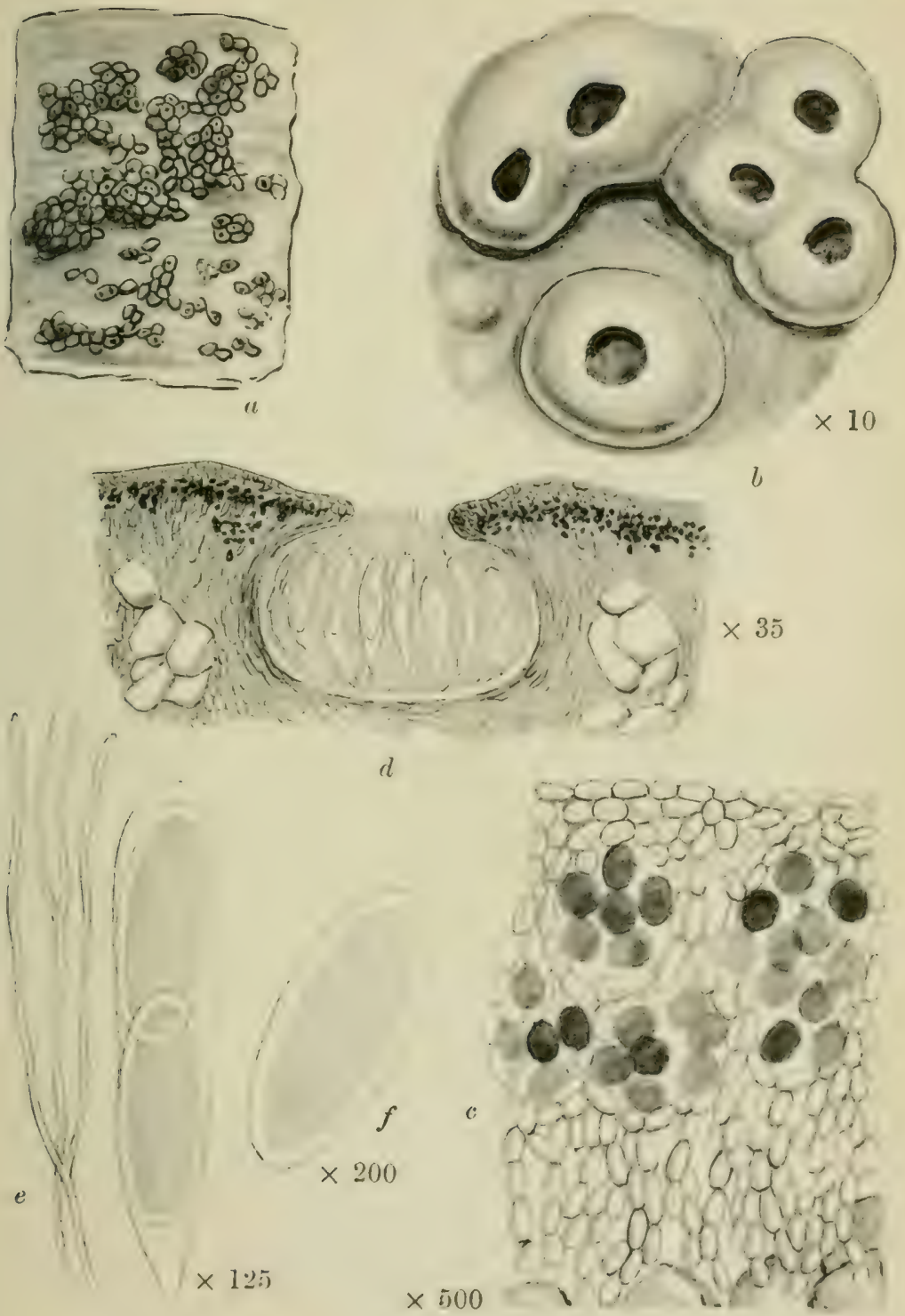

PERTUSARIA PERTUSA Dalla Torre and Sarnth.

a. Plant on rock. b. Portion of plant. c. Fertical section cf thallus. d. Verticul section of thallus and apothecium. e. Ascus and paraphyses. $f$. Spore. 


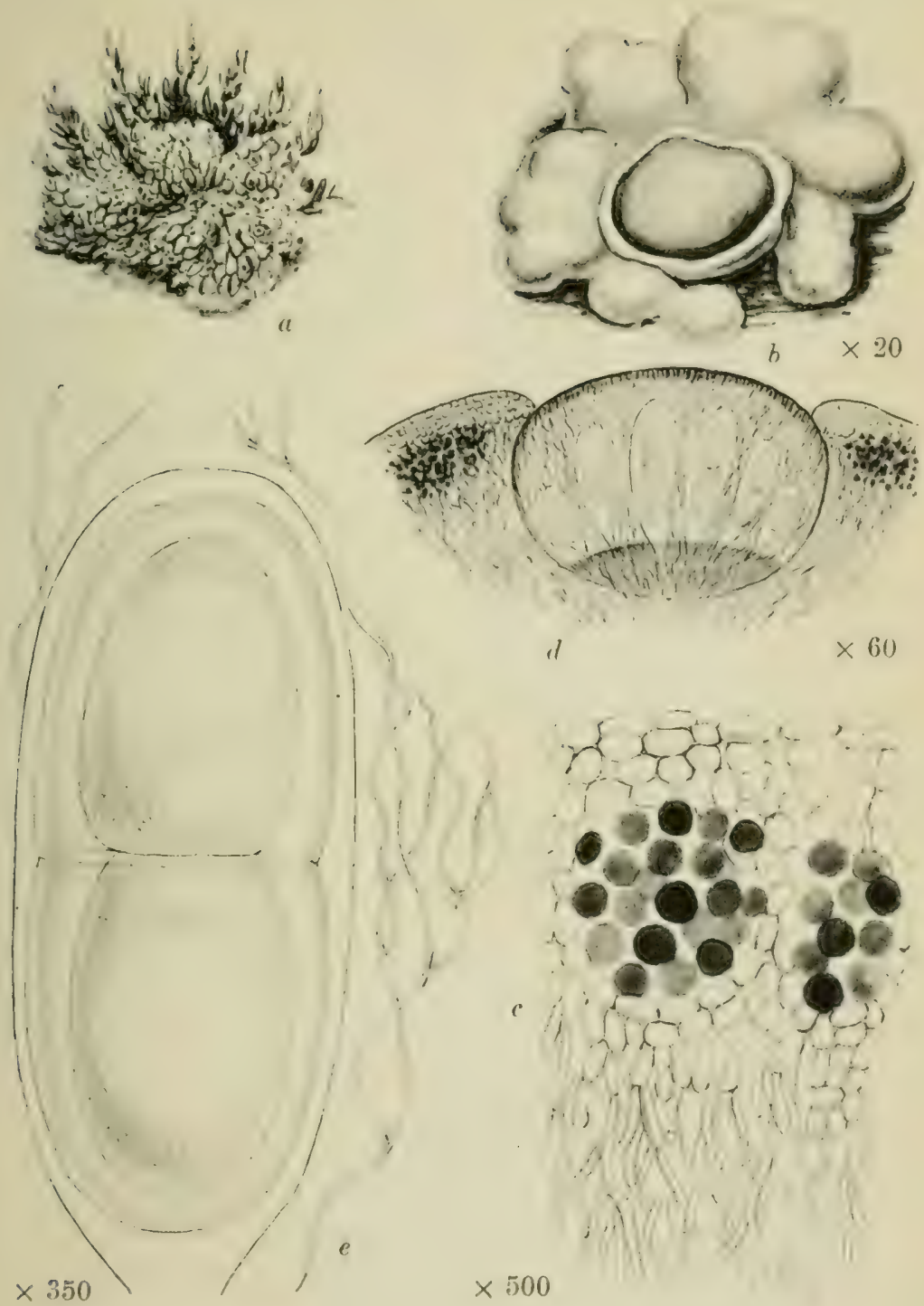

VARICELLARTA MICROSTICTA Nỵ.

a. Plant on mossy soil. $b$. Portion of plant. e. Vortical sectim of thullus. d. Vertical section of thallus and apotheoium. r. Ascus with spore and paraphyses. 


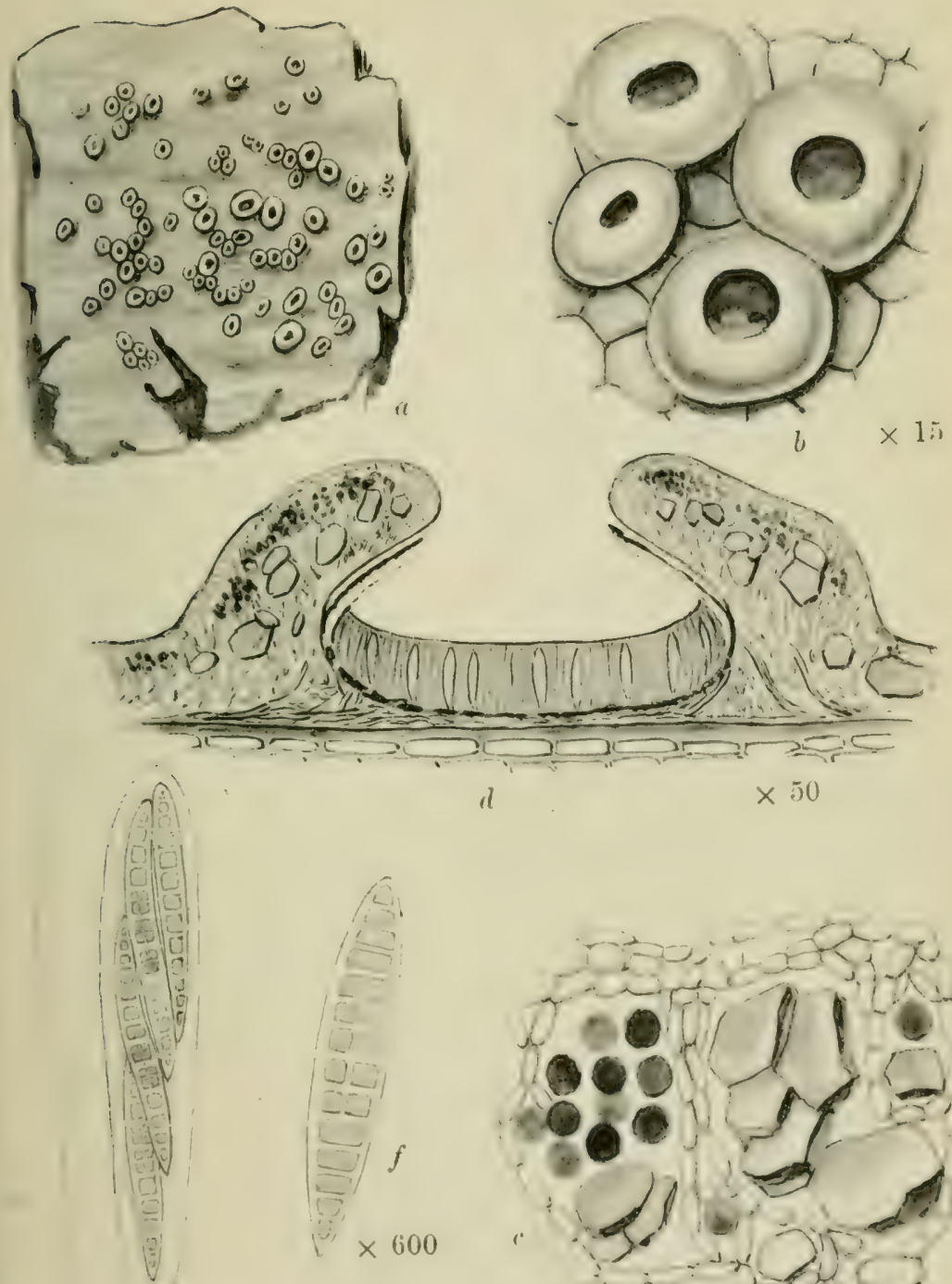

$\times 450$

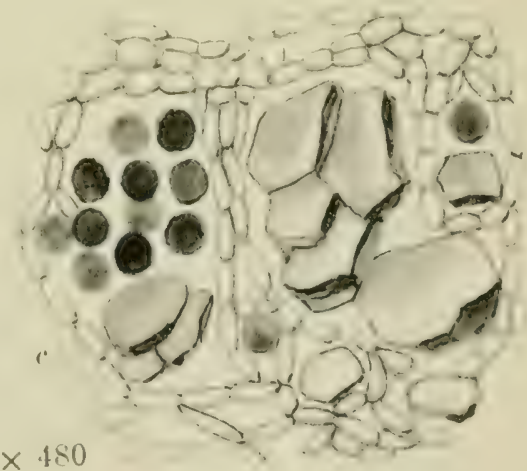

THELOTREMA LEPADINUM Ach.

a. Plant un bark. b. Lortion of plant. c. Vertical section of thullus. i. Iertical section of thallus and apothecium. $r$. Aseus and paraphysis. i. spure 


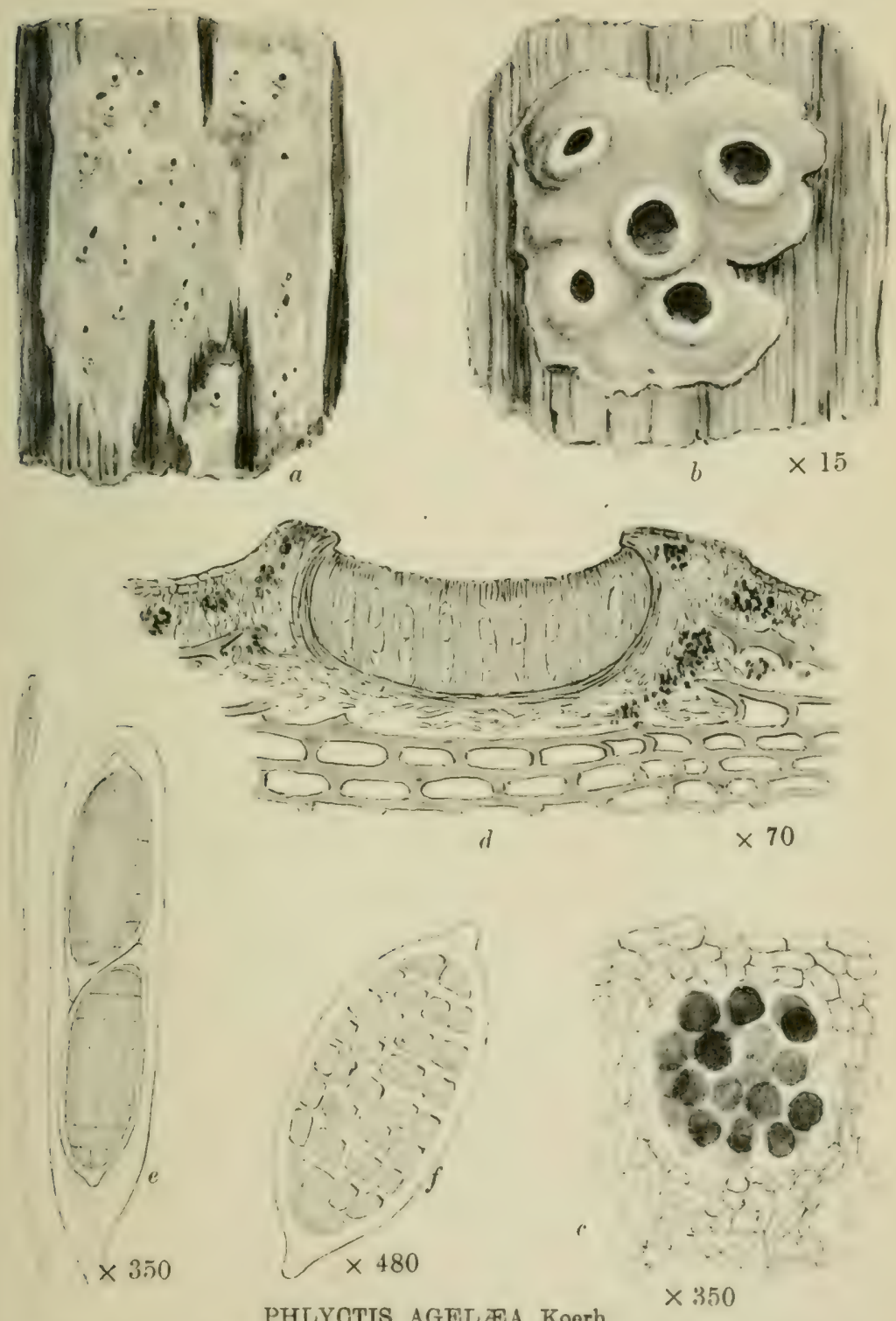

PHLYCTIS AGELFA Koerb.

a. Plant on bark. b. Portion of plant. c. Vertical section of thallus. d. Vertical section of thallus and apotbecium. e. Aseus and parapbrsis. $f$. Spore. 


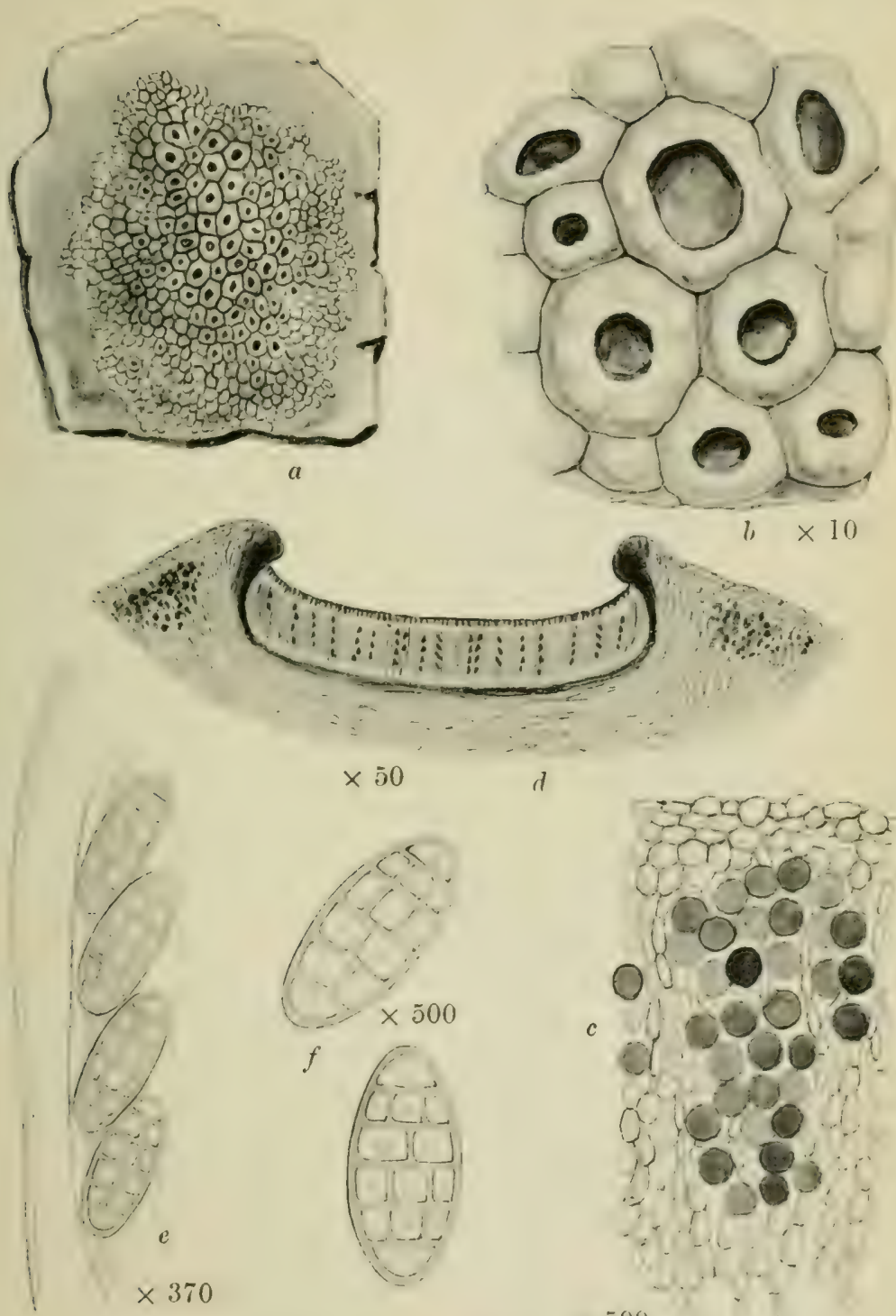

d

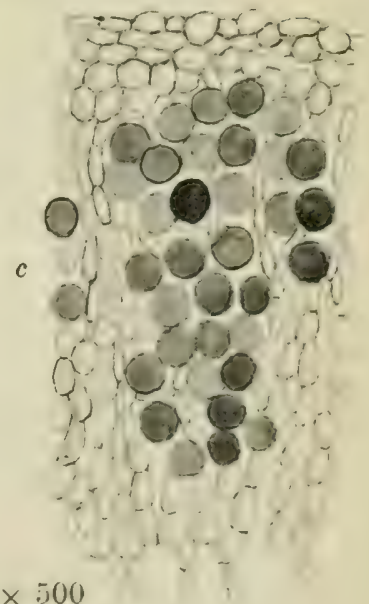

DIPLOSCHISTES SCRUPOSUS Norm.

$a$. Plant on stone. b. Portion of plant. c. Vertical section of thallus. $d$. Vortical section of thallus and apothecium.

e. Ascus and paraphysio. f. Spores. 



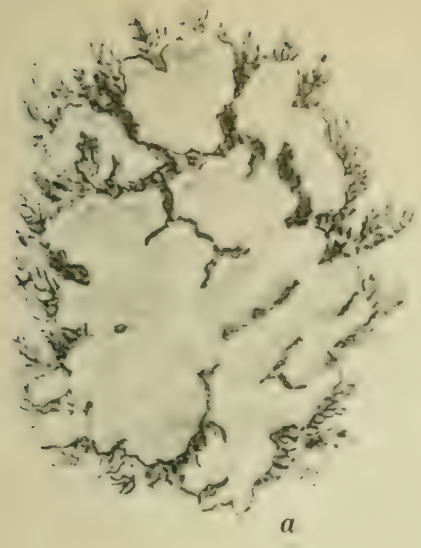

A
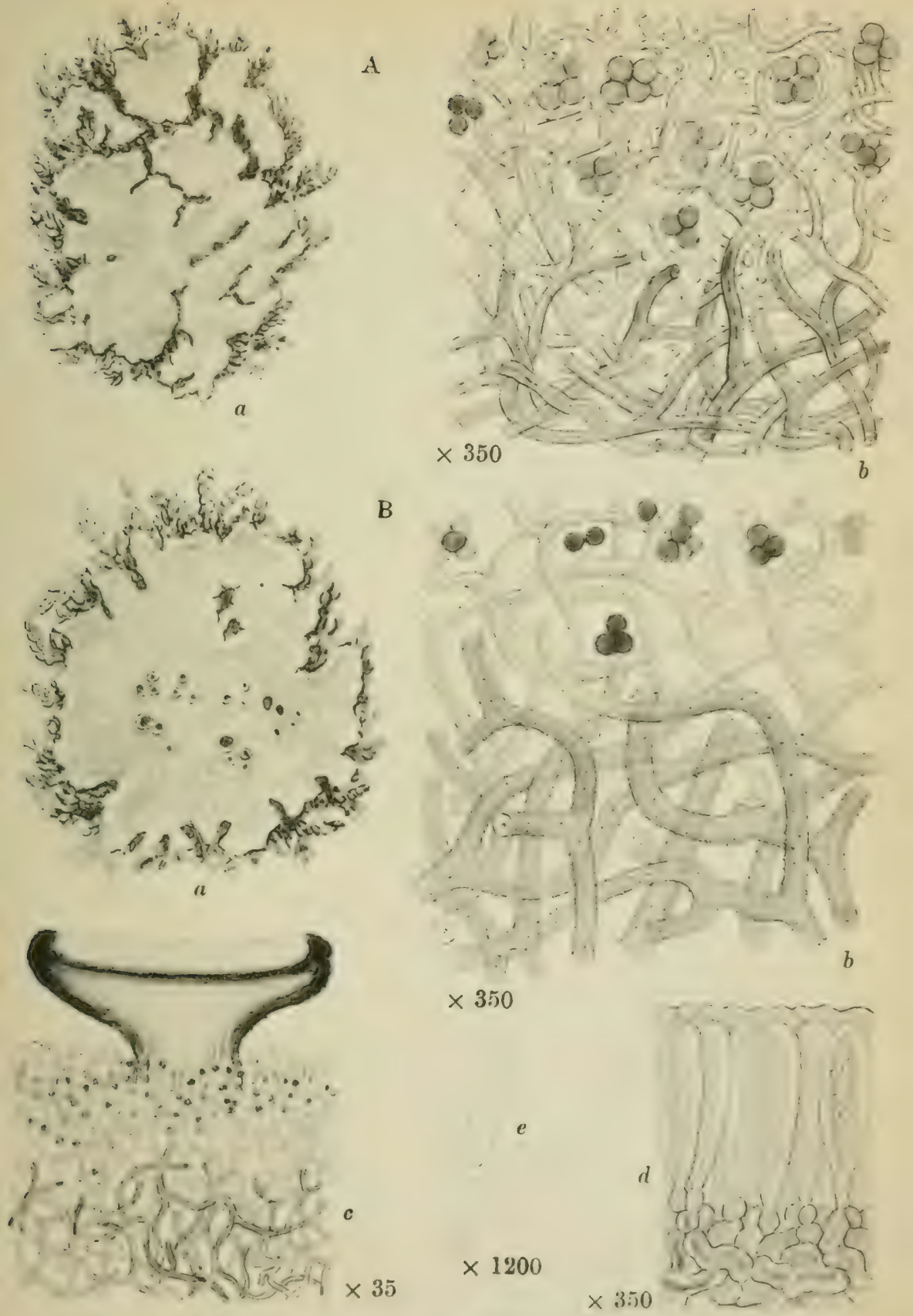

CROCYNIA Mnssal.

A-C. Lanuginosa Hue. a. Plant on moss. . Vertical section of sterilo thallus. B-C. gossyjina Nyl. (suntrupical). a. Plant on moss. . Vertical section of tiallus. c Vertical section of thallus and apothecium. d. Asci. c. Spores 


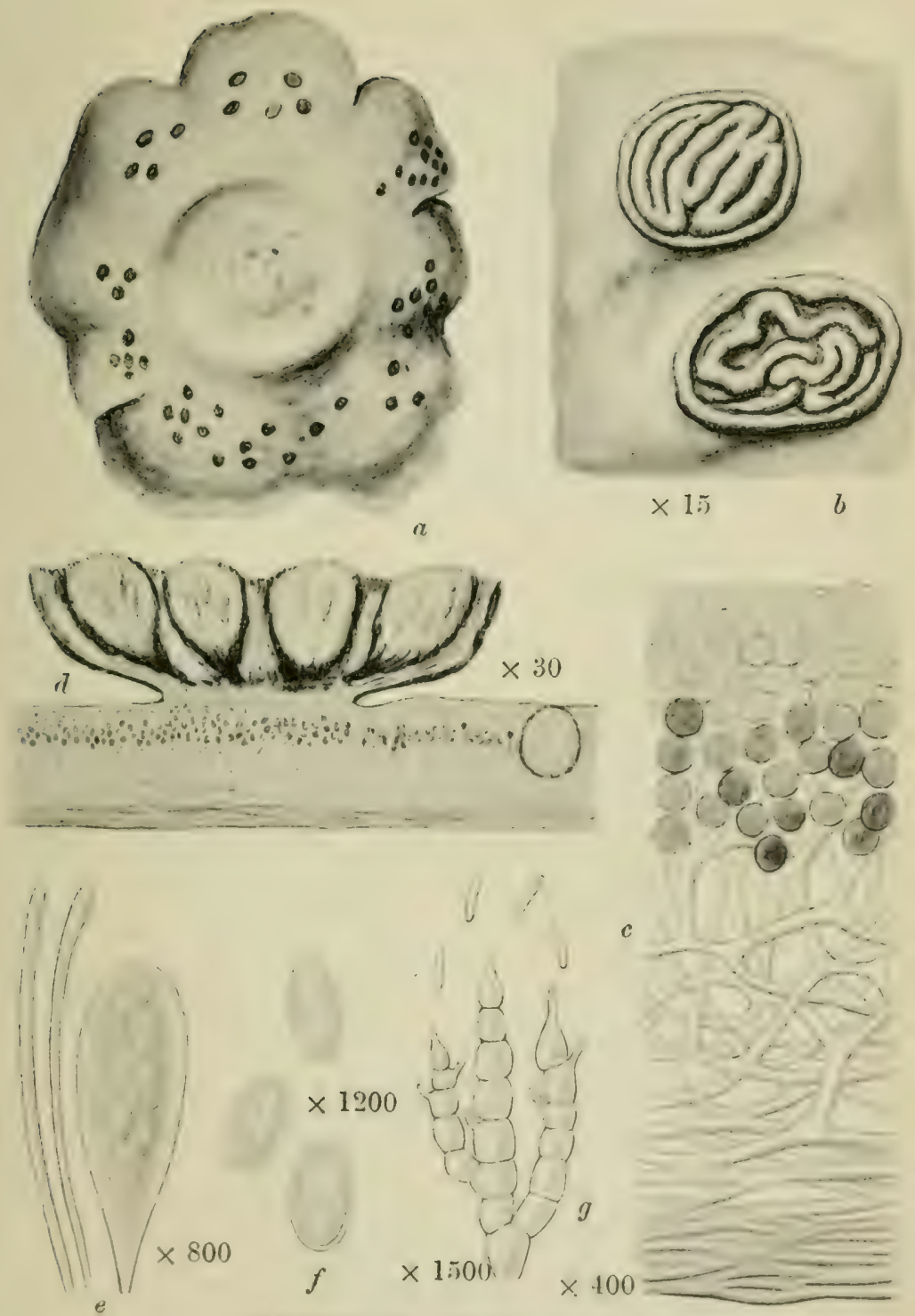

GYROPHORA PROBOSCIDEA Ach.

a. Plant from rock. b. Portion of plant and apothecia. c. Vertical section of thallus, d. Vertical section of thallus, apothecium and spermogene. $c$ Ascus and paraphyses. $f$. Spores. g. Storigmata and spermatia. 


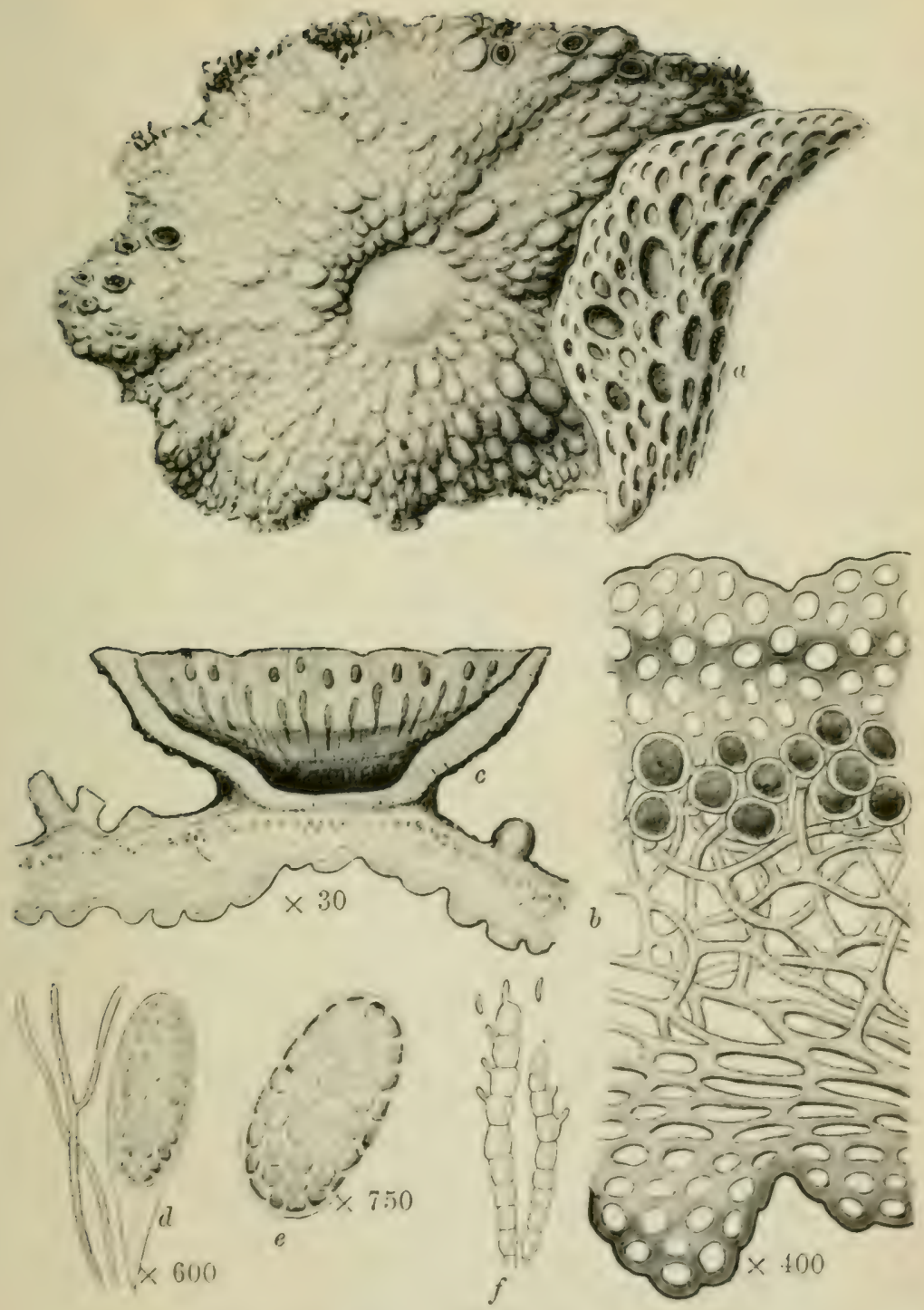

UMBILICARIA PUSTULATA Hofim.

a. ILant from rosk, i. Virtical section of thallus. c. Vertiral section of thallum aud apothecium. d. Ascus and paraphysos. c. Spore. f. Sterigmata and spermatia. 


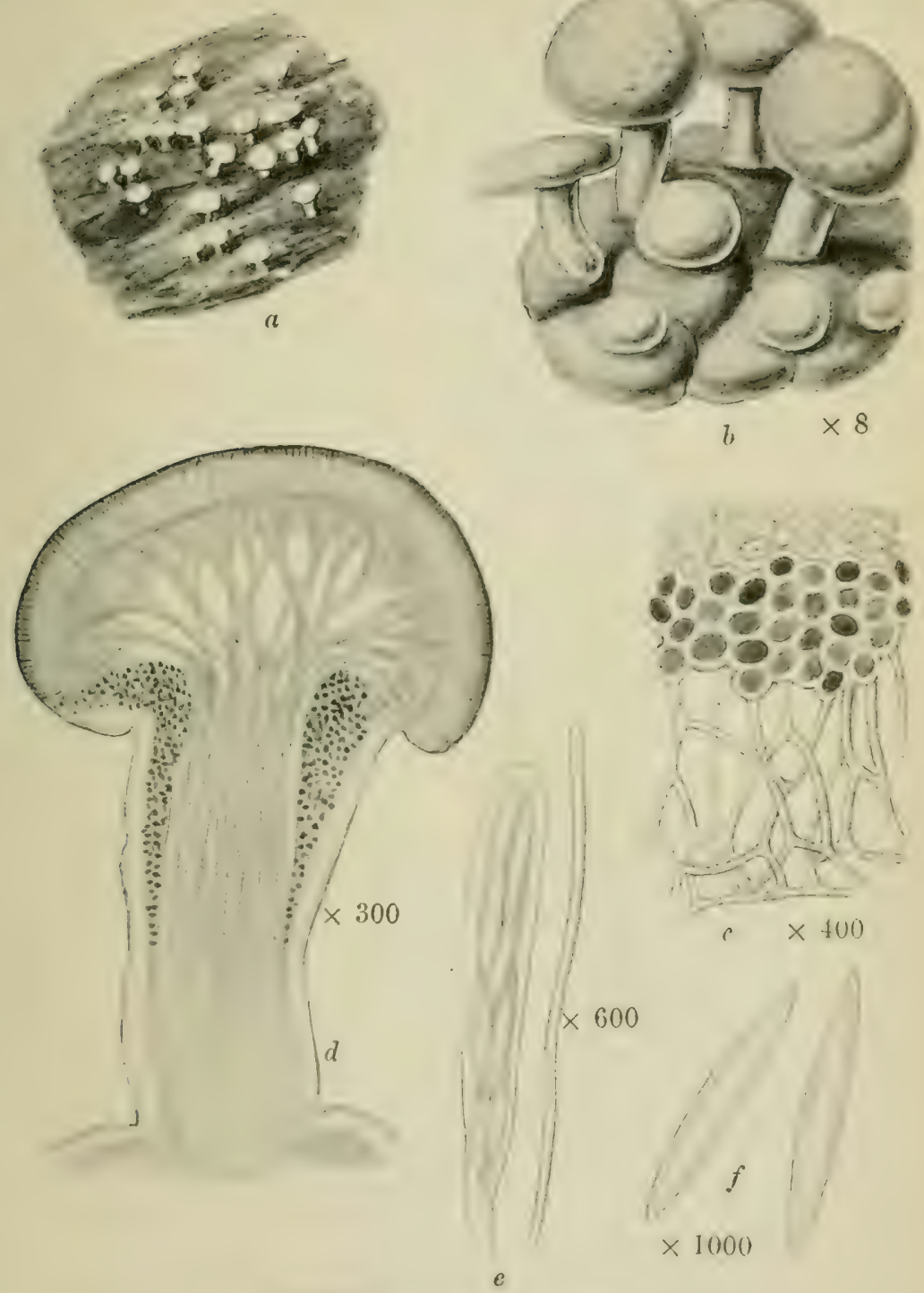

BAOMYYES ROSEUS Pers.

a. Plant on soil. b. Portion of plant. c. Section of thallus. d. Section of apothecium. e. Ascus and paraphysis. $f$. Spores. 


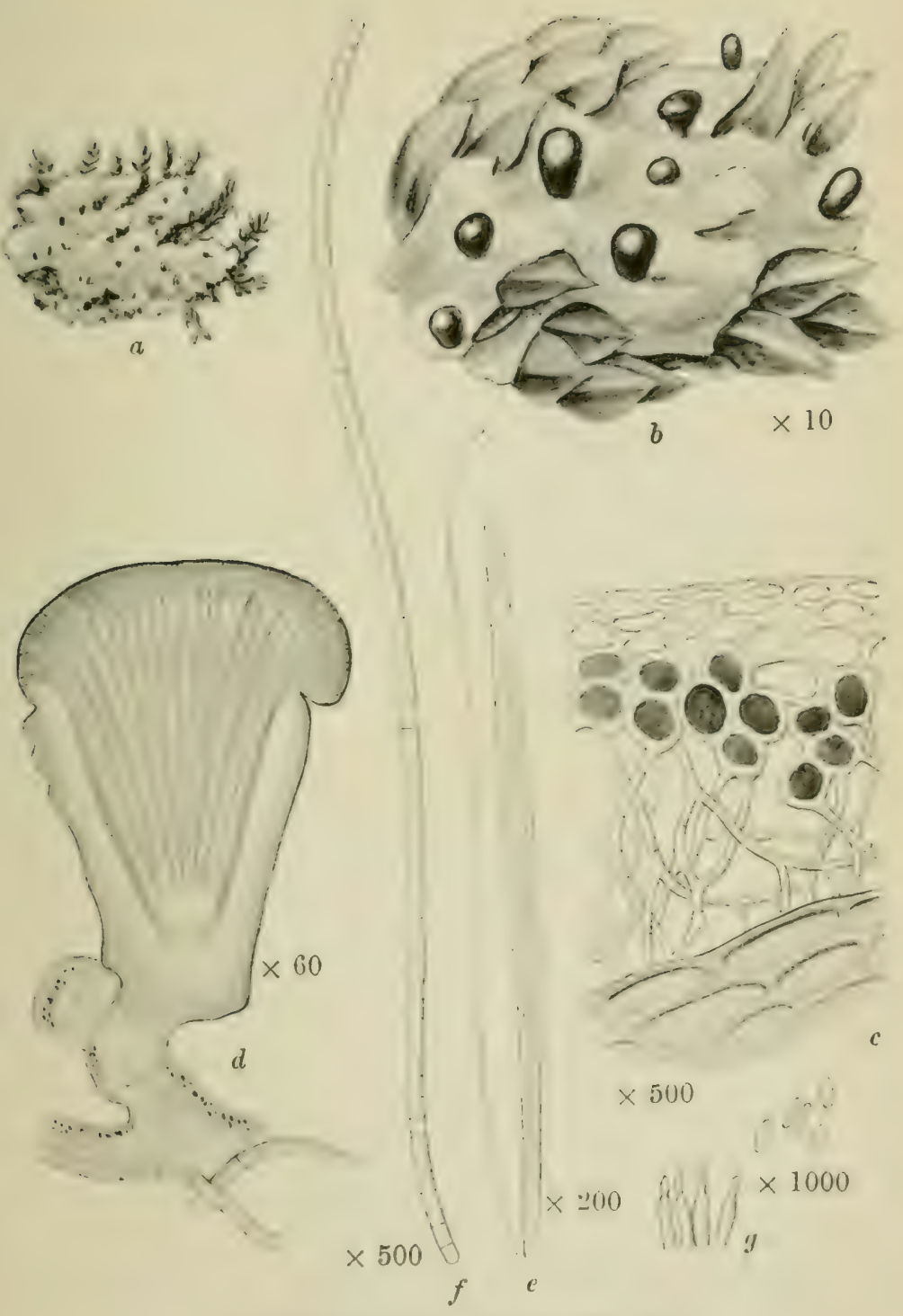

GOMPHILLUS CALYCIOIDES Nyl.

a. Plant on moss, b. Fortion of plant. c. Vertical acction of thallus. d. Verticul section of apothecium. e. Ascus and paraphyses, $f$. Spore. g. Sterigmata and spermatia. 


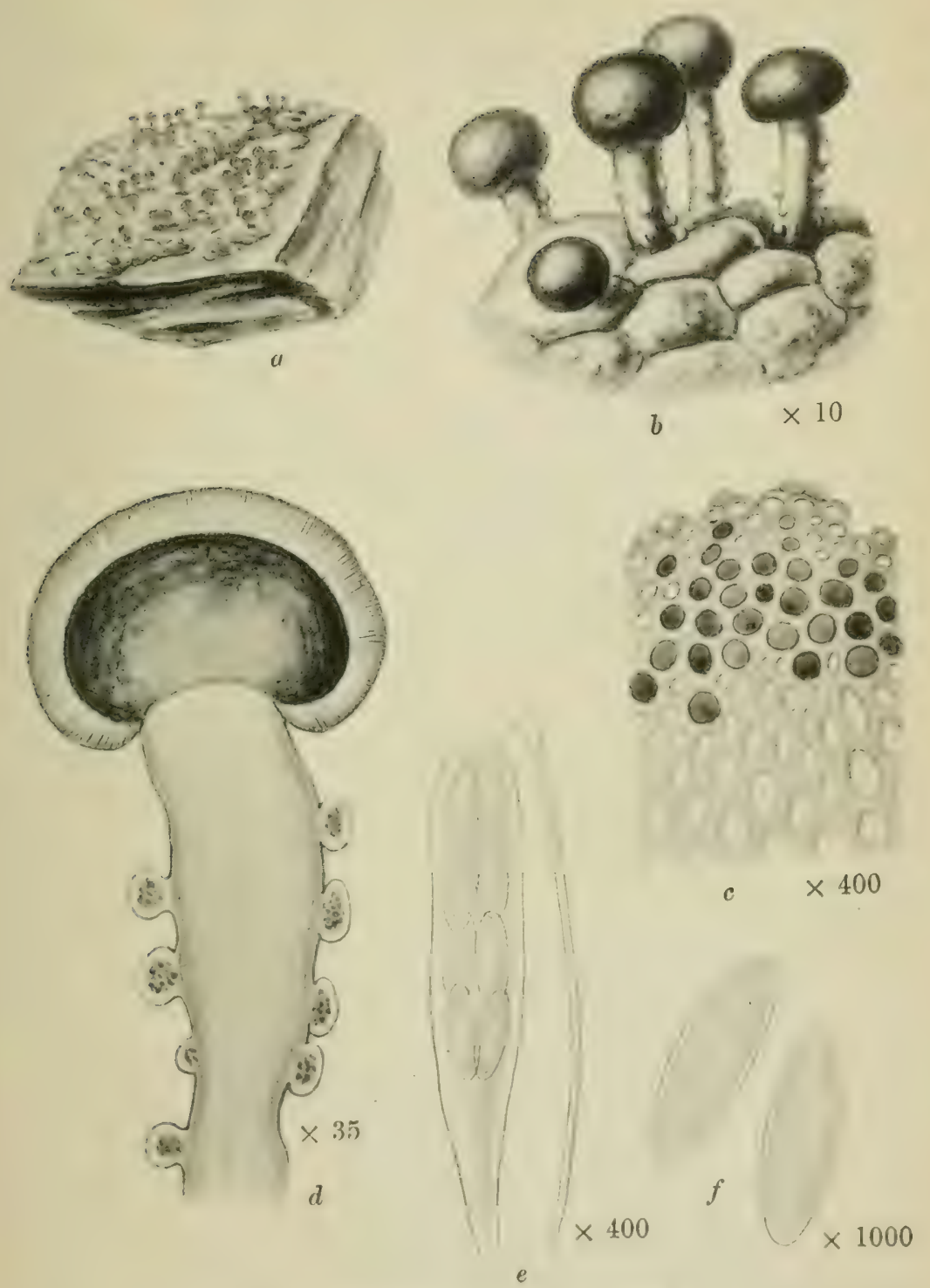

PILOPHORUS CEREOLUS Stizenb. r. Plant on rock. b. Portion of plant. c. Section of thallus. d. Ycrtical section
of apothecium. c. Ascus and paraphysis. $f$. Spores. 


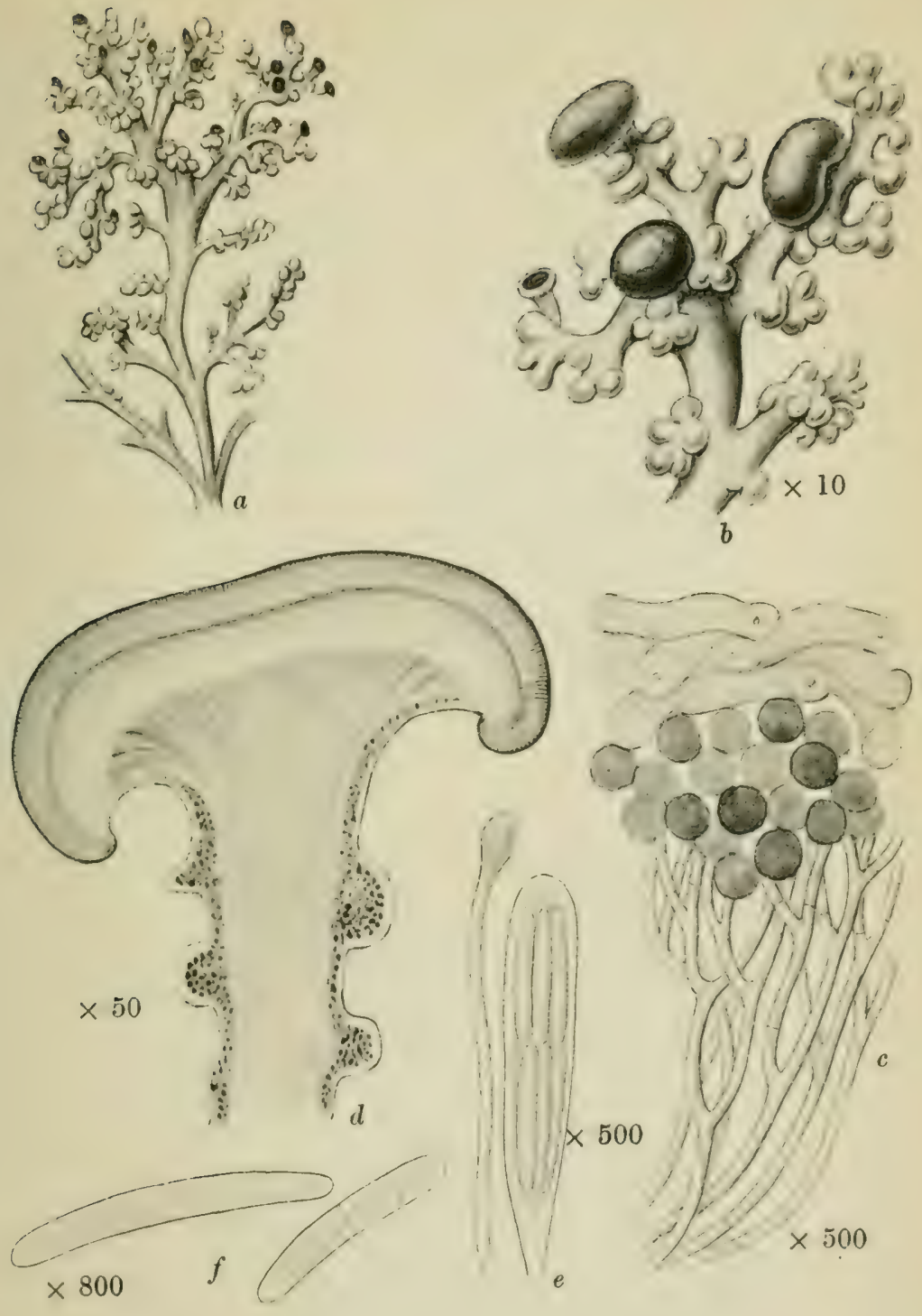

STEREOCAULON CORALLOIDES Fr.

a. Frond of plant. b. Portion of plant. c. Section of outer portion of upright thallus. d. Vertical section of apothecium. e. Ascus and paraphysis. $f$. Spores. 


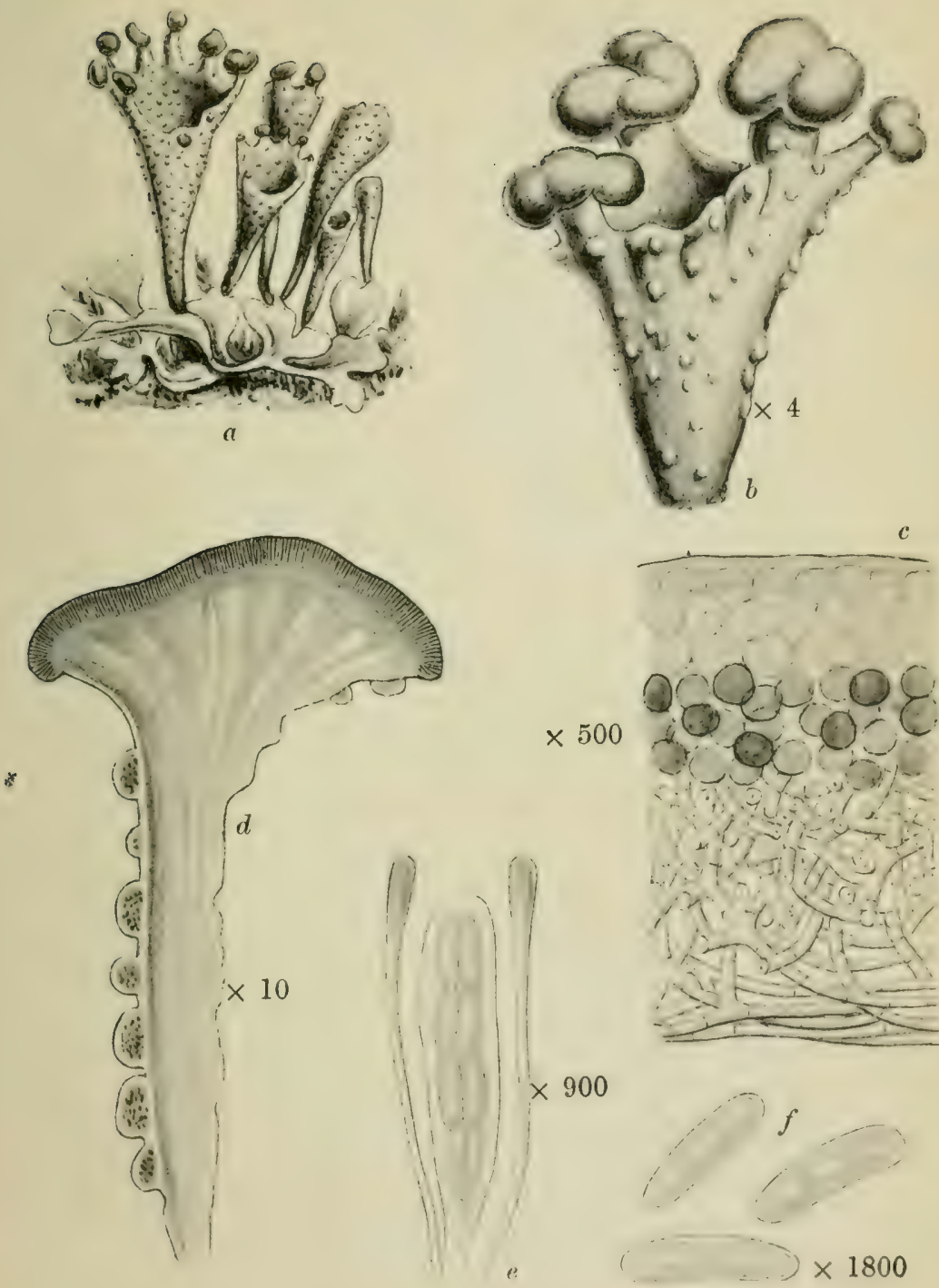

CLADONIA COCCIFERA Willd.

a. Plant with squamules and scyphi. b. Apex of seyphus. c. Vertical section of thallus, $d$. Vertical section of apothecium. c. Ascus and paraphyses. $f$. Spores. 


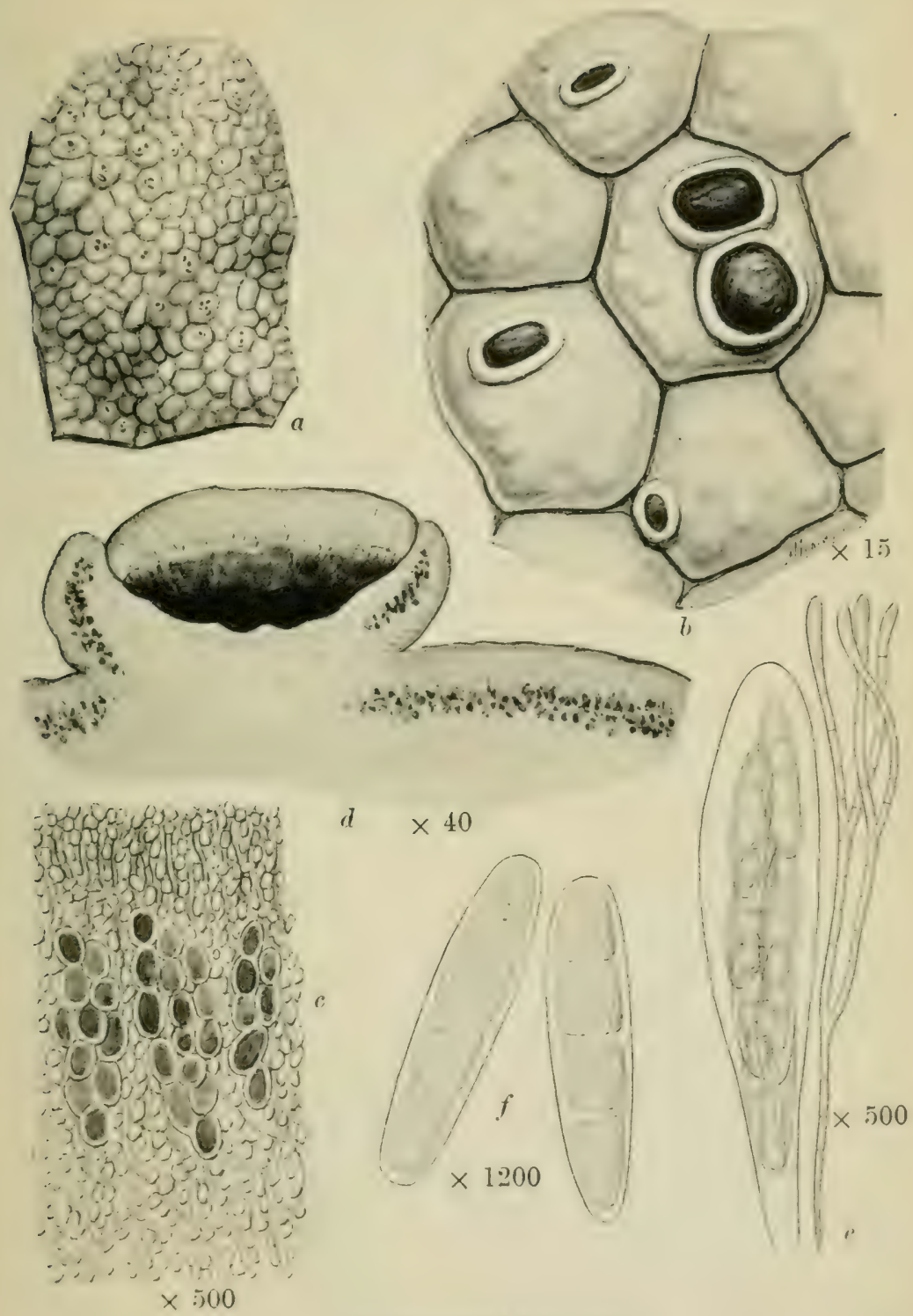

DIRINA REPANDA Nyl. a. Plant on rock. b. Portion of plant. c. Vertical section of thallus. d. Vertical
section of thallus and apothecinm. $\therefore$ Ascus and paraphysis. f. Spores. 



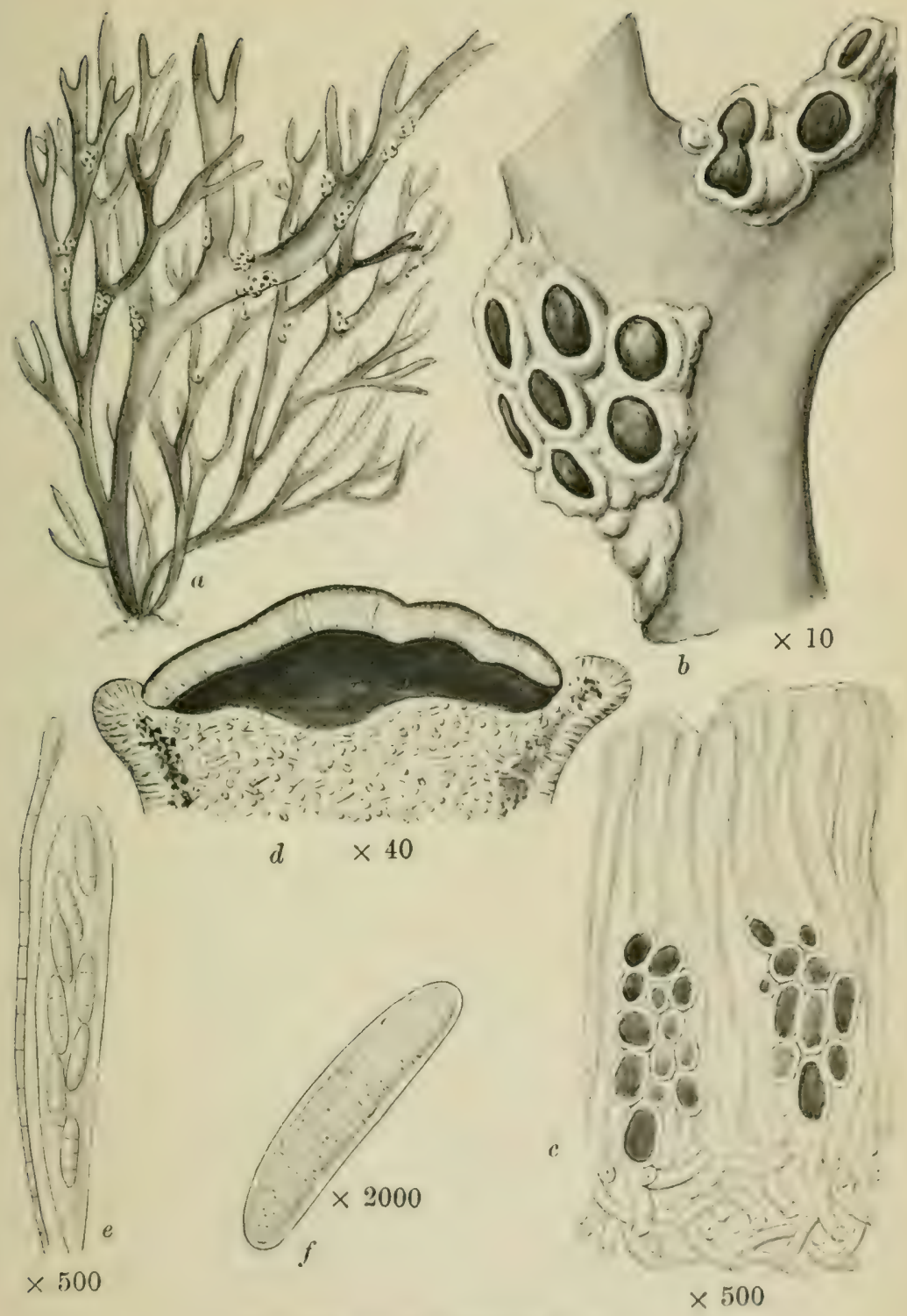

ROCCELIAA FUCIFORMLIS DC.

a. Plant from rock. b. Portion of plant with apothecia. c. Transverse section of frond. $d$. Vertical section of apothecium. $e$. Ascus and paraphysis, $f$. Spore. 


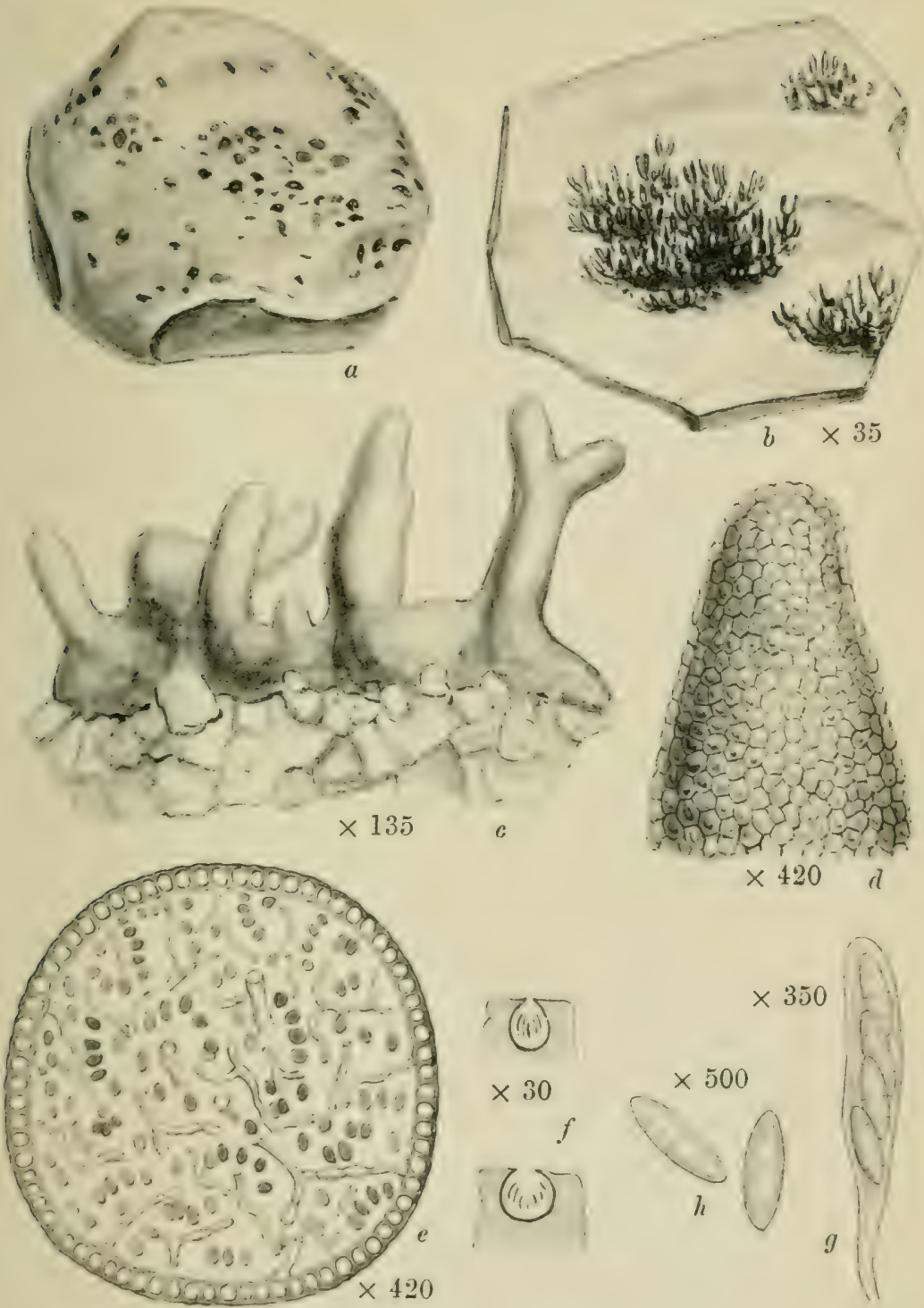

\section{PYRENIDIUM ACTINELLUM Nyl.}

a. Plants on rock. b. Plant group. c. P'ortion of plant. (l. Surface of frond. $e$. Transverse section of frond. $f$. Vertical section of perithecia. g. Ascus. h. Spores. (f.g.h. after Crombie.) 

$\therefore$

$\ldots$ 


$$
5
$$




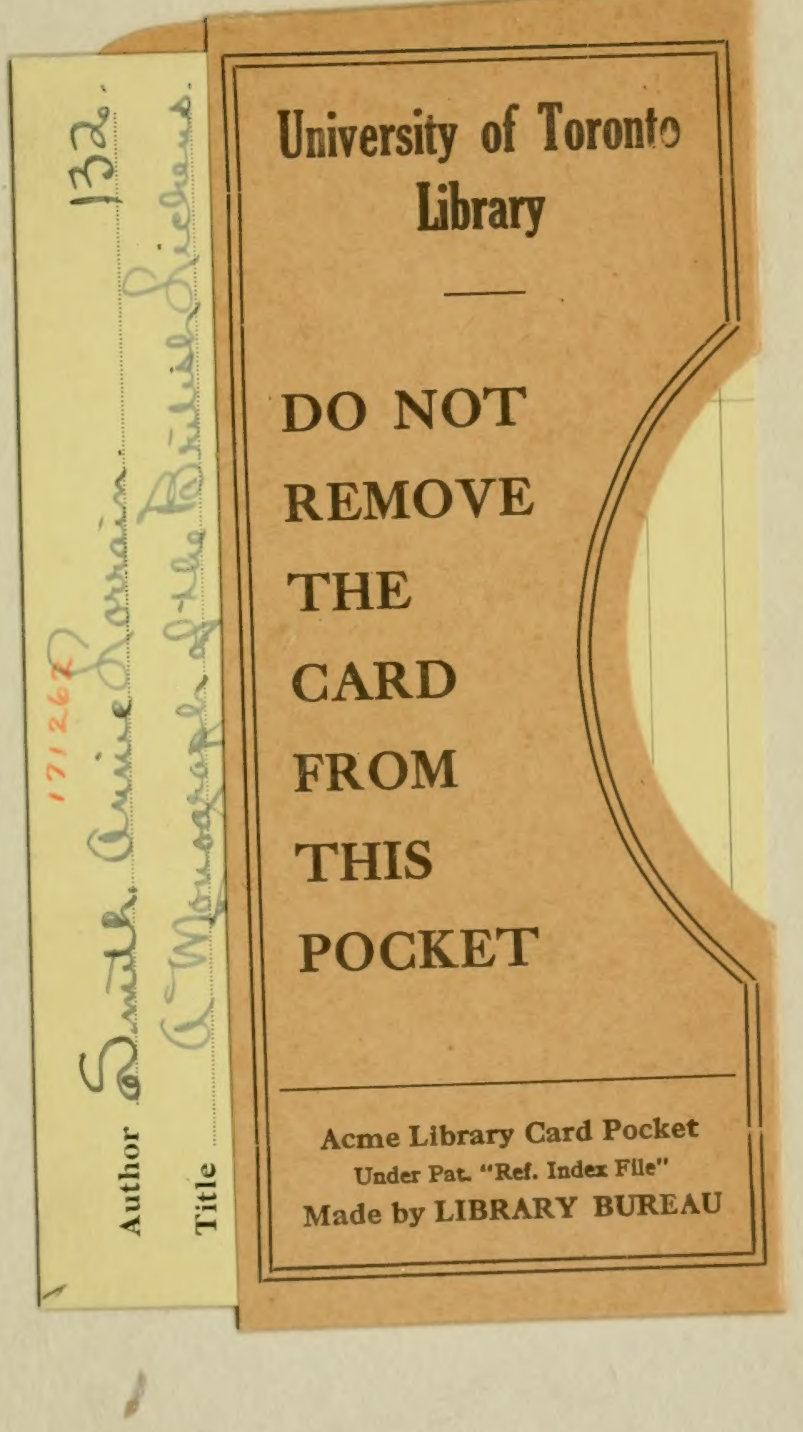




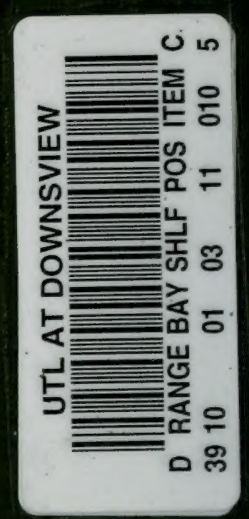

